\begin{tabular}{|l|l|}
\hline 2. To: (Receiving Organization) & 3. From: (Originating Organization) \\
LLW Project, HLW Project & Process Technology, 73510 \\
\hline 5. Proj./Prog./Dept./Div.: & $\begin{array}{l}\text { 6. Design Authority/ Design Agent/Cog. } \\
\text { Engr: }\end{array}$ \\
TWRS Disposal & R. M. Orme
\end{tabular}

8. Originator Remarks:

For approval and release.

11. Receiver Remarks: 11A. Design Basel ine Document? [] Yes [X] No
4. Related EDT No.:
N/A

7. Purchase Order No.:

N/A

9. Equip./Component No.:

N/A

10. System/Bldg./Facility: N/A

12. Major Assm. Dwg. No.: $N / A$

13. Permit/Permit Application No.: $N / A$

14. Required Response Date: 9/15/96

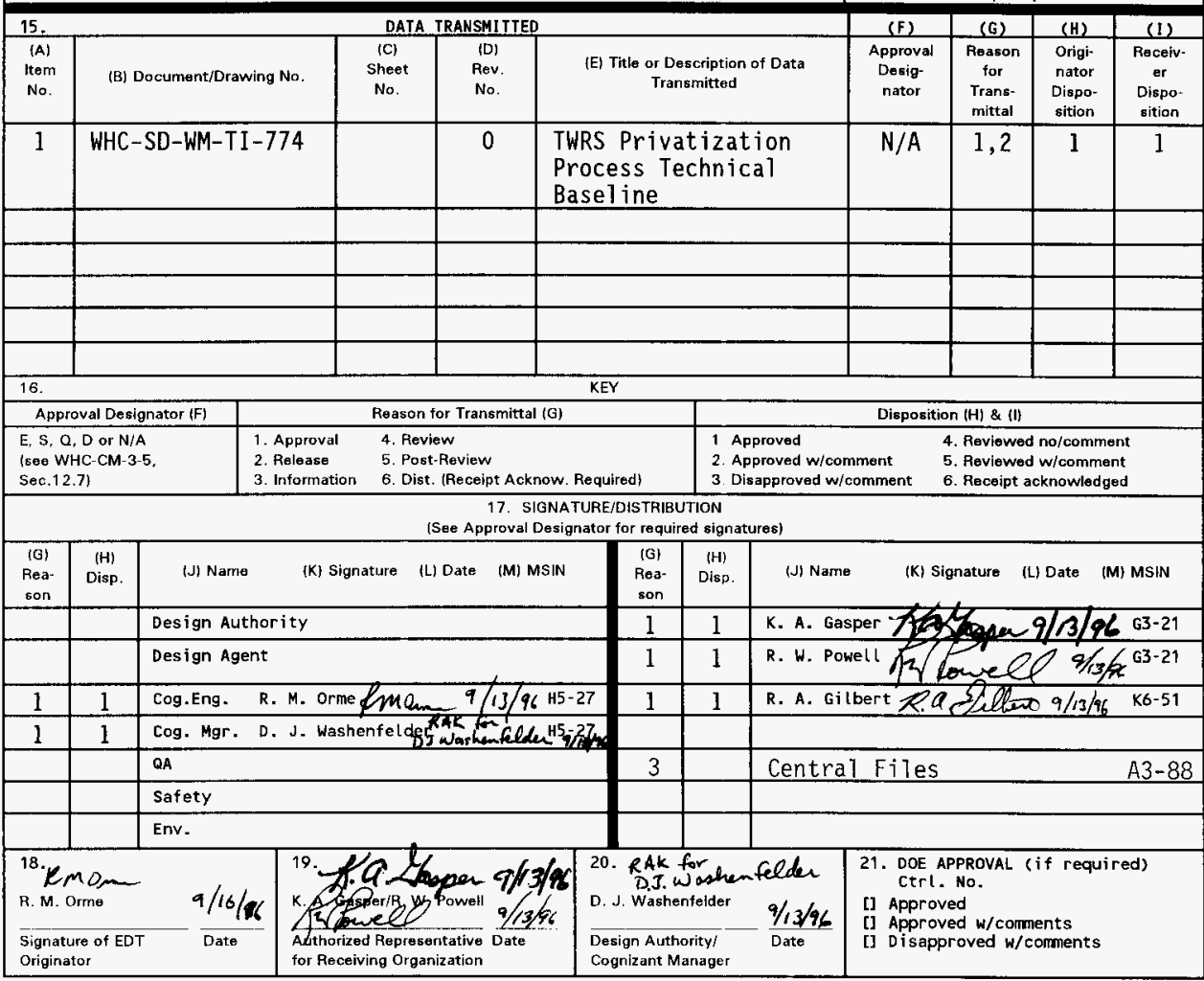




\title{
TWRS Privatization Process Technical Baseline
}

\author{
R. M. Orme \\ A. F. Manuel \\ L. W. She1ton \\ E. J. Slaathaug \\ West inghouse Hanford Company, Richland, WA 99352 \\ U.S. Department of Energy Contract DE-AC06-87RL 10930
Org Code: 73510
UC: 2000
B\&R Code: EW3130010
Charge Code: D6127/D5125
Tota1 Pages: 374 \\ EDT/ECN: 607741
}

Key Words: low-level waste, high-level waste, process flowsheet, process mass balance, Phase 1 privatization, Phase 2 privatization, process technical baseline.

Abstract: The U. S. Department of Energy (DOE) is planning a two-phased program for the remediation of Hanford tank waste. Phase 1 is a pilot program to demonstrate the procurement of treatment services. The volume of waste treated during Phase 1 is a small percentage of the tank waste. During Phase 2, DOE intends to procure treatment services for the balance of the waste. The TWRS Privatization Process Technical Baseline (PPTB) provides a summary level flowsheet/mass balance of tank waste treatment operations which is consistent with the tank inventory information, waste feed staging studies, and privatization guidelines currently available. The PPTB will be revised periodically as privatized processing concepts are crystallized.

TRADEMARK DISCLAIMER. Reference herein to any specific comercial product, process, or service by trade name, trademark, manufacturer, or otherwise, does not necessarily constitute or imply its endorsement, recommendation, or favoring by the United States Government or any agency thereof or its contractors or subcontractors.

Printed in the United states of America. To obtain copies of this document, contact: WHC/BCS Document Control Services, P.O. Box 1970, Mailstop H6-08, Richland HA 99352, Phone (509) 372-2420; Fax (509) 376-4989.
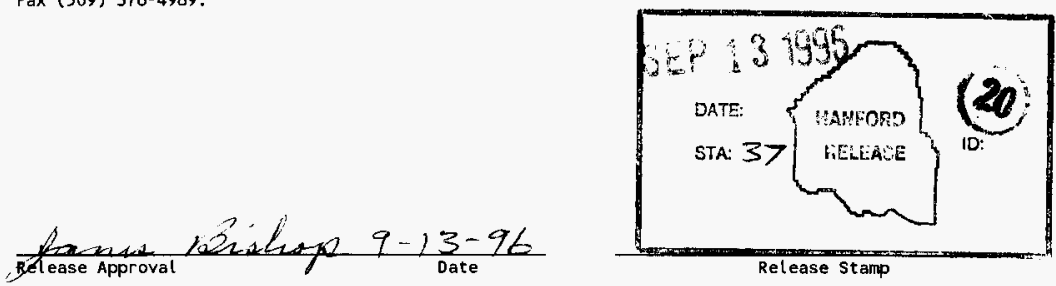

\section{Approved for Public Release}


WHC-SD-WM-TI-774 Rev. 0

TWRS PRIVATIZATION PROCESS TECHNICAL BASELINE

\title{
TANK WASTE REMEDIATION SYSTEM PRIVATIZATION PROCESS TECHNICAL BASELINE
}

September 1996

\author{
R. M. Orme \\ A. F. Manuel \\ L. W. Shelton \\ E. J. Slaathaug
}

Westinghouse Hanford Company

Richland, Washington

Prepared for

U. S. Department of Energy

Richland, Washington 
WHC-SD-WM-TI-774 Rev. 0

TWRS PRIVATIZATION PROCESS TECHNICAL BASELINE

TABLE OF CONTENTS

SUMMARY

Phase 117

$\begin{array}{ll}\text { Phase } 2 & 12\end{array}$

$\begin{array}{ll}1.0 & \text { INTRODUCTION }\end{array}$

2.0 PHASE 1 FLOWSHEET/MASS BALANCE 13

2.1 SUPERNATE STAGING OPERATIONS 16

2.1.1 Chemistry of Phase 1 Envelope A 22

2.1.1.1 AN-105 Staging 22

2.1.1.2 AP-104 Staging 24

2.1.1.3 AP-106 Staging 24

2.1.1.4 AN-104 Staging 26

2.1.1.5 AW-101 Staging 26

2.1.1.6 AN-103 Staging 26

2.1.2 Chemistry of Phase 1 Envelope B 30

2.1.3 Chemistry of Phase l Envelope C 30

2.2 LOW-ACTIVITY WASTE PRIVATE CONTRACTOR OPERATIONS 30

2.2.1 Entrained Solids Intermediate Product 39

2.2.2 Strontium/TRU Intermediate Product 41

2.2.3 Cesium Intermediate Product 41

2.2.4 Technetium Intermediate Product 41

2.2.5 Immobilized Low Activity Waste 42

2.2.6 Condensation $\quad 42$

$2.3 \mathrm{HIGH}-\mathrm{LEVEL}$ WASTE PRETREATMENT AND STAGING

$\begin{array}{ll}2.3 .1 \mathrm{AZ}-101 & 43 \\ 2.3 .2 \text { AZ-102 } & 43\end{array}$

$2.3 .2 \mathrm{AZ}-102 \quad 55$

2.3.3 AY-102/C-106 55

2.4 HIGH-LEVEL WASTE PRIVATE CONTRACTOR OPERATIONS

$\begin{array}{ll}2.5 \text { ENHANCED SLUDGE WASHING ADJUSTMENT } & 82\end{array}$

3.0 PHASE 2 FLOWSHEET/MASS BALANCE 83

3.1 THE PHASE 2 FEED STREAM 83

3.1.1 Initial Wash 83

3.1.2 Total Composite Feed Stream 85

3.1.3 Adjusted Composite Feed Stream 85

3.2 SOLID/LIQUID SEPARATIONS $\quad 85$

3.2.1 Settle and Decant 107

3.2.2 Caustic Leach 110

3.2.2.1 Single-Shell Tank Caustic Leach Factors 110

3.2.2.2 Double-Shell Tank Caustic Leach Factors 110

3.2.2.3 Potential Chromium Problem 111

3.2.3 Dilute Caustic Washing 112

3.2 .4 Flocculents $\quad 112$

3.2.5 Continuous Organic Decanting 113 
WHC-SD-WM-TI-774 Rev. 0

TWRS PRIVATIZATION PROCESS TECHNICAL BASELINE

3.3 CESIUM ION EXCHANGE FEED EVAPORATION 113

3.4 RADIONUCLIDE SEPARATIONS 113

3.4.1 Cesium Ion Exchange 113

3.4.1.1 Loading Cycle 114

3.4.1.2 Elution/Regeneration Cycle 115

3.4.1.3 Eluate Concentration and Acid Recycle 115

3.4.1.4 Resin Degeneration 115

3.4.2 Other Radionuclide Separations 115

3.5 LOW-ACTIVITY WASTE FEED EVAPORATION 116

3.6 LOW-ACTIVITY WASTE VITRIFICATION 116

3.6.1 Low-Activity Waste Vitrification 116

3.6.2 Immobilized Low-Activity Waste Packaging 117

3.7 LOW-ACTIVITY WASTE OFFGAS TREATMENT 117

3.7.1 Sulfur Recovery 117

3.7.2 Chloride and Fluoride Control 117

3.7.3 Mercury Recovery 118

3.8 HIGH-LEVEL WASTE FEED EVAPORATION 118

3.9 HIGH-LEVEL WASTE VITRIFICATION 118

3.9.1 Feed Adjustment 118

3.9.2 High-Level Waste Vitrification 118

$\begin{array}{ll}3.9 .3 \text { Final Packaging } & 119\end{array}$

$3.10 \mathrm{HIGH}-L E V E L$ WASTE OFFGAS TREATMENT 119

3.11 WATER RECYCLE 121

3.12 PHASE 2 WITH REVISED TWRS INVENTORY 121

$\begin{array}{ll}4.0 & 122\end{array}$

APPENDIX A INVENTORY ESTIMATES OF DST SUPERNATES \& PHASE 1 FEEDS A-1

APPENDIX B MASS BALANCES FOR ENVELOPE A, B, AND C PROCESSING B-1

APPENDIX C ENVIRONMENTAL SIMULATION PROGRAM C-1

APPENDIX D INVENTORY ESTIMATE FOR ENVELOPE D D-1

APPENDIX E PHASE 2 MASS BALANCE WITH REVISED TWRS INVENTORY E-1

APPENDIX $F$ ASSUMPTIONS AND BASES $\quad F-1$ 
WHC-SD-WM-TI-774 Rev. 0

TWRS PRIVATIZATION PROCESS TECHNICAL BASELINE

\section{LIST OF FIGURES}

Figure S-1 HLW and LAW Processing 8

Figure S-2 LAW Only Processing 9

$\begin{array}{ll}\text { Figure } 1 \text { Privatization of TWRS Functions } & 14\end{array}$

Figure 2 Diagram of Phase I Supernate Staging Transfers 17

Figure 3 AN-105 Dilution $840^{\circ} \mathrm{C} \quad 23$

Figure 4 AP-106 Dilution o $40{ }^{\circ} \mathrm{C} \quad 25$

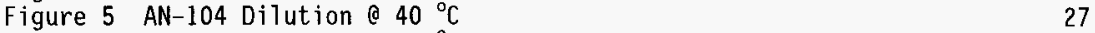

Figure 6 AW-101 Dilution $40{ }^{\circ} \mathrm{C} \quad 28$

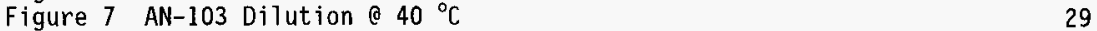

Figure 8 Phase 1 Private Contractor LAW Processing 32

Figure 9 Residual $\mathrm{Na}$ versus Displacement Fraction -- 7M Solution 40

Figure 10 In-Tank Sludge Washing of DST 241-AZ-101 44

Figure 11 In-Tank Sludge Washing of DST 241-AZ-102 56

Figure 12 In-Tank Sludge Washing of DST 24l-AY-102/SST 241-C-106 69

Figure 13 Initial Wash and In-Tank Processing Conceptual Configuration 84

Figure 14 Phase 2 Waste Processing 86

Figure 15 In-Tank Enhanced Sludge Wash Diagram 108

Figure 16 Typical DST Equipment and Instruments 109

Figure B-1 Phase 1 Private Contractor LAW Processing B-2

Figure E-1 Major Components of Inventory E-2

Figure E-2 Comparison of Products E-2

Figure E-3 Phase 2 Waste Processing E-3 
WHC-SD-WM-TI-774 Rev. 0

TWRS PRIVATIZATION PROCESS TECHNICAL BASELINE

\section{LIST OF TABLES}

Table S-1 Phase 1 IHLW Canister Count From PC1

10

Table S-2 Phase 1 ILAW Product Summary and Package Count 11

Table 1 Comparison of Phase 1 and Phase 2 Flowsheets 15

Table 2a PCl LAW Feed Batches 18

Table 2b PC2 LAW Feed Batches 20

Table 3 AN-105 Dilution $40{ }^{\circ} \mathrm{C} \quad 23$

Table 4 AP-106 Dilution a $40^{\circ} \mathrm{C} \quad 25$

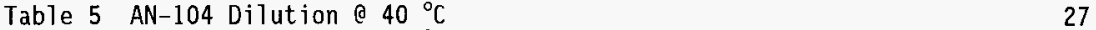

Table 6 AW-101 Dilution a $40{ }^{\circ} \mathrm{C} \quad 28$

$\begin{array}{lll}\text { Table } 7 & \text { AN-103 Dilution } 040{ }^{\circ} \mathrm{C} & 29\end{array}$

Table 8 Mass Balance -- Phase 1 LAW -- Batch PCl/1 33

Table 9 Displacement of $7 M$ Na Interstitial Liquid By Solids 40

Table 10 Phase 1 In-Tank Sludge Washing of DST 241-AZ-101 45

Table 11 Phase 1 In-Tank Sludge Washing of DST 241-AZ-102 57

Table 12 Phase 1 In-Tank Sludge Washing of DST 241-AY-102/SST

Table 13 Phase 2 Mass Balance with TWRS Inventory 87

Table 14 01d and New SST Caustic Leach Factors 111

Table 15 Cesium Ion Exchange Summary 114

Table 16 LLW Glass Formulation Constraints 116

Table 17 HLW Glass Formulation Ranges 120

Table A-1 Inventory Estimates of DST Supernates \& Phase 1 Feeds A-2

Table B-1 Phase 1 LAW Mass Balance for Batch PCl/1 B-3

Table B-2 Phase 1 LAW Mass Balance for Batch PCl/2

Table B-3 Phase 1 LAW Mass Balance for Batch PC1/3 B-15

Table B-4 Phase 1 LAW Mass Balance for Batch PCl/4 $\quad$ B-21

Table B-5 Phase 1 LAW Mass Balance for Batch PC1/5

Table B-6 Phase 1 LAW Mass Balance for Batch PCl/6

Table B-7 Phase 1 LAW Mass Balance for Batch PCl/7 $3-39$

Table B-8 Phase 1 LAW Mass Balance for Batch PCl/8

Table B-9 Phase 1 LAW Mass Balance for Batch PC1/9 B-51

Table B-10 Phase 1 LAW Mass Balance for Batch PC1/10 B-57

Table B-1l Phase 1 LAW Mass Balance for Batch PC1/11 B-63

Table B-12 Phase 1 LAW Mass Balance for Batch PC1/12 B-69

Table B-13 Phase 1 LAW Mass Balance for Batch PC2/13 B-75

Table B-14 Phase 1 LAW Mass Balance for Batch PC2/14 B-81

Table B-15 Phase 1 LAW Mass Balance for Batch PC2/15 B-87

Table B-16 Phase 1 LAW Mass Balance for Batch PC2/16 B-93

Table B-17 Phase 1 LAW Mass Balance for Batch PC2/17 B-99

Table B-18 Phase 1 LAW Mass Balance for Batch PC2/18 B-105

Table B-19 Phase 1 LAW Mass Balance for Batch PC2/19 B-111

Table B-20 Phase 1 LAW Mass Balance for Batch PC2/20 B-117

Table B-21 Phase 1 LAW Mass Balance for Batch PC2/21 B-123

Table B-22 Phase 1 LAW Mass Balance for Batch PC2/22 B-129

Table B-23 Phase 1 LAW Mass Balance for Batch PC2/23 B-135

Table B-24 Phase 1 LAW Mass Balance for Batch PC2/24 B-14l 
WHC-SD-WM-TI-774 ReV. 0

TWRS PRIVATIZATION PROCESS TECHNICAL BASELINE

Exhibit 1 -- Conversion of Raw Composition Data to ESP Input C-2

Exhibit 2 -- Typical ESP Equilibrium Results $\quad$ C-3

Table D-1 Inventory Assumptions for 241-AZ-101 $\quad$ D-2

Table D-2 Inventory Assumptions for 241-AZ-102 D-6

Table D-3 Inventory Assumptions for 241-AY-102 D-10

Table D-4 Inventory Assumptions for 241-C-106 $\quad$ D-14

Table D-5 Total Phase I HLW Tank Inventory $\quad$ D-18

Table E-1 Comparison of Revised TWRS Inventory and TWRS Inventory E-2

Table E-2 Phase 2 Mass Balance with Revised TWRS Inventory E-4 


\author{
WHC-SD-WM-TI-774 Rev. 0 \\ TWRS PRIVATIZATION PROCESS TECHNICAL BASELINE
}

\title{
SUMMARY
}

The operating contractor' $s^{1}$ functions described in this Privatization Process Technical Baseline (PPTB) are supported by flowsheet work and substantial planning documentation developed previously for the Tank Waste Remediation System (TWRS). The private contractors' functions are modeled without any specific knowledge of their process technology, but within the limits and information currently available through the TWRS Privatization Request for Proposals (DOE-RL 1996). This situation will be remedied in future revisions of the PPTB when more information about the private contractors' processes becomes available. In the meantime, the reader is advised that the private contractor portion of the PPTB is tentative.

Phase 1

If the U.S. Department of Energy (DOE) elects to have one its Phase 1 private contractors immobilize high-level waste (HLW), then the Hanford operating contractor will pretreat selected HLW sludge. In any event, the operating contractor will prepare batches of supernate for further treatment by private contractors. For this PPIB, the DOE exercises the option to purchase immobilization services for pretreated HLW from one private contractor. DOE will likewise purchase services for the pretreatment of supernates and the immobilization of low-activity waste (LAW) from the HLW private contractor and from one other private contractor. Figure S-1 depicts the privatization concept for processing HLW and LAW. Figure S-2 depicts the privatization concept for processing LAW only. Throughout the PPTB, Private Contractor \#1 (PC1) refers to the HLW private contractor; Private Contractor \#2 (PC2) processes supernate only.

The operating contractor pretreats HLW sludges in AZ-101, AZ-102 and AY-102 (including retrieved C-106 sludge) and stages $375,000 \mathrm{kgs}$ of washed sludges (oxide equivalent, not including $\mathrm{Na}$ and $\mathrm{Si}$ ) in 16 batches to the $\mathrm{HLW}$ private contractor. Table S-1 summarizes the canister count of immobilized high-level waste (IHLW) returning from the HLW private contractor, assuming a standard canister size $\left(1,650 \mathrm{~kg}\right.$ or $\left.0.62 \mathrm{~m}^{3}\right)$ and a waste oxide loading of 25 wt\% (not including $\mathrm{Na}$, Si, or private contractor added material). Note that the HLW private contractor does not return separated strontium/transuranic (TRU), cesium, and technetium to the operating contractor as intermediate product, but incorporates this material with the IHLW product (see Figure S-1). Material balances for the pretreatment and immobilization of each tank are provided in Section 2.4. The mass of washed solids provided to PC1 is more than the minimum order of $245,000 \mathrm{kgs}$ but less than the maximum order of $465,000 \mathrm{kgs}$. Additional feeds to meet the maximum order will be identified in future revisions.

\footnotetext{
"Operating contractor" is a generic term having reference to the contractor(s) who conduct non-privatized operations for the DOE.
} 
Figure S-1 HLW and LAW Processing

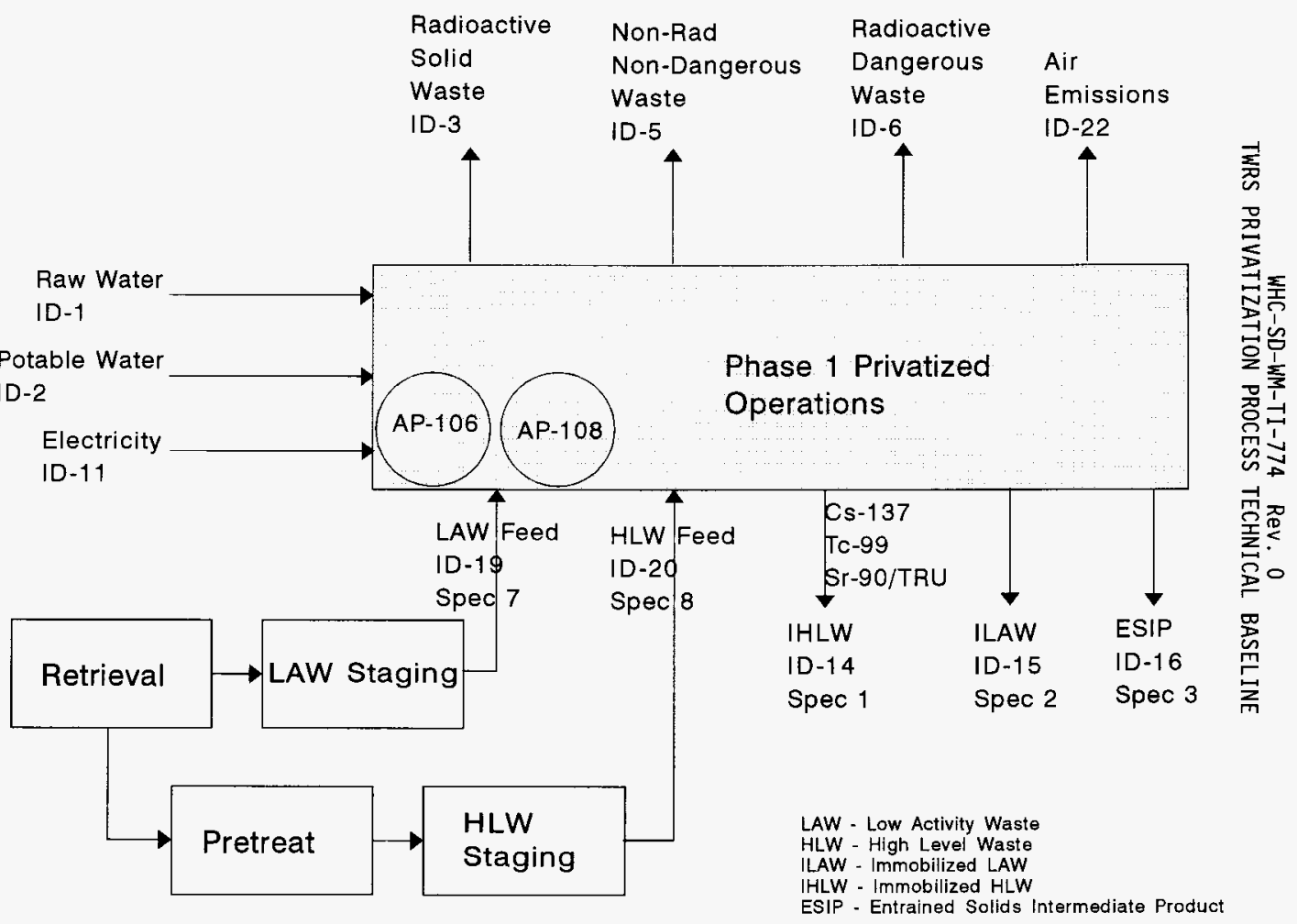


Figure S-2 LAW Only Processing

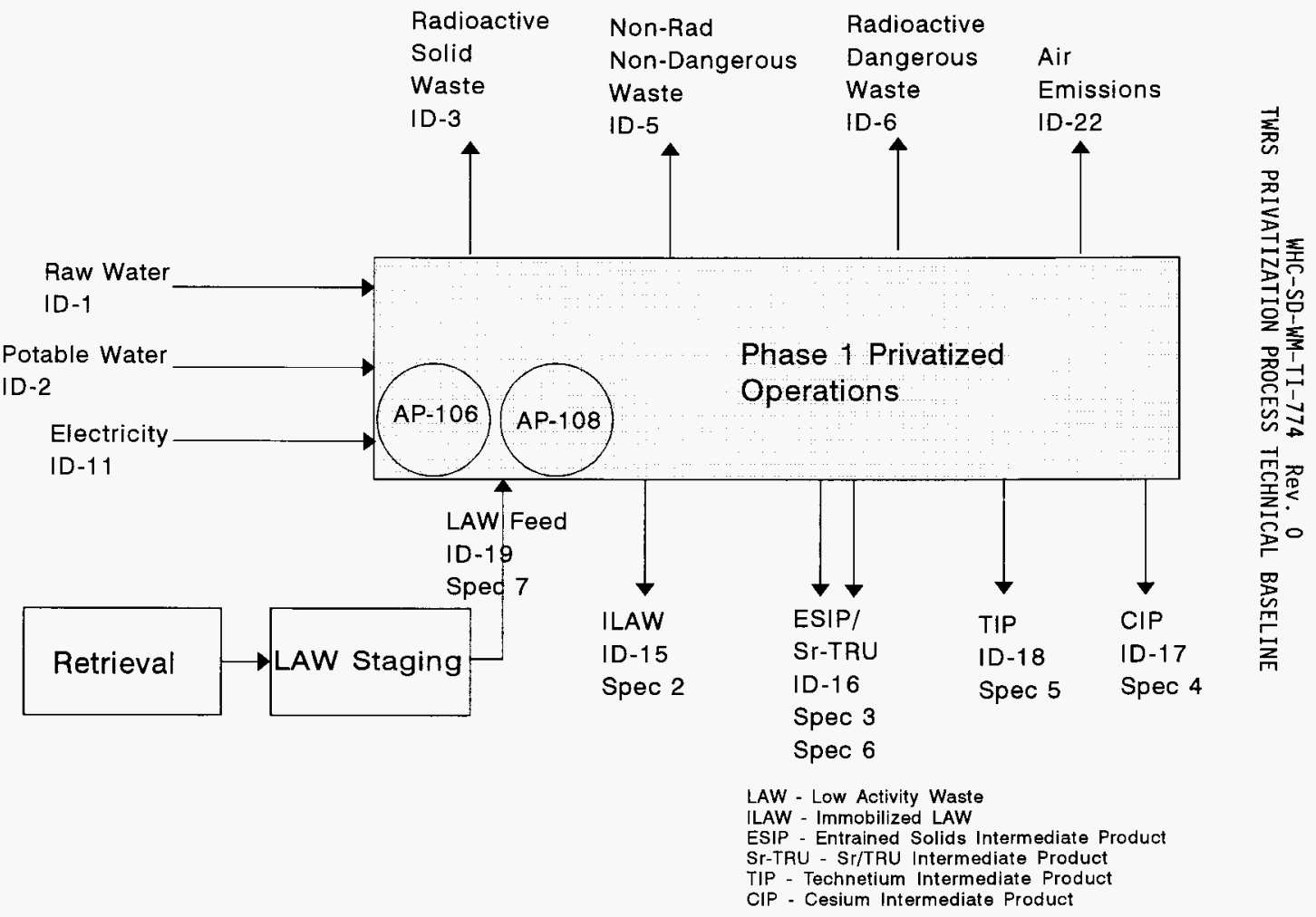




\section{TWRS PRIVATIZATION PROCESS TECHNICAL BASELINE}

Twelve batches of supernate are prepared and staged to each of the private contractors. Each private contractor receives 5,100 MT of soluble sodium for a total of $\sim 10,200$ MT of sodium. The private contractors separate solids and remove (as needed to satisfy DOE product specifications) strontium/TRU, cesium, and technetium. The pretreated LAW is immobilized in a currently unspecified waste form in $2.6 \mathrm{~m}^{3}$ ILAW packages. Table $\mathrm{S}-2$ summarizes the radionuclide loading and ILAW package count for the 24 Phase 1 supernate batches. Appendix B provides material balances for each of the batches, including the volume of intermediate radionuclide products returned to the operating contractor.

Table S-1 Phase 1 IHLW Canister Count From PCl

\begin{tabular}{|c|c|}
\hline Batch \# & $\begin{array}{c}\text { Canisters } \\
\left(1,650 \mathrm{~kg} \text { or } 0.62 \mathrm{~m}^{3}\right)\end{array}$ \\
\hline $1(\mathrm{AZ}-101)$ & 94 \\
\hline $2(\mathrm{AZ}-101)$ & 94 \\
\hline $3(\mathrm{AZ}-102)$ & 81 \\
\hline $4(\mathrm{AZ}-102)$ & 81 \\
\hline $5(\mathrm{AY} / \mathrm{C})$ & 47 \\
\hline $6(\mathrm{AY} / \mathrm{C})$ & 47 \\
\hline $7(\mathrm{AY} / \mathrm{C})$ & 47 \\
\hline $8(\mathrm{AY} / \mathrm{C})$ & 47 \\
\hline $9(\mathrm{AY} / \mathrm{C})$ & 47 \\
\hline $10(\mathrm{AY} / \mathrm{C})^{\mathrm{a}}$ & 47 \\
\hline $11(\mathrm{AY} / \mathrm{C})$ & 47 \\
\hline $12(\mathrm{AY} / \mathrm{C})$ & 47 \\
\hline $13(\mathrm{AY} / \mathrm{C})$ & 46 \\
\hline $14(\mathrm{AY} / \mathrm{C})$ & 46 \\
\hline $15(\mathrm{AY} / \mathrm{C})$ & 46 \\
\hline $16(\mathrm{AY} / \mathrm{C})$ & 46 \\
\hline Tota1 & 910 \\
\hline
\end{tabular}

This batch satisfies the HLW minimum order quantity. 
Table S-2 Phase 1 ILAW Product Summary and Package Count

\begin{tabular}{|c|c|c|c|c|c|c|c|c|c|c|c|c|c|c|}
\hline & & & \multicolumn{6}{|c|}{ Private Contractor \#1 } & \multicolumn{6}{|c|}{ Private Contractor \#2 } \\
\hline & & & \multicolumn{4}{|c|}{ ILAW LOADING } & & & \multicolumn{4}{|c|}{ ILAW LOADING } & \multirow[b]{2}{*}{ ILAW } & \multirow[b]{2}{*}{ Cs } \\
\hline & \multicolumn{2}{|c|}{ Envelope } & TRU & $S r$ & Cs & Tc & ILAW & $85^{2}$ & TRU & $\mathrm{Sr}$ & Cs & Tc & & \\
\hline Batch & $\mathrm{PCl}$ & PC2 & $\mathrm{nCi} / \mathrm{g}$ & $\mathrm{Ci} / \mathrm{m}^{3}$ & $\mathrm{Ci} / \mathrm{m}^{3}$ & $\mathrm{Ci} / \mathrm{m}^{3}$ & $\begin{array}{l}2.6 \mathrm{~m}^{3} \\
\text { Pkgs }\end{array}$ & $8 \% 95$. & $\mathrm{nCi} / \mathrm{g}$ & $\mathrm{Ci} / \mathrm{m}^{3}$ & $\mathrm{Ci} / \mathrm{m}^{3}$ & $\mathrm{Ci} / \mathrm{m}^{3}$ & $\begin{array}{l}2.6 \mathrm{~m}^{3} \\
\text { Pkgs } \\
\end{array}$ & Pkgs \\
\hline 1 & A & A & 6.1 & 4.5 & 3.0 & 0.18 & 708 & 4. & 6.3 & 4.5 & 3.0 & 0.18 & 683 & 4 \\
\hline 2 & A & A & 0.6 & 3.9 & 3.0 & 0.02 & 766 & $\frac{1}{4}$ & 0.6 & 3.9 & 3.0 & 0.02 & 745 & 1 \\
\hline 3 & A & A & 6.0 & 13.3 & 3.0 & 0.17 & 497 & 4 & 6.0 & 13.3 & 3.0 & 0.17 & 496 & 4 \\
\hline 4 & A & A & 1.8 & 2.7 & 3.0 & 0.25 & 545 & 4 & 1.8 & 2.7 & 3.0 & 0.25 & 543 & 3 \\
\hline 5 & A & A & 2.0 & 14.5 & 3.0 & 0.20 & 733 & b. & 2.0 & 14.5 & 3.0 & 0.20 & 733 & 5 \\
\hline 6 & $\mathrm{~B}$ & B & 16.3 & 5.6 & 3.0 & 0.30 & 383 & 6 & 16.3 & 5.6 & 3.0 & 0.30 & 383 & 6 \\
\hline $7^{\mathrm{a}}$ & $\mathrm{C}$ & $\mathrm{C}$ & 100.0 & 20.0 & 3.0 & 0.30 & 147 & 1 & 100.0 & 20.0 & 3.0 & 0.30 & 147 & 1 \\
\hline $8^{a}$ & $C$ & $\mathrm{C}$ & 100.0 & 20.0 & 3.0 & 0.30 & 307 & 2 & 100.0 & 20.0 & 3.0 & 0.30 & 307 & 2 \\
\hline $9^{a}$ & $C$ & $\mathrm{C}$ & 96.1 & 20.0 & 3.0 & 0.30 & 605 & 2. & 96.5 & 20.0 & 3.0 & 0.30 & 601 & 2 \\
\hline 10 & $\mathrm{C}$ & $c$ & 4.8 & 6.2 & 3.0 & 0.02 & 717 & t) & 4.8 & 6.2 & 3.0 & 0.02 & 717 & 1 \\
\hline 11 & $C$ & $C$ & 2.5 & 20.0 & 3.0 & 0.05 & 714 & 1. & 4.9 & 20.0 & 3.0 & 0.10 & 704 & 1 \\
\hline 12 & $B$ & $C$ & 17.9 & 6.4 & 3.0 & 0.30 & 623 & 10 & 5.0 & 20.0 & 3.0 & 0.10 & 352 & 1 \\
\hline & & & & & & Total & 6745 & 41 & & & & Total & 6412 & 31 \\
\hline
\end{tabular}

${ }^{a}$ In practice, the private contractors will target TRU concentration well below $100 \mathrm{nC} i / g$ to ensure that ILAW is suitable for near-surface disposal.

${ }^{\mathrm{b}}$ Shaded values are Cs packages not produced by HLW private contractor. 


\section{WHC-SD-WM-TI-774 Rev. 0 \\ TWRS PRIVATIZATION PROCESS TECHNICAL BASELINE}

Table S-2 shows the projected cesium intermediate product (CIP) package count for PC2. Table S-2 also indicates the number of cesium packages that are not produced by the HLW private contractor.

Phase 2

For Phase 2, DOE's intention is to continue procuring services from private contractors for the balance of the tank waste, expanding the scope to include all retrieval and pretreatment in addition to immobilization. There is nothing equivalent to the TWRS Privatization Request for Proposals (DOE-RL 1996) and feed staging plans (Manuel 1996, Certa 1996) to provide guidance for Phase 2. The feed to Phase 2 consists of all tank waste retrieved together into a composite feed stream, with adjustments to account for Phase 1 operations.

The PPTB mode1s Phase 2 in a manner similar to previous TWRS Process Flowsheets (Orme 1994, Orme 1995). The composite feed is separated into sludge and supernates by a settle/decant operation. The sludges are subjected to caustic leaching to solubilize a portion of the solids, then washed to dilute the content of the interstitial liquid. The pretreated solids are then immobilized in glass. Enhanced sludge washing laboratory results indicate that chromium caustic leach is not very effective for certain wastes that were evaluated for the first time this year. Due to the large volume of these wastes, the net effect was a drastic reduction in the overall mass-weighted chromium caustic leach factor.

The PPTB projects a canister count of 22,420 standard canisters $(1,650$ $\mathrm{kgs}$ or $0.62 \mathrm{~m}^{3}$ per canister $)$ or 12,890 proposed standard canisters $(2,870 \mathrm{kgs}$ or $1.08 \mathrm{~m}^{3}$ per canister) of IHLW from Phase 2.

The above results are based on the TWRS Inventory which was carried over from Revision 1 of the TWRS Process Flowsheet. The PPTB also considers a second inventory case which is based on draft standard inventory values (Kupfer et al. 1996). While the standard inventory is subject to change over the next year, these tentative values nonetheless indicate trends for certain key components. There will be a significant increase in the inventory of chromium. The current chromium solubility limit drives the canister count to 49,500 and 28,460 for the standard canister and proposed standard canister, respectively.

Al1 liquid effluents from settle/decant separations are pretreated to remove cesium, thereby removing the primary soluble radionuclide, ${ }^{137} \mathrm{Cs}$. Subsequent revisions of the PPTB will reflect additional separation requirements when and if they are added to Phase 2. The pretreated liquids are likewise immobilized in glass.

The past year's inventory and enhanced sludge washing developments focus future Phase 2 flowsheet efforts on controlling a burgeoning IHLW volume. 


\author{
WHC-SD-WM-TI-774 Rev. 0 \\ TWRS PRIVATIZATION PROCESS TECHNICAL BASELINE
}

\title{
1.0 INTRODUCTION
}

Selected TWRS functions that are pertinent to the management and treatment of tank waste are depicted in Figure 1. Hanford's operating contractor will perform certain functions, but the DOE has elected to procure the services of private contractors for other functions. The DOE will pursue the privatization of waste treatment services in a two-phased approach. Figure 1 shows the current assignment of functions during the two phases of privatization. The TWRS PPTB is a summary-level flowsheet/mass balance of Phases 1 and 2.

During Phase 1, the Hanford operating contractor prepares and stages 1 iquid wastes (supernates) to two private contractors that are providing LAW processing services. The operating contractor also pretreats and transfers HLW sludges from selected tanks to one of the two private contractors. These activities are categorized as LAW Staging Operations, and HLW Pretreatment and Staging Operations, respectively. The operating contractor ensures that waste is transferred to the private contractors on schedule and within contractual specifications. The private contractors receive waste transfers and treat the waste to contractual specifications, returning intermediate products and final products to the operating contractor for interim storage or disposal. Phase 1 is intended to be a demonstration, processing up to $13 \%$ of the water-soluble inventory and $6 \%$ of the HLW inventory.

Phase 2 private contractor requirements have not been finalized, although work to identify a Phase 2 retrieval and processing sequence is proceeding (Penwell 1996). For the purposes of the Phase 2 flowsheet/mass balance, the post-Phase 1 tank waste inventory is composited as a single feed stream and processed through a settle/decant-sludge washing-radionuclide separation-immobilization process similar (but not identical) to previous revisions of the TWRS Process Flowsheet (Orme 1995).

Table 1 compares some primary characteristics of the flowsheets for Phase 1 and Phase 2.

\subsection{PHASE 1 FLOWSHEET/MASS BALANCE}

Supernate preparation by the operating contractor generally consists of diluting double-shel1 tank (DST) supernates and batching appropriate amounts to the private contractors' receiving tanks. Both private contractors receive supernates, separate entrained solids, recover radionuclides (strontium/TRU, cesium, and technetium) from the supernates, convert them to intermediate products, and immobilize the decontaminated supernates.

The operating contractor conducts sludge-washing operations to prepare HLW sludges for PC1. PCl converts the sludges and intermediate radionuclide waste products recovered from supernates into an IHLW form in a container suitable for disposal at a geologic repository. 
WHC-SD-WM-TI-774 Rev. 0

TWRS PRIVATIZATION PROCESS TECHNICAL BASELINE

Figure 1 Privatization of TWRS Functions

Pre-Privatization

\begin{tabular}{|l|}
\hline Store Managed \\
Tank Waste \\
\hline
\end{tabular}

\begin{tabular}{|l|}
\hline $\begin{array}{l}\text { Characterize } \\
\text { Waste }\end{array}$ \\
\hline
\end{tabular}

\begin{tabular}{|l|}
\hline Transfer Managed \\
Tank Waste \\
\hline
\end{tabular}

Concentrate

Waste

Retrieve SSTs

Retrieve DSTs

Retrieve MUSTs

Store In-process

Waste

\begin{tabular}{|l|}
\hline Pretreat \\
Sludges \\
\hline
\end{tabular}

\begin{tabular}{l|}
\hline Pretreat \\
Supernatants
\end{tabular}

\begin{tabular}{|l|}
\hline Immobilize \\
LAW \\
\hline
\end{tabular}

Immobilize

HLW
Phase 1 Assignments

\begin{tabular}{|l|}
\hline Store Managed \\
Tank Waste \\
\hline
\end{tabular}

\begin{tabular}{|l|}
\hline $\begin{array}{l}\text { Characterize } \\
\text { Waste }\end{array}$ \\
\hline
\end{tabular}

Transfer Managed

Tank Waste

\begin{tabular}{|l|}
\hline $\begin{array}{l}\text { Concentrate } \\
\text { Waste }\end{array}$ \\
\hline
\end{tabular}

Retrieve SSTs

Retrieve DSTs

Retrieve MUSTs

Store In-process

Waste

\begin{tabular}{|l|}
\hline Pretreat \\
Sludges \\
\hline
\end{tabular}

Pretreat

Immobilize

Immobilize

$\mathrm{HLW}$
Phase 2 Assignments

Store Managed

Tank Waste

Characterize

Waste

Transfer Managed

Tank Waste

Concentrate

Waste

Retrieve SSTS

Retrieve DSTS

Retrieve MUSTs

Store In-process

Waste

Pretreat:

Sludges

Pretreat

supernatants

Immobilize

LAW

Immobilize

HLW

\section{Operating Contractor Functions}

Privatized Functions 
WHC-SD-WM-TI-774 Rev. 0

TWRS PRIVATIZATION PROCESS TECHNICAL BASELINE

Table 1 Comparison of Phase 1 and Phase 2 Flowsheets

\begin{tabular}{|c|c|c|}
\hline & Phase 1 & Phase 2 \\
\hline Number of Streams & Major streams only & Major streams only \\
\hline Batching Approach & $\begin{array}{l}\text { Batches from specific } \\
\text { tanks conform to feed } \\
\text { staging plans and } \\
\text { comply with Phase } 1 \\
\text { feed envelopes } A, B, C \\
\text { and D }\end{array}$ & $\begin{array}{l}\text { Composite the remainder } \\
\text { of the waste as a } \\
\text { single "batch" }\end{array}$ \\
\hline Stream Composition & $\begin{array}{l}\text { Same leve } 1 \text { of } \\
\text { definition as Phase } 2\end{array}$ & $\begin{array}{l}\text { Same level of } \\
\text { definition as Phase } 1\end{array}$ \\
\hline Inventory & $\begin{array}{l}\text { Developed specifically } \\
\text { for Phase } 1 \text { feed tanks }\end{array}$ & $\begin{array}{l}\text { Existing global } \\
\text { inventory from TWRS } \\
\text { Process Flowsheet }\end{array}$ \\
\hline $\begin{array}{l}\text { Liquid/Solid } \\
\text { Distribution }\end{array}$ & $\begin{array}{l}\text { Developed specifically } \\
\text { for Phase } 1 \text { feeds }\end{array}$ & $\begin{array}{l}\text { Mass-weighted } \\
\text { solubility factors } \\
\text { based on available } \\
\text { characterization and } \\
\text { enhanced sludge-washing } \\
\text { data }\end{array}$ \\
\hline $\begin{array}{l}\text { Process Technology for } \\
\text { Sludges }\end{array}$ & $\begin{array}{l}\text { Sludge washing (removal } \\
\text { of interstitial liquid } \\
\text { components by dilution) }\end{array}$ & $\begin{array}{l}\text { Enhanced sludge washing } \\
\text { (additional dilution of } \\
\text { solids by caustic } \\
\text { leaching and removal of } \\
\text { interstitial components } \\
\text { by dilution) }\end{array}$ \\
\hline $\begin{array}{l}\text { Process Technology for } \\
\text { Supernates }\end{array}$ & $\begin{array}{l}\text { Separation requirements } \\
\text { only; no specific } \\
\text { technology }\end{array}$ & $\begin{array}{l}\text { Organic phase } \\
\text { separation added to } \\
\text { TWRS Process Flowsheet } \\
\text { technology }\end{array}$ \\
\hline Offgas Treatment & $\begin{array}{l}\text { Not addressed (private } \\
\text { contractor } \\
\text { responsibility) }\end{array}$ & $\begin{array}{l}\text { Included in TWRS } \\
\text { Process Flowsheet model }\end{array}$ \\
\hline Waste Loading in IHLW & $\begin{array}{l}25 \% \text { (not including } \mathrm{Na} \\
\text { and } \mathrm{Si} \text { ) }\end{array}$ & Controlled by chromium \\
\hline Sensitivity Cases & None & $\begin{array}{l}\text { Revised TWRS inventory } \\
\text { with selected standard } \\
\text { inventory values }\end{array}$ \\
\hline
\end{tabular}




\section{WHC-SD-WM-TI-774 Rev. 0 \\ TWRS PRIVATIZATION PROCESS TECHNICAL BASELINE}

\subsection{SUPERNATE STAGING OPERATIONS}

Single-shell tank (SST) pumping and waste evaporation continue for several more years, so the inventory profile of DSTs is changing. Shelton (1996) has projected the supernate ${ }^{2}$ content of DSTs into the Fiscal Year (FY) -2002 time frame. ${ }^{3}$ The projected supernate inventories are shown in Appendix A. As tank farm operations play out over the next few years, some of the actual transfers are 1ikely to depart from Shelton's assumed transfers. Therefore, the DST feed batches described below will be revised one or more times before Phase 1 staging begins.

With Shelton's projected inventory as a starting point, Certa (1996) has developed a staging plan for selected Phase 1 supernates. Supernate staging operations revolve around two tanks (AP-102 and AP-104) set aside as operating contractor intermediate staging tanks, and two tanks (AP-106 and AP-108) that are turned over to the private contractors as LAW receiving tanks. For insight into logistical considerations and the rationale behind Phase 1 supernate feed selection, the reader is referred to the staging plan.

Figure 2 depicts the chronological order of the transfers that set up the supernate receiving tanks with the first 10 batches of Phase 1 Envelope $A$ feed (each private contractor receives 5 batches). Several preliminary transfers are required to set up the initial batches of private contractor feed. For example, transfers \#1 and \#2 clear the existing waste out of AP-102 and AP-104, respectively, to prepare them for receiving Envelope A waste. Diagrams for Envelope $B$ and $C$ are not provided, but they would continue in a very similar pattern.

The operating contractor stages five batches of Envelope A, one batch of Envelope $B$, and one batch of Envelope $C$ to each of two private contractors ( $P C 1$ and $P C 2)$ for the Phase 1 proof-of-concept $(P-0-C)$. The Phase 1 extension provides four additional batches of Envelope $C$ and one batch of Envelope $B$ to PC1. PC2 receives five extension batches of Envelope $C$. Tables $2 a$ and $2 b$ summarize the batch inventory. These batches account for dilution by retrieval water, retrieval inefficiencies and heel mixing during the staging operations.

"The term "supernate" is used rather loosely in this context. Many DST supernates are highly concentrated, being close to or exceeding the solubility of some constituents. Precipitated salts are known to be present in some.

${ }^{3}$ Shelton's supernate projections are based on the near-term tank farm operating scenario outlined in Washenfelder (1996). 
TWRS PRIVATIZATION PROCESS TECHNICAL BASELINE

Figure 2 Diagram of Envelope "A" Staging Transfers in Chronological Order
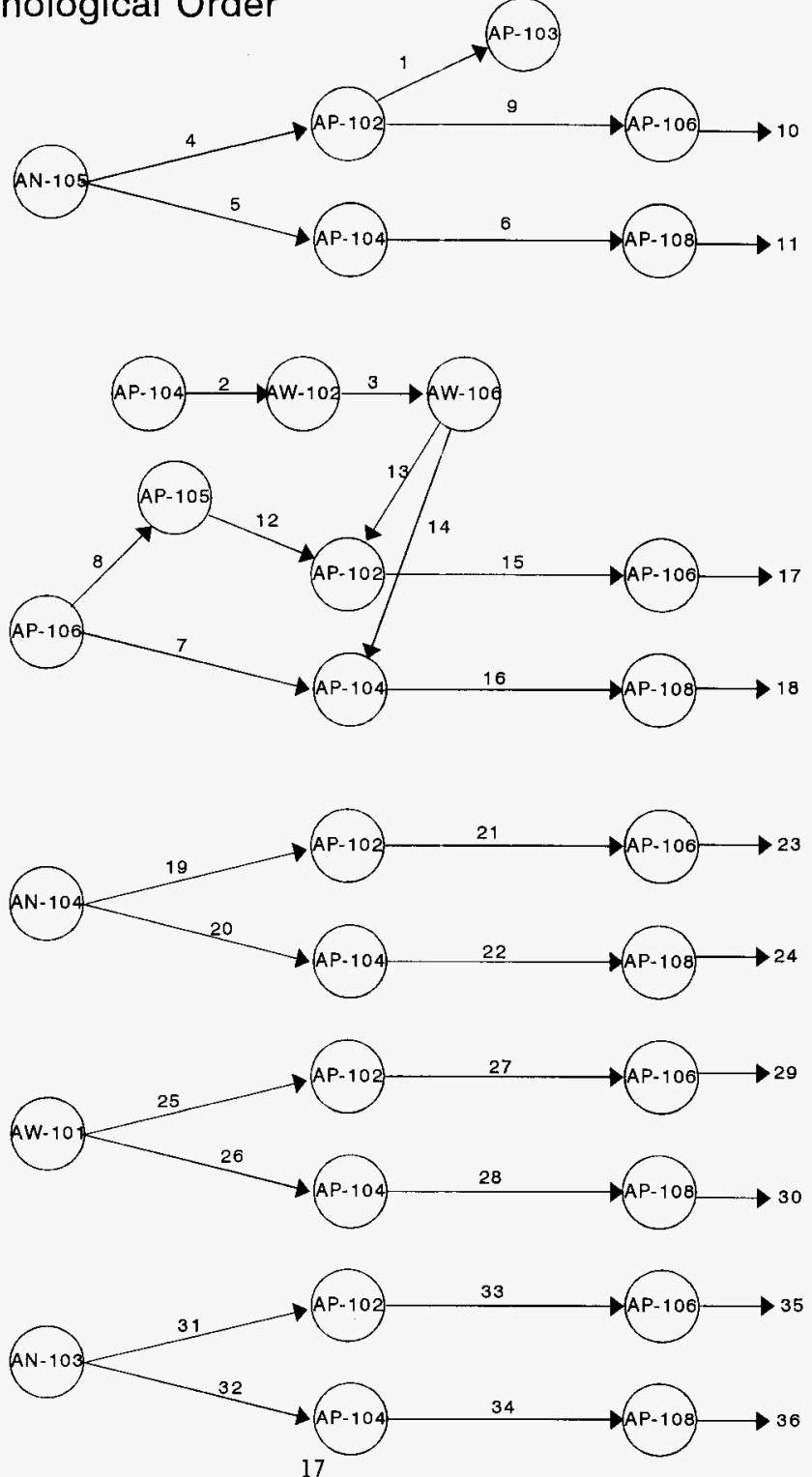
WHC-SD-WM-TI-774 Rev. 0

TWRS PRIVATIZATION PROCESS TECHNICAL BASELINE

Table 2a PC1 LAW Feed Batches (2 sheets)

\begin{tabular}{|c|c|c|c|c|c|c|c|c|c|c|c|c|}
\hline Batch & BATCH 1 & BATCH 2 & BATCH 3 & BATCH 4 & BATCH 5 & BATCH 6 & BATCH 7 & BATCH 8 & BATCH 9 & BATCH 10 & BATCH 11 & BATCH 12 \\
\hline Date & $01-J u n-02$ & $03-\mathrm{Apr}-03$ & $17-$ Feb- 04 & $16-\mathrm{sep}-04$ & 04-May- 05 & $06-M a r-06$ & 05 - Jun- 06 & 13-Aug - 06 & 25 -Dec-06 & $09-$ sep- 07 & $06-\mathrm{Jul}-08$ & 30-Арг -09 \\
\hline Chemical & MT & MT & MT & MT & MT & MT & MT & MT & MT & MT & MT & MI \\
\hline $\mathrm{Al}(\mathrm{OH}) 4-$ & $3.43 E+02$ & $2.92 \mathrm{E}+02$ & $1.94 E+02$ & $1.92 \mathrm{E}+02$ & $3.56 \mathrm{E}+02$ & $4.01 \mathrm{E}+01$ & $6.09 E+00$ & $6.95 E+00$ & $9.18 E+01$ & $1.11 E+02$ & $1.10 E+02$ & 4. $72 E+01$ \\
\hline $\mathrm{Ba}+2$ & $2.89 E-0.5$ & $3.15 E-04$ & $1.46 \mathrm{E}-05$ & $8.37 E-07$ & $3.93 E-08$ & $4.68 E-05$ & $5.03 E-06$ & $3.38 \mathrm{E}-06$ & $3.83 \mathrm{E}-07$ & $8.39 \mathrm{E}-05$ & $1.39 \mathrm{E}-03$ & $1.56 \mathrm{E}-04$ \\
\hline $\mathrm{Ca}+2$ & $7.30 \mathrm{E}-04$ & $2.93 E-02$ & $1.36 \mathrm{E}-03$ & $5.99 E-02$ & $1.51 E-01$ & 8.83E-03 & $2.65 \mathrm{E}-01$ & $6.01 \mathrm{E}-01$ & $8.41 E-01$ & $5.24 E-02$ & $5.29 E-02$ & $5.73 E-03$ \\
\hline$c d+2$ & $1.39 \varepsilon-04$ & $1.17 \mathrm{E}-04$ & $5.37 E-06$ & $3.05 E-07$ & $2.71 \mathrm{E}-02$ & $1.29 \mathrm{E}-03$ & $1.21 \mathrm{E}-04$ & $5.18 E-05$ & $5.52 E-06$ & $2.06 \mathrm{E}-04$ & $1.96 \mathrm{E}-04$ & $1.00 \mathrm{E}-05$ \\
\hline $\mathrm{Cr}(\mathrm{OH}) 4-$ & $3.26 E+00$ & $2.44 \mathrm{E}-01$ & $2.15 E+00$ & $8.35 E-01$ & $3.37 \mathrm{E}+00$ & $2.46 \mathrm{E}+00$ & $4.51 \mathrm{E}-01$ & $6.01 \mathrm{E}-01$ & $1.22 \mathrm{E}+00$ & $8.09 E-02$ & $4.23 E-02$ & 4.13E+00 \\
\hline $\mathrm{Fe}+3$ & $2.31 \mathrm{E}-02$ & $1.83 E-02$ & $1.61 \mathrm{E}-02$ & $1.22 E-03$ & $1.19 \mathrm{E}-01$ & $5.78 \mathrm{E}-03$ & 7.22E-01 & $1.64 E+00$ & $1.98 \mathrm{E}-01$ & $1.21 \mathrm{E}-02$ & 4.39E-03 & $3.64 \mathrm{E}-04$ \\
\hline $\mathrm{Hg}+2$ & 0.00 & $3.47 E-07$ & $1.62 E-08$ & $9.24 \mathrm{E}-10$ & $2.71 \mathrm{E}-02$ & $1.29 \mathrm{E}-03$ & $1.21 E-04$ & $5.18 E-05$ & $5.52 E-06$ & $7.22 \mathrm{E}-07$ & $2.72 E-07$ & $1.35 E-08$ \\
\hline $\mathrm{K}+$ & $1.27 E+01$ & $8.26 E+00$ & $1.02 \mathrm{E}+01$ & $7.63 \mathrm{E}+01$ & $3.11 \mathrm{E}+01$ & $4.23 \mathrm{E}+00$ & $1.45 E+00$ & $2.57 E+00$ & $7.12 E+00$ & $4.50 \mathrm{E}-01$ & $1.58 E+00$ & $5.12 \mathrm{E}+00$ \\
\hline$L a+3$ & 0.00 & 1.89E-03 & $8.80 \mathrm{E}-05$ & $5.03 E-06$ & $2.36 \mathrm{E}-07$ & $4.99 \mathrm{E}-04$ & $5.36 E-05$ & $3.61 \mathrm{E}-05$ & $4.08 \mathrm{E}-06$ & $1.89 \mathrm{E}-07$ & $1.39 E-02$ & $1.61 E-03$ \\
\hline $\mathrm{Na}+$ & $5.79 E+02$ & $6.27 E+02$ & $4.07 E+02$ & $4.46 \mathrm{E}+02$ & $6.00 \mathrm{E}+02$ & $1.26 \mathrm{E}+02$ & $1.20 \mathrm{E}+02$ & $2.51 \mathrm{E}+02$ & $4.95 \mathrm{E}+02$ & $5.87 E+02$ & $5.84 E+02$ & $2.04 E+02$ \\
\hline $\mathrm{Ni}+3$ & $2.52 \mathrm{E}-03$ & $2.15 \mathrm{E}-03$ & $9.87 \mathrm{E}-05$ & $5.61 E-06$ & $4.06 \mathrm{E}-02$ & $2.45 \mathrm{E}-03$ & $2.17 E-01$ & 4.91E-01 & $6.73 E-01$ & $4.18 \mathrm{E}-02$ & $1.64 \mathrm{E}-02$ & $1.73 \mathrm{E}-03$ \\
\hline $\mathrm{Pb}+4$ & $3.12 \mathrm{E}-04$ & $7.45 E-05$ & $3.28 \mathrm{E}-06$ & $5.47 \mathrm{E}-01$ & $1.61 \mathrm{E}-01$ & $7.22 \mathrm{E}-03$ & $1.59 \mathrm{E}-01$ & $3.60 \mathrm{E}-01$ & $4.36 \mathrm{E}-02$ & $3.01 E-03$ & $8.52 E-04$ & $4.20 \mathrm{E}-0.05$ \\
\hline U & $7.38 \mathrm{E}-04$ & $1.69 E-02$ & $7.88 E-04$ & $4.05 E-01$ & $2.95 \mathrm{E}-02$ & $8.86 \mathrm{E}-01$ & $2.03 \mathrm{E}-01$ & $3.09 \mathrm{E}-01$ & $3.69 \mathrm{E}-02$ & $2.06 \mathrm{E}-03$ & $6.68 \mathrm{E}-03$ & $1.59 E+00$ \\
\hline $\cos -2$ & $4.83 E+01$ & $8.26 \varepsilon+01$ & $4.26 \mathrm{E}+01$ & $2.54 E+01$ & $1.69 E+01$ & $3.76 \mathrm{E}+01$ & $4.01 E+01$ & $8.45 E+01$ & $1.27 E+02$ & $9.60 \mathrm{E}+01$ & $9.42 \mathrm{E}+01$ & $7.08 \mathrm{E}+01$ \\
\hline $\mathrm{CL}$ - & $1.81 E+01$ & $2.93 \mathrm{E}+01$ & $1.17 E+01$ & $1.02 E+01$ & $1.70 E+01$ & $9.26 E-01$ & $1.58 E+00$ & $3.42 E+00$ & $7.21 E+00$ & $4.75 E-01$ & $2.43 \mathrm{E}-01$ & $2.35 E-01$ \\
\hline F- & $7.58 \mathrm{E}-01$ & $2.64 \mathrm{E}+01$ & $1.23 E+00$ & $7.03 E-02$ & $1.25 E+00$ & $1.74 E+00$ & $1.86 \mathrm{E}-01$ & $1.24 \mathrm{E}-01$ & $3.65 \mathrm{E}+00$ & $4.66 \mathrm{E}+00$ & $4.63 \mathrm{E}+00$ & $3.25 E+00$ \\
\hline $\mathrm{SO}_{4}-2$ & $1.40 \mathrm{E}+01$ & $1.73 E+01$ & $9.78 \mathrm{E}+00$ & $2.59 \mathrm{E}+00$ & $2.88 \mathrm{E}+00$ & $2.08 \mathrm{E}+01$ & $8.82 \mathrm{E}+00$ & $1.64 E+01$ & $2.71 \mathrm{E}+01$ & $1.88 E+01$ & $1.88 \mathrm{E}+01$ & $3.81 E+01$ \\
\hline NO3 - & $4.07 E+02$ & $4.85 \mathrm{E}+02$ & $2.86 E+02$ & $4.08 \mathrm{E}+02$ & $2.99 E+02$ & $7.41 \mathrm{E}+01$ & $1.22 E+02$ & $2.63 \mathrm{E}+02$ & 4.17E+02 & $4.51 \mathrm{E}+02$ & $4.49 \mathrm{E}+02$ & $1.31 \mathrm{E}+02$ \\
\hline $\mathrm{NO}_{2-}$ & $2.50 \mathrm{E}+02$ & $2.33 E+02$ & $1.32 \mathrm{E}+02$ & $1.94 \mathrm{E}+02$ & $2.47 E+02$ & $6.71 E+01$ & $3.07 \mathrm{E}+01$ & $5.83 E+01$ & $1.53 E+02$ & $1.86 \mathrm{E}+02$ & $1.83 E+02$ & $1.09 \mathrm{E}+02$ \\
\hline $\mathrm{PO}$-3 & $5.21 \mathrm{E}+00$ & $1.27 E+01$ & $4.42 \mathrm{E}+00$ & $4.14 E+00$ & $1.86 E+00$ & $1.01 \mathrm{E}+00$ & $3.62 \mathrm{E}-01$ & $6.48 \mathrm{E}-01$ & $8.68 \mathrm{E}+00$ & 1.17E+01 & $1.15 E+01$ & $2.24 E+00$ \\
\hline $\mathrm{OH}-$ & $1.29 \mathrm{E}+02$ & $1.46 \mathrm{E}+02$ & $1.02 \mathrm{E}+02$ & $1.64 E+02$ & $1.77 \mathrm{E}+02$ & $1.74 \mathrm{E}+01$ & $1.03 E+01$ & $2.05 E+01$ & $2.12 E+01$ & $1.64 E+01$ & $1.93 E+01$ & $1.72 E+01$ \\
\hline TOC & $8.44 E+00$ & $1.82 E+01$ & $7.16 \mathrm{E}+00$ & $4.97 \mathrm{E}+00$ & $1.28 \mathrm{E}+01$ & $2.27 E+00$ & 2.09E+01 & 4.70E+01 & $5.15 \mathrm{E}+01$ & $8.36 \mathrm{E}+01$ & $8.29 E+01$ & $7.20 \mathrm{E}+00$ \\
\hline
\end{tabular}


WHC-SD-WM-TI-774 Rev. 0

TWRS PRIVATIZATION PROCESS TECHNICAL BASELINE

Table $2 a$ PC1 LAW Feed Batches (2 sheets)

\begin{tabular}{|c|c|c|c|c|c|c|c|c|c|c|c|c|}
\hline Batch & BATCH 1 & BATCH 2 & BATCH 3 & BAICH 4 & BATCH 5 & BATCH 6 & BATCH 7 & BATCH 8 & BATCH 9 & BATCH 10 & BATCH 11 & BATCH 12 \\
\hline Nuclide & $\mathrm{Ci}$ & $\mathrm{Ci}$ & $\mathrm{Ci}$ & $\mathrm{C} i$ & $\mathrm{Ci}$ & $\mathrm{Ci}$ & $\mathrm{Ci}$ & $\mathrm{Ci}$ & $\mathrm{Ci}$ & $\mathrm{Ci}$ & ci & $\mathrm{Ci}$ \\
\hline $14 \mathrm{C}$ & 4.73E-02 & $6.55 E-03$ & $2.76 E-04$ & $6.66 \mathrm{E}-01$ & $3.43 \mathrm{E}+00$ & $1.89 \mathrm{E}+00$ & 2.01E-01 & $1.31 \mathrm{E}-01$ & 3. $19 \mathrm{E}+01$ & $2.03 E+00$ & $9.16 \mathrm{E}-02$ & $3.10 \mathrm{E}+00$ \\
\hline $90 \mathrm{~s} r$ & $6.61 \mathrm{E}+03$ & $6.26 \mathrm{E}+03$ & $1.38 E+04$ & $3.02 E+03$ & $2.22 \mathrm{E}+04$ & $4.46 \mathrm{E}+03$ & $4.48 E+04$ & $1.01 E+05$ & $1.50 \mathrm{E}+05$ & $9.32 \mathrm{E}+03$ & $4.39 \mathrm{E}+04$ & $8.37 \mathrm{E}+03$ \\
\hline $90 Y$ & $6.61 E+03$ & $6.26 \mathrm{E}+03$ & $1.38 E+04$ & $3.02 E+03$ & $2.22 E+04$ & $4.46 \mathrm{E}+03$ & $4.48 E+04$ & $1.01 E+05$ & $1.50 E+05$ & $9.32 E+03$ & $4.39 \mathrm{E}+04$ & $8.37 E+03$ \\
\hline $991 \mathrm{TC}$ & 2.71E+02 & $2.48 E+01$ & $1.81 E+02$ & $2.86 \mathrm{E}+02$ & $3.08 \mathrm{E}+02$ & $3.55 \mathrm{E}+02$ & 1.87E+02 & $3.64 E+02$ & $5.84 E+02$ & $3.66 E+01$ & $7.23 E+01$ & $6.15 E+02$ \\
\hline $137 \mathrm{Cs}$ & $1.03 E+06$ & $6.12 \mathrm{E}+04$ & $1.04 E+06$ & $9.62 E+05$ & $1.34 E+06$ & 1. $77 \mathrm{E}+06$ & $3.14 E+05$ & 4. $09 \mathrm{E}+05$ & 4. $97 E+05$ & $3.12 E+04$ & $4.10 \mathrm{E}+04$ & $3.06 \mathrm{E}+06$ \\
\hline 137Ba & $9.80 \mathrm{E}+05$ & $5.82 E+04$ & $9.86 \mathrm{E}+05$ & $9.14 E+05$ & $1.27 E+06$ & $1.68 \mathrm{E}+06$ & $2.98 \mathrm{E}+05$ & $3.89 \mathrm{E}+05$ & $4.72 E+05$ & $2.96 E+04$ & $3.89 \mathrm{E}+04$ & $2.90 \mathrm{E}+06$ \\
\hline $154 \mathrm{EU}$ & 0.00 & $2.10 E-04$ & $9.77 \mathrm{E}-06$ & $5.58 \mathrm{E}-07$ & $2.62 \mathrm{E}-08$ & $2.69 \mathrm{E}+03$ & $2.89 E+02$ & $1.95 \mathrm{E}+02$ & $1.41 \mathrm{E}+03$ & $8.92 E+01$ & $3.56 \mathrm{E}+00$ & $4.83 E+03$ \\
\hline 2350 & 0.00 & 0.00 & 0.00 & 0.00 & 0.00 & 0.00 & 0.00 & 0.00 & 0.00 & 0.00 & 0.00 & 0.00 \\
\hline 2380 & $1.12 E-04$ & $2.01 E-04$ & $9.32 \mathrm{E}-06$ & $1.36 \mathrm{E}-01$ & $9.90 \mathrm{E}-03$ & $2.98 \mathrm{E}-01$ & $6.83 \mathrm{E}-02$ & $1.04 \mathrm{E}-01$ & $1.24 \mathrm{E}-02$ & $5.86 \mathrm{E}-04$ & $1.46 \mathrm{E}-03$ & $5.33 \mathrm{E}-01$ \\
\hline $237 \mathrm{~Np}$ & $1.53 E-04$ & $4.45 E-03$ & $2.07 E-04$ & $1.18 \mathrm{E}-05$ & $3.39 E-02$ & $7.44 \mathrm{E}-02$ & $7.97 \mathrm{E}-03$ & $5.32 E-03$ & $6.02 \mathrm{E}-04$ & $2.78 \mathrm{E}-05$ & $9.76 \mathrm{E}-07$ & $1.30 \mathrm{E}-01$ \\
\hline $238 \mathrm{Pu}$ & 0.00 & 0.00 & 0.00 & 0.00 & 0.00 & 0.00 & 0.00 & 0.00 & 0.00 & 0.00 & 0.00 & 0.00 \\
\hline $239 \mathrm{Pu}$ & $1.67 E+01$ & $1.19 \mathrm{E}+00$ & $1.14 E+01$ & $2.54 \mathrm{E}+00$ & $3.38 E+00$ & $1.26 \mathrm{E}+01$ & $1.44 E+01$ & $3.05 \mathrm{E}+01$ & $1.06 \mathrm{E}+02$ & $6.69 E+00$ & $2.38 E+00$ & $2.23 E+01$ \\
\hline $240 \mathrm{Pu}$ & 4.17E+00 & $2.98 \mathrm{E}-01$ & $2.86 \mathrm{E}+00$ & $6.34 \mathrm{E}-01$ & $8.45 E-01$ & $3.14 \mathrm{E}+00$ & $3.59 \mathrm{E}+00$ & $7.62 \mathrm{E}+00$ & $2.66 \mathrm{E}+01$ & $1.67 \mathrm{E}+00$ & 5.95E-01 & $5.58 E+00$ \\
\hline $241 \mathrm{Pu}$ & $2.63 \mathrm{E}+01$ & $1.88 \mathrm{E}+00$ & $1.80 \mathrm{E}+01$ & $4.00 \mathrm{E}+00$ & $5.33 \mathrm{E}+00$ & $1.98 \mathrm{E}+01$ & $2.26 \mathrm{E}+01$ & 4. $80 \mathrm{E}+01$ & $1.67 E+02$ & $1.05 E+01$ & $3.74 E+00$ & $3.52 \mathrm{E}+01$ \\
\hline $241 \mathrm{Am}$ & $3.07 E+00$ & $1.07 E+00$ & $2.12 \mathrm{E}+00$ & $2.33 \mathrm{E}+00$ & $4.06 \mathrm{E}+00$ & $1.91 \mathrm{E}+01$ & $3.03 \mathrm{E}+02$ & $6.84 E+02$ & $1.91 \mathrm{tE}+02$ & $1.08 \mathrm{E}+01$ & $7.03 E+00$ & $3.42 E+01$ \\
\hline Vol (L) & $3.62 \mathrm{E}+06$ & $4.10 E+06$ & $2.53 E+06$ & $2.77 E+06$ & $3.73 E+06$ & $1.11 E+06$ & $7.81 \mathrm{E}+05$ & $1.58 \mathrm{E}+06$ & $3.07 E+06$ & $3.65 E+06$ & $3.63 E+06$ & $1.86 \mathrm{E}+06$ \\
\hline $\mathrm{Na}(M)$ & $6.95 \mathrm{E}+00$ & $6.65 \mathrm{E}+00$ & $6.99 E+00$ & $6.99 \mathrm{E}+00$ & $6.99 \mathrm{E}+00$ & $4.92 E+00$ & $6.69 \mathrm{E}+00$ & $6.91 \mathrm{E}+00$ & $7.01 \mathrm{E}+00$ & $6.99 \mathrm{E}+00$ & $6.99 \mathrm{E}+00$ & $4.77 \mathrm{E}+00$ \\
\hline Spg & $1.33 E+00$ & $1.31 E+00$ & $1.31 \mathrm{E}+00$ & $1.37 \mathrm{E}+00$ & $1.32 E+00$ & $1.23 \mathrm{E}+00$ & $1.26 \mathrm{E}+00$ & $1.27 E+00$ & $1.28 \mathrm{E}+00$ & $1.27 \mathrm{E}+00$ & $1.27 E+00$ & $1.22 E+00$ \\
\hline
\end{tabular}


WHC-SD-WM-TI-774 Rev. 0

TWRS PRIVATIZATION PROCESS TECHNICAL BASELINE

Table 2b PC2 LAW Feed Batches ( 2 sheets)

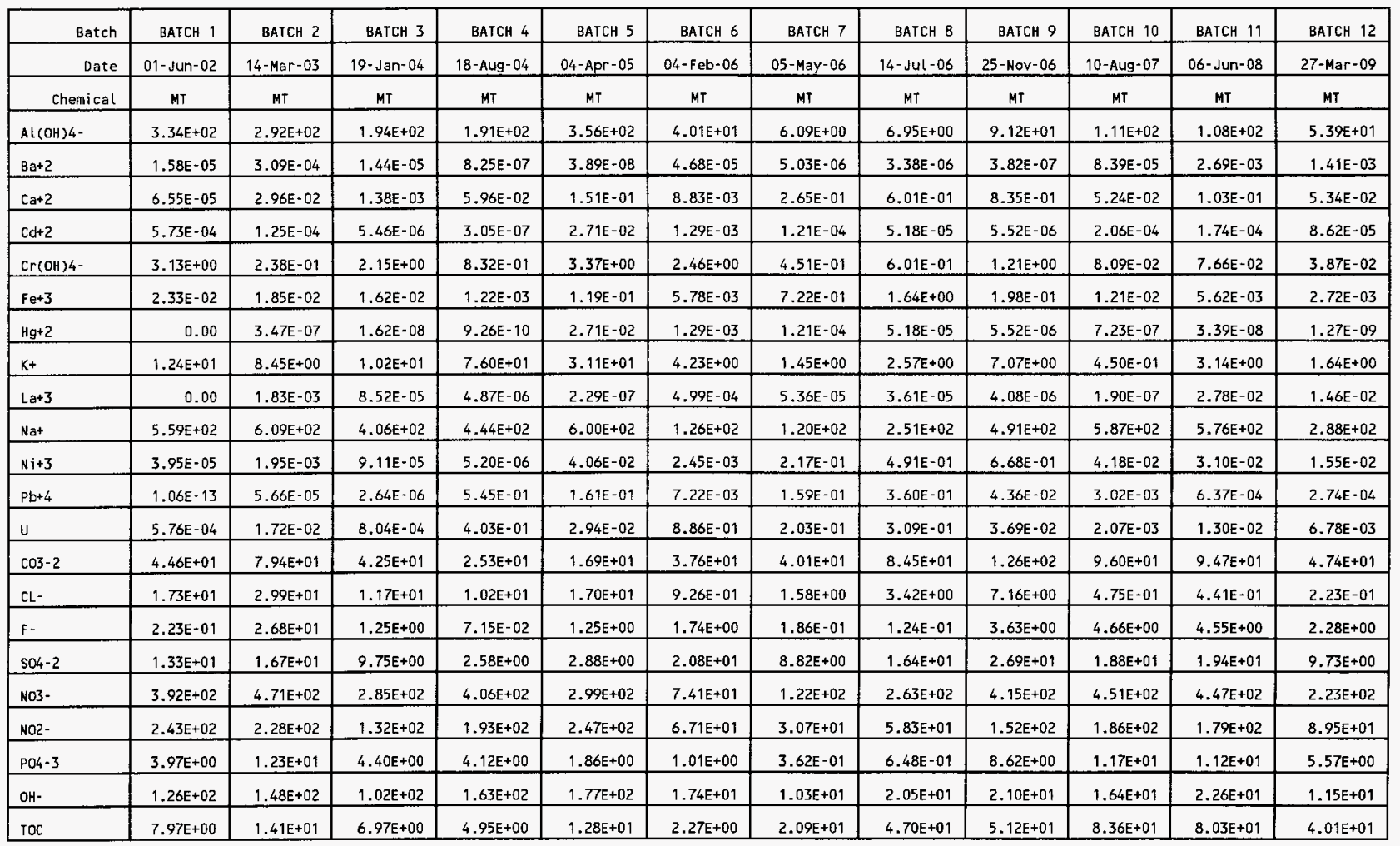


WHC-SD-WM-TI-774 Rev. 0

TWRS PRIVATIZATION PROCESS TECHNICAL BASELINE

Table 2b PC2 LAW Feed Batches (2 sheets)

\begin{tabular}{|c|c|c|c|c|c|c|c|c|c|c|c|c|}
\hline Batch & BATCH 1 & BATCH 2 & BATCH 3 & BATCH 4 & BATCH 5 & BATCH 6 & BATCH 7 & BATCH 8 & BATCH 9 & BATCH 10 & BATCH 11 & BATCH 12 \\
\hline Nuclide & $\mathrm{Ci}$ & $\mathrm{Ci}$ & $\mathrm{Ci}$ & $\mathrm{Ci}$ & $\mathrm{Ci}$ & $\mathrm{Ci}$ & $\mathrm{Ci}$ & $\mathrm{Ci}$ & $\mathrm{Ci}$ & $\mathrm{Ci}$ & $\mathrm{Ci}$ & $\mathrm{Ci}$ \\
\hline $14 \mathrm{C}$ & $7.51 \mathrm{E}-10$ & $3.96 \mathrm{E}-03$ & $1.85 \mathrm{E}-04$ & $6.63 \mathrm{E}-01$ & $3.43 \mathrm{E}+00$ & $1.89 \mathrm{E}+00$ & 2.01E-01 & $1.31 \mathrm{E}-01$ & $3.17 \mathrm{E}+01$ & $2.03 E+00$ & $1.01 \mathrm{E}-01$ & $1.34 \mathrm{E}-02$ \\
\hline $90 \mathrm{Sr}$ & $6.48 \mathrm{E}+03$ & $6.05 \mathrm{E}+03$ & $1.38 \mathrm{E}+04$ & $3.01 E+03$ & $2.22 \mathrm{E}+04$ & $4.46 \mathrm{E}+03$ & $4.48 \mathrm{E}+04$ & $1.01 \mathrm{E}+05$ & $1.49 \mathrm{E}+05$ & $9.32 \mathrm{E}+03$ & $8.74 E+04$ & $4.58 E+04$ \\
\hline $90 Y$ & $6.48 \mathrm{E}+03$ & $6.05 E+03$ & $1.38 E+04$ & $3.01 \mathrm{E}+03$ & $2.22 \mathrm{E}+04$ & $4.46 E+03$ & $4.48 \mathrm{E}+04$ & $1.01 E+05$ & $1.49 E+05$ & $9.32 \mathrm{E}+03$ & $8.74 \mathrm{E}+04$ & $4.58 \mathrm{E}+04$ \\
\hline $99 \mathrm{Tc}$ & $2.63 \mathrm{E}+02$ & $2.40 \mathrm{E}+01$ & $1.80 E+02$ & $2.85 E+02$ & $3.08 E+02$ & $3.55 E+02$ & $1.87 \mathrm{E}+02$ & $3.64 \mathrm{E}+02$ & $5.80 \mathrm{E}+02$ & $3.66 \mathrm{E}+01$ & $1.43 E+02$ & $7.45 E+01$ \\
\hline $137 \mathrm{cs}$ & $1.01 E+06$ & $5.99 E+04$ & $1.04 E+06$ & $9.59 \mathrm{E}+05$ & $1.34 E+06$ & $1.77 \mathrm{E}+06$ & $3.14 \mathrm{E}+05$ & 4.09E +05 & $4.94 E+05$ & $3.12 E+04$ & $8.03 E+04$ & $4.16 E+04$ \\
\hline 137Ba & $9.60 E+05$ & $5.69 E+04$ & $9.86 \mathrm{E}+05$ & $9.11 E+05$ & $1.27 E+06$ & $1.68 \mathrm{E}+06$ & $2.98 \mathrm{E}+05$ & $3.89 E+05$ & $4.69 \mathrm{E}+05$ & $2.96 \mathrm{E}+0.4$ & $7.63 E+04$ & $3.96 \mathrm{E}+04$ \\
\hline 154EU & 0.00 & $2.10 E-04$ & $9.79 E-06$ & $5.60 \mathrm{E}-07$ & $2.64 \mathrm{E}-08$ & $2.69 E+03$ & $2.89 \mathrm{E}+02$ & $1.95 \mathrm{E}+02$ & $1.40 E+03$ & $8.91 \mathrm{E}+01$ & $3.56 E+00$ & $1.25 \mathrm{E}-01$ \\
\hline $235 \mathrm{U}$ & 0.00 & 0.00 & 0.00 & 0.00 & 0.00 & 0.00 & 0.00 & 0.00 & 0.00 & 0.00 & 0.00 & 0.00 \\
\hline 2384 & $4.18 \mathrm{E}-06$ & $1.89 E-04$ & $8.82 \mathrm{E}-06$ & $1.35 \mathrm{E}-01$ & $9.89 \mathrm{E}-03$ & $2.98 \mathrm{E}-01$ & $6.83 E-02$ & $1.04 \mathrm{E}-01$ & $1.24 \mathrm{E}-02$ & $5.89 E-04$ & $2.90 \mathrm{E}-03$ & $1.52 \mathrm{E}-03$ \\
\hline $237 \mathrm{~Np}$ & $5.31 E-08$ & $4.58 \mathrm{E}-03$ & $2.14 E-04$ & $1.22 \mathrm{E}-05$ & $3.39 \mathrm{E}-02$ & $7.44 \mathrm{E}-02$ & $7.97 \mathrm{E}-03$ & $5.32 E-03$ & $6.01 \mathrm{E}-04$ & $2.80 E-05$ & $9.82 \mathrm{E}-07$ & $3.20 E-08$ \\
\hline $238 \mathrm{Pu}$ & 0.00 & 0.00 & 0.00 & 0.00 & 0.00 & 0.00 & 0.00 & 0.00 & 0.00 & 0.00 & 0.00 & 0.00 \\
\hline $239 \mathrm{Pu}$ & $1.67 E+01$ & $1.18 E+00$ & $1.14 \mathrm{E}+01$ & $2.53 E+00$ & $3.38 \mathrm{E}+00$ & $1.26 \mathrm{E}+01$ & $1.44 E+01$ & $3.05 E+01$ & $1.06 \mathrm{E}+02$ & $6.69 E+00$ & $4.49 \mathrm{E}+00$ & $2.23 E+00$ \\
\hline $240 \mathrm{Pu}$ & $4.17 \mathrm{E}+00$ & $2.96 E-01$ & $2.86 \mathrm{E}+00$ & $6.33 \mathrm{E}-01$ & $8.45 E-01$ & $3.14 \mathrm{E}+00$ & $3.59 \mathrm{E}+00$ & $7.62 E+00$ & $2.64 E+01$ & $1.67 \mathrm{E}+00$ & $1.12 E+00$ & $5.57 \mathrm{E}-01$ \\
\hline $241 \mathrm{Pu}$ & $2.63 \mathrm{E}+01$ & $1.86 E+00$ & $1.80 \mathrm{E}+01$ & $3.99 \mathrm{E}+00$ & $5.33 E+00$ & $1.98 \mathrm{E}+01$ & $2.26 E+01$ & $4.80 E+01$ & $1.66 \mathrm{E}+02$ & $1.05 E+01$ & $7.06 E+00$ & $3.51 E+00$ \\
\hline $241 \mathrm{Am}$ & $3.03 E+00$ & $1.04 E+00$ & $2.12 \mathrm{E}+00$ & $2.32 \mathrm{E}+00$ & $4.06 \mathrm{E}+00$ & $1.91 \mathrm{E}+01$ & $3.03 E+02$ & $6.84 E+02$ & $1.90 \mathrm{E}+02$ & $1.08 E+01$ & $1.36 \mathrm{E}+01$ & $6.97 \mathrm{E}+00$ \\
\hline Vol (L) & $3.62 E+06$ & $4.09 E+06$ & $2.53 E+06$ & $2.76 \mathrm{E}+06$ & $3.73 E+06$ & 1. $11 \mathrm{E}+06$ & $7.81 \mathrm{E}+05$ & $1.58 \varepsilon+06$ & $3.05 E+06$ & $3.65 E+06$ & $3.58 E+06$ & $1.79 E+06$ \\
\hline $\mathrm{Na}(M)$ & $6.71 E+00$ & $6.47 \mathrm{E}+00$ & $6.98 E+00$ & $6.99 \mathrm{E}+00$ & $6.99 \mathrm{E}+00$ & $4.92 \mathrm{E}+00$ & $6.69 E+00$ & $6.91 E+00$ & $7.01 \mathrm{E}+00$ & $6.99 E+00$ & $7.00 \mathrm{E}+00$ & $7.00 \mathrm{E}+00$ \\
\hline Spg & $1.32 \mathrm{E}+00$ & $1.31 E+00$ & $1.31 E+00$ & $1.37 \mathrm{~F}+00$ & $1.32 E+00$ & $1.23 \mathrm{E}+00$ & $1.26 E+00$ & $1.27 E+00$ & $1.28 \mathrm{E}+00$ & $1.27 E+00$ & $1.27 E+00$ & $1.27 E+00$ \\
\hline
\end{tabular}




\section{WHC-SD-WM-TI-774 Rev. 0 \\ TWRS PRIVATIZATION PROCESS TECHNICAL BASELINE}

\subsubsection{Chemistry of Phase 1 Envelope A}

The following sections discuss the chemical and phase equilibrium of Envelope A feeds during dilution, as modeled with the Environmental Simulation Program (ESP). There are known deficiencies with the ESP software, so it is not fully validated, but for the most part ESP predictions are qualitatively (if not quantitatively) consistent with experimental observation. The known deficiencies are discussed below, where appropriate. ${ }^{4}$

Envelope A tanks typically contain non-complexed waste with sodium ranging from 10 to $15 \mathrm{~mol} / \mathrm{L}$. Concentrated solutions containing aluminum can exhibit unexpected precipitation when diluted. The solubility of aluminum is a complex function of hydroxide, as well as total ionic strength. The main purpose of this modeling was to identify tanks that have the potential to be problematical. The tanks are discussed below in the order of staging.

\subsubsection{AN-105 Staging}

The following simulation results suggest that further modeling studies and experimental work with actual AN-105 supernate are warranted to verify suitable conditions for its recovery and staging.

The chemical and phase equilibrium of $\mathrm{AN}-105$ supernate at $40{ }^{\circ} \mathrm{C}$ was modeled with the ESP. Table 3 and Figure 3 depict the phase equilibrium for a unit mass of AN-105 supernate as it is diluted with water. The presence of $\mathrm{NaNO}_{3}$ precipitate indicates that this supernate is saturated at this temperature, so pipeline transfer without heating or dilution is not advisable. Dilution with water down to approximately $9.5 \mathrm{M} \mathrm{Na}$ dissolves the salts. Dilution beyond $8.5 \mathrm{M}$ Na favors the precipitation of gibbsite $\left(\mathrm{Al}(\mathrm{OH})_{3}\right)$. Continuing the dilution down to $7 \mathrm{M} \mathrm{Na}$, the concentration assumed for the staging plan (Certa 1996), generates approximately $0.14 \mathrm{~kg}$ gibbsite per $\mathrm{kg}$ diluted supernate $(0.2 \mathrm{~kg}$ gibbsite per $\mathrm{kg}$ of supernate). Such extensive precipitation would exceed the allawable 5 vol\% settled solids in feeds transferred to the private contractors.

${ }^{4}$ ESP is a trademark of OLI Systems, Inc. ESP results provide insight. into the chemistry of high ionic strength mixtures, but experimental verification is advisable. For a discussion of how the ESP electrolyte simulation was used to support this work, refer to Appendix C. 
WHC-SD-WM-TI-774 ReV. 0

TWRS PRIVATIZATION PROCESS TECHNICAL BASELINE

Table 3 AN-105 Dilution @ 40 C

\begin{tabular}{|c|c|c|c|c|c|c|c|}
\hline $\begin{array}{l}\text { Mass } \\
\text { kgs }\end{array}$ & $\begin{array}{l}\text { OHION } \\
\text { moles/L }\end{array}$ & $\begin{array}{l}\text { ALOH4ION } \\
\text { moles/L }\end{array}$ & $\begin{array}{l}\text { NAION } \\
\text { moles/L }\end{array}$ & $\begin{array}{l}\text { NO2ION } \\
\text { moles/L }\end{array}$ & $\begin{array}{l}\text { NO3ION } \\
\text { moles/L }\end{array}$ & $\begin{array}{l}\text { ALOH3PPT } \\
\text { moles/L }\end{array}$ & $\begin{array}{l}\text { NANO3PPT } \\
\text { moles/L }\end{array}$ \\
\hline 1.000 & 3.180 & 1.635 & 10.823 & 2.450 & 2.600 & 0.000 & 0.309 \\
\hline 1.099 & 2.761 & 1.420 & 9.668 & 2.128 & 2.519 & 0.000 & 0.000 \\
\hline 1.198 & 2.460 & 1.265 & 8.605 & 1.896 & 2.241 & 0.000 & 0.000 \\
\hline 1.297 & 2.310 & 1.062 & 7.788 & 1.716 & 2.028 & 0.082 & 0.000 \\
\hline 1.395 & 2.218 & 0.866 & 7.117 & 1.568 & 1.853 & 0.180 & 0.000 \\
\hline 1.494 & 2.112 & 0.723 & 6.542 & 1.442 & 1.703 & 0.239 & 0.000 \\
\hline 1.593 & 2.006 & 0.616 & 6.050 & 1.333 & 1.575 & 0.273 & 0.000 \\
\hline 1.692 & 1.903 & 0.534 & 5.620 & 1.239 & 1.464 & 0.292 & 0.000 \\
\hline 1.791 & 1.806 & 0.469 & 5.246 & 1.156 & 1.366 & 0.302 & 0.000 \\
\hline 1.890 & 1.715 & 0.417 & 4.917 & 1.084 & 1.281 & 0.306 & 0.000 \\
\hline
\end{tabular}

Figure 3 AN-105 Dilution @ 40 C

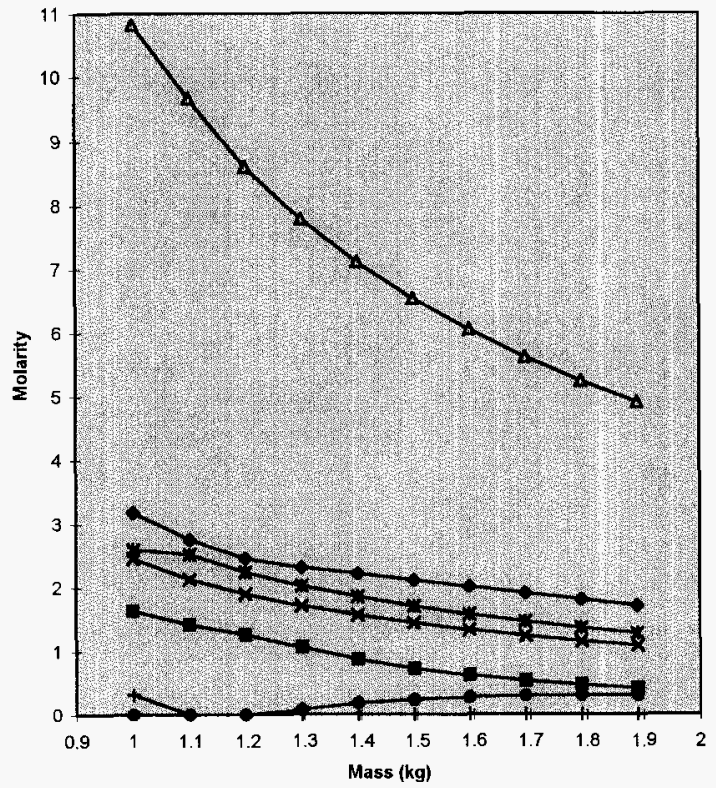

$\rightarrow$ OHION moles/L

$\rightarrow$ ALOH4ION moles/L

$\triangle$ NAION moles $/ L$

$\rightarrow$ NO2ION moles/L

$\rightarrow$ NOBION moles/L

- ALOH3PPT moles/L

$\longrightarrow$ NANO3PPT moles/L 


\section{WHC-SD-WM-TI-774 ReV. 0 \\ TWRS PRIVATIZATION PROCESS TECHNICAL BASELINE}

For the time, being the flowsheet acknowledges precjpitation as a potential problem, but does not propose control measures. ${ }^{5}$ Subsequent dilution by private contractors could precipitate more gibbsite.

The retrieval of AN-105 supernate requires mixer pumps and in-line dilution to generate a stream that is suitable for pipeline transfer.

\subsubsection{AP-104 Staging}

AP-104 contains a dilute supernate that is evaporated during staging. The concentrate, residing in $A W-106$, tops off the next two batches of feed that originate from AP-106 (See Section 2.1.1.3, "AP-106 Staging").

\subsubsection{AP-106 Staging}

Figure 2 depicts the chronological order of a series of transfers whose net effect is to set up the LAW receiving tanks with their second batch of private contractor feed. AP-106 is diluted and split between the two operating contractor staging tanks. Half of AP-106 is retrieved directly into a staging tank (AP-104). The other half reaches AP-102 via AP-105.

Not being quite as concentrated as AN-105, AP-106 is mobilized with a recirculation loop and equipped with in-line dilution to generate a stream that is suitable for pipeline transfer.

The phase equilibrium and chemistry of AP-106 supernate during dilution at $40{ }^{\circ} \mathrm{C}$ was modeled with the ESP. Table 4 and Figure 4 depict the phase equilibrium for a unit mass of AP-106 supernate. The high fluoride content is i Tlustrated by the presence of $\mathrm{NaF}$ precipitate. Cooling this supernate to 25 ${ }^{\circ} \mathrm{C}$ also precipitates gibbsite, so pipeline transfer without heating or dilution is not advisable. Dilution down to $~ 2 M M N a$ generates gibbsite, with a large amount of gibbsite appearing for dilutions to $7 \mathrm{M} \mathrm{Na}$, the concentration assumed for the staging plan (Certa 1996). The private contractors should be aware that further dilution could cause precipitation. (Note: The ESP calculated initial concentration of hydroxide is somewhat lower than expected, although the other species appear to be correct. This may contribute to the early onset of gibbsite formation in this model run, since higher hydroxide helps to keep the aluminum in solution).

${ }^{5}$ Measures to deal with precipitation will be addressed in future revisions of the staging $\mathrm{plan}$ and the PPTB. Prevention by chemical adjustment is one option for dealing with precipitates. If the precipitation is minor, physical separation in the staging tanks could be a preferable alternative. Either approach will change the composition of the private contractor feed, which must remain within the contractual feed composition window. 
WHC-SD-WM-TI-774 Rev. 0

TWRS PRIVATIZATION PROCESS TECHNICAL BASELINE

Table 4 AP-106 Dilution @ 40 C

\begin{tabular}{|c|c|c|c|c|c|c|c|}
\hline $\begin{array}{l}\text { Mass } \\
\text { kgs }\end{array}$ & $\begin{array}{l}\text { OHION } \\
\text { moles/L }\end{array}$ & $\begin{array}{l}\text { ALOH4ION } \\
\text { moles/L }\end{array}$ & $\begin{array}{l}\text { NAION } \\
\text { moles/L }\end{array}$ & $\begin{array}{l}\text { NO21ON } \\
\text { moles/L }\end{array}$ & $\begin{array}{l}\text { NO3ION } \\
\text { moles/L }\end{array}$ & $\begin{array}{l}\text { ALOH3PPT } \\
\text { moles/L }\end{array}$ & $\begin{array}{l}\text { NAFPPT } \\
\text { moles/L }\end{array}$ \\
\hline 1.000 & 1.876 & 1.191 & 9.570 & 1.917 & 2.962 & 0.000 & 0.569 \\
\hline 1.107 & 1.761 & 0.928 & 8.398 & 1.681 & 2.593 & 0.117 & 0.478 \\
\hline 1.213 & 1.685 & 0.706 & 7.489 & 1.495 & 2.306 & 0.223 & 0.402 \\
\hline 1.320 & 1.588 & 0.561 & 6.749 & 1.343 & 2.071 & 0.273 & 0.335 \\
\hline 1.427 & 1.487 & 0.461 & 6.143 & 1.218 & 1.878 & 0.296 & 0.276 \\
\hline 1.533 & 1.391 & 0.388 & 5.637 & 1.112 & 1.715 & 0.303 & 0.223 \\
\hline 1.640 & 1.304 & 0.333 & 5.213 & 1.023 & 1.578 & 0.302 & 0.176 \\
\hline 1.746 & 1.224 & 0.291 & 4.853 & 0.947 & 1.461 & 0.297 & 0.133 \\
\hline 1.853 & 1.152 & 0.258 & 4.544 & 0.881 & 1.359 & 0.290 & 0.093 \\
\hline 1.960 & 1.087 & 0.231 & 4.277 & 0.824 & 1.271 & 0.281 & 0.056 \\
\hline
\end{tabular}

Figure 4 AP-106 Dilution @ 40 C
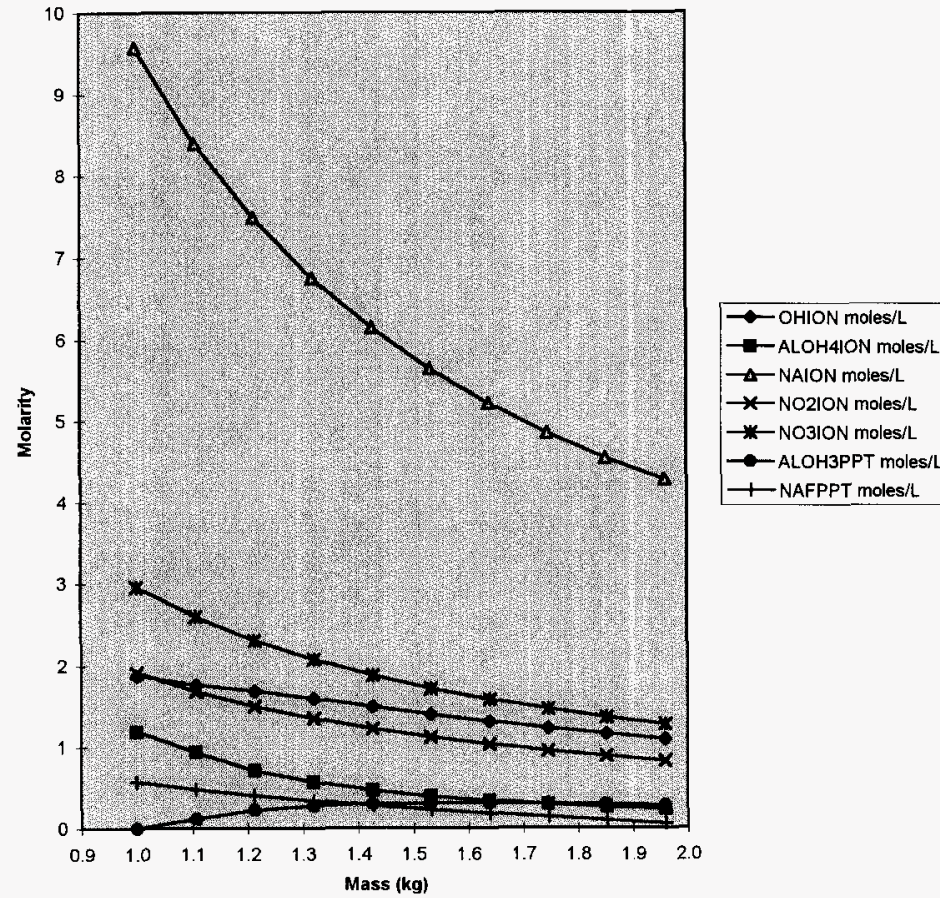


\subsubsection{AN-104 Staging}

The phase equilibrium and chemistry of AN-104 supernate during dilution at $40{ }^{\circ} \mathrm{C}$ was modeled with the ESP. Table 5 and Figure 5 depict the phase equilibrium for a unit mass of AN-104 supernate. The presence of $\mathrm{NaNO}_{3}$ precipitate indicates that this supernate is saturated at this temperature, so pipeline transfer without heating or dilution is not advisable. Dilution down to $6 M \mathrm{Na}$ generates gibbsite, but no gibbsite appears for dilutions to $7 \mathrm{M} \mathrm{Na}$, the concentration assumed for the staging $\mathrm{pl}$ an (Certa 1996). Subsequent di7ution by private contractors could cause precipitation.

\subsubsection{AW-101 Staging}

The phase equilibrium and chemistry of AW-101 supernate during dilution at $40{ }^{\circ} \mathrm{C}$ was modeled with ESP. Table 6 and Figure 6 depict the phase equilibrium for a unit mass of AW-101 supernate. The presence of $\mathrm{KNO}_{3}$ precipitate indicates that this supernate is saturated at this temperature, so pipeline transfer without heating or dilution is not advisable. Dilution beyond $5 \mathrm{M} \mathrm{Na}$ begins to generate gibbsite, but no gibbsite appears for dilutions to $7 \mathrm{M} \mathrm{Na}$, the concentration assumed for the staging plan (Certa 1996). Subsequent dilution by private contractors could cause precipitation.

\subsubsection{AN-103 Staging}

The phase equilibrium and chemistry of AN-103 supernate during dilution at $40{ }^{\circ} \mathrm{C}$ was modeled with ESP. Table 7 and Figure 7 depict the phase equilibrium for a unit mass of AN-103 supernate. The presence of 1 arge amounts of precipitated salt is consistent with this tank's designation as a Double-Shelf Slurry (DSS) tank. Pipeline transfer without heating or dilution is not advisable. Dilution down to $7 \mathrm{M} \mathrm{Na}$, the concentration assumed for the staging plan (Certa 1996), appears to be possible without gibbsite formation, but gibbsite precipitates at a slightly lower sodium concentration.

Subsequent dilution by private contractors could cause precipitation.

DSS was concentrated beyond the phase boundary where $\mathrm{NaAlO}_{2}$ should have formed. A known deficiency of the current version of ESP is that it does not predict the existence of $\mathrm{NaAlO}_{2}$ precipitate when that compound should obviously be present. The ESP data banks are being corrected to fix this deficiency, but the fix will not be available in time to include in this release. The equilibrium at the dilute end of Figure 7 , however, should be valid. 
WHC-SD-WM-TI-774 Rev. 0

TWRS PRIVATIZATION PROCESS TECHNICAL BASELINE

Table 5 AN-104 Dilution @ 40C

\begin{tabular}{|c|c|c|c|c|c|c|c|}
\hline $\begin{array}{l}\text { Mass } \\
\text { kgs }\end{array}$ & $\begin{array}{l}\text { OHION } \\
\text { moles/L }\end{array}$ & $\begin{array}{l}\text { ALOH4ION } \\
\text { moles/L }\end{array}$ & $\begin{array}{l}\text { NAION } \\
\text { moles/L }\end{array}$ & $\begin{array}{l}\mathrm{NO} 2 \mathrm{ION} \\
\text { moles/L }\end{array}$ & $\begin{array}{l}\text { NO3ION } \\
\text { moles/L }\end{array}$ & $\begin{array}{l}\text { ALOH3PPT } \\
\text { moles/L }\end{array}$ & $\begin{array}{l}\text { NANO3PPT } \\
\text { moles/L }\end{array}$ \\
\hline 1.000 & 4.015 & 1.320 & 10.590 & 1.822 & 2.547 & 0.000 & 0.375 \\
\hline 1.107 & 3.420 & 1.124 & 9.552 & 1.552 & 2.483 & 0.000 & 0.000 \\
\hline 1.213 & 3.024 & 0.994 & 8.443 & 1.373 & 2.194 & 0.000 & 0.000 \\
\hline 1.320 & 2.711 & 0.891 & 7.564 & 1.230 & 1.964 & 0.000 & 0.000 \\
\hline 1.427 & 2.454 & 0.806 & 6.844 & 1.113 & 1.777 & 0.000 & 0.000 \\
\hline 1.534 & 2.257 & 0.722 & 6.255 & 1.017 & 1.624 & 0.014 & 0.000 \\
\hline 1.640 & 2.133 & 0.615 & 5.768 & 0.938 & 1.497 & 0.064 & 0.000 \\
\hline 1.747 & 2.016 & 0.533 & 5.348 & 0.870 & 1.389 & 0.097 & 0.000 \\
\hline 1.854 & 1.907 & 0.468 & 4.983 & 0.810 & 1.294 & 0.119 & 0.000 \\
\hline 1.960 & 1.806 & 0.416 & 4.663 & 0.758 & 1.211 & 0.133 & 0.000 \\
\hline
\end{tabular}

Figure 5 AN-104 Dilution @ $40 \mathrm{C}$

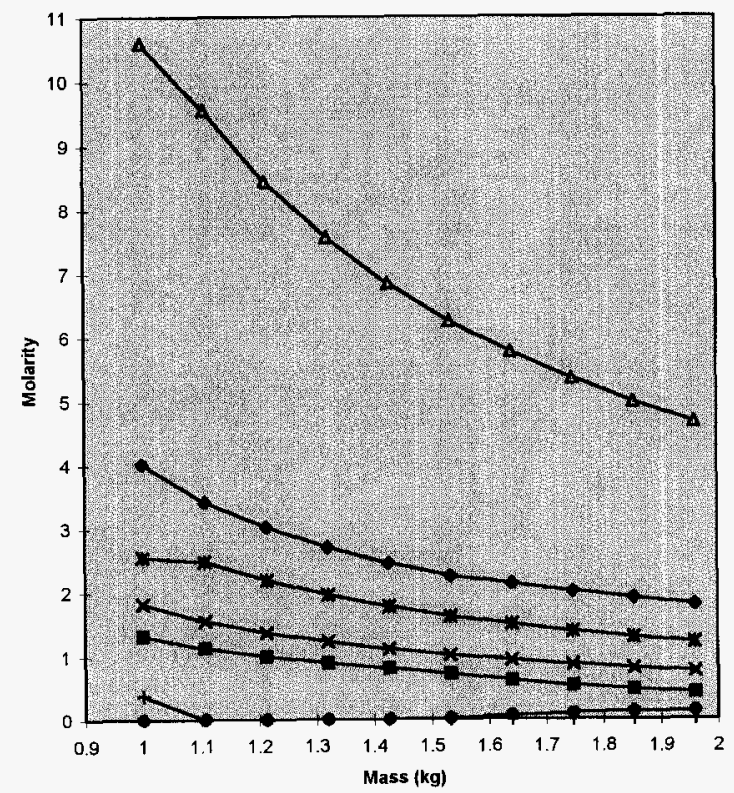


WHC-SD-WM-TI-774 Rev. 0

TWRS PRIVATIZATION PROCESS TECHNICAL BASELINE

Table 6 AW-101 Dilution @ $40 \mathrm{C}$

\begin{tabular}{|c|c|c|c|c|c|c|c|}
\hline $\begin{array}{l}\text { Mass } \\
\text { kgs }\end{array}$ & $\begin{array}{l}\text { OHION } \\
\text { moles } / \mathrm{L}\end{array}$ & $\begin{array}{l}\text { ALOH4ION } \\
\text { moles/L }\end{array}$ & $\begin{array}{l}\text { NAION } \\
\text { moles/L }\end{array}$ & $\begin{array}{l}\text { NO2ION } \\
\text { moles/L }\end{array}$ & $\begin{array}{l}\text { NO3ION } \\
\text { moles/L }\end{array}$ & $\begin{array}{l}\text { ALOH3PPT } \\
\text { moles/L }\end{array}$ & $\begin{array}{l}\text { KNO3PPT } \\
\text { moles/L }\end{array}$ \\
\hline 1.000 & 3.392 & 0.964 & 9.227 & 2.067 & 3.139 & 0.000 & 0.051 \\
\hline 1.112 & 2.932 & 0.833 & 7.969 & 1.786 & 2.754 & 0.000 & 0.000 \\
\hline 1.225 & 2.584 & 0.734 & 7.023 & 1.574 & 2.426 & 0.000 & 0.000 \\
\hline 1.337 & 2.308 & 0.656 & 6.273 & 1.406 & 2.166 & 0.000 & 0.000 \\
\hline 1.450 & 2.085 & 0.592 & 5.666 & 1,270 & 1.956 & 0.000 & 0.000 \\
\hline 1.562 & 1.899 & 0.540 & 5.162 & 1.157 & 1.783 & 0.000 & 0.000 \\
\hline 1.674 & 1.777 & 0.467 & 4.749 & 1.064 & 1.640 & 0.029 & 0.000 \\
\hline 1.787 & 1.672 & 0.406 & 4.399 & 0.985 & 1.519 & 0.054 & 0.000 \\
\hline 1.899 & 1.576 & 0.357 & 4.094 & 0.917 & 1.414 & 0.071 & 0.000 \\
\hline 2.012 & 1.489 & 0.318 & 3.827 & 0.857 & 1.322 & 0.082 & 0.000 \\
\hline
\end{tabular}

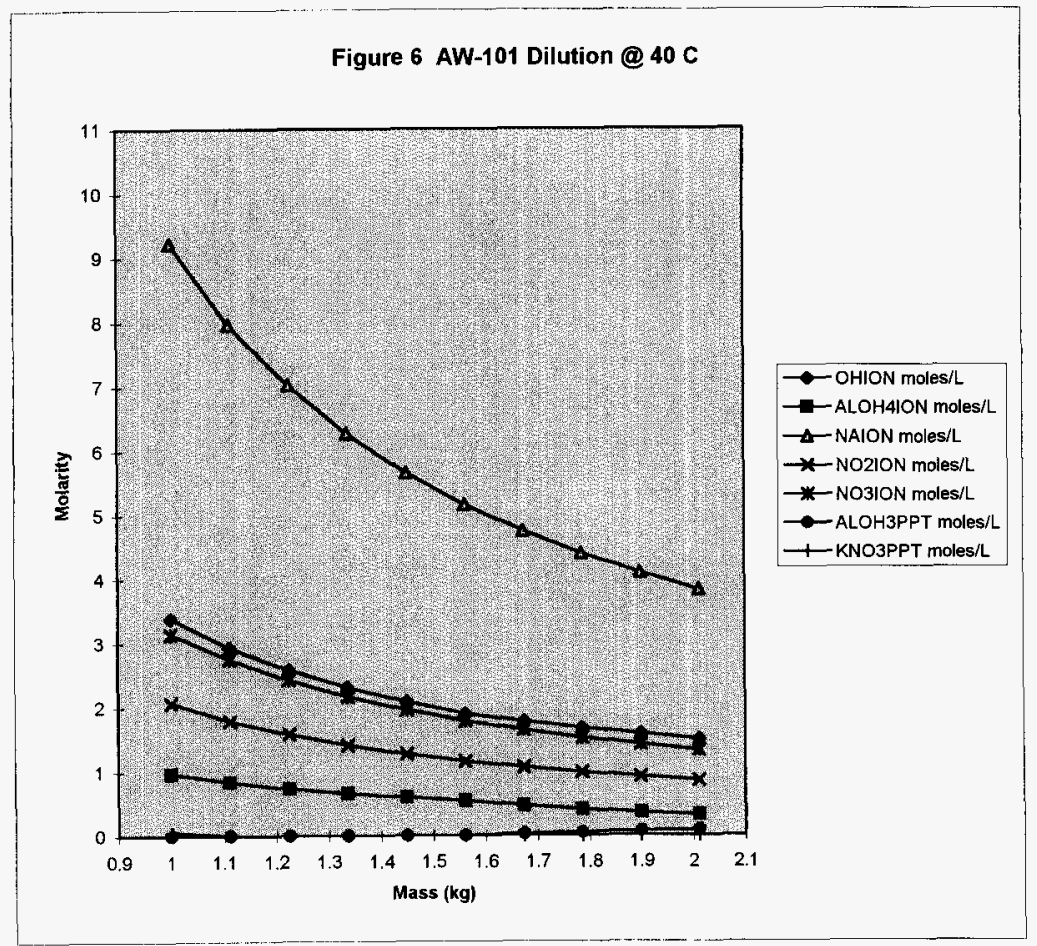


WHC-SD-WM-TI-774 Rev. 0

TWRS PRIVATIZATION PROCESS TECHNICAL BASELINE

Table 7 AN-103 Dilution @ $40 \mathrm{C}$

MasS OHION ALOH4ION NAION NO2ION NO3ION ALOH3PPT NANO2PPT NANO3PPT

$\mathrm{kg}$

1.000 moles/L moles/L

1.086

6.445

5.345

2.162

1.173

4.699

1.793

moles/L

moles/L moles/L moles/L

moles/L moles/L

12.143

1.995

1.201

11.596

2.520

1.570

0.000

10.703

2.215

1.890

0.000

1.043

1.405

1.259

4.268

1.432

9.721

2.012

1.714

0.000

0.000

0.587

3.905

1.310

8.895

1.841

1.567

0.000

0.000

0.000

1.432

1.207

8.193

1.696

1.443

0.000

0.000

0.000

1.119

7.594

1.572

1.337

0.000

0.000

0.000

7.073

1.465

1.245

0.000

0.000

0.000

1.605

3.107

0.975

6.619

1.371

1.165

0.000

0.000

0.000

1.778

2.758

0.896

6.229

1.290

1.096

0.000

0.000

0.000

0.000

0.000

Figure 7 AN-103 Dilution @ 40 C
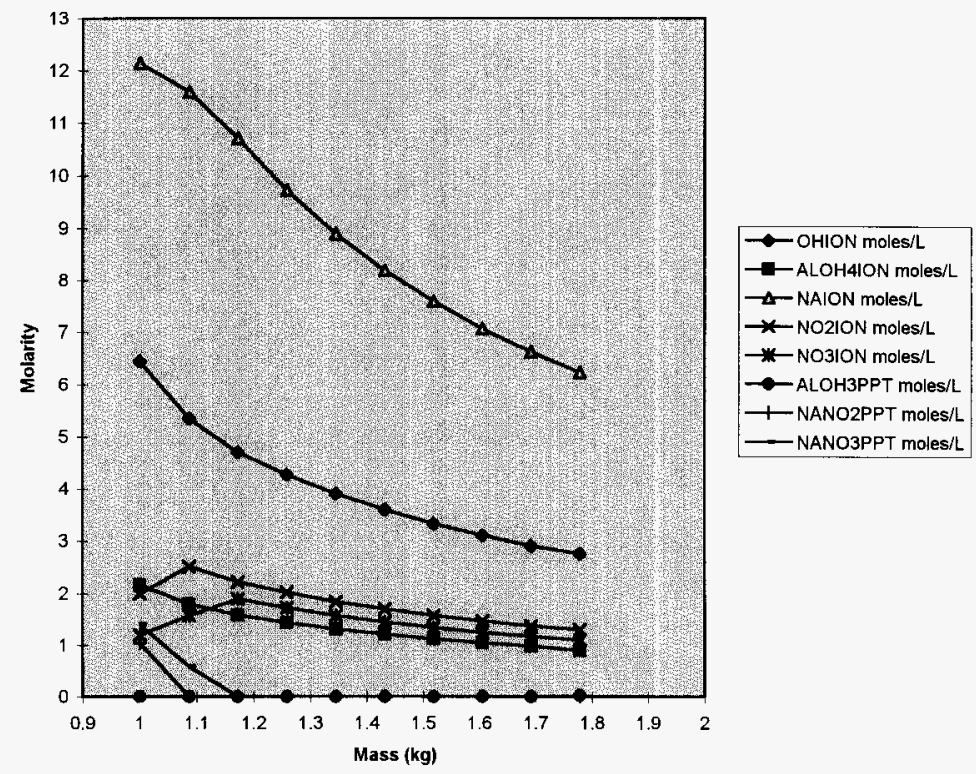


\section{WHC-SD-WM-TI-774 Rev. 0 \\ TWRS PRIVATIZATION PROCESS TECHNICAL BASELINE}

\subsubsection{Chemistry of Phase 1 Envelope B}

Since this supernate is suitable for staging without dilution, it was not modeled. Part of $A Y-101$ is retrieved for Phase 1 P-0-C batches; a third batch is retrieved at the end of the extension.

\subsubsection{Chemistry of Phase 1 Envelope C}

Reliable speciation data for the organics in Envelope $C$ is not available, so the dilution of Envelope $C$ was not modeled. If the species were known, they would also have to be present in the ESP database. The precipitation phenomenon has been observed in the laboratory with some samples. Further testing is advisable to identify potential problems.

\subsection{LOW-ACTIVITY WASTE PRIVATE CONTRACTOR OPERATIONS}

Information pertaining to the processes within the Phase 1 private contractor envelope will be available at some future date. The DOE has delegated to private contractors the responsibility for selecting and deploying their own process technology. Consequently, the PPTB does not address private contractor technology specifics, as it would in a more highly developed flowsheet.

The following discussion pertains to the process block diagram depicted Figure 8 . Compliance with request for privatization (RFP) requirements has been the primary objective in developing this block diagram and the associated mass balances. The mass balance in Table 8 is for the first batch only, but is typical. A complete set of 24 batch mass balances is provided in Appendix B.

Each process block is geared toward defining "what" the private contractor is required to accomplish rather than "how". Each column of process blocks pertains to an intermediate product, LAW product, or secondary product that the private contractor is returning to the DOE. Some of the streams in Figure 8 are not actual process streams, since this is not a true process flow diagram. These streams are for mass balance purposes only.

While supernate is intended to be a liquid, entrainment of some solids with the LAW is inevitable. The solids come from inadvertent resuspension during retrieval, and possibly from precipitation during dilution. The precipitation phenomenon was discussed previously.

It is incumbent on the operating contractor to ensure that a visible sludge layer of settlable solids occupies no more than 5 vol\% of the total transfer, as required by the Request for Proposals (DOE-RL 1996). Non-settling solids (cloudiness) may be present in some transfers nevertheless. 


\section{WHC-SD-WM-TI-774 Rev. 0 \\ TWRS PRIVATIZATION PROCESS TECHNICAL BASELINE}

Since current inventory and DST supernate projections are lacking solids composition information for many DSTs of interest, and since the extent of entrainment is a matter of conjecture, Stream 1 is assigned a "SOLIDS" component equivalent to $1 \mathrm{wt} \%$ of the supernate. The solids have an assigned $2.5 \mathrm{spg}$. There is no direct correlation between wt\% solids and vol\% settled solids since the latter depends on the extent of thickening. Based on experimentally observed "fluffing", 1 wt\% solids should be around 3 vol\% settled solids, which is within the RFP requirement of $<5$ vol\% settled solids.

Stream 1 of Figure 8 is the transfer of custody to the private contractor's receiving tank (AP-106 or AP-108). As discussed above, the feed staging plan has identified 24 discrete feed batches for Phase 1 LAW processing, 12 batches for each contractor. The content of the batches (sans the "SOLIDS" component) was previously tabulated in Tables $2 a$ and $2 b$. 


\section{Figure 8 Phase 1 Private Contrator LAW Processing}

$\stackrel{\omega}{\sim}$
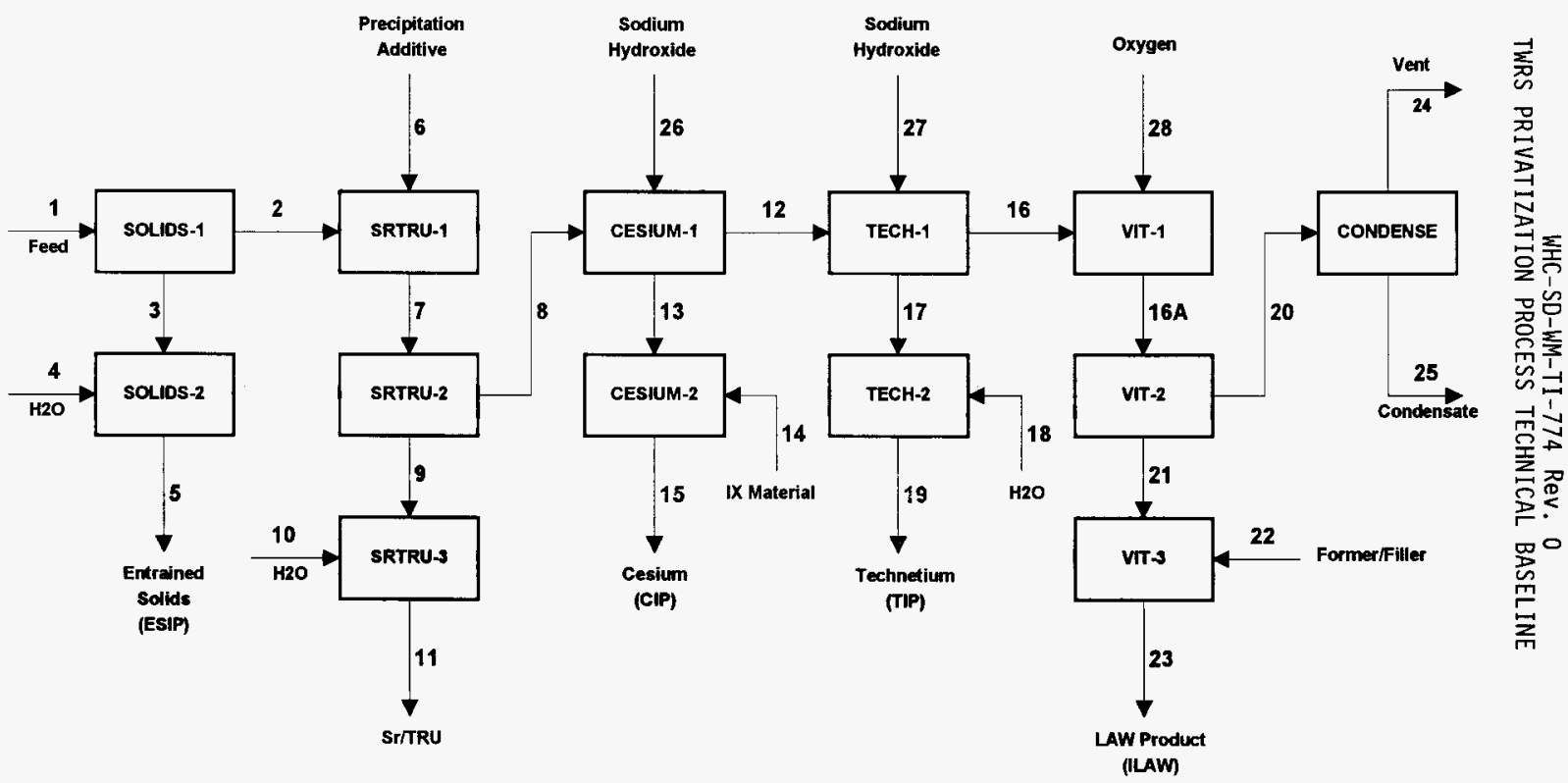
WHC-SD-WM-TI-774 ReV. 0

TWRS PRIVATIZATION PROCESS TECHNICAL BASELINE

Table 8 Mass Balance -- Phase 1 LAW -- Batch PC1/1 (6 sheets)

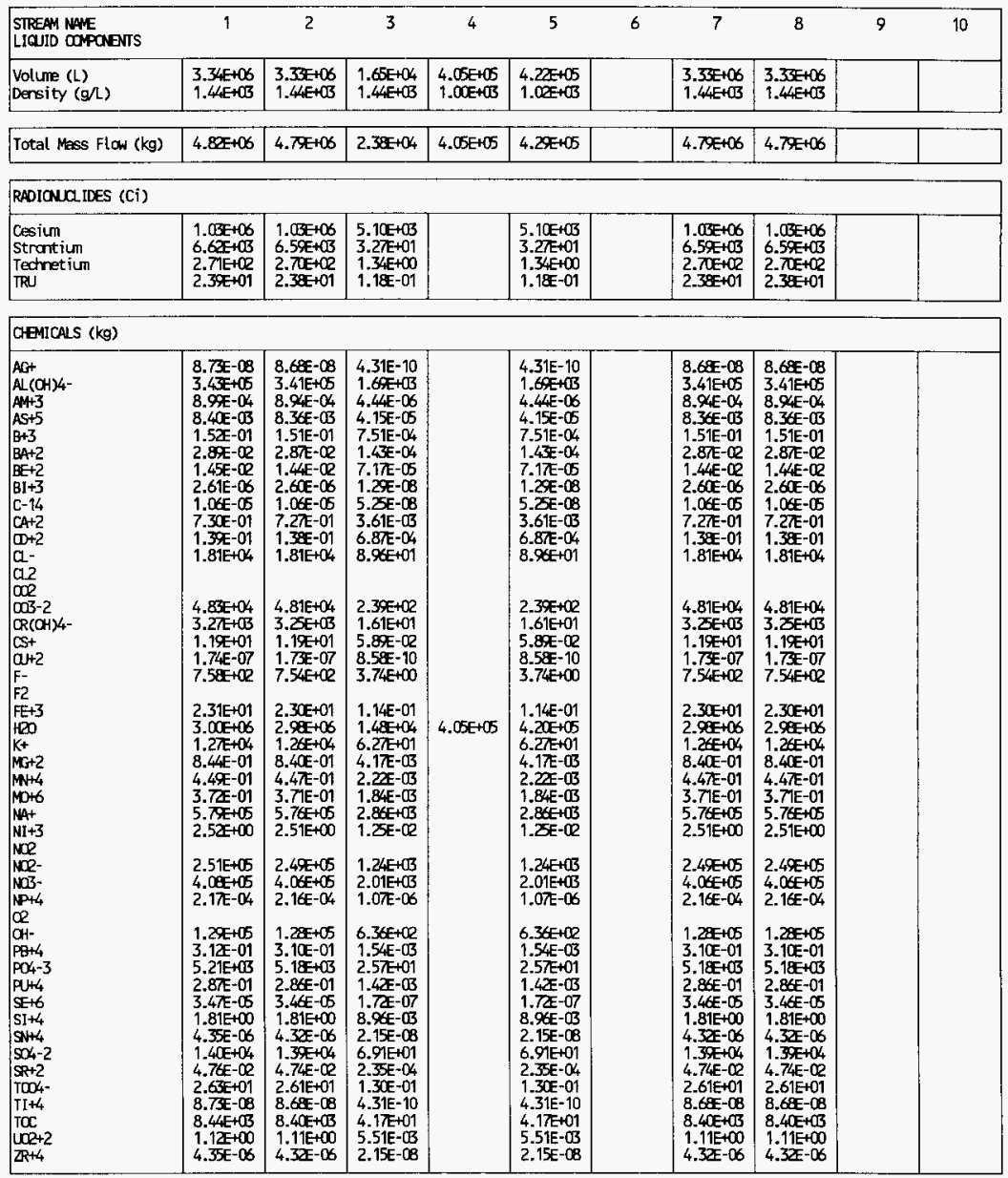


WHC-SD-WM-TI-774 Rev. 0

TWRS PRIVATIZATION PROCESS TECHNICAL BASELINE

Table 8 Mass Balance - Phase 1 LAW -- Batch PC1/1 (6 sheets)

\begin{tabular}{|c|c|c|c|c|c|c|c|c|c|c|}
\hline $\begin{array}{l}\text { STREAM NAME } \\
\text { SQ. ID OOMPOENTS }\end{array}$ & 1 & 2 & 3 & 4 & 5 & 6 & 7 & 8 & 9 & 10 \\
\hline Total Mass Flow (kg) & $4.81 E+04$ & $4.81 E+\infty 2$ & $4.76 E+04$ & & $4.76 E+04$ & & $4.81 E+02$ & $4.81 E+C 2$ & & \\
\hline \multicolumn{11}{|l|}{ RADIONUAIDES (Ci) } \\
\hline $\begin{array}{l}\text { Cesiun } \\
\text { Strontium } \\
\text { Tednetium } \\
\text { IRU }\end{array}$ & & & & & & & & & & \\
\hline \multicolumn{11}{|l|}{ CHEICALS (kg) } \\
\hline 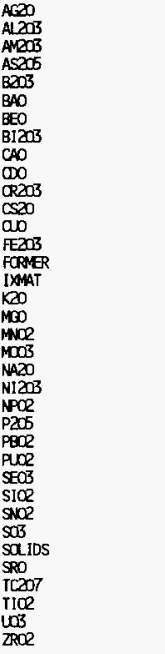 & $4.81 \mathrm{E}+04$ & $4.81 E+\infty 2$ & 4.7GE+04 & & $4.76 E+04$ & & $4.81 E+02$ & $4.81 E+\infty 2$ & & \\
\hline
\end{tabular}


WHC-SD-WM-TI-774 Rev. 0

TWRS PRIVATIZATION PROCESS TECHNICAL BASELINE

Table 8 Mass Balance -- Phase 1 LAW - Batch PCl/1 (6 sheets)

\begin{tabular}{|c|c|c|c|c|c|c|c|c|c|c|}
\hline $\begin{array}{l}\text { STREAM NAME } \\
\text { LIQUID OOMPAENS }\end{array}$ & 11 & 12 & 13 & 14 & 15 & 16 & 164 & 17 & 18 & 19 \\
\hline $\begin{array}{l}\text { Volume }(L) \\
\text { Density }(g / L)\end{array}$ & & $\begin{array}{l}3.33 E+06 \\
1.44 E+03\end{array}$ & $\begin{array}{l}3.052+03 \\
3.35+03\end{array}$ & & $\begin{array}{l}3.035+03 \\
3.35 x+03\end{array}$ & $\begin{array}{l}3.35 E+06 \\
1.44 E+03\end{array}$ & $\begin{array}{l}4.80 E+06 \\
1.00 E+03\end{array}$ & & $\begin{array}{l}1.00 E-09 \\
1.00 E+03\end{array}$ & $\begin{array}{l}1.00 E-09 \\
1.00 E+03\end{array}$ \\
\hline Total Mass flow $(\mathrm{kg})$ & & 4.796+106 & $1.01 \mathrm{EH} 04$ & & $1.01 E+04$ & $4.75 E+06$ & $4.80 E+06$ & & $1.00 E-09$ & $1.00 E-09$ \\
\hline \multicolumn{11}{|l|}{ RADIONALIDES (Ci) } \\
\hline $\begin{array}{l}\text { Cesium } \\
\text { Strontium } \\
\text { redretium } \\
\text { RBd }\end{array}$ & & $\begin{array}{l}4.42 x+13 \\
6.59+03 \\
2.67+20 \\
2.38+01\end{array}$ & $\begin{array}{l}1.02 E+106 \\
2.71 E+00\end{array}$ & & $\begin{array}{l}1.025+06 \\
2.71 E+\infty 0\end{array}$ & $\begin{array}{l}4.42 x+03 \\
6.59+03 \\
2.6 \pi+20 \\
2.38+01\end{array}$ & & & & \\
\hline \multicolumn{11}{|l|}{ OFIICALS (kg) } \\
\hline 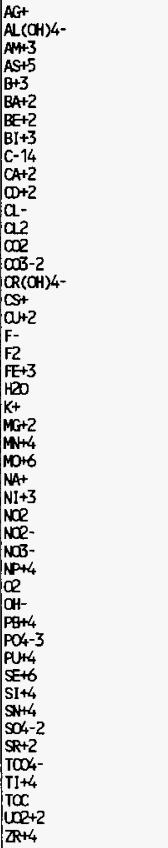 & & 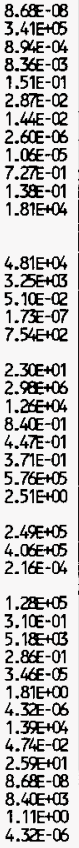 & $4.25+03$ & & $\begin{array}{l}4.28 \mathrm{E}+03 \\
2.63 \mathrm{E}-01\end{array}$ & 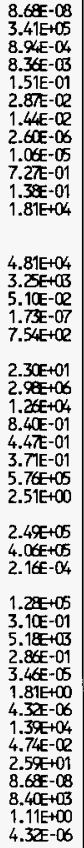 & $\begin{array}{l}1.81 E+04 \\
6.60 E+04 \\
7.54 E+102 \\
3.18 E+106 \\
5.50 E+05 \\
9.85 E+06\end{array}$ & & $1.00 E-09$ & $1.00 E-09$ \\
\hline
\end{tabular}


WHC-SD-WM-TI-774 Rev. 0

TWRS PRIVATIZATION PROCESS TECHNICAL BASELINE

Table 8 Mass Balance -- Phase 1 LAW - Batch PCI/1 (6 sheets)

\begin{tabular}{|c|c|c|c|c|c|c|c|c|c|c|}
\hline $\begin{array}{l}\text { SIREAM NAE } \\
\text { SOLID DOMPOENTS }\end{array}$ & 11 & 12 & 13 & 14 & 15 & 16 & $16 A$ & 17 & 18 & 19 \\
\hline Total Mass Flow (kg) & & $4.81 E+C 2$ & & $5.7 x+13$ & 5. $\not A+[B$ & $4.81 \mathrm{E}+\infty 2$ & $9.93 E+05$ & & & \\
\hline \multicolumn{11}{|l|}{ RADIONOCLIDES (Ci) } \\
\hline $\begin{array}{l}\text { Cesium } \\
\text { Strantium } \\
\text { Tedmetiun } \\
\text { TRU }\end{array}$ & & & & & & & $\begin{array}{l}4.4 Z E+03 \\
6.59 E+03 \\
2.6 \bar{F}+02 \\
2.36 E+01\end{array}$ & & & \\
\hline
\end{tabular}

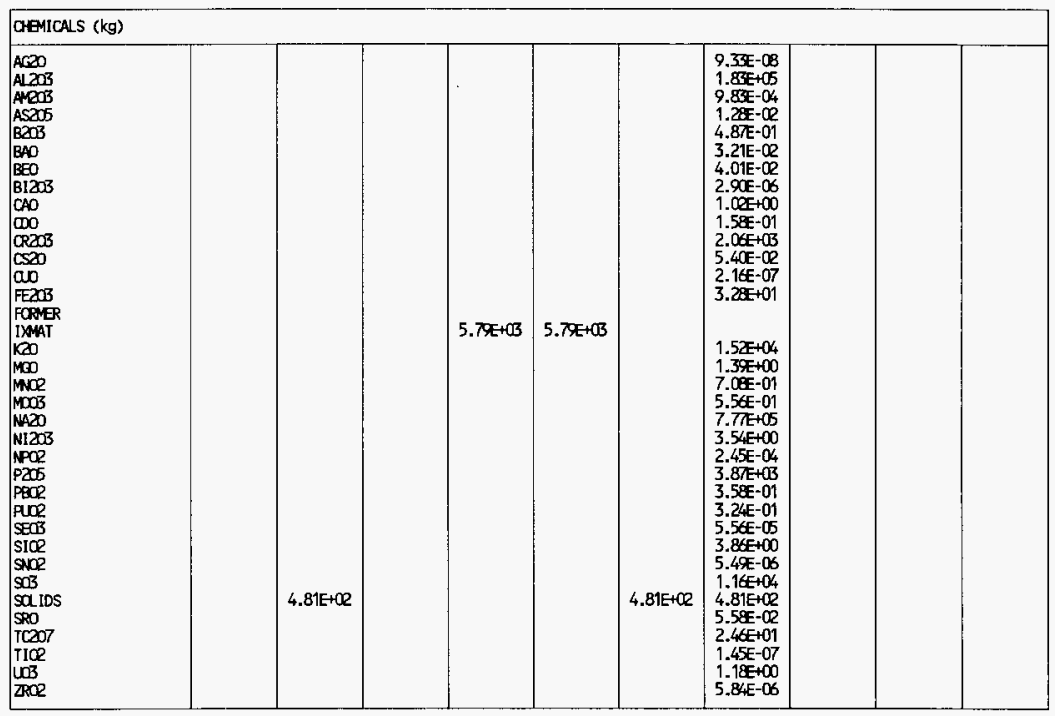


WHC-SD-WM-TI-774 Rev. 0

TWRS PRIVATIZATION PROCESS TECHNICAL BASELINE

Table 8 Mass Balance -- Phase 1 LAW -- Batch PC1/1 (6 sheets)

\begin{tabular}{|c|c|c|c|c|c|c|c|c|c|}
\hline $\begin{array}{l}\text { STREAM NAME } \\
\text { LIQUID COMPOENTS }\end{array}$ & 20 & 21 & 22 & 23 & 24 & 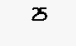 & 36 & 27 & 28 \\
\hline $\begin{array}{l}\text { Volume }(L) \\
\text { Density }(\mathrm{g} / \mathrm{L})\end{array}$ & $\begin{array}{l}4.80 E+06 \\
1.00 E+1 B\end{array}$ & & & & $\begin{array}{l}1.6 \mathrm{E}+06 \\
1.00 \mathrm{E}+0 \mathrm{~B}\end{array}$ & $\begin{array}{l}3.18 E+06 \\
1.00 E+0 B\end{array}$ & $\begin{array}{l}3.02 \mathrm{E}+03 \\
3.3 / \mathrm{E}+03\end{array}$ & $\begin{array}{l}\text { 3.00E-10 } \\
\text { 3.34E+0B }\end{array}$ & $\begin{array}{l}\text { 1. } 00 \mathrm{E}+06 \\
1.00 \mathrm{E}+03\end{array}$ \\
\hline Total Mass Flow (kg) & 4.80E+06 & & & & $1.62+06$ & $3.18 E+06$ & $1.01 \mathrm{E}+04$ & $1.00 E-09$ & 1.00E+06 \\
\hline \multicolumn{10}{|l|}{ RNDIANCLIDES (Ci) } \\
\hline $\begin{array}{l}\text { Cesium } \\
\text { Strontium } \\
\text { Tectmet ium } \\
\text { TRU }\end{array}$ & & & & & & & & & \\
\hline
\end{tabular}

\begin{tabular}{|c|c|c|c|c|c|c|}
\hline WEMICALS & & & & & & \\
\hline 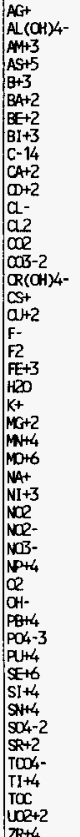 & $\begin{array}{l}1.81 E+04 \\
6.60 E+04 \\
\\
7.54 E+00 \\
3.18 E+106 \\
5.50 E+06 \\
9.85 E+05\end{array}$ & $\begin{array}{l}1.81 E+04 \\
6.60 E+04 \\
7.54 E+02 \\
5.50 E+105 \\
9.85 E+05\end{array}$ & 3. $185+106$ & $\begin{array}{l}5.75 x+0 B \\
4.28 \pm+103\end{array}$ & $\begin{array}{l}5.75 E-10 \\
4.28 E-10\end{array}$ & $1.00 E+06$ \\
\hline
\end{tabular}


WHC-SD-WM-TI-774 Rev. 0

TWRS PRIVATIZATION PROCESS TECHNICAL BASELINE

Table 8 Mass Balance -- Phase 1 LAW -- Batch PCl/1 (6 sheets)

\begin{tabular}{|c|c|c|c|c|c|c|c|c|c|}
\hline $\begin{array}{l}\text { STREAM MAE } \\
\text { SQID COPOENTS }\end{array}$ & 20 & 21 & 22 & 23 & 24 & 25 & zo & 27 & 28 \\
\hline Total Mass Flow (kg) & & $9.93 E+05$ & $3.61 E+106$ & $4.60 E+06$ & & & & & \\
\hline \multicolumn{10}{|l|}{ RADIONCLIDES (Ci) } \\
\hline $\begin{array}{l}\text { Cesium } \\
\text { Strontium } \\
\text { Teddnetium } \\
\text { RUJ }\end{array}$ & & $\begin{array}{l}4.42 E+03 \\
6.5 \%+03 \\
2.67 E+02 \\
2.36 E+01\end{array}$ & & $\begin{array}{l}4.425+03 \\
6.59+03 \\
2.67+02 \\
2.36 E+01\end{array}$ & & & & & \\
\hline \multicolumn{10}{|l|}{ CHOMICALS (kg) } \\
\hline 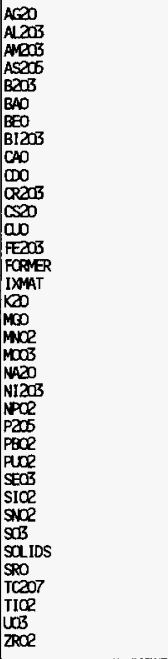 & & 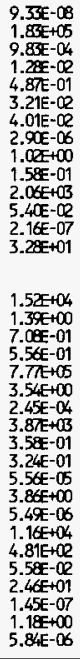 & $3.61 E+06$ & 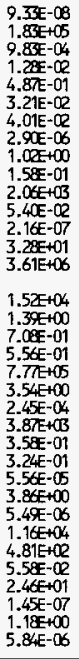 & & & & & \\
\hline
\end{tabular}

See other Phase 1 LAW mess belances in Appendix B 


\section{WHC-SD-WM-TI-774 Rev, 0 \\ TWRS PRIVATIZATION PROCESS TECHNICAL BASELINE}

\subsubsection{Entrained Solids Intermediate Product}

Process block SOLIDS-1 thickens entrained solids, distributing $1 \%$ of the solids to Stream 2 and $99 \%$ to the thickened Stream 3 . Stream 3 is allowed to contain $<60 \mathrm{~g} \mathrm{Na}$ per $\mathrm{kg}$ of solid, the Specification $10^{6}$ allowance for sodium in the Entrained Solids Intermediate Product (ESIP). The extent to which liquids (and sodium) can be displaced from a thickened sludge is limited 60 to 70 vol\% by the natural void fraction of a porous bed, which is in the range of 30 to 40 vol\%. Figure 9 illustrates the residual $\mathrm{Na}$ content in a sludge as a function of the displacement fraction (volume fraction of sludge occupied by solid) and the density of the solid. For a sludge containing $7 \mathrm{M} \mathrm{Na}$ liquid and $2.5 \mathrm{spg}$ solids, the solids must displace at least 50 vol\% of a sludge to achieve the desired residual sodium content.

The Stream 3 emerging from process block SOLIDS-1 is much too dense and viscous for pipeline transfer; bulk density of $1.9 \mathrm{~kg} / \mathrm{L}$ or higher is typical. Process block SOLIDS-2 dilutes the high bulk density sludge with water to yield slurries containing 10 wt\% solids, which should be in the range of 20 to 30 settled vol\% $\%^{8}$, and $<1.5 \mathrm{spg}$ in accordance with Specification 9 . ESIP returning from $\mathrm{PC}{ }^{\prime} \mathrm{s}$ twelve batches of supernate will contain $420,000 \mathrm{kgs}$ of solids in $3,700,000 \mathrm{~L}$ of 1 iquid. PC2 returns virtually the same amount.

${ }^{6} \mathrm{All}$ specifications in the PРТВ have reference to Specifications 1 through 10 in the RFP (DOE 1996). Typical washed solids contain more sodium than Specification 10 allows. For the PPTB, Specification 10 was interpreted to apply to the interstitial liquor only.

${ }^{7}$ Obviously, sludge thickening by itself cannot displace enough sodium to satisfy the requirement if the interstitial liquid is highly concentrated. Additional measures such as washing would be required.

${ }^{8}$ There is a correlation between wt\% solids and vol\% displaced by solids, but there is no correlation with vol\% settled solids. Therefore, given a wt\% solids, one can only estimate the vol\% settled solids. 
WHC-SD-WM-TI-774 ReV. 0

TWRS PRIVATIZATION PROCESS TECHNICAL BASELINE

Table 9 Displacement of 7M Na Interstitial Liquid by Solids

\begin{tabular}{|cccccc|}
\hline \multicolumn{2}{c}{ df solid spg } & solid spg & \multicolumn{2}{c|}{ solid spg } & \multicolumn{2}{c|}{ solid spg } & \multicolumn{2}{c|}{ solid spg } \\
& 2 & 2.25 & 2.5 & 2.75 & 3 \\
\hline & \multicolumn{2}{c}{ Kgs Residual } & Sodium per Kg of solid & \\
\hline 0.01 & 7.970 & 7.084 & 6.376 & 5.796 & 5.313 \\
0.03 & 2.603 & 2.314 & 2.082 & 1.893 & 1.735 \\
0.05 & 1.530 & 1.360 & 1.224 & 1.112 & 1.020 \\
0.10 & 0.725 & 0.644 & 0.580 & 0.527 & 0.483 \\
0.15 & 0.456 & 0.405 & 0.365 & 0.332 & 0.304 \\
0.20 & 0.322 & 0.286 & 0.258 & 0.234 & 0.215 \\
0.25 & 0.242 & 0.215 & 0.193 & 0.176 & 0.161 \\
0.30 & 0.188 & 0.167 & 0.150 & 0.137 & 0.125 \\
0.35 & 0.150 & 0.133 & 0.120 & 0.109 & 0.100 \\
0.40 & 0.121 & 0.107 & 0.097 & 0.088 & 0.081 \\
0.45 & 0.098 & 0.087 & 0.079 & 0.072 & 0.066 \\
0.50 & 0.081 & 0.072 & 0.064 & & \\
0.55 & 0.066 & & & 0.048 & 0.044 \\
0.60 & & 0.048 & 0.043 & 0.039 & 0.036 \\
0.65 & 0.043 & 0.039 & 0.035 & 0.032 & 0.029 \\
0.70 & 0.035 & 0.031 & 0.028 & 0.025 & 0.023 \\
0.75 & 0.027 & 0.024 & 0.021 & 0.020 & 0.018 \\
\hline
\end{tabular}

Figure 9 Residual Na vs. Displacement Fraction 7 M Solution

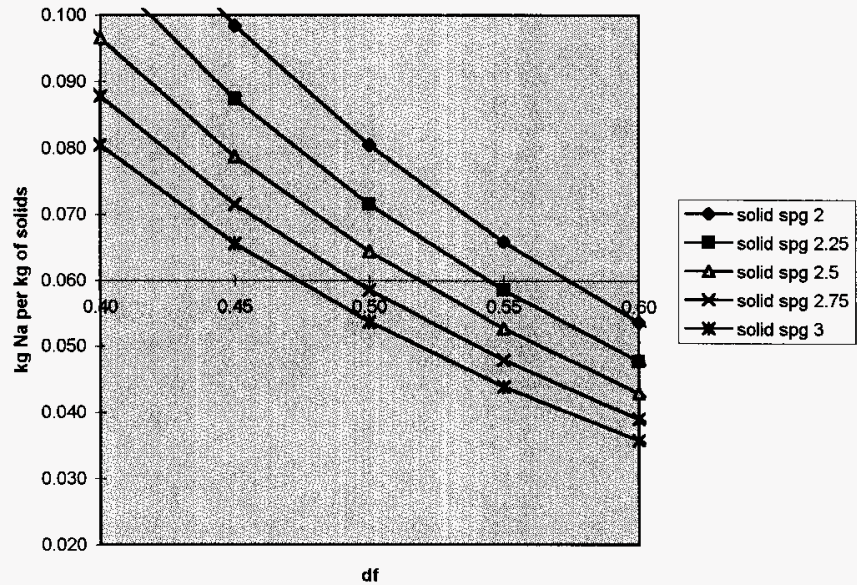

$\mathrm{Na}$ content of $<0.06 \mathrm{kgs} \mathrm{Na} / \mathrm{kgs}$ solids required by Entrained Solids specification 


\section{WHC-SD-WM-TI-774 Rev. 0 \\ TWRS PRIVATIZATION PROCESS TECHNICAL BASELINE}

\subsubsection{Strontium/TRU Intermediate Product}

Supernate that would cause either ${ }^{90} \mathrm{Sr}$ or TRU to exceed ILAW concentration limits $\left(20 \mathrm{Ci} / \mathrm{m}^{3}\right.$ or $100 \mathrm{nCi} / \mathrm{g}$, respectively) invokes process blocks SRTRU-1 through -3. SRTRU-1 is a coprecipitation operation. Process blocks SRTRU-2 and SRTRU-3 are analogous to SOLIDS-1 and SOLIDS-2, i.e., a thickening step to displace sodium from the precipitate, and a dilution step to prepare slurry for return to the operating contractor. Process block SRTRU-2 distributes $1 \%$ of the Strontium/TRU solids to Stream 8 and $99 \%$ to Stream 9. The interstitial liquid in Stream 9 contains $<60 \mathrm{~g} \mathrm{Na}$ per $\mathrm{kg}$ of solid, the Specification 10 allowance for sodium in Strontium/TRU Intermediate Product. Process block SRTRU-3 dilutes the Strontium/TRU high density sludge with water to yield slurries containing $10 \mathrm{wt} \%$ solids, which will be in the range of 20 to 30 settled vol\%, and $<1.5 \mathrm{spg}$ in accordance with

Specification 9. PC2 returns $12,000 \mathrm{~L}$ Sr/TRU intermediate product. More than likely it would be combined with the ESIP.

\subsubsection{Cesium Intermediate Product}

Supernate that would cause the ILAW concentration of ${ }^{137} \mathrm{CS}$ to exceed $3 \mathrm{Ci} / \mathrm{m}^{3}$ invokes process blocks CESIUM- 1 and -2 . Process block CESIUM-1 removes the requisite amount of radiocesium. Process block CESIUM-2 produces the dry, free-flowing cesium product (Stream 15). Specification 10 allows for a total of $10 \mathrm{~kg}$ of miscellaneous oxides (excluding sodium and silicon) to be added to the intermediate product streams, per metric ton of $\mathrm{Na}$ in the feed. The entire allowance of miscellaneous oxides (Stream 14) is added through process block CESIUM-2 to become part of the CIP. Process block CESIUM-1 also distributes $1 \%$ of the technetium and $10 \mathrm{~kg} \mathrm{Na}$ per metric ton of feed sodium to Stream 13, the maximum allowance in Specification 4 and Specification 10, respectively. PC2 will return 31 standard CS packages, based on the maximum heat load of 1,500 watts per package.

\subsubsection{Technetium Intermediate Product (TIP)}

Supernate that would cause the ILAW concentration of ${ }^{99} \mathrm{Tc}$ to exceed 0.3 $\mathrm{Ci} / \mathrm{m}^{3}$ invokes process block TECH-1, which removes the requisite amount of radiotechnetium. Process block $\mathrm{TECH}-1$ distributes $10 \mathrm{~kg} \mathrm{Na}$ per metric ton of feed sodium to Stream 17, the maximum allowance in Specification 10. Process block TECH-1 also distributes all of the remaining ${ }^{137} \mathrm{CS}$ to Stream 16 so that Stream 19 will contain less than $0.0015 \mathrm{Ci} / \mathrm{L}$ of gamma emitters, as required per Specification 5. Only four of $P C 2$ 's twelve batches require Tc treatment; $15,000 \mathrm{~L}$ of $\mathrm{Tc}$ concentrate are returned. 


\section{WHC-SD-WM-TI-774 Rev. 0 \\ TWRS PRIVATIZATION PROCESS TECHNICAL BASELINE}

\subsubsection{Immobilized Low Activity Waste}

After the removal of entrained solids, strontium/TRU, cesium, and technetium as needed, the pretreated LAW (Stream 16) is suitable for immobilization. Process block VIT-1 volatilizes water, fluoride, iodide, chloride, carbonate, nitrite and nitrate to their gaseous equivalent, and converts non-volatile constituents to their oxide equivalent. Process block VIT-2 is a gas/solid separation that routes the volatile species to condensation and the oxide equivalents to immobilization. The final packaged volume is dictated by the amount of sodium in the feed stream $\left(3.18 \mathrm{~m}^{3} / 1,000\right.$ $\mathrm{kg}$ sodium for Envelopes $A$ and $C$, and $7.95 \mathrm{~m}^{3} / 1,000 \mathrm{~kg}$ sodium for Envelope $\left.B\right)$. The final packaged volume is filled to 80 vol\% with ILAW and 20 vol\% with filler. To finish the immobilization, process block VIT-3 adds a sufficient mass of former/filler material to produce a final bulk density of $2.5 \mathrm{~kg} / \mathrm{L}$ within the waste package. The addition of former/filler material is obviously sensitive to the value assumed for the bulk density.

The final packaged volume divided by the standard package volume $(2.59$ $\mathrm{m}^{3}$ ) yields the ILAW standard package count. PC1 produces 6745 packages; PC2 produces 6412 packages. The difference is primarily due to the larger volume of Envelope B processed by PC1.

\subsubsection{Condensation}

The volatile species directed to Stream 20 by process block VIT-2 are separated into the non-condensables (Stream 24) and the condensables (Stream 25) by process block CONDENSE.

\subsection{HIGH-LEVEL WASTE PRETREATMENT AND STAGING}

The operating contractor pretreats and stages Envelope D HLW sludge to one private contractor. The pretreatment process entails separating water soluble components from sludges by washing, settling, and decanting. The HLW feed staging plan (Manuel 1996) identifies three tanks for staging (AZ-101, AZ-102, AY-102). These tanks are involved in a near-term in-tank retrieval test (Project $W-151$ ), a retrieval demonstration (Project $W-320$ ), and waste consolidation activities (Bacon 1996) that have been integrated with the process flow diagram and mass balance. Pretreatment and staging activities for each tank are described below. Unlike LAW, pretreated HLW is pumped directly from the source tanks to the private contractor's facility. 


\section{WHC-SD-WM-TI-774 Rev. 0 \\ TWRS PRIVATIZATION PROCESS TECHNICAL BASELINE}

Appendix D tabulates the inventory of AZ-101, AZ-102, and AY-102, as well as $\mathrm{C}-106$ (which is retrieved into $A Y-102$ ). Appendix D also shows how the inventory distributes between liquid and solid. Due to physical characteristics, the susceptibility of these solids to retrieval by mixer-pump technology differs from tank to tank. Retrieval efficiencies with two $300 \mathrm{hp}$ pumps have been estimated for each of the Envelope D source tanks, as noted below. The retrievable fraction is $95 \%$ of the 1 iquids, plus one of the following for solids: $90 \%$ of AZ-101, $60 \%$ of AZ-102, 36\% of AY-102, and $99 \%$ of C-106. The retrievable fraction comprises Stream 1 on the following sludge washing flowsheets.

To be conservative, all of the solids in a tank were assumed to occupy a 20 wt\% settled solids layer, and the best combinations of wash repetitions and wash ratio were determined to optimize schedule and wash volume (Washenfelder 1996). The wash volume in the following flowsheets is sized for complete mobilization, even though the feed stream itself is based on a fractional retrieval efficiency. Consequently, the wash volume depicted in these flowsheets is adequate even if actual solid retrieval efficiency is better than expected.

The residual waste in these tanks is composited with the Phase 2 pretreatment feed stream.

\subsubsection{AZ-101}

Figure 10 is the process flow diagram ${ }^{9}$ for $A Z-101$ waste and Table 10 shows the associated mass balance for the retrievable portion of the waste. Stream 1 consists of $95 \%$ of the liquids and $90 \%$ of the solids in AZ-101. Stream 1 supernates concentrate to $5 \mathrm{M} \mathrm{Na}$ (Stream 3) by in-tank evaporation prior to an in-tank mixer pump test. The mobilized slurry settles and a 20 wt\% solids layer (plus $1 \mathrm{ft}$ of supernate liquid) remains (Stream 6), after the balance of the supernate is decanted to AY-101 (Stream 5). The decanted supernate is suitable for Envelope B feed.

A single wash with three volumes of dilute caustic per volume of settled solids, followed by settling and decanting, yields a sludge with sufficiently dilute interstitial liquid (Stream 10). With transfer solution added back to satisfy Specification 8 (HLW feed slurry parameters), AZ-101 produces two $540,000 \mathrm{~L}(143,000 \mathrm{gal})$ batches of HLW feed (Stream 12).

${ }^{9}$ Note that this diagram depicts a series of operations in the same tank. Each effluent stream represents the contents of the tank after each operation is completed. The waste does not actually flow from tank to tank. 
Figure 10. In-Tank Sludge Washing of Double-Shell Tank 241-AZ-101

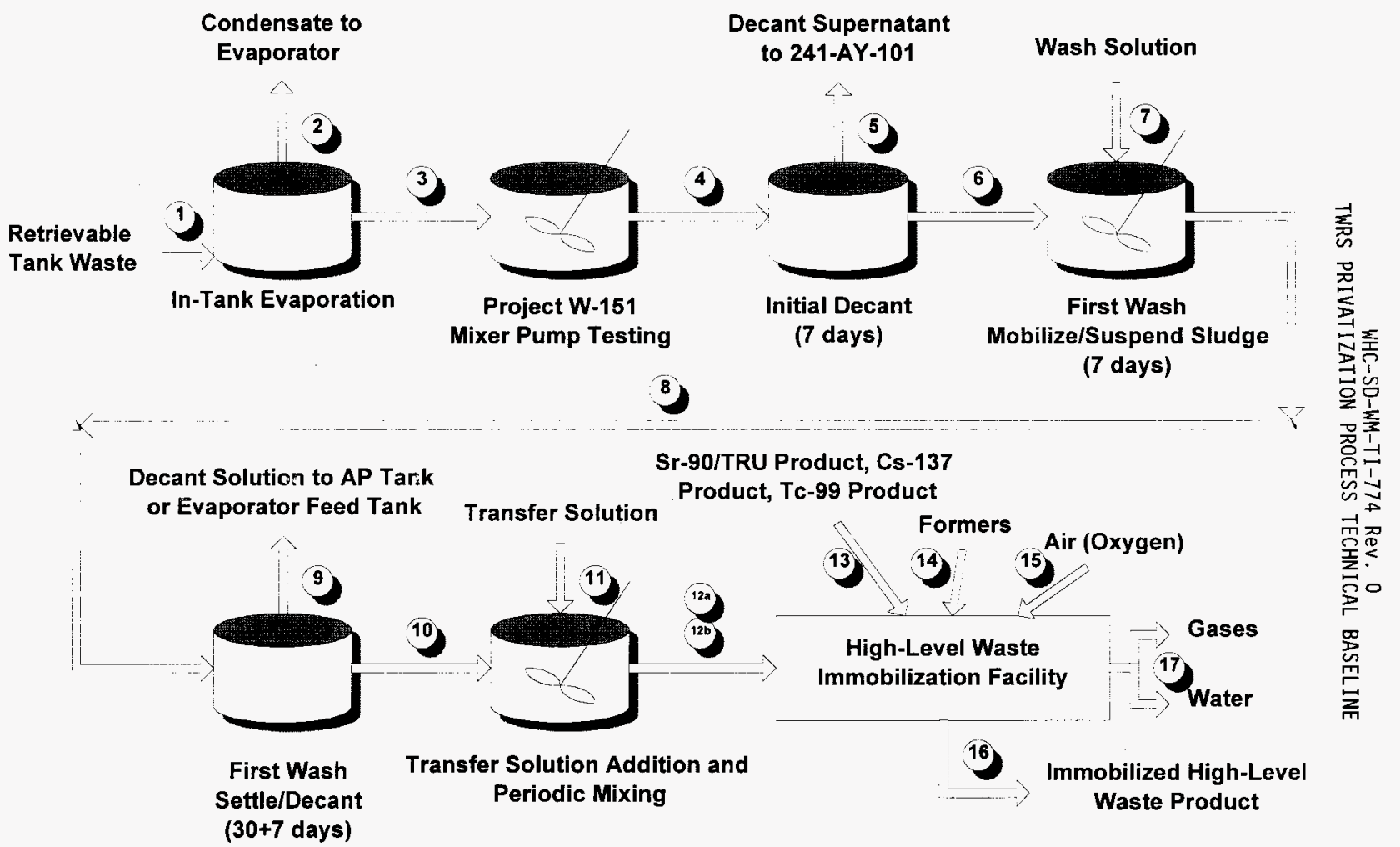




\section{WHC-SD-WM-TI-774 Rev. 0 \\ TWRS PRIVATIZATION PROCESS TECHNICAL BASELINE}

Table 10 Phase 1 In-Tank Sludge Washing of DST 241-AZ-101 (10 sheets)

\begin{tabular}{|c|c|c|c|c|c|c|c|c|c|c|}
\hline STREAM NAEE & 1 & 2 & 3 & 4 & 5 & 6 & 7 & 8 & 9 & 10 \\
\hline \multicolumn{11}{|l|}{ LIQUID COMPAENTS } \\
\hline $\begin{array}{l}\text { Total Mass Flow (kg) } \\
\text { Volume (L) } \\
\text { specific Gravity }\end{array}$ & $\begin{array}{l}4.09 E+06 \\
3.28 E+06 \\
1.25 E+\infty 0\end{array}$ & $\begin{array}{l}4.02 E+05 \\
4.00 E+05 \\
1.00 E+00\end{array}$ & $\begin{array}{l}3.68 E+06 \\
2.86 E+06 \\
1.28 E+\infty 0\end{array}$ & $\begin{array}{l}3.68 \mathrm{E}+06 \\
2.89 E+16 \\
1.28 E+\infty 0\end{array}$ & $\begin{array}{l}3.06 E+06 \\
2.38 E+06 \\
1.20 E+\infty 0\end{array}$ & $\begin{array}{l}6.33 E+05 \\
4.95 E+05 \\
1.28 E+\infty\end{array}$ & $\begin{array}{l}1.52 \mathrm{E}+06 \\
1.51 \mathrm{E}+06 \\
1.00 \mathrm{E}+\infty\end{array}$ & $\begin{array}{l}2.15 \mathrm{E}+06 \\
2.01 \mathrm{E}+06 \\
1.07 \mathrm{E}+\infty\end{array}$ & $\begin{array}{l}1.55 E+06 \\
1.44 E+06 \\
1.07 E+00\end{array}$ & $\begin{array}{l}6.06 E+05 \\
5.65 E+05 \\
1.07 E+\infty\end{array}$ \\
\hline \multicolumn{11}{|l|}{ Radianurlides (Ci) } \\
\hline $\begin{array}{l}\text { Arr } 241 \\
c-14 \\
0 \pi r 244 \\
\text { Cs-137 } \\
\text { Ba-137 } \\
\text { Eu-154 } \\
\text { Np-237 } \\
\text { Pur } 239 \\
\text { Pur-240 } \\
\text { Pur-241 } \\
\text { Sr-90 } \\
\text { Y-90 } \\
\text { Tc-99 } \\
\text { Total aries }\end{array}$ & $\begin{array}{l}8.21 \mathrm{E}+02 \\
1.79 \mathrm{E}+02 \\
1.82 \mathrm{E}+01 \\
5.78 \mathrm{E}+06 \\
5.50 \mathrm{E}+06 \\
\\
1.03 \mathrm{E}+00 \\
\\
2.70 \mathrm{E}+05 \\
2.7 \mathrm{EE}+05 \\
6.41 \mathrm{E}+02 \\
1.18 \mathrm{E}+07\end{array}$ & & $\begin{array}{l}1.03 E+\infty 0 \\
2 . \pi 0 E+05 \\
2 . \pi E++05 \\
6.41 E+02 \\
1.18 E+07\end{array}$ & $\begin{array}{l}8.21 \mathrm{E}+02 \\
1.76 \mathrm{E}+02 \\
1.89 \mathrm{E}+01 \\
5.78 \mathrm{EE}+06 \\
5.50 \mathrm{E}+06 \\
1.03 \mathrm{E}+00 \\
\\
2.70 \mathrm{E}+05 \\
2.70 \mathrm{E}+05 \\
6.41 \mathrm{E}+02 \\
1.1 \mathrm{EE}+07\end{array}$ & $\begin{array}{l}6.80 E+02 \\
1.4 \mathrm{EE}+02 \\
1.51 E+01 \\
4.79 E+06 \\
4.55 E+106 \\
\\
8.52 \mathrm{X}-01 \\
\\
2.24 E+05 \\
2.24 E+05 \\
5.31 E+102 \\
9.79 E+06\end{array}$ & $\begin{array}{l}1.41 E+02 \\
3.08 E+01 \\
3.13 E+00 \\
9.94 E+05 \\
9.45 E+05 \\
1.77 E-01 \\
\\
4.65 E+04 \\
4.65 E+04 \\
1.10 E+02 \\
2.03 E+06\end{array}$ & & $\begin{array}{l}1.41 E+02 \\
3.0 E E+01 \\
3.13 E+00 \\
9.94 E+05 \\
9.45 E+05 \\
1.7 \pi E-01 \\
\\
4.6 E E+04 \\
4.6 E E+04 \\
1.10 E+02 \\
2.03 E+06\end{array}$ & $\begin{array}{l}1.01 E+02 \\
2.21 E+01 \\
2.2 E E+\infty \\
7.15 E+05 \\
6.79 E+05 \\
1.27 E-01 \\
\\
3.34 E+04 \\
3.34 E+04 \\
7.92 E+01 \\
1.46 E+06\end{array}$ & $\begin{array}{l}3.97 E+01 \\
8.67 E+00 \\
8.80 E-01 \\
2.80 E+05 \\
2.66 E+05 \\
\\
4.96 E-02 \\
\\
1.31 E+04 \\
1.31 E+04 \\
3.10 E+01 \\
5.72 E+05\end{array}$ \\
\hline
\end{tabular}

\begin{tabular}{|c|c|c|c|c|c|c|c|c|c|}
\hline \multicolumn{10}{|c|}{ Ohemicals (kg) } \\
\hline $\mathrm{Ag}^{+}$ & & & & & & & & & \\
\hline$A m+3$ & $2.39-01$ & $2.39-01$ & $2.39 E-01$ & $1.9 \mathrm{EE}-01$ & 4.11E-CR & & 4.11E- $\infty 2$ & 2.96E- $\mathbb{R}$ & $1.16 E-02$ \\
\hline Ast 5 & $2.51 \mathrm{E}+\infty$ & $2.51 \mathrm{E}+00$ & $2.51 E+00$ & $2.08 E+\infty 0$ & $4.3 \mathrm{a}-01$ & & 4.32䞓-01 & 3.11E-01 & 1.2ZE-01 \\
\hline$B+3$ & 8.53E-01 & $8.53 E-01$ & 8.53E-01 & 7.06E-01 & $1.4 \pi \mathrm{E}-\mathbf{0 1}$ & & $1.4 \pi-01$ & $1.05 \mathrm{E}-01$ & 4.13E-CD \\
\hline $\mathrm{B} a+2$ & $9.07 \mathrm{E}-102$ & $9.07 E-02$ & $9.07 \mathrm{E}-12$ & 7.51E-@ & $1.56 \mathrm{E}-02$ & & $1.56 \mathrm{E}-\mathbb{Q}$ & $1.12 \mathbb{E}-02$ & 4.39E-C3 \\
\hline Bet2 & $1.08 E-03$ & 1. 0 CEE -03 & $1.03 E-03$ & 8.51E- $\alpha_{4}$ & $1.77 \mathrm{E}-04$ & & $1.77 \mathrm{E}-04$ & $1.2 \pi-04$ & 4.97E- 15 \\
\hline $\mathrm{Bi}+3$ & & & & & & & & & \\
\hline $\cot 2$ & $1.5 x+\infty 0$ & $1.52 x+\infty 0$ & $1.52 z+\infty$ & $1.26 E+\infty 0$ & 2.61E-01 & & 2.61E-01 & $1.88 \mathrm{E}-01$ & 7.36E- 02 \\
\hline $\operatorname{cod}+2$ & 5.59E-œ & $5.59-02$ & $5.59 \mathrm{E}-\mathscr{Q}$ & $4.6 \bar{E}-\infty 2$ & $9.61 \mathrm{E}-03$ & & $9.61 \mathrm{E}-\mathrm{CB}$ & $6.91 \mathrm{E}-03$ & $2 . \pi \mathrm{E}-03$ \\
\hline $\cot 3$ & $2.30 E+\infty$ & $2.30 \mathrm{E}+\infty 0$ & $2.30 E+\infty 0$ & $1.90 E+00$ & $3.95 x-01$ & & $3.95 \mathrm{E}-01$ & 2.84E-01 & 1.11E-01 \\
\hline $0 n+3$ & $2.25 E-O_{4}$ & 2.2EE- $\alpha_{4}$ & 2. $25 E-04$ & $1.84 \mathbf{E}-04$ & 3.845-05 & & $3.86 \mathrm{E}-05$ & $2.78 \mathrm{E}-05$ & 1.0\%E-C5 \\
\hline $\cot 3$ & $7.12 \mathbb{z}-04$ & 7.1 王-04 & $7.1 \mathbf{Z}-04$ & $5.90 \mathrm{E}-\alpha_{4}$ & $1.22 \mathbb{E}-04$ & & $1.2 Z \mathrm{FF}-0_{4}$ & $8.80 \mathrm{E}-05$ & $3.44 E-05$ \\
\hline Cst & $2.60 E+02$ & $2.60 E+102$ & $2.60 E+C R$ & $2.15 E+02$ & $4.46 E+01$ & & $4.4 E E+01$ & 3.21E+01 & $1.26 E+01$ \\
\hline $\mathrm{a}+2$ & $1.92 E-01$ & $1.90 \mathrm{X}-01$ & $1.98 E-01$ & $1.64 \mathrm{E}-01$ & $3.40 \mathrm{E}-02$ & & $3.40 \mathrm{E}-0 \mathrm{R}$ & $2.44 E-02$ & $9.57 \mathrm{E}-03$ \\
\hline $\mathrm{Fe}+3$ & 4.60E-01 & 4.60E-01 & $4.60 \mathrm{E}-01$ & $3.81 E-01$ & 7.90E-02 & & 7.90E-02 & $5.6 \mathrm{EE}-02$ & 2.2ZE-CR \\
\hline $\mathrm{Hg}+2$ & & & & & & & & & \\
\hline K+ & $6.48 E+C 2$ & $6.48 E+02$ & $6.4 E+C Q$ & $5.37 E+C R$ & 1.11E+0Q & & 1.11E+CR & 8.01E+01 & $3.13 E+01$ \\
\hline La+3 & 1.73E-01 & 1. $73 E-01$ & $1.73 E-01$ & $1.43 \mathrm{E}-01$ & $2.97 \mathrm{E}-02$ & & 2.97E- $@$ & $2.14 \mathrm{E}-\mathrm{CR}$ & $8.36 E-03$ \\
\hline $\mathrm{Li}_{+}$ & $4.28 \mathrm{E}-01$ & 4.28E-01 & 4.28E-01 & $3.54 \mathrm{E}-01$ & $7.35 \mathrm{E}-02$ & & $7.35 E-02$ & $5.2 \mathrm{EE}-02$ & $2.07 \mathrm{E}-\infty$ \\
\hline $\mathrm{Mg}+2$ & 8.24E-CQ & 8.24E-CR & $8.24 \mathrm{E}-\infty 2$ & $6.83 \mathrm{E}-02$ & $1.4 Z-\infty$ & & $1.42 \mathbb{E}-02$ & $1.02-\mathbb{2}$ & 3.99E- 03 \\
\hline $\mathrm{N}^{+4}$ & 4.21E-02 & 4.21E-CR & 4.21E-02 & 3.48E-0R & 7.ZZE-CB & & 7.23E-03 & $5.20 \mathrm{E}-03$ & 2.04E- 03 \\
\hline Mot6 & $1.31 E+01$ & 1.31E+01 & $1.31 \mathrm{E}+01$ & $1.08 E+01$ & $2.24 E+\infty$ & & $2.24 E+\infty 0$ & $1.61 E+\infty$ & 6.31E-01 \\
\hline $\mathrm{Na}+$ & 3.31E+05 & $3.31 E+05$ & $3.31 E+05$ & $2.74 E+05$ & $5.69 \mathrm{E}+04$ & $3.83 E+03$ & $6.07 \mathrm{E}+04$ & $4.36 \mathrm{E}+04$ & $1.71 E+04$ \\
\hline $\mathrm{Ni}+3$ & 1.21E-01 & 1.21E-01 & $1.21 \mathrm{E}-01$ & 1.00E-01 & $2.08 E-\infty 2$ & & $2.08 E-02$ & 1.49-02 & 5.85E-03 \\
\hline$P+4+4$ & $9.07 \mathrm{E}-01$ & $9.07 \mathrm{E}=01$ & $9.07 \mathrm{~F}-01$ & 7.51E-01 & $1.56 \mathbf{E}-01$ & & $1.565-01$ & 1.12E-01 & 4. $39-\infty 2$ \\
\hline Put 4 & $1.66 E-12$ & 1. $.66 \mathrm{E}-\mathrm{CQ}$ & 1. $66 E-02$ & $1.37 \mathrm{E}-02$ & 2.85E-03 & & $2.85 E-13$ & 2.05E-03 & $8.02 E-04$ \\
\hline Ret7 & 2.13E-01 & 2.13E-01 & 2.13E-01 & $1.77 E-01$ & $3.6 \pi-02$ & & $3.6 \pi \mathrm{E}-02$ & $2.64 \mathrm{E}-02$ & 1. 1BE- 02 \\
\hline$R+3$ & 1.53E+10 & $1.53 \mathrm{E}+00$ & $1.53 \mathrm{E}+00$ & $1.27=+\infty$ & $2.63 \mathrm{E}-01$ & & $2.63 \mathrm{E}-01$ & 1.89-01 & $7.40 \mathrm{E}-02$ \\
\hline Rut3 & 7.29-01 & 7.29E-01 & 7.2\%E-01 & 6.04E-01 & $1.25 E-01$ & & $1.25 \mathrm{E}-01$ & $9.01 \mathrm{E}-\infty 2$ & $3.53 \mathrm{E}-02$ \\
\hline Sb+5 & $1.96+\infty$ & $1.9 \pm+\infty$ & $1.9 x+\infty$ & $1.64 \mathrm{E}+\infty 0$ & $3.40 \mathrm{E}-01$ & & 3.40E-01 & 2.-44E-01 & $9.5 \pi \mathrm{E}-02$ \\
\hline Set6 & $3.71 E+\infty$ & $3.71 E+\infty$ & $3.71 E+\infty 0$ & $3.07 E+\infty$ & $6.37 \mathrm{E}-01$ & & $6.37 \mathrm{E}-01$ & $4.5 x-01$ & $1 . \overline{T E}-01$ \\
\hline $\mathrm{Si}+4$ & $5.37 \mathrm{E}+01$ & $5.3 \pi+01$ & 5.37E+01 & $4.45 E+01$ & $9.24 E+\infty$ & & $9.24 E+\infty 0$ & $6.64 E+\infty 0$ & $2.60 E+\infty 0$ \\
\hline
\end{tabular}




\section{WHC-SD-WM-TI-774 Rev. 0 \\ TWRS PRIVATIZATION PROCESS TECHNICAL BASELINE}

Table 10 Phase 1 In-Tank Sludge Washing of DST 241-AZ-101 (10 sheets)

\begin{tabular}{|lllllllllll|}
\hline STREAM NAME & 1 & 2 & 3 & 4 & 5 & 6 & 7 & 8 & 9 & 10 \\
\hline LIQUID DOMPONENTS & & & & & & & & & &
\end{tabular}

\begin{tabular}{|c|c|c|c|c|c|c|c|c|c|c|}
\hline \multicolumn{11}{|c|}{ Chenricals (kg) (cant.) } \\
\hline 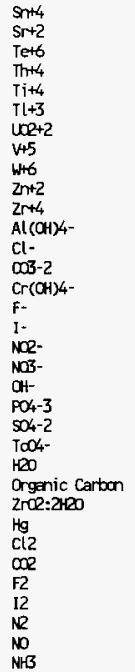 & $\begin{array}{l}9.36 E+00 \\
3.97 E+00 \\
3.21 E+00 \\
1.14 E+00 \\
3.97 E+01 \\
8.81 E+00 \\
1.37 E-01 \\
2.03 E-01 \\
1.15 E+05 \\
5.79 E+02 \\
9.68 E+04 \\
4.56 E+02 \\
5.63 E+13 \\
3.25 E-01 \\
1.93 E+05 \\
2.24 E+05 \\
3.15 E+04 \\
3.72 E+01 \\
2.09 E+01 \\
6.24 E+01 \\
3.08 E+06 \\
3.42 E+03 \\
1.23 E-01\end{array}$ & $4.02 \mathrm{Z}+05$ & $\begin{array}{l}9.36 E+\infty 00 \\
3.97 E+00 \\
3.21 E+00 \\
1.14 E+00 \\
3.97 E+01 \\
8.81 E+00 \\
1.37 E-01 \\
2.03 E-01 \\
1.15 E+05 \\
5.79 E+02 \\
9.68 E+04 \\
4.56 E+02 \\
5.63 E+13 \\
3.25 E-01 \\
1.93 E+06 \\
2.24 E+05 \\
3.15 E+04 \\
3.72 E+01 \\
2.09 E+01 \\
6.24 E+01 \\
2.68 E+06 \\
3.4 Z E+013 \\
1.23 E-01\end{array}$ & $\begin{array}{l}9.36 E+00 \\
3.97 E+00 \\
3.21 E+00 \\
1.14 E+00 \\
3.97 E+01 \\
8.81 E+00 \\
1.37 E-01 \\
2.03 E-01 \\
1.15 E+05 \\
5.76+00 \\
9.68 E+04 \\
4.56 E+02 \\
5.63 E+13 \\
3.25 E-01 \\
1.93 E+05 \\
2.24 E+05 \\
3.15 E+04 \\
3.72 E+01 \\
2.09 E+01 \\
6.24 E+01 \\
2.68 E+06 \\
3.4 Z E+03 \\
1.23 E-01\end{array}$ & $\begin{array}{l}7.75 E+00 \\
3.28 E+00 \\
2.65 E+00 \\
9.44 E-01 \\
3.28 E+01 \\
7.30 E+00 \\
1.13 E-01 \\
1.68 E-01 \\
9.52 E+04 \\
4.79 E+0 R \\
8.01 E+04 \\
3.78 E+02 \\
4.6 \pi E+03 \\
2.6 E-01 \\
1.60 E+105 \\
1.85 E+05 \\
2.60 E+04 \\
3.08 E+01 \\
1.73 E+01 \\
5.17 E+01 \\
2.22 E+06 \\
2.83 E+13 \\
1.02 E-01\end{array}$ & $\begin{array}{l}1.61 E+00 \\
6.82 E-01 \\
5.51 E-01 \\
1.96 E-01 \\
6.82 E+00 \\
1.52 E+00 \\
2.35 E-02 \\
3.49 E-02 \\
1.96 E+04 \\
9.95 E+01 \\
1.66 E+04 \\
7.84 E+01 \\
9.68 E+02 \\
5.59 E-02 \\
3.31 E+04 \\
3.85 E+04 \\
5.41 E+03 \\
6.39 E+00 \\
3.59+00 \\
1.07 E+01 \\
4.61 E+05 \\
5.89 E+02 \\
2.11 E-02\end{array}$ & $\begin{array}{l}6.97 E+0 R \\
2.5 E E+03 \\
1.51 E+06\end{array}$ & $\begin{array}{l}1.61 E+\infty 0 \\
6.82 E-01 \\
5.51 E-01 \\
1.96 E-01 \\
6.88 E+00 \\
1.52 E+00 \\
2.35 E-02 \\
3.49 E-02 \\
1.98 E+04 \\
9.95 E+01 \\
1.66 E+04 \\
7.84 E+01 \\
9.68 E+02 \\
5.59 E-02 \\
3.3 E E+04 \\
3.85 E+04 \\
7.98 E+03 \\
6.39 E+00 \\
3.59 E+00 \\
1.07 E+01 \\
1.97 E+06 \\
5.88 E+02 \\
2.11 E-02\end{array}$ & 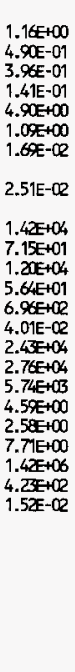 & $\begin{array}{l}4.53 E-01 \\
1.92 E-01 \\
1.55 E-01 \\
5.52 E-Q 2 \\
1.92 E+00 \\
4.26 E-01 \\
6.60 E-03 \\
9.82 E-03 \\
5.56 E+03 \\
2.80 E+01 \\
4.68 E+03 \\
2.21 E+01 \\
2.73 E+02 \\
1.57 E-Q 2 \\
9.52 E+03 \\
1.08 E+04 \\
2.25 E+03 \\
1.80 E+00 \\
1.01 E+00 \\
3.02 E+00 \\
5.55 E+05 \\
1.66 E+10 \\
5.93 E-03\end{array}$ \\
\hline
\end{tabular}




\section{WHC-SD-WM-TI-774 Rev. 0 \\ TWRS PRIVATIZATION PROCESS TECHNICAL BASELINE}

Table 10 Phase 1 In-Tank Sludge Washing of DST 241-AZ-101 (10 sheets)

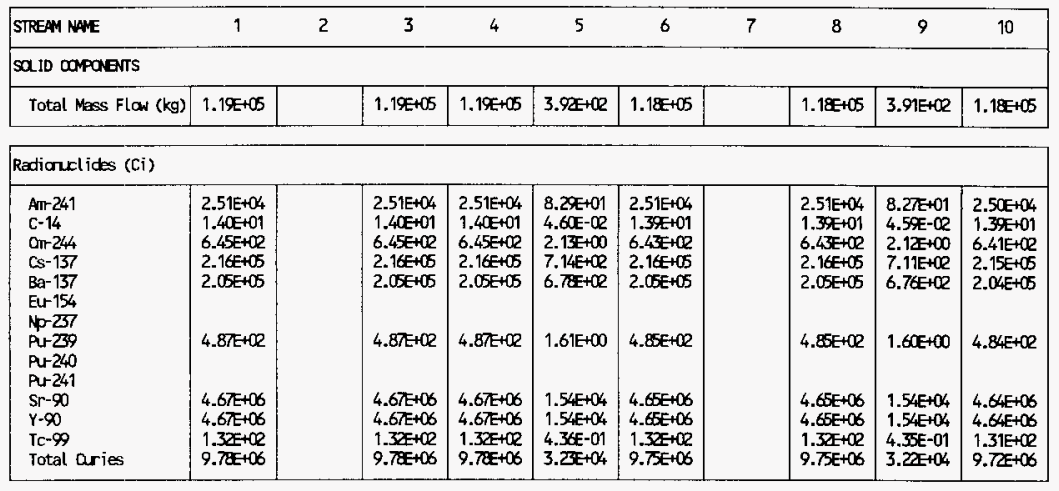

\begin{tabular}{|c|c|c|c|c|c|c|c|c|}
\hline \multicolumn{9}{|c|}{ Ohemicals (kg) } \\
\hline $\mathrm{Al}+3$ & $1.05 E+04$ & $1.05 E+04$ & $1.05 E+04$ & $3.45 E+01$ & $1.04 E+04$ & 1.04E+O4 & $3.44 \mathrm{E}+01$ & $1.04 E+0_{4}$ \\
\hline$A m+3$ & $7.33 \mathrm{E}+\infty$ & $7.33 E+100$ & $7.35 E+\infty 0$ & $2.42 \mathbb{I}-12$ & $7.30 E+\infty 0$ & $7.30 \mathrm{E}+00$ & $2.41 E-\infty$ & $7.28 \pm+\infty 0$ \\
\hline Ast 5 & $1.21 \mathrm{E}+\mathrm{CR}$ & 1.21EHRR & 1.21E+02 & $3.99-01$ & 1.21E+MR & 1.21E+CQ & $3.965-01$ & $1.20 E+02$ \\
\hline$B+3$ & $6.39+01$ & $6.39 E+01$ & $6.39+01$ & 2.11E-01 & $6.36 \mathrm{E}+01$ & $6.36 E+01$ & 2.10E-01 & $6.34 E+01$ \\
\hline Bat2 & $1.57 \mathrm{E}+02$ & $1.57+02$ & $1.5 \pi+\infty 2$ & 5. 19E-01 & $1.5 \pi+02$ & $1.5 \pi+0 R$ & $5.17 E-01$ & $1.56 E+02$ \\
\hline $\mathrm{Be}+2$ & $3.79+\infty$ & $3.79+00$ & $3.7 x+\infty 0$ & $1.3 \mathrm{EE}-\infty 2$ & $3.72 E+\infty 0$ & $3.7 x+\infty 0$ & $1.25 \mathrm{E}-\mathbb{Q}$ & $3.7 \pi+\infty$ \\
\hline Cat2 & $5.26 E+Q R$ & $5.2+02$ & $5 . \not X E+12$ & $1.74 E+\infty 0$ & $5.24 E+C 2$ & $5.24 E+10$ & $1.73 E+100$ & 5.ZBE+QR \\
\hline$c d+2$ & $1.23 E+03$ & $1.23+03$ & $1.23+013$ & $4.05 E+00$ & $1.22 E+013$ & $1.22 \mathrm{E}+0 \mathrm{~B}$ & 4. $04 \mathrm{E}+100$ & $1.22 x+03$ \\
\hline $\mathrm{Ce}+3$ & $2.62 E+\infty 2$ & $2.62+\infty 2$ & $2.62+\infty 2$ & $8.64 \mathrm{E}-01$ & $2.61 E+02$ & $2.61 E+\infty$ & $8.61 \mathrm{E}-01$ & $2.60 \mathrm{E}+\mathrm{KC}$ \\
\hline $0 m+3$ & $7.97 \mathrm{E}-13$ & $7.97 \mathrm{E}-03$ & $7.97 \mathrm{E}-03$ & $2.63 E-15$ & $7.94 \mathrm{E}-\mathrm{CB}$ & $7.94 \mathrm{E}-\mathrm{CB}$ & $2.627-05$ & 7.91E- 03 \\
\hline $\cot 3$ & 7.5 ZI -04 & $7.5 z-04$ & $7.5 z z-04$ & $2.48 E-06$ & 7.49E-04 & $7.49 E-04$ & $2.4 \pi-06$ & $7.47 \mathrm{k}-04$ \\
\hline $\mathrm{Cr}+3$ & $1.71 E+\infty 2$ & $1.71 E+\infty 2$ & 1.71E+OR & $5.65 \mathrm{E}-01$ & $1.71 \in=\infty$ & $1.71 \mathrm{E}+\infty$ & $5.63 \mathrm{E}-01$ & $1 . \pi \mathbb{R}+\infty R$ \\
\hline Cs+ & $9 . \pi E+\infty 0$ & $9.70 E+\infty 0$ & $9.70 E+\infty$ & 3. $20 \mathrm{E}-\propto 2$ & $9.6 \pi+\infty 0$ & $9.67 E+00$ & 3.19E- 02 & $9.64 E+00$ \\
\hline$a+2$ & $9.335+01$ & $9.335+01$ & $9.335+01$ & $3.08 E-01$ & $9.30 E+01$ & $9.30 E+01$ & $3.07 \mathrm{E}-01$ & $9.27 \mathrm{E}+01$ \\
\hline $\mathrm{Fe}+3$ & $2.17 E+04$ & $2.17 E+04$ & $2.17 E+04$ & 7. 16E +01 & 2. $16 E+04$ & $2.16 \mp+04$ & $7.13 E+01$ & $2.15 E+04$ \\
\hline $\mathrm{K}+$ & $6.64 E+02$ & $6.64 E+\infty 2$ & $6.64 E+02$ & $2.19 E+\infty$ & $6.62=02$ & $6.62=+02$ & $2.19 x+\infty$ & $6.60 E+02$ \\
\hline $\mathrm{La}+3$ & $8.20 E+02$ & 8. $20 E+02$ & $8.20 E+02$ & $2.71 E+\infty$ & $8.17 E+02$ & $8.17 E+\infty$ & 2. $7 \pi E+\infty$ & $8.15 E+Q R$ \\
\hline $\mathrm{Lit}$ & $1.54 \mathrm{E}+01$ & $1.54 E+01$ & $1.54 E+01$ & $5.08 E-\infty 2$ & $1.5 \mathrm{E}+01$ & $1.535+01$ & $5.06 E-\infty 2$ & $1.53 E+01$ \\
\hline $\mathrm{Mg}+2$ & $1.32 \pm+02$ & $1.32 x+02$ & $1.3 Z+02$ & $4.36 E=01$ & $1.32 E+02$ & $1.32 x+\infty 2$ & $4.35 E-01$ & $1.31 \mathrm{E}+02$ \\
\hline$M+4$ & $6.55 E+C 2$ & $6.55 E+12$ & $6.55 E+102$ & 2. $16 E+\infty 0$ & $6.53 E+02$ & $6.53 E+02$ & $2.15 E+00$ & $6.51 E+02$ \\
\hline Mot6 & 1.18E+01 & $1.18 \times+01$ & $1.18=+01$ & $3.88 E-œ 2$ & $1.1 \pi+01$ & $1.1 \pi+01$ & $3.8 \pi-02$ & $1.17 E+01$ \\
\hline Nat & $3.51 \mathrm{E}+03$ & $3.51 E+03$ & $3.51 E+013$ & 1. 16E+01 & $3.50 E+103$ & $3.50 \mathrm{E}+\mathrm{CB}$ & 1.15E+O1 & 3.49E+103 \\
\hline $\mathrm{Ni}+3$ & $9.59 E+12$ & $9.59+02$ & $9.59+02$ & 3. $17 E+\infty$ & $9.56 E+02$ & $9.56 \mathrm{E}+02$ & $3.15 E+00$ & $9.53 E+0 R$ \\
\hline $\mathrm{Pt}_{\mathrm{b}+4}$ & $1.14 \mathrm{E}+02$ & $1.14 E+\infty$ & 1.14E+Ce & $3.7 \notin \leq-01$ & 1.14E+02 & 1.14E+C & $3.75 \mathrm{E}-01$ & $1.13 \mathrm{E}+\infty \mathbf{2}$ \\
\hline Puthí & $7.85 E+\infty 0$ & $7.85 E+100$ & $7.85 E+\infty 0$ & $2.59-\cong 2$ & $7.835+\infty 0$ & $7.83 E+00$ & $2.58 E-02$ & $7.80 \mathrm{E}+00$ \\
\hline $\mathrm{Re}+7$ & $1.23 \mathrm{E}+01$ & 1. $2 \bar{E} E+01$ & 1. ZEE+01 & 4.05E-D2 & $1.22=01$ & $1.22=01$ & $4.04 E-\infty 2$ & $1.22 E+01$ \\
\hline $\mathrm{R}+3$ & $9.33 \mathrm{E}+01$ & $9.33 E+01$ & $9.335+01$ & $3.08=-01$ & $9.30 E+01$ & $9.30 E+01$ & $3.07 \mathrm{E}-01$ & $9.27 \mathrm{E}+01$ \\
\hline$R u+3$ & $1.92+02$ & $1.92 \mathbb{E}+02$ & $1.92 E+\infty$ & $6.35 \mathrm{x}-01$ & $1.91 \mathrm{E}+\infty$ & 1.91E+CR & 6.31E-01 & $1.91 E+C 2$ \\
\hline $5 b+5$ & $5.8 x+02$ & $5.88 E+02$ & $5.80 \pm+\infty 2$ & $1.94 E+\infty 0$ & $5.86 E+02$ & $5.86 E+02$ & 1.94E $+\infty$ & $5.85 E+02$ \\
\hline Set6 & $3.86 E+102$ & $3.86 E+102$ & $3.86 E+02$ & $1.27 E+\infty 0$ & $3.85 E+02$ & $3.85+C 2$ & $1.27 E+\infty 0$ & $3.84 E+\mathbb{Q}$ \\
\hline $\mathrm{Si}+4$ & $1.2 \mathrm{ZE}+\mathrm{OB}$ & $1.22 \mathbb{E}+03$ & $1.22 E+03$ & $4.02+\infty 0$ & 1.21E+013 & $1.21 E+13$ & 4.01E+00 & $1.21 E+03$ \\
\hline $\mathrm{s} r+2$ & $1.62 \pm+02$ & $1.62 E+02$ & $1.62 x+02$ & $5.34 \mathrm{E}-01$ & 1.61E+QR & $1.61 E+Q R$ & $5.32 \mathbb{X}-01$ & $1.61 E+C R$ \\
\hline Tet6 & 4.15E+102 & $4.15 E+102$ & $4.15 E+12$ & $1.37 \mathrm{E}+\infty 0$ & 4. $13 E+102$ & 4.13E+R2 & 1.36E+100 & $4.12 E+10$ \\
\hline$T h+4$ & $2.66 E+02$ & $2.66 \pm+102$ & $2.66 E+C 2$ & $8.78 x-01$ & $2.65 E+02$ & $2.65 E+02$ & 8.TSE-01 & $2.64 \mathrm{E}+102$ \\
\hline $\mathrm{Ti}+4$ & $1.43 x+02$ & $1.43 E+\infty 2$ & $1.43 E+\infty 2$ & 4.70E-01 & $1.42 E+02$ & $1.4 x+02$ & 4.69E-01 & $1.4 x+02$ \\
\hline $\mathrm{Tl}+3$ & $1.43 E+03$ & $1.43 x+03$ & $1.43+0 B$ & $4.7 \pi E+\infty 0$ & $1.4 Z E+03$ & $1.4 \mathbb{Z}+03$ & $4.69+\infty$ & $1.42 F+03$ \\
\hline
\end{tabular}




\section{WHC-SD-WM-TI-774 Rev. 0 \\ TWRS PRIVATIZATION PROCESS TECHNICAL BASELINE}

Table 10 Phase 1 In-Tank Sludge Washing of DST 241-AZ-101 (10 sheets)

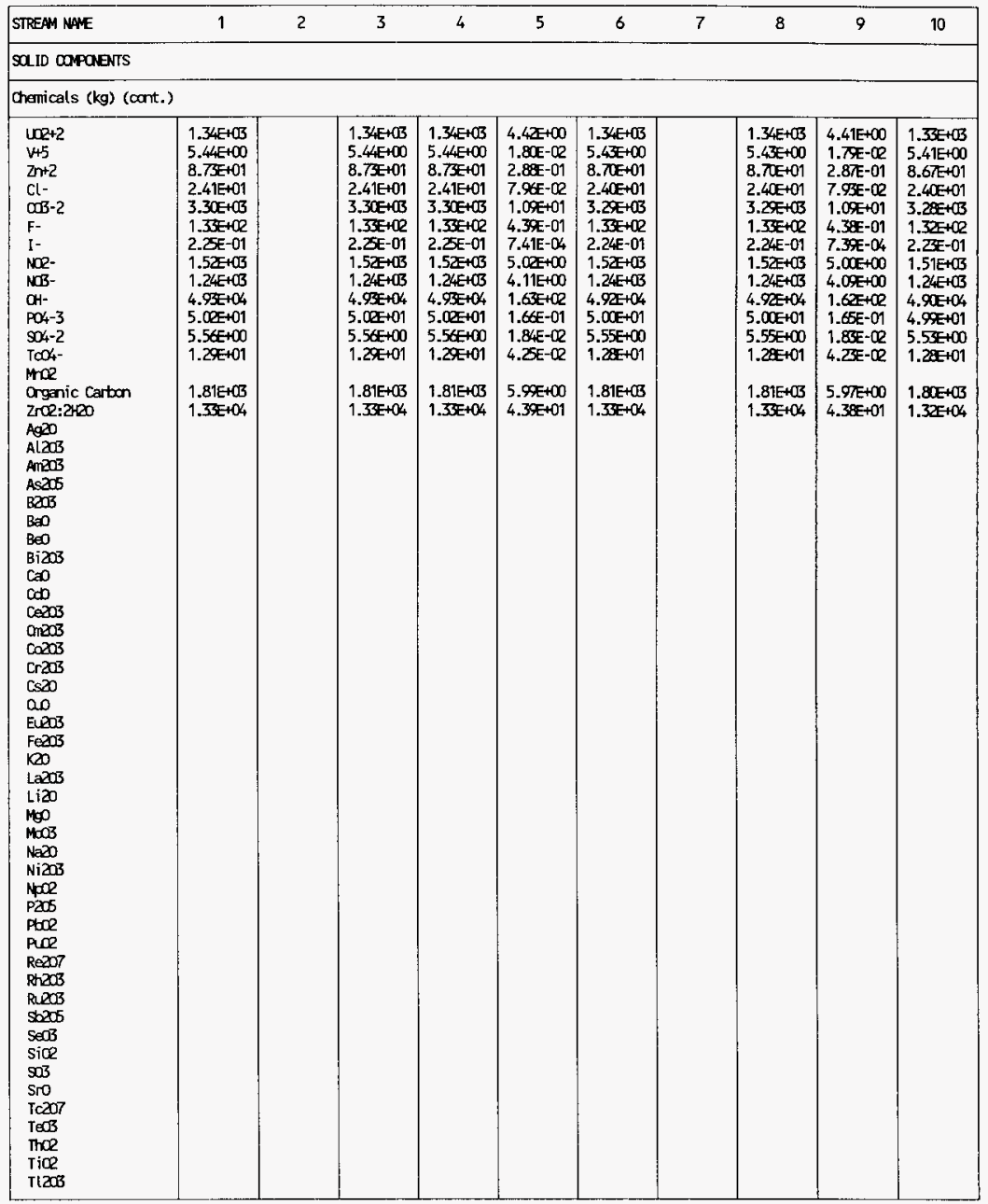




\section{WHC-SD-WM-TI-774 Rev. 0 TWRS PRIVATIZATION PROCESS TECHNICAL BASELINE}

Table 10 Phase 1 In-Tank Sludge Washing of DST 241-AZ-101 (10 sheets)

\begin{tabular}{|lllllllllll|}
\hline STREAM NAME & 1 & 2 & 3 & 4 & 5 & 6 & 7 & 8 & 9 & 10 \\
\hline SO ID COMPONETS & & & & & & & & & & \\
\hline
\end{tabular}

Chemicals (kg) (cont.)

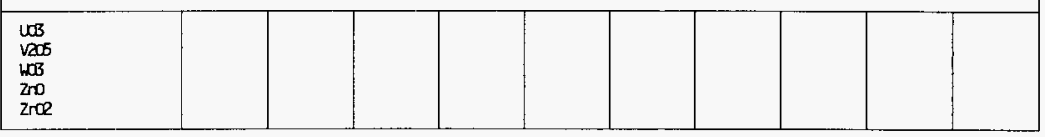


WHC-SD-WM-TI-774 Rev. 0

TWRS PRIVATIZATION PROCESS TECHNICAL BASELINE

Table 10 Phase 1 In-Tank Sludge Washing of DST 241-AZ-101 (10 sheets)

\begin{tabular}{|c|c|c|c|c|c|c|c|}
\hline STREAM NAE & 11 & 12 & 13 & 14 & 15 & 16 & 17 \\
\hline \multicolumn{8}{|l|}{ LIQUID COMPONENTS } \\
\hline $\begin{array}{l}\text { Total Mass Flow (kg) } \\
\text { Volume (L) } \\
\text { Specific Gravity }\end{array}$ & $\begin{array}{l}5.16 E+05 \\
5.16 E+05 \\
1.00 E+\infty 0\end{array}$ & $\begin{array}{l}1.12 E+06 \\
1.08 E+06 \\
1.04 E+\infty 0\end{array}$ & $\begin{array}{l}3.40 E+04 \\
1.41 E+04 \\
2.41 E+00\end{array}$ & & & & $\begin{array}{l}1.14 E+06 \\
1.14 E+06 \\
1.00 E+\infty 0\end{array}$ \\
\hline
\end{tabular}

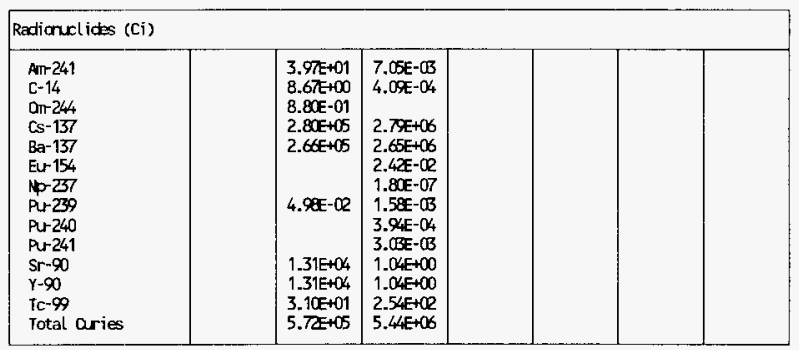

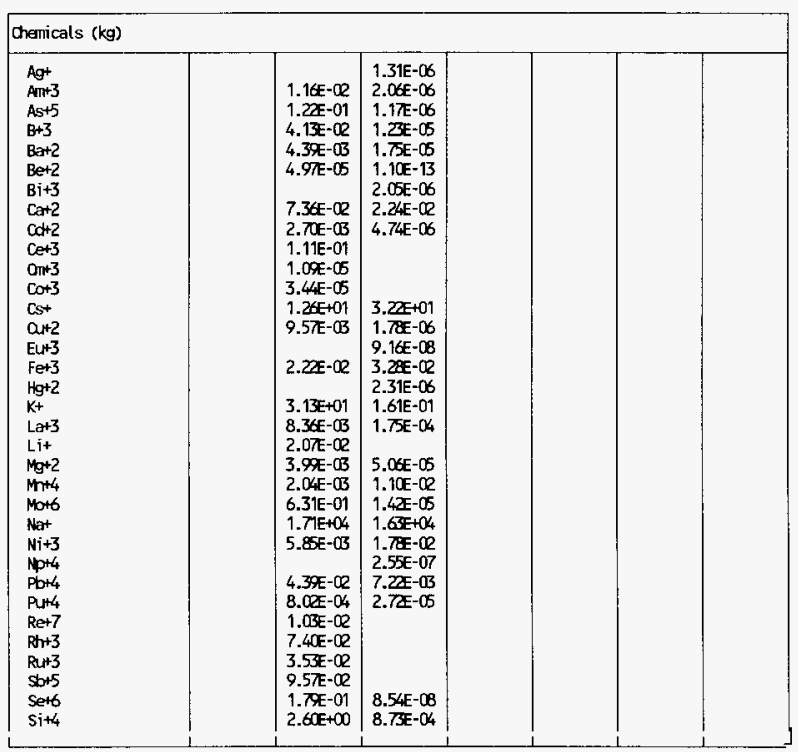


WHC-SD-WM-TI-774 Rev, 0

TWRS PRIVATIZATION PROCESS TECHNICAL BASELINE

Table 10 Phase 1 In-Tank Sludge Washing of DST 241-AZ-101 (10 sheets)

\begin{tabular}{|c|c|c|c|c|c|c|c|}
\hline STREAM NAME & 11 & 12 & 13 & 14 & 15 & 16 & 17 \\
\hline \multicolumn{8}{|l|}{ LIOUID COMPAENTS } \\
\hline \multicolumn{8}{|c|}{ Chemicals (kg) (oont.) } \\
\hline 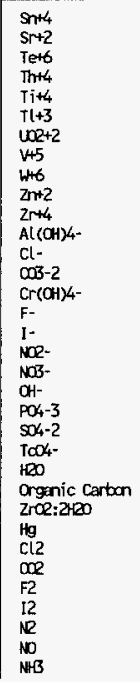 & $5.16 E+05$ & 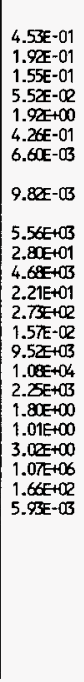 & 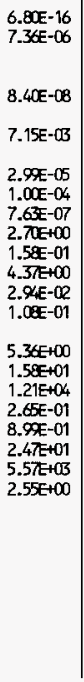 & & & & $\begin{array}{l}1.1 z+06 \\
\\
2.31 E-06 \\
5.21 E+01 \\
1.31 E+04 \\
4.05 E+10 \\
2.39 E-01 \\
1.47 E+13 \\
9.83 E+13 \\
2.96 E+01\end{array}$ \\
\hline
\end{tabular}


WHC-SD-WM-TI-774 Rev, 0

TWRS PRIVATIZATION PROCESS TECHNICAL BASELINE

Table 10 Phase 1 In-Tank Sludge Washing of DST 241-AZ-101 (10 sheets)

\begin{tabular}{|c|c|c|c|c|c|c|c|}
\hline STREAM NAME & 11 & 12 & 13 & 14 & 15 & 16 & 17 \\
\hline \multicolumn{8}{|l|}{ SQ_ID COPONENTS } \\
\hline Total Mass ftow (kg) & & $1.18 E+05$ & $9.01 \mathrm{E}-01$ & $1.81 \mathrm{E}+05$ & & $3.11 E+05$ & \\
\hline \multicolumn{8}{|l|}{ Radianul ides (Ci) } \\
\hline 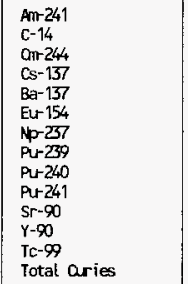 & & $\begin{array}{l}2.50 E+04 \\
1.39 E+01 \\
6.41 E+02 \\
2.15 E+05 \\
2.04 E+05 \\
\\
4.84 E+02 \\
\\
4.64 E+06 \\
4.64 E+06 \\
1.31 E+02 \\
9.72 E+06\end{array}$ & $\begin{array}{l}7.50 E+\infty 0 \\
1.87 E+00 \\
6.98 E+04 \\
6.92 E+04 \\
1.39 E+105\end{array}$ & & & $\begin{array}{l}2.5 z+04 \\
6.4 z E+02 \\
3.29+06 \\
3.12 E+06 \\
2.42 E-02 \\
1.80 E-07 \\
4.91 E+02 \\
1.87 E+00 \\
3.018 z-03 \\
4.7 z=06 \\
4.72 E+06 \\
4.16 E+02 \\
1.59+07\end{array}$ & \\
\hline
\end{tabular}

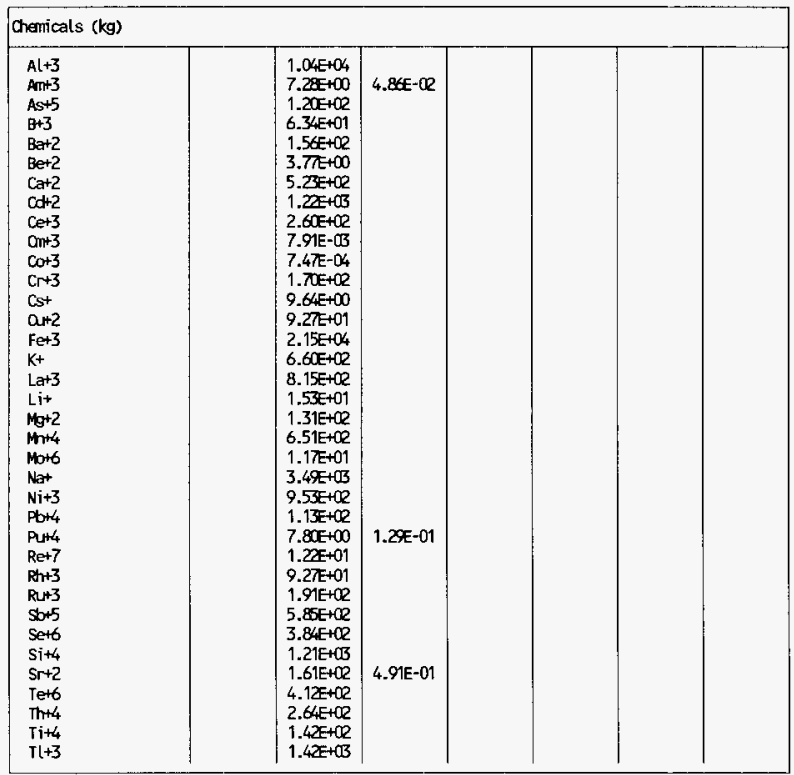




\section{WHC-SD-WM-TI-774 Rev. 0 \\ TWRS PRIVATIZATION PROCESS TECHNICAL BASELINE}

Table 10 Phase 1 In-Tank Sludge Washing of DST 241-AZ-101 (10 sheets)

\begin{tabular}{|c|c|c|c|c|c|c|c|}
\hline STREAM NME & 11 & 12 & 13 & 14 & 15 & 16 & 17 \\
\hline
\end{tabular}

\begin{tabular}{|c|c|c|c|c|}
\hline \multicolumn{5}{|c|}{ Qhanicals (kg) (cont.) } \\
\hline 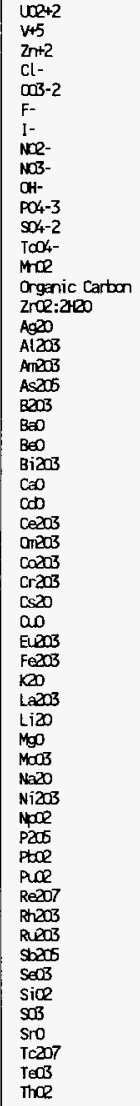 & $\begin{array}{l}1.33 E+03 \\
5.41 E+00 \\
8.67 E+01 \\
2.40 E+01 \\
3.28 E+03 \\
1.32 E+02 \\
2.23 E-01 \\
1.51 E+013 \\
1.24 E+03 \\
4.90 E+04 \\
4.99 E+01 \\
5.53 E+00 \\
1.28 E+01 \\
1.80 E+03 \\
1.32 E+04\end{array}$ & $2.32 E-01$ & $3.085+13$ & 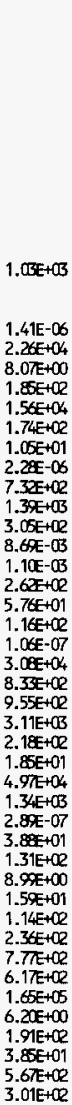 \\
\hline
\end{tabular}




\section{WHC-SD-WM-TI-774 Rev. 0 TWRS PRIVATIZATION PROCESS TECHNICAL BASELINE}

Table 10 Phase 1 In-Tank Sludge Washing of DST 241-AZ-101 (10 sheets)

\begin{tabular}{|c|c|c|c|c|c|c|c|}
\hline STREAM NAME & 11 & 12 & 13 & 14 & 15 & 16 & 17 \\
\hline \multicolumn{8}{|c|}{ SOID COMPOENIS } \\
\hline \multicolumn{8}{|c|}{ Ohenicals (kg) (oont.) } \\
\hline $\begin{array}{l}r i 02 \\
\text { TL203 } \\
103 \\
V 205 \\
103 \\
200 \\
2002\end{array}$ & & & & & & $\begin{array}{l}2.36 E+02 \\
1.59+03 \\
1.41 E+103 \\
9.6 \pi+00 \\
3.7 \pi E-05 \\
1.06 E+00 \\
1.02 E+04\end{array}$ & \\
\hline
\end{tabular}




\section{WHC-SD-WM-TI-774 ReV. 0 \\ TWRS PRIVATIZATION PROCESS TECHNICAL BASELINE}

The number of batches resulting from a tank of washed sludge is controlled by the assumed volume of a private contractor receiving tank, and the Specification 8 requirement of no more than $100 \mathrm{~g}$ of oxide equivalent of non-volatiles per liter of HLW feed. ${ }^{10}$

\subsubsection{AZ-102}

Figure 11 is the process flow diagram for $A Z-102$ waste and Table 11 shows the associated mass balance for the retrievable portion of the waste. Stream 1 consists of $95 \%$ of the liquids and $60 \%$ of the solids in $A Z-102$. Stream 1 is allowed to self-concentrate to $5 \mathrm{M} \mathrm{Na}$ (Stream 3). A compacted sludge layer of 50 wt\% solids (plus $1 \mathrm{ft}$ of concentrated supernate) remains (Stream 5), after the balance of the supernate is decanted (Stream 4).

Manuel (1996) determined that two washes with two volumes of dilute caustic per volume of settled sludge is appropriate for AZ-102. With transfer solution added back to satisfy Specification 8 (HLW feed slurry parameters), AZ-102 produces two $415,000 \mathrm{~L}(110,000 \mathrm{gal})$ batches of HLW feed (Stream 16).

\section{3 .3 AY $-102 / C-106$}

Figure 12 is the process flow diagram for $\mathrm{AY}-102$ and $\mathrm{C}-106$, and Table 12 shows the associated mass balance for the retrievable portion of the waste. Stream 1 consists of $95 \%$ of the 1 iquids, $36 \%$ of the AY-102 solids, and $99 \%$ of the C-106 solids. A compacted sludge layer (64\% of AY-102) and a fluffed sludge layer $(36 \%$ of $A Y-102$ and $99 \%$ of $C-106)$, plus $1 \mathrm{ft}$ of supernate, remain (Stream 5) after the balance of the supernate is decanted.

Manuel (1996) determined that two washes with one volume of dilute caustic per volume of settled sludge is appropriate for this blend of sludges. With transfer solution added back to satisfy Specification 8 (HLW feed slurry parameters), AY-102/C-106 produces twelve 430,000 L $(113,00$ gal) batches of HLW feed (Stream 16).

${ }^{10}$ Assumptions have not been made about the private contractor's facility, but assuming the size of the HLW receiving tank is unavoidable. The oxide equivalent limit $(100 \mathrm{~g} / \mathrm{L})$ for $\mathrm{HLW}$ transfers also has ramifications for the number of canisters that result from a batch. The $A Y / C$ sludge is higher in sodium than $A Z$ sludge. While $A Z$ sludges produce around 85 canisters per batch, $A Y / C$ sludge produces around 45 canisters per batch, because only the non-sodium/non-silicon oxides are counted toward 25 wt\% waste loading. 


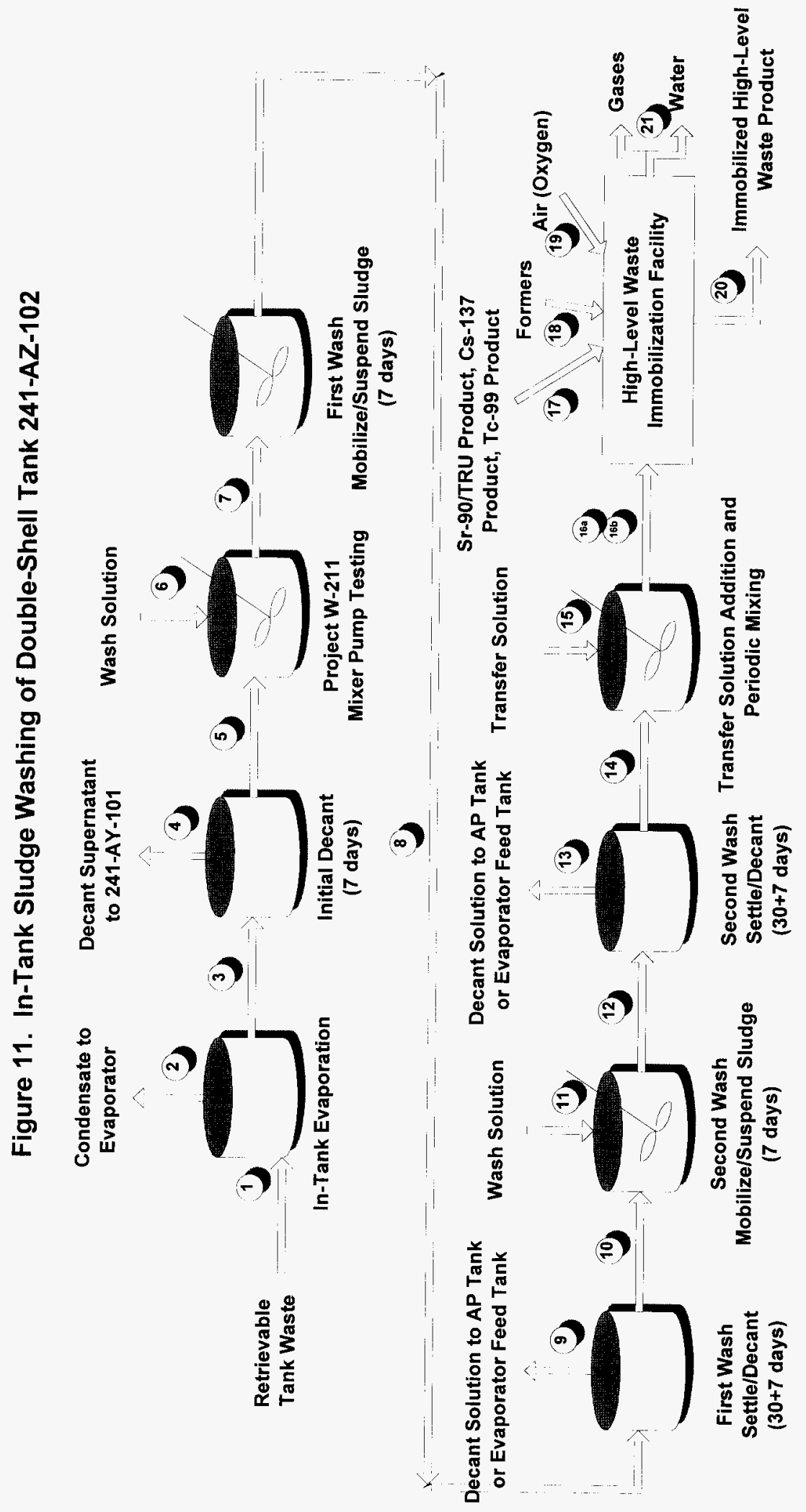




\section{WHC-SD-WM-TI-774 Rev. 0 \\ TWRS PRIVATIZATION PROCESS TECHNICAL BASELINE}

Table 11 Phase 1 In-Tank Sludge Washing of DST 241-AZ-102 (60\% Retrieval) (12 sheets)

\begin{tabular}{|c|c|c|c|c|c|c|c|c|c|c|}
\hline STREAM NAME & 1 & 2 & 3 & 4 & 5 & 6 & 7 & 8 & 9 & 10 \\
\hline \multicolumn{11}{|l|}{ LIQUID COMPONENTS } \\
\hline $\begin{array}{l}\text { Total Mess flow }(\mathrm{kg}) \\
\text { Volume }(\mathrm{L}) \\
\text { Specific Gravity }\end{array}$ & $\begin{array}{l}3.83 E+06 \\
3.45 E+06 \\
1.11 E+\infty\end{array}$ & $\begin{array}{l}1.93 E+\infty 6 \\
1.93 E+06 \\
1.00 E+\infty\end{array}$ & $\begin{array}{l}1.90 E+06 \\
1.52 E+06 \\
1 . Z E+\infty 0\end{array}$ & $\begin{array}{l}1.63 E+06 \\
1.30 E+06 \\
1.2 E+\infty 0\end{array}$ & $\begin{array}{l}2.68 E+05 \\
2.15 E+05 \\
1.2 E+00\end{array}$ & $\begin{array}{l}1.44 E+06 \\
1.44 E+06 \\
1.00 E+00\end{array}$ & $\begin{array}{l}1.71 \mathrm{E}+06 \\
1.65 \mathrm{E}+06 \\
1.04 \mathrm{E}+00\end{array}$ & $\begin{array}{l}1.71 E+06 \\
1.65 E+06 \\
1.04 E+00\end{array}$ & $\begin{array}{l}1.13 E+06 \\
1.09 E+06 \\
1.04 E+100\end{array}$ & $\begin{array}{l}5.7 \mathrm{TE}+05 \\
5.57 \mathrm{E}+05 \\
1.04 \mathrm{E}+00\end{array}$ \\
\hline \multicolumn{11}{|l|}{ Radianulides (Ci) } \\
\hline $\begin{array}{l}\text { Amr } 241 \\
c-14 \\
c s-137 \\
B a-137 \\
E u-154 \\
N p-237 \\
\text { Pur } 339 \\
\text { Pur-240 } \\
\text { Pur-241 } \\
\text { Sr-90 } \\
Y-90 \\
\text { Tc-99 } \\
\text { Total aries }\end{array}$ & $\begin{array}{l}1.60 E+00 \\
1.27 E+02 \\
3.08+06 \\
2.87 E+06 \\
\\
3.83 E+01 \\
\\
8.49 E+03 \\
8.49+03 \\
2.86 E+\infty 2 \\
5.91 E+06\end{array}$ & & $\begin{array}{l}1.60 E+\infty 0 \\
1.27 E+\infty 2 \\
3.02++06 \\
2.87 E+06 \\
3.83 E+01 \\
\\
8.49 E+13 \\
8.49++03 \\
2.86 E+\infty 2 \\
5.91 E+06\end{array}$ & $\begin{array}{l}1.37 \mathrm{E}+00 \\
1.09 \mathrm{E}+02 \\
2.60 \mathrm{E}+06 \\
2.4 \mathrm{TE}+06 \\
3.28 \mathrm{E}+01 \\
7.29 \mathrm{E}+03 \\
7.29 \mathrm{E}+013 \\
2.45 \mathrm{E}+02 \\
5.08 \mathrm{E}+06\end{array}$ & $\begin{array}{l}2.26 E-01 \\
1.75+01 \\
4.27 E+05 \\
4.06 E+05 \\
5.41 E+00 \\
1.20 E+03 \\
1.20 E+03 \\
4.04 E+01 \\
8.36 E+05\end{array}$ & & $\begin{array}{l}2.26 E-01 \\
1.79+01 \\
4.27 E+05 \\
4.06 E+05 \\
5.41 E+00 \\
1.20 E+03 \\
1.20 E+03 \\
4.04 E+01 \\
8.36 E+05\end{array}$ & $\begin{array}{l}\text { 2.26E-01 } \\
1.79+09 \\
4.27 E+05 \\
4.06 E+05 \\
5.41 E+00 \\
1.20 E+03 \\
1.20 E+05 \\
4.04 E+01 \\
8.36 E+05\end{array}$ & $\begin{array}{l}1.50 E-01 \\
1.19 E+01 \\
2.83 E+05 \\
2.68 \mathrm{E}+05 \\
\\
3.58 E+00 \\
\\
7.95 \mathrm{E}+02 \\
7.95 \mathrm{E}+02 \\
2.68 \mathrm{E}+01 \\
5.54 \mathrm{E}+05\end{array}$ & $\begin{array}{l}7.63 E-02 \\
6.05 E+00 \\
1.44 E+05 \\
1.3 E E+05 \\
1.83 E+00 \\
4.05 E+02 \\
4.05 E+02 \\
1.36 E+01 \\
2.82 E+05\end{array}$ \\
\hline
\end{tabular}

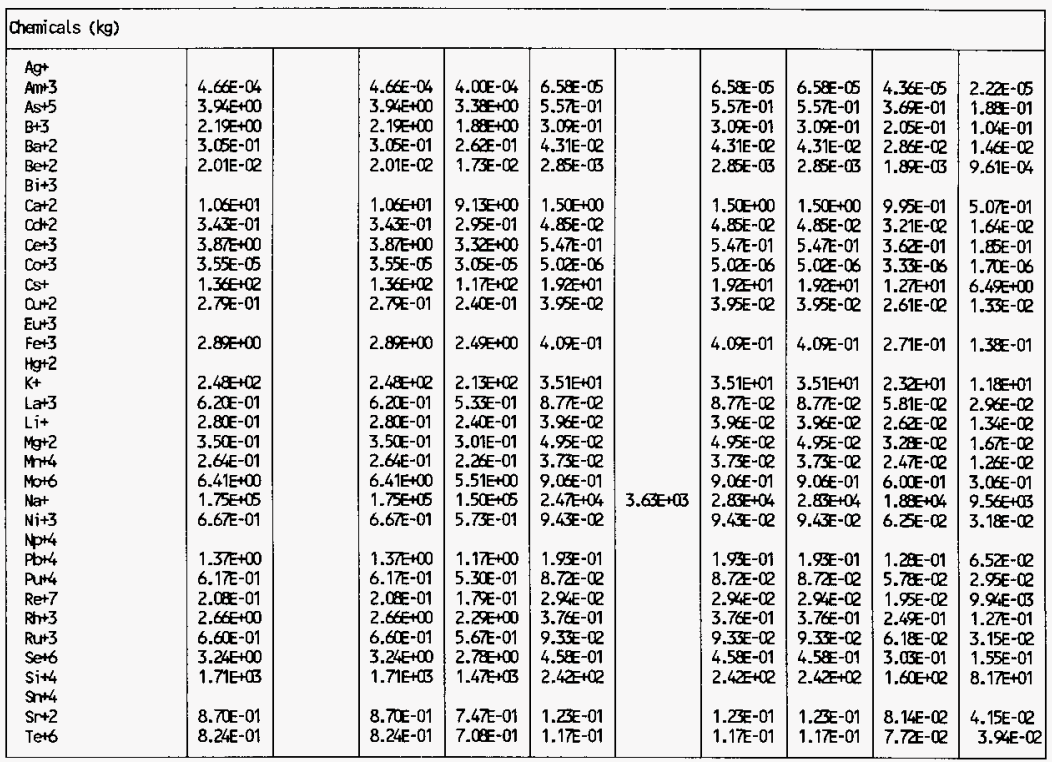


WHC-SD-WM-TI-774 Rev. 0

TWRS PRIVATIZATION PROCESS TECHNICAL BASELINE

Table 11 Phase 1 In-Tank Sludge Washing of DST 241-AZ-102 (60\% Retrieval) (12 sheets)

\begin{tabular}{|c|c|c|c|c|c|c|c|c|c|c|}
\hline STREMM NAME & 1 & 2 & 3 & 4 & 5 & 6 & 7 & 8 & 9 & 10 \\
\hline
\end{tabular}

\begin{tabular}{|c|c|c|c|c|c|c|c|c|c|c|}
\hline \multicolumn{11}{|c|}{ Chemicals (kg) (cont.) } \\
\hline 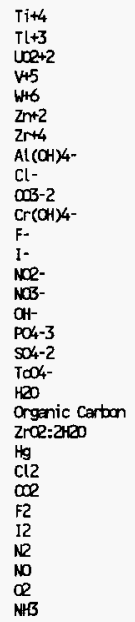 & $\begin{array}{l}2.32 E-01 \\
5.68 E-01 \\
5.48 E+03 \\
2.45 E-01 \\
1.32 E-01 \\
\\
1.6 E E+04 \\
8.99 E+04 \\
7.27 E+03 \\
3.18 E+03 \\
8.13 E-02 \\
8.81 E+04 \\
7.34 E+04 \\
5.14 E+03 \\
3.14 E+01 \\
5.31 E+04 \\
2.78 E+01 \\
3.31 E+06 \\
4.72 E+03 \\
1.12 E+00\end{array}$ & $1.93 E+06$ & $\begin{array}{l}2.32 E-01 \\
5.6 E E-01 \\
5.48 E+03 \\
2.45 E-01 \\
1.38 E-01 \\
1.6 E E+04 \\
8.99 E+04 \\
7.27 E+13 \\
3.18 E+13 \\
8.13 E-02 \\
8.81 E+04 \\
7.34 E+04 \\
5.14 E+13 \\
3.14 E+01 \\
5.31 E+04 \\
2.78 E+01 \\
1.38 E+06 \\
4.72 E+013 \\
1.12 E+\infty 0\end{array}$ & $\begin{array}{l}2.00 E-01 \\
4.88 E-01 \\
4.70 E+013 \\
2.10 E-01 \\
1.14 E-01 \\
1.45 E+04 \\
7.72 E+04 \\
6.24 E+13 \\
2.73 E+13 \\
6.98 E-02 \\
7.57 E+04 \\
6.30 E+04 \\
4.41 E+013 \\
2.68 E+01 \\
4.56 E+04 \\
2.35 E+01 \\
1.18 E+06 \\
4.05 E+013 \\
9.64 E-01\end{array}$ & 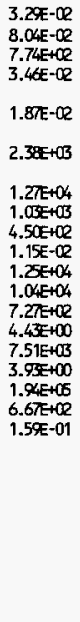 & $\begin{array}{l}6.60 E+102 \\
2.44 E+03 \\
1.43 E+06\end{array}$ & $\begin{array}{l}3.29 E-02 \\
8.04 E-12 \\
7.74 E+\infty 2 \\
3.46 E-12 \\
1.87 E-02 \\
2.38 E+03 \\
1.27 E+04 \\
1.03 E+03 \\
4.50 E+\infty 2 \\
1.15 E-12 \\
1.31 E+04 \\
1.04 E+04 \\
3.17 E+03 \\
4.43 E+\infty \\
7.51 E+033 \\
3.93 E+\infty \\
1.63 E+\infty 6 \\
6.67 E+\infty 2 \\
1.59 E-01\end{array}$ & 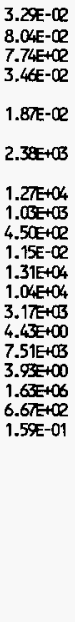 & 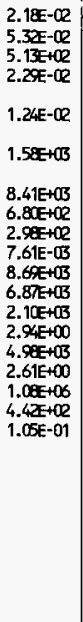 & 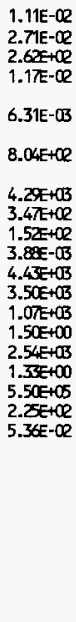 \\
\hline
\end{tabular}


WHC-SD-WM-TI-774 Rev. 0

TWRS PRIVATIZATION PROCESS TECHNICAL BASELINE

Table 11 Phase 1 In-Tank Sludge Washing of DST 241-AZ-102 (60\% Retrieval) (12 sheets)

\begin{tabular}{|c|c|c|c|c|c|c|c|c|c|c|}
\hline STREAM NAE & 1 & 2 & 3 & 4 & 5 & 6 & 7 & 8 & 9 & 10 \\
\hline \multicolumn{11}{|l|}{ SOLID COPOAENTS } \\
\hline Total Mass Flow (kg) & $1.13 E+05$ & & $1.13 x+05$ & $3.72 E+\infty 2$ & $1.12 E+05$ & & $1.1 x+05$ & 1.12E+05 & 3.TUE+QR & $1.1 z+05$ \\
\hline \multicolumn{11}{|l|}{ Radionuclides (Ci) } \\
\hline $\begin{array}{l}\text { An-241 } \\
c-14 \\
\text { on-244 } \\
\text { cs-137 } \\
\text { Ba- } 137 \\
\text { Eu-154 } \\
\text { Np-237 } \\
\text { Pur-239 } \\
\text { Pur-240 } \\
\text { Pur-241 } \\
\text { Sr-90 } \\
\text { Y-90 } \\
\text { Tc-99 } \\
\text { Total aries }\end{array}$ & $\begin{array}{l}1.01 E+04 \\
7.48 E+00 \\
3.25 E+\infty 2 \\
1.73 E+05 \\
1.64 E+05 \\
\\
2.89 E+\infty 2 \\
\\
1.72+06 \\
1.78+06 \\
8.83 E+01 \\
3.91 E+06\end{array}$ & & $\begin{array}{l}1.01 E+04 \\
7.48 E+100 \\
3.25 E+02 \\
1.73 E+105 \\
1.64 E+05 \\
\\
2.89 E+12 \\
\\
1.7 E+06 \\
1.78 E+06 \\
8.83 E+01 \\
3.91 E+06\end{array}$ & $\begin{array}{l}3.33 E+01 \\
2.47 E-02 \\
1.07 E+00 \\
5.70 E+02 \\
5.4 X+102 \\
9.55 E-01 \\
5.87 E+03 \\
5.87 E+013 \\
2.91 E-01 \\
1.26 E+04\end{array}$ & $\begin{array}{l}1.00 E+04 \\
7.45 E+00 \\
3.24 E+02 \\
1.72 E+05 \\
1.64 E+05 \\
\\
2.88 E+02 \\
1.7 \pi E+06 \\
1.7 \pi E+06 \\
8.80 E+01 \\
3.8 E+06\end{array}$ & & $\begin{array}{l}1.00 E+04 \\
7.45 E+00 \\
3.24 E+02 \\
1.72 E+05 \\
1.64 E+06 \\
\\
2.89 E+\infty 2 \\
1.77 E+06 \\
1.77 E+06 \\
8.80+01 \\
3.89 E+06\end{array}$ & $\begin{array}{l}1.00 E+04 \\
7.45 E+00 \\
3.24 E+102 \\
1.72 E+05 \\
1.64 E+05 \\
\\
2.88+02 \\
\\
1.77 E+06 \\
1.77 E+06 \\
8.80 E+01 \\
3.89 E+06\end{array}$ & $\begin{array}{l}3.31 E+01 \\
2.46 E-02 \\
1.07 E+\infty \\
5.69 E+\infty 2 \\
5.40 E+\infty 2 \\
\\
9.51 E-01 \\
\\
5.8 E+03 \\
5.85 E+03 \\
2.90 \mathrm{E}-01 \\
1.28 \mathrm{E}+04\end{array}$ & $\begin{array}{l}1.00 E+04 \\
7.43 E+00 \\
3.23 E+02 \\
1.72 E+05 \\
1.63 E+05 \\
\\
2.87 E+02 \\
1.7 \pi+06 \\
1.77 E+06 \\
8.77 E+01 \\
3.89 E+06\end{array}$ \\
\hline
\end{tabular}

\begin{tabular}{|c|c|c|c|c|c|c|c|c|}
\hline \multicolumn{9}{|c|}{ Chermicals $(\mathrm{kg})$} \\
\hline $\mathrm{Al}+3$ & 9. $.5 \mathrm{E}+\mathrm{CB}$ & $9.25 E+103$ & $3.05 E+01$ & $9.21 E+03$ & 9.21E+03 & 9.21E+Cos & 3.04E+01 & $9.18 E+c 3$ \\
\hline$A m+3$ & $2.94 E+\infty 0$ & $2.94 E+\infty 0$ & $9.69 E-03$ & $2.95+00$ & $2.93 E+00$ & $2.93 E+\infty 0$ & $9.66 E-03$ & $2.92 E+\infty 0$ \\
\hline$A s+5$ & $9.94 \mathrm{E}+01$ & $9.94 \mathrm{E}+01$ & 3.28E-01 & $9.90 E+01$ & $9.90 E+01$ & $9.90 E+01$ & 3.27E-01 & $9.87 E+01$ \\
\hline $0+3$ & $8.34 E+01$ & $8.34 E+01$ & 2. $\overline{B E}-01$ & 8.31E+01 & $8.31 E+01$ & $8.31 \mathrm{E}+01$ & 2.74E-01 & 8.28E+01 \\
\hline $\mathrm{Ba}+2$ & $9.50 \mathrm{E}+01$ & $9.50 \mathrm{E}+01$ & 3. $14 \mathrm{E}-01$ & $9.47 \pm 01$ & $9.4 \pi+01$ & $9.47 \mathrm{E}+01$ & $3.13 \mathrm{E}-01$ & 9.44E+01 \\
\hline $\mathrm{Be}+2$ & $2.31 E+\infty 0$ & $2.31 E+\infty 0$ & 7.61E-@3 & $2.3 C E+\infty 0$ & $2.30 E+\infty 0$ & $2.30 E+\infty 0$ & $7.59 E-C B$ & 2. $29 E+10$ \\
\hline $\mathrm{Ca}^{2}+2$ & $4.86 E+02$ & $4.86 E+02$ & 1.61E+00 & $4.85 E+\infty 2$ & $4.85 E+02$ & $4.85 E+02$ & $1.60 E+\infty)$ & $4.83 \mathrm{E}+102$ \\
\hline$c d+2$ & $2.59+013$ & $2.59+013$ & $8.55 E+00$ & $2.58+a+a 3$ & $2.58 E+\square 3$ & $2.58 E+1 B$ & $8.55 E+\infty 0$ & $2.58 E+13$ \\
\hline $\operatorname{ce}+3$ & $1.33 E+C R$ & $1.35 E+02$ & 4.39-01 & $1.33 E+\infty 2$ & $1.33 x+02$ & $1.33 E+0 R$ & $4.38 \mathrm{E}-01$ & 1.32102 \\
\hline $0 m+3$ & $4.01 \mathrm{E}-03$ & 4.01E- 03 & $1.32-05$ & 4.0OE- 13 & 4. $.0 \mathrm{E}-0 \mathrm{BB}$ & $4.00 E-0 B$ & $1.3 x-05$ & $3.96 E-13$ \\
\hline $\cot 3$ & $3.21 \mathrm{E}-05$ & 3.21E-05 & $1.06 E-07$ & $3.20 \mathrm{E}-05$ & 3.20E-05 & 3.20E-05 & 1. $.0<E-07$ & 3. $19 \mathrm{E}-05$ \\
\hline $\mathrm{Cr}+3$ & $2.1 \pi+C R$ & $2.17 E+102$ & 7.16E-01 & $2.16 E+\infty$ & 2.1GE+R & $2.16 E+10$ & $7.13 \mathrm{E}-01$ & 2. $15 E+02$ \\
\hline Cst & $7.74 \mathrm{E}+\infty$ & 7.74E+00 & $2.56 \mathfrak{E}-\infty 2$ & $7.72 E+\infty 0$ & $7.7 x+\infty 0$ & 7.72100 & $2.55 E-0 R$ & $7.696+00$ \\
\hline$a+2$ & $6.00 E+01$ & 6.00E+01 & $1.92-01$ & $5.98=01$ & 5.9EE01 & $5.9 E+01$ & $1.97 \mathrm{E}-01$ & $5.96 \mathrm{CE}+01$ \\
\hline $\mathrm{Fe}+3$ & $2.26 \mathrm{E}+04$ & 2.26E+04 & $7.4 \bar{E}+01$ & $2.264+04$ & $2.24 \times+04$ & 2. $6 E+04$ & $7.45 E+01$ & $2.2 \mathrm{E}+04$ \\
\hline $\mathrm{K}+$ & $2.02 E+C 2$ & $2.02+02$ & $6.67 \mathrm{E}-01$ & $2.02 \pi+\infty$ & $2.02 E+02$ & $2.02+\infty$ & $6.68 \mathrm{E}-01$ & 2.01E+(R) \\
\hline $\mathrm{La}+3$ & $7.74 E+C Q$ & $7.74 E+02$ & $2.56 E+\infty 0$ & $7.72+\infty$ & $7.72+\infty 2$ & $7 . \pi x+\infty$ & $2.55 E+100$ & $7.69 x+102$ \\
\hline $\mathrm{Li}^{+}$ & $4.84 \mathrm{E}+\infty 0$ & $4.84 E+\infty 0$ & 1.60E- -2 & $4.82=+00$ & $4.8 \pi+00$ & $4.802+00$ & $1.59 \mathrm{E}-02$ & $4.81 E+00$ \\
\hline $\mathrm{Mg}+2$ & $1.64 \mathrm{E}+C Q$ & $1.64 E+02$ & $5.42 E-01$ & $1.64 E+02$ & $1.64 \mathrm{E}+02$ & $1.64 E+C 2$ & $5.40 \mathrm{E}-01$ & $1.63 E+C Q$ \\
\hline Mnt4 & $4.9 B E+02$ & $4.90+02$ & $1.64 E+\infty 0$ & 4.96E $+\infty 2$ & $4.96 E+\infty 2$ & 4. $96 E+02$ & $1.64 E+\infty 0$ & $4.94 \mathrm{E}+02$ \\
\hline Mo+6 & 4.05E +00 & $4.05 E+00$ & $1.34 E-Q$ & 4. $04 E+\infty$ & $4.04 E+00$ & $4,04 E+\infty 0$ & $1.35 E-\infty 2$ & $4.03 E+\infty 0$ \\
\hline Nat & $7.14 E+03$ & $7.14 E+03$ & $2.36 E+01$ & $7.11 E+a B$ & 7.11E+a3 & $7.11 E+03$ & $2.35 E+01$ & $7.09 E+03$ \\
\hline $\mathrm{Ni}+3$ & $1.53 \mathrm{E}+03$ & $1.53 E+013$ & $5.05 E+\infty 0$ & $1.52 \pm+03$ & $1.5 x+03$ & $1.52 z+03$ & $5.0 x+\infty$ & $1.5 x+03$ \\
\hline$P b+4$ & $1.89+0 R$ & $1.89+02$ & 6.24E-01 & $1.89 \mathrm{E}+\infty 2$ & $1.89+02$ & $1.89+0 R$ & $6.221-01$ & $1.88 E+\infty 2$ \\
\hline Put4 & $4.6 \pi+\infty 0$ & $4.6 \pi+100$ & $1.54 \mathrm{E}-02$ & 4. $65 E+00$ & 4. $65 E+100$ & $4.66 \mathrm{E}+100$ & $1.54 E-\infty 2$ & $4.64 E+\infty 0$ \\
\hline Ret7 & $1.24 \mathrm{E}+01$ & 1.24E+01 & 4.06E-02 & 1. $23 E+01$ & $1.23 E+01$ & 1. ZEE+01 & 4.0KE-DQ & $1.2 \mathrm{EE}+01$ \\
\hline$n+3$ & 7.14E+01 & 7.14E+01 & $2.36 \mathrm{E}-01$ & 7.11E+01 & 7.11E+01 & 7.11E+01 & 2.35E-01 & $7.09 E+01$ \\
\hline Ru+3 & $3.09+01$ & $3.09+01$ & 1.02E-01 & $3.08+01$ & $3.08+01$ & $3.08 E+01$ & 1.0 EF-01 & $3.07 E+01$ \\
\hline $5 e+6$ & 1. $\bar{B} E+\infty$ & 1. $\bar{B} E+\infty$ & 5.79E-01 & $1 . \overline{B S E}+\infty$ & 1. $\bar{B} E+\infty$ & 1.JEE & $5.77 \mathrm{E}-01$ & $1.74 E+1 Q 2$ \\
\hline $5 i+4$ & $7.26 E+02$ & $7.26 E+\infty 2$ & $2.40 E+\infty 0$ & $7.23 E+02$ & $7.23 E+\infty 2$ & $7 . Z E+\infty 2$ & $2.39+\infty$ & $7.21 E+Q 2$ \\
\hline $\mathrm{S} r+2$ & 7.00E+01 & $7.00 E+01$ & 2.31E-01 & $6.98+01$ & $6.9 E+01$ & $6.98+01$ & 2.30E-01 & 6.55E+01 \\
\hline Te+6 & 5.90E+01 & $5.90 \mathrm{E}+0\}$ & $1.95 E-01$ & $5.88+01$ & $5.88 E+01$ & $5.8 \mathrm{EE}+01$ & 1.94E-01 & 5.86E+01 \\
\hline $\mathrm{Ti}+4$ & $1.38+01$ & $1.32 \mathbb{2}+01$ & $4.36 E-\infty 2$ & 1.32101 & $1.38 \times+01$ & $1.3 x+01$ & 4.35E-CR & $1.31 \mathrm{E}+0\}$ \\
\hline $\mathrm{Tl}+3$ & $9.50 E+100$ & 9.50E+O0 & $3.14 E-02$ & $9.4 \pi+00$ & $9.47 E+\infty 0$ & $9.4 \pi+\infty 0$ & $3.13 \mathbb{E}-\mathbb{Q}$ & 9. $44 E+\infty 0$ \\
\hline $1002+2$ & $2.37 E+13$ & $2.37 E+03$ & $7.81 E+\infty$ & $2.36 E+03$ & $2.36 \mathrm{E}+03$ & $2.36 E+03$ & $7.7 x+\infty$ & $2.35 E+C B 3$ \\
\hline$v+5$ & $5.4 F+00$ & $5.49+\infty$ & 1.81E- -2 & $5.4 \pi+\infty 0$ & $5.4 \pi+100$ & $5.4 \pi+00$ & $1.81 \mathrm{E}-\mathscr{C R}$ & $5.45 E+00$ \\
\hline $2 n+2$ & $2.43 E+01$ & $2.43 E+01$ & 8.01E- - & $2.42 E+01$ & $2.4 Z \mathbf{E}+01$ & $2.42 E+01$ & $7.99-12$ & $2.41 E+01$ \\
\hline
\end{tabular}


WHC-SD-WM-TI-774 Rev. 0

TWRS PRIVATIZATION PROCESS TECHNICAL BASELINE

Table 11 Phase 1 In-Tank Sludge Washing of DST 241-AZ-102 (60\% Retrieval) (12 sheets)

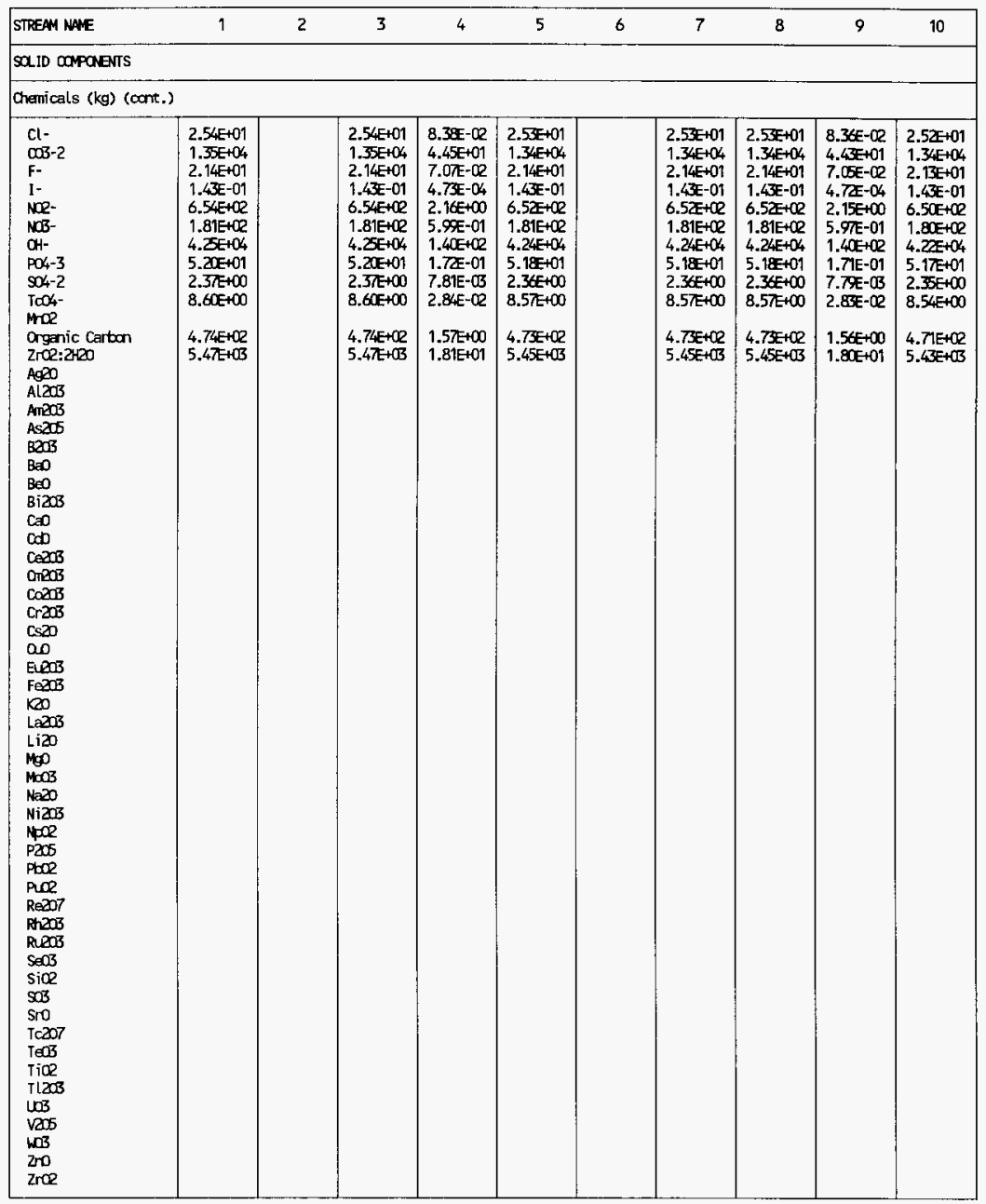


WHC-SD-WM-TI-774 Rev. 0

TWRS PRIVATIZATION PROCESS TECHNICAL BASELINE

Table 11 Phase 1 In-Tank Sludge Washing of DST 241-AZ-102 (60\% Retrieval) (12 sheets)

\begin{tabular}{|c|c|c|c|c|c|c|c|c|c|c|}
\hline STREAM NAEE & 11 & 12 & 13 & 14 & 15 & 16 & 17 & 18 & 19 & 20 \\
\hline \multicolumn{11}{|l|}{ LIAID capanents } \\
\hline $\begin{array}{l}\text { Iotal Mass Flow }(\mathrm{kg}) \\
\text { Volume (L) } \\
\text { Specific Gravity }\end{array}$ & $\begin{array}{l}1.44 E+106 \\
1.44 E+106 \\
1.00 E+00\end{array}$ & $\begin{array}{l}2.08+106 \\
1.99 E+106 \\
1.01 E+00\end{array}$ & $\begin{array}{l}1.4 \mathrm{AE}+06 \\
1.4 \mathrm{EE}+106 \\
1.0 \mathrm{EE}+00\end{array}$ & $\begin{array}{l}5.72=105 \\
5.66 E+105 \\
1.01 E+00\end{array}$ & $\begin{array}{l}2.65 E+05 \\
2.65 E+05 \\
1.00 E+00\end{array}$ & $\begin{array}{l}8.37 \mathrm{E}+106 \\
8.30 \mathrm{E}+105 \\
1.01 \mathrm{E}+100\end{array}$ & $\begin{array}{l}2.55 E+04 \\
1.06 E+04 \\
2.41 E+00\end{array}$ & & $\begin{array}{l}3.93 E+02 \\
3.93 E+12 \\
1.00 E+\infty 0\end{array}$ & \\
\hline
\end{tabular}

\begin{tabular}{|c|c|c|c|c|c|}
\hline \multicolumn{6}{|c|}{ Radionucl ices (Ci) } \\
\hline $\begin{array}{l}\text { Ant-241 } \\
\text { C-14 } \\
\text { Cs-137 } \\
\text { Ba-137 } \\
\text { Eur-154 } \\
\text { Np-237 } \\
\text { Pur-399 } \\
\text { Pur-240 } \\
\text { Pur-241 } \\
\text { Sr-90 } \\
\text { Y-90 } \\
\text { Tc-99 } \\
\text { Total aries }\end{array}$ & $\begin{array}{l}7.63 \mathrm{E}-02 \\
6.05 \mathrm{E}+00 \\
1.44 \mathrm{E}+05 \\
1.3 \mathrm{EE}+05 \\
1.83 \mathrm{E}+00 \\
4.05 \mathrm{E}+02 \\
4.05 \mathrm{E}+02 \\
1.36 \mathrm{E}+01 \\
2.82 \mathrm{E}+05\end{array}$ & $\begin{array}{l}5.46 \mathrm{E}-\infty \\
4.34 \mathrm{E}+\infty \\
1.0 \mathrm{EE}+05 \\
9.82 \mathrm{E}+04 \\
1.31 \mathrm{E}+\infty \\
\\
2.90 \mathrm{E}+\infty \\
2.90 \mathrm{E}+\infty \\
9.77 \mathrm{E}+\infty \\
2.0 \mathrm{E}+05\end{array}$ & $\begin{array}{l}2.17 E-\infty 2 \\
1.7 \pm+00 \\
4.10 E+04 \\
3.89+04 \\
5.18 E-01 \\
\\
1.15 E+02 \\
1.15 E+02 \\
3.87 E+00 \\
8.01 E+04\end{array}$ & $\begin{array}{l}2.17 \mathrm{E}-\infty 2 \\
1.7 \mathrm{E}+\infty \\
4.10 \mathrm{E}+04 \\
3.89 \mathrm{E}+04 \\
\\
5.18 \mathrm{E}-01 \\
\\
1.15 \mathrm{E}+\infty \\
1.15 \mathrm{E}+02 \\
3.87 \mathrm{E}+\infty \\
8.01 \mathrm{E}+04\end{array}$ & $\begin{array}{l}5.31 E-03 \\
3.06 E-04 \\
2.10 E+06 \\
1.99 E+06 \\
1.81 E-\infty 2 \\
1.35 E-07 \\
1.18 E-03 \\
2.94 E-04 \\
2.27 E-03 \\
7.79 E-01 \\
7.79 E-01 \\
1.90 E+02 \\
4.09 E+06\end{array}$ \\
\hline
\end{tabular}

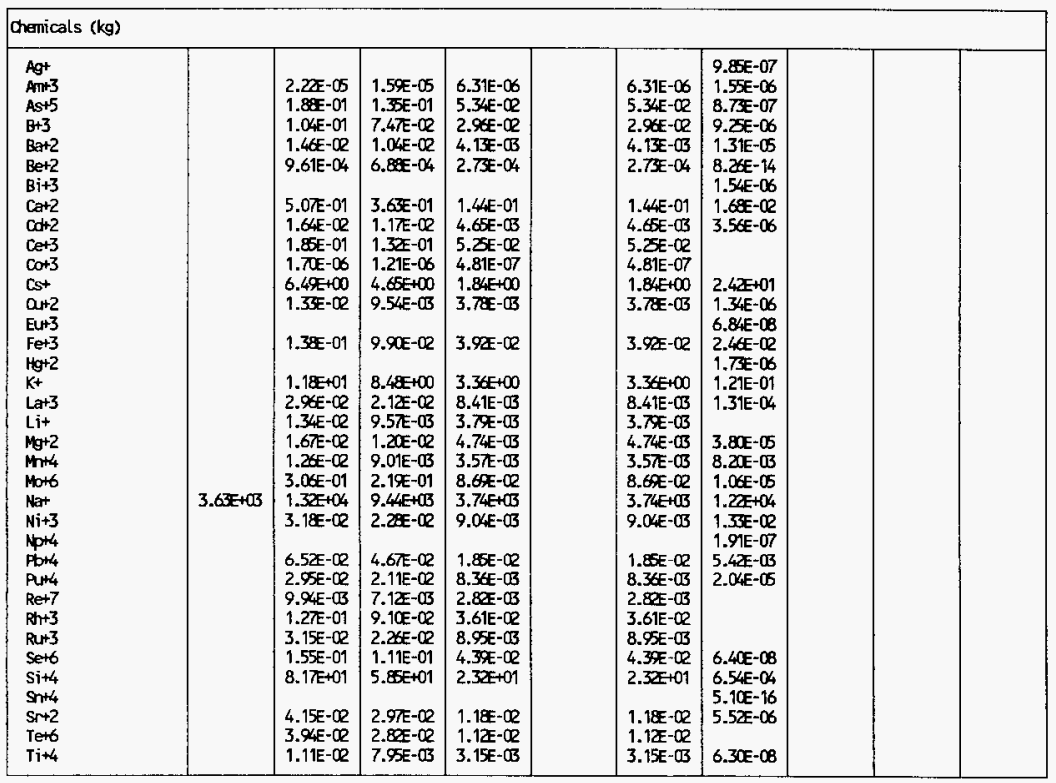


WHC-SD-WM-TI-774 Rev. 0

TWRS PRIVATIZATION PROCESS TECHNICAL BASELINE

Table 11 Phase 1 In-Tank Sludge Washing of DST 241-AZ-102 (60\% Retrieval) (12 sheets)

\begin{tabular}{|lllllllllll|}
\hline STREMM NAF & 11 & 12 & 13 & 14 & 15 & 16 & 17 & 18 & 19 & 20 \\
\hline LIOUID COMPONENT & & & & & & & & & & \\
\hline
\end{tabular}

\begin{tabular}{|c|c|c|c|c|c|c|c|c|}
\hline \multicolumn{9}{|c|}{ Chenicals (kg) (ocht.) } \\
\hline 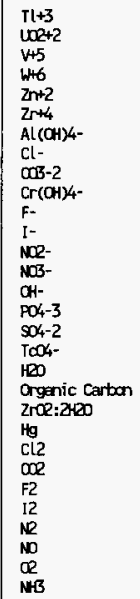 & $\begin{array}{l}0.60 E+102 \\
2.44 E+13 \\
1.43 E+106\end{array}$ & 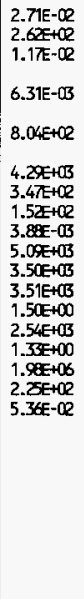 & 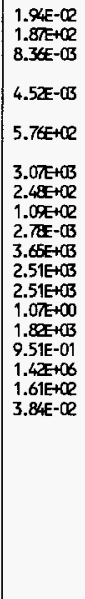 & 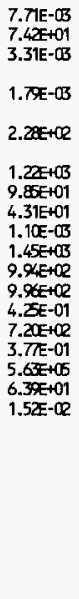 & $2.65 E+05$ & 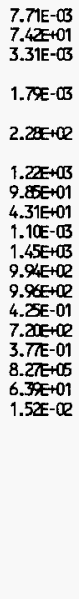 & 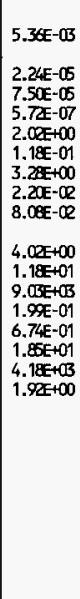 & $3.935+02$ \\
\hline
\end{tabular}




\section{WHC-SD-WM-TI-774 Rev. 0 \\ TWRS PRIVATIZATION PROCESS TECHNICAL BASELINE}

Table 11 Phase 1 In-Tank Sludge Washing of DST 241-AZ-102 (60\% Retrieval) (12 sheets)

\begin{tabular}{|c|c|c|c|c|c|c|c|c|c|c|}
\hline STREAM NANE & 11 & 12 & 13 & 14 & 15 & 16 & 17 & 18 & 19 & 20 \\
\hline \multicolumn{11}{|l|}{ SOLID COMPAEMTS } \\
\hline Total Mass Flow (kg) & & $1.12 \pi+\infty 5$ & $3.69+\infty$ & $1.12+05$ & & $1.12 z+05$ & $6.75 E-01$ & $1.68 E+05$ & & $2.67 t+05$ \\
\hline \multicolumn{11}{|l|}{ Radiourclides (Ci) } \\
\hline $\begin{array}{l}\text { Amr-241 } \\
\text { c-14 } \\
0 m-244 \\
\text { Cs-137 } \\
B a-137 \\
\text { Eur-154 } \\
\text { Np-237 } \\
\text { Pur } 239 \\
\text { Pur-240 } \\
\text { Pur-241 } \\
\text { Sr-90 } \\
\text { Y-90 } \\
\text { Tc-99 } \\
\text { Total aries }\end{array}$ & & $\begin{array}{l}1.00 E+04 \\
7.43 E+00 \\
3.73 E+02 \\
1.72 E+05 \\
1.63 E+05 \\
\\
2.87 E+\infty 2 \\
\\
1.7 \pi E+06 \\
1.7 \pi E+06 \\
8.7 \pi E+01 \\
3.88 E+16\end{array}$ & $\begin{array}{l}3.30 E+01 \\
2.45 E-02 \\
1.07 E+\infty 0 \\
5.67 E+\infty 2 \\
5.38 E+02 \\
\\
9.48 E-01 \\
\\
5.83 E+03 \\
5.83 E+13 \\
2.90 E-01 \\
1.28 E+104\end{array}$ & $\begin{array}{l}9.96+03 \\
7.40 E+00 \\
3.22 E+08 \\
1.71 E+06 \\
1.63 E+06 \\
\\
2.84 E+02 \\
\\
1.76 E+06 \\
1.76 E+06 \\
8.74 E+01 \\
3.87 E+106\end{array}$ & & $\begin{array}{l}9.98 E+03 \\
7.40 E+00 \\
3.22 E+102 \\
1.71 E+05 \\
1.63 E+05 \\
\\
2.86 E+02 \\
\\
1.76 E+06 \\
1.76 E+06 \\
8.74 E+01 \\
3.87 E+06\end{array}$ & $\begin{array}{l}5.63 E+\infty 0 \\
1.40 E+00 \\
5.19 E+04 \\
5.19 E+04 \\
1.04 E+105\end{array}$ & & & $\begin{array}{l}1.01 \mathrm{E}+04 \\
3.2 \mathrm{E}+02 \\
2.31 \mathrm{E}+06 \\
2.19 \mathrm{E}+06 \\
1.81 \mathrm{E}-02 \\
1.35 \mathrm{E}-07 \\
2.93 \mathrm{E}+02 \\
1.40 \mathrm{E}+00 \\
2.27 \mathrm{E}-03 \\
1.81 \mathrm{E}+06 \\
1.81 \mathrm{E}+06 \\
2.82 \mathrm{E}+02 \\
8.14 \mathrm{E}+06\end{array}$ \\
\hline
\end{tabular}

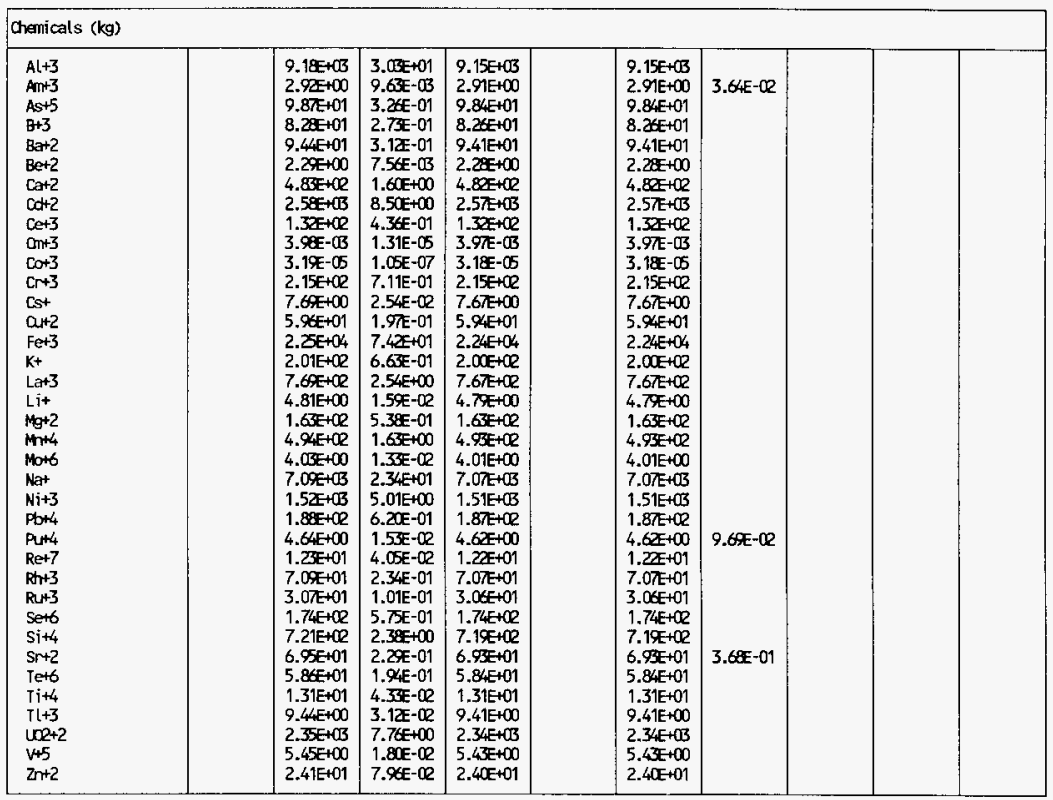




\section{WHC-SD-WM-TI-774 Rev. 0 \\ TWRS PRIVATIZATION PROCESS TECHNICAL BASELINE}

Table 11 Phase 1 In-Tank Sludge Washing of DST 241-AZ-102 (60\% Retrieval) (12 sheets)

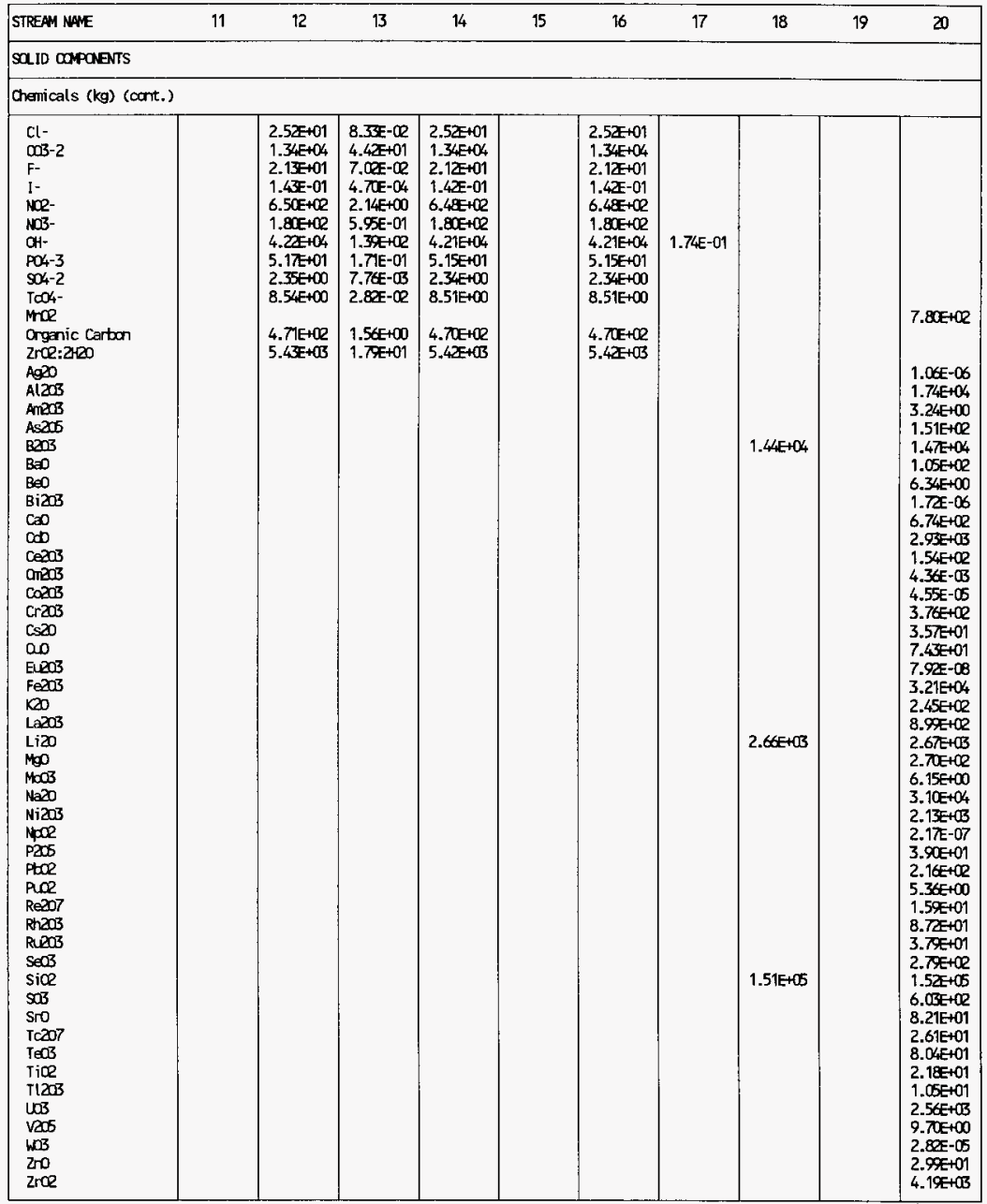




\section{WHC-SD-WM-TI-774 Rev. 0 \\ TWRS PRIVATIZATION PROCESS TECHNICAL BASELINE}

Table 11 Phase 1 In-Tank Sludge Washing of DST 241-AZ-102 (60\% Retrieva1) (12 sheets)

\begin{tabular}{|l|c|}
\hline STREAM MANE & 21 \\
\hline \multicolumn{2}{|l|}{} \\
\hline LIQUID COMANaNTS \\
\hline Total Mass Flow $(\mathrm{kg})$ & $8.75 E+05$ \\
Volume (L) & $8.75 E+05$ \\
Specific Gravity & $1.00 \mathrm{E}+00$ \\
\hline
\end{tabular}

\begin{tabular}{|l|l|}
\hline Radionucl ides (Ci) \\
\hline An-241 \\
C-14 \\
Cs-137 \\
Ba-137 \\
Eur-154 \\
Np-237 \\
Pur-239 \\
Pur-240 \\
Pur241 \\
Sr-90 \\
Y-90 \\
Tc-99 \\
Total aries \\
\hline
\end{tabular}

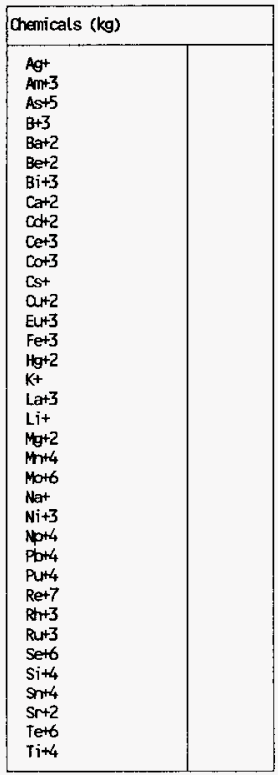


WHC-SD-WM-TI-774 Rev. 0

TWRS PRIVATIZATION PROCESS TECHNICAL BASELINE

Table 11 Phase 1 In-Tank Sludge Washing of DST 241-AZ-102 (60\% Retrieval) (12 sheets)

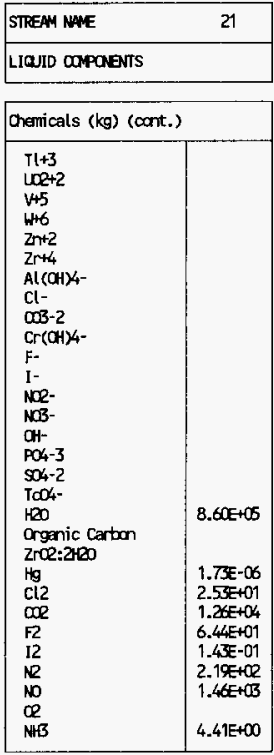


WHC-SD-WM-TI-774 ReV. 0

TWRS PRIVATIZATION PROCESS TECHNICAL BASELINE

Table 11 Phase 1 In-Tank Sludge Washing of DST 241-AZ-102 (60\% Retrieval) (12 sheets)

\begin{tabular}{|c|c|}
\hline STREAM NAE & 21 \\
\hline \multicolumn{2}{|l|}{ Sa ID COPOENTS } \\
\hline Total Mass Flow $(\mathrm{kg})$ & \\
\hline \multicolumn{2}{|l|}{ Radionuclides (Ci) } \\
\hline $\begin{array}{l}\text { Am-241 } \\
\text { C-14 } \\
\text { Om-244 } \\
\text { Cs-137 } \\
\text { Ba-137 } \\
\text { Eu-154 } \\
\text { No- }-257 \\
\text { Pur } 239 \\
\text { Pur-240 } \\
\text { Pur-241 } \\
\text { Sr-90 } \\
Y-90 \\
\text { Tc-99 } \\
\text { Total Cries }\end{array}$ & \\
\hline
\end{tabular}

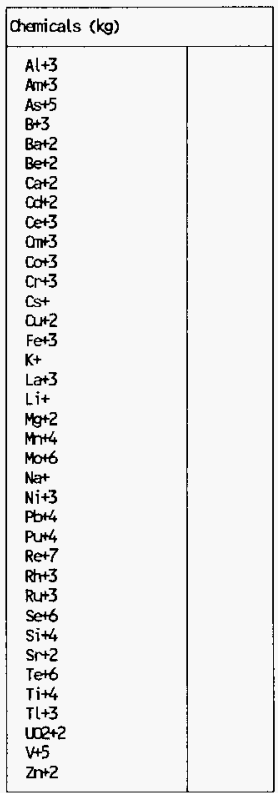


WHC-SD-WM-TI-774 Rev. 0

TWRS PRIVATIZATION PROCESS TECHNICAL BASELINE

Table 11 Phase 1 In-Tank Sludge Washing of DST 241-AZ-102 (60\% Retrieval) (12 sheets)

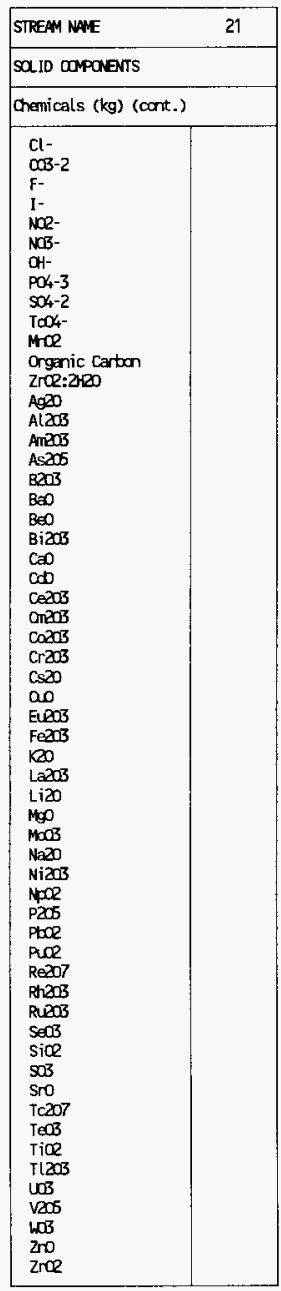


Figure 12. In-Tank Sludge Washing of Double-Shell Tank 241-AY-102/SST 241-C-106

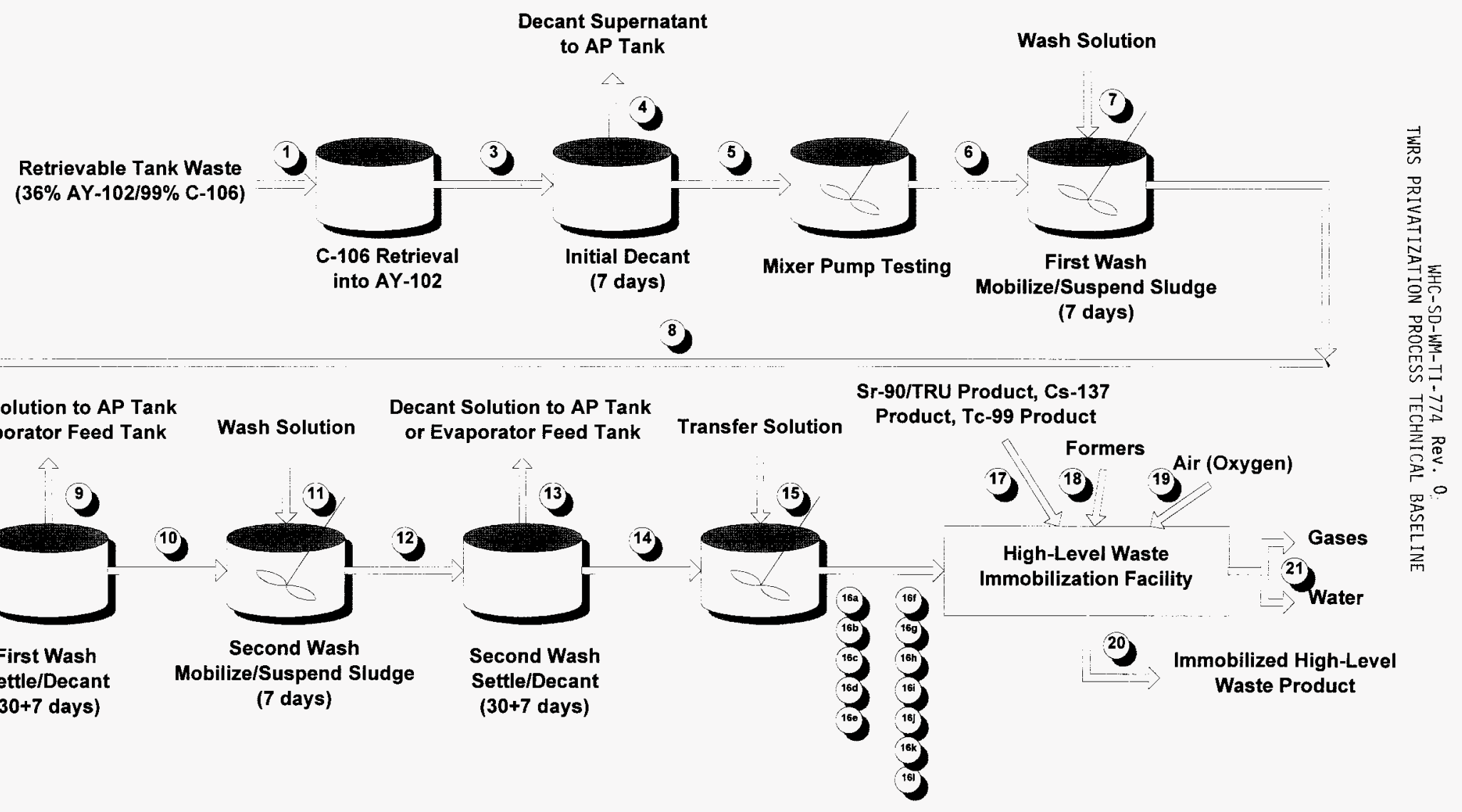


WHC-SD-WM-TI-774 Rev. 0

TWRS PRIVATIZATION PROCESS TECHNICAL BASELINE

Table 12 Phase 1 In-Tank Sludge Washing of DST 241-AY-102/SST 241-C-106 (36\%/99\% Retrieval)

(12 sheets)

\begin{tabular}{|c|c|c|c|c|c|c|c|c|c|c|}
\hline STREAM NANE & 1 & 2 & 3 & 4 & 5 & 6 & 7 & 8 & 9 & 10 \\
\hline \multicolumn{11}{|l|}{ LIQUID COPAENTS } \\
\hline $\begin{array}{l}\text { Total Mass Flow (kg) } \\
\text { Volume (L) } \\
\text { Specific Gravity }\end{array}$ & $\begin{array}{l}3.90 E+06 \\
3.87 E+06 \\
1.01 E+00\end{array}$ & & $\begin{array}{l}3.90 E+06 \\
3.87 E+06 \\
1.01 E+\infty\end{array}$ & $\begin{array}{l}2.46 F+06 \\
2.44 E+06 \\
1.01 E+\infty 0\end{array}$ & $\begin{array}{l}1.44 E+06 \\
1.43 E+06 \\
1.01 E+00\end{array}$ & $\begin{array}{l}1.44 E+06 \\
1.43 E+06 \\
1.01 E+00\end{array}$ & $\begin{array}{l}1.45 E+O S \\
1.44 E+O S \\
1.00 E+O O\end{array}$ & $\begin{array}{l}2.89 E+06 \\
2.87 E+06 \\
1.00 E+\infty\end{array}$ & $\begin{array}{l}1.45 E+06 \\
1.45 E+06 \\
1.00 E+00\end{array}$ & $\begin{array}{l}1.43 E+06 \\
1.43 E+06 \\
1.00 E+\infty 0\end{array}$ \\
\hline
\end{tabular}

\begin{tabular}{|c|c|c|c|c|c|c|c|c|}
\hline \multicolumn{9}{|c|}{ Radianul ides (Ci) } \\
\hline Amr 241 & $1.55 E+01$ & $1.55 E+01$ & $9.78 E+\infty$ & $5.72=00$ & $5 . \pi a+\infty$ & $5.7 a 100$ & $2.88 E+00$ & $2.84 E+\infty 0$ \\
\hline $0 \pi-244$ & $1.34 E-\infty R$ & $1.34 E-\infty$ & 8.48E-03 & 4.96E-03 & 4.96E-CB & 4.94年-0B & $2.50 \mathrm{E}-\mathrm{CB}$ & $2.46 E-13$ \\
\hline $\cos 60$ & $4.57 \mathrm{E}+00$ & $4.57 \mathrm{E}+\infty$ & $2.88 E+\infty 0$ & $1.6 \%+\infty 0$ & $1.6 E+\infty$ & $1.6 \mathscr{E}+\infty$ & $8.49-01$ & $8.38 \pm-01$ \\
\hline Cs-137 & $6.86 E+04$ & $6.86 E+04$ & $4.35+04$ & $2.53 \times 104$ & $2.53 \mathrm{E}+04$ & $2.53 \mathrm{E}+0_{4}$ & $1.28 E+04$ & $1.2 \mathrm{E}+04$ \\
\hline $\mathrm{Ba}-137$ & $6.52 E+04$ & $6.52 E+04$ & 4.11E+0 & $2.41 E+04$ & $2.41 E+04$ & $2.41 E+04$ & $1.21 E+04$ & $1.20 E+\alpha_{4}$ \\
\hline \multicolumn{9}{|l|}{ Eur-154 } \\
\hline PurZ39 & $1.54 E+0 R$ & $1.54 E+O R$ & 9.त्रि+01 & $5.68 E+01$ & $5.68 E+01$ & $5.68 \mathrm{E}+01$ & 2.86E+01 & $2.82 E+01$ \\
\hline \multicolumn{9}{|l|}{ Pu-240 } \\
\hline $\mathrm{Sr}-90$ & $3.72 E+0 B$ & 3. TaE+13 & $2.34 E+03$ & $1.37 \mathrm{E}+\mathrm{CB}$ & $1.37 E+03$ & 1.37 HOB & $6.90 \mathrm{E}+\mathrm{R}$ & $6.81 E+C 2$ \\
\hline$Y-90$ & $3.72+0 B$ & $3.72 \mathrm{E}+13$ & $2.34 \mathrm{E}+03$ & $1.37 E+03$ & $1.37 \mathrm{E}+03$ & $1.3 \pi E+03$ & $6.90 E+C R$ & $6.81 E+C 2$ \\
\hline Tc-99 & $6.16 E+1$ & 6. $16 \mp+01$ & 3.89+01 & 2.27E+01 & 2. $27 \mathrm{E}+01$ & $2.27 \mathrm{E}+01$ & $1.14 E+01$ & 1.13E+01 \\
\hline Total aries & $1.4 Z \mathbf{Z}+06$ & $1.4 Z \mathbf{Z}+05$ & $8.925+04$ & $5.27 \mathrm{~F}+04$ & $5.27+04$ & $5.22 E 104$ & $2.63 E+04$ & 2.59E+04 \\
\hline
\end{tabular}

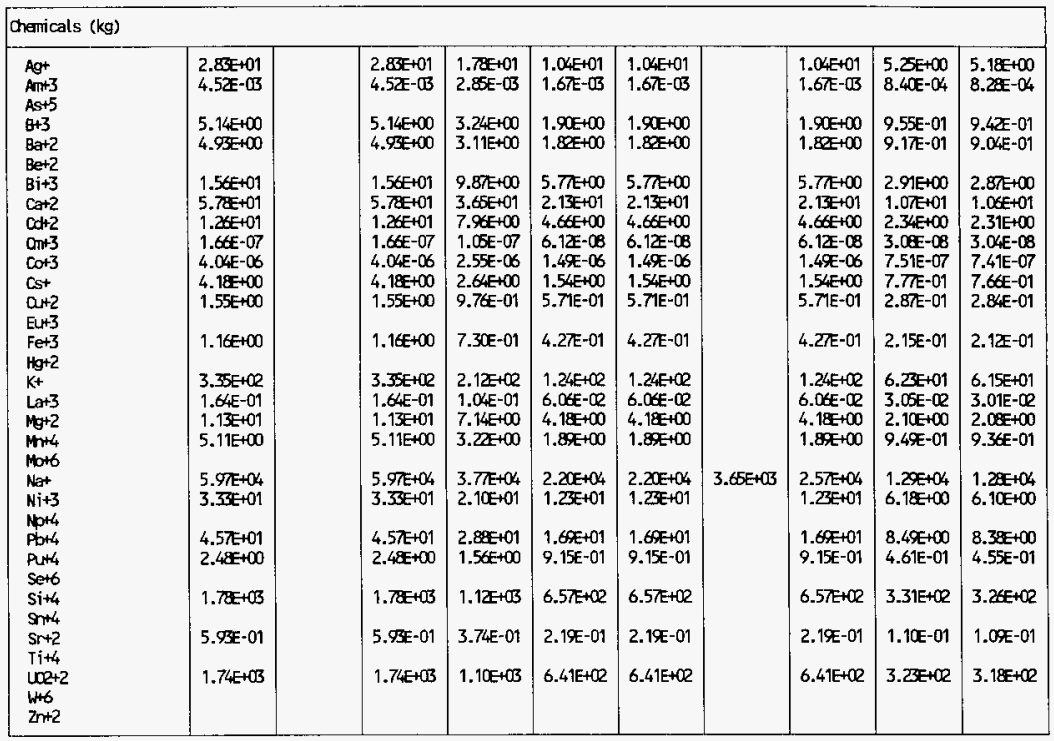




\section{WHC-SD-WM-TI-774 Rev. 0 \\ TWRS PRIVATIZATION PROCESS TECHNICAL BASELINE}

Table 12 Phase 1 In-Tank Sludge Washing of DST 241-AY-102/241-C-106 (36\%/99\% Retrieval) (12 sheets)

\begin{tabular}{|c|c|c|c|c|c|c|c|c|c|c|}
\hline STREAM NAME & 1 & 2 & 3 & 4 & 5 & 6 & 7 & 8 & 9 & 10 \\
\hline
\end{tabular}

\begin{tabular}{|c|c|c|c|c|c|c|c|c|c|}
\hline \multicolumn{10}{|c|}{ Chenicals (kg) (cant.) } \\
\hline 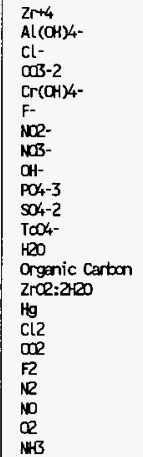 & $\begin{array}{l}1.17 E+02 \\
9.50 E+01 \\
2.61 E+03 \\
1.47 E+02 \\
6.26 E+00 \\
3.28 E+03 \\
1.65 E+03 \\
7.11 E+03 \\
1.72 E+03 \\
5.96 E+03 \\
6.00 E+00 \\
3.80 E+06 \\
6.1 Z E+03 \\
4.94 E-01\end{array}$ & $\begin{array}{l}1.17 E+02 \\
9.50 E+01 \\
2.61 E+03 \\
1.47 E+02 \\
6.26 E+02 \\
3.28 E+013 \\
1.65 E+03 \\
7.11 E+03 \\
1.72 E+013 \\
5.90 E+013 \\
6.00 E+00 \\
3.80 E+06 \\
6.12 E+013 \\
4.94 E-01\end{array}$ & $\begin{array}{l}7.36 \mathrm{E}+01 \\
6.00 \mathrm{E}+01 \\
1.65 \mathrm{E}+03 \\
\\
9.27 \mathrm{E}+01 \\
3.95 \mathrm{E}+02 \\
2.0 \mathrm{E}+03 \\
1.04 \mathrm{E}+03 \\
4.49 \mathrm{E}+03 \\
1.09 \mathrm{E}+03 \\
3.77 \mathrm{E}+03 \\
3.78 \mathrm{E}+\infty \\
2.40 \mathrm{E}+06 \\
3.86 \mathrm{E}+03 \\
3.12 \mathrm{E}-01\end{array}$ & $\begin{array}{l}4.31 E+01 \\
3.51 E+01 \\
9.63 E+02 \\
5.42 E+01 \\
2.31 E+\infty 2 \\
1.21 E+03 \\
6.09 E+\infty 2 \\
2.63 E+03 \\
6.35 E+02 \\
2.21 E+03 \\
2.21 E+\infty 0 \\
1.40 E+06 \\
2.26 E+03 \\
1.88 E-01\end{array}$ & $\begin{array}{l}4.31 E+01 \\
3.51 E+01 \\
9.63 E+02 \\
5.42 E+01 \\
2.31 E+02 \\
1.21 E+03 \\
6.09 E+02 \\
2.63 E+03 \\
6.35 E+12 \\
2.21 E+03 \\
2.21 E+\infty 0 \\
1.40 E+06 \\
2.26 E+03 \\
1.82 E-01\end{array}$ & $\begin{array}{l}6.64 E+02 \\
2.46 E+13 \\
1.44 E+06\end{array}$ & 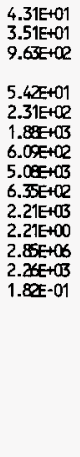 & $\begin{array}{l}2.17 \mathrm{E}+01 \\
1.77 \mathrm{E}+01 \\
4.85 \mathrm{E}+02 \\
2.73 \mathrm{E}+01 \\
1.16 \mathrm{E}+02 \\
9.44 \mathrm{E}+02 \\
3.07 \mathrm{E}+02 \\
2.56 \mathrm{E}+03 \\
3.20 \mathrm{E}+02 \\
1.11 \mathrm{E}+03 \\
1.1 \mathrm{EE}+00 \\
1.43 \mathrm{E}+06 \\
1.14 \mathrm{E}+13 \\
9.18 \mathrm{E}-102\end{array}$ & $\begin{array}{l}2.14 \mathrm{E}+01 \\
1.74 \mathrm{E}+01 \\
4.72 \mathrm{E}+\infty 2 \\
2.69 \mathrm{E}+01 \\
1.15 \mathrm{E}+\infty 2 \\
9.32 \mathrm{E}+02 \\
3.03 \mathrm{E}+\infty 2 \\
2.52 \mathrm{E}+03 \\
3.15 \mathrm{E}+\infty 2 \\
1.10 \mathrm{E}+103 \\
1.10 \mathrm{E}+\infty 0 \\
1.41 \mathrm{E}+06 \\
1.12 \mathrm{E}+103 \\
9.06 \mathrm{E}-\infty 2\end{array}$ \\
\hline
\end{tabular}


WHC-SD-WM-TI-774 Rev. 0

TWRS PRIVATIZATION PROCESS TECHNICAL BASELINE

Table 12 Phase 1 In-Tank Sludge Washing of DST 241-AY-102/241-C-106 (36\%/99\% Retrieval) (12 sheets)

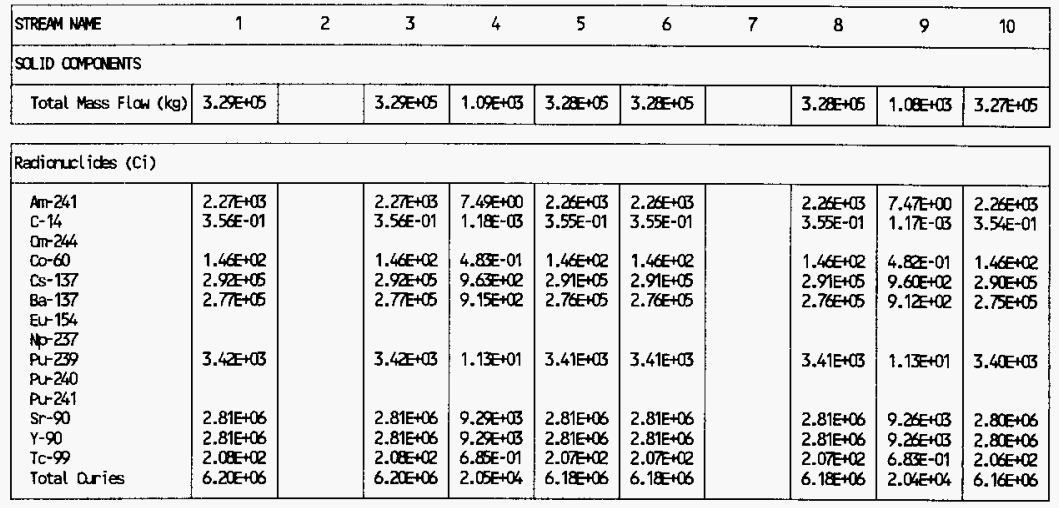

\begin{tabular}{|c|c|c|c|c|c|c|c|c|}
\hline \multicolumn{9}{|c|}{ Chemicals $(\mathrm{kg})$} \\
\hline $\mathrm{Ag}+$ & $9.35 E+12$ & $9.35 E+1 R$ & $3.08++\infty$ & $9.30 E+\infty 2$ & $9.30 E+02$ & $9.30=+\infty$ & $3.07 \pi+\infty 0$ & $9.27 E+\infty 2$ \\
\hline $\mathrm{Al}+3$ & $4.5 x+104$ & $4.52=+04$ & $1.49=+10$ & $4.50 E+04$ & $4.50 E+04$ & $4.50 \mathrm{E}+\alpha_{4}$ & $1.49 \mathrm{E}+0$ & $4-49+04$ \\
\hline Am+3 & $6.6 \pi-01$ & $6.62 \mathbb{E}-01$ & 2.18E-03 & $6.60 \mathrm{E}-01$ & $6.60 \mathrm{E}-01$ & $6.60 \mathrm{E}-01$ & $2.18 \mathrm{E}-03$ & $6.58 \mathrm{PE}-01$ \\
\hline$B+3$ & $1.65 E+01$ & $1.68 E+01$ & $5.45 E-12$ & $1.65 \mathrm{E}+01$ & $1.65 E+01$ & $1.65 E+01$ & $5.43 E-\mathbb{R}$ & $1.64 \mathrm{E}+01$ \\
\hline $\mathrm{Be}+2$ & 5.26E+03 & 5. $\angle C E+C B$ & $1.74 E+01$ & $5.24 E+103$ & 5. $24 \mathrm{E}+103$ & $5.24 \mathrm{E}+03$ & 1.73E+01 & $5.2 Z^{2}+03$ \\
\hline $\mathrm{Bi}+3$ & 5.2TE+CR & $5.27 t+102$ & 1.74E+ +0 & $5.2 \mathrm{EE}+\infty$ & $5.28 E+0 R$ & $5 . \mathrm{BE}+\infty$ & $1.7 \leq+00$ & $5,24=+02$ \\
\hline $\mathrm{Ca}+2$ & $1.33 E+04$ & $1.33 E+06$ & $4.39+101$ & $1.35 \mathrm{E}+0_{4}$ & $1.35 E+04$ & $1.3 \mathrm{E}+04$ & 4.J8E+01 & $1.325+04$ \\
\hline $\operatorname{cod}+2$ & $4.03 E+102$ & 4. $03 E+02$ & $1.35 E+100$ & 4.01EHQR & 4.01E+102 & 4.01E+102 & $1.32+\infty 0$ & $4.00 E+\infty$ \\
\hline $\cot 3$ & $5.08+\infty$ & $5.08 E+100$ & $1.68 E-\infty R$ & $5.06 E+\infty 0$ & $5.06 E+100$ & $5.06 E+100$ & $1.6 \bar{\pi}-\mathbb{Q R}$ & $5,05 E+\infty 0$ \\
\hline $\mathrm{C} \Gamma+3$ & $1.21 E+03$ & $1.21 E+03$ & $3.99+\infty$ & $1.21 E+03$ & $1.21 \mathrm{E}+03$ & $1.21 E+0 B$ & $3.98+\infty$ & $1.20 \mathrm{C}+\mathrm{CB}$ \\
\hline $\mathrm{Cs}+$ & $1.78+01$ & $1.7 x=01$ & $5.87 \mathrm{E}-02$ & $1.7 \pi=01$ & $1.7 \pi+01$ & $1.77=01$ & 5. $85 E-12$ & $1.7 \pi E+01$ \\
\hline$a+2$ & $1.34 E+\infty$ & $1.34 E+\infty$ & $4.4 x-01$ & $1.34 E+02$ & $1.34 \mathrm{E}+0$ & $1.34 \mathrm{E}+Q 2$ & 4.41E-01 & $1.33 E+02$ \\
\hline $\mathrm{Fe}+3$ & $5.945+04$ & $5.94 E+04$ & $1.96 E+\infty 2$ & $5.92 x+04$ & $5.92=04$ & $5.92 E+04$ & $1.95 E+C 2$ & $5.90 \mathrm{c}+04$ \\
\hline$K+$ & $1.50 \mathrm{E}+03$ & $1.50 E+03$ & $4.93 E+00$ & $1.49+03$ & $1.49+03$ & $1.49+03$ & $4.98 \mathrm{~F}+00$ & $1.49 \mathrm{E}+03$ \\
\hline $\mathrm{La}+3$ & $2.07 t+\infty 2$ & $2.07 \pm+\infty 2$ & $6.84 \mathrm{E}-01$ & $2.07=0 R$ & $2.07 E+\infty$ & $2.0 \pi+\infty 2$ & $6.82 \mathrm{x}-01$ & $2.06 E+02$ \\
\hline $\mathrm{Mg}+2$ & $6.91 \mathrm{E}+03$ & $6.91 \mathrm{E}+13$ & 2. $28 E+01$ & $6.89+03$ & $6.89+13$ & $6.89 \times+03$ & $2.27=01$ & $6.87 E+03$ \\
\hline Mn+4 & $2.43 E+C 13$ & $2.43 E+03$ & $8.01 E+\infty 0$ & $2.4 Z E+13$ & $2.42+03$ & $2.42=003$ & $7.99+00$ & 2.41E+013 \\
\hline $\mathrm{Na}+$ & $8.4 \mathrm{I}+04$ & $8.4 x+04$ & 2. $\pi E+\infty$ & $8.40 E+04$ & $8.40=+04$ & $8.40 E+04$ & $2.7 \pi+\infty$ & $8.37 \mathrm{E}+04$ \\
\hline $\mathrm{Ni}+3$ & $1.16 E+03$ & 1. $16 E+0 B$ & $3.82+00$ & $1.15 E+C B$ & $1.15 E+03$ & $1.15 \mathrm{E}+\mathbb{1 0}$ & $3.81=+00$ & $1.15 \mathrm{E}+13$ \\
\hline$P b+4$ & $2.51 \mathrm{E}+03$ & $2.51 \mathrm{E}+0 \mathrm{BS}$ & $8.27 E+\infty 0$ & $2.50 \mathrm{E}+0 \mathrm{CB}$ & $2.50 E+03$ & $2.5 C E+03$ & $8.24 E+00$ & $2.49+13$ \\
\hline$P d+2$ & $1.69 E+Q R$ & $1.69+02$ & $5.56 \mathrm{E}-01$ & $1.68 \mathrm{E}+02$ & $1.68 \mathrm{E}+0 \mathrm{R}$ & $1.6 \mathbb{E E}+\mathbb{R}$ & $5.54 E-01$ & $1.6 \pi+\infty 2$ \\
\hline Put & 5.5x $x+0 t$ & $5.52 Z+01$ & $1.88 \pm-01$ & $5.50 \mathrm{E}+01$ & $5.50 \mathrm{E}+01$ & $5.50 E+01$ & $1.82 \mathrm{E}-01$ & $5.49+01$ \\
\hline $\mathrm{Si}+4$ & $7.64 E+04$ & $7.64 E+04$ & $2.5 x+02$ & $7.61 E+04$ & $7.61 \mathrm{E}+04$ & $7.61 E+04$ & $2.51 E+\infty$ & $7.59+04$ \\
\hline $5 r+2$ & $1.67+\infty 2$ & $1.67 t+\infty$ & $5.51 \mathrm{E}-01$ & $1.66 E+102$ & $1.66 E+\infty e$ & $1.66 E+0 R$ & $5.49-01$ & $1.66 E+\mathbb{Q}$ \\
\hline $102+2$ & $9.4 \pi+\infty 2$ & $9.4 \pi+02$ & $3.11 E+\infty$ & $9.39+02$ & $9.39+02$ & $9.39+0 R$ & 3. $1 \mathrm{EE}+\infty$ & $9.36 E+02$ \\
\hline $2 n+2$ & $4.89+01$ & $4.89+01$ & $1.61 \mathrm{E}-01$ & $4.87 E+01$ & $4.87 E+01$ & $4.87 \mathrm{E}+01$ & 1.61E-01 & $4.86 E+01$ \\
\hline $2 r+4$ & 2. $20 E+03$ & 2. $20=01$ & $7.27=+\infty$ & $2.20 \mathrm{E}+03$ & $2.20 E+13$ & $2.20 E+C B$ & $7.5 E+\infty$ & 2.19t+03 \\
\hline $\mathrm{CL}=$ & $5.64 E+01$ & $5.64 E+01$ & 1.86E-01 & $5.62+01$ & $5.62=01$ & $5.62 \pm+01$ & $1.84 \mathrm{E}-01$ & $5.61 E+01$ \\
\hline $\mathrm{F}-$ & 6.71EE+01 & $6.71 E+01$ & $2.22 E-01$ & $6.696+01$ & $6.68 E+01$ & $6.69 \mathrm{E}+01$ & $2.21 E-01$ & $6.67 \bar{l}+01$ \\
\hline NO2- & 1. $2 \mathrm{EE}+01$ & 1.ZEE+01 & $4.13 E-\infty R$ & $1.25+01$ & $1.25 E+01$ & 1. $\mathrm{EE}+01$ & $4.12 \mathrm{E}-02$ & $1.25 E+01$ \\
\hline $\mathrm{NOS}^{-}$ & 1. ORE +01 & $1.02 E+01$ & $3.36 E-12$ & $1.08 \pm+01$ & $1.0 \overline{2}+01$ & $1.08 \mathrm{E}+01$ & $3.35 E-02$ & $1.01 E+01$ \\
\hline $\mathrm{OH}-$ & $1.36 E+04$ & $1.36 E+04$ & 4. $\angle 8 E+01$ & $1.35 E+04$ & $1.35 E+104$ & $1.35 E+04$ & $4.46 E+01$ & $1.35 E+04$ \\
\hline $\mathrm{PO}_{4}-3$ & 7.9 $4 \mathrm{E}+\mathrm{CB}$ & $7.94 E+03$ & $2.62 \mathbb{F}+01$ & $7.91 \mathrm{E}+\mathrm{QB}$ & $7.91 \mathrm{E}+03$ & 7.91E+03 & $2.61 E+01$ & $7.89 x+03$ \\
\hline $\mathrm{SO}_{4}-2$ & $1 . \not z+\infty$ & 1. $26 E+02$ & 4.16E-01 & 1. ZXE+CR & 1. $26 E+02$ & 1.ZKE+QR & 4-15E-01 & $1.25 \mathrm{E}+0$ \\
\hline $\mathrm{T}_{0} \mathrm{O}_{4}-$ & $2.08+01$ & $2.0 x+01$ & $6.67 \mathrm{~T}-\mathscr{Q}$ & $2.02=01$ & $2.02 z+01$ & $2.02 E+01$ & $6.65 E-02$ & $2.01 E+01$ \\
\hline MnOE & & & & & & & & \\
\hline
\end{tabular}


WHC-SD-WM-TI-774 Rev. 0

TWRS PRIVATIZATION PROCESS TECHNICAL BASELINE

Table 12 Phase 1 In-Tank Sludge Washing of DST 241-AY-102/241-C-106 (36\%/99\% Retrieval) (12 sheets)

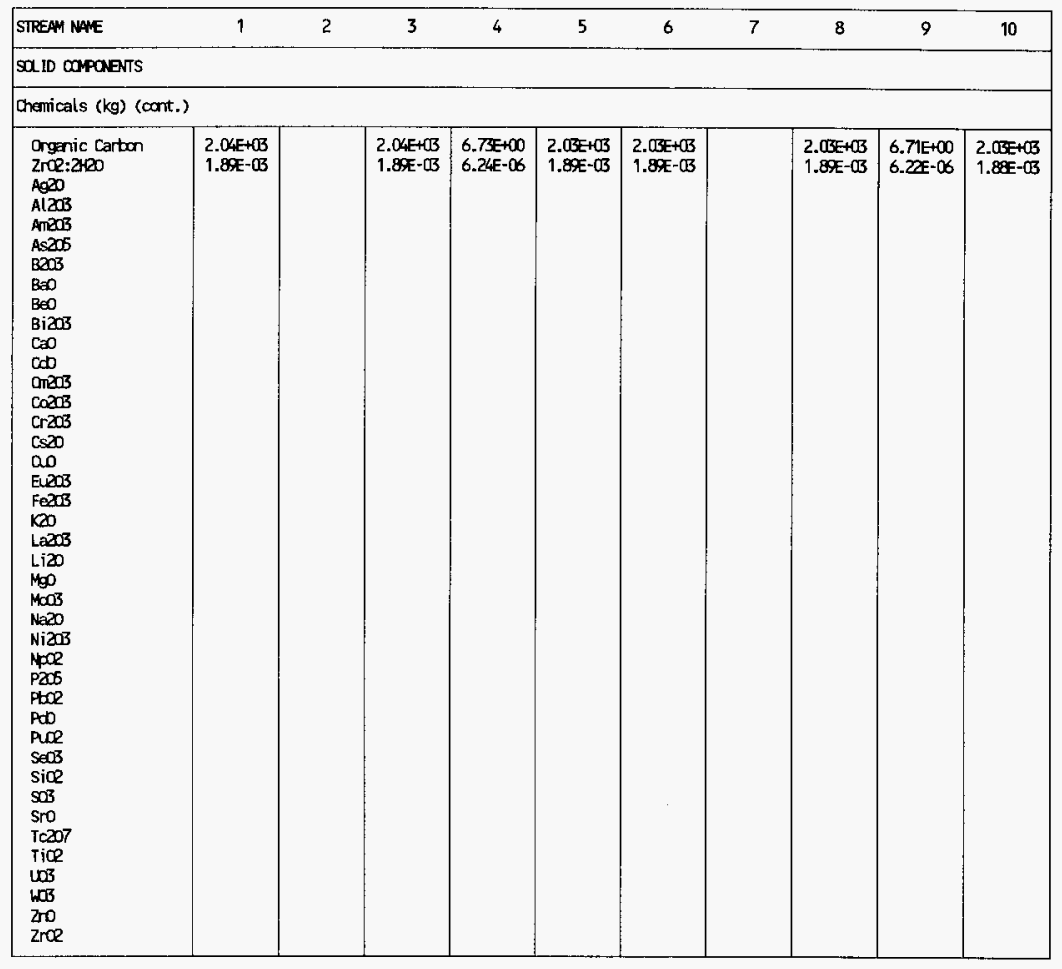


WHC-SD-WM-TI-774 Rev. 0

TWRS PRIVATIZATION PROCESS TECHNICAL BASELINE

Table 12 Phase 1 In-Tank Sludge Washing of DST 241-AY-102/241-C-106 (36\%/99\% Retrieval) (12 sheets)

\begin{tabular}{|c|c|c|c|c|c|c|c|c|c|c|}
\hline STREAM NAME & 11 & 12 & 13 & 14 & 15 & 16 & 17 & 18 & 19 & 20 \\
\hline \multicolumn{11}{|l|}{ LIOID COMPOENIS } \\
\hline $\begin{array}{l}\text { Total Mass flow (kg) } \\
\text { Volume (L) } \\
\text { Specific Gravity }\end{array}$ & $\begin{array}{l}1.45 E+06 \\
1.44 E+06 \\
1.00 E+00\end{array}$ & $\begin{array}{l}2.80=06 \\
2.87 E+06 \\
1.00 E+00\end{array}$ & $\begin{array}{l}1.45 E+\infty \\
1.45 E+\infty \\
1.00 E+\infty\end{array}$ & $\begin{array}{l}1.43 E+\infty \\
1.4 \mathrm{E}+06 \\
1.00 \mathrm{E}+00\end{array}$ & $\begin{array}{l}3.7 x+06 \\
3.7 x+06 \\
1.00 E+\infty 0\end{array}$ & $\begin{array}{l}5.16 E+06 \\
5.15 E+06 \\
1.00 E+\infty\end{array}$ & $\begin{array}{l}6.80 E+04 \\
2.85 E+04 \\
2.41 E+00\end{array}$ & & $\begin{array}{l}1.95 E+05 \\
1.95 E+05 \\
1.00 E+00\end{array}$ & \\
\hline
\end{tabular}

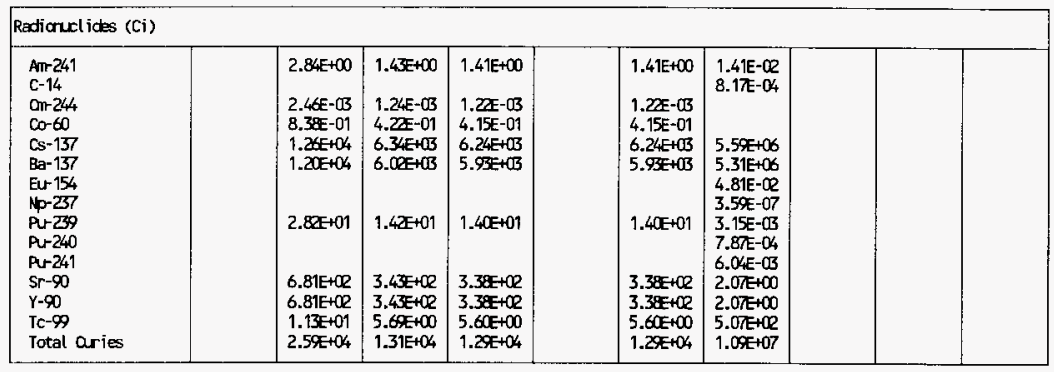

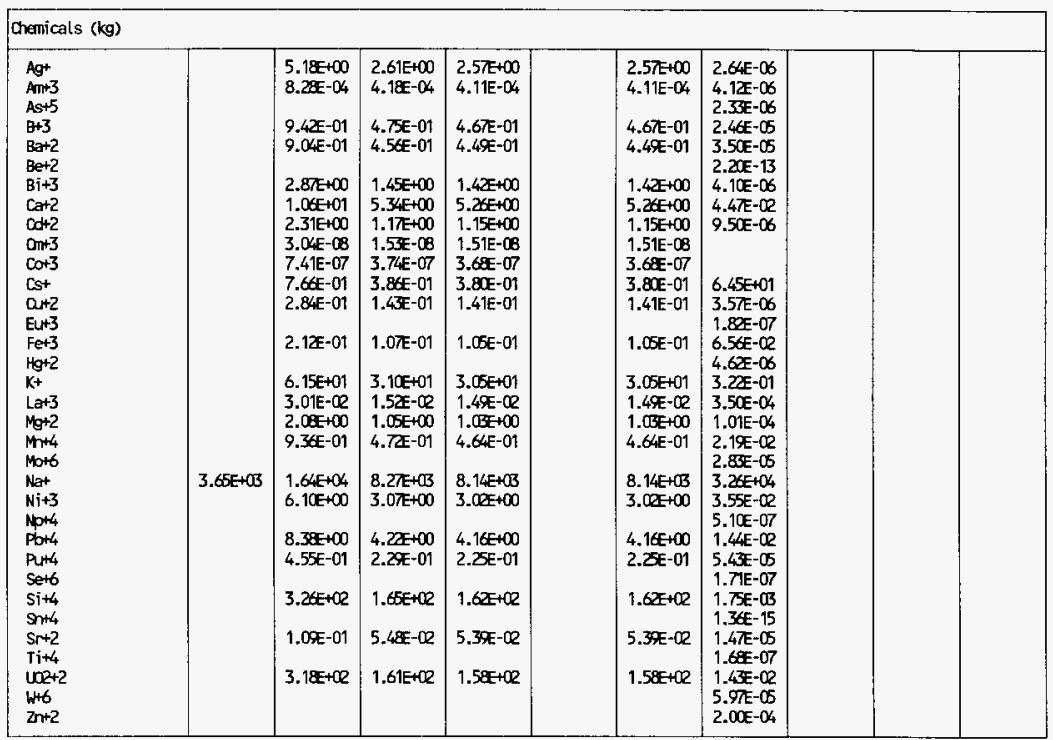




\section{WHC-SD-WM-TI-774 Rev. 0 \\ TWRS PRIVATIZATION PROCESS TECHNICAL BASELINE}

Table 12 Phase 1 In-Tank Sludge Washing of DST 241-AY-102/241-C-106 (36\%/99\% Retrieval) (12 sheets)

\begin{tabular}{|c|c|c|c|c|c|c|c|c|c|c|}
\hline ISTREAM NAE & 11 & 12 & 13 & 14 & 15 & 16 & 17 & 18 & 19 & 20 \\
\hline
\end{tabular}

\begin{tabular}{|c|c|c|c|c|c|c|c|c|}
\hline \multicolumn{9}{|c|}{ Whemicals (kg) (cont.) } \\
\hline 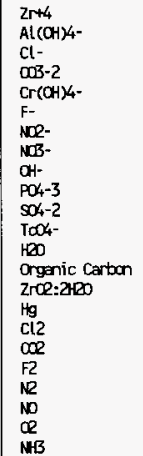 & $\begin{array}{l}6.64 E+C R \\
2.46 E+013 \\
1.44 E+06\end{array}$ & $\begin{array}{l}2.14 E+01 \\
1.74 E+01 \\
4.78 E+0 R \\
\\
2.69 E+01 \\
1.15 E+02 \\
1.60 E+03 \\
3.0 E E+02 \\
4.9 E+03 \\
3.15 E+02 \\
1.10 E+03 \\
1.10 E+\infty 0 \\
2.05 E+06 \\
1.12 E+03 \\
9.0 E-\infty 2\end{array}$ & $\begin{array}{l}1.08 \mathrm{E}+01 \\
8.78 \mathrm{E}+00 \\
2.41 \mathrm{E}+\infty 2 \\
1.36 \mathrm{E}+01 \\
5.78 \mathrm{E}+01 \\
8.04 \mathrm{E}+\infty \\
1.53 \mathrm{E}+02 \\
2.51 \mathrm{E}+03 \\
1.56 \mathrm{E}+02 \\
5.53 \mathrm{E}+02 \\
5.54 \mathrm{E}-01 \\
1.44 \mathrm{E}+06 \\
5.65 \mathrm{E}+\infty \\
4.57 \mathrm{E}-\infty\end{array}$ & 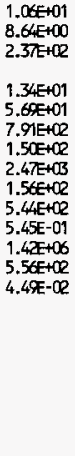 & $3.7 x+06$ & $\begin{array}{l}1.06 E+01 \\
8.64 E+\infty 0 \\
2.37 E+\infty 2 \\
1.34 E+01 \\
5.6 E+01 \\
7.91 E+\infty 2 \\
1.50 E+\infty R \\
2.47 E+03 \\
1.56 E+02 \\
5.44 E+\infty R \\
5.45 E-01 \\
5.15 E+\infty 6 \\
5.56 E+\infty R \\
4.4 C E-\infty 2\end{array}$ & $\begin{array}{l}1.53 E-06 \\
5.38 E+00 \\
3.15 E-01 \\
8.75 E+\infty 0 \\
5.87 E-02 \\
2.15 E-01 \\
1.07 E+01 \\
3.16 E+01 \\
2.41 E+04 \\
5.31 E-01 \\
1.80 E+\infty 0 \\
4.94 E+01 \\
1.12 E+04 \\
5.11 E+\infty 0\end{array}$ & 更 \\
\hline
\end{tabular}


WHC-SD-WM-TI-774 Rev. 0

TWRS PRIVATIZATION PROCESS TECHNICAL BASELINE

Table 12 Phase 1 In-Tank Sludge Washing of DST 241-AY-102/241-C-106 (36\%/99\% Retrieval) (12 sheets)

\begin{tabular}{|c|c|c|c|c|c|c|c|c|c|c|}
\hline STREAM NAME & 11 & 12 & 13 & 14 & 15 & 16 & 17 & 18 & 19 & 20 \\
\hline \multicolumn{11}{|l|}{ SA.ID COPOAENTS } \\
\hline Total Mass Flow (kg) & & $3.27 \mathrm{E}+05$ & $1.08 E+03$ & $3.26+06$ & & $3.23 \pm+05$ & $1.80 E+\infty$ & $3.60 \mathrm{E}+05$ & & 9.19E+05 \\
\hline \multicolumn{11}{|l|}{ Radionulides (Ci) } \\
\hline 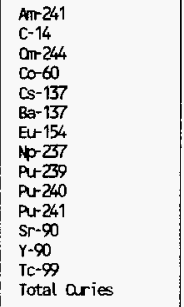 & & $\begin{array}{l}2.26 E+03 \\
3.54 E-01 \\
1.46 E+012 \\
2.90 E+05 \\
2.75 E+05 \\
\\
3.40 E+03 \\
\\
2.80 E+06 \\
2.80 E+06 \\
2.06 E+02 \\
6.16 E+06\end{array}$ & $\begin{array}{l}7.44 E+00 \\
1.17 E-13 \\
4.80 E-01 \\
9.57 E+02 \\
9.09 E+12 \\
\\
1.1 Z E+01 \\
9.2 E E+03 \\
9.2 E+13 \\
6.81 E-01 \\
2.03 E+04\end{array}$ & $\begin{array}{l}2.2 E E+03 \\
3.53 E-01 \\
1.45 E+02 \\
2.89 E+05 \\
2.75 E+05 \\
\\
3.39 E+013 \\
2.79 E+06 \\
2.79 E+06 \\
2.06 E+\infty 2 \\
6.14 E+06\end{array}$ & & $\begin{array}{l}2.25 E+03 \\
3.55 E-01 \\
1.45 E+02 \\
2.89 E+05 \\
2.75 E+05 \\
\\
3.39 E+03 \\
\\
2.79 E+06 \\
2.79 E+06 \\
2.06 E+02 \\
6.14 E+06\end{array}$ & $\begin{array}{l}1.50 E+01 \\
3.75 E+00 \\
1.39 E+05 \\
1.39+05 \\
2.78 E+05\end{array}$ & & & $\begin{array}{l}2.58 E+03 \\
1.22 E-03 \\
1.48 E+02 \\
5.88 E+06 \\
5.59 E+06 \\
4.82 E-02 \\
3.59 E-07 \\
3.42 E+03 \\
3.75 E+00 \\
6.04 E-03 \\
2.93 E+06 \\
2.95 E+06 \\
7.19 E+02 \\
1.73 E+07\end{array}$ \\
\hline
\end{tabular}

\begin{tabular}{|c|c|c|c|c|c|c|}
\hline \multicolumn{7}{|c|}{ Chemicals $(\mathrm{kg})$} \\
\hline 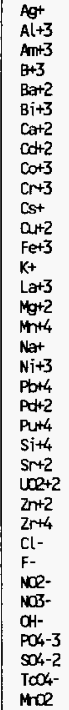 & $\begin{array}{l}9.27 E+02 \\
4.49 E+04 \\
6.58 E-01 \\
1.64 E+01 \\
5.2 E E+03 \\
5.24 E+02 \\
1.32 E+04 \\
4.00 E+02 \\
5.05 E+00 \\
1.20 E+03 \\
1.77 E+01 \\
1.33 E+02 \\
5.90 E+04 \\
1.49 E+03 \\
2.06 E+02 \\
6.87 E+13 \\
2.41 E+03 \\
8.37 E+04 \\
1.15 E+03 \\
2.49 E+03 \\
1.67 E+02 \\
5.49 E+01 \\
7.59 E+04 \\
1.66 E+02 \\
9.36 E+02 \\
4.86 E+01 \\
2.19 E+03 \\
5.61 E+01 \\
6.67 E+01 \\
1.26 E+01 \\
1.01 E+01 \\
1.35 E+04 \\
7.89 E+03 \\
1.25 E+02 \\
2.01 E+01\end{array}$ & 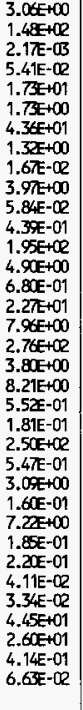 & 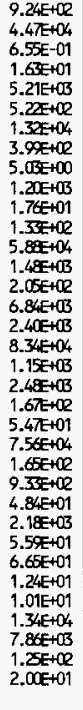 & $\begin{array}{l}9.24 E+02 \\
4.47 E+04 \\
6.55 E-01 \\
1.63 E+01 \\
5.21 E+03 \\
5.22 E+\infty 2 \\
1.32 E+04 \\
3.99 E+02 \\
5.03 E+00 \\
1.20 E+03 \\
1.76 E+01 \\
1.33 E+02 \\
5.88 E+04 \\
1.48 E+03 \\
2.05 E+02 \\
6.84 E+03 \\
2.40 E+03 \\
8.34 E+04 \\
1.15 E+013 \\
2.48 E+03 \\
1.67 E+02 \\
5.47 E+01 \\
7.56 E+04 \\
1.65 E+02 \\
9.33 E+02 \\
4.84 E+01 \\
2.18 E+13 \\
5.59 E+01 \\
6.65 E+01 \\
1.24 E+01 \\
1.01 E+01 \\
1.34 E+04 \\
7.86 E+013 \\
1.25 E+10 \\
2.00 E+01\end{array}$ & $\begin{array}{l}2.58 E-01 \\
9.85 E-01 \\
4.64 E-01\end{array}$ & $3.81 E+03$ \\
\hline
\end{tabular}




\section{WHC-SD-WM-TI-774 Rev. 0 \\ TWRS PRIVATIZATION PROCESS TECHNICAL BASELINE}

Table 12 Phase 1 In-Tank Sludge Washing of DST 24l-AY-102/241-C-106 (36\%/99\% Retrieval) (12 sheets)

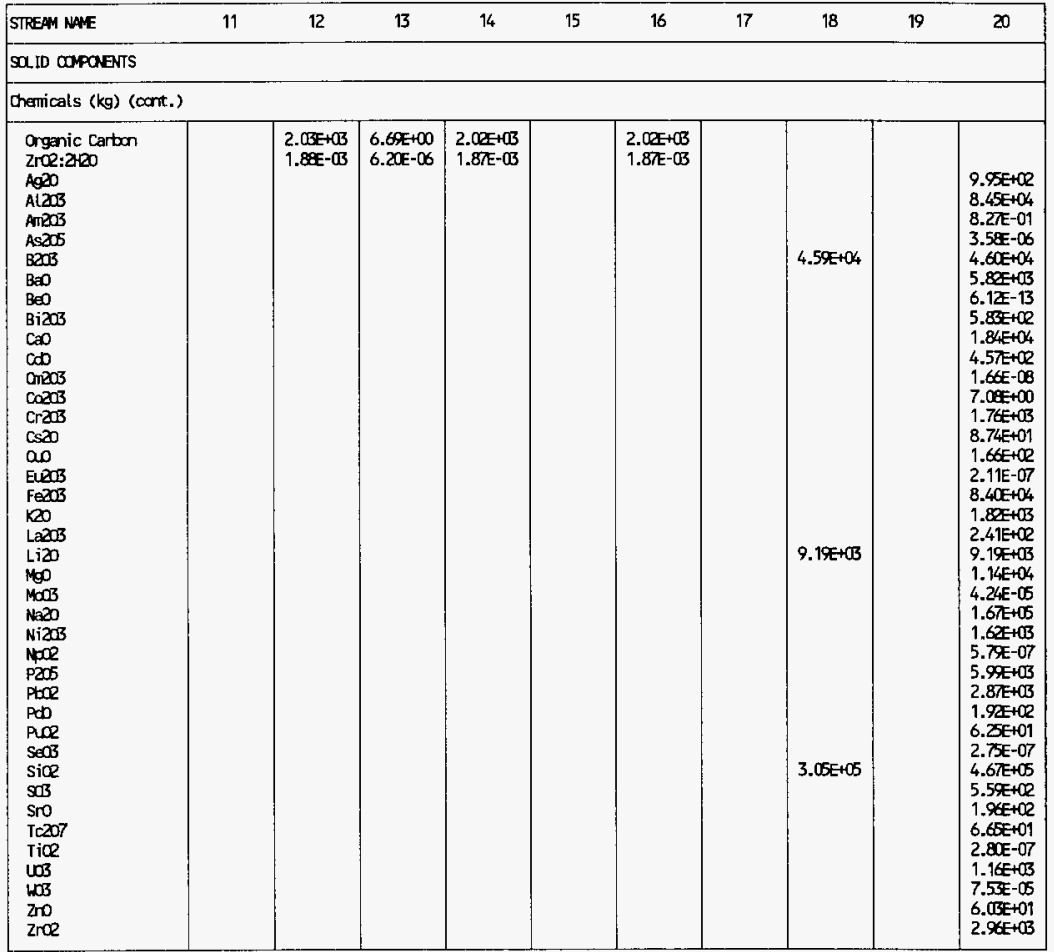


WHC-SD-WM-TI-774 ReV. 0

TWRS PRIVATIZATION PROCESS TECHNICAL BASELINE

Table 12 Phase 1 In-Tank Sludge Washing of DST 241-AY-102/241-C-106 (36\%/99\% Retrieval) (12 sheets)

\begin{tabular}{|c|c|}
\hline STREAM NAME & 21 \\
\hline \multicolumn{2}{|l|}{ LIQUID COPOENTS } \\
\hline $\begin{array}{l}\text { Total Mass Flow (kg) } \\
\text { Volume (L) } \\
\text { Specific Gravity }\end{array}$ & $\begin{array}{l}5.19 E+06 \\
5.19 E+06 \\
1.00 E+\infty\end{array}$ \\
\hline \multicolumn{2}{|l|}{ Radionulides (Ci) } \\
\hline $\begin{array}{l}\text { Amr241 } \\
\text { C-14 } \\
0 \pi-244 \\
\text { Co-60 } \\
C s-137 \\
B a-137 \\
\text { Eu-154 } \\
\text { Np-237 } \\
\text { Pu-239 } \\
\text { Pu-240 } \\
\text { Pu-241 } \\
\$ r-90 \\
Y-90 \\
\text { Tc-99 } \\
\text { Total aries }\end{array}$ & \\
\hline
\end{tabular}

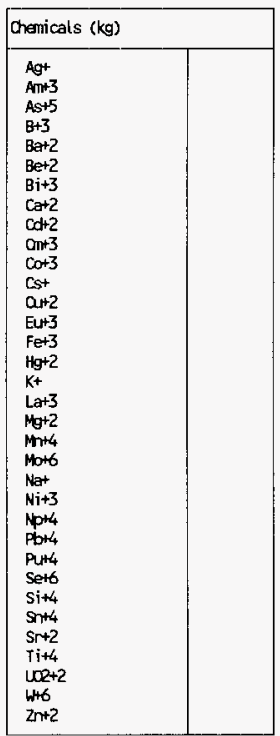




\section{WHC-SD-WM-TI-774 Rev. 0 \\ TWRS PRIVATIZATION PROCESS TECHNICAL BASELINE}

Table 12 Phase 1 In-Tank Sludge Washing of DST 241-AY-102/241-C-106 (36\%/99\% Retrieval) (12 sheets)

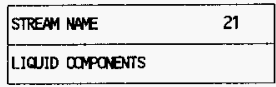

\begin{tabular}{|c|c|}
\hline \multicolumn{2}{|c|}{ cherricals (kg) (cont.) } \\
\hline$Z r+4$ & \\
\hline Al (OH $) 4-$ & \\
\hline $\begin{array}{l}\text { Cl- } \\
\text { cor-2 }\end{array}$ & \\
\hline $\mathrm{Cr}(\mathrm{OH}) 4-$ & \\
\hline F- & \\
\hline NOZ- & \\
\hline $\begin{array}{l}\mathrm{H}- \\
\mathrm{PO}_{4}-3\end{array}$ & \\
\hline $\mathrm{SO}_{4}-2$ & \\
\hline ToO4- & $5,18 E+06$ \\
\hline $\begin{array}{l}\text { Hor } \\
\text { Organic Carbon }\end{array}$ & . \\
\hline $\begin{array}{l}\mathrm{ZrCQ2:2H20} \\
\mathrm{Hg}\end{array}$ & $4.62 \mathrm{~F}-06$ \\
\hline $\mathrm{cl} 2$ & $2.95 E+0 R$ \\
\hline we & $9.46 E+103$ \\
\hline$F 2$ & $\begin{array}{l}1.24 E=02 \\
7.05 E+01\end{array}$ \\
\hline No & $\begin{array}{l}7.05 E=+1 \\
471 E+\infty\end{array}$ \\
\hline $\begin{array}{l}\mathrm{NO} \\
\mathrm{C}\end{array}$ & $4.71 \mathrm{E}+\infty \mathrm{e}$ \\
\hline $\mathrm{NH3}$ & $1.4 \pi+00$ \\
\hline
\end{tabular}




\section{WHC-SD-WM-TI-774 Rev. 0 \\ TWRS PRIVATIZATION PROCESS TECHNICAL BASELINE}

Table 12 Phase 1 In-Tank Sludge Washing of DST 241-AY-102/241-C-106 (36\%/99\% Retrieval) (12 sheets)

\begin{tabular}{|c|c|}
\hline STREAM NAME & 21 \\
\hline \multicolumn{2}{|l|}{ SaID OOMPOENIS } \\
\hline Iotal Mass Flow $(\mathrm{kg})$ & \\
\hline \multicolumn{2}{|l|}{ Radianelides (Ci) } \\
\hline $\begin{array}{l}\text { Am-241 } \\
c-14 \\
0 \pi-244 \\
C 0-60 \\
c s-137 \\
B a-137 \\
E u-154 \\
\text { - }-237 \\
P u-239 \\
\text { Pu-240 } \\
\text { Pur-241 } \\
\text { Sr-90 } \\
y-90 \\
\text { Tc- } 99 \\
\text { Total aries }\end{array}$ & \\
\hline
\end{tabular}

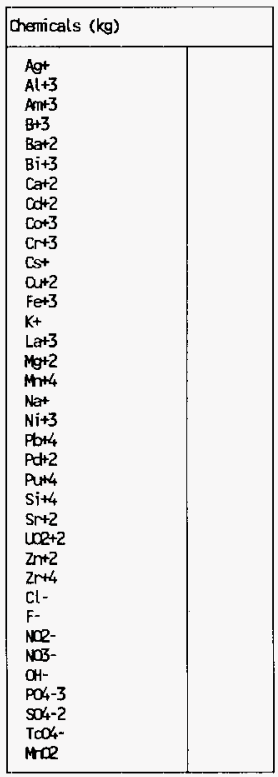




\section{WHC-SD-WM-TI-774 ReV. 0 \\ TWRS PRIVATIZATION PROCESS TECHNICAL BASELINE}

Table 12 Phase 1 In-Tank Sludge Washing of DST 241-AY-102/241-C-106 (36\%/99\% Retrieval) (12 sheets)

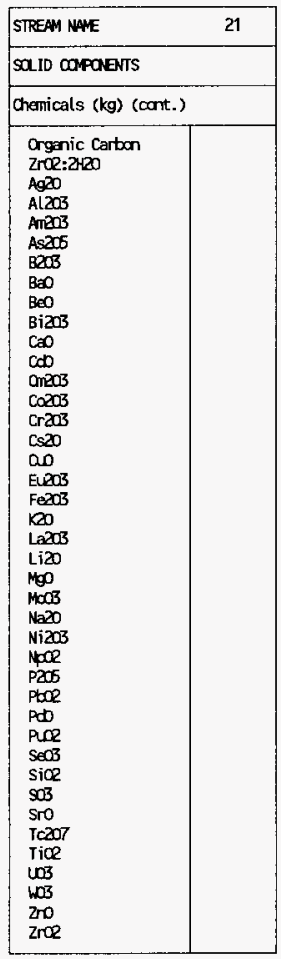




\section{WHC-SD-WM-TI-774 Rev. 0 \\ TWRS PRIVATIZATION PROCESS TECHNICAL BASELINE}

\subsection{HIGH-LEVEL WASTE PRIVATE CONTRACTOR OPERATIONS}

The Phase $1 \mathrm{HLW}$ contractor returns entrained solids to the operating contractor, but incorporates the other intermediate waste products (strontium/TRU, CIP and TIP) into IHLW. The CIP (Stream 15 on Figure 8) contains "IX Material" that is assumed to become part of the dry, free-flowing product. Since the HLW contractor probably would not produce a dry, free-flowing CIP, "IX Material" is deleted from the CIP stream that is routed to $H L W$ immobilization.

The major feed streams and products of HLW immobilization are depicted on Figures 10, 11, and 12. Sixteen batches of pretreated HLW solids are transferred to the $H L W$ contractor: 2 from $A Z-101,2$ from $A Z-102$ and 12 from $A Y-102$. For this model, the HLW contractor divides the intermediate waste products equally between the $16 \mathrm{HLW}$ feed batches.

The PPTB mass balances account for the vitrification of $375,000 \mathrm{kgs}$ (oxide equivalent) of washed HLW. This exceeds the minimum order quantity $(245,000 \mathrm{kgs})$, but falls short of the maximum order quantity $(465,000 \mathrm{kgs})$. Future revisions of the PPTB will identify additional solids for Phase 1.

G] ass formers (Stream 14 on Figure 10 and Stream 18 on Figures 11 and 12) are added to reach $25 \%$ waste oxide loading in the IHLW. No sodium, silicon or private contractor-added material counts toward the waste oxide loading. The mass balance also accounts for oxygen consumed in the cold cap and volatile species. With standard canisters containing a net $1650 \mathrm{kgs}$ or $0.62 \mathrm{~m}^{3}$ per canister, $P C 1$ returns 910 standard canisters ( 350 from AZ-101/AZ102 and 560 from $A Y-102 / C-106)$. The number of canisters from each batch was previously summarized in Table $\mathrm{S}-1$.

\subsection{ENHANCED SLUDGE WASHING ADJUSTMENT}

The PPTB does not model enhanced sludge washing (ESW) of Phase $1 \mathrm{HLW}$ solids, but this section estimates the ESW effect on residual HLW solids. The TWRS Process Flowsheet used DST caustic leach factors of $85 \%, 75 \%$ and $70 \%$ for $A 1, C r$, and $P$, respectively. Since no new ESW data specific to NCAW is available, the same factors were used for $A Z-101$ and $A Z-102$. Experimental caustic leach factors for $\mathrm{C}-103$ (same waste type as $\mathrm{C}-106$ ) waste are available: $44 \%, 11 \%$, and $43 \%$ for $A 1, C r$, and $P$, respectively. These were used for $A Y-102 / C-106$ waste.

$A Z-101$ and $A Z-102$ ESW waste oxides are approximately $75 \%$ of the water washed amount. AY-102/C-106 ESW waste oxides are approximately $82 \%$ of the water washed amount. The corresponding canister count is 725 (265 from AZ$101 / A Z-102$ and 460 from $A Y-102 / C-106)$. This is equivalent to $300,000 \mathrm{kgs}$ of washed HLW oxides, which exceeds the minimum order quantity of $245,000 \mathrm{kgs}$.

This estimate should be regarded cautiously in view of the tentative ESW data that it is based on. 


\section{WHC-SD-WM-TI-774 Rev. 0 \\ TWRS PRIVATIZATION PROCESS TECHNICAL BASELINE}

\subsection{PHASE 2 FLOWSHEET/MASS BALANCE}

The operating contractor's Phase 2 function is limited to day-to-day management of tank waste (see Figure 1), while DOE will procure all retrieval and treatment services from private contractors. There are some programmatic planning assumptions available for Phase 2, but nothing equivalent to the Phase 1 RFP (DOE-RL 1996) to provide guidance on feed envelopes, separation requirements, product specifications, or how to distribute and schedule procured services among the Phase 2 private contractors.

In the absence of specific guidance, the PPTB models Phase 2 processing in a manner similar to the TWRS Process Flowsheet (Orme 1995). The feed stream to Phase 2 is a composite of the total tank inventory with appropriate adjustments to account for prior Phase 1 processing. The calculation engine underlying the Phase 2 flowsheet/mass balance is the TWRS Process Flowsheet ASPEN PLUS model that simulates waste processing in considerable detail.

The TWRS Process Flowsheet (Orme 1995) baseline architecture for sludge pretreatment is in-tank enhanced sludge washing. During FY-1995, a proposed change to out-of-tank enhanced sludge washing was postponed because of DOE's preference to maintain the same process baseline during the early stages of privatization negotiations. The change to an out-of-tank enhanced sludge washing architecture will be completed in FY-1997, and reflected in Revision 1 of the PPTB. A study addressing the tradeoffs of in-tank vs. out-of-tank pretreatment is available (Raytheon 1995).

A conceptual in-tank architecture is shown in Figure 13.

\subsection{THE PHASE 2 FEED STREAM}

\subsubsection{Initial Wash}

The retrieval of waste from different tanks constitutes an initial wash. The initial wash occurs during retrieval with dilute caustic, as salts are dissolved and insoluble solids are mobilized and dispersed through the slurry. The output from several simultaneous retrieval operations is accumulated in million-gallon staging tanks. Blending occurs when slurries from different sources are combined in the accumulation tanks. The energy and turbulence imparted to the slurries by sluicers, mixer pumps, transfer pumps, and the ensuing temperature rise are factors that affect the extent of the initial wash. This initial stage of washing and blending is actually allocated to the retrieval function. SY Tank Farm provides staging capacity for 200 West Area. Two 200 East Area DSTs are set aside for receiving retrieved waste.

${ }^{11}$ Figure 14 (Phase 2 Waste Processing) and the associated mass balance in Table 13 reflect major streams, or combined streams extracted from the detailed model, to provide a summary level flowsheet of Phase 2 . 
Figure 13 Initial Wash and In-Tank Processing Conceptual Configuration ${ }^{12}$

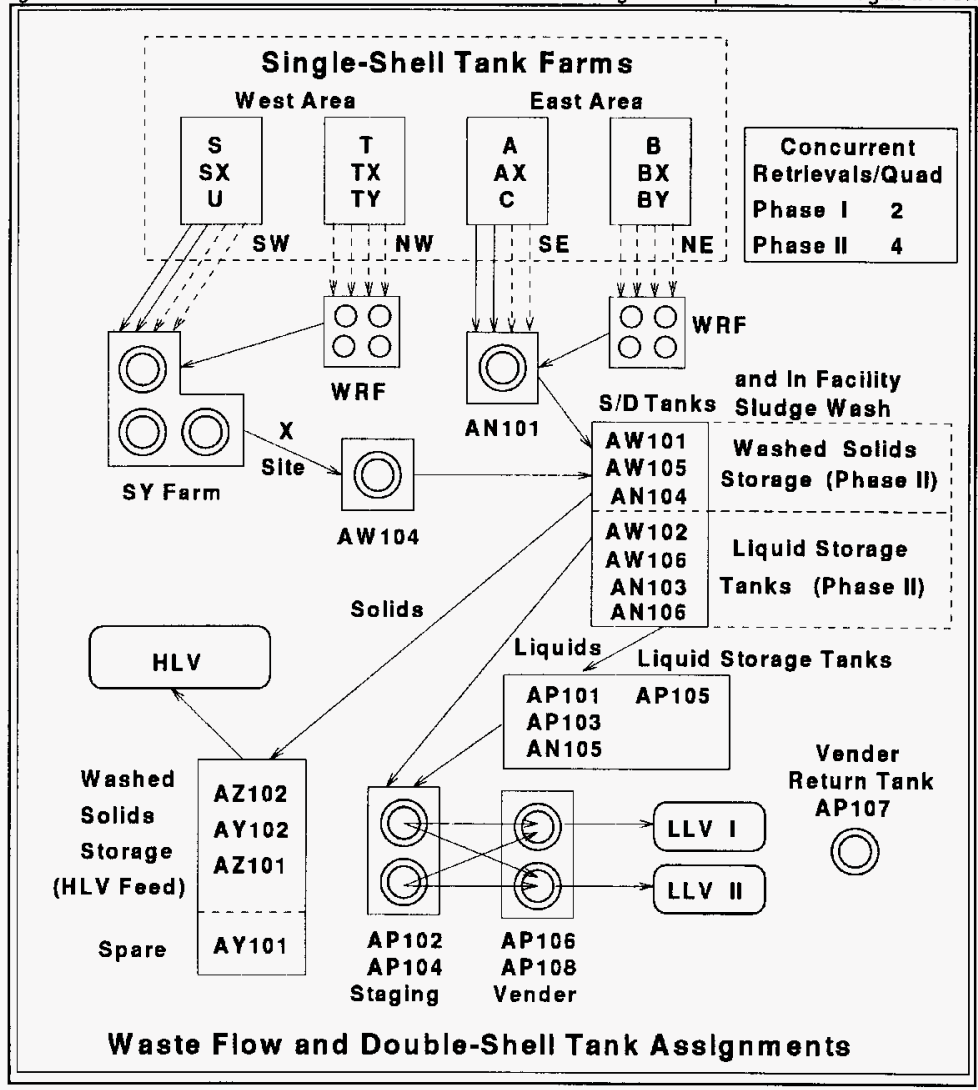

${ }^{12}$ This tentative configuration has been used for sequence modelling studies (Penwell et al. 1996). 


\section{WHC-SD-WM-TI-774 Rev. 0 \\ TWRS PRIVATIZATION PROCESS TECHNICAL BASELINE}

\subsubsection{Total Composite Feed Stream}

For flowsheet calculations, the retrieved waste is a $5 \mathrm{M}$ sodium slurry composited from the contents of all DSTs and SSTs. All of the water soluble components of the waste are in solution as a result of the initial retrieval wash. The total tank inventory (Stream l on Figure 14) is consistent with the total inventory from the TWRS Process Flowsheet (Orme 1995). The water soluble portion of the SST waste has been revised in accordance with the latest evaluation of water solubility, incorporating data from 18 additional SSTs (Colton 1996) than the 27 SSTs that were evaluated previously (Colton 1995). The liquid and solid distribution of DST waste was not revised because new data was not available.

\subsubsection{Adjusted Composite Feed Stream}

For Figure 14 and Table 13, the total tank inventory is adjusted to account for the Phase 1 sludge-washing operation, for the supernates and solids fed to the Phase 1 contractors (Stream 5), and for the intermediate products (Streams 2 and 3 ) returned by the Phase 1 private contractors. The resulting Stream 6 on Figure 14 is the composite feed to Phase 2 . The TANK FARMS process block on Figure 14 performs the adjustment.

\subsection{SOLID/LIQUID SEPARATIONS}

The SOLID/LIQUID (S/L) SEPARATION process block includes the established TWRS Process Flowsheet steps of (1) initial separation of waste liquids from solids by settle/decant, (2) leaching of caustic soluble components, and (3) adjustment of the interstitial liquid concentration by repeated washings with dilute hydroxide/nitrite solution. To prevent adverse effects on downstream operations from organic phases that might be retrieved from some SSTs, the PPTB adds a new continuous decanter capability to separate organics from decanted supernates, leachates, and wash solutions. The amount of separable organic has been difficult to estimate and the assumed flowsheet value is $78,000 \mathrm{~kg}$ (K1 em 1996).

The enhanced sludge-washing process utilizes leaching washes with $3 \mathrm{M}$ caustic solution to remove selected components (primarily aluminum, chromium, phosphorus and sodium) from the tank waste sludges, followed by dilute caustic washes to remove the interstitial dissolved components. The process is based on experience at the Savannah River Site, and preliminary caustic washing results with a limited number of Hanford sludge samples (Colton 1996). Initial indications from process mass balance calculations are that the HLW oxides remaining after enhanced sludge washing will be approximately $75 \%$ of the amount remaining after simple water washing alone. 


\section{Figure 14 Phase 2 Waste Processing}

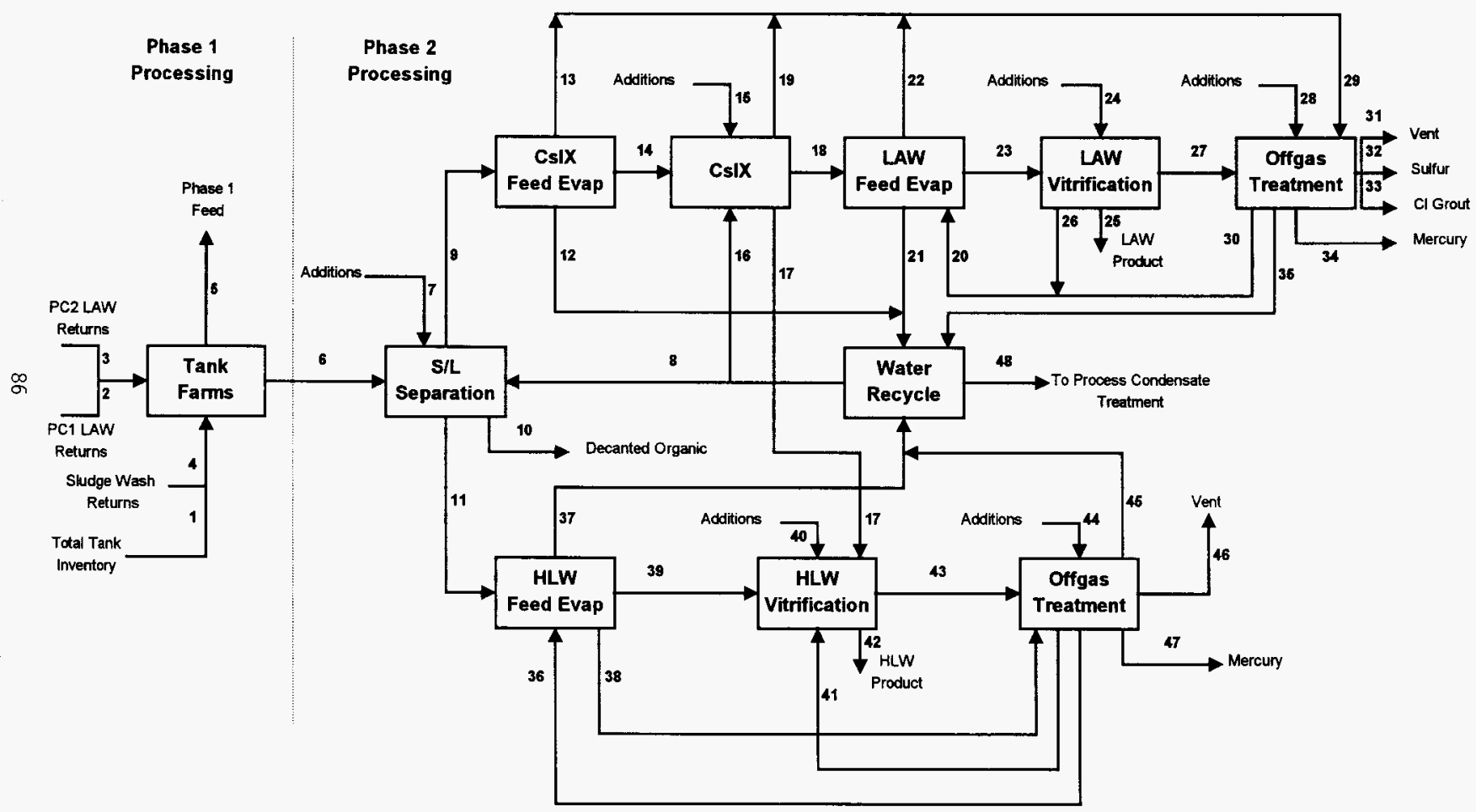




\section{WHC-SD-WM-TI-774 Rev. 0 TWRS PRIVATIZATION PROCESS TECHNICAL BASELINE}

Table 13 Phase 2 Mass Balance with TwRS Inventory

\begin{tabular}{|c|c|c|c|c|c|c|c|c|c|c|}
\hline STKFAM NAME & 1 & 2. & 3 & 4 & 5 & 6 & 7 & 8 & 9 & 10 \\
\hline \multicolumn{11}{|l|}{ LIQUID OMFAEMS } \\
\hline $\begin{array}{l}\text { Total Mass Flow (MIr) } \\
\text { Volume (L) } \\
\text { Specific Gravity }\end{array}$ & $\begin{array}{l}7.21 \mathrm{E}+05 \\
5.89 \mathrm{E}+08 \\
1.23 \mathrm{E}+00\end{array}$ & $\begin{array}{l}3.795+03 \\
3.692+06 \\
1.01 \mathrm{E}+00\end{array}$ & $\begin{array}{l}3.77 \mathrm{E}+03 \\
3.71 \mathrm{E}+06 \\
1.02 \mathrm{E}+00\end{array}$ & $\begin{array}{l}9.46 \mathrm{E}+03 \\
9.28 \mathrm{E}+06 \\
1.02 \mathrm{Z}+00\end{array}$ & $\begin{array}{l}9.57 \mathrm{E}+04 \\
7.34 \mathrm{E}+07 \\
1.30 \mathrm{E}+00\end{array}$ & $\begin{array}{l}\text { 6. } 42 \mathrm{E}+05 \\
5.32 \mathrm{E}+08 \\
1.21 \mathrm{E}+00\end{array}$ & $\begin{array}{l}3.38 \mathrm{E}+04 \\
2.26 \mathrm{E}+07 \\
1.50 \mathrm{E}+00\end{array}$ & $\begin{array}{l}\text { 4. } 88 \mathrm{dE}+05 \\
\text { 4. } 89 \mathrm{gE}+08 \\
1.00 \mathrm{O}+00\end{array}$ & $\begin{array}{l}1.00 \mathrm{E}+06 \\
8.72 \mathrm{E}+08 \\
1.1 \mathrm{E}+00\end{array}$ & $\begin{array}{l}7.79 \mathrm{E}+01 \\
7.79 \mathrm{E}+04 \\
1.00 \mathrm{E}+00\end{array}$ \\
\hline
\end{tabular}

\begin{tabular}{|c|c|c|c|c|c|c|c|c|}
\hline \multicolumn{9}{|c|}{ Redianuclides (Ci) } \\
\hline $\begin{array}{l}\mathrm{Amr}-241 \\
\mathrm{C}-14 \\
\mathrm{Cs}-137 \\
\mathrm{Ba}-137 \\
\mathrm{~Np}-237 \\
\mathrm{Fu}-239 \\
\mathrm{Pu}-240 \\
\mathrm{Fu}-241 \\
\mathrm{Sr}-90 \\
\mathrm{Y}-90 \\
\text { Tc-99 } \\
\text { Total Ouries }\end{array}$ & $\begin{array}{l}8.00 \mathrm{E}+03 \\
3.22 \mathrm{E}+03 \\
3.18 \mathrm{E}+07 \\
3.02 \mathrm{E}+07 \\
6.94 \mathrm{E}+00 \\
1.6 \mathrm{E}+03 \\
4.30 \mathrm{E}+02 \\
4.76 \mathrm{E}+03 \\
1.88 \mathrm{E}+06 \\
1.88 \mathrm{E}+06 \\
2.27 \mathrm{E}+04 \\
6.58 \mathrm{E}+07\end{array}$ & $\begin{array}{l}6.11 \mathrm{E}+00 \\
2.09 \mathrm{E}-01 \\
5.96 \mathrm{E}+04 \\
5.67 \mathrm{E}+04 \\
1.60 \mathrm{E}-03 \\
1.16 \mathrm{E}+00 \\
2.90 \mathrm{E}-01 \\
1.81 \mathrm{E}+00 \\
2.02 \mathrm{E}+03 \\
2.02 \mathrm{E}+03 \\
1.75 \mathrm{E}+01 \\
1.20 \mathrm{E}+05\end{array}$ & $\begin{array}{l}5.96 \mathrm{E}+00 \\
1.89 \mathrm{E}-01 \\
3.99 \mathrm{E}+04 \\
3.79 \mathrm{E}+04 \\
7.43 \mathrm{E}-04 \\
1.03 \mathrm{E}+00 \\
2.61 \mathrm{E}-01 \\
1.62 \mathrm{E}+00 \\
2.39 \mathrm{E}+03 \\
2.39 \mathrm{E}+03 \\
5.7 \mathrm{EE}+02 \\
8.31 \mathrm{E}+04\end{array}$ & $\begin{array}{l}\text { 1. } 15 \mathrm{E}+02 \\
3.72 \mathrm{E}+01 \\
1.36 \mathrm{E}+06 \\
1.10 \mathrm{E}+06 \\
1.45 \mathrm{E}+02 \\
\\
3.84 \mathrm{E}+04 \\
3.84 \mathrm{E}+04 \\
1.71 \mathrm{E}+02 \\
2.34 \mathrm{E}+06\end{array}$ & $\begin{array}{l}3.35 \mathrm{E}+03 \\
3.7 \mathrm{EE}+02 \\
2.70 \mathrm{E}+07 \\
2.57 \mathrm{E}+07 \\
3.84 \mathrm{E}-01 \\
6.32 \mathrm{E}+02 \\
1.10 \mathrm{E}+02 \\
6.90 \mathrm{E}+02 \\
1.21 \mathrm{E}+06 \\
1.21 \mathrm{E}+06 \\
7.04 \mathrm{E}+03 \\
5.51 \mathrm{E}+07\end{array}$ & $\begin{array}{l}4.77 \mathrm{E}+03 \\
2.8 \mathrm{BE}+03 \\
6.07 \mathrm{E}+06 \\
5.77 \mathrm{E}+06 \\
6.5 \mathrm{gE}+00 \\
1.16 \mathrm{E}+03 \\
3.20 \mathrm{E}+02 \\
4.08 \mathrm{E}+03 \\
7.12 \mathrm{E}+05 \\
7.12 \mathrm{E}+05 \\
1.64 \mathrm{E}+04 \\
1.33 \mathrm{E}+07\end{array}$ & $\begin{array}{l}4.61 \mathrm{E}-04 \\
2.78 \mathrm{gE}-04 \\
4.4 \mathrm{E}-01 \\
4.2 \mathrm{E}-01 \\
1.34 \mathrm{E}-04 \\
1.12 \mathrm{E}-04 \\
3.09 \mathrm{E}-05 \\
3.94 \mathrm{E}-04 \\
6.89 \mathrm{E}-02 \\
6.88 \mathrm{E}-02 \\
3.54 \mathrm{E}-03 \\
1.01 \mathrm{E}+00\end{array}$ & $\begin{array}{l}4.76 \mathrm{E}+03 \\
2.87 \mathrm{E}+03 \\
1.39 \mathrm{E}+07 \\
1.32 \mathrm{E}+07 \\
6.57 \mathrm{E}+00 \\
1.16 \mathrm{E}+03 \\
3.19 \mathrm{E}+02 \\
4.07 \mathrm{E}+03 \\
7.10 \mathrm{E}+05 \\
7.10 \mathrm{E}+05 \\
1.64 \mathrm{E}+04 \\
2.8 \mathrm{E}+07\end{array}$ \\
\hline
\end{tabular}

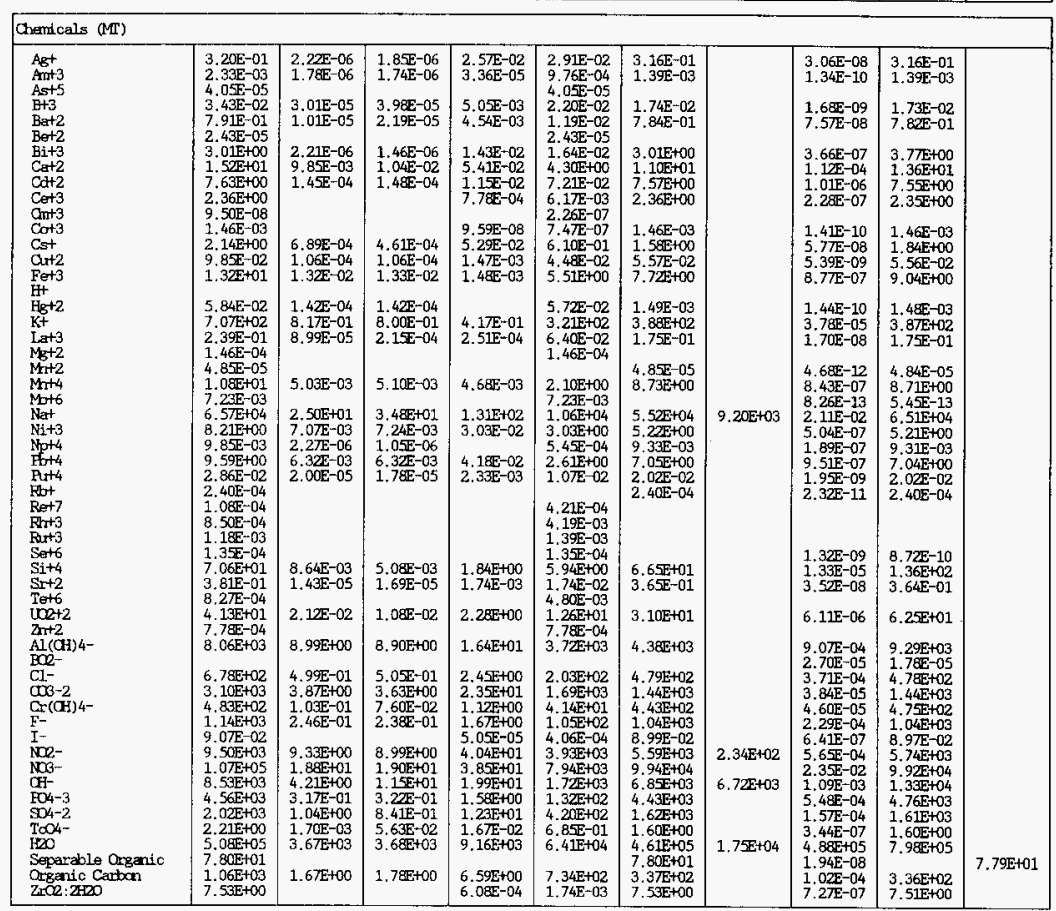


WHC-SD-WM-TI-774 ReV. 0

TWRS PRIVATIZATION PROCESS TECHNICAL BASELINE

Table 13 Phase 2 Mass Balance with TWRS Inventory

\begin{tabular}{|c|c|c|c|c|c|c|c|c|c|c|}
\hline SIREAM NAE & 1 & 2 & 3 & 4 & 5 & 6 & 7 & 8 & 9 & 10 \\
\hline \multicolumn{11}{|l|}{ LIQID COMFONEMIS } \\
\hline \multicolumn{11}{|c|}{ Chenicals Contisred (MI) } \\
\hline 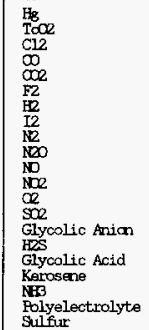 & & & & & & & $1,54 \mathrm{E}+02$ & $\begin{array}{l}1.72 E-07 \\
1.92 E-06\end{array}$ & $\begin{array}{l}1.16 \mathrm{E}-07 \\
1.71 \mathrm{E}+01\end{array}$ & \\
\hline
\end{tabular}


WHC-SD-WM-TI-774 Rev. 0

TWRS PRIVATIZATION PROCESS TECHNICAL BASELINE

Table 13 Phase 2 Mass Balance with TWRS Inventory

\begin{tabular}{|c|c|c|c|c|c|c|c|c|c|c|}
\hline SIREAM NAME & 1 & 2 & 3 & 4 & 5 & 6 & 7 & 8 & 9 & 10 \\
\hline \multicolumn{11}{|l|}{ SQID COMANENS } \\
\hline Total Mass Flon (MI) & $2.23 E+04$ & & $4.35-03$ & $5.04 \mathrm{E}+00$ & $5.53 \mathrm{E}+02$ & $2.17 \mathrm{E}+04$ & & & $1.96 \mathrm{E}+02$ & \\
\hline \multicolumn{11}{|l|}{ Radianxlides (Ci) } \\
\hline $\begin{array}{l}\text { An } 241 \\
\mathrm{C}-14 \\
\mathrm{Cs}-137 \\
\mathrm{Ba}-137 \\
\mathrm{~K}-237 \\
\mathrm{PL}-239 \\
\mathrm{Pu}-240 \\
\mathrm{P} 2-241 \\
\mathrm{~S}-90 \\
\mathrm{Y}-90 \\
\mathrm{Tc}-99 \\
\text { Total Curies }\end{array}$ & $\begin{array}{l}9.7 \mathrm{E}+04 \\
2.12 \mathrm{E}+03 \\
1.39 \mathrm{E}+07 \\
1.32 \mathrm{E}+07 \\
6.27 \mathrm{E}+01 \\
2.53 \mathrm{E}+04 \\
6.26 \mathrm{E}+03 \\
6.95 \mathrm{E}+04 \\
5.18 \mathrm{E}+07 \\
5.18 \mathrm{E}+07 \\
9.32 \mathrm{EE}+03 \\
1.31 \mathrm{E}+08\end{array}$ & & $\begin{array}{l}\text { 7. } 38 E+02 \\
\\
3.35 E+01 \\
8.38 E+00 \\
3.42 E+05 \\
3.42 E+05 \\
6.85 E+05\end{array}$ & $\begin{array}{l}2.8 \mathrm{EE}+02 \\
1.64 \mathrm{E}-01 \\
6.01 \mathrm{E}+03 \\
5.71 \mathrm{E}+03 \\
3.99 \mathrm{E}+01 \\
\\
7.72 \mathrm{E}+04 \\
7.72 \mathrm{E}+04 \\
3.79 \mathrm{E}+00 \\
1.67 \mathrm{E}+05\end{array}$ & $\begin{array}{l}3.76 \mathrm{E}+04 \\
2.11 \mathrm{E}+01 \\
6.81 \mathrm{E}+05 \\
6.47 \mathrm{E}+05 \\
4.19 \mathrm{E}+03 \\
\\
9.39 \mathrm{E}+06 \\
9.39 \mathrm{E}+06 \\
4.29 \mathrm{E}+02 \\
2.02 \mathrm{E}+07\end{array}$ & $\begin{array}{l}6.11 \mathrm{E}+04 \\
2.10 \mathrm{E}+03 \\
1.32 \mathrm{E}+07 \\
1.26 \mathrm{E}+07 \\
6.27 \mathrm{E}+01 \\
2.1 \mathrm{EE}+04 \\
6.28 \mathrm{E}+03 \\
6.9 \mathrm{SE}+04 \\
4.28 \mathrm{E}+07 \\
4.22 \mathrm{EE}+07 \\
8.8 \mathrm{TE}+03 \\
1.12 \mathrm{E}+08\end{array}$ & & & $\begin{array}{l}8.03 E+02 \\
2.7 \mathrm{E}+01 \\
7.01 \mathrm{E}+04 \\
6.66 \mathrm{E}+04 \\
8.25 \mathrm{E}-01 \\
2.78 \mathrm{EE}+02 \\
8.25 \mathrm{~F}+01 \\
9.14 \mathrm{E}+02 \\
5.62 \mathrm{E}+05 \\
5.62 \mathrm{E}+05 \\
1.17 \mathrm{E}+02 \\
1.26 \mathrm{E}+06\end{array}$ & \\
\hline
\end{tabular}

\begin{tabular}{|c|c|c|c|c|c|c|}
\hline \multicolumn{7}{|l|}{ Chenicals (MT) } \\
\hline 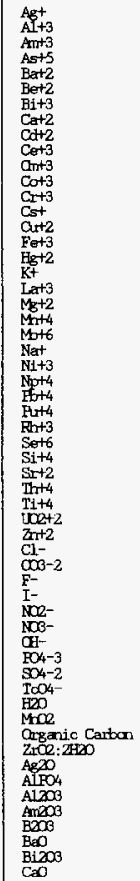 & 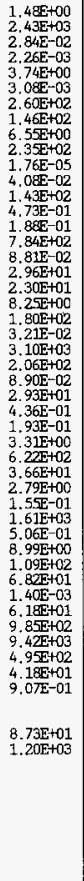 & $\begin{array}{l}5.77 \mathrm{E}-04 \\
2.43 \mathrm{E}-03\end{array}$ & 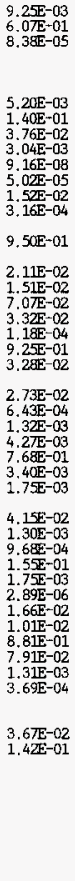 & 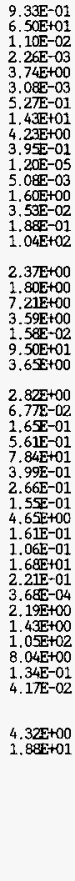 & 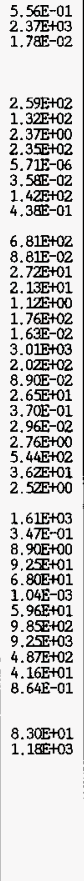 & 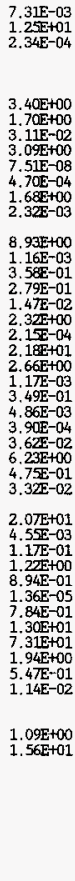 \\
\hline
\end{tabular}


WHC-SD-WM-TI-774 Rev. 0

TWRS PRIVATIZATION PROCESS TECHNICAL BASELINE

Table 13 Phase 2 Mass Balance with TwRS Inventory

\begin{tabular}{|c|c|c|c|c|c|c|c|c|c|c|}
\hline SIFEPM NAYE & 1 & 2 & 3 & 4 & 5 & 6 & 7 & 8 & 9 & 10 \\
\hline \multicolumn{11}{|l|}{ SLID COMEONENIS } \\
\hline \multicolumn{11}{|c|}{ Chenicals Contirued (MT) } \\
\hline 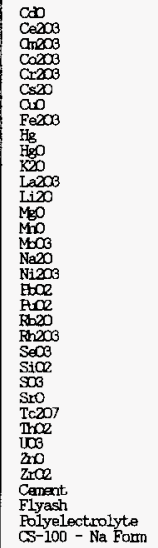 & & & & & & & & & $1.32 E+\infty 0$ & \\
\hline
\end{tabular}




\section{WHC-SD-WM-TI-774 Rev, 0 TWRS PRIVATIZATION PROCESS TECHNICAL BASELINE}

Table 13 Phase 2 Mass Balance with TWRS Irventory

\begin{tabular}{|c|c|c|c|c|c|c|c|c|c|c|}
\hline STREAM NAME & 11 & 12 & 13 & 14 & 15 & 16 & 17 & 18 & 19 & 20 \\
\hline \multicolumn{11}{|l|}{ LIQUID COMENENIS } \\
\hline $\begin{array}{l}\text { Total Mass Flow (MT) } \\
\text { Volume (L) } \\
\text { Specific Gravity }\end{array}$ & $\begin{array}{l}1.70 \mathrm{E}+05 \\
1.69 \mathrm{E}+08 \\
1.01 \mathrm{E}+00\end{array}$ & $\begin{array}{l}4.63 \mathrm{E}+05 \\
4.63 \mathrm{E}+08 \\
1.00 \mathrm{E}+00\end{array}$ & $\begin{array}{l}5.14 E+03 \\
5.14 E+06 \\
1.00 E+00\end{array}$ & $\begin{array}{l}\text { 5. } 33 E+05 \\
4.05 E+08 \\
1.32 E+00\end{array}$ & $\begin{array}{l}\text { 7. } 82 \mathrm{EZ}+04 \\
7.65 \mathrm{ES}+07 \\
1.02 \mathrm{E}+00\end{array}$ & $\begin{array}{l}\text { 1.20E+04 } \\
1.20 \mathrm{E}+07 \\
1.00 \mathrm{E}+00\end{array}$ & $\begin{array}{l}9.54 \mathrm{E}+03 \\
8.57 \mathrm{E}+06 \\
1.11 \mathrm{E}+00\end{array}$ & $\begin{array}{l}6.13 \mathrm{E}+05 \\
4.84 \mathrm{E}+08 \\
1.27 \mathrm{E}+00\end{array}$ & $\begin{array}{l}\text { 1.01E+03 } \\
1.00 \text { +06 } \\
1.01 \text { Et00 }\end{array}$ & $\begin{array}{l}8.14 \mathrm{E}+05 \\
8.01 \mathrm{E}+08 \\
1.02 \mathrm{E}+00\end{array}$ \\
\hline
\end{tabular}

\begin{tabular}{|c|c|c|c|c|c|c|c|c|c|}
\hline \multicolumn{10}{|c|}{ Fadianaclides (Ci) } \\
\hline $\begin{array}{l}A n-241 \\
\mathrm{C}-14 \\
\mathrm{Cs}-137 \\
\mathrm{Ba}-137 \\
\mathrm{~N}-237 \\
\mathrm{Ru}-239 \\
\mathrm{Ru}-240 \\
\mathrm{R}-241 \\
\mathrm{~S}-90 \\
\mathrm{Y}-90 \\
\text { Tc-99 } \\
\text { Total Curies }\end{array}$ & $\begin{array}{l}9.37 \mathrm{E}+00 \\
5.6 \mathrm{E}+00 \\
1.27 \mathrm{E}+05 \\
1.20 \mathrm{E}+05 \\
1.30 \mathrm{E}-02 \\
2.28 \mathrm{E}+00 \\
6.26 \mathrm{E}-01 \\
8.01 \mathrm{E}+00 \\
1.40 \mathrm{E}+03 \\
1.40 \mathrm{E}+03 \\
3.23 \mathrm{E}+01 \\
2.50 \mathrm{E}+05\end{array}$ & $\begin{array}{l}4.17 \mathrm{E}-04 \\
2.52 \mathrm{E}-04 \\
1.21 \mathrm{E}+00 \\
1.15 \mathrm{E}+00 \\
5.75 \mathrm{E}-07 \\
1.02 \mathrm{E}-04 \\
2.79 \mathrm{E}-05 \\
3.56 \mathrm{E}-0 . \\
6.22 \mathrm{E}-02 \\
6.22 \mathrm{E}-02 \\
1.44 \mathrm{E}-03 \\
2.49 \mathrm{E}+00\end{array}$ & $\begin{array}{l}4.1 \mathrm{E}-07 \\
2.52 \mathrm{E}-07 \\
1.22 \mathrm{E}-03 \\
1.1 \mathrm{E}-03 \\
5.76 \mathrm{E}-10 \\
1.02 \mathrm{E}-07 \\
2.80 \mathrm{E}-08 \\
3.5 \mathrm{E}-07 \\
6.2 \mathrm{2JE}-0 . \\
6.22 \mathrm{E}-05 \\
1.44 \mathrm{E}-06 \\
2.50 \mathrm{E}-03\end{array}$ & $\begin{array}{l}4.76 E+03 \\
2.87 E+03 \\
1.39 E+07 \\
1.32 E+07 \\
6.57 E+00 \\
1.16 E+03 \\
3.19 E+02 \\
4.07 E+03 \\
7.10 E+05 \\
7.10 E+05 \\
1.64 E+04 \\
2.85 E+07\end{array}$ & $\begin{array}{l}1.13 \mathrm{E}-05 \\
6.81 \mathrm{E}-06 \\
1.10 \mathrm{E}-02 \\
1.04 \mathrm{E}-02 \\
3.27 \mathrm{E}-06 \\
2.75 \mathrm{E}-06 \\
7.5 \mathrm{E}-07 \\
9.6 \mathrm{SE}-06 \\
1.69 \mathrm{E}-03 \\
1.69 \mathrm{E}-03 \\
8.67 \mathrm{E}-05 \\
2.49 \mathrm{E}-02\end{array}$ & $\begin{array}{l}1.33 \mathrm{E}+07 \\
1,26 \mathrm{E}+07 \\
2.59 \mathrm{E}+07\end{array}$ & $\begin{array}{l}4.76 \mathrm{E}+03 \\
2.87 \mathrm{E}+03 \\
5.84 \mathrm{E}+05 \\
5.55 \mathrm{E}+05 \\
6.57 \mathrm{E}+00 \\
1.16 \mathrm{E}+03 \\
3.19 \mathrm{E}+02 \\
4.07 \mathrm{E}+03 \\
7.10 \mathrm{E}+05 \\
7.10 \mathrm{E}+05 \\
1.64 \mathrm{E}+04 \\
2.59 \mathrm{E}+06\end{array}$ & $\begin{array}{l}\frac{1.02 \mathrm{E}-02}{9.6 \mathrm{E}-03} \\
1.99 \mathrm{E}-02\end{array}$ & $\begin{array}{l}3.40 \mathrm{E}+05 \\
3.23 \mathrm{E}+05 \\
2.79 \mathrm{E}+03\end{array}$ \\
\hline
\end{tabular}

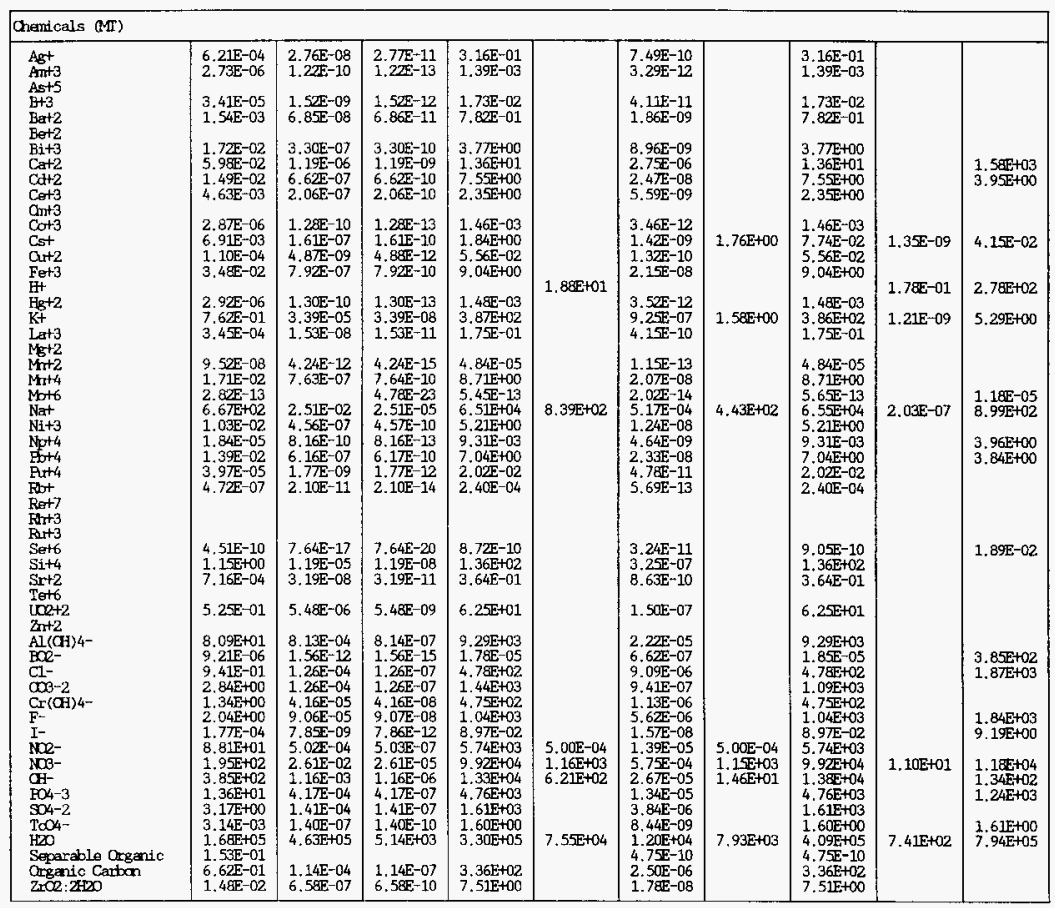


WHC-SD-WM-TI-774 Rev. 0

TWRS PRIVATIZATION PROCESS TECHNICAL BASELINE

Table 13 Phase 2 Mass Balance with TWRS Inventory

\begin{tabular}{|c|c|c|c|c|c|c|c|c|c|c|}
\hline SIJEAM NAME & 11 & 12 & 13 & 14 & 15 & 16 & 17 & 18 & 19 & 20 \\
\hline \multicolumn{11}{|l|}{ LTQJID COMPAENIS } \\
\hline \multicolumn{11}{|c|}{ Ohemicals Contirued (MI) } \\
\hline 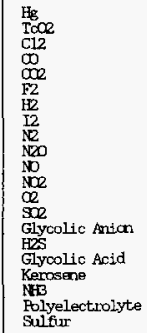 & $\begin{array}{l}5.98 E-08 \\
2.098+00\end{array}$ & $\begin{array}{l}1.01 \mathrm{E}-14 \\
1.50 \mathrm{E}-06\end{array}$ & $\begin{array}{l}1.01 \mathrm{E}-17 \\
1.50 \mathrm{E}-09\end{array}$ & $\begin{array}{l}1.16 \mathrm{E}-07 \\
1.71 \mathrm{E}+01\end{array}$ & & $\begin{array}{l}4.30 \mathrm{E}-09 \\
4.70 \mathrm{E}-08\end{array}$ & & $\begin{array}{l}1.20 \mathrm{E}-07 \\
1.71 \mathrm{E}+01\end{array}$ & 2. $54 \mathrm{E}+02$ & $\begin{array}{l}2.90 \mathrm{E}-07 \\
6.46 \mathrm{E}-0.5\end{array}$ \\
\hline
\end{tabular}


WHC-SD-WM-TI-774 Rev. 0

TWRS PRIVATIZATION PROCESS TECHNICAL BASELINE

Table 13 Phase 2 Mass Balance with TWRS Inventory

\begin{tabular}{|c|c|c|c|c|c|c|c|c|c|c|}
\hline STKEAM NAME & 11 & 12 & 13 & 14 & 15 & 16 & 17 & 18 & 19 & 20 \\
\hline \multicolumn{11}{|l|}{ SaID aMraris } \\
\hline Total Mass Flow (MI) & $1.48 E+04$ & & & $1.96 \mathrm{E}+02$ & $6.68 \mathrm{E}+02$ & & & 8.64E+02. & & $1.91 E+04$ \\
\hline \multicolumn{11}{|l|}{ Radicnuclides (Ci) } \\
\hline $\begin{array}{l}\mathrm{Am}-241 \\
\mathrm{C}-14 \\
\mathrm{Cs}-137 \\
\mathrm{Ba}-137 \\
\mathrm{No}-237 \\
\mathrm{Pu}-239 \\
\mathrm{Pu}-240 \\
\mathrm{Pu}-241 \\
\mathrm{~S}-90 \\
\mathrm{Y}-90 \\
\mathrm{Tc}-99 \\
\text { Total Curies }\end{array}$ & $\begin{array}{l}6.03 \mathrm{E}+04 \\
2.07 \mathrm{E}+03 \\
5.25 \mathrm{E}+06 \\
4.99 \mathrm{E}+06 \\
6.19 \mathrm{E}+01 \\
2.09 \mathrm{E}+04 \\
6.19 \mathrm{E}+03 \\
6.86 \mathrm{E}+04 \\
4.22 \mathrm{E}+07 \\
4.22 \mathrm{E}+07 \\
8.76 \mathrm{E}+03 \\
9.48 \mathrm{E}+07 \\
\end{array}$ & & & $\begin{array}{l}8.03 \mathrm{E}+02 \\
2.75 \mathrm{EE}+01 \\
7.01 \mathrm{E}+04 \\
6.66 \mathrm{E}+04 \\
8.25 \mathrm{E}-01 \\
2.78 \mathrm{E}+02 \\
8.25 \mathrm{E}+01 \\
9.14 \mathrm{E}+02 \\
5.62 \mathrm{E}+05 \\
5.62 \mathrm{E}+05 \\
1.17 \mathrm{E}+02 \\
1.26 \mathrm{E}+06\end{array}$ & & & & $\begin{array}{l}8.03 E+02 \\
2.75 E+01 \\
7.01 E+04 \\
6.66 E+04 \\
8.25 E-01 \\
2.78 E+02 \\
8.25 E+01 \\
9.14 E+02 \\
5.62 E+05 \\
5.62 E+05 \\
1.1 \pi E+02 \\
1.26 E+06\end{array}$ & & $\begin{array}{l}2.3 \mathrm{EE}+02 \\
2.76 \mathrm{E}+04 \\
2.6 \mathrm{EE}+04 \\
3.4 \mathrm{EE}-02 \\
6.07 \mathrm{E}+01 \\
1.69 \mathrm{E}+01 \\
2.10 \mathrm{E}+02 \\
5.37 \mathrm{E}+04 \\
5.37 \mathrm{~F}+04 \\
6.96 \mathrm{E}+02 \\
1.62 \mathrm{E}+05\end{array}$ \\
\hline \multicolumn{11}{|l|}{ Ohenicals (MI) } \\
\hline 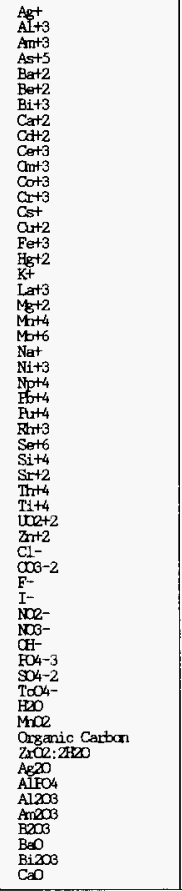 & $\begin{array}{l}5.49 \mathrm{E}-01 \\
9.39 \mathrm{E}+02 \\
1.76 \mathrm{E}-02 \\
\\
2.55 \mathrm{E}+02 \\
1.2 \mathrm{EE}+02 \\
2.34 \mathrm{E}+00 \\
2.32 \mathrm{E}+02 \\
5.64 \mathrm{E}-06 \\
3.53 \mathrm{E}-02 \\
1.26 \mathrm{E}+02 \\
1.74 \mathrm{E}-01 \\
6.71 \mathrm{E}+02 \\
8.70 \mathrm{E}-02 \\
2.69 \mathrm{E}+01 \\
2.10 \mathrm{E}+01 \\
1.10 \mathrm{E}+00 \\
1.74 \mathrm{E}+02 \\
1.61 \mathrm{E}-02 \\
1.64 \mathrm{E}+03 \\
2.00 \mathrm{E}+02 \\
8.78 \mathrm{E}-02 \\
2.62 \mathrm{E}+01 \\
3.65 \mathrm{E}-01 \\
2.93 \mathrm{E}-02 \\
2.72 \mathrm{E}+00 \\
4.6 \mathrm{EE}+02 \\
3.57 \mathrm{E}+01 \\
2.49 \mathrm{E}+00 \\
1.55 \mathrm{E}+03 \\
3.42 \mathrm{E}-01 \\
8.78 \mathrm{E}+00 \\
9.12 \mathrm{E}+01 \\
6.71 \mathrm{E}+01 \\
1.02 \mathrm{E}-03 \\
5.8 \mathrm{EE}+01 \\
9.72 \mathrm{E}+02 \\
5.49 \mathrm{E}+03 \\
1.45 \mathrm{E}+02 \\
4.11 \mathrm{E}+01 \\
8.53 \mathrm{E}-01 \\
\end{array}$ & & & $\begin{array}{l}7.31 \mathrm{E}-03 \\
1.25 \mathrm{~F}+01 \\
2.34 \mathrm{E}-04 \\
\\
3.40 \mathrm{E}+00 \\
1.70 \mathrm{E}+00 \\
3.11 \mathrm{E}-02 \\
3.09 \mathrm{E}+00 \\
7.51 \mathrm{E}-08 \\
4.70 \mathrm{E}-04 \\
1.6 \mathrm{Eg}+00 \\
2.32 \mathrm{E}-03 \\
8.93 \mathrm{E}+00 \\
1.16 \mathrm{E}-03 \\
3.58 \mathrm{E}-01 \\
2.79 \mathrm{E}-01 \\
1.47 \mathrm{E}-02 \\
2.32 \mathrm{E}+00 \\
2.15 \mathrm{E}-04 \\
2.18 \mathrm{E}+01 \\
2.66 \mathrm{E}+00 \\
1.17 \mathrm{E}-03 \\
3.49 \mathrm{E}-01 \\
4.86 \mathrm{E}-03 \\
3.90 \mathrm{E}-04 \\
3.62 \mathrm{E}-02 \\
6.23 \mathrm{E}+00 \\
4.75 \mathrm{E}-01 \\
3.32 \mathrm{E}-02 \\
2.07 \mathrm{E}+01 \\
4.55 \mathrm{E}-03 \\
1.17 \mathrm{E}-01 \\
1.22 \mathrm{E}+00 \\
8.94 \mathrm{E}-01 \\
1.36 \mathrm{E}-05 \\
7.84 \mathrm{E}-01 \\
1.30 \mathrm{E}+01 \\
7.31 \mathrm{E}+01 \\
1.94 \mathrm{E}+00 \\
5.47 \mathrm{E}-01 \\
1.14 \mathrm{E}-02 \\
1.09 \mathrm{E}+00 \\
1.56 \mathrm{E}+01\end{array}$ & (1) & & & $\begin{array}{l}7.31 \mathrm{E}-03 \\
1.25 \mathrm{E}+01 \\
2.34 \mathrm{E}-04 \\
\\
3.40 \mathrm{E}+00 \\
1.70 \mathrm{E}+00 \\
3.11 \mathrm{E}-02 \\
3.09 \mathrm{E}+00 \\
7.51 \mathrm{E}+08 \\
4.70 \mathrm{E}-04 \\
1.68 \mathrm{E}+00 \\
2.32 \mathrm{E}-03 \\
8.93 \mathrm{E}+00 \\
1.16 \mathrm{E}-03 \\
3.58 \mathrm{E}-01 \\
2.79 \mathrm{E}-01 \\
1.4 \mathrm{EE}-02 \\
2.32 \mathrm{E}+00 \\
2.1 \mathrm{~F}-04 \\
2.18 \mathrm{E}+01 \\
2.66 \mathrm{E}+00 \\
1.17 \mathrm{E}-03 \\
3.49 \mathrm{E}-01 \\
4.86 \mathrm{E}-03 \\
3.90 \mathrm{E}-04 \\
3.62 \mathrm{E}-02 \\
6.23 \mathrm{E}+00 \\
4.75 \mathrm{E}-01 \\
3.32 \mathrm{E}-02 \\
2.07 \mathrm{E}+01 \\
4.55 \mathrm{E}-03 \\
1.17 \mathrm{E}-01 \\
1.22 \mathrm{E}+00 \\
8.94 \mathrm{E}-01 \\
1.36 \mathrm{E}-05 \\
7.84 \mathrm{E}-01 \\
1.30 \mathrm{E}+01 \\
7.31 \mathrm{E}+01 \\
1.94 \mathrm{E}+00 \\
5.4 \mathrm{E}-01 \\
1.14 \mathrm{E}-02 \\
1.09 \mathrm{E}+00 \\
1.56 \mathrm{E}+01 \\
7.46 \mathrm{E}+00 \\
5.33 \mathrm{E}-01 \\
\end{array}$ & & $\begin{array}{l} \\
\\
4.93 E-05 \\
\\
4.77 \mathrm{E}+00 \\
1.91 \mathrm{E}+02 \\
3.75 \mathrm{E}-03 \\
\\
\\
7.36 \mathrm{E}-01 \\
1.46 \mathrm{E}-02 \\
2.52 \mathrm{E}+02 \\
2.13 \mathrm{E}+03 \\
9.52 \mathrm{E}-05 \\
3.6 \mathrm{EE}+02 \\
3.37 \mathrm{E}-01 \\
7.45 \mathrm{EE}+02 \\
\end{array}$ \\
\hline
\end{tabular}




\section{WHC-SD-WM-TI-774 Rev. 0 \\ TWRS PRIVATIZATION PROCESS TECHNICAL BASELINE}

Table 13 Phase 2 Mass Balance with TWRS Inventory

\begin{tabular}{|c|c|c|c|c|c|c|c|c|c|c|}
\hline SIREAM NAEE & 11 & 12 & 13 & 14 & 15 & 16 & 17 & 18 & 19 & 20 \\
\hline \multicolumn{11}{|l|}{ sam compovens } \\
\hline \multicolumn{11}{|c|}{ ChemLcals Continued (MT) } \\
\hline 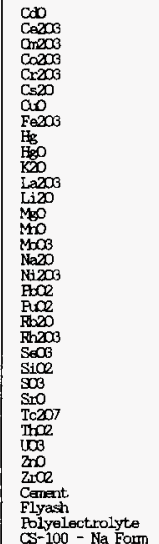 & $1.34 E+02$ & & & $1.32 E+00$ & $\begin{array}{l}2.66 \mathrm{E}+\infty \\
5.33 \mathrm{E}-01 \\
\\
3.73 \mathrm{E}+01 \\
6.20 \mathrm{E}+02\end{array}$ & & & $\begin{array}{l}2.66 \mathrm{E}+00 \\
5.33 \mathrm{E}-01 \\
\\
3.73 \mathrm{E}+01 \\
\\
\frac{1.32 \mathrm{E}+00}{6.20 \mathrm{~F}+02}\end{array}$ & & 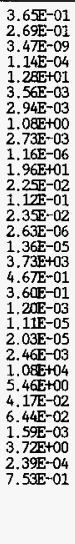 \\
\hline
\end{tabular}




\section{WHC-SD-WM-TI-774 Rev. 0 \\ TWRS PRIVATIZATION PROCESS TECHNICAL BASELINE}

Table 13 Phase 2 Mass Balance with TWRS Inventory

\begin{tabular}{|c|c|c|c|c|c|c|c|c|c|c|}
\hline STREAM NAME & 21 & 22 & 23 & 24 & 25 & 26 & 27 & 28 & 29 & 30 \\
\hline \multicolumn{11}{|l|}{ 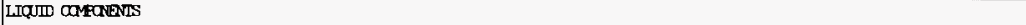 } \\
\hline $\begin{array}{l}\text { Total Mass Flow (MI) } \\
\text { Volime (L) } \\
\text { Specific Gravity }\end{array}$ & $\begin{array}{l}9.72 \mathrm{E}+05 \\
9.72 \mathrm{E}+08 \\
1.00 \mathrm{E}+00\end{array}$ & $\begin{array}{l}1.16 \mathrm{E}+04 \\
1.16 \mathrm{E}+07 \\
1.00 \mathrm{E}+00\end{array}$ & $\begin{array}{l}4.44 \mathrm{E}+05 \\
3.11 \mathrm{E}+08 \\
1.43 \mathrm{E}+00\end{array}$ & $\begin{array}{l}\text { 4. } 23 \mathrm{E}+06 \\
4.23 \mathrm{E}+09 \\
1.00 \mathrm{E}+00\end{array}$ & & $\begin{array}{l}4.80 \mathrm{E}+05 \\
4.80 \mathrm{E}+08 \\
1.00 \mathrm{E}+00\end{array}$ & $\begin{array}{l}\text { 4. } 10 \mathrm{E}+06 \\
4.09 \mathrm{E}+09 \\
1.00 \mathrm{E}+00\end{array}$ & $\begin{array}{l}\text { 1. } 65 E+05 \\
1.59 E+08 \\
1.04 E+00\end{array}$ & $\begin{array}{l}1.77 \mathrm{E}+04 \\
1.77 \mathrm{E}+07 \\
1.00 \mathrm{E}+00\end{array}$ & $\begin{array}{l}3.34 \mathrm{E}+05 \\
3.20 \mathrm{E}+08 \\
1.04 \mathrm{E}+00\end{array}$ \\
\hline
\end{tabular}

\begin{tabular}{|c|c|c|c|c|c|c|}
\hline \multicolumn{7}{|c|}{ Radianuclides (Ci) } \\
\hline $\begin{array}{l}\mathrm{Am}-241 \\
\mathrm{C}-14 \\
\mathrm{Cs}-137 \\
\mathrm{Ba}-137 \\
\mathrm{~Np}-237 \\
\mathrm{pu}-239 \\
\mathrm{Fu}-240 \\
\mathrm{Pu}-241 \\
\mathrm{Sr}-90 \\
\mathrm{Y}-90 \\
\mathrm{~T}-99 \\
\text { Total Curies }\end{array}$ & $\begin{array}{l}1.11 \mathrm{E}-03 \\
6.68 \mathrm{E}-04 \\
2.1 \mathrm{E}-01 \\
2.04 \mathrm{E}-01 \\
6.51 \mathrm{E}-04 \\
2.70 \mathrm{E}-04 \\
7.43 \mathrm{E}-05 \\
9.47 \mathrm{E}-04 \\
1.6 \mathrm{EE}-01 \\
1.65 \mathrm{E}-01 \\
7.65 \mathrm{E}-03 \\
7.61 \mathrm{E}-01\end{array}$ & $\begin{array}{l}1.11 \mathrm{E}-06 \\
6.6 \mathrm{E}-07 \\
2.1 \mathrm{~F}-04 \\
2.04 \mathrm{E}-04 \\
6.52 \mathrm{E}-07 \\
2.70 \mathrm{E}-07 \\
7.43 \mathrm{E}-08 \\
9.48 \mathrm{E}-07 \\
1.65 \mathrm{E}-04 \\
1.65 \mathrm{E}-04 \\
7.66 \mathrm{E}-06 \\
7.62 \mathrm{E}-04\end{array}$ & $\begin{array}{l}4.76 \mathrm{E}+03 \\
2.87 \mathrm{E}+03 \\
9.24 \mathrm{E}+05 \\
8.78 \mathrm{E}+05 \\
2.80 \mathrm{E}+03 \\
1.16 \mathrm{E}+03 \\
3.19 \mathrm{E}+02 \\
4.07 \mathrm{E}+03 \\
7.10 \mathrm{E}+05 \\
7.10 \mathrm{E}+05 \\
3.29 \mathrm{E}+04 \\
3.27 \mathrm{E}+06\end{array}$ & $\begin{array}{l}2.90 \mathrm{E}+03 \\
3.40 \mathrm{E}+05 \\
3.23 \mathrm{E}+05 \\
2.80 \mathrm{E}+03 \\
\\
1.65 \mathrm{E}+04 \\
6.86 \mathrm{E}+05\end{array}$ & $\begin{array}{l}1.53 \mathrm{E}-06 \\
9.21 \mathrm{E}-07 \\
1.16 \mathrm{E}-02 \\
1.10 \mathrm{E}-02 \\
6.53 \mathrm{E}-07 \\
3.72 \mathrm{E}-07 \\
1.02 \mathrm{E}-07 \\
1.30 \mathrm{E}-06 \\
2.28 \mathrm{E}-04 \\
2.28 \mathrm{E}-04 \\
9.10 \mathrm{E}-06 \\
2.31 \mathrm{E}-02\end{array}$ & $\begin{array}{l}3.40 \mathrm{E}+05 \\
3.23 \mathrm{E}+05 \\
2.79 \mathrm{E}+03\end{array}$ \\
\hline
\end{tabular}

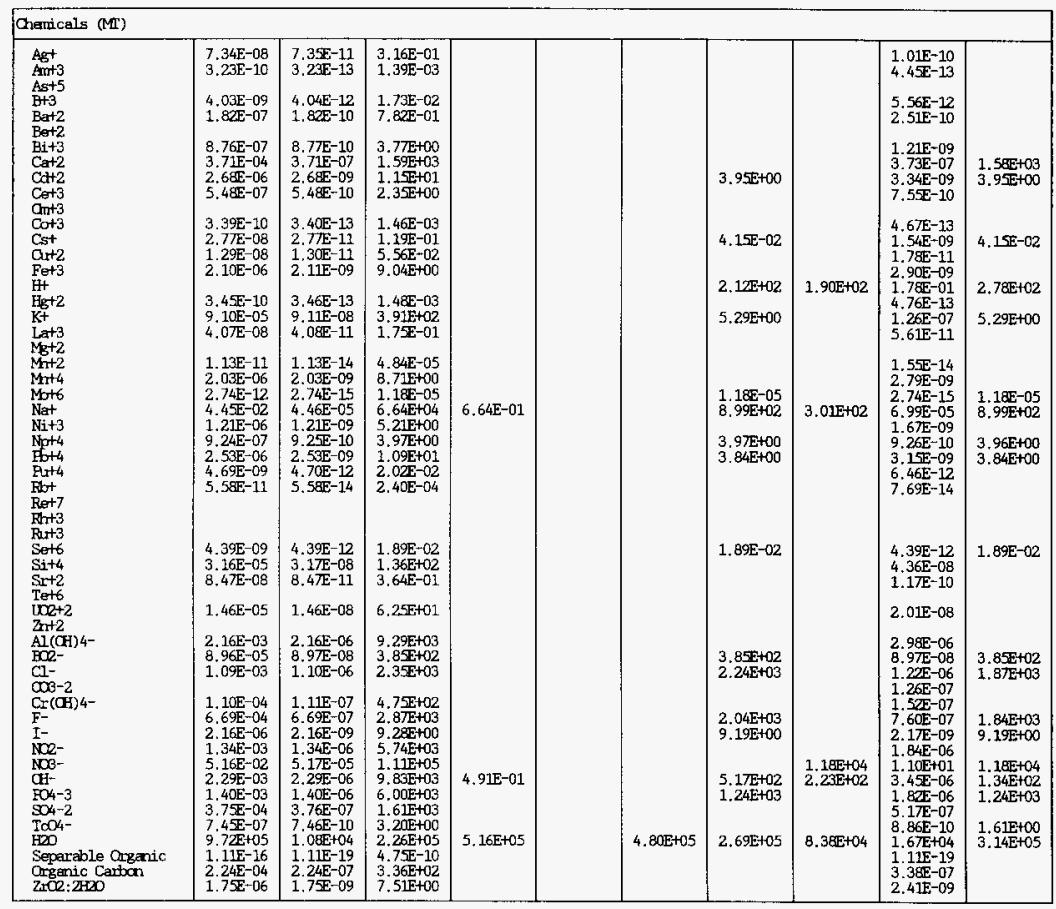


WHC-SD-WM-TI-774 Rev. 0

TWRS PRIVATIZATION PROCESS TECHNICAL BASELINE

Table 13 Phase 2 Mass Balance with TwRS Irventory

\begin{tabular}{|c|c|c|c|c|c|c|c|c|c|c|}
\hline SIREAM NAME & 21 & 22 & 23 & 24 & 25 & 26 & 27 & 28 & 29 & 30 \\
\hline \multicolumn{11}{|l|}{ LIQUD COMEANENIS } \\
\hline \multicolumn{11}{|c|}{ Chemicals Continued (MT) } \\
\hline 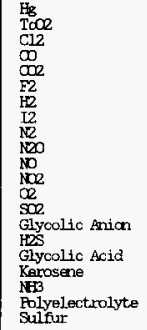 & $\begin{array}{l}2.79 \mathrm{E}-14 \\
3.99 \mathrm{E}-06\end{array}$ & $\begin{array}{l}2.79 \mathrm{E}-17 \\
3.99 \mathrm{E}-09\end{array}$ & $\begin{array}{l}1.20 \mathrm{E}-07 \\
1.71 \mathrm{E}+01\end{array}$ & $\begin{array}{l}2.94 \mathrm{E}+06 \\
7.81 \mathrm{E}+0.5\end{array}$ & & & $\begin{array}{l}2.62 \mathrm{E}-03 \\
1.29 \mathrm{E}+00 \\
3.04 \mathrm{E}+03 \\
\\
2.96 \mathrm{E}+06 \\
1.35 \mathrm{E}+02 \\
8.25 \mathrm{E}+02 \\
8.52 \mathrm{E}+05 \\
9.72 \mathrm{E}+02\end{array}$ & $\begin{array}{l}5.30 E+04 \\
1.41 E+04 \\
1.00 E+01 \\
1.70 E+03\end{array}$ & $\begin{array}{l}3.81 \mathrm{E}-17 \\
5.49 \mathrm{E}-09\end{array}$ & $\begin{array}{l}2.90 \mathrm{E}-07 \\
6.46 \mathrm{E}-05\end{array}$ \\
\hline
\end{tabular}


WHC-SD-WM-TI-774 Rev, 0

TWRS PRIVATIZATION PROCESS TECHNICAL BASELINE

Table 13 Phase 2 Mass Balance with TWRS Inventory

\begin{tabular}{|c|c|c|c|c|c|c|c|c|c|c|}
\hline SIREAM NPE & 21 & 22 & 23 & 24 & 25 & 26 & 27 & 28 & 29 & 30 \\
\hline \multicolumn{11}{|l|}{ SOJI GAFANIS } \\
\hline Total Mass Flow (MI) & & & $2.00 E+04$ & $3.40 E+05$ & 4.42E+05 & $8.98 E+03$ & $9.66 E+03$ & $6.20 \mathrm{E}+03$ & & $1.01 E+04$ \\
\hline \multicolumn{11}{|l|}{ Radianuclides (Ci) } \\
\hline $\begin{array}{l}A m-241 \\
C-14 \\
C s-137 \\
\mathrm{Ba}-137 \\
\mathrm{Mp}-237 \\
\mathrm{Fu}-239 \\
\mathrm{Fu}-240 \\
\mathrm{Fu}-241 \\
\mathrm{Sr}-90 \\
\mathrm{Y}-90 \\
\text { Tc-99 } \\
\text { Total Curies }\end{array}$ & & & $\begin{array}{l}1.04 \mathrm{E}+03 \\
2.7 \mathrm{E}+01 \\
9.76 \mathrm{E}+04 \\
9.28 \mathrm{E}+04 \\
8.60 \mathrm{E}-01 \\
3.39 \mathrm{E}+02 \\
9.94 \mathrm{E}+01 \\
1.17 \mathrm{E}+03 \\
6.16 \mathrm{E}+05 \\
6.16 \mathrm{E}+05 \\
8.13 \mathrm{E}+02 \\
1.43 \mathrm{E}+06\end{array}$ & & $\begin{array}{l}5.57 \mathrm{E}+03 \\
6.54 \mathrm{E}+05 \\
6.21 \mathrm{E}+05 \\
8.2 \mathrm{E}-01 \\
1.44 \mathrm{E}+03 \\
4.02 \mathrm{E}+02 \\
4.9 \mathrm{EE}+03 \\
1.27 \mathrm{E}+06 \\
1.27 \mathrm{E}+06 \\
1.6 \mathrm{E}+04 \\
3.85 \mathrm{E}+06\end{array}$ & $\begin{array}{l}1.13 \mathrm{E}+02 \\
1.33 \mathrm{~F}+04 \\
1.26 \mathrm{E}+04 \\
1.6 \mathrm{EE}-02 \\
2.92 \mathrm{EE}+01 \\
8.16 \mathrm{E}+00 \\
1.01 \mathrm{E}+02 \\
2.58 \mathrm{gE}+04 \\
2.5 \mathrm{gE}+04 \\
3.3 \mathrm{E}+02 \\
7.82 \mathrm{E}+04\end{array}$ & $\begin{array}{l}1.22 \mathrm{E}+02 \\
1.43 \mathrm{E}+04 \\
1.36 \mathrm{E}+04 \\
1.80 \mathrm{E}-02 \\
3.14 \mathrm{E}+01 \\
8.78 \mathrm{E}+00 \\
1.09 \mathrm{E}+02 \\
2.78 \mathrm{E}+04 \\
2.7 \mathrm{EE}+04 \\
3.61 \mathrm{E}+02 \\
8.41 \mathrm{E}+04\end{array}$ & & & $\begin{array}{l}1.22 \mathrm{E}+02 \\
1.43 \mathrm{E}+04 \\
1.36 \mathrm{E}+04 \\
1.80 \mathrm{E}-02 \\
3.14 \mathrm{E}+01 \\
8.78 \mathrm{E}+00 \\
1.09 \mathrm{E}+02 \\
2.7 \mathrm{gE}+04 \\
2.7 \mathrm{gE}+04 \\
3.61 \mathrm{E}+02 \\
8.41 \mathrm{E}+04\end{array}$ \\
\hline
\end{tabular}

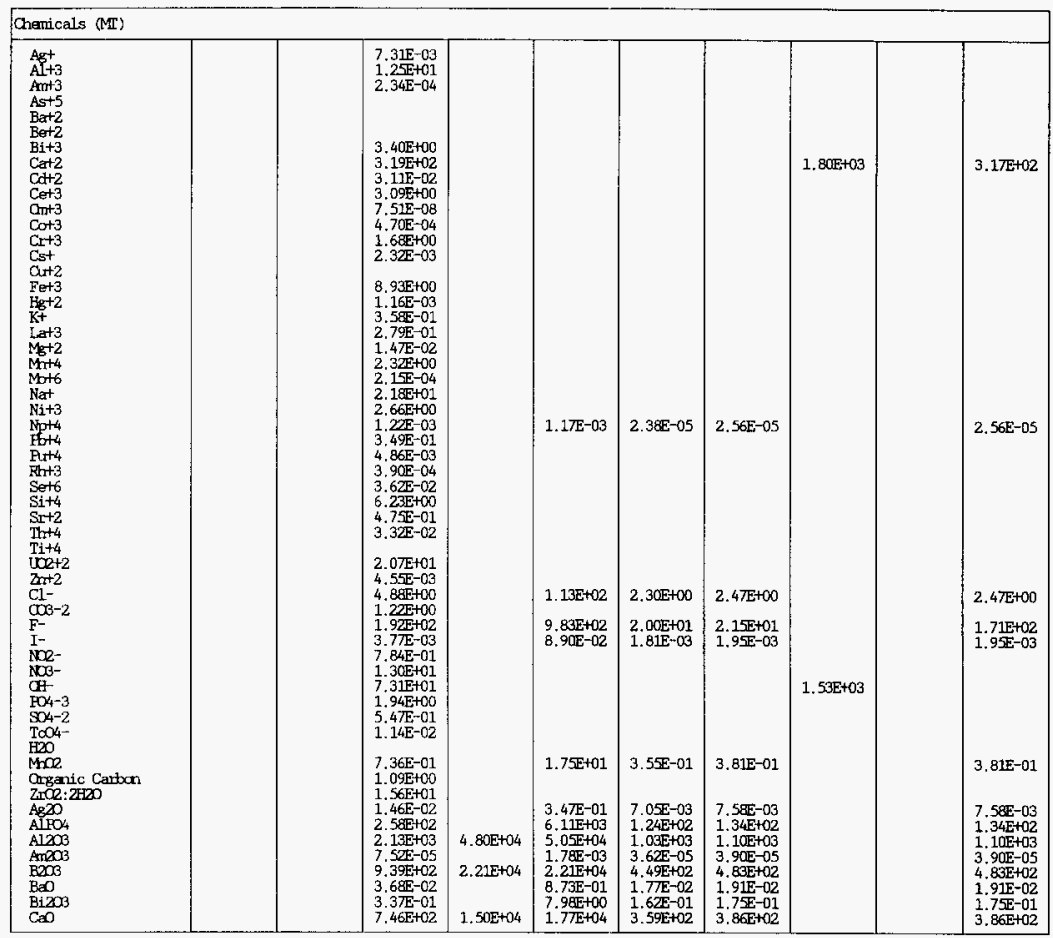




\section{WHC-SD-WM-TI-774 ReV. 0 \\ TWRS PRIVATIZATION PROCESS TECHNICAL BASELINE}

Table 13 Phase 2 Mass Balance with TWRS Inventory

\begin{tabular}{|c|c|c|c|c|c|c|c|c|c|c|}
\hline SIREAM NAME & 21 & 22 & 23 & 24 & 25 & 26 & 27 & 28 & 29 & 30 \\
\hline \multicolumn{11}{|l|}{ SO.ID COMFONENIS } \\
\hline \multicolumn{11}{|c|}{ Chenicals Contirued (MI) } \\
\hline 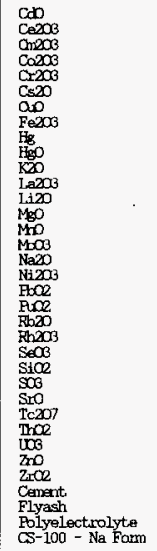 & & & $\begin{array}{l}3.6 . \mathrm{F}-01 \\
2.69 \mathrm{E}-01 \\
3.47 \mathrm{E}-09 \\
1.14 \mathrm{E}-04 \\
1.28 \mathrm{E}+01 \\
3.56 \mathrm{E}-03 \\
2.94 \mathrm{E}-03 \\
1.08 \mathrm{E}+00 \\
2.73 \mathrm{E}-03 \\
1.16 \mathrm{E}-06 \\
1.96 \mathrm{E}+01 \\
2.2 \mathrm{E}-02 \\
2.7 \mathrm{E}+00 \\
5.56 \mathrm{E}-01 \\
2.63 \mathrm{E}-06 \\
1.36 \mathrm{E}-05 \\
3.73 \mathrm{E}+03 \\
4.67 \mathrm{E}-01 \\
3.60 \mathrm{E}-01 \\
1.20 \mathrm{E}-03 \\
1.11 \mathrm{E}-05 \\
2.03 \mathrm{E}-05 \\
2.46 \mathrm{E}-03 \\
1.08 \mathrm{E}+04 \\
5.46 \mathrm{E}+00 \\
4.17 \mathrm{E}-02 \\
6.44 \mathrm{E}-02 \\
1.59 \mathrm{E}-03 \\
3.72 \mathrm{E}+00 \\
2.39 \mathrm{E}-04 \\
7.53 \mathrm{E}-01 \\
\\
1.32 \mathrm{E}+00 \\
6.20 \mathrm{E}+02\end{array}$ & 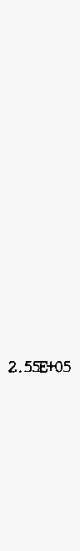 & $\begin{array}{l}8.67 \mathrm{E}+00 \\
6.38 \mathrm{E}+00 \\
8.24 \mathrm{E}-08 \\
2.71 \mathrm{E}-03 \\
3.03 \mathrm{E}+02 \\
8.43 \mathrm{E}-02 \\
6.96 \mathrm{E}-02 \\
2.57 \mathrm{E}+01 \\
2.62 \mathrm{E}-03 \\
2.74 \mathrm{E}-05 \\
4.65 \mathrm{E}+02 \\
5.33 \mathrm{E}-01 \\
2.66 \mathrm{E}+00 \\
5.57 \mathrm{E}-01 \\
6.2 \mathrm{E}-05 \\
3.22 \mathrm{E}-04 \\
8.84 \mathrm{E}+04 \\
1.21 \mathrm{E}+01 \\
8.53 \mathrm{E}+00 \\
2.84 \mathrm{E}-02 \\
2.62 \mathrm{E}-04 \\
4.80 \mathrm{E}-04 \\
5.83 \mathrm{E}-02 \\
2.5 \mathrm{E}+05 \\
1.30 \mathrm{E}+02 \\
9.88 \mathrm{E}-01 \\
1.53 \mathrm{E}+00 \\
3.77 \mathrm{E}-02 \\
8.82 \mathrm{E}+01 \\
5.67 \mathrm{E}-03 \\
1.79 \mathrm{E}+01\end{array}$ & $\begin{array}{l}1.76 \mathrm{E}-01 \\
1.30 \mathrm{E}-01 \\
1.67 \mathrm{E}-09 \\
5.5 \mathrm{E}-05 \\
6.1 \mathrm{E}+00 \\
1.71 \mathrm{E}-03 \\
1.41 \mathrm{E}-03 \\
5.27 \mathrm{E}-01 \\
5.32 \mathrm{E}-05 \\
5.56 \mathrm{E}-07 \\
9.45 \mathrm{E}+00 \\
1.02 \mathrm{E}-02 \\
5.41 \mathrm{E}-02 \\
1.13 \mathrm{E}-02 \\
1.2 \mathrm{E}-06 \\
6.54 \mathrm{E}-06 \\
1.80 \mathrm{E}+03 \\
2.25 \mathrm{E}-01 \\
1.73 \mathrm{E}-01 \\
5.76 \mathrm{E}-04 \\
5.33 \mathrm{E}-06 \\
9.76 \mathrm{E}-06 \\
1.18 \mathrm{E}-03 \\
5.1 \mathrm{E}+03 \\
2.63 \mathrm{E}+00 \\
2.01 \mathrm{E}-02 \\
3.10 \mathrm{E}-02 \\
7.6 \mathrm{E}-04 \\
1.79 \mathrm{E}+00 \\
1.15 \mathrm{E}-04 \\
3.63 \mathrm{E}-01\end{array}$ & $\begin{array}{l}1.89 \mathrm{E}-01 \\
1.39 \mathrm{E}-01 \\
1.80 \mathrm{E}-09 \\
5.93 \mathrm{E}-05 \\
6.62 \mathrm{E}+00 \\
1.84 \mathrm{E}-03 \\
1.5 \mathrm{E}-03 \\
5.62 \mathrm{E}-01 \\
5.72 \mathrm{E}-05 \\
5.99 \mathrm{E}-07 \\
1.02 \mathrm{E}+01 \\
1.1 \mathrm{E}-02 \\
5.82 \mathrm{E}-02 \\
1.22 \mathrm{E}-02 \\
1.3 \mathrm{E}-06 \\
7.04 \mathrm{E}-06 \\
1.93 \mathrm{E}+03 \\
2.42 \mathrm{E}-01 \\
1.86 \mathrm{E}-01 \\
6.20 \mathrm{E}-04 \\
5.73 \mathrm{E}-06 \\
1.05 \mathrm{E}-05 \\
1.27 \mathrm{E}-03 \\
5.5 \mathrm{E}+03 \\
2.8 \mathrm{EE}+00 \\
2.16 \mathrm{E}-02 \\
3.34 \mathrm{E}-02 \\
8.2 \mathrm{E}-04 \\
1.93 \mathrm{~g}+00 \\
1.24 \mathrm{E}-04 \\
3.90 \mathrm{E}-01\end{array}$ & $\begin{array}{l}1.44 \mathrm{E}+03 \\
1.44 \mathrm{E}+03\end{array}$ & & $\begin{array}{l}1.89 \mathrm{E}-01 \\
1.39 \mathrm{E}-01 \\
1.80 \mathrm{E}-09 \\
5.93 \mathrm{E}-05 \\
6.62 \mathrm{E}+00 \\
1.84 \mathrm{E}-03 \\
1.52 \mathrm{E}-03 \\
5.62 \mathrm{E}-01 \\
2.67 \mathrm{E}-03 \\
5.98 \mathrm{E}-07 \\
1.02 \mathrm{E}+01 \\
1.17 \mathrm{E}-02 \\
5.82 \mathrm{E}-02 \\
1.22 \mathrm{E}-02 \\
1.37 \mathrm{E}-06 \\
7.04 \mathrm{E}-06 \\
1.93 \mathrm{E}+03 \\
2.42 \mathrm{E}-01 \\
1.86 \mathrm{E}-01 \\
6.20 \mathrm{E}-04 \\
5.73 \mathrm{E}-06 \\
1.05 \mathrm{E}-05 \\
1.27 \mathrm{E}-03 \\
5.57 \mathrm{E}+03 \\
2.83 \mathrm{E}+00 \\
2.16 \mathrm{E}-02 \\
3.34 \mathrm{E}-02 \\
8.2 \mathrm{E}-04 \\
1.93 \mathrm{E}+00 \\
1.24 \mathrm{E}-04 \\
3.90 \mathrm{E}-01\end{array}$ \\
\hline
\end{tabular}




\section{WHC-SD-WM-TI-774 Rev. 0 \\ TWRS PRIVATIZATION PROCESS TECHNICAL BASELINE}

Table 13 Phase 2 Mass Balance with TWRS Inventory

\begin{tabular}{|c|c|c|c|c|c|c|c|c|c|c|}
\hline STREAM NAME & 31 & 32 & 33 & 34 & 35 & 36 & 37 & 38 & 39 & 40 \\
\hline \multicolumn{11}{|l|}{ LIQUID CMFORENS } \\
\hline $\begin{array}{l}\text { Total Mass Flow (MI) } \\
\text { Volume (L) } \\
\text { Specific Gravity }\end{array}$ & $\begin{array}{l}3,95+06 \\
3,95+09 \\
1,00 E+00\end{array}$ & $\begin{array}{l}4.08 \mathrm{E}+02 \\
4.08 \mathrm{gE}+05 \\
1.00 \mathrm{E}+00\end{array}$ & & & $\begin{array}{l}7.31 E+02 \\
7.31 E+05 \\
1.005+00\end{array}$ & $\begin{array}{l}1.83 \mathrm{E}+03 \\
1.83 \mathrm{E}+06 \\
1.00 \mathrm{E}+00\end{array}$ & $\begin{array}{l}1.36 \mathrm{~F}+05 \\
1.36 \mathrm{E}+08 \\
1.00 \mathrm{E}+00\end{array}$ & $\begin{array}{l}1.51 \mathrm{E}+03 \\
1.51 \mathrm{E}+06 \\
1.00 \mathrm{E}+00\end{array}$ & $\begin{array}{l}3.42 E+04 \\
3.31 E+07 \\
1.03 E+00\end{array}$ & $\begin{array}{l}\text { 8. } 13 E+03 \\
8.13 E+06 \\
1.00 E+00\end{array}$ \\
\hline
\end{tabular}

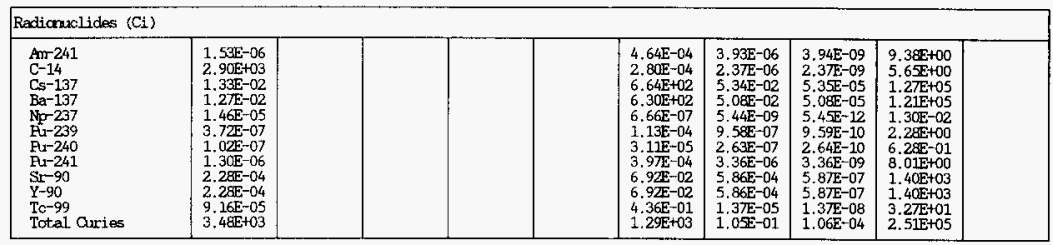

\begin{tabular}{|c|c|c|c|c|c|c|c|c|}
\hline \multicolumn{9}{|l|}{ Qhemicals (M) } \\
\hline 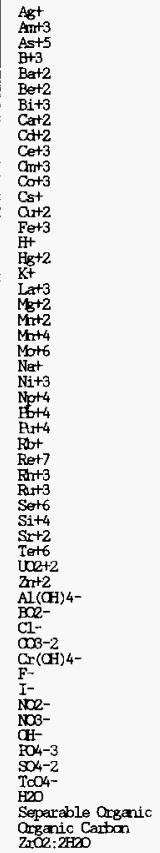 & $\begin{array}{l}1.01 \mathrm{E}-10 \\
4.4 \mathrm{E}-13 \\
5.56 \mathrm{E}-12 \\
2.51 \mathrm{E}-10 \\
1.21 \mathrm{E}-09 \\
3.73 \mathrm{E}-07 \\
2.3 \mathrm{E}-08 \\
7.5 \mathrm{E}-10 \\
4.67 \mathrm{E}-13 \\
1.7 \mathrm{E}-09 \\
1.78 \mathrm{E}-11 \\
2.90 \mathrm{E}-09 \\
1.78 \mathrm{E}-01 \\
4.76 \mathrm{E}-13 \\
1.53 \mathrm{E}-07 \\
5.61 \mathrm{E}-11 \\
1.5 \mathrm{E}-14 \\
2.79 \mathrm{E}-09 \\
6.16 \mathrm{E}-14 \\
7.44 \mathrm{E}-05 \\
1.67 \mathrm{E}-09 \\
2.08 \mathrm{E}-08 \\
2.24 \mathrm{E}-08 \\
6.46 \mathrm{E}-12 \\
7.69 \mathrm{E}-14 \\
\end{array}$ & , & $\begin{array}{l}\text { 9.97E-06 } \\
\text { 2.12E-08 } \\
1.30 \mathrm{E}-06 \\
7.31 \mathrm{E}+02\end{array}$ & $\begin{array}{l}3.09 \mathrm{E}-08 \\
1.3 \mathrm{E}-10 \\
1.69 \mathrm{E}-09 \\
7.62 \mathrm{E}-08 \\
8.49 \mathrm{E}-07 \\
2.96 \mathrm{E}-06 \\
7.36 \mathrm{E}-07 \\
2.29 \mathrm{E}-07 \\
1.4 \mathrm{E}-10 \\
8.7 \mathrm{EE}-05 \\
5.42 \mathrm{E}-09 \\
1.73 \mathrm{E}-06 \\
2.12 \mathrm{E}-05 \\
1.45 \mathrm{E}-10 \\
1.16 \mathrm{E}-04 \\
1.71 \mathrm{E}-08 \\
4.71 \mathrm{E}-12 \\
8.49 \mathrm{E}-07 \\
5.49 \mathrm{E}-02 \\
5.08 \mathrm{E}-07 \\
9.4 \mathrm{E}-10 \\
6.86 \mathrm{E}-07 \\
1.96 \mathrm{E}-09 \\
2.34 \mathrm{E}-11 \\
\end{array}$ & $\begin{array}{l}2.61 \mathrm{E}-10 \\
1.15 \mathrm{E}-12 \\
1.43 \mathrm{E}-11 \\
6.46 \mathrm{E}-10 \\
7.19 \mathrm{E}-09 \\
2.51 \mathrm{E}-08 \\
6.24 \mathrm{E}-09 \\
1.94 \mathrm{E}-09 \\
1.20 \mathrm{E}-12 \\
2.93 \mathrm{E}-09 \\
4.59 \mathrm{E}-11 \\
1.46 \mathrm{E}-08 \\
1.22 \mathrm{E}-12 \\
3.20 \mathrm{E}-07 \\
1.45 \mathrm{E}-10 \\
3.99 \mathrm{E}-14 \\
7.19 \mathrm{E}-09 \\
3.71 \mathrm{E}-04 \\
4.30 \mathrm{E}-09 \\
7.72 \mathrm{E}-12 \\
5.81 \mathrm{E}-09 \\
1.66 \mathrm{E}-11 \\
1.98 \mathrm{E}-13 \\
\end{array}$ & $\begin{array}{l}2.61 \mathrm{E}-13 \\
1.15 \mathrm{E}-15 \\
1.43 \mathrm{E}-14 \\
6.46 \mathrm{E}-13 \\
7.20 \mathrm{E}-12 \\
2.51 \mathrm{E}-11 \\
6.24 \mathrm{E}-12 \\
1.95 \mathrm{E}-12 \\
1.20 \mathrm{E}-15 \\
2.94 \mathrm{E}-12 \\
4.60 \mathrm{E}-14 \\
1.46 \mathrm{E}-11 \\
1.23 \mathrm{E}-15 \\
3.20 \mathrm{E}-10 \\
1.4 \mathrm{E}-13 \\
4.00 \mathrm{E}-17 \\
7.20 \mathrm{E}-12 \\
1.18 \mathrm{E}-22 \\
3.71 \mathrm{E}-07 \\
4.30 \mathrm{E}-12 \\
7.72 \mathrm{E}-15 \\
5.82 \mathrm{E}-12 \\
1.6 \mathrm{E}-14 \\
1.98 \mathrm{E}-16\end{array}$ & $\begin{array}{l}6.21 \mathrm{E}-04 \\
2.73 \mathrm{E}-06 \\
3.41 \mathrm{E}-05 \\
1.54 \mathrm{E}-03 \\
1.72 \mathrm{E}-02 \\
5.98 \mathrm{E}-02 \\
1.49 \mathrm{E}-02 \\
4.63 \mathrm{E}-03 \\
2.8 \mathrm{E}-06 \\
6.99 \mathrm{E}-03 \\
1.10 \mathrm{E}-04 \\
3.48 \mathrm{E}-02 \\
2.92 \mathrm{E}-06 \\
7.62 \mathrm{E}-01 \\
3.45 \mathrm{E}-04 \\
9.52 \mathrm{E}-08 \\
1.72 \mathrm{E}-02 \\
2.82 \mathrm{E}-13 \\
6.6 \mathrm{E}+02 \\
1.03 \mathrm{E}-02 \\
1.84 \mathrm{E}-05 \\
1.39 \mathrm{E}-02 \\
3.97 \mathrm{E}-05 \\
4.72 \mathrm{E}-07\end{array}$ & $1.70 \mathrm{E}+03$ \\
\hline
\end{tabular}


WHC-SD-WM-TI-774 Rev. 0

TWRS PRIVATIZATION PROCESS TECHNICAL BASELINE

Table 13 Phase 2 Mass Balance with TwRS Inventory

\begin{tabular}{|c|c|c|c|c|c|c|c|c|c|c|}
\hline SIREAM NAME & 31 & 32 & 33 & 34 & 35 & 36 & 37 & 38 & 39 & 40 \\
\hline \multicolumn{11}{|l|}{ LIQUD DOMFANEMIS } \\
\hline \multicolumn{11}{|c|}{ Chemicals Continued (MI) } \\
\hline 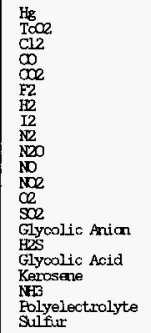 & $\begin{array}{l}1.53 \mathrm{E}-08 \\
6.46 \mathrm{E}-09 \\
2.04 \mathrm{E}+01 \\
4.10 \mathrm{E}+03 \\
7.09 \mathrm{E}+01 \\
3.02 \mathrm{E}+06 \\
1.35 \mathrm{E}+00 \\
1.03 \mathrm{E}+01 \\
8.65 \mathrm{E}+05 \\
9.72 \mathrm{E}+01 \\
3.81 \mathrm{E}-17 \\
3.20 \mathrm{E}+01 \\
\\
1.79 \mathrm{E}+01 \\
5.49 \mathrm{E}-09\end{array}$ & 更 & & & & $\begin{array}{l}1.39 \mathrm{E}+00 \\
1.04 \mathrm{E}-04\end{array}$ & $\begin{array}{l}5.81 E-07 \\
8.78 E-07\end{array}$ & 5. $82 E-10$ & $\begin{array}{l}1.39 E+00 \\
2.09 E+00\end{array}$ & $\begin{array}{l}2.36 \mathrm{E}+03 \\
4.07 \mathrm{E}+03\end{array}$ \\
\hline
\end{tabular}


WHC-SD-WM-TI-774 Rev. 0

TWRS PRIVATIZATION PROCESS TECHNICAL BASELINE

Table 13 Phase 2 Mass Balance with TwRS Inventory

\begin{tabular}{|c|c|c|c|c|c|c|c|c|c|c|}
\hline SIDFAM NAE & 31 & 32 & 33 & 34 & 35 & 36 & 37 & 38 & 39 & 40 \\
\hline \multicolumn{11}{|l|}{ SQID OARANENSS } \\
\hline Total Mass Flow (MT) & $2.23 \mathrm{E}-01$ & & $5.75 \mathrm{E}+03$ & & & $1.96 \mathrm{E}+00$ & & & $1.48 E+04$ & $2.51 E+04$ \\
\hline \multicolumn{11}{|l|}{ Radianuclides (Ci) } \\
\hline $\begin{array}{l}\text { ATr-241 } \\
\mathrm{C}-14 \\
\mathrm{Cs}-137 \\
\mathrm{Ba}-137 \\
\mathrm{~Np}-237 \\
\mathrm{Ru}-239 \\
\mathrm{Au}-240 \\
\mathrm{Pu}-241 \\
\mathrm{Sr}-90 \\
\mathrm{Y}-90 \\
\text { To-99 } \\
\text { Total aries }\end{array}$ & $\begin{array}{l}2.82 \mathrm{E}-03 \\
3.31 \mathrm{E}-01 \\
3.14 \mathrm{E}-01 \\
4.1 \mathrm{E}-07 \\
7.27 \mathrm{E}-04 \\
2.03 \mathrm{E}-04 \\
2.52 \mathrm{E}-03 \\
6.4 \mathrm{BE}-01 \\
6.43 \mathrm{E}-01 \\
8.34 \mathrm{E}-03 \\
1.95 \mathrm{E}+00\end{array}$ & & & & & $\begin{array}{l}2.99 \mathrm{E}+00 \\
1.02 \mathrm{E}-01 \\
2.62 \mathrm{E}+02 \\
2.49 \mathrm{E}+02 \\
3.0 \mathrm{E}-03 \\
1.04 \mathrm{E}+00 \\
3.07 \mathrm{E}-01 \\
3.40 \mathrm{E}+00 \\
2.09 \mathrm{E}+03 \\
2.09 \mathrm{E}+03 \\
4.6 \mathrm{E}-01 \\
4.73 \mathrm{E}+03\end{array}$ & & & $\begin{array}{l}6.03 \mathrm{E}+04 \\
2.07 \mathrm{E}+03 \\
5.2 \mathrm{E}+06 \\
4.99 \mathrm{E}+06 \\
6.19 \mathrm{E}+01 \\
2.09 \mathrm{E}+04 \\
6.19 \mathrm{E}+03 \\
6.86 \mathrm{E}+04 \\
4.22 \mathrm{E}+07 \\
4.22 \mathrm{E}+07 \\
8.76 \mathrm{E}+03 \\
9.48 \mathrm{E}+07\end{array}$ & \\
\hline \multicolumn{11}{|l|}{ Chamicals (MI) } \\
\hline 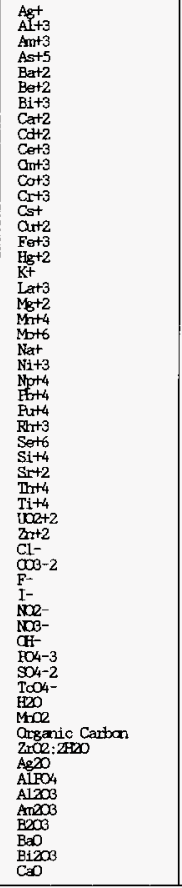 & $\begin{array}{l}\text { 8. } 82 \mathrm{E}-06 \\
1.75 \mathrm{E}-07 \\
3.09 \mathrm{E}-03 \\
2.5 \mathrm{E}-02 \\
9.02 \mathrm{E}-10 \\
1.12 \mathrm{E}-02 \\
4.42 \mathrm{E}-07 \\
4.04 \mathrm{E}-06 \\
8.93 \mathrm{E}-03\end{array}$ & & $\begin{array}{l}3.01 \mathrm{E}+02 \\
3.65 \mathrm{E}+02 \\
5.30 \mathrm{E}+01 \\
7.77 \mathrm{E}-01 \\
5.22 \mathrm{E}+01 \\
1.99 \mathrm{E}+03\end{array}$ & & & $\begin{array}{l}2.7 \mathrm{E}-05 \\
4.6 \mathrm{E}-02 \\
8.70 \mathrm{E}-07 \\
\\
1.26 \mathrm{E}-02 \\
6.33 \mathrm{E}-03 \\
1.16 \mathrm{E}-04 \\
1.15 \mathrm{E}-02 \\
2.79 \mathrm{E}-10 \\
1.75 \mathrm{E}-06 \\
6.23 \mathrm{E}-03 \\
8.60 \mathrm{E}-06 \\
3.32 \mathrm{E}-02 \\
4.31 \mathrm{E}-06 \\
1.33 \mathrm{E}-03 \\
1.04 \mathrm{E}-03 \\
5.45 \mathrm{E}-05 \\
8.61 \mathrm{E}-03 \\
7.98 \mathrm{E}-07 \\
8.10 \mathrm{E}-02 \\
9.8 \mathrm{EE}-03 \\
4.36 \mathrm{E}-06 \\
1.30 \mathrm{E}-03 \\
1.81 \mathrm{E}-05 \\
1.45 \mathrm{E}-06 \\
1.3 \mathrm{E}-04 \\
2.32 \mathrm{E}-02 \\
1.77 \mathrm{E}-03 \\
1.23 \mathrm{E}-04 \\
7.69 \mathrm{E}-02 \\
1.69 \mathrm{E}-05 \\
9.15 \mathrm{E}-04 \\
4.52 \mathrm{E}-03 \\
4.46 \mathrm{E}-03 \\
5.07 \mathrm{E}-08 \\
2.91 \mathrm{E}-03 \\
4.81 \mathrm{E}-02 \\
2.47 \mathrm{E}-01 \\
7.20 \mathrm{E}-03 \\
2.03 \mathrm{E}-03 \\
4.22 \mathrm{E}-05 \\
2.73 \mathrm{E}-05 \\
4.06 \mathrm{E}-03 \\
5.78 \mathrm{E}-02 \\
5.86 \mathrm{E}-08 \\
2.03 \mathrm{E}-05 \\
1.72 \mathrm{E}-04 \\
1.92 \mathrm{E}-09 \\
2.33 \mathrm{E}-01 \\
1.71 \mathrm{E}-10 \\
2.82 \mathrm{E}-05 \\
1.78 \mathrm{E}-05 \\
\end{array}$ & & & $\begin{array}{l}5.49 \mathrm{E}-01 \\
9.39 \mathrm{E}+02 \\
1.76 \mathrm{E}-02 \\
\\
2.55 \mathrm{E}+02 \\
1.28 \mathrm{E}+02 \\
2.34 \mathrm{E}+00 \\
2.32 \mathrm{E}+02 \\
5.64 \mathrm{E}-06 \\
3.53 \mathrm{E}-02 \\
1.26 \mathrm{E}+02 \\
1.74 \mathrm{E}-01 \\
6.71 \mathrm{E}+02 \\
8.70 \mathrm{E}-02 \\
2.69 \mathrm{E}+01 \\
2.10 \mathrm{E}+01 \\
1.10 \mathrm{E}+00 \\
1.74 \mathrm{E}+02 \\
1.61 \mathrm{E}-02 \\
1.64 \mathrm{E}+03 \\
2.00 \mathrm{E}+02 \\
8.78 \mathrm{E}-02 \\
2.62 \mathrm{E}+01 \\
3.65 \mathrm{E}-01 \\
2.93 \mathrm{E}-02 \\
2.72 \mathrm{E}+00 \\
4.6 \mathrm{EE}+02 \\
3.5 \mathrm{E}+01 \\
2.49 \mathrm{E}+00 \\
1.55 \mathrm{E}+03 \\
3.42 \mathrm{E}-01 \\
8.78 \mathrm{E}+00 \\
9.12 \mathrm{E}+01 \\
6.71 \mathrm{E}+01 \\
1.02 \mathrm{E}-03 \\
5.88 \mathrm{E}+01 \\
9.72 \mathrm{E}+02 \\
5.49 \mathrm{E}+03 \\
1.45 \mathrm{E}+02 \\
4.11 \mathrm{E}+01 \\
8.53 \mathrm{E}-01 \\
2.73 \mathrm{E}-05 \\
8.19 \mathrm{E}+01 \\
1.17 \mathrm{E}+03 \\
5.86 \mathrm{E}-08 \\
2.03 \mathrm{E}-05 \\
1.72 \mathrm{E}-04 \\
1.92 \mathrm{E}-09 \\
2.33 \mathrm{E}-01 \\
1.71 \mathrm{E}-10 \\
2.82 \mathrm{E}-05 \\
1.78 \mathrm{E}-05\end{array}$ & 4.66e+03 \\
\hline
\end{tabular}




\section{WHC-SD-WM-TI-774 Rev. 0 \\ TWRS PRIVATIZATION PROCESS TECHNICAL BASELINE}

Table 13 Phase 2 Mass Balance with TWRS Inventory

\begin{tabular}{|c|c|c|c|c|c|c|c|c|c|c|}
\hline SIREAM NAME & 31 & 32 & 33 & 34 & 35 & 36 & 37 & 38 & 39 & 40 \\
\hline \multicolumn{11}{|l|}{ SOLW COMANENIS } \\
\hline \multicolumn{11}{|c|}{ Chenicals Cuntinued (MT) } \\
\hline 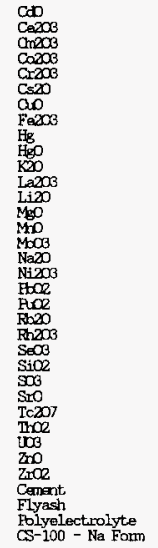 & 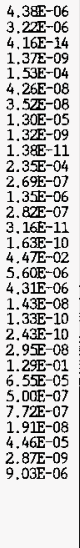 & & $\begin{array}{l}1.44 \mathrm{E}+03 \\
1.44 \mathrm{E}+03\end{array}$ & & & 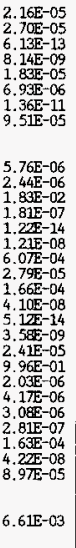 & & & 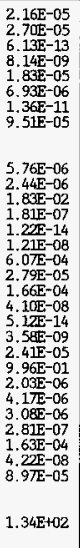 & 3. $70 \mathrm{E}+02$ \\
\hline
\end{tabular}




\section{WHC-SD-WM-TI-774 Rev. 0 \\ TWRS PRIVATIZATION PROCESS TECHNICAL BASELINE}

Table 13 Phase 2 Mass Balance with TwRS Inventory

\begin{tabular}{|c|c|c|c|c|c|c|c|c|}
\hline SIREAM NAME & 41 & 42 & 43 & 44 & 45 & 46 & 47 & 48 \\
\hline \multicolumn{9}{|l|}{ IIguIl campands } \\
\hline $\begin{array}{l}\text { Total Mass Flow (MI) } \\
\text { Volum (L) } \\
\text { Specific Gravity }\end{array}$ & $\begin{array}{l}1.60 \mathrm{E}+04 \\
1.59 \mathrm{E}+07 \\
1.00 \mathrm{E}+00\end{array}$ & & $\begin{array}{l}7.07 \mathrm{E}+04 \\
7.07 \mathrm{E}+07 \\
1.00 \mathrm{E}+00\end{array}$ & $\begin{array}{l}1.16 \mathrm{E}+01 \\
1.16 \mathrm{E}+04 \\
1.00 \mathrm{E}+00\end{array}$ & $\begin{array}{l}\text { 4. } 73 \mathrm{E}+04 \\
4.73 E+07 \\
1.00 E+00\end{array}$ & $\begin{array}{l}7.11 \mathrm{E}+03 \\
7.11 \mathrm{E}+06 \\
1.00 \mathrm{E}+00\end{array}$ & $\begin{array}{l}\text { 8. } 22 \mathrm{E}-02 \\
\text { 8. } 22 \mathrm{E}+01 \\
\text { 1. } 00 \mathrm{E}+00\end{array}$ & $\begin{array}{l}\text { 1. } 12 \mathrm{E}+06 \\
\text { 1. } 12 \mathrm{E}+09 \\
\text { 1. } 00 \mathrm{E}+00\end{array}$ \\
\hline \multicolumn{9}{|l|}{ Radicunclides (Ci) } \\
\hline $\begin{array}{l}\text { Am-241 } \\
C-14 \\
C s-137 \\
\mathrm{Ba}-137 \\
\mathrm{Na}-237 \\
\mathrm{Pu}-239 \\
\mathrm{Eu}-240 \\
\mathrm{Eu}-241 \\
\mathrm{Sr}-90 \\
\mathrm{Y}-90 \\
\text { Tc-99 } \\
\text { Total curies }\end{array}$ & $\begin{array}{l}4.82 \mathrm{E}-04 \\
8.7 \mathrm{gE}+03 \\
8.7 \mathrm{~g}+03\end{array}$ & & $\begin{array}{l}4.69 \mathrm{E}-04 \\
2.07 \mathrm{E}+03 \\
6.70 \mathrm{E}+02 \\
6.37 \mathrm{E}+02 \\
1.3 \mathrm{E}-02 \\
1.14 \mathrm{E}-04 \\
3.14 \mathrm{E}-05 \\
4.01 \mathrm{E}-04 \\
6.99 \mathrm{E}-02 \\
6.99 \mathrm{E}-02 \\
8.78 \mathrm{E}+03 \\
1.26 \mathrm{E}+04\end{array}$ & & $\begin{array}{l}1.44 \mathrm{E}-10 \\
\\
2.63 \mathrm{E}-03 \\
2.63 \mathrm{E}-03\end{array}$ & $\begin{array}{l}4.69 \mathrm{E}-06 \\
2.07 \mathrm{E}+03 \\
6.70 \mathrm{E}+\infty \\
6.37 \mathrm{E}+00 \\
8.57 \mathrm{E}-06 \\
1.14 \mathrm{E}-06 \\
3.14 \mathrm{E}-07 \\
4.01 \mathrm{E}-06 \\
6.99 \mathrm{E}-04 \\
6.99 \mathrm{E}-04 \\
5.60 \mathrm{E}+00 \\
2.51 \mathrm{E}+03\end{array}$ & & $\begin{array}{l}1.06 \mathrm{E}-03 \\
6.37 \mathrm{E}-04 \\
1.02 \mathrm{E}+00 \\
9.73 \mathrm{E}-01 \\
3.06 \mathrm{E}-04 \\
2.57 \mathrm{E}-04 \\
7.08 \mathrm{E}-05 \\
9.03 \mathrm{E}-04 \\
1.58 \mathrm{E}-01 \\
1.58 \mathrm{E}-01 \\
8.11 \mathrm{E}-03 \\
2.32 \mathrm{E}+00\end{array}$ \\
\hline \multicolumn{9}{|l|}{ Chemicals (MT) } \\
\hline 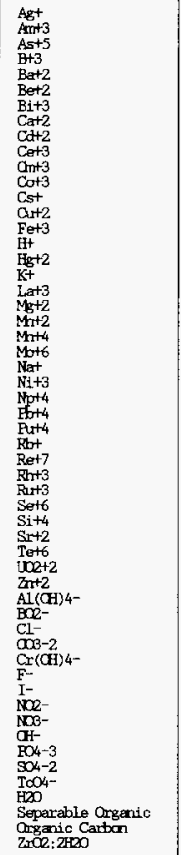 & $\begin{array}{l}1.87 \mathrm{E}+01 \\
4.92 \mathrm{E}+00 \\
8.5 \mathrm{E}-01 \\
1.59 \mathrm{E}+04\end{array}$ & & $\begin{array}{l}3.11 \mathrm{E}-08 \\
1.37 \mathrm{E}-10 \\
1.71 \mathrm{E}-09 \\
7.70 \mathrm{E}-08 \\
8.57 \mathrm{E}-07 \\
2.99 \mathrm{E}-06 \\
7.44 \mathrm{E}-07 \\
2.32 \mathrm{E}-07 \\
1.43 \mathrm{E}-10 \\
8.83 \mathrm{E}-05 \\
5.48 \mathrm{E}-09 \\
1.74 \mathrm{E}-06 \\
2.14 \mathrm{E}-05 \\
1.46 \mathrm{E}-10 \\
1.17 \mathrm{E}-04 \\
1.72 \mathrm{E}-08 \\
4.76 \mathrm{E}-12 \\
8.57 \mathrm{E}-07 \\
5.5 \mathrm{E}-02 \\
5.13 \mathrm{E}-07 \\
1.91 \mathrm{E}-05 \\
6.93 \mathrm{E}-07 \\
1.98 \mathrm{E}-09 \\
2.36 \mathrm{E}-11 \\
\\
2.25 \mathrm{E}-14 \\
5.77 \mathrm{E}-05 \\
3.58 \mathrm{E}-08 \\
2.63 \mathrm{E}-05 \\
4.05 \mathrm{E}-03 \\
4.60 \mathrm{E}-10 \\
4.70 \mathrm{E}-05 \\
6.72 \mathrm{E}-05 \\
1.02 \mathrm{E}-04 \\
8.84 \mathrm{E}-09 \\
2.20 \mathrm{E}-03 \\
6.84 \mathrm{E}-02 \\
6.82 \mathrm{E}-04 \\
4.05 \mathrm{E}-04 \\
4.29 \mathrm{E}-05 \\
6.39 \mathrm{E}+04 \\
7.66 \mathrm{E}-06 \\
2.32 \mathrm{E}-04 \\
7.39 \mathrm{E}-07\end{array}$ & 1. $16 \mathrm{E}+01$ & $\begin{array}{l}1.12 \mathrm{E}-05 \\
1.48 \mathrm{E}-06 \\
2.56 \mathrm{E}-07 \\
4.73 \mathrm{E}+04\end{array}$ & $\begin{array}{l}3.11 \mathrm{E}-10 \\
1.37 \mathrm{E}-12 \\
1.71 \mathrm{E}-11 \\
7.70 \mathrm{E}-10 \\
8.57 \mathrm{E}-09 \\
2.99 \mathrm{E}-08 \\
7.44 \mathrm{E}-09 \\
2.32 \mathrm{E}-09 \\
1.44 \mathrm{E}-12 \\
8.83 \mathrm{E}-07 \\
5.48 \mathrm{E}-11 \\
1.74 \mathrm{E}-08 \\
2.59 \mathrm{E}-04 \\
1.46 \mathrm{E}-12 \\
1.17 \mathrm{E}-06 \\
1.72 \mathrm{E}-10 \\
4.76 \mathrm{E}-14 \\
8.5 \mathrm{E}-09 \\
5.55 \mathrm{E}-04 \\
5.1 \mathrm{EE}-09 \\
1.22 \mathrm{E}-09 \\
6.93 \mathrm{E}-09 \\
1.98 \mathrm{E}-11 \\
2.36 \mathrm{E}-13\end{array}$ & & $\begin{array}{l}7.00 \mathrm{E}-08 \\
3.08 \mathrm{E}-10 \\
3.85 \mathrm{E}-09 \\
1.74 \mathrm{E}-07 \\
8.38 \mathrm{E}-07 \\
2.57 \mathrm{E}-04 \\
2.31 \mathrm{E}-06 \\
5.22 \mathrm{E}-07 \\
3.23 \mathrm{E}-10 \\
1.32 \mathrm{E}-07 \\
1.23 \mathrm{E}-08 \\
2.01 \mathrm{E}-06 \\
3.29 \mathrm{E}-10 \\
8.65 \mathrm{E}-05 \\
3.88 \mathrm{E}-08 \\
1.07 \mathrm{E}-11 \\
1.93 \mathrm{E}-06 \\
1.89 \mathrm{E}-12 \\
4.84 \mathrm{E}-02 \\
1.16 \mathrm{E}-06 \\
4.34 \mathrm{E}-07 \\
2.18 \mathrm{E}-06 \\
4.47 \mathrm{E}-09 \\
5.32 \mathrm{E}-11\end{array}$ \\
\hline
\end{tabular}


WHC-SD-WM-TI-774 Rev. 0

TWRS PRIVATIZATION PROCESS TECHNICAL BASELINE

Table 13 Phase 2 Mass Balance with TWRS Inventory

\begin{tabular}{|c|c|c|c|c|c|c|c|c|}
\hline SIREAM NAE & 41 & 42 & 43 & 44 & 45 & 46 & 47 & 48 \\
\hline \multicolumn{9}{|l|}{ I.TQJI CMFONOMS } \\
\hline \multicolumn{9}{|c|}{ Chanicals Contirued (MT) } \\
\hline 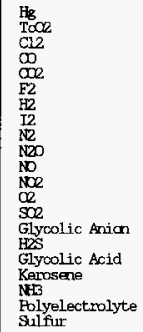 & $9.61 \mathrm{E}-02$ & & $\begin{array}{l}1.83 E-01 \\
6.87 \mathrm{E}-01 \\
1.94 \mathrm{E}-02 \\
5.46 \mathrm{E}+03 \\
9.22 \mathrm{E}-02 \\
1.20 \mathrm{E}-03 \\
1.35 \mathrm{E}+02 \\
1.40 \mathrm{E}+01 \\
9.14 \mathrm{E}+02 \\
2.15 \mathrm{E}+02 \\
1.64 \mathrm{E}+01 \\
1.40 \mathrm{E}+00 \\
\\
2.72 \mathrm{E}+00 \\
1.05 \mathrm{E}-04\end{array}$ & & $2.89 \mathrm{E}-08$ & $\begin{array}{l}1.25 \mathrm{E}-03 \\
4.37 \mathrm{E}-04 \\
1.94 \mathrm{E}-02 \\
5.46 \mathrm{E}+03 \\
9.2 \pi \mathrm{E}-02 \\
1.20 \mathrm{E}-03 \\
1.35 \mathrm{E}+02 \\
1.40 \mathrm{E}+01 \\
9.05 \mathrm{E}+02 \\
2.07 \mathrm{E}+02 \\
1.31 \mathrm{E}+01 \\
1.40 \mathrm{E}-02 \\
\\
2.72 \mathrm{E}+00 \\
1.05 \mathrm{E}-06\end{array}$ & 8.22ब-02 & $\begin{array}{l}4.02 \mathrm{E}-07 \\
4.39 \mathrm{E}-06\end{array}$ \\
\hline
\end{tabular}


WHC-SD-WM-TI-774 Rev. 0

TWRS PRIVATIZATION PROCESS TECHNICAL BASELINE

Table 13 Phase 2 Mass Balance with TWRS Irventory

\begin{tabular}{|c|c|c|c|c|c|c|c|c|}
\hline SIREAM NAE & 41 & 42 & 43 & 44 & 45 & 46 & 47 & 48 \\
\hline \multicolumn{9}{|l|}{ SOLII OMFONENS } \\
\hline Total Mass Flow (MT) & 1. $54 \mathrm{E}+02$ & $3.70 \mathrm{E}+04$ & $1.56 \mathrm{E}+02$ & & & $2.94 \mathrm{E}-08$ & & \\
\hline \multicolumn{9}{|l|}{ Radianuclides (Ci) } \\
\hline $\begin{array}{l}\mathrm{Am}-241 \\
\mathrm{C}-14 \\
\mathrm{C} s-137 \\
\mathrm{Ba}-137 \\
\mathrm{Ng}-237 \\
\mathrm{E}-239 \\
\mathrm{Pu}-240 \\
\mathrm{Fu}-241 \\
\mathrm{Sr}-90 \\
\mathrm{Y}-90 \\
\text { Tc-99 } \\
\text { Total Curies }\end{array}$ & $\begin{array}{l}1.21 \mathrm{E}+02 \\
1.03 \mathrm{E}-03 \\
3.74 \mathrm{E}+04 \\
3.5 \mathrm{EE}+04 \\
1.24 \mathrm{E}-01 \\
4.19 \mathrm{E}+01 \\
1.24 \mathrm{E}+01 \\
1.38 \mathrm{E}+02 \\
8.46 \mathrm{E}+04 \\
8.46 \mathrm{E}+04 \\
6.71 \mathrm{E}+02 \\
2.43 \mathrm{E}+05\end{array}$ & $\begin{array}{l}6.03 E+04 \\
1.87 \mathrm{E}+07 \\
1.7 \mathrm{E}+07 \\
6.19 \mathrm{E}+01 \\
2.09 \mathrm{E}+04 \\
6.19 \mathrm{E}+03 \\
6.86 \mathrm{E}+04 \\
4.22 \mathrm{E}+07 \\
4.22 \mathrm{E}+07 \\
8.7 \mathrm{E}+03 \\
1.21 \mathrm{E}+08\end{array}$ & $\begin{array}{l}1.24 \mathrm{E}+02 \\
1.03 \mathrm{E}-01 \\
3.77 \mathrm{E}+04 \\
3.58 \mathrm{E}+04 \\
1.27 \mathrm{E}-01 \\
4.29 \mathrm{E}+01 \\
1.27 \mathrm{E}+01 \\
1.41 \mathrm{E}+02 \\
8.67 \mathrm{E}+04 \\
8.67 \mathrm{E}+04 \\
6.72 \mathrm{E}+02 \\
2.48 \mathrm{E}+05\end{array}$ & & & $\begin{array}{l}2.68 \mathrm{E}-08 \\
2.59 \mathrm{E}-10 \\
6.61 \mathrm{E}-06 \\
6.25 \mathrm{E}-06 \\
2.75 \mathrm{E}-11 \\
9.28 \mathrm{E}-09 \\
2.75 \mathrm{E}-09 \\
3.05 \mathrm{E}-08 \\
1.87 \mathrm{E}-05 \\
1.87 \mathrm{E}-05 \\
1.08 \mathrm{~g}-07 \\
5.06 \mathrm{E}-05\end{array}$ & & \\
\hline
\end{tabular}

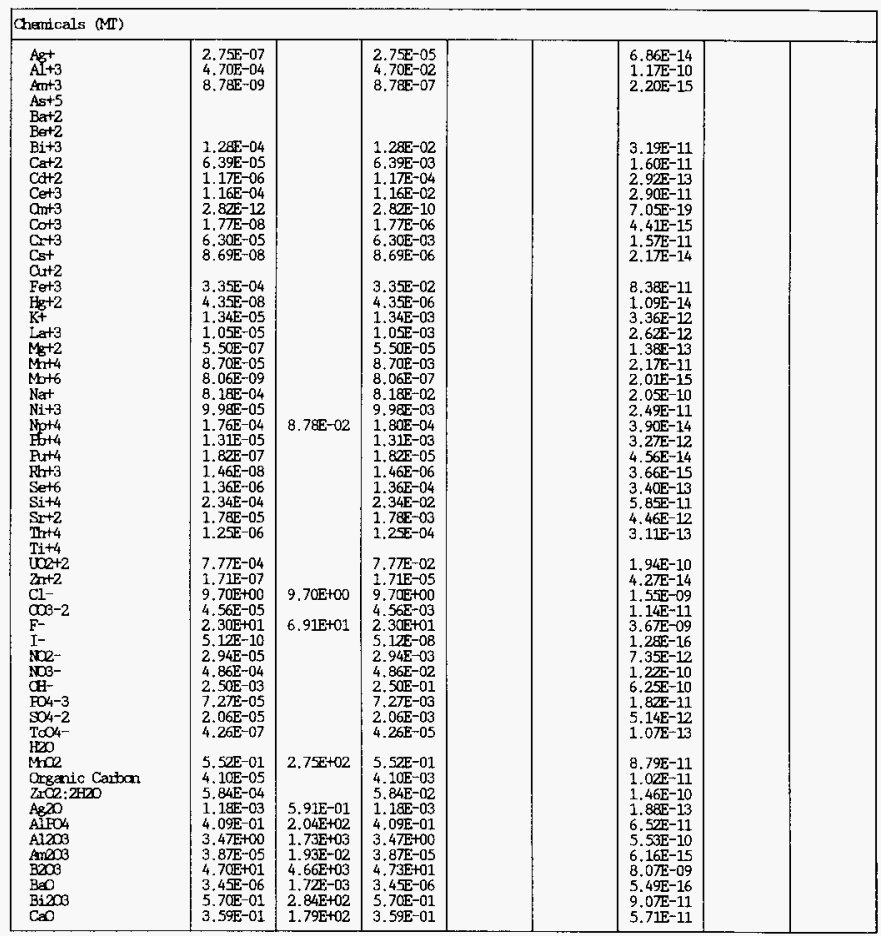




\section{WHC-SD-WM-TI-774 Rev. 0 \\ TWRS PRIVATIZATION PROCESS TECHNICAL BASELINE}

Table 13 Phase 2 Mass Balance with TWRS Inventory

\begin{tabular}{|c|c|c|c|c|c|c|c|c|}
\hline SIREAM NAAE & 41 & 42 & 43 & 44 & 45 & 46 & 47 & 48 \\
\hline \multicolumn{9}{|l|}{ SOLI OONFONEIS } \\
\hline \multicolumn{9}{|c|}{ Chenicals Contirued (MT) } \\
\hline $\cos$ & $4.37 \mathrm{E}-0 \mathrm{1}$ & $2.69 \mathrm{E}+00$ & $4.3 \pi-01$ & & & $6.96 \mathrm{E}-11$ & & \\
\hline $\operatorname{Cos} 203$ & $5.44 \mathrm{E}-01$ & 2.72 E +02 & $5.44 \mathrm{E}-01$ & & & $8.67 \mathrm{E}^{-11}$ & & \\
\hline$\frac{102003}{0.0208}$ & $\left|\begin{array}{l}1.24 \mathrm{E}-08 \\
1.65 \mathrm{E}-04\end{array}\right|$ & $\begin{array}{l}6.18 \mathrm{E}-06 \\
4.97 \mathrm{0} 2\end{array}$ & $\begin{array}{l}1.24 \mathrm{E}-08 \\
1.65 \mathrm{E}-04\end{array}$ & & & $\begin{array}{l}1.97 \mathrm{E}-18 \\
2.62 \mathrm{E}-14\end{array}$ & & \\
\hline${ }_{C=200}^{C r O S}$ & $\left|\begin{array}{l}3.70 \mathrm{E}-01 \\
1.40 \mathrm{EE}-01\end{array}\right|$ & $\begin{array}{l}1.86+02 \\
2.05 t+00\end{array}$ & $\begin{array}{l}\text { 3. } 71 \mathrm{EE}-01 \\
1.40 \mathrm{E}-01\end{array}$ & & & $5.90 \mathrm{~F}-11$ & & \\
\hline $\begin{array}{l}\text { an } \\
\text { Fener }\end{array}$ & $\begin{array}{l}2.75 F-07 \\
1.92+00\end{array}$ & $\begin{array}{l}1.37 \mathrm{E}-04 \\
9.59 \mathrm{E}+02\end{array}$ & $\begin{array}{l}2.73 \mathrm{E}-07 \\
1.92 \mathrm{E}+00\end{array}$ & & & $\begin{array}{l}4.37 \mathrm{E}-17 \\
3.06 \mathrm{E}-10\end{array}$ & & \\
\hline 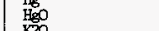 & & & & & & & & \\
\hline$x_{102003}$ & $\begin{array}{l}1,16 \mathrm{E}-01 \\
4.93 \mathrm{E}-02\end{array}$ & $3.525+01$ & $\frac{1.17-01}{4}$ & & & $\frac{1}{7} .85 E-11$ & & \\
\hline$\frac{1 i 20}{100}$ & $\begin{array}{l}7.4 \mathrm{EE}-01 \\
3.66 \mathrm{E}-03\end{array}$ & $3.70 \mathrm{EF}+02$ & $7.59 \mathrm{E}-01$ & & & 1. $.64 \mathrm{E}-10$ & & \\
\hline 140 & $\begin{array}{l}3.46 E-10 \\
2.46-10\end{array}$ & $1.23 E-07$ & $\begin{array}{l}3.466 \mathrm{E}-10 \\
2.40\end{array}$ & & & $\begin{array}{l}3.825-13 \\
3.925-20\end{array}$ & & \\
\hline $\begin{array}{l}\mathrm{M}_{\mathrm{Na} O 3} \\
\mathrm{Na} 2 \mathrm{O}\end{array}$ & $\begin{array}{l}2.44 \mathrm{E}-04 \\
1.23 \mathrm{E}+01\end{array}$ & $\begin{array}{l}2.42 E-02 \\
3.70 E+03\end{array}$ & $\begin{array}{l}2.44 E-04 \\
1.23 E+01\end{array}$ & & & $\begin{array}{l}3.89 E-14 \\
1.95 E-09\end{array}$ & & \\
\hline Nizos & $5.63 \mathrm{E}-01$ & $\begin{array}{l}2.81 E+02 \\
2.01 E\end{array}$ & $5.63 E-01$ & & & $8.97-11$ & & \\
\hline RRO & a. $29 \mathrm{E}-04$ & 4. $14 \mathrm{E}-01$ & $8.29 \mathrm{E}=04$ & & & $1.322-13$ & & \\
\hline 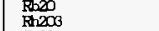 & $\begin{array}{l}1 \\
7.238 E \\
7.235\end{array}$ & $\begin{array}{l}5.16 E^{-07} \\
3.61-02\end{array}$ & $\begin{array}{l}1.03 E^{-09} \\
7.23 \mathrm{E}-05\end{array}$ & & & $\begin{array}{l}1.65 E^{-19} \\
1.19\end{array}$ & & \\
\hline $\begin{array}{lll}S+009 \\
\text { Side }\end{array}$ & $4.86 E-01$ & $\begin{array}{l}4.37 \mathrm{E}+00 \\
2.11 \mathrm{E}+04\end{array}$ & $4,86 E^{-}-01$ & & & $7.74 \mathrm{E}-11$ & & \\
\hline $\overrightarrow{s 03}$ & 4. $10 \mathrm{ER}-02$ & $2.0 \mathrm{sE}+01$ & 4. $10 \mathrm{EE}-02$ & & & $6.54 \mathrm{E}-12$ & & \\
\hline $\begin{array}{l}\mathrm{SrO} \\
\mathrm{To} 0207\end{array}$ & $\begin{array}{l}8.425-02 \\
6.228-02\end{array}$ & 8. $133 \mathrm{E}-01$ & $6.225=02$ & & & $9.90 \mathrm{E}-12$ & & \\
\hline$\frac{\pi n g e}{103}$ & $\begin{array}{l}5.68 \mathrm{E}-03 \\
3.30 \mathrm{~F}+00\end{array}$ & $2.83 \mathrm{E}+00$ & 5. $68 \mathrm{E}-03$ & & & $9.04 \mathrm{E}-13$ & & \\
\hline$\frac{20}{2 \pi c 0}$ & $\begin{array}{l}8.53 E-04 \\
1.81 E+00\end{array}$ & $\begin{array}{l}4.26 \mathrm{E}-01 \\
9.04 \mathrm{E}+02\end{array}$ & $\begin{array}{l}8.53 \mathrm{E}-04 \\
1.81 \mathrm{E}+100\end{array}$ & & & $\begin{array}{l}1.36 \mathrm{E}-13 \\
2.82 \mathrm{E}-10\end{array}$ & & \\
\hline $\begin{array}{l}\text { Canent, } \\
\text { Flyash }\end{array}$ & $6,69 \mathrm{gP}-0.5$ & & $6.68 \mathrm{~F}-03$ & & & $6 \pi-11$ & & \\
\hline $\begin{array}{l}\text { Diselectrol } \\
\text { CS-100-Na }\end{array}$ & & & & & & & & \\
\hline
\end{tabular}




\section{WHC-SD-WM-TI-774 Rev. 0 \\ TWRS PRIVATIZATION PROCESS TECHNICAL BASELINE}

The pretreatment facilities are scheduled to begin operations in the year 2011. Implementation of the Phase 2 pretreatment operation requires that sufficient tank space has been freed to receive retrieved sludges into the 241-AN, -AW and -AP tank farms. The space is made available by evaporating dilute waste, and by processing some of the DST wastes during Phase 1.

The following text describes the operation of an in-tank sludge treatment operation that accomplishes multiple stages of washing (initial wash concurrent with retrieval, followed by an enhanced caustic wash, followed by three dilute caustic washes), and three stages of blending to arrive at treated sludges that are suitable for vitrification.

\subsubsection{Settle and Decant}

Figure 15 depicts an operating scenario ${ }^{13}$ utilizing DSTs to perform the functions of settling, decanting, leaching, washing, accumulating, and staging pretreated waste to subsequent out-of-tank pretreatment operations for supernates, or to vitrification for pretreated HLW solids. Figure 16 depicts a DST modified and equipped for in-tank sludge washing. Each washing tank is equipped with a floating suction decant pump, a transfer pump, and two or more mixing pumps. The waste inlet lines extend to near the bottom of the tank to facilitate settling.

Retrieved slurry is transferred to a first-stage settling tank. The retrieved slurries are on the average $3 \mathrm{wt} \%$ solids, although wide variations in solids loading can be expected in actual practice. In the first stage settling tank, the slurries settle to a solids layer containing $20 \mathrm{wt} \%$ solids. The operation of the several first-stage tanks is staggered so that each tank is at a different point in the settling process. After a one-month settling period ${ }^{14}$, the supernatant is decanted by the floating suction decant pump to one of the second-stage settling tanks. On the average, a cumulative 13.7 million liters of retrieved slurry will be processed through a settling tank, to accumulate 1.3 million liters of settled solids before the settled solids are washed with caustic, and 12.4 million liters will be decanted. The cycle for transferring, settling and decanting waste requires 45 days. On the average, each first-stage tank is capable of accumulating a 1.3 million-liter batch of solids in approximately 6 to 7.5 months (4 to 5 settling cycles).

Decantation of supernatants from first-stage settling tanks is expected to entrain some solids. The supernatants will be allowed to settle for 1 month in the second-stage settling tanks. When second-stage settling is complete, the supernatants are decanted to supernatant accumulation tanks. Small volumes of solids can be expected to accumulate in the second-stage settling tanks over long periods of time. Accumulations of solids in the second-stage settling tanks are transferred out to the first-wash tank as required.

${ }^{13}$ Sludge washing can be performed in one tank; the diagram depicts the steps in the process, not necessarily the required number of tanks.

${ }^{14}$ Supernates that clear in less than a month may be decanted any time a receiver tank is available. 


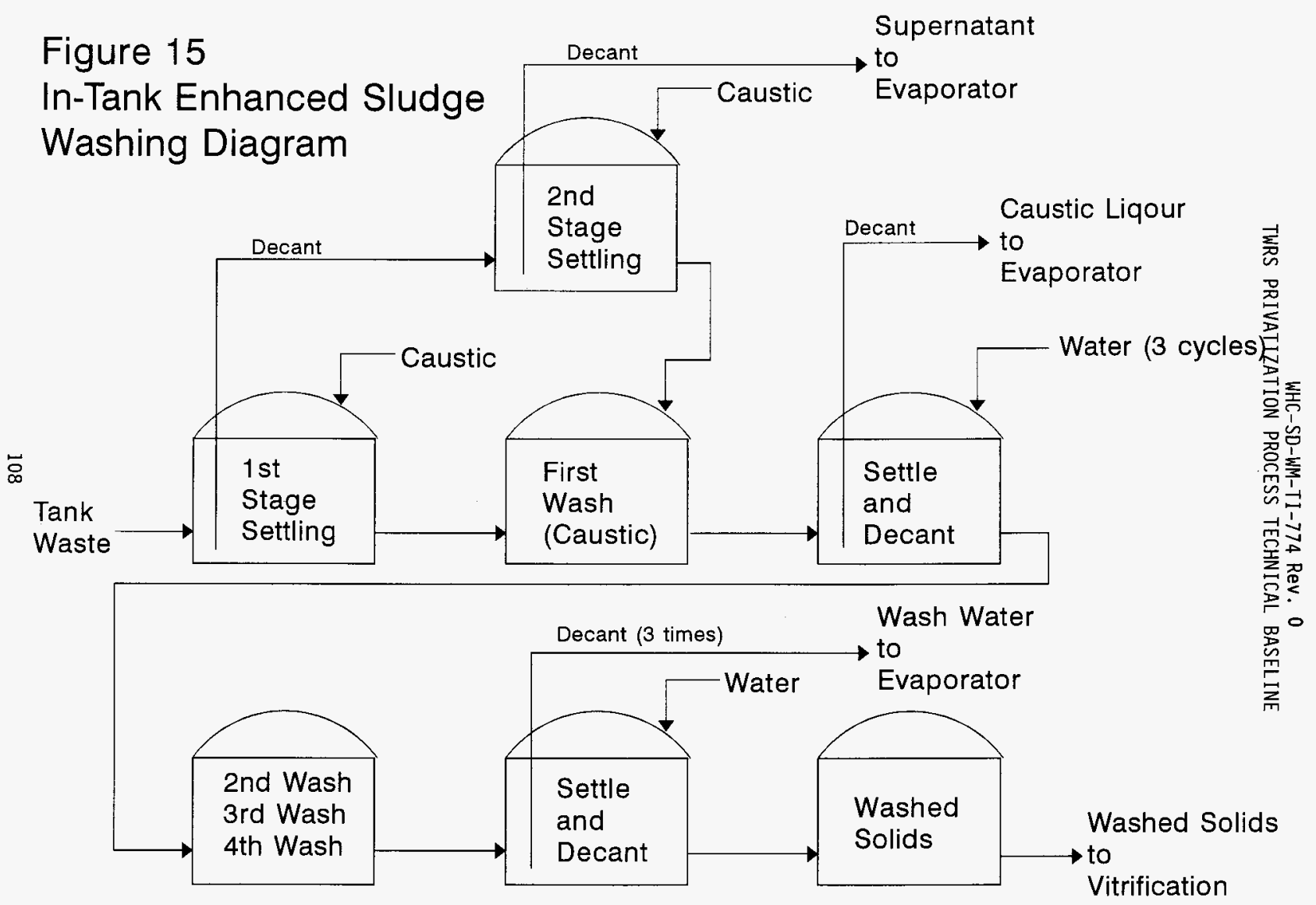




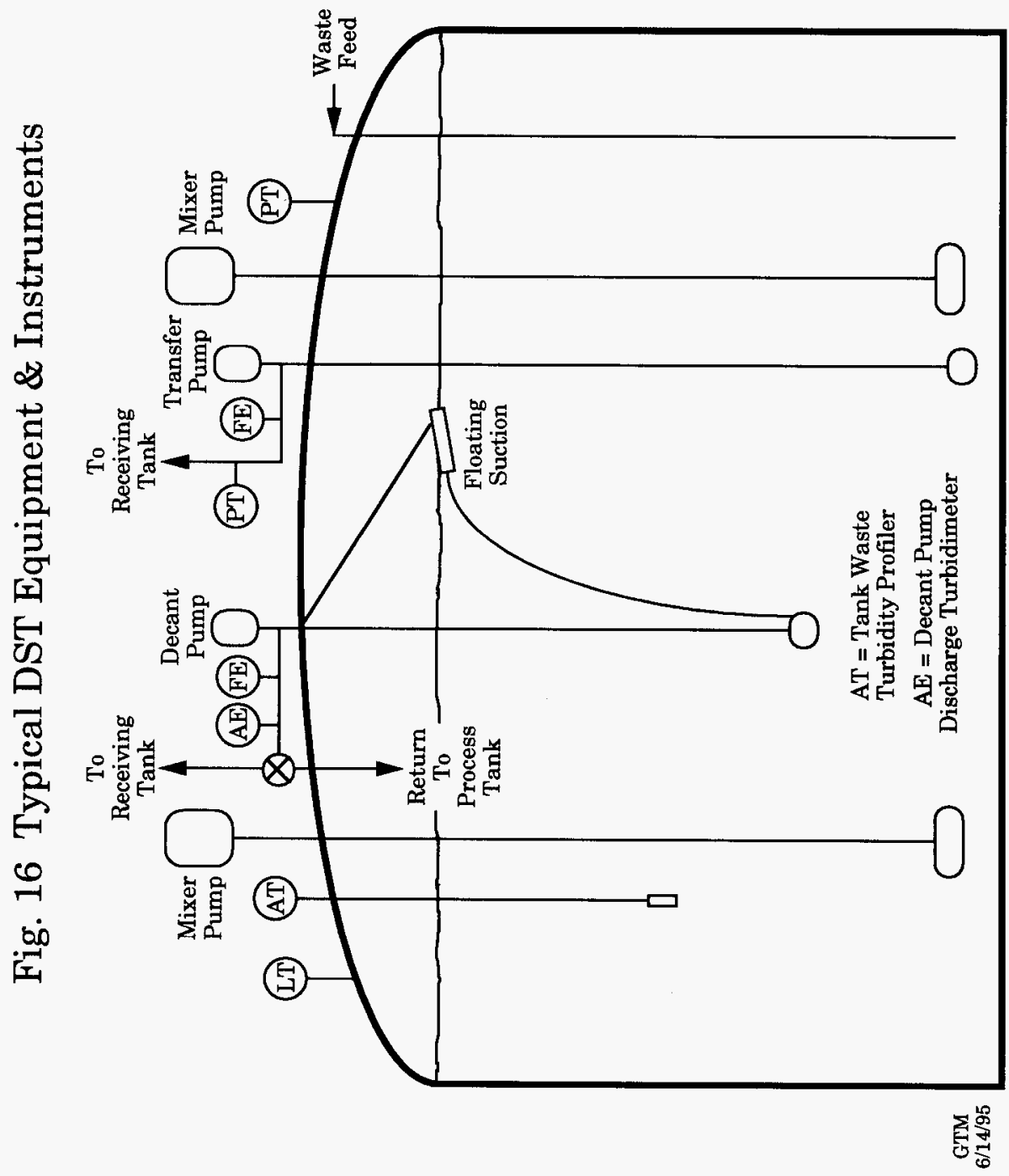




\section{WHC-SD-WM-TI-774 ReV. 0 \\ TWRS PRIVATIZATION PROCESS TECHNICAL BASELINE}

\subsubsection{Caustic Leach}

After a 1.3 million-1iter batch of solids is accumulated in a first-stage settling tank, sodium hydroxide solution is added to the tank to remobilize the solids and initiate the caustic leach process. The volume of solution added is calculated to yield a mobilized slurry that is 8 wt\% solids and $3 M \mathrm{NaOH}$ after the leaching step has gone to completion. The remobilization of settled solids during leaching also blends the contents of the first-stage settling tank. The leaching and blending is allowed to proceed for up to 30 days if necessary. Once again, mixer pumps provide the required energy for the leaching and blending operation.

When leaching and blending is complete, the slurry in a first-stage settling tank is transferred to the first-wash tank. Thirty days is allowed for settling. The supernatant is decanted to the wash solution accumulation tank by a floating suction pump. Because the operation of the first-stage settling tanks is staggered (each requiring several months to accumulate solids), the enhanced washing process requires only one first-wash tank and the associated wash solution accumulation tank.

The flowsheet calculations do not reflect a second caustic leach at this time. As more information about the leaching process becomes available, it may be advisable to add a second leach cycle, or permanganate oxidative leach for specific wastes. This second cycle of leaching can be added with little impact to the flowsheet.

\subsubsection{Single-Shell Tank Caustic Leach Factors}

Revision 1 of the TWRS Process Flowsheet (Orme 1995) accounted for the removal of the four components of aluminum, chromium, sodium, and phosphorus during caustic leaching. Colton's (1996) updated pretreatment chemistry evaluation provides additional caustic leach factors that have been applied in the S/L SEPARATION process block. Table 14 shows the components and revised mass-weighted leach factors used in the PPJB. The caustic leach factor is the fraction of the water-insoluble component removed by caustic leaching. Enhanced sludge-washing results for a total of 22 SSTs are incorporated into the leach factor projection.

\subsubsection{Double-She11 Tank Caustic Leach Factors}

Caustic leach data for DSTs is currently limited to SY-103, although data for $A Z-101$ and $A Z-102$ should be available in the near future. After water washing, $88 \%$ of the aluminum was removed by caustic. After water washing, $8 \%$ of the chromium was removed by caustic. No data was available for phosphorus removal. In the absence of caustic leaching data, previous revisions of the TWRS Process Flowsheet assumed DST caustic leach factors of $0.85,0.75$, and 0.70 for aluminum, chromium, and phosphorus, respectively. Assuming that SY-103 results can be extrapolated to other DSTs, it appears that 0.85 is stil1 reasonable for aluminum, while 0.10 is more reasonable for chromium. There is no basis for changing the phosphorus leach factor. 
TWRS PRIVATIZATION PROCESS TECHNICAL BASELINE

Table 14 01d and New SST Caustic Leach Factors

\begin{tabular}{||c|c|c||}
\hline Component & $\begin{array}{c}\text { 01d SST Leach Factors } \\
\text { TWRS Process Flowsheet } \\
\text { Revision 1 }\end{array}$ & $\begin{array}{c}\text { New SST Leach Factors } \\
\text { PPTB } \\
\text { Revision 0 }\end{array}$ \\
\hline $\mathrm{Al}$ & 0.67 & 0.60 \\
\hline $\mathrm{Bi}$ & & 0.003 \\
\hline $\mathrm{Ca}$ & & 0.02 \\
\hline $\mathrm{Cr}$ & 0.60 & $0.10^{15}$ \\
\hline $\mathrm{Fe}$ & & 0.002 \\
\hline $\mathrm{Na}$ & 0.25 & 0.45 \\
\hline $\mathrm{P}$ & 0.74 & 0.70 \\
\hline $\mathrm{Si}$ & & 0.13 \\
\hline $\mathrm{Sr}$ & & \\
\hline $\mathrm{U}$ & & 0.002 \\
\hline
\end{tabular}

\subsubsection{Potential Chromium Problem}

Estimated chromium inventory has increased as a result of efforts to establish best-basis estimates (Kupfer et al. 1996). At the same time, enhanced sludge-washing results indicate an apparent reduction in overall chromium leach efficiency (Colton 1996). While these trends are disturbing, it is premature to conclude from the available data that a serious chromium issue exists. Chromium solubility limits for glass are highly dependent on glass formulation, not to mention that operability of a top-outlet melter is currently the primary driver for preventing solid phase formation (Lambert and Kim 1994). Gaining acceptance of a two phase product, so long as it meets performance requirements, is a non-process alternative that could be explored.

${ }^{15}$ Waste of the TBP/EB type are the 2nd 1argest group considered in Colton's evaluation. New ESW results for BY-104 and BY-110, which represent 16 vol\% of that group, show that $70 \%$ and $47 \%$ of the $\mathrm{Cr}$ was water soluble, respectively. Further $\mathrm{Cr}$ removal by caustic leaching was ineffective. Because of its large volume, this waste group accounts for a significant mass of residual $\mathrm{Cr}$.

In the largest waste group, primarily REDOX evaporator bottoms, $\mathrm{Cr}$ was $70 \%$ water soluble, and since no caustic leach data were available, the balance of the $\mathrm{Cr}$ was assigned to residual solids.

These two "new" sources account for nearly $70 \%$ of the residual solid $\mathrm{Cr}$ in colton's evaluation, and the significant reduction in caustic leach factor. 


\section{WHC-SD-WM-TI-774 ReV. 0 \\ TWRS PRIVATIZATION PROCESS TECHNICAL BASELINE}

Several countermeasures for dealing with higher chromium concentration in glass could be considered:

Augment the standard caustic leaching process. Laboratory tests have verified that permanganate oxidative leaching can remove up to $90 \%$ of the chromium from selected sludges (Rapko et al. 1996).

Enhance chromium solubility by glass reformulation.

Enhance chromium solubility with higher melter temperature.

Leave the selection of melters to the Phase 2 HLW contractor(s). There are melters that are less sensitive to solids formation than the current top-outlet design.

It may be necessary, in future revisions of the PPTB, to implement such countermeasures if the chromium trends noted above become problematical. For the time being, the effect of chromium on glass volume is simply being documented, rather than changing the processing assumptions that were established for the PPTB (Washenfelder 1996b).

\subsubsection{Dilute Caustic Washing}

Dilute caustic is added to the first-wash tank (7 days allowed), the solids are mobilized and washed for 7 days, and the mobilized slurry is transferred to the second-wash tank (7 days allowed). Another month is allowed for settling in the second-wash tank, and the supernatant solution is decanted ( 7 days allowed). The wash is repeated two more times. The number of washing stages is determined by the desired concentration of the interstitial liquor and the assumed concentration of the settled solids layer, which is 20 wt\% solids. The washed solids in the fourth-wash tank are remobilized with recycled condensate and transferred to washed-solids storage tanks that are available to accumulate and blend washed solids. In effect, a third stage of blending can occur in these tanks by combining batches of washed solids to optimize the overall composition.

\subsubsection{Flocculents}

A flocculating agent (polyelectrolyte) is added by in-line blending when the slurry transfers are made to the first-stage and second-stage settling tanks, and to the first-wash, second-wash, and third-wash tanks. The purpose is to promote settling. This is a conservative assumption for an early stage of flowsheet development. The effectiveness of flocculating agents with Hanford tank solids has not been demonstrated. If future experience shows that flocculating agents are not effective (or needed) for accelerating settling of Hanford solids, then the inter-tank slurry transfers to add flocculating agent are unnecessary and consolidating the entire enhanced sludge-wash process into a single tank could be considered. 


\section{WHC-SD-WM-TI-774 ReV. 0 \\ TWRS PRIVATIZATION PROCESS TECHNICAL BASELINE}

\subsubsection{Continuous Organic Decanting}

An organic phase is present in $\mathrm{C}-103$, and more is expected to be found as other SSTs are retrieved. The PPTB has included continuous organic decanting of waste liquors, leach liquors, and wash liquors to protect the downstream process from organic fouling. Currently, the contamination level of the C-103 organic phase is known, but other tanks need to be sampled and analyzed when organics are found. For the time being, the organic phase is assumed to be compatible with shipping to an incinerator. Future revisions of the PРTB may require washing with waste-compatible extractants to remove radionuclides from the organic.

\subsection{CESIUM ION EXCHANGE FEED EVAPORATION ${ }^{16}$}

The combined supernatants (Stream 9$)^{17}$ of the enhanced sludge-washing operation are evaporated and filtered in the CSIX FEED EVAPORATION process block before ion exchange. For sizing the evaporator load, a bottoms concentration of $7 M$ sodium is assumed. In actual practice, the chemistry of the waste supernatants will control the extent of evaporation to a point short of precipitating of salts. The evaporation is done early in the process to concentrate the waste prior to cesium ion exchange and to decrease the load on the $L L W$ melter and offgas system. The evaporator also reduces volume in the event that the bottoms are returned to in-process storage. Evaporator bottoms returned to in-process storage may require chemical adjustment to ensure tank farm specifications for $\mathrm{OH}^{-}$and $\mathrm{NO}_{2}^{-}$are satisfied.

\subsection{RADIONUCLIDE SEPARATIONS}

\subsubsection{Cesium Ion Exchange}

All feeds to ion exchange will be processed through a deep-bed filter of glass frit or similar material, to remove solids that could adversely affect ion exchange column operations. Under normal conditions, the evaporator bottoms proceed to clarification through a glass frit deep-bed filter. Evaporated supernatants are likely to contain small amounts of solids that were entrained during decanting, that precipitated during evaporation or storage, or that were entrained during pipeline transfers to and from in-process storage.

Spent filter material is periodically flushed out and replaced with fresh frit. The spent filter bed is added to the cesium-depleted ion exchange effluent in the LLW evaporator feed tank.

${ }^{16}$ The Phase 2 private contractor could elect to forego evaporation if that is conducive to their process. However, since the evaporator in question is assumed to replace the 242-A Evaporator, TWRS would have to evaluate how to provide evaporation for tank farm volume control.

${ }^{17}$ It is assumed that facility wastes that are currently evaporated in the 242-A Evaporator will be added to the feed for the pretreatment process (i.e., facility wastes are included in the filtrates). 


\section{WHC-SD-WM-TI-774 Rev. 0 \\ TWRS PRIVATIZATION PROCESS TECHNICAL BASELINE}

The CsIX process block houses a three-cycle operation in which an organic ion exchange resin is loaded with cesium, eluted with nitric acid, and regenerated with caustic. The ion exchange cycle is summarized in Table 15. The eluate, containing approximately $98 \%$ of the cesium, is concentrated to reduce its acid content and volume. Approximately $89 \%$ of the volume and $70 \%$ of the acid in the eluate is recycled for use in subsequent elutions. The cesium-depleted effluent, flushes, and regeneration streams feed forward to the LAW treatment process to be mixed with other miscellaneous LAW recycle streams.

Table 15 Cesium Ion Exchange Summary

\begin{tabular}{|c|c|c|}
\hline Stream Name & Bed Volumes & Composition \\
\hline Column loading & Variable $(35)$ & -- \\
\hline Feed flush & 2 & water \\
\hline Cesium elution & 6 & $0.5 \mathrm{M} \mathrm{HNO}$ \\
\hline Eluate flush & $\begin{array}{l}0.5 \\
1.5 \\
\end{array}$ & water \\
\hline Regeneration\#1 & 1 & $0.5 \mathrm{M} \mathrm{NaOH}$ \\
\hline Regeneration\#2 & 1 & $2.0 M \mathrm{NaOH}$ \\
\hline
\end{tabular}

\subsubsection{Loading Cycle}

During the loading cycle, two ion exchange beds in series receive filtered evaporator bottoms (Stream 14) until the cumulative breakthrough of ${ }^{137} \mathrm{Cs}$ approaches $1 \mathrm{Ci}$ per $115 \mathrm{~kg}$ of treated sodium ( $1 \mathrm{Ci}$ per 5,000 mol of sodium). The loading cycle is modeled with a resin having the properties of $\mathrm{CS}-100^{18}$, which allows a feed rate of 1 bed volume (BV) $/ \mathrm{h}$. Under these conditions, the second bed in series is partially loaded when the first bed is fully loaded with cesium. The typical length of a loading cycle is $24 \mathrm{~h}$ or greater.

${ }^{28} \mathrm{CS}-100$ is a trademark of Rohm and Haas. The resin has been extensively tested over several years at the Westinghouse Process Chemistry Laboratory, Pacific Northwest National Laboratory, and Los Alamos National Laboratory, but is no longer commercially available. The Phase 2 private contractor will select its own separating agent for cesium. 


\section{WHC-SD-WM-TI-774 Rev. 0 \\ TWRS PRIVATIZATION PROCESS TECHNICAL BASELINE}

\subsubsection{Elution/Regeneration Cycle}

While the first pair of beds is loading, a second pair of beds is in the elution/regeneration cycle. A water flush at $2 \mathrm{BV} / \mathrm{h}$ displaces waste that remains in the two beds. ${ }^{19}$ The flush effluents are sent to LAW. A $0.5 \mathrm{M} \mathrm{HNO}$ cesium eluant at $1 \mathrm{BV} / \mathrm{h}$ then displaces cesium, sodium, and potassium from the resin. An eluate water flush at $2 \mathrm{BV} / \mathrm{h}$ removes any remaining eluate. The initial $25 \%$ of the flush stream goes with the eluate and the remainder with LAW. Finally, a $0.5 \mathrm{M} \mathrm{NaOH}$ stream at $2 \mathrm{BV} / \mathrm{h}$ regenerates approximately $25 \%$ of the resin back to the sodium form, followed by a $2.0 \mathrm{M} \mathrm{NaOH}$ stream that converts the balance of the resin to the sodium form. The spent regeneration streams go with the LAW. ${ }^{20}$ The typical length of the elution/regeneration cycle is 10 to $12 \mathrm{~h}$.

\subsubsection{Eluate Concentration and Acid Recycle}

The cesium eluate is concentrated to a bottoms concentration of $8 M$ nitrate. The acidic condensate from the eluate concentrator is suitable for use as eluant in subsequent elutions. The Phase 2 contractor may elect to provide storage for the acidic cesium concentrate, but for the PPTB the concentrate is neutralized with $\mathrm{NaOH}$ and adjusted to DST concentration specifications (Stream 17). The additional sodium does not affect glass volume because the glass is currently chromium-limited (See Section 3.2.2.3).

\subsubsection{Resin Degeneration}

The degeneration of resin performance is reflected in the mass balance calculations. The resin is expected to 100 se $20 \%$ of its capacity over ten cycles.

After ten cycles, eluted and spent resin is flushed out to the LAW stream and replaced with fresh resin. The spent resin is oxidized in the LAW melter.

\subsubsection{0ther Radionuclide Separations}

The absence of TRU/Sr and Tc removal from the Phase 2 flowsheet should not be construed to mean that these separations will not be required for any portion of the Phase 2 waste. The PPTB approach to Phase 2 , as conveyed in APPENDIX $F$, has been to model Phase 2 with the existing TWRS Process Flowsheet model because (1) it still provides a reasonable projection of product volume even if special separations for particular wastes are not included, (2) there was no guidance for Phase 2 other than it entails treatment of the balance of

19Practical experience with operation of this system may dictate a dilute caustic flush before the water flush, to preclude aluminum precipitation in the column, or even within the resin beads. There is a minimum ionic strength and hydroxide concentration required, which was discussed in some detail in Section 2.1.

${ }^{20}$ In the future, reuse of the spent regeneration caustic in sludge washing will be considered. 


\section{WHC-SD-WM-TI-774 ReV. 0 \\ TWRS PRIVATIZATION PROCESS TECHNICAL BASELINE}

the waste, and (3) selection of additional separations technology is now a private contractor responsibility.

Phase 2 is also based on a composite feed stream. Cs removal is the only separation that would be widely applied during Phase 2. TRU/Sr and Tc separation would undoubtedly be required for only a small subset of the Phase 2 feed. These special treatments will not be shown until there is a differentiation of Phase 2 feed into volumes that require special treatment (as there is in Phase 1), nor until private contractors have proposed technology to make the separations.

\subsection{LOW-ACTIVITY WASTE FEED EVAPORATION}

The effluent from ion exchange (Stream 18) is combined with miscellaneous streams from offgas treatment (Stream 30), filter wash liquids, recycled glass product, and other dilute process recycle streams (Stream 26), before evaporation to a IOM sodium slurry (Stream 23) in the LAW FEED EVAPORATION process block.

\subsection{LOW-ACTIVITY WASTE VITRIFICATION}

\subsubsection{Low-Activity Waste Vitrification}

The LAW VITRIFICATION process block treats LAW slurry (Stream 23) in a melter of unspecified design. The glass formulation constraints are listed in Table 16.

Table 16 LLW Glass Formulation Constraints (Orme 1996)

\begin{tabular}{|l|l|}
\hline \hline $\mathrm{Al}_{2} \mathrm{O}_{3}$ & $=12 \mathrm{wt} \%$ \\
\hline $\mathrm{B}_{2} \mathrm{O}_{3}$ & $=5 \mathrm{wt} \%$ \\
\hline $\mathrm{CaO}$ & $=4 \mathrm{wt} \%$ \\
\hline $\mathrm{Na}_{2} \mathrm{O}$ & $=20 \mathrm{wt} \%$ \\
\hline $\mathrm{SiO}_{2}$ & $>=50 \mathrm{wt} \%$ \\
\hline
\end{tabular}

The dry glass formers (contained in Stream 24) are tailored to the waste feed to obtain the desired glass formulation.

Glass that does not meet acceptance requirements for disposal is routed to a roll crusher for size reduction. Crushed out-of-specification rework is slurried back to evaporation and recycled to the melter for remelting. For a flowsheet assumption, approximately $1 \%$ is reworked.

The Phase 2 private contractor's plan will address strategy for compliance. The private contractor may elect to qualify the treatment process rather than providing for rework of off-specification material. In general, a qualified process would require a long period of feed validation, while a process with recycle would have less stringent feed characterization requirements as long as the product could be sampled, analyzed, and reworked if found to be out of specification. 


\section{WHC-SD-WM-TI-774 ReV. 0 \\ TWRS PRIVATIZATION PROCESS TECHNICAL BASELINE}

\subsubsection{Immobilized Low-Activity Waste Packaging}

The ILAW package for the TWRS Process Flowsheet was a $32-\mathrm{m}^{3}$ rectangular container intended specifically for the sulfur polymer concrete waste form. The maximum size of a rectangular container for a glass monolith has not been analyzed. Since no specific guidance is provided for Phase 2 ILAW packaging, the Phase 1 standard package is used. This is the 2.6- $\mathrm{m}^{3}$ package filled to a net volume of $2.08 \mathrm{~m}^{3}(80 \mathrm{vo} \%)$. Phase 2 produces $\approx 5,000$ ILAW packages.

\subsection{LOW-ACTIVITY WASTE OFFGAS TREATMENT}

The OFFGAS TREATMENT process block consists of a quench tower, venturi scrubber/separator, demister, $\mathrm{CuO} \mathrm{SO}_{2}$ absorber, $\mathrm{NO}_{x}$ catalytic reactor, and high-efficiency particulate air (HEPA) filtration. The quench tower, venturi scrubber, and demister are included to remove particulates entrained in the offgas. These devices also cool the offgas, condense water vapor, and condense and scrub semi-volatile waste components like technetium. There are currently no provisions to recover technetium from the decanted wastes, so the scrub wi17 become enriched with technetium over time. Recirculated nitric acid is used as the scrub medium, so it is not effective for removal of the $\mathrm{NO}_{x}$ and $\mathrm{SO}_{2}$, both of which are criteria air pollutants.

Sulfur dioxide is removed from the gas stream by the Shell Flue Gas Desulfurization process. Nitrogen oxides are removed by selective catalytic reduction with $\mathrm{NH}_{3}$. A combination of washable-metal HEPA filters and paper HEPA filters are used to filter the offgas before discharge to a stack. Liquid condensates from the offgas system are routed to the LAW evaporator.

\subsubsection{Sulfur Recovery}

$\mathrm{SO}_{2}$ is removed from melter offgas by trapping on a CuO bed (as CuSO${ }_{4}$ ) at $400{ }^{\circ} \mathrm{C}$. The CuO beds are approximately $90 \%$ effective at removing $\mathrm{SO}_{2}$. After loading, the $\mathrm{CuSO}_{4}$ is reduced with $\mathrm{H}_{2}$, which releases the sulfur as $\mathrm{H}_{2} \mathrm{~S}$. The Cu0 bed is regenerated by purging with air.

The $\mathrm{H}_{2} \mathrm{~S}$ released from the $\mathrm{Cu} 0$ bed is burned to a stoichiometric mixture $\left(2 \mathrm{H}_{2} \mathrm{~S}\right.$ to $1 \mathrm{SO}_{2}$ ) in a combustion chamber. The stoichiometric mixture is reduced to elemental sulphur in a two-stage claus reactor. The overall conversion efficiency of the claus reactors is $99 \%$. The tail gas from the Claus reactor is recycled to the inlet of the cuo bed.

The recovered sulfur is poured into 55-gal drums while still molten, allowed to coo?, and packed out as a secondary waste (Stream 32).

\subsubsection{Chloride and Fluoride Control}

The quench tower and venturi are effective at scrubbing volatile chlorine and fluorine from the melter offgas, so the scrub solution becomes enriched in chloride and fluoride. Offgas treatment includes an operation to recover and discharge chloride as a secondary solid-waste grout. Fluoride is returned to the melter in a non-volatile $\mathrm{CaF}_{2}$ form.

The chloride recovery operation consists of diverting a side stream of the recirculating scrub solution to a series of evaporators and distillation columns. A nitric acid product stream (containing all of the entrained 


\section{WHC-SD-WM-TI-774 Rev. 0 \\ TWRS PRIVATIZATION PROCESS TECHNICAL BASELINE}

solids, most of the nitric acid, $90 \%$ of the fluorine, and $35 \%$ of the chlorine) is neutralized with $10 \%$ excess $\mathrm{Ca}(\mathrm{OH})_{2}$, to precipitate $\mathrm{CaF}_{2}$ before recycling to the LLW evaporator in Stream 30. The $\mathrm{CaF}_{2}$ will not re-volatilize from the melter. The calcium added in this operation reduces the amount of calcium added directly to the melter.

$\mathrm{HC} 1$ concentrate (containing $65 \%$ of the chlorine and $10 \%$ of the fluorine) is neutralized, evaporated to reduce volume, grouted, and packed out in 55-gal drums as a secondary waste (Stream 33).

\subsubsection{Mercury Recovery}

The OFFGAS TREATMENT process block currently does not contain a separation for the mercury. Most of the mercury carried in the melter offgas (Stream 27) is recovered in the nitric acid scrub medium and recycled. Stream 34 is provided strictly as a convenience to quantify how much mercury is available for separation from the chloride side stream.

\subsection{HIGH-LEVEL WASTE FEED EVAPORATION}

The HLW FEED EVAPORATION process block combines offgas condensates and recycled scrub liquid (Stream 36) with pretreated solids (Stream 11), and dewaters the slurry by a combination of centrifugation and evaporation to reduce the evaporative load on the HLW melter. Process condensate (Stream 37) and condenser vent (Stream 38 ) result from dewatering.

The dewatered solids (Stream 39) are ready for feed adjustment.

\subsection{HIGH-LEVEL WASTE VITRIFICATION}

The HLW VITRIFICATION process block combines Stream 39 with recovered cesium (Stream 17) and a concentrated spent scrub solution (Stream 41), performs the feed adjustment, and vitrifies the solids.

\subsubsection{Feed Adjustment}

For feed adjustment, glycolic acid (included in Stream 40) is added to adjust the $\mathrm{pH}$ to approximately 6 and provide sufficient reductant (organic carbon). An addition of $6.4 \mathrm{~g}$-mol glycolic acid per $\mathrm{kg}$ of waste oxides is expected to provide a sufficient excess for redox/oxidation control in the melter.

The organic acid digest is followed by the dry addition of glass-former chemicals such as silica, boric oxide and lithium oxide (included in Stream 40). The feed slurry is then concentrated by evaporation to a total oxide concentration of approximately $500 \mathrm{~g} / \mathrm{L}$ and transferred to one of the melter feed tanks.

\subsubsection{High-Level Waste Vitrification}

The melter is assumed to be a low-temperature, joule-heated, slurry-fed ceramic melter. Scaling up of the Defense Waste Processing Facility (DWPF) joule-heated melter will be necessary to provide the required throughput rate 


\section{WHC-SD-WM-TI-774 Rev. 0 \\ TWRS PRIVATIZATION PROCESS TECHNICAL BASELINE}

if that design is selected. The number and sizing of melters is a Phase 2 private contractor decision.

For the flowsheet, the adjusted feed slurry from the melter feed tank is continuously fed to a joule-heated melter where slurry water is evaporated and calcination reactions proceed in the "cold cap" over the molten glass pool. Water and other volatile feed components are driven off, while nonvolatile components oxidize and melt into the glass. The molten borosilicate glass product flows (by pressure differential) from the melter into stainless-steel canisters, where the product cools to form a monolithic glass.

The process model predicts glass composition from the glass formulation ranges stated in Table 17 . These ranges are for low-temperature $\left(1150^{\circ} \mathrm{C}\right)$ melting.

With the current formulation ranges and HLW waste feed, the waste loading in IHLW is $37 \%$ (including sodium and silicon). The reduced caustic leach factor for chromium, discussed in Section 3.2.2.1, is responsible for chromium controlling the volume of IHLW.

\subsubsection{Final Packaging}

When sufficiently cooled, the filled canisters are sealed with an inner canister closure plug. A preliminary decontamination is performed by a low pressure water spray that removes loose contamination. Final decontamination is accomplished by a frit-blasting process. A final canister seal is provided by a welded closure.

A variety of canisters containing somewhat different net waste volumes are available for consideration, including the DWPF canister $\left(0.62 \mathrm{~m}^{3}\right)$, the West Valley Demonstration Project canister $\left(0.8 \mathrm{~m}^{3}\right)$, or a $4.5 \mathrm{~m} \mathrm{tall}$ contractor-proposed standard canister $\left(1.08 \mathrm{~m}^{3}\right)$ that the office of Civilian Radioactive Waste Management may be willing to consider (Honeyman 1996). Phase 2 produces 12,890 contractor-proposed standard canisters.

\section{10 HIGH-LEVEL WASTE OFFGAS TREATMENT}

Offgas from the feed adjustment evaporation step is condensed and collected. Reduced mercury contained in the condensate is accumulated in a mercury sump built into the condensate collection tank. A total of $70 \mathrm{~kg}$ mercury $(5 \mathrm{~L})$ is expected to accumulate over the life of the plant.

Melter offgases (included in Stream 43 with feed adjustment vapors) flow to a quench tower and venturi scrubber to cool and condense the offgas, and separate entrained particulates from the gas stream. The offgas then passes through a chiller, demister, and HEPA filter. Levels of sulfur in the HLW melter feed will probably not require a reactor ( $\mathrm{CuO}$ bed) for $\mathrm{SO}_{2}$ abatement; likewise, the amount of nitrate in $\mathrm{HLW}$ is small so $\mathrm{NO}_{\mathrm{x}}$ abatement is not an issue. Melter offgas exiting the HEPA filter will be combined with building ventilation exhaust air and released to the atmosphere via the plant stack. 
WHC-SD-WM-TI-774 Rev. 0

TWRS PRIVATIZATION PROCESS TECHNICAL BASELINE

Table 17 HLW Glass Formulation Ranges (CVSe $1150^{\circ} \mathrm{C}$ )

\begin{tabular}{|c|c|c|}
\hline \multirow[t]{2}{*}{ Component } & \multicolumn{2}{|c|}{ Glass } \\
\hline & Lower & Upper \\
\hline \multicolumn{3}{|c|}{ single-Component Ranges ${ }^{a}$} \\
\hline $\mathrm{Al}_{2} \mathrm{O}_{3}$ & $0.0 \%$ & $15.0 \%$ \\
\hline $\mathrm{B}_{2} \mathrm{O}_{3}$ & $5.0 \%$ & $20.0 \%$ \\
\hline $\mathrm{CaO}$ & $0.0 \%$ & $10.0 \%$ \\
\hline $\mathrm{Fe}_{2} \mathrm{O}_{3}$ & $2.0 \%$ & $15.0 \%$ \\
\hline $\mathrm{Li}_{2} \mathrm{O}$ & $1.0 \%$ & $7.0 \%$ \\
\hline MgO & $0.0 \%$ & $8.0 \%$ \\
\hline $\mathrm{Na}_{2} \mathrm{O}^{\mathrm{b}}$ & $5.0 \%$ & $20.0 \%$ \\
\hline $\mathrm{SiO}_{2}$ & $42.0 \%$ & $57.0 \%$ \\
\hline $\mathrm{ZrO}_{2}$ & $0.0 \%$ & $13.0 \%$ \\
\hline \multicolumn{3}{|c|}{ Multi-Component Ranges ${ }^{c}$} \\
\hline $\mathrm{Al}_{2} \mathrm{O}_{3}+2 \mathrm{rO}_{2}$ & \multicolumn{2}{|c|}{$<=16.0 \%$} \\
\hline $\mathrm{Al}_{2} \mathrm{O}_{3}+\mathrm{ZrO}_{2}+\mathrm{Fe}_{2} \mathrm{O}_{3}$ & \multicolumn{2}{|c|}{$<=24.0 \%$} \\
\hline $\mathrm{MgO}+\mathrm{CaO}_{\mathrm{aO}}$ & \multicolumn{2}{|c|}{$<=10.0 \%$} \\
\hline \multicolumn{3}{|c|}{ Solubility Limits } \\
\hline $\mathrm{Cr}_{2} \mathrm{O}_{3}$ & \multicolumn{2}{|c|}{$<=0.5 \%$} \\
\hline$F$ & \multicolumn{2}{|c|}{$<=1.7 \%$} \\
\hline $\mathrm{P}_{2} \mathrm{O}_{5}{ }^{\mathrm{d}}$ & \multicolumn{2}{|c|}{$<=3.0 \%$} \\
\hline $\mathrm{Rh}_{2} \mathrm{O}_{3}+\mathrm{Ru}_{2} \mathrm{O}_{3}+\mathrm{Ru}_{2} \mathrm{O}_{3}$ & \multicolumn{2}{|c|}{$<=0.25 \%$} \\
\hline $\mathrm{SO}_{3}$ & \multicolumn{2}{|c|}{$<=0.5 \%$} \\
\hline
\end{tabular}

a The sum of all components not listed may range from $1 \%$ to $10 \%$.

$b_{\text {Includes }} \mathrm{K}_{2} \mathrm{O}$.

Attempts to el iminate formulations with poor processability by the application of multiple component constraints have been "only partially successful" per Hrma 1994. Multi-component constraints are ignored in the model.

This limit differs from the $1 \%$ ceiling used for HWVP formulations as shown in Hrma 1994 . It is an engineering judgment that TWRS composite glass can solubilize up to $3 \% \mathrm{P}_{2} \mathrm{O}_{5}$.

Spent scrubber solution collected from the quench tower and venturi scrubber is evaporated in the secondary waste evaporator and recycled to the feed collection tank.

Because of the potential for contamination, condenser vent gases in the HLW process are all scrubbed through the condenser vent scrubber. The condenser vent scrub solutions are combined with feed adjustment condensate and returned to the HLW FEED EVAPORATION process block.

${ }^{21}$ The portion of the spent scrub that was previously routed to the salt waste adjustment tank purged the melter system of hal ides and other volatile compounds not soluble in the glass. In Revision 1, the HLH process operates beyond the completion of pretreatment and LLW treatment, and it is assumed that routing purges out of the facility is discouraged. Further study will determine if HLW scrub solution treatment similar to the LLW scrub solution treatment is required. 


\section{TWRS PRIVATIZATION PROCESS TECHNICAL BASELINE}

\subsection{WATER RECYCLE}

The TWRS flowsheet recycles process condensates extensively where the use of condensates is acceptable. The WATER RECYCLE process block shows where recycled water is used. Excess process condensates from the TWRS flowsheet are routed to the Liquid Effluent Treatment Facility for conditioning before release to the environment. Condensate treatment is an Environmental Restoration function outside of the scope of the TWRS Process Flowsheet.

\subsection{PHASE 2 WITH REVISED TWRS INVENTORY}

There is uncertainty, not directly addressed in this flowsheet, in estimating glass properties, durability, and melter operability as a function of glass formulation. There is also uncertainty in regard to the degree of chemical separation attainable in the enhanced sludge-washing process and in the waste inventories.

Appendix $\mathbf{E}$ contains a special case of the Phase 2 flowsheet based on a revised TWRS inventory. Standard inventory projections for several major components were substituted for the TWRS inventory values. The glass volume projection for this special case is profoundly affected by the large increase in chromium inventory left over after enhanced sludge washing. The revised TWRS inventory produces 28,460 contractor-proposed standard canisters during Phase 2. 
WHC-SD-WM-TI-774 Rev. 0

TWRS PRIVATIZATION PROCESS TECHNICAL BASELINE

\subsection{REFERENCES}

Bacon, R. F., 1996, Final Neutralized Current Acid Waste Consolidation Recommendation, External Letter 9651466, R. F. Bacon to J. E. Kinzer, May 10, 1996, Westinghouse Hanford Company, Richland, Washington.

Certa, P. J., W. H. Grams, C. M. McConville, L. W. Shelton, and E. J. Slaathaug, 1996, Low-Level Waste Feed Staging Plan, WHC-SD-WM-RPT-224, Revision 1, Westinghouse Hanford Company, Richland, Washington.

Colton, N. G., 1995, Sludge Pretreatment Chemistry Evaluation: Enhanced Sludge Washing Separation Factors, PNL-10512, Pacific Northwest Laboratory, Richland, Washington.

Colton, N. G., 1996, Status Report: Pretreatment Chemistry Evaluation - Wash and Leach Factors for the Single-Shell Tank Waste Inventory, PNNL-11290, Pacific Northwest National Laboratory, Richland, Washington.

DOE-RL, 1996, TWRS Privatization Request for Proposals, DE-RP06-96RL13308, U.S. Department of Energy Richland Operations Office, Richland, Washington.

Honeyman, J. 0., 1996, Proposed Standard Canister for Tank Waste Remediation System High-Level Waste Disposa7, External Letter 9653251, J. 0.

Honeyman to W. J. Taylor, August 1, 1996, Westinghouse Hanford Company, Richland, Washington.

Hrma, P. R. et al., 1994, Property/Composition Relationships for Hanford HighLevel Waste Glasses Melting at $1150^{\circ}{ }^{\circ} \mathrm{C}$, PNL-10359, Vol. 1, Pacific Northwest Laboratory, Richland, Washington.

Klem 1996, Preliminary Estimate of Process Organic Volume in Waste Tanks, Internal Memo 73510-96-029, M. J. Klem to D. J. Washenfelder, August, 1996.

Kupfer, M. J. et a1., 1996, Interim Report: Best-Basis Inventories of Chemicals and Radionuclides in Hanford Site Tank Waste, WHC-SD-WM-TI-740 Revision C, Westinghouse Hanford Company, Richland, Washington.

Lambert, S. L. and D. S. Kim, 1994, Tank Waste Remediation System High-Level Waste Feed Processability Assessment Report, WHC-SP-1143, Westinghouse Hanford Company, Richland, Washington.

Lumetta, G. J. and B. M. Rapko, 1994, Washing and Alkaline Leaching of Hanford Tank Sludges: A Status Report, PNL-10078, Pacific Northwest Laboratory, Richland Washington.

Lumetta, G. J., B. M. Rapko, M. J. Wagner and J. Liu, Washing and Caustic Leaching of Hanford Tank Sludges: Results of FY 1996 Studies, PNNL11278, Pacific Northwest National Laboratory, Richland, Washington.

Manue1, A. F., 1996, Phase 1 High-Level Waste Pretreatment and Feed Staging $P 7 a n$, WHC-SD-WM-ES-370, Revision 0, Westinghouse Hanford Company, Richland, Washington. 


\section{WHC-SD-WM-TI-774 Rev. 0 \\ TWRS PRIVATIZATION PROCESS TECHNICAL BASELINE}

Orme, R. M., 1994, TWRS Process Flowsheet, WHC-SD-WM-TI-613 Revision 0, Westinghouse Hanford Company, Richland, Washington.

Orme, R. M., 1995, TWRS Process Flowsheet, WHC-SD-WM-TI-613 Revision 1, Westinghouse Hanford Company, Richland, Washington.

Penwel1, D. L., C. E. Grenard and R. S. Wittman, 1996, Initial Retrieval Sequence and Blending Strategy, WHC-SD-WM-RPT-229 Revision 0, Westinghouse Hanford Company, Richland, Washington.

Rapko, B. M., G. J. Lumetta, and M. J. Wagner, 1995, Washing and Caustic Leaching of Hanford Tank Sludges: Results of FY 1995 Studies, PNL-10712, Pacific Northwest Laboratory, Richland, Washington.

Raytheon 1995, Initial Pretreatment Module Trade Studies -- In-Tank vs. Outof-Tank Pretreatment, E/B-SD-W236B-RPT-017 Revision 1, Raytheon/BNFL, Rich1 and, Washington.

Shelton, L. W., 1996, Projected Double-She11 Tank Supernatant Composition and Inventory for Phase I Privatization, WHC-SD-WM-TI-751 Revision 0, Westinghouse Hanford Company, Richland, Washington.

Washenfelder, D. J., 1996, Revised TWRS Disposal Program Assumptions for Operational Waste Volume Projection, Internal Memo 73510-96-013 dated May 14, 1996 (and amended July 29, 1996), Westinghouse Hanford Company, Richland, Washington.

Washenfelder, D. J., 1996b, TWRS Process Technical Baseline Assumptions and Bases, Internal Memo 73510-96-014 dated May 7, 1996, Westinghouse Hanford Company, Richland, Washington.

WHC, 1996, Tank Waste Remediation System Functions and Requirements Document, WHC-SD-WM-FRD-020, Revision 0, March 1996, Westinghouse Hanford Company, Richland, Washington. 


\section{APPENDIX A INVENTORY ESTIMATES OF DST SUPERNATES \& PHASE 1 FEEDS}

The following table projects DST supernate as it will exist per Shelton (1996), and identifies the tanks that have been selected as Phase 1 feeds. These are "as is" values. They have not been diluted by retrieval water or adjusted for retrieval inefficiencies and heel mixing like the actual feed batches in Tables $2 a$ and $2 b$.

Explanation of headings:

P-o-C or Extension refers to the proof-of-concept or extension part of Phase 1.

Envelope A, B, or C refers to the Phase 1 supernate envelopes.

PC1 Batch\# and PC2 Batch\# refer to the private contractor feed batch in which each waste will appear. 


\section{WHC-SD-WM-TI-774 Rev. 0 TWRS PRIVATIZATION PROCESS TECHNICAL BASELINE}

Table A-1 INVENTORY ESTIMATES OF DST SUPERNATES \& PHASE 1 fEEDS (ENVELOPES A, B, AND C) (10 sheets)

\begin{tabular}{|c|c|c|c|c|c|c|c|c|c|c|}
\hline super & $01 \mathrm{AN}$ & 102AN & $103 \mathrm{AN}$ & 104AN & $105 \mathrm{AN}$ & $106 \mathrm{AN}$ & $107 \mathrm{AN}$ & $101 \mathrm{AP}$ & 102AP & 103AP \\
\hline $\begin{array}{c}\text { P-o-C or } \\
\text { Extension }\end{array}$ & & Extension & $P=0-C$ & $P-O-C$ & $P=0-C$ & Extension & Both & & & \\
\hline Envelope & & c & A & A & A & $\mathrm{c}$ & C & & & \\
\hline PC1 B & & 9 & 5 & 3 & 1 & 10 and 17 & 7 and 8 & & & \\
\hline PC2 Batch\# & & 9 & 5 & 3 & 1 & 10 & 7 and 8 & & & \\
\hline \\
\hline$g^{+}$ & $1 \mathrm{E}$. & $0 E+00$ & $00 E+00$ & 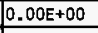 & $0 E+00$ & .04 & $0.00 E+00$ & $5.69 \mathrm{E}-03$ & $0.00 E+00$ & 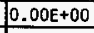 \\
\hline $\mathrm{I}(\mathrm{OH}) 4-$ & $97 \varepsilon+01$ & $97 \mathrm{E}+02$ & $7.33 E+02$ & $99 E+02$ & $.09 E+02$ & 2.8 & $1.48 \mathrm{E}+01$ & $1.30 E+02$ & $1.70 E+02$ & $8.85 \mathrm{E}-02$ \\
\hline+5 & $5.46 \mathrm{E}-03$ & $00 \mathrm{E}+00$ & $.00 E+00$ & $.00 E+00$ & $0.00 E+00$ & $2.49 \mathrm{E}-04$ & $0.00 E+00$ & $5.35 \mathrm{E}-03$ & $3.69 E-04$ & \\
\hline 3 & $58 \mathrm{E}-02$ & $00 \mathrm{E}+00$ & $.00 E+00$ & $.00 E+00$ & $0.00 E+00$ & $0.00 E+00$ & $0.00 E+00$ & $5.78 \mathrm{E}-02$ & $0.00 E+00$ & \\
\hline $3+2$ & $05 E-02$ & $00 E+00$ & $.00 E+00$ & $.00 E+00$ & $0.00 E+00$ & $2.24 E-04$ & $0.00 \mathrm{E}+00$ & $9.89 \mathrm{E}-03$ & $1.18 \mathrm{E}-03$ & $0.00 E+00$ \\
\hline$e+2$ & 1.97E-05 & $00 \mathrm{E}+00$ & $0.00 E+00$ & $.00 E+00$ & $0.00 E+00$ & $0.00 E+00$ & $0.00 E+00$ & $0.00 E+00$ & $6.07 \mathrm{E}-04$ & $0.00 E+00$ \\
\hline$i+3$ & $1.39 \mathrm{E}-$ & 0.00 & & & $0.00 E+00$ & & $0.00 E+00$ & 0.0 & $0.00 \mathrm{E}+00$ & $0.00 E+00$ \\
\hline$a+$ & 3 & 00 & 3.13 & 30 & +00 & & 1.92 & 4.2 & -00 & 0.00 \\
\hline$d+2$ & $y / E$ & 00 & 5.79 & 00 & +00 & 04 & +00 & 8.1 & $6.11 \mathrm{E}-03$ & $1.13 E-05$ \\
\hline+3 & SE & +00 & 0.00 & 00 & +00 & 00 & +00 & 0.0 & $+\infty 0$ & $0.00 \mathrm{E}+00$ \\
\hline 60 & $72 E+00$ & $48 E+00$ & $7.08 E+00$ & $71 \mathrm{E}+00$ & $6.70 E+00$ & .02 & $1.37 \mathrm{E}+00$ & $+\infty 0$ & $.93 \mathrm{E}+00$ & -03 \\
\hline$u+2$ & $.40 E-03$ & $.00 E+00$ & $4.34 \mathrm{E}-02$ & $00 \mathrm{E}+00$ & $0.00 E+00$ & -05 & $0.00 E+00$ & $0.00 \mathrm{E}+00$ & $0.00 \mathrm{E}+00$ & $0.00 E+00$ \\
\hline $\mathrm{fe}+3$ & $4.09 E-01$ & $0.00 E+00$ & $2.55 \mathrm{E}-01$ & $.37 \mathrm{E}-02$ & $4.79 \mathrm{E}-02$ & & $5.24 E+00$ & 1.1 & 1.58 & -04 \\
\hline $\mathrm{Hg}+2$ & $2.46 \mathrm{E}$ & $00 E+00$ & $5.79 \mathrm{E}-02$ & & $\mathrm{E}+00$ & & 0.00 & 05 & 0.0 & $5.11 \mathrm{E}-07$ \\
\hline$k+$ & $1.48 \mathrm{E}$ & 31 & 5.50 & 11 & 01 & & 00 & 8.9 & 5.3 & 1.55 \\
\hline$L a+3$ & 6.288 & -00 & 0.0 & 00 & +00 & & 00 & 6.0 & 0.0 & 0.0 \\
\hline it & $5.61 \mathrm{E}$ & +00 & 0.00 & 10 & +00 & 00 & .00 & 0.0 & 00 & 0.0 \\
\hline $\operatorname{tg}^{+2}$ & $6.26 E$ & 00 & 1.0 & 00 & 0.0 & 03 & +00 & 5.0 & 0. & -04 \\
\hline$n+4$ & 8.11 & +00 & 1.04 & $00 E+00$ & +00 & 04 & $1.75 \mathrm{E}+00$ & $7.40 \mathrm{E}-03$ & +00 & $4.40 \mathrm{E}-06$ \\
\hline In02 & $00 \mathrm{E}$ & +00 & 0.00 & $00 E+00$ & +00 & +00 & +00 & $0.00 E+00$ & +00 & $0.00 \mathrm{E}+00$ \\
\hline $40+6$ & $63 E$ & +00 & 3.18 & +00 & $0.00 E+00$ & 04 & $0.00 E+00$ & $7.32 E-04$ & $0.00 E+00$ & $0.00 E+00$ \\
\hline $\mathrm{Na}^{+}$ & $2.19 \mathrm{E}+02$ & O0E +03 & $1.22 \varepsilon+03$ & $.34 E+02$ & $1.18 E+03$ & $1.49 \mathrm{E}+03$ & $7.78 E+02$ & $6.01 \mathrm{E}+02$ & $4.24 E+02$ & $5.43 E-01$ \\
\hline $\mathrm{Ni}+3$ & $8.39 \mathrm{E}-$ & $1.32 \mathrm{E}+00$ & 8.68 & $0.00 \mathrm{E}+00$ & $0.00 E+00$ & & $1.57 \mathrm{E}+00$ & $9.21 \mathrm{E}-02$ & $1.11 \mathrm{E}-01$ & $0.00 E+00$ \\
\hline$P b+4$ & & & 11 & & & & 1.1 & $1.54 \mathrm{E}-02$ & $1.37 \mathrm{E}-02$ & $0.00 E+00$ \\
\hline$b+$ & 0. & & 0.00 & 10 & 0.0 & & 00 & 0.00 & 0.00 & $0.00 E+00$ \\
\hline$e+$ & $44 \mathrm{E}$ & 00 & 0.00 & 0.00 & 0.0 & & & 0.0 & & +00 \\
\hline$h+3$ & 56E- & 00 & 0.00 & 00 & 0.0 & 0.1 & $0.00 E+00$ & $0.00 E+00$ & 10.0 & 0.0 \\
\hline 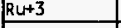 & $13 E-03$ & .00 & 0.0 & .00 & $0.00 E+00$ & 0. & $0.00 E+00$ & $0.00 E+00$ & $0.00 \mathrm{E}+00$ & 0.0 \\
\hline$s b+5$ & $1.37 \mathrm{E}-03$ & $0.00 E+00$ & $0.00 \mathrm{E}+00$ & $0.00 E+00$ & $0.00 E+00$ & 0.0 & $0.00 E+00$ & $0.00 E+00$ & +00 & $0.00 E+00$ \\
\hline Se+6 & $5.62 \mathrm{E}-03$ & $0.00 E+00$ & $0.00 E+00$ & $0.00 E+00$ & $0,00 E+00$ & $1.51 E-06$ & $0.00 E+00$ & $3.90 \mathrm{E}-04$ & $1.53 E-06$ & $0.00 E+00$ \\
\hline $5 i+4$ & $1.60 E+00$ & $0.00 E+00$ & $9.84 \mathrm{E}-01$ & $0.00 E+00$ & $0.00 \mathrm{E}+00$ & $0.00 E+00$ & $0.00 E+00$ & $4.62 \mathrm{E}-01$ & $0.00 E+00$ & $0.00 E+00$ \\
\hline $6 n+4$ & $0.00 \mathrm{E}$ & $+\infty$ & $0.00 E+00$ & $0.00 \mathrm{E}+00$ & $0.00 E+00$ & +00 & $0.00 E+00$ & $0.00 E+00$ & $0.00 E+00$ & $0.00 \mathrm{E}+00$ \\
\hline$m+3$ & $0.00 \mathrm{E}$ & & 0.0 & $0.00 \mathrm{E}+00$ & 0.0 & & & 0.0 & $=00$ & $0.00 E+00$ \\
\hline Te+6 & $3.53 E-$ & & & & 0.0 & & 0.0 & & & $0.00 \mathrm{E}+00$ \\
\hline$h+$ & 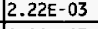 & & & 0 & 00 & & 0.0 & 0.0 & $0.00 \mathrm{E}+00$ & $0.00 \mathrm{E}+00$ \\
\hline$i$ & $01 \mathrm{E}$ & +00 & $0.00 \mathrm{E}+00$ & $0.00 \mathrm{E}+00$ & $0.00 E+00$ & & $0.00 \mathrm{E}+00$ & $1.72 \mathrm{E}-10$ & 0.0 & \\
\hline $\mathrm{Tl}+3$ & $2.80 \mathrm{E}-02$ & $0.00 E+00$ & $0.00 E+00$ & $0.00 E+00$ & 0.0 & $0.00 E+00$ & $0.00 E+00$ & $0.00 E+00$ & 0.00 & $0.00 \mathrm{E}+00$ \\
\hline$U(g)$ & 9.92E-01 & $0.00 E+00$ & $1.87 \mathrm{E}-03$ & $0.00 E+00$ & $0.00 \mathrm{E}+00$ & $8.51 E-04$ & $7.85 \mathrm{E}-01$ & $1.50 \mathrm{E}-01$ & $1.46 \mathrm{E}-02$ & $3.77 \mathrm{E}-04$ \\
\hline $\mathrm{v}+5$ & $3.25 E-04$ & $0.00 E+00$ & $0.00 E+00$ & $0.00 E+00$ & $0.00 E+00$ & $0.00 E+00$ & $0.00 \mathrm{E}+00$ & $0.00 \mathrm{E}+00$ & $0.00 E+00$ & $0.00 E+00$ \\
\hline $1+6$ & $2.52 E-03$ & $0.00 E+00$ & $7.53 E-01$ & $0.00 E+00$ & $0.00 E+00$ & $0.00 \mathrm{E}+00$ & $0.00 E+00$ & $0.00 \mathrm{E}+00$ & $0.00 E+00$ & $0.00 E+0$ \\
\hline
\end{tabular}




\section{WHC-SD-WM-TI-774 Rev. 0 TWRS PRIVATIZATION PROCESS TECHNICAL BASELINE}

Table A-1 INVENTORY ESTIMATES OF DST SUPERNATES \& PHASE 1 FEEDS (ENVELOPES A, B, AND C) (10 sheets)

\begin{tabular}{|c|c|c|c|c|c|c|c|c|c|c|}
\hline Supernatant & 101AN & 102AN & 103AN & 104AN & 105AN & 106AN & $107 \mathrm{AN}$ & 101AP & 102AP & 103AP \\
\hline $\begin{array}{l}\mathrm{P}-\mathrm{O}-\mathrm{C} \text { or } \\
\text { Extension }\end{array}$ & & Extension & $P-O-C$ & $P-O-C$ & $P-o-C$ & Extension & Both & & & \\
\hline Envel ope & & C & A & A & A & C & c & & & \\
\hline PC1 Batch\# & & 9 & 5 & 3 & 1 & 10 and 11 & 7 and 8 & & & \\
\hline PC2 Batch\# & & 9 & 5 & 3 & 1 & 10 & 7 and 8 & & & \\
\hline \multicolumn{11}{|l|}{$\begin{array}{c}\text { Chemica! } \\
\text { (MT) }\end{array}$} \\
\hline $2 n+2$ & $3.55 \mathrm{E}-04$ & $0.00 E+00$ & $1.74 \mathrm{E}-01$ & $0.00 E+00$ & $0.00 \mathrm{E}+00$ & $9.89 \mathrm{E}-03$ & $0.00 \mathrm{E}+00$ & $2.87 \mathrm{E}-01$ & $0.00 \mathrm{E}+00$ & $4.51 \mathrm{E}-05$ \\
\hline $2 r+4$ & $6.65 \mathrm{E}-04$ & $0.00 E+00$ & $0.00 E+00$ & $0.00 \mathrm{E}+00$ & $0.00 E+00$ & $1.51 \mathrm{E}-04$ & $0.00 \mathrm{E}+00$ & $0.00 \mathrm{E}+00$ & $0.00 E+00$ & $0.00 E+00$ \\
\hline $\cos -2$ & $3.31 E+01$ & $2.53 \mathrm{E}+02$ & $3.24 \mathrm{E}+01$ & $8.56 \mathrm{E}+01$ & $9.35 \mathrm{E}+01$ & $2.35 E+02$ & $2.62 E+02$ & $8.66 \mathrm{E}+01$ & $1.11 E+02$ & $2.63 \mathrm{E}-01$ \\
\hline $\mathrm{CL}-$ & $1.27 E+00$ & $1.47 E+01$ & $3.47 E+01$ & $2.27 E+01$ & $3.65 E+01$ & $6.40 \mathrm{E}-02$ & $1.08 \mathrm{E}+01$ & $7.51 \mathrm{E}+00$ & $1.21 \mathrm{E}+01$ & $5.06 \mathrm{E}-03$ \\
\hline $\mathrm{F}-$ & $2.20 E+00$ & $7.86 E+00$ & $2.66 \mathrm{E}+00$ & $0.00 E+00$ & $0.00 E+00$ & $1.18 E+01$ & $0.00 E+00$ & $1.71 \mathrm{E}+01$ & $0.00 E+00$ & $1.32 \mathrm{E}-02$ \\
\hline $504-2$ & $1.65 E+01$ & $5.42 E+01$ & $5.79 \mathrm{E}+00$ & $1.98 \mathrm{E}+01$ & $2.81 \mathrm{E}+01$ & $4.57 \mathrm{E}+01$ & $4.79 E+01$ & 1.77E+01 & $1.88 E+01$ & $3.58 \mathrm{E}-02$ \\
\hline NO3- & $5.49 \mathrm{E}+01$ & $8.33 E+02$ & $5.79 \mathrm{E}+02$ & $5.81 E+02$ & $8.30 \mathrm{E}+02$ & $1.14 E+03$ & $8.28 \mathrm{E}+02$ & $5.70 \mathrm{E}+02$ & $3.25 E+02$ & $4.13 E-01$ \\
\hline NO2- & $4.68 \mathrm{E}+01$ & $3.15 E+02$ & $4.99 \mathrm{E}+02$ & $2.67 \mathrm{E}+02$ & $5.15 E+02$ & $4.70 E+02$ & $1.72 \mathrm{E}+02$ & $1.66 E+02$ & $1.58 \mathrm{E}+02$ & $1.33 \mathrm{E}-01$ \\
\hline $\mathrm{PO4}-3$ & $4.01 \mathrm{E}+01$ & $1.86 E+01$ & $3.36 \mathrm{E}+00$ & $8.43 E+00$ & $8.15 E+00$ & $2.97 E+01$ & $1.85 \mathrm{E}+00$ & $3.58 \mathrm{E}+00$ & $4.83 E+01$ & $1.42 \mathrm{E}-02$ \\
\hline $\mathrm{OH}-$ & $9.64 \mathrm{E}+01$ & $4.04 \mathrm{E}+01$ & $3.53 E+02$ & $2.10 \mathrm{E}+02$ & $2.66 \mathrm{E}+02$ & $4.02 \mathrm{E}+01$ & $6.25 E+01$ & $1.69 E+02$ & $3.81 E+01$ & $1.73 E-01$ \\
\hline TOC & $7.40 E+00$ & $9.89 E+01$ & $2.66 E+01$ & $1.39 \mathrm{E}+01$ & $1.67 E+01$ & $2.15 \mathrm{E}+02$ & $1.50 \mathrm{E}+02$ & $1.92 E+01$ & $1.36 \mathrm{E}+01$ & $1.14 \mathrm{E}-02$ \\
\hline
\end{tabular}




\section{WHC-SD-WM-TI-774 Rev. 0 TWRS PRIVATIZATION PROCESS TECHNICAL BASELINE}

Table A-1 INVENTORY ESTIMATES OF DST SUPERNATES \& PHASE 1 FEEDS (ENVELOPES A, B, AND C) (10 sheets)

\begin{tabular}{|c|c|c|c|c|c|c|c|c|c|c|}
\hline Supernatant & $101 \mathrm{AN}$ & $102 \mathrm{AN}$ & $103 \mathrm{AN}$ & 104AN & 105AN & 106AN & $107 \mathrm{AN}$ & 101AP & 102AP & $103 \mathrm{AP}$ \\
\hline $\begin{array}{l}\text { P-o-C or } \\
\text { Extension }\end{array}$ & & Extension & $P-0-C$ & $P-O-C$ & P-O-C & Extension & Both & & & \\
\hline Envelope & & $\mathrm{c}$ & A & A & A & c & C & & & \\
\hline PC1 Batch\# & & 9 & 5 & 3 & 1 & 10 and 11 & 7 and 8 & & & \\
\hline PC2 Batch\# & & 9 & 5 & 3 & 1 & 10 & 7 and 8 & & & \\
\hline \multicolumn{11}{|l|}{$\begin{array}{l}\text { Radionuclide } \\
\text { (Ci) }\end{array}$} \\
\hline $14 \mathrm{C}$ & $2.08 \mathrm{E}+01$ & $6.89 E+01$ & $7.24 \mathrm{E}+00$ & $0.00 E+00$ & $0.00 E+00$ & $1.82 \mathrm{E}-03$ & $0.00 \mathrm{E}+00$ & $6.76 \mathrm{E}-01$ & $2.08 \mathrm{E}+00$ & $4.56 \mathrm{E}-04$ \\
\hline $90 \mathrm{sr}$ & $1.32 E+05$ & $2.16 \mathrm{E}+05$ & $3.05 \mathrm{E}+04$ & $2.11 E+04$ & $9.82 \mathrm{E}+03$ & $7.71 \mathrm{E}+00$ & $2.32 \mathrm{E}+05$ & $1.34 \mathrm{E}+05$ & $4.20 \mathrm{E}+03$ & $1.81 E-01$ \\
\hline $90 Y$ & $1.32 E+05$ & $2.16 \mathrm{E}+05$ & $3.05 \mathrm{E}+04$ & $2.11 E+04$ & $9.82 \mathrm{E}+03$ & $7.71 \mathrm{E}+00$ & $2.32 E+05$ & $1.34 \mathrm{E}+05$ & $4.20 \mathrm{E}+03$ & 1.81E-01 \\
\hline 99Tc & $3.28 \mathrm{E}+02$ & $1.17 E+03$ & $6.15 E+02$ & $3.96 E+02$ & $5.62 E+02$ & $3.76 \mathrm{E}-01$ & $1.08 \mathrm{E}+03$ & $5.03 E+02$ & $3.57 \mathrm{E}+02$ & 1.11E-01 \\
\hline $137 \mathrm{cs}$ & $1.05 \mathrm{E}+06$ & $7.16 E+05$ & $1.80 E+06$ & $1.65 E+06$ & $1.56 E+06$ & $7.26 \mathrm{E}+02$ & $6.64 \mathrm{E}+05$ & $4.80 \mathrm{E}+05$ & $6.77 \mathrm{E}+05$ & $4.62 E+02$ \\
\hline $137 \mathrm{Ba}$ & $1.00 \mathrm{E}+06$ & $6.80 \mathrm{E}+05$ & $1.71 E+06$ & $1.56 E+06$ & $1.48 E+06$ & $6.89 \mathrm{E}+02$ & $6.31 E+05$ & $4.56 E+05$ & $6.43 E+05$ & $4.39 E+02$ \\
\hline $154 \mathrm{EU}$ & $8.38 \mathrm{E}+02$ & $3.00 E+03$ & $0.00 \mathrm{E}+00$ & $0.00 E+00$ & $0.00 E+00$ & $0.00 \mathrm{E}+00$ & $0.00 \mathrm{E}+00$ & $2.18 \mathrm{E}-02$ & $0.00 E+00$ & $0.00 E+00$ \\
\hline 2350 & $0.00 \mathrm{E}+00$ & $0.00 \mathrm{E}+00$ & $0.00 \mathrm{E}+00$ & $0.00 E+00$ & $0.00 \mathrm{E}+00$ & $0.00 \mathrm{E}+00$ & $0.00 \mathrm{E}+00$ & $0.00 E+00$ & $0.00 \mathrm{E}+00$ & $0.00 E+00$ \\
\hline 2380 & $3.66 \mathrm{E}-01$ & $0.00 E+00$ & $6.30 \mathrm{E}-04$ & $0.00 E+00$ & $0.00 \mathrm{E}+00$ & $3.10 \mathrm{E} \cdot 08$ & $2.64 \mathrm{E}-01$ & $6.27 \mathrm{E}-03$ & $4.92 \mathrm{E}-03$ & $1.27 \mathrm{E}-04$ \\
\hline $237 \mathrm{~Np}$ & $4.93 E+00$ & $0.00 E+00$ & $7.24 \mathrm{E}-02$ & $0.00 \mathrm{E}+00$ & $0.00 E+00$ & $0.00 \mathrm{E}+00$ & $0.00 E+00$ & $0.00 E+00$ & $0.00 E+00$ & $0.00 E+00$ \\
\hline 238Pu & $0.00 \mathrm{E}+00$ & $0.00 E+00$ & $0.00 E+00$ & $0.00 \mathrm{E}+00$ & $0.00 \mathrm{E}+00$ & $0.00 E+00$ & $0.00 E+00$ & $0.00 \mathrm{E}+00$ & $0.00 \mathrm{E}+00$ & $0.00 E+00$ \\
\hline $239 \mathrm{Pu}$ & $8.54 E+01$ & $2.22 E+02$ & $6.88 \mathrm{E}+00$ & $2.51 \mathrm{E}+01$ & $3.57 E+01$ & $1.64 \mathrm{E}-04$ & $9.47 E+01$ & $9.59 \mathrm{E}+00$ & $0.00 \mathrm{E}+00$ & $0.00 \mathrm{E}+00$ \\
\hline $240 \mathrm{Pu}$ & $3.71 \mathrm{E}+00$ & $5.54 \mathrm{E}+01$ & $1.72 E+00$ & $6.28 E+00$ & $8.93 \mathrm{E}+00$ & $4.11 E-05$ & $2.37 E+01$ & $2.35 \mathrm{E}+00$ & $0.00 \mathrm{E}+00$ & $0.00 E+00$ \\
\hline $241 \mathrm{Pu}$ & $1.16 \mathrm{E}+01$ & $1.87 \mathrm{E}+02$ & $4.63 \mathrm{E}+00$ & $2.02 \mathrm{E}+01$ & $2.86 E+01$ & $1.32 E-04$ & $7.81 E+01$ & $7.39 \mathrm{E}+00$ & $0.00 \mathrm{E}+00$ & $0.00 E+00$ \\
\hline $241 \mathrm{Am}$ & $5.44 \mathrm{E}+02$ & $2.33 \mathrm{E}+02$ & $8.32 E+00$ & $4.58 \mathrm{E}+00$ & $6.49 \mathrm{E}+00$ & $3.28 E-03$ & $2.19 \mathrm{E}+03$ & $3.01 \mathrm{E}+01$ & $1.74 E+00$ & $0.00 E+00$ \\
\hline Volume, $(L)$ & $3.46 \mathrm{E}+06$ & $3.84 E+06$ & $3.62 E+06$ & $3.02 E+06$ & $4.29 E+06$ & $4.00 E+06$ & $3.68 \mathrm{E}+06$ & $4.31 E+06$ & $4.16 E+06$ & $1.02 E+05$ \\
\hline Volume, (kgal) & $9.14 E+02$ & $1.01 E+03$ & $9.56 \mathrm{E}+02$ & $7.98 \mathrm{E}+02$ & $1.13 E+03$ & $1.06 \mathrm{E}+03$ & $9.73 E+02$ & $1.14 \mathrm{E}+03$ & $1.10 E+03$ & $2.70 E+01$ \\
\hline Na Molarity & $2.75 E+00$ & $1.14 \mathrm{E}+01$ & $1.46 \mathrm{E}+01$ & $1.20 E+01$ & $1.20 E+01$ & $1.61 E+01$ & $9.19 E+00$ & $6.06 E+00$ & $4.43 \mathrm{E}+00$ & 2.31E-01 \\
\hline H2O Estimate & $2.98 E+06$ & $2.08 E+06$ & $1.65 E+06$ & $1.54 E+06$ & $2.05 \mathrm{E}+06$ & $1.91 E+06$ & $2.12 E+06$ & $2.90 \mathrm{E}+06$ & $3.09 E+06$ & $1.00 E+05$ \\
\hline
\end{tabular}




\section{WHC-SD-WM-TI-774 Rev. 0 TWRS PRIVATIZATION PROCESS TECHNICAL BASELINE}

Table A-1 INVENTORY ESTIMATES OF DST SUPERnATES \& PHASE 1 fEEDS (ENVELOPES A, B, AND C) (10 sheets)

\begin{tabular}{|c|c|c|c|c|c|c|c|c|c|c|}
\hline Supernatant & 104AP & 105AP & $106 \mathrm{AP}$ & $107 \mathrm{AP}$ & 108AP & $101 \mathrm{AW}$ & 102AW & 103AH & 104AW & 105AW \\
\hline $\begin{array}{l}\text { P-o-C or } \\
\text { Extension }\end{array}$ & $P-O-C$ & & $P=O-C$ & Extension & & $P-o-C$ & & & & \\
\hline Envel ope & A & & $\mathrm{A}$ & C & & A & & & & \\
\hline PC1 Batch\# & 2. & & 2 & 11 & & 4 & & & & \\
\hline PC2 Batch\# & 2 & & 2 & 11 and 12 & & 4 & & & & \\
\hline \multicolumn{11}{|l|}{$\begin{array}{l}\text { Chemical } \\
\text { (MT) }\end{array}$} \\
\hline $\mathrm{Ag+}$ & $1.18 \mathrm{E}-13$ & $3.16 \mathrm{E}-08$ & $5.57 \mathrm{E}-09$ & $3.44 E-05$ & $0.00 E+00$ & $0.00 \mathrm{E}+00$ & & $0.00 \mathrm{E}+00$ & $1.22 E-09$ & $0.00 \mathrm{E}+00$ \\
\hline AL (OH) 4- & $1.13 E+02$ & $6.25 \mathrm{E}+00$ & $4.77 \mathrm{E}+02$ & $2.73 E+02$ & $7.77 \mathrm{E}-02$ & $3.87 E+02$ & & $7.92 \mathrm{E}-02$ & $2.11 E+00$ & $1.89 \mathrm{E}-03$ \\
\hline$A S+5$ & $1.18 \mathrm{E}-14$ & $2.07 E-07$ & $5.57 \mathrm{E}-10$ & $2.24 \mathrm{E}-04$ & $0.00 E+00$ & $0.00 \mathrm{E}+00$ & & $0.00 E+00$ & $0.00 E+00$ & $0.00 E+00$ \\
\hline$B+3$ & $3.70 \mathrm{E}-08$ & $4.87 \mathrm{E}-06$ & $9.73 E-03$ & $5.27 \mathrm{E}-03$ & $0.00 \mathrm{E}+00$ & $0.00 \mathrm{E}+00$ & & $0.00 \mathrm{E}+00$ & 7.25E-07 & $0.00 E+00$ \\
\hline$B a+2$ & $7.93 \mathrm{E}-13$ & $6.60 \mathrm{E}-06$ & 1.27E-04 & $7.16 \mathrm{E}-03$ & $1.62 \mathrm{E}-05$ & $0.00 \mathrm{E}+00$ & & $3.03 E-04$ & $6.33 E-06$ & $9.52 E-08$ \\
\hline $\mathrm{Be}+2$ & $7.13 E-14$ & $0.00 \mathrm{E}+00$ & $4.42 \mathrm{E}-05$ & $0.00 E+00$ & $6.72 \mathrm{E}-08$ & $0.00 E+00$ & & $0.00 \mathrm{E}+00$ & $0.00 \mathrm{E}+00$ & $3.31 E-08$ \\
\hline$B i+3$ & $3.53 \mathrm{E}-12$ & $0.00 E+00$ & $1.67 \mathrm{E}-07$ & $0.00 \mathrm{E}+00$ & $0.00 \mathrm{E}+00$ & $0.00 \mathrm{E}+00$ & & $0.00 \mathrm{E}+00$ & $0.00 \mathrm{E}+00$ & $0.00 E+00$ \\
\hline $\mathrm{Ca}+2$ & $9.71 \mathrm{E}-09$ & $2.49 E-04$ & $4.67 \mathrm{E}-02$ & $2.71 E-01$ & $6.73 E-05$ & $1.30 \mathrm{E}-01$ & & $3.34 E-03$ & $6.08 \mathrm{E}-05$ & $3.31 E-05$ \\
\hline $\mathrm{Cd}+2$ & $2.35 \mathrm{E}-13$ & $4.03 E-07$ & $1.11 \mathrm{E}-08$ & $4.36 \mathrm{E}-04$ & $5.89 \mathrm{E}-04$ & $0.00 \mathrm{E}+00$ & & $0.00 E+00$ & $0.00 E+00$ & $0.00 E+00$ \\
\hline $\mathrm{Ce}+3$ & $0.00 E+00$ & $0.00 \mathrm{E}+00$ & $0.00 \mathrm{E}+00$ & $0.00 \mathrm{E}+00$ & $0.00 \mathrm{E}+00$ & $0.00 \mathrm{E}+00$ & & $0.00 \mathrm{E}+00$ & $0.00 \mathrm{E}+00$ & $0.00 E+00$ \\
\hline $\mathrm{Cr}(\mathrm{OH}) 4-$ & $7.43 \mathrm{E}-08$ & $1.79 E-04$ & $1.32 \mathrm{E}-01$ & $1.96 \mathrm{E}-01$ & $1.26 \mathrm{E}-03$ & $1.46 \mathrm{E}+00$ & & $9.09 \mathrm{E}-02$ & $3.56 \mathrm{E}-05$ & $8.45 E-05$ \\
\hline $\mathrm{Cu}+2$ & $2.35 \mathrm{E}-13$ & $0.00 \mathrm{E}+00$ & $1.11 \mathrm{E}-08$ & $0.00 E+00$ & $0.00 \mathrm{E}+00$ & $0.00 \mathrm{E}+00$ & & $0.00 \mathrm{E}+00$ & 1.59E-07 & $0.00 E+00$ \\
\hline $\mathrm{Fe}+3$ & $1.09 \mathrm{E}-02$ & $1.27 \mathrm{E}-05$ & $2.06 \mathrm{E}-02$ & $1.37 \mathrm{E}-02$ & $7.11 \mathrm{E}-04$ & $0.00 \mathrm{E}+00$ & & $0.00 \mathrm{E}+00$ & $6.91 \mathrm{E}-04$ & $4.96 \mathrm{E}-03$ \\
\hline $\mathrm{Hg}+2$ & $0.00 E+00$ & $0.00 \mathrm{E}+00$ & $0.00 E+00$ & $0.00 E+00$ & $0.00 E+00$ & $0.00 E+00$ & & $0.00 E+00$ & $0.00 E+00$ & $0.00 E+00$ \\
\hline $\mathrm{K}+$ & $8.08 \mathrm{E}-06$ & $7.42 \mathrm{E}-03$ & $1.59 \mathrm{E}+01$ & $8.33 E+00$ & $1.02 \mathrm{E}-01$ & $1.65 \mathrm{E}+02$ & & $1.10 \mathrm{E}+01$ & $2.45 \mathrm{E}-04$ & $1.03 \mathrm{E}-02$ \\
\hline $\mathrm{La}+3$ & $0.00 \mathrm{E}+00$ & $6.88 \mathrm{E}-05$ & $0.00 E+00$ & $7.44 E-02$ & $0.00 \mathrm{E}+00$ & $0.00 \mathrm{E}+00$ & & $0.00 \mathrm{E}+00$ & $0.00 \mathrm{E}+00$ & $0.00 \mathrm{E}+00$ \\
\hline $\mathrm{Li+}$ & $0.00 E+00$ & $0.00 E+00$ & $0.00 \mathrm{E}+00$ & $0.00 \mathrm{E}+00$ & $0.00 \mathrm{E}+00$ & $0.00 E+00$ & & $0.00 E+00$ & $0.00 \mathrm{E}+00$ & $0.00 E+00$ \\
\hline $\mathrm{Mg}+2$ & $8.91 \mathrm{E}-11$ & $1.70 \mathrm{E}-05$ & $5.40 \mathrm{E}-02$ & $1.85 \mathrm{E}-02$ & $8.22 E-05$ & $2.06 \mathrm{E}-01$ & & $3.71 E-04$ & $2.00 \mathrm{E}-06$ & $4.05 E-05$ \\
\hline$M n+4$ & $1.52 E-01$ & $0.00 E+00$ & $2.87 \mathrm{E}-02$ & $2.55 E-07$ & $0.00 \mathrm{E}+00$ & $1.03 \mathrm{E}-01$ & & $0.00 \mathrm{E}+00$ & $1.31 \mathrm{E}-07$ & $0.00 E+00$ \\
\hline MnO2 & $0.00 \mathrm{E}+00$ & $0.00 \mathrm{E}+00$ & $0.00 \mathrm{E}+00$ & $0.00 E+00$ & $0.00 E+00$ & $0.00 \mathrm{E}+00$ & & $0.00 \mathrm{E}+00$ & $0.00 \mathrm{E}+00$ & $0.00 E+00$ \\
\hline$M 0+6$ & $4.43 E-11$ & $0.00 \mathrm{E}+00$ & $2.38 \mathrm{E}-02$ & $4.03 E-05$ & $3.62 E-05$ & $2.27 E-01$ & & $1.40 \mathrm{E}-03$ & $2.24 \mathrm{E}-06$ & $1.79 \mathrm{E}-05$ \\
\hline $\mathrm{Nat}$ & $2.36 E+02$ & $3.30 E+01$ & $1.00 E+03$ & $1.46 \mathrm{E}+03$ & $5.90 \mathrm{E}-01$ & $9.06 \mathrm{E}+02$ & & $1.06 \mathrm{E}+01$ & $1.03 E+01$ & $2.18 \mathrm{E}-01$ \\
\hline $\mathrm{Ni}+3$ & $2.35 E-13$ & $7.26 \mathrm{E}-05$ & $1.11 \mathrm{E}-08$ & $7.85 \mathrm{E}-02$ & 4.06E-05 & $0.00 \mathrm{E}+00$ & & $1.60 \mathrm{E}-03$ & $2.76 \mathrm{E}-07$ & $0.00 \mathrm{E}+00$ \\
\hline $\mathrm{Pb}+4$ & $4.70 E-12$ & $1.23 \mathrm{E}-06$ & $2.22 \mathrm{E}-07$ & $1.37 E-03$ & $0.00 \mathrm{E}+00$ & $1.19 \mathrm{E}+00$ & & $0.00 \mathrm{E}+00$ & $1.41 \mathrm{E}-06$ & $0.00 E+00$ \\
\hline $\mathrm{Rb+}$ & $0.00 \mathrm{E}+00$ & $0.00 \mathrm{E}+00$ & $0.00 E+00$ & $0.00 E+00$ & $0.00 \mathrm{E}+00$ & $0.00 \mathrm{E}+00$ & & $0.00 \mathrm{E}+00$ & $0.00 \mathrm{E}+00$ & $0.00 \mathrm{E}+00$ \\
\hline $\mathrm{Re}+7$ & $0.00 E+00$ & $0.00 \mathrm{E}+00$ & $0.00 \mathrm{E}+00$ & $0.00 \mathrm{E}+00$ & $0.00 \mathrm{E}+00$ & $0.00 \mathrm{E}+00$ & & $0.00 \mathrm{E}+00$ & $0.00 \mathrm{E}+00$ & $0.00 \mathrm{E}+00$ \\
\hline$R h+3$ & $0.00 E+00$ & $0.00 \mathrm{E}+00$ & $0.00 E+00$ & $0.00 \mathrm{E}+00$ & $0.00 \mathrm{E}+00$ & $0.00 \mathrm{E}+00$ & & $0.00 \mathrm{E}+00$ & $0.00 \mathrm{E}+00$ & $0.00 \mathrm{E}+00$ \\
\hline$R u+3$ & $0.00 E+00$ & $0.00 E+00$ & $0.00 E+00$ & $0.00 E+00$ & $0.00 E+00$ & $0.00 \mathrm{E}+00$ & & $0.00 \mathrm{E}+00$ & $0.00 \mathrm{E}+00$ & $0.00 E+00$ \\
\hline$s b+5$ & $0.00 \mathrm{E}+00$ & $0.00 \mathrm{E}+00$ & $0.00 E+00$ & $0.00 \mathrm{E}+00$ & $0.00 \mathrm{E}+00$ & $0.00 \mathrm{E}+00$ & & $0.00 \mathrm{E}+00$ & $0.00 E+00$ & $0.00 E+00$ \\
\hline $\mathrm{Se}+6$ & $0.00 E+00$ & $3.21 \mathrm{E}-08$ & $0.00 E+00$ & $3.47 \mathrm{E}-05$ & $0.00 E+00$ & $1.30 \mathrm{E}-04$ & & $0.00 \mathrm{E}+00$ & $0.00 E+00$ & $0.00 E+00$ \\
\hline $\mathrm{Si+4}$ & $4.42 E-07$ & $3.30 \mathrm{E}-05$ & $1.16 \mathrm{E}-01$ & $3.95 \mathrm{E}-02$ & $0.00 \mathrm{E}+00$ & $0.00 E+00$ & & $1.34 \mathrm{E}-01$ & $5.81 \mathrm{E}-07$ & $0.00 E+00$ \\
\hline $5 n+4$ & $5.88 \mathrm{E}-12$ & $0.00 E+00$ & $2.78 \mathrm{E}-07$ & $0.00 E+00$ & $0.00 E+00$ & $0.00 \mathrm{E}+00$ & & $0.00 \mathrm{E}+00$ & $0.00 E+00$ & $0.00 E+00$ \\
\hline $5 m+3$ & $0.00 \mathrm{E}+00$ & $0.00 \mathrm{E}+00$ & $0.00 \mathrm{E}+00$ & $0.00 E+00$ & $0.00 E+00$ & $0.00 \mathrm{E}+00$ & & $0.00 \mathrm{E}+00$ & $0.00 \mathrm{E}+00$ & $0.00 \mathrm{E}+00$ \\
\hline Te+6 & $0.00 E+00$ & $0.00 E+00$ & $0.00 E+00$ & $0.00 \mathrm{E}+00$ & $0.00 \mathrm{E}+00$ & $0.00 \mathrm{E}+00$ & & $0.00 \mathrm{E}+00$ & $0.00 \mathrm{E}+00$ & $0.00 \mathrm{E}+00$ \\
\hline $\mathrm{Th}+4$ & $0.00 E+00$ & $0.00 E+00$ & $0.00 E+00$ & $0.00 \mathrm{E}+00$ & $0.00 \mathrm{E}+00$ & $0.00 E+00$ & & $0.00 E+00$ & $0.00 \mathrm{E}+00$ & $0.00 E+00$ \\
\hline $\mathrm{Ti}+4$ & $1.18 \mathrm{E}-13$ & $1.45 E-14$ & $5.57 \mathrm{E}-09$ & $1.57 \mathrm{E}-11$ & $0.00 E+00$ & $1.86 \mathrm{E}-02$ & & $0.00 \mathrm{E}+00$ & $0.00 E+00$ & $0.00 E+00$ \\
\hline$T l+3$ & $0.00 \mathrm{E}+00$ & $0.00 \mathrm{E}+00$ & $0.00 E+00$ & $0.00 E+00$ & $0.00 E+00$ & $0.00 \mathrm{E}+00$ & & $0.00 \mathrm{E}+0.0$ & $0.00 E+00$ & $0.00 E+00$ \\
\hline $\mathrm{U}(\mathrm{g} / \mathrm{I})$ & $8.70 \mathrm{E}-03$ & 3.17E-05 & $2.59 \mathrm{E}-02$ & $3.44 \mathrm{E}-02$ & $3.91 E-04$ & $8.83 E-01$ & & $5.34 \mathrm{E}-03$ & $4.93 \mathrm{E}-02$ & $1.99 \mathrm{E}-03$ \\
\hline$v+5$ & $0.00 \mathrm{E}+00$ & $0.00 \mathrm{E}+00$ & $0.00 E+00$ & $0.00 E+00$ & $0.00 \mathrm{E}+00$ & $0.00 E+00$ & & $0.00 \mathrm{E}+00$ & $0.00 E+00$ & $0.00 \mathrm{E}+00$ \\
\hline$w+6$ & $0.00 E+00$ & $0.00 \mathrm{E}+00$ & $0.00 \mathrm{E}+00$ & $0.00 E+00$ & $0.00 E+00$ & $0.00 E+00$ & & $0.00 E+00$ & $4.55 \mathrm{E}-06$ & $0.00 E+00$ \\
\hline
\end{tabular}


WHC-SD-WM-TI-774 Rev. 0

TWRS PRIVATIZATION PROCESS TECHNICAL BASELINE

Table A-1 INVENTORY ESTIMATES OF DST SUPERNATES \& PHASE 1 FEEDS (ENVELOPES A, B, AND C) (10 sheets)

\begin{tabular}{|c|c|c|c|c|c|c|c|c|c|c|}
\hline Supernatant & $104 \mathrm{AP}$ & 105AP & 106AP & 107AP & 108AP & $101 \mathrm{AW}$ & 102AW & $103 \mathrm{AW}$ & 104AH & $105 \mathrm{AW}$ \\
\hline $\begin{array}{l}\text { P-o-C or } \\
\text { Extension }\end{array}$ & P-o-C & & P-O-C & Extension & & $P-0-C$ & & & & \\
\hline Envel ope & A & & A & $C$ & & A & & & & \\
\hline PC1 Batch\# & 2 & & 2 & 11 & & 4 & & & & \\
\hline PC2 Batch\# & 2 & & 2 & 11 and 12 & & 4 & & & & \\
\hline \multicolumn{11}{|l|}{$\begin{array}{l}\text { Chemical } \\
\text { (MT) }\end{array}$} \\
\hline $2 n+2$ & $0.00 \mathrm{E}+00$ & $2.55 \mathrm{E}-05$ & $0.00 E+00$ & $2.77 \mathrm{E}-02$ & $2.92 \mathrm{E}-08$ & $1.25 \mathrm{E}+00$ & & $2.49 \mathrm{E}-03$ & $5.13 E-07$ & $0.00 \mathrm{E}+00$ \\
\hline $2 r+4$ & $5.88 \mathrm{E}-12$ & $0.00 E+00$ & $2.78 \mathrm{E}-07$ & $0.00 E+00$ & $0.00 \mathrm{E}+00$ & $1.99 \mathrm{E}-01$ & & $0.00 E+00$ & $2.35 \mathrm{E}-08$ & $0.00 E+00$ \\
\hline $\cos -2$ & $3.14 E+01$ & $5.25 \mathrm{E}+00$ & $1.33 E+02$ & $2.39 E+02$ & $2.61 \mathrm{E}-01$ & $4.85 \mathrm{E}+01$ & & $2.49 E+00$ & $1.10 \mathrm{E}+00$ & $2.14 \mathrm{E}-03$ \\
\hline CL- & $1.22 E+01$ & $1.04 \mathrm{E}-03$ & $5.02 E+01$ & $1.13 E+00$ & $5.89 \mathrm{E}-03$ & $2.04 \mathrm{E}+01$ & & $7.31 \mathrm{E}-02$ & $4.22 \mathrm{E}-01$ & $4.10 E-03$ \\
\hline $\mathrm{F}-$ & $8.37 \mathrm{E}+00$ & $2.50 \mathrm{E}-09$ & $4.85 E+01$ & $1.15 \mathrm{E}+01$ & $3.64 \mathrm{E}-02$ & $0.00 \mathrm{E}+00$ & & $9.42 E+00$ & $1.54 \mathrm{E}-02$ & $9.45 \mathrm{E}-03$ \\
\hline $504-2$ & $6.58 \mathrm{E}+00$ & $1.02 \mathrm{E}+00$ & $2.72 \mathrm{E}+01$ & $4.92 \mathrm{E}+01$ & $1.51 E-02$ & $4.06 E+00$ & & $3.05 \mathrm{E}-02$ & $5.75 \mathrm{E}-02$ & $2.34 \mathrm{E}-02$ \\
\hline NO3- & $1.79 E+02$ & $2.53 \mathrm{E}+01$ & $7.82 \mathrm{E}+02$ & $1.13 E+03$ & $4.35 E-01$ & $8.43 E+02$ & & $1.90 E+00$ & $8.81 E+00$ & $1.97 E+00$ \\
\hline NO2- & $8.80 E+01$ & $1.05 \mathrm{E}+01$ & $3.72 E+02$ & $4.53 \mathrm{E}+02$ & $1.17 \mathrm{E}-01$ & $4.02 E+02$ & & $6.60 \mathrm{E}-01$ & $1.16 \mathrm{E}+00$ & $6.46 E-02$ \\
\hline $\mathrm{PO4}-3$ & $6.39 \mathrm{E}+00$ & $6.59 \mathrm{E}-01$ & $1.97 E+01$ & $2.82 \mathrm{E}+01$ & $2-13 E-02$ & $8.31 E+00$ & & $3.14 \mathrm{E}-02$ & $5.62 \mathrm{E}-01$ & $2.29 \varepsilon-02$ \\
\hline $\mathrm{OH}^{-}$ & $6.04 \mathrm{E}+01$ & $8.94 \mathrm{E}-01$ & $2.42 E+02$ & $5.81 \mathrm{E}+01$ & $1.58 \mathrm{E}-01$ & $3.40 \mathrm{E}+02$ & & $1.73 \mathrm{E}+00$ & $3.83 \mathrm{E}+00$ & $7.51 \varepsilon-02$ \\
\hline TOC & $6.34 E+00$ & $4.78 \mathrm{E}+00$ & $2.23 E+01$ & $2.03 E+02$ & $5.07 \mathrm{E}-02$ & $9.69 \mathrm{E}+00$ & & $5.06 \mathrm{E}-01$ & $9.16 \mathrm{E}-01$ & $2.39 \varepsilon-02$ \\
\hline
\end{tabular}




\section{WHC-SD-WM-TI-774 Rev. 0 \\ TWRS PRIVATIZATION PROCESS TECHNICAL BASELINE}

Table A-1 INVENTORY ESTIMATES OF DST SUPERNATES \& PHASE 1 fEedS (ENVELOPES A, B, AND C) (10 sheets)

\begin{tabular}{|c|c|c|c|c|c|c|c|c|c|c|}
\hline Supernatant & $104 \mathrm{AP}$ & 105AP & 106AP & 107AP & $108 \mathrm{AP}$ & 101AW & $102 \mathrm{AW}$ & 103AW & $104 \mathrm{AW}$ & 105AW \\
\hline $\begin{array}{l}P-o-C \text { or } \\
\text { Extension }\end{array}$ & $P=0-C$ & & $P-o-C$ & Extension & & $P-o-C$ & & & & \\
\hline Envelope & A & & $\mathrm{A}$ & $\mathrm{C}$ & & A & & & & \\
\hline PC1 Batch\# & 2 & & 2 & 11 & & 4 & & & & \\
\hline PC2 Batch\# & 2 & & 2 & 11 and 12 & & 4 & & & & \\
\hline \multicolumn{11}{|l|}{$\begin{array}{l}\text { Radionucl ide } \\
\text { (Ci) }\end{array}$} \\
\hline $14 \mathrm{C}$ & $1.38 \mathrm{E}-12$ & $4.95 \mathrm{E}-05$ & $1.89 E-07$ & $5.35 \mathrm{E}-02$ & $7.72 E-10$ & $1.45 E+00$ & $0,00 E+00$ & $0.00 \mathrm{E}+00$ & $1.39 \mathrm{E}-05$ & $0.00 E+00$ \\
\hline $90 \mathrm{sr}$ & $1.72 E-05$ & $1.50 E+02$ & 1.18E-01 & $1.64 E+05$ & $5.41 E-03$ & $2.81 E+03$ & $0.00 \mathrm{E}+00$ & $8.55 E-02$ & $6.85 \mathrm{E}-03$ & $0.00 \mathrm{E}+00$ \\
\hline $90 Y$ & $1.72 \mathrm{E}-05$ & $1.50 E+02$ & 1.18E-01 & $1.64 E+05$ & $5.41 \mathrm{E}-03$ & $2.81 E+03$ & $0.00 E+00$ & $8.55 \mathrm{E}-02$ & $6.85 \mathrm{E}-03$ & $0.00 \mathrm{E}+00$ \\
\hline $991 \mathrm{c}$ & $3.14 \mathrm{E}-07$ & $3.50 \mathrm{E}-01$ & 1.49E-02 & $3.78 E+02$ & $2.05 \mathrm{E}-02$ & $5.94 E+02$ & $0.00 \mathrm{E}+00$ & $1.23 E+01$ & $5.26 \mathrm{E}-03$ & $1.01 \mathrm{E}-02$ \\
\hline $137 \mathrm{Cs}$ & $1.42 \mathrm{E}-02$ & $1.39 E+02$ & $2.81 E+02$ & $1.52 E+05$ & $1.70 E+02$ & $1.29 \mathrm{E}+06$ & $0.00 \mathrm{E}+00$ & $8.14 E+03$ & $7.72 E+00$ & $7.86 \mathrm{E}+01$ \\
\hline $137 \mathrm{Ba}$ & $1.35 \mathrm{E}-02$ & $1.32 E+02$ & $2.67 \mathrm{E}+02$ & $1.44 E+05$ & $1.61 \mathrm{E}+02$ & $1.22 E+06$ & $0.00 E+00$ & $7.74 E+03$ & $7.33 \mathrm{E}+00$ & $7.46 \mathrm{E}+01$ \\
\hline 154EU & $0.00 \mathrm{E}+00$ & $0.00 \mathrm{E}+00$ & $0.00 \mathrm{E}+00$ & $3.84 \mathrm{E}-04$ & $0.00 E+00$ & $0.00 \mathrm{E}+00$ & $0.00 \mathrm{E}+00$ & $0.00 E+00$ & $0.00 E+00$ & $0.00 E+00$ \\
\hline $235 \mathrm{U}$ & $0.00 \mathrm{E}+00$ & $0.00 E+00$ & $0.00 E+00$ & $0.00 E+00$ & $0.00 E+00$ & $0.00 E+00$ & $0.00 E+00$ & $0.00 \mathrm{E}+00$ & $0.00 \mathrm{E}+00$ & $0.00 E+00$ \\
\hline 2380 & $4.18 \mathrm{E}-12$ & $7.12 \mathrm{E}-06$ & $2.00 \mathrm{E}-07$ & $7.69 \mathrm{E}-03$ & $4.29 E-06$ & 2.97E-01 & $0.00 \mathrm{E}+00$ & $1.79 \mathrm{E}-03$ & $6.04 \mathrm{E}-07$ & $1.90 \mathrm{E}-06$ \\
\hline $237 \mathrm{~Np}$ & $5.61 \mathrm{E}-07$ & $0.00 \mathrm{E}+00$ & $9.78 \mathrm{E}-03$ & $0.00 \mathrm{E}+00$ & $4.16 \mathrm{E}-08$ & $0.00 \mathrm{E}+00$ & $0.00 \mathrm{E}+00$ & $0.00 \mathrm{E}+00$ & $0.00 \mathrm{E}+00$ & $0.00 E+00$ \\
\hline $238 \mathrm{Pu}$ & $0.00 E+00$ & $0.00 \mathrm{E}+00$ & $0.00 \mathrm{E}+00$ & $0.00 E+00$ & $0.00 E+00$ & $0.00 E+00$ & $0.00 E+00$ & $0.00 \mathrm{E}+00$ & $0.00 E+00$ & $0.00 E+00$ \\
\hline $239 \mathrm{Pu}$ & $3.23 E-06$ & $1.04 \mathrm{E}-02$ & $1.44 \mathrm{E}-02$ & $1.13 \mathrm{E}+01$ & $0.00 E+00$ & $3.63 \mathrm{E}+00$ & $0.00 E+00$ & $0.00 \mathrm{E}+00$ & $4.47 \mathrm{E}-05$ & $0.00 \mathrm{E}+00$ \\
\hline $240 \mathrm{Pu}$ & $2.06 \mathrm{E}-07$ & $2.61 \mathrm{E}-03$ & $3.59 \mathrm{E}-03$ & $2.82 E+00$ & $0.00 E+00$ & $9.07 \mathrm{E}-01$ & $0.00 E+00$ & $0.00 \mathrm{E}+00$ & $8.81 E-07$ & $0.00 E+00$ \\
\hline $241 P u$ & $5.12 E-07$ & $8.13 E-03$ & $1.12 \mathrm{E}-02$ & $8.95 E+00$ & $0.00 E+00$ & $2.49 E+00$ & $0.00 E+00$ & $0.00 \mathrm{E}+00$ & $2.96 \mathrm{E}-06$ & $0.00 E+00$ \\
\hline $241 \mathrm{Am}$ & $4.78 \mathrm{E}-05$ & $3.27 \mathrm{E}-02$ & $4.15 \mathrm{E}-04$ & $3.53 E+01$ & $9.50 \mathrm{E}-12$ & 4. $73 E+00$ & $0.00 E+00$ & $0.00 \mathrm{E}+00$ & $3.25 \mathrm{E}-0$. & $0.00 E+00$ \\
\hline volume, (L) & $4.22 E+06$ & $9.99 E+04$ & $4.10 E+06$ & $4.10 E+06$ & $1.02 E+05$ & $3.94 E+06$ & $0.00 E+00$ & $5.41 \mathrm{E}+05$ & $2.27 \mathrm{E}+06$ & 1.00E+05 \\
\hline Volume, (kgal) & $1.11 E+03$ & $2.64 \mathrm{E}+01$ & $1.08 \mathrm{E}+03$ & $1.08 \mathrm{E}+03$ & $2.68 \mathrm{E}+01$ & $1.04 E+03$ & $0.00 \mathrm{E}+00$ & $1.43 E+02$ & $6.00 \mathrm{E}+02$ & $2.64 E+01$ \\
\hline Na Molarity & $2.43 E+00$ & $1.44 E+01$ & $1.06 \mathrm{E}+01$ & $1.55 E+01$ & $2.53 E-01$ & $1.00 E+01$ & & $8.52 \mathrm{E}-01$ & $1.97 \mathrm{E}-01$ & $9.47 \mathrm{E}-02$ \\
\hline H20 Estimate & $3.56 \mathrm{E}+06$ & $5.09 E+04$ & $2.09 \mathrm{E}+06$ & $1.98 E+06$ & $9.97 E+04$ & $1.92 E+06$ & & $5.04 E+05$ & $2.24 E+06$ & $9.75 E+04$ \\
\hline
\end{tabular}


WHC-SD-WM-TI-774 Rev. 0

TWRS PRIVATIZATION PROCESS TECHNICAL BASELINE

Table A-1 INVENTORY ESTIMATES OF DST SUPERNATES \& PHASE 1 FEedS (ENVELOPES A, B, AND C) (10 sheets)

\begin{tabular}{|c|c|c|c|c|c|c|c|c|c|c|}
\hline Supernatant & 106AW & 101AY & $102 \mathrm{AY}$ & $101 \mathrm{~A} 2$ & $102 \mathrm{AZ}$ & $101 \mathrm{SY}$ & $101 \mathrm{SY}-\mathrm{TOT}$ & $102 S Y$ & $103 S Y$ & 103SY-TOT \\
\hline $\begin{array}{l}\text { P-o-C or } \\
\text { Extension }\end{array}$ & & Both & & & & & & & & \\
\hline Envelope & & B & & & & & & & & \\
\hline PC1 Batch\# & & 6 and 12 & & & & & & & & \\
\hline PC2 Batch\# & & 6 & & & & & & & & \\
\hline \multicolumn{11}{|l|}{$\begin{array}{l}\text { Chemical } \\
\text { (MT) }\end{array}$} \\
\hline $\mathrm{Ag}+$ & & $0.00 E+00$ & $2.14 \mathrm{E}-05$ & $0.00 E+00$ & $0.00 E+00$ & $0.00 \mathrm{E}+00$ & $0.00 \mathrm{E}+00$ & $0.00 E+00$ & $0.00 \mathrm{E}+00$ & $0.00 \mathrm{E}+00$ \\
\hline$A(\mathrm{COH}) 4-$ & & $1.04 \mathrm{E}+02$ & $1.84 \mathrm{E}-02$ & $4.86 E+00$ & $6.47 E-02$ & $1.02 E+01$ & $6.52 E+02$ & $8.49 \mathrm{E}-01$ & $4.99 \mathrm{E}+01$ & $4.92 \mathrm{E}+02$ \\
\hline As+5 & & $0.00 E+00$ & $0.00 \mathrm{E}+00$ & $9.02 E-04$ & $4.40 \mathrm{E}-04$ & $0.00 \mathrm{E}+00$ & $0.00 E+00$ & $0.00 \mathrm{E}+00$ & $0.00 E+00$ & $0.00 \mathrm{E}+00$ \\
\hline$B+3$ & & $0.00 E+00$ & $2.47 E-05$ & $3.06 E-04$ & $2.43 E-04$ & $0.00 \mathrm{E}+00$ & $0.00 E+00$ & $2.06 \mathrm{E}-11$ & $1.55 E-02$ & $1.14 \mathrm{E}-01$ \\
\hline$B a+2$ & & $2.09 \mathrm{e}-04$ & 1.97E-05 & $3.24 E-05$ & $3.40 \mathrm{E}-05$ & $0.00 E+00$ & $0.00 E+00$ & $0.00 E+00$ & $0.00 E+00$ & $2.93 \mathrm{E}-02$ \\
\hline $\mathrm{Be}+2$ & & $0.00 E+00$ & $0.00 E+00$ & $3.67 E-07$ & $2.25 \mathrm{E}-0.6$ & $0.00 E+00$ & $0.00 E+00$ & $0.00 E+00$ & $0.00 E+00$ & $0.00 E+00$ \\
\hline$B i+3$ & & $0.00 E+00$ & $2.68 \mathrm{E}-04$ & $0.00 E+00$ & $0.00 E+00$ & $0.00 E+00$ & $0.00 E+00$ & $0.00 \mathrm{E}+00$ & $0.00 E+00$ & $0.00 E+00$ \\
\hline $\mathrm{Ca}+2$ & & $7.57 \mathrm{E}-03$ & $7.20 \mathrm{E}-04$ & 5.44E-04 & $1.18 \mathrm{E}-03$ & $5.11 \mathrm{E}-02$ & $3.68 \mathrm{E}+00$ & $5.35 E-12$ & $2.06 \mathrm{E}-02$ & $8.45 E-01$ \\
\hline $\mathrm{Cd}+2$ & & $0.00 E+00$ & $1.15 E-04$ & $2.00 \mathrm{E}-05$ & $3.83 E-05$ & $0.00 E+00$ & $0.00 E+00$ & $0.00 E+00$ & $0.00 \mathrm{E}+00$ & $0.00 \mathrm{E}+00$ \\
\hline $\mathrm{Ce}+3$ & & $0.00 E+00$ & $0.00 E+00$ & $8.23 E-04$ & $4.31 \mathrm{E}-04$ & $0.00 E+00$ & $0.00 \mathrm{E}+00$ & $0.00 \mathrm{E}+00$ & $0.00 \mathrm{E}+00$ & $0.00 \mathrm{E}+00$ \\
\hline $\mathrm{Cr}(\mathrm{OH}) 4$ - & & $1.03 E+01$ & $9.94 E-04$ & $2.87 \mathrm{E}-01$ & $1.93 E-01$ & $1.28 \varepsilon-02$ & $2.72 \mathrm{E}+00$ & $4.11 E-11$ & $1.32 \mathrm{E}-02$ & $4.81 E+01$ \\
\hline Cu+2 & & $0.00 E+00$ & $9.63 \mathrm{E}-06$ & $7.07 E-05$ & $3.11 \mathrm{E}-05$ & $0.00 E+00$ & $0.00 E+00$ & $0.00 \mathrm{E}+00$ & $0.00 E+00$ & $0.00 E+00$ \\
\hline $\mathrm{Fe}+3$ & & $3.63 E-04$ & $7.85 E-04$ & $1.65 \mathrm{E}-04$ & $3.23 E-04$ & $1.34 E-03$ & $1.43 \mathrm{E}-01$ & $3.62 E-04$ & $0.00 E+00$ & $5.52 E+00$ \\
\hline $\mathrm{Hg}+2$ & & $0.00 \mathrm{E}+00$ & $4.75 E-06$ & $0.00 E+00$ & $0.00 E+00$ & $0.00 E+00$ & $0.00 \mathrm{E}+00$ & $0.00 E+00$ & $0.00 E+00$ & $0.00 E+00$ \\
\hline $\mathrm{K}+$ & & $1.26 \mathrm{E}+01$ & $0.00 \mathrm{E}+00$ & $5.71 E-01$ & $2.77 \mathrm{E}-02$ & $3.37 E-01$ & $1.90 \mathrm{E}+01$ & $4.48 \mathrm{E}-09$ & $6.81 E-01$ & $1.27 E+01$ \\
\hline$L a+3$ & & $2.23 E-03$ & $1.20 \mathrm{E}-04$ & $6.21 E-05$ & $6.92 E-05$ & $0.00 E+00$ & $0.00 \mathrm{E}+00$ & $0.00 \mathrm{E}+00$ & $0.00 \mathrm{E}+00$ & $0.00 E+00$ \\
\hline Li+ & & $0.00 \mathrm{E}+00$ & $0.00 \mathrm{E}+00$ & $1.53 E-04$ & $3.13 E-05$ & $0.00 \mathrm{E}+00$ & $0.00 \mathrm{E}+00$ & $0.00 \mathrm{E}+00$ & $0.00 \mathrm{E}+00$ & $0.00 E+00$ \\
\hline $\mathrm{Mg}+2$ & & $4.85 \mathrm{E}-04$ & $1.20 \mathrm{E}-04$ & 2.95E-05 & $3.90 E-05$ & $0.00 E+00$ & $0.00 E+00$ & $0.00 \mathrm{E}+00$ & $0.00 \mathrm{E}+00$ & $0.00 E+00$ \\
\hline$M n+4$ & & $0.00 E+00$ & $1.56 \mathrm{E}-04$ & 1.51E-05 & $2.93 \mathrm{E}-05$ & $0.00 E+00$ & $0.00 \mathrm{E}+00$ & $5.88 \mathrm{E}-03$ & $0.00 \mathrm{E}+00$ & $0.00 E+00$ \\
\hline MnO2 & & $0.00 \mathrm{E}+00$ & $0.00 \mathrm{E}+00$ & $0.00 E+00$ & $0.00 \mathrm{E}+00$ & $0.00 \mathrm{E}+00$ & $0.00 \mathrm{E}+00$ & $0.00 E+00$ & $0.00 \mathrm{E}+00$ & $0.00 E+00$ \\
\hline Mo+6 & & $0.00 E+00$ & $0.00 E+00$ & $4.65 E-03$ & $7.15 E-04$ & $1.01 \mathrm{E}-02$ & $0.00 \mathrm{E}+00$ & $0.00 \mathrm{E}+00$ & $0.00 \mathrm{E}+00$ & $0.00 E+00$ \\
\hline Na+ & & $4.36 \mathrm{E}+02$ & $8.39 \mathrm{E}+00$ & $1.43 E+01$ & $7.63 \mathrm{E}+00$ & $1.83 \mathrm{E}+01$ & $1.19 \mathrm{E}+03$ & $2.00 E+00$ & $1.66 \mathrm{E}+02$ & $7.12 E+02$ \\
\hline $\mathrm{Ni}+3$ & & $2.28 E-03$ & $0.00 E+00$ & $4.32 E-05$ & $7.44 \mathrm{E}-05$ & $3.54 \mathrm{E}-03$ & $1.70 E-01$ & $0.00 E+00$ & $8.45 \mathrm{E}-03$ & $2.76 \mathrm{E}-01$ \\
\hline $\mathrm{Pb}+4$ & & $0.00 E+00$ & $1.55 E-04$ & $3.25 E-04$ & $1.53 E-04$ & $0.00 E+00$ & $0.00 \mathrm{E}+00$ & $0.00 \mathrm{E}+00$ & $0.00 E+00$ & $0.00 E+00$ \\
\hline $\mathrm{Rb}+$ & & $0.00 \mathrm{E}+00$ & $0.00 \mathrm{E}+00$ & $0.00 E+00$ & $0.00 E+00$ & $0.00 E+00$ & $0.00 E+00$ & $0.00 E+00$ & $0.00 E+00$ & $0.00 E+00$ \\
\hline Re+7 & & $0.00 E+00$ & $0.00 \mathrm{E}+00$ & $7.66 \mathrm{E}-05$ & $2.32 \mathrm{E}-05$ & $0.00 \mathrm{E}+0.0$ & $0.00 E+00$ & $0.00 E+00$ & $0.00 E+00$ & $0.00 E+00$ \\
\hline $\mathrm{Rh}+3$ & & $0.00 \mathrm{E}+00$ & $0.00 \mathrm{E}+00$ & $5.47 \mathrm{E}-04$ & $2.97 \mathrm{E}-04$ & $0.00 E+00$ & $0.00 \mathrm{E}+00$ & $0.00 E+00$ & $0.00 E+00$ & $0.00 E+00$ \\
\hline Ru+3 & & $0.00 \mathrm{E}+00$ & $0.00 E+00$ & $2.61 E-04$ & $7.36 \mathrm{E}-05$ & $0.00 E+00$ & $0.00 \mathrm{E}+00$ & $0.00 E+00$ & $0.00 E+00$ & $0.00 E+00$ \\
\hline$S b+5$ & & $0.00 \mathrm{E}+00$ & $0.00 \mathrm{E}+00$ & $7.07 \mathrm{E}-04$ & $0.00 \mathrm{E}+00$ & $0.00 E+00$ & $0.00 E+00$ & $0.00 E+00$ & $0.00 E+00$ & $0.00 E+00$ \\
\hline $\mathrm{Se}+6$ & & $0.00 \mathrm{E}+00$ & $0.00 \mathrm{E}+00$ & $1.33 \mathrm{E}-03$ & $3.61 \mathrm{E}-04$ & $0.00 E+00$ & $0.00 \mathrm{E}+00$ & $0.00 E+00$ & $0.00 E+00$ & $0.00 E+00$ \\
\hline $\mathrm{Si}+4$ & & $1.37 E+00$ & $2.32 \mathrm{E}-03$ & $1.92 E-02$ & $4.28 \mathrm{E}-02$ & $0.00 E+00$ & $0.00 \mathrm{E}+00$ & $2.46 \mathrm{E}-10$ & $1.38 \mathrm{E}-02$ & $0.00 E+00$ \\
\hline$S n+4$ & & $0.00 E+00$ & $0.00 \mathrm{E}+00$ & $0.00 E+00$ & $0.00 \mathrm{E}+00$ & $0.00 E+00$ & $0.00 E+00$ & $0.00 E+00$ & $0.00 E+00$ & $0.00 E+00$ \\
\hline $5 m+3$ & & $0.00 E+00$ & $0.00 \mathrm{E}+00$ & $0.00 \mathrm{E}+00$ & $0.00 E+00$ & $0.00 E+00$ & $0.00 E+00$ & $0.00 \mathrm{E}+00$ & $0.00 E+00$ & $0.00 E+00$ \\
\hline Te+6 & & $0.00 E+00$ & $0.00 E+00$ & $1.42 E-03$ & $9.20 \mathrm{E}-05$ & $0.00 E+00$ & $0.00 \mathrm{E}+00$ & $0.00 E+00$ & $0.00 E+00$ & $0.00 E+00$ \\
\hline $\mathrm{Th}+4$ & & $0.00 E+00$ & $0.00 E+00$ & $1.15 E-03$ & $0.00 E+00$ & $0.00 E+00$ & $0.00 \mathrm{E}+00$ & $0.00 E+00$ & $0.00 E+00$ & $0.00 E+00$ \\
\hline$T i+4$ & & $0.00 E+00$ & $0.00 \mathrm{E}+00$ & $4.07 E-04$ & $2.59 \mathrm{E}-05$ & $0.00 E+00$ & $0.00 E+00$ & $0.00 E+00$ & $0.00 E+00$ & $0.00 E+00$ \\
\hline $\mathrm{TL}+3$ & & $0.00 E+00$ & $0.00 \mathrm{E}+00$ & $1.42 \mathrm{E}-02$ & $6.34 \mathrm{E}-05$ & $0.00 E+00$ & $0.00 E+00$ & $0.00 E+00$ & $0.00 E+00$ & $0.00 E+00$ \\
\hline$U(g / t)$ & & $3.96 \mathrm{E}+00$ & $3.63 \mathrm{E}-05$ & 2.79E-03 & $1.15 \mathrm{E}-01$ & $2.31 E-04$ & $0.00 \mathrm{E}+00$ & $2.90 \mathrm{E}-04$ & 4.91E-04 & $1.59 E+00$ \\
\hline$v+5$ & & $0.00 E+00$ & $0.00 E+00$ & $4.90 E-05$ & $2.73 E-05$ & $0.00 E+00$ & $0.00 \mathrm{E}+00$ & $0.00 E+00$ & $0.00 E+00$ & $0.00 E+00$ \\
\hline $\mathrm{H}+6$ & & $0.00 E+00$ & $0.00 E+00$ & $0.00 E+00$ & $0.00 E+00$ & $0.00 E+00$ & $0.00 E+00$ & $0.00 E+00$ & $0.00 E+00$ & $0.00 \mathrm{E}+00$ \\
\hline
\end{tabular}


WHC-SD-WM-TI-774 Rev. 0

TWRS PRIVATIZATION PROCESS TECHNICAL. BASELINE

Table A-1 INVENTORY ESTJMATES of DSt SUPERHATES \& PHASE 1 fEedS (ENVELOPES A, B, AND C) (10 sheets)

\begin{tabular}{|c|c|c|c|c|c|c|c|c|c|c|}
\hline Supernatant & $106 \mathrm{AH}$ & $101 \mathrm{AY}$ & $102 \mathrm{AY}$ & $101 \mathrm{AZ}$ & $102 \mathrm{AZ}$ & $1015 Y$ & $101 \mathrm{SY}-\mathrm{TOT}$ & $102 S Y$ & $103 \mathrm{sr}$ & 103SY-TOT \\
\hline $\begin{array}{l}\text { P-o-C or } \\
\text { Extension }\end{array}$ & & Both & & & & & & & & \\
\hline Envelope & & $B$ & & & & & & & & \\
\hline PC1 Batch\# & & 6 and 12 & & & & & & & & \\
\hline PC2 Batch\# & & 6 & & & & & & & & \\
\hline \multicolumn{11}{|l|}{$\begin{array}{l}\text { Chemical } \\
\text { (MT) }\end{array}$} \\
\hline $2 n+2$ & & $3.94 \mathrm{E}-04$ & $0.00 E+00$ & $7.28 \mathrm{E}-05$ & $1.47 \mathrm{E}-05$ & $7.15 E-03$ & $0.00 E+00$ & $0.00 \mathrm{E}+00$ & $0.00 E+00$ & $4.86 \mathrm{E}-02$ \\
\hline $2 r+4$ & & $0.00 E+00$ & $0.00 E+00$ & $2.50 \mathrm{E}-05$ & $7.15 E-05$ & $0.00 E+00$ & $0.00 E+00$ & $0.00 E+00$ & $0.00 \mathrm{E}+00$ & $0.00 E+00$ \\
\hline $\cos -2$ & & $1.65 \mathrm{E}+02$ & $1.80 \mathrm{E}-02$ & $2.66 \mathrm{E}+00$ & $1.89 \mathrm{E}+00$ & $0.00 \mathrm{E}+00$ & $0.00 E+00$ & $2.61 \mathrm{E}-01$ & $2.06 \mathrm{E}+01$ & $9.37 E+01$ \\
\hline $\mathrm{CL}-$ & & $5.57 E-01$ & $5.72 E-04$ & $1.46 \mathrm{E}-02$ & $0.00 \mathrm{E}+00$ & $9.40 \mathrm{E}-01$ & $4.82 E+01$ & $1.02 \mathrm{E}-01$ & $2.02 \mathrm{E}+00$ & $3.12 E+01$ \\
\hline $\mathrm{F}-$ & & $7.52 E+00$ & $8.59 E-04$ & $2.67 E-01$ & $7.59 E-02$ & $0.00 \mathrm{E}+00$ & $6.95 \mathrm{E}-01$ & 6.03E-02 & $9.81 \mathrm{E}-01$ & $3.32 E+00$ \\
\hline $504-2$ & & $9.26 E+01$ & $7.48 \mathrm{E}-03$ & $1.30 E+00$ & $1.13 E+00$ & $9.33 \mathrm{E}-02$ & $2.54 E+01$ & $6.17 \mathrm{E}-02$ & $3.97 \mathrm{E}+00$ & $1.68 \mathrm{E}+01$ \\
\hline NO3- & & $2.69 E+02$ & $2.13 E-02$ & $7.37 E+00$ & $1.60 \mathrm{E}+00$ & $1.55 E+01$ & $2.65 E+02$ & $1.36 E+00$ & $1.30 \mathrm{E}+02$ & $4.91 E+01$ \\
\hline NO2- & & $2.48 E+02$ & $1.47 \mathrm{E}+00$ & $6.52 \mathrm{E}+00$ & $2.73 E+00$ & $1.34 E+01$ & $2.28 \mathrm{E}+02$ & 6.70E-01 & $6.59 E+01$ & $3.73 E+02$ \\
\hline $\mathrm{PO4}-3$ & & $4.13 E+00$ & $7.63 \mathrm{E}-02$ & $1.23 \mathrm{E}-01$ & $3.50 E-03$ & $5.40 \mathrm{E}-01$ & $4.01 E+01$ & $1.05 \mathrm{E}-01$ & $3.13 \mathrm{E}+00$ & $4.01 \mathrm{E}+01$ \\
\hline $\mathrm{OH}-$ & & $4.06 \mathrm{E}+01$ & $2.75 E+01$ & $1.87 E+00$ & $2.05 E+00$ & $2.81 \mathrm{E}+00$ & $7.26 \mathrm{E}+02$ & $6.13 \mathrm{E}-01$ & $8.40 E+00$ & $7.41 E+01$ \\
\hline TOC & & $7.42 E+00$ & $1.14 \mathrm{E}-02$ & $8.63 E-02$ & $1.11 \mathrm{E}-01$ & $9.33 E-01$ & $9.44 E+01$ & $9.30 \mathrm{E}-02$ & $2.05 E+01$ & $7.04 E+00$ \\
\hline
\end{tabular}




\section{WHC-SD-WM-TI-774 Rev. 0 \\ TWRS PRIVATIZATION PROCESS TECHNICAL BASELINE}

Table A-1 InVENTORY ESTIMATES OF DST SUPERnATES \& PHASE 1 fEedS (ENVELOPES A, B, AND C) (10 sheets)

\begin{tabular}{|c|c|c|c|c|c|c|c|c|c|}
\hline Supernatant & $101 \mathrm{AY}$ & $102 \mathrm{AY}$ & $101 \mathrm{AZ}$ & 102AZ & $101 \$ Y$ & 101SY-TOT & $102 s Y$ & $103 s Y$ & 103SY-TOT \\
\hline $\begin{array}{l}\text { P-O-C or } \\
\text { Extension }\end{array}$ & Both & & & & & & & & \\
\hline Envel ope & B & & & & & & & & \\
\hline PC1 Batch\# & 6 and 12 & & & & & & & & \\
\hline PC2 Batch\# & 6 & & & & & & & & \\
\hline \multicolumn{10}{|l|}{$\begin{array}{l}\text { Radionuct ide } \\
\text { (Ci) }\end{array}$} \\
\hline $14 \mathrm{C}$ & $7.73 E+00$ & $0.00 E+00$ & $3.59 E+00$ & $1.64 E+00$ & $0.00 E+00$ & $0.00 \mathrm{E}+00$ & $0.00 E+00$ & $0.00 E+00$ & $0.00 \mathrm{E}+00$ \\
\hline $90 \mathrm{Sr}$ & $8.76 E+03$ & $9.46 E+00$ & $6.83 E+04$ & $8.42 E+01$ & $1.72 E+02$ & $3.08 E+04$ & $5.20 \mathrm{E}-07$ & $2.23 E+02$ & $6.37 E+04$ \\
\hline $90 \mathrm{Y}$ & $8.76 E+03$ & $9.46 E+00$ & $6.83 E+04$ & $8.42 E+01$ & $1.72 \mathrm{E}+02$ & $3.08 E+04$ & $5.20 E-07$ & $2.23 E+02$ & $6.37 E+04$ \\
\hline $99 T \mathrm{c}$ & $1.53 E+03$ & $2.40 \mathrm{E}-01$ & 4.08E+01 & $1.46 E+01$ & $7.56 \mathrm{E}+00$ & $2.57 \mathrm{E}+03$ & $0.00 E+00$ & $1.93 E+01$ & $1.88 E+03$ \\
\hline $137 \mathrm{Cs}$ & $4.51 E+06$ & $3.28 \mathrm{E}+02$ & $1.70 E+05$ & $7.05 E+04$ & $2.90 \mathrm{E}+04$ & $9.75 E+05$ & 1.12E-05 & $2.99 E+04$ & $8.25 E+05$ \\
\hline $137 \mathrm{Ba}$ & $4.28 E+06$ & $3.12 E+02$ & $1.62 \mathrm{E}+05$ & $6.69 E+04$ & $2.76 E+04$ & $9.26 \mathrm{E}+05$ & $1.06 \mathrm{E}-05$ & $2.84 E+04$ & $7.83 E+05$ \\
\hline $154 \mathrm{Eu}$ & $1.21 E+04$ & $0.00 E+00$ & $3.00 E+02$ & $3.03 E+01$ & $0.00 E+00$ & $0.00 \mathrm{E}+00$ & $0.00 E+00$ & $0.00 \mathrm{E}+00$ & $0.00 \mathrm{E}+00$ \\
\hline $235 \mathrm{U}$ & $0.00 E+00$ & $0.00 \mathrm{E}+00$ & $0.00 \mathrm{E}+00$ & $0.00 \mathrm{E}+00$ & $0.00 E+00$ & $0.00 \mathrm{E}+00$ & $0.00 E+00$ & $0.00 E+00$ & $0.00 E+00$ \\
\hline 2380 & $1.33 E+00$ & $0.00 \mathrm{E}+00$ & $0.00 E+00$ & $4.33 \mathrm{E}-02$ & $7.77 \mathrm{E}-05$ & $0.00 \mathrm{E}+00$ & $0.00 \mathrm{E}+00$ & $1.65 \mathrm{E}-0.04$ & $0.00 \mathrm{E}+00$ \\
\hline $237 \mathrm{~Np}$ & $3.26 \mathrm{E}-01$ & $0.00 \mathrm{E}+00$ & $3.09 \mathrm{E}-01$ & 5. $14 \mathrm{E}-01$ & $0.00 \mathrm{E}+00$ & $0.00 E+00$ & $3.11 \mathrm{E}-10$ & $0.00 E+00$ & $0.00 \mathrm{E}+00$ \\
\hline $238 \mathrm{Pu}$ & $0.00 E+00$ & $0.00 \mathrm{E}+00$ & $0.00 \mathrm{E}+00$ & $0.00 \mathrm{E}+00$ & $0.00 E+00$ & $0.00 E+00$ & $0.00 \mathrm{E}+00$ & $0.00 E+00$ & $0.00 \mathrm{E}+00$ \\
\hline $239 \mathrm{Pu}$ & $5.54 E+01$ & $1.37 E-01$ & $4.45 E-02$ & $1.74 E+00$ & $7.95 \mathrm{E}-03$ & $8.81 E+00$ & $8.33 E-08$ & $5.80 \mathrm{E}-03$ & $1.14 \mathrm{E}+01$ \\
\hline $240 \mathrm{Pu}$ & $1.39 E+01$ & $1.80 \mathrm{E}-05$ & $1.11 \mathrm{E}-02$ & $4.35 \mathrm{E}-01$ & $1.99 E-03$ & $2.39 \mathrm{E}+00$ & $1.14 \mathrm{E}-10$ & $1.45 \mathrm{E}-03$ & $3.11 \mathrm{E}+00$ \\
\hline $241 \mathrm{Pu}$ & $2.96 \mathrm{E}+01$ & $6.11 \mathrm{E}-05$ & $3.81 \mathrm{E}-02$ & $1.49 \mathrm{E}+00$ & $5.68 \mathrm{E}-03$ & $5.85 \mathrm{E}+00$ & $3.74 \mathrm{E}-10$ & $3.14 \mathrm{E}-03$ & $9.25 \mathrm{E}+00$ \\
\hline $241 \mathrm{Am}$ & $8.44 E+01$ & $2.72 \mathrm{E}-03$ & $2.79 \mathrm{E}+02$ & $1.04 \mathrm{E}-01$ & $4.97 \mathrm{E}-02$ & $8.03 E+01$ & $1.70 \mathrm{E}-06$ & $2.07 E-01$ & $8.21 \mathrm{E}+01$ \\
\hline Vol ume, (L) & $4.18 E+06$ & $2.90 \mathrm{E}+06$ & $6.25 E+05$ & $1.16 \mathrm{E}+06$ & $6.81 E+04$ & $7.37 E+06$ & $9.98 \mathrm{E}+04$ & $6.43 E+05$ & $4.42 \mathrm{E}+06$ \\
\hline Volume, (kgal) & 1. $11 \mathrm{E}+03$ & $7.66 \mathrm{E}+02$ & $1.65 E+02$ & $3.06 \mathrm{E}+02$ & $1.80 E+01$ & $1.95 \mathrm{E}+03$ & $2.64 \mathrm{E}+09$ & $1.70 \mathrm{E}+02$ & 1.17E+03 \\
\hline Na Molarity & $4.53 E+00$ & $1.26 \mathrm{E}-01$ & $9.96 \mathrm{E}-01$ & 2.87E-01 & $1.17 E+01$ & $7.00 \mathrm{E}+00$ & $8.72 \mathrm{E}-01$ & $1.12 E+01$ & $7.00 E+00$ \\
\hline H2O Estimate & $3.06 E+06$ & $2.86 \mathrm{E}+06$ & $5.86 E+05$ & $1.14 E+06$ & $2.97 E+04$ & $5.00 E+06$ & $9.39 \mathrm{E}+04$ & $3.52 E+05$ & $3.00 E+06$ \\
\hline
\end{tabular}


WHC-SD-WM-TI-774 ReV, 0

TWRS PRIVATIZATION PROCESS TECHNICAL BASELINE

APPENDIX B MASS BALANCES FOR ENVELOPE A, B, AND C PROCESSING

Private Contractor 1 Batches 1 to 12

Private Contractor 2 Batches 1 to 12 


\section{Figure B-1 Phase 1 Private Contrator LAW Processing}

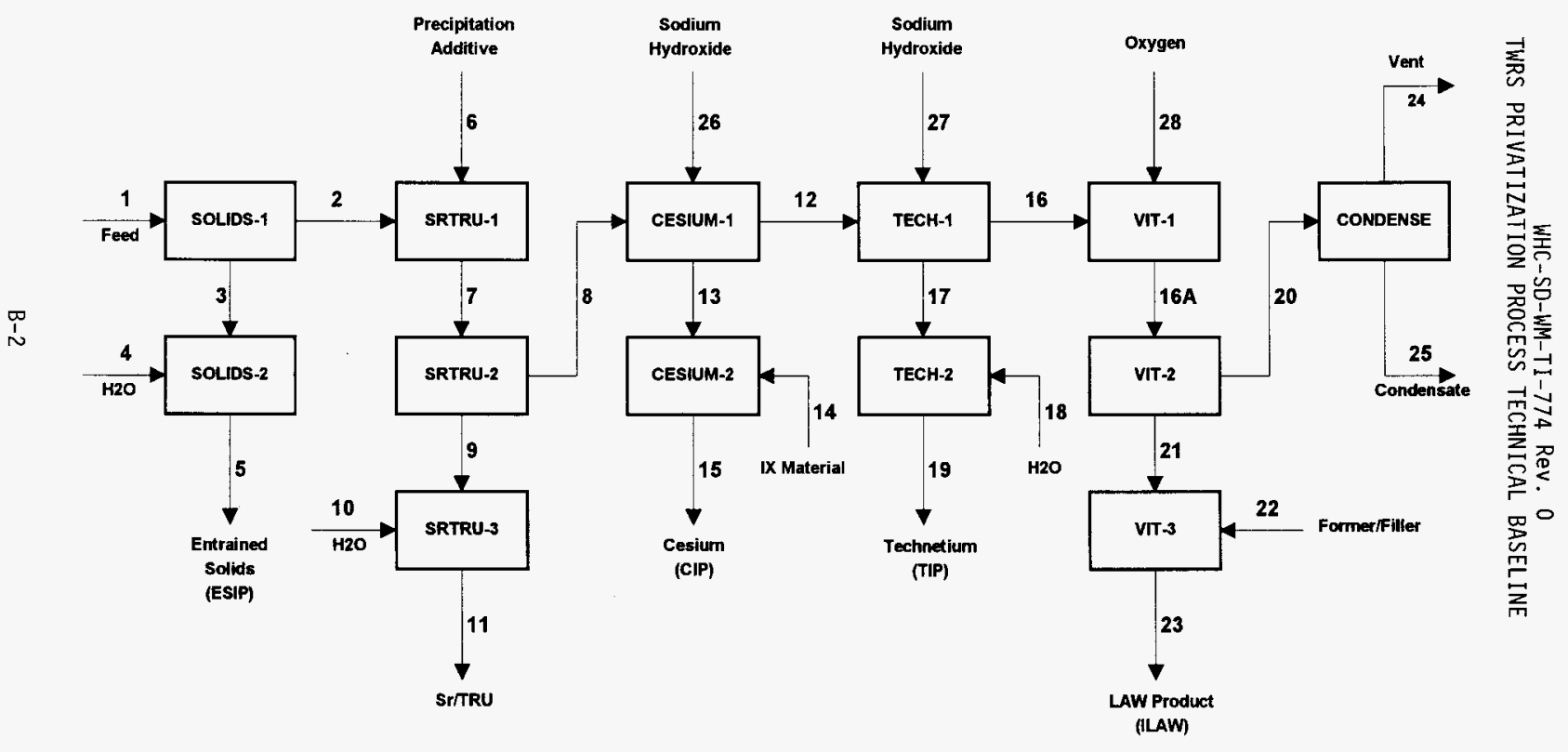


WHC-SD-WM-TI-774 ReV. 0

TWRS PRIVATIZATION PROCESS TECHNICAL BASELINE

Table B-1 Phase 1 LAW Mass Balance for Batch PCl/1 (6 sheets)

\begin{tabular}{|c|c|c|c|c|c|c|c|c|c|c|}
\hline $\begin{array}{l}\text { STREAM NAME } \\
\text { LTQHD COMEANENIS }\end{array}$ & 1 & 2 & 3 & 4 & 5 & 6 & 7 & 8 & 9 & 10 \\
\hline $\begin{array}{l}\text { Volume }(L) \\
\text { Density }(g / L)\end{array}$ & $\begin{array}{l}3.34 \mathrm{E}+06 \\
1.44 \mathrm{E}+03\end{array}$ & $\begin{array}{l}3.33 E+06 \\
1.44 E+03\end{array}$ & $\begin{array}{l}1.6 \mathrm{EE}+04 \\
1.44 \mathrm{E}+03\end{array}$ & $\begin{array}{l}\text { 4. } 05 \mathrm{E}+05 \\
1.00 \mathrm{E}+03\end{array}$ & $\begin{array}{l}4.22 E+05 \\
1.02 E+03\end{array}$ & & $\begin{array}{l}3.33 E+06 \\
1.44 E+03\end{array}$ & $\begin{array}{l}3.33 \mathrm{E}+06 \\
1.44 \mathrm{E}+03\end{array}$ & & \\
\hline Total Mass Flow (kg) & 4. $822+06$ & $4.79 \mathrm{E}+06$ & $2.38 E+04$ & $4.05 \mathrm{E}+05$ & $4.29 \mathrm{E}+05$ & & $4.79 E+06$ & $4.79 \mathrm{E}+06$ & & \\
\hline \multicolumn{11}{|l|}{ RADIONUCTIDS (Ci) } \\
\hline $\begin{array}{l}\text { Cesium } \\
\text { Strantium } \\
\text { Technet.ium } \\
\text { IRU }\end{array}$ & $\begin{array}{l}1.03 \mathrm{E}+06 \\
6.62 \mathrm{E}+03 \\
2.71 \mathrm{E}+02 \\
2.39 \mathrm{E}+01\end{array}$ & $\begin{array}{l}1.03 E+06 \\
6.59 E+03 \\
2.70 E+02 \\
2.38 E+01\end{array}$ & $\begin{array}{l}5.10 E+03 \\
3.27 E+01 \\
1.34 E+00 \\
1.18 E-01\end{array}$ & & $\begin{array}{l}5.10 E+03 \\
3.27 \mathrm{E}+01 \\
1.34 \mathrm{E}+00 \\
1.18 \mathrm{E}-01\end{array}$ & & $\begin{array}{l}\text { 1. } 03 \mathrm{E}+06 \\
6.59 \mathrm{E}+03 \\
2.70 \mathrm{E}+02 \\
2.38 \mathrm{E}+01\end{array}$ & $\begin{array}{l}1.03 E+06 \\
6.59 E+03 \\
2.70 E+02 \\
2.38 E+01\end{array}$ & & \\
\hline \multicolumn{11}{|l|}{ CREMCAIS $(\mathrm{kg})$} \\
\hline 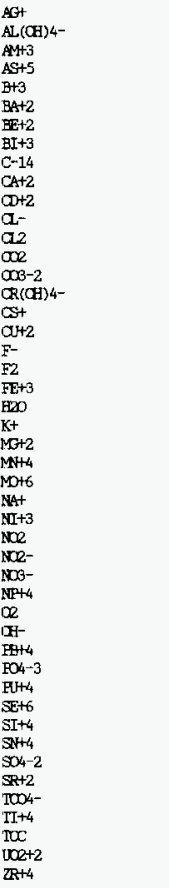 & $\begin{array}{l}8.73 \mathrm{E}-08 \\
3.43 \mathrm{E}+05 \\
8.99 \mathrm{E}-04 \\
8.40 \mathrm{E}-03 \\
1.52 \mathrm{E}-01 \\
2.89 \mathrm{E}-02 \\
1.45 \mathrm{E}-02 \\
2.61 \mathrm{E}-06 \\
1.06 \mathrm{E}-05 \\
7.30 \mathrm{E}-01 \\
1.39 \mathrm{E}-01 \\
1.81 \mathrm{E}+04 \\
\\
4.83 \mathrm{E}+04 \\
3.27 \mathrm{E}+03 \\
1.19 \mathrm{E}+01 \\
1.74 \mathrm{E}-07 \\
7.58 \mathrm{E}+02 \\
2.31 \mathrm{E}+01 \\
3.00 \mathrm{E}+06 \\
1.27 \mathrm{E}+04 \\
8.44 \mathrm{E}-01 \\
4.49 \mathrm{E}-01 \\
3.72 \mathrm{E}-01 \\
5.79 \mathrm{E}+05 \\
2.52 \mathrm{E}+00 \\
2.51 \mathrm{E}+05 \\
4.08 \mathrm{E}+05 \\
2.17 \mathrm{E}-04 \\
1.29 \mathrm{E}+05 \\
3.12 \mathrm{E}-01 \\
5.21 \mathrm{E}+03 \\
2.87 \mathrm{E}-01 \\
3.4 \pi \mathrm{E}-05 \\
1.81 \mathrm{E}+00 \\
4.35 \mathrm{E}-06 \\
1.40 \mathrm{E}+04 \\
4.76 \mathrm{E}-02 \\
2.63 \mathrm{E}+01 \\
8.73 \mathrm{E}-08 \\
8.44 \mathrm{E}+03 \\
1.12 \mathrm{E}+00 \\
4.3 \mathrm{EE}-06\end{array}$ & 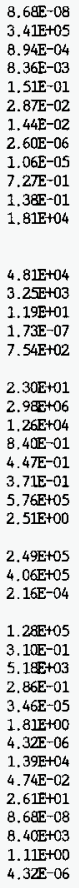 & $\begin{array}{l}4.31 E-10 \\
1.69 E+03 \\
4.44 E-06 \\
4.15 E-05 \\
7.51 E-04 \\
1.43 E-04 \\
7.17 E-05 \\
1.29 E-08 \\
5.25 E-08 \\
3.61 E-03 \\
6.87 E-04 \\
8.96 E+01 \\
\\
2.39 E+02 \\
1.61 E+01 \\
5.89 E-02 \\
8.58 E-10 \\
3.74 E+00 \\
1.14 E-01 \\
1.48 E+04 \\
6.27 E+01 \\
4.17 E-03 \\
2.22 E-03 \\
1.84 E-03 \\
2.86 E+03 \\
1.25 E-02 \\
1.24 E+03 \\
2.01 E+03 \\
1.07 E-06 \\
6.36 E+02 \\
1.54 E-03 \\
2.57 E+01 \\
1.42 E-03 \\
1.72 E-07 \\
8.96 E-03 \\
2.15 E-08 \\
6.91 E+01 \\
2.35 E-04 \\
1.30 E-01 \\
4.31 E-10 \\
4.17 E+01 \\
5.51 E-03 \\
2.15 E-08\end{array}$ & $4.058+05$ & $\begin{array}{l}4.31 E-10 \\
1.69 E+03 \\
4.44 E-06 \\
4.15 E-05 \\
7.51 E-04 \\
1.43 E-04 \\
7.17 E-05 \\
1.29 E-08 \\
5.25 E-08 \\
3.61 E-03 \\
6.87 E-04 \\
8.96 E+01 \\
\\
2.39 E+02 \\
1.61 E+01 \\
5.89 E-02 \\
8.58 E-10 \\
3.74 E+00 \\
1.14 E-01 \\
4.20 E+05 \\
6.27 E+01 \\
4.17 E-03 \\
2.22 E-03 \\
1.84 E-03 \\
2.86 E+03 \\
1.25 E-02 \\
1.24 E+03 \\
2.01 E+03 \\
1.07 E-06 \\
6.36 E+02 \\
1.54 E-03 \\
2.57 E+01 \\
1.42 E-03 \\
1.72 E-07 \\
8.96 E-03 \\
2.15 E-08 \\
6.91 E+01 \\
2.35 E-04 \\
1.30 E-01 \\
4.31 E-10 \\
4.17 E+01 \\
5.51 E-03 \\
2.15 E-08\end{array}$ & & $\begin{array}{l}8.68 E-08 \\
3.41 E+05 \\
8.94 E-04 \\
8.36 E-03 \\
1.51 E-01 \\
2.87 E-02 \\
1.44 E-02 \\
2.60 E-06 \\
1.06 E-05 \\
7.27 E-01 \\
1.38 E-01 \\
1.81 E+04 \\
\\
4.81 E+04 \\
3.25 E+03 \\
1.19 E+01 \\
1.73 E-07 \\
7.54 E+02 \\
2.30 E+01 \\
2.98 E+06 \\
1.26 E+04 \\
8.40 E-01 \\
4.47 E-01 \\
3.71 E-01 \\
5.76 E+05 \\
2.51 E+00 \\
2.49 E+05 \\
4.06 E+05 \\
2.16 E-04 \\
1.28 E+05 \\
3.10 E-01 \\
5.18 E+03 \\
2.86 E-01 \\
3.46 E-05 \\
1.81 E+00 \\
4.32 E-06 \\
1.39 E+04 \\
4.74 E-02 \\
2.61 E+01 \\
8.68 E-08 \\
8.40 E+03 \\
1.11 E+00 \\
4.32 E-06\end{array}$ & $\begin{array}{l}8.68 \mathrm{E}-08 \\
3.41 \mathrm{E}+05 \\
8.94 \mathrm{E}-04 \\
8.36 \mathrm{E}-03 \\
1.51 \mathrm{E}-01 \\
2.87 \mathrm{E}-02 \\
1.44 \mathrm{E}-02 \\
2.60 \mathrm{E}-06 \\
1.06 \mathrm{E}-05 \\
7.27 \mathrm{E}-01 \\
1.3 \mathrm{EE}-01 \\
1.81 \mathrm{E}+04 \\
\\
4.81 \mathrm{E}+04 \\
3.25 \mathrm{E}+03 \\
1.19 \mathrm{E}+01 \\
1.73 \mathrm{E}-07 \\
7.54 \mathrm{E}+02 \\
2.30 \mathrm{E}+01 \\
2.98 \mathrm{E}+06 \\
1.26 \mathrm{E}+04 \\
8.40 \mathrm{E}-01 \\
4.47 \mathrm{E}-01 \\
3.71 \mathrm{E}-01 \\
5.76 \mathrm{E}+05 \\
2.51 \mathrm{E}+00 \\
2.49 \mathrm{E}+05 \\
4.06 \mathrm{E}+05 \\
2.16 \mathrm{E}-04 \\
1.28 \mathrm{E}+05 \\
3.10 \mathrm{E}-01 \\
5.18 \mathrm{E}+03 \\
2.86 \mathrm{E}-01 \\
3.46 \mathrm{E}-05 \\
1.81 \mathrm{E}+00 \\
4.32 \mathrm{E}-06 \\
1.39 \mathrm{E}+04 \\
4.74 \mathrm{E}-02 \\
2.61 \mathrm{E}+01 \\
8.68 \mathrm{E}-08 \\
8.40 \mathrm{E}+03 \\
1.11 \mathrm{E}+00 \\
4.32 \mathrm{E}-06\end{array}$ & & \\
\hline
\end{tabular}


WHC-SD-WM-TI-774 ReV, 0

TWRS PRIVATIZATION PROCESS TECHNICAL BASELINE

Table B-1 Phase 1 LAW Mass Balance for Batch PGI/1 ( 6 sheets)

\begin{tabular}{|c|c|c|c|c|c|c|c|c|c|c|}
\hline $\begin{array}{l}\text { SIREAM NAME } \\
\text { SOUD COFCNOMIS }\end{array}$ & 1 & 2 & 3 & 4 & 5 & 6 & 7 & 8 & 9 & 10 \\
\hline Total Mass Flow (kg) & $4.81 E+04$ & $4.81 E+02$ & $4.76 \mathrm{E}+04$ & & $4.76 \mathrm{E}+04$ & & 4. $81 \mathrm{E}+02$ & 4. $81 E+02$ & & \\
\hline \multicolumn{11}{|l|}{ FADIONCJITES (Ci) } \\
\hline $\begin{array}{l}\text { Cesiun } \\
\text { Strantilum } \\
\text { Techretilum } \\
\text { TRU }\end{array}$ & & & & & & & & & & \\
\hline \multicolumn{11}{|l|}{ GHMICALS (kg) } \\
\hline 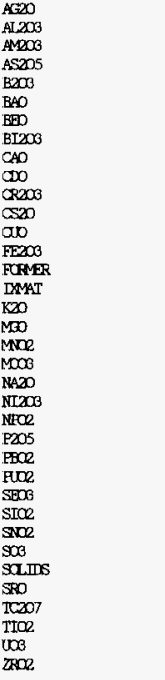 & $4.81 E+04$ & 4.81E+02 & $4.76 E+04$ & & $4.76 \mathrm{E}+04$ & & 4. $81 E+02$ & 4.81E+02 & & \\
\hline
\end{tabular}


WHC-SD-WM-TI-774 Rev. 0

TWRS PRIVATIZATION PROCESS TECHNICAL BASELINE

Table B-1 Phase 1 LAW Mass Balance for Batch PCl/1 (6 sheets)

\begin{tabular}{|c|c|c|c|c|c|c|c|c|c|c|}
\hline $\begin{array}{l}\text { SIRFMM NAME } \\
\text { ZFOUID COMFAWWIS }\end{array}$ & 11 & 12 & 13 & 14 & 15 & 16 & $15 \mathrm{~A}$ & 17 & 18 & 19 \\
\hline $\begin{array}{l}\text { Volum }(\mathrm{L}) \\
\text { Density }(\mathrm{g} / \mathrm{L})\end{array}$ & & $\begin{array}{l}3.33 \mathrm{E}+06 \\
1.44 \mathrm{E}+03\end{array}$ & $\begin{array}{l}3.03 E+03 \\
3.33 E+03\end{array}$ & & $\begin{array}{l}3.03 E+03 \\
3.33 E+03\end{array}$ & $\begin{array}{l}\text { 3. } 33 \mathrm{E}+06 \\
\text { 1. } 44 \mathrm{E}+03\end{array}$ & $\begin{array}{l}\text { 4. } 80 E+06 \\
\text { 1. } 00 E+03\end{array}$ & & $\begin{array}{l}1.00 \mathrm{E}-09 \\
1.00 \mathrm{E}+03\end{array}$ & $\begin{array}{l}1.00 \mathrm{E}-09 \\
1.00 \mathrm{E}+03\end{array}$ \\
\hline Total Mass Flov (kg) & & $4.79 \mathrm{E}+06$ & $1.01 E+04$ & & $1.01 E+04$ & $4.79 \mathrm{E}+06$ & 4. $80 \mathrm{E}+06$ & & $1.00 \mathrm{E}-09$ & $1.00 \mathrm{E}-09$ \\
\hline \multicolumn{11}{|l|}{ RADIONLIIIES (Ci) } \\
\hline $\begin{array}{l}\text { Cesilm } \\
\text { Strantium } \\
\text { Teclnetiun } \\
\text { TIVI }\end{array}$ & & $\begin{array}{l}4.42 \mathrm{E}+03 \\
6.59 \mathrm{E}+03 \\
2.67 \mathrm{E}+02 \\
2.38 \mathrm{E}+01\end{array}$ & $\begin{array}{l}1.02 E+06 \\
2.71 E+00\end{array}$ & & $\begin{array}{l}1.02 E+06 \\
2.71 E+00\end{array}$ & $\begin{array}{l}4.42 E+03 \\
6.59 E+03 \\
2.67 E+02 \\
2.38 E+01 .\end{array}$ & & & & \\
\hline
\end{tabular}

\begin{tabular}{|c|c|c|c|c|c|c|c|}
\hline \multicolumn{8}{|c|}{ OHFMCALS (kg) } \\
\hline 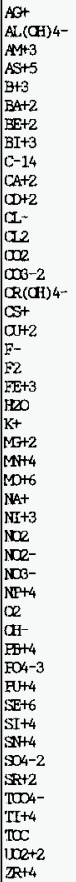 & $\begin{array}{l}8.68 \mathrm{E}-08 \\
3.41 \mathrm{E}+05 \\
8.94 \mathrm{E}-04 \\
8.36 \mathrm{E}-03 \\
1.51 \mathrm{E}-01 \\
2.87 \mathrm{E}-02 \\
1.44 \mathrm{E}-02 \\
2.60 \mathrm{E}-06 \\
1.06 \mathrm{E}-05 \\
7.27 \mathrm{E}-01 \\
1.35 \mathrm{E}-01 \\
1.81 \mathrm{E}+04 \\
\\
4.81 \mathrm{E}+04 \\
3.25 \mathrm{E}+03 \\
5.10 \mathrm{E}-02 \\
1.73 \mathrm{E}-07 \\
7.54 \mathrm{E}+02 \\
\\
2.30 \mathrm{E}+01 \\
2.98 \mathrm{E}+06 \\
1.26 \mathrm{E}+04 \\
8.40 \mathrm{E}-01 \\
4.4 \mathrm{E}-01 \\
3.71 \mathrm{E}-01 \\
5.76 \mathrm{E}+05 \\
2.51 \mathrm{E}+00 \\
\\
2.49 \mathrm{E}+05 \\
4.06 \mathrm{E}+05 \\
2.16 \mathrm{E}-04 \\
\\
1.28 \mathrm{E}+05 \\
3.10 \mathrm{E}-01 \\
5.18 \mathrm{E}+03 \\
2.86 \mathrm{E}-01 \\
3.46 \mathrm{E}-05 \\
1.81 \mathrm{E}+00 \\
4.32 \mathrm{E}-06 \\
1.39 \mathrm{E}+04 \\
4.74 \mathrm{E}-02 \\
2.59 \mathrm{E}+01 \\
8.68 \mathrm{E}-08 \\
8.40 \mathrm{E}+03 \\
1.11 \mathrm{E}+00 \\
4.32 \mathrm{E}-06\end{array}$ & $\begin{array}{l}1.18 \mathrm{E}+01 \\
5.79 \mathrm{E}+03 \\
4.28 \mathrm{BE}+63\end{array}$ & $\begin{array}{l}1.18 E+01 \\
5.79 E+03 \\
4.28 E+013 \\
2.63 E-01\end{array}$ & $\begin{array}{l}8.68 \mathrm{E}-08 \\
3.41 \mathrm{E}+05 \\
8.94 \mathrm{E}-04 \\
8.36 \mathrm{E}-03 \\
1.51 \mathrm{E}-01 \\
2.87 \mathrm{E}-02 \\
1.44 \mathrm{E}-02 \\
2.60 \mathrm{E}-06 \\
1.06 \mathrm{E}-05 \\
7.27 \mathrm{E}-01 \\
1.38 \mathrm{E}-01 \\
1.81 \mathrm{E}+04 \\
\\
4.81 \mathrm{E}+04 \\
3.25 \mathrm{E}+03 \\
5.10 \mathrm{E}-02 \\
1.73 \mathrm{E}-07 \\
7.54 \mathrm{E}+02 \\
\\
2.30 \mathrm{E}+01 \\
2.98 \mathrm{E}+06 \\
1.26 \mathrm{E}+04 \\
8.40 \mathrm{E}-01 \\
4.4 \mathrm{E}-01 \\
3.71 \mathrm{E}-01 \\
5.76 \mathrm{E}+05 \\
2.51 \mathrm{E}+00 \\
\\
2.49 \mathrm{E}+05 \\
4.06 \mathrm{E}+05 \\
2.16 \mathrm{E}-04 \\
\\
1.28 \mathrm{E}+05 \\
3.10 \mathrm{E}-01 \\
5.18 \mathrm{E}+03 \\
2.86 \mathrm{E}-01 \\
3.46 \mathrm{E}-05 \\
1.81 \mathrm{E}+00 \\
4.32 \mathrm{E}-06 \\
1.39 \mathrm{E}+04 \\
4.74 \mathrm{E}-02 \\
2.59 \mathrm{E}+01 \\
8.68 \mathrm{E}-08 \\
8.40 \mathrm{E}+03 \\
1.11 \mathrm{E}+00 \\
4.32 \mathrm{E}-06\end{array}$ & $\begin{array}{l}1.81 \mathrm{E}+0.4 \\
6.60 \mathrm{E}+04 \\
7.54 \mathrm{E}+02 \\
3.18 \mathrm{E}+06\end{array}$ & $1.00 \mathrm{E}-09$ & $1.00 \mathrm{E}-09$ \\
\hline
\end{tabular}


WHC-SD-WM-TI-774 Rev. 0

TWRS PRIVATIZATION PROCESS TECHNICAL BASELINE

Table B-1 Thase 1 LAW Mass Balance for Batch PCl/1 (6 sheets)

\begin{tabular}{|c|c|c|c|c|c|c|c|c|c|c|}
\hline $\begin{array}{l}\text { SIRFAM NAEE } \\
\text { SOLID CONEANDNES }\end{array}$ & 11 & 12 & 13 & 14 & 15 & 16 & $16 \mathrm{~A}$ & 17 & 18 & 19 \\
\hline Total Mass Flow (kg) & & $4.81 E+02$ & & $5.79 E+03$ & $5.79 \mathrm{E}+03$ & $4.81 E+02$ & $9.93 \mathrm{E}+05$ & & & \\
\hline \multicolumn{11}{|l|}{ RADTONURI.IES (Ci) } \\
\hline $\begin{array}{l}\text { Cesium } \\
\text { Strantium } \\
\text { Tecknetium } \\
\text { TRI }\end{array}$ & & & & & & & $\begin{array}{l}4.42 E+03 \\
6.59 E+03 \\
2.67 E+02 \\
2.36 E+01\end{array}$ & & & \\
\hline
\end{tabular}

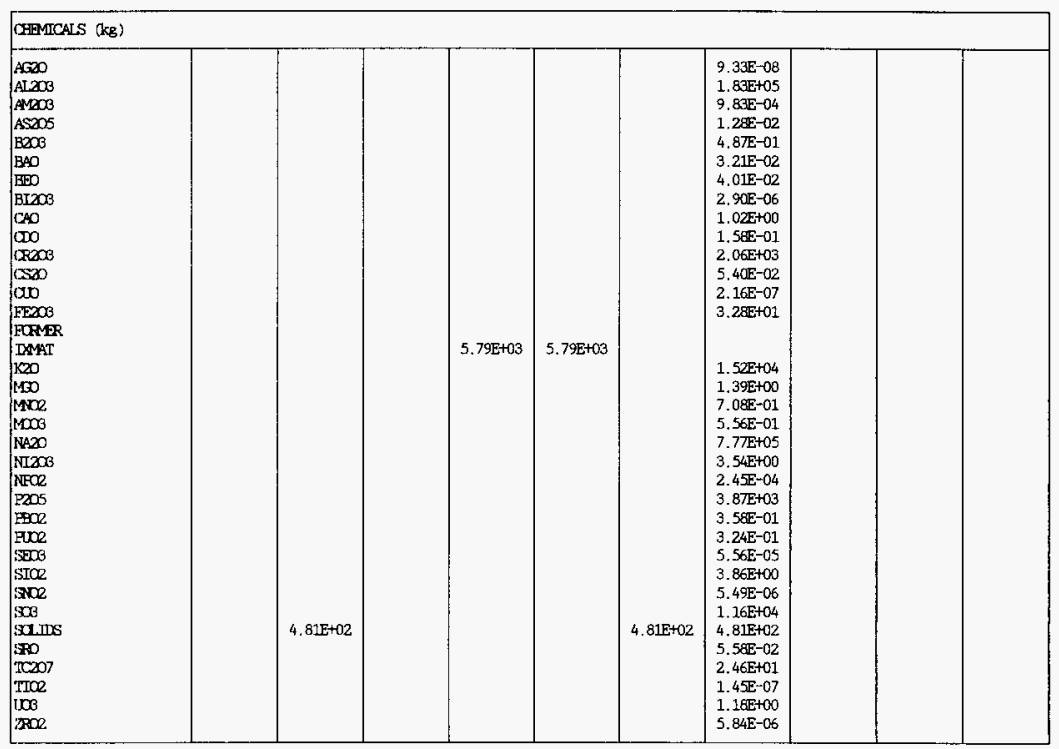


WHC-SD-WM-TI-774 Rev. 0

TWRS PRIVATIZATION PROCESS TECHNICAL BASELINE

Table B-1 Phase 1 IAW Mass Balance for Batch PC1/1 (6 sheets)

\begin{tabular}{|c|c|c|c|c|c|c|c|c|c|}
\hline $\begin{array}{l}\text { SIREAM NAME } \\
\text { LITID OAMFANENS }\end{array}$ & 20 & 21 & 22 & 23 & 24 & 25 & 26 & 27 & 28 \\
\hline $\begin{array}{l}\text { Volume (L) } \\
\text { Density }(\mathrm{B} / \mathrm{L})\end{array}$ & $\begin{array}{l}\text { 4. } 80 \mathrm{E}+06 \\
\text { 1. } 00 \mathrm{E}+03\end{array}$ & & & & $\begin{array}{l}1.62 \mathrm{E}+06 \\
1.00 \mathrm{E}+03\end{array}$ & $\begin{array}{l}3.18 \mathrm{E}+06 \\
1.00 \mathrm{E}+03\end{array}$ & $\begin{array}{l}3.02 \mathrm{E}+03 \\
3.34 \mathrm{E}+03\end{array}$ & $\begin{array}{l}3.00 \mathrm{E}-10 \\
3.34 \mathrm{E}+03\end{array}$ & $\begin{array}{l}\text { 1.00E+06 } \\
1.00 \mathrm{E}+03\end{array}$ \\
\hline Total Mass Flow (kg) & $4.80 \mathrm{E}+06$ & & & & $1.62 \mathrm{E}+06$ & $3.18 E+06$ & $1.01 \mathrm{E}+04$ & $1.00 E-09$ & $1.00 E+06$ \\
\hline \multicolumn{10}{|l|}{ RADIONUCIIIES (Ci) } \\
\hline $\begin{array}{l}\text { Cesium } \\
\text { Strmatium } \\
\text { Technetium } \\
\text { TRI }\end{array}$ & & & & & & & & & \\
\hline
\end{tabular}

\begin{tabular}{|c|c|c|c|c|c|c|}
\hline \multicolumn{7}{|c|}{ (AREMCALS (kg) } \\
\hline 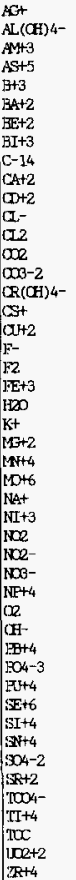 & $\begin{array}{l}1.81 E+04 \\
6.60 E+04 \\
7.54 E+102 \\
3.18 E+06 \\
\\
5.50 E+05 \\
9.85 E+05\end{array}$ & $\begin{array}{l}1.81 \mathrm{E}+04 \\
6.60 \mathrm{E}+04 \\
7.54 \mathrm{E}+02 \\
5.50 \mathrm{E}+05 \\
9.85 \mathrm{E}+05\end{array}$ & $3.18 E+06$ & $\begin{array}{l}5.79 \mathrm{E}+03 \\
4.28 \mathrm{E}+103\end{array}$ & $\begin{array}{l}5.75 \mathrm{E}-10 \\
4.2 \mathrm{EE}-10\end{array}$ & $1.00 E+06$ \\
\hline
\end{tabular}


WHC-SD-WM-TI-774 Rev. 0

TWRS PRIVATIZATION PROCESS TECHNICAL BASELINE

Table B-1 Phase 1 LAW Mass Balance for Batch PC1/1 (6 sheets)

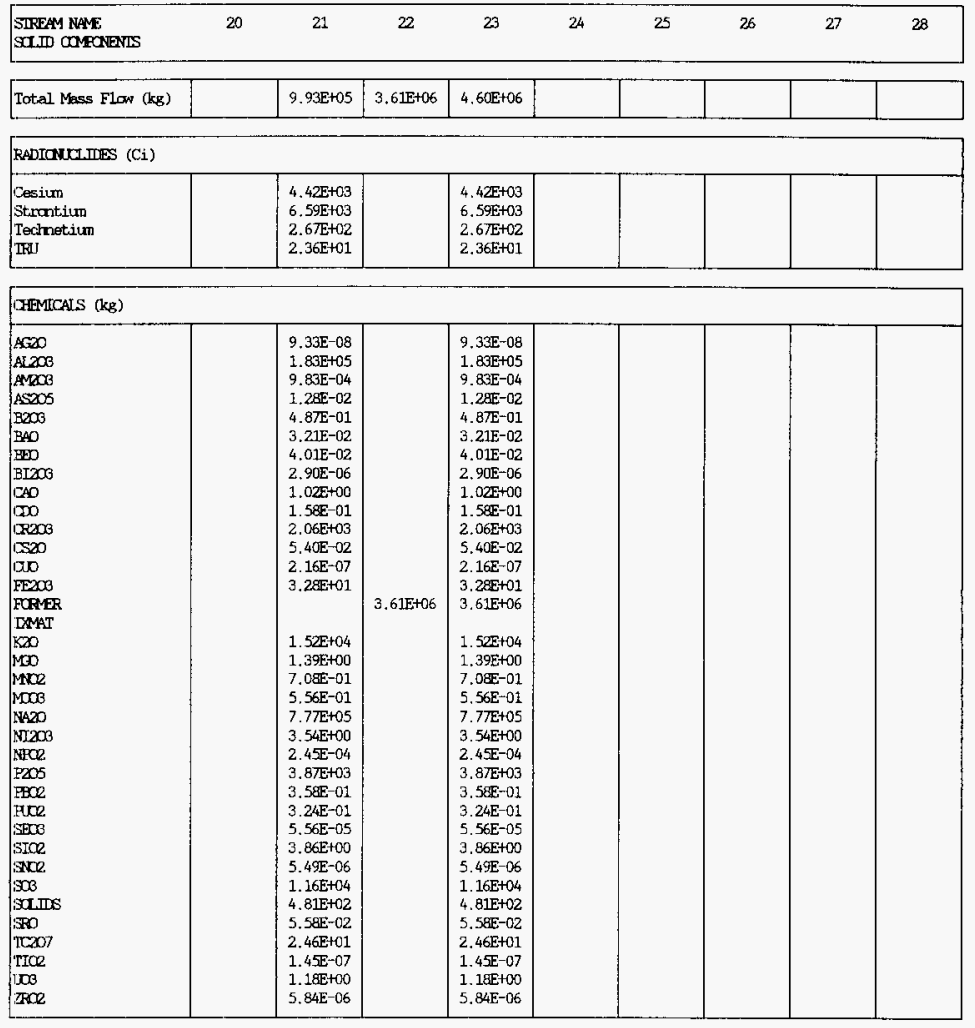


WHC-SD-WM-TI-774 Rev. 0

TWRS PRIVATIZATION PROCESS TECHNICAL BASELINE

Table B-2 Phase 1 IAW Mass Balance for Batch PCl/2 ( 6 sheets)

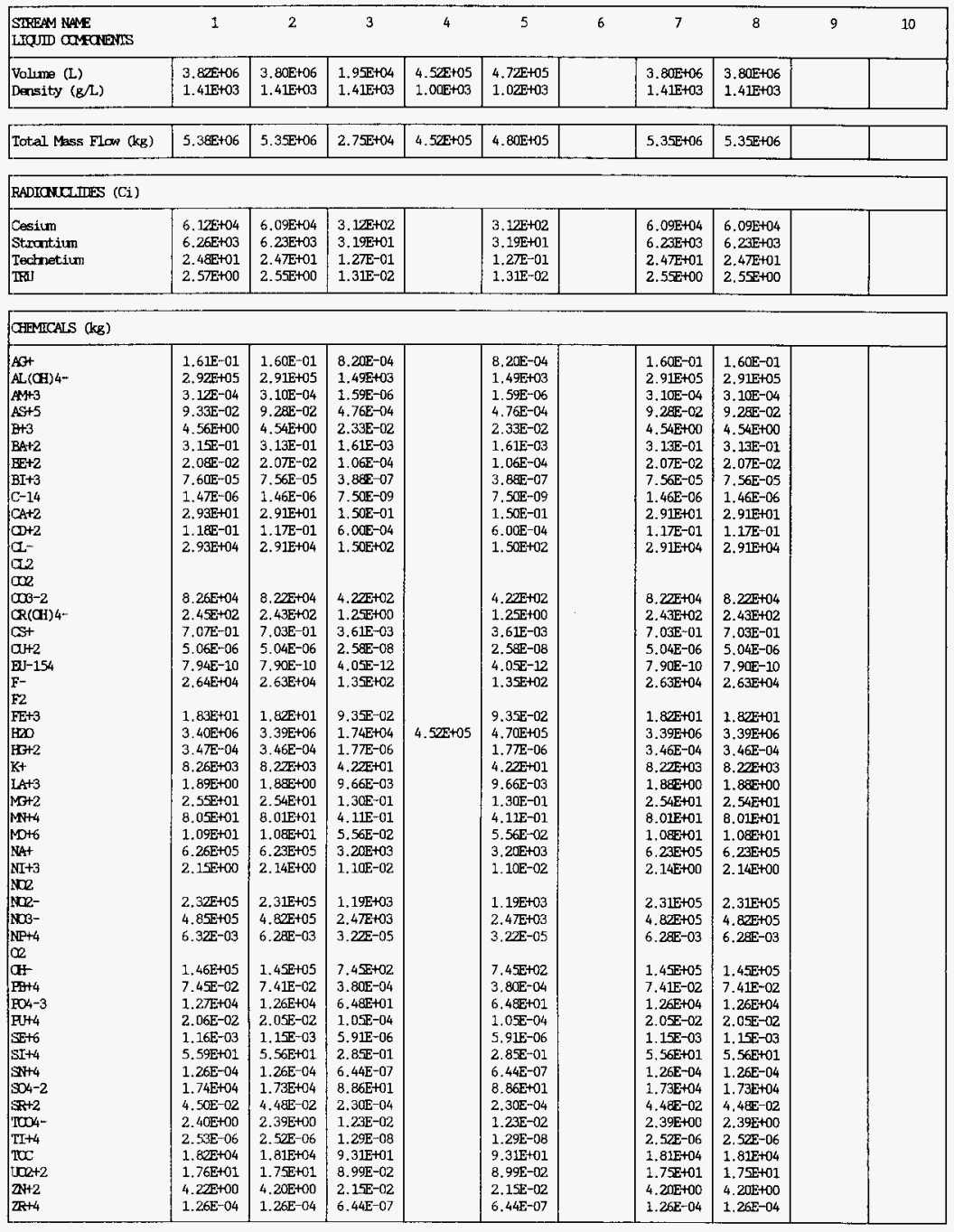


WHC-SD-WM-TI-774 Rev. 0

TWRS PRIVATIZATION PROCESS TECHNICAL BASELINE

Table B-2 Phase 1 LAW Mass Balance for Batch PCl/2 (6 sheets)

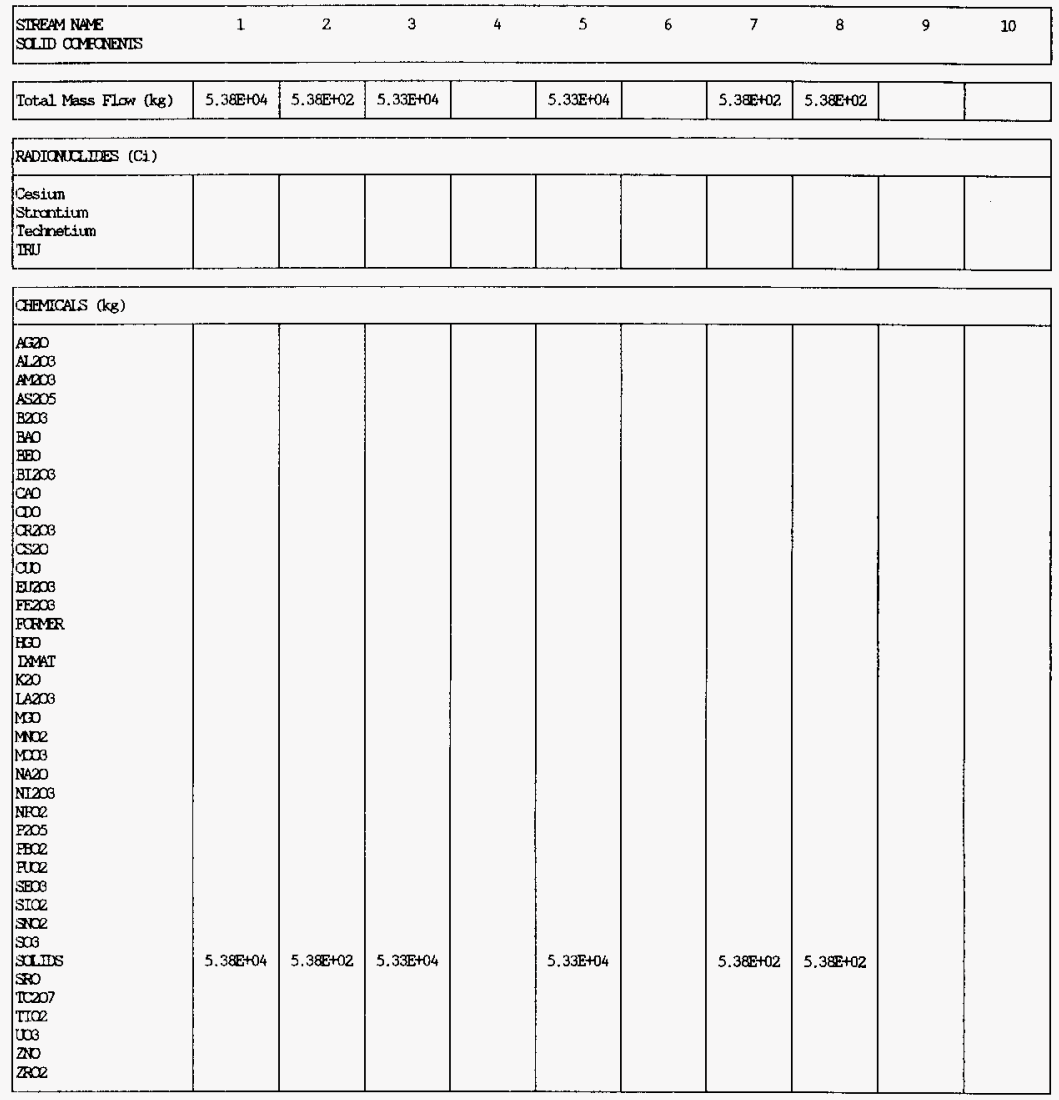


WHC-SD-WM-TI-774 ReV. 0

TWRS PRIVATIZATION PROCESS TECHNICAL BASEL INE

Table B-2 Phase 1 LAW Mass Balance for Batch PC1/2 (6 sheets)

\begin{tabular}{|c|c|c|c|c|c|c|c|c|c|c|}
\hline $\begin{array}{l}\text { SIREAM NAYE } \\
\text { LIQUID CQMADENIS }\end{array}$ & 11 & 12 & 13 & 14 & 15 & 16 & $16 \mathrm{~A}$ & 17 & 18 & 19 \\
\hline $\begin{array}{l}\text { Volims (L) } \\
\text { Density }(g / L)\end{array}$ & & $\begin{array}{l}3.80 \mathrm{E}+06 \\
1.41 E+03\end{array}$ & $\begin{array}{l}3.27 \mathrm{E}+03 \\
3.34 \mathrm{E}+03\end{array}$ & & $\begin{array}{l}3.27 \mathrm{E}+03 \\
3.34 \mathrm{E}+03\end{array}$ & $\begin{array}{l}3.80 E+06 \\
1.41 E+03\end{array}$ & $\begin{array}{l}5.32 \mathrm{E}+06 \\
1.00 \mathrm{E}+03\end{array}$ & & $\begin{array}{l}1.00 \mathrm{E}-09 \\
1.00 \mathrm{E}+03\end{array}$ & $\begin{array}{l}1.00 \mathrm{E}-09 \\
1.00 \mathrm{EE}+03\end{array}$ \\
\hline Total Mass Flow (kg) & & $5.35 \mathrm{E}+06$ & $1.09 \mathrm{E}+04$ & & $1.09 \mathrm{E}+04$ & 5.35E+06 & 5. $32 E+06$ & & $1.00 \mathrm{E}-09$ & $1.00 \mathrm{E}-09$ \\
\hline \multicolumn{11}{|l|}{ RADIONCIIIES (Ci) } \\
\hline $\begin{array}{l}\text { Cesium } \\
\text { Strantium } \\
\text { Technetium } \\
\text { IRU }\end{array}$ & & $\begin{array}{l}4.78 \mathrm{E}+03 \\
6.23 \mathrm{E}+03 \\
2.44 \mathrm{E}+01 \\
2.55 \mathrm{E}+00\end{array}$ & $\begin{array}{l}5.61 E+04 \\
2.48 E-01\end{array}$ & & $\begin{array}{l}5.61 \mathrm{E}+04 \\
2.48 \mathrm{E}-01\end{array}$ & $\begin{array}{l}4.78 E+03 \\
6.23 E+03 \\
2.44 E+01 \\
2.55 E+00\end{array}$ & & & & \\
\hline
\end{tabular}

\begin{tabular}{|c|c|c|c|c|c|c|c|}
\hline \multicolumn{8}{|c|}{ OHPMICALS (kg) } \\
\hline 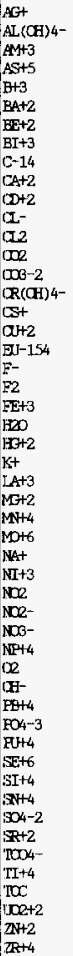 & $\begin{array}{l}1.60 \mathrm{E}-01 \\
2.91 \mathrm{E}+05 \\
3.10 \mathrm{E}-04 \\
9.2 \mathrm{EE}-02 \\
4.54 \mathrm{E}+00 \\
3.13 \mathrm{E}-01 \\
2.07 \mathrm{E}-02 \\
7.56 \mathrm{E}-05 \\
1.46 \mathrm{E}-06 \\
2.91 \mathrm{E}+01 \\
1.17 \mathrm{E}-01 \\
2.91 \mathrm{E}+04 \\
\\
8.22 \mathrm{E}+04 \\
2.43 \mathrm{E}+02 \\
5.5 \mathrm{E}-02 \\
5.04 \mathrm{E}-06 \\
7.90 \mathrm{E}-10 \\
2.63 \mathrm{E}+04 \\
1.82 \mathrm{E}+01 \\
3.39 \mathrm{E}+06 \\
3.46 \mathrm{E}-04 \\
8.22 \mathrm{E}+03 \\
1.88 \mathrm{E}+00 \\
2.54 \mathrm{E}+01 \\
8.01 \mathrm{E}+01 \\
1.08 \mathrm{E}+01 \\
6.23 \mathrm{E}+05 \\
2.14 \mathrm{E}+00 \\
2.31 \mathrm{E}+05 \\
4.82 \mathrm{E}+05 \\
6.28 \mathrm{E}-03 \\
1.4 \mathrm{E}+05 \\
7.41 \mathrm{E}-02 \\
1.25 \mathrm{E}+04 \\
2.05 \mathrm{E}-02 \\
1.15 \mathrm{E}-03 \\
5.56 \mathrm{E}+01 \\
1.26 \mathrm{E}-04 \\
1.73 \mathrm{E}+04 \\
4.4 \mathrm{EE}-02 \\
2.3 \mathrm{E}+00 \\
2.52 \mathrm{E}-06 \\
1.81 \mathrm{E}+04 \\
1.75 \mathrm{E}+01 \\
4.20 \mathrm{E}+00 \\
1.26 \mathrm{E}-04\end{array}$ & $\begin{array}{l}6.48 \mathrm{E}-01 \\
6.26 \mathrm{E}+03 \\
4.64 \mathrm{E}+03 \\
2.40 \mathrm{E}-02\end{array}$ & $\begin{array}{l}6.48 E-01 \\
6.26 E+03 \\
4.64 E+03 \\
2.40 E-02\end{array}$ & $\begin{array}{l}1.60 \mathrm{E}-01 \\
2.91 \mathrm{E}+05 \\
3.10 \mathrm{E}-04 \\
9.28 \mathrm{E}-02 \\
4.54 \mathrm{E}+00 \\
3.13 \mathrm{E}-01 \\
2.07 \mathrm{E}-02 \\
7.56 \mathrm{E}-05 \\
1.46 \mathrm{E}-06 \\
2.91 \mathrm{E}+01 \\
1.17 \mathrm{E}-01 \\
2.91 \mathrm{E}+04 \\
\\
8.22 \mathrm{E}+04 \\
2.43 \mathrm{E}+02 \\
5.52 \mathrm{E}-02 \\
5.04 \mathrm{E}-06 \\
7.90 \mathrm{E}-10 \\
2.63 \mathrm{E}+04 \\
1.82 \mathrm{E}+01 \\
3.39 \mathrm{E}+06 \\
3.46 \mathrm{E}-04 \\
8.22 \mathrm{E}+03 \\
1.88 \mathrm{E}+00 \\
2.54 \mathrm{E}+01 \\
8.01 \mathrm{E}+01 \\
1.08 \mathrm{E}+01 \\
6.23 \mathrm{E}+05 \\
2.14 \mathrm{E}+00 \\
2.31 \mathrm{E}+05 \\
4.82 \mathrm{E}+05 \\
6.28 \mathrm{E}-03 \\
1.4 \mathrm{~F}+05 \\
1.75 \mathrm{E}+01 \\
1.26 \mathrm{E}-04 \\
1.4 \mathrm{E}-02 \\
2.0 \mathrm{E}+04 \\
1.15 \mathrm{E}-02 \\
5.56 \mathrm{E}+01 \\
1.26 \mathrm{E}-04 \\
1.73 \mathrm{E}+04 \\
4.48 \mathrm{E}-02 \\
2.37 \mathrm{E}+00 \\
2.52 \mathrm{E}-06 \\
1.81 \mathrm{f}+04\end{array}$ & $\begin{array}{l}2.91 \mathrm{E}+04 \\
1.27 \mathrm{E}+05 \\
2.63 \mathrm{E}+04 \\
3.57 \mathrm{E}+06 \\
5.89 \mathrm{E}+0.5 \\
9.78 \mathrm{E}+05\end{array}$ & 1.00E-09 & $1.00 \mathrm{E}-09$ \\
\hline
\end{tabular}


WHC-SD-WM-TI-774 Rev. 0

TWRS PRIVATIZATION PROCESS TECHNICAL BASELINE

Table B-2 Phase 1 IAW Mass Balance for Batch PCl/2 (6 sheets)

\begin{tabular}{|c|c|c|c|c|c|c|c|c|c|c|}
\hline $\begin{array}{l}\text { SIFFAM NAME } \\
\text { SOL.D DOMFONEMIS }\end{array}$ & 11 & 12 & 13 & 14 & 15 & 16 & $16 \mathrm{~A}$ & 17 & 18 & 19 \\
\hline Total Mass Flor (kg) & & $5.38 E+02$ & & $6.26 \mathrm{E}+03$ & $6.26 \mathrm{E}+03$ & $5.38 \mathrm{EE}+02$ & $1,03 E+06$ & & & \\
\hline \multicolumn{11}{|l|}{ RAJIONUCLIIES (Ci) } \\
\hline $\begin{array}{l}\text { Cesiun } \\
\text { Strantium } \\
\text { Technetiun } \\
\text { TRI }\end{array}$ & & & & & & & $\begin{array}{l}4.78 E+03 \\
6.23 E+03 \\
2.44 E+01 \\
2.54 E+00\end{array}$ & & & \\
\hline
\end{tabular}

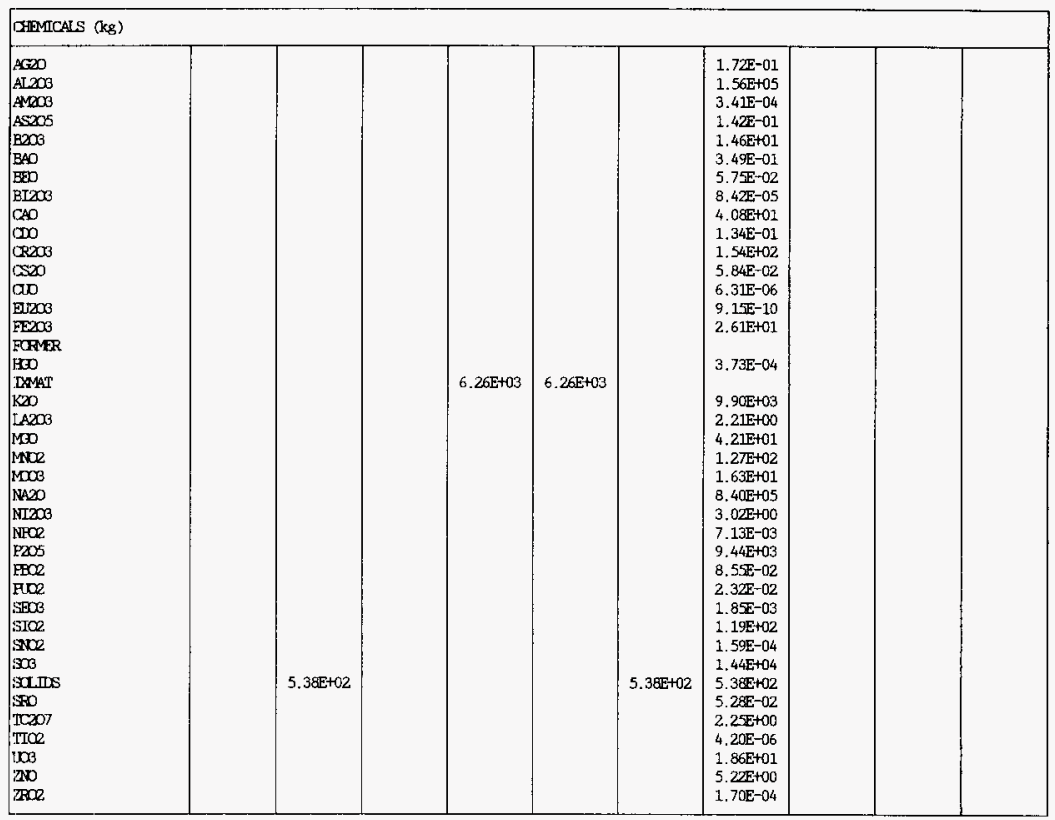


WHC-SD-WM-TI-774 Rev. 0

TWRS PRIVATIZATION PROCESS TECHNICAL BASELINE

Table B-2 Phase 1 LAW Mass Balance for Batch PCl/2 ( 6 sheets)

\begin{tabular}{|c|c|c|c|c|c|c|c|c|c|}
\hline $\begin{array}{l}\text { SLFFAM NAME } \\
\text { IIQUII COMFANENIS }\end{array}$ & 20 & 21 & 22 & 23 & 24 & 25 & 26 & 27 & 28 \\
\hline $\begin{array}{l}\text { Volume (L) } \\
\text { Density (g/L) }\end{array}$ & $\begin{array}{l}5.325+06 \\
1.00 E+03\end{array}$ & & & & $\begin{array}{l}1.7 E+06 \\
1.00 E+03\end{array}$ & $\begin{array}{l}3.57 \mathrm{E}+06 \\
1.00 \mathrm{E}+03\end{array}$ & $\begin{array}{l}3.27 E+03 \\
3.34 E+03\end{array}$ & $\begin{array}{l}3.00 \mathrm{E}-10 \\
3.34 \mathrm{E}+03\end{array}$ & $\begin{array}{l}1.00 E+06 \\
1.00 E+03\end{array}$ \\
\hline Total Mass Flaw (kg) & $5.32 E+06$ & & & & $1.75 E+06$ & $3.57 \varepsilon+06$ & $1.09 E+04$ & $1.00 \mathrm{E}-09$ & 1. OOEFOE \\
\hline \multicolumn{10}{|l|}{ RADIONCJ.MTES (Ci) } \\
\hline $\begin{array}{l}\text { Cesiun } \\
\text { Strantiun } \\
\text { Technetium } \\
\text { IRJ }\end{array}$ & & & & & & & & & \\
\hline
\end{tabular}

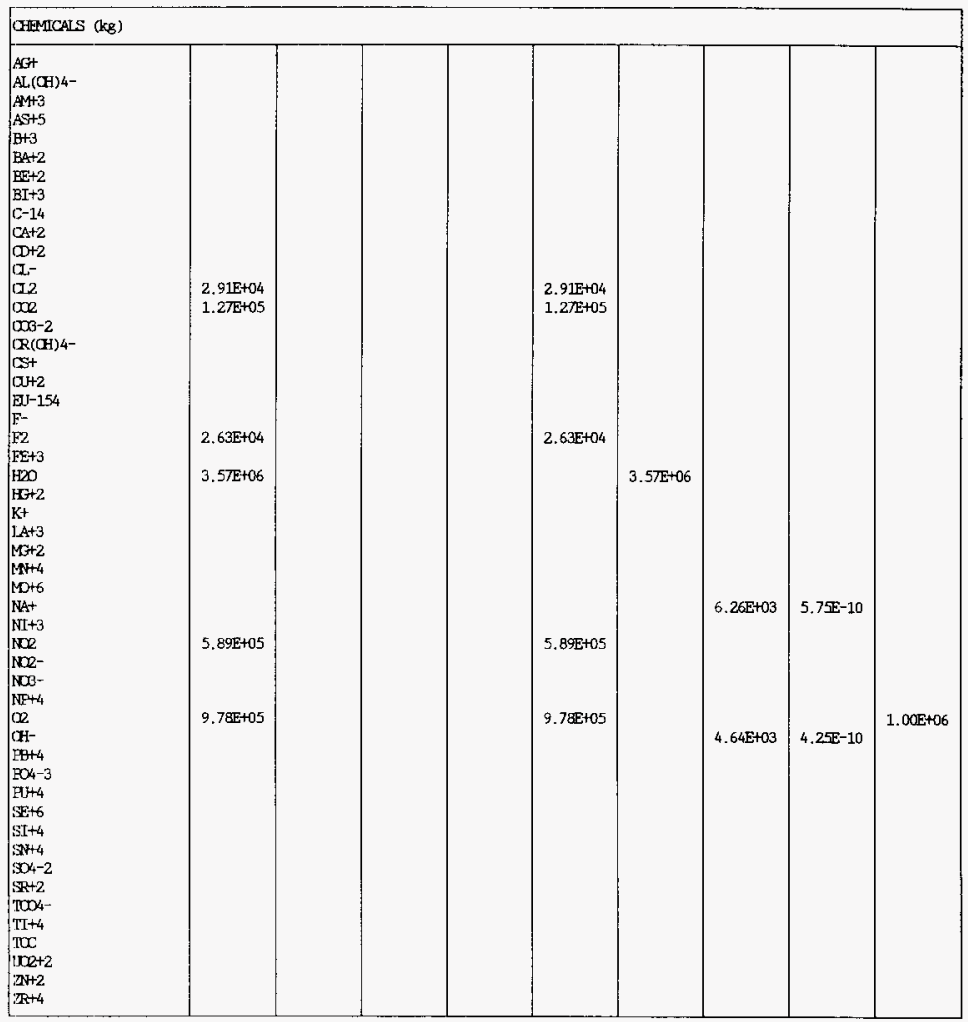


WHC-SD-WM-TI-774 Rev. 0

TWRS PRIVATIZATION PROCESS TECHNICAL BASELINE

Table B-2 Phase 1 LAW Mass Balance for Batch FCl/2 (6 sheets)

\begin{tabular}{|c|c|c|c|c|c|c|c|c|c|}
\hline $\begin{array}{l}\text { SIRFAM NAME } \\
\text { SOD OOMOAEMS }\end{array}$ & 20 & 21 & 22 & 23 & 24 & 25 & 26 & 27 & 28 \\
\hline Total Mass Flow (ks) & & $1.03 E+06$ & $3.95+06$ & $4,98 E+06$ & & & & & \\
\hline \multicolumn{10}{|l|}{ RADIONUCHIIES (Ci) } \\
\hline $\begin{array}{l}\text { Cesium } \\
\text { Struntium } \\
\text { Technetium } \\
\text { TRI }\end{array}$ & & $\begin{array}{l}\text { 4. } 78 E+03 \\
6.23 E+03 \\
2.44 E+01 \\
2.54 E+00\end{array}$ & & $\begin{array}{l}4.78 E+03 \\
6.23 E+03 \\
2.44 E+01 \\
2.54 E+00\end{array}$ & & & & & \\
\hline \multicolumn{10}{|l|}{ OFIICAIS (KG) } \\
\hline 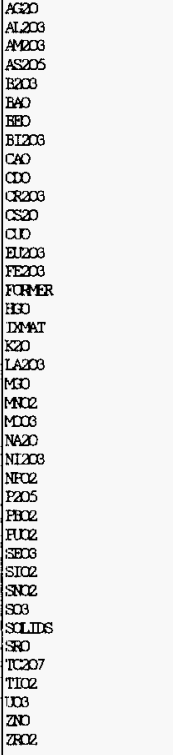 & & $\begin{array}{l}1.72 E-01 \\
1.56 \mathrm{E}+05 \\
3.41 \mathrm{E}-04 \\
1.42 \mathrm{E}-01 \\
1.46 \mathrm{E}+01 \\
3.49 \mathrm{E}-01 \\
5.7 \mathrm{E}-02 \\
8.42 \mathrm{E}-05 \\
4.08 \mathrm{E}+01 \\
1.34 \mathrm{E}-01 \\
1.54 \mathrm{E}+02 \\
5.84 \mathrm{E}-02 \\
6.31 \mathrm{E}-06 \\
9.1 \mathrm{E}-10 \\
2.61 \mathrm{E}+01 \\
\\
3.73 \mathrm{E}-04 \\
\\
9.90 \mathrm{E}+03 \\
2.21 \mathrm{E}+00 \\
4.21 \mathrm{E}+01 \\
1.27 \mathrm{E}+02 \\
1.63 \mathrm{E}+01 \\
8.40 \mathrm{E}+05 \\
3.02 \mathrm{E}+00 \\
7.13 \mathrm{E}-03 \\
9.44 \mathrm{E}+03 \\
8.55 \mathrm{E}-02 \\
2.32 \mathrm{E}-02 \\
1.85 \mathrm{E}-03 \\
1.19 \mathrm{E}+02 \\
1.59 \mathrm{E}-04 \\
1.44 \mathrm{E}+04 \\
5.38 \mathrm{E}+02 \\
5.22 \mathrm{E}-02 \\
2.25 \mathrm{E}+00 \\
4.20 \mathrm{E}-06 \\
1.86 \mathrm{E}+01 \\
5.22 \mathrm{E}+00 \\
1.70 \mathrm{E}-04\end{array}$ & $3.95 \mathrm{E}+06$ & $\begin{array}{l}1.72 \mathrm{E}-01 \\
1.56 \mathrm{E}+05 \\
3.4 \mathrm{E}-04 \\
1.42 \mathrm{E}-01 \\
1.46 \mathrm{E}+01 \\
3.49 \mathrm{E}-01 \\
5.7 \mathrm{E}-02 \\
8.42 \mathrm{E}-05 \\
4.08 \mathrm{E}+01 \\
1.34 \mathrm{E}-01 \\
1.54 \mathrm{E}+02 \\
5.84 \mathrm{E}-02 \\
6.31 \mathrm{E}-06 \\
9.1 \mathrm{E}-10 \\
2.61 \mathrm{E}+01 \\
3.95 \mathrm{E}+06 \\
3.73 \mathrm{E}-04 \\
\\
9.90 \mathrm{E}+03 \\
2.21 \mathrm{E}+00 \\
4.21 \mathrm{E}+01 \\
1.27 \mathrm{E}+02 \\
1.63 \mathrm{E}+01 \\
8.40 \mathrm{E}+05 \\
3.02 \mathrm{E}+00 \\
7.13 \mathrm{E}-03 \\
9.44 \mathrm{E}+03 \\
8.55 \mathrm{E}-02 \\
2.32 \mathrm{E}-02 \\
1.8 \mathrm{E}-03 \\
1.19 \mathrm{E}+02 \\
1.59 \mathrm{E}-04 \\
1.44 \mathrm{E}+04 \\
5.38 \mathrm{E}+02 \\
5.28 \mathrm{E}-02 \\
2.2 \mathrm{E}+00 \\
4.20 \mathrm{E}-06 \\
1.86 \mathrm{E}+01 \\
5.22 \mathrm{E}+00 \\
1.70 \mathrm{E}-04\end{array}$ & & & & & \\
\hline
\end{tabular}


WHC-SD-WM-TI-774 ReV. 0

TWRS PRIVATIZATION PROCESS TECHNICAL BASELINE

Table B-3 Phase 1 IAW Mass Balance for Batch PCl/3 (6 sheets)

\begin{tabular}{|c|c|c|c|c|c|c|c|c|c|}
\hline $\begin{array}{l}\text { SIRFAM NAME } \\
\text { LIQUID COMFANENS }\end{array}$ & 1 & 2 & 3 & 4 & 5 & 6 & 8 & 9 & 10 \\
\hline $\begin{array}{l}\text { Volime (L) } \\
\text { Density (g/L) }\end{array}$ & $\begin{array}{l}2.38 E+06 \\
1.40 E+03\end{array}$ & $\begin{array}{l}2.37 E+06 \\
1.40 E+03\end{array}$ & $\begin{array}{l}1.16 \mathrm{E}+04 \\
1.40 \mathrm{E}+03\end{array}$ & $\begin{array}{l}2.80 E+05 \\
1.00 E+03\end{array}$ & $\begin{array}{l}2.92 \mathrm{E}+05 \\
1.02 \mathrm{E}+03\end{array}$ & $\begin{array}{l}2.37 \mathrm{E}+06 \\
1.40 \mathrm{E}+03\end{array}$ & $\begin{array}{l}2.37 E+06 \\
1.40 E+03\end{array}$ & & \\
\hline Total Mass Flow (kg) & $3.33 E+06$ & $3.31 \mathrm{E}+06$ & $1.62 \mathrm{E}+04$ & $2.80 E+05$ & $2.96 \mathrm{E}+05$ & $3.31 E+06$ & 3.31E+06 & & \\
\hline \multicolumn{10}{|l|}{ RADraNCITIES (Ci) } \\
\hline $\begin{array}{l}\text { Cesium } \\
\text { Strantium } \\
\text { Technetium } \\
\text { IRJ }\end{array}$ & $\begin{array}{l}1.04 \mathrm{E}+06 \\
1.38 \mathrm{gE}+04 \\
1.80 \mathrm{E}+02 \\
1.65 \mathrm{E}+01\end{array}$ & $\begin{array}{l}1.04 \mathrm{E}+06 \\
1.37 \mathrm{E}+04 \\
1.79 \mathrm{E}+02 \\
1.64 \mathrm{E}+01\end{array}$ & $\begin{array}{l}5.05 \mathrm{E}+03 \\
6.71 \mathrm{E}+01 \\
8.7 \mathrm{E}-01 \\
7.99 \mathrm{E}-02\end{array}$ & & $\begin{array}{l}5.0 \mathrm{EE}+03 \\
6.71 \mathrm{E}+01 \\
8.7 \mathrm{E}-01 \\
7.99 \mathrm{E}-02\end{array}$ & $\begin{array}{l}1.04 \mathrm{E}+06 \\
1.3 \mathrm{E}+04 \\
1.7 \mathrm{EE}+02 \\
1.64 \mathrm{E}+01\end{array}$ & $\begin{array}{l}1.04 \mathrm{E}+06 \\
1.37 \mathrm{E}+04 \\
1.79 \mathrm{E}+02 \\
1.64 \mathrm{E}+01\end{array}$ & & \\
\hline
\end{tabular}

\begin{tabular}{|c|c|c|c|c|c|c|c|}
\hline \multicolumn{8}{|c|}{ CHEMCALS (kg) } \\
\hline AG+ & $7.4 \mathrm{BE}-03$ & $7.45 \mathrm{E}-03$ & $3.63 \mathrm{E} \sim 05$ & & 3. $63 \mathrm{E}-05$ & 7.4FE-03 & 7.4.E- 03 \\
\hline $\operatorname{AL}(\mathbf{O H})_{4-}^{-}$ & $1.94 E+05$ & $1.94 \mathrm{E}+05$ & $9.44 E+02$ & & $9.44 \mathrm{E}+02$ & $1.94 \mathrm{E}+05$ & $1.94 \mathrm{E}+05$ \\
\hline$A M+3$ & $6.20 \mathrm{E}-04$ & $6.17 \mathrm{E}-04$ & $3.01 \mathrm{E}-06$ & & $3.01 \mathrm{E}-06$ & $6.17 \mathrm{E}-04$ & $6.1 \pi-04$ \\
\hline$A S+5$ & 4. $34 \mathrm{E}-03$ & $4.3 \mathbb{E}-03$ & $2.11 E-05$ & & $2.11 \mathrm{E}-05$ & 4.3ZE-03 & $4.32 \mathrm{E}-03$ \\
\hline$B+3$ & 2. $13 \mathrm{E}-01$ & $2.12 \mathrm{E}-01$ & $1.03 E-03$ & & $1.03 E^{-}-03$ & $2.12 \mathrm{E}-01$ & $2.12 \mathbb{E}-01$ \\
\hline $\mathrm{BA+2}$ & $1.47 \mathrm{E}-02$ & $1.46 \mathrm{E}-02$ & $7.13 \mathrm{E}-05$ & & $7.13 \mathrm{E}-05$ & $1.46 \mathrm{E}-02$ & $1.46 E-62$ \\
\hline $\mathrm{BE}+2$ & $9.59 \mathrm{E}-04$ & $9.54 E-04$ & $4.66 \mathrm{E}-06$ & & $4.66 \mathrm{E}-06$ & $9.54 \mathrm{E}-04$ & $9.54 \mathrm{E}-04$ \\
\hline $\mathrm{BI}+3$ & 3. $53 E-06$ & $3.52 \mathrm{E}-06$ & $1.72 E-08$ & & $1.72 \mathrm{E}-08$ & $3.52 \mathrm{E}-06$ & $3.52 \mathrm{E}-06$ \\
\hline$c-14$ & $6.19 \mathrm{E}-08$ & $6.16 \mathrm{E}-08$ & $3.00 \mathbf{E}-10$ & & 3.00E-10 & $6.16 \mathrm{E}-08$ & $6,16 \mathrm{E}-08$ \\
\hline $\mathrm{CA}+2$ & $1.37 \mathrm{E}+00$ & 1. $36 \mathrm{E}+00$ & $6.69 \mathrm{E}-03$ & & $6.63 \mathrm{E}-03$ & $1.36 E+00$ & $1.36 \mathrm{E}+00$ \\
\hline$\alpha+2$ & $5.37 \mathrm{E}-03$ & $5.34 \mathrm{E}-03$ & $2.61 E-05$ & & $2.61 \mathrm{E}-05$ & $5.34 \mathrm{E}-03$ & $5.34 \mathrm{E}-03$ \\
\hline$a^{-}$ & $1.17 \mathrm{E}+04$ & $1.16 \mathrm{E}+04$ & $5.66 E+01$ & & $5.66 \mathrm{E}+01$ & 1. $16 \mathrm{E}+04$ & $1.16 \mathrm{E}+04$ \\
\hline \multicolumn{8}{|l|}{0.2} \\
\hline 1002 & & & & & & & \\
\hline$w_{3}-2$ & $4.26 \mathrm{E}+04$ & 4. $24 E+04$ & $2.07 \mathrm{~F}+02$ & & $2.07 \mathrm{E}+02$ & $4.24 \mathrm{E}+04$ & $4.24 \mathrm{E}+04$ \\
\hline $\mathrm{GR}(\mathbf{O H}) 4^{-}$ & $2.15 \mathrm{~F}+03$ & 2. $14 \mathrm{E}+03$ & $1.05 E+101$ & & $1.05+01$ & 2. $14 \mathrm{E}+03$ & 2. $14 \mathrm{E}+03$ \\
\hline $\operatorname{cst}$ & $1.20 \mathrm{OE}+01$ & 1.20E+01 & $5.83 \mathrm{E}-02$ & & $5.83 E-02$ & $1.20 \mathrm{E}+01$ & $1.20 \mathrm{E}+01$ \\
\hline$a+2$ & $2.36 \mathrm{E}-07$ & $2.3 \mathbb{E}-07$ & $1.15 \mathrm{E}-09$ & & $1.15-09$ & $2.35 E-07$ & $2.35 \mathrm{E}-07$ \\
\hline Ev -154 & $3.70 E-11$ & $3.68 \mathrm{E}-11$ & $1.80 \mathrm{E}-13$ & & $1.80 \mathrm{E}-13$ & $3.6 \mathrm{E}-11$ & $3.68 \mathrm{E}-11$ \\
\hline$F^{-}$ & $1,23 \mathrm{E}+03$ & 1. 22E+03 & 5. $96 \mathrm{E}+00$ & & $5.96 \mathrm{E}+00$ & $1.22 \pi+03$ & $1.22 \mathrm{E}+03$ \\
\hline \multicolumn{8}{|l|}{ F2 } \\
\hline $\mathrm{FE}+3$ & $1.62 E+01$ & $1.61 \mathrm{E}+01$ & $7.85 E-02$ & & $7,8 \mathrm{E}-02$ & $1.61 \mathrm{E}+01$ & $1.61 \mathrm{E}+01$ \\
\hline $1+20$ & 2.12E+06 & $2.11 \mathrm{E}+06$ & $1.03 E+04$ & $2.80 \mathrm{E}+05$ & 2. $91 \mathbf{E}+05$ & 2.11E+06 & $2.11 E+06$ \\
\hline $\mathrm{H}+2$ & $1.62 E-05$ & $1.61 E-05$ & $7.85 E-08$ & & $7.8 \mathrm{E}-08$ & $1.61 \mathrm{E}-05$ & $1.61 \mathrm{E}-05$ \\
\hline K+ & $1.02 E+04$ & $1.02 E+04$ & $4.955+01$ & & $4.9 \mathbb{E}+01$ & $1.025+04$ & $1.02 E+04$ \\
\hline $\mathrm{LA}+3$ & $8.81 \mathrm{E}-02$ & $8.77 \mathrm{E}-02$ & $4.28 \mathrm{E}-04$ & & $4.28 E-04$ & $8.7 \pi-02$ & $8.77 \mathrm{E}-02$ \\
\hline $\mathrm{ME}+2$ & 1. $18 \mathrm{E}+00$ & $1.18 \mathrm{E}+00$ & $5.75 E-03$ & & $5.79-03$ & $1.1 \mathrm{EE}+00$ & 1. $18 \mathrm{BE}+00$ \\
\hline$M N+4$ & 3. $7 \mathrm{EE}+00$ & 3. $73 \mathrm{E}+00$ & $1.82 E-02$ & & $1.82 \Sigma-02$ & 3. $73 E+00$ & $3.73 E+00$ \\
\hline$M D+6$ & $5.06 \mathrm{E}-01$ & $5.04 E-03$ & $2.46 \mathrm{E}-03$ & & $2.46 E-03$ & $5.04 \sqrt{2}-01$ & $5.04 \mathrm{E}-01$ \\
\hline $\mathrm{NA}+$ & $4.07 \mathrm{E}+05$ & $4.0 .5+05$ & $1.98 \mathrm{E}+03$ & & $1.98 \mathrm{E}+03$ & $4.05 x+05$ & $4.05 \mathrm{E}+05$ \\
\hline $\mathrm{MI}+3$ & $9.85 E-02$ & $9.80 \mathrm{E}-02$ & $4.78 E-04$ & & $4.78 E-04$ & $9.80 E-02$ & $9.80 \mathrm{E}-02$ \\
\hline \multicolumn{8}{|l|}{ NQQ } \\
\hline NC2- & 1. $31 E+05$ & 1.31E+05 & $6.38 E+02$ & & $6.38 E+02$ & 1.31E +05 & $1.31 E+05$ \\
\hline $\mathrm{NOS}^{-}$ & $2.36 \mathrm{E}+05$ & 2. $6 \mathrm{E}+05$ & $1.39 \mathrm{E}+03$ & & $1.39 \mathrm{E}+03$ & $2.85 E+05$ & $2.855+05$ \\
\hline $\mathrm{NE}+4$ & $2.94 E-04$ & $2.9 \mathbb{E}-04$ & $1.43 \mathrm{E}-06$ & & $1.43 E-06$ & $2.92 \mathrm{E}-04$ & $2.92 \mathrm{E}-04$ \\
\hline \multicolumn{8}{|l|}{$\infty$} \\
\hline $\mathrm{CH}^{-}$ & $1.02 \mathrm{E}+05$ & $1.02 E+05$ & $4.9 F+02$ & & 4.9正+02 & $1.02 \mathrm{E}+0.5$ & $1.02 E+05$ \\
\hline$F+4$ & $3.28 \mathrm{E}-03$ & $3.26 \mathrm{E}-03$ & $1.59 \mathrm{E}-05$ & & $1.59 \mathrm{E}-05$ & $3.26 \mathrm{E}-03$ & $3.26 \mathrm{E}-03$ \\
\hline $\mathrm{FO}_{4}-3$ & $4.42 \mathrm{E}+03$ & $4.395+03$ & $2.14 E+01$ & & $2.24 E+01$ & 4. $39 \mathrm{E}+03$ & 4. $39 \mathrm{E}+03$ \\
\hline $\mathrm{FH}+4$ & $1.98 \mathrm{E}-01$ & $1.9 \pi-01$ & $9.60 \mathrm{E}-04$ & & $9.60 \mathrm{E}-04$ & $1.97 \mathrm{E}-01$ & $1.97 \mathrm{E}-01$ \\
\hline SE+6 & $5.38 \mathrm{E}-05$ & 5. $36 \mathrm{E}-05$ & $2.6 \mathrm{E}-07$ & & $2,61 \mathrm{E}-07$ & $5.36 \mathrm{E}-05$ & $5.36 \mathrm{E}-05$ \\
\hline $\mathrm{SI}+4$ & $2.60 \mathrm{E}+60$ & $2.59 \mathrm{E}+00$ & $1.25 \mathrm{E}-02$ & & $1.26 \mathrm{E}-02$ & $2.59 \mathrm{E}+00$ & 2. $.59 \mathrm{E}+00$ \\
\hline$E N+4$ & $5.89 \mathrm{E}-06$ & $5.86 \mathrm{E}-06$ & $2.86 \mathrm{E}-08$ & & $2.86 \mathrm{E}-08$ & $5.86 \mathrm{E}-06$ & 5. $86 \mathrm{E}-06$ \\
\hline $\mathrm{SO}_{4}-2$ & $9.76 \mathrm{E}+03$ & $9.72 E+03$ & $4.74 \mathrm{E}+01$ & & $4.74 E+01$ & $9.72 x+03$ & $9.72 \mathrm{E}+03$ \\
\hline$\$ 2+2$ & $9.94 \mathrm{E}-02$ & $9.89 \mathrm{E}-02$ & $4.82 E-04$ & & $4.82 E-04$ & $9.89 \mathrm{E}-02$ & $9.89 \mathrm{E}-02$ \\
\hline $7004-$ & 1. $7 \mathrm{EE}+01$ & $1.74 \mathrm{E}+01$ & $8.4 \mathrm{t}-02$ & & $8.4 \mathrm{E}-02$ & $1.74 E+01$ & $1.74 \mathrm{E}+01$ \\
\hline$T+4$ & $1.18 E-07$ & $1.18 \mathrm{E}-07$ & $5.75 \mathrm{E}-10$ & & $5.75 E-10$ & $1.1 \mathrm{EE}-07$ & $1.18 \mathrm{BE}-07$ \\
\hline$T \times C$ & $7.16 \mathrm{E}+03$ & 7. $1.3 E+06$ & $3.4 \mathrm{EF}+01$ & & $3.48 \mathrm{EE}+01$ & $7.13 E+03$ & 7.13E+03 \\
\hline InQ +2 & $8.19 \mathrm{E}-01$ & $8.16 \mathrm{E}-01$ & $3.98 \mathrm{E}-03$ & & $3.98 \mathrm{E}-03$ & $8.16 \mathrm{E}-01$ & $8.16 \mathrm{E}-01$ \\
\hline $2 \mathrm{~N}+2$ & $1.9 \pi-01$ & $1.96 \mathrm{E}-01$ & $9.5 \pi-04$ & & $9.5 \pi \mathrm{z}-04$ & $1.96 \mathrm{E}-01$ & $1.96 \mathrm{E}-01$ \\
\hline $2 R+4$ & $5,89 \mathrm{E}-06$ & $5.86 \mathrm{E}-06$ & $2.86 \mathrm{E}-08$ & & $2.86 \mathrm{E}-08$ & $5,86 \mathrm{E}-06$ & $5,86 \mathrm{E}-06$ \\
\hline
\end{tabular}


WHC-SD-WM-TI-774 Rev. 0

TWRS PRIVATIZATION PROCESS TECHNICAL BASELINE

Table B-3 Phase 1 LAW Mass Balance for Batch PC1/3 (6 sheets)

\begin{tabular}{|c|c|c|c|c|c|c|c|c|c|c|}
\hline $\begin{array}{l}\text { SLFEMM NAYE } \\
\text { SODD COMEONENIS }\end{array}$ & 1 & 2 & 3 & 4 & 5 & 6 & 7 & 8 & 9 & 10 \\
\hline Total Mass Flow (ks) & $3.33 E+04$ & $3.33 E+02$ & $3.29 E+04$ & & $3.29 \mathrm{E}+04$ & & 3. $33 E+02$ & 3.33E+02 & & \\
\hline \multicolumn{11}{|l|}{ RADIONUCLIES (Ci) } \\
\hline $\begin{array}{l}\text { Cesium } \\
\text { Struntium } \\
\text { Technetium } \\
\text { IEJ }\end{array}$ & & & & & & & & & & \\
\hline \multicolumn{11}{|l|}{ AREMTCALS (kg) } \\
\hline 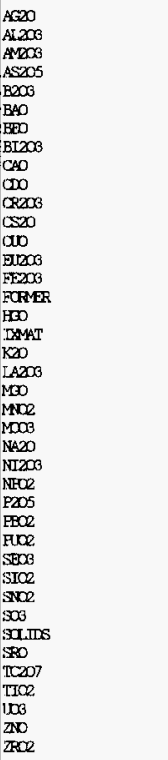 & $3.33 E+04$ & $3.33 E+02$ & $3.29 \mathrm{E}+64$ & & $3.29 \mathrm{E}+04$ & & 3. $33 \mathrm{E}+02$ & $3.33 \mathrm{E}+02$ & & \\
\hline
\end{tabular}


WHC-SD-WM-TI-774 Rev. 0

TWRS PRIVATIZATION PROCESS TECHNICAL BASELINE

Table B-3 Phase 1 LAW Mass Balance for Batch PCl/3 (6 sheets)

\begin{tabular}{|c|c|c|c|c|c|c|c|c|c|c|}
\hline $\begin{array}{l}\text { SIREAM NAME } \\
\text { LTQIII COMFUNENS }\end{array}$ & 11 & 12 & 13 & 14 & 15 & 16 & $16 \mathrm{~A}$ & 17 & 18 & 19 \\
\hline $\begin{array}{l}\text { Volume }(L) \\
\text { Density }(g / L)\end{array}$ & & $\begin{array}{l}2.37 \mathrm{E}+06 \\
1.40 \mathrm{E}+03\end{array}$ & $\begin{array}{l}2.14 E+03 \\
3.32 E+03\end{array}$ & & $\begin{array}{l}2.14 E+03 \\
3.32 \pi+03\end{array}$ & $\begin{array}{l}2.37 \mathrm{E}+06 \\
1.40 \mathrm{E}+03\end{array}$ & $\begin{array}{l}3.64 E+06 \\
1.00 E+03\end{array}$ & & $\begin{array}{l}1.00 \mathrm{E}-09 \\
1.00 \mathrm{E}+03\end{array}$ & $\begin{array}{l}1.00 \mathrm{E}-09 \\
1.00 \mathrm{E}+03\end{array}$ \\
\hline Total Mass Flow (kg) & & $3.31 E+06$ & $7.09 E+03$ & & $7.09 \mathrm{E}+03$ & $3.31 E+06$ & $3.64 E+06$ & & $1.00 \mathrm{E}-09$ & $1,00 \mathrm{E}-09$ \\
\hline \multicolumn{11}{|l|}{ RADIONOC.IDES (Ci) } \\
\hline $\begin{array}{l}\text { Cesium } \\
\text { Strantium } \\
\text { Tedhnetium } \\
\text { 'IEJ }\end{array}$ & & $\begin{array}{l}3.10 \mathrm{E}+03 \\
1.37 \mathrm{E}+04 \\
1.78 \mathrm{E}+02 \\
1.64 \mathrm{E}+01\end{array}$ & $\begin{array}{l}1.03 E+06 \\
1.80 E+00\end{array}$ & & $\begin{array}{l}1.03 E+06 \\
1.80 E+00\end{array}$ & $\begin{array}{l}3.10 \mathrm{E}+03 \\
1.3 \mathrm{ZE}+04 \\
1.78 \mathrm{E}+02 \\
1.64 \mathrm{E}+01\end{array}$ & & & & \\
\hline \multicolumn{11}{|l|}{ GFMICALS (kg) } \\
\hline 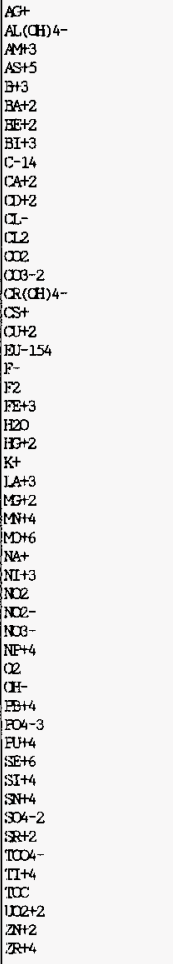 & & $\begin{array}{l}7.45 E-03 \\
1.94 E+05 \\
6.17 \mathrm{E}-04 \\
4.32 \mathrm{E}-03 \\
2.12 \mathrm{E}-01 \\
1.46 \mathrm{E}-02 \\
9.54 \mathrm{E}-04 \\
3.52 \mathrm{E}-06 \\
6.16 \mathrm{E}-08 \\
1.36 \mathrm{E}+00 \\
5.34 \mathrm{E}-03 \\
1.16 \mathrm{E}+04 \\
\\
4.24 \mathrm{E}+04 \\
2.14 \mathrm{E}+03 \\
3.58 \mathrm{E}-02 \\
2.35 \mathrm{E}-07 \\
3.6 \mathrm{E}-11 \\
1.22 \mathrm{E}+03 \\
1.61 \mathrm{E}+01 \\
2.11 \mathrm{E}+06 \\
1.61 \mathrm{E}-05 \\
1.02 \mathrm{E}+04 \\
8.77 \mathrm{E}-02 \\
1.18 \mathrm{E}+00 \\
3.73 \mathrm{E}+00 \\
5.04 \mathrm{E}-01 \\
4.0 \mathrm{E}+05 \\
9.80 \mathrm{E}-02 \\
1.31 \mathrm{E}+05 \\
2.85 \mathrm{E}+05 \\
2.92 \mathrm{E}-04 \\
1.02 \mathrm{E}+05 \\
3.26 \mathrm{E}-03 \\
4.39 \mathrm{E}+03 \\
1.97 \mathrm{E}-01 \\
5.36 \mathrm{E}-05 \\
2.59 \mathrm{E}+00 \\
5.86 \mathrm{E}-06 \\
9.72 \mathrm{E}+03 \\
9.89 \mathrm{E}-02 \\
1.72 \mathrm{E}+01 \\
1.18 \mathrm{E}-07 \\
7.13 \mathrm{E}+03 \\
8.16 \mathrm{E}-01 \\
1.96 \mathrm{E}-01 \\
5.86 \mathrm{E}-06\end{array}$ & $\begin{array}{l}1.19 E+01 \\
4.07 E+03 \\
3.02 E+03\end{array}$ & & $\begin{array}{l}1.192+01 \\
4.07 E+03 \\
3.01 E+03\end{array}$ & $\begin{array}{l}7.45 E-03 \\
1.94 E+05 \\
6.17 \mathrm{E}-04 \\
4.32 \mathrm{E}-03 \\
2.12 \mathrm{E}-01 \\
1.46 \mathrm{E}-02 \\
9.54 \mathrm{E}-04 \\
3.52 \mathrm{E}-06 \\
6.16 \mathrm{E}-08 \\
1.36 \mathrm{E}+00 \\
5.34 \mathrm{E}-03 \\
1.16 \mathrm{E}+04 \\
\\
4.24 \mathrm{E}+04 \\
2.14 \mathrm{E}+03 \\
3.58 \mathrm{E}-02 \\
2.35 \mathrm{E}-07 \\
3.68 \mathrm{E}-11 \\
1.22 \mathrm{E}+03 \\
1.61 \mathrm{E}+01 \\
2.11 \mathrm{E}+06 \\
1.61 \mathrm{E}-05 \\
1.02 \mathrm{E}+04 \\
8.77 \mathrm{E}-02 \\
1.18 \mathrm{E}+00 \\
3.73 \mathrm{E}+00 \\
5.04 \mathrm{E}-01 \\
4.05 \mathrm{E}+05 \\
9.80 \mathrm{E}-02 \\
1.31 \mathrm{E}+05 \\
2.85 \mathrm{E}+05 \\
2.92 \mathrm{E}-04 \\
1.02 \mathrm{E}+05 \\
3.26 \mathrm{E}-03 \\
4.39 \mathrm{E}+03 \\
1.97 \mathrm{E}-01 \\
5.36 \mathrm{E}-05 \\
2.59 \mathrm{E}+00 \\
5.86 \mathrm{E}-06 \\
9.72 \mathrm{E}+03 \\
9.89 \mathrm{E}-02 \\
1.72 \mathrm{E}+01 \\
1.18 \mathrm{E}-07 \\
7.13 \mathrm{E}+03 \\
8.16 \mathrm{E}-01 \\
1.96 \mathrm{E}-01 \\
5.86 \mathrm{E}-06\end{array}$ & $\begin{array}{l}1.16 E+04 \\
5.72 E+04 \\
1.22 E+03 \\
2.23 E+06 \\
3.42 E+05 \\
9.90 E+05\end{array}$ & & 1. $00 \mathrm{E}-09$ & $1,00 \mathrm{E}-09$ \\
\hline
\end{tabular}


WHC-SD-WM-TI-774 ReV. 0

TWRS PRIVATIZATION PROCESS TECHNICAL BASELINE

Table B-3 Phase 1 LAW Mass Balance for Batch PCl/3 (6 sheets)

\begin{tabular}{|c|c|c|c|c|c|c|c|c|c|c|}
\hline $\begin{array}{l}\text { SIFFAM NAME } \\
\text { SLED ONFANENS }\end{array}$ & 11 & 12 & 13 & 14 & 15 & 16 & $16 A$ & 17 & 18 & 19 \\
\hline Total Mass Flow (kg) & & $3.33 \mathrm{E}+02$ & & 4.07E+C3 & $4.0 \mathrm{~F}+03$ & $3.33 E+02$ & $6.75 E+05$ & & & \\
\hline \multicolumn{11}{|l|}{ RADICNUEITES (Ci) } \\
\hline $\begin{array}{l}\text { Cessium } \\
\text { Struntium } \\
\text { Techretium } \\
\text { TIN }\end{array}$ & & & & & & & $\begin{array}{l}3.10 \mathrm{E}+03 \\
1.37 \mathrm{E}+04 \\
1.78 \mathrm{E}+02 \\
1.62 \mathrm{E}+01\end{array}$ & & & \\
\hline \multicolumn{11}{|l|}{ CHMMICALS (kg) } \\
\hline 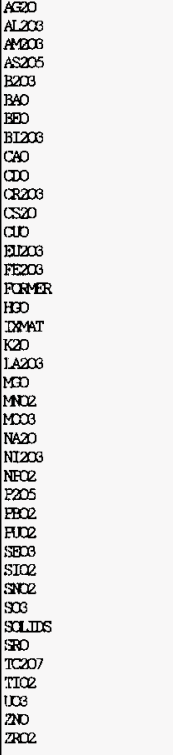 & & $3.33 \mathrm{E}+02$ & & $4,0 \pi E+03$ & $4.07 \mathrm{E}+03$ & $3.33 \mathrm{E}+02$ & $\begin{array}{l}8.00 \mathrm{E}-03 \\
1.04 \mathrm{E}+05 \\
6.78 \mathrm{E}-04 \\
6.62 \mathrm{E}-03 \\
6.81 \mathrm{E}-01 \\
1.63 \mathrm{E}-02 \\
2.6 \mathrm{EE}-03 \\
3.92 \mathrm{E}-06 \\
1.90 \mathrm{E}+00 \\
6.10 \mathrm{E}-03 \\
1.36 \mathrm{E}+03 \\
3.79 \mathrm{E}-02 \\
2.94 \mathrm{E}-07 \\
4.26 \mathrm{E}-11 \\
2.30 \mathrm{E}+01 \\
1.74 \mathrm{E}-05 \\
\\
1.22 \mathrm{E}+04 \\
1.03 \mathrm{E}-01 \\
1.95 \mathrm{E}+00 \\
5.91 \mathrm{E}+00 \\
7.56 \mathrm{E}-01 \\
5.46 \mathrm{E}+05 \\
1.38 \mathrm{E}-01 \\
3.32 \mathrm{E}-04 \\
3.28 \mathrm{E}+03 \\
3.76 \mathrm{E}-03 \\
2.23 \mathrm{E}-01 \\
8.6 \mathrm{E}-05 \\
5.54 \mathrm{E}+00 \\
7.4 \mathrm{EE}-06 \\
8.10 \mathrm{E}+03 \\
3.33 \mathrm{E}+02 \\
1.17 \mathrm{E}-01 \\
1.64 \mathrm{E}+01 \\
1.97 \mathrm{E}-07 \\
8.64 \mathrm{E}-01 \\
2.44 \mathrm{E}-01 \\
7.92 \mathrm{E}-06\end{array}$ & & & \\
\hline
\end{tabular}


WHC-SD-WM-TI-774 ReV. 0

TWRS PRIVATIZATION PROCESS TECHNICAL BASELINE

Table B-3 Phase 1 LAW Mass Balance for Batch PCl/3 (6 sheets)

\begin{tabular}{|c|c|c|c|c|c|c|c|c|c|}
\hline $\begin{array}{l}\text { SIREAM NMME } \\
\text { L.TOWD CIMFONDIS }\end{array}$ & 20 & 21 & 22 & 23 & 24 & 25 & 26 & 27 & 28 \\
\hline $\begin{array}{l}\text { Volume (L) } \\
\text { Density (g/L) }\end{array}$ & $\begin{array}{l}3.64 \mathrm{E}+06 \\
1.00 \mathrm{E}+03\end{array}$ & & & & $\begin{array}{l}1.40 \mathrm{E}+06 \\
1.00 \mathrm{E}+03\end{array}$ & $\begin{array}{l}2.23 E+06 \\
1.00 E+03\end{array}$ & $\begin{array}{l}2.12 E+03 \\
3.34 E+03\end{array}$ & $\begin{array}{l}3.00 E-10 \\
3.34 E+03\end{array}$ & $\begin{array}{l}\text { 1.00E+06 } \\
1.00 \mathrm{E}+03\end{array}$ \\
\hline Total Mass Floo (kg) & $3.64 \mathrm{E}+06$ & & & & $1.40 \mathrm{E}+06$ & 2.23E+06 & $7.08 \mathrm{E}+03$ & 1. $00 \mathrm{E}-09$ & $1.00 \mathrm{E}+06$ \\
\hline \multicolumn{10}{|l|}{ RADIONCLES (Cl) } \\
\hline $\begin{array}{l}\text { Cesium } \\
\text { Strantium } \\
\text { Technetium } \\
\text { TNI. }\end{array}$ & & & & & & & & & \\
\hline
\end{tabular}

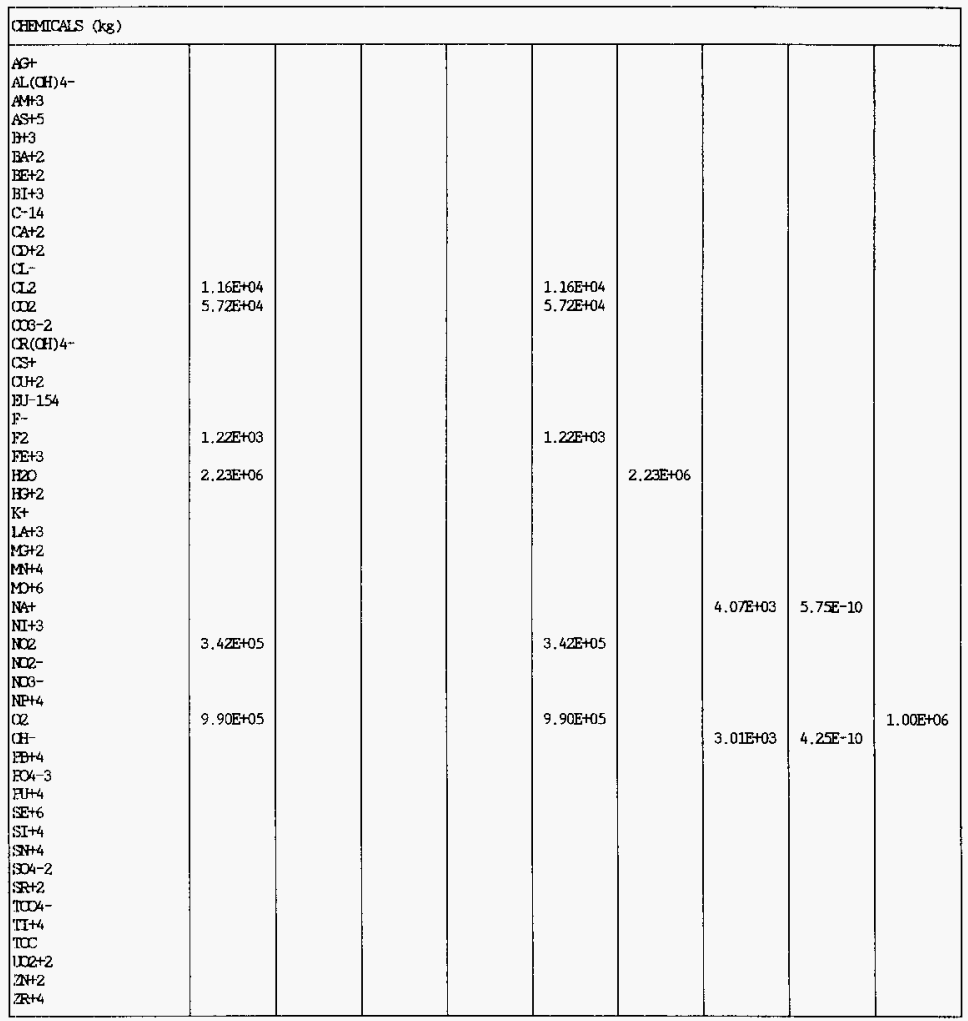


WHC-SD-WM-TI-774 Rev. 0

TWRS PRIVATIZATION PROCESS TECHNICAL BASELINE

Table B-3 Phase 1 LAW Mass Balance for Batch PC1/3 (6 sheets)

\begin{tabular}{|c|c|c|c|c|c|c|c|c|c|}
\hline $\begin{array}{l}\text { SIFEAM NANE } \\
\text { SOLD OARAENIS }\end{array}$ & 20 & 21 & 22 & 23 & 24 & 25 & 26 & 27 & 28 \\
\hline Total Mass Flow (kg) & & $6.752+05$ & $2.56 \mathrm{E}+06$ & $3.23 \mathrm{E}+06$ & & & & & \\
\hline \multicolumn{10}{|l|}{ RADIONUDIIIES (Ci) } \\
\hline $\begin{array}{l}\text { Cesium } \\
\text { Strontium } \\
\text { Technetium } \\
\text { TRI }\end{array}$ & & $\begin{array}{l}\text { 3. } 10 E+03 \\
1.37 E+04 \\
1.78 E+02 \\
1.62 E+01\end{array}$ & & $\begin{array}{l}3.10 \mathrm{E}+03 \\
1.37 \mathrm{E}+04 \\
1.78 \mathrm{E}+02 \\
1.62 \mathrm{E}+01\end{array}$ & & & & & \\
\hline \multicolumn{10}{|l|}{ OHIMICALS (kg) } \\
\hline 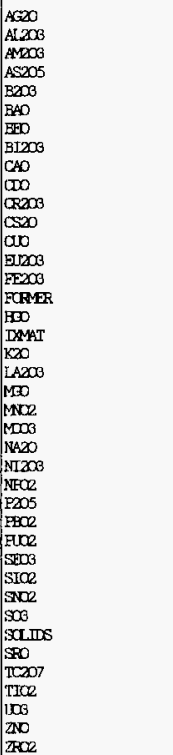 & & $\begin{array}{l}8.00 \mathrm{E}-03 \\
1.04 \mathrm{E}+05 \\
6.78 \mathrm{E}-04 \\
6.62 \mathrm{E}-03 \\
6.81 \mathrm{E}-01 \\
1.63 \mathrm{E}-02 \\
2.6 \mathrm{E}-03 \\
3.92 \mathrm{E}-06 \\
1.90 \mathrm{E}+00 \\
6.10 \mathrm{E}-03 \\
1.36 \mathrm{E}+03 \\
3.79 \mathrm{E}-02 \\
2.94 \mathrm{E}-07 \\
4.26 \mathrm{E}-11 \\
2.30 \mathrm{E}+01 \\
\\
1.74 \mathrm{E}-05 \\
\\
1.22 \mathrm{E}+04 \\
1.03 \mathrm{E}-01 \\
1.95 \mathrm{E}+00 \\
5.91 \mathrm{E}+00 \\
7.56 \mathrm{E}-01 \\
5.46 \mathrm{E}+05 \\
1.36 \mathrm{E}-01 \\
3.32 \mathrm{E}-04 \\
3.25 \mathrm{E}+03 \\
3.76 \mathrm{E}-03 \\
2.23 \mathrm{E}-01 \\
8.61 \mathrm{E}-05 \\
5.54 \mathrm{E}+00 \\
7.4 \mathrm{E}-06 \\
8.10 \mathrm{E}+03 \\
3.39 \mathrm{E}+02 \\
1.17 \mathrm{E}-011 \\
1.64 \mathrm{E}+01 \\
1.97 \mathrm{E}-07 \\
8.64 \mathrm{E}-01 \\
2.44 \mathrm{E}-01 \\
7.92 \mathrm{E}-06\end{array}$ & $2.56 \mathrm{E}+06$ & $\begin{array}{l}8.00 \mathrm{E}-03 \\
1.04 \mathrm{E}+05 \\
6.78 \mathrm{E}-04 \\
6.62 \mathrm{E}-03 \\
6.81 \mathrm{E}-01 \\
1.63 \mathrm{E}-02 \\
2.65 \mathrm{E}-03 \\
3.92 \mathrm{E}-06 \\
1.90 \mathrm{E}+00 \\
6.10 \mathrm{E}-03 \\
1.36 \mathrm{E}+03 \\
3.79 \mathrm{E}-02 \\
2.94 \mathrm{E}-07 \\
4.26 \mathrm{E}-11 \\
2.30 \mathrm{E}+01 \\
2.56 \mathrm{E}+06 \\
1.74 \mathrm{E}-05 \\
\\
1.22 \mathrm{E}+04 \\
1.03 \mathrm{E}-01 \\
1.95 \mathrm{E}+00 \\
5.91 \mathrm{E}+00 \\
7.56 \mathrm{E}-01 \\
5.46 \mathrm{E}+05 \\
1.38 \mathrm{E}-01 \\
3.32 \mathrm{E}-04 \\
3.28 \mathrm{E}+03 \\
3.76 \mathrm{E}-03 \\
2.23 \mathrm{E}-01 \\
8.61 \mathrm{E}-05 \\
5.54 \mathrm{E}+00 \\
7.4 \mathrm{E}-06 \\
8.10 \mathrm{E}+03 \\
3.33 \mathrm{E}+02 \\
1.17 \mathrm{E}-01 \\
1.64 \mathrm{E}+01 \\
1.97 \mathrm{E}-07 \\
8.64 \mathrm{E}-01 \\
2.44 \mathrm{E}-01 \\
7.92 \mathrm{E}-06\end{array}$ & & & & & \\
\hline
\end{tabular}


WHC-SD-WM-TI-774 Rev. 0

TWRS PRIVATIZATION PROCESS TECHNICAL BASELINE

Table B-4 Phase 1 IAW Mass Balance for Batch PC1/4 (6 sheets)

\begin{tabular}{|c|c|c|c|c|c|c|c|c|c|c|}
\hline $\begin{array}{l}\text { SIREAM NAME } \\
\text { LIQUID COMFONENIS }\end{array}$ & 1 & 2 & 3 & 4 & 5 & 6 & 7 & 8 & 9 & 10 \\
\hline $\begin{array}{l}\text { Volme }(L) \\
\text { Density }(g / L)\end{array}$ & $\begin{array}{l}2.63 E+06 \\
1.45 E+03\end{array}$ & $\begin{array}{l}2.62 \mathrm{E}+06 \\
1.45 \mathrm{E}+03\end{array}$ & $\begin{array}{l}1.34 \mathrm{E}+04 \\
1.45 \mathrm{E}+03\end{array}$ & $\begin{array}{l}3.20 \mathrm{E}+05 \\
1.00 \mathrm{E}+03\end{array}$ & $\begin{array}{l}3.34 E+05 \\
1.02 E+03\end{array}$ & & $\begin{array}{l}2.62 E+06 \\
1.4 \mathrm{SE}+03\end{array}$ & $\begin{array}{l}2.62 \mathrm{E}+06 \\
1.4 .5 \mathrm{E}+03\end{array}$ & & \\
\hline Total Mass Flow (kg) & $3.81 E+06$ & $3.79 \mathrm{E}+06$ & $1.94 E+04$ & $3.20 E+0.5$ & 3. $40 E+05$ & & $3,79 \mathrm{E}+06$ & 3.79E+06 & & \\
\hline \multicolumn{11}{|l|}{ RADIONCIMEES (Ci) } \\
\hline $\begin{array}{l}\text { Cesium } \\
\text { Strrantium } \\
\text { Technetium } \\
\text { [IIV]. }\end{array}$ & $\begin{array}{l}9.65 \mathrm{E}+05 \\
3.01 \mathrm{E}+03 \\
2.86 \mathrm{E}+02 \\
5.50 \mathrm{E}+00\end{array}$ & $\begin{array}{l}9.60 \mathrm{E}+05 \\
3.00 \mathrm{E}+03 \\
2.85 \mathrm{E}+02 \\
5.47 \mathrm{E}+00\end{array}$ & $\begin{array}{l}4.90 \mathrm{E}+03 \\
1.53 \mathrm{E}+01 \\
1.4 \mathrm{E}+00 \\
2.79 \mathrm{E}-02\end{array}$ & & $\begin{array}{l}4.90 \mathrm{E}+03 \\
1.53 \mathrm{E}+01 \\
1.45 \mathrm{E}+00 \\
2.79 \mathrm{E}-02\end{array}$ & & $\begin{array}{l}9.60 E+05 \\
3.00 E+03 \\
2.85 E+02 \\
5.47 E+00\end{array}$ & $\begin{array}{l}9.60 \mathrm{E}+05 \\
3.00 \mathrm{E}+03 \\
2.8 \mathrm{EE}+02 \\
5.4 \mathrm{FE}+00\end{array}$ & & \\
\hline \multicolumn{11}{|l|}{ OHRMCALS (kg) } \\
\hline 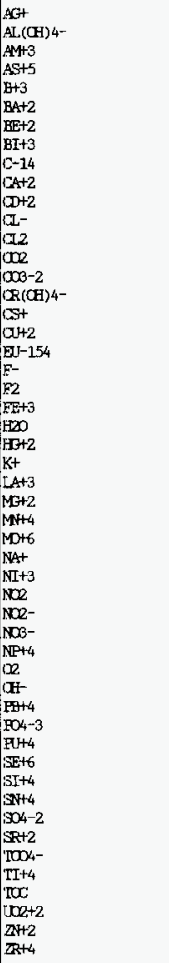 & $\begin{array}{l}2.54 \mathrm{E}+04 \\
8.3 \mathrm{EE}+02 \\
1.12 \mathrm{E}+01 \\
1.35 \mathrm{E}-08 \\
2.12 \mathrm{E}-12 \\
7.03 \mathrm{E}+01 \\
\\
1.2 \mathrm{E}+00 \\
2.2 \mathrm{EE}+06 \\
9.2 \mathrm{E}-07 \\
7.63 \mathrm{E}+04 \\
5.03 \mathrm{E}-03 \\
9.50 \mathrm{E}+01 \\
4.74 \mathrm{E}+01 \\
1.04 \mathrm{E}+02 \\
4.46 \mathrm{E}+05 \\
5.6 \mathrm{EE}-03 \\
\\
1.94 \mathrm{E}+05 \\
4.08 \mathrm{E}+05 \\
1.6 \mathrm{EE}-05 \\
\\
1.63 \mathrm{E}+05 \\
5.4 \mathrm{E}+02 \\
4.14 \mathrm{E}+03 \\
4.3 \mathrm{EE}-02 \\
5.98 \mathrm{E}-02 \\
1.49 \mathrm{E}-01 \\
3.37 \mathrm{E}-07 \\
2.59 \mathrm{E}+03 \\
2.12 \mathrm{E}-02 \\
2.77 \mathrm{E}+01 \\
8.5 \mathrm{EE}+00 \\
4.98 \mathrm{E}+03 \\
8.63 \mathrm{E}+02 \\
5.70 \mathrm{E}+02 \\
9.16 \mathrm{E}+01\end{array}$ & $\begin{array}{l}4.26 \mathrm{E}-04 \\
1.91 \mathrm{E}+05 \\
6.76 \mathrm{E}-04 \\
2.47 \mathrm{E}-04 \\
1.20 \mathrm{E}-02 \\
8.32 \mathrm{E}-04 \\
5.46 \mathrm{E}-05 \\
2.01 \mathrm{E}-07 \\
1.49 \mathrm{E}-04 \\
5.96 \mathrm{E}+01 \\
3.03 \mathrm{E}-04 \\
1.01 \mathrm{E}+04 \\
\\
2.53 \mathrm{E}+04 \\
8.30 \mathrm{E}+02 \\
1.11 \mathrm{E}+01 \\
1.34 \mathrm{E}-08 \\
2.11 \mathrm{E}-12 \\
7.00 \mathrm{E}+01 \\
\\
1.21 \mathrm{E}+00 \\
2.27 \mathrm{E}+06 \\
9.20 \mathrm{E}-07 \\
7.59 \mathrm{E}+04 \\
5.00 \mathrm{E}-03 \\
9.46 \mathrm{E}+01 \\
4.71 \mathrm{E}+01 \\
1.03 \mathrm{E}+02 \\
4.44 \mathrm{E}+05 \\
5.59 \mathrm{E}-03 \\
1.93 \mathrm{E}+05 \\
4.06 \mathrm{E}+05 \\
1.67 \mathrm{E}-05 \\
1.63 \mathrm{E}+05 \\
5.44 \mathrm{E}+02 \\
4.12 \mathrm{E}+03 \\
4.36 \mathrm{E}-02 \\
5.95 \mathrm{E}-02 \\
1.48 \mathrm{E}-01 \\
3.35 \mathrm{E}-07 \\
2.58 \mathrm{E}+03 \\
2.16 \mathrm{E}-02 \\
2.76 \mathrm{E}+01 \\
8.50 \mathrm{E}+00 \\
4.95 \mathrm{E}+03 \\
8.59 \mathrm{E}+02 \\
9.11 \mathrm{E}+01\end{array}$ & $\begin{array}{l}2.17 \mathrm{E}-06 \\
9.74 \mathrm{E}+02 \\
3.45 \mathrm{E}-06 \\
1.26 \mathrm{E}-06 \\
6.14 \mathrm{E}-05 \\
4.25 \mathrm{E}-06 \\
2.79 \mathrm{E}-07 \\
1.03 \mathrm{E}-09 \\
7.59 \mathrm{E}-07 \\
3.04 \mathrm{E}-01 \\
1.55 \mathrm{E}-06 \\
5.18 \mathrm{E}+01 \\
\\
1.29 \mathrm{E}+02 \\
4.24 \mathrm{E}+00 \\
5.66 \mathrm{E}-02 \\
6.84 \mathrm{E}-11 \\
1.08 \mathrm{E}-14 \\
3.5 \mathrm{E}-01 \\
\\
6.19 \mathrm{E}-03 \\
1.16 \mathrm{E}+04 \\
4.69 \mathrm{E}-09 \\
3.8 \mathrm{E}+02 \\
2.55 \mathrm{E}-05 \\
4.83 \mathrm{E}-01 \\
2.40 \mathrm{E}-01 \\
5.26 \mathrm{E}-01 \\
2.26 \mathrm{E}+03 \\
2.85 \mathrm{E}-05 \\
9.8 \mathrm{E}+02 \\
2.07 \mathrm{E}+03 \\
8.5 \mathrm{E}-08 \\
8.29 \mathrm{E}+02 \\
2.78 \mathrm{E}+00 \\
2.10 \mathrm{E}+01 \\
2.22 \mathrm{E}-04 \\
3.04 \mathrm{E}-04 \\
7.54 \mathrm{E}-04 \\
1.71 \mathrm{E}-09 \\
1.32 \mathrm{E}+01 \\
1.10 \mathrm{E}-04 \\
1.41 \mathrm{E}-01 \\
4.34 \mathrm{E}-02 \\
2.53 \mathrm{E}+01 \\
4.38 \mathrm{E}+00 \\
2.90 \mathrm{E}+00 \\
4.65 \mathrm{E}-01\end{array}$ & 3.20E+05 & $\begin{array}{l}2.17 \mathrm{E}-06 \\
9.74 \mathrm{E}+02 \\
3.45 \mathrm{E}-06 \\
1.26 \mathrm{E}-06 \\
6.14 \mathrm{E}-05 \\
4.25 \mathrm{E}-06 \\
2.79 \mathrm{E}-07 \\
1.03 \mathrm{E}-09 \\
7.59 \mathrm{E}-07 \\
3.04 \mathrm{E}-01 \\
1.55 \mathrm{E}-06 \\
5.18 \mathrm{E}+01 \\
\\
1.29 \mathrm{E}+02 \\
4.24 \mathrm{E}+00 \\
5.66 \mathrm{E}-02 \\
6.84 \mathrm{E}-11 \\
1.08 \mathrm{E}-14 \\
3.57 \mathrm{E}-01 \\
\\
6.19 \mathrm{E}-03 \\
3.32 \mathrm{E}+05 \\
4.69 \mathrm{E}-09 \\
3.8 \mathrm{E}+02 \\
2.5 \mathrm{E}-05 \\
4.83 \mathrm{E}-01 \\
2.40 \mathrm{E}-01 \\
5.26 \mathrm{E}-01 \\
2.26 \mathrm{E}+03 \\
2.85 \mathrm{E}-05 \\
9.87 \mathrm{E}+02 \\
2.07 \mathrm{E}+03 \\
8.5 \mathrm{E}-08 \\
8.29 \mathrm{E}+02 \\
2.78 \mathrm{E}+00 \\
2.10 \mathrm{E}+01 \\
2.22 \mathrm{E}-04 \\
3.04 \mathrm{E}-04 \\
7.54 \mathrm{E}-04 \\
1.71 \mathrm{E}-09 \\
1.32 \mathrm{E}+01 \\
1.10 \mathrm{E}-04 \\
1.41 \mathrm{E}-01 \\
4.34 \mathrm{E}-02 \\
2.53 \mathrm{E}+01 \\
4.38 \mathrm{E}+00 \\
2.90 \mathrm{E}+00 \\
4.6 \mathrm{E}-01\end{array}$ & & $\begin{array}{l}4.26 \mathrm{E}-04 \\
1.91 \mathrm{E}+05 \\
6.76 \mathrm{E}-04 \\
2.4 \mathrm{E}-04 \\
1.20 \mathrm{E}-02 \\
8.32 \mathrm{E}-04 \\
5.46 \mathrm{E}-05 \\
2.01 \mathrm{E}-07 \\
1.49 \mathrm{E}-04 \\
5.96 \mathrm{E}+01 \\
3.03 \mathrm{E}-04 \\
1.01 \mathrm{E}+04 \\
\\
2.53 \mathrm{E}+04 \\
8.30 \mathrm{E}+02 \\
1.11 \mathrm{E}+01 \\
1.34 \mathrm{E}-08 \\
2.11 \mathrm{E}-12 \\
7.00 \mathrm{E}+01 \\
\\
1.21 \mathrm{E}+00 \\
2.27 \mathrm{E}+06 \\
9.20 \mathrm{E}-07 \\
7.59 \mathrm{E}+04 \\
5.00 \mathrm{E}-03 \\
9.46 \mathrm{E}+01 \\
4.71 \mathrm{E}+01 \\
1.03 \mathrm{E}+02 \\
4.44 \mathrm{E}+05 \\
5.59 \mathrm{E}-03 \\
1.93 \mathrm{E}+05 \\
4.06 \mathrm{E}+05 \\
1.67 \mathrm{E}-05 \\
1.63 \mathrm{E}+05 \\
5.44 \mathrm{E}+02 \\
4.12 \mathrm{E}+03 \\
4.36 \mathrm{E}-02 \\
5.95 \mathrm{E}-02 \\
1.48 \mathrm{E}-01 \\
3.35 \mathrm{E}-07 \\
2.58 \mathrm{E}+03 \\
2.16 \mathrm{E}-02 \\
2.76 \mathrm{E}+01 \\
8.50 \mathrm{E}+00 \\
4.95 \mathrm{E}+03 \\
8.59 \mathrm{E}+02 \\
5.67 \mathrm{E}+02 \\
9.11 \mathrm{E}+01\end{array}$ & $\begin{array}{l}4.26 \mathrm{E}-04 \\
1.91 \mathrm{E}+05 \\
6.76 \mathrm{E}-04 \\
2.47 \mathrm{E}-04 \\
1.20 \mathrm{E}-02 \\
8.32 \mathrm{E}-04 \\
5.46 \mathrm{E}-05 \\
2.01 \mathrm{E}-07 \\
1.49 \mathrm{E}-04 \\
5.96 \mathrm{E}+01 \\
3.03 \mathrm{E}-04 \\
1.01 \mathrm{E}+04 \\
\\
2.53 \mathrm{E}+04 \\
8.30 \mathrm{E}+02 \\
1.11 \mathrm{E}+01 \\
1.34 \mathrm{E}-08 \\
2.11 \mathrm{E}-12 \\
7.00 \mathrm{E}+01 \\
\\
1.21 \mathrm{E}+00 \\
2.27 \mathrm{E}+06 \\
9.20 \mathrm{E}-07 \\
7.59 \mathrm{E}+04 \\
5.00 \mathrm{E}-03 \\
9.46 \mathrm{E}+01 \\
4.71 \mathrm{E}+01 \\
1.03 \mathrm{E}+02 \\
4.44 \mathrm{E}+05 \\
5.59 \mathrm{E}-03 \\
1.93 \mathrm{E}+05 \\
4.06 \mathrm{E}+05 \\
1.6 \mathrm{E}-05 \\
1.63 \mathrm{E}+05 \\
5.44 \mathrm{E}+02 \\
4.12 \mathrm{E}+03 \\
4.36 \mathrm{E}-02 \\
5.95 \mathrm{E}-02 \\
1.48 \mathrm{E}-01 \\
3.3 \mathrm{E}-07 \\
2.58 \mathrm{E}+03 \\
2.16 \mathrm{E}-02 \\
2.76 \mathrm{E}+01 \\
8.50 \mathrm{E}+00 \\
4.9 \mathrm{E}+03 \\
8.59 \mathrm{E}+02 \\
9.67 \mathrm{E}+02 \\
.11 \mathrm{E}+01\end{array}$ & & \\
\hline
\end{tabular}


WHC-SD-WM-TI-774 Rev. 0

TWRS PRIVATIZATION PROCESS TECHNICAL BASELINE

Table B-4 Phase 1 LAW Mass Balance for Batch PCl/4 ( 6 sheets)

\begin{tabular}{|c|c|c|c|c|c|c|c|c|c|c|}
\hline $\begin{array}{l}\text { SIREAM NAM } \\
\text { SOID OOMOCWMIS }\end{array}$ & 1 & 2 & 3 & 4 & 5 & 6 & 7 & 8 & 9 & 10 \\
\hline 'Total Mass Flow (kg) & $3.81 E+04$ & $3.81 \mathrm{E}+02$ & $3.77 \mathrm{E}+04$ & & $3.77 \mathrm{E}+04$ & & $3.81 \mathrm{E}+02$ & $3.81 E+02$ & & \\
\hline \multicolumn{11}{|l|}{ RADITNLCIILS (Ci) } \\
\hline $\begin{array}{l}\text { Cesium } \\
\text { Struntium } \\
\text { Technetium } \\
\text { THL }\end{array}$ & & & & & & & & & & \\
\hline
\end{tabular}

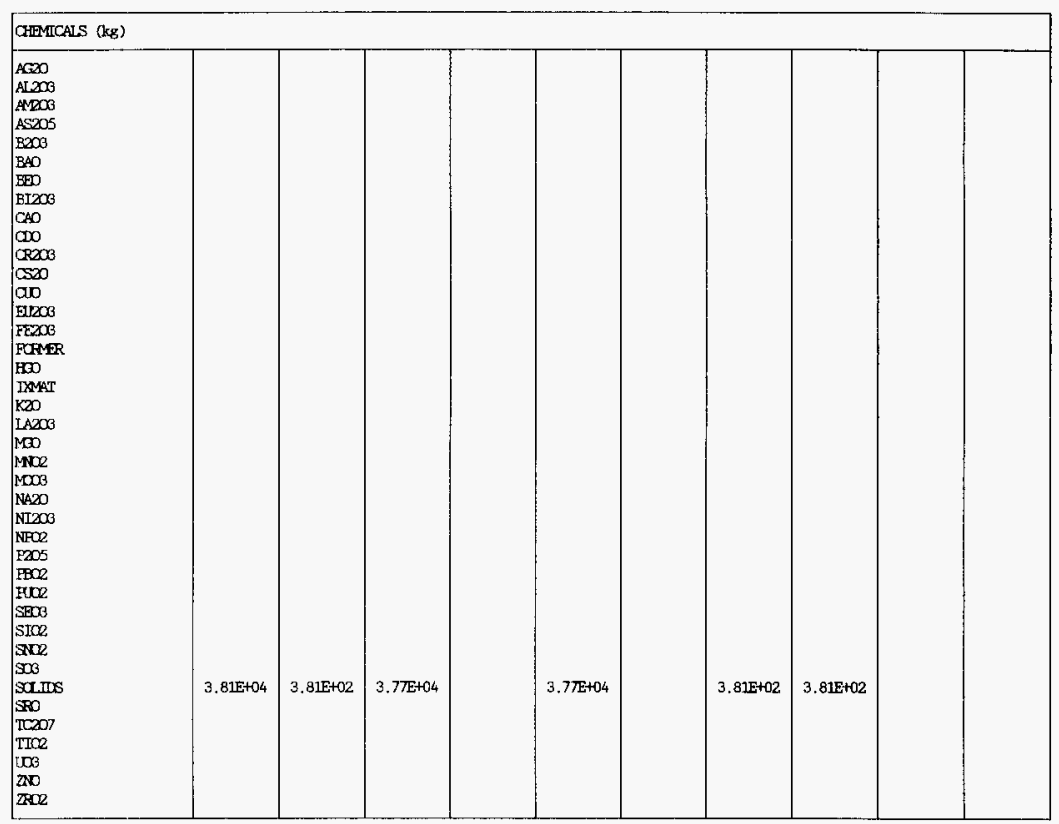


WHC-SD-WM-TI-774 Rev. 0

TWRS PRIVATIZATION PROCESS TECHNICAL BASELINE

Table B-4 Phase 1 LAW Mass Balance for Batch PCl/4 (6 sheets)

\begin{tabular}{|c|c|c|c|c|c|c|c|c|c|c|}
\hline $\begin{array}{l}\text { STREAM NAME } \\
\text { IIQUID COMFONENIS }\end{array}$ & 11 & 12 & 13 & 14 & 15 & 16 & $16 \mathrm{~A}$ & 17 & 18 & 19 \\
\hline $\begin{array}{l}\text { Volime (L) } \\
\text { Density }(g / L)\end{array}$ & & $\begin{array}{l}2.62 \mathrm{E}+06 \\
1.45 \mathrm{E}+03\end{array}$ & $\begin{array}{l}2.34 \mathrm{E}+03 \\
3.33 \mathrm{E}+03\end{array}$ & & $\begin{array}{l}2.34 \mathrm{E}+03 \\
3.33 \mathrm{E}+03\end{array}$ & $\begin{array}{l}2.625+06 \\
1.45 \mathrm{E}+03\end{array}$ & $\begin{array}{l}3.99 \mathrm{E}+06 \\
1.00 \mathrm{E}+03\end{array}$ & & $\begin{array}{l}1.00 \mathrm{E}-09 \\
1.00 \mathrm{E}+09\end{array}$ & $\begin{array}{l}1.00 E-09 \\
1.00 E+03\end{array}$ \\
\hline Total Mass Flow (kg) & & $3.79 \mathrm{E}+06$ & $7.77 \mathrm{E}+03$ & & $7.7 / \mathrm{E}+103$ & $3.79 \mathrm{E}+06$ & $3.99 \mathrm{E}+06$ & & $1.00 \mathrm{E}-09$ & $1.00 \mathrm{E}-09$ \\
\hline \multicolumn{11}{|l|}{ RADIONCINIES (Ci) } \\
\hline $\begin{array}{l}\text { Cesium } \\
\text { Strantium } \\
\text { Technotium } \\
\text { IRJ }\end{array}$ & & $\begin{array}{l}3.40 \mathrm{E}+03 \\
3.00 \mathrm{E}+03 \\
2.82 \mathrm{E}+02 \\
5.4 \mathrm{~F}+00\end{array}$ & $\begin{array}{l}9.57 E+05 \\
2.86 E+00\end{array}$ & & $\begin{array}{l}9.5 / \mathrm{E}+05 \\
2.86 \mathrm{E}+00\end{array}$ & $\begin{array}{l}3.40 \mathrm{E}+03 \\
3.00 \mathrm{E}+03 \\
2.82 \mathrm{E}+02 \\
5.4 \mathrm{E}+00\end{array}$ & & & & \\
\hline
\end{tabular}

\begin{tabular}{|c|c|c|c|c|c|c|c|}
\hline \multicolumn{8}{|c|}{ CFIICALS (kg) } \\
\hline 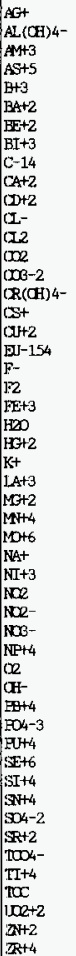 & 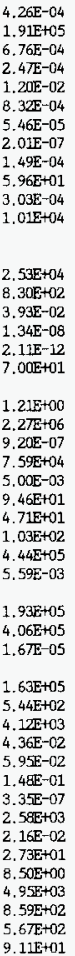 & $\begin{array}{l}4.46 \mathrm{E}+03 \\
3.30 \mathrm{E}+03\end{array}$ & $\begin{array}{l}1.11 \mathrm{E}+01 \\
4.46 \mathrm{E}+03 \\
3.30 \mathrm{E}+03\end{array}$ & $\begin{array}{l}4.26 \mathrm{E}-04 \\
1.91 \mathrm{E}+05 \\
6.76 \mathrm{E}-04 \\
2.47 \mathrm{E}-04 \\
1.20 \mathrm{E}-02 \\
8.32 \mathrm{E}-04 \\
5.46 \mathrm{E}-05 \\
2.01 \mathrm{E}-07 \\
1.49 \mathrm{E}-04 \\
5.96 \mathrm{E}+01 \\
3.03 \mathrm{E}-04 \\
1.01 \mathrm{E}+04 \\
\\
2.53 \mathrm{E}+04 \\
8.30 \mathrm{E}+02 \\
3.93 \mathrm{E}-02 \\
1.34 \mathrm{E}-08 \\
2.11 \mathrm{E}-12 \\
7.00 \mathrm{E}+01 \\
\\
1.21 \mathrm{E}+00 \\
2.27 \mathrm{E}+06 \\
9.20 \mathrm{E}-07 \\
7.59 \mathrm{E}+04 \\
5.00 \mathrm{E}-03 \\
9.46 \mathrm{E}+01 \\
4.71 \mathrm{E}+01 \\
1.03 \mathrm{E}+02 \\
4.44 \mathrm{E}+05 \\
5.59 \mathrm{E}-03 \\
\\
1.93 \mathrm{E}+05 \\
4.06 \mathrm{E}+05 \\
1.67 \mathrm{E}-0.05 \\
1.63 \mathrm{E}+05 \\
5.44 \mathrm{E}+02 \\
4.12 \mathrm{E}+03 \\
4.36 \mathrm{E}-02 \\
5.95 \mathrm{E}-02 \\
1.48 \mathrm{E}-01 \\
3.35 \mathrm{E}-07 \\
2.58 \mathrm{E}+03 \\
2.16 \mathrm{E}-02 \\
2.73 \mathrm{E}+01 \\
8.50 \mathrm{E}+00 \\
4.95 \mathrm{E}+03 \\
8.59 \mathrm{E}+02 \\
5.67 \mathrm{E}+02 \\
9.11 \mathrm{E}+01\end{array}$ & $\begin{array}{l}1.01 \mathrm{E}+04 \\
3.6 \mathrm{E}+04 \\
\\
7.00 \mathrm{E}+01 \\
2.43 \mathrm{E}+06\end{array}$ & $1.00 \mathrm{E}-09$ & $1.00 \mathrm{E}-09$ \\
\hline
\end{tabular}


WHC-SD-WM-TI-774 Rev. 0

TWRS PRIVATIZATION PROCESS TECHNICAL BASELINE

Table B-4 Phase 1 LAW Mass Balance for Batch PCl/4 (6 sheets)

\begin{tabular}{|c|c|c|c|c|c|c|c|c|c|c|}
\hline $\begin{array}{l}\text { STREAM NAME } \\
\text { SOLI OARONENS }\end{array}$ & 11 & 12 & 13 & 14 & 15 & 16 & $16 \mathrm{~A}$ & 17 & 18 & 19 \\
\hline Total Mass Flow (kg) & & $3.81 \mathrm{E}+02$ & & $4.46 \mathrm{E}+03$ & $4.46 \mathrm{E}+03$ & $3.81 E+02$ & $8.018+05$ & & & \\
\hline \multicolumn{11}{|l|}{ RADICNDIIVS (Ci) } \\
\hline $\begin{array}{l}\text { Cesium } \\
\text { Sturantium } \\
\text { Technetium } \\
\text { TIVI }\end{array}$ & & & & & & & $\begin{array}{l}3.40 \mathrm{E}+03 \\
3.00 \mathrm{E}+03 \\
2.82 \mathrm{E}+02 \\
5.44 \mathrm{E}+00\end{array}$ & & & \\
\hline
\end{tabular}

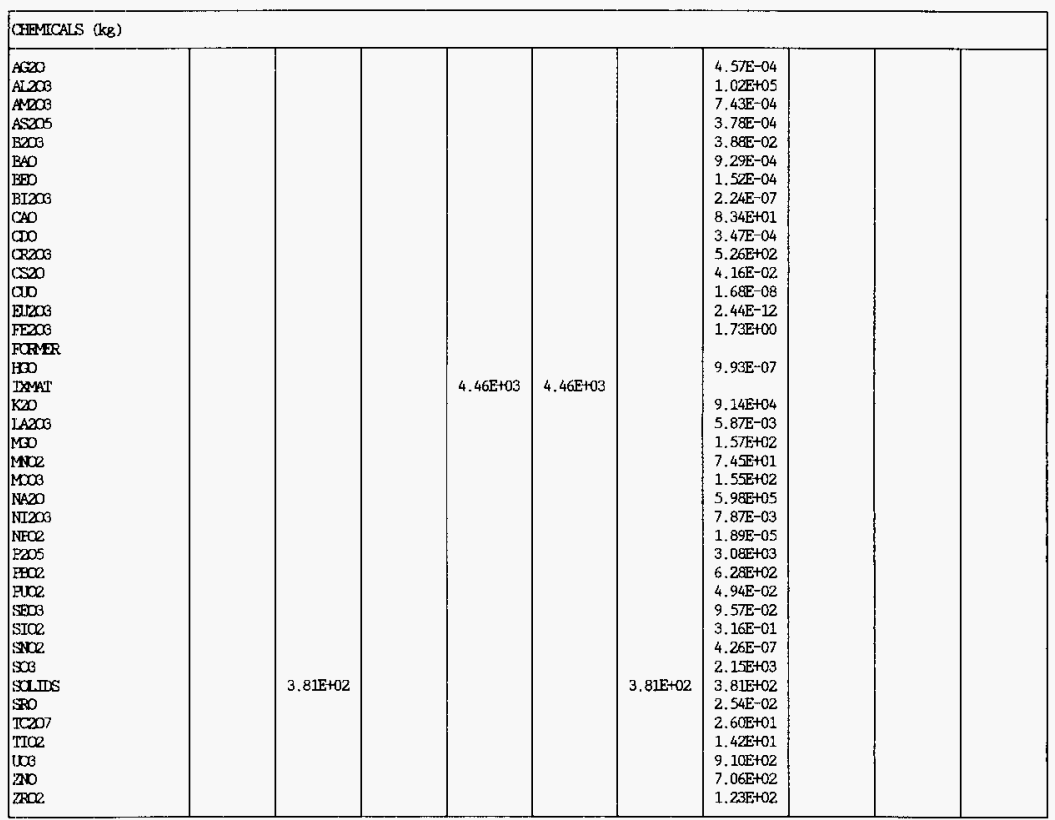


WHC-SD-WM-TI-774 ReV. 0

TWRS PRIVATIZATION PROCESS TECHNICAL. BASELINE

Table B-4 Phase 1 LAW Mass Balance for Batch PCl/4 (6 sheets)

\begin{tabular}{|c|c|c|c|c|c|c|c|c|c|}
\hline $\begin{array}{l}\text { SIREAM NAM } \\
\text { LIQID CMROIENIS }\end{array}$ & 20 & 21 & 22 & 23 & 24 & 25 & 26 & 27 & 28 \\
\hline $\begin{array}{l}\text { Volume (L) } \\
\text { Density }(\mathrm{g} / \mathrm{L})\end{array}$ & $\begin{array}{l}3.99 \mathrm{E}+06 \\
1.00 \mathrm{E}+03\end{array}$ & & & & $\begin{array}{l}1.56 E+06 \\
1.00 E+03\end{array}$ & $\begin{array}{l}2.43 \mathrm{E}+06 \\
1.00 \mathrm{E}+03\end{array}$ & $\begin{array}{l}\text { 2. } 33 E+03 \\
3.34 E+03\end{array}$ & $\begin{array}{l}3.00 E-10 \\
3.34 E+03\end{array}$ & $\begin{array}{l}\text { 1. } 00 \mathrm{E}+06 \\
\text { 1. } 00 \mathrm{E}+03\end{array}$ \\
\hline Cotal Mass Flow (kg) & $3.995+06$ & & & & 1. $56 E+06$ & $2.43 \mathrm{E}+06$ & $7.76 \mathrm{E}+03$ & $1.00 \mathrm{E}-09$ & 1.00+06 \\
\hline \multicolumn{10}{|l|}{ RADIONUC IIXS (Ci) } \\
\hline $\begin{array}{l}\text { Cesium } \\
\text { Struntium } \\
\text { Tecknetiun } \\
\text { Tril }\end{array}$ & & & & & & & & & \\
\hline
\end{tabular}

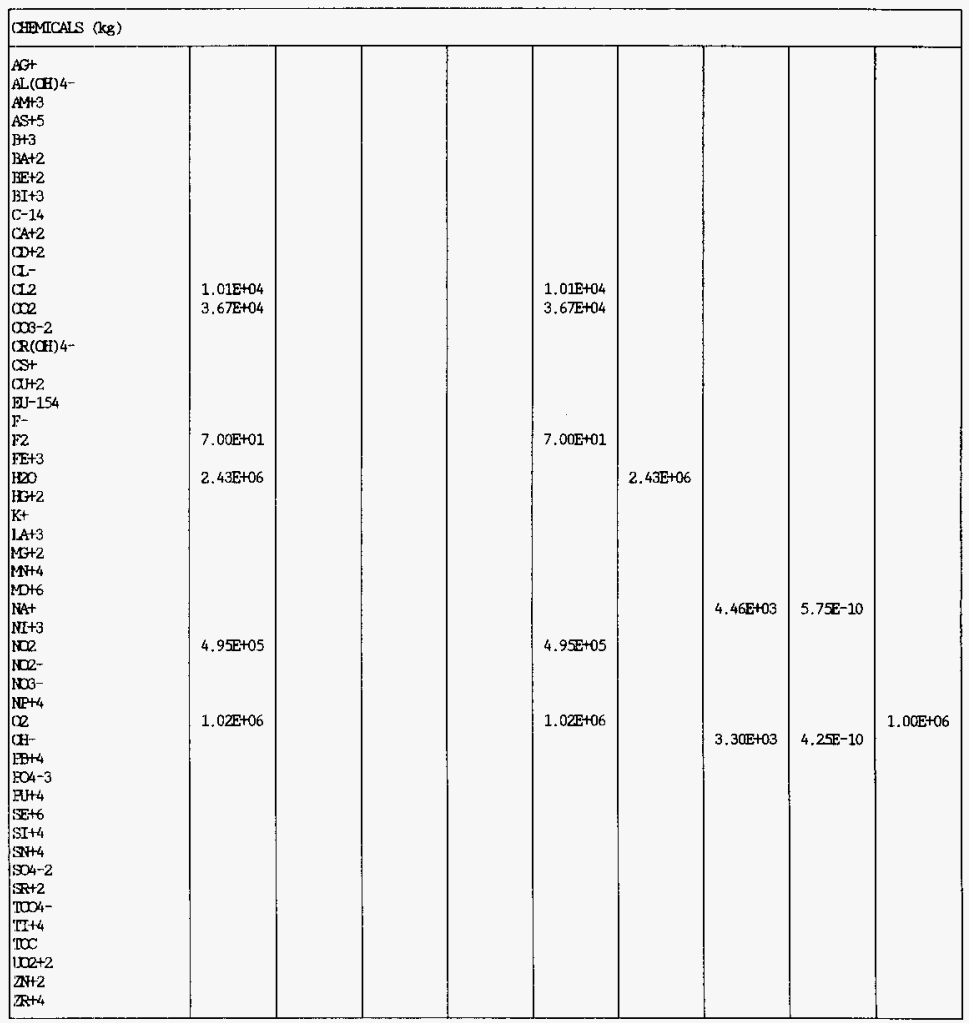


WHC-SD-WM-TI-774 Rev. 0

TWRS PRIVATIZATION PROCESS TECHNICAL BASELINE

Table B-4 Phase 1 LAW Mass Balance for Batch PCl/4 (6 sheets)

\begin{tabular}{|c|c|c|c|c|c|c|c|c|c|}
\hline $\begin{array}{l}\text { SIREAM NAME } \\
\text { SLD DOMFANLIS }\end{array}$ & 20 & 21 & 22 & 23 & 24 & 25 & 26 & 27 & 28 \\
\hline Total Mass Flow (kg) & & $8.01 \mathrm{E}+05$ & $2.74 \mathrm{E}+06$ & $3.54 \mathrm{E}+06$ & & & & & \\
\hline \multicolumn{10}{|l|}{ RADIONUCJIIES (Ci) } \\
\hline $\begin{array}{l}\text { Cesium } \\
\text { Strantium } \\
\text { Technetium } \\
\text { 'IRU }\end{array}$ & & $\begin{array}{l}3.40 \mathrm{E}+03 \\
3.00 \mathrm{E}+03 \\
2.82 \mathrm{E}+02 \\
5.44 \mathrm{E}+00\end{array}$ & & $\begin{array}{l}3.40 \mathrm{E}+03 \\
3.00 \mathrm{E}+03 \\
2.82 \mathrm{E}+02 \\
5.44 \mathrm{E}+00\end{array}$ & & & & & \\
\hline \multicolumn{10}{|l|}{ (CHFMICAIS $(\mathrm{kg})$} \\
\hline 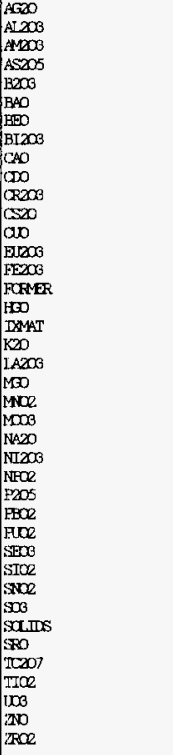 & & $\begin{array}{l}4.57 \mathrm{E}-04 \\
1.02 \mathrm{E}+05 \\
7.43 \mathrm{E}-04 \\
3.78 \mathrm{E}-04 \\
3.8 \mathrm{EE}-02 \\
9.29 \mathrm{E}-04 \\
1.52 \mathrm{E}-04 \\
2.24 \mathrm{E}-07 \\
8.34 \mathrm{E}+01 \\
3.4 \mathrm{E}-04 \\
5.26 \mathrm{E}+02 \\
4.16 \mathrm{E}-02 \\
1.6 \mathrm{E}-08 \\
2.44 \mathrm{E}-12 \\
1.73 \mathrm{E}+00 \\
\\
9.93 \mathrm{E}-07 \\
\\
9.14 \mathrm{E}+04 \\
5.8 \mathrm{E}-03 \\
1.57 \mathrm{E}+02 \\
7.45 \mathrm{E}+01 \\
1.55 \mathrm{E}+02 \\
5.9 \mathrm{EE}+05 \\
7.87 \mathrm{E}-03 \\
1.89 \mathrm{E}-05 \\
3.08 \mathrm{E}+03 \\
6.28 \mathrm{E}+02 \\
4.94 \mathrm{E}-02 \\
9.57 \mathrm{E}-02 \\
3.16 \mathrm{E}-01 \\
4.26 \mathrm{E}-07 \\
2.15 \mathrm{E}+03 \\
3.81 \mathrm{E}+02 \\
2.54 \mathrm{E}-02 \\
2.60 \mathrm{E}+01 \\
1.42 \mathrm{E}+01 \\
9.10 \mathrm{E}+02 \\
7.06 \mathrm{E}+02 \\
1.23 \mathrm{E}+02\end{array}$ & $2.74 \mathrm{E}+06$ & $\begin{array}{l}4.57 \mathrm{E}-04 \\
1.02 \mathrm{E}+05 \\
7.43 \mathrm{E}-04 \\
3.78 \mathrm{E}-04 \\
3.88 \mathrm{E}-02 \\
9.29 \mathrm{E}-04 \\
1.52 \mathrm{E}-04 \\
2.24 \mathrm{E}-07 \\
8.34 \mathrm{E}+01 \\
3.4 \mathrm{E}-04 \\
5.26 \mathrm{E}+02 \\
4.16 \mathrm{E}-02 \\
1.68 \mathrm{E}-08 \\
2.44 \mathrm{E}-12 \\
1.73 \mathrm{E}+00 \\
2.74 \mathrm{E}+06 \\
9.93 \mathrm{E}-07 \\
\\
9.14 \mathrm{E}+04 \\
5.87 \mathrm{E}-03 \\
1.57 \mathrm{E}+02 \\
7.45 \mathrm{E}+01 \\
1.55 \mathrm{E}+02 \\
5.96 \mathrm{E}+05 \\
7.87 \mathrm{E}-03 \\
1.89 \mathrm{E}-05 \\
3.08 \mathrm{E}+03 \\
6.28 \mathrm{E}+02 \\
4.94 \mathrm{E}-02 \\
9.57 \mathrm{E}-02 \\
3.16 \mathrm{E}-01 \\
4.26 \mathrm{E}-07 \\
2.15 \mathrm{E}+03 \\
3.81 \mathrm{E}+02 \\
2.54 \mathrm{E}-02 \\
2.60 \mathrm{E}+01 \\
1.42 \mathrm{~F}+01 \\
9.10 \mathrm{E}+02 \\
7.06 \mathrm{E}+02 \\
1.23 \mathrm{E}+02\end{array}$ & & & & & \\
\hline
\end{tabular}


WHC-SD-WM-TI-774 Rev. 0

TWRS PRIVATIZATION PROCESS TECHNICAL BASELINE

Table B-5 Phase 1 LAW Mass Balance for Batch PC1/5 (6 sheets)

\begin{tabular}{|c|c|c|c|c|c|c|c|c|c|c|}
\hline $\begin{array}{l}\text { SIFEMM NAME } \\
\text { LIQUID COMFONENIS }\end{array}$ & 1 & 2 & 3 & 4 & 5 & 6 & 7 & 8 & 9 & 10 \\
\hline $\begin{array}{l}\text { Volume }(\mathrm{L}) \\
\text { Density }(\mathrm{g} / \mathrm{L})\end{array}$ & $\begin{array}{l}3.51 \mathrm{E}+06 \\
1.41 \mathrm{E}+03\end{array}$ & $\begin{array}{l}3.49 \mathrm{E}+06 \\
1.41 \mathrm{E}+03\end{array}$ & $\begin{array}{l}1,71 \mathrm{E}+04 \\
1,41 \mathrm{E}+03\end{array}$ & $\begin{array}{l}\text { 4. } 16 \mathrm{E}+05 \\
1.00 \mathrm{E}+03\end{array}$ & $\begin{array}{l}4.33 E+05 \\
1.02 E+03\end{array}$ & & $\begin{array}{l}3.49 \mathrm{E}+06 \\
1.41 \mathrm{E}+03\end{array}$ & $\begin{array}{l}3.49 \mathrm{E}+06 \\
1.41 \mathrm{E}+03\end{array}$ & & \\
\hline Total Mass Flow (kg) & $4.93 \mathrm{E}+06$ & $4.91 E+06$ & $2.41 E+04$ & 4.16E+05 & 4. $40 \mathrm{E}+05$ & & $4.91 \mathrm{E}+06$ & 4.91E+06 & & \\
\hline \multicolumn{11}{|l|}{ RALTOMLIIDES (Ci) } \\
\hline $\begin{array}{l}\text { Cesium } \\
\text { Struantium } \\
\text { Technetium } \\
\text { IIIJ }\end{array}$ & $\begin{array}{l}1.34 E+06 \\
2.22 E+04 \\
3.08 E+02 \\
8.322 E+00\end{array}$ & $\begin{array}{l}1.33 E+06 \\
2.21 E+04 \\
3.06 E+02 \\
8.28 E+00\end{array}$ & $\begin{array}{l}6.55 \mathrm{E}+03 \\
1.09 \mathrm{E}+02 \\
1.50 \mathrm{E}+00 \\
4.07 \mathrm{E}-02\end{array}$ & & $\begin{array}{l}6.5 \mathrm{~F}+03 \\
1.09 \mathrm{E}+02 \\
1.50 \mathrm{E}+00 \\
4.0 \mathrm{~F}-02\end{array}$ & & $\begin{array}{l}1.33 \mathrm{E}+06 \\
2.21 \mathrm{E}+04 \\
3.06 \mathrm{E}+02 \\
8.28 \mathrm{E}+00\end{array}$ & $\begin{array}{l}\text { 1. } 33 \mathrm{E}+06 \\
2.21 \mathrm{E}+04 \\
3.06 \mathrm{E}+02 \\
\text { 8. } 2 \mathrm{EE}+00\end{array}$ & & \\
\hline
\end{tabular}

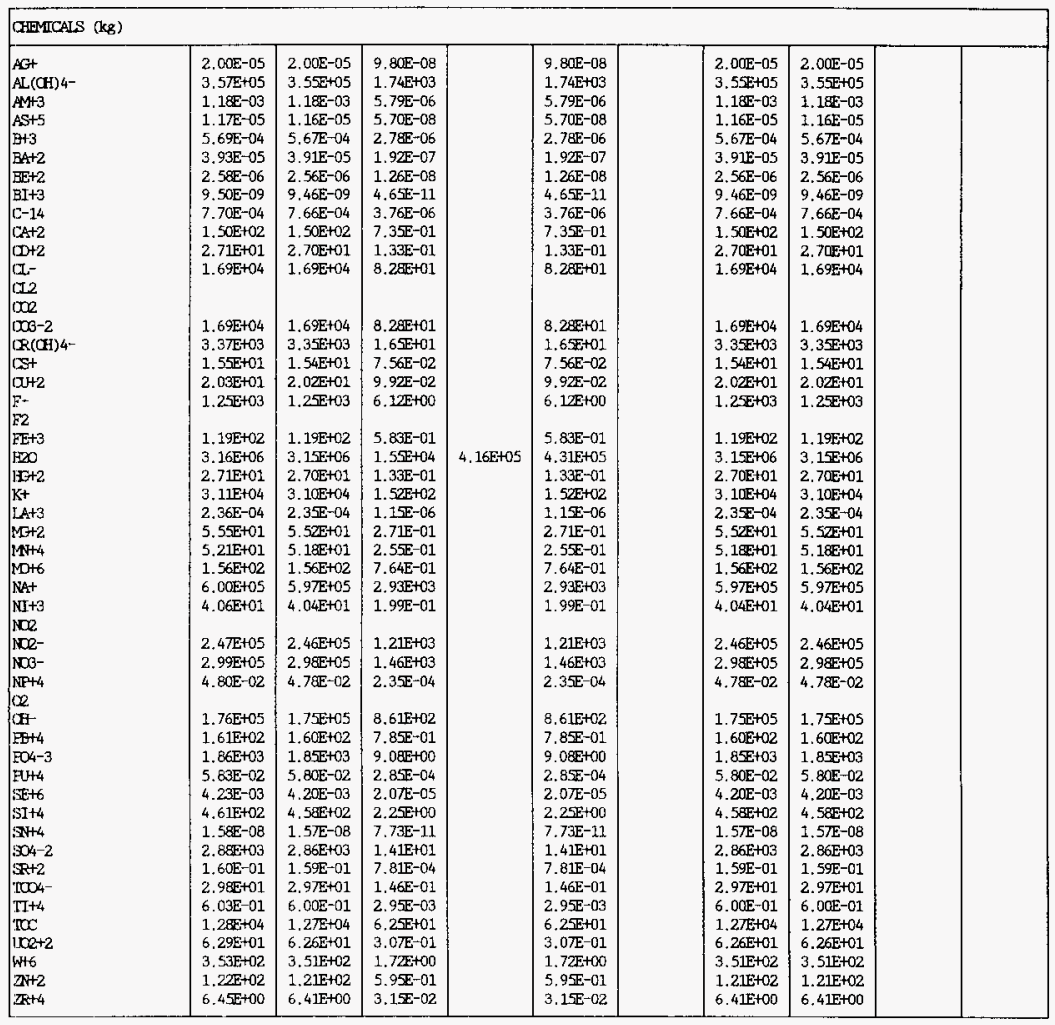


WHC-SD-WM-TI-774 Rev. 0

TWRS PRIVATIZATION PROCESS TECHNICAL BASELINE

Table B- 5 Thase 1 LAW Mass Balance for Batch $\mathrm{PCl} / 5$ (6 sheets)

\begin{tabular}{|c|c|c|c|c|c|c|c|c|c|c|}
\hline $\begin{array}{l}\text { SIIFEAM NAME } \\
\text { SODI COMONENS }\end{array}$ & 1 & 2 & 3 & 4 & 5 & 6 & 7 & 8 & 9 & 10 \\
\hline Total Mass Flow (kg) & 4. $93 \mathrm{E}+04$ & 4. $93 E+02$ & 4. $88 E+04$ & & 4. $888+04$ & & 4. $93 \mathrm{E}+02$ & 4. $93 E+02$ & & \\
\hline \multicolumn{11}{|l|}{ RADIDNUCLImES (Ci) } \\
\hline $\begin{array}{l}\text { Cesium } \\
\text { Strontiun } \\
\text { Tecinetiun } \\
\text { TRU }\end{array}$ & & & & & & & & & & \\
\hline \multicolumn{11}{|l|}{ (CHEMICAIS (kg) } \\
\hline 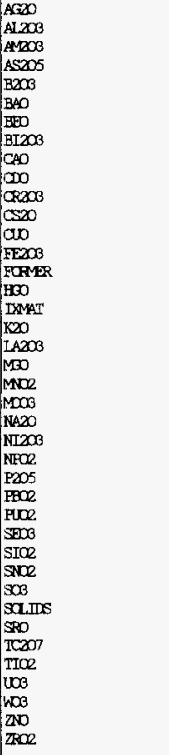 & $4.93 E+04$ & $4.93 E+02$ & $4.888+04$ & & $4.88 E+04$ & & $4,93 E+02$ & $4.93 \mathrm{E}+02$ & & \\
\hline
\end{tabular}


WHC-SD-WM-TI-774 Rev. 0

TWRS PRIVATIZATION PROCESS TECHNICAL BASELINE

Table B-5 Phase 1 LAW Mass Balance for Batch PCl/5 (6 sheets)

\begin{tabular}{|c|c|c|c|c|c|c|c|c|c|c|}
\hline $\begin{array}{l}\text { SIHEAM NGME } \\
\text { IIOUID COMROWWIS }\end{array}$ & 11 & 12 & 23 & 14 & 15 & 16 & 164 & 17 & 18 & 19 \\
\hline $\begin{array}{l}\text { Volume (L) } \\
\text { Density }(g / L)\end{array}$ & & $\begin{array}{l}3.49 E+06 \\
1.41 E+03\end{array}$ & $\begin{array}{l}3.14 \mathrm{E}+03 \\
3.32 \mathrm{E}+03\end{array}$ & & $\begin{array}{l}3.14 \mathrm{E}+03 \\
3.32 \mathrm{E}+03\end{array}$ & $\begin{array}{l}3.49 E+06 \\
1.41 E+03\end{array}$ & $\begin{array}{l}4.87 \mathrm{E}+06 \\
1.00 \mathrm{D}+03\end{array}$ & & $\begin{array}{l}\text { 1. } 00 E-09 \\
1.00 E+03\end{array}$ & $\begin{array}{l}1.00 E-09 \\
1.00 E+03\end{array}$ \\
\hline Total Mass Flaw (kg) & & $4.91 \mathrm{E}+06$ & $1.05 \mathrm{E}+04$ & & $1.0 \mathrm{EE}+04$ & $4.91 E+06$ & $4.87 \mathrm{E}+06$ & & 1. $00 \mathrm{E}-09$ & 1. $00 \mathrm{E}-09$ \\
\hline \multicolumn{11}{|l|}{ RADIOACLIES (Ci) } \\
\hline $\begin{array}{l}\text { Cesiun } \\
\text { Struntium } \\
\text { Technetium } \\
\text { TFU }\end{array}$ & & $\begin{array}{l}4.57 E+03 \\
2.21 E+04 \\
3.03 E+02 \\
8.28 E+00\end{array}$ & $\begin{array}{l}1.33 \mathrm{E}+06 \\
3.08 \mathrm{E}+00\end{array}$ & & $\begin{array}{l}1.33 \mathrm{E}+06 \\
3.08 \mathrm{E}+00\end{array}$ & $\begin{array}{l}4.57 \mathrm{E}+03 \\
2.21 \mathrm{E}+04 \\
3.03 \mathrm{E}+02 \\
8.28 \mathrm{E}+00\end{array}$ & & & & \\
\hline
\end{tabular}

\begin{tabular}{|c|c|c|c|c|c|c|c|}
\hline \multicolumn{8}{|c|}{ GRMACALS (kg) } \\
\hline 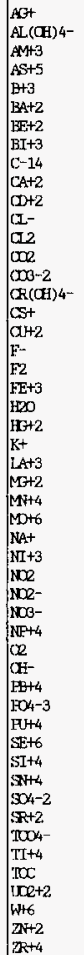 & 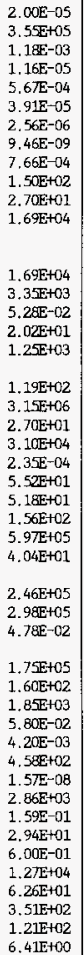 & $\begin{array}{l}\text { 6.00E+03 } \\
\text { 4.44E+03 }\end{array}$ & $\begin{array}{l}1.53 \mathrm{E}+01 \\
6.00 \mathrm{E}+03 \\
\text { 4. } 44 \mathrm{EE}+03\end{array}$ & 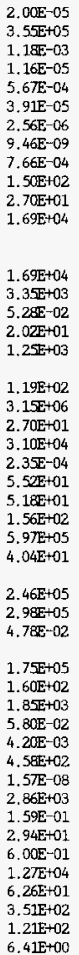 & $\begin{array}{l}\text { 1. } 699 \mathrm{E}+104 \\
5.90 \mathrm{E}+04 \\
1.2 \mathrm{EE}+03 \\
3.38 \mathrm{E}+06\end{array}$ & $1.00 \mathrm{E}-09$ & 1. $00 \mathrm{CE}-09$ \\
\hline
\end{tabular}


WHC-SD-WM-TI-774 Rev. 0

TWRS PRIVATIZATION PROCESS TECHNICAL BASELINE

Table B-5 Fhase 1 IAW Mass Balance for Batch PC1/5 ( 6 sheets)

\begin{tabular}{|c|c|c|c|c|c|c|c|c|c|c|}
\hline $\begin{array}{l}\text { SIREAM RAME } \\
\text { SOID COMONENIS }\end{array}$ & 11 & 12 & 13 & 14 & 15 & 16 & $16 \mathrm{~A}$ & 17 & 18 & 19 \\
\hline Total Mass Flow (cg) & & 4. $93 \mathrm{E}+02$ & & $6.00 \mathrm{E}+03$ & $6.00 \mathrm{E}+03$ & $4.93 E+02$ & $1.04 E+06$ & & & \\
\hline \multicolumn{11}{|l|}{ RADIONUCDISS (Ci) } \\
\hline $\begin{array}{l}\text { Cesium } \\
\text { Strantium } \\
\text { Technetiun } \\
\text { TINJ }\end{array}$ & & & & & & & $\begin{array}{l}\text { 4. } 57 \mathrm{E}+03 \\
2.21 \mathrm{E}+04 \\
3.03 \mathrm{E}+02 \\
8.23 \mathrm{2}+00\end{array}$ & & & \\
\hline \multicolumn{11}{|l|}{ (GEMICAIS (kg) } \\
\hline 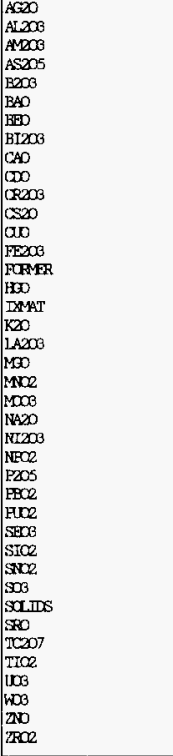 & & $4.93 \mathrm{E}+02$ & & $6.00 \mathrm{E}+03$ & $6.00 \mathrm{E}+03$ & 4. $93 E+02$ & $\begin{array}{l}2.14 \mathrm{E}-05 \\
1.91 \mathrm{E}+05 \\
1.30 \mathrm{E}-03 \\
1.78 \mathrm{E}-05 \\
1.82 \mathrm{E}-03 \\
4.37 \mathrm{E}-05 \\
7.11 \mathrm{E}-06 \\
1.0 \mathrm{E}-08 \\
2.09 \mathrm{E}+02 \\
3.08 \mathrm{E}+01 \\
2.12 \mathrm{E}+03 \\
5.59 \mathrm{E}-02 \\
2.53 \mathrm{E}+01 \\
1.70 \mathrm{E}+02 \\
2.92 \mathrm{E}+01 \\
\\
3.73 \mathrm{E}+04 \\
2.75 \mathrm{E}-04 \\
9.1 \mathrm{E}+01 \\
8.20 \mathrm{E}+01 \\
2.34 \mathrm{E}+02 \\
8.04 \mathrm{E}+05 \\
5.69 \mathrm{E}+01 \\
5.43 \mathrm{E}-02 \\
1.38 \mathrm{E}+03 \\
1.85 \mathrm{E}+02 \\
6.58 \mathrm{E}-02 \\
6.76 \mathrm{E}-03 \\
9.80 \mathrm{E}+02 \\
2.00 \mathrm{E}-08 \\
2.39 \mathrm{E}+03 \\
4.93 \mathrm{E}+02 \\
1.97 \mathrm{E}-01 \\
2.79 \mathrm{E}+01 \\
1.00 \mathrm{E}+00 \\
6.63 \mathrm{E}+01 \\
4.42 \mathrm{E}+02 \\
1.51 \mathrm{E}+02 \\
8.66 \mathrm{E}+00\end{array}$ & & & \\
\hline
\end{tabular}


WHC-SD-WM-TI-774 ReV. 0

TWRS PRIVATIZATION PROCESS TECHNICAL BASELINE

Table B-5 Fhase I LAW Mass Balance for Batch PCl/5 (6 sheets)

\begin{tabular}{|c|c|c|c|c|c|c|c|c|c|}
\hline $\begin{array}{l}\text { ISIREAM NAME } \\
\text { LIRUID OOMFONDIS }\end{array}$ & 20 & 21 & 22 & 23 & 24 & 25 & 26 & 27 & 28 \\
\hline $\begin{array}{l}\text { Volume }(\mathrm{L}) \\
\text { Density }(\mathrm{g} / \mathrm{L})\end{array}$ & $\begin{array}{l}4.87 \mathrm{E}+06 \\
1.00 \mathrm{E}+03\end{array}$ & & & & $\begin{array}{l}1.49 \mathrm{E}+06 \\
1.00 \mathrm{E}+03\end{array}$ & $\begin{array}{l}3.38 \mathrm{E}+06 \\
1.00 \mathrm{E}+03\end{array}$ & $\begin{array}{l}3.13 E+03 \\
3.34 E+03\end{array}$ & $\begin{array}{l}3.00 E-10 \\
3.34 E+03\end{array}$ & $\begin{array}{l}1.00 \mathrm{E}+06 \\
1.00 \mathrm{E}+03\end{array}$ \\
\hline Total Mass Flon (kg) & $4.87 z+06$ & & & & 1.49E+06 & $3.32 E+06$ & $1.04 E+04$ & $1.00 E-09$ & $1.00 \mathrm{E}+06$ \\
\hline \multicolumn{10}{|l|}{ RADIONUCLIIAS (C1) } \\
\hline $\begin{array}{l}\text { Cesium } \\
\text { Strontium } \\
\text { Techrnetium } \\
\text { IRIJ }\end{array}$ & & & & & & & & & \\
\hline
\end{tabular}

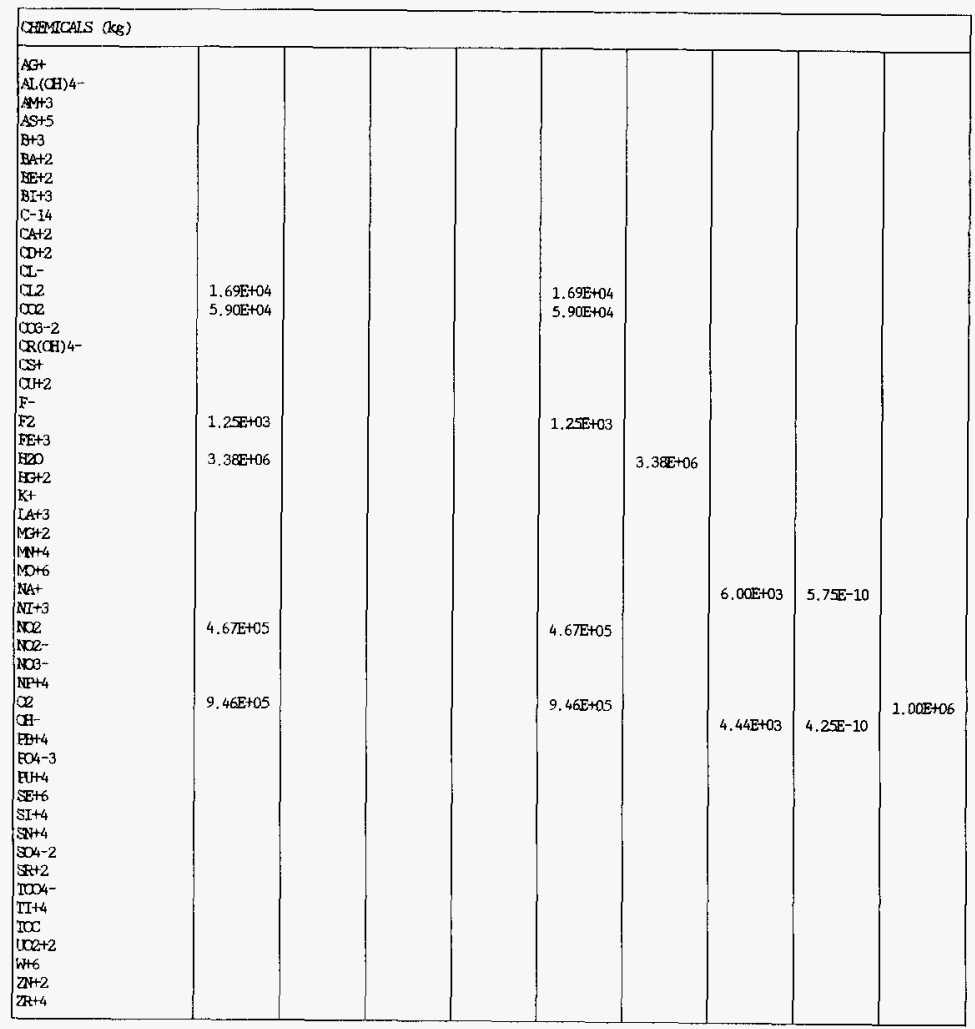


WHC-SD-WM-TI-774 Rev. 0

TWRS PRIVATIZATION PROCESS TECHNICAL BASELINE

Table B-5 Phase 1 LAW Mass Balance for Batch PCl/5 (6 sheets)

\begin{tabular}{|c|c|c|c|c|c|c|c|c|c|}
\hline $\begin{array}{l}\text { SIREAM NAE } \\
\text { Sa.ID COMRGENIS }\end{array}$ & 20 & 21 & 22 & 23 & 24 & 25 & 26 & 27 & 28 \\
\hline Total Mass Flow (kg) & & 1.04E+06 & $3.72 \mathrm{E}+06$ & 4. $76 \mathrm{E}+06$ & & & & & \\
\hline \multicolumn{10}{|l|}{ RADIONUCLIIES (Ci) } \\
\hline $\begin{array}{l}\text { Cosium } \\
\text { Struntium } \\
\text { Technetium } \\
\text { TRU }\end{array}$ & & $\begin{array}{l}4.57 \mathrm{E}+03 \\
2.21 \mathrm{E}+04 \\
3.03 \mathrm{E}+02 \\
8.23 \mathrm{E}+00\end{array}$ & & $\begin{array}{l}4.57 \mathrm{E}+03 \\
2.21 \mathrm{E}+04 \\
3.03 \mathrm{E}+02 \\
8.23 \mathrm{E}+00\end{array}$ & & & & & \\
\hline \multicolumn{10}{|l|}{ (AHFMTCALS (kg) } \\
\hline 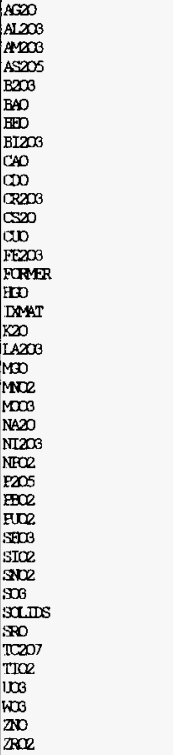 & & $\begin{array}{l}2.14 \mathrm{E}-05 \\
1.91 \mathrm{E}+05 \\
1.30 \mathrm{E}-03 \\
1.78 \mathrm{E}-05 \\
1.82 \mathrm{E}-03 \\
4.37 \mathrm{E}-05 \\
7.11 \mathrm{E}-06 \\
1.05 \mathrm{E}-08 \\
2.09 \mathrm{E}+02 \\
3.08 \mathrm{E}+01 \\
2.12 \mathrm{E}+03 \\
5.59 \mathrm{E}-02 \\
2.53 \mathrm{E}+01 \\
1.70 \mathrm{E}+02 \\
\\
2.92 \mathrm{E}+01 \\
\\
3.73 \mathrm{E}+04 \\
2.75 \mathrm{E}-04 \\
9.1 \mathrm{E}+01 \\
8.20 \mathrm{E}+01 \\
2.34 \mathrm{E}+02 \\
8.04 \mathrm{E}+05 \\
5.69 \mathrm{E}+01 \\
5.43 \mathrm{E}-02 \\
1.38 \mathrm{E}+03 \\
1.85 \mathrm{E}+02 \\
6.58 \mathrm{E}-02 \\
6.76 \mathrm{E}-03 \\
9.80 \mathrm{E}+02 \\
2.00 \mathrm{E}-08 \\
2.39 \mathrm{E}+03 \\
4.93 \mathrm{E}+02 \\
1.87 \mathrm{E}-01 \\
2.79 \mathrm{E}+01 \\
1.00 \mathrm{E}+00 \\
6.63 \mathrm{E}+01 \\
4.42 \mathrm{E}+02 \\
1.51 \mathrm{E}+02 \\
8.66 \mathrm{E}+00\end{array}$ & $3,72 E+06$ & $\begin{array}{l}2.14 \mathrm{E}-05 \\
1.91 \mathrm{E}+05 \\
1.30 \mathrm{E}-03 \\
1.78 \mathrm{E}-05 \\
1.82 \mathrm{E}-03 \\
4.37 \mathrm{E}-05 \\
7.11 \mathrm{E}-06 \\
1.05 \mathrm{E}-08 \\
2.09 \mathrm{E}+02 \\
3.08 \mathrm{E}+01 \\
2.12 \mathrm{E}+03 \\
5.59 \mathrm{E}-02 \\
2.53 \mathrm{E}+01 \\
1.70 \mathrm{E}+02 \\
3.72 \mathrm{E}+06 \\
2.92 \mathrm{E}+01 \\
\\
3.73 \mathrm{E}+04 \\
2.75 \mathrm{E}-04 \\
9.15 \mathrm{E}+01 \\
8.20 \mathrm{E}+01 \\
2.34 \mathrm{E}+02 \\
8.04 \mathrm{E}+05 \\
5.69 \mathrm{E}+01 \\
5.43 \mathrm{E}-02 \\
1.38 \mathrm{E}+03 \\
1.85 \mathrm{E}+02 \\
6.58 \mathrm{E}-02 \\
6.76 \mathrm{E}-03 \\
9.80 \mathrm{E}+02 \\
2.00 \mathrm{E}-08 \\
2.39 \mathrm{E}+03 \\
4.93 \mathrm{E}+02 \\
1.87 \mathrm{E}-01 \\
2.79 \mathrm{E}+01 \\
1.00 \mathrm{E}+00 \\
6.63 \mathrm{E}+01 \\
4.42 \mathrm{E}+02 \\
1.51 \mathrm{E}+02 \\
8.66 \mathrm{E}+00\end{array}$ & & & & & \\
\hline
\end{tabular}


WHC-SD-WM-TI-774 ReV. 0

\section{TWRS PRIVATIZATION PROCESS TECHNICAL BASELINE}

Table B-6 Phase 1 LAW Mass Balance for Batch PC1/6 (6 sheets)

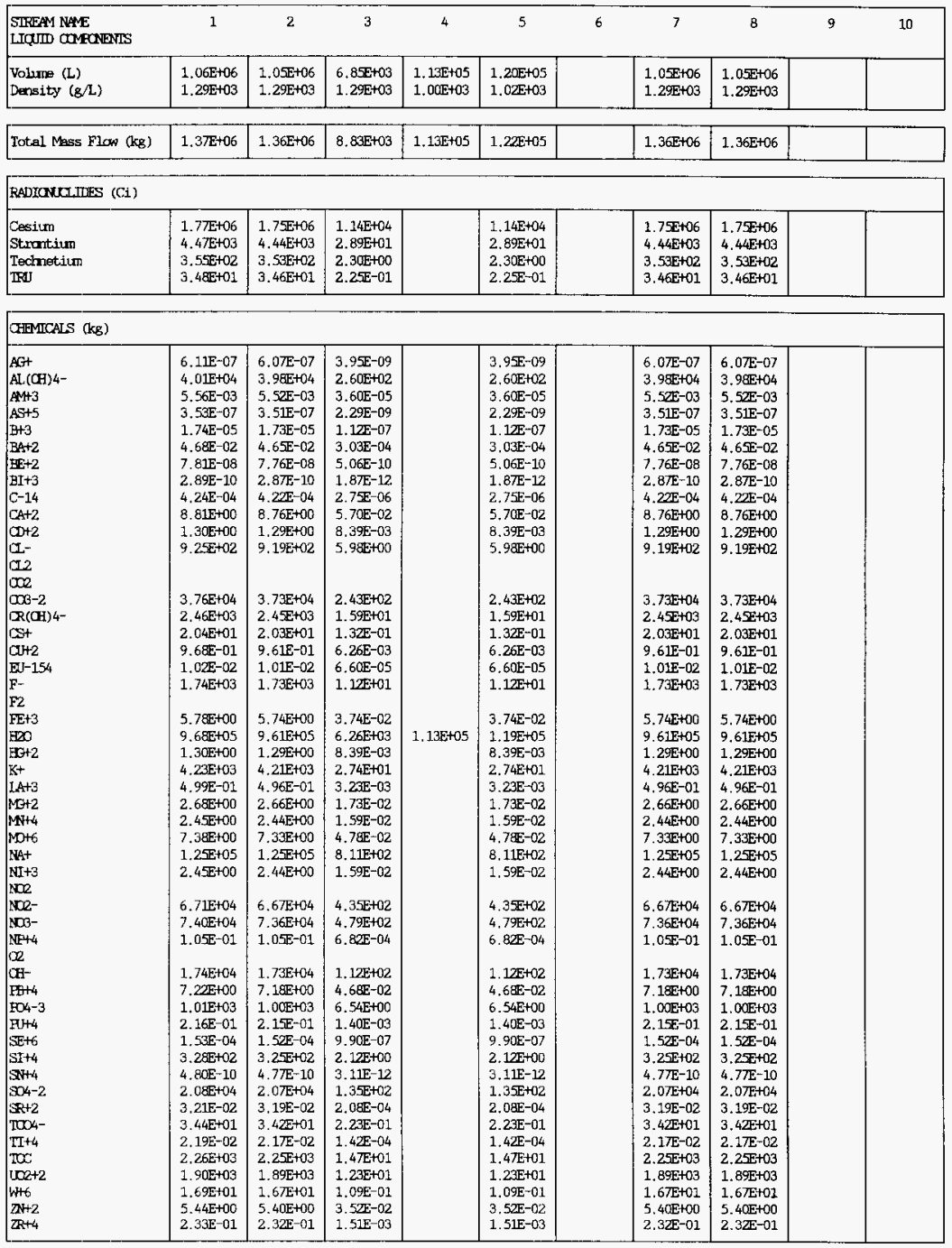


WHC-SD-WM-TI-774 Rev. 0

\section{TWRS PRIVATIZATION PROCESS TECHNICAL BASELINE}

Table B- 6 Phase 1 IAW Mass Balance for Batch $\mathrm{PCl} / 6$ (6 sheets)

\begin{tabular}{|c|c|c|c|c|c|c|c|c|c|c|}
\hline $\begin{array}{l}\text { SIREAM NAME } \\
\text { SAID CMFAOISS }\end{array}$ & 1 & 2 & 3 & 4 & 5 & 6 & 7 & 8 & 9 & 10 \\
\hline Total Mass Flow (kg) & $1.37 E+04$ & $1.37 \mathrm{E}+02$ & $1.35 E+04$ & & $1.35 \mathrm{EE}+04$ & & $1.37 \mathrm{E}+02$ & $1,37 \mathrm{E}+02$ & & \\
\hline \multicolumn{11}{|l|}{ RADIONUIIIES (Ci) } \\
\hline $\begin{array}{l}\text { Cesium } \\
\text { Strantium } \\
\text { Technetium } \\
\text { IRI }\end{array}$ & & & & & & & & & & \\
\hline
\end{tabular}

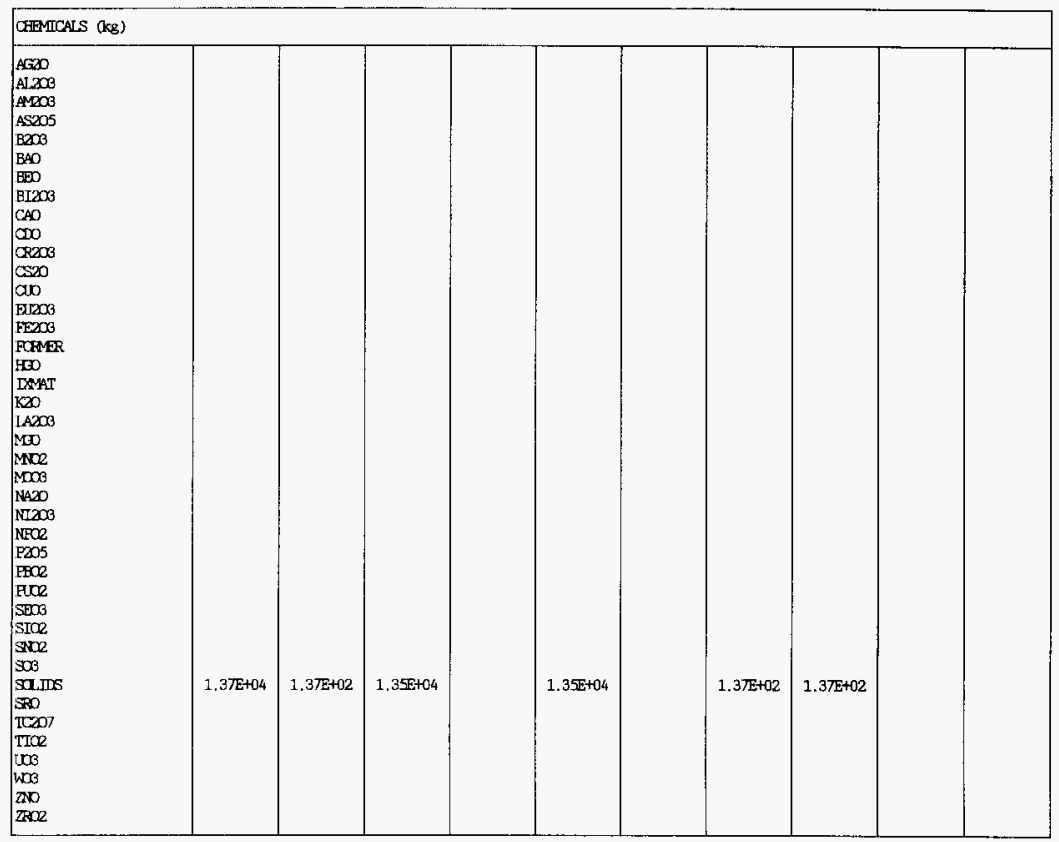


WHC-SD-WM-TI-774 Rev. 0

TWRS PRIVATIZATION PROCESS TECHNICAL BASELINE

Table B-6 Phase 1 LAW Mass Balance for Batch $\mathrm{PCl} / 6$ (6 sheets)

\begin{tabular}{|c|c|c|c|c|c|c|c|c|c|c|}
\hline $\begin{array}{l}\text { STHFAM NAME } \\
\text { IIQUID CIMFANDIS }\end{array}$ & 11 & 12 & 13 & 14 & 15 & 16 & $16 \mathrm{~A}$ & 17 & 18 & 19 \\
\hline $\begin{array}{l}\text { Volume }(L) \\
\text { Density }(g / L)\end{array}$ & & $\begin{array}{l}1.05 E+06 \\
1.29 E+03\end{array}$ & $\begin{array}{l}6.74 E+02 \\
3.27 E+03\end{array}$ & & $\begin{array}{l}6.74 \mathrm{E}+02 \\
3.27 \mathrm{E}+03\end{array}$ & $\begin{array}{l}1.05 E+06 \\
1.29 E+03\end{array}$ & $\begin{array}{l}2.14 E+06 \\
1.00 E+03\end{array}$ & $\begin{array}{l}6.64 E+02 \\
3.30 E+03\end{array}$ & $\begin{array}{l}1.29 \mathrm{E}+03 \\
1.00 \mathrm{E}+03\end{array}$ & $\begin{array}{l}1.925+03 \\
1.80 \mathrm{E}+03\end{array}$ \\
\hline Total Mass Elow (kg) & & $1.36 \mathrm{E}+06$ & $2.20 \mathrm{E}+03$ & & $2.20 \mathrm{E}+03$ & $1.36 \mathrm{E}+06$ & $2.14 E+06$ & $2.19 \mathrm{E}+03$ & 1.2SE+03 & $3.44 \mathrm{E}+03$ \\
\hline \multicolumn{11}{|l|}{ RADIONUCIIDES (Ci) } \\
\hline $\begin{array}{l}\text { Cesium } \\
\text { Strantium } \\
\text { Technetium } \\
\text { 'IRU }\end{array}$ & & $\begin{array}{l}2.39 \mathrm{E}+03 \\
4.44 \mathrm{E}+03 \\
3.49 \mathrm{E}+02 \\
3.46 \mathrm{E}+01\end{array}$ & $\begin{array}{l}1.75 E+06 \\
3.55+00\end{array}$ & & $\begin{array}{l}1.75 \mathrm{E}+06 \\
3.55 \mathrm{~F}+00\end{array}$ & $\begin{array}{l}2.39 E+03 \\
4.44 E+03 \\
2.39 E+02 \\
3.46 E+01\end{array}$ & & $1.10 \mathrm{E}+02$ & & 1. 10E+02 \\
\hline \multicolumn{11}{|l|}{ CHIMICAIS (kg) } \\
\hline 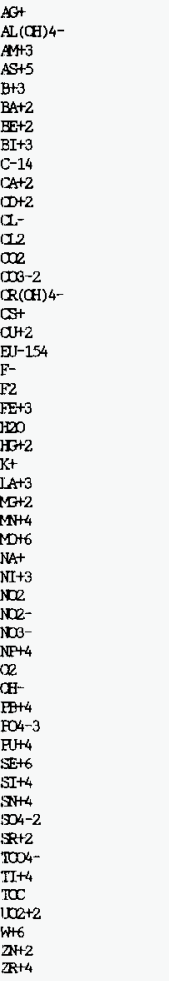 & & $\begin{array}{l}6.07 \mathrm{E}-07 \\
3.98 \mathrm{E}+04 \\
5.52 \mathrm{E}-03 \\
3.51 \mathrm{E}-07 \\
1.73 \mathrm{E}-05 \\
4.6 \mathrm{E}-02 \\
7.76 \mathrm{E}-08 \\
2.87 \mathrm{E}-10 \\
4.22 \mathrm{E}-04 \\
8.76 \mathrm{E}+00 \\
1.29 \mathrm{E}+00 \\
9.19 \mathrm{E}+02 \\
\\
3.73 \mathrm{E}+04 \\
2.45 \mathrm{E}+03 \\
2.76 \mathrm{E}-02 \\
9.61 \mathrm{E}-01 \\
1.01 \mathrm{E}-02 \\
1.73 \mathrm{E}+03 \\
\\
5.74 \mathrm{E}+00 \\
9.61 \mathrm{E}+05 \\
1.29 \mathrm{E}+00 \\
4.21 \mathrm{E}+03 \\
4.96 \mathrm{E}-01 \\
2.66 \mathrm{E}+00 \\
2.44 \mathrm{E}+00 \\
7.33 \mathrm{E}+00 \\
1.25 \mathrm{E}+05 \\
2.44 \mathrm{E}+00 \\
6.67 \mathrm{E}+04 \\
7.36 \mathrm{E}+04 \\
1.05 \mathrm{E}-01 \\
1.73 \mathrm{E}+04 \\
7.18 \mathrm{E}+00 \\
1.00 \mathrm{E}+03 \\
2.15 \mathrm{E}-01 \\
1.52 \mathrm{E}-04 \\
3.25 \mathrm{E}+02 \\
4.7 \mathrm{E}-10 \\
2.07 \mathrm{E}+04 \\
3.19 \mathrm{E}-02 \\
3.39 \mathrm{E}+01 \\
2.17 \mathrm{E}-02 \\
2.25 \mathrm{E}+03 \\
1.89 \mathrm{E}+03 \\
1.67 \mathrm{E}+01 \\
5.40 \mathrm{E}+00 \\
2.32 \mathrm{E}-01\end{array}$ & $\begin{array}{l}2.02 \mathrm{E}+01 \\
1.25 \mathrm{E}+03 \\
9.27 \mathrm{E}+02 \\
3.44 \mathrm{E}-01\end{array}$ & & $\begin{array}{l}2.02 \mathrm{E}+01 \\
1.25 \mathrm{E}+03 \\
9.27 \mathrm{E}+02 \\
3.44 \mathrm{E}-01\end{array}$ & $\begin{array}{l}6.07 \mathrm{E}-07 \\
3.98 \mathrm{E}+04 \\
5.52 \mathrm{E}-03 \\
3.51 \mathrm{E}-07 \\
1.73 \mathrm{E}-05 \\
4.65 \mathrm{E}-02 \\
7.76 \mathrm{E}-08 \\
2.87 \mathrm{E}-10 \\
4.22 \mathrm{E}-04 \\
8.76 \mathrm{E}+00 \\
1.29 \mathrm{E}+00 \\
9.19 \mathrm{E}+02 \\
\\
3.73 \mathrm{E}+04 \\
2.4 \mathrm{EE}+03 \\
2.76 \mathrm{E}-02 \\
9.61 \mathrm{E}-01 \\
1.01 \mathrm{E}-02 \\
1.73 \mathrm{E}+03 \\
\\
5.74 \mathrm{E}+00 \\
9.61 \mathrm{E}+05 \\
1.29 \mathrm{E}+00 \\
4.21 \mathrm{E}+03 \\
4.96 \mathrm{E}-01 \\
2.66 \mathrm{E}+00 \\
2.44 \mathrm{E}+00 \\
7.33 \mathrm{E}+00 \\
1.25 \mathrm{E}+05 \\
2.44 \mathrm{E}+00 \\
6.6 \mathrm{E}+04 \\
7.36 \mathrm{E}+04 \\
1.05 \mathrm{E}-01 \\
1.73 \mathrm{E}+04 \\
5.40 \mathrm{E}+00 \\
2.32 \mathrm{E}-01\end{array}$ & $\begin{array}{l}9.19 \mathrm{E}+02 \\
3.56 \mathrm{E}+04 \\
1.73 \mathrm{E}+03 \\
9.86 \mathrm{E}+05 \\
1.21 \mathrm{E}+05 \\
9.94 \mathrm{E}+05\end{array}$ & $\begin{array}{l}1.25 \mathrm{E}+03 \\
1.07 \mathrm{E}+01 \\
9.27 \mathrm{E}+02\end{array}$ & $1.25+03$ & $\begin{array}{l}\text { 1. 25E+03 } \\
\text { 1.2सE+03 } \\
\text { 9.27E+02 }\end{array}$ \\
\hline
\end{tabular}


WHC-SD-WM-TI-774 Rev. 0

TWRS PRIVATIZATION PROCESS TECHNICAL BASELINE

Table B-6 Phase 1 IAW Mass Balance for Batch PC1/6 (6 sheets)

\begin{tabular}{|c|c|c|c|c|c|c|c|c|c|c|}
\hline $\begin{array}{l}\text { SIREAM NAM } \\
\text { SODD COMONENIS }\end{array}$ & 11 & 12 & 13 & 14 & 15 & 16 & $16 \mathrm{~A}$ & 17 & 18 & 19 \\
\hline Total Mass Flow (kg) & & $1.37 \mathrm{E}+02$ & & 1. $25 E+03$ & 1.2SE+03 & 1. $37 E+02$ & $2.17 E+05$ & & & \\
\hline \multicolumn{11}{|l|}{ RADTONUCLIIES (Ci) } \\
\hline $\begin{array}{l}\text { Cesium } \\
\text { Strantium } \\
\text { Technetium } \\
\text { TRU }\end{array}$ & & & & & & & $\begin{array}{l}2.39 \mathrm{E}+03 \\
4.44 \mathrm{E}+03 \\
2.39 \mathrm{E}+02 \\
3.44 \mathrm{E}+01\end{array}$ & & & \\
\hline \multicolumn{11}{|l|}{ CERMICALS (KR) } \\
\hline 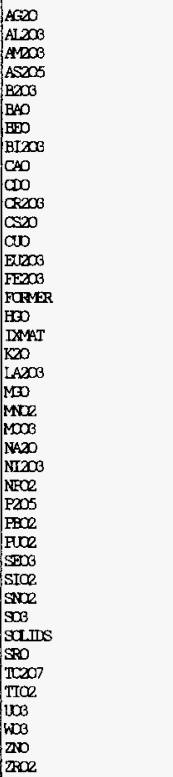 & & $1.37 \mathrm{E}+02$ & & $1.25 \mathrm{E}+03$ & $1.255+03$ & $1.3 \pi+02$ & $\begin{array}{l}6.52 \mathrm{E}-07 \\
2.14 \mathrm{E}+04 \\
6.07 \mathrm{E}-03 \\
5.39 \mathrm{E}-07 \\
5.56 \mathrm{E}-05 \\
5.20 \mathrm{E}-02 \\
2.15 \mathrm{E}-07 \\
3.20 \mathrm{E}-10 \\
1.23 \mathrm{E}+01 \\
1.47 \mathrm{E}+00 \\
1.55 \mathrm{E}+03 \\
2.92 \mathrm{E}-02 \\
1.20 \mathrm{E}+00 \\
1.17 \mathrm{E}-02 \\
8.21 \mathrm{E}+00 \\
\\
1.39 \mathrm{E}+00 \\
\\
5.07 \mathrm{E}+03 \\
5.82 \mathrm{E}-01 \\
4.41 \mathrm{E}+00 \\
3.86 \mathrm{E}+00 \\
1.10 \mathrm{E}+01 \\
1.68 \mathrm{E}+0.5 \\
3.43 \mathrm{E}+00 \\
1.19 \mathrm{E}-01 \\
7.51 \mathrm{E}+02 \\
8.29 \mathrm{E}+00 \\
2.44 \mathrm{E}-01 \\
2.44 \mathrm{E}-04 \\
6.96 \mathrm{E}+02 \\
6.06 \mathrm{E}-10 \\
1.72 \mathrm{E}+04 \\
1.37 \mathrm{E}+02 \\
3.76 \mathrm{E}-02 \\
2.20 \mathrm{E}+01 \\
3.62 \mathrm{E}-02 \\
2.00 \mathrm{E}+03 \\
2.11 \mathrm{E}+01 \\
6.72 \mathrm{E}+00 \\
3.13 \mathrm{E}-01\end{array}$ & & & \\
\hline
\end{tabular}


WHC-SD-WM-TI-774 Rev. 0

TWRS PRIVATIZATION PROCESS TECHNICAL BASELINE

Table B-6 Phase 1 LAW Mass Balance for Batch PCl/6 (6 sheets)

\begin{tabular}{|c|c|c|c|c|c|c|c|c|c|}
\hline $\begin{array}{l}\text { SIREAM NAME } \\
\text { LTQUID COMFUNENS }\end{array}$ & 20 & 21 & 22 & 23 & 24 & 25 & 26 & 27 & 28 \\
\hline $\begin{array}{l}\text { Volume (L) } \\
\text { Dansity }(\& / L)\end{array}$ & $\begin{array}{l}2.14 E+06 \\
1.00 E+03\end{array}$ & & & & $\begin{array}{l}1.15 \mathrm{E}+06 \\
1.00 \mathrm{E}+03\end{array}$ & $\begin{array}{l}9.86 E+05 \\
1.00 E+03\end{array}$ & $\begin{array}{l}6.54 E+02 \\
3.34 E+03\end{array}$ & $\begin{array}{l}\text { 6. } 54 \mathrm{E}+02 \\
\text { 3. } 34 \mathrm{E}+03\end{array}$ & $\begin{array}{l}1.00 \mathrm{E}+06 \\
1.00 \mathrm{E}+03\end{array}$ \\
\hline Total Mass Flow (kg) & 2.14E+06 & & & & 1.12E+06 & $9.86 \mathrm{E}+05$ & $2.18 E+03$ & $2.18 E+03$ & $1,00 E+06$ \\
\hline \multicolumn{10}{|l|}{ RADIOMUCLIDES (Ci) } \\
\hline $\begin{array}{l}\text { Cesium } \\
\text { Strantium } \\
\text { Technetium } \\
\text { IRI }\end{array}$ & & & & & & & & & \\
\hline
\end{tabular}

\begin{tabular}{|c|c|c|c|c|c|c|}
\hline \multicolumn{7}{|c|}{ Carmicals (kg) } \\
\hline 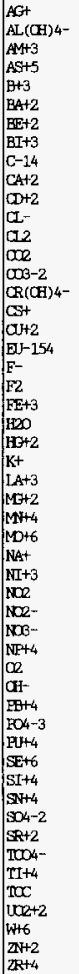 & $\begin{array}{l}9.19 \mathrm{EE}+02 \\
3.56 \mathrm{E}+04 \\
\\
1.73 \mathrm{E}+03 \\
9.86 \mathrm{E}+05 \\
1.21 \mathrm{E}+05 \\
9.94 \mathrm{E}+05\end{array}$ & $\begin{array}{l}9.19 \mathrm{E}+02 \\
3.56 \mathrm{E}+04 \\
1.73 \mathrm{E}+03\end{array}$ & $9.86 E+05$ & $\begin{array}{l}1.2 \pi \mathrm{F}+03 \\
9.2 \pi \mathrm{z}+02 .\end{array}$ & $\begin{array}{l}1.25 \mathrm{E}+03 \\
9.27 \mathrm{E}+02\end{array}$ & 1.00E+06 \\
\hline
\end{tabular}


WHC-SD-WM-TI-774 ReV. 0

TWRS PRIVATIZATION PROCESS TECHNICAL BASELINE

Table B-6 Phase 1 LAW Mass Balance for Batch PCl $/ 6$ (6 sheets)

\begin{tabular}{|c|c|c|c|c|c|c|c|c|c|}
\hline $\begin{array}{l}\text { SIRFAM NAME } \\
\text { SO.J COMFONOIS }\end{array}$ & 20 & 21 & 22 & 23 & 24 & 25 & 26 & 27 & 28 \\
\hline Total Mass Flow (kg) & & $2.17 \mathrm{E}+05$ & $2.27 \mathrm{E}+06$ & $2.49 \mathrm{E}+06$ & & & & & \\
\hline \multicolumn{10}{|l|}{ RADIONUCIIIES (Ci) } \\
\hline $\begin{array}{l}\text { Cesium } \\
\text { Struntiun } \\
\text { Technetium } \\
\text { THJ }\end{array}$ & & $\begin{array}{l}2.39 \mathrm{E}+03 \\
4.44 \mathrm{E}+03 \\
2.39 \mathrm{E}+02 \\
3.44 \mathrm{E}+01\end{array}$ & & $\begin{array}{l}2.39 \mathrm{E}+03 \\
4.44 \mathrm{E}+03 \\
2.39 \mathrm{E}+02 \\
3.44 \mathrm{E}+01\end{array}$ & & & & & \\
\hline \multicolumn{10}{|l|}{ AFMICALS (kg) } \\
\hline 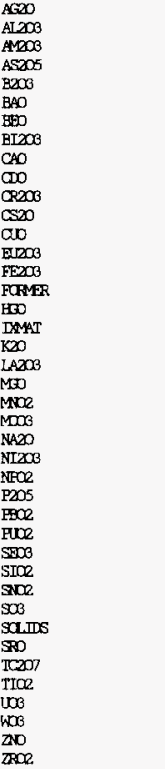 & & $\begin{array}{l}6.52 \mathrm{E}-07 \\
2.14 \mathrm{E}+04 \\
6.07 \mathrm{E}-03 \\
5.39 \mathrm{E}-07 \\
5.56 \mathrm{E}-05 \\
5.20 \mathrm{E}-02 \\
2.15 \mathrm{E}-07 \\
3.20 \mathrm{E}-10 \\
1.23 \mathrm{E}+01 \\
1.47 \mathrm{E}+00 \\
1.55 \mathrm{E}+03 \\
2.92 \mathrm{E}-02 \\
1.20 \mathrm{E}+00 \\
1.17 \mathrm{E}-02 \\
8.21 \mathrm{E}+00 \\
\\
1.39 \mathrm{E}+00 \\
\\
5.07 \mathrm{E}+03 \\
5.82 \mathrm{E}-01 \\
4.41 \mathrm{E}+00 \\
3.86 \mathrm{E}+00 \\
1.10 \mathrm{E}+01 \\
1.68 \mathrm{E}+05 \\
3.43 \mathrm{E}+00 \\
1.19 \mathrm{E}-01 \\
7.51 \mathrm{E}+02 \\
8.29 \mathrm{E}+00 \\
2.44 \mathrm{E}-01 \\
2.44 \mathrm{E}-04 \\
6.96 \mathrm{E}+02 \\
6.06 \mathrm{E}-10 \\
1.72 \mathrm{~F}+04 \\
1.37 \mathrm{E}+02 \\
3.76 \mathrm{E}-02 \\
2.20 \mathrm{E}+01 \\
3.62 \mathrm{E}-02 \\
2.00 \mathrm{E}+03 \\
2.11 \mathrm{E}+01 \\
6.72 \mathrm{E}+00 \\
3.13 \mathrm{E}-01\end{array}$ & $2.27 \mathrm{~F}+06$ & $\begin{array}{l}6.52 \mathrm{E}-07 \\
2.14 \mathrm{E}+04 \\
6.07 \mathrm{E}-03 \\
5.39 \mathrm{E}-07 \\
5.56 \mathrm{E}-05 \\
5.20 \mathrm{E}-02 \\
2.15 \mathrm{E}-07 \\
3.20 \mathrm{E}-10 \\
1.23 \mathrm{E}+01 \\
1.47 \mathrm{E}+00 \\
1.55 \mathrm{E}+03 \\
2.92 \mathrm{E}-02 \\
1.20 \mathrm{E}+00 \\
1.17 \mathrm{E}-02 \\
8.21 \mathrm{E}+00 \\
2.27 \mathrm{E}+06 \\
1.39 \mathrm{E}+00 \\
\\
5.07 \mathrm{E}+03 \\
5.82 \mathrm{E}-01 \\
4.41 \mathrm{E}+00 \\
3.86 \mathrm{E}+00 \\
1.10 \mathrm{E}+01 \\
1.68 \mathrm{E}+05 \\
3.43 \mathrm{E}+00 \\
1.19 \mathrm{E}-01 \\
7.51 \mathrm{E}+02 \\
8.29 \mathrm{E}+00 \\
2.44 \mathrm{E}-01 \\
2.44 \mathrm{E}-04 \\
6.96 \mathrm{E}+02 \\
6.06 \mathrm{E}-10 \\
1.72 \mathrm{E}+04 \\
1.37 \mathrm{E}+02 \\
3.76 \mathrm{E}-02 \\
2.20 \mathrm{E}+01 \\
3.62 \mathrm{E}-02 \\
2.00 \mathrm{E}+03 \\
2.11 \mathrm{E}+01 \\
6.72 \mathrm{E}+00 \\
3.13 \mathrm{E}-01\end{array}$ & & & & & \\
\hline
\end{tabular}


WHC-SD-WM-TI-774 Rev. 0

TWRS PRIVATIZATION PROCESS TECHNICAL BASELINE

Table B-7 Phase 1 LAW Mass Balance for Batch $\mathrm{PCl} / 7$ (6 sheets)

\begin{tabular}{|c|c|c|c|c|c|c|c|c|c|c|}
\hline $\begin{array}{l}\text { SIREAM NAME } \\
\text { LTOUID COMRAENIS }\end{array}$ & 1 & 2 & 3 & 4 & 5 & 6 & 7 & 8 & 9 & 10 \\
\hline $\begin{array}{l}\text { Volume }(\mathrm{L}) \\
\text { Density }(g / \mathrm{L})\end{array}$ & $\begin{array}{l}7.51 \mathrm{E}+05 \\
1.31 \mathrm{E}+03\end{array}$ & $\begin{array}{l}7.4 \mathrm{FE}+05 \\
1.31 \mathrm{E}+03\end{array}$ & $\begin{array}{l}3.66 \mathrm{E}+03 \\
1.31 \mathrm{E}+03\end{array}$ & $\begin{array}{l}8.30 E+04 \\
1.00 E+03\end{array}$ & $\begin{array}{l}8.66 \mathrm{~F}+04 \\
1.01 \mathrm{E}+03\end{array}$ & & $\begin{array}{l}7.47 \mathrm{E}+05 \\
1.31 \mathrm{E}+03\end{array}$ & $\begin{array}{l}7.4 \mathrm{E}+05 \\
1.31 \mathrm{E}+03\end{array}$ & $\begin{array}{l}3.68 \mathrm{E}+01 \\
1.31 \mathrm{E}+03\end{array}$ & $\begin{array}{l}8.36 \mathrm{E}+02 \\
1.00 \mathrm{E}+03\end{array}$ \\
\hline Total Mass Flow (kg) & $9.86 E+05$ & $9.81 E+05$ & $4.80 \mathrm{E}+03$ & $8.30 E+04$ & $8.78 \mathrm{E}+04$ & & $9.81 E+05$ & $9,81 E+05$ & 4. $84 E+01$ & $8.36 E+02$ \\
\hline \multicolumn{11}{|l|}{ RADIONUCIMES (Ci) } \\
\hline $\begin{array}{l}\text { Cestum } \\
\text { Strantium } \\
\text { Technetium } \\
\text { Tस! }\end{array}$ & $\begin{array}{l}3.14 \mathrm{E}+05 \\
4.4 \mathrm{EE}+04 \\
1.87 \mathrm{E}+02 \\
3.20 \mathrm{E}+02\end{array}$ & $\begin{array}{l}3.12 E+05 \\
4.46 E+04 \\
1.86 E+02 \\
3.19 E+02\end{array}$ & $\begin{array}{l}1.53 \mathrm{E}+03 \\
2.18 \mathrm{E}+02 \\
9.13 \mathrm{E}-01 \\
1.56 \mathrm{E}+00\end{array}$ & & $\begin{array}{l}1.53 \mathrm{E}+03 \\
2.18 \mathrm{E}+02 \\
9.13 \mathrm{E}-01 \\
1.56 \mathrm{E}+00\end{array}$ & & $\begin{array}{l}3.12 E+05 \\
5.72 E+03 \\
1.86 E+02 \\
8.11 E+01\end{array}$ & $\begin{array}{l}3.12 \mathrm{E}+0.5 \\
5.72 \mathrm{E}+03 \\
1.86 \mathrm{E}+02 \\
8.11 \mathrm{E}+01\end{array}$ & $\begin{array}{l}1.54 \mathrm{E}+01 \\
2.82 \mathrm{E}-01 \\
9.19 \mathrm{E}-03 \\
4.00 \mathrm{E}-03\end{array}$ & \\
\hline
\end{tabular}

\begin{tabular}{|c|c|c|c|c|c|c|c|c|c|}
\hline \multicolumn{10}{|c|}{ CHEMICALS (kg) } \\
\hline AGH & $5.20 \mathrm{E}-08$ & $5.18 \mathrm{E}-08$ & $2.53 \mathrm{E}-10$ & & $2.53 \mathrm{E}-10$ & $5.18 \mathrm{E}-08$ & $5.18 \mathrm{E}-08$ & $2.55 \mathrm{E}-12$ & \\
\hline AL(OH) 4- & $6.09 E+03$ & $6.05 E+03$ & $2.97 \mathrm{E}+01$ & & $2.97 \mathrm{E}+01$ & $6.06 E+03$ & $6.06 \mathrm{E}+03$ & $2,99 \mathrm{E}-01$ & \\
\hline AMt3 & $8.81 \mathrm{E}-02$ & $8.77 \mathrm{E}-02$ & $4.29 \mathrm{E}-04$ & & $4.29 E-04$ & $2.238-02$ & $2.23 E-02$ & 1. $10 \mathrm{E}-06$ & \\
\hline$A S+5$ & $3,01 \mathrm{E}-08$ & $2.99 \mathrm{E}-08$ & $1,47 \mathrm{E}-10$ & & $1.47 \mathrm{E}-10$ & $2,99 \mathrm{E}-08$ & $2.99 \mathrm{E}-08$ & $1.48 \mathrm{E}-12$ & \\
\hline $\mathrm{B}+3$ & $1.48 \mathrm{E}-06$ & $1.4 \pi \mathrm{E}-06$ & $7.20 \mathrm{E}-09$ & & $7.20 \mathrm{E}-09$ & $1.47 \mathrm{E}-06$ & $1.4 \pi-06$ & $7.25 \mathrm{E}-11$ & \\
\hline $\mathrm{BA}+2$ & $5.03 \mathbf{E}-03$ & $5.00 \mathrm{E}-03$ & $2.45 \mathrm{E}-05$ & & $2.4 \mathrm{EE}-05$ & $5.00 E-03$ & $5.00 \mathrm{E}-03$ & $2.4 \pi \mathrm{E}-07$ & \\
\hline $\mathrm{EE}+2$ & $6.65 \mathrm{E}-09$ & $6.62 \mathrm{E}-09$ & 3. $24 \mathrm{E}-11$ & & $3.24 \mathrm{E}-11$ & 6. $62 \mathrm{E}-09$ & $6.62 \mathrm{E}-09$ & $3.26 \mathrm{E}-13$ & \\
\hline $\mathrm{BI}+3$ & $2.45 E-11$ & $2.44 \mathrm{E}-11$ & $1,20 \mathrm{E}-13$ & & $1.20 \mathrm{E}-13$ & $2.44 E-11$ & $2.44 \mathrm{E}-11$ & 1. $20 \mathrm{E}-15$ & \\
\hline$c-14$ & $4.50 \mathrm{EE}-05$ & $4.48 \mathrm{E}-05$ & $2.19 \mathrm{E}-07$ & & $2.19 \mathrm{E}-07$ & $4.48 E-05$ & $4,48 E-05$ & $2.21 E-09$ & \\
\hline $\mathrm{CA}+2$ & $2.652+02$ & $2.64 E+02$ & $1.29 \mathrm{E}+00$ & & $1.29 \mathrm{E}+00$ & $2.64 E+02$ & $2.64 \mathrm{E}+02$ & 1. $30 \mathrm{E}-02$ & \\
\hline$\alpha+2$ & $1.2 .18-01$ & $1.20 \mathrm{E}-01$ & $5.89 \mathrm{E}-04$ & & $5.89 \mathrm{E}-04$ & 1. $20 \mathrm{E}-01$ & 1. $20 \mathrm{E}-01$ & $5.93 \mathrm{E}-06$ & \\
\hline $\bar{c}-$ & $1.582+03$ & $1.5 \pi+03$ & $7.70 \mathrm{E}+\infty 0$ & & $7.70 \mathrm{E}+00$ & $1.57 \mathrm{E}+03$ & $1.57 \mathrm{E}+03$ & $7.76 E-02$ & \\
\hline \multicolumn{10}{|l|}{012} \\
\hline \multicolumn{10}{|l|}{$\cos$} \\
\hline$\infty \mathrm{O}-2$ & 4. $01 E+04$ & $3.99 E+04$ & $1.95 \mathrm{E}+02$ & & 1. $95 \mathrm{E}+02$ & 3. $99 \mathrm{E}+04$ & $3.99 E+04$ & 1. $97 \mathrm{E}+00$ & \\
\hline $\mathrm{R}(\mathrm{CH})_{4-}$ & $4.51 E+02$ & $4.49 E+02$ & 2. $20 \mathrm{E}+00$ & & $2.200+00$ & $4.49 \mathrm{E}+02$ & $4.49 \mathrm{E}+02$ & $2.21 \mathrm{E}-02$ & \\
\hline cst & $3.6 \mathrm{Z}+00$ & $3.60 \mathrm{E}+00$ & $1.76 \mathrm{E}-02$ & & $1.76 \mathrm{E}-02$ & $3.60 \mathrm{E}+00$ & $3.60 \mathrm{E}+00$ & $1.788=04$ & \\
\hline $\bar{a}+2$ & $9.0 \pi-02$ & $9.03 \mathrm{E}-02$ & 4. $42 \mathrm{E}-04$ & & $4.4 \mathbb{E}-04$ & $9.03 \mathrm{E}-02$ & $9.03 \mathrm{E}-02$ & $4,4 \sqrt{E}-06$ & \\
\hline ๒ูป-154 & 1. $10 \mathrm{E}-03$ & $1.09 \mathrm{E}-03$ & 5.35E-06 & & $5.35-06$ & 1.09E-03 & 1. $09 \mathrm{E}-03$ & $5,38 E-08$ & \\
\hline $\mathrm{F}-$ & 1. $86 \mathrm{E}+02$ & $1.85 \mathrm{E}+02$ & $9.05 \mathrm{E}-01$ & & $9.05 \mathrm{E}-01$ & $1.850+02$ & 1. $85 \mathrm{E}+02$ & $9.11 \mathrm{E}-03$ & \\
\hline \multicolumn{10}{|l|}{52} \\
\hline $\mathrm{EE}+3$ & 7.21E+02 & 7. 18E+02 & 3. $52 \mathrm{E}+00$ & & $3.52 \mathrm{E}+00$ & 7. 18E+02 & 7. $18 \mathrm{E}+02$ & $3.54 \mathrm{E}-02$ & \\
\hline $\mathrm{H} D 0$ & 6.21E+05 & 6. $18 \mathrm{EE}+05$ & $3.03 \mathrm{E}+03$ & $8.30 \mathrm{E}+04$ & $8.60 \mathrm{E}+04$ & $6.18 \mathrm{E}+05$ & $6.18 \mathrm{E}+05$ & 3.058+01 & 8.36E+02 \\
\hline $\mathrm{HF}+2$ & $1.21 \mathrm{E}-01$ & $1.20 \mathrm{E}-01$ & $5.89 \mathrm{E}-04$ & & $5.89 \mathrm{E}-04$ & $1.200-01$ & $1.20 \mathrm{E}-01$ & $5.93 \mathrm{z}-06$ & \\
\hline $\mathrm{K}^{+}$ & $1.4 \mathrm{EE}+03$ & $1.44 E+03$ & $7.0 \mathrm{~F}+00$ & & $7.07 \mathrm{E}+00$ & $1.44 \mathrm{E}+03$ & $1.44 \mathrm{E}+03$ & $7.12 \mathrm{E}-02$ & \\
\hline $\mathrm{LA}+3$ & $5.37 \mathrm{E}-02$ & $5.34 \mathrm{E}-02$ & $2.61 \mathbb{E}-04$ & & $2.61 \mathrm{E}-04$ & $5.34 \mathrm{E}-02$ & 5. $34 \mathrm{E}-02$ & $2.63 \mathrm{~A}-06$ & \\
\hline $\mathrm{MS}+2$ & $2.51 \mathrm{E}-01$ & $2.49 \mathrm{E}-01$ & $1.22 \mathrm{E}-03$ & & $1.22 \mathrm{E}-03$ & $2.49 \mathrm{E}-01$ & $2.49 \mathrm{E}-01$ & 1. $23 \mathrm{E}-05$ & \\
\hline $\mathrm{MN}+4$ & $2.41 \mathrm{E}+02$ & $2.40 \mathrm{E}+02$ & $1.1 \mathrm{TE}+00$ & & 1. $17 \mathrm{E}+00$ & $2.40 \mathrm{E}+02$ & $2.40 \mathrm{E}+02$ & $1.185-02$ & \\
\hline $\mathrm{M}+6$ & $6.87 \mathrm{E}-01$ & $6.84 \mathrm{E}-01$ & $3.35 \mathrm{E}-03$ & & $3.35-03$ & $6.84 \mathrm{E}-01$ & 6. $84 \mathrm{E}-01$ & $3.37 \mathrm{E}-05$ & \\
\hline NAt & 1.20E+05 & $1.20 \mathrm{E}+0 \mathrm{~s}$ & 5. 8SE+02 & & $5.85+02$ & 1.20E+0.5 & 1. $20 \mathrm{E}+05$ & 5. $89 \mathrm{E}+00$ & \\
\hline$N[+3$ & $2.17 \mathrm{E}+02$ & $2.16 \mathrm{E}+02$ & $1.06 E+00$ & & $1.065+00$ & $2.16 \mathrm{E}+02$ & 2. $16 E+02$ & 1. $06 \mathrm{E}-02$ & \\
\hline \multicolumn{10}{|l|}{$\mathrm{NOE}$} \\
\hline $\mathrm{NOE}^{-}$ & $3.08 E+04$ & $3.06 E+04$ & $1.50 \mathrm{E}+02$ & & 1. $50 \mathrm{OE}+02$ & $3.06 E+04$ & $3,06 \mathrm{E}+04$ & $1.51 E+00$ & \\
\hline NOS- & $1.22 \mathrm{~F}+05$ & $1.21 \mathrm{E}+05$ & $5,94 E+02$ & & $5.94 E+02$ & 1.21E+05 & 1. $21 E+05$ & 5. $98 \mathrm{gE}+00$ & \\
\hline $\begin{array}{l}\mathrm{NP}+4 \\
\mathrm{Q}\end{array}$ & $1.13 \mathrm{E}-02$ & $1.13 \mathrm{E}-02$ & $5.51 \mathrm{E}-05$ & & $5.51 \mathrm{E}-05$ & 1. $13 \mathrm{E}-02$ & 1. 13E-02 & $5.550-07$ & \\
\hline $\mathbf{H}^{-}$ & $1.04 \mathrm{E}+04$ & 1.03E+04 & $5.05 E+01$ & & $5.05 E+01$ & 1. $03 E+04$ & 1. $03 E+04$ & $5.09 \mathrm{E}-01$ & \\
\hline $\mathrm{PB}+4$ & $1.59 \mathrm{E}+02$ & $1.58 \mathrm{EE}+02$ & $7.75 \mathrm{E}-01$ & & $7.75 x^{-02}$ & 1. $58 \mathrm{BE}+02$ & 1. $58 E+02$ & 7. $80 \mathrm{E}-03$ & \\
\hline FO4-3 & $3.625+02$ & $3.60 \mathrm{E}+02$ & $1,76 \mathrm{E}+00$ & & $1.76 \mathrm{E}+00$ & $3.60 E+02$ & $3.60 \mathrm{E}+02$ & $1.78 \mathrm{E}-02$ & \\
\hline Fut 4 & $2.4 \overline{E E}-01$ & $2.46 \mathrm{E}-01$ & $1.21 \mathrm{E}-03$ & & $1,21 E-03$ & $6,29 \mathrm{E}-02$ & $6.29 \mathrm{E}-02$ & $3.10 \mathrm{E}-06$ & \\
\hline SE+6 & $1.36 \mathrm{E}-05$ & 1.3E-05 & $6.61 \mathrm{E}-08$ & & $6.61 \mathrm{E}-08$ & $1.358-05$ & 1. $35 \mathrm{~s}-05$ & $6.56 \mathrm{E}-10$ & \\
\hline$S I+4$ & $3.49 \mathrm{E}+01$ & $3.47 \mathrm{E}+01$ & $1.70 \mathrm{E}-01$ & & $1.708-01$ & $3.4 \pi \mathrm{E}+01$ & $3.47 \mathrm{E}+01$ & $1.71 \mathrm{E}-03$ & \\
\hline Sxt+4 & $4.105-11$ & 4. $088-11$ & $2.00 \mathrm{E}-13$ & & $2.00 \mathrm{E}-13$ & 4. OBE-11 & 4.08E-11 & $2.01 \mathrm{E}-15$ & \\
\hline $504-2$ & $8.81 E+03$ & $8.77 \mathrm{E}+03$ & $4.29 \mathrm{E}+01$ & & 4. $29 \mathrm{E}+01$ & $8.7 / \mathrm{E}+03$ & 8.77E+03 & 4. $32 \mathrm{ZE}-01$ & \\
\hline $\mathbb{R}+2$ & $3.225-01$ & $3.21 E-01$ & $1.57 \mathrm{E}-03$ & & $1.5 \mathrm{TE}-03$ & 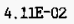 & $4.21 \mathrm{E}-02$ & $2.03 \mathrm{E}-06$ & \\
\hline $700_{4}-$ & $1.81 \mathrm{E}+01$ & $1.81 E+01$ & $8.84 \mathrm{E}-02$ & & $8.84 \mathrm{E}-02$ & $1,81 \mathbb{E}+01$ & $1,81 \mathrm{E}+01$ & $8.90 \mathrm{E}-04$ & \\
\hline IIt4 & $1.94 \mathrm{E}-03$ & $1.93 \mathrm{E}-03$ & $9.43 \mathrm{E}-06$ & & $9.43 \mathrm{E}-106$ & 1. $93 \mathrm{E}-03$ & 1. $93 \mathrm{E}-03$ & $9.50 \mathrm{E}-08$ & \\
\hline $\mathrm{TOC}$ & 2. $.08 E+04$ & $2.07 \mathrm{E}+04$ & 1.01E+02 & & $1.01 E+02$ & $2.07 E+04$ & $2.07 E+04$ & 1. $0 Z E+00$ & \\
\hline $100+2$ & 4. $33 \mathrm{EE}+02$ & 4.31E+02 & $2.118+00$ & & 2. $11 \mathrm{E}+\infty 0$ & 4.31E+02 & $4,31 E+02$ & $2,13 \mathrm{E}-02$ & \\
\hline $\mathrm{W}+6$ & $1.57 \mathrm{E}+00$ & $1.57 \mathrm{E}+\infty 0$ & $7.66 \mathrm{E}-03$ & & $7.66 \mathrm{E}-03$ & $1.5 \mathrm{FE}+00$ & $1.57 \mathrm{E}+00$ & $7.72 \mathrm{E}-05$ & \\
\hline$a+2$ & 5. $01 E-01$ & 4. $99 \mathrm{E}-01$ & $2.44 \mathrm{E}-03$ & & $2.44 \mathrm{E}-03$ & $4.99 \mathrm{E}-01$ & 4. $99 \mathrm{E}-01$ & $2.46 \mathrm{E}-05$ & \\
\hline $2 R+4$ & $2.0 \pi \mathrm{E}-02$ & $2.06 \mathrm{E}^{-02}$ & 1.01E-04 & & $1.01 \mathrm{E}-04$ & $2.06 \mathrm{E}-02$ & $2,06 \mathrm{E}-02$ & $1.02 \mathrm{E}-06$ & \\
\hline
\end{tabular}


WHC-SD-WM-TI-774 Rev. 0

TWRS PRIVATIZATION PROCESS TECHNICAL BASELINE

Table B-7 Phase 1 LAW Mass Balance for Batch $\mathrm{PCl} / 7$ ( 6 sheets)

\begin{tabular}{|c|c|c|c|c|c|c|c|c|c|c|}
\hline $\begin{array}{l}\text { SLEEM NAME } \\
\text { SOLT COMPONENIS }\end{array}$ & 1 & 2 & 3 & 4 & 5 & 6 & 7 & 8 & 9 & 10 \\
\hline Total Mass Flow (kg) & 9.8 正 +03 & $9.85 E+01$ & $9.75 E+03$ & & $9.756+03$ & & $9.92 \mathrm{ZE}+01$ & $9.92 \mathrm{E}-01$ & $9.825+01$ & \\
\hline \multicolumn{11}{|l|}{ RADIONULIDES (Ci) } \\
\hline $\begin{array}{l}\text { Casium } \\
\text { Strantium } \\
\text { Technetium } \\
\text { IRI }\end{array}$ & & & & & & & $\begin{array}{l}3.89 \mathrm{E}+04 \\
2.38 \mathrm{E}+02\end{array}$ & $\begin{array}{l}3,89 \mathrm{E}+02 \\
2,38 \mathrm{E}+00\end{array}$ & $\begin{array}{l}3.85 E+04 \\
2.35 E+02\end{array}$ & \\
\hline
\end{tabular}

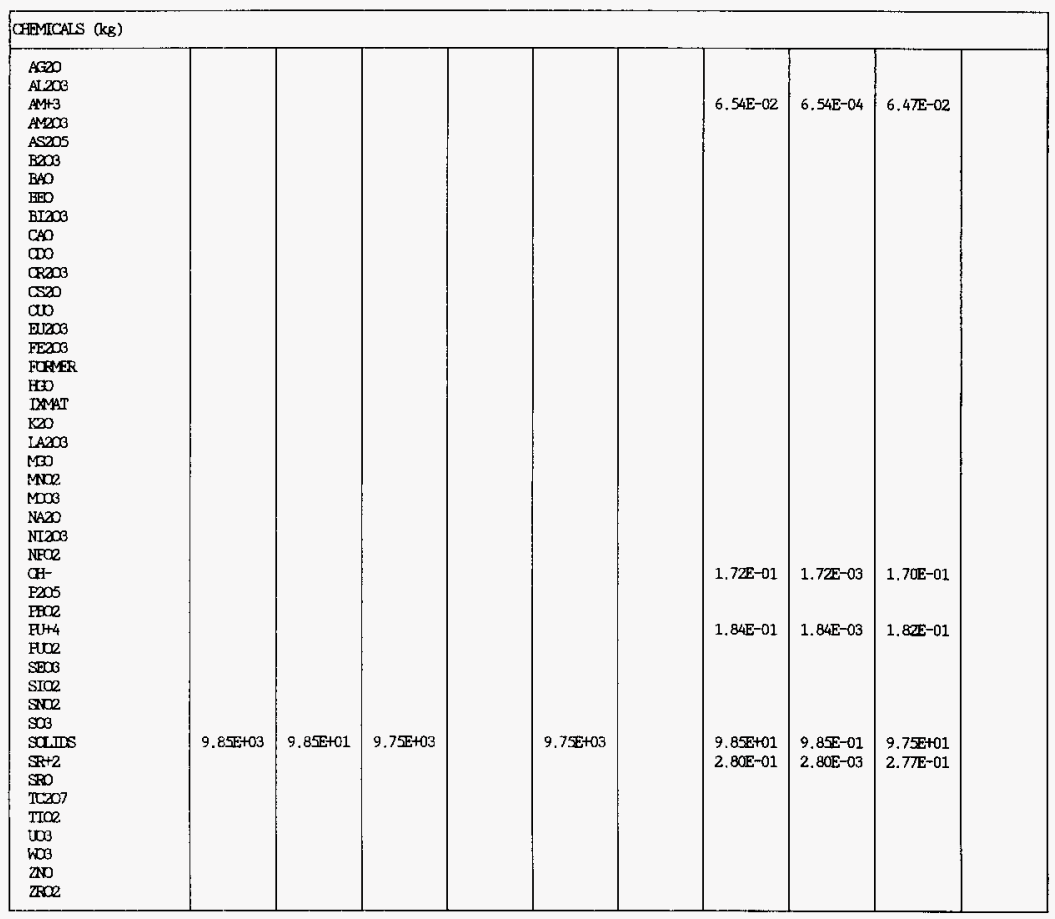


TWRS PRIVATIZATION PROCESS TECHNICAL BASELINE

Table B-7 Phase 1 IAW Mass Balance for Batch PC1/7 (6 sheets)

\begin{tabular}{|c|c|c|c|c|c|c|c|c|c|c|}
\hline $\begin{array}{l}\text { SIRFAM NAME } \\
\text { LIQUID COMFANENIS }\end{array}$ & 11 & 12 & 13 & 14 & 15 & 16 & $16 A$ & 17 & 18 & 19 \\
\hline $\begin{array}{l}\text { Volime }(L) \\
\text { Density }(g / L)\end{array}$ & $\begin{array}{l}8.72 \mathrm{E}+02 \\
1.01 \mathrm{E}+03\end{array}$ & $\begin{array}{l}7.4 \pi+05 \\
1.31 E+03\end{array}$ & $\begin{array}{l}6.30 E+02 \\
3.32 E+03\end{array}$ & & $\begin{array}{l}6.30 \mathrm{E}+02 \\
3.32 \mathrm{E}+03\end{array}$ & $\begin{array}{l}7.4 \pi+05 \\
1.31 E+03\end{array}$ & $\begin{array}{l}1.81 E+06 \\
1.00 E+03\end{array}$ & $\begin{array}{l}6.36 E+02 \\
3.30 E+03\end{array}$ & $\begin{array}{l}1.20 \mathrm{E}+03 \\
1.00 \mathrm{E}+03\end{array}$ & $\begin{array}{l}1.84 \mathrm{E}+03 \\
1.80 \mathrm{E}+03\end{array}$ \\
\hline Total Mess Flow (kg) & 8. $84 \mathrm{E}+02$ & 9.81E+05 & $2.09 \mathrm{E}+03$ & & $2,09 E+03$ & $9.81 E+05$ & $1.81 E+06$ & $2.10 \mathrm{E}+03$ & 1. $20 \mathrm{E}+03$ & $3.302+03$ \\
\hline \multicolumn{11}{|l|}{ RADIONUCLIIES (Ci) } \\
\hline $\begin{array}{l}\text { Cesium } \\
\text { Strontiun } \\
\text { Technetium } \\
\text { THU }\end{array}$ & $\begin{array}{l}1.54 \mathrm{E}+01 \\
2.82 \mathrm{E}-01 \\
9.19 \mathrm{E}-03 \\
4.00 \mathrm{E}-03\end{array}$ & $\begin{array}{l}9.16 \mathrm{E}+02 \\
5.72 \mathrm{E}+03 \\
1.85 \mathrm{E}+02 \\
8.11 \mathrm{E}+01\end{array}$ & $\begin{array}{l}3.11 \mathrm{E}+05 \\
1.8 \mathrm{E}+00\end{array}$ & & $\begin{array}{l}3.11 \mathrm{E}+05 \\
1.87 \mathrm{E}+00\end{array}$ & $\begin{array}{l}9.16 E+02 \\
5.72 E+03 \\
9.16 E+01 \\
8.11 E+01\end{array}$ & & $9.29 \mathrm{E}+01$ & & $9.29 E+01$ \\
\hline
\end{tabular}

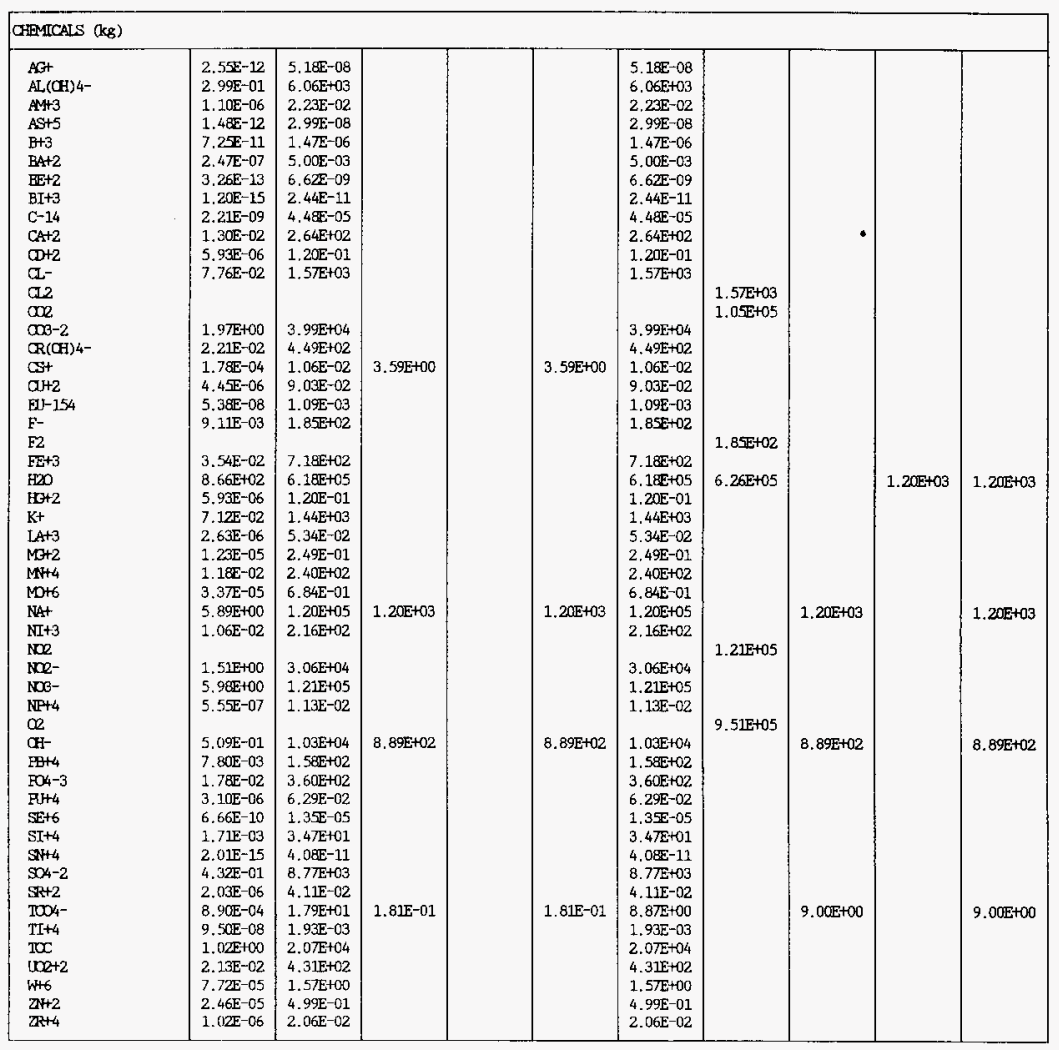


WHC-SD-WM-TI-774 Rev. 0

TWRS PRIVATIZATION PROCESS TECHNICAL BASELINE

Table B-7 Phase 1 IAW Mass Balance for Batch $\mathrm{PCl} / 7$ (6 sheets)

\begin{tabular}{|c|c|c|c|c|c|c|c|c|c|c|}
\hline $\begin{array}{l}\text { STRRAM NAME } \\
\text { SOID COMUNENIS }\end{array}$ & 11 & 12 & 13 & 14 & 15 & 16 & $16 \mathrm{~A}$ & 17 & 18 & 19 \\
\hline Total Mass Flow (kg) & $9.82 \pi+01$ & $9.92 \mathrm{E}-01$ & & 1. $20 \mathrm{E}+03$ & $1.20 \mathrm{E}+03$ & $9.92 E-01$ & $1.77 E+05$ & & & \\
\hline \multicolumn{11}{|l|}{ RADIONOCIIIES (Ci) } \\
\hline $\begin{array}{l}\text { Cesium } \\
\text { Strantiun } \\
\text { Technotiun } \\
\text { TKI }\end{array}$ & $\begin{array}{l}3.85 \mathrm{E}+04 \\
2.35 \mathrm{E}+02\end{array}$ & $\begin{array}{l}3.89 \mathrm{E}+02 \\
2.38 \mathrm{E}+00\end{array}$ & & & & $\begin{array}{l}3.89 \mathrm{E}+02 \\
2.38 \mathrm{E}+00\end{array}$ & $\begin{array}{l}9.16 \mathrm{E}+02 \\
6.11 \mathrm{E}+03 \\
9.16 \mathrm{E}+01 \\
8.12 \mathrm{E}+01\end{array}$ & & & \\
\hline \multicolumn{11}{|l|}{ ABMMCALS (kg) } \\
\hline 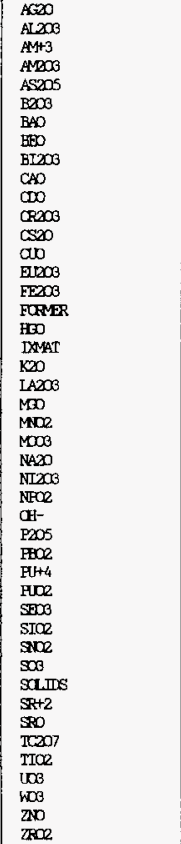 & $\begin{array}{l}1.70 \mathrm{E}-01 \\
1.82 \mathrm{E}-01\end{array}$ & $\begin{array}{l}1.72 \mathrm{E}-03 \\
1.84 \mathrm{E}-03\end{array}$ & & $1.20 \mathrm{E}+03$ & $1.20 \mathrm{E}+103$ & $\begin{array}{l}1.72 \mathrm{E}-03 \\
1.84 \mathrm{E}-03 \\
9.85 \mathrm{E}-01 \\
2.80 \mathrm{E}-03\end{array}$ & $\begin{array}{l}5.56 \mathrm{E}-08 \\
3.25 \mathrm{E}+03 \\
\\
2.53 \mathrm{E}-02 \\
4.59 \mathrm{E}-08 \\
4.73 \mathrm{E}-06 \\
5.59 \mathrm{E}-03 \\
1.84 \mathrm{E}-08 \\
2.72 \mathrm{E}-11 \\
3.69 \mathrm{E}+02 \\
1.38 \mathrm{E}-01 \\
2.84 \mathrm{E}+02 \\
1.12 \mathrm{E}-02 \\
1.13 \mathrm{E}-01 \\
1.26 \mathrm{E}-03 \\
1.03 \mathrm{E}+03 \\
1.30 \mathrm{E}-01 \\
1.74 \mathrm{E}+03 \\
6.26 \mathrm{E}-02 \\
4.14 \mathrm{E}-01 \\
3.80 \mathrm{E}+02 \\
1.03 \mathrm{E}+00 \\
1.6 \mathrm{E}+05 \\
3.04 \mathrm{E}+02 \\
1.28 \mathrm{E}-02 \\
\\
2.69 \mathrm{E}+02 \\
1.83 \mathrm{E}+02 \\
\\
7.34 \mathrm{E}-02 \\
2.1 \mathrm{E}-02 \\
7.43 \mathrm{E}+01 \\
5.17 \mathrm{E}-11 \\
7.31 \mathrm{E}+03 \\
9.85 \mathrm{E}-01 \\
\\
5.17 \mathrm{E}-02 \\
8.44 \mathrm{E}+00 \\
3.21 \mathrm{E}-03 \\
4.57 \mathrm{E}+02 \\
1.97 \mathrm{E}+00 \\
6.21 \mathrm{E}-01 \\
2.79 \mathrm{E}-02\end{array}$ & & & \\
\hline
\end{tabular}


WHC-SD-WM-TI-774 ReV. 0

TWRS PRIVATIZATION PROCESS TECHNICAL BASELINE

Table B-7 Phase 1 IAW Mass Balance for Batch PCl/7 (6 sheets)

\begin{tabular}{|c|c|c|c|c|c|c|c|c|c|}
\hline $\begin{array}{l}\text { STREAM NAME } \\
\text { LTQUID OOMFONENIS }\end{array}$ & 20 & 21 & 22 & 23 & 24 & 25 & 26 & 27 & 28 \\
\hline $\begin{array}{l}\text { Volume (L) } \\
\text { Density }(\mathrm{g} / \mathrm{L})\end{array}$ & $\begin{array}{l}1.81 \mathrm{E}+06 \\
1.00 \mathrm{E}+03\end{array}$ & & & & $\begin{array}{l}1.18 z+06 \\
1.00 E+03\end{array}$ & $\begin{array}{l}6.26 \mathrm{E}+05 \\
1.00 \mathrm{E}+03\end{array}$ & $\begin{array}{l}6.27 E+02 \\
3.34 \mathrm{E}+03\end{array}$ & $\begin{array}{l}6.27 \mathrm{E}+02 \\
3.34 \mathrm{E}+03\end{array}$ & $\begin{array}{l}\text { 1.00E+06 } \\
1.00 \mathrm{E}+03\end{array}$ \\
\hline Total Mass Flow (kg) & 1. $81 E+06$ & & & & $1.18 \mathrm{E}+06$ & $6.26 E+05$ & $2.09 \mathrm{E}+03$ & 2. $09 \mathrm{E}+03$ & $1,00 E+06$ \\
\hline \multicolumn{10}{|l|}{ RADICRUOLIIES (Ci) } \\
\hline $\begin{array}{l}\text { Cesium } \\
\text { Strontiun } \\
\text { Technet.ium } \\
\text { WRU }\end{array}$ & & & & & & & & & \\
\hline
\end{tabular}

\begin{tabular}{|c|c|c|c|c|c|c|}
\hline \multicolumn{7}{|c|}{ (HEMICALS (kg) } \\
\hline 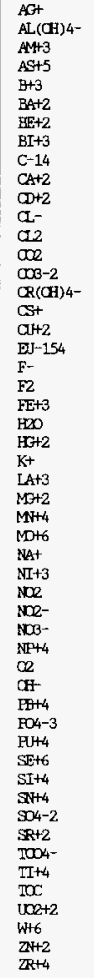 & $\begin{array}{l}1.57 \mathrm{E}+03 \\
1.05 \mathrm{E}+05 \\
\\
1.8 \mathrm{EE}+02 \\
6.26 \mathrm{E}+05\end{array}$ & $\begin{array}{l}1.5 \mathrm{~F}+03 \\
1.05 \mathrm{E}+05 \\
\\
1.85 \mathrm{E}+02\end{array}$ & $6.26 \mathrm{E}+05$ & $\begin{array}{l}1.20 E+03 \\
8.89 E+02\end{array}$ & $\begin{array}{l}1.20 \mathrm{E}+03 \\
8.89 \mathrm{E}+02\end{array}$ & $1.00 E+06$ \\
\hline
\end{tabular}


WHC-SD-WM-TI-774 ReV. 0

TWRS PRIVATIZATION PROCESS TECHNICAL BASELINE

Table B-7 Phase 1 IAW Mass Balance for Batch PCl/7 (6 sheets)

\begin{tabular}{|c|c|c|c|c|c|c|c|c|c|}
\hline $\begin{array}{l}\text { STREAM NAME } \\
\text { SOLD COMRONENS }\end{array}$ & 20 & 21 & 22 & 23 & 24 & 25 & 26 & 27 & 28 \\
\hline Total Mass Flow (kg) & & $1.77 \mathrm{E}+05$ & $7.78 E+05$ & $9.54 \mathrm{E}+05$ & & & & & \\
\hline \multicolumn{10}{|l|}{ RADIONCLIDES (Ci) } \\
\hline $\begin{array}{l}\text { Cesium } \\
\text { Strantiun } \\
\text { Technetium } \\
\text { IRU }\end{array}$ & & $\begin{array}{l}9.16 \mathrm{E}+02 \\
6.11 \mathrm{E}+03 \\
9.16 \mathrm{E}+01 \\
8.12 \mathrm{E}+01\end{array}$ & & $\begin{array}{l}9.16 \mathrm{E}+02 \\
6.11 \mathrm{E}+03 \\
9.16 \mathrm{E}+01 \\
8.12 \mathrm{E}+01\end{array}$ & & & & & \\
\hline \multicolumn{10}{|l|}{ OHFMICALS (kg) } \\
\hline 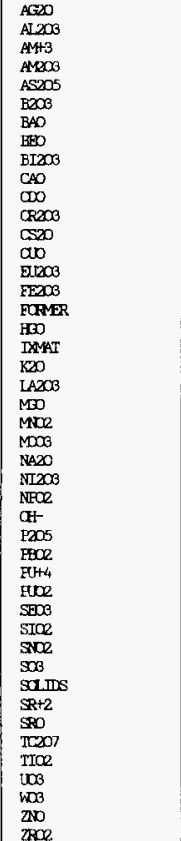 & & $\begin{array}{l}5.56 \mathrm{E}-08 \\
3.25 \mathrm{E}+03 \\
\\
2.53 \mathrm{E}-02 \\
4.59 \mathrm{E}-08 \\
4.73 \mathrm{E}-06 \\
5.59 \mathrm{E}-03 \\
1.84 \mathrm{E}-08 \\
2.72 \mathrm{E}-11 \\
3.69 \mathrm{E}+02 \\
1.3 \mathrm{EE}-01 \\
2.84 \mathrm{E}+02 \\
1.12 \mathrm{E}-02 \\
1.13 \mathrm{E}-01 \\
1.26 \mathrm{E}-03 \\
1.03 \mathrm{E}+03 \\
1.30 \mathrm{E}-01 \\
1.74 \mathrm{E}+03 \\
6.26 \mathrm{E}-02 \\
4.14 \mathrm{E}-01 \\
3.80 \mathrm{E}+02 \\
1.03 \mathrm{E}+00 \\
1.61 \mathrm{E}+05 \\
3.04 \mathrm{E}+02 \\
1.25 \mathrm{E}-02 \\
\\
2.69 \mathrm{E}+02 \\
1.83 \mathrm{E}+02 \\
7.34 \mathrm{E}-02 \\
2.17 \mathrm{E}-05 \\
7.43 \mathrm{E}+01 \\
5.17 \mathrm{E}-11 \\
7.31 \mathrm{E}+03 \\
9.8 \mathrm{E}-01 \\
5.17 \mathrm{E}-02 \\
8.44 \mathrm{E}+00 \\
3.21 \mathrm{E}-03 \\
4.57 \mathrm{E}+02 \\
1.97+00 \\
6.2 \mathrm{E}-01 \\
2.79 \mathrm{E}-02\end{array}$ & $7.78 E+05$ & $\begin{array}{l}5.56 \mathrm{E}-08 \\
3.2 \mathrm{E}+03 \\
\\
2.53 \mathrm{E}-02 \\
4.59 \mathrm{E}-08 \\
4.73 \mathrm{E}-06 \\
5.59 \mathrm{E}-03 \\
1.84 \mathrm{E}-08 \\
2.72 \mathrm{E}-11 \\
3.69 \mathrm{E}+02 \\
1.38 \mathrm{E}-01 \\
2.84 \mathrm{E}+02 \\
1.12 \mathrm{E}-02 \\
1.13 \mathrm{E}-01 \\
1.26 \mathrm{E}-03 \\
1.03 \mathrm{E}+03 \\
7.78 \mathrm{E}+05 \\
1.30 \mathrm{E}-01 \\
1.74 \mathrm{E}+03 \\
6.26 \mathrm{E}-02 \\
4.14 \mathrm{E}-01 \\
3.80 \mathrm{E}+02 \\
1.03 \mathrm{E}+00 \\
1.61 \mathrm{E}+05 \\
3.04 \mathrm{E}+02 \\
1.28 \mathrm{E}-02 \\
\\
2.69 \mathrm{E}+02 \\
1.83 \mathrm{E}+02 \\
7.34 \mathrm{E}-02 \\
2.17 \mathrm{E}-05 \\
7.43 \mathrm{E}+01 \\
5.17 \mathrm{E}-11 \\
7.31 \mathrm{E}+03 \\
9.85 \mathrm{E}-01 \\
5.17 \mathrm{E}-02 \\
8.44 \mathrm{E}+00 \\
3.21 \mathrm{E}-03 \\
4.57 \mathrm{E}+02 \\
1.97 \mathrm{E}+00 \\
6.21 \mathrm{E}-01 \\
2.79 \mathrm{E}-02\end{array}$ & & & & & \\
\hline
\end{tabular}


WHC-SD-WM-TI-774 Rev. 0

\section{TWRS PRIVATIZATION PROCESS TECHNICAL BASELINE}

Table B-8 Phase 1 IAW Mass Balance for Batch PC1/8 (6 sheets)

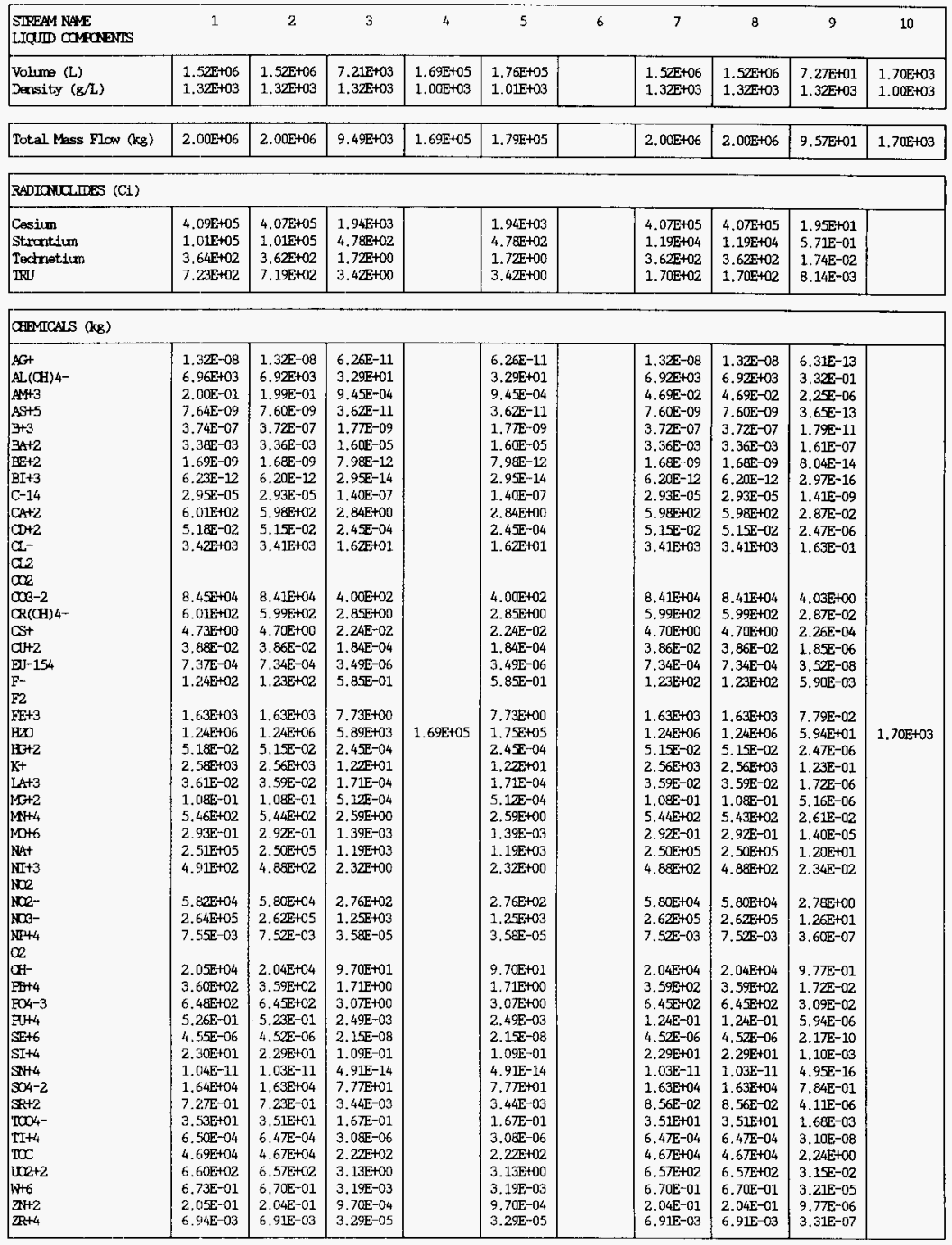


WHC-SD-WM-TI-774 Rev. 0

TWRS PRIVATIZATION PROCESS TECHNICAL BASELINE

Table B- 8 Phase 1 LAW Mass Balance for Batch PCl/8 (6 sheets)

\begin{tabular}{|c|c|c|c|c|c|c|c|c|c|c|}
\hline $\begin{array}{l}\text { SIFEAM NAE } \\
\text { SLD DOMFANDNS }\end{array}$ & 1 & 2 & 3 & 4 & 5 & 6 & 7 & 8 & 9 & 10 \\
\hline Total Mass Flow (kg) & $2.00 \mathrm{E}+04$ & $2.00 \mathrm{E}+02$ & $1.98 E+04$ & & $1.98 \mathrm{~F}+04$ & & $2.02 E+02$ & 2. $02 E+\infty 0$ & $2.00 E+02$ & \\
\hline \multicolumn{11}{|l|}{ RADIONUCLIIES (Ci) } \\
\hline \begin{tabular}{|l} 
Cesium \\
Strantium \\
Technotium \\
TIU
\end{tabular} & & & & & & & $\begin{array}{l}8.86 E+04 \\
5.50 E+02\end{array}$ & $\begin{array}{l}8.86 E+02 \\
5.50 E+00\end{array}$ & $\begin{array}{l}8.77 E+04 \\
5.44 E+02\end{array}$ & \\
\hline \multicolumn{11}{|l|}{ CHEMTCALS (kg) } \\
\hline 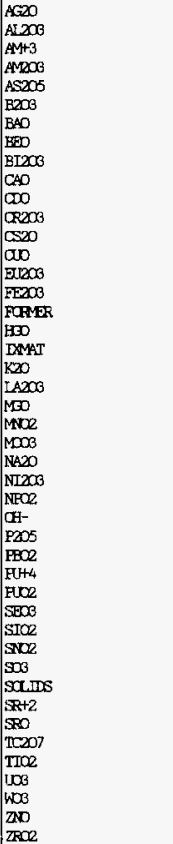 & $2.00 \mathrm{E}+04$ & $2.00 \mathrm{E}+02$ & $1.98 \mathrm{E}+04$ & & $1.98 \mathrm{E}+04$ & & $\begin{array}{l}3.87 \mathrm{E}-01 \\
3.99 \mathrm{E}-01 \\
\\
2.00 \mathrm{E}+02 \\
6.38 \mathrm{E}-01\end{array}$ & $\begin{array}{l}3.87 \mathrm{E}-03 \\
3.99 \mathrm{E}-03 \\
\\
2.00 \mathrm{E}+00 \\
6.38 \mathrm{E}-03\end{array}$ & $\begin{array}{l}3.83 \mathrm{E}-01 \\
3.95 \mathrm{E}-01 \\
\\
\begin{array}{l}1.98 \mathrm{E}+02 \\
6.31 \mathrm{E}-01\end{array}\end{array}$ & \\
\hline
\end{tabular}


WHC-SD-WM-TI-774 Rev. 0

TWRS PRIVATIZATION PROCESS TECHNICAL BASELINE

Table B-8 Phase 1 LAW Mass Balance for Batch PCl/8 (6 sheets)

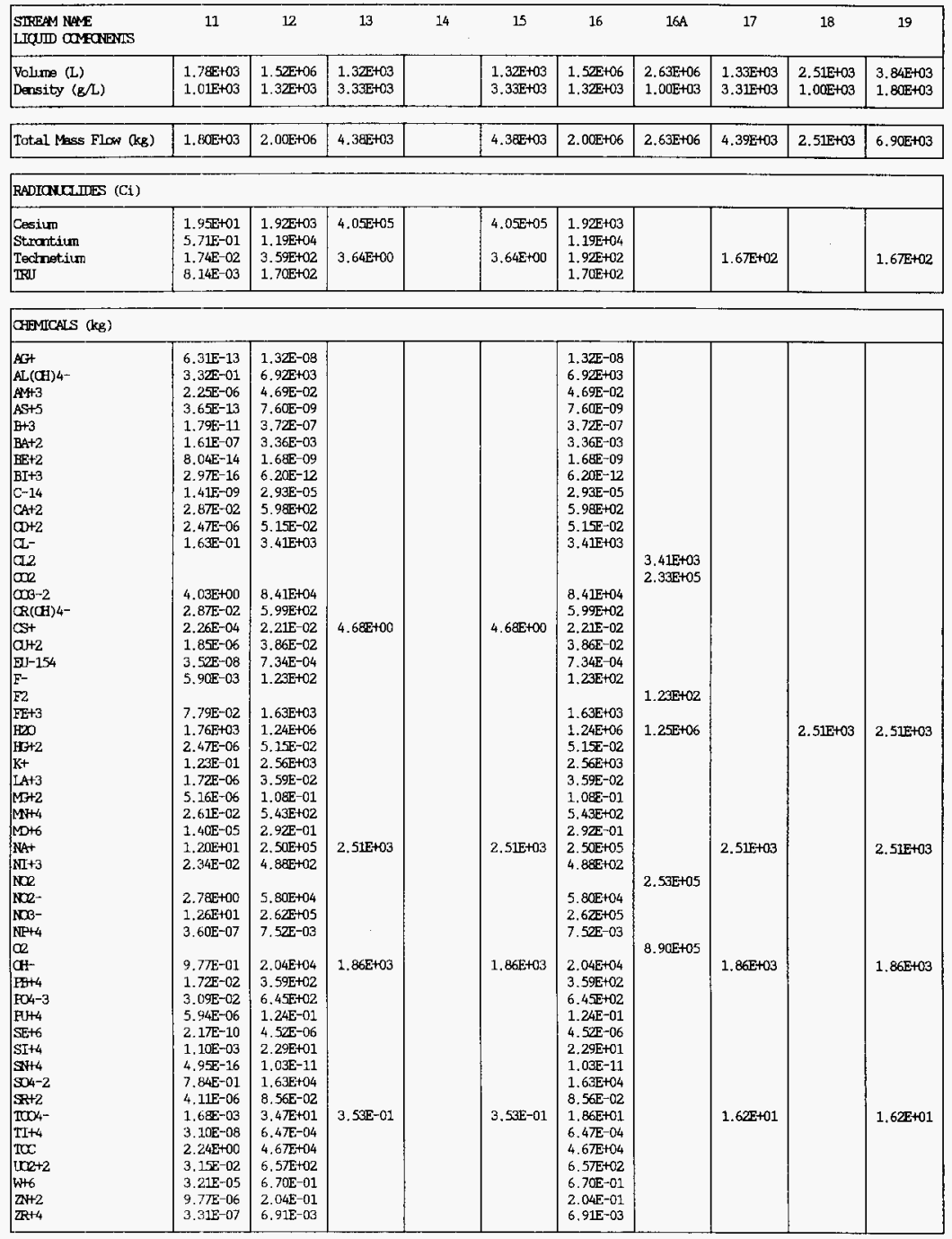


WHC-SD-WM-TI-774 Rev. 0

TWRS PRIVATIZATION PROCESS TECHNICAL BASELINE

Table B- 8 Phase 1 IAW Mass Balance for Batch PC1/8 (6 sheets)

\begin{tabular}{|c|c|c|c|c|c|c|c|c|c|c|}
\hline 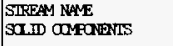 & 11 & 12 & 13 & 14 & 15 & 16 & $16 \mathrm{~A}$ & 17 & 18 & 19 \\
\hline Total Mass Flow (kg) & 2. $000+02$ & $2.02 E+00$ & & $2.51 E+03$ & $2.51 E+03$ & $2.02 \mathrm{E}+00$ & $3.6 \mathrm{SE}+05$ & & & \\
\hline \multicolumn{11}{|l|}{ FADIONCLIDES (Ci) } \\
\hline $\begin{array}{l}\text { Cesium } \\
\text { Strantium } \\
\text { Technetium } \\
\text { TRU }\end{array}$ & $\begin{array}{l}8.77 \mathrm{E}+04 \\
5.44 \mathrm{E}+02\end{array}$ & $\begin{array}{l}8.86 \mathrm{E}+02 \\
5.50 \mathrm{E}+00\end{array}$ & & & & $\begin{array}{l}8.86 E+02 \\
5.50 E+00\end{array}$ & $\begin{array}{l}1.92 \mathrm{ZE}+03 \\
1.28 \mathrm{E}+04 \\
1.92 \mathrm{E}+02 \\
1.70 \mathrm{E}+02\end{array}$ & & & \\
\hline \multicolumn{11}{|l|}{ GHMICAIS (kg) } \\
\hline 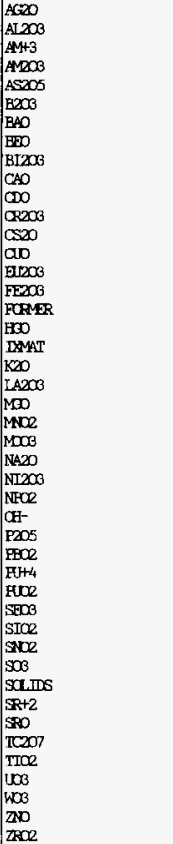 & $\begin{array}{l}3.83 E-01 \\
3.9 F-01 \\
1.96 E+02 \\
6.31 E-01\end{array}$ & $\begin{array}{l}3.8 \mathrm{E}-03 \\
3.99 \mathrm{E}-03 \\
2.00 \mathrm{E}+00 \\
6.38 \mathrm{E}-03\end{array}$ & & $2.51 \mathrm{E}+03$ & $2.51 E+03$ & $\begin{array}{l}3.87 \mathrm{E}-\mathrm{C3} \\
3.99 \mathrm{E}-03 \\
\\
2.00 \mathrm{E}+\infty 0 \\
6.38 \mathrm{E}-03\end{array}$ & $\begin{array}{l}1.41 \mathrm{E}-08 \\
3.71 \mathrm{E}+03 \\
\\
5.32 \mathrm{E}-02 \\
1.1 \mathrm{E}-08 \\
1.20 \mathrm{E}-06 \\
3.75 \mathrm{E}-03 \\
4.65 \mathrm{E}-09 \\
6.91 \mathrm{E}-12 \\
8.36 \mathrm{E}+02 \\
5.88 \mathrm{E}-02 \\
3.79 \mathrm{E}+02 \\
2.34 \mathrm{E}-02 \\
4.83 \mathrm{E}-02 \\
8.49 \mathrm{E}-04 \\
2.32 \mathrm{E}+03 \\
5.56 \mathrm{E}-02 \\
3.09 \mathrm{E}+03 \\
4.22 \mathrm{E}-02 \\
1.78 \mathrm{E}-01 \\
8.600 \mathrm{E}+02 \\
4.37 \mathrm{E}-01 \\
3.37 \mathrm{E}+05 \\
6.88 \mathrm{E}+02 \\
8.53 \mathrm{E}-03 \\
\\
4.82 \mathrm{E}+02 \\
4.14 \mathrm{E}+02 \\
1.4 \mathrm{E}-01 \\
7.2 \mathrm{E}-06 \\
4.89 \mathrm{E}+01 \\
1.31 \mathrm{E}-11 \\
1.36 \mathrm{E}+04 \\
2.00 \mathrm{E}+00 \\
1.08 \mathrm{E}-01 \\
1.77 \mathrm{E}+01 \\
1.08 \mathrm{E}-03 \\
6.96 \mathrm{E}+02 \\
8.4 \mathrm{E}-01 \\
2.54 \mathrm{E}-01 \\
9.33 \mathrm{E}-03\end{array}$ & & & \\
\hline
\end{tabular}


WHC-SD-WM-TI-774 Rev. 0

TWRS PRIVATIZATION PROCESS TECHNICAL BASELINE

Table B- 8 Phase 1 LAW Mass Balance for Batch PCl/8 (6 sheets)

\begin{tabular}{|c|c|c|c|c|c|c|c|c|c|}
\hline $\begin{array}{l}\text { SIRFAM NAE } \\
\text { LIQUID COMEAENIS }\end{array}$ & 20 & 21 & 22 & 23 & 24 & 25 & 26 & 27 & 28 \\
\hline $\begin{array}{l}\text { Volume }(\mathrm{L}) \\
\text { Density }(g / L)\end{array}$ & $\begin{array}{l}2.63 \mathrm{E}+06 \\
1.00 \mathrm{E}+03\end{array}$ & & & & $\begin{array}{l}1.38 E+06 \\
1.00 E+03\end{array}$ & $\begin{array}{l}1.25 \mathrm{E}+06 \\
1.00 \mathrm{E}+03\end{array}$ & $\begin{array}{l}\text { 1. } 31 E+03 \\
\text { 3. } 34 E+03\end{array}$ & $\begin{array}{l}1.31 E+03 \\
3.34 E+03\end{array}$ & $\begin{array}{l}\text { 1. } 00 \mathrm{E}+06 \\
1.00 \mathrm{E}+03\end{array}$ \\
\hline Total Mss Flow (kg) & $2.63 \mathrm{E}+06$ & & & & $1.38 E+06$ & 1. 25E+06 & 4. $38 \mathrm{EE}+03$ & 4.38E+03 & $1.00 \mathrm{E}+06$ \\
\hline \multicolumn{10}{|l|}{ RADTCMCI.IIES (Ci) } \\
\hline $\begin{array}{l}\text { Cesium } \\
\text { Struntium } \\
\text { Tecknetium } \\
\text { [RI }\end{array}$ & & & & & & & & & \\
\hline
\end{tabular}

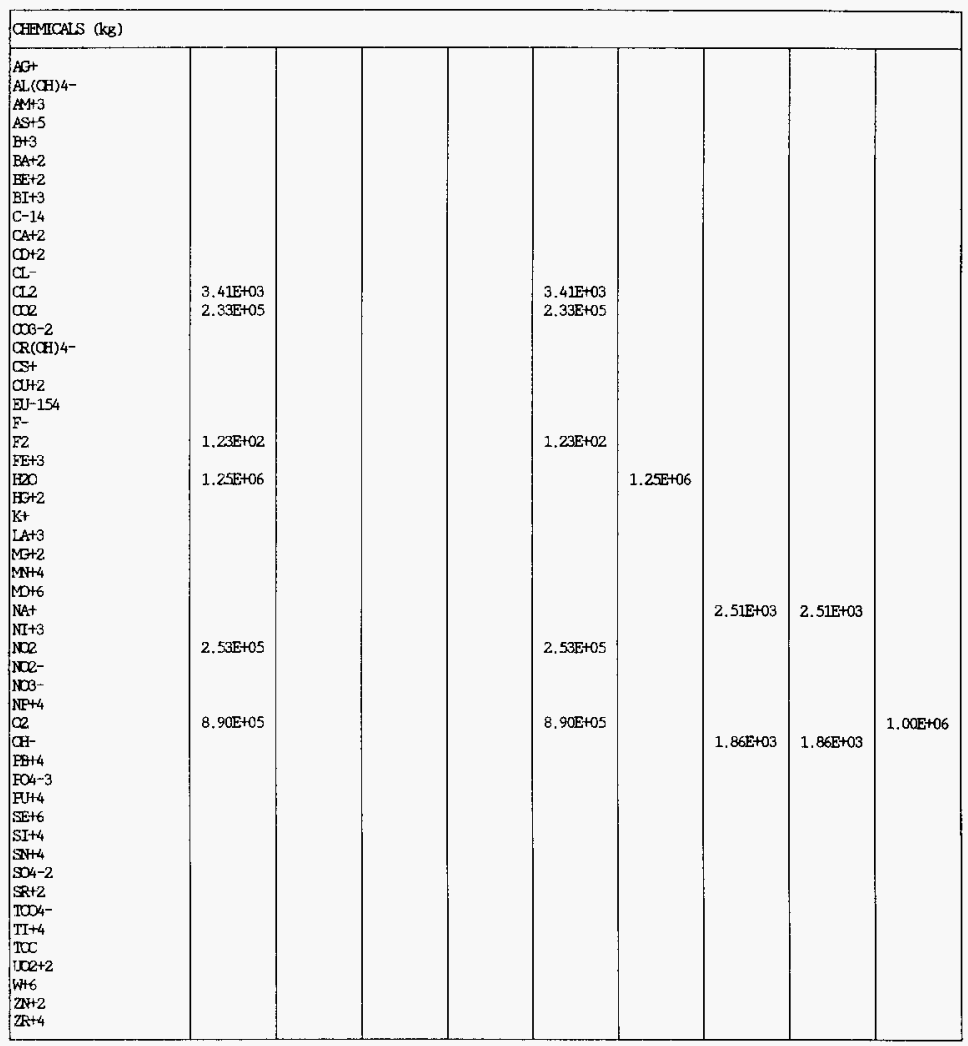


WHC-SD-WM-TI-774 ReV. 0

TWRS PRIVATIZATION PROCESS TECHNICAL BASELINE

Table B-8 Phase 1 LAW Mass Balance for Batch PCl/8 (6 sheets)

\begin{tabular}{|c|c|c|c|c|c|c|c|c|c|}
\hline $\begin{array}{l}\text { SLLEAM NAME } \\
\text { SOLD OOMFONDIS }\end{array}$ & 20 & 21 & 22 & 23 & 24 & 25 & 26 & 27 & 28 \\
\hline Total Mass Flow (kg) & & $3.65 \mathrm{E}+05$ & $1.63 E+06$ & $2.008+06$ & & & & & \\
\hline \multicolumn{10}{|l|}{ RADIONCIIIIES (Ci) } \\
\hline $\begin{array}{l}\text { Cesium } \\
\text { Strantium } \\
\text { Tecinet.ium } \\
\text { TRIJ }\end{array}$ & & $\begin{array}{l}1.92 \mathrm{E}+03 \\
1.2 \mathrm{BE}+04 \\
1.92 \mathrm{E}+02 \\
1.70 \mathrm{E}+02\end{array}$ & & $\begin{array}{l}1.92 E+03 \\
1.28 E+04 \\
1.92 E+02 \\
1.70 E+02\end{array}$ & & & & & \\
\hline \multicolumn{10}{|l|}{ OHEMCALS（kg） } \\
\hline 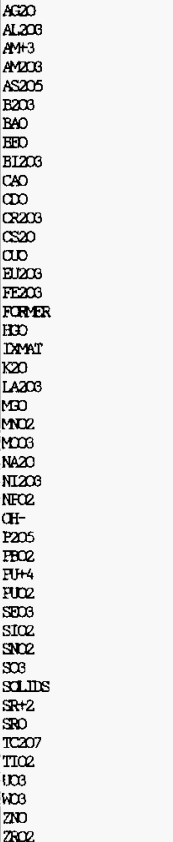 & & $\begin{array}{l}1.41 \mathrm{E}-08 \\
3.71 \mathrm{E}+03 \\
\\
5.32 \mathrm{E}-02 \\
1.17 \mathrm{E}-08 \\
1.20 \mathrm{E}-06 \\
3.75 \mathrm{E}-03 \\
4.65 \mathrm{E}-09 \\
6.91 \mathrm{E}-12 \\
8.36 \mathrm{E}+02 \\
5.88 \mathrm{E}-02 \\
3.79 \mathrm{E}+02 \\
2.34 \mathrm{E}-02 \\
4.83 \mathrm{E}-02 \\
8.49 \mathrm{E}-04 \\
2.32 \mathrm{E}+03 \\
\\
5.56 \mathrm{E}-02 \\
\\
3.09 \mathrm{E}+03 \\
4.22 \mathrm{E}-02 \\
1.78 \mathrm{E}-01 \\
8.60 \mathrm{E}+02 \\
4.37 \mathrm{~F}-01 \\
3.37+05 \\
6.88 \mathrm{E}+02 \\
8.53 \mathrm{E}-03 \\
\\
4.82 \mathrm{E}+02 \\
4.14 \mathrm{E}+02 \\
1.4 \mathrm{E}-01 \\
7.27 \mathrm{E}-06 \\
4.89 \mathrm{E}+01 \\
1.31 \mathrm{E}-11 \\
1.36 \mathrm{E}+04 \\
2.00 \mathrm{E}+00 \\
1.08 \mathrm{E}-01 \\
1.77 \mathrm{E}+01 \\
1.08 \mathrm{E}-03 \\
6.96 \mathrm{E}+02 \\
8.45 \mathrm{E}-01 \\
2.54 \mathrm{E}-01 \\
9.3 \mathrm{E}-03\end{array}$ & $1.63 \mathrm{E}+06$ & $\begin{array}{l}1.41 \mathrm{E}-08 \\
3.71 \mathrm{E}+03 \\
\\
5.32 \mathrm{E}-02 \\
1.17 \mathrm{E}-08 \\
1.20 \mathrm{E}-06 \\
3.75 \mathrm{E}-03 \\
4.65 \mathrm{E}-09 \\
6.91 \mathrm{E}-12 \\
8.36 \mathrm{E}+02 \\
5.88 \mathrm{E}-02 \\
3.79 \mathrm{E}+02 \\
2.34 \mathrm{E}-02 \\
4.83 \mathrm{E}-02 \\
8.49 \mathrm{E}-04 \\
2.32 \mathrm{E}+03 \\
1.63 \mathrm{E}+06 \\
5.56 \mathrm{E}-02 \\
\\
3.09 \mathrm{E}+03 \\
4.22 \mathrm{E}-02 \\
1.78 \mathrm{E}-01 \\
8.60 \mathrm{E}+02 \\
4.37 \mathrm{E}-01 \\
3.37 \mathrm{E}+05 \\
6.89 \mathrm{E}+02 \\
8.53 \mathrm{E}-03 \\
\\
4.82 \mathrm{E}+02 \\
4.14 \mathrm{E}+02 \\
1.45 \mathrm{E}-01 \\
7.27 \mathrm{E}-06 \\
4.89 \mathrm{E}+01 \\
1.31 \mathrm{E}-11 \\
1.36 \mathrm{E}+04 \\
2.00 \mathrm{E}+00 \\
1.08 \mathrm{E}-01 \\
1.77 \mathrm{E}+01 \\
1.08 \mathrm{E}-03 \\
6.96 \mathrm{E}+02 \\
8.4 \mathrm{EE}-01 \\
2.54 \mathrm{E}-01 \\
9.33 \mathrm{E}-03\end{array}$ & & & & & \\
\hline
\end{tabular}




\section{TWRS PRIVATIZATION PROCESS TECHNICAL BASELINE}

Table B-9 Phase 1 LAW Mass Balance for Batch PC1/9 (6 sheets)

\begin{tabular}{|c|c|c|c|c|c|c|c|c|c|c|}
\hline $\begin{array}{l}\text { STREAM NAME } \\
\text { TIOID CONEONDMIS }\end{array}$ & 1 & 2 & 3 & 4 & 5 & 5 & 7 & 8 & 9 & 10 \\
\hline Volume (L) & $2.99 \mathrm{E}+06$ & $2.98 E+06$ & 1. $41 E+04$ & 3. $31 E+05$ & $3.4 \mathbf{E}+0.5$ & & $2.98 E+06$ & $2.98 E+06$ & 1.41E+02 & $3.325+03$ \\
\hline Density $(\mathrm{g} / \mathrm{L})$ & $1.31 E+03$ & $1.31 E+03$ & $1.31 \mathrm{E}+03$ & 1. $00 E+03$ & $1.01 E+03$ & & 1.31E+03 & 1.31E+03 & $1.31 \mathrm{E}+03$ & $1.00 E+03$ \\
\hline Total Mass Flow (kg) & $3.92 \mathrm{E}+06$ & $3.90 E+06$ & $1.84 E+04$ & $3.31 E+05$ & 3.50E+05 & & $3,90 E+06$ & $3.90 \mathrm{E}+06$ & $1.85 E+02$ & $3.32 E+03$ \\
\hline \multicolumn{11}{|l|}{ RADIONUCLIOES (Ci) } \\
\hline Cesium & 4. $98 E+05$ & 4. $95 \mathrm{EE}+05$ & 2. $34 E+03$ & & $2.34 \mathrm{E}+03$ & & 4. $9 \mathrm{E}+05$ & 4.95E+05 & $2.35 E+01$ & \\
\hline Strantiun & $1.50 E+05$ & $1.49 E+05$ & $7.07 \mathrm{E}+02$ & & $7.07 E+02$ & & 2. 39E+04 & 2. $39 \mathrm{E}+04$ & $1.14 E+00$ & \\
\hline Technetiun & $5.84 E+02$ & 5. $82 E+02$ & $2.7 \mathrm{E}+00$ & & $2.75 E+00$ & & $5.22 \mathrm{E}+02$ & $5.82 E+02$ & $2.76 \mathrm{E}-02$ & \\
\hline & $3.23 \mathrm{E}+02$ & $3.225+02$ & $1.52 \mathrm{E}+00$ & & $1.52 \mathrm{E}+00$ & & $3.22 \mathrm{E}+02$ & $3.22 \mathrm{E}+02$ & 1. $53 \mathrm{E}-02$ & \\
\hline \multicolumn{11}{|l|}{ CHEMTCAIS (kg) } \\
\hline$A G+$ & $1.24 \mathrm{E}-09$ & $1.24 \mathrm{E}-09$ & $5.86 \mathrm{E}-12$ & & $5.86 \mathrm{E}-12$ & & $1.24 \mathrm{E}-09$ & $1.24 \mathrm{E}-09$ & $5.8 \%-14$ & \\
\hline$A L\langle C H\rangle 4^{-}$ & $9.16 E+04$ & $9.12 E+04$ & $4.31 E+02$ & & $4.31 \mathrm{E}+02$ & & $9.12 E+04$ & $9.12 \mathrm{E}+04$ & $4.32 E+\infty 0$ & \\
\hline$A M+3$ & $5.56 \mathrm{E}-02$ & $5.54 E-02$ & $2.62 \mathrm{E}-04$ & & $2.62 \mathrm{~F}-04$ & & $5.54 \mathrm{E}-02$ & $5.54 \mathrm{E}-02$ & $2.63 \mathrm{E}-06$ & \\
\hline$A S+5$ & $7.21 \mathrm{E}-10$ & $7.188-10$ & $3.40 \mathrm{E}-12$ & & $3.40 \mathrm{E}-12$ & & $7.18 E-10$ & $7.18 \mathrm{E}-10$ & $3.41 \mathrm{E}-14$ & \\
\hline $\mathrm{B}+3$ & $3.535-08$ & $3.525-08$ & $1,66 \mathrm{E}-10$ & & $1.66 \mathrm{E}-10$ & & $3.52 \mathrm{E}-08$ & $3.52 E-08$ & $1.6 \pi-12$ & \\
\hline$B A+2$ & $3.83 E-04$ & $3.81 E-04$ & $1.80 \mathrm{E}-06$ & & $1.80 \mathrm{E}-06$ & & $3.81 \mathrm{E}-04$ & $3.81 \mathrm{E}-04$ & $1.81 \mathrm{E}-08$ & \\
\hline $\mathrm{EE}+2$ & $1.59 \mathrm{E}-10$ & $1.58 \mathrm{~g}-10$ & $7.48 \mathrm{E}-13$ & & $7.48 \mathrm{EE}-13$ & & $1.58 E-10$ & $1.58 E-10$ & $7.51 \mathrm{E}-15$ & \\
\hline$B I+3$ & $5.88 E-13$ & $5.86 \mathrm{E}-13$ & $2.77 \mathrm{E}-15$ & & $2.77 E-15$ & & 5. $86 \mathrm{E}-13$ & 5. $86 \mathrm{E}-13$ & $2.78 \mathrm{E}-17$ & \\
\hline$C-14$ & $7.16 \mathrm{E}-03$ & $7.13 \mathrm{E}-03$ & $3.37 \mathrm{E}-05$ & & $3.37 \mathrm{E}-05$ & & $7.13 E-03$ & 7. $13 \mathrm{E}-03$ & $3.38 E-07$ & \\
\hline $\mathrm{CA}+2$ & $8.41 E+02$ & $8.37 \mathrm{E}+02$ & $3,96 \mathrm{E}+00$ & & $3.968+00$ & & 8. $37 \mathrm{E}+02$ & $8.37 E+02$ & $3.9 \pi-02$ & \\
\hline$\omega+2$ & 5.52E-03 & $5.50 E-03$ & 2. $60 \mathrm{E}-05$ & & $2.60 E-05$ & & $5.50 \mathrm{E}-03$ & $5.50 \mathrm{E}-03$ & $2.61 \mathrm{E}-07$ & \\
\hline Ci- & $7.21 \mathrm{E}+03$ & $7.17 \mathrm{E}+03$ & 3. $39 \mathrm{E}+01$ & & $3.39 \mathrm{E}+01$ & & $7.17 \mathrm{E}+03$ & 7.17E+03 & $3.40 \mathrm{E}-01$ & \\
\hline \multirow{2}{*}{\multicolumn{11}{|c|}{$\begin{array}{l}012 \\
020\end{array}$}} \\
\hline $\mid \begin{array}{l}\infty 02 \\
\infty\end{array}$ & & & & & & & & & & \\
\hline $\mid 000-2$ & $1.2 \pi+05$ & $1.26 \mathrm{E}+05$ & 5. $98 \mathrm{E}+02$ & & $5.98 \mathrm{E}+02$ & & $1.26 \mathrm{E}+05$ & $1.26 \mathrm{E}+05$ & $6.00 E+00$ & \\
\hline OR(CH)4- & $1.22 x+03$ & $1.21 \mathrm{E}+03$ & $5.73 \mathrm{E}+00$ & & $5.73 \mathrm{E}+00$ & & $1.21 E+03$ & 1. 21E+03 & $5.75 \mathbf{E}-02$ & \\
\hline CSt & $5.75+00$ & $5.725+\infty 0$ & $2,70 \mathrm{E}-02$ & & $2.70 \mathrm{E}-02$ & & $5.72 E+00$ & $5.72 E+00$ & $2.71 E-04$ & \\
\hline $\bar{a}+2$ & $4.14 \mathrm{E}-03$ & $4.12 \mathrm{E}-03$ & $1.95 \mathrm{E}-05$ & & $1.95 \mathrm{SE}-05$ & & 4. $12 E-03$ & $4.128-03$ & $1.95-07$ & \\
\hline DU-154 & $5.34 \mathrm{E}-03$ & $5.31 E-03$ & $2.51 \mathrm{E}-05$ & & $2.51 \mathrm{E}-05$ & & $5.31 \mathrm{E}-03$ & $5.31 \mathrm{E}-03$ & $2.52 E-07$ & \\
\hline F- & $3.66 E+03$ & $3.64 E+03$ & $1.72 \mathrm{E}+01$ & & $1.72 E+01$ & & $3,64 E+03$ & $3.64 E+03$ & $1.73 \mathrm{E}-01$ & \\
\hline \multicolumn{11}{|l|}{ F2 } \\
\hline $\mathrm{FE}+3$ & $1.96 \mathrm{EE}+02$ & $1.97 \mathrm{E}+\mathrm{C2}$ & $9.31 \mathrm{E}-01$ & & $9.31 \mathrm{E}-01$ & & $1.97 \mathrm{E}+02$ & $1.97 \mathrm{E}+02$ & 9.34E-03 & \\
\hline 1100 & $2.51 \mathrm{E}+06$ & $2.49 E+06$ & $1.18 E+04$ & $3.31 \mathrm{E}+05$ & $3.43 \mathrm{E}+05$ & & $2.49 E+06$ & $2.49 E+06$ & 1. $188+02$ & $3.32 E+03$ \\
\hline $\mathrm{HG}+2$ & $5.52 \mathrm{E}-03$ & 5. $50 \mathrm{E}-03$ & 2. $60 \mathrm{E}-05$ & & $2.60 \mathrm{E}-05$ & & $5.50 \mathrm{E}-03$ & 5. $50 \mathrm{E}-03$ & $2.61 \mathrm{E}-07$ & \\
\hline $\mathrm{K}+$ & $7.12 \mathrm{E}+03$ & 7.09E+03 & $3.3 \mathrm{EE}+01$ & & $3.35 \mathrm{SE}+01$ & & $7.09 \mathrm{E}+03$ & 7. $09 \mathrm{E}+03$ & $3,36 \mathrm{E}-01$ & \\
\hline$I A+3$ & $4.081-03$ & $4.06 \mathrm{E}-03$ & $1.92 \mathrm{E}-05$ & & $1.92 \mathrm{E}-0.5$ & & $4.06 \mathrm{E}-0.3$ & 4. $06 \mathrm{E}-03$ & $1.93 \mathrm{E}-07$ & \\
\hline $1 \mathrm{nO}+2$ & $1.16 \mathrm{E}-02$ & $1.15 \mathrm{~F}-02$ & $5.45-05$ & & $5.45 \mathrm{E}-0.5$ & & $1.158-02$ & $1.15 \mathrm{E}-02$ & $5.4 \pi \mathrm{E}-07$ & \\
\hline wat+4 & 6.61E+01 & $6.58 E+01$ & $3.11 \mathrm{E}-01$ & & $3.11 \mathrm{E}-01$ & & $6.58 E+01$ & 6. $58 \mathrm{E}+01$ & $3.12 \mathrm{E}-03$ & \\
\hline $10+6$ & $3.125-02$ & 3. $10 \mathrm{E}-02$ & $1.4 \pi \mathrm{E}-04$ & & $1.4 \pi-04$ & & $3.10 \mathrm{E}-02$ & 3. $10 \mathrm{E}-02$ & $1.4 \pi-06$ & \\
\hline $\mathrm{NA}+$ & $4.9 \mathrm{NE}+05$ & $4.93 \mathrm{E}+05$ & $2.33 \mathrm{E}+03$ & & $2.33 \mathrm{E}+03$ & & $4.93 E+0.5$ & 4. $93 \mathrm{E}+05$ & 2. $34 \mathrm{E}+01$ & \\
\hline NI+3 & $6.73 E+02$ & $6.70 E+02$ & $3.17 \bar{E}+00$ & & $3.17 \mathrm{E}+00$ & & $6.70 \mathrm{E}+02$ & $6.70 \mathrm{E}+02$ & $3.18 E-02$ & \\
\hline \multicolumn{11}{|c|}{ 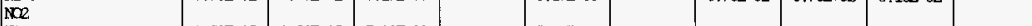 } \\
\hline $\mathrm{NOO}-$ & $1.53 \mathrm{E}+05$ & $1.52 \sqrt{2}+05$ & 7.20E+02 & & $7.20 \mathrm{E}+02$ & & $1.52 \mathrm{E}+05$ & 1. $52 \mathrm{E}+05$ & 7. $222 \mathrm{E}+00$ & \\
\hline NOO- & 4.17E+05 & 4. 1SE+05 & $1.96 \mathrm{E}+03$ & & $1.96 \mathrm{E}+03$ & & 4.15E+05 & $4.15 \mathrm{E}+05$ & $1.97 \mathrm{E}+01$ & \\
\hline $\mathrm{NF}+4$ & $8.54 E^{-04}$ & $8.50 \mathrm{E}^{-04}$ & $4.02 E-06$ & & $4.02 E-106$ & & $8.50 \mathrm{E}-04$ & $8.50 \mathrm{E}-04$ & $4.03 E-08$ & \\
\hline \multicolumn{11}{|l|}{$\infty$} \\
\hline |'t- & $2.12 E+04$ & $2.11 \mathrm{E}+04$ & $9.96 \mathrm{E}+01$ & & $9.96 \mathrm{E}+01$ & & $2.11 E+04$ & $2.11 \mathrm{E}+04$ & $9.99 \mathrm{E}-01$ & \\
\hline EB+4 & $4.36 \mathrm{E}+01$ & 4. $34 E+01$ & $2.05 E-01$ & & $2.05 \sqrt{E}-01$ & & $4,34 E+01$ & $4.34 \mathrm{E}+01$ & $2.06 \mathrm{E}-03$ & \\
\hline $\mathrm{FO}_{4}-3$ & 8. $64 \mathrm{E}+03$ & $8.60 \mathrm{E}+\mathrm{CB} 3$ & $4.07 \mathrm{E}+01$ & & 4.07E+01 & & $8,60 \mathrm{E}+03$ & $8.60 \mathrm{E}+03$ & $4.08 E-01$ & \\
\hline $\mathrm{Fl}+4$ & $1.85 \mathrm{E}+\infty$ & $1.82 E+\infty$ & $8.61 E-03$ & & $8.61 \mathrm{E}-03$ & & 1. $Q 2 E+\infty 0$ & 1. $82 E+00$ & 8. $64 E-05$ & \\
\hline $\mathrm{SE}+6$ & $4.63 \mathrm{E}-07$ & $4.61 \mathrm{E}-07$ & $2.18 E-09$ & & $2.18 \mathrm{p}-09$ & & $4.61 \mathrm{E}-07$ & $4.61 \mathrm{E}-07$ & 2. $19 \mathrm{E}-11$ & \\
\hline SIIt4 & $2.59 \mathrm{E}+00$ & $2.5 \mathrm{aE}+00$ & 1.22E- 02 & & $1.22 \mathrm{E}-02$ & & $2.58 E+00$ & 2. $58 \mathrm{E}+00$ & $1.22 \mathrm{E}-04$ & \\
\hline $52+4$ & $9.85 E-13$ & $9.80 E-13$ & $4.64 E-15$ & & $4.64 \mathrm{E}-15$ & & $9.80 \mathrm{E}-13$ & $9.80 \mathrm{E}-13$ & $4.65-17$ & \\
\hline $504-2$ & 2. $70 \mathrm{EE}+04$ & $2.69 \mathrm{E}+04$ & $1.27 \mathbb{E}+02$ & & $1.2 \mathrm{~F}+02$ & & $2.69 \mathrm{E}+04$ & 2. 69E+04 & $1.28 \mathrm{E}+00$ & \\
\hline $5 R+2$ & $1.08 E+00$ & $1.08 E+\infty 0$ & $5.08 \mathrm{~B}-03$ & & $5.08 \mathrm{E}-03$ & & $1,7 \mathbb{E}-01$ & $1.72 E-01$ & $8.16 \mathrm{E}-06$ & \\
\hline 100$)_{4}^{-}$ & 5. $66 \mathrm{E}+01$ & 5. $63 \mathrm{EE}+01$ & $2.66 \mathrm{E}-01$ & & 2. $66 \mathrm{E}-01$ & & 5. $6 \mathrm{JE}+01$ & $5.63 \mathrm{E}+01$ & $2.6 \pi-03$ & \\
\hline $\mathrm{Ti}+4$ & $6.61 \mathrm{E}-05$ & $6.58 \mathrm{E}-0.5$ & $3.11 \mathrm{E}-07$ & & $3.11 \mathrm{E}-07$ & & $6.588-0.5$ & $6.588-05$ & 3. $122-09$ & \\
\hline$T 0 \mathrm{C}$ & $5.15 \mathrm{E}+04$ & $5.13 \mathrm{E}+04$ & $2.42 E+02$ & & $2.42 \mathrm{E}+02$ & & $5.13 E+04$ & $5.13 E+04$ & $2.43 \mathrm{E}+\infty 0$ & \\
\hline $100+2$ & $7.88 \mathrm{E}+01$ & 7. $84 \mathrm{E}+01$ & 3.71E-01 & & $3.712-01$ & & 7.84E+01 & $7.84 \mathrm{E}+01$ & $3.72 \mathrm{E}-03$ & \\
\hline$w+6$ & $7.18 \mathrm{E}-02$ & $7.15-02$ & $3.38 E-04$ & & $3.38 \bar{E}-04$ & & $7.15-02$ & $7.15 \mathrm{E}-02$ & $3.39 \mathrm{E}-06$ & \\
\hline $2 \mathrm{z}+2$ & $2.1 \pi-02$ & $2.16 \mathrm{E}-02$ & $1.02 E-04$ & & $1.02 \mathrm{E}-04$ & & $2.16 \mathrm{E}-02$ & $2.16 \mathrm{E}-02$ & $1.02 \mathrm{E}-06$ & \\
\hline$\pi \mathbb{R}+4$ & $7.06 \mathrm{E}-04$ & $7.03 \mathrm{E}-04$ & 3. $32 E-06$ & & 3. $32 \mathrm{E}-06$ & & 7. $03 \mathrm{E}-04$ & 7. $03 \mathrm{E}-0.4$ & 3. $33 \mathrm{E}-08$ & \\
\hline
\end{tabular}


WHC-SD-WM-TI-774 Rev. 0

TWRS PRIVATIZATION PROCESS TECHNICAL BASELINE

Table B- 9 Phase 1 LAW Mass Balance for Batch PCl/9 (6 sheets)

\begin{tabular}{|c|c|c|c|c|c|c|c|c|c|c|}
\hline $\begin{array}{l}\text { SIREAM NAME } \\
\text { SIID COMFONEMS }\end{array}$ & 1 & 2 & 3 & 4 & 5 & 6 & 7 & 8 & 9 & 10 \\
\hline Total Mass Flow (kg) & $3.92 E+04$ & $3.92 \mathrm{E}+02$ & $3.88 \pm+04$ & & $3.88 \mathrm{E}+04$ & & $3.94 \mathrm{E}+02$ & $3.94 \mathrm{E}+00$ & $3.90 E+02$ & \\
\hline \multicolumn{11}{|l|}{ RADIONULIDES (Ci) } \\
\hline $\begin{array}{l}\text { Cesium } \\
\text { Stucntiun } \\
\text { Technetium } \\
\text { TRI }\end{array}$ & & & & & & & $1.26 \mathrm{E}+05$ & $1.26 \mathrm{E}+03$ & $1.24 \mathrm{E}+0.5$ & \\
\hline
\end{tabular}

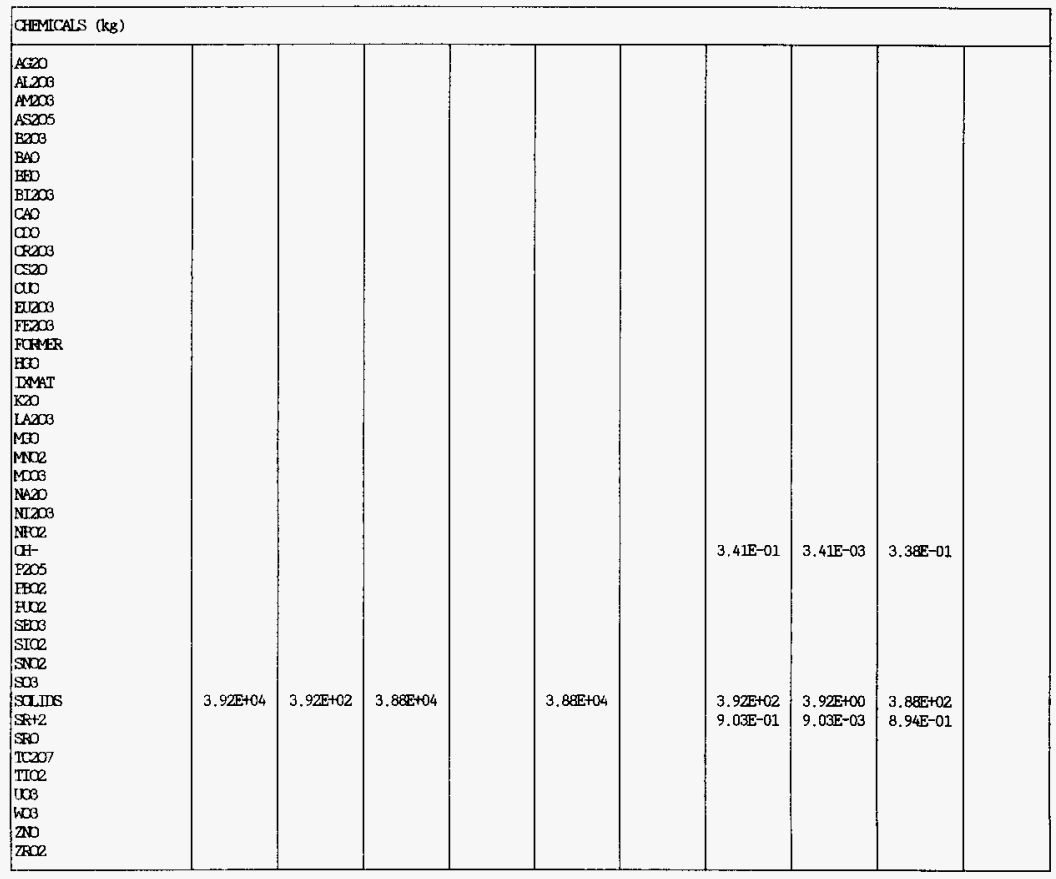


WHC-SD-WM-TI-774 ReV. 0

\section{TWRS PRIVATIZATION PROCESS TECHNICAL BASELINE}

Table B-9 Phase 1 LAW Mass Balance for Batch PGl/9 (6 sheets)

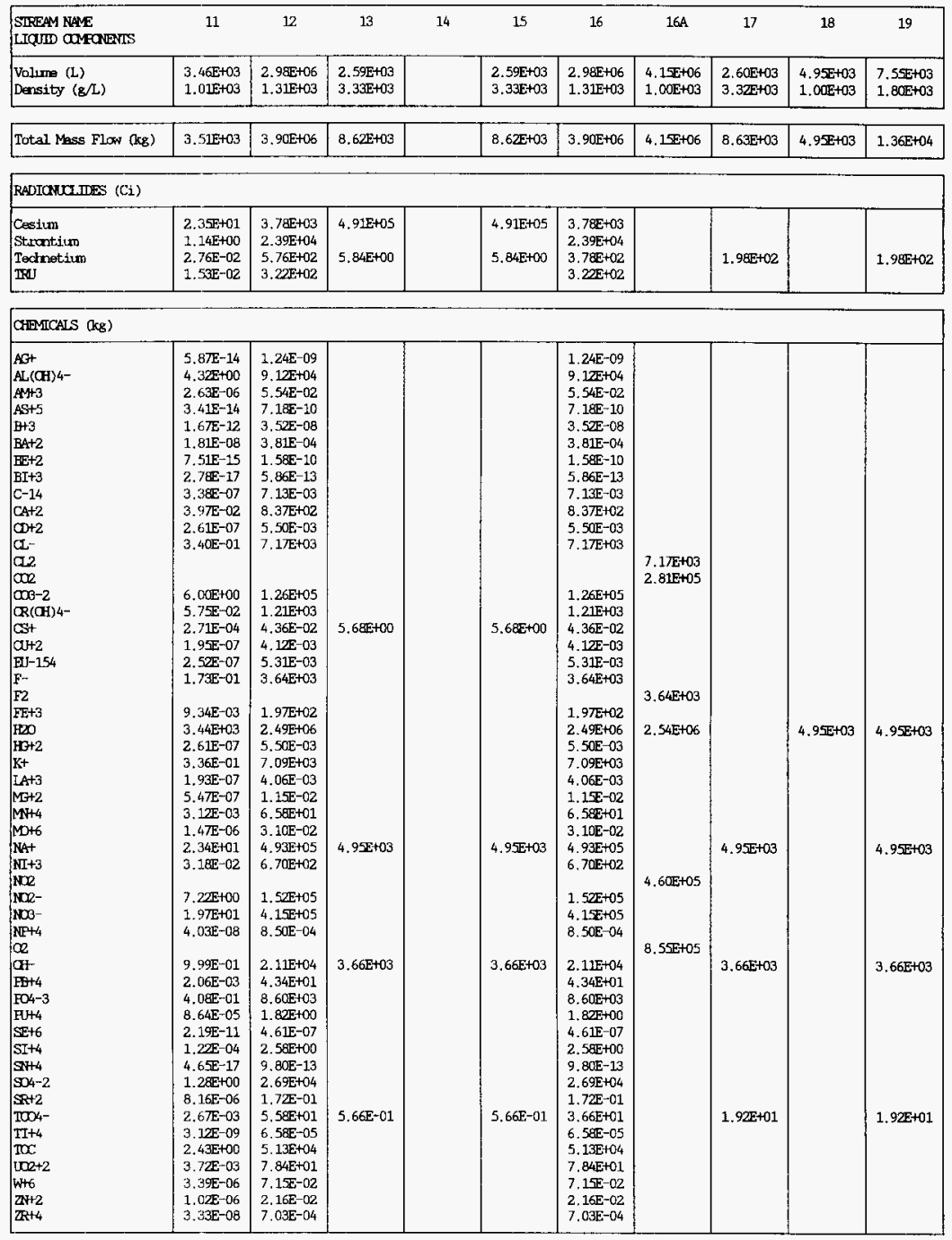


WHC-SD-WM-TI-774 Rev. 0

TWRS PRIVATIZATION PROCESS TECHNICAL BASELINE

Table B- 9 Phase 1 LAW Mass Balance for Batch PCl/9 (6 sheets)

\begin{tabular}{|c|c|c|c|c|c|c|c|c|c|c|}
\hline $\begin{array}{l}\text { SIKEAM NAYE } \\
\text { SLID OAFONDNIS }\end{array}$ & 11 & 12 & 13 & 24 & 15 & 16 & IEA & 17 & 18 & 19 \\
\hline Total Mass Flow (kg) & $3.90 \mathrm{E}+02$ & 3.94E+00 & & $4.95 E+03$ & $4.95 E+03$ & $3.94 \mathrm{E}+00$ & $7.54 \mathrm{E}+0.5$ & & & \\
\hline \multicolumn{11}{|l|}{ RADIONOCIIIES (Ci) } \\
\hline $\begin{array}{l}\text { Cesium } \\
\text { Strontium } \\
\text { Tectretiun } \\
\text { TRI }\end{array}$ & $1.24 E+05$ & $1.26 E+03$ & & & & $1,26 \mathrm{E}+03$ & $\begin{array}{l}3.78 E+03 \\
2.52 E+04 \\
3.79 E+02 \\
3.20 E+02\end{array}$ & & & \\
\hline \multicolumn{11}{|l|}{ CAMICALS (kg) } \\
\hline 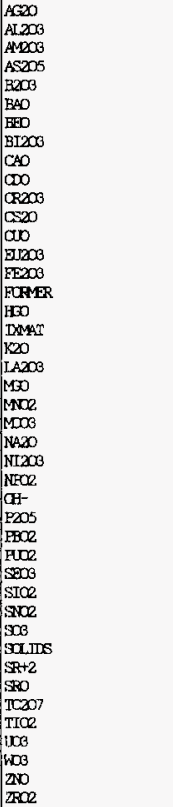 & $\begin{array}{l}3.38 \mathrm{E}-01 \\
\\
3.86 \mathrm{E}+02 \\
8.94 \mathrm{E}-01\end{array}$ & $\begin{array}{l}3.41 E-03 \\
\\
3.92 E+00 \\
9.03 E-03\end{array}$ & & $4.95 \mathrm{E}+03$ & $4.95 \mathrm{~F}+03$ & $\begin{array}{l}3.41 \mathrm{E}-03 \\
\\
3.92 \mathrm{E}+00 \\
9.02 \mathrm{E}-03\end{array}$ & $\begin{array}{l}1.33 \mathrm{E}-09 \\
4.89 \mathrm{E}+04 \\
6.09 \mathrm{E}-02 \\
1.10 \mathrm{E}-09 \\
1.13 \mathrm{E}-07 \\
4.25 \mathrm{E}-04 \\
4.39 \mathrm{E}-10 \\
6.53 \mathrm{E}-13 \\
1.17 \mathrm{E}+03 \\
6.28 \mathrm{E}-03 \\
7.68 \mathrm{E}+02 \\
4.62 \mathrm{E}-02 \\
5.16 \mathrm{E}-03 \\
6.15 \mathrm{E}-03 \\
2.82 \mathrm{E}+02 \\
5.93 \mathrm{E}-03 \\
8.54 \mathrm{E}+03 \\
4.76 \mathrm{E}-03 \\
1.91 \mathrm{E}-02 \\
1.04 \mathrm{E}+02 \\
4.66 \mathrm{E}-02 \\
6.64 \mathrm{E}+05 \\
9.44 \mathrm{E}+02 \\
9.64 \mathrm{E}-04 \\
\\
6.43 \mathrm{E}+03 \\
5.01 \mathrm{E}+01 \\
2.06 \mathrm{E}+00 \\
7.4 \mathrm{E}-07 \\
5.52 \mathrm{E}+00 \\
1.25 \mathrm{E}-12 \\
2.24 \mathrm{E}+04 \\
3.92 \mathrm{E}+00 \\
\\
2.13 \mathrm{E}-01 \\
3.48 \mathrm{E}+01 \\
1.10 \mathrm{E}-04 \\
8.30 \mathrm{E}+01 \\
9.01 \mathrm{E}-02 \\
2.69 \mathrm{E}-02 \\
9.49 \mathrm{E}-04\end{array}$ & & & \\
\hline
\end{tabular}


WHC-SD-WM-TI-774 Rev. 0

TWRS PRIVATIZATION PROCESS TECHNICAL BASELINE

Table B-9 Phase 1 LAW Mass Balance for Batch PC1/9 (6 sheets)

\begin{tabular}{|c|c|c|c|c|c|c|c|c|c|}
\hline $\begin{array}{l}\text { SIREAM NAME } \\
\text { IIQUID OMFANENIS }\end{array}$ & 20 & 21 & 22 & 23 & 24 & 25 & 26 & 27 & 28 \\
\hline $\begin{array}{l}\text { Volume (L) } \\
\text { Density (g/L) }\end{array}$ & $\begin{array}{l}\text { 4. } 1.5+06 \\
\text { 1. } 000+033\end{array}$ & & & & $\begin{array}{l}1.61 E+06 \\
1.00 E+03\end{array}$ & $\begin{array}{l}2.54 \mathrm{E}+06 \\
1.00 \mathrm{E}+03\end{array}$ & $\begin{array}{l}2.56 E+03 \\
3.34 E+03\end{array}$ & $\begin{array}{l}2.58 E+03 \\
\text { 3. } 34 \mathrm{E}+03\end{array}$ & $\begin{array}{l}1.00 E+06 \\
1.00 E+03\end{array}$ \\
\hline Total Mass Flow (kg) & 4. $15 \mathrm{E}+06$ & & & & $1.61 E+06$ & $2.54 \mathrm{E}+06$ & 8. $62 \mathrm{E}+113$ & $8.62 E+03$ & 1.00E+06 \\
\hline \multicolumn{10}{|l|}{ RADIONUCIIIES (Ci) } \\
\hline $\begin{array}{l}\text { Cesiun } \\
\text { Struntiun } \\
\text { Technetium } \\
\text { TRU }\end{array}$ & & & & & & & & & \\
\hline
\end{tabular}

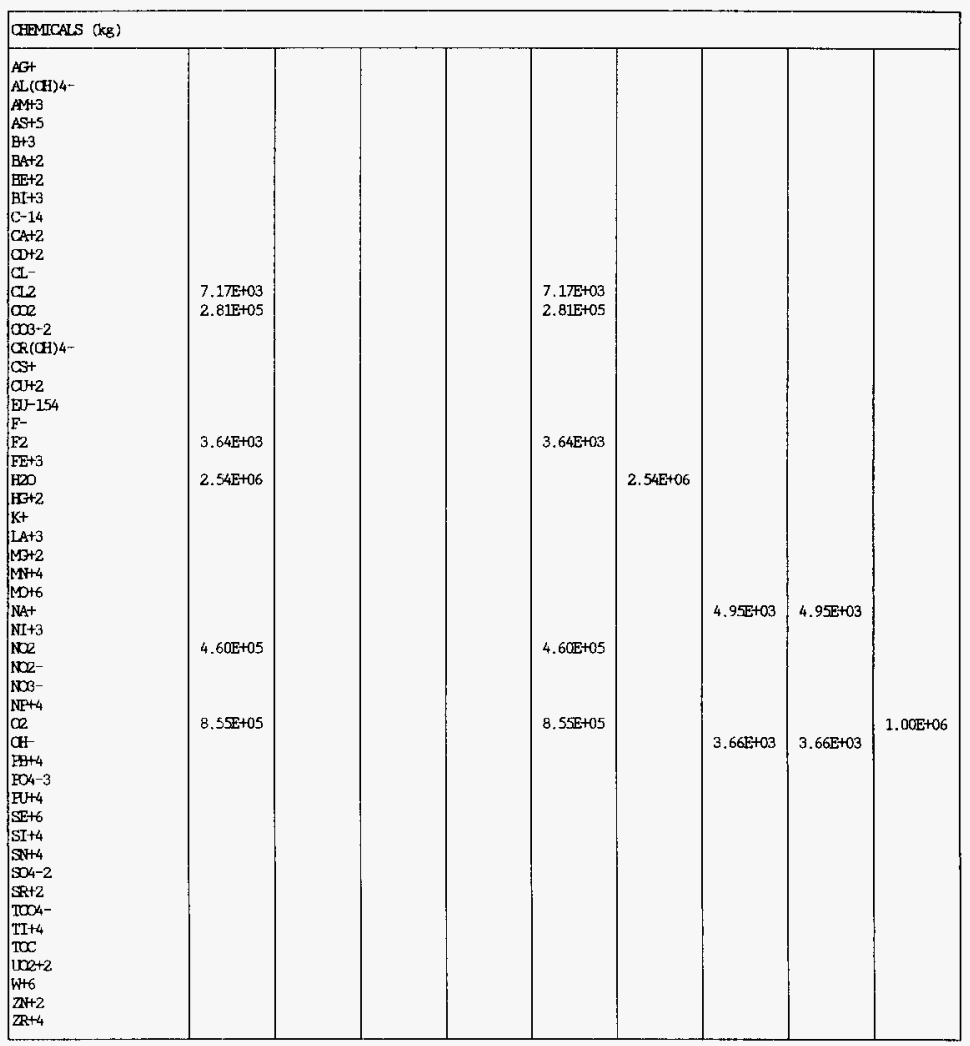


WHC-SD-WM-TI-774 Rev. 0

TWRS PRIVATIZATION PROCESS TECHNICAL BASELINE

Table B-9 Phase 1 LAW Mass Balance for Batch PC1/9 (6 sheets)

\begin{tabular}{|c|c|c|c|c|c|c|c|c|c|}
\hline $\begin{array}{l}\text { SIRFAM NAME } \\
\text { SOLD COMEONDNSS }\end{array}$ & 20 & 21 & 22 & 23 & 24 & 25 & 26 & 27 & 28 \\
\hline Total Mass Flow (kg) & & $7.54 \mathrm{E}+05$ & $3.18 \mathrm{E}+06$ & $3,93 \mathrm{E}+06$ & & & & & \\
\hline \multicolumn{10}{|l|}{ RADIONUCIIIES (Ci) } \\
\hline $\begin{array}{l}\text { Cesiun } \\
\text { Strantium } \\
\text { Technetium } \\
\text { TIRI }\end{array}$ & & $\begin{array}{l}3.78 \mathrm{E}+03 \\
2.52 \mathrm{E}+04 \\
3.78 \mathrm{E}+02 \\
3.20 \mathrm{E}+02\end{array}$ & & $\begin{array}{l}3.78 \mathrm{E}+03 \\
2.52 \mathrm{E}+04 \\
3.78 \mathrm{E}+02 \\
3.20 \mathrm{E}+02\end{array}$ & & & & & \\
\hline \multicolumn{10}{|l|}{ GEMACALS (kg) } \\
\hline 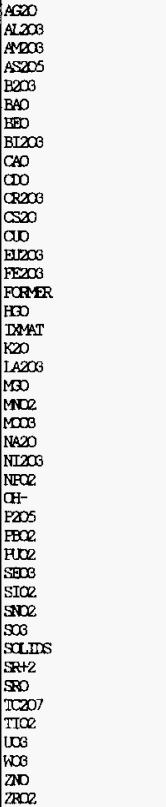 & & $\begin{array}{l}1.33 \mathrm{E}-09 \\
4.89 \mathrm{E}+04 \\
6.09 \mathrm{E}-02 \\
1.10 \mathrm{E}-09 \\
1.13 \mathrm{E}-07 \\
4.25 \mathrm{E}-04 \\
4.39 \mathrm{E}-10 \\
6.55 \mathrm{E}-13 \\
1.13 \mathrm{E}+03 \\
6.2 \mathrm{gE}-03 \\
7.68 \mathrm{E}+02 \\
4.62 \mathrm{E}-02 \\
5.16 \mathrm{E}-03 \\
6.15 \mathrm{~F}-03 \\
2.82 \mathrm{E}+02 \\
\\
5.93 \mathrm{E}-03 \\
8.54 \mathrm{E}+03 \\
4.76 \mathrm{E}-03 \\
1.91 \mathrm{E}-02 \\
1.04 \mathrm{E}+02 \\
4.66 \mathrm{E}-02 \\
6.64 \mathrm{E}+05 \\
9.44 \mathrm{E}+02 \\
9.64 \mathrm{E}-04 \\
\\
6.43 \mathrm{E}+03 \\
5.01 \mathrm{E}+01 \\
2.06 \mathrm{E}+00 \\
7.4 \mathrm{E}-07 \\
5.52 \mathrm{E}+00 \\
1.25 \mathrm{E}-12 \\
2.24 \mathrm{E}+04 \\
3.92 \mathrm{E}+00 \\
\\
2.13 \mathrm{E}-01 \\
3.48 \mathrm{E}+01 \\
1.10 \mathrm{E}-04 \\
8.30 \mathrm{E}+01 \\
9.01 \mathrm{E}-02 \\
2.69 \mathrm{E}-02 \\
9.49 \mathrm{E}-04\end{array}$ & $3.18 \mathrm{E}+06$ & $\begin{array}{l}1.33 \mathrm{E}-09 \\
4.89 \mathrm{E}+04 \\
6.09 \mathrm{E}-02 \\
1.10 \mathrm{E}-09 \\
1.13 \mathrm{E}-07 \\
4.25 \mathrm{E}-04 \\
4.39 \mathrm{E}-10 \\
6.53 \mathrm{E}-13 \\
1.17 \mathrm{E}+03 \\
6.28 \mathrm{E}-03 \\
7.68 \mathrm{E}+02 \\
4.62 \mathrm{E}-02 \\
5.16 \mathrm{E}-03 \\
6.15 \mathrm{E}-03 \\
2.82 \mathrm{E}+02 \\
3.18 \mathrm{E}+06 \\
5.93 \mathrm{E}-03 \\
8.54 \mathrm{E}+03 \\
4.76 \mathrm{E}-03 \\
1.91 \mathrm{E}-02 \\
1.04 \mathrm{E}+02 \\
4.66 \mathrm{E}-02 \\
6.64 \mathrm{E}+05 \\
9.44 \mathrm{E}+02 \\
9.64 \mathrm{E}-04 \\
\\
6.43 \mathrm{E}+03 \\
5.01 \mathrm{E}+01 \\
2.06 \mathrm{E}+00 \\
7.41 \mathrm{E}=07 \\
5.52 \mathrm{E}+00 \\
1.25 \mathrm{E}-12 \\
2.24 \mathrm{E}+04 \\
3.92 \mathrm{E}+00 \\
\\
2.13 \mathrm{E}-01 \\
3.48 \mathrm{E}+01 \\
1.10 \mathrm{E}-04 \\
8.30 \mathrm{E}+01 \\
9.01 \mathrm{E}-02 \\
2.69 \mathrm{E}-02 \\
9.49 \mathrm{E}-04\end{array}$ & & & & & \\
\hline
\end{tabular}


WHC-SD-WM-TI-774 Rev. 0

TWRS PRIVATIZATION PROCESS TECHNICAL BASELINE

Table B-10 Phase 1 LAW Mass Balance for Batch PCl/10 (6 sheeets)

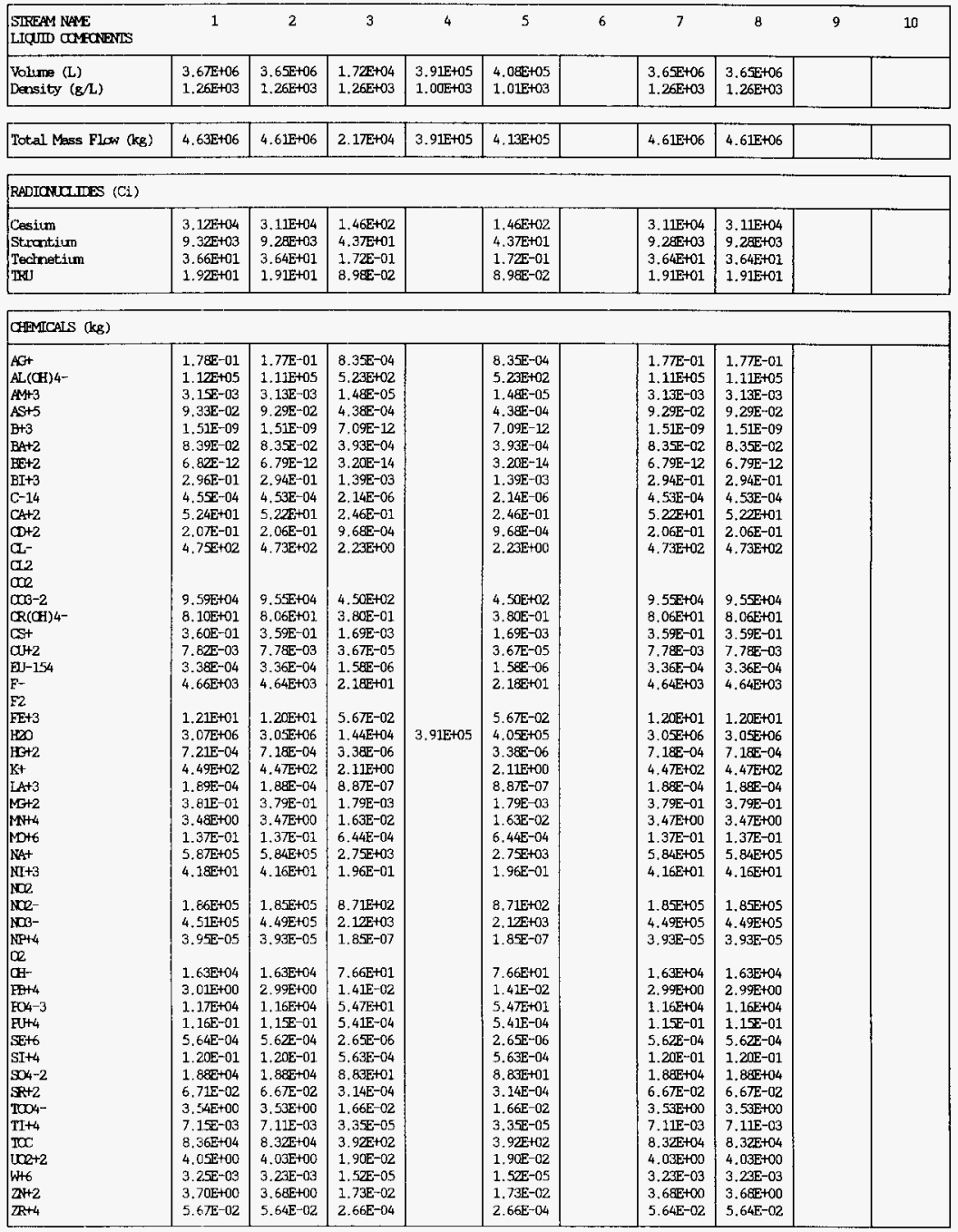


WHC-SD-WM-TI-774 Rev. 0

TWRS PRIVATIZATION PROCESS TECHNICAL BASELINE

Table B-10 Phase 1 IAW Mass Balance for Batch PCl/10 (6 sheeets)

\begin{tabular}{|c|c|c|c|c|c|c|c|c|c|c|}
\hline $\begin{array}{l}\text { SIFEAM NAE } \\
\text { SOII OOEONENIS }\end{array}$ & 1 & 2 & 3 & 4 & 5 & 6 & 7 & 8 & 9 & 10 \\
\hline Total Mass Flaw (kg) & $4.63 E+04$ & $4.63 E+02$ & $4.59 \mathrm{E}+04$ & & $4.59 \mathrm{E}+04$ & & $4.63 \mathrm{E}+02$ & $4.63 E+02$ & & \\
\hline \multicolumn{11}{|l|}{ RADIONCLIIES (Ci) } \\
\hline $\begin{array}{l}\text { Cesium } \\
\text { Strantium } \\
\text { Technetium } \\
\text { TRI }\end{array}$ & & & & & & & & & & \\
\hline
\end{tabular}

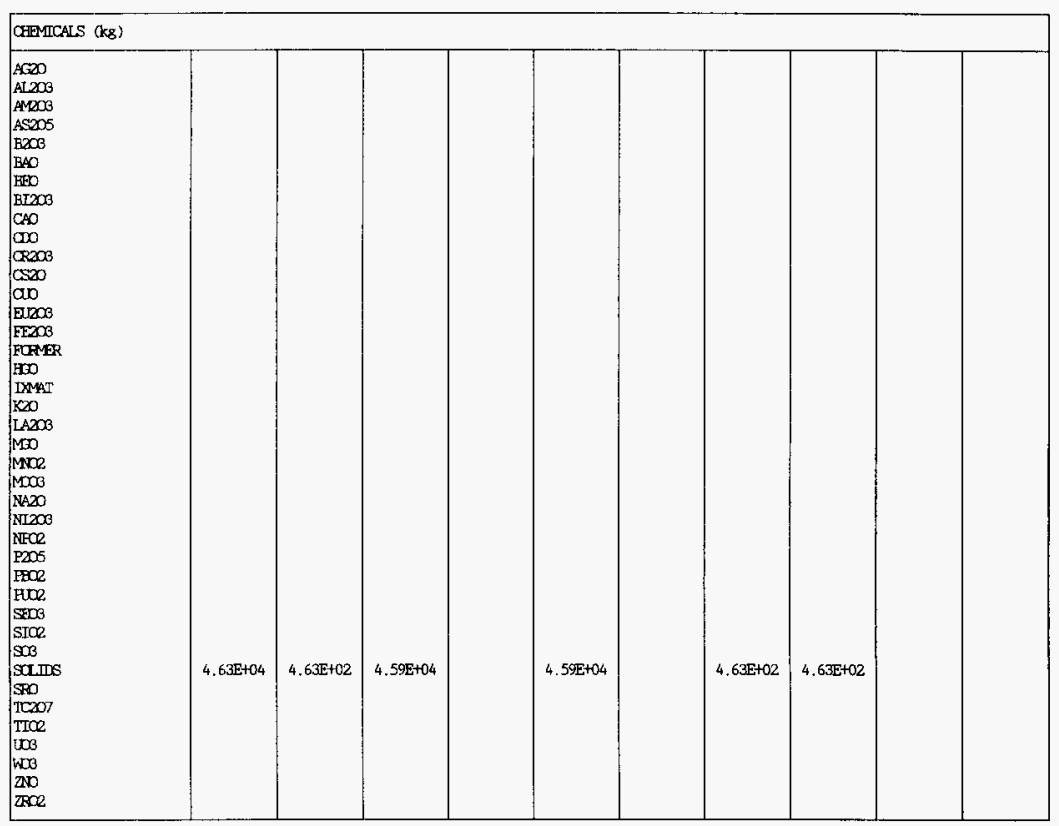


WHC-SD-WM-TI-774 Rev. 0

TWRS PRIVATIZATION PROCESS TECHNICAL BASELINE

Table B-10 Phase 1 IAW Mass Balance for Batch PC1/10 (6 sheeets)

\begin{tabular}{|c|c|c|c|c|c|c|c|c|c|c|}
\hline $\begin{array}{l}\text { STREAM NAME } \\
\text { LTQNID OOMFANENIS }\end{array}$ & 11 & 12 & 13 & 14 & 15 & 16 & $16 A$ & 17 & 18 & 19 \\
\hline $\begin{array}{l}\text { Volume }(\mathrm{L}) \\
\text { Density }(\mathrm{g} / \mathrm{L})\end{array}$ & & $\begin{array}{l}3.65 \mathrm{E}+06 \\
1.26 \mathrm{E}+03\end{array}$ & $\begin{array}{l}3.06 \mathrm{E}+03 \\
3.34 \mathrm{E}+\mathrm{CO}\end{array}$ & & $\begin{array}{l}3.06 E+03 \\
3.34 E+03\end{array}$ & $\begin{array}{l}3.65 E+06 \\
1.26 E+03\end{array}$ & $\begin{array}{l}4.74 E+06 \\
1.00 E+03\end{array}$ & & $\begin{array}{l}1.00 \mathrm{E}-09 \\
1.00 \mathrm{E}+03\end{array}$ & $\begin{array}{l}1.00 \mathrm{E}-09 \\
1.00 \mathrm{E}+03\end{array}$ \\
\hline Total Mess Flow (kg) & & $4.61 E+06$ & $1.02 E+04$ & & $1.02 E+04$ & $4.61 \mathrm{E}+06$ & $4.74 E+06$ & & $1.00 \mathrm{E}-09$ & $1.00 \mathrm{E}-09$ \\
\hline \multicolumn{11}{|l|}{ RADICNUCIIIES (Ci) } \\
\hline $\begin{array}{l}\text { Cesium } \\
\text { Strantium } \\
\text { Tochnetiun } \\
\text { IRI }\end{array}$ & & $\begin{array}{l}4.48 \mathrm{E}+03 \\
9.28 \mathrm{E}+03 \\
3.60 \mathrm{E}+01 \\
1.91 \mathrm{E}+01\end{array}$ & $\begin{array}{l}2.66 \mathrm{E}+04 \\
3.66 \mathrm{E}-01\end{array}$ & & $\begin{array}{l}2.66 \mathrm{E}+04 \\
3.66 \mathrm{E}-01\end{array}$ & $\begin{array}{l}4.48 E+03 \\
9.28 E+03 \\
3.60 E+01 \\
1.91 E+01\end{array}$ & & & & \\
\hline \multicolumn{11}{|l|}{ GREMCALS (kg) } \\
\hline 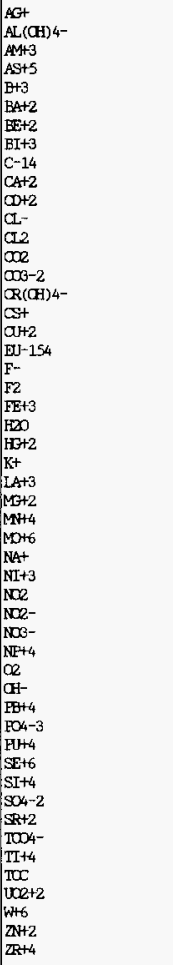 & & 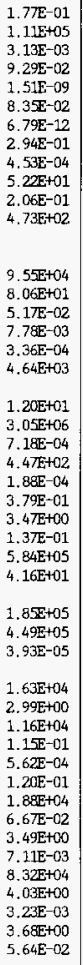 & $\begin{array}{l}5.87 \mathrm{E}+03 \\
4.34 \mathrm{E}+03 \\
3.54 \mathrm{E}-02\end{array}$ & & $\begin{array}{l}3.07 \mathrm{E}-01 \\
5.87 \mathrm{E}+03 \\
4.34 \mathrm{E}+03 \\
3.54 \mathrm{E}-02\end{array}$ & $\begin{array}{l}1.77 \mathrm{E}-01 \\
1.11 \mathrm{E}+05 \\
3.13 \mathrm{E}-03 \\
9.29 \mathrm{E}-02 \\
1.51 \mathrm{E}-09 \\
8.35 \mathrm{E}-02 \\
6.79 \mathrm{E}-12 \\
2.94 \mathrm{E}-01 \\
4.53 \mathrm{E}-04 \\
5.22 \mathrm{E}+01 \\
2.06 \mathrm{E}-01 \\
4.73 \mathrm{E}+02 \\
\\
9.55 \mathrm{E}+04 \\
8.06 \mathrm{E}+01 \\
5.17 \mathrm{E}-02 \\
7.78 \mathrm{E}-03 \\
3.36 \mathrm{E}-04 \\
4.64 \mathrm{E}+03 \\
\\
1.20 \mathrm{E}+01 \\
3.05 \mathrm{E}+06 \\
7.18 \mathrm{E}-04 \\
4.4 \mathrm{E}+02 \\
1.88 \mathrm{E}-04 \\
3.79 \mathrm{E}-01 \\
3.4 \mathrm{E}+00 \\
1.37 \mathrm{E}-01 \\
5.84 \mathrm{E}+05 \\
4.16 \mathrm{E}+01 \\
\\
1.8 \mathrm{E}+05 \\
4.49 \mathrm{E}+05 \\
3.93 \mathrm{E}-05 \\
1.63 \mathrm{E}+04 \\
2.99 \mathrm{E}+00 \\
1.16 \mathrm{E}+04 \\
1.1 \mathrm{E}-01 \\
5.62 \mathrm{E}-04 \\
1.20 \mathrm{E}-01 \\
1.88 \mathrm{~B}+04 \\
6.6 \mathrm{E}-02 \\
3.49 \mathrm{E}+00 \\
7.11 \mathrm{E}-03 \\
8.32 \mathrm{E}+04 \\
4.03 \mathrm{E}+00 \\
3.23 \mathrm{E}-03 \\
3.6 \mathrm{E} \mathrm{E}+00 \\
5.64 \mathrm{E}-02\end{array}$ & $\begin{array}{l}4.73 E+02 \\
3.75 E+05 \\
\\
4.64 E+03 \\
3.10 E+06 \\
5.18 E+05 \\
7.40 E+05\end{array}$ & & $1.00 \mathrm{E}-09$ & $1.00 \mathrm{E}-09$ \\
\hline
\end{tabular}


WHC-SD-WM-TI-774 Rev. 0

TWRS PRIVATIZATION PROCESS TECHNICAL BASELINE

Table B-10 Phase 1 IAW Mass Balance for Batch PCl/10 (6 sheeets)

\begin{tabular}{|c|c|c|c|c|c|c|c|c|c|c|}
\hline $\begin{array}{l}\text { SIFEAM NANE } \\
\text { SOID COMEONDNSS }\end{array}$ & 11 & 12 & 13 & 14 & 15 & 16 & $16 \mathrm{~A}$ & 17 & 18 & 19 \\
\hline Total Mass Flow (kg) & & $4.63 E+02$ & & $5.87 \mathrm{~T}+03$ & $5.87 \mathrm{E}+03$ & $4.63 E+02$ & $8.72 E+05$ & & & \\
\hline \multicolumn{11}{|l|}{ RADIOAUCLIIES (Ci) } \\
\hline $\begin{array}{l}\text { Cesiun } \\
\text { Struntium } \\
\text { Technetium } \\
\text { TRI }\end{array}$ & & & & & & & $\begin{array}{l}\text { 4. } 48 \mathrm{E}+03 \\
9.2 \mathrm{EE}+03 \\
3.60 \mathrm{E}+01 \\
1.90 \mathrm{E}+01\end{array}$ & & & \\
\hline \multicolumn{11}{|l|}{ CAEMICALS (kg) } \\
\hline 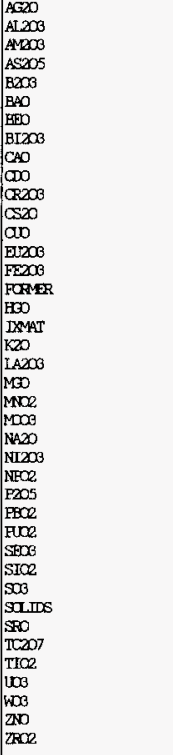 & & $4.63 E+02$ & & 5. $87 \mathrm{E}+103$ & $5.87 \mathrm{E}+03$ & $4.63 E+02$ & $\begin{array}{l}1.90 \mathrm{E}-01 \\
5.95 \mathrm{E}+04 \\
3.44 \mathrm{E}-03 \\
1.43 \mathrm{E}-01 \\
4.85 \mathrm{E}-09 \\
9.32 \mathrm{E}-02 \\
1.88 \mathrm{E}-11 \\
3.28 \mathrm{E}-01 \\
7.30 \mathrm{E}+01 \\
2.35 \mathrm{E}-01 \\
5.10 \mathrm{E}+01 \\
5.47 \mathrm{E}-02 \\
9.74 \mathrm{E}-03 \\
3.89 \mathrm{E}-04 \\
1.72 \mathrm{E}+01 \\
\\
7.75 \mathrm{E}-04 \\
\\
5.39 \mathrm{E}+02 \\
2.21 \mathrm{E}+04 \\
6.29 \mathrm{E}-01 \\
5.4 \mathrm{E}+00 \\
2.05 \mathrm{E}-01 \\
7.87 \mathrm{E}+05 \\
5.86 \mathrm{E}+01 \\
4.46 \mathrm{E}-05 \\
8.68 \mathrm{E}+03 \\
3.46 \mathrm{E}+00 \\
1.30 \mathrm{E}-01 \\
9.03 \mathrm{E}-04 \\
2.56 \mathrm{E}-01 \\
1.56 \mathrm{E}+04 \\
4.63 \mathrm{E}+02 \\
7.86 \mathrm{E}-02 \\
3.32 \mathrm{E}+00 \\
1.19 \mathrm{E}-02 \\
4.26 \mathrm{E}+00 \\
4.08 \mathrm{E}-03 \\
4.58 \mathrm{E}+00 \\
7.62 \mathrm{E}-02\end{array}$ & & & \\
\hline
\end{tabular}


WHC-SD-WM-TI-774 Rev. 0

TWRS PRIVATIZATION PROCESS TECHNICAL BASELINE

Table B-10 Phase 1 LAW Mass Balance for Batch PCl/10 ( 6 sheeets)

\begin{tabular}{|c|c|c|c|c|c|c|c|c|c|}
\hline 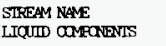 & 20 & 21 & 22 & 23 & 24 & 25 & 26 & 27 & 28 \\
\hline $\begin{array}{l}\text { Volume }(L) \\
\text { Density }(g / L)\end{array}$ & $\begin{array}{l}4.74 \mathrm{E}+06 \\
1.00 \mathrm{E}+03\end{array}$ & & & & $\begin{array}{l}1.64 \mathrm{E}+06 \\
1.00 \mathrm{E}+03\end{array}$ & $\begin{array}{l}3.10 \mathrm{E}+06 \\
1.00 \mathrm{E}+03\end{array}$ & $\begin{array}{l}3.06 E+03 \\
3.34 E+03\end{array}$ & $\begin{array}{l}\text { 3.00E-10 } \\
3.34 E+03\end{array}$ & $\begin{array}{l}1.00 E+06 \\
1.00 E+03\end{array}$ \\
\hline Total Mass Flow (kg) & 4.74E+106 & & & & 1. $64 \mathrm{E}+06$ & $3.10 E+06$ & $1.02 E+04$ & $1.00 \mathrm{E}-09$ & $1.00 E+06$ \\
\hline \multicolumn{10}{|l|}{ RADIONUCDES (Ci) } \\
\hline $\begin{array}{l}\text { Cesium } \\
\text { Strantium } \\
\text { Technotiun } \\
\text { THJ }\end{array}$ & & & & & & & & & \\
\hline
\end{tabular}

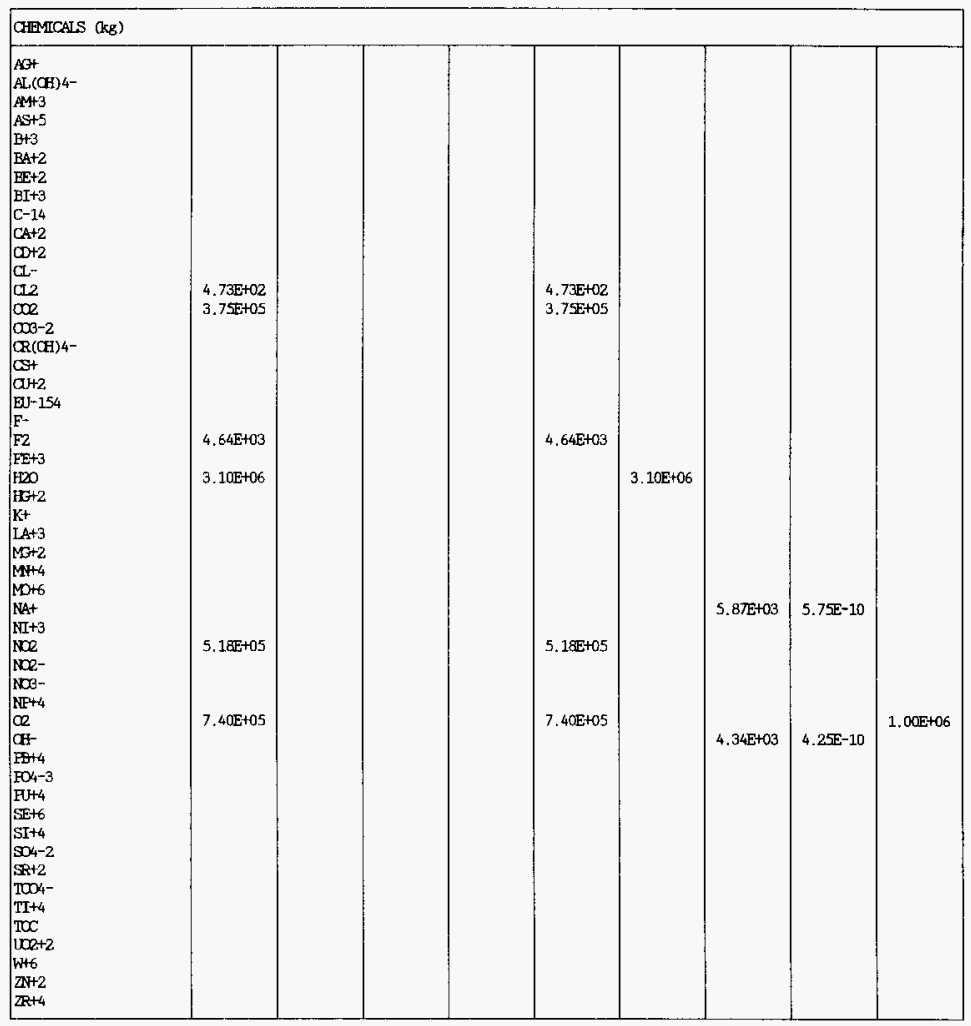


WHC-SD-WM-TI-774 Rev. 0

TWRS PRIVATIZATION PROCESS TECHNICAL BASELINE

Table B-10 Phase 1 IAW Mass Balance for Batch PC1/10 (6 sheeets)

\begin{tabular}{|c|c|c|c|c|c|c|c|c|c|}
\hline $\begin{array}{l}\text { STFEAM NAY } \\
\text { SOLD OOMFONDNSS }\end{array}$ & 20 & 21 & 22 & 23 & 24 & 25 & 26 & 27 & $2 B$ \\
\hline |Total Mass Flow (kg) & & $8.72 \mathrm{E}+05$ & $3.79 E+06$ & $4.66 \mathrm{E}+06$ & & & & & \\
\hline \multicolumn{10}{|l|}{ RADIONCDIIES (Ci) } \\
\hline $\begin{array}{l}\text { Cesium } \\
\text { Strontium } \\
\text { Teckmetium } \\
\text { TRI }\end{array}$ & & $\begin{array}{l}4.48 \mathrm{EE}+03 \\
9.2 \mathrm{gE}+03 \\
3.60 \mathrm{E}+01 \\
1.90 \mathrm{E}+01\end{array}$ & & $\begin{array}{l}\text { 4. } 48 E+03 \\
9.28 E+03 \\
3.60 E+01 \\
1.90 E+01\end{array}$ & & & & & \\
\hline \multicolumn{10}{|l|}{ CHEMTCAIS (kg) } \\
\hline 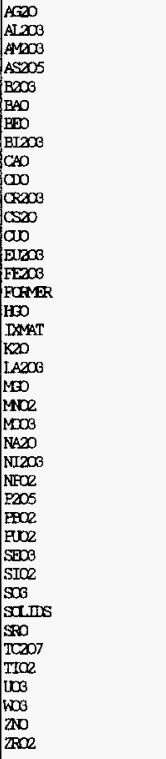 & & $\begin{array}{l}1.90 \mathrm{E}-01 \\
5.95 \mathrm{E}+04 \\
3.44 \mathrm{E}-03 \\
1.43 \mathrm{E}-01 \\
4.8 \mathrm{E}-09 \\
9.32 \mathrm{E}-02 \\
1.8 \mathrm{EE}-11 \\
3.28 \mathrm{E}-01 \\
7.30 \mathrm{E}+01 \\
2.35 \mathrm{E}-01 \\
5.10 \mathrm{E}+01 \\
5.4 \mathrm{E}-02 \\
9.74 \mathrm{E}-03 \\
3.89 \mathrm{E}-04 \\
1.72 \mathrm{E}+01 \\
\\
7.75 \mathrm{E}-04 \\
\\
5.39 \mathrm{E}+02 \\
2.21 \mathrm{E}-04 \\
6.29 \mathrm{E}-01 \\
5.4 \mathrm{E}+00 \\
2.05 \mathrm{E}-01 \\
7.87 \mathrm{E}+05 \\
5.86 \mathrm{E}+01 \\
4.46 \mathrm{E}-05 \\
8.6 \mathrm{EE}+03 \\
3.46 \mathrm{E}+00 \\
1.30 \mathrm{E}-01 \\
9.03 \mathrm{E}-04 \\
2.56 \mathrm{E}-01 \\
1.56 \mathrm{E}+04 \\
4.63 \mathrm{E}+02 \\
7.86 \mathrm{E}-02 \\
3.32 \mathrm{E}+00 \\
1.19 \mathrm{E}-02 \\
4.26 \mathrm{E}+00 \\
4.08 \mathrm{E}-03 \\
4.58 \mathrm{E}+00 \\
7.62 \mathrm{E}-02\end{array}$ & $3.79 E+06$ & $\begin{array}{l}1.90 \mathrm{E}-01 \\
5.95 \mathrm{E}+04 \\
3.44 \mathrm{E}-03 \\
1.43 \mathrm{E}-01 \\
4.85 \mathrm{E}-09 \\
9.32 \mathrm{E}-02 \\
1.8 \mathrm{gEE}-11 \\
3.28 \mathrm{E}-01 \\
7.30 \mathrm{E}+01 \\
2.35 \mathrm{E}-01 \\
5.10 \mathrm{E}+01 \\
5.4 \mathrm{TE}-02 \\
9.74 \mathrm{E}-03 \\
3.89 \mathrm{E}-04 \\
1.72 \mathrm{E}+01 \\
3.79 \mathrm{E}+06 \\
7.75 \mathrm{E}-04 \\
\\
5.39 \mathrm{E}+02 \\
2.21 \mathrm{E}-04 \\
6.29 \mathrm{E}-01 \\
5.48 \mathrm{E}+00 \\
2.05 \mathrm{E}-01 \\
7.87 \mathrm{E}+05 \\
5.86 \mathrm{E}+01 \\
4.46 \mathrm{E}-05 \\
8.68 \mathrm{E}+03 \\
3.46 \mathrm{E}+00 \\
1.30 \mathrm{E}-01 \\
9.03 \mathrm{E}-04 \\
2.56 \mathrm{E}-01 \\
1.56 \mathrm{E}+04 \\
4.63 \mathrm{E}+02 \\
7.86 \mathrm{E}-02 \\
3.32 \mathrm{E}+100 \\
1.19 \mathrm{E}-02 \\
4.26 \mathrm{E}+00 \\
4.08 \mathrm{E}-03 \\
4.58 \mathrm{E}+00 \\
7.62 \mathrm{E}-02\end{array}$ & & & & & \\
\hline
\end{tabular}


WHC-SD-WM-TI-774 Rev. 0

TWRS PRIVATIZATION PROCESS TECHNICAL BASELINE

Table B-11 Phase 1 LAW Mass Balance for Batch PCl/11 (6 sheets)

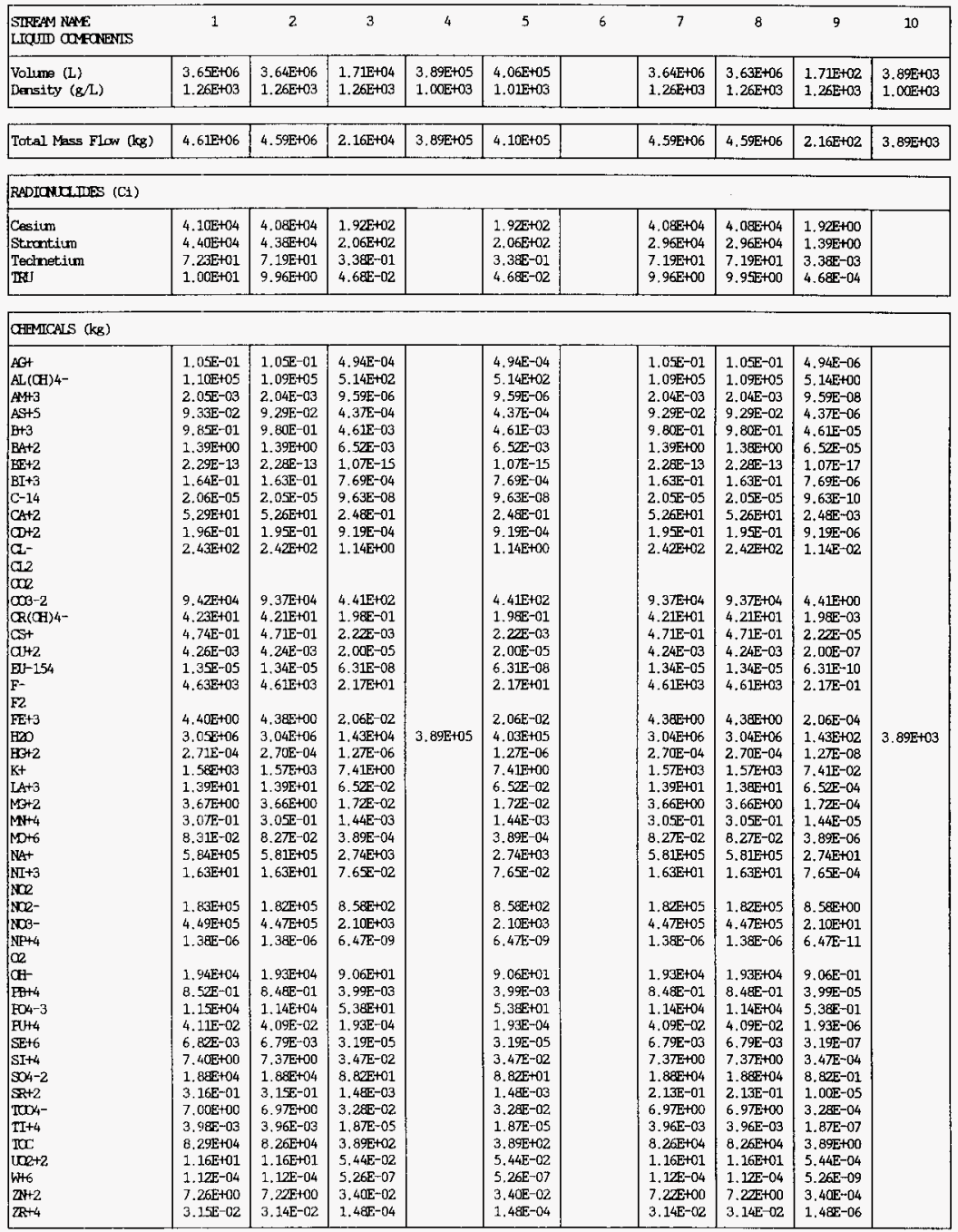


WHC-SD-WM-TI-774 Rev. 0

TWRS PRIVATIZATION PROCESS TECHNICAL BASELINE

Table B-11 Phase 1 LAW Mass Balance for Batch FCl/11 (6 sheets)

\begin{tabular}{|c|c|c|c|c|c|c|c|c|c|c|}
\hline $\begin{array}{l}\text { SIREAM NAME } \\
\text { SUDD OMEQNENIS }\end{array}$ & 1 & 2 & 3 & 4 & 5 & 6 & 7 & 8 & 9 & 10 \\
\hline Total Mass Flow (kg) & $4.61 \mathrm{E}+04$ & $4.61 \mathrm{E}+02$ & $4.56 \mathrm{E}+04$ & & $4.56 \mathrm{E}+0.4$ & & $4,61 \mathrm{E}+02$ & $4.61 E+\infty$ & 4. $56 \mathrm{E}+02$ & \\
\hline \multicolumn{11}{|l|}{ RADTaNCIIIES (Ci) } \\
\hline \begin{tabular}{|l} 
Cesium \\
Sturntium \\
Tedrettium \\
TRIJ
\end{tabular} & & & & & & & $1.42 E+04$ & 1. $42 E+02$ & 1. $4 \mathrm{EE}+04$ & \\
\hline \multicolumn{11}{|l|}{ GRMTCAIS (kg) } \\
\hline 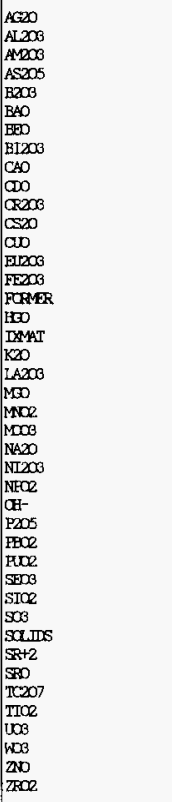 & $4.61 E+04$ & $4.61 E+02$ & $4.56 E+0.4$ & & $4.56 \mathrm{E}+04$ & & $\begin{array}{l}3.86 \mathrm{E}-02 \\
\\
4.61 \mathrm{E}+02 \\
1.02 \mathrm{E}-01\end{array}$ & $\begin{array}{l}3.86 E-04 \\
\\
4.61 E+00 \\
1.02 E-03\end{array}$ & $\begin{array}{l}3.82 \mathrm{E}-02 \\
\\
4.56 \mathrm{E}+02 \\
1.01 \mathrm{E}-01\end{array}$ & \\
\hline
\end{tabular}


WHC-SD-WM-TI-774 Rev. 0

TWRS PRIVATIZATION PROCESS TECHNICAL BASELINE

Table B-11 Phase 1 LAW Mass Balance for Batch PCl/11 (6 sheets)

\begin{tabular}{|c|c|c|c|c|c|c|c|c|c|c|}
\hline $\begin{array}{l}\text { SIREAM NAME } \\
\text { LIQUID COMFONENIS }\end{array}$ & 11 & 12 & 13 & 14 & 15 & 16 & 16A & 17 & 18 & 19 \\
\hline $\begin{array}{l}\text { Volume }(\mathrm{L}) \\
\text { Density }(\mathrm{g} / \mathrm{L})\end{array}$ & $\begin{array}{l}4.06 \mathrm{E}+03 \\
1.01 \mathrm{E}+03\end{array}$ & $\begin{array}{l}3.63 \mathrm{E}+06 \\
1.26 \mathrm{E}+03\end{array}$ & $\begin{array}{l}3.05 E+03 \\
3.34 E+03\end{array}$ & & $\begin{array}{l}3.05 E+03 \\
3.34 E+03\end{array}$ & $\begin{array}{l}3.63 \mathrm{E}+06 \\
1.26 \mathrm{E}+03\end{array}$ & $\begin{array}{l}\text { 4. } 72 E+06 \\
1.00 E+03\end{array}$ & & $\begin{array}{l}1.00 E-09 \\
1.00 \mathrm{E}+03\end{array}$ & $\begin{array}{l}1.00 \mathrm{E}-09 \\
1.00 \mathrm{E}+03\end{array}$ \\
\hline Total Mass Flow (kg) & $4.10 E+03$ & $4.59 \mathrm{E}+06$ & $1.02 E+04$ & & $1.02 E+04$ & $4.59 \mathrm{E}+06$ & $4.72 E+06$ & & $1.00 \mathrm{E}-09$ & $1.00 \mathrm{E}-09$ \\
\hline \multicolumn{11}{|l|}{ RADICAMADES (Ci) } \\
\hline \begin{tabular}{|l} 
Cesium \\
Strantium \\
Technetium \\
IRI
\end{tabular} & $\begin{array}{l}1.92 \mathrm{E}+00 \\
1.39 \mathrm{E}+00 \\
3.38 \mathrm{E}-03 \\
4.68 \mathrm{E}-04\end{array}$ & $\begin{array}{l}4.46 \mathrm{E}+03 \\
2.96 \mathrm{E}+04 \\
7.12 \mathrm{E}+01 \\
9.95 \mathrm{E}+00\end{array}$ & $\begin{array}{l}3.64 \mathrm{E}+04 \\
7.23 \mathrm{E}-01\end{array}$ & & $\begin{array}{l}3.64 \mathrm{E}+04 \\
7.23 \mathrm{E}-01\end{array}$ & $\begin{array}{l}4.46 \mathrm{E}+03 \\
2.96 \mathrm{E}+04 \\
7.12 \mathrm{E}+01 \\
9.95 \mathrm{E}+00\end{array}$ & & & & \\
\hline \multicolumn{11}{|l|}{ CHIMICALS (kg) } \\
\hline 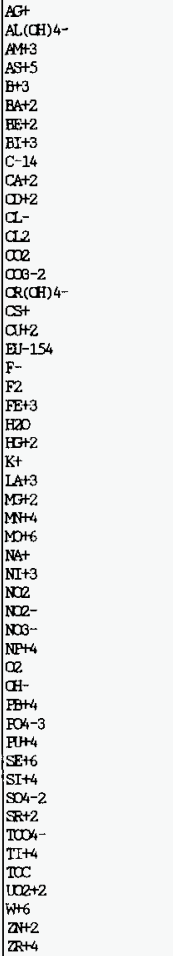 & $\begin{array}{l}4.94 \mathrm{E}-06 \\
5.24 \mathrm{E}+00 \\
9.59 \mathrm{E}-08 \\
4.3 \mathrm{E}-06 \\
4.6 \mathrm{E}-05 \\
6.52 \mathrm{E}-05 \\
1.0 \mathrm{E}-17 \\
7.69 \mathrm{E}-06 \\
9.63 \mathrm{E}-10 \\
2.48 \mathrm{E}-03 \\
9.19 \mathrm{E}-06 \\
1.14 \mathrm{E}-02 \\
\\
4.41 \mathrm{E}+00 \\
1.98 \mathrm{E}-03 \\
2.22 \mathrm{E}-05 \\
2.00 \mathrm{E}-07 \\
6.31 \mathrm{E}-10 \\
2.17 \mathrm{E}-01 \\
\\
2.06 \mathrm{E}-04 \\
4.03 \mathrm{E}+03 \\
1.2 \mathrm{E}-08 \\
7.41 \mathrm{E}-02 \\
6.52 \mathrm{E}-04 \\
1.7 \mathrm{E}-04 \\
1.44 \mathrm{E}-05 \\
3.89 \mathrm{E}-06 \\
2.74 \mathrm{E}+01 \\
7.6 \mathrm{E}-04 \\
\\
8.58 \mathrm{E}+00 \\
2.10 \mathrm{E}+01 \\
6.4 \mathrm{E}-11 \\
\\
9.06 \mathrm{E}-01 \\
3.99 \mathrm{E}-05 \\
5.36 \mathrm{E}-01 \\
1.93 \mathrm{E}-06 \\
3.19 \mathrm{E}-07 \\
3.47 \mathrm{E}-04 \\
8.82 \mathrm{E}-01 \\
1.00 \mathrm{E}-05 \\
3.28 \mathrm{E}-04 \\
1.87 \mathrm{E}-07 \\
3.89 \mathrm{E}+00 \\
5.44 \mathrm{E}-04 \\
5.26 \mathrm{E}-09 \\
3.40 \mathrm{E}-04 \\
1.48 \mathrm{E}-06\end{array}$ & $\begin{array}{l}1.05 \mathrm{E}-01 \\
1.09 \mathrm{E}+05 \\
2.04 \mathrm{E}-03 \\
9.29 \mathrm{E}-02 \\
9.80 \mathrm{E}-01 \\
1.38 \mathrm{E}+00 \\
2.28 \mathrm{E}-13 \\
1.63 \mathrm{E}-01 \\
2.05 \mathrm{E}-05 \\
5.26 \mathrm{E}+01 \\
1.95 \mathrm{E}-01 \\
2.42 \mathrm{E}+02 \\
\\
9.37 \mathrm{E}+04 \\
4.21 \mathrm{E}+01 \\
5.14 \mathrm{E}-02 \\
4.24 \mathrm{E}-03 \\
1.34 \mathrm{E}-05 \\
4.61 \mathrm{E}+03 \\
4.38 \mathrm{E}+00 \\
3.04 \mathrm{E}+06 \\
2.70 \mathrm{E}-04 \\
1.57 \mathrm{E}+03 \\
1.38 \mathrm{E}+01 \\
3.66 \mathrm{E}+00 \\
3.05 \mathrm{E}-01 \\
8.27 \mathrm{E}-02 \\
5.81 \mathrm{E}+05 \\
1.63 \mathrm{E}+01 \\
\\
1.82 \mathrm{E}+05 \\
4.47 \mathrm{E}+05 \\
1.38 \mathrm{E}-06 \\
\\
1.93 \mathrm{E}+04 \\
8.48 \mathrm{E}-01 \\
1.14 \mathrm{E}+04 \\
4.09 \mathrm{E}-02 \\
6.79 \mathrm{E}-03 \\
7.37 \mathrm{E}+00 \\
1.88 \mathrm{E}+04 \\
2.13 \mathrm{E}-01 \\
6.90 \mathrm{E}+00 \\
3.96 \mathrm{E}-03 \\
8.26 \mathrm{E}+04 \\
1.16 \mathrm{E}+01 \\
1.12 \mathrm{E}-04 \\
7.22 \mathrm{E}+00 \\
3.14 \mathrm{E}-02\end{array}$ & $\begin{array}{l}4.20 \mathrm{E}-01 \\
5.84 \mathrm{E}+03 \\
4.32 \mathrm{E}+03\end{array}$ & & $\begin{array}{l}4.20 \mathrm{E}-01 \\
5.84 \mathrm{E}+03 \\
4.32 \mathrm{E}+03\end{array}$ & $\begin{array}{l}1.05 E-01 \\
1.09 E+05 \\
2.04 \mathrm{E}-03 \\
9.29 \mathrm{E}-02 \\
9.80 \mathrm{E}-01 \\
1.38 \mathrm{E}+00 \\
2.28 \mathrm{E}-13 \\
1.63 \mathrm{E}-01 \\
2.05 \mathrm{E}-05 \\
5.26 \mathrm{E}+01 \\
1.95 \mathrm{E}-01 \\
2.42 \mathrm{E}+02 \\
\\
9.37 \mathrm{E}+04 \\
4.21 \mathrm{E}+01 \\
5.14 \mathrm{E}-02 \\
4.24 \mathrm{E}-03 \\
1.34 \mathrm{E}-0.5 \\
4.61 \mathrm{E}+03 \\
4.38 \mathrm{E}+00 \\
3.04 \mathrm{E}+06 \\
2.70 \mathrm{E}-04 \\
1.57 \mathrm{E}+03 \\
1.38 \mathrm{E}+01 \\
3.66 \mathrm{E}+00 \\
3.05 \mathrm{E}-01 \\
8.27 \mathrm{E}-02 \\
5.81 \mathrm{E}+05 \\
1.63 \mathrm{E}+01 \\
\\
1.82 \mathrm{E}+05 \\
4.4 \pi \mathrm{E}+05 \\
1.38 \mathrm{E}-06 \\
1.93 \mathrm{E}+04 \\
8.48 \mathrm{E}-01 \\
1.14 \mathrm{E}+04 \\
4.09 \mathrm{E}-02 \\
6.79 \mathrm{E}-03 \\
7.37 \mathrm{E}+00 \\
1.88 \mathrm{E}+04 \\
2.23 \mathrm{E}-01 \\
6.90 \mathrm{E}+00 \\
3.96 \mathrm{E}-03 \\
8.26 \mathrm{E}+04 \\
1.16 \mathrm{E}+01 \\
1.12 \mathrm{E}-04 \\
7.22 \mathrm{E}+00 \\
3.14 \mathrm{E}-02\end{array}$ & $\begin{array}{l}2.42 \mathrm{E}+02 \\
3.71 \mathrm{E}+05 \\
\\
4.61 \mathrm{E}+03 \\
3.09 \mathrm{E}+06\end{array}$ & & $1.00 E-09$ & $1.00 \mathrm{E}-09$ \\
\hline
\end{tabular}


WHC-SD-WM-TI-774 Rev. 0

TWRS PRIVATIZATION PROCESS TECHNICAL BASELINE

Table B-11 Phase 1 LAW Mass Balance for Batch PCl/11 (6 sheets)

\begin{tabular}{|c|c|c|c|c|c|c|c|c|c|c|}
\hline $\begin{array}{l}\text { SIREAM NAE } \\
\text { SOID OOMFAENIS }\end{array}$ & 11 & 12 & 13 & 14 & 15 & 16 & $16 \mathrm{~A}$ & 17 & 18 & 19 \\
\hline Total Mass Flow (kg) & $4.56 \mathrm{E}+02$ & $4.61 E+\infty 0$ & & 5. $84 \mathrm{E}+03$ & $5.84 E+03$ & $4.61 \mathrm{E}+00$ & $8.68 \mathrm{E}+0.5$ & & & \\
\hline \multicolumn{11}{|l|}{ RADICNLLIDES (Ci) } \\
\hline $\begin{array}{l}\text { Cesium } \\
\text { Strantium } \\
\text { Tectmetium } \\
\text { TIN!! }\end{array}$ & $1.4 \mathrm{IE}+04$ & $1.42 \mathrm{E}+02$ & & & & $1.42 \mathrm{E}+02$ & $\begin{array}{l}4.46 \mathrm{E}+03 \\
2.9 \sqrt{\mathrm{E}}+04 \\
7.12 \mathrm{E}+01 \\
9.92 \mathrm{E}+00\end{array}$ & & & \\
\hline \multicolumn{11}{|l|}{ CARMCALS (kg) } \\
\hline 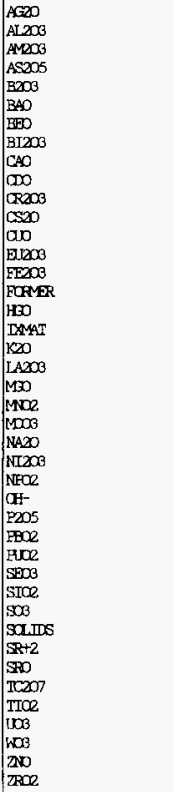 & $\begin{array}{l}3.82 \mathrm{E}-02 \\
\\
4.56 \mathrm{E}+02 \\
1.01 \mathrm{E}-01\end{array}$ & $\begin{array}{l}3.86 E-04 \\
\\
4.61 E+00 \\
1.02 E-03\end{array}$ & & $5.84 \mathrm{E}+\mathrm{CO}$ & $5.84 E+03$ & $\begin{array}{l}3.86 \mathrm{E}-04 \\
\\
4.61 \mathrm{E}+00 \\
1.02 \mathrm{E}-03\end{array}$ & $\begin{array}{l}1.13 \mathrm{E}-01 \\
5.86 \mathrm{E}+04 \\
2.24 \mathrm{E}-03 \\
1.43 \mathrm{E}-01 \\
3.16 \mathrm{E}+00 \\
1.55 \mathrm{E}+00 \\
6.32 \mathrm{E}-13 \\
1.82 \mathrm{E}-01 \\
7.36 \mathrm{E}+01 \\
2.23 \mathrm{E}-01 \\
2.66 \mathrm{E}+01 \\
5.4 \mathrm{EE}-02 \\
5.31 \mathrm{E}-03 \\
1.55 \mathrm{E}-05 \\
6.26 \mathrm{E}+00 \\
\\
2.92 \mathrm{E}-04 \\
\\
1.90 \mathrm{E}+03 \\
1.62 \mathrm{E}+01 \\
6.06 \mathrm{E}+00 \\
4.83 \mathrm{E}-01 \\
1.24 \mathrm{E}-01 \\
7.84 \mathrm{E}+05 \\
2.29 \mathrm{E}+01 \\
1.56 \mathrm{E}-06 \\
\\
8.55 \mathrm{E}+03 \\
9.79 \mathrm{E}-01 \\
4.64 \mathrm{E}-02 \\
1.09 \mathrm{E}-02 \\
1.58 \mathrm{E}+01 \\
1.56 \mathrm{E}+04 \\
4.61 \mathrm{E}+\infty 0 \\
2.52 \mathrm{E}-01 \\
6.56 \mathrm{E}+00 \\
6.61 \mathrm{E}-03 \\
1.23 \mathrm{E}+01 \\
1.41 \mathrm{E}-04 \\
8.99 \mathrm{E}+00 \\
4.24 \mathrm{E}-02\end{array}$ & & & \\
\hline
\end{tabular}


WHC-SD-WM-TI-774 Rev. 0

TWRS PRIVATIZATION PROCESS TECHNICAL BASELINE

Table B-11 Phase 1. LAW Mass Balance for Batch FC1/11 ( 6 sheets)

\begin{tabular}{|c|c|c|c|c|c|c|c|c|c|}
\hline $\begin{array}{l}\text { SIREAM NAME } \\
\text { LIAID CTMONONIS }\end{array}$ & 20 & 21 & 22 & 23 & 24 & 25 & 26 & 27 & 28 \\
\hline $\begin{array}{l}\text { Volume (L) } \\
\text { Density }(\mathrm{g} / \mathrm{L})\end{array}$ & $\begin{array}{l}4.72 \mathrm{E}+06 \\
1.00 \mathrm{E}+03\end{array}$ & & & & $\begin{array}{l}1.63 E+06 \\
1.00 E+03\end{array}$ & $\begin{array}{l}3.09 \mathrm{E}+06 \\
1.00 \mathrm{E}+03\end{array}$ & $\begin{array}{l}3.05 E+03 \\
3.34 E+03\end{array}$ & $\begin{array}{l}3.00 \mathrm{E}-10 \\
3.34 \mathrm{E}+03\end{array}$ & $\begin{array}{l}\text { 1. DCE+06 } \\
\text { 1. OCE+03 }\end{array}$ \\
\hline Total Mass Flow (kg) & $4.72 \mathbb{E}+06$ & & & & $1.63 \mathrm{E}+06$ & $3.09 \mathrm{E}+06$ & $1.02 E+04$ & $1.00 \mathrm{E}-09$ & 1.00E+06 \\
\hline \multicolumn{10}{|l|}{ RADICUNCIIIES (Ci) } \\
\hline $\begin{array}{l}\text { Cesium } \\
\text { Strantium } \\
\text { Tecknetiun } \\
\text { TRI }\end{array}$ & & & & & & & & & \\
\hline
\end{tabular}

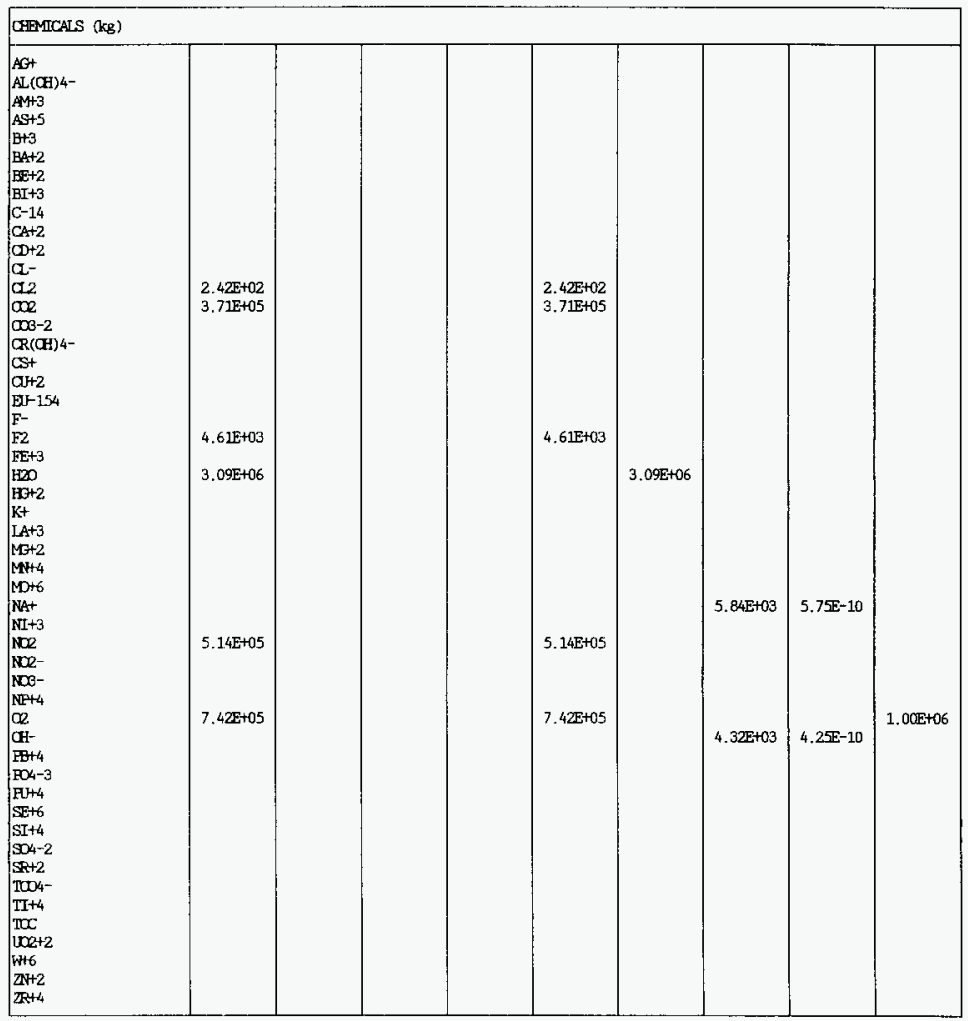


WHC-SD-WM-TI-774 Rev. 0

TWRS PRIVATIZATION PROCESS TECHNICAL BASELINE

Table B-11 Phase 1 LAW Mass Balance for Batch PCl/11 (6 sheets)

\begin{tabular}{|c|c|c|c|c|c|c|c|c|c|}
\hline 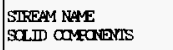 & 20 & 21 & 22 & 23 & 24 & 25 & 26 & 27 & 28 \\
\hline Total Mass Flow (kg) & & $8.68 E+05$ & $3.772+06$ & $4.64 \mathrm{E}+06$ & & & & & \\
\hline \multicolumn{10}{|l|}{ RADICMLIIIES (C1) } \\
\hline $\begin{array}{l}\text { Cesium } \\
\text { Strantium } \\
\text { Tecknetiun } \\
\text { TRI }\end{array}$ & & $\begin{array}{l}4.46 \mathrm{E}+03 \\
2.97 \mathrm{E}+04 \\
7.12 \mathrm{E}+01 \\
9.92 \mathrm{E}+00\end{array}$ & & $\begin{array}{l}4.46 \mathrm{E}+03 \\
2.97 \mathrm{E}+04 \\
7.12 \mathrm{E}+01 \\
9.92 \mathrm{E}+00\end{array}$ & & & & & \\
\hline \multicolumn{10}{|l|}{ CAEMICALS (kg) } \\
\hline 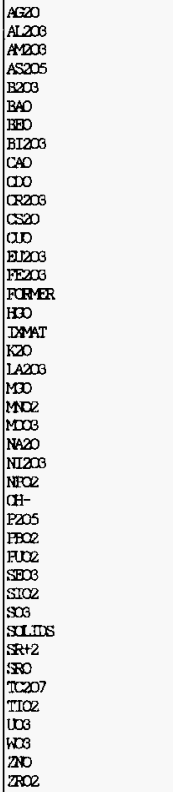 & & $\begin{array}{l}1.13 \mathrm{E}-01 \\
5.86 \mathrm{E}+04 \\
2.24 \mathrm{E}-03 \\
1.43 \mathrm{E}-01 \\
3.16 \mathrm{E}+00 \\
1.5 \mathrm{E}+00 \\
6.32 \mathrm{E}-13 \\
1.82 \mathrm{E}-01 \\
7.36 \mathrm{E}+01 \\
2.23 \mathrm{E}-01 \\
2.66 \mathrm{E}+01 \\
5.4 \mathrm{E}-02 \\
5.31 \mathrm{E}-03 \\
1.55 \mathrm{E}-05 \\
6.26 \mathrm{E}+00 \\
\\
2.92 \mathrm{E}-04 \\
1.90 \mathrm{E}+03 \\
1.62 \mathrm{E}+01 \\
6.06 \mathrm{E}+00 \\
4.83 \mathrm{E}-01 \\
1.24 \mathrm{E}-01 \\
7.84 \mathrm{E}+05 \\
2.29 \mathrm{E}+01 \\
1.56 \mathrm{E}-06 \\
\\
8.55 \mathrm{E}+03 \\
9.79 \mathrm{E}-01 \\
4.64 \mathrm{E}-02 \\
1.09 \mathrm{E}-02 \\
1.58 \mathrm{E}+01 \\
1.56 \mathrm{E}+04 \\
4.61 \mathrm{E}+00 \\
2.52 \mathrm{E}-01 \\
6.56 \mathrm{E}+00 \\
6.61 \mathrm{E}-03 \\
1.23 \mathrm{E}+01 \\
1.41 \mathrm{E}-04 \\
8.99 \mathrm{E}+00 \\
4.24 \mathrm{E}-02\end{array}$ & $3.77 \mathrm{E}+06$ & $\begin{array}{l}1.13 \mathrm{E}-01 \\
5.86 \mathrm{E}+04 \\
2.24 \mathrm{E}-03 \\
1.43 \mathrm{E}-01 \\
3.16 \mathrm{E}+00 \\
1.55 \mathrm{E}+00 \\
6.32 \mathrm{E}-13 \\
1.82 \mathrm{E}-01 \\
7.36 \mathrm{E}+01 \\
2.23 \mathrm{E}-01 \\
2.66 \mathrm{E}+01 \\
5.45 \mathrm{E}-02 \\
5.3 \mathrm{E}-03 \\
1.55 \mathrm{E}-05 \\
6.26 \mathrm{E}+00 \\
3.77 \mathrm{E}+06 \\
2.92 \mathrm{E}-04 \\
1.90 \mathrm{E}+03 \\
1.62 \mathrm{E}+01 \\
6.06 \mathrm{E}+00 \\
4.83 \mathrm{E}-01 \\
1.24 \mathrm{E}-01 \\
7.84 \mathrm{E}+05 \\
2.29 \mathrm{E}+01 \\
1.56 \mathrm{E}-06 \\
\\
8.55 \mathrm{E}+03 \\
9.79 \mathrm{E}-01 \\
4.64 \mathrm{E}-02 \\
1.09 \mathrm{E}-02 \\
1.58 \mathrm{E}+01 \\
1.56 \mathrm{E}+04 \\
4.61 \mathrm{E}+00 \\
2.52 \mathrm{E}-01 \\
6.56 \mathrm{E}+00 \\
6.61 \mathrm{E}-03 \\
1.23 \mathrm{E}+01 \\
1.41 \mathrm{E}-04 \\
8.99 \mathrm{E}+00 \\
4.24 \mathrm{E}-02\end{array}$ & & & & & \\
\hline
\end{tabular}


WHC-SD-WM-TI-774 Rev. 0

TWRS PRIVATIZATION PROCESS TECHNICAL BASELINE

Table B-12 Phase 1 LAW Mass Balance for Batch PCl/12 (6 sheets)

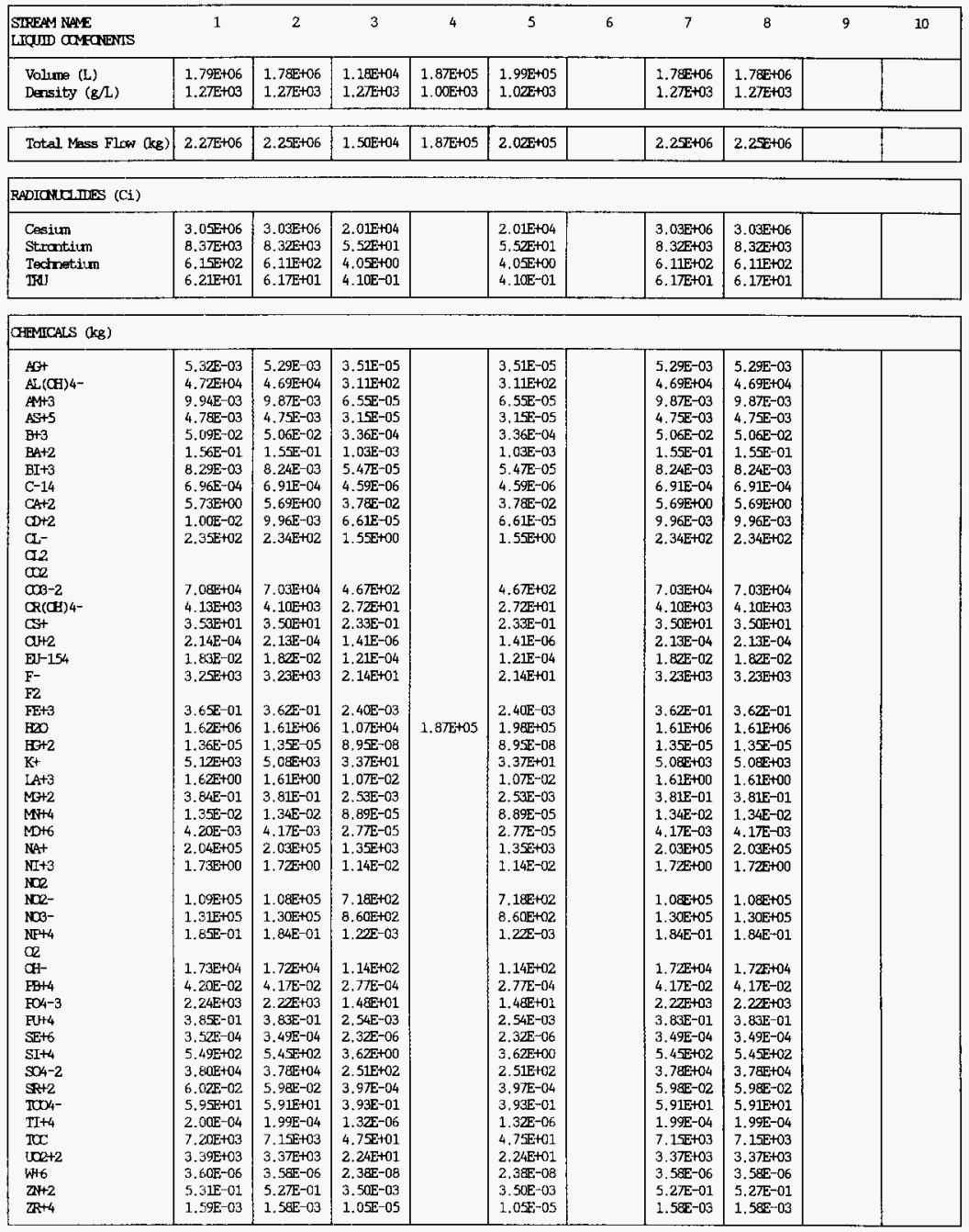


WHC-SD-WM-TI-774 ReV. 0

TWRS PRIVATIZATION PROCESS TECHNICAL BASELINE

Table B-12 Phase 1 IAW Mass Balance for Batch PCl/12 (6 sheets)

\begin{tabular}{|c|c|c|c|c|c|c|c|c|c|c|}
\hline $\begin{array}{l}\text { SIREAM NAE } \\
\text { STD COMRANDNS }\end{array}$ & 1 & 2 & 3 & 4 & 5 & 6 & 7 & 8 & 9 & 10 \\
\hline Total Mess Flow (kg) & $2.26 \mathrm{E}+04$ & $2.26 \mathrm{E}+02$ & $2.24 E+04$ & & $2.24 E+04$ & & $2.26 E+02$ & $2.26 \mathrm{E}+02$ & & \\
\hline \multicolumn{11}{|l|}{ RADIONOCLIDES (Ci) } \\
\hline $\begin{array}{l}\text { Cesium } \\
\text { Strantiun } \\
\text { Technetium } \\
\text { IFI }\end{array}$ & & & & & & & & & & \\
\hline
\end{tabular}

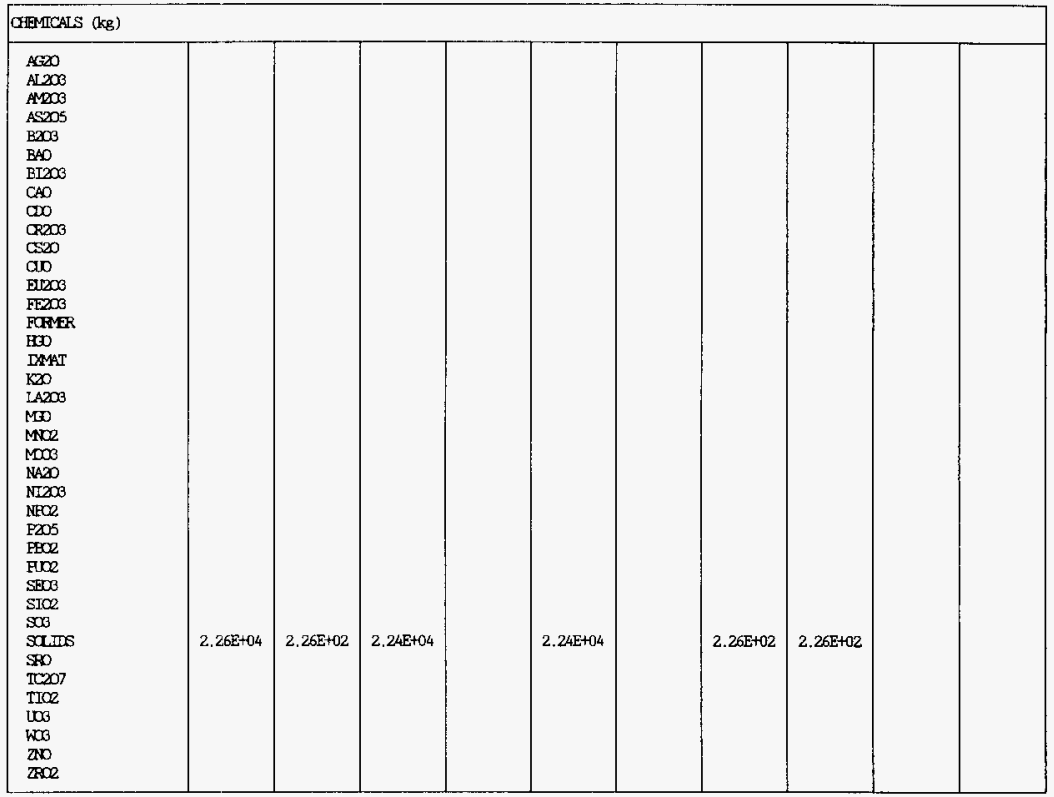


WHC-SD-WM-TI-774 Rev. 0

TWRS PRIVATIZATION PROCESS TECHNICAL BASELINE

Table B-12 Phase 1 LAW Mass Balance for Batch PC1/12 (6 sheets)

\begin{tabular}{|c|c|c|c|c|c|c|c|c|c|c|}
\hline $\begin{array}{l}\text { SIREAM NAME } \\
\text { LIQUII COMEONENIS }\end{array}$ & 11 & 12 & 13 & 14 & 15 & 16 & $16 \mathrm{~A}$ & 17 & 18 & 19 \\
\hline $\begin{array}{l}\text { Volums (L) } \\
\text { Density }(\mathrm{g} / \mathrm{L})\end{array}$ & & $\begin{array}{l}1.78 \mathrm{E}+06 \\
1.27 \mathrm{E}+03\end{array}$ & $\begin{array}{l}\text { 1. } 10 \mathrm{E}+03 \\
3.26 \mathrm{E}+03\end{array}$ & & $\begin{array}{l}\text { 1. } 10 \mathrm{E}+03 \\
3.26 \mathrm{E}+03\end{array}$ & $\begin{array}{l}\text { 1. } 78 E+06 \\
1.27 E+03\end{array}$ & $\begin{array}{l}2.91 E+06 \\
1.00 E+03\end{array}$ & $\begin{array}{l}1.09 \mathrm{E}+03 \\
3.29 \mathrm{E}+03\end{array}$ & $\begin{array}{l}2.04 E+03 \\
1.00 E+03\end{array}$ & $\begin{array}{l}3.12 \mathrm{E}+03 \\
1.80 \mathrm{E}+03\end{array}$ \\
\hline Total Mass Flow (kg) & & $2.25 E+06$ & $3.58 E+03$ & & $3,58 \mathrm{BE}+03$ & $2.25 E+06$ & $2.91 \mathrm{E}+06$ & $3.57 \mathrm{E}+03$ & $2.04 \mathrm{E}+03$ & $5.61 E+03$ \\
\hline \multicolumn{11}{|l|}{ RADIONUCLEDS(CI) } \\
\hline $\begin{array}{l}\text { Cesium } \\
\text { Strantium } \\
\text { Technotium } \\
\text { TRU }\end{array}$ & & $\begin{array}{l}3.89 E+03 \\
8.32 E+03 \\
6.05 E+02 \\
6.17 E+01\end{array}$ & $\begin{array}{l}3.03 \mathrm{E}+06 \\
6.15 \mathrm{~F}+00\end{array}$ & & $\begin{array}{l}3.03 E+06 \\
6.15 E+00\end{array}$ & $\begin{array}{l}3.89 \mathrm{E}+03 \\
8.32 \mathrm{E}+03 \\
3.89 \mathrm{E}+02 \\
6.17 \mathrm{E}+01\end{array}$ & & $2.16 E+02$ & & $2.16 E+02$ \\
\hline \multicolumn{11}{|l|}{ CHEMCALS (kg) } \\
\hline 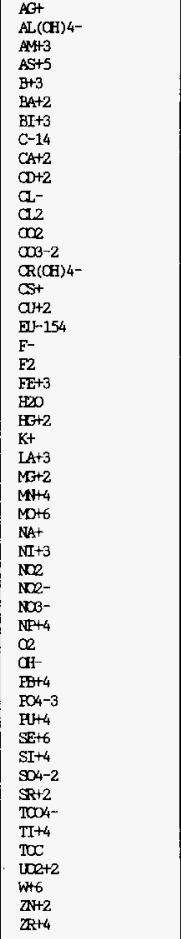 & & $\begin{array}{l}5.29 \mathrm{E}-03 \\
4.69 \mathrm{E}+04 \\
9.87 \mathrm{E}-03 \\
4.75 \mathrm{E}-03 \\
5.06 \mathrm{E}-02 \\
1.5 \mathrm{EE}-01 \\
8.24 \mathrm{E}-03 \\
6.91 \mathrm{E}-04 \\
5.69 \mathrm{E}+00 \\
9.96 \mathrm{E}-03 \\
2.34 \mathrm{E}+02 \\
\\
7.03 \mathrm{E}+04 \\
4.10 \mathrm{E}+03 \\
4.49 \mathrm{E}-02 \\
2.13 \mathrm{E}-04 \\
1.82 \mathrm{E}-02 \\
3.23 \mathrm{E}+03 \\
\\
3.62 \mathrm{E}-01 \\
1.61 \mathrm{E}+06 \\
1.35 \mathrm{E}-05 \\
5.08 \mathrm{E}+03 \\
1.61 \mathrm{E}+00 \\
3.81 \mathrm{E}-01 \\
1.34 \mathrm{E}-02 \\
4.17 \mathrm{E}-03 \\
2.03 \mathrm{E}+05 \\
1.72 \mathrm{E}+00 \\
1.08 \mathrm{E}+05 \\
1.30 \mathrm{E}+05 \\
1.84 \mathrm{E}-01 \\
1.72 \mathrm{E}+04 \\
4.1 \mathrm{E}-02 \\
2.22 \mathrm{E}+03 \\
3.83 \mathrm{E}-01 \\
3.49 \mathrm{E}-04 \\
5.4 \mathrm{EE}+02 \\
3.78 \mathrm{E}+04 \\
5.98 \mathrm{E}-02 \\
5.85 \mathrm{E}+01 \\
1.99 \mathrm{E}-04 \\
7.15 \mathrm{E}+03 \\
3.37 \mathrm{E}+03 \\
3.58 \mathrm{E}-06 \\
1.27 \mathrm{E}-01 \\
\end{array}$ & $\begin{array}{l}3.50 \mathrm{E}+01 \\
2.04 \mathrm{E}+03 \\
1.51 \mathrm{E}+03\end{array}$ & & $\begin{array}{l}3.50 E+01 \\
2.04 E+03 \\
1.51 E+03 \\
5.955-01\end{array}$ & $\begin{array}{l}5.29 \mathrm{E}-03 \\
4.69 \mathrm{E}+04 \\
9.87 \mathrm{E}-03 \\
4.7 \mathrm{E}-03 \\
5.06 \mathrm{E}-02 \\
1.5 \mathrm{E}-01 \\
8.24 \mathrm{E}-03 \\
6.91 \mathrm{E}-04 \\
5.69 \mathrm{E}+00 \\
9.96 \mathrm{E}-03 \\
2.34 \mathrm{E}+02 \\
\\
7.03 \mathrm{E}+04 \\
4.10 \mathrm{E}+03 \\
4.49 \mathrm{E}-02 \\
2.13 \mathrm{E}-04 \\
1.82 \mathrm{E}-02 \\
3.23 \mathrm{E}+03 \\
3.62 \mathrm{E}-01 \\
1.61 \mathrm{E}+06 \\
1.35 \mathrm{E}-05 \\
5.08 \mathrm{E}+03 \\
1.61 \mathrm{E}+00 \\
3.81 \mathrm{E}-01 \\
1.34 \mathrm{E}-02 \\
4.17 \mathrm{E}-03 \\
2.03 \mathrm{E}+05 \\
1.72 \mathrm{E}+00 \\
1.08 \mathrm{E}+05 \\
1.30 \mathrm{E}+05 \\
1.84 \mathrm{E}-01 \\
1.72 \mathrm{E}+04 \\
4.17 \mathrm{E}-02 \\
2.22 \mathrm{E}+03 \\
3.83 \mathrm{E}-01 \\
3.49 \mathrm{E}-04 \\
5.4 \mathrm{E}+02 \\
3.78 \mathrm{E}+04 \\
5.98 \mathrm{E}-02 \\
3.77 \mathrm{E}+01 \\
1.99 \mathrm{E}-04 \\
7.15 \mathrm{E}+03 \\
3.37 \mathrm{E}+03 \\
3.58 \mathrm{E}-06 \\
5.27 \mathrm{E}-01 \\
1.58 \mathrm{E}-03\end{array}$ & $\begin{array}{l}\text { 2. 34E+02 } \\
7.78 \mathrm{E}+04 \\
\text { 3. } 23 \mathrm{E}+03 \\
1.64 \mathrm{E}+06 \\
2.04 \mathrm{E}+05 \\
9.80 \mathrm{E}+05\end{array}$ & $2.04 E+03$ & $2.04 \mathrm{E}+03$ & $\begin{array}{l}2.04 E+03 \\
2.04 E+03\end{array}$ \\
\hline
\end{tabular}


WHC-SD-WM-TI-774 Rev. 0

TWRS PRIVATIZATION PROCESS TECHNICAL BASELINE

Table B-12 Phase 1 LAW Mass Balance for Batch PCl/12 (6 sheets)

\begin{tabular}{|c|c|c|c|c|c|c|c|c|c|c|}
\hline $\begin{array}{l}\text { SIREAM NAE } \\
\text { SOID OAFANEMIS }\end{array}$ & 11 & 12 & 13 & 14 & 15 & 16 & $16 \mathrm{~A}$ & 17 & 18 & 19 \\
\hline Total Mass Flow (kg) & & $2.26 \mathrm{E}+02$ & & $2.04 \mathrm{E}+03$ & $2.04 \mathrm{E}+03$ & $2.26 \mathrm{E}+02$ & $3.45 \mathrm{~F}+05$ & & & \\
\hline \multicolumn{11}{|l|}{ RADIOMOL.WES (Ci) } \\
\hline $\begin{array}{l}\text { Cesium } \\
\text { Struntiun } \\
\text { Technetium } \\
\text { IRI }\end{array}$ & & & & & & & $\begin{array}{l}3.89 \mathrm{E}+03 \\
8.32 \mathrm{E}+03 \\
3.89 \mathrm{E}+02 \\
6.14 \mathrm{E}+01\end{array}$ & & & \\
\hline \multicolumn{11}{|l|}{ OHIICALS (kg) } \\
\hline 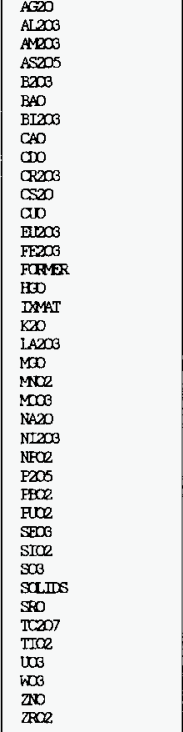 & & $2.26 \mathrm{E}+02$ & & $2.04 \mathrm{E}+03$ & $2,04 E+03$ & $2.26 \mathrm{E}+02$ & $\begin{array}{l}5.68 \mathrm{E}-03 \\
2.52 \mathrm{E}+04 \\
1.09 \mathrm{E}-02 \\
7.28 \mathrm{E}-03 \\
1.63 \mathrm{E}-01 \\
1.73 \mathrm{E}-01 \\
9.19 \mathrm{E}-03 \\
7.96 \mathrm{E}+00 \\
1.14 \mathrm{E}-02 \\
2.60 \mathrm{E}+03 \\
4.7 \mathrm{E}-02 \\
2.6 \mathrm{E}-04 \\
2.11 \mathrm{E}-02 \\
5.18 \mathrm{E}-01 \\
\\
1.46 \mathrm{E}-0 . \\
\\
6.12 \mathrm{E}+03 \\
1.88 \mathrm{E}+00 \\
6.32 \mathrm{E}-01 \\
2.12 \mathrm{E}-02 \\
6.26 \mathrm{E}-03 \\
2.73 \mathrm{E}+05 \\
2.42 \mathrm{E}+00 \\
2.09 \mathrm{E}-01 \\
3.66 \mathrm{E}+03 \\
4.82 \mathrm{E}-02 \\
4.34 \mathrm{E}-01 \\
5.62 \mathrm{E}-04 \\
1.17 \mathrm{E}+03 \\
3.15 \mathrm{E}+04 \\
2.26 \mathrm{E}+02 \\
7.0 \mathrm{E}-02 \\
3.58 \mathrm{E}+01 \\
3.32 \mathrm{E}-04 \\
3.5 \mathrm{E}+03 \\
4.51 \mathrm{E}-06 \\
6.56 \mathrm{E}-01 \\
2.13 \mathrm{E}-03\end{array}$ & & & \\
\hline
\end{tabular}


WHC-SD-WM-TI-774 Rev. 0

TWRS PRIVATIZATION PROCESS TECHNICAL BASELINE

Table B-12 Phase 1 LAW Mass Balance for Batch FC1/12 (6 sheets)

\begin{tabular}{|c|c|c|c|c|c|c|c|c|c|}
\hline $\begin{array}{l}\text { STREAM NAE } \\
\text { L.TQUID COMFOWEMS }\end{array}$ & 20 & 21 & 22 & 23 & 24 & 25 & 26 & 27 & 28 \\
\hline $\begin{array}{l}\text { Volume (L) } \\
\text { Density }(\mathrm{g} / \mathrm{L})\end{array}$ & $\begin{array}{l}2.91 E+06 \\
1.00 E+03\end{array}$ & & & & $\begin{array}{l}1.2 \sqrt{5}+06 \\
1.00 E+03\end{array}$ & $\begin{array}{l}1.64 \mathrm{E}+06 \\
1.00 \mathrm{E}+03\end{array}$ & $\begin{array}{l}1.06 E+03 \\
3.34 E+03\end{array}$ & $\begin{array}{l}1.06 \mathrm{E}+03 \\
3.34 \mathrm{E}+03\end{array}$ & $\begin{array}{l}1.00 \mathrm{E}+06 \\
1.00 \mathrm{E}+03\end{array}$ \\
\hline Total Mass F1ow (kg) & $2.91 \mathrm{E}+06$ & & & & $1.2 \pi \mathrm{I}+06$ & $1.64 \mathrm{E}+06$ & $3.5 x+03$ & $3.55+03$ & 1. $00 \mathrm{E}+06$ \\
\hline
\end{tabular}

RADIONCIIIES (Ci)

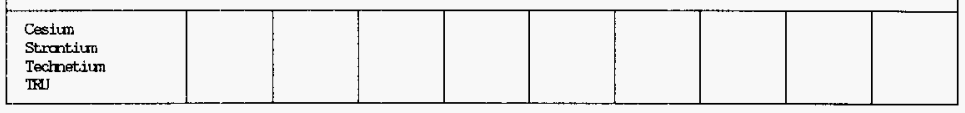

\begin{tabular}{|c|c|c|c|c|c|c|}
\hline \multicolumn{7}{|c|}{ (HEMICALS (kg) } \\
\hline 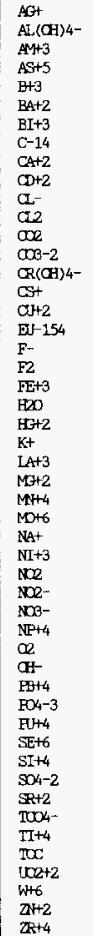 & $\begin{array}{l}2.34 \mathrm{E}+02 \\
7.78 \mathrm{E}+04 \\
\\
3.23 \mathrm{E}+03 \\
1.64 \mathrm{E}+06\end{array}$ & $\begin{array}{l}2.34 \mathrm{E}+02 \\
7.78 \mathrm{BR}+04 \\
3.23 \mathrm{E}+03\end{array}$ & $1.64 \mathrm{E}+06$ & $\begin{array}{l}2.04 \mathrm{E}+03 \\
1.51 \mathrm{E}+03\end{array}$ & $\begin{array}{l}2.04 E+03 \\
1.51 E+03\end{array}$ & 1. $00 \mathrm{E}+06$ \\
\hline
\end{tabular}


WHC-SD-WM-TI-774 Rev. 0

TWRS PRIVATIZATION PROCESS TECHNICAL BASELINE

Table B-12 Phase 1 LAW Mass Balance for Batch PCl/12 (6 sheets)

\begin{tabular}{|c|c|c|c|c|c|c|c|c|c|}
\hline $\begin{array}{l}\text { SIFEMM NAME } \\
\text { SQLD COMEAWMS }\end{array}$ & 20 & 21 & 22 & 23 & 24 & 25 & 26 & 27 & 28 \\
\hline \multicolumn{10}{|l|}{ RADIQNUD.TIES (C1) } \\
\hline $\begin{array}{l}\text { Cesium } \\
\text { Struntiun } \\
\text { Technetium } \\
\text { TRI }\end{array}$ & & $\begin{array}{l}3.89 \mathrm{E}+03 \\
8.32 \mathrm{E}+03 \\
3.89 \mathrm{E}+02 \\
6.14 \mathrm{E}+01\end{array}$ & & $\begin{array}{l}3.89 \mathrm{E}+03 \\
8.32 \mathrm{E}+03 \\
3.89 \mathrm{E}+02 \\
6.14 \mathrm{E}+01\end{array}$ & & & & & \\
\hline \multicolumn{10}{|l|}{ CHEMCALS (kg) } \\
\hline 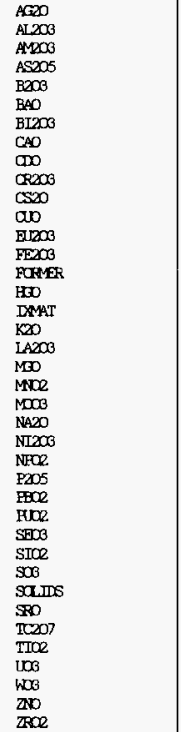 & & $\begin{array}{l}5.6 a E-03 \\
2.52 E+04 \\
1.09 E-02 \\
7.2 E E-03 \\
1.63 E-01 \\
1.73 E-01 \\
9.19 E-03 \\
7.96 E+00 \\
1.14 E-02 \\
2.60 E+03 \\
4.75 E-02 \\
2.67 E-04 \\
2.11 E-02 \\
5.18 E-01 \\
\\
1.46 E-05 \\
6.12 E+03 \\
1.82 E+00 \\
6.32 E-01 \\
2.12 E-02 \\
6.26 E-03 \\
2.73 E+05 \\
2.42 E+00 \\
2.09 E-01 \\
1.66 E+03 \\
4.82 E-02 \\
4.34 E-01 \\
5.62 E-04 \\
1.17 E+03 \\
3.15 E+04 \\
2.26 E+02 \\
7.05 E-02 \\
3.58 E+01 \\
3.32 E-04 \\
3.57 E+03 \\
4.51 E-06 \\
6.56 E-01 \\
2.13 E-03\end{array}$ & $3.71 E+06$ & $\begin{array}{l}5.68 \mathrm{E}-03 \\
2.52 \mathrm{E}+04 \\
1.09 \mathrm{E}-02 \\
7.28 \mathrm{E}-03 \\
1.63 \mathrm{E}-01 \\
1.73 \mathrm{E}-01 \\
9.19 \mathrm{E}-03 \\
7.96 \mathrm{E}+00 \\
1.14 \mathrm{E}-02 \\
2.60 \mathrm{E}+03 \\
4.75 \mathrm{E}-02 \\
2.67 \mathrm{E}-04 \\
2.11 \mathrm{E}-02 \\
5.18 \mathrm{E}-01 \\
3.71 \mathrm{E}+06 \\
1.46 \mathrm{E}-05 \\
\\
6.12 \mathrm{E}+03 \\
1.86 \mathrm{E}+00 \\
6.32 \mathrm{E}-01 \\
2.12 \mathrm{E}-02 \\
6.26 \mathrm{E}-03 \\
2.73 \mathrm{E}+05 \\
2.42 \mathrm{E}+00 \\
2.09 \mathrm{E}-01 \\
1.66 \mathrm{E}+03 \\
4.82 \mathrm{E}-02 \\
4.34 \mathrm{E}-01 \\
5.62 \mathrm{E}-04 \\
1.17 \mathrm{E}+03 \\
3.15 \mathrm{E}+04 \\
2.26 \mathrm{E}+02 \\
7.05 \mathrm{E}-02 \\
3.58 \mathrm{E}+01 \\
3.32 \mathrm{E}-04 \\
3.57 \mathrm{E}+03 \\
4.51 \mathrm{E}-06 \\
6.56 \mathrm{E}-01 \\
2.13 \mathrm{E}-03\end{array}$ & & & & & \\
\hline
\end{tabular}


WHC-SD-WM-TI-774 Rev. 0

TWRS PRIVATIZATION PROCESS TECHNICAL BASELINE

Table B-13 Phase 1 LAW Mass Balance for Batch PC2/13 (6 sheets)

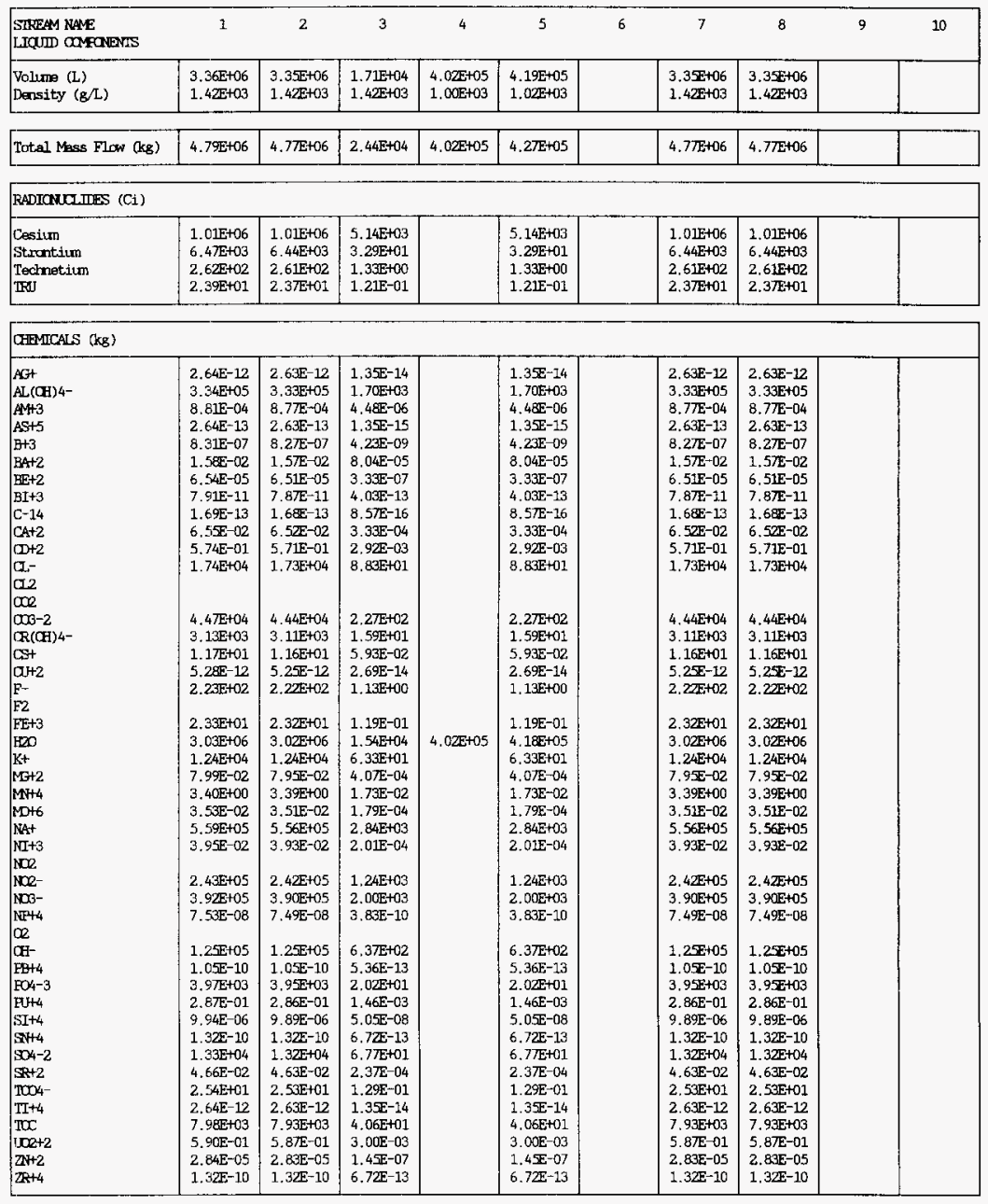


WHC-SD-WM-TI-774 Rev. 0

TWRS PRIVATIZATION PROCESS TECHNICAL BASELINE

Table B-13 Phase 1 IAW Mass Balance for Batch PC2/13 (6 sheets)

\begin{tabular}{|c|c|c|c|c|c|c|c|c|c|c|}
\hline $\begin{array}{l}\text { SIREMM NAEE } \\
\text { SOLD OAFANDIS }\end{array}$ & 1 & 2 & 3 & 4 & 5 & 6 & 7 & 8 & 9 & 10 \\
\hline Total Mass Flow (kg) & 4.79E+04 & $4.79 \mathrm{E}+02$ & $4.74 E+04$ & & $4.74 E+04$ & & 4. $79 \mathrm{E}+02$ & 4. $79 \mathrm{E}+02$ & & \\
\hline \multicolumn{11}{|l|}{ RADIaNCLIDES (C1) } \\
\hline $\begin{array}{l}\text { Cesium } \\
\text { Strantium } \\
\text { Technetium } \\
\text { [IFU }\end{array}$ & & & & & & & & & & \\
\hline \multicolumn{11}{|l|}{ OAFMICALS (kg) } \\
\hline 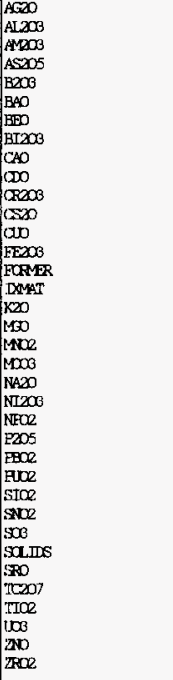 & 4. $79 \mathrm{E}+04$ & $4.79 E+02$ & $4.74 \mathrm{E}+04$ & & $4.74 \mathrm{E}+04$ & & $4.79 \mathrm{E}+02$ & $4.79 E+02$ & & \\
\hline
\end{tabular}


WHC-SD-WM-TI-774 Rev. 0

TWRS PRIVATIZATION PROCESS TECHNICAL BASELINE

Table B-13 Phase 1 LAW Mass Balance for Batch PC2/13 (6 sheets)

\begin{tabular}{|c|c|c|c|c|c|c|c|c|c|c|}
\hline $\begin{array}{l}\text { SIREAM NAME } \\
\text { LITUID OOMFONENIS }\end{array}$ & 11 & 12 & 13 & 14 & 15 & 16 & $16 \mathrm{~A}$ & 17 & 18 & 19 \\
\hline $\begin{array}{l}\text { Volime }(\mathrm{L}) \\
\text { Density }(\mathrm{g} / \mathrm{L})\end{array}$ & & $\begin{array}{l}3.35 \mathrm{E}+06 \\
1.42 \mathrm{E}+03\end{array}$ & $\begin{array}{l}2.93 \mathrm{E}+03 \\
3.33 \mathrm{E}+03\end{array}$ & & $\begin{array}{l}2.93 \mathrm{E}+03 \\
3.33 \mathrm{E}+03\end{array}$ & $\begin{array}{l}3.35 E+06 \\
1.42 E+03\end{array}$ & $\begin{array}{l}\text { 4. 81E+06 } \\
1.00 \mathrm{E}+03\end{array}$ & & $\begin{array}{l}1.00 \mathrm{E}-09 \\
1.00 \mathrm{E}+03\end{array}$ & $\begin{array}{l}1.00 \mathrm{E}-09 \\
1.00 \mathrm{E}+03\end{array}$ \\
\hline Iotal Mass Flow (kg) & & $4.77 \mathrm{E}+06$ & $9.74 \mathrm{E}+03$ & & $9.74 E+03$ & $4,77 E+06$ & $4.81 E+06$ & & $1.00 \mathrm{E}-09$ & $1.00 \mathrm{E}-09$ \\
\hline \multicolumn{11}{|l|}{ FADIONICDITES (Ci) } \\
\hline $\begin{array}{l}\text { Cesium } \\
\text { Struntium } \\
\text { Technetium } \\
\text { IRII }\end{array}$ & & $\begin{array}{l}4.26 \mathrm{E}+03 \\
6.44 \mathrm{E}+03 \\
2.58 \mathrm{E}+02 \\
2.37 \mathrm{E}+01\end{array}$ & $\begin{array}{l}1.00 \mathrm{E}+06 \\
2.62 \mathrm{E}+00\end{array}$ & & $\begin{array}{l}1.00 E+06 \\
2.62 E+00\end{array}$ & $\begin{array}{l}\text { 4. } 26 \mathrm{E}+03 \\
6.44 \mathrm{E}+03 \\
2.58 \mathrm{E}+02 \\
2.37 \mathrm{E}+01\end{array}$ & & & & \\
\hline \multicolumn{11}{|l|}{ CHFMTCALS (kg) } \\
\hline 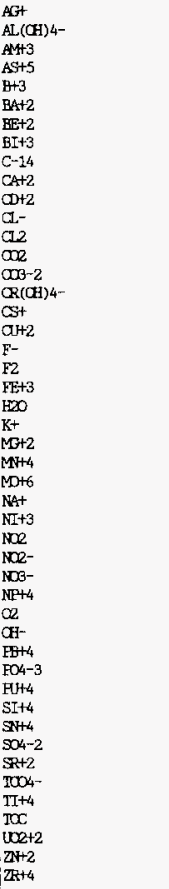 & & $\begin{array}{l}2.63 \mathrm{E}-12 \\
3.33 \mathrm{E}+05 \\
8.7 \mathrm{E}-04 \\
2.63 \mathrm{E}-13 \\
8.2 \mathrm{E}-07 \\
1.57 \mathrm{E}-02 \\
6.51 \mathrm{E}-05 \\
7.8 \mathrm{E}-11 \\
1.6 \mathrm{E}-13 \\
6.5 \mathrm{E}-02 \\
5.7 \mathrm{E}-01 \\
1.73 \mathrm{E}+04 \\
\\
4.44 \mathrm{E}+04 \\
3.11 \mathrm{E}+03 \\
4.92 \mathrm{E}-02 \\
5.2 \mathrm{E}-12 \\
2.22 \mathrm{E}+02 \\
2.32 \mathrm{E}+01 \\
3.02 \mathrm{E}+06 \\
1.24 \mathrm{E}+04 \\
7.9 \mathrm{~F}-02 \\
3.39 \mathrm{E}+00 \\
3.51 \mathrm{E}-02 \\
5.56 \mathrm{E}+05 \\
3.93 \mathrm{E}-02 \\
2.42 \mathrm{E}+05 \\
3.90 \mathrm{E}+05 \\
7.49 \mathrm{E}-08 \\
1.2 \mathrm{E}+05 \\
1.0 \mathrm{E}-10 \\
3.9 \mathrm{E}+03 \\
2.86 \mathrm{E}-01 \\
9.89 \mathrm{E}-06 \\
1.32 \mathrm{E}-10 \\
1.32 \mathrm{E}+04 \\
4.63 \mathrm{E}-02 \\
2.50 \mathrm{E}+01 \\
2.63 \mathrm{E}-12 \\
7.93 \mathrm{E}+03 \\
5.67 \mathrm{E}-01 \\
2.83 \mathrm{E}-05 \\
1.32 \mathrm{E}-10\end{array}$ & $\begin{array}{l}1.16 \mathrm{E}+01 \\
5.59 \mathrm{E}+03 \\
4.14 \mathrm{E}+03 \\
2.54 \mathrm{E}-01\end{array}$ & & $\begin{array}{l}1.16 \mathrm{E}+01 \\
5.59 \mathrm{E}+03 \\
4.14 \mathrm{E}+03 \\
2.54 \mathrm{E}-01\end{array}$ & $\begin{array}{l}2.63 \mathrm{E}-12 \\
3.33 \mathrm{E}+05 \\
8.77 \mathrm{E}-04 \\
2.63 \mathrm{E}-13 \\
8.27 \mathrm{E}-07 \\
1.57 \mathrm{E}-02 \\
6.51 \mathrm{E}-05 \\
7.87 \mathrm{E}-11 \\
1.68 \mathrm{E}-13 \\
6.52 \mathrm{E}-02 \\
5.71 \mathrm{E}-01 \\
1.73 \mathrm{E}+04 \\
\\
4.44 \mathrm{E}+04 \\
3.11 \mathrm{E}+03 \\
4.92 \mathrm{E}-02 \\
5.25 \mathrm{E}-12 \\
2.22 \mathrm{E}+02 \\
2.32 \mathrm{E}+01 \\
3.02 \mathrm{E}+06 \\
1.24 \mathrm{E}+04 \\
7.95 \mathrm{E}-02 \\
3.39 \mathrm{E}+00 \\
3.51 \mathrm{E}-02 \\
5.56 \mathrm{E}+05 \\
3.93 \mathrm{E}-02 \\
2.42 \mathrm{E}+05 \\
3.90 \mathrm{E}+05 \\
7.49 \mathrm{E}-08 \\
1.25 \mathrm{E}+05 \\
1.05 \mathrm{E}-10 \\
3.95 \mathrm{E}+03 \\
2.86 \mathrm{E}-01 \\
9.89 \mathrm{E}-06 \\
1.32 \mathrm{E}-10 \\
1.32 \mathrm{E}+04 \\
4.63 \mathrm{E}-02 \\
2.50 \mathrm{E}+01 \\
2.63 \mathrm{E}-12 \\
7.93 \mathrm{E}+03 \\
5.87 \mathrm{E}-01 \\
2.83 \mathrm{E}-05 \\
1.32 \mathrm{E}-10\end{array}$ & $\begin{array}{l}\text { 1. } 73 E+04 \\
6.17 E+04 \\
2.22 E+02 \\
3.21 E+06\end{array}$ & & $1.00 \mathrm{E}-09$ & $1.00 \mathrm{~F}-09$ \\
\hline
\end{tabular}


WHC-SD-WM-TI-774 Rev. 0

TWRS PRIVATIZATION PROCESS TECHNICAL BASELINE

Table B-13 Phase 1 IAW Mass Balance for Batch $\mathrm{PC} 2 / 3$ (6 sheets)

\begin{tabular}{|c|c|c|c|c|c|c|c|c|c|c|}
\hline $\begin{array}{l}\text { SIFFAM NAE } \\
\text { SOID COMRONENT; }\end{array}$ & 11 & 12 & 13 & 14 & 15 & 16 & $16 A$ & 17 & 18 & 19 \\
\hline Total Mass Flow (kg) & & 4.79E+02 & & 5. $59 \mathrm{E}+03$ & 5. $59 \mathrm{E}+03$ & 4.79E+02 & $9.60 \mathrm{E}+05$ & & & \\
\hline \multicolumn{11}{|l|}{ RADIaNuCLIDES (Ct) } \\
\hline $\begin{array}{l}\text { Cesium } \\
\text { Strontium } \\
\text { Technetium } \\
\text { TRIJ }\end{array}$ & & & & & & & $\begin{array}{l}4.26 \mathrm{E}+03 \\
6.44 \mathrm{E}+03 \\
2.5 \mathrm{E}+02 \\
2.3 \mathrm{E}+01\end{array}$ & & & \\
\hline \multicolumn{11}{|l|}{ OFEMICALS (kg) } \\
\hline 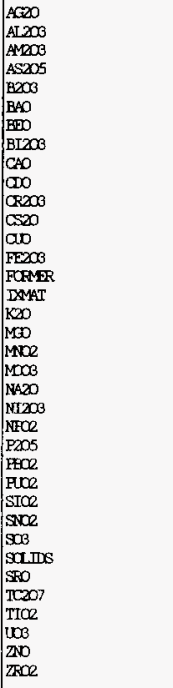 & & 4. $79 \mathrm{E}+02$ & & $5.59 E \div 03$ & $5.59 \mathrm{E}+03$ & 4. 79E+02 & $\begin{array}{l}2.83 \mathrm{E}-12 \\
1.79 \mathrm{E}+05 \\
9.64 \mathrm{E}-04 \\
4.04 \mathrm{E}-13 \\
2.66 \mathrm{E}-06 \\
1.76 \mathrm{E}-02 \\
1.81 \mathrm{E}-04 \\
8.78 \mathrm{E}-11 \\
9.12 \mathrm{E}-02 \\
6.52 \mathrm{E}-01 \\
1.97 \mathrm{E}+03 \\
5.21 \mathrm{E}-02 \\
6.5 \mathrm{E}-12 \\
3.32 \mathrm{E}+01 \\
\\
1.49 \mathrm{E}+04 \\
1.32 \mathrm{E}-01 \\
5.36 \mathrm{E}+00 \\
5.26 \mathrm{E}-02 \\
7.50 \mathrm{E}+05 \\
5.53 \mathrm{E}-02 \\
8.50 \mathrm{E}-08 \\
2.96 \mathrm{E}+03 \\
1.21 \mathrm{E}-10 \\
3.24 \mathrm{E}-01 \\
2.12 \mathrm{E}-05 \\
1.67 \mathrm{E}-10 \\
1.10 \mathrm{E}+04 \\
4.79 \mathrm{E}+02 \\
5.46 \mathrm{E}-02 \\
2.38 \mathrm{E}+01 \\
4.39 \mathrm{E}-12 \\
6.22 \mathrm{E}-01 \\
3.52 \mathrm{E}-05 \\
1.78 \mathrm{E}-10\end{array}$ & & & \\
\hline
\end{tabular}


WHC-SD-WM-TI-774 Rev. 0

TWRS PRIVATIZATION PROCESS TECHNICAL BASELINE

Table B-13 Phase 1 LAW Mass Balance for Batch PC2/13 ( 6 sheets)

\begin{tabular}{|c|c|c|c|c|c|c|c|c|c|}
\hline $\begin{array}{l}\text { SIRFAM NAME } \\
\text { LTAUD OOMOQNENS }\end{array}$ & 20 & 21 & 22 & 23 & 24 & 25 & 26 & 27 & 28 \\
\hline $\begin{array}{l}\text { Volume }(L) \\
\text { Density }(g / L)\end{array}$ & $\begin{array}{l}4.81 E+06 \\
1.00 \mathrm{E}+03\end{array}$ & & & & $\begin{array}{l}\text { 1. } 60 \mathrm{E}+06 \\
1.00 \mathrm{E}+03\end{array}$ & $\begin{array}{l}3.21 E+06 \\
1.00 E+03\end{array}$ & $\begin{array}{l}2.92 \mathrm{E}+03 \\
3.34 \mathrm{E}+03\end{array}$ & $\begin{array}{l}3.00 \mathrm{E}-10 \\
3.34 \mathrm{E}+03\end{array}$ & $\begin{array}{l}1.00 E+06 \\
1.00 E+03\end{array}$ \\
\hline Total Mass Flow (kg) & 4.81E+06 & & & & 1. $60 \mathrm{E}+06$ & $3.21 E+06$ & $9,73 E+03$ & $1.00 \mathrm{E}-09$ & $1.00 E+06$ \\
\hline \multicolumn{10}{|l|}{ RADIONUCLJTES (Ci) } \\
\hline $\begin{array}{l}\text { Cesium } \\
\text { Strantium } \\
\text { Technetium } \\
\text { TRJ }\end{array}$ & & & & & & & & & \\
\hline
\end{tabular}

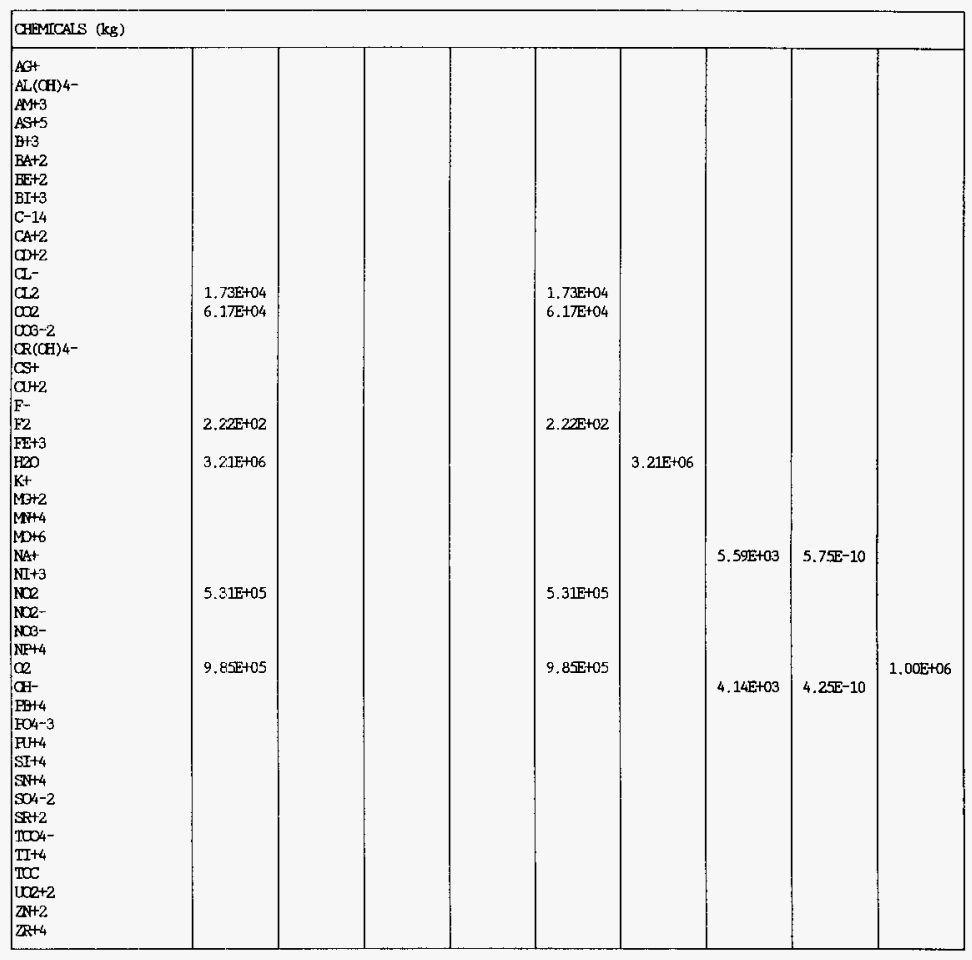


WHC-SD-WM-TI-774 Rev. 0

TWRS PRIVATIZATION PROCESS TECHNICAL BASELINE

Table B-13 Phase 1 LAW Mass Balance for Batch PC2/13 (6 sheets)

\begin{tabular}{|c|c|c|c|c|c|c|c|c|c|}
\hline $\begin{array}{l}\text { SIFEM NAE } \\
\text { SOD COMONENIS }\end{array}$ & 20 & 21 & 22 & 23 & 24 & 25 & 26 & 27 & 28 \\
\hline Total Mass Flow (kg) & & $9.60 \mathrm{E}+05$ & $3.48 \mathrm{E}+06$ & $4,44 \mathrm{E}+06$ & & & & & \\
\hline \multicolumn{10}{|l|}{ RADIOMCLIDES (Ci) } \\
\hline $\begin{array}{l}\text { Cesium } \\
\text { Strantium } \\
\text { Terhnetium } \\
\text { TIN }\end{array}$ & & $\begin{array}{l}4.26 \mathrm{E}+03 \\
6.44 \mathrm{E}+03 \\
2.58 \mathrm{E}+02 \\
2.35 \mathrm{E}+01\end{array}$ & & $\begin{array}{l}4.26 \mathrm{E}+03 \\
6.44 \mathrm{E}+03 \\
2.58 \mathrm{E}+02 \\
2.35 \mathrm{E}+01\end{array}$ & & & & & \\
\hline \multicolumn{10}{|l|}{ OHEMICAIS (kg) } \\
\hline 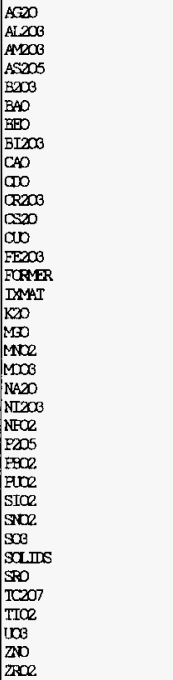 & & $\begin{array}{l}2.83 \mathrm{E}-12 \\
1.79 \mathrm{E}+05 \\
9.64 \mathrm{E}-04 \\
4.04 \mathrm{E}-13 \\
2.66 \mathrm{E}-06 \\
1.76 \mathrm{E}-02 \\
1.81 \mathrm{E}-04 \\
8.78 \mathrm{E}-11 \\
9.12 \mathrm{E}-02 \\
6.52 \mathrm{E}-01 \\
1.97 \mathrm{E}+03 \\
5.21 \mathrm{E}-02 \\
6.58 \mathrm{E}-12 \\
3.32 \mathrm{E}+01 \\
\\
1.49 \mathrm{E}+04 \\
1.32 \mathrm{E}-01 \\
5.36 \mathrm{E}+00 \\
5.26 \mathrm{E}-02 \\
7.50 \mathrm{E}+05 \\
5.53 \mathrm{E}-02 \\
8.50 \mathrm{E}-08 \\
2.96 \mathrm{E}+03 \\
1.21 \mathrm{E}-10 \\
3.24 \mathrm{E}-01 \\
2.12 \mathrm{E}-05 \\
1.67 \mathrm{E}-10 \\
1.10 \mathrm{E}+04 \\
4.79 \mathrm{E}+02 \\
5.46 \mathrm{E}-02 \\
2.38 \mathrm{E}+01 \\
4.39 \mathrm{E}-12 \\
6.22 \mathrm{E}-01 \\
3.52 \mathrm{E}-05 \\
1.78 \mathrm{E}-10\end{array}$ & $3.48 E+06$ & $\begin{array}{l}2.83 \mathrm{E}-12 \\
1.79 \mathrm{E}+05 \\
9.64 \mathrm{E}-04 \\
4.04 \mathrm{E}-13 \\
2.66 \mathrm{E}-06 \\
1.76 \mathrm{E}-02 \\
1.81 \mathrm{E}-04 \\
8.78 \mathrm{E}-11 \\
9.12 \mathrm{E}-02 \\
6.52 \mathrm{E}-01 \\
1.97 \mathrm{E}+03 \\
5.21 \mathrm{E}-02 \\
6.58 \mathrm{E}-12 \\
3.32 \mathrm{E}+01 \\
3.48 \mathrm{E}+06 \\
1.49 \mathrm{E}+04 \\
1.32 \mathrm{E}-01 \\
5.36 \mathrm{E}+00 \\
5.26 \mathrm{E}-02 \\
7.50 \mathrm{E}+05 \\
5.53 \mathrm{E}-02 \\
8.50 \mathrm{E}-08 \\
2.96 \mathrm{E}+03 \\
1.21 \mathrm{E}-10 \\
3.24 \mathrm{E}-01 \\
2.12 \mathrm{E}-05 \\
1.67 \mathrm{E}-10 \\
1.10 \mathrm{E}+04 \\
4.79 \mathrm{E}+02 \\
5.46 \mathrm{E}-02 \\
2.38 \mathrm{E}+01 \\
4.39 \mathrm{E}-12 \\
6.225-01 \\
3.52 \mathrm{E}-05 \\
1.78 \mathrm{E}-10\end{array}$ & & & & & \\
\hline
\end{tabular}


WHC-SD-WM-TI-774 Rev. 0

TWRS PRIVATIZATION PROCESS TECHNICAL BASELINE

Table B-14 Phase 1 LAW Mass Balance for Batch PC2/14 (6 sheets)

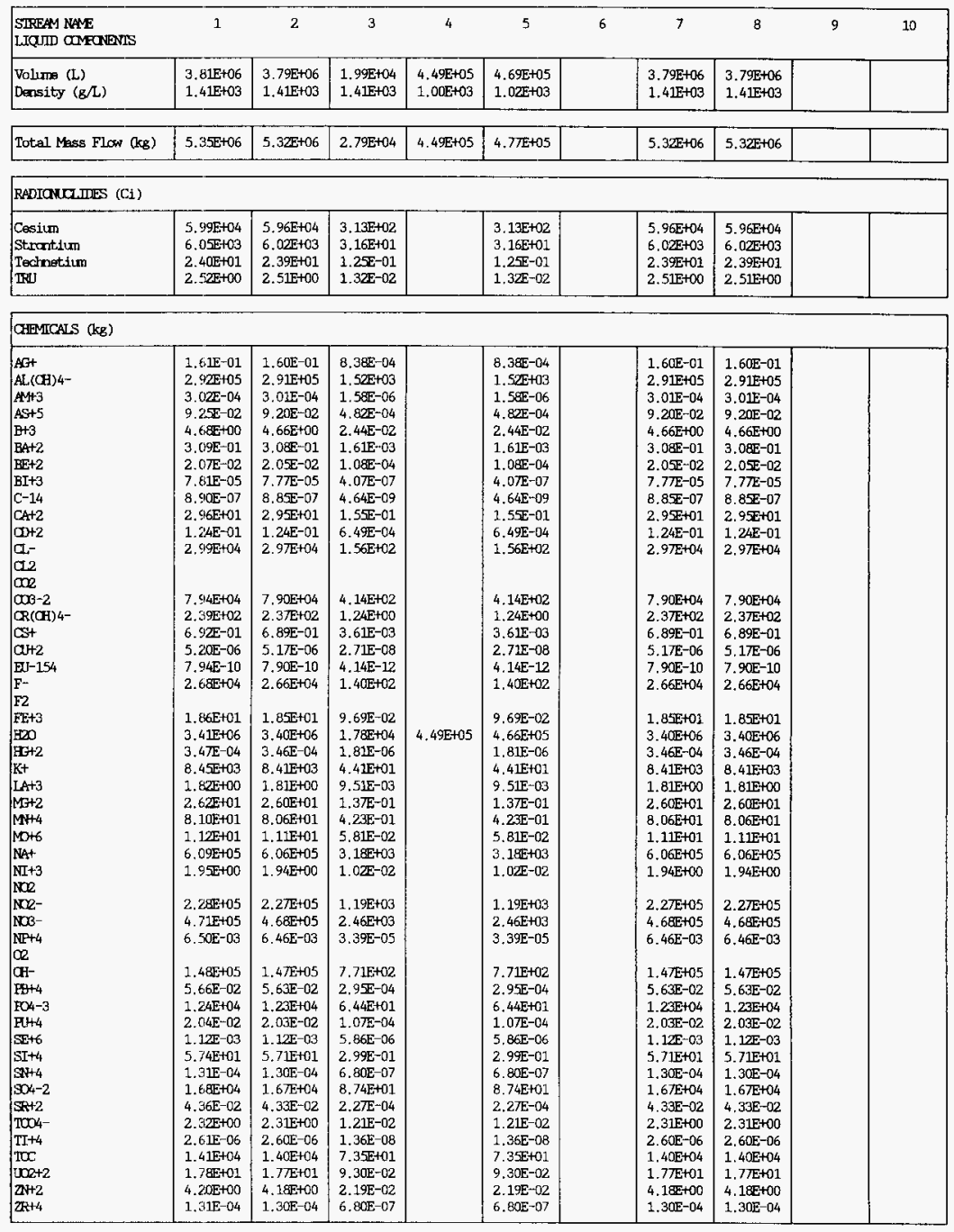


WHC-SD-WM-TI-774 Rev. 0

TWRS PRIVATIZATION PROCESS TECHNICAL BASELINE

Table B-14 Phase 1 LAW Mass Balance for Batch PC2/14 (6 sheets)

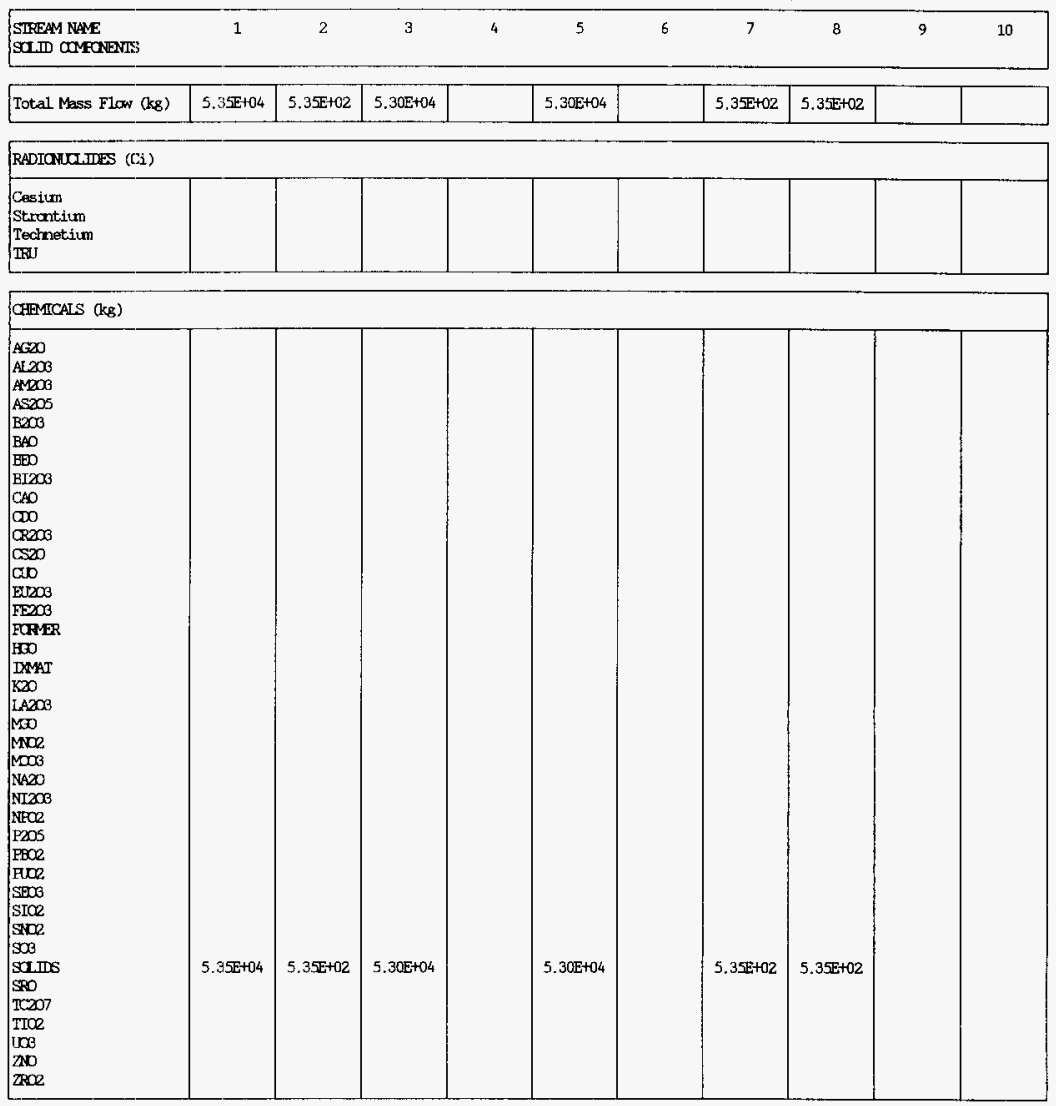


WHC-SD-WM-TI-774 ReV. 0

\section{TWRS PRIVATIZATION PROCESS TECHNICAL BASELINE}

Table B-14 Phase 1 LAW Mass Balance for Batch PC2/14 (6 sheets)

\begin{tabular}{|c|c|c|c|c|c|c|c|c|c|c|}
\hline $\begin{array}{l}\text { STPEAM NAYE } \\
\text { LTQUID OOMFANPIS }\end{array}$ & 11 & 12 & 13 & 14 & 15 & 16 & $16 \mathrm{~A}$ & 17 & 18 & 19 \\
\hline $\begin{array}{l}\text { Volume }(\mathrm{L}) \\
\text { Density }(\mathrm{g} / \mathrm{L})\end{array}$ & & $\begin{array}{l}\text { 3. } 79 \mathrm{E}+06 \\
1.41 \mathrm{E}+03\end{array}$ & $\begin{array}{l}3.18 \mathrm{BE}+03 \\
3.34 \mathrm{E}+03\end{array}$ & & $\begin{array}{l}3.18 E+03 \\
3.34 E+03\end{array}$ & $\begin{array}{l}3.79 \mathrm{E}+06 \\
1.41 \mathrm{E}+03\end{array}$ & $\begin{array}{l}5.32 \mathrm{E}+06 \\
1.00 \mathrm{E}+03\end{array}$ & & $\begin{array}{l}1.00 E-09 \\
1.00 E+03\end{array}$ & $\begin{array}{l}1.00 E-09 \\
1.00 E+03\end{array}$ \\
\hline Total Mass Flow (kg) & & 5. $32 E+06$ & $1.06 E+04$ & & $1.06 \mathrm{E}+04$ & $5.32 \mathrm{E}+06$ & $5.325+06$ & & $1.00 \mathrm{E}-09$ & $1.005-09$ \\
\hline \multicolumn{11}{|l|}{ RADIONUCIIIES (Ci) } \\
\hline $\begin{array}{l}\text { Cesium } \\
\text { Strontium } \\
\text { Technetiun } \\
\text { TRI }\end{array}$ & & $\begin{array}{l}4.65 E+03 \\
6.02 E+03 \\
2.36 E+01 \\
2.51 E+00\end{array}$ & $\begin{array}{l}5.50 \mathrm{E}+04 \\
2.40 \mathrm{DE}-01\end{array}$ & & $\begin{array}{l}5,50 \mathrm{E}+04 \\
2,40 \mathrm{E}-01\end{array}$ & $\begin{array}{l}4.6 \mathrm{EE}+03 \\
6.02 \mathrm{E}+03 \\
2.36 \mathrm{E}+01 \\
2.51 \mathrm{E}+00\end{array}$ & & & & \\
\hline \multicolumn{11}{|l|}{ CHEMCALS (kg) } \\
\hline 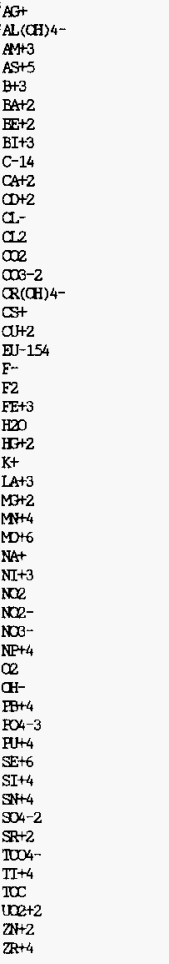 & & $\begin{array}{l}1.60 \mathrm{E}-01 \\
2.91 \mathrm{E}+05 \\
3.01 \mathrm{E}-04 \\
9.20 \mathrm{E}-02 \\
4.66 \mathrm{E}+00 \\
3.08 \mathrm{E}-01 \\
2.05 \mathrm{E}-02 \\
7.77 \mathrm{E}-0.5 \\
8.85 \mathrm{E}-07 \\
2.95 \mathrm{E}+01 \\
1.24 \mathrm{E}-01 \\
2.97 \mathrm{E}+04 \\
\\
7.90 \mathrm{E}+04 \\
2.37 \mathrm{E}+02 \\
5.37 \mathrm{E}-02 \\
5.17 \mathrm{E}-06 \\
7.90 \mathrm{E}-10 \\
2.66 \mathrm{E}+04 \\
1.85 \mathrm{E}+01 \\
3.40 \mathrm{E}+06 \\
3.46 \mathrm{E}-04 \\
8.41 \mathrm{E}+03 \\
1.81 \mathrm{E}+00 \\
2.60 \mathrm{E}+01 \\
8.06 \mathrm{E}+01 \\
1.11 \mathrm{E}+01 \\
6.06 \mathrm{E}+05 \\
1.94 \mathrm{E}+00 \\
2.2 \mathrm{E}+05 \\
4.68 \mathrm{E}+05 \\
6.46 \mathrm{E}-03 \\
1.4 \mathrm{TE}+05 \\
5.63 \mathrm{E}-02 \\
1.23 \mathrm{E}+04 \\
2.03 \mathrm{E}-02 \\
1.12 \mathrm{E}-03 \\
5.71 \mathrm{E}+01 \\
1.30 \mathrm{E}-04 \\
1.67 \mathrm{E}+04 \\
4.33 \mathrm{E}-02 \\
2.29 \mathrm{E}+00 \\
2.60 \mathrm{E}-06 \\
1.40 \mathrm{E}+04 \\
1.7 \mathrm{E}+01 \\
4.18 \mathrm{E}+00 \\
1.30 \mathrm{E}-04\end{array}$ & $\begin{array}{l}6.09 \mathrm{E}+03 \\
4.51 E+03\end{array}$ & & $\begin{array}{l}6.352-01 \\
6.09 E+03 \\
4.51 E+03 \\
2.32 E-02\end{array}$ & $\begin{array}{l}1.60 \mathrm{E}-01 \\
2.91 \mathrm{E}+05 \\
3.01 \mathrm{E}-04 \\
9.20 \mathrm{E}-02 \\
4.66 \mathrm{E}+00 \\
3.08 \mathrm{E}-01 \\
2.05 \mathrm{E}-02 \\
7.77 \mathrm{E}-05 \\
8.85 \mathrm{E}-07 \\
2.95 \mathrm{E}+01 \\
1.24 \mathrm{E}-01 \\
2.97 \mathrm{E}+04 \\
\\
7.90 \mathrm{E}+04 \\
2.37 \mathrm{E}+02 \\
5.37 \mathrm{E}-02 \\
5.17 \mathrm{E}-06 \\
7.90 \mathrm{E}-10 \\
2.66 \mathrm{E}+04 \\
1.65 \mathrm{E}+01 \\
3.40 \mathrm{E}+06 \\
3.46 \mathrm{E}-04 \\
8.41 \mathrm{E}+03 \\
1.61 \mathrm{E}+00 \\
2.60 \mathrm{E}+01 \\
8.06 \mathrm{E}+01 \\
1.11 \mathrm{E}+01 \\
6.06 \mathrm{E}+05 \\
1.94 \mathrm{E}+00 \\
2.27 \mathrm{E}+05 \\
4.68 \mathrm{E}+05 \\
6.46 \mathrm{E}-03 \\
1.4 \mathrm{E}+05 \\
5.63 \mathrm{E}-02 \\
1.23 \mathrm{E}+04 \\
2.03 \mathrm{E}-02 \\
1.12 \mathrm{E}-03 \\
5.71 \mathrm{E}+01 \\
1.30 \mathrm{E}-04 \\
1.67 \mathrm{E}+04 \\
4.33 \mathrm{E}-02 \\
2.29 \mathrm{E}+00 \\
2.60 \mathrm{E}-06 \\
1.40 \mathrm{E}+04 \\
1.77 \mathrm{E}+01 \\
4.18 \mathrm{E}+00 \\
1.30 \mathrm{E}-04\end{array}$ & $\begin{array}{l}2.97 \mathrm{E}+04 \\
1.09 \mathrm{E}+05 \\
\\
2.66 \mathrm{E}+04 \\
3.56 \mathrm{EE}+06\end{array}$ & & $1.00 \mathrm{E}-09$ & $1.00 \mathrm{E}-09$ \\
\hline
\end{tabular}


WHC-SD-WM-TI-774 Rev. 0

TWRS PRIVATIZATION PROCESS TECHNICAL BASELINE

Table B-14 Phase 1 LAW Mass Balance for Batch PC2/14 (6 sheets)

\begin{tabular}{|c|c|c|c|c|c|c|c|c|c|c|}
\hline $\begin{array}{l}\text { SIREAM NAME } \\
\text { SOLD OOMONENSS }\end{array}$ & 11 & 12 & 13 & 14 & 15 & 16 & IGA & 17 & 18 & 19 \\
\hline Total Mass Flow (kg) & & $5.35 \mathrm{EE}+02$ & & $6.09 \mathrm{E}+03$ & $6.09 \mathrm{E}+03$ & $5.35 \mathrm{E}+02$ & 1.01E+06 & & & \\
\hline \multicolumn{11}{|l|}{ RADIONUCLIIES (Ci) } \\
\hline $\begin{array}{l}\text { Cesiun } \\
\text { Strantium } \\
\text { Tecdnet:ium } \\
\text { TWI }\end{array}$ & & & & & & & $\begin{array}{l}4.65 E+03 \\
6.02 E+03 \\
2.36 E+01 \\
2.49 E+00\end{array}$ & & & \\
\hline \multicolumn{11}{|l|}{ CAEMICALS (Kg) } \\
\hline 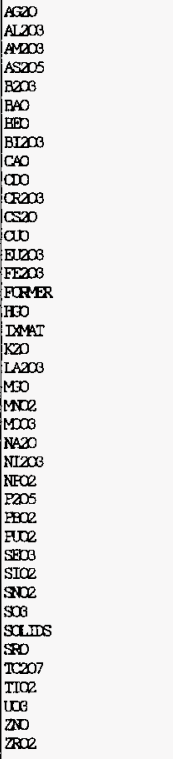 & & $5.35+02$ & & $6.09 E+03$ & $6.09 \mathrm{E}+03$ & $5.3[5+02$ & $\begin{array}{l}1.72 \mathrm{E}-01 \\
1.56 \mathrm{E}+05 \\
3.31 \mathrm{E}-04 \\
1.4 \mathrm{E}-01 \\
1.50 \mathrm{E}+01 \\
3.44 \mathrm{E}-01 \\
5.70 \mathrm{E}-02 \\
8.66 \mathrm{E}-05 \\
4.13 \mathrm{E}+01 \\
1.41 \mathrm{E}-01 \\
1.50 \mathrm{E}+02 \\
5.6 \mathrm{EE}-02 \\
6.48 \mathrm{E}-06 \\
9.15 \mathrm{E}-10 \\
2.64 \mathrm{E}+01 \\
\\
3.73 \mathrm{E}-04 \\
\\
1.01 \mathrm{E}+04 \\
2.13 \mathrm{E}+00 \\
4.32 \mathrm{E}+01 \\
1.28 \mathrm{E}+02 \\
1.66 \mathrm{E}+01 \\
8.17 \mathrm{E}+05 \\
2.74 \mathrm{E}+00 \\
7.34 \mathrm{E}-03 \\
9.19 \mathrm{E}+03 \\
6.50 \mathrm{E}-02 \\
2.30 \mathrm{E}-02 \\
1.80 \mathrm{E}-03 \\
1.22 \mathrm{E}+02 \\
1.65 \mathrm{E}-04 \\
1.39 \mathrm{E}+04 \\
5.35 \mathrm{E}+02 \\
5.10 \mathrm{E}-02 \\
2.1 \mathrm{EE}+00 \\
4.33 \mathrm{E}-06 \\
1.88 \mathrm{E}+01 \\
5.20 \mathrm{E}+00 \\
1.75 \mathrm{E}-04\end{array}$ & & & \\
\hline
\end{tabular}


WHC-SD-WM-TI-774 ReV. 0

TWRS PRIVATIZATION PROCESS TECHNICAL BASELINE

Table B-14 Phase 1 LAW Mass Balance for Batch PC2/14 (6 sheets)

\begin{tabular}{|c|c|c|c|c|c|c|c|c|c|}
\hline $\begin{array}{l}\text { STREAM NME } \\
\text { LIOUID COMONEMIS }\end{array}$ & 20 & 21 & 22 & 23 & 24 & 25 & 26 & 27 & 28 \\
\hline $\begin{array}{l}\text { Volume (L) } \\
\text { Density }(g / L)\end{array}$ & $\begin{array}{l}5.32 \mathrm{E}+06 \\
1.00 \mathrm{E}+03\end{array}$ & & & & $\begin{array}{l}1.73 E+06 \\
1.00 E+03\end{array}$ & $\begin{array}{l}3.58 E+06 \\
1.00 E+03\end{array}$ & $\begin{array}{l}3.18 E+03 \\
3.34 E+03\end{array}$ & $\begin{array}{l}3.00 \mathrm{E}-10 \\
3.34 \mathrm{E}+03\end{array}$ & $\begin{array}{l}1.00 E+06 \\
1.00 E+03\end{array}$ \\
\hline Total Mass Flon (kg) & $5.32 \mathbf{E}+06$ & & & & $1.73 \mathrm{E}+06$ & $3.58 \mathrm{E}+06$ & $1.06 \mathrm{E}+04$ & $1.00 \mathrm{E}-09$ & $1.00 \mathrm{E}+06$ \\
\hline \multicolumn{10}{|l|}{ RADTaNCLISES (Ci) } \\
\hline $\begin{array}{l}\text { Cesium } \\
\text { Strantium } \\
\text { Technetium } \\
\text { TRI }\end{array}$ & & & & & & & & & \\
\hline \multicolumn{10}{|l|}{ CFEMICALS (kg) } \\
\hline 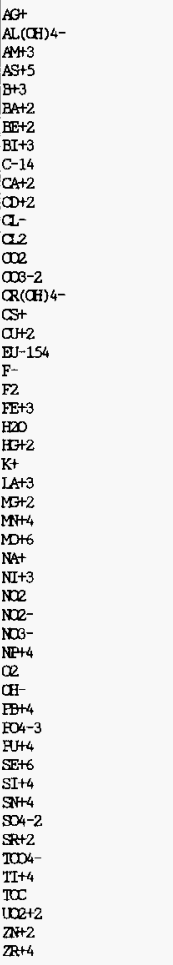 & $\begin{array}{l}2.97 E+04 \\
1.09 E+05 \\
\\
2.66 E+04 \\
3.58 E+06 \\
5.75 E+05 \\
9.91 E+0.5\end{array}$ & & & & $\begin{array}{l}2.97 \mathrm{E}+04 \\
1.09 \mathrm{E}+05 \\
2.66 \mathrm{E}+04 \\
5.75 \mathrm{E}+0.5 \\
9.91 \mathrm{E}+05\end{array}$ & $3.586+06$ & $\begin{array}{l}6.09 \mathrm{E}+03 \\
4.51 \mathrm{E}+03\end{array}$ & $\begin{array}{l}5.7 . \mathrm{E}-10 \\
4.2 \mathrm{E}-10\end{array}$ & $1,00 \mathrm{E}+06$ \\
\hline
\end{tabular}


WHC-SD-WM-TI-774 Rev. 0

TWRS PRIVATIZATION PROCESS TECHNICAL BASELINE

Table B-14 Phase 1 LAW Mass Balance for Batch PC2/14 ( 6 sheets)

\begin{tabular}{|c|c|c|c|c|c|c|c|c|c|}
\hline $\begin{array}{l}\text { SIFEAM NAME } \\
\text { SOLD OOMFONDNIS }\end{array}$ & 20 & 21 & 22 & 23 & 24 & 25 & 26 & 27 & 28 \\
\hline Total Mass Flow (kg) & & $1.01 E+06$ & $3.83 E+06$ & $4.84 \mathrm{E}+06$ & & & & & \\
\hline \multicolumn{10}{|l|}{ RabIanCLIDES (Ci) } \\
\hline $\begin{array}{l}\text { Cesium } \\
\text { Strantium } \\
\text { Techretium } \\
\text { TRI] }\end{array}$ & & $\begin{array}{l}4.6 \mathrm{E}+03 \\
6.02 \mathrm{E}+03 \\
2.36 \mathrm{~F}+01 \\
2.49 \mathrm{E}+00\end{array}$ & & $\begin{array}{l}4.65 \mathrm{E}+03 \\
6.02 \mathrm{E}+03 \\
2.36 \mathrm{E}+01 \\
2.49 \mathrm{E}+00\end{array}$ & & & & & \\
\hline \multicolumn{10}{|l|}{ OARICALS (kg) } \\
\hline 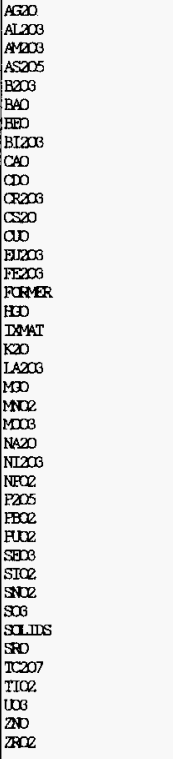 & & $\begin{array}{l}1.72 \mathrm{E}-01 \\
1.56 \mathrm{E}+05 \\
3.31 \mathrm{E}-04 \\
1.4 \mathrm{E}-01 \\
1.5 \mathrm{EE}+01 \\
3.44 \mathrm{E}-01 \\
5.70 \mathrm{E}-02 \\
8.66 \mathrm{E}-05 \\
4.13 \mathrm{E}+01 \\
1.4 \mathrm{E}-01 \\
1.50 \mathrm{E}+02 \\
5.6 \mathrm{EE}-02 \\
6.4 \mathrm{EE}-06 \\
9.15 \mathrm{E}-10 \\
2.64 \mathrm{E}+01 \\
\\
3.73 \mathrm{E}-04 \\
\\
1.01 \mathrm{E}+04 \\
2.13 \mathrm{E}+00 \\
4.32 \mathrm{E}+01 \\
1.28 \mathrm{E}+02 \\
1.66 \mathrm{E}+01 \\
8.17 \mathrm{E}+05 \\
2.74 \mathrm{E}+00 \\
7.34 \mathrm{E}-03 \\
9.19 \mathrm{E}+03 \\
6.50 \mathrm{E}-02 \\
2.30 \mathrm{E}-02 \\
1.80 \mathrm{E}-03 \\
1.22 \mathrm{E}+02 \\
1.65 \mathrm{E}-04 \\
1.39 \mathrm{E}+04 \\
5.3 \mathrm{E}+02 \\
5.10 \mathrm{E}-02 \\
2.18 \mathrm{E}+00 \\
4.33 \mathrm{E}-06 \\
1.86 \mathrm{E}+01 \\
5.20 \mathrm{E}+00 \\
1.7 \mathrm{E}-04\end{array}$ & 3. $83 E+06$ & $\begin{array}{l}1.72 \mathrm{E}-01 \\
1.56 \mathrm{E}+05 \\
3.31 \mathrm{E}-04 \\
1.41 \mathrm{E}-01 \\
1.50 \mathrm{E}+01 \\
3.44 \mathrm{E}-01 \\
5.70 \mathrm{E}-02 \\
8.66 \mathrm{E}-05 \\
4.13 \mathrm{E}+01 \\
1.4 \mathrm{E}-01 \\
1.50 \mathrm{E}+02 \\
5.6 \mathrm{EE}-02 \\
6.48 \mathrm{E}-06 \\
9.15 \mathrm{E}-10 \\
2.64 \mathrm{E}+01 \\
3.85 \mathrm{E}+06 \\
3.73 \mathrm{E}-04 \\
\\
1.01 \mathrm{E}+04 \\
2.13 \mathrm{E}+00 \\
4.32 \mathrm{E}+01 \\
1.28 \mathrm{E}+02 \\
1.66 \mathrm{E}+01 \\
8.17 \mathrm{E}+05 \\
2.74 \mathrm{E}+00 \\
7.34 \mathrm{E}-03 \\
9.19 \mathrm{E}+03 \\
6.50 \mathrm{E}-02 \\
2.30 \mathrm{E}-02 \\
1.80 \mathrm{E}-03 \\
1.22 \mathrm{E}+02 \\
1.65 \mathrm{E}-04 \\
1.39 \mathrm{E}+04 \\
5.35 \mathrm{E}+02 \\
5.10 \mathrm{E}-02 \\
2.18 \mathrm{E}+00 \\
4.33 \mathrm{E}-06 \\
1.86 \mathrm{E}+01 \\
5.20 \mathrm{E}+00 \\
1.75 \mathrm{E}-04\end{array}$ & & & & & \\
\hline
\end{tabular}


WHC-SD-WM-TI-774 Rev. 0

TWRS PRIVATIZATION PROCESS TECHNICAL BASELINE

Table B-15 Phase 1 IAW Mass Balance for Batch PC2/15 (6 sheets)

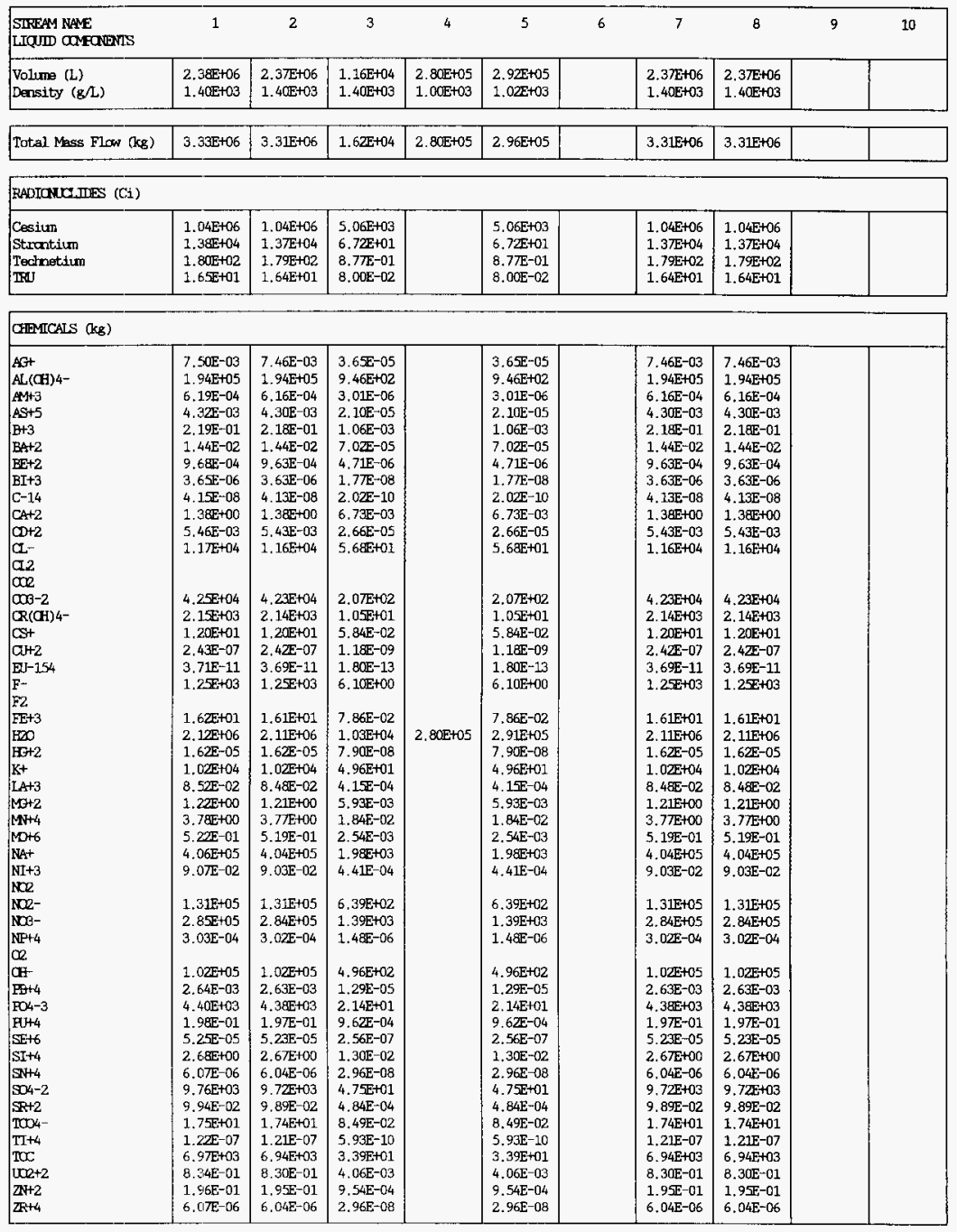


WHC-SD-WM-TI-774 Rev. 0

TWRS PRIVATIZATION PROCESS TECHNICAL BASELINE

Table B-15 Phase 1 LAW Mass Balance for Batch PC2/15 (6 sheets)

\begin{tabular}{|c|c|c|c|c|c|c|c|c|c|c|}
\hline $\begin{array}{l}\text { SIFWM NAE } \\
\text { SOL OMFOWMIS }\end{array}$ & 1 & 2 & 3 & 4 & 5 & 6 & 7 & 8 & 9 & 10 \\
\hline Total Mass Flow (kg) & $3.33 E+04$ & $3.33 E+02$ & $3.29 E+04$ & & $3.29 E+04$ & & $3.33 E+02$ & $3.33 E+02$ & & \\
\hline \multicolumn{11}{|l|}{ FADTONCLIIES (Ci) } \\
\hline \begin{tabular}{|l|} 
Cesium \\
Struntium \\
Technetium \\
TRII
\end{tabular} & & & & & & & & & & \\
\hline \multicolumn{11}{|l|}{ GIEMTCAIS (kg) } \\
\hline 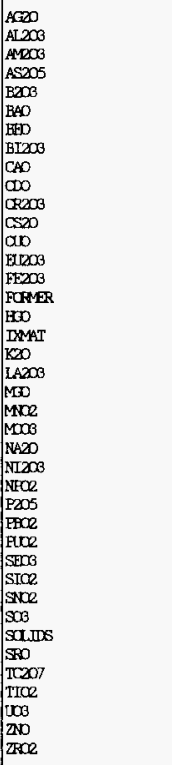 & $3.33 E+04$ & $3.33 E+02$ & $3.29 E+04$ & & $3.29 E+04$ & & 3.33E+02 & 3. $33 \mathrm{E}+02$ & & \\
\hline
\end{tabular}


WHC-SD-WM-TI-774 Rev. 0

TWRS PRIVATIZATION PROCESS TECHNICAL BASELINE

Table B-15 Phase 1 LAW Mass Balance for Batch PC2/15 (6 sheets)

\begin{tabular}{|c|c|c|c|c|c|c|c|c|c|c|}
\hline $\begin{array}{l}\text { STREAM NAE } \\
\text { LIQUID COMEONENIS }\end{array}$ & 11 & 12 & 13 & 14 & 15 & 16 & $16 \mathrm{~A}$ & 17 & 18 & 19 \\
\hline $\begin{array}{l}\text { Volume }(\mathrm{L}) \\
\text { Density }(\mathrm{g} / \mathrm{L})\end{array}$ & & $\begin{array}{l}2.37 \mathrm{E}+06 \\
1.40 \mathrm{E}+03\end{array}$ & $\begin{array}{l}2.138+03 \\
3,325+03\end{array}$ & & $\begin{array}{l}2.13 E+03 \\
3,32 E+03\end{array}$ & $\begin{array}{l}2.37 \mathrm{E}+06 \\
1.40 \mathrm{E}+03\end{array}$ & $\begin{array}{l}3.64 \mathrm{E}+06 \\
1.00 \mathrm{E}+03\end{array}$ & & $\begin{array}{l}1.00 E-09 \\
1.000+03\end{array}$ & $\begin{array}{l}1.00 \mathrm{E}-09 \\
1.00 E+03\end{array}$ \\
\hline Total Mass Flow (kg) & & 3.31E+06 & $7.08+03$ & & $7,08 \mathrm{E}+03$ & $3.31 E+06$ & $3.64 \mathrm{E}+06$ & & 1.00E-09 & 1.00E-09 \\
\hline \multicolumn{11}{|l|}{ RADIONCIHSS (Ci) } \\
\hline $\begin{array}{l}\text { Cesium } \\
\text { Strontium } \\
\text { Technetiun } \\
\text { IRU }\end{array}$ & & $\begin{array}{l}3.10 \mathrm{E}+03 \\
1.37 \mathrm{E}+04 \\
1.78 \mathrm{E}+02 \\
1.64 \mathrm{E}+01\end{array}$ & $\begin{array}{l}\text { 1. } 03 E+06 \\
\text { 1. } 80 \mathrm{E}+00\end{array}$ & & $\begin{array}{l}1.03 E+06 \\
1.80 E+00\end{array}$ & $\begin{array}{l}3.10 E+03 \\
1.37 E+04 \\
1.78 E+02 \\
1.64 E+01\end{array}$ & & & & \\
\hline \multicolumn{11}{|l|}{ CHEMICALS (kg) } \\
\hline 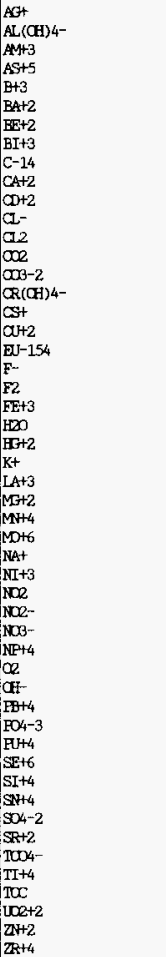 & & $\begin{array}{l}7.46 \mathrm{E}-03 \\
1.94 \mathrm{E}+05 \\
6.16 \mathrm{E}-04 \\
4.30 \mathrm{E}-03 \\
2.18 \mathrm{E}-01 \\
1.44 \mathrm{E}-02 \\
9.63 \mathrm{E}-04 \\
3.63 \mathrm{E}-06 \\
4.13 \mathrm{E}-08 \\
1.38 \mathrm{E}+00 \\
5.43 \mathrm{E}-03 \\
1.16 \mathrm{E}+04 \\
\\
4.23 \mathrm{E}+04 \\
2.14 \mathrm{E}+03 \\
3.58 \mathrm{E}-02 \\
2.42 \mathrm{E}-07 \\
3.69 \mathrm{E}-11 \\
1.25 \mathrm{E}+03 \\
1.61 \mathrm{E}+01 \\
2.11 \mathrm{E}+06 \\
1.62 \mathrm{E}-05 \\
1.02 \mathrm{E}+04 \\
8.48 \mathrm{E}-02 \\
1.21 \mathrm{E}+00 \\
3.77 \mathrm{E}+00 \\
5.19 \mathrm{E}-01 \\
4.04 \mathrm{E}+05 \\
9.03 \mathrm{E}-02 \\
1.31 \mathrm{E}+05 \\
2.84 \mathrm{E}+05 \\
3.02 \mathrm{E}-04 \\
1.02 \mathrm{E}+05 \\
2.63 \mathrm{E}-03 \\
4.38 \mathrm{E}+03 \\
1.97 \mathrm{E}-01 \\
5.23 \mathrm{E}-05 \\
2.67 \mathrm{E}+00 \\
6.04 \mathrm{E}-06 \\
9.72 \mathrm{E}+03 \\
9.89 \mathrm{E}-02 \\
1.72 \mathrm{E}+01 \\
1.21 \mathrm{E}-07 \\
6.94 \mathrm{E}+03 \\
8.30 \mathrm{E}-01 \\
1.9 \mathrm{E}-01 \\
6.04 \mathrm{E}-06\end{array}$ & $\begin{array}{l}1.29 \mathrm{E}+01 \\
4.06 \mathrm{E}+03 \\
3.01 \mathrm{E}+03 \\
1.75 \mathrm{E}-01\end{array}$ & & $\begin{array}{l}1.19 E+01 \\
4.06 E+03 \\
3.01 \mathbb{E}+03 \\
1.75 \mathbb{E}-01\end{array}$ & $\begin{array}{l}7.46 \mathrm{E}-03 \\
1.94 \mathrm{E}+05 \\
6.16 \mathrm{E}-04 \\
4.30 \mathrm{E}-0.3 \\
2.18 \mathrm{E}-01 \\
1.44 \mathrm{E}-02 \\
9.63 \mathrm{E}-04 \\
3.63 \mathrm{E}-06 \\
4.13 \mathrm{E}-08 \\
1.38 \mathrm{E}+00 \\
5.43 \mathrm{E}-03 \\
1.16 \mathrm{E}+04 \\
\\
4.23 \mathrm{E}+04 \\
2.14 \mathrm{E}+03 \\
3.58 \mathrm{E}-02 \\
2.42 \mathrm{E}-07 \\
3.69 \mathrm{E}-11 \\
1.25 \mathrm{E}+03 \\
1.61 \mathrm{E}+01 \\
2.11 \mathrm{E}+06 \\
1.62 \mathrm{E}-05 \\
1.02 \mathrm{E}+04 \\
8.48 \mathrm{E}-02 \\
1.21 \mathrm{E}+00 \\
3.77 \mathrm{E}+00 \\
5.19 \mathrm{E}-01 \\
4.04 \mathrm{E}+05 \\
9.03 \mathrm{E}-02 \\
\\
1.31 \mathrm{E}+05 \\
2.84 \mathrm{E}+05 \\
3.02 \mathrm{E}-04 \\
1.02 \mathrm{E}+05 \\
2.63 \mathrm{E}-03 \\
4.38 \mathrm{E}+03 \\
1.97 \mathrm{E}-01 \\
5.23 \mathrm{E}-05 \\
2.67 \mathrm{E}+00 \\
6.04 \mathrm{E}-06 \\
9.72 \mathrm{E}+03 \\
9.89 \mathrm{E}-02 \\
1.72 \mathrm{E}+01 \\
1.21 \mathrm{E}-07 \\
6.94 \mathrm{E}+03 \\
8.30 \mathrm{E}-01 \\
1.9 \mathrm{E}-01 \\
6.04 \mathrm{E}-06\end{array}$ & $\begin{array}{l} \\
1.16 \mathrm{E}+04 \\
5.65 \mathrm{E}+04 \\
1.2 \mathrm{E}+03 \\
2.23 \mathrm{E}+06 \\
3.41 \mathrm{E}+05 \\
9.90 \mathrm{E}+05\end{array}$ & & $1.00 \mathrm{E}-09$ & 1.00E-09 \\
\hline
\end{tabular}


WHC-SD-WM-TI-774 Rev. 0

TWRS PRIVATIZATION PROCESS TECHNICAL BASELINE

Table B-15 Phase 1 LAW Mass Balance for Batch PC2/15 (6 sheets)

\begin{tabular}{|c|c|c|c|c|c|c|c|c|c|c|}
\hline $\begin{array}{l}\text { SIFEMM NAME } \\
\text { STID COMEADNSS }\end{array}$ & 11 & 12 & 13 & 14 & 15 & 16 & $16 A$ & 17 & 18 & 19 \\
\hline Total Mass Flow (kg) & & $3.33 \mathrm{E}+02$ & & $4.06 E+03$ & $4.06 \mathrm{E}+03$ & $3.33 E+02$ & $6.74 E+05$ & & & \\
\hline \multicolumn{11}{|l|}{ RAJICNUCLIIES (Ci) } \\
\hline $\begin{array}{l}\text { Cesium } \\
\text { Strantium } \\
\text { Technetium } \\
\text { TEI }\end{array}$ & & & & & & & $\begin{array}{l}3.10 \mathrm{E}+03 \\
1.37 \mathrm{E}+04 \\
1.79 \mathrm{E}+02 \\
1.62 \mathrm{E}+01\end{array}$ & & & \\
\hline \multicolumn{11}{|l|}{ CHEMICALS (Kg) } \\
\hline 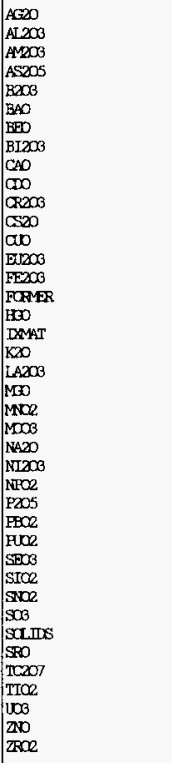 & & $3.33 \mathrm{E}+02$ & & $4.06 \mathrm{E}+03$ & $4.06 E+03$ & $3.33 \mathrm{E}+02$ & $\begin{array}{l}8.02 \mathrm{E}-03 \\
1.04 \mathrm{E}+05 \\
6.77 \mathrm{E}-04 \\
6.59 \mathrm{E}-03 \\
7.01 \mathrm{E}-01 \\
1.60 \mathrm{E}-02 \\
2.67 \mathrm{E}-03 \\
4.05 \mathrm{E}-06 \\
1.93 \mathrm{E}+00 \\
6.2 \mathrm{E}-03 \\
1.36 \mathrm{E}+03 \\
3.79 \mathrm{E}-02 \\
3.02 \mathrm{E}-07 \\
4.27 \mathrm{E}-11 \\
2.30 \mathrm{E}+01 \\
\\
1.75 \mathrm{E}-05 \\
1.22 \mathrm{E}+04 \\
9.94 \mathrm{E}-02 \\
2.01 \mathrm{E}+00 \\
5.96 \mathrm{E}+00 \\
7.79 \mathrm{E}-01 \\
5.4 \mathrm{E}+05 \\
1.27 \mathrm{E}-01 \\
3.43 \mathrm{E}-04 \\
3.2 \mathrm{E}+03 \\
3.04 \mathrm{E}-03 \\
2.23 \mathrm{E}-01 \\
8.41 \mathrm{E}-05 \\
5.70 \mathrm{E}+00 \\
7.6 \mathrm{E}-06 \\
8.10 \mathrm{E}+03 \\
3.33 \mathrm{E}+02 \\
1.17 \mathrm{E}-01 \\
1.64 \mathrm{E}+01 \\
2.02 \mathrm{E}-07 \\
8.79 \mathrm{E}-01 \\
2.43 \mathrm{E}-01 \\
8.17 \mathrm{E}-06\end{array}$ & & & \\
\hline
\end{tabular}


WHC-SD-WM-TI-774 Rev. 0

TWRS PRIVATIZATION PROCESS TECHNICAL BASELINE

Table B-15 Phase 1 LAW Mass Balance for Batch PC2/15 (6 sheets)

\begin{tabular}{|c|c|c|c|c|c|c|c|c|c|}
\hline $\begin{array}{l}\text { STFEAM NAE } \\
\text { IIQID COMFAEMIS }\end{array}$ & 20 & 21 & 22 & 23 & 24 & 25 & 26 & 27 & 28 \\
\hline $\begin{array}{l}\text { Volume }(L) \\
\text { Density }(g / L)\end{array}$ & $\begin{array}{l}\text { 3. } 64 \mathrm{E}+05 \\
1.00 \mathrm{E}+03\end{array}$ & & & & $\begin{array}{l}1.40 \mathrm{E}+06 \\
1.00 \mathrm{E}+03\end{array}$ & $\begin{array}{l}\text { 2. } 23 \mathrm{E}+06 \\
1.00 \mathrm{E}+03\end{array}$ & $\begin{array}{l}\text { 2. } 12 \mathrm{E}+03 \\
3.34 \mathrm{E}+03\end{array}$ & $\begin{array}{l}3.00 \mathrm{E}-10 \\
3.34 \mathrm{E}+03\end{array}$ & $\begin{array}{l}1.00 E+06 \\
1.00 E+03\end{array}$ \\
\hline Total Mass Flow (kg) & $3.64 \mathrm{E}+66$ & & & & 1.40E+06 & $2.23 \mathrm{E}+06$ & $7.07 \mathrm{E}+03$ & $1.00 E-09$ & $1.00 \mathrm{E}+06$ \\
\hline \multicolumn{10}{|l|}{ RADIOAUCLIDES (Ci) } \\
\hline $\begin{array}{l}\text { Cesium } \\
\text { Strantium } \\
\text { Technetium } \\
\text { TRI }\end{array}$ & & & & & & & & & \\
\hline
\end{tabular}

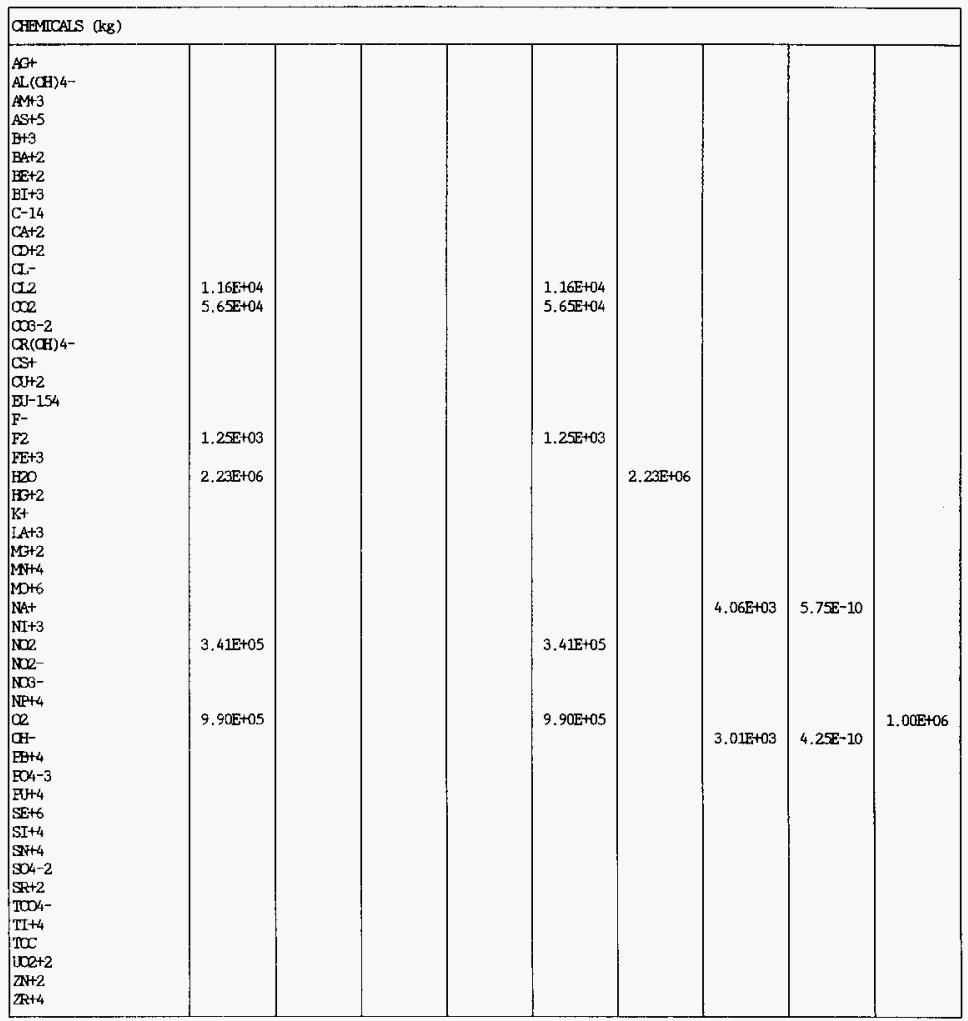


WHC-SD-WM-TI-774 Rev. 0

TWRS PRIVATIZATION PROCESS TECHNICAL BASELINE

Table B-15 Thase 1 LAW Mass Balance for Batch PC2/15 (6 sheets)

\begin{tabular}{|c|c|c|c|c|c|c|c|c|c|}
\hline $\begin{array}{l}\text { SHIFEAM NEME } \\
\text { SO.W OOMONENIE: }\end{array}$ & 20 & 21 & 22 & 23 & 24 & 25 & 26 & 27 & 28 \\
\hline Total Mass Flow (kg) & & $6.74 E+05$ & $2.55 E+06$ & $3.23 \mathrm{E}+06$ & & & & & \\
\hline \multicolumn{10}{|l|}{ RADIONUCZIDES (Ci) } \\
\hline $\begin{array}{l}\text { Cesium } \\
\text { Strantium } \\
\text { Technetiun } \\
\text { TRI }\end{array}$ & & $\begin{array}{l}3.10 \mathrm{E}+03 \\
1.37 \mathrm{E}+04 \\
1.78 \mathrm{E}+02 \\
1.62 \mathrm{E}+01\end{array}$ & & $\begin{array}{l}3.10 \mathrm{E}+03 \\
1.37 \mathrm{E}+04 \\
1.78 \mathrm{E}+02 \\
1.62 \mathrm{E}+01\end{array}$ & & & & & \\
\hline \multicolumn{10}{|l|}{ CHameats (kg) } \\
\hline 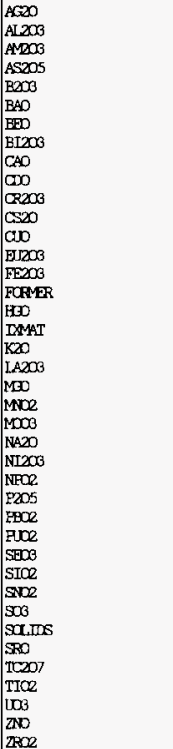 & & $\begin{array}{l}8.02 E-03 \\
1.04 E+05 \\
6.77 E-04 \\
6.59 E-03 \\
7.01 E-01 \\
1.60 \mathrm{E}-02 \\
2.67 \mathrm{E}-03 \\
4.05 \mathrm{E}-06 \\
1.93 \mathrm{E}+00 \\
6.21 \mathrm{E}-03 \\
1.36 \mathrm{E}+03 \\
3.79 \mathrm{E}-02 \\
3.02 \mathrm{E}-07 \\
4.27 \mathrm{E}-11 \\
2.30 \mathrm{E}+01 \\
\\
1.7 \mathrm{E}-05 \\
\\
1.2 \mathrm{E}+04 \\
9.94 \mathrm{E}-02 \\
2.01 \mathrm{E}+00 \\
5.96 \mathrm{E}+00 \\
7.79 \mathrm{E}-01 \\
5.4 \mathrm{E}+05 \\
1.27 \mathrm{E}-01 \\
3.43 \mathrm{E}-04 \\
3.27 \mathrm{E}+03 \\
3.04 \mathrm{E}-03 \\
2.23 \mathrm{E}-01 \\
8.41 \mathrm{E}-05 \\
5.70 \mathrm{E}+00 \\
7.67 \mathrm{E}-06 \\
8.10 \mathrm{E}+03 \\
3.33 \mathrm{E}+02 \\
1.17 \mathrm{E}-01 \\
1.64 \mathrm{E}+01 \\
2.02 \mathrm{E}-07 \\
8.79 \mathrm{E}-01 \\
2.43 \mathrm{E}-01 \\
8.17 \mathrm{E}-06\end{array}$ & $2.55 \mathrm{E}+06$ & $\begin{array}{l}8.02 \mathrm{E}-03 \\
1.04 \mathrm{E}+05 \\
6.77 \mathrm{E}-04 \\
6.59 \mathrm{E}-03 \\
7.01 \mathrm{E}-01 \\
1.60 \mathrm{E}-02 \\
2.67 \mathrm{E}-03 \\
4.05 \mathrm{E}-06 \\
1.93 \mathrm{E}+00 \\
6.21 \mathrm{E}-03 \\
1.36 \mathrm{E}+03 \\
3.79 \mathrm{E}-02 \\
3.02 \mathrm{E}-07 \\
4.27 \mathrm{E}-11 \\
2.30 \mathrm{E}+01 \\
2.55 \mathrm{E}+06 \\
1.7 \mathrm{E}-05 \\
\\
1.22 \mathrm{E}+04 \\
9.94 \mathrm{E}-02 \\
2.01 \mathrm{E}+00 \\
5.96 \mathrm{E}+00 \\
7.79 \mathrm{E}-01 \\
5.45 \mathrm{E}+05 \\
1.27 \mathrm{E}-01 \\
3.43 \mathrm{E}-04 \\
3.27 \mathrm{E}+03 \\
3.04 \mathrm{E}-03 \\
2.23 \mathrm{E}-01 \\
8.41 \mathrm{E}-05 \\
5.70 \mathrm{E}+00 \\
7.67 \mathrm{E}-06 \\
8.10 \mathrm{E}+03 \\
3.33 \mathrm{E}+02 \\
1.17 \mathrm{E}-01 \\
1.64 \mathrm{E}+01 \\
2.02 \mathrm{E}-07 \\
8.79 \mathrm{E}-01 \\
2.43 \mathrm{E}-01 \\
8.17 \mathrm{E}-06\end{array}$ & & & & & \\
\hline
\end{tabular}


WHC-SD-WM-TI-774 Rev. 0

TWRS PRIVATIZATION PROCESS TECHNICAL BASELINE

Table B-16 Phase 1 LAW Mass Balance for Batch PC2/16 (6 sheets)

\begin{tabular}{|c|c|c|c|c|c|c|c|c|c|c|}
\hline $\begin{array}{l}\text { SIREAM NAM } \\
\text { IIQUID COMFONEMIS }\end{array}$ & 1 & 2 & 3 & 4 & 5 & 6 & 7 & 8 & 9 & 10 \\
\hline $\begin{array}{l}\text { Volume }(L) \\
\text { Density }(g / L)\end{array}$ & $\begin{array}{l}2.6 \text { सE+06 } \\
1.45+03\end{array}$ & $\begin{array}{l}2.61 E+06 \\
1.45 E+03\end{array}$ & $\begin{array}{l}1,33 E+04 \\
1.45 E+03\end{array}$ & $\begin{array}{l}\text { 3. } 19 \mathrm{E}+05 \\
1.00 \mathrm{E}+03\end{array}$ & $\begin{array}{l}3.32 \mathrm{E}+05 \\
1.02 \mathrm{E}+03\end{array}$ & & $\begin{array}{l}2.61 E+06 \\
1.45 E+03\end{array}$ & $\begin{array}{l}2.61 \mathrm{E}+06 \\
1.45 \mathrm{E}+03\end{array}$ & & \\
\hline Total Mass Flon (kg) & $3.80 \mathrm{E}+06$ & $3.78 E+06$ & $1.93 E+04$ & $3.19 \mathrm{E}+05$ & $3.38 \mathrm{E}+05$ & & $3.78 \mathrm{E}+06$ & $3.78 \mathrm{E}+06$ & & \\
\hline \multicolumn{11}{|l|}{ RADTONULIDES (Ci) } \\
\hline $\begin{array}{l}\text { Cesiun } \\
\text { Stirantiun } \\
\text { Technetium } \\
\text { IFI }\end{array}$ & $\begin{array}{l}9.58 E+05 \\
3.00 E+03 \\
2.86 \mathrm{E}+02 \\
5.48 \mathrm{E}+00\end{array}$ & $\begin{array}{l}9.53 \mathrm{E}+05 \\
2.99 \mathrm{E}+03 \\
2.84 \mathrm{E}+02 \\
5.46 \mathrm{E}+C 0\end{array}$ & $\begin{array}{l}4.86 \mathrm{E}+03 \\
1.52 \mathrm{E}+01 \\
1.45 \mathrm{E}+00 \\
2.78 \mathrm{E}-02\end{array}$ & & $\begin{array}{l}4.86 \mathrm{E}+03 \\
1.52 \mathrm{E}+01 \\
1.45 \mathrm{E}+00 \\
2.78 \mathrm{E}-02\end{array}$ & & $\begin{array}{l}9.53 \mathrm{E}+05 \\
2.99 \mathrm{E}+03 \\
2.84 \mathrm{E}+02 \\
5.46 \mathrm{E}+00\end{array}$ & $\begin{array}{l}9.53 \mathrm{E}+05 \\
2.99 \mathrm{E}+03 \\
2.84 \mathrm{E}+02 \\
5.46 \mathrm{E}+00\end{array}$ & & \\
\hline \multicolumn{11}{|l|}{ CAPMCALS (kg) } \\
\hline 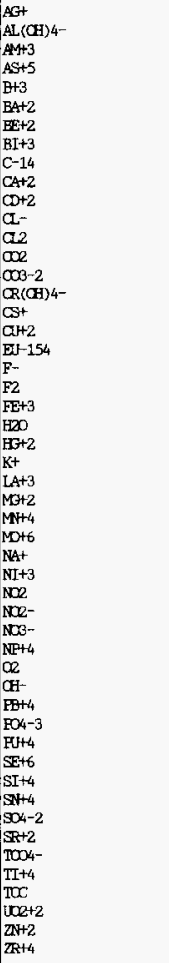 & 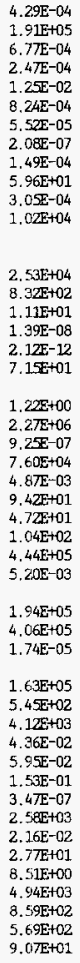 & $\begin{array}{l}4.26 \mathrm{E}-04 \\
1.90 \mathrm{E}+05 \\
6.73 \mathrm{E}-04 \\
2.46 \mathrm{E}-04 \\
1.25 \mathrm{E}-02 \\
8.20 \mathrm{E}-04 \\
5.49 \mathrm{E}-05 \\
2.07 \mathrm{E}-07 \\
1.4 \mathrm{BE}-04 \\
5.93 \mathrm{E}+01 \\
3.03 \mathrm{E}-04 \\
1.01 \mathrm{E}+04 \\
\\
2.52 \mathrm{E}+04 \\
8.28 \mathrm{E}+02 \\
1.10 \mathrm{E}+01 \\
1.38 \mathrm{E}-08 \\
2.11 \mathrm{E}-12 \\
7.12 \mathrm{E}+01 \\
\\
1.21 \mathrm{E}+00 \\
2.26 \mathrm{E}+06 \\
9.20 \mathrm{E}-07 \\
7.56 \mathrm{E}+04 \\
4.85 \mathrm{E}-03 \\
9.37 \mathrm{E}+01 \\
4.69 \mathrm{E}+01 \\
1.03 \mathrm{E}+02 \\
4.42 \mathrm{E}+05 \\
5.18 \mathrm{E}-03 \\
1.93 \mathrm{E}+05 \\
4.04 \mathrm{E}+05 \\
1.73 \mathrm{E}-05 \\
1.63 \mathrm{E}+05 \\
5.42 \mathrm{E}+02 \\
4.10 \mathrm{E}+03 \\
4.34 \mathrm{E}-02 \\
5.92 \mathrm{E}-02 \\
1.52 \mathrm{E}-01 \\
3.46 \mathrm{E}-07 \\
2.57 \mathrm{E}+03 \\
2.15 \mathrm{E}-02 \\
2.75 \mathrm{E}+01 \\
8.47 \mathrm{E}+00 \\
4.92 \mathrm{E}+03 \\
8.5 \mathrm{E}+02 \\
5.66 \mathrm{E}+02 \\
9.03 \mathrm{E}+01\end{array}$ & $\begin{array}{l}2.17 \mathrm{E}-06 \\
9.69 \mathrm{E}+02 \\
3.43 \mathrm{E}-06 \\
1.2 \mathrm{E}-06 \\
6.36 \mathrm{E}-05 \\
4.18 \mathrm{E}-06 \\
2.80 \mathrm{E}-07 \\
1.06 \mathrm{E}-09 \\
7.54 \mathrm{E}-07 \\
3.02 \mathrm{E}-02 \\
1.55 \mathrm{E}-06 \\
5.17 \mathrm{E}+01 \\
\\
1.28 \mathrm{E}+02 \\
4.22 \mathrm{E}+00 \\
5.61 \mathrm{E}-02 \\
7.06 \mathrm{E}-11 \\
1.07 \mathrm{E}-14 \\
3.63 \mathrm{E}-01 \\
\\
6.18 \mathrm{E}-03 \\
1.1 \mathrm{E}+04 \\
4.69 \mathrm{E}-09 \\
3.85 \mathrm{E}+02 \\
2.47 \mathrm{E}-05 \\
4.7 \mathrm{BE}-01 \\
2.39 \mathrm{E}-01 \\
5.26 \mathrm{E}-01 \\
2.25 \mathrm{E}+03 \\
2.64 \mathrm{E}-05 \\
9.82 \mathrm{E}+02 \\
2.06 \mathrm{E}+03 \\
8.81 \mathrm{E}-08 \\
\\
8.28 \mathrm{E}+02 \\
2.77 \mathrm{E}+00 \\
2.09 \mathrm{E}+01 \\
2.21 \mathrm{E}-04 \\
3.02 \mathrm{E}-04 \\
7.76 \mathrm{E}-04 \\
1.76 \mathrm{E}-09 \\
1.31 \mathrm{E}+01 \\
1.10 \mathrm{E}-04 \\
1.40 \mathrm{E}-01 \\
4.32 \mathrm{E}-02 \\
2.51 \mathrm{E}+01 \\
4.36 \mathrm{E}+00 \\
2.88 \mathrm{E}+00 \\
4.60 \mathrm{E}-01\end{array}$ & $3.19 E+05$ & $\begin{array}{l}2.17 \mathrm{E}-06 \\
9.69 \mathrm{E}+02 \\
3.43 \mathrm{E}-06 \\
1.25 \mathrm{E}-06 \\
6.36 \mathrm{E}-05 \\
4.18 \mathrm{E}-06 \\
2.80 \mathrm{E}-07 \\
1.06 \mathrm{E}-09 \\
7.54 \mathrm{E}-07 \\
3.02 \mathrm{E}-01 \\
1.55 \mathrm{E}-06 \\
5.17 \mathrm{E}+01 \\
\\
1.28 \mathrm{E}+02 \\
4.22 \mathrm{E}+00 \\
5.61 \mathrm{E}-02 \\
7.06 \mathrm{E}-11 \\
1.07 \mathrm{E}-14 \\
3.63 \mathrm{E}-01 \\
\\
6.18 \mathrm{E}-03 \\
3.30 \mathrm{E}+05 \\
4.69 \mathrm{E}-09 \\
3.85 \mathrm{E}+02 \\
2.4 \mathrm{~F}-05 \\
4.78 \mathrm{E}-01 \\
2.39 \mathrm{E}-01 \\
5.26 \mathrm{E}-01 \\
2.25 \mathrm{E}+03 \\
2.64 \mathrm{E}-05 \\
9.82 \mathrm{E}+02 \\
2.06 \mathrm{E}+03 \\
8.81 \mathrm{E}-08 \\
8.28 \mathrm{E}+02 \\
2.77 \mathrm{E}+00 \\
2.09 \mathrm{E}+01 \\
2.21 \mathrm{E}-04 \\
3.02 \mathrm{E}-04 \\
7.76 \mathrm{E}-04 \\
1.76 \mathrm{E}-09 \\
1.31 \mathrm{E}+01 \\
1.10 \mathrm{E}-04 \\
1.40 \mathrm{E}-01 \\
4.32 \mathrm{E}-02 \\
2.51 \mathrm{E}+01 \\
4.36 \mathrm{E}+00 \\
2.88 \mathrm{~s}+00 \\
4.60 \mathrm{E}-01\end{array}$ & & $\begin{array}{l}4.26 \mathrm{E}-04 \\
1.90 \mathrm{E}+05 \\
6.73 \mathrm{E}-04 \\
2.46 \mathrm{E}-04 \\
1.2 \mathrm{E}-02 \\
8.20 \mathrm{E}-04 \\
5.49 \mathrm{E}-05 \\
2.07 \mathrm{E}-07 \\
1.48 \mathrm{E}-04 \\
5.93 \mathrm{E}+01 \\
3.03 \mathrm{E}-04 \\
1.01 \mathrm{E}+04 \\
\\
2.52 \mathrm{E}+04 \\
8.28 \mathrm{E}+02 \\
1.10 \mathrm{E}+01 \\
1.3 \mathrm{EE}-08 \\
2.11 \mathrm{E}-12 \\
7.12 \mathrm{E}+01 \\
\\
1.21 \mathrm{E}+00 \\
2.26 \mathrm{E}+06 \\
9.20 \mathrm{E}-07 \\
7.56 \mathrm{E}+04 \\
4.85 \mathrm{E}-03 \\
9.37 \mathrm{E}+01 \\
4.69 \mathrm{E}+01 \\
1.03 \mathrm{E}+02 \\
4.42 \mathrm{E}+05 \\
5.18 \mathrm{E}-03 \\
1.93 \mathrm{E}+05 \\
4.04 \mathrm{E}+05 \\
1.73 \mathrm{E}-05 \\
1.63 \mathrm{E}+05 \\
5.42 \mathrm{E}+02 \\
4.10 \mathrm{E}+03 \\
4.34 \mathrm{E}-02 \\
5.92 \mathrm{E}-02 \\
1.52 \mathrm{E}-01 \\
3.46 \mathrm{E}-07 \\
2.57 \mathrm{E}+03 \\
2.1 \mathrm{E}-02 \\
2.75 \mathrm{E}+01 \\
8.47 \mathrm{E}+00 \\
4.92 \mathrm{E}+03 \\
8.5 \mathrm{E}+02 \\
5.66 \mathrm{E}+02 \\
9.03 \mathrm{E}+01\end{array}$ & $\begin{array}{l}4.26 \mathrm{E}-04 \\
1.90 \mathrm{E}+05 \\
6.73 \mathrm{E}-04 \\
2.46 \mathrm{E}-04 \\
1.2 \mathrm{EE}-02 \\
8.20 \mathrm{E}-04 \\
5.49 \mathrm{E}-05 \\
2.07 \mathrm{E}-07 \\
1.4 \mathrm{EE}-04 \\
5.93 \mathrm{E}+01 \\
3.03 \mathrm{E}-04 \\
1.01 \mathrm{E}+04 \\
\\
2.52 \mathrm{E}+04 \\
8.28 \mathrm{E}+02 \\
1.10 \mathrm{E}+01 \\
1.38 \mathrm{E}-08 \\
2.11 \mathrm{E}-12 \\
7.12 \mathrm{E}+01 \\
\\
1.21 \mathrm{E}+00 \\
2.26 \mathrm{E}+06 \\
9.20 \mathrm{E}-07 \\
7.56 \mathrm{E}+04 \\
4.85 \mathrm{E}-03 \\
9.37 \mathrm{E}+01 \\
4.69 \mathrm{E}+01 \\
1.03 \mathrm{E}+02 \\
4.42 \mathrm{E}+05 \\
5.18 \mathrm{E}-03 \\
1.93 \mathrm{E}+05 \\
4.04 \mathrm{E}+0.5 \\
1.73 \mathrm{E}-05 \\
1.63 \mathrm{E}+05 \\
5.42 \mathrm{E}+02 \\
4.10 \mathrm{E}+03 \\
4.34 \mathrm{E}-02 \\
5.92 \mathrm{E}-02 \\
1.52 \mathrm{E}-01 \\
3.46 \mathrm{E}-07 \\
2.57 \mathrm{E}+03 \\
2.1 \mathrm{E}-02 \\
2.75 \mathrm{E}+01 \\
8.47 \mathrm{E}+00 \\
4.92 \mathrm{E}+03 \\
8.55 \mathrm{E}+02 \\
5.66 \mathrm{E}+02 \\
9.03 \mathrm{E}+01\end{array}$ & & \\
\hline
\end{tabular}


WHC-SD-WM-TI-774 Rev. 0

TWRS PRIVATIZATION PROCESS TECHNICAL BASELINE

Table B-16 Phase 1 LAW Mass Balance for Batch PC2/16 (6 sheets)

\begin{tabular}{|c|c|c|c|c|c|c|c|c|c|c|}
\hline 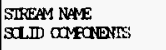 & 1 & 2 & 3 & 4 & 5 & 6 & 7 & 8 & 9 & 10 \\
\hline Total Mass Flow (kg) & $3.79 E+04$ & 3. $79 \mathrm{E}+02$ & $3.76 E+04$ & & $3.76 \mathrm{E}+04$ & & 3. $79 \mathrm{E}+02$ & $3.79 \mathrm{E}+02$ & & \\
\hline \multicolumn{11}{|l|}{ RADIONUCIIES (Ci) } \\
\hline $\begin{array}{l}\text { Cesium } \\
\text { Strantium } \\
\text { Technetiun } \\
\text { TRU }\end{array}$ & & & & & & & & & & \\
\hline
\end{tabular}

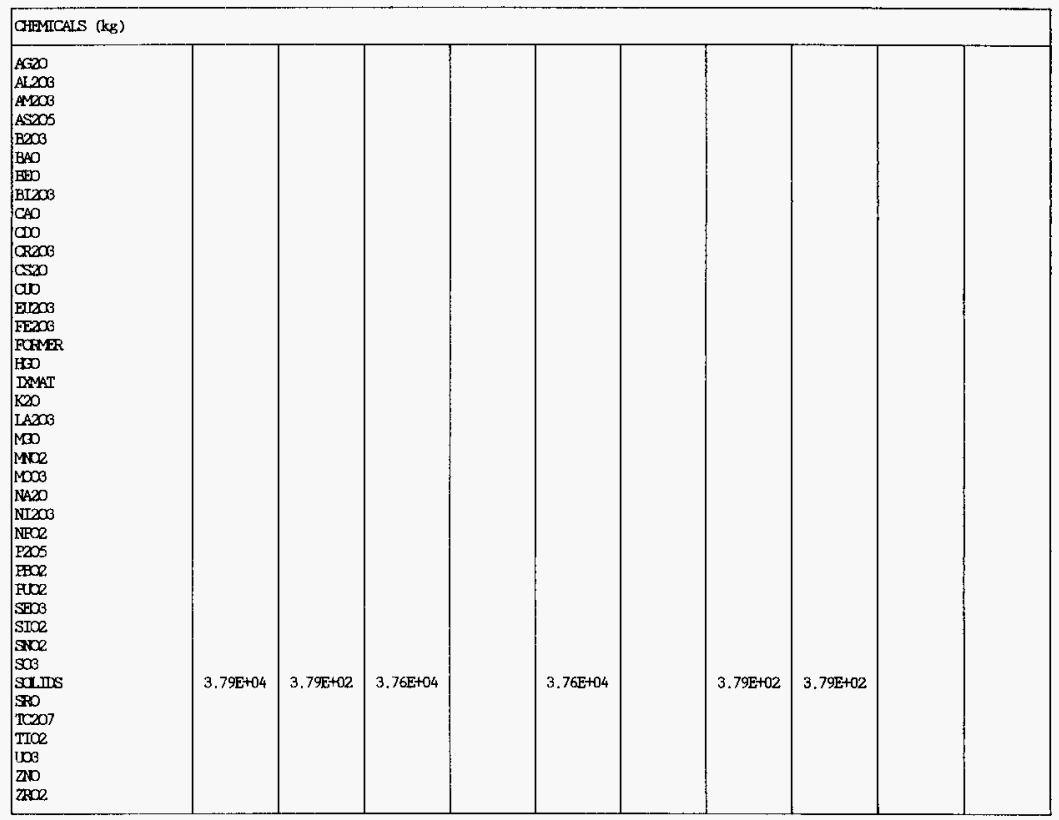


WHC-SD-WM-TI-774 Rev. 0

TWRS PRIVATIZATION PROCESS TECHNICAL BASELINE

Table B-16 Phase 1 IAW Mass Balance for Batch PC2/16 (6 sheets)

\begin{tabular}{|c|c|c|c|c|c|c|c|c|c|c|}
\hline $\begin{array}{l}\text { STREAM NMME } \\
\text { IIOUID COMRQWENIS }\end{array}$ & 11 & 12 & 13 & 14 & 15 & 16 & $15 \mathrm{~A}$ & 17 & 18 & 19 \\
\hline $\begin{array}{l}\text { Volunn (L) } \\
\text { Density }(g / L)\end{array}$ & & $\begin{array}{l}2.63 E+06 \\
1.4 E+03\end{array}$ & $\begin{array}{l}2.33 \mathrm{E}+03 \\
3.33 \mathrm{E}+03\end{array}$ & & $\begin{array}{l}2.33 \mathrm{E}+03 \\
3.33 \mathrm{E}+03\end{array}$ & $\begin{array}{l}2.61 E+06 \\
1.45 E+03\end{array}$ & $\begin{array}{l}3.98 \mathrm{CE}+06 \\
1.00 \mathrm{E}+03\end{array}$ & & $\begin{array}{l}1.00 \mathrm{E}-09 \\
1.00 \mathrm{E}+03\end{array}$ & $\begin{array}{l}1.00 E-09 \\
1.00 E+03\end{array}$ \\
\hline Total Mass Flow (kg) & & $3.78 E+06$ & 7.74E+03 & & 7.74E+03 & $3.78 \mathrm{ge}+06$ & $3.98 \mathrm{E}+06$ & & $1.00 \mathrm{E}-09$ & $1.00 \mathrm{E}-09$ \\
\hline \multicolumn{11}{|l|}{ RADIONUCLIIIES (Ci) } \\
\hline $\begin{array}{l}\text { Cesium } \\
\text { Struntium } \\
\text { Technetium } \\
\text { TRI }\end{array}$ & & $\begin{array}{l}3.39 E+03 \\
2.99 E+03 \\
2.81 E+02 \\
5.46 E+00\end{array}$ & $\begin{array}{l}9.50 \mathrm{E}+05 \\
2.86 \mathrm{E}+00\end{array}$ & & $\begin{array}{l}9.50 E+05 \\
2.86 E+00\end{array}$ & $\begin{array}{l}3.39 \mathrm{E}+03 \\
2.99 \mathrm{E}+03 \\
2.81 \mathrm{E}+02 \\
5.46 \mathrm{E}+00\end{array}$ & & & & \\
\hline \multicolumn{11}{|l|}{ OHMICAIS (kg) } \\
\hline 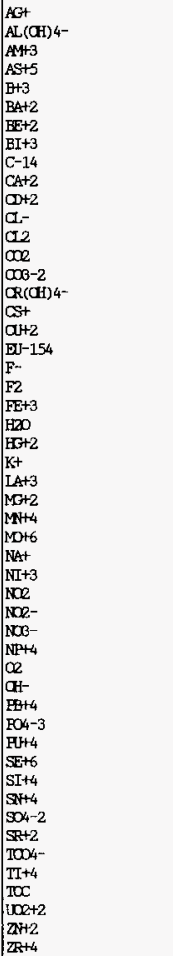 & & $\begin{array}{l}4.26 \mathrm{E}-04 \\
1.90 \mathrm{E}+05 \\
6.73 \mathrm{E}-04 \\
2.46 \mathrm{E}-04 \\
1.2 \mathrm{E}-02 \\
8.20 \mathrm{E}-04 \\
5.49 \mathrm{E}-05 \\
2.07 \mathrm{E}-07 \\
1.48 \mathrm{E}-04 \\
5.93 \mathrm{E}+01 \\
3.03 \mathrm{E}-04 \\
1.01 \mathrm{E}+04 \\
\\
2.52 \mathrm{E}+04 \\
8.28 \mathrm{E}+02 \\
3.91 \mathrm{E}-02 \\
1.38 \mathrm{E}-08 \\
2.11 \mathrm{E}-12 \\
7.12 \mathrm{E}+01 \\
\\
1.21 \mathrm{E}+00 \\
2.26 \mathrm{E}+06 \\
9.20 \mathrm{E}-07 \\
7.56 \mathrm{E}+04 \\
4.85 \mathrm{E}-03 \\
9.37 \mathrm{E}+01 \\
4.69 \mathrm{E}+01 \\
1.03 \mathrm{E}+02 \\
4.4 \mathrm{E}+05 \\
5.18 \mathrm{E}-03 \\
\\
1.93 \mathrm{E}+05 \\
4.04 \mathrm{E} E-05 \\
1.73 \mathrm{E}-05 \\
1.63 \mathrm{E}+05 \\
5.42 \mathrm{E}+02 \\
4.10 \mathrm{E}+03 \\
4.34 \mathrm{E}-02 \\
5.92 \mathrm{E}-02 \\
1.52 \mathrm{E}-01 \\
3.46 \mathrm{E}-07 \\
2.57 \mathrm{E}+03 \\
2.15 \mathrm{E}-02 \\
2.72 \mathrm{E}+01 \\
8.47 \mathrm{E}+00 \\
4.92 \mathrm{E}+03 \\
8.55 \mathrm{E}+02 \\
5.66 \mathrm{E}+02 \\
9.03 \mathrm{E}+01\end{array}$ & $\begin{array}{l}1.10 \mathrm{E}+01 \\
4.44 \mathrm{E}+03 \\
3.29 \mathrm{E}+03 \\
2.7 \mathrm{E}-01\end{array}$ & & $\begin{array}{l}1.10 E+01 \\
4.44 E+03 \\
3.29 E+03 \\
2.77 E-01\end{array}$ & $\begin{array}{l}4.26 \mathrm{E}-04 \\
1.90 \mathrm{E}+05 \\
6.73 \mathrm{E}-04 \\
2.46 \mathrm{E}-04 \\
1.23 \mathrm{E}-02 \\
8.20 \mathrm{E}-04 \\
5.49 \mathrm{E}-05 \\
2.07 \mathrm{E}-07 \\
1.48 \mathrm{E}-04 \\
5.93 \mathrm{E}+01 \\
3.03 \mathrm{E}-04 \\
1.01 \mathrm{E}+04 \\
\\
2.52 \mathrm{E}+04 \\
8.28 \mathrm{E}+02 \\
3.91 \mathrm{E}-02 \\
1.38 \mathrm{E}-08 \\
2.17 \mathrm{E}-12 \\
7.22 \mathrm{E}+01 \\
1.21 \mathrm{E}+00 \\
2.26 \mathrm{E}+06 \\
9.20 \mathrm{E}-07 \\
7.56 \mathrm{E}+04 \\
4.85 \mathrm{E}-03 \\
9.37 \mathrm{E}+01 \\
4.69 \mathrm{E}+01 \\
1.03 \mathrm{E}+02 \\
4.42 \mathrm{E}+05 \\
5.18 \mathrm{E}-03 \\
\\
1.93 \mathrm{E}+05 \\
4.04 \mathrm{E}+05 \\
1.73 \mathrm{E}-05 \\
1.63 \mathrm{E}+05 \\
5.42 \mathrm{E}+02 \\
4.10 \mathrm{E}+03 \\
4.34 \mathrm{E}-02 \\
5.92 \mathrm{E}-02 \\
1.52 \mathrm{E}-01 \\
3.46 \mathrm{E}-07 \\
2.57 \mathrm{E}+03 \\
2.1 \mathrm{E}-02 \\
2.72 \mathrm{E}+01 \\
8.47 \mathrm{E}+00 \\
4.92 \mathrm{E}+03 \\
8.55 \mathrm{E}+02 \\
5.66 \mathrm{E}+02 \\
9.03 \mathrm{E}+01\end{array}$ & $\begin{array}{l}1.01 E+04 \\
3.65+04 \\
7.12 E+01 \\
2.42 E+06\end{array}$ & & $1.00 \mathrm{E}-09$ & 1.00E-09 \\
\hline
\end{tabular}


WHC-SD-WM-TI-774 Rev. 0

TWRS PRIVATIZATION PROCESS TECHNICAL BASELINE

Table B-16 Phase 1 LAW Mass Balance for Batch PC2/16 (6 sheets)

\begin{tabular}{|c|c|c|c|c|c|c|c|c|c|c|}
\hline $\begin{array}{l}\text { SIREAM NAME } \\
\text { SOLI COMRAENIS }\end{array}$ & 11 & 12 & 23 & 14 & 15 & 16 & $16 \mathrm{~A}$ & 17 & 18 & 19 \\
\hline Total Mass Flow (kg) & & $3.79 \mathrm{E}+02$ & & 4. $44 \mathrm{E}+03$ & $4.44 E+03$ & $3.79 \mathrm{E}+02$ & $7.9885+05$ & & & \\
\hline \multicolumn{11}{|l|}{ RADIONCIIIES (Ci) } \\
\hline \begin{tabular}{|l} 
Cesium \\
Stzantiun \\
Technetium \\
TRI
\end{tabular} & & & & & & & $\begin{array}{l}3.39 E+03 \\
2.99 E+03 \\
2.81 E+02 \\
5.42 E+00\end{array}$ & & & \\
\hline \multicolumn{11}{|l|}{ GFEMICALS (kg) } \\
\hline 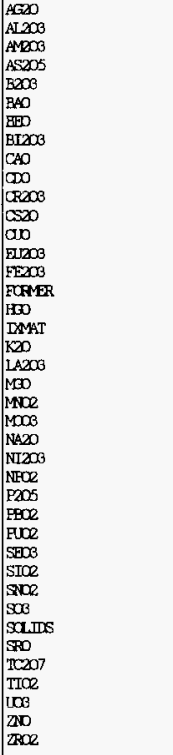 & & $3.79 \mathrm{E}+02$ & & $4.44 E+03$ & $4.44 E+03$ & $3.79 \mathrm{E}+02$ & $\begin{array}{l}4.58 \mathrm{E}-04 \\
1.02 \mathrm{E}+05 \\
7.40 \mathrm{E}-04 \\
3.7 \mathrm{E}-04 \\
4.01 \mathrm{E}-02 \\
9.16 \mathrm{E}-04 \\
1.52 \mathrm{E}-04 \\
2.31 \mathrm{E}-07 \\
8.30 \mathrm{E}+01 \\
3.47 \mathrm{E}-04 \\
5.24 \mathrm{E}+02 \\
4.14 \mathrm{E}-02 \\
1.73 \mathrm{E}-08 \\
2.44 \mathrm{E}-12 \\
1.73 \mathrm{E}+00 \\
\\
9.93 \mathrm{E}-07 \\
\\
9.10 \mathrm{E}+04 \\
5.69 \mathrm{E}-03 \\
1.55 \mathrm{E}+02 \\
7.43 \mathrm{E}+01 \\
1.55 \mathrm{E}+02 \\
5.96 \mathrm{E}+05 \\
7.29 \mathrm{E}-03 \\
1.96 \mathrm{E}-05 \\
3.06 \mathrm{E}+03 \\
6.26 \mathrm{E}+02 \\
4.92 \mathrm{E}-02 \\
9.52 \mathrm{E}-02 \\
3.26 \mathrm{E}-01 \\
4.39 \mathrm{E}-07 \\
2.14 \mathrm{E}+03 \\
3.79 \mathrm{E}+02 \\
2.53 \mathrm{E}-02 \\
2.59 \mathrm{E}+01 \\
1.41 \mathrm{E}+01 \\
9.06 \mathrm{E}+02 \\
7.04 \mathrm{E}+02 \\
1.22 \mathrm{E}+02\end{array}$ & & & \\
\hline
\end{tabular}


WHC-SD-WM-TI-774 Rev. 0

TWRS PRIVATIZATION PROCESS TECHNICAL BASELINE

Table B-16 Phase 1 LAW Mass Balance for Batch PC2/16 (6 sheets)

\begin{tabular}{|c|c|c|c|c|c|c|c|c|c|}
\hline $\begin{array}{l}\text { SIREAM NAME } \\
\text { LIQUID OOMECNISIS }\end{array}$ & 20 & 21 & 22 & 23 & 24 & 25 & 26 & 27 & 28 \\
\hline $\begin{array}{l}\text { Volume (L) } \\
\text { Density }(\mathrm{g} / \mathrm{L})\end{array}$ & $\begin{array}{l}3.98 \mathrm{E}+06 \\
1.00 \mathrm{E}+03\end{array}$ & & & & $\begin{array}{l}1.56 E+06 \\
1.00 E+03\end{array}$ & $\begin{array}{l}2.42 \mathrm{E}+06 \\
1.00 \mathrm{E}+03\end{array}$ & $\begin{array}{l}\text { 2. } 32 E+03 \\
3.34 E+03\end{array}$ & $\begin{array}{l}\text { 3. } C 0 E-10 \\
\text { 3. } 34 E+03\end{array}$ & $\begin{array}{l}\text { 1. } 00 \mathrm{E}+06 \\
1.00 \mathrm{E}+03\end{array}$ \\
\hline Total Mass Flow (kg) & 3. $98 \mathrm{BE}+06$ & & & & $1.56 \mathrm{E}+06$ & $2.42 \mathrm{E}+06$ & $7.73 E+03$ & 1. $00 \mathrm{E}-09$ & 1. $00 \mathrm{E}+06$ \\
\hline \multicolumn{10}{|l|}{ RADIQNUCIJISS(Ci) } \\
\hline $\begin{array}{l}\text { Cesium } \\
\text { Strantiun } \\
\text { Technotium } \\
\text { TWU }\end{array}$ & & & & & & & & & \\
\hline
\end{tabular}

\begin{tabular}{|c|c|c|c|c|c|c|}
\hline \multicolumn{7}{|c|}{ GFMICASS (kg) } \\
\hline 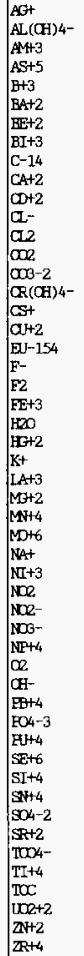 & $\begin{array}{l}1.01 \mathrm{E}+04 \\
3.6 \mathrm{EE}+04 \\
\\
7.32 \mathrm{E}+01 \\
2.42 \mathrm{E}+06\end{array}$ & $\begin{array}{l}1.01 E+04 \\
3.6 E+04 \\
7.12 E+01 \\
4.92 E+05 \\
1.02 E+06\end{array}$ & $2.42 E+06$ & $\begin{array}{l}4.44 E+03 \\
3.29 E+03\end{array}$ & $\begin{array}{l}5.75 E-10 \\
4.25 E-10\end{array}$ & $1.00 E+106$ \\
\hline
\end{tabular}


WHC-SD-WM-TI-774 Rev. 0

TWRS PRIVATIZATION PROCESS TECHNICAL BASELINE

Table B-16 Fhase 1 LAW Mass Balance for Batch PC2/16 (6 sheets)

\begin{tabular}{|c|c|c|c|c|c|c|c|c|c|}
\hline $\begin{array}{l}\text { STREAM NAME } \\
\text { SOLI COMEANENIS }\end{array}$ & 20 & 21 & 22 & 23 & 24 & 25 & 26 & 27 & 28 \\
\hline Total Mass Flow (kg) & & $7.98 \mathrm{E}+05$ & $2.73 \mathrm{E}+06$ & $3.53 \mathrm{E}+06$ & & & & & \\
\hline \multicolumn{10}{|l|}{ RADIONICHFS (Ci) } \\
\hline $\begin{array}{l}\text { Casium } \\
\text { Struntium } \\
\text { Technetium } \\
\text { TRI }\end{array}$ & & $\begin{array}{l}3.39 \mathrm{E}+03 \\
2.99 \mathrm{E}+03 \\
2.81 \mathrm{E}+02 \\
5.42 \mathrm{E}+00\end{array}$ & & $\begin{array}{l}3.39 \mathrm{E}+03 \\
2.99 \mathrm{E}+03 \\
2.81 \mathrm{E}+02 \\
5.42 \mathrm{E}+00\end{array}$ & & & & & \\
\hline \multicolumn{10}{|l|}{ CHEMICALS (kg) } \\
\hline 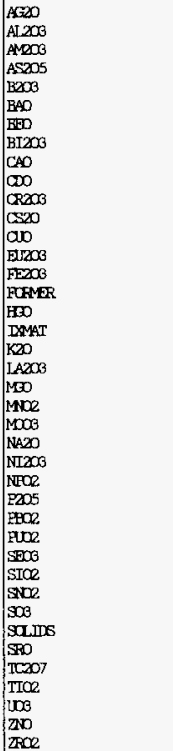 & & $\begin{array}{l}4.58 \mathrm{E}-04 \\
1.02 \mathrm{E}+05 \\
7.4 \mathrm{E}-04 \\
3.7 \mathrm{E}-04 \\
4.01 \mathrm{E}-02 \\
9.16 \mathrm{E}-04 \\
1.52 \mathrm{E}-04 \\
2.31 \mathrm{E}-07 \\
8.30 \mathrm{E}+01 \\
3.47 \mathrm{E}-04 \\
5.24 \mathrm{E}+02 \\
4.14 \mathrm{E}-02 \\
1.73 \mathrm{E}-08 \\
2.44 \mathrm{E}-12 \\
1.73 \mathrm{E}+00 \\
\\
9.93 \mathrm{E}-07 \\
9.10 \mathrm{E}+04 \\
5.69 \mathrm{E}-03 \\
1.55 \mathrm{E}+02 \\
7.43 \mathrm{E}+01 \\
1.55 \mathrm{E}+02 \\
5.96 \mathrm{E}+05 \\
7.29 \mathrm{E}-03 \\
1.96 \mathrm{E}-05 \\
3.06 \mathrm{E}+03 \\
6.26 \mathrm{E}+02 \\
4.92 \mathrm{E}-02 \\
9.52 \mathrm{E}-02 \\
3.26 \mathrm{E}-01 \\
4.39 \mathrm{E}-07 \\
2.14 \mathrm{E}+03 \\
3.79 \mathrm{E}+02 \\
2.53 \mathrm{E}-02 \\
2.59 \mathrm{E}+01 \\
1.41 \mathrm{E}+01 \\
9.06 \mathrm{E}+02 \\
7.04 \mathrm{E}+02 \\
1.22 \mathrm{E}+02\end{array}$ & $2.73 E+06$ & $\begin{array}{l}4.58 \mathrm{E}-04 \\
1.02 \mathrm{E}+05 \\
7.40 \mathrm{E}-04 \\
3.77 \mathrm{E}-04 \\
4.01 \mathrm{E}-02 \\
9.16 \mathrm{E}-04 \\
1.52 \mathrm{E}-04 \\
2.31 \mathrm{E}-07 \\
8.30 \mathrm{E}+01 \\
3.47 \mathrm{E}-04 \\
5.24 \mathrm{E}+02 \\
4.14 \mathrm{E}-02 \\
1.73 \mathrm{E}-08 \\
2.44 \mathrm{E}-12 \\
1.73 \mathrm{E}+00 \\
2.73 \mathrm{E}+06 \\
9.93 \mathrm{E}-07 \\
\\
9.10 \mathrm{E}+04 \\
5.69 \mathrm{E}-03 \\
1.55 \mathrm{E}+02 \\
7.43 \mathrm{E}+01 \\
1.55 \mathrm{E}+02 \\
5.96 \mathrm{E}+05 \\
7.29 \mathrm{E}-03 \\
1.96 \mathrm{E}-05 \\
3.06 \mathrm{E}+03 \\
6.26 \mathrm{E}+02 \\
4.92 \mathrm{E}-02 \\
9.52 \mathrm{E}-02 \\
3.26 \mathrm{E}-01 \\
4.39 \mathrm{E}-07 \\
2.14 \mathrm{E}+03 \\
3.79 \mathrm{E}+02 \\
2.53 \mathrm{E}-02 \\
2.59 \mathrm{E}+01 \\
1.41 \mathrm{E}+01 \\
9.06 \mathrm{E}+02 \\
7.04 \mathrm{E}+02 \\
1.22 \mathrm{E}+02\end{array}$ & & & & & \\
\hline
\end{tabular}


WHC-SD-WM-TI-774 Rev. 0

TWRS PRIVATIZATION PROCESS TECHNICAL BASELINE

Table B-17 Phase 1 LAW Mass Balance for Batch PC2/17 ( 6 sheets)

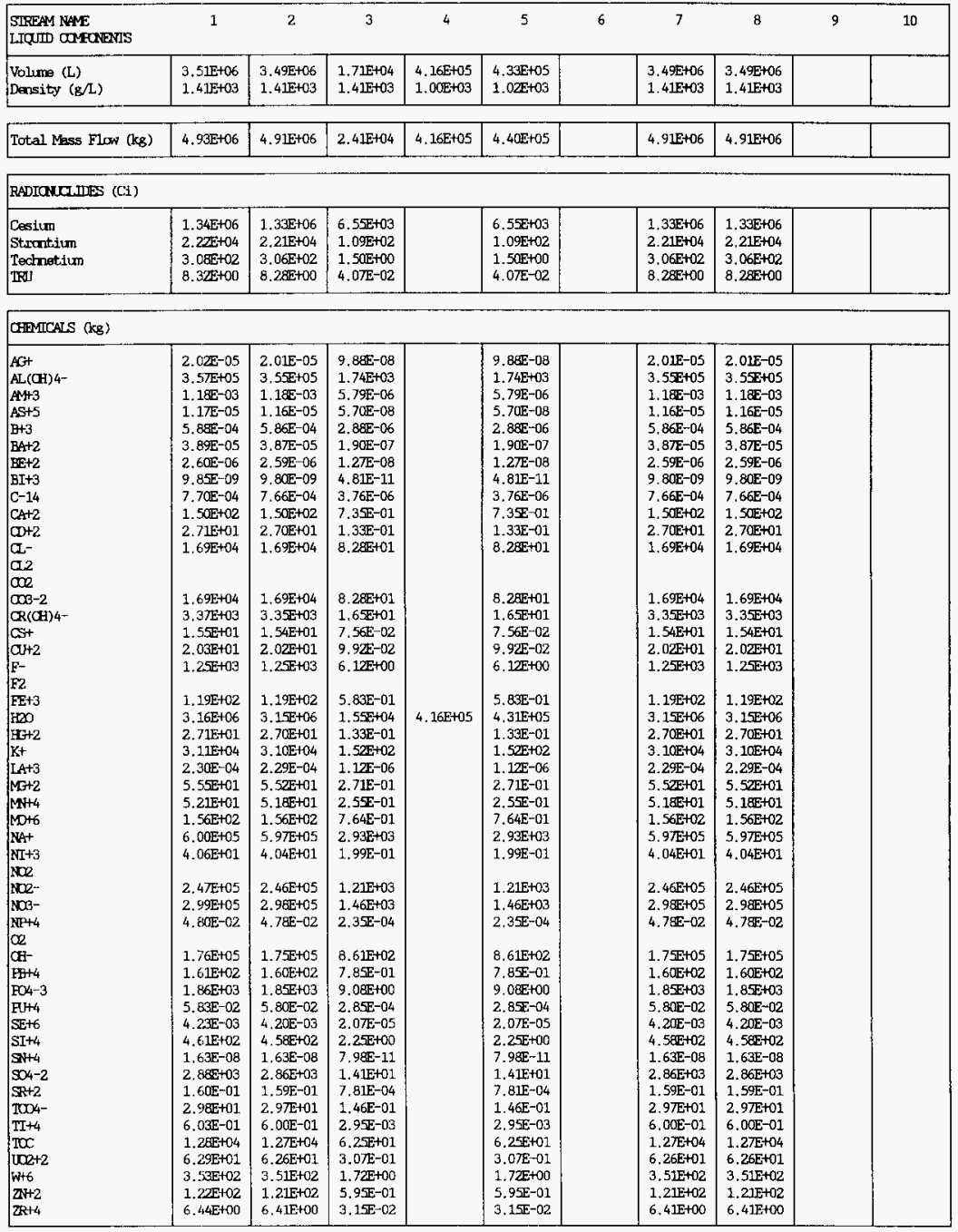


WHC-SD-WM-TI-774 Rev. 0

TWRS PRIVATIZATION PROCESS TECHNICAL BASELINE

Table B-17 Phase 1 LAW Mass Balance for Batch PC2/17 (6 sheets)

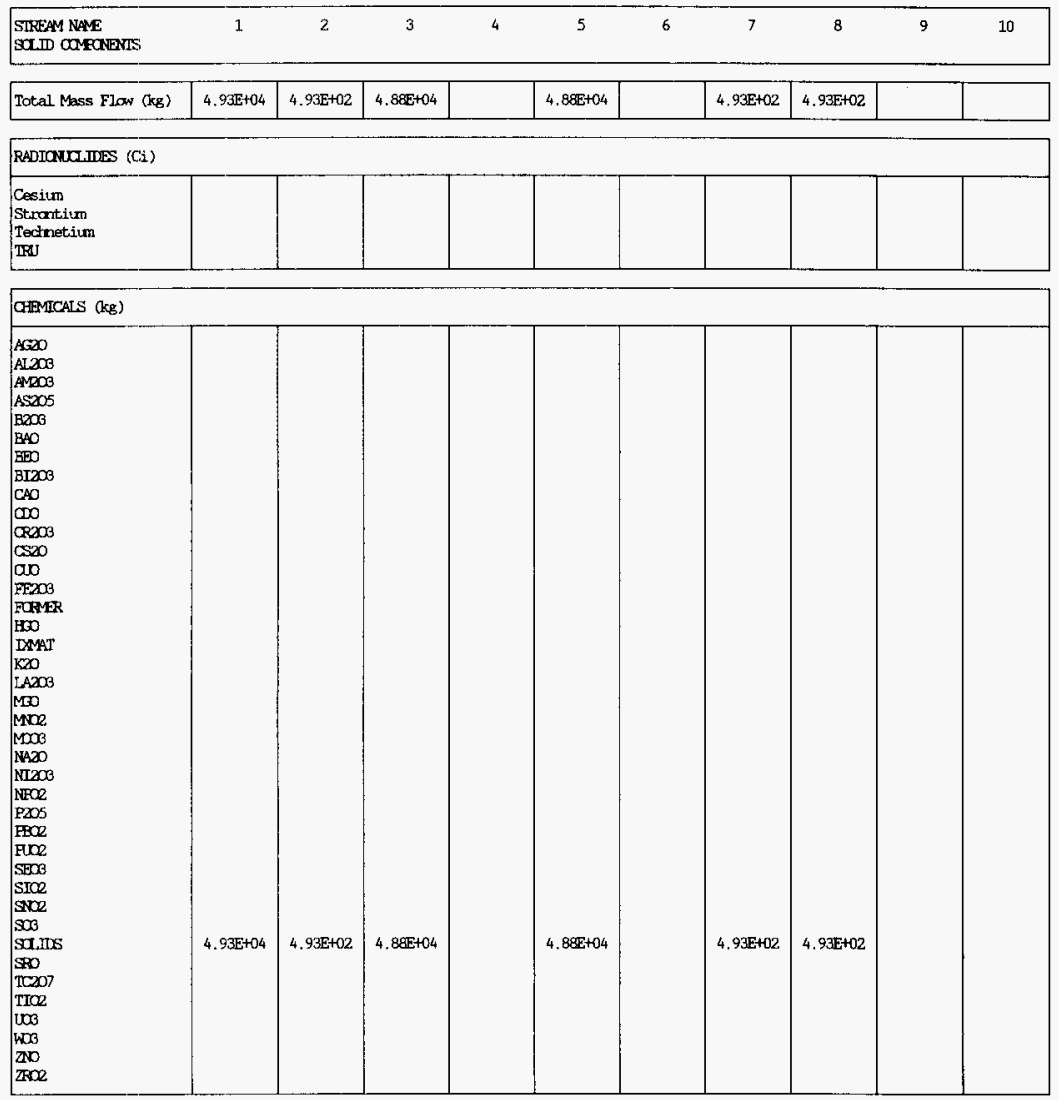


WHC-SD-WM-TI-774 Rev. 0

TWRS PRIVATIZATION PROCESS TECHNICAL BASELINE

Table B-17 Phase 1 LAW Mass Balance for Batch PC2/17 (6 sheets)

\begin{tabular}{|c|c|c|c|c|c|c|c|c|c|c|}
\hline $\begin{array}{l}\text { STREAM NMM } \\
\text { IIQUID CAMANENIS }\end{array}$ & 11 & 12 & 13 & 14 & 15 & 16 & $16 A$ & 17 & 18 & 19 \\
\hline $\begin{array}{l}\text { Volume }(L) \\
\text { Density }(g / L)\end{array}$ & & $\begin{array}{l}3.49 E+06 \\
1.41 F+03\end{array}$ & $\begin{array}{l}3.14 E+03 \\
3.32 E+03\end{array}$ & & $\begin{array}{l}3.14 E+033 \\
3.32 E+033\end{array}$ & $\begin{array}{l}3.49 \mathrm{E}+06 \\
1.4 \mathrm{EE}+03\end{array}$ & $\begin{array}{l}\text { 4. } 87 \mathrm{E}+06 \\
1.00 \mathrm{E}+03\end{array}$ & & $\begin{array}{l}\text { 1. } 00 \mathrm{E}-09 \\
1.00 \mathrm{E}+03\end{array}$ & $\begin{array}{l}1.00 \mathrm{E}-09 \\
1.00 \mathrm{E}+03\end{array}$ \\
\hline Total Mass Flow (kg) & & $4.91 E+06$ & $1.05 \mathrm{E}+04$ & & $1.05 \mathrm{E}+04$ & 4. $91 \mathrm{E}+06$ & $4.87 E+06$ & & $1.00 \mathrm{E}-09$ & $1.00 \mathrm{E}-09$ \\
\hline \multicolumn{11}{|l|}{ RADIONOLIDES (Ci) } \\
\hline $\begin{array}{l}\text { Cesium } \\
\text { Sturntium } \\
\text { Technetilum } \\
\text { IRU }\end{array}$ & & $\begin{array}{l}4.5 / \mathrm{E}+03 \\
2.21 \mathrm{E}+04 \\
3.03 \mathrm{E}+02 \\
8.28 \mathrm{EE}+00\end{array}$ & $\begin{array}{l}1.33 \mathrm{E}+06 \\
3.08 \mathrm{E}+00\end{array}$ & & $\begin{array}{l}1.33 \mathrm{E}+06 \\
3.08 \mathrm{E}+\infty 0\end{array}$ & $\begin{array}{l}4.5 / E+03 \\
2.21 E+04 \\
3.03 E+02 \\
8.28 E+00\end{array}$ & & & & \\
\hline \multicolumn{11}{|l|}{ CHFMICAIS (kg) } \\
\hline 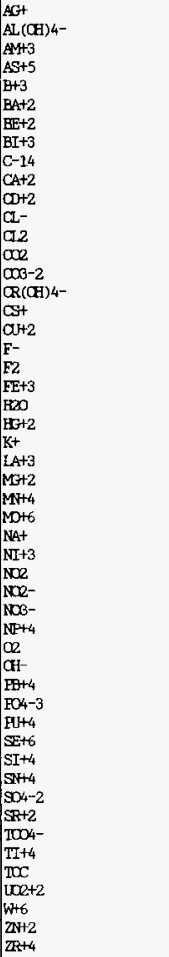 & & $\begin{array}{l}2.01 \mathrm{E}-05 \\
3.55 \mathrm{E}+05 \\
1.18 \mathrm{E}-03 \\
1.16 \mathrm{E}-05 \\
5.86 \mathrm{E}-04 \\
3.87 \mathrm{E}-05 \\
2.59 \mathrm{E}-06 \\
9.80 \mathrm{E}-09 \\
7.66 \mathrm{E}-04 \\
1.50 \mathrm{E}+02 \\
2.70 \mathrm{E}+01 \\
1.69 \mathrm{E}+04 \\
\\
1.69 \mathrm{E}+04 \\
3.35 \mathrm{E}+03 \\
5.28 \mathrm{E}-02 \\
2.02 \mathrm{E}+01 \\
1.25 \mathrm{E}+03 \\
1.19 \mathrm{E}+02 \\
3.15 \mathrm{E}+06 \\
2.70 \mathrm{E}+01 \\
3.10 \mathrm{E}+04 \\
2.29 \mathrm{E}-04 \\
5.52 \mathrm{E}+01 \\
5.18 \mathrm{E}+01 \\
1.56 \mathrm{E}+02 \\
5.97 \mathrm{E}+05 \\
4.04 \mathrm{E}+01 \\
2.46 \mathrm{E}+05 \\
2.98 \mathrm{E}+05 \\
4.78 \mathrm{E}-02 \\
1.75 \mathrm{E}+05 \\
1.60 \mathrm{E}+02 \\
1.85 \mathrm{E}+03 \\
5.80 \mathrm{E}-02 \\
4.20 \mathrm{E}-03 \\
4.58 \mathrm{E}+02 \\
1.63 \mathrm{E}-08 \\
2.86 \mathrm{E}+03 \\
1.59 \mathrm{E}-01 \\
2.94 \mathrm{E}+01 \\
6.00 \mathrm{E}-01 \\
1.27 \mathrm{E}+04 \\
6.26 \mathrm{E}+01 \\
3.51 \mathrm{E}+02 \\
1.21 \mathrm{E}+02 \\
6.41 \mathrm{E}+00\end{array}$ & $\begin{array}{l}1.53 E+01 \\
6.00 E+03 \\
4.44 E+03 \\
2.98 E-01\end{array}$ & & $\begin{array}{l}1.53 E+01 \\
6.00 \mathrm{E}+03 \\
4.44 \mathrm{E}+03 \\
2.98 \mathrm{E}-01\end{array}$ & $\begin{array}{l}2.01 E-05 \\
3.55 E+05 \\
1.18 E-03 \\
1.16 E-05 \\
5.86 E-04 \\
3.87 E-05 \\
2.59 E-06 \\
9.80 E-09 \\
7.66 E-04 \\
1.50 E+02 \\
2.70 E+01 \\
1.69 E+04 \\
\\
1.69 E+04 \\
3.35 E+03 \\
5.28 E-02 \\
2.02 E+01 \\
1.25 E+03 \\
1.19 E+02 \\
3.15 E+06 \\
2.70 E+01 \\
3.10 E+04 \\
2.29 E-04 \\
5.52 E+01 \\
5.18 E+01 \\
1.56 E+02 \\
5.97 E+05 \\
4.04 E+01 \\
2.46 E+05 \\
2.98 E+05 \\
4.78 E-02 \\
1.75+05 \\
1.60 E+02 \\
1.85 E+03 \\
5.80 E-02 \\
4.20 E-03 \\
4.58 E+02 \\
1.63 E-08 \\
2.86 E+03 \\
1.59 E-01 \\
2.94 E+01 \\
6.00 E-01 \\
1.27 E+04 \\
6.26 E+01 \\
3.51 E+02 \\
1.21 E+02 \\
6.41 E+00\end{array}$ & $\begin{array}{l}1.69 \mathrm{E}+04 \\
5.90 \mathrm{E}+04 \\
1.25 \mathrm{E}+03 \\
3.38 \mathrm{E}+06 \\
4.67 \mathrm{E}+05 \\
9.46 \mathrm{E}+05\end{array}$ & & 1. $00 \mathrm{DE}-09$ & $1.00 \mathrm{E}-09$ \\
\hline
\end{tabular}


WHC-SD-WM-TI-774 Rev. 0

TWRS PRIVATIZATION PROCESS TECHNICAL BASELINE

Table B-17 Phase 1 LAW Mass Balance for Batch PC2/17 (6 sheets)

\begin{tabular}{|c|c|c|c|c|c|c|c|c|c|c|}
\hline $\begin{array}{l}\text { STIFAM NAME } \\
\text { SA.D COMFONENIS }\end{array}$ & 11 & 12. & 13 & 14 & 15 & 16 & $16 A$ & 17 & 18 & 19 \\
\hline Total Mass Flow (kg) & & 4. $93 \mathrm{E}+02$ & & $6.00 \mathrm{E}+03$ & $6.00 E+03$ & $4.93 \mathrm{gE}+02$ & $1.04 \mathrm{E}+06$ & & & \\
\hline \multicolumn{11}{|l|}{ RADIONLEINS (C1) } \\
\hline $\begin{array}{l}\text { Cesium } \\
\text { Strontium } \\
\text { Tectnetiun } \\
\text { ITRI }\end{array}$ & & & & & & & $\begin{array}{l}4.57 E+03 \\
2.21 E+04 \\
3.03 E+02 \\
8.23 E+00\end{array}$ & & & \\
\hline \multicolumn{11}{|l|}{ GHICALS (kg) } \\
\hline 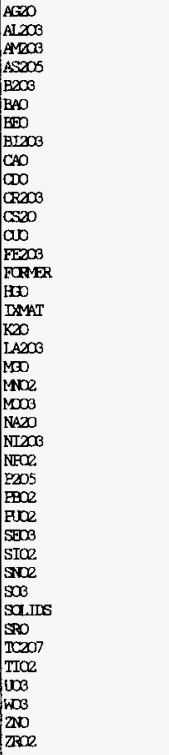 & & $4.93 E+02$ & & $6.00 \mathrm{E}+03$ & $6.00 E+03$ & $4.935+02$ & $\begin{array}{l}2.16 \mathrm{E}-05 \\
1.91 \mathrm{E}+05 \\
1.30 \mathrm{E}-03 \\
1.78 \mathrm{E}-05 \\
1.89 \mathrm{E}-03 \\
4.32 \mathrm{E}-05 \\
7.18 \mathrm{E}-06 \\
1.09 \mathrm{E}-08 \\
2.09 \mathrm{E}+02 \\
3.06 \mathrm{E}+01 \\
2.12 \mathrm{E}+03 \\
5.59 \mathrm{E}-02 \\
2.53 \mathrm{E}+01 \\
1.70 \mathrm{E}+02 \\
\\
2.92 \mathrm{E}+01 \\
\\
3.73 \mathrm{E}+04 \\
2.6 \mathrm{EE}-04 \\
9.15 \mathrm{E}+01 \\
8.20 \mathrm{E}+01 \\
2.34 \mathrm{E}+02 \\
8.04 \mathrm{E}+05 \\
5.69 \mathrm{E}+01 \\
5.43 \mathrm{E}-02 \\
1.38 \mathrm{E}+03 \\
1.82 \mathrm{E}+02 \\
6.58 \mathrm{E}-02 \\
6.76 \mathrm{E}-03 \\
9.80 \mathrm{E}+02 \\
2.06 \mathrm{E}-08 \\
2.39 \mathrm{E}+03 \\
4.93 \mathrm{E}+02 \\
1.87 \mathrm{E}-01 \\
2.79 \mathrm{E}+01 \\
1.00 \mathrm{E}+00 \\
6.63 \mathrm{E}+01 \\
4.42 \mathrm{E}+02 \\
1.51 \mathrm{E}+02 \\
8.6 \mathrm{EE}+00\end{array}$ & & & \\
\hline
\end{tabular}


WHC-SD-WM-TI-774 Rev. 0

TWRS PRIVATIZATION PROCESS TECHNICAL BASELINE

Table B-17 Phase 1 LAW Mass Balance for Batch PC2/17 ( 6 sheets)

\begin{tabular}{|c|c|c|c|c|c|c|c|c|c|}
\hline $\begin{array}{l}\text { SIREAM NAME } \\
\text { LIQUID OOMFANENIS }\end{array}$ & 20 & 21 & 22 & 23 & 24 & 25 & 26 & 27 & 28 \\
\hline $\begin{array}{l}\text { Volume (L) } \\
\text { Density }(\mathrm{g} / \mathrm{L})\end{array}$ & $\begin{array}{l}\text { 4. } 87 E+06 \\
1.00 E+03\end{array}$ & & & & $\begin{array}{l}1.49 \mathrm{E}+06 \\
1.00 \mathrm{E}+03\end{array}$ & $\begin{array}{l}3.38 E+06 \\
1.00 E+03\end{array}$ & $\begin{array}{l}\text { 3. } 13 E+03 \\
\text { 3. } 34 E+03\end{array}$ & $\begin{array}{l}\text { 3. } 00 \mathrm{E}-10 \\
\text { 3. } 34 \mathrm{E}+03\end{array}$ & $\begin{array}{l}1.00 E+06 \\
1.00 E+03\end{array}$ \\
\hline Total Mass Fiow (kg) & $4.8 \mathrm{TE}+06$ & & & & $1.49 \mathrm{E}+06$ & $3.38 E+06$ & $1.04 \mathrm{E}+04$ & 1. $000-09$ & 1. 00E+06 \\
\hline \multicolumn{10}{|l|}{ RADIONUCIITES (Ci) } \\
\hline $\begin{array}{l}\text { Cesium } \\
\text { Strontium } \\
\text { Tecinetium } \\
\text { TRJ. }\end{array}$ & & & & & & & & & \\
\hline
\end{tabular}

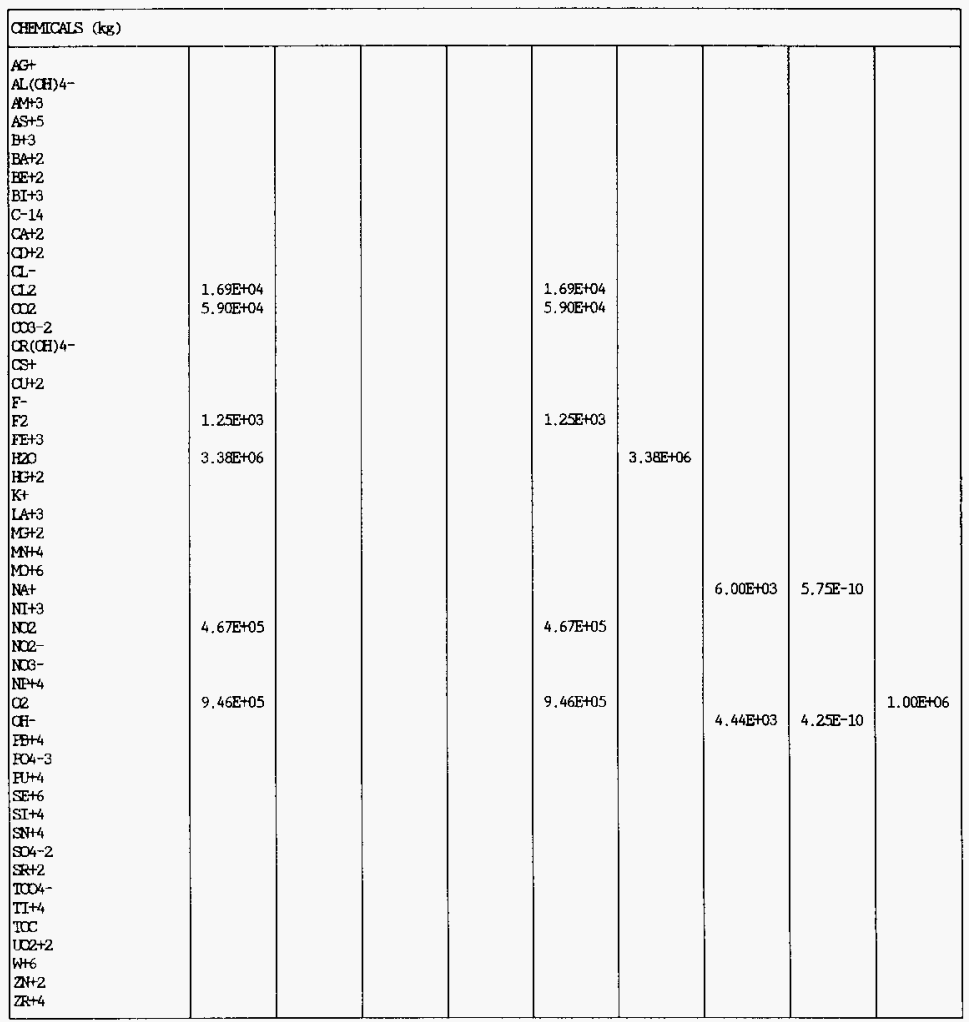


WHC-SD-WM-TI-774 ReV. 0

TWRS PRIVATIZATION PROCESS TECHNICAL BASELINE

Table B-17 Phase 1 LAW Mass Balance for Batch PC2/17 (6 sheets)

\begin{tabular}{|c|c|c|c|c|c|c|c|c|c|}
\hline $\begin{array}{l}\text { SIREAM NAYE } \\
\text { SOLD COMEAVENS }\end{array}$ & 20 & 21 & 22 & 23 & 24 & 25 & 26 & 27 & 28 \\
\hline Total Mass Flow (kg) & & $1.04 \mathrm{E}+06$ & $3.722+06$ & $4.76 \mathrm{E}+06$ & & & & & \\
\hline \multicolumn{10}{|l|}{ RADICNCIETES (Ci) } \\
\hline $\begin{array}{l}\text { Cosiun } \\
\text { Strantium } \\
\text { Tectretium } \\
\text { THJ }\end{array}$ & & $\begin{array}{l}4.55 \mathrm{E}+03 \\
2.21 \mathrm{E}+04 \\
3.03 \mathrm{E}+02 \\
8.23 \mathrm{E}+00\end{array}$ & & $\begin{array}{l}4.57 \mathrm{E}+03 \\
2.21 \mathrm{E}+04 \\
3.03 \mathrm{E}+02 \\
8.23 \mathrm{E}+00\end{array}$ & & & & & \\
\hline \multicolumn{10}{|l|}{ CAIEMICALS (kg) } \\
\hline 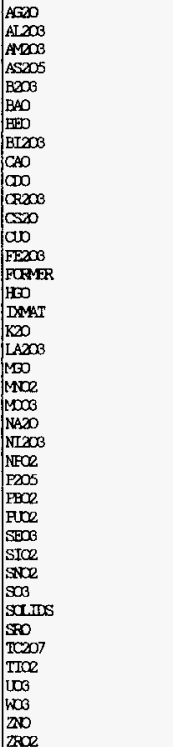 & & $\begin{array}{l}2.16 \mathrm{E}-05 \\
1.91 \mathrm{E}+05 \\
1.30 \mathrm{E}-03 \\
1.7 \mathrm{E}-05 \\
1.89 \mathrm{E}-03 \\
4.32 \mathrm{E}-05 \\
7.18 \mathrm{E}-05 \\
1.09 \mathrm{E}-08 \\
2.09 \mathrm{E}+02 \\
3.08 \mathrm{E}+01 \\
2.12 \mathrm{E}+03 \\
5.59 \mathrm{E}-02 \\
2.53 \mathrm{E}+01 \\
1.70 \mathrm{E}+02 \\
\\
2.92 \mathrm{E}+01 \\
\\
3.73 \mathrm{E}+04 \\
2.68 \mathrm{E}-04 \\
9.15 \mathrm{E}+01 \\
8.20 \mathrm{E}+01 \\
2.34 \mathrm{E}+02 \\
8.04 \mathrm{E}+05 \\
5.69 \mathrm{E}+01 \\
5.43 \mathrm{E}-02 \\
1.39 \mathrm{E}+03 \\
1.8 \mathrm{E}+02 \\
6.5 \mathrm{EE}-02 \\
6.76 \mathrm{E}-03 \\
9.80 \mathrm{E}+02 \\
2.06 \mathrm{E}-08 \\
2.39 \mathrm{E}+03 \\
4.93 \mathrm{E}+02 \\
1.87 \mathrm{E}-01 \\
2.79 \mathrm{E}+01 \\
1.00 \mathrm{E}+00 \\
6.63 \mathrm{E}+01 \\
4.42 \mathrm{E}+02 \\
1.51 \mathrm{E}+02 \\
8.65 \mathrm{E}+00\end{array}$ & $3.72 \mathrm{E}+06$ & $\begin{array}{l}2.16 \mathrm{E}-05 \\
1.91 \mathrm{E}+05 \\
1.30 \mathrm{E}-03 \\
1.78 \mathrm{E}-05 \\
1.89 \mathrm{E}-03 \\
4.32 \mathrm{E}-05 \\
7.18 \mathrm{E}-06 \\
1.09 \mathrm{E}-08 \\
2.09 \mathrm{E}+02 \\
3.08 \mathrm{E}+01 \\
2.12 \mathrm{E}+03 \\
5.59 \mathrm{E}-02 \\
2.53 \mathrm{E}+01 \\
1.70 \mathrm{E}+02 \\
3.72 \mathrm{E}+06 \\
2.92 \mathrm{E}+01 \\
\\
3.73 \mathrm{E}+04 \\
2.68 \mathrm{E}-04 \\
9.15 \mathrm{E}+01 \\
8.20 \mathrm{E}+01 \\
2.34 \mathrm{E}+02 \\
8.04 \mathrm{E}+05 \\
5.69 \mathrm{E}+01 \\
5.43 \mathrm{E}-02 \\
1.38 \mathrm{E}+03 \\
1.85 \mathrm{E}+02 \\
6.58 \mathrm{E}-02 \\
6.76 \mathrm{E}-03 \\
9.80 \mathrm{E}+02 \\
2.06 \mathrm{E}-08 \\
2.39 \mathrm{E}+03 \\
4.93 \mathrm{E}+02 \\
1.87 \mathrm{E}-01 \\
2.79 \mathrm{E}+01 \\
1.00 \mathrm{E}+00 \\
6.63 \mathrm{E}+01 \\
4.42 \mathrm{E}+02 \\
1.51 \mathrm{E}+02 \\
8.65 \mathrm{E}+00\end{array}$ & & & & & \\
\hline
\end{tabular}


WHC-SD-WM-TI-774 Rev. 0

TWRS PRIVATIZATION PROCESS TECHNICAL BASELINE

Table B-18 Phase 1 LAW Mass Balance for Batch PC2/18 (6 sheets)

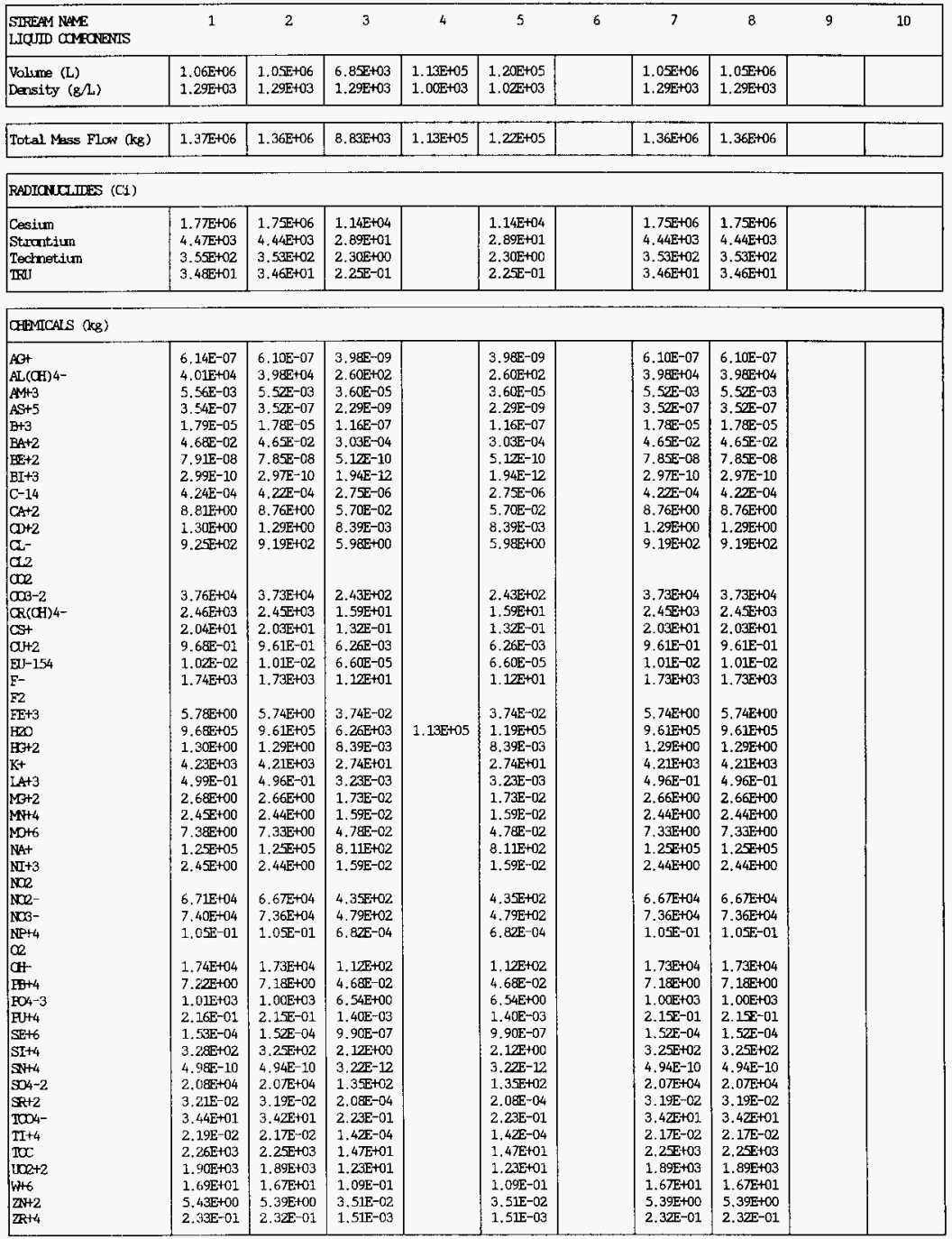


WHC-SD-WM-TI-774 Rev. 0

TWRS PRIVATIZATION PROCESS TECHNICAL BASELINE

Table B-18 Phase 1 LAW Mass Balance for Batch PC2/18 (6 sheets)

\begin{tabular}{|c|c|c|c|c|c|c|c|c|c|c|}
\hline $\begin{array}{l}\text { SIRFAM NAE } \\
\text { SO.JD WOFOWDIS }\end{array}$ & 1 & 2 & 3 & 4 & 5 & 6 & 7 & 8 & 9 & 10 \\
\hline Total Mass Flon (kg) & $1.37 \mathrm{E}+04$ & 1. $37 \mathrm{E}+02$ & $1.35 \mathrm{E}+04$ & & $1.3 \mathbf{E}+04$ & & $1.3 \pi+02$ & 1.37E+02 & & \\
\hline \multicolumn{11}{|l|}{ RADTONUCIIFES (Ci) } \\
\hline $\begin{array}{l}\text { Cesium } \\
\text { Strantium } \\
\text { Technotiun } \\
\text { TFII }\end{array}$ & & & & & & & & & & \\
\hline
\end{tabular}

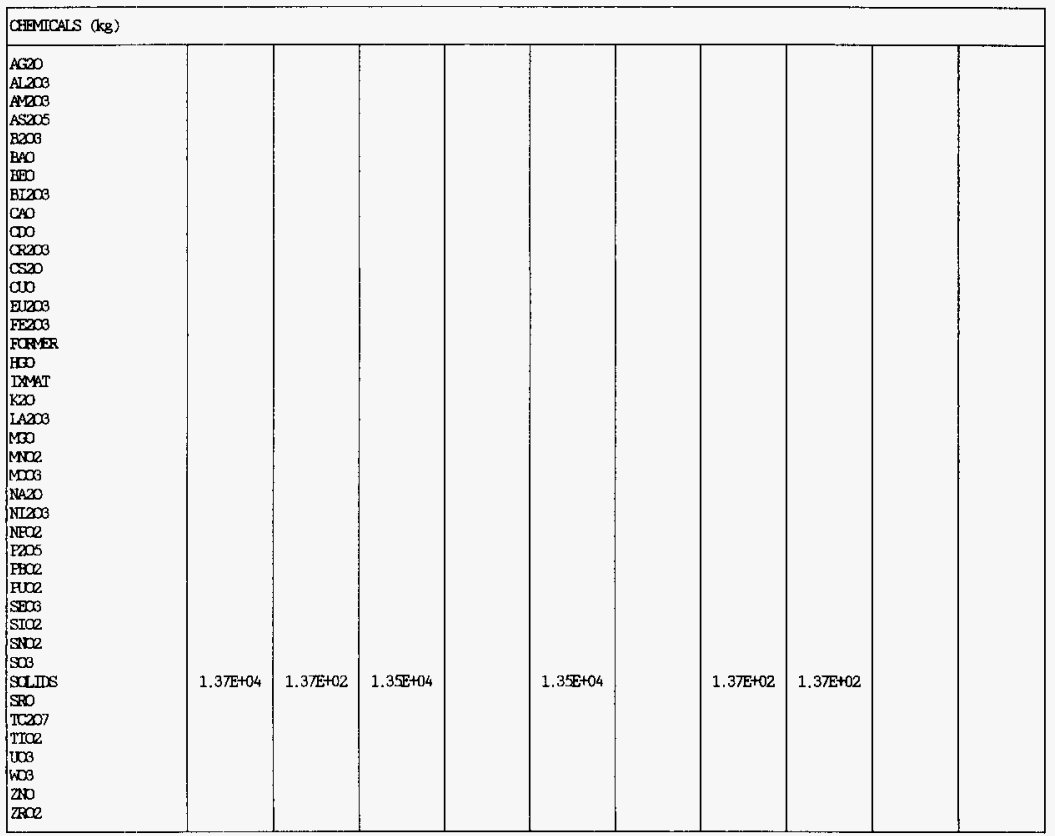


WHC-SD-WM-TI-774 Rev. 0

\section{TWRS PRIVATIZATION PROCESS TECHNICAL BASELINE}

Table B-18 Phase 1 IAW Mass Balance for Batch PC2/18 ( 6 sheets)

\begin{tabular}{|c|c|c|c|c|c|c|c|c|c|c|}
\hline $\begin{array}{l}\text { STRFAM NAME } \\
\text { LTUID COMEAENIS }\end{array}$ & 11 & 12 & 13 & 14 & 15 & 16 & $16 \mathrm{~A}$ & 17 & 18 & 19 \\
\hline $\begin{array}{l}\text { Volume }(L) \\
\text { Density }(g / \lambda)\end{array}$ & & $\begin{array}{l}\text { 1.05E+06 } \\
1.29 E+03\end{array}$ & $\begin{array}{l}6.74 \mathrm{E}+02 \\
3.27 \mathrm{E}+03\end{array}$ & & $\begin{array}{l}6.74 E+02 \\
3.27 E+03\end{array}$ & $\begin{array}{l}1.05 \mathrm{E}+06 \\
1.29 \mathrm{E}+03\end{array}$ & $\begin{array}{l}2.14 \mathrm{E}+06 \\
1.00 \mathrm{E}+03\end{array}$ & $\begin{array}{l}6.64 \mathrm{E}+02 \\
3.30 \mathrm{E}+03\end{array}$ & $\begin{array}{l}1.22 \mathrm{E}+03 \\
1.00 \mathrm{E}+03\end{array}$ & $\begin{array}{l}1.92 E+03 \\
1.80 E+03\end{array}$ \\
\hline Total Mass Flow (kg) & & $1.36 \mathrm{E}+06$ & $2,20 \mathrm{E}+03$ & & $2.20 \mathrm{E}+03$ & $1.36 \mathrm{E}+06$ & $2.14 \mathrm{E}+06$ & $2.19 E+03$ & $1.2 \pi E+03$ & $3.44 \mathrm{E}+03$ \\
\hline \multicolumn{11}{|l|}{ RADIaNuCLIIES (Ci) } \\
\hline $\begin{array}{l}\text { Cesium } \\
\text { Strantium } \\
\text { Tecknetium } \\
\text { TRI }\end{array}$ & & $\begin{array}{l}2.39 \mathrm{E}+03 \\
4.44 \mathrm{E}+03 \\
3.49 \mathrm{E}+02 \\
3.46 \mathrm{E}+01\end{array}$ & $\begin{array}{l}1.7 \mathrm{E}+06 \\
3.5 \mathrm{E}+00\end{array}$ & & $\begin{array}{l}1.75 E+06 \\
3.55 E+00\end{array}$ & $\begin{array}{l}2.39 \mathrm{E}+03 \\
4.44 \mathrm{E}+03 \\
2.39 \mathrm{E}+02 \\
3.46 \mathrm{E}+01\end{array}$ & & 1. $10 E+02$ & & $1.10 E+02$ \\
\hline \multicolumn{11}{|l|}{ OHRMTCAIS (kg) } \\
\hline 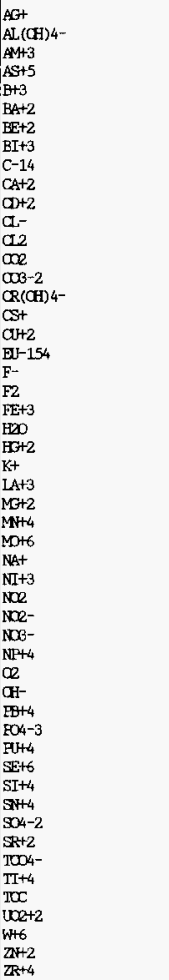 & & $\begin{array}{l}6.10 \mathrm{E}-07 \\
3.98 \mathrm{G}+04 \\
5.52 \mathrm{E}-03 \\
3.52 \mathrm{E}-07 \\
1.78 \mathrm{E}-05 \\
4.6 \mathrm{E}-02 \\
7.85 \mathrm{E}-08 \\
2.97 \mathrm{E}-10 \\
4.22 \mathrm{E}-04 \\
8.76 \mathrm{E}+00 \\
1.29 \mathrm{E}+00 \\
9.19 \mathrm{E}+02 \\
\\
3.73 \mathrm{E}+04 \\
2.4 \mathrm{EE}+03 \\
2.76 \mathrm{E}-02 \\
9.6 \mathrm{E}-01 \\
1.01 \mathrm{E}-02 \\
1.73 \mathrm{E}+03 \\
5.74 \mathrm{E}+00 \\
9.6 \mathrm{E}+05 \\
1.29 \mathrm{E}+00 \\
4.21 \mathrm{E}+03 \\
4.96 \mathrm{E}-01 \\
2.66 \mathrm{E}+00 \\
2.44 \mathrm{E}+00 \\
7.33 \mathrm{E}+00 \\
1.25 \mathrm{E}+05 \\
2.44 \mathrm{E}+00 \\
6.6 \mathrm{E}+04 \\
7.36 \mathrm{E}+04 \\
1.05 \mathrm{E}-01 \\
1.73 \mathrm{E}+04 \\
7.18 \mathrm{E}+00 \\
1.00 \mathrm{E}+03 \\
2.15 \mathrm{E}-01 \\
1.52 \mathrm{E}-04 \\
3.25 \mathrm{E}+02 \\
4.94 \mathrm{E}-10 \\
2.0 \mathrm{E}+04 \\
3.19 \mathrm{E}-02 \\
3.38 \mathrm{E}+01 \\
2.17 \mathrm{E}-02 \\
2.25 \mathrm{E}+03 \\
1.89 \mathrm{E}+03 \\
1.67 \mathrm{E}+01 \\
5.39 \mathrm{E}+00 \\
2.32 \mathrm{E}-01\end{array}$ & $\begin{array}{l}2.02 \mathrm{E}+01 \\
1.25 \mathrm{E}+03 \\
9.2 \mathrm{E}+02 \\
3.44 \mathrm{E}-01\end{array}$ & & $\begin{array}{l}2.02 \mathrm{EL1} \\
1.25 \mathrm{E}+03 \\
9.2 \pi+02 \\
\end{array}$ & $\begin{array}{l}6.10 \mathrm{E}-07 \\
3.98 \mathrm{E}+04 \\
5.52 \mathrm{E}-03 \\
3.52 \mathrm{E}-07 \\
1.78 \mathrm{E}-05 \\
4.65 \mathrm{E}-02 \\
7.85 \mathrm{E}-08 \\
2.97 \mathrm{E}-10 \\
4.22 \mathrm{E}-04 \\
8.76 \mathrm{E}+00 \\
1.29 \mathrm{E}+00 \\
9.19 \mathrm{E}+02 \\
\\
3.73 \mathrm{E}+04 \\
2.45 \mathrm{E}+03 \\
2.76 \mathrm{E}-02 \\
9.61 \mathrm{E}-01 \\
1.01 \mathrm{E}-02 \\
1.73 \mathrm{E}+03 \\
\\
5.74 \mathrm{E}+00 \\
9.61 \mathrm{E}+05 \\
1.29 \mathrm{E}+00 \\
4.21 \mathrm{E}+03 \\
4.96 \mathrm{E}-01 \\
2.66 \mathrm{E}+00 \\
2.44 \mathrm{E}+00 \\
7.33 \mathrm{E}+00 \\
1.25 \mathrm{E}+05 \\
2.44 \mathrm{E}+00 \\
6.67 \mathrm{E}+04 \\
7.36 \mathrm{E}+04 \\
1.05 \mathrm{E}-01 \\
1.73 \mathrm{E}+04 \\
7.18 \mathrm{E}+00 \\
1.00 \mathrm{E}+03 \\
2.1 \mathrm{E}-01 \\
1.52 \mathrm{E}-04 \\
3.25 \mathrm{E}+02 \\
4.94 \mathrm{E}-10 \\
2.07 \mathrm{E}+04 \\
3.19 \mathrm{E}-02 \\
2.31 \mathrm{E}+01 \\
2.17 \mathrm{E}-02 \\
2.25 \mathrm{E}+03 \\
1.89 \mathrm{E}+03 \\
1.67 \mathrm{E}+01 \\
5.39 \mathrm{E}+00 \\
2.32 \mathrm{E}-01\end{array}$ & $\begin{array}{l}9.19 E+02 \\
3.56 \mathrm{E}+04 \\
\\
1.73 \mathrm{E}+03 \\
9.86 \mathrm{E}+05 \\
\\
1.21 \mathrm{E}+05 \\
9.94 \mathrm{E}+05\end{array}$ & $\begin{array}{l}1.25+03 \\
9.2 \pi+02\end{array}$ & $1.25 \mathrm{E}+03$ & $\begin{array}{l}1.25 E+03 \\
1.258+03 \\
9.27 E+02\end{array}$ \\
\hline
\end{tabular}


WHC-SD-WM-TI-774 Rev. 0

TWRS PRIVATIZATION PROCESS TECHNICAL BASELINE

Table B-18 Thase 1 IAW Mass Balance for Batch PC2/18 (6 sheets)

\begin{tabular}{|c|c|c|c|c|c|c|c|c|c|c|}
\hline $\begin{array}{l}\text { SIREAM NAE } \\
\text { SOID COMONEMS }\end{array}$ & 11 & 12 & 13 & 14 & 15 & 16 & $16 \mathrm{~A}$ & 17 & 18 & 19 \\
\hline Total Mass Flow (kg) & & 1. $37 \mathrm{E}+02$ & & 1.25E+03 & $1.25 \mathrm{E}+03$ & $1.37 \mathrm{E}+02$ & $2.17 \mathrm{E}+05$ & & & \\
\hline \multicolumn{11}{|l|}{ RADIONUCLIIIES (Ci) } \\
\hline \begin{tabular}{|l} 
Cosium \\
Strontiun \\
Tecdmetium \\
TRU
\end{tabular} & & & & & & & $\begin{array}{l}2.39 \mathrm{E}+03 \\
4.44 \mathrm{E}+03 \\
2.39 \mathrm{E}+02 \\
3.44 \mathrm{E}+01\end{array}$ & & & \\
\hline \multicolumn{11}{|l|}{ CHEMICAIS (kg) } \\
\hline 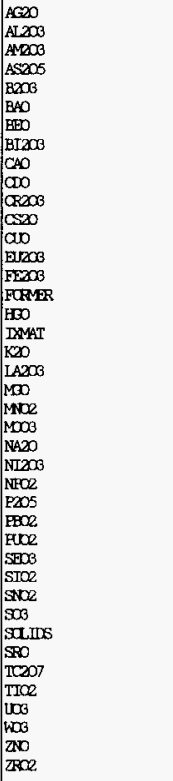 & & $1.37 \mathrm{E}+02$ & & $1.25 E+03$ & $1.25 E+03$ & $1.37 \mathrm{E}+02$ & $\begin{array}{l}6.56 \mathrm{E}-07 \\
2.14 \mathrm{E}+04 \\
6.07 \mathrm{E}-03 \\
5.40 \mathrm{E}-07 \\
5.72 \mathrm{E}-05 \\
5.20 \mathrm{E}-02 \\
2.18 \mathrm{E}-07 \\
3.31 \mathrm{E}-10 \\
1.23 \mathrm{E}+01 \\
1.47 \mathrm{E}+00 \\
1.55 \mathrm{E}+03 \\
2.92 \mathrm{E}-02 \\
1.20 \mathrm{E}+00 \\
1.17 \mathrm{E}-02 \\
8.21 \mathrm{E}+00 \\
1.39 \mathrm{E}+00 \\
5.07 \mathrm{E}+03 \\
5.82 \mathrm{E}-01 \\
4.41 \mathrm{E}+00 \\
3.86 \mathrm{E}+00 \\
1.10 \mathrm{E}+01 \\
1.68 \mathrm{E}+05 \\
3.43 \mathrm{E}+00 \\
1.19 \mathrm{E}-01 \\
7.51 \mathrm{E}+02 \\
8.29 \mathrm{E}+00 \\
2.44 \mathrm{E}-01 \\
2.44 \mathrm{E}-04 \\
6.96 \mathrm{E}+02 \\
6.28 \mathrm{E}-10 \\
1.72 \mathrm{E}+04 \\
1.37 \mathrm{E}+02 \\
3.76 \mathrm{E}-02 \\
2.20 \mathrm{E}+01 \\
3.62 \mathrm{E}-02 \\
2.00 \mathrm{E}+03 \\
2.11 \mathrm{E}+01 \\
6.71 \mathrm{E}+00 \\
3.13 \mathrm{E}-01\end{array}$ & & & \\
\hline
\end{tabular}


WHC-SD-WM-TI-774 Rev. 0

TWRS PRIVATIZATION PROCESS TECHNICAL BASELINE

Table B-18 Phase 1 LAW Mass Balance for Batch PC2/18 (6 sheets)

\begin{tabular}{|c|c|c|c|c|c|c|c|c|c|}
\hline $\begin{array}{l}\text { SIFFAM NAME } \\
\text { ITLUD OOMFUDMS }\end{array}$ & 20 & 21 & 22 & 23 & 24 & 25 & 26 & 27 & 28 \\
\hline $\begin{array}{l}\text { Volume (L) } \\
\text { Density }(\& / L)\end{array}$ & $\begin{array}{l}2.14 \mathrm{E}+06 \\
1.00 \mathrm{E}+03\end{array}$ & & & & $\begin{array}{l}1.15 E+06 \\
1.00 E+03\end{array}$ & $\begin{array}{l}9.86 \mathrm{E}+05 \\
1.00 \mathrm{E}+03\end{array}$ & $\begin{array}{l}6.54 \mathrm{E}+02 \\
3.34 \mathrm{E}+03\end{array}$ & $\begin{array}{l}6.54 \mathrm{E}+02 \\
3.34 \mathrm{E}+03\end{array}$ & $\begin{array}{l}1.00 E+06 \\
1.00 E+03\end{array}$ \\
\hline Total Mass Flow (kg) & $2.14 E+06$ & & & & 1.1.15F+06 & $9.86 \mathrm{E}+05$ & $2.18 \mathrm{E}+03$ & $2.18 \mathrm{E}+03$ & $1.0015+06$ \\
\hline \multicolumn{10}{|l|}{ RADIancLIES (Ci) } \\
\hline $\begin{array}{l}\text { Cessium } \\
\text { Strantium } \\
\text { Tedmetium } \\
\text { IRI }\end{array}$ & & & & & & & & & \\
\hline
\end{tabular}

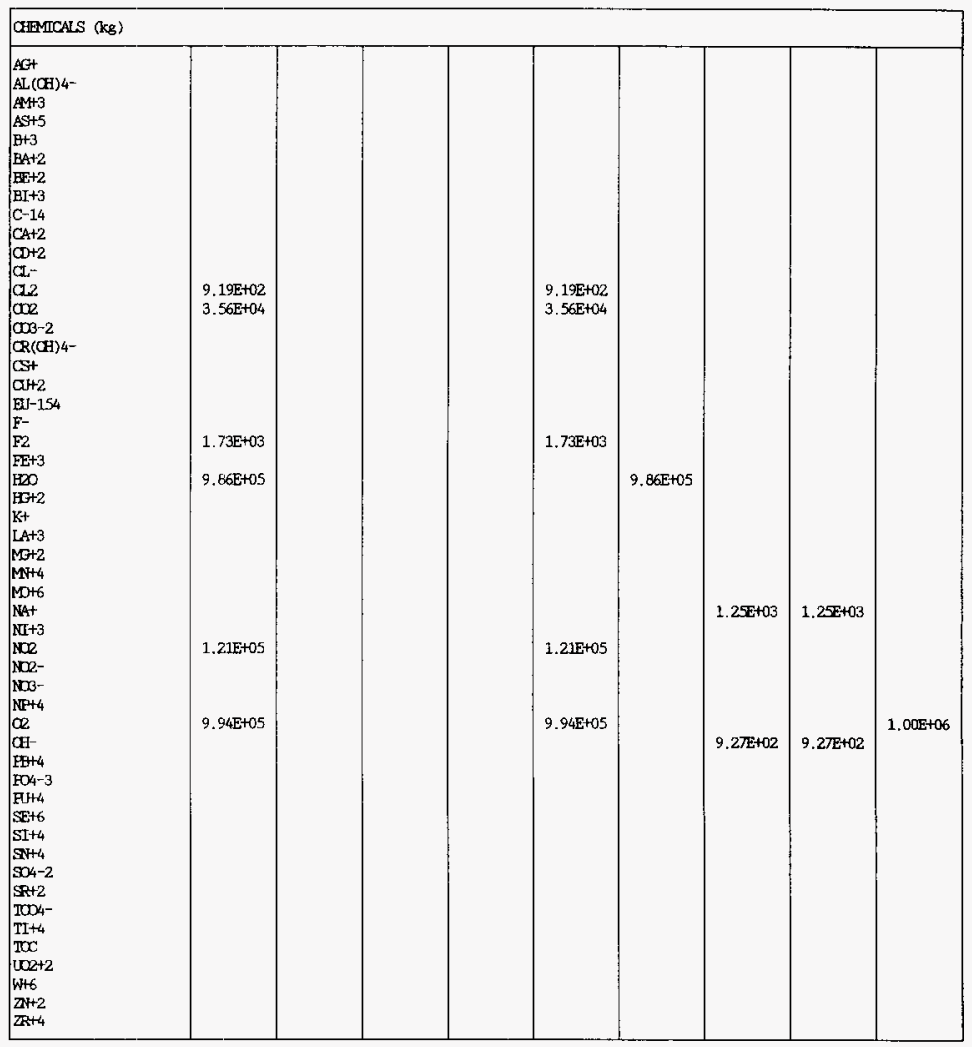


WHC-SD-WM-TI-774 Rev. 0

TWRS PRIVATIZATION PROCESS TECHNICAL BASELINE

Table B-18 Phase 1 IAW Mass Balance for Batch PC2/18 (6 sheets)

\begin{tabular}{|c|c|c|c|c|c|c|c|c|c|}
\hline $\begin{array}{l}\text { SIFEAM NAME } \\
\text { SODD COMONENS: }\end{array}$ & 20 & 21 & 22 & 23 & 24 & 25 & 26 & 27 & 28 \\
\hline Total Mass Flow (kg) & & 2. 1 स+05 & 2. $27 E+06$ & $2.49 \mathrm{E}+06$ & & & & & \\
\hline \multicolumn{10}{|l|}{ RADIONULIDES (Ci) } \\
\hline $\begin{array}{l}\text { Cesium } \\
\text { Strantium } \\
\text { Technetiun } \\
\text { TRा }\end{array}$ & & $\begin{array}{l}2.39 \mathrm{E}+03 \\
4.44 \mathrm{E}+03 \\
2.39 \mathrm{E}+02 \\
3.44 \mathrm{E}+01\end{array}$ & & $\begin{array}{l}2.39 \mathrm{E}+03 \\
4.44 \mathrm{E}+03 \\
2.39 \mathrm{E}+02 \\
3.44 \mathrm{E}+01\end{array}$ & & & & & \\
\hline \multicolumn{10}{|l|}{ ATEMCALS (kg) } \\
\hline 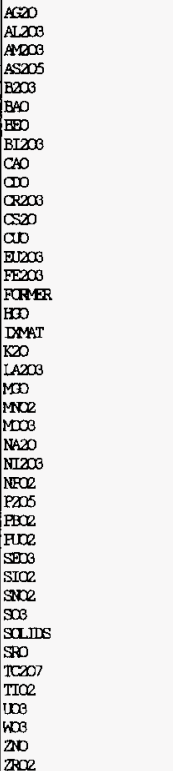 & & $\begin{array}{l}6.56 \mathrm{E}-07 \\
2.14 \mathrm{E}+04 \\
6.07 \mathrm{E}-03 \\
5.40 \mathrm{E}-07 \\
5.72 \mathrm{E}-05 \\
5.20 \mathrm{E}-02 \\
2.1 \mathrm{BE}-07 \\
3.31 \mathrm{E}-10 \\
1.23 \mathrm{E}+01 \\
1.47 \mathrm{E}+00 \\
1.5 \mathrm{E}+03 \\
2.92 \mathrm{E}-02 \\
1.20 \mathrm{E}+00 \\
1.17 \mathrm{E}-02 \\
8.21 \mathrm{E}+00 \\
\\
1.39 \mathrm{E}+00 \\
\\
5.07 \mathrm{E}+03 \\
5.82 \mathrm{E}-01 \\
4.4 \mathrm{E}+00 \\
3.86 \mathrm{E}+00 \\
1.10 \mathrm{E}+01 \\
1.68 \mathrm{E}+05 \\
3.43 \mathrm{E}+00 \\
1.19 \mathrm{E}-01 \\
7.51 \mathrm{E}+02 \\
8.29 \mathrm{E}+00 \\
2.44 \mathrm{E}-01 \\
2.44 \mathrm{E}-04 \\
6.96 \mathrm{E}+02 \\
6.28 \mathrm{E}-100 \\
1.72 \mathrm{E}+04 \\
1.37 \mathrm{E}+02 \\
3.76 \mathrm{E}-02 \\
2.20 \mathrm{E}+01 \\
3.62 \mathrm{E}-02 \\
2.00 \mathrm{E}+03 \\
2.11 \mathrm{E}+01 \\
6.71 \mathrm{E}+00 \\
3.13 \mathrm{E}-01\end{array}$ & $2.27 \mathrm{E}+06$ & $\begin{array}{l}6.56 \mathrm{E}-07 \\
2.14 \mathrm{E}+04 \\
6.0 \mathrm{E}-03 \\
5.4 \mathrm{E}-07 \\
5.72 \mathrm{E}-05 \\
5.20 \mathrm{E}-02 \\
2.1 \mathrm{EE}-07 \\
3.31 \mathrm{E}-10 \\
1.23 \mathrm{E}+01 \\
1.4 \pi+00 \\
1.55 \mathrm{E}+03 \\
2.92 \mathrm{E}-02 \\
1.20 \mathrm{E}+00 \\
1.17 \mathrm{E}-02 \\
8.21 \mathrm{E}+00 \\
2.27 \mathrm{E}+06 \\
1.39 \mathrm{E}+00 \\
\\
5.07 \mathrm{E}+03 \\
5.82 \mathrm{E}-01 \\
4.41 \mathrm{E}+00 \\
3.86 \mathrm{E}+00 \\
1.10 \mathrm{E}+01 \\
1.6 \mathrm{EE}+05 \\
3.43 \mathrm{E}+00 \\
1.19 \mathrm{E}-01 \\
7.51 \mathrm{E}+02 \\
8.29 \mathrm{E}+00 \\
2.44 \mathrm{E}-01 \\
2.44 \mathrm{E}-04 \\
6.96 \mathrm{E}+02 \\
6.28 \mathrm{E}-10 \\
1.72 \mathrm{E}+04 \\
1.37 \mathrm{E}+02 \\
3.76 \mathrm{E}-02 \\
2.20 \mathrm{E}+01 \\
3.62 \mathrm{E}-02 \\
2.00 \mathrm{E}+03 \\
2.11 \mathrm{E}+01 \\
6.71 \mathrm{E}+00 \\
3.13 \mathrm{E}-01\end{array}$ & & & & & \\
\hline
\end{tabular}


WHC-SD-WM-TI-774 Rev. 0

TWRS PRIVATIZATION PROCESS TECHNICAL BASELINE

Table B-19 Phase 1 IAW Mass Balance for Batch PC2/19 (6 sheets)

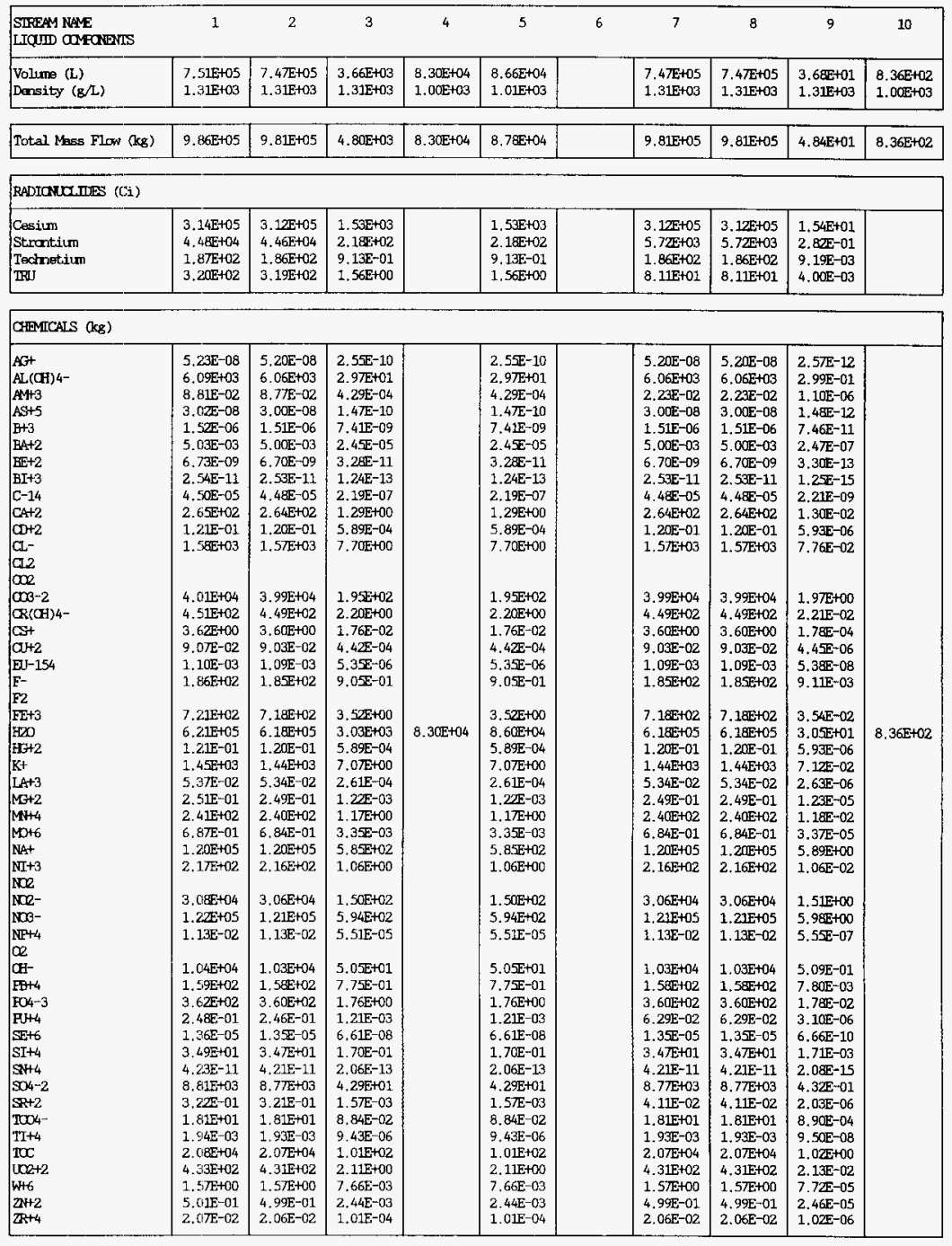


WHC-SD-WM-TI-774 Rev, 0

TWRS PRIVATIZATION PROCESS TECHNICAL BASELINE

Table B-19 Phase 1 LAW Mass Balance for Batch PC2/19 (6 sheets)

\begin{tabular}{|c|c|c|c|c|c|c|c|c|c|c|}
\hline $\begin{array}{l}\text { SIRFAM NAME } \\
\text { SL.WD CMEONERTS }\end{array}$ & 1 & 2 & 3 & 4 & 5 & 6 & 7 & 8 & 9 & 10 \\
\hline Total Mass Flow (kg) & $9.85 E+03$ & $9.85 E+01$ & $9.75 E+03$ & & $9.75 E+03$ & & $9.92 \mathrm{E}+01$ & $9.92 \mathrm{E}-01$ & $9.82 E+01$ & \\
\hline \multicolumn{11}{|l|}{ RADIONUCIIIES (Ci) } \\
\hline $\begin{array}{l}\text { Cesium } \\
\text { Strantiun } \\
\text { Technetiun } \\
\text { TIV }\end{array}$ & & & & & & & $\begin{array}{l}3.89 E+04 \\
2.38 E+02\end{array}$ & $\begin{array}{l}3.89 E+02 \\
2.38 E+00\end{array}$ & $\begin{array}{l}3.85 \mathbf{E}+04 \\
2.3 \mathbf{E}+02\end{array}$ & \\
\hline
\end{tabular}

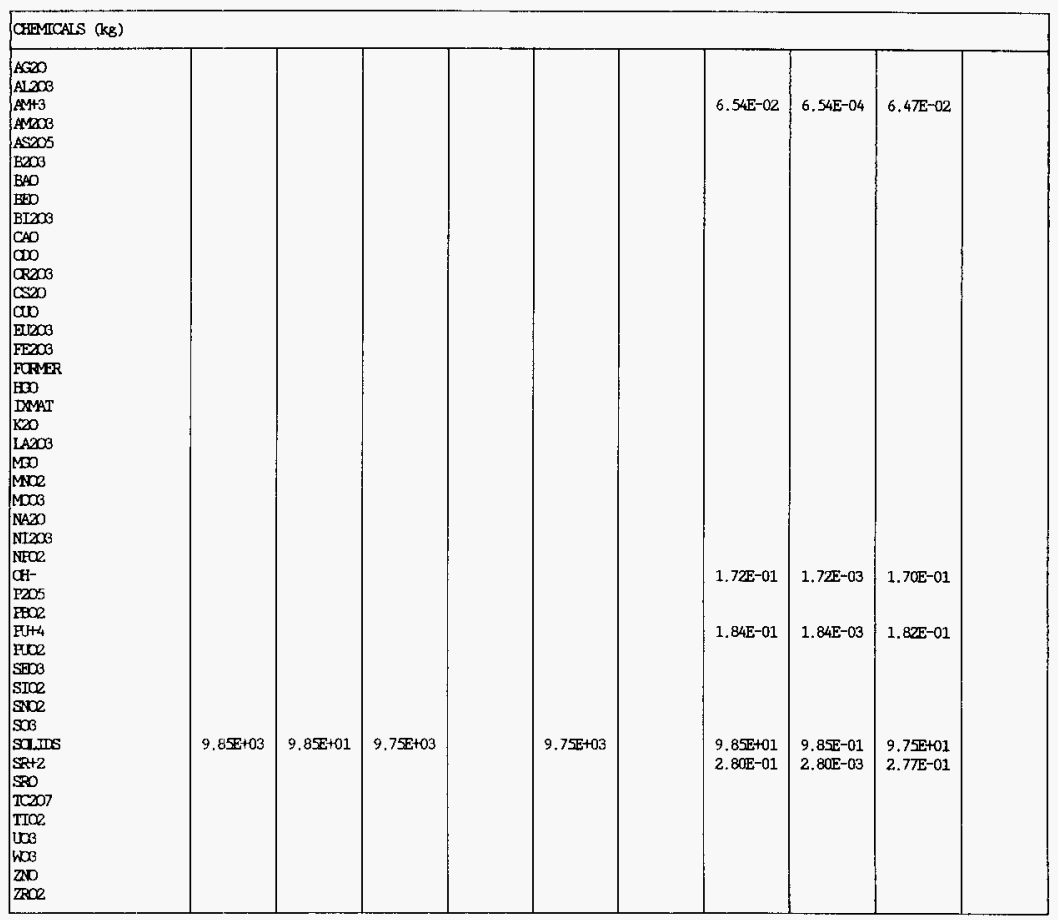


WHC-SD-WM-TI-774 ReV. 0

\section{TWRS PRIVATIZATION PROCESS TECHNICAL BASELINE}

Table B-19 Phase 1 LAW Mass Balance for Batch PC2/19 (6 sheets)

\begin{tabular}{|c|c|c|c|c|c|c|c|c|c|c|}
\hline $\begin{array}{l}\text { STRFAM NAME } \\
\text { LIQUID COMFUNENIS }\end{array}$ & 11 & 12 & 13 & 14 & 15 & 16 & $16 \mathrm{~A}$ & 17 & 18 & 19 \\
\hline $\begin{array}{l}\text { Volume (L) } \\
\text { Density (g/L) }\end{array}$ & $\begin{array}{l}8.72 \mathrm{E}+02 \\
1.01 \mathrm{E}+03\end{array}$ & $\begin{array}{l}7.4 \mathrm{E}+05 \\
1.31 \mathrm{E}+03\end{array}$ & $\begin{array}{l}6.30 E+02 \\
3.32 E+03\end{array}$ & & $\begin{array}{l}6.30 \mathrm{E}+02 \\
3.32 \mathrm{E}+03\end{array}$ & $\begin{array}{l}7.4 \mathrm{E}+05 \\
1.31 \mathrm{E}+03\end{array}$ & $\begin{array}{l}1.81 E+06 \\
1.00 E+03\end{array}$ & $\begin{array}{l}6.36 E+02 \\
3.30 E+03\end{array}$ & $\begin{array}{l}1.20 \mathrm{E}+03 \\
1.00 \mathrm{E}+03\end{array}$ & $\begin{array}{l}\text { 1. } 84 \mathrm{E}+03 \\
1.80 \mathrm{E}+03\end{array}$ \\
\hline Total Mess Flow (kg) & $8.84 \mathrm{E}+02$ & $9.81 E+05$ & $2.09 \mathrm{E}+\mathrm{C3}$ & & $2.09 E+03$ & $9.81 E+05$ & $1.81 E+06$ & $2.100+03$ & $1.20 E+03$ & $3.30 \mathrm{E}+03$ \\
\hline \multicolumn{11}{|l|}{ RADTONUCIIIES (Ci) } \\
\hline \begin{tabular}{|l} 
Cesium \\
Strantium \\
Tochnetiun \\
TRI
\end{tabular} & $\begin{array}{l}1.54 \mathrm{E}+01 \\
2.82 \mathrm{E}-01 \\
9.19 \mathrm{E}-03 \\
4.00 \mathrm{E}-03\end{array}$ & $\begin{array}{l}9.16 \mathrm{E}+02 \\
5.72 \mathrm{E}+03 \\
1.85 \mathrm{E}+02 \\
8.11 \mathrm{E}+01\end{array}$ & $\begin{array}{l}3.11 E+05 \\
1.8 \pi+00\end{array}$ & & $\begin{array}{l}3.11 \mathrm{E}+05 \\
1.8 \pi+\infty\end{array}$ & $\begin{array}{l}9.16 \mathrm{E}+02 \\
5.72 \mathrm{E}+03 \\
9.16 \mathrm{E}+01 \\
8.11 \mathrm{E}+01\end{array}$ & & $9.29 \mathrm{E}+01$ & & $9.29 \mathrm{E}+01$ \\
\hline \multicolumn{11}{|l|}{ CAFMICALS (kg) } \\
\hline 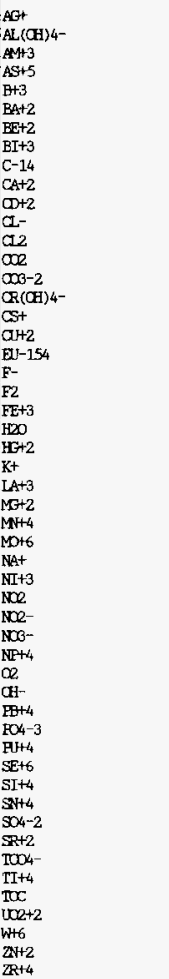 & $\begin{array}{l}2.57 \mathrm{E}-12 \\
2.99 \mathrm{E}-01 \\
1.10 \mathrm{E}-06 \\
1.48 \mathrm{E}-12 \\
7.46 \mathrm{E}-11 \\
2.4 \mathrm{E}-07 \\
3.30 \mathrm{E}-13 \\
1.25 \mathrm{E}-15 \\
2.21 \mathrm{E}-09 \\
1.30 \mathrm{E}-02 \\
5.93 \mathrm{E}-06 \\
7.76 \mathrm{E}-02 \\
\\
1.97 \mathrm{E}+00 \\
2.21 \mathrm{E}-02 \\
1.78 \mathrm{E}-04 \\
4.4 \mathrm{E}-06 \\
5.38 \mathrm{E}-08 \\
9.11 \mathrm{E}-03 \\
\\
3.54 \mathrm{E}-02 \\
8.66 \mathrm{E}+02 \\
5.93 \mathrm{E}-06 \\
7.12 \mathrm{E}-02 \\
2.63 \mathrm{E}-06 \\
1.23 \mathrm{E}-05 \\
1.19 \mathrm{E}-02 \\
3.37 \mathrm{E}-05 \\
5.89 \mathrm{E}+00 \\
1.06 \mathrm{E}-02 \\
1.51 \mathrm{E}+00 \\
5.98 \mathrm{E}+00 \\
5.5 \mathrm{E}-07 \\
5.09 \mathrm{E}-01 \\
7.80 \mathrm{E}-03 \\
1.78 \mathrm{E}-02 \\
3.10 \mathrm{E}-06 \\
6.66 \mathrm{E}-10 \\
1.71 \mathrm{E}-03 \\
2.08 \mathrm{E}-15 \\
4.32 \mathrm{E}-01 \\
2.03 \mathrm{E}-06 \\
8.90 \mathrm{E}-04 \\
9.50 \mathrm{E}-08 \\
1.02 \mathrm{E}+00 \\
2.13 \mathrm{E}-02 \\
7.72 \mathrm{E}-05 \\
2.46 \mathrm{E}-05 \\
1.02 \mathrm{E}-06\end{array}$ & 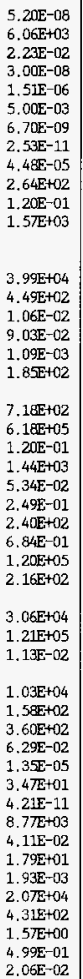 & 8. 89Et02 & & $\begin{array}{l}1.20 \mathrm{E}+03 \\
8.89 \mathrm{E}+02\end{array}$ & $\begin{array}{l}5.20 \mathrm{E}-08 \\
6.06 \mathrm{E}+03 \\
2.23 \mathrm{E}-02 \\
3.00 \mathrm{E}-08 \\
1.51 \mathrm{E}-06 \\
5.00 \mathrm{E}-03 \\
6.70 \mathrm{E}-09 \\
2.53 \mathrm{E}-11 \\
4.48 \mathrm{E}-05 \\
2.64 \mathrm{E}+02 \\
1.20 \mathrm{E}-01 \\
1.57 \mathrm{E}+03 \\
\\
3.99 \mathrm{E}+04 \\
4.49 \mathrm{E}+02 \\
1.06 \mathrm{E}-02 \\
9.03 \mathrm{E}-02 \\
1.09 \mathrm{E}-03 \\
1.85 \mathrm{E}+02 \\
\\
7.1 \mathrm{EE}+02 \\
6.18 \mathrm{E}+05 \\
1.20 \mathrm{E}-01 \\
1.44 \mathrm{E}+03 \\
5.34 \mathrm{E}-02 \\
2.49 \mathrm{E}-01 \\
2.40 \mathrm{E}+02 \\
6.84 \mathrm{E}-01 \\
1.20 \mathrm{E}+05 \\
2.16 \mathrm{E}+02 \\
3.06 \mathrm{E}+04 \\
1.21 \mathrm{E}+05 \\
1.13 \mathrm{E}-02 \\
1.03 \mathrm{E}+04 \\
1.5 \mathrm{E}+02 \\
3.60 \mathrm{E}+02 \\
6.2 \mathrm{E}-02 \\
1.35 \mathrm{E}-05 \\
3.4 \pi \mathrm{E}+01 \\
4.21 \mathrm{E}-11 \\
8.77 \mathrm{E}+03 \\
4.1 \mathrm{E}-02 \\
8.87 \mathrm{E}+00 \\
1.93 \mathrm{E}-03 \\
2.07 \mathrm{E}+04 \\
4.31 \mathrm{E}+02 \\
1.57 \mathrm{E}+00 \\
4.99 \mathrm{E}-01 \\
2.06 \mathrm{E}-02\end{array}$ & $\begin{array}{l}1.5 \pi \mathrm{E}+03 \\
1.05 \mathrm{E}+05 \\
1.8 \mathrm{EE}+02 \\
6.26 \mathrm{E}+05\end{array}$ & $8.895+02$ & $1.20 \mathrm{E}+03$ & $8.89 \mathrm{E}+02$ \\
\hline
\end{tabular}


WHC-SD-WM-TI-774 Rev. 0

TWRS PRIVATIZATION PROCESS TECHNICAL BASELINE

Table B-19 Phase 1 IAW Mass Balance for Batch PC2/19 (6 sheets)

\begin{tabular}{|c|c|c|c|c|c|c|c|c|c|c|}
\hline $\begin{array}{l}\text { SIFEAM NAME } \\
\text { SDLD COMEADENIS }\end{array}$ & 11 & 12 & 13 & 14 & 15 & 16 & IEA & 17 & 18 & 19 \\
\hline Total Mass Flow (kg) & $9.825+01$ & $9.92 \mathrm{E}-01$ & & $1.20 \mathrm{E}+03$ & $1.20 \mathrm{E}+03$ & $9.92 \mathrm{E}-01$ & $1.77 \mathrm{E}+05$ & & & \\
\hline \multicolumn{11}{|l|}{ RADIONUCIIES (Ci) } \\
\hline $\begin{array}{l}\text { Cesium } \\
\text { Strantium } \\
\text { Teclmet.ium } \\
\text { TRI }\end{array}$ & $\begin{array}{l}3.85 \mathrm{E}+04 \\
2.35 \mathrm{E}+02\end{array}$ & $\begin{array}{l}3.89 \mathrm{E}+02 \\
2.3 \mathrm{BE}+00\end{array}$ & & & & $\begin{array}{l}3.89 \mathrm{E}+02 \\
2.38 \mathrm{E}+00\end{array}$ & $\begin{array}{l}9.16 E+02 \\
6.11 E+03 \\
9.16 E+01 \\
8.12 E+01\end{array}$ & & & \\
\hline \multicolumn{11}{|l|}{ CHEMCALS (kg) } \\
\hline 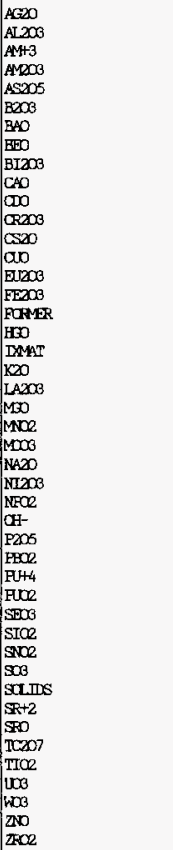 & $\begin{array}{l}1.70 \mathrm{CE}-01 \\
1.62 \mathrm{E}-01 \\
\\
9.7 \mathrm{FE}+01 \\
2.7 \pi \mathrm{E}-01\end{array}$ & $\begin{array}{l}1.72 \mathrm{E}-03 \\
1.84 \mathrm{E}-03 \\
\\
9.85 \mathrm{E}-01 \\
2.80 \mathrm{E}-03\end{array}$ & & $1.20 \mathrm{E}+\mathrm{G} 3$ & $1.20 \mathrm{E}+03$ & $\begin{array}{l}1.72 E-03 \\
1.84 E-03 \\
\\
9.85 E-01 \\
2.80 E-03\end{array}$ & $\begin{array}{l}5.59 \mathrm{E}-08 \\
3.25 \mathrm{E}+03 \\
2.53 \mathrm{E}-02 \\
4.60 \mathrm{E}-08 \\
4.87 \mathrm{E}-06 \\
5.59 \mathrm{E}-03 \\
1.86 \mathrm{E}-08 \\
2.82 \mathrm{E}-11 \\
3.69 \mathrm{E}+02 \\
1.3 \mathrm{E}-01 \\
2.84 \mathrm{E}+02 \\
1.12 \mathrm{E}-02 \\
1.13 \mathrm{E}-01 \\
1.26 \mathrm{E}-03 \\
1.63 \mathrm{E}+03 \\
\\
1.30 \mathrm{E}-01 \\
\\
1.74 \mathrm{E}+03 \\
6.26 \mathrm{E}-02 \\
4.14 \mathrm{E}-01 \\
3.80 \mathrm{E}+02 \\
1.03 \mathrm{E}+00 \\
1.61 \mathrm{E}+05 \\
3.04 \mathrm{E}+02 \\
1.28 \mathrm{E}-02 \\
\\
2.69 \mathrm{E}+02 \\
1.83 \mathrm{E}+02 \\
7.34 \mathrm{E}-02 \\
2.17 \mathrm{E}-05 \\
7.43 \mathrm{E}+01 \\
5.3 \mathrm{~F}-11 \\
7.31 \mathrm{E}+03 \\
9.85 \mathrm{E}-01 \\
5.17 \mathrm{E}-02 \\
8.44 \mathrm{E}+00 \\
3.21 \mathrm{E}-03 \\
4.57 \mathrm{E}+02 \\
1.97 \mathrm{E}+00 \\
6.21 \mathrm{E}-01 \\
2.79 \mathrm{E}-02\end{array}$ & & & \\
\hline
\end{tabular}


WHC-SD-WM-TI-774 ReV. 0

TWRS PRIVATIZATION PROCESS TECHNICAL BASELINE

Table B-19 Phase 1 LAW Mass Balance for Batch PC2/19 (6 sheets)

\begin{tabular}{|c|c|c|c|c|c|c|c|c|c|}
\hline $\begin{array}{l}\text { SIRFAM NAME } \\
\text { LIOUID COMRTEMIS }\end{array}$ & 20 & 21 & 22 & 23 & 24 & 25 & 26 & 27 & 28 \\
\hline $\begin{array}{l}\text { Volume (L) } \\
\text { Density }(\mathrm{g} / \mathrm{L})\end{array}$ & $\begin{array}{l}1.81 E+06 \\
1.00 E+03\end{array}$ & & & & $\begin{array}{l}1.1 \mathrm{EE}+06 \\
1.00 \mathrm{E}+03\end{array}$ & $\begin{array}{l}6.26 \mathrm{E}+05 \\
1.00 \mathrm{E}+03\end{array}$ & $\begin{array}{l}6.2 \pi+02 \\
3.34 E+03\end{array}$ & $\begin{array}{l}6.27 E+02 \\
3.34 E+03\end{array}$ & $\begin{array}{l}1.000+06 \\
1.00 E+03\end{array}$ \\
\hline Total Mass Flow (kg) & $1.81 E+06$ & & & & $1.18 \%+06$ & $6.26 \mathrm{E}+05$ & $2.09 E+03$ & $2.09 E+03$ & $1.00 \mathrm{E}+06$ \\
\hline \multicolumn{10}{|l|}{ RADIONuaIDES (Ci) } \\
\hline \begin{tabular}{|l|} 
Cesium \\
Stircntium \\
Technetium \\
TRl]
\end{tabular} & & & & & & & & & \\
\hline
\end{tabular}

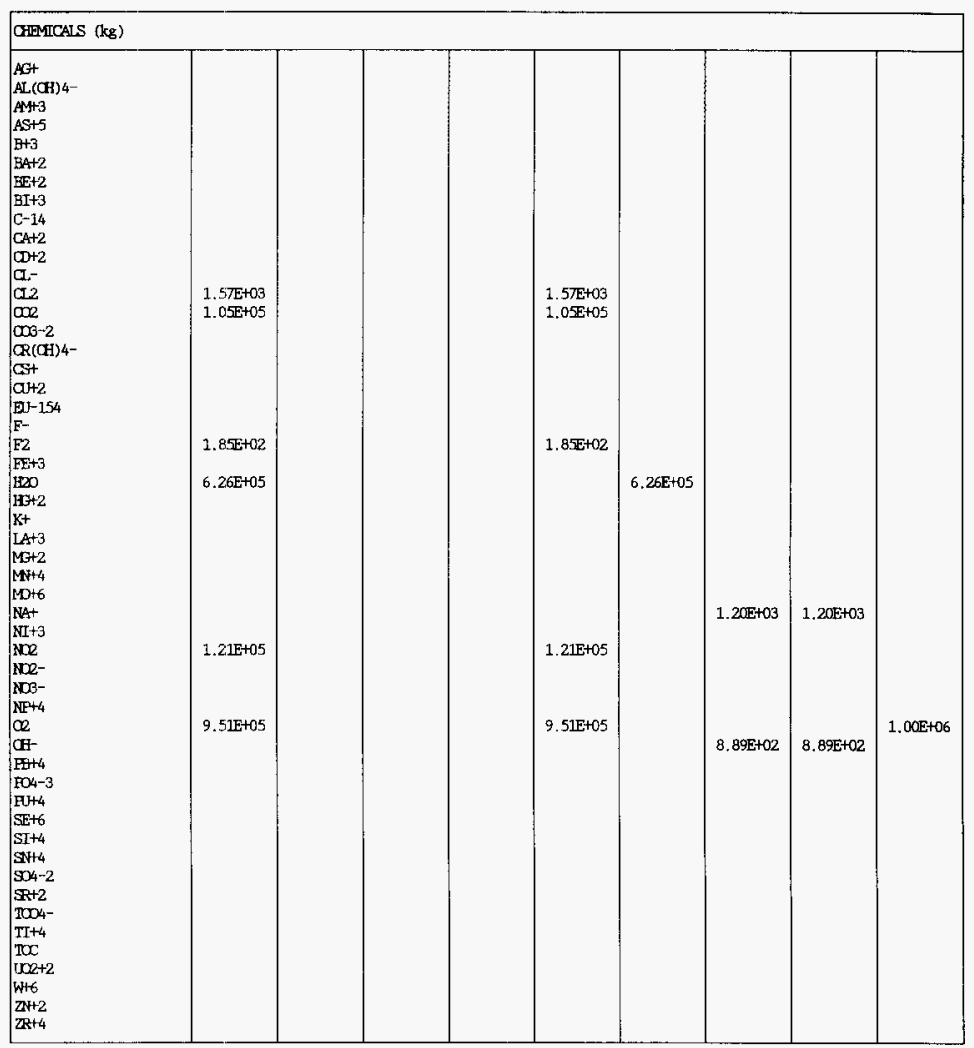


WHC-SD-WM-TI-774 Rev. 0

TWRS PRIVATIZATION PROCESS TECHNICAL BASELINE

Table B-19 Phase 1 IAW Mass Balance for Batch PC2/19 (6 sheets)

\begin{tabular}{|c|c|c|c|c|c|c|c|c|c|}
\hline $\begin{array}{l}\text { STIFEM NAME } \\
\text { SQLID COMONENIS }\end{array}$ & 20 & 21 & 22 & 23 & 24 & 25 & 26 & 27 & 28 \\
\hline Total Mass Flow (kg) & & $1.7 \mathrm{TE}+05$ & $7.78 \mathrm{E}+05$ & $9.54 \mathrm{E}+05$ & & & & & \\
\hline \multicolumn{10}{|l|}{ RADIONUUDIES (C1) } \\
\hline $\begin{array}{l}\text { Cesium } \\
\text { Strantium } \\
\text { Tednetium } \\
\text { TRIJ }\end{array}$ & & $\begin{array}{l}9.16 \mathrm{E}+02 \\
6.11 \mathrm{E}+03 \\
9.16 \mathrm{E}+01 \\
8.12 \mathrm{E}+01\end{array}$ & & $\begin{array}{l}9.16 \mathrm{E}+02 \\
6.11 \mathrm{E}+03 \\
9.16 \mathrm{E}+01 \\
8.12 \mathrm{E}+01\end{array}$ & & & & & \\
\hline \multicolumn{10}{|l|}{ CHEMICALS (kg) } \\
\hline 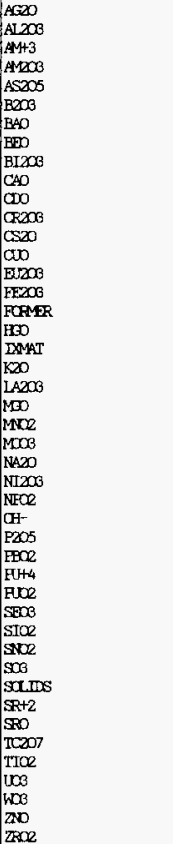 & & $\begin{array}{l}5.59 \mathrm{E}-08 \\
3.25 \mathrm{E}+03 \\
\\
2.53 \mathrm{E}-02 \\
4.60 \mathrm{E}-08 \\
4.87 \mathrm{E}-06 \\
5.59 \mathrm{E}-03 \\
1.86 \mathrm{E}-08 \\
2.82 \mathrm{E}-11 \\
3.69 \mathrm{E}+02 \\
1.38 \mathrm{E}-01 \\
2.84 \mathrm{E}+02 \\
1.12 \mathrm{E}-02 \\
1.13 \mathrm{E}-01 \\
1.26 \mathrm{E}-03 \\
1.0 \mathrm{E}+03 \\
1.30 \mathrm{E}-01 \\
1.74 \mathrm{E}+03 \\
6.26 \mathrm{E}-02 \\
4.14 \mathrm{E}-01 \\
3.80 \mathrm{E}+02 \\
1.03 \mathrm{E}+00 \\
1.61 \mathrm{E}+05 \\
3.04 \mathrm{E}+02 \\
1.28 \mathrm{E}-02 \\
\\
2.6 \mathrm{E}+02 \\
1.83 \mathrm{E}+02 \\
7.34 \mathrm{E}-02 \\
2.17 \mathrm{E}-05 \\
7.43 \mathrm{E}+01 \\
5.3 \mathrm{E}-11 \\
7.31 \mathrm{E}+03 \\
9.8 \mathrm{E}-01 \\
5.17 \mathrm{E}-02 \\
8.44 \mathrm{E}+00 \\
3.21 \mathrm{E}-03 \\
4.57 \mathrm{E}+02 \\
1.97 \mathrm{E}+00 \\
6.21 \mathrm{E}-01 \\
2.79 \mathrm{E}-02\end{array}$ & $7.78 \mathrm{E}+05$ & $\begin{array}{l}5.59 \mathrm{E}-08 \\
3.25 \mathrm{E}+03 \\
\\
2.53 \mathrm{E}-02 \\
4.60 \mathrm{E}-08 \\
4.87 \mathrm{E}-06 \\
5.59 \mathrm{E}-03 \\
1.86 \mathrm{E}-08 \\
2.82 \mathrm{E}-11 \\
3.69 \mathrm{E}+02 \\
1.38 \mathrm{E}-01 \\
2.84 \mathrm{E}+02 \\
1.12 \mathrm{E}-02 \\
1.13 \mathrm{E}-01 \\
1.26 \mathrm{E}-03 \\
1.03 \mathrm{E}+03 \\
7.78 \mathrm{E}+05 \\
1.30 \mathrm{E}-01 \\
1.74 \mathrm{E}+03 \\
6.26 \mathrm{E}-02 \\
4.14 \mathrm{E}-01 \\
3.80 \mathrm{E}+02 \\
1.03 \mathrm{E}+00 \\
1.61 \mathrm{~F}+05 \\
3.04 \mathrm{E}+02 \\
1.28 \mathrm{E}-02 \\
\\
2.69 \mathrm{E}+02 \\
1.83 \mathrm{E}+02 \\
\\
7.34 \mathrm{E}-02 \\
2.17 \mathrm{E}-05 \\
7.43 \mathrm{E}+01 \\
5.35 \mathrm{E}-11 \\
7.31 \mathrm{E}+03 \\
9.85 \mathrm{E}-01 \\
5.17 \mathrm{E}-02 \\
8.44 \mathrm{E}+00 \\
3.21 \mathrm{E}-03 \\
4.5 \mathrm{E}+02 \\
1.97 \mathrm{E}+00 \\
6.21 \mathrm{E}-01 \\
2.79 \mathrm{E}-02\end{array}$ & & & & & \\
\hline
\end{tabular}


WHC-SD-WM-TI-774 ReV. 0

TWRS PRIVATIZATION PROCESS TECHNICAL BASELINE

Table B-20 Phase 1 LAW Mass Balance for Batch PC2/20 (6 sheets)

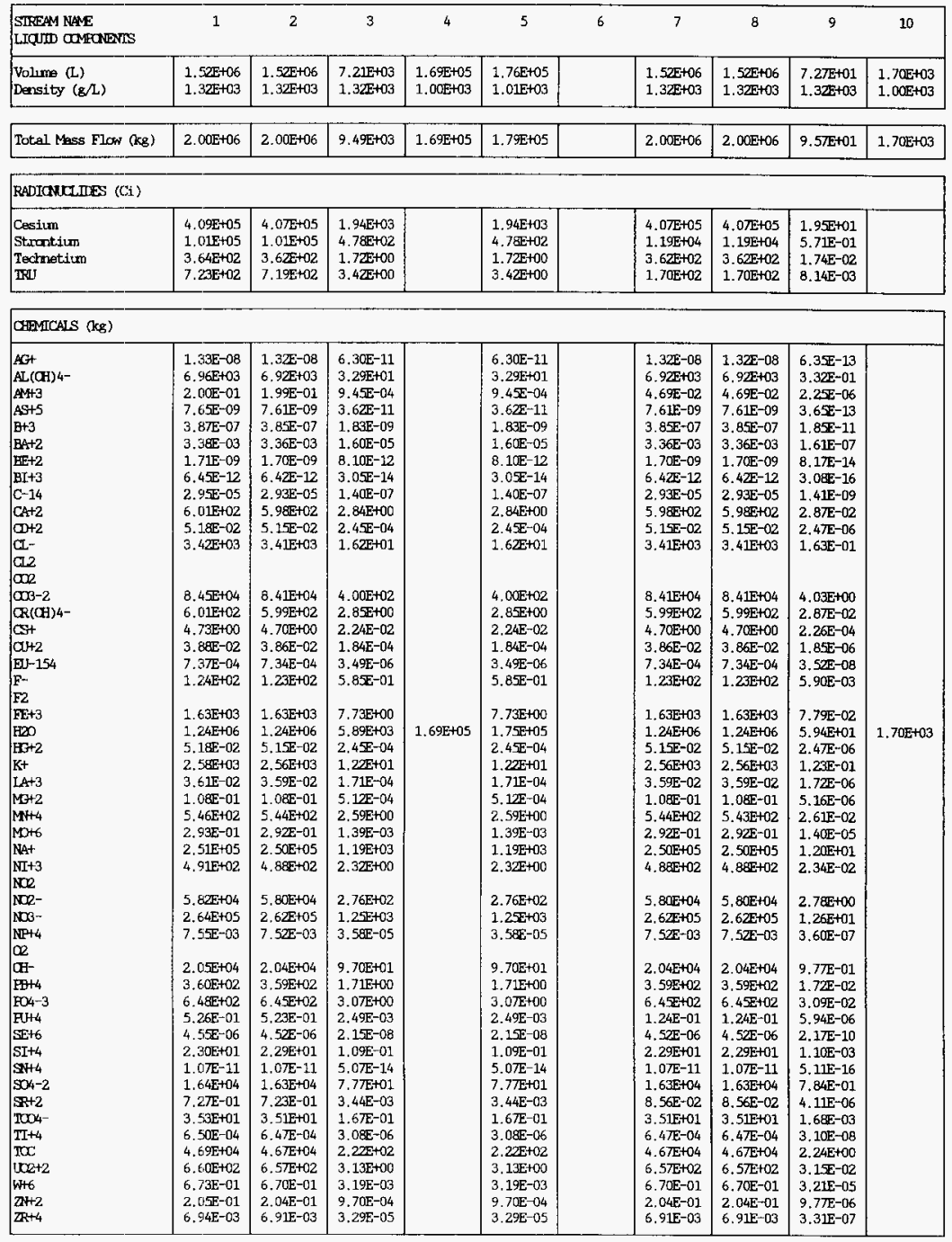


WHC-SD-WM-TI-774 Rev. 0

TWRS PRIVATIZATION PROCESS TECHNICAL BASELINE

Table B-20 Phase 1 LAW Mass Balance for Batch $\mathrm{PC} 2 / 20$ (6 sheets)

\begin{tabular}{|c|c|c|c|c|c|c|c|c|c|c|}
\hline $\begin{array}{l}\text { STREAM NAME } \\
\text { SO.TO COMONENIS }\end{array}$ & 1 & 2 & 3 & 4 & 5 & 6 & 7 & 8 & 9 & 10 \\
\hline Total Mass Flow (kg) & $2.00 E+04$ & $2.00 \mathrm{E}+02$ & $1.98 \mathrm{EE}+04$ & & $1.98 \mathrm{dE}+04$ & & $2.02 \mathrm{z}+02$ & $2.02 \mathrm{E}+00$ & $2.00 \mathrm{E}+02$ & \\
\hline \multicolumn{11}{|l|}{ RADIanuLIDES (CI) } \\
\hline $\begin{array}{l}\text { Cesium } \\
\text { Strantium } \\
\text { Technetium } \\
\text { TKN }\end{array}$ & & & & & & & $\begin{array}{l}8.86 E+04 \\
5.50 E+02\end{array}$ & $\begin{array}{l}8.86 \mathrm{E}+02 \\
5.50 \mathrm{E}+00\end{array}$ & $\begin{array}{l}8.77 E+04 \\
5.44 E+02\end{array}$ & \\
\hline \multicolumn{11}{|l|}{ GIEMCALS (kB) } \\
\hline 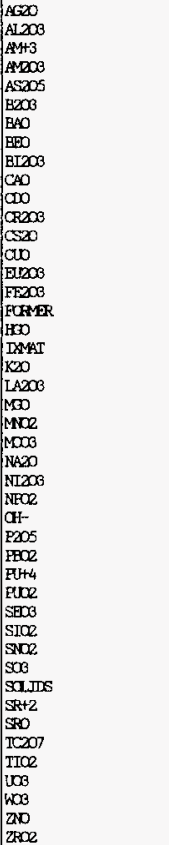 & 2.00E+04 & $2.00 \mathbb{E}+02$ & $1.98 \mathrm{EE}+04$ & & $1.98 \mathrm{E}+04$ & & $\begin{array}{l}1.52 E-01 \\
\\
3.8 \pi-01 \\
3.99 E=01 \\
2.00 E+02 \\
6.38 E-01\end{array}$ & $\begin{array}{l}3.87 \mathrm{E}-03 \\
3.99 \mathrm{E}-03 \\
\\
2.00 \mathrm{E}+00 \\
6.38 \mathrm{E}-03\end{array}$ & $\begin{array}{l} \\
\text { 3.83E-01 } \\
3.95 E-01 \\
\\
1.98 E+02 \\
6.31 E-01\end{array}$ & \\
\hline
\end{tabular}


WHC-SD-WM-TI-774 Rev. 0

\section{TWRS PRIVATIZATION PROCESS TECHNICAL BASELINE}

Table B-20 Phase 1 LAW Mass Balance for Batch PC2/20 (6 sheets)

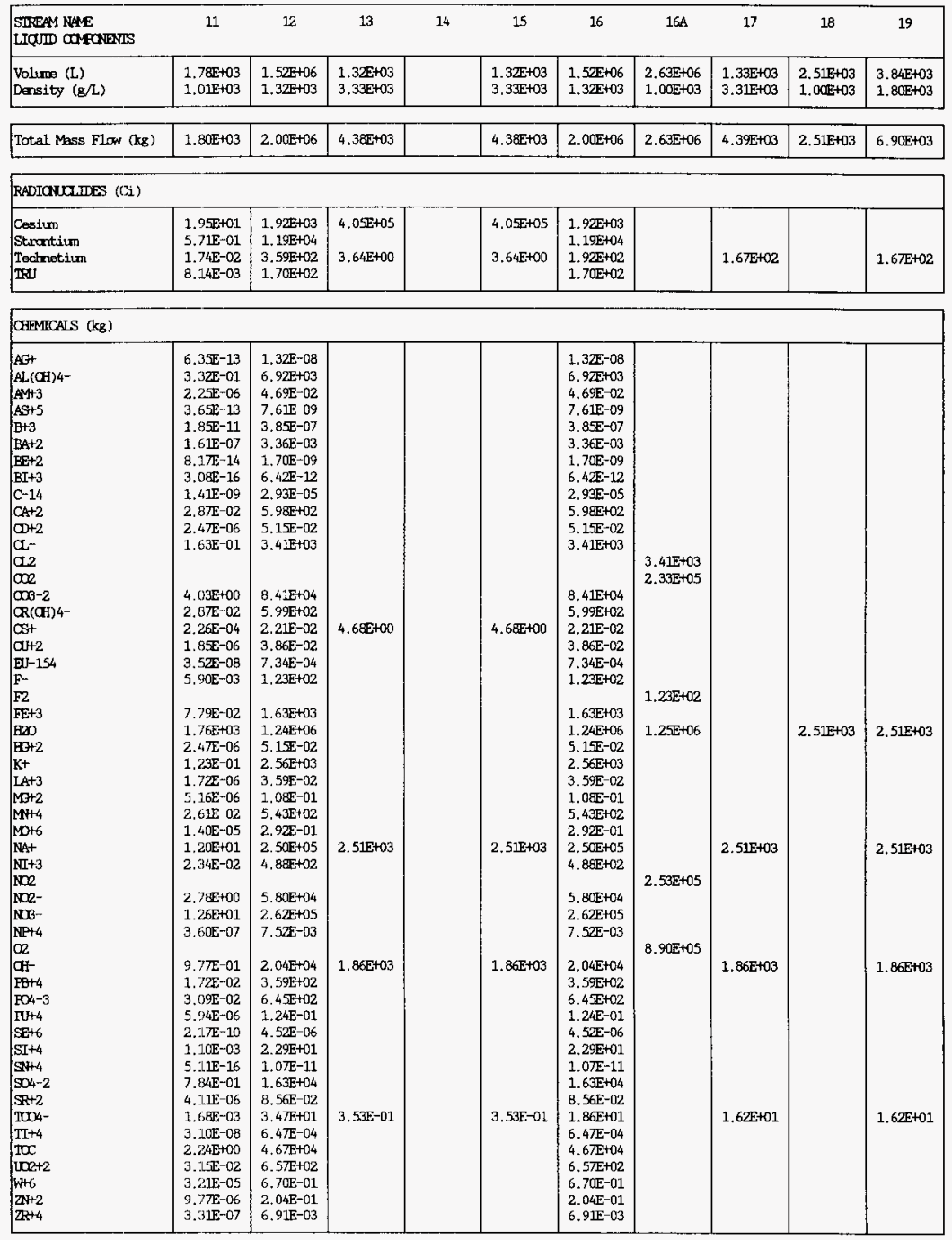


WHC-SD-WM-TI-774 Rev. 0

TWRS PRIVATIZATION PROCESS TECHNICAL BASELINE

Table B-20 Phase 1 LAW Mass Balance for Batch PC2/20 (6 sheets)

\begin{tabular}{|c|c|c|c|c|c|c|c|c|c|c|}
\hline $\begin{array}{l}\text { SIREAM NAME } \\
\text { SL.ID OMFONENS }\end{array}$ & 11 & 12 & 13 & 14 & 15 & 16 & $16 \mathrm{~A}$ & 17 & 18 & 19 \\
\hline Total Mass Flow $(\mathrm{kg})$ & $2.00 \mathrm{E}+02$ & $2.02 \mathrm{E}+00$ & & $2.51 E+03$ & $2.51 E+03$ & $2.02 \mathrm{E}+00$ & $3.65 E+05$ & & & \\
\hline \multicolumn{11}{|l|}{ RADIancines (Ci) } \\
\hline $\begin{array}{l}\text { Cesium } \\
\text { Strantiun } \\
\text { Technetiun } \\
\text { TRIJ }\end{array}$ & $\begin{array}{l}8.77 \mathrm{E}+04 \\
5.44 \mathrm{E}+02\end{array}$ & $\begin{array}{l}8.86 \mathrm{E}+02 \\
5.50 \mathrm{E}+00\end{array}$ & & & & $\begin{array}{l}8.86 E+02 \\
5.50 E+00\end{array}$ & $\begin{array}{l}1.92 E+03 \\
1.28 E+04 \\
1.92 E+02 \\
1.70 E+02\end{array}$ & & & \\
\hline \multicolumn{11}{|l|}{ CEMMCALS (kg) } \\
\hline 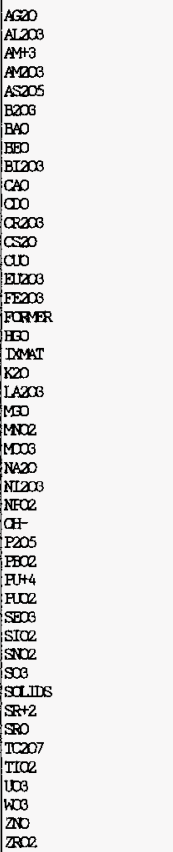 & $\begin{array}{l}3.83 \mathrm{E}-01 \\
3.9 \mathrm{E}-01 \\
\\
1.9 \mathrm{gE}+02 \\
6.31 \mathrm{E}-01\end{array}$ & $\begin{array}{l}3.8 \mathrm{E}-03 \\
3.99 \mathrm{E}-03 \\
\\
2.00 \mathrm{E}+00 \\
6.38 \mathrm{E}-03\end{array}$ & & $2.51 E+03$ & $2.51 E+03$ & $\begin{array}{l}3.8 \pi-0.3 \\
3.99 \mathrm{E}-03 \\
2.00 \mathrm{E}+00 \\
6.38 \mathrm{E}-03\end{array}$ & $\begin{array}{l}1.42 \mathrm{E}-08 \\
3.71 \mathrm{E}+03 \\
5.32 \mathrm{E}-02 \\
1.17 \mathrm{E}-08 \\
1.24 \mathrm{E}-06 \\
3.7 \mathrm{E}-03 \\
4.73 \mathrm{E}-09 \\
7.15 \mathrm{E}-12 \\
8.36 \mathrm{E}+02 \\
5.88 \mathrm{E}-02 \\
3.79 \mathrm{E}+02 \\
2.34 \mathrm{E}-02 \\
4.83 \mathrm{E}-02 \\
8.49 \mathrm{E}-04 \\
2.32 \mathrm{E}+03 \\
\\
5.56 \mathrm{E}-02 \\
\\
3.09 \mathrm{E}+03 \\
4.22 \mathrm{E}-02 \\
1.78 \mathrm{E}-01 \\
8.60 \mathrm{E}+02 \\
4.3 \mathrm{E}-01 \\
3.37 \mathrm{E}+05 \\
6.88 \mathrm{E}+02 \\
8.53 \mathrm{E}-03 \\
\\
4.82 \mathrm{E}+02 \\
4.14 \mathrm{E}+02 \\
1.4 \mathrm{E}-01 \\
7.27 \mathrm{E}-01 \\
4.89 \mathrm{E}+01 \\
1.35 \mathrm{E}-11 \\
1.36 \mathrm{E}+04 \\
2.00 \mathrm{E}+00 \\
1.08 \mathrm{E}-01 \\
1.77 \mathrm{E}+01 \\
1.08 \mathrm{E}-03 \\
6.96 \mathrm{E}+02 \\
8.4 \mathrm{E}-01 \\
2.54 \mathrm{E}-01 \\
9.33 \mathrm{E}-03\end{array}$ & & & \\
\hline
\end{tabular}


WHC-SD-WM-TI-774 Rev. 0

TWRS PRIVATIZATION PROCESS TECHNICAL BASELINE

Table B-20 Phase 1 IAW Mass Balance for Batch FC2/20 (6 sheets)

\begin{tabular}{|c|c|c|c|c|c|c|c|c|c|}
\hline $\begin{array}{l}\text { SIREAM NAME } \\
\text { LIQUID COMFONDIS }\end{array}$ & 20 & 21 & 22 & 23 & 24 & 25 & 26 & 27 & 28 \\
\hline $\begin{array}{l}\text { Volume (L) } \\
\text { Density }(g / L)\end{array}$ & $\begin{array}{l}2.63 \mathrm{E}+05 \\
1.00 \mathrm{E}+03\end{array}$ & & & & $\begin{array}{l}1.3 \mathrm{BE}+06 \\
1.00 E+0.3\end{array}$ & $\begin{array}{l}1.25 \mathrm{E}+06 \\
1.00 \mathrm{E}+03\end{array}$ & $\begin{array}{l}\text { 1. } 31 E+03 \\
3.34 E+03\end{array}$ & $\begin{array}{l}\text { 1. } 31 E+03 \\
3.34 E+03\end{array}$ & $\begin{array}{l}\text { 1. } 00 \mathrm{E}+06 \\
\text { 1. } 00 \mathrm{E}+03\end{array}$ \\
\hline Total Mass Flaw (kg) & 2.63E+05 & & & & 1.3SE+06 & 1.2SE+06 & $4.3 \%+03$ & 4. $38 \mathrm{EE}+03$ & 1. $00 \mathrm{E}+06$ \\
\hline \multicolumn{10}{|l|}{ RADIONOLIIDES (Ci) } \\
\hline $\begin{array}{l}\text { Cosium } \\
\text { Strontium } \\
\text { Technetitm } \\
\text { TRU }\end{array}$ & & & & & & & & & \\
\hline
\end{tabular}

\begin{tabular}{|c|c|c|c|c|c|c|}
\hline \multicolumn{7}{|c|}{ CreMICALS (kg) } \\
\hline 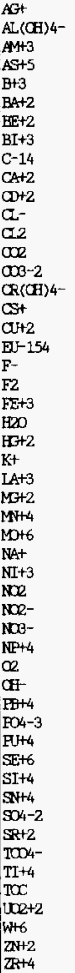 & $\begin{array}{l}3.41 \mathrm{E}+03 \\
2.33 \mathrm{E}+05 \\
1.23 \mathrm{E}+02 \\
1.2 \mathrm{EE}+06\end{array}$ & $\begin{array}{l}3.41 E+03 \\
2.33 E+05 \\
1.23 E+02 \\
\end{array}$ & $1.25 \mathrm{E}+06$ & $\begin{array}{l}2.51 \mathrm{E}+03 \\
1.86 \mathrm{E}+03\end{array}$ & $\begin{array}{l}2.51 E+03 \\
1.86 E+03\end{array}$ & $1.00 E+06$ \\
\hline
\end{tabular}


WHC-SD-WM-TI-774 Rev. 0

TWRS PRIVATIZATION PROCESS TECHNICAL BASELINE

Table B-20 Phase 1 IAW Mass Balance for Batch PC2/20 (6 sheets)

\begin{tabular}{|c|c|c|c|c|c|c|c|c|c|}
\hline $\begin{array}{l}\text { SIRFAM NAME } \\
\text { SUD DOFONENIS }\end{array}$ & 20 & 21 & 22 & 23 & 24 & 25 & 26 & 27 & 28 \\
\hline Total Mass Flow (kg) & & $3.65 \mathrm{EE}+05$ & $1.63 E+06$ & $2.00 E+06$ & & & & & \\
\hline \multicolumn{10}{|l|}{ RADIONUCLIDES (Ci) } \\
\hline $\begin{array}{l}\text { Cesium } \\
\text { Strcantium } \\
\text { Technetium } \\
\text { TRS }\end{array}$ & & $\begin{array}{l}1.92 \mathrm{E}+03 \\
1.25 \mathrm{E}+04 \\
1.92 \mathrm{E}+02 \\
1.70 \mathrm{E}+02\end{array}$ & & $\begin{array}{l}1.92 \mathrm{E}+03 \\
1.28 \mathrm{E}+04 \\
1.92 \mathrm{E}+02 \\
1.70 \mathrm{E}+02\end{array}$ & & & & & \\
\hline \multicolumn{10}{|l|}{ OHEMCALS (kg) } \\
\hline 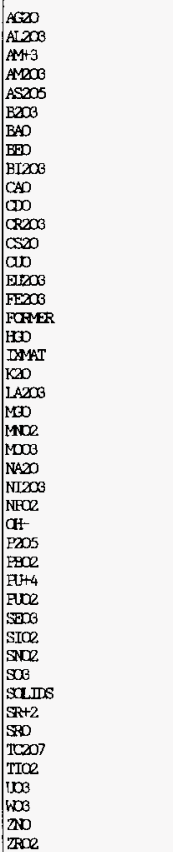 & & 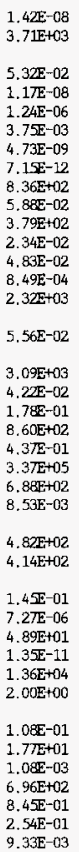 & $1.63 \mathrm{E}+06$ & $\begin{array}{l}1.42 \mathrm{E}-08 \\
3.71 \mathrm{E}+03 \\
\\
5.32 \mathrm{E}-02 \\
1.1 \mathrm{E}-08 \\
1.24 \mathrm{E}-06 \\
3.75 \mathrm{E}-03 \\
4.73 \mathrm{E}-09 \\
7.15 \mathrm{E}-12 \\
8.36 \mathrm{E}+02 \\
5.88 \mathrm{EE}-02 \\
3.79 \mathrm{E}+02 \\
2.34 \mathrm{E}-02 \\
4.83 \mathrm{E}-02 \\
8.49 \mathrm{E}-04 \\
2.32 \mathrm{E}+03 \\
1.63 \mathrm{E}+06 \\
5.56 \mathrm{E}-02 \\
\\
3.09 \mathrm{E}+03 \\
4.22 \mathrm{E}-02 \\
1.78 \mathrm{E}-01 \\
8.60 \mathrm{E}+02 \\
4.3 \mathrm{E}-01 \\
3.37 \mathrm{E}+05 \\
6.88 \mathrm{E}+02 \\
8.53 \mathrm{E}-03 \\
\\
4.82 \mathrm{E}+02 \\
4.14 \mathrm{E}+02 \\
1.4 \mathrm{EE}-01 \\
7.27 \mathrm{E}-06 \\
4.89 \mathrm{E}+01 \\
1.35 \mathrm{E}-11 \\
1.36 \mathrm{E}+04 \\
2.00 \mathrm{E}+00 \\
1.08 \mathrm{E}-01 \\
1.77 \mathrm{E}+01 \\
1.08 \mathrm{E}-03 \\
6.96 \mathrm{E}+02 \\
8.4 \mathrm{E}-01 \\
2.54 \mathrm{E}-01 \\
9.33 \mathrm{E}-03\end{array}$ & & & & & \\
\hline
\end{tabular}


WHC-SD-WM-TI-774 Rev. 0

TWRS PRIVATIZATION PROCESS TECHNICAL BASELINE

Table B-21 Phase 1 LAW Mass Balance for Batch PC2/21 (6 sheets)

\begin{tabular}{|c|c|c|c|c|c|c|c|c|c|c|}
\hline $\begin{array}{l}\text { SIRFAM NAME } \\
\text { LIQID CIMCNDMIS }\end{array}$ & 1 & 2 & 3 & 4 & 5 & 6 & 7 & 8 & 9 & 10 \\
\hline $\begin{array}{l}\text { Volume }(L) \\
\text { Density }(g / L)\end{array}$ & $\begin{array}{l}2.97 E+06 \\
1.32 E+03\end{array}$ & $\begin{array}{l}2.95 \mathrm{E}+06 \\
1.31 \mathrm{E}+03\end{array}$ & $\begin{array}{l}1.40 \mathrm{E}+04 \\
1.31 \mathrm{E}+03\end{array}$ & $\begin{array}{l}\text { 3. } 29 \mathrm{E}+05 \\
\text { 1. } 00 \mathrm{E}+03\end{array}$ & $\begin{array}{l}3.43 \mathrm{E}+05 \\
1.01 \mathrm{E}+03\end{array}$ & & $\begin{array}{l}2.95 \mathrm{E}+06 \\
1.31 \mathrm{E}+03\end{array}$ & $\begin{array}{l}2.95 \mathrm{E}+06 \\
1.31 \mathrm{E}+03\end{array}$ & $\begin{array}{l}1.40 \mathrm{E}+02 \\
1.31 \mathrm{E}+03\end{array}$ & $\begin{array}{l}3.30 E+03 \\
1.00 E+03\end{array}$ \\
\hline Total Mass Flow (kg) & 3.89F+06 & $3.88 E+06$ & $1.83 \mathrm{E}+04$ & $3.29 \mathrm{E}+05$ & $3.4 \pi+05$ & & 3. $88 \mathrm{E}+06$ & $3.88 E+06$ & 1. $84 E+02$ & $3.30 E+03$ \\
\hline \multicolumn{11}{|l|}{ RADIONLCLICS (Ci) } \\
\hline $\begin{array}{l}\text { Cesium } \\
\text { Strontiun } \\
\text { Tedmetiun } \\
\text { TRU }\end{array}$ & $\begin{array}{l}4.94 \mathrm{E}+05 \\
1.49 \mathrm{E}+05 \\
5.81 \mathrm{E}+02 \\
3.22 \mathrm{E}+02\end{array}$ & $\begin{array}{l}4.92 \mathrm{E}+0.5 \\
1.48 \mathrm{E}+05 \\
5.78 \mathrm{EE}+02 \\
3.21 \mathrm{E}+02\end{array}$ & $\begin{array}{l}2.33 E+03 \\
7.01 E+02 \\
2.73 E+00 \\
1.52 E+00\end{array}$ & & $\begin{array}{l}2.33 \mathrm{E}+03 \\
7.01 \mathrm{E}+02 \\
2.73 \mathrm{E}+00 \\
1.52 \mathrm{E}+\infty\end{array}$ & & $\begin{array}{l}4.92 \mathrm{EE}+05 \\
2.38 E+04 \\
5.78 E+02 \\
3.21 E+02\end{array}$ & $\begin{array}{l}\text { 4. } 92 \mathrm{E}+05 \\
2.38 \mathrm{EE}+04 \\
5.7 \mathrm{BE}+02 \\
3.21 \mathrm{E}+02\end{array}$ & $\begin{array}{l}2.33 \mathrm{E}+01 \\
1.13 \mathrm{E}+00 \\
2.74 \mathrm{E}-02 \\
1.52 \mathrm{E}-02\end{array}$ & \\
\hline \multicolumn{11}{|l|}{ AFMICALS (kg) } \\
\hline 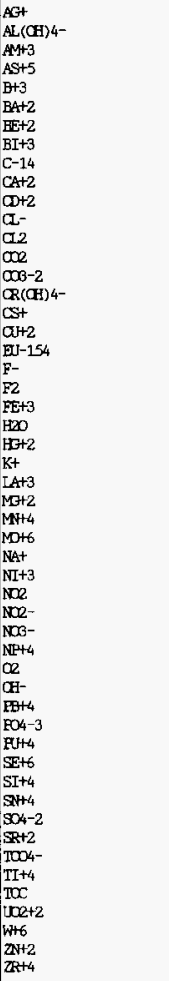 & $\begin{array}{l}1.26 \mathrm{E}+05 \\
1.21 \mathrm{E}+03 \\
5.70 \mathrm{E}+00 \\
4.14 \mathrm{E}-03 \\
5.30 \mathrm{E}-03 \\
3.6 \mathrm{E}+03 \\
1.9 \mathrm{EE}+02 \\
2.49 \mathrm{E}+06 \\
5.52 \mathrm{E}-03 \\
7.0 \mathrm{E}+03 \\
4.0 \mathrm{E}-03 \\
1.16 \mathrm{E}-02 \\
6.60 \mathrm{E}+01 \\
3.12 \mathrm{E}-02 \\
4.92 \mathrm{E}+05 \\
6.69 \mathrm{E}+02 \\
1.5 \mathrm{E}+05 \\
4.15 \mathrm{E}+05 \\
8.53 \mathrm{E}-04 \\
2.10 \mathrm{E}+04 \\
4.36 \mathrm{E}+01 \\
8.62 \mathrm{E}+03 \\
1.82 \mathrm{E}+00 \\
4.62 \mathrm{E}-07 \\
2.59 \mathrm{E}+00 \\
1.61 \mathrm{E}-12 \\
2.69 \mathrm{E}+04 \\
1.617 \mathrm{E}+00 \\
5.63 \mathrm{E}+01 \\
6.61 \mathrm{E}-05 \\
5.12 \mathrm{E}+04 \\
7.66 \mathrm{E}+01 \\
7.18 \mathrm{E}-02 \\
2.17 \mathrm{E}-02 \\
7.06 \mathrm{E}-04\end{array}$ & $\begin{array}{l}1.26 E+05 \\
1.20 E+03 \\
5.68 E+00 \\
4.12 E-03 \\
5.27 E-03 \\
3.61 E+03 \\
1.97 E+02 \\
2.48 E+06 \\
5.50 E-03 \\
7.03 E+03 \\
4.05 E-03 \\
1.15 E-02 \\
6.57 E+01 \\
3.10 E-02 \\
4.89 E+05 \\
6.66 E+02 \\
1.51 E+05 \\
4.13 E+05 \\
8.49 E-04 \\
2.09 E+04 \\
4.34 E+01 \\
8.58 E+03 \\
1.81 E+00 \\
4.60 E-07 \\
2.58 E+00 \\
1.01 E-12 \\
2.67 E+04 \\
1.07 E+00 \\
5.60 E+01 \\
6.58 E-05 \\
5.09 E+04 \\
7.84 E+01 \\
7.15 E-02 \\
2.16 E-02 \\
7.03 E-04\end{array}$ & $\begin{array}{l}5.94 \mathrm{E}+02 \\
5.70 \mathrm{E}+00 \\
2.69 \mathrm{E}-02 \\
1.95 \mathrm{E}-05 \\
2.49 \mathrm{E}-05 \\
1.71 \mathrm{E}+01 \\
9.32 \mathrm{E}-01 \\
1.17 \mathrm{E}+04 \\
2.60 \mathrm{E}-05 \\
3.33 \mathrm{E}+01 \\
1.92 \mathrm{E}-05 \\
5.4 \mathrm{E}-05 \\
3.11 \mathrm{E}-01 \\
1.47 \mathrm{E}-04 \\
2.32 \mathrm{E}+03 \\
3.15 \mathrm{E}+00 \\
7.16 \mathrm{E}+02 \\
1.95 \mathrm{E}+03 \\
4.02 \mathrm{E}-06 \\
\\
9.89 \mathrm{E}+01 \\
2.05 \mathrm{E}-01 \\
4.06 \mathrm{E}+01 \\
8.57 \mathrm{E}-03 \\
2.18 \mathrm{E}-09 \\
1.22 \mathrm{E}-02 \\
4.76 \mathrm{E}-15 \\
1.27 \mathrm{E}+02 \\
5.04 \mathrm{E}-03 \\
2.65 \mathrm{E}-01 \\
3.11 \mathrm{E}-07 \\
2.41 \mathrm{E}+02 \\
3.71 \mathrm{E}-01 \\
3.38 \mathrm{E}-04 \\
1.02 \mathrm{E}-04 \\
3.32 \mathrm{E}-06\end{array}$ & $3.29 \mathrm{E}+05$ & $\begin{array}{l}5.94 \mathrm{E}+02 \\
5.70 \mathrm{E}+00 \\
2.69 \mathrm{E}-02 \\
1.95 \mathrm{E}-05 \\
2.49 \mathrm{E}-05 \\
1.71 \mathrm{E}+01 \\
9.32 \mathrm{E}-01 \\
3.41 \mathrm{E}+05 \\
2.60 \mathrm{E}-05 \\
3.33 \mathrm{E}+01 \\
1.92 \mathrm{E}-05 \\
5.42 \mathrm{E}-05 \\
3.11 \mathrm{E}-01 \\
1.47 \mathrm{E}-04 \\
2.32 \mathrm{E}+03 \\
3.15 \mathrm{E}+00 \\
7.16 \mathrm{E}+02 \\
1.95 \mathrm{E}+03 \\
4.02 \mathrm{E}-06 \\
\\
9.89 \mathrm{E}+01 \\
2.05 \mathrm{E}-01 \\
4.06 \mathrm{E}+01 \\
8.57 \mathrm{E}-03 \\
2.18 \mathrm{E}-09 \\
1.22 \mathrm{~F}-02 \\
4.76 \mathrm{E}-15 \\
1.27 \mathrm{E}+02 \\
5.04 \mathrm{E}-03 \\
2.6 \mathrm{E}-01 \\
3.11 \mathrm{E}-07 \\
2.41 \mathrm{E}+02 \\
3.71 \mathrm{E}-01 \\
3.38 \mathrm{E}-04 \\
1.02 \mathrm{E}-04 \\
3.32 \mathrm{E}-06\end{array}$ & & $\begin{array}{l}1.26 E+05 \\
1.20 E+03 \\
5.68 E+00 \\
4.12 E-03 \\
5.27 E-03 \\
3.61 E+03 \\
1.97 E+02 \\
2.48 E+06 \\
5.50 E-03 \\
7.03 E+03 \\
4.06 E-03 \\
1.15 E-02 \\
6.57 E+01 \\
3.10 E-02 \\
4.89 E+05 \\
6.66 E+02 \\
1.51 E+05 \\
4.13 E+05 \\
8.49 E-04 \\
2.09 E+04 \\
4.34 E+01 \\
8.58 E+03 \\
1.81 E+00 \\
4.60 E-07 \\
2.58 E+00 \\
1.01 E-12 \\
2.67 E+04 \\
1.71 E-01 \\
5.60 E+01 \\
6.58 E-05 \\
5.09 E+04 \\
7.84 E+01 \\
7.15 E-02 \\
2.16 E-02 \\
7.03 E-04\end{array}$ & $\begin{array}{l}1.26 \mathrm{E}+05 \\
1.20 \mathrm{E}+03 \\
5.68 \mathrm{E}+00 \\
4.12 \mathrm{E}-03 \\
5.27 \mathrm{E}-03 \\
3.61 \mathrm{E}+03 \\
1.97 \mathrm{E}+02 \\
2.48 \mathrm{E}+06 \\
5.50 \mathrm{E}-03 \\
7.03 \mathrm{E}+03 \\
4.06 \mathrm{E}-03 \\
1.15 \mathrm{E}-02 \\
6.57 \mathrm{E}+01 \\
3.10 \mathrm{E}-02 \\
4.89 \mathrm{E}+05 \\
6.66 \mathrm{E}+02 \\
\\
1.51 \mathrm{E}+05 \\
4.13 \mathrm{E}+05 \\
8.49 \mathrm{E}-04 \\
\\
2.09 \mathrm{E}+04 \\
4.34 \mathrm{E}+01 \\
8.58 \mathrm{E}+03 \\
1.81 \mathrm{E}+00 \\
4.60 \mathrm{E}-07 \\
2.58 \mathrm{E}+00 \\
1.01 \mathrm{E}-12 \\
2.67 \mathrm{E}+04 \\
1.71 \mathrm{E}-01 \\
5.60 \mathrm{E}+01 \\
6.58 \mathrm{E}-05 \\
5.09 \mathrm{E}+04 \\
7.84 \mathrm{E}+01 \\
7.15 \mathrm{E}-02 \\
2.16 \mathrm{E}-02 \\
7.03 \mathrm{E}-04\end{array}$ & $\begin{array}{l}5.92 \mathrm{E}-14 \\
4.33 \mathrm{E}+00 \\
2.62 \mathrm{E}-06 \\
3.41 \mathrm{E}-14 \\
1.73 \mathrm{E}-12 \\
1.81 \mathrm{E}-08 \\
7.63 \mathrm{E}-15 \\
2.88 \mathrm{E}-17 \\
3.36 \mathrm{E}-07 \\
3.9 \mathrm{E}-02 \\
2.61 \mathrm{E}-07 \\
3.3 \mathrm{EE}-01 \\
\\
5.96 \mathrm{E}+00 \\
5.71 \mathrm{E}-02 \\
2.69 \mathrm{E}-04 \\
1.96 \mathrm{E}-07 \\
2.50 \mathrm{E}-07 \\
1.71 \mathrm{E}-01 \\
9.3 \mathrm{E}-03 \\
1.18 \mathrm{E}+02 \\
2.61 \mathrm{E}-07 \\
3.34 \mathrm{E}-01 \\
1.93 \mathrm{E}-07 \\
5.47 \mathrm{E}-07 \\
3.12 \mathrm{E}-03 \\
1.47 \mathrm{E}-06 \\
2.32 \mathrm{E}+01 \\
3.16 \mathrm{E}-02 \\
7.18 \mathrm{E}+00 \\
1.96 \mathrm{E}+01 \\
4.03 \mathrm{E}-08 \\
3.72 \mathrm{E}-03 \\
1.02 \mathrm{E}-06 \\
3.33 \mathrm{E}-08 \\
2.92 \mathrm{E}-01 \\
2.06 \mathrm{E}-03 \\
4.07 \mathrm{E}-01 \\
8.60 \mathrm{E}-05 \\
2.18 \mathrm{E}-11 \\
1.22 \mathrm{E}-04 \\
4.77 \mathrm{E}-17 \\
1.27 \mathrm{E}+00 \\
8.11 \mathrm{E}-06 \\
3.12 \mathrm{E}-03 \\
3.42 \mathrm{E}+00 \\
3\end{array}$ & $3.30 \mathbf{E}+03$ \\
\hline
\end{tabular}


WHC-SD-WM-TI-774 Rev. 0

TWRS PRIVATIZATION PROCESS TECHNICAL BASELINE

Table B-21 Phase 1 IAW Mass Balance for Batch PC2/21 (6 sheets)

\begin{tabular}{|c|c|c|c|c|c|c|c|c|c|c|}
\hline $\begin{array}{l}\text { SIREAM NAE } \\
\text { SA-D CAEANENIS }\end{array}$ & 1 & 2 & 3 & 4 & 5 & 6 & 7 & 8 & 9 & 10 \\
\hline Total Mass Flow (kg) & $3.90 \mathrm{E}+04$ & $3.90 E+02$ & $3.86 E+04$ & & $3.86 E+04$ & & $3.91 E+02$ & 3.91E+00 & $3,8 \pi+102$ & \\
\hline \multicolumn{11}{|l|}{ RADIONCD.MES (Ci) } \\
\hline $\begin{array}{l}\text { Cesium } \\
\text { Struntium } \\
\text { Tectretium } \\
\text { TRI }\end{array}$ & & & & & & & $1.22 E+05$ & 1.2.E+03 & 1.23E+0.5 & \\
\hline \multicolumn{11}{|l|}{ OAFMMICAIS (kg) } \\
\hline 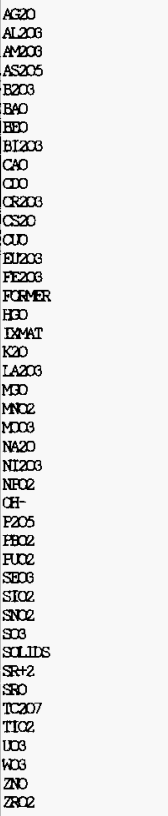 & $3.90 \mathrm{E}+04$ & $3.90 E+02$ & $3.86 E+04$ & & $3.86 E+04$ & & 3. $38 \mathrm{E}-01$ & $3.38 z-03$ & $\begin{array}{l}3.35 \mathrm{E}-01 \\
\\
3.86 \mathrm{E}+02 \\
8.8 \mathrm{E}-01\end{array}$ & \\
\hline
\end{tabular}


WHC-SD-WM-TI-774 Rev. 0

TWRS PRIVATIZATION PROCESS TECHNICAL BASELINE

Table B-21 Ptase 1 IAW Mass Balance for Batch PC2/21 (6 sheets)

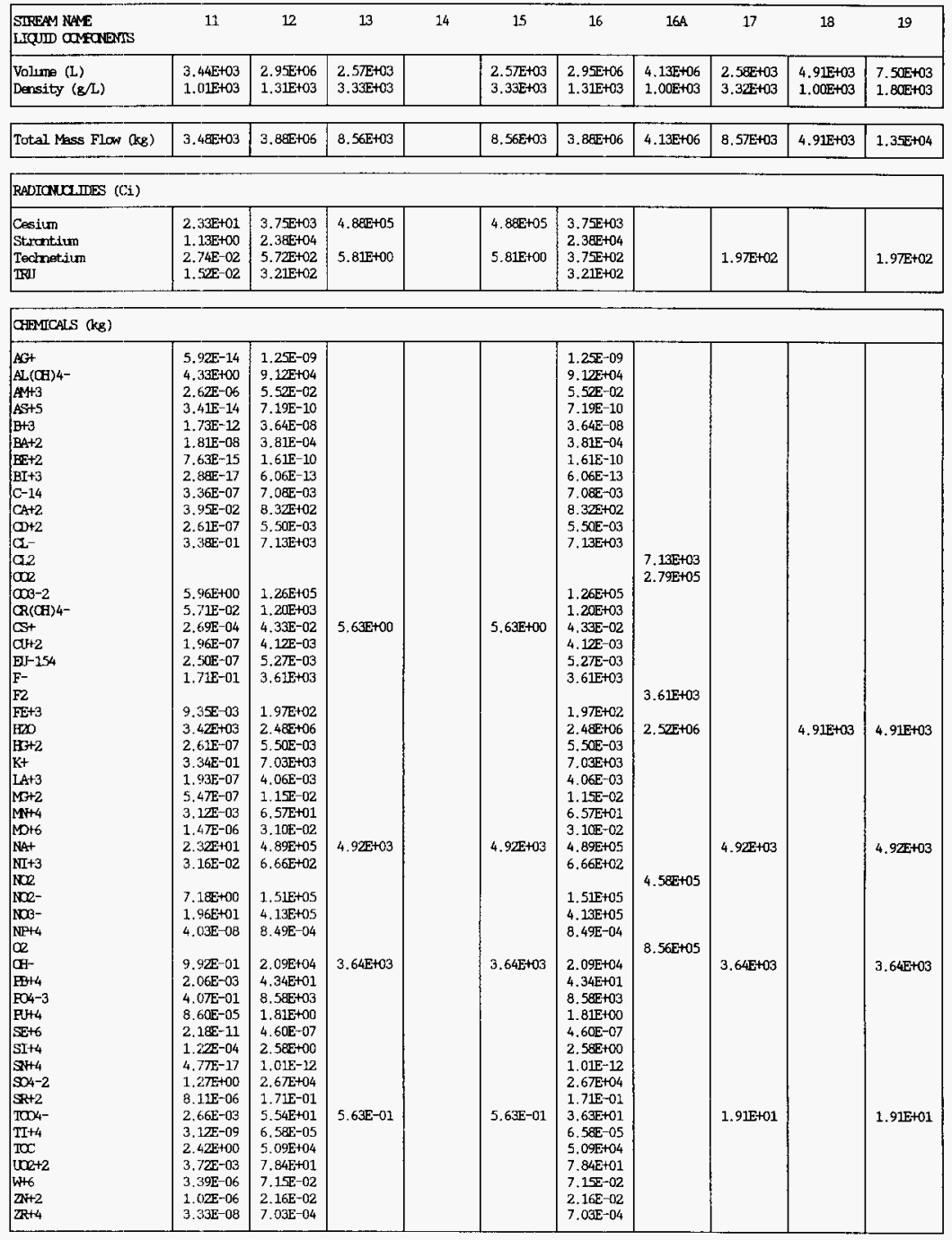


WHC-SD-WM-TI-774 ReV. 0

TWRS PRIVATIZATION PROCESS TECHNICAL BASELINE

Table B-21 Phase 1 LAW Mass Balance for Batch PC2/21 ( 6 sheets)

\begin{tabular}{|c|c|c|c|c|c|c|c|c|c|c|}
\hline $\begin{array}{l}\text { SIREAM NAME } \\
\text { SOLID CMFANENE }\end{array}$ & 11 & 12 & 13 & 14 & 15 & 16 & 16A & 17 & 18 & 19 \\
\hline Total Mass Flow (kg) & $3.87 \mathrm{E}+02$ & $3.91 \mathrm{E}+00$ & & 4. $92 \mathrm{E}+03$ & 4. $922 E+03$ & $3.91 \mathrm{E}+00$ & $7.49 E+05$ & & & \\
\hline \multicolumn{11}{|l|}{ 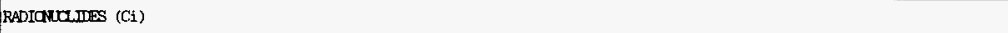 } \\
\hline $\begin{array}{l}\text { Cesium } \\
\text { Strintium } \\
\text { Technetium } \\
\text { THI }\end{array}$ & $1.23 \mathrm{E}+05$ & $1.25 \mathrm{E}+03$ & & & & $1.2 \mathrm{EE}+03$ & $\begin{array}{l}\text { 3. } 7 E E+03 \\
2.50 E+04 \\
3.7 F+02 \\
3.19 E+02\end{array}$ & & & \\
\hline \multicolumn{11}{|l|}{ GEMICALS (kg) } \\
\hline 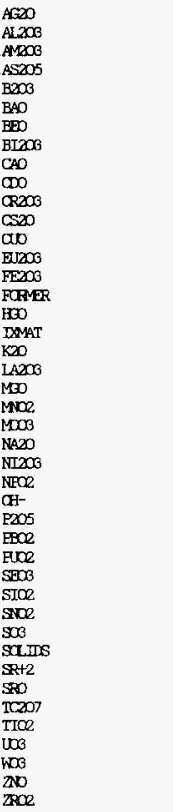 & $\begin{array}{l}3.35-01 \\
\\
3.86 E+02 \\
8.87 \mathrm{E}-01\end{array}$ & $\begin{array}{l}3.38 \mathrm{E}-03 \\
\\
3.90 \mathrm{E}+00 \\
8.9 \mathbb{E}-03\end{array}$ & & $4.92 \mathrm{E}+03$ & $4.92 \mathrm{E}+03$ & $\begin{array}{l}3.38 \mathrm{E}-03 \\
\\
3.90 \mathrm{E}+00 \\
8.95 \mathrm{E}-03\end{array}$ & $\begin{array}{l}1.34 \mathrm{E}-09 \\
4.89 \mathrm{E}+04 \\
6.07 \mathrm{E}-02 \\
1.10 \mathrm{E}-09 \\
1.17 \mathrm{E}-07 \\
4.25 \mathrm{E}-04 \\
4.46 \mathrm{E}-10 \\
6.76 \mathrm{E}-13 \\
1.16 \mathrm{E}+03 \\
6.28 \mathrm{E}-03 \\
7.62 \mathrm{E}+02 \\
4.59 \mathrm{E}-02 \\
5.16 \mathrm{E}-03 \\
6.10 \mathrm{E}-03 \\
2.82 \mathrm{E}+02 \\
5.93 \mathrm{E}-03 \\
8.4 \mathrm{E}+03 \\
4.76 \mathrm{E}-03 \\
1.91 \mathrm{E}-02 \\
1.04 \mathrm{E}+02 \\
4.66 \mathrm{E}-02 \\
6.60 \mathrm{E}+05 \\
9.38 \mathrm{E}+02 \\
9.63 \mathrm{E}-04 \\
6.41 \mathrm{E}+03 \\
5.01 \mathrm{E}+01 \\
2.05 \mathrm{~S}+00 \\
7.40 \mathrm{E}-07 \\
5.52 \mathrm{E}+00 \\
1.28 \mathrm{E}-12 \\
2.23 \mathrm{E}+04 \\
3.90 \mathrm{E}+00 \\
\\
2.12 \mathrm{E}-01 \\
3.4 \mathrm{E}+01 \\
1.10 \mathrm{E}-04 \\
8.30 \mathrm{E}+01 \\
9.01 \mathrm{E}-02 \\
2.69 \mathrm{E}-02 \\
9.49 \mathrm{E}-04\end{array}$ & & & \\
\hline
\end{tabular}


WHC-SD-WM-TI-774 Rev. 0

TWRS PRIVATIZATION PROCESS TECHNICAL BASELINE

Table B-21 Phase 1 LAW Mass Balance for Batch PC2/21 (6 sheets)

\begin{tabular}{|c|c|c|c|c|c|c|c|c|c|}
\hline $\begin{array}{l}\text { STRFAM NAME } \\
\text { LIQUID CMFOMIIS }\end{array}$ & 20 & 21 & 22 & 23 & 24 & 25 & 26 & 27 & 28 \\
\hline $\begin{array}{l}\text { Volume (L) } \\
\text { Density }(g / L)\end{array}$ & $\begin{array}{l}\text { 4. } 13 E+06 \\
1.00 E+03\end{array}$ & & & & $\begin{array}{l}1.60 \mathrm{E}+06 \\
1.00 \mathrm{E}+0.3\end{array}$ & $\begin{array}{l}2.52 \mathrm{E}+06 \\
1.00 \mathrm{E}+03\end{array}$ & $\begin{array}{l}2.56 E+03 \\
3.34 E+03\end{array}$ & $\begin{array}{l}2.56 E+03 \\
3.34 \mathrm{E}+03\end{array}$ & $\begin{array}{l}\text { 1. } 00 E+06 \\
1.00 E+03\end{array}$ \\
\hline Total Mass Flow (kg) & $4.23 \mathrm{E}+06$ & & & & $1.60 \mathrm{E}+106$ & $2.52 \mathrm{E}+06$ & 8.56E+03 & $8.56 \mathrm{E}+03$ & $1.00 E+06$ \\
\hline \multicolumn{10}{|l|}{ RADIONUCIJDS (Ci) } \\
\hline $\begin{array}{l}\text { Cesium } \\
\text { Strantiun } \\
\text { Tectrnetium } \\
\text { TWI }\end{array}$ & & & & & & & & & \\
\hline \multicolumn{10}{|l|}{ OHEMCALS (kg) } \\
\hline 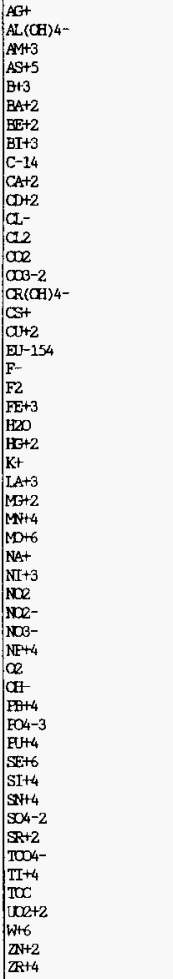 & $\begin{array}{l}7.13 \mathrm{E}+03 \\
2.79 \mathrm{E}+05 \\
3.61 \mathrm{E}+03 \\
2.52 \mathrm{E}+06 \\
4.58 \mathrm{E}+05 \\
8.56 \mathrm{E}+05\end{array}$ & & & & $\begin{array}{l}7.135+03 \\
2.79 \mathrm{E}+05 \\
\\
3.61 \mathrm{E}+03 \\
4.59 \mathrm{E}+05 \\
8.56 \mathrm{E}+05\end{array}$ & $2.52+06$ & $\begin{array}{l}4.92 \mathrm{E}+03 \\
3.64 \mathrm{E}+03\end{array}$ & $\begin{array}{l}4.92 E+03 \\
3.64 E+03\end{array}$ & 1. $00 \mathrm{E}+06$ \\
\hline
\end{tabular}


WHC-SD-WM-TI-774 Rev. 0

TWRS PRIVATIZATION PROCESS TECHNICAL BASELINE

Table B-21 Phase 1 LAW Mass Balance for Batch PC2/21 (6 sheets)

\begin{tabular}{|c|c|c|c|c|c|c|c|c|c|}
\hline $\begin{array}{l}\text { SIREAM NAME } \\
\text { SUID COMEONONSS }\end{array}$ & 20 & 21 & 22 & 23 & 24 & 25 & 26 & 27 & 28 \\
\hline Total Mass Flow (kg) & & $7.49 \mathrm{E}+05$ & $3.16 \mathrm{E}+06$ & $3.91 E+06$ & & & & & \\
\hline \multicolumn{10}{|l|}{ RADIONUCLIES $\langle\mathrm{Ci}\rangle$} \\
\hline $\begin{array}{l}\text { Cosiun } \\
\text { Struntium } \\
\text { Tectmetium } \\
\text { TRIJ }\end{array}$ & & $\begin{array}{l}3.75 \mathrm{E}+03 \\
2.50 \mathrm{E}+04 \\
3.75 \mathrm{E}+02 \\
3.19 \mathrm{E}+02\end{array}$ & & $\begin{array}{l}3.75 E+03 \\
2.50 E+04 \\
3.75 E+02 \\
3.19 E+02\end{array}$ & & & & & \\
\hline \multicolumn{10}{|l|}{ CAEMICAIS (kg) } \\
\hline 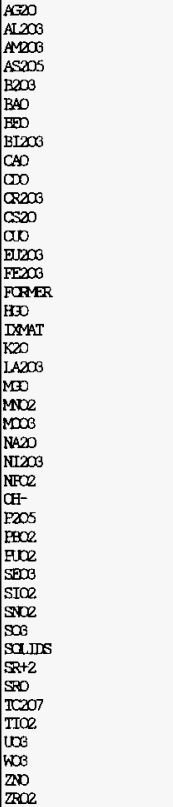 & & $\begin{array}{l}1.34 \mathrm{E}-09 \\
4.89 \mathrm{E}+04 \\
6.07 \mathrm{E}-02 \\
1.10 \mathrm{E}-09 \\
1.17 \mathrm{E}-07 \\
4.25 \mathrm{E}-04 \\
4.46 \mathrm{E}-10 \\
6.76 \mathrm{E}-13 \\
1.16 \mathrm{E}+03 \\
6.29 \mathrm{E}-03 \\
7.62 \mathrm{E}+02 \\
4.5 \mathrm{EE}-02 \\
5.16 \mathrm{E}-03 \\
6.10 \mathrm{E}-03 \\
2.82 \mathrm{E}+02 \\
5.93 \mathrm{E}-03 \\
8.4 \mathrm{E}+03 \\
4.76 \mathrm{E}-03 \\
1.91 \mathrm{E}-02 \\
1.04 \mathrm{E}+02 \\
4.66 \mathrm{E}-02 \\
6.60 \mathrm{E}+05 \\
9.3 \mathrm{E}+02 \\
9.63 \mathrm{E}-04 \\
\\
6.41 \mathrm{E}+03 \\
5.01 \mathrm{E}+01 \\
2.05 \mathrm{E}+00 \\
7.40 \mathrm{E}-07 \\
5.52 \mathrm{E}+00 \\
1.23 \mathrm{E}-12 \\
2.23 \mathrm{E}+04 \\
3.90 \mathrm{E}+00 \\
\\
2.12 \mathrm{E}-01 \\
3.4 \mathrm{E}+01 \\
1.10 \mathrm{E}-04 \\
8.30 \mathrm{E}+01 \\
9.01 \mathrm{E}-02 \\
2.69 \mathrm{E}-02 \\
9.49 \mathrm{E}-04\end{array}$ & $3.16 \mathrm{E}+06$ & $\begin{array}{l}1.34 \mathrm{E}-09 \\
4.89 \mathrm{E}+04 \\
6.07 \mathrm{E}-02 \\
1.10 \mathrm{E}-09 \\
1.17 \mathrm{E}-07 \\
4.25 \mathrm{E}-04 \\
4.46 \mathrm{E}-10 \\
6.76 \mathrm{E}-13 \\
1.16 \mathrm{E}+03 \\
6.28 \mathrm{E}-03 \\
7.62 \mathrm{E}+02 \\
4.58 \mathrm{E}-02 \\
5.16 \mathrm{E}-03 \\
6.10 \mathrm{E}-03 \\
2.82 \mathrm{E}+02 \\
3.16 \mathrm{E}+06 \\
5.93 \mathrm{E}-03 \\
8.4 \mathrm{E}+003 \\
4.76 \mathrm{E}-03 \\
1.91 \mathrm{E}-02 \\
1.04 \mathrm{E}+02 \\
4.66 \mathrm{E}-02 \\
6.60 \mathrm{E}+05 \\
9.3 \mathrm{E}+02 \\
9.63 \mathrm{E}-04 \\
\\
6.41 \mathrm{E}+03 \\
5.01 \mathrm{E}+01 \\
2.05 \mathrm{E}+00 \\
7.40 \mathrm{E}-07 \\
5.52 \mathrm{E}+00 \\
1.28 \mathrm{E}-12 \\
2.23 \mathrm{E}+04 \\
3.90 \mathrm{E}+00 \\
\\
2.12 \mathrm{E}-01 \\
3.45 \mathrm{E}+01 \\
1.10 \mathrm{E}-04 \\
8.30 \mathrm{E}+01 \\
9.01 \mathrm{E}-02 \\
2.69 \mathrm{E}-02 \\
9.49 \mathrm{E}-04\end{array}$ & & & & & \\
\hline
\end{tabular}


WHC-SD-WM-TI-774 Rev. 0

TWRS PRIVATIZATION PROCESS TECHNICAL BASELINE

Table B-22 Phase 1 IAW Mass Balance for Batch PC2/22 (6 sheets)

\begin{tabular}{|c|c|c|c|c|c|c|c|c|c|c|}
\hline $\begin{array}{l}\text { SIFEAM NAME } \\
\text { LIQUD COMFOWNIS }\end{array}$ & 1 & 2 & 3 & 4 & 5 & 6 & 7 & 8 & 9 & 10 \\
\hline $\begin{array}{l}\text { Volime }(\mathrm{L}) \\
\text { Density }(\mathrm{g} / \mathrm{L})\end{array}$ & $\begin{array}{l}3.67 \mathrm{E}+06 \\
1.26 \mathrm{E}+03\end{array}$ & $\begin{array}{l}3.65 \mathrm{E}+06 \\
1.26 \mathrm{E}+03\end{array}$ & $\begin{array}{l}1.72 \mathrm{E}+04 \\
1.26 \mathrm{E}+03\end{array}$ & $\begin{array}{l}3.91 \mathrm{E}+05 \\
1.00 \mathrm{E}+03\end{array}$ & $\begin{array}{l}4.08 E+05 \\
1.01 E+03\end{array}$ & & $\begin{array}{l}3.65 \mathrm{E}+06 \\
1.26 \mathrm{E}+03\end{array}$ & $\begin{array}{l}3.6 \mathbf{E}+06 \\
1.26 \mathrm{E}+03\end{array}$ & & \\
\hline Total Mass Flow (kg) & 4. $63 \mathrm{E}+06$ & $4.61 E+06$ & $2.17 E+04$ & $3.91 \mathbb{E}+05$ & 4.13E+05 & & $4.61 E+06$ & 4. $61 \mathrm{E}+06$ & & \\
\hline \multicolumn{11}{|l|}{ RADIONLIIIES (Ci) } \\
\hline $\begin{array}{l}\text { Cesiun } \\
\text { Struntium } \\
\text { Tecknetium } \\
\text { TIN }\end{array}$ & $\begin{array}{l}3.12 \mathrm{E}+04 \\
9.32 \mathrm{E}+03 \\
3.66 \mathrm{E}+01 \\
1.92 \mathrm{E}+01\end{array}$ & $\begin{array}{l}3.11 \mathrm{E}+04 \\
9.28 \mathrm{E}+03 \\
3.64 \mathrm{E}+01 \\
1.91 \mathrm{E}+01\end{array}$ & $\begin{array}{l}1.46 \mathrm{E}+02 \\
4.37 \mathrm{E}+01 \\
1.72 \mathrm{E}-01 \\
9.00 \mathrm{E}-02\end{array}$ & & $\begin{array}{l}1.46 \mathrm{E}+02 \\
4.3 \mathrm{E}+01 \\
1.7 \mathrm{E}-01 \\
9.00 \mathrm{E}-02\end{array}$ & & $\begin{array}{l}3.11 E+04 \\
9.28 E+03 \\
3.64 E+01 \\
1.91 E+01\end{array}$ & $\begin{array}{l}3.11 E+04 \\
9.28 E+03 \\
3,64 E+01 \\
1.91 E+01\end{array}$ & & \\
\hline \multicolumn{11}{|l|}{ AEMICALS (kg) } \\
\hline 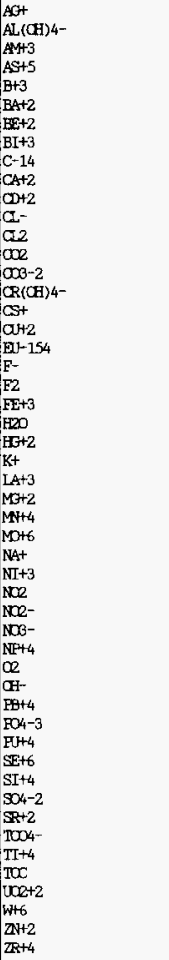 & 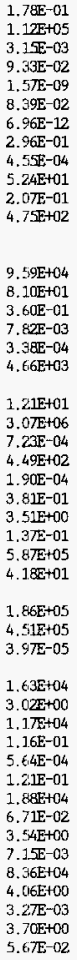 & $\begin{array}{l}1.77 \mathrm{E}-01 \\
1.11 \mathrm{E}+05 \\
3.14 \mathrm{E}-03 \\
9.29 \mathrm{E}-02 \\
1.5 \mathrm{E}-09 \\
8.35 \mathrm{E}-02 \\
6.93 \mathrm{E}-12 \\
2.94 \mathrm{E}-01 \\
4.53 \mathrm{E}-04 \\
5.22 \mathrm{E}+01 \\
2.06 \mathrm{E}-01 \\
4.73 \mathrm{E}+02 \\
\\
9.55 \mathrm{E}+04 \\
8.06 \mathrm{E}+01 \\
3.59 \mathrm{E}-01 \\
7.78 \mathrm{E}-03 \\
3.36 \mathrm{E}-04 \\
4.64 \mathrm{E}+03 \\
\\
1.20 \mathrm{E}+01 \\
3.05 \mathrm{E}+06 \\
7.20 \mathrm{E}-04 \\
4.47 \mathrm{E}+02 \\
1.89 \mathrm{E}-04 \\
3.79 \mathrm{E}-01 \\
3.49 \mathrm{E}+00 \\
1.37 \mathrm{E}-01 \\
5.84 \mathrm{E}+05 \\
4.16 \mathrm{E}+01 \\
1.85 \mathrm{E}+05 \\
4.49 \mathrm{E}+05 \\
3.96 \mathrm{E}-05 \\
1.63 \mathrm{E}+04 \\
3.00 \mathrm{E}+00 \\
1.16 \mathrm{E}+04 \\
1.15 \mathrm{E}-01 \\
5.62 \mathrm{E}-04 \\
1.20 \mathrm{E}-01 \\
1.8 \mathrm{EE}+04 \\
6.67 \mathrm{E}-02 \\
3.53 \mathrm{E}+00 \\
7.11 \mathrm{E}-03 \\
8.32 \mathrm{E}+04 \\
4.04 \mathrm{E}+00 \\
3.25 \mathrm{E}-03 \\
3.68 \mathrm{E}+00 \\
5.64 \mathrm{E}-02\end{array}$ & $\begin{array}{l}8.35 \mathrm{E}-04 \\
5.23 \mathrm{E}+02 \\
1.48 \mathrm{E}-05 \\
4.38 \mathrm{E}-04 \\
7.37 \mathrm{E}-12 \\
3.93 \mathrm{E}-04 \\
3.27 \mathrm{E}-14 \\
1.39 \mathrm{E}-03 \\
2.14 \mathrm{E}-06 \\
2.46 \mathrm{E}-01 \\
9.6 \mathrm{EE}-04 \\
2.23 \mathrm{E}+00 \\
\\
4.50 \mathrm{E}+02 \\
3.80 \mathrm{E}-01 \\
1.69 \mathrm{E}-03 \\
3.67 \mathrm{E}-05 \\
1.58 \mathrm{E}-06 \\
2.18 \mathrm{E}+01 \\
\\
5.67 \mathrm{E}-02 \\
1.44 \mathrm{E}+04 \\
3.39 \mathrm{E}-06 \\
2.11 \mathrm{E}+00 \\
8.91 \mathrm{E}-07 \\
1.79 \mathrm{E}-03 \\
1.65 \mathrm{E}-02 . \\
6.44 \mathrm{E}-04 \\
2.75 \mathrm{E}+03 \\
1.96 \mathrm{E}-01 \\
8.71 \mathrm{E}+02 \\
2.12 \mathrm{E}+03 \\
1.86 \mathrm{E}-07 \\
7.66 \mathrm{E}+01 \\
1.41 \mathrm{E}-02 \\
5.4 \mathrm{E}+01 \\
5.4 \mathrm{E}-04 \\
2.65 \mathrm{E}-06 \\
5.67 \mathrm{E}-04 \\
8.83 \mathrm{E}+01 \\
3.14 \mathrm{E}-04 \\
1.66 \mathrm{E}-02 \\
3.35 \mathrm{E}-05 \\
3.92 \mathrm{E}+02 \\
1.91 \mathrm{E}-02 \\
1.53 \mathrm{E}-05 \\
1.73 \mathrm{E}-02 \\
2.66 \mathrm{E}-04\end{array}$ & $3.91 E+05$ & $\begin{array}{l}8.35 \mathrm{E}-04 \\
5.23 \mathrm{E}+02 \\
1.4 \mathrm{EE}-05 \\
4.38 \mathrm{E}-04 \\
7.37 \mathrm{E}-12 \\
3.93 \mathrm{E}-04 \\
3.27 \mathrm{E}-14 \\
1.39 \mathrm{E}-03 \\
2.14 \mathrm{E}-06 \\
2.46 \mathrm{E}-01 \\
9.62 \mathrm{E}-04 \\
2.23 \mathrm{E}+00 \\
\\
4.50 \mathrm{E}+02 \\
3.80 \mathrm{E}-01 \\
1.69 \mathrm{E}-03 \\
3.67 \mathrm{E}-05 \\
1.58 \mathrm{E}-06 \\
2.18 \mathrm{E}+01 . \\
\\
5.67 \mathrm{E}-02 \\
4.05 \mathrm{E}+05 \\
3.39 \mathrm{E}-06 \\
2.11 \mathrm{E}+00 \\
8.91 \mathrm{E}-07 \\
1.79 \mathrm{E}-03 \\
1.65 \mathrm{E}-02 \\
6.44 \mathrm{E}-04 \\
2.75 \mathrm{E}+03 \\
1.96 \mathrm{E}-01 \\
8.71 \mathrm{E}+02 \\
2.12 \mathrm{E}+03 \\
1.86 \mathrm{E}-07 \\
7.66 \mathrm{E}+01 \\
1.41 \mathrm{E}-02 \\
5.4 \mathrm{E}+01 \\
5.4 \mathrm{E}-04 \\
2.6 \mathrm{E}-06 \\
5.67 \mathrm{E}-04 \\
8.93 \mathrm{E}+01 \\
3.14 \mathrm{E}-04 \\
1.66 \mathrm{E}-02 \\
3.3 \mathrm{E}-05 \\
3.92 \mathrm{E}+02 \\
1.91 \mathrm{E}-02 \\
1.53 \mathrm{E}-05 \\
1.73 \mathrm{E}-02 \\
2.66 \mathrm{E}-04\end{array}$ & & $\begin{array}{l}1.77 \mathrm{E}-01 \\
1.11 \mathrm{E}+05 \\
3.14 \mathrm{E}-03 \\
9.29 \mathrm{E}-02 \\
1.57 \mathrm{E}-09 \\
8.35 \mathrm{E}-02 \\
6.93 \mathrm{E}-12 \\
2.94 \mathrm{E}-01 \\
4.53 \mathrm{E}-04 \\
5.22 \mathrm{E}+01 \\
2.06 \mathrm{E}-01 \\
4.73 \mathrm{E}+02 \\
\\
9.55 \mathrm{E}+04 \\
8.06 \mathrm{E}+01 \\
3.59 \mathrm{E}-01 \\
7.78 \mathrm{E}-03 \\
3.36 \mathrm{E}-04 \\
4.64 \mathrm{E}+03 \\
\\
1.20 \mathrm{E}+01 \\
3.0 \mathrm{E}+06 \\
7.20 \mathrm{E}-04 \\
4.47 \mathrm{E}+02 \\
1.89 \mathrm{E}-04 \\
3.79 \mathrm{E}-01 \\
3.49 \mathrm{E}+00 \\
1.37 \mathrm{E}-01 \\
5.84 \mathrm{E}+05 \\
4.16 \mathrm{E}+01 \\
1.85 \mathrm{E}+05 \\
4.49 \mathrm{E}+05 \\
3.96 \mathrm{E}-05 \\
1.63 \mathrm{E}+04 \\
3.00 \mathrm{E}+00 \\
1.16 \mathrm{E}+04 \\
1.15 \mathrm{E}-01 \\
5.62 \mathrm{E}-04 \\
1.20 \mathrm{E}-01 \\
1.8 \mathrm{EE}+04 \\
6.67 \mathrm{E}-02 \\
3.53 \mathrm{E}+00 \\
7.11 \mathrm{E}-03 \\
8.32 \mathrm{E}+04 \\
4.04 \mathrm{E}+00 \\
3.25 \mathrm{E}-03 \\
3.6 \mathrm{BE}+00 \\
5.64 \mathrm{E}-02\end{array}$ & $\begin{array}{l}1.77 \mathrm{E}-01 \\
1.11 \mathrm{E}+05 \\
3.14 \mathrm{E}-03 \\
9.29 \mathrm{E}-02 \\
1.57 \mathrm{E}-09 \\
8.3 \mathrm{E}-02 \\
6.93 \mathrm{E}-12 \\
2.94 \mathrm{E}-01 \\
4.53 \mathrm{E}-04 \\
5.22 \mathrm{E}+01 \\
2.06 \mathrm{E}-01 \\
4.73 \mathrm{E}+02 \\
\\
9.55 \mathrm{E}+04 \\
8.06 \mathrm{E}+01 \\
3.59 \mathrm{E}-01 \\
7.78 \mathrm{E}-03 \\
3.36 \mathrm{E}-04 \\
4.64 \mathrm{E}+03 \\
\\
1.20 \mathrm{E}+01 \\
3.05 \mathrm{E}+06 \\
7.20 \mathrm{E}-04 \\
4.47 \mathrm{E}+02 \\
1.89 \mathrm{E}-04 \\
3.79 \mathrm{E}-01 \\
3.49 \mathrm{E}+00 \\
1.37 \mathrm{E}-01 \\
5.84 \mathrm{E}+05 \\
4.16 \mathrm{E}+01 \\
1.85 \mathrm{E}+05 \\
4.49 \mathrm{E}+05 \\
3.96 \mathrm{E}-05 \\
1.63 \mathrm{E}+04 \\
3.00 \mathrm{E}+00 \\
1.16 \mathrm{E}+04 \\
1.15 \mathrm{E}-01 \\
5.62 \mathrm{E}-04 \\
1.20 \mathrm{E}-01 \\
1.86 \mathrm{E}+04 \\
6.67 \mathrm{E}-02 \\
3.53 \mathrm{E}+00 \\
7.11 \mathrm{E}-03 \\
8.37 \mathrm{E}+04 \\
4.04 \mathrm{E}+00 \\
3.25 \mathrm{E}-03 \\
3.68 \mathrm{E}+00 \\
5.64 \mathrm{E}-02\end{array}$ & & \\
\hline
\end{tabular}


WHC-SD-WM-TI-774 Rev. 0

TWRS PRIVATIZATION PROCESS TECHNICAL BASELINE

Table B-22 Phase 1 LAW Mass Balance for Batch PC2/22 (6 sheets)

\begin{tabular}{|c|c|c|c|c|c|c|c|c|c|c|}
\hline $\begin{array}{l}\text { SIREAY NAYE } \\
\text { SLDD COMFCNENIS }\end{array}$ & 1 & 2 & 3 & 4 & 5 & 6 & 7 & 8 & 9 & 10 \\
\hline Total Mass Flow (kg) & 4. $63 \mathrm{E}+04$ & $4.63 \mathrm{E}+02$ & $4.59 \mathrm{E}+04$ & & $4.59 \mathrm{E}+0.4$ & & $4.63 E+02$ & 4. $63 \mathrm{E}+02$ & & \\
\hline \multicolumn{11}{|l|}{ RADTaNuCLIIES (Ci) } \\
\hline $\begin{array}{l}\text { Cesium } \\
\text { Struntiun } \\
\text { Technetium } \\
\text { IEV }\end{array}$ & & & & & & & & & & \\
\hline \multicolumn{11}{|l|}{ OHEMICAIS (kg) } \\
\hline 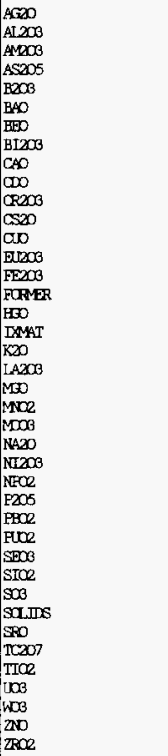 & 4. $63 E+04$ & $4.63 \mathrm{E}+02$ & 4. $59 \mathrm{E}+04$ & & 4. $99 E+04$ & & 4. $63 \mathrm{E}+02$ & 4. $63 \mathrm{E}+02$ & & \\
\hline
\end{tabular}


WHC-SD-WM-TI-774 Rev. 0

TWRS PRIVATIZATION PROCESS TECHNICAL BASELINE

Table B-22 Ptase 1 LAW Mass Balance for Batch PC2/22 (6 sheets)

\begin{tabular}{|c|c|c|c|c|c|c|c|c|c|c|}
\hline $\begin{array}{l}\text { SIFEAM NAME } \\
\text { LIDUID OOMEONENIS }\end{array}$ & 11 & 12 & 13 & 14 & 15 & 16 & $16 \mathrm{~A}$ & 17 & 18 & 19 \\
\hline $\begin{array}{l}\text { Volume }(L) \\
\text { Density }(\mathrm{g} / \mathrm{L})\end{array}$ & & $\begin{array}{l}3.6 \mathrm{EE}+06 \\
1.26 \mathrm{E}+03\end{array}$ & $\begin{array}{l}3.06 \mathrm{E}+03 \\
3.34 \mathrm{E}+03\end{array}$ & & $\begin{array}{l}3.06 \mathrm{E}+03 \\
3.34 \mathrm{E}+03\end{array}$ & $\begin{array}{l}3.6 \mathrm{EE}+06 \\
1.26 \mathrm{E}+03\end{array}$ & $\begin{array}{l}4.74 \mathrm{E}+06 \\
1.00 \mathrm{E}+03\end{array}$ & & $\begin{array}{l}\text { 1. } 000 \mathrm{E}-09 \\
1.00 \mathrm{E}+03\end{array}$ & $\begin{array}{l}1.00 \mathrm{E}-09 \\
1.00 \mathrm{E}+03\end{array}$ \\
\hline Total Mass Flow (kg) & & $4.61 E+06$ & $1.02 E+04$ & & $1.02 E+04$ & $4.61 \mathrm{E}+06$ & $4.74 \mathrm{E}+06$ & & $1.00 \mathrm{E}-09$ & 1.00 - 09 \\
\hline \multicolumn{11}{|l|}{ RADIONUCIIIES (Ci) } \\
\hline $\begin{array}{l}\text { Cesium } \\
\text { Strontiun } \\
\text { Technetium } \\
\text { INI }\end{array}$ & & $\begin{array}{l}4.48 \mathrm{E}+03 \\
9.28 \mathrm{E}+03 \\
3.60 \mathrm{E}+01 \\
1.91 \mathrm{E}+01\end{array}$ & $\begin{array}{l}2.66 \mathrm{E}+04 \\
3.66 \mathrm{E}-01\end{array}$ & & $\begin{array}{l}2.66 \mathrm{E}+04 \\
3.66 \mathrm{E}-01\end{array}$ & $\begin{array}{l}\text { 4. } 48 \mathrm{E}+03 \\
9.28 \mathrm{E}+03 \\
3.60 \mathrm{E}+01 \\
1.91 \mathrm{E}+01\end{array}$ & & & & \\
\hline \multicolumn{11}{|l|}{ CHFMICAIS (kg) } \\
\hline 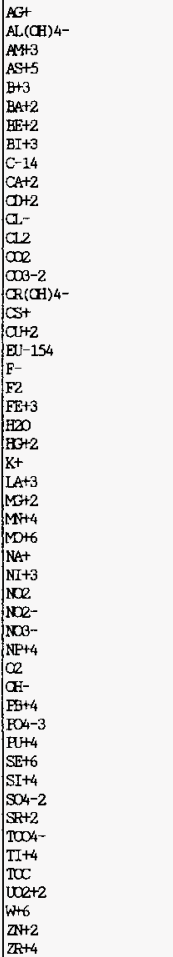 & & $\begin{array}{l}1.77 \mathrm{E}-01 \\
1.11 \mathrm{E}+05 \\
3.14 \mathrm{E}-03 \\
9.29 \mathrm{E}-02 \\
1.5 \mathrm{E}-09 \\
8.35 \mathrm{E}-02 \\
6.93 \mathrm{E}-12 \\
2.94 \mathrm{E}-01 \\
4.53 \mathrm{E}-04 \\
5.22 \mathrm{E}+01 \\
2.06 \mathrm{E}-01 \\
4.73 \mathrm{E}+02 \\
\\
9.55 \mathrm{E}+04 \\
8.06 \mathrm{E}+01 \\
5.17 \mathrm{E}-02 \\
7.78 \mathrm{E}-03 \\
3.36 \mathrm{E}-04 \\
4.64 \mathrm{E}+03 \\
\\
1.20 \mathrm{E}+01 \\
3.05 \mathrm{E}+06 \\
7.20 \mathrm{E}-04 \\
4.4 \mathrm{E}+02 \\
1.89 \mathrm{E}-04 \\
3.79 \mathrm{E}-01 \\
3.49 \mathrm{E}+00 \\
1.37 \mathrm{E}-01 \\
5.84 \mathrm{E}+05 \\
4.16 \mathrm{E}+01 \\
\\
1.85 \mathrm{E}+05 \\
4.49 \mathrm{E}+05 \\
3.96 \mathrm{E}-05 \\
1.63 \mathrm{E}+04 \\
3.00 \mathrm{E}+00 \\
1.16 \mathrm{E}+04 \\
1.15 \mathrm{E}-01 \\
5.62 \mathrm{E}-04 \\
1.20 \mathrm{E}-01 \\
1.88 \mathrm{E}+04 \\
6.67 \mathrm{E}-02 \\
3.49 \mathrm{E}+00 \\
7.11 \mathrm{E}-03 \\
8.32 \mathrm{E}+04 \\
4.04 \mathrm{E}+00 \\
3.25 \mathrm{E}-03 \\
3.68 \mathrm{E}+00 \\
5.64 \mathrm{E}-02\end{array}$ & $\begin{array}{l}5.8 \mathrm{E}+03 \\
4.34 \mathrm{E}+03\end{array}$ & & $\begin{array}{l}3.07 \mathrm{E}-01 \\
5.87 \mathrm{E}+03 \\
4.34 \mathrm{E}+03 \\
\\
3.54 E-02\end{array}$ & $\begin{array}{l}1.77 \mathrm{E}-01 \\
1.11 \mathrm{E}+05 \\
3.14 \mathrm{E}-03 \\
9.29 \mathrm{E}-02 \\
1.57 \mathrm{E}-09 \\
8.35 \mathrm{E}-02 \\
6.93 \mathrm{E}-12 \\
2.94 \mathrm{E}-01 \\
4.53 \mathrm{E}-04 \\
5.22 \mathrm{E}+01 \\
2.06 \mathrm{E}-01 \\
4.73 \mathrm{E}+02 \\
\\
9.55 \mathrm{E}+04 \\
8.06 \mathrm{E}+01 \\
5.17 \mathrm{E}-02 \\
7.78 \mathrm{E}-03 \\
3.36 \mathrm{E}-04 \\
4.64 \mathrm{E}+03 \\
\\
1.20 \mathrm{E}+01 \\
3.05 \mathrm{E}+06 \\
7.20 \mathrm{E}-04 \\
4.47 \mathrm{E}+02 \\
1.89 \mathrm{E}-04 \\
3.79 \mathrm{E}-01 \\
3.49 \mathrm{E}+00 \\
1.37 \mathrm{E}-01 \\
5.34 \mathrm{E}+05 \\
4.16 \mathrm{E}+01 \\
\\
1.85 \mathrm{E}+05 \\
4.49 \mathrm{E}+05 \\
3.96 \mathrm{E}-05 \\
1.63 \mathrm{E}+04 \\
3.00 \mathrm{E}+00 \\
1.16 \mathrm{E}+04 \\
1.1 \mathrm{E}-01 \\
5.62 \mathrm{E}-04 \\
1.20 \mathrm{E}-01 \\
1.88 \mathrm{E}+04 \\
6.67 \mathrm{E}-02 \\
3.49 \mathrm{E}+00 \\
7.11 \mathrm{E}-03 \\
8.32 \mathrm{E}+04 \\
4.04 \mathrm{E}+00 \\
3.25 \mathrm{E}-03 \\
3.68 \mathrm{E}+00 \\
5.64 \mathrm{E}-02\end{array}$ & $\begin{array}{l}4.73 \mathrm{E}+02 \\
3.7 \mathrm{E}+05 \\
\\
4.64 \mathrm{E}+03 \\
3.10 \mathrm{E}+06\end{array}$ & & $1.00 \mathrm{E}-09$ & $1.00 \mathrm{E}-09$ \\
\hline
\end{tabular}


WHC-SD-WM-TI-774 Rev. 0

TWRS PRIVATIZATION PROCESS TECHNICAL BASELINE

Table B-22 Phase 1 LAW Mass Balance for Batch PC2/22 ( 6 sheets)

\begin{tabular}{|c|c|c|c|c|c|c|c|c|c|c|}
\hline $\begin{array}{l}\text { SIREAM NAME } \\
\text { SULD COFONENS }\end{array}$ & 11 & 12 & 13 & 14 & 15 & 16 & $16 \mathrm{~A}$ & 17 & 18 & 19 \\
\hline Total Mass Flow (kg) & & $4.63 E+02$ & & $5.87 \mathrm{E}+03$ & $5.8 \pi+03$ & 4. $63 \mathrm{E}+02$ & 8. $72 \mathbb{E}+05$ & & & \\
\hline \multicolumn{11}{|l|}{ RADIONUCIIIES (Ci) } \\
\hline $\begin{array}{l}\text { Cesium } \\
\text { Struntium } \\
\text { Techretiun } \\
\text { TWII }\end{array}$ & & & & & & & $\begin{array}{l}4.48 E+03 \\
9.2 \mathrm{EE}+03 \\
3.60 \mathrm{E}+01 \\
1.90 \mathrm{E}+01\end{array}$ & & & \\
\hline \multicolumn{11}{|l|}{ CAFMICALS (kg) } \\
\hline 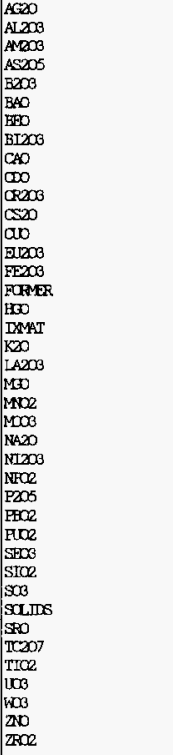 & & 4. $63 \mathrm{SE}+02$ & & $5.87 \mathrm{E}+03$ & $5.87 \mathbf{E}+03$ & $4.63 E+02$ & $\begin{array}{l}1.90 \mathrm{E}-01 \\
5.95 \mathrm{E}+04 \\
3.45 \mathrm{E}-03 \\
1.43 \mathrm{E}-01 \\
5.04 \mathrm{E}-09 \\
9.32 \mathrm{E}-02 \\
1.92 \mathrm{E}-11 \\
3.28 \mathrm{E}-01 \\
7.30 \mathrm{E}+01 \\
2.35 \mathrm{E}-01 \\
5.10 \mathrm{E}+01 \\
5.47 \mathrm{E}-02 \\
9.74 \mathrm{E}-03 \\
3.89 \mathrm{E}-04 \\
1.72 \mathrm{E}+01 \\
\\
7.77 \mathrm{E}-04 \\
\\
5.39 \mathrm{E}+02 \\
2.22 \mathrm{E}-04 \\
6.29 \mathrm{E}-01 \\
5.53 \mathrm{E}+00 \\
2.05 \mathrm{E}-01 \\
7.87 \mathrm{E}+05 \\
5.86 \mathrm{E}+01 \\
4.49 \mathrm{E}-05 \\
8.6 \mathrm{EE}+03 \\
3.4 \mathrm{E}+00 \\
1.30 \mathrm{E}-01 \\
9.03 \mathrm{E}-04 \\
2.58 \mathrm{E}-01 \\
1.56 \mathrm{E}+04 \\
4.63 \mathrm{E}+02 \\
7.86 \mathrm{E}-02 \\
3.32 \mathrm{E}+00 \\
1.19 \mathrm{E}-02 \\
4.28 \mathrm{E}+00 \\
4.10 \mathrm{E}-03 \\
4.58 \mathrm{E}+00 \\
7.62 \mathrm{E}-02\end{array}$ & & & \\
\hline
\end{tabular}


WHC-SD-WM-TI-774 Rev. 0

TWRS PRIVATIZATION PROCESS TECHNICAL BASELINE

Table B-22 Phase 1 LAW Mass Balance for Batch PC2/22 (6 sheets)

\begin{tabular}{|c|c|c|c|c|c|c|c|c|c|}
\hline $\begin{array}{l}\text { SIREAM NAE } \\
\text { LIQUID COMONEMIS }\end{array}$ & 20 & 21 & 22 & 23 & 24 & 25 & 26 & 27 & 28 \\
\hline $\begin{array}{l}\text { Volume (L) } \\
\text { Density }(g / L)\end{array}$ & $\begin{array}{l}4.74 E+06 \\
1.00 E+03\end{array}$ & & & & $\begin{array}{l}1.64 \mathrm{E}+06 \\
1.00 \mathrm{E}+03\end{array}$ & $\begin{array}{l}3.10 \mathrm{E}+06 \\
1.00 \mathrm{E}+03\end{array}$ & $\begin{array}{l}3.06 \mathrm{E}+03 \\
3.34 \mathrm{E}+03\end{array}$ & $\begin{array}{l}3.00 E-10 \\
3.34 E+03\end{array}$ & $\begin{array}{l}1.00 E+06 \\
1.00 E+03\end{array}$ \\
\hline Total Mass Flow (kg) & $4.74 E+06$ & & & & $1.64 \mathrm{E}+06$ & $3.10 \mathrm{E}+06$ & $1.02 \mathrm{E}+04$ & $1.00 \mathrm{E}-09$ & $1.000+06$ \\
\hline \multicolumn{10}{|l|}{ RADICUNCDDES (Cii) } \\
\hline $\begin{array}{l}\text { Cesium } \\
\text { Strantium } \\
\text { Technetilum } \\
\text { TRJ }\end{array}$ & & & & & & & & & \\
\hline \multicolumn{10}{|l|}{ CHEMICALS (kg) } \\
\hline 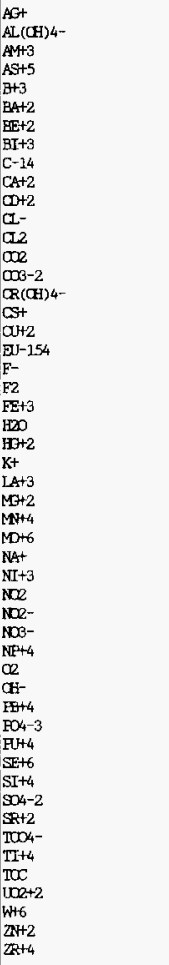 & $\begin{array}{l}4.73 \mathrm{E}+02 \\
3.75 \mathrm{E}+05 \\
\\
4.64 \mathrm{E}+03 \\
3.10 \mathrm{E}+06 \\
5.18 \mathrm{E}+05 \\
7.40 \mathrm{E}+05\end{array}$ & & & & $\begin{array}{l}4.73 \mathrm{E}+02 \\
3.75 \mathrm{E}+05 \\
4.64 \mathrm{E}+03 \\
5.18 \mathrm{E}+05 \\
7.40 \mathrm{E}+05\end{array}$ & $3.10 \mathrm{E}+06$ & $\begin{array}{l}5.87 \mathrm{E}+03 \\
4.34 E+03\end{array}$ & $\begin{array}{l}5.7 \mathrm{EE}-10 \\
4.25 \mathrm{E}-10\end{array}$ & 1. OOE+06 \\
\hline
\end{tabular}


WHC-SD-WM-TI-774 Rev. 0

TWRS PRIVATIZATION PROCESS TECHNICAL BASELINE

Table B-22 Phase 1 IAW Mass Balance for Batch PC2/22 (6 sheets)

\begin{tabular}{|c|c|c|c|c|c|c|c|c|c|}
\hline $\begin{array}{l}\text { SIREAM NAME } \\
\text { SOLID COMFANENIS }\end{array}$ & 20 & 21 & 22 & 23 & 24 & 25 & 26 & 27 & 28 \\
\hline Total Mass Flow (kg) & & $8.72 \mathrm{E}+05$ & $3.79 \mathrm{E}+06$ & $4.66 \mathrm{E}+06$ & & & & & \\
\hline \multicolumn{10}{|l|}{ RADIONLCDIES (Ci) } \\
\hline $\begin{array}{l}\text { Cesium } \\
\text { Strantitm } \\
\text { Technetium } \\
\text { IFU }\end{array}$ & & $\begin{array}{l}4.48 \mathrm{E}+03 \\
9.28 \mathrm{E}+03 \\
3.60 \mathrm{E}+01 \\
1.90 \mathrm{E}+01\end{array}$ & & $\begin{array}{l}4.48 \mathrm{E}+03 \\
9.28 \mathrm{E}+03 \\
3.60 \mathrm{E}+01 \\
1.90 \mathrm{E}+01\end{array}$ & & & & & \\
\hline \multicolumn{10}{|l|}{ CAFMICALS (kg) } \\
\hline 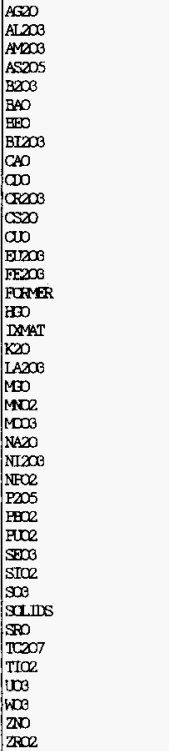 & & $\begin{array}{l}1.90 \mathrm{E}-01 \\
5.95 \mathrm{E}+04 \\
3.4 \mathrm{E}-03 \\
1.43 \mathrm{E}-01 \\
5.04 \mathrm{E}-09 \\
9.32 \mathrm{E}-02 \\
1.92 \mathrm{E}-11 \\
3.28 \mathrm{E}-01 \\
7.30 \mathrm{E}+01 \\
2.35 \mathrm{E}-01 \\
5.10 \mathrm{E}+01 \\
5.4 \mathrm{E}-02 \\
9.74 \mathrm{E}-03 \\
3.89 \mathrm{E}-04 \\
1.72 \mathrm{E}+01 \\
\\
7.77 \mathrm{E}-04 \\
5.39 \mathrm{E}+02 \\
2.22 \mathrm{E}-04 \\
6.29 \mathrm{E}-01 \\
5.53 \mathrm{E}+00 \\
2.0 \mathrm{E}-01 \\
7.87 \mathrm{E}+05 \\
5.86 \mathrm{E}+01 \\
4.49 \mathrm{E}-05 \\
8.68 \mathrm{E}+03 \\
3.4 \mathrm{E}+00 \\
1.30 \mathrm{E}-01 \\
9.03 \mathrm{E}-04 \\
2.5 \mathrm{E}-01 \\
1.56 \mathrm{E}+04 \\
4.63 \mathrm{E}+02 \\
7.86 \mathrm{E}-02 \\
3.32 \mathrm{E}+00 \\
1.19 \mathrm{E}-02 \\
4.28 \mathrm{E}+00 \\
4.10 \mathrm{E}-03 \\
4.58 \mathrm{E}+00 \\
7.62 \mathrm{E}-02\end{array}$ & $3.79 \mathrm{E}+06$ & $\begin{array}{l}1.90 \mathrm{E}-01 \\
5.95 \mathrm{E}+04 \\
3.45 \mathrm{E}-03 \\
1.43 \mathrm{E}-01 \\
5.04 \mathrm{E}-09 \\
9.32 \mathrm{E}-02 \\
1.92 \mathrm{E}-11 \\
3.28 \mathrm{E}-01 \\
7.30 \mathrm{E}+01 \\
2.35 \mathrm{E}-01 \\
5.10 \mathrm{E}+01 \\
5.47 \mathrm{E}-02 \\
9.74 \mathrm{E}-03 \\
3.89 \mathrm{E}-04 \\
1.72 \mathrm{E}+01 \\
3.79 \mathrm{E}+06 \\
7.77 \mathrm{E}-04 \\
5.39 \mathrm{E}+02 \\
2.22 \mathrm{E}-04 \\
6.29 \mathrm{E}-01 \\
5.53 \mathrm{E}+00 \\
2.05 \mathrm{E}-01 \\
7.87 \mathrm{E}+05 \\
5.86 \mathrm{E}+01 \\
4.49 \mathrm{E}-05 \\
8.68 \mathrm{E}+03 \\
3.4 \mathrm{E}+00 \\
1.30 \mathrm{E}-01 \\
9.03 \mathrm{E}-04 \\
2.58 \mathrm{E}-01 \\
1.56 \mathrm{E}+04 \\
4.63 \mathrm{E}+02 \\
7.86 \mathrm{E}-02 \\
3.32 \mathrm{E}+00 \\
1.19 \mathrm{E}-02 \\
4.28 \mathrm{E}+00 \\
4.10 \mathrm{E}-03 \\
4.58 \mathrm{E}+00 \\
7.62 \mathrm{E}-02\end{array}$ & & & & & \\
\hline
\end{tabular}


Table B-23 Phase 1 LAW Mass Balance for Batch PC2/23 (6 sheets)

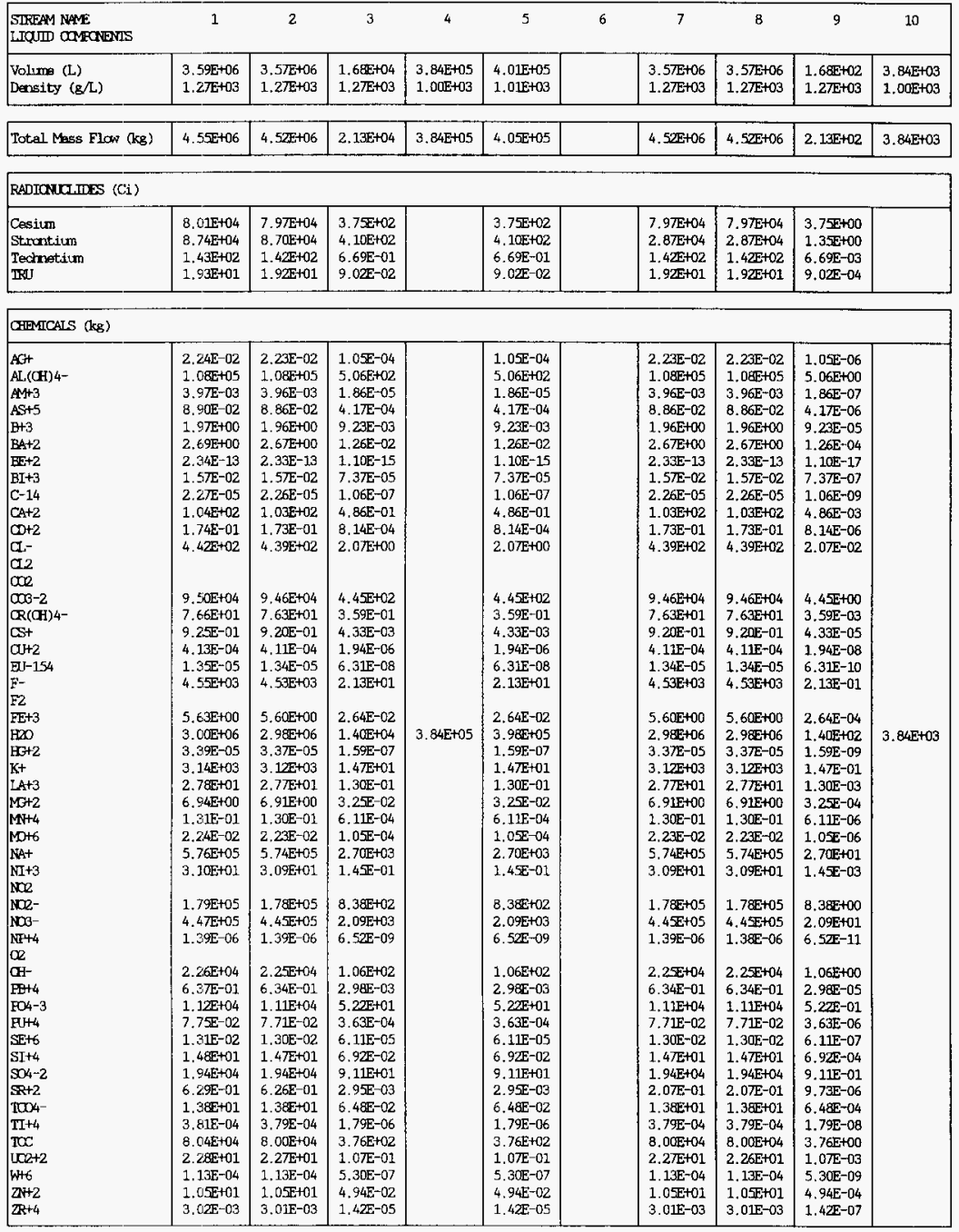


WHC-SD-WM-TI-774 Rev. 0

TWRS PRIVATIZATION PROCESS TECHNICAL BASELINE

Table B-23 Phase 1 LAW Mass Balance for Batch PC2/23 ( 6 sheets)

\begin{tabular}{|c|c|c|c|c|c|c|c|c|c|c|}
\hline $\begin{array}{l}\text { SIFEAM NAE } \\
\text { SO.D OOMFANENIS }\end{array}$ & 1 & 2 & 3 & 4 & 5 & 6 & 7 & 8 & 9 & 10 \\
\hline Total Mass Flow (kg) & $4.5 \mathrm{SE}+04$ & $4.55 E+02$ & $4.50 \mathrm{E}+04$ & & 4. $50 \mathrm{E}+0.4$ & & 4. $5 \mathrm{SE}+02$ & 4. $55 \mathrm{E}+00$ & 4. $51 \mathrm{E}+02$ & \\
\hline \multicolumn{11}{|l|}{ RADITUNCLIIES (Ci) } \\
\hline $\begin{array}{l}\text { Cesium } \\
\text { Strantium } \\
\text { Techrotium } \\
\text { TRI }\end{array}$ & & & & & & & $5.83 \mathrm{E}+04$ & 5. $83 \mathrm{E}+02$ & $5.77 \mathrm{E}+04$ & \\
\hline \multicolumn{11}{|l|}{ GHEMICALS (kg) } \\
\hline 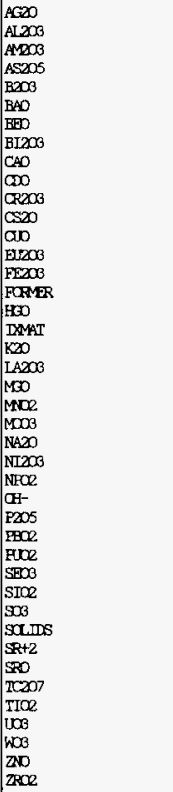 & $4.55+04$ & 4. $5 \mathrm{EE}+02$ & 4. $50 \mathrm{E}+04$ & & $4.50 E+04$ & & $\begin{array}{l}1.59 \mathrm{E}-01 \\
\\
4.55 \mathrm{E}+02 \\
4.19 \mathrm{E}-01\end{array}$ & $\begin{array}{l}1.59 \mathrm{E}-03 \\
\\
4.55 \mathrm{E}+00 \\
4.19 \mathrm{E}-03\end{array}$ & $\begin{array}{l}1.57 \mathrm{E}-01 \\
\\
4.50 E+02 \\
4.15 \mathrm{E}-01\end{array}$ & \\
\hline
\end{tabular}


WHC-SD-WM-TI-774 Rev. 0

TWRS PRIVATIZATION PROCESS TECHNICAL BASELINE

Table B-23 Phase 1 LAW Mass Balance for Batch PC2/23 (6 sheets)

\begin{tabular}{|c|c|c|c|c|c|c|c|c|c|c|}
\hline $\begin{array}{l}\text { SIFFAM NAME } \\
\text { LTQIII OOMFNENIS }\end{array}$ & 11 & 12 & 13 & 14 & 15 & 16 & $16 \mathrm{~A}$ & 17 & 18 & 29 \\
\hline $\begin{array}{l}\text { Volume }(L) \\
\text { Dansity }(g / L)\end{array}$ & $\begin{array}{l}4.01 E+03 \\
1.01 E+03\end{array}$ & $\begin{array}{l}3.57 \mathrm{E}+06 \\
1.27 \mathrm{E}+03\end{array}$ & $\begin{array}{l}3.01 \mathrm{E}+03 \\
3.34 \mathrm{E}+03\end{array}$ & & $\begin{array}{l}3.01 \mathrm{E}+03 \\
3.34 \mathrm{E}+03\end{array}$ & $\begin{array}{l}3.57 \mathrm{E}+06 \\
1.27 \mathrm{~F}+03\end{array}$ & $\begin{array}{l}4.66 \mathrm{E}+06 \\
1.00 \mathrm{E}+03\end{array}$ & & $\begin{array}{l}1.00 \mathrm{E}-09 \\
1.00 \mathrm{E}+03\end{array}$ & $\begin{array}{l}1.000-09 \\
1.00 E+03\end{array}$ \\
\hline Total Mass Flow (kg) & $4.052+03$ & 4. $52 E+06$ & 1. $00 \mathrm{E}+04$ & & $1.00 \mathrm{E}+04$ & $4,525+06$ & $4.66 \mathrm{E}+06$ & & $1.00 \mathrm{E}-09$ & $1.00 \mathrm{E}-09$ \\
\hline \multicolumn{11}{|l|}{ RADIRUCLIIES (C1) } \\
\hline $\begin{array}{l}\text { Cesium } \\
\text { Strantilum } \\
\text { Technetium } \\
\text { IRJ }\end{array}$ & $\begin{array}{l}3.75 \mathrm{E}+00 \\
1.35 \mathrm{~F}+00 \\
6.69 \mathrm{E}-03 \\
9.02 \mathrm{E}-04\end{array}$ & $\begin{array}{l}\text { 4. } 40 \mathrm{E}+03 \\
2.87 \mathrm{E}+04 \\
1.41 \mathrm{E}+02 \\
1.92 \mathrm{E}+01\end{array}$ & $\begin{array}{l}7.53 \mathrm{E}+04 \\
1.43 \mathrm{E}+00\end{array}$ & & $\begin{array}{l}7.53 E+04 \\
1.43 E+00\end{array}$ & $\begin{array}{l}4.40 \mathrm{E}+03 \\
2.87 \mathrm{E}+04 \\
1.41 \mathrm{E}+02 \\
1.92 \mathrm{E}+01\end{array}$ & & & & \\
\hline \multicolumn{11}{|l|}{ APMICALS (kg) } \\
\hline 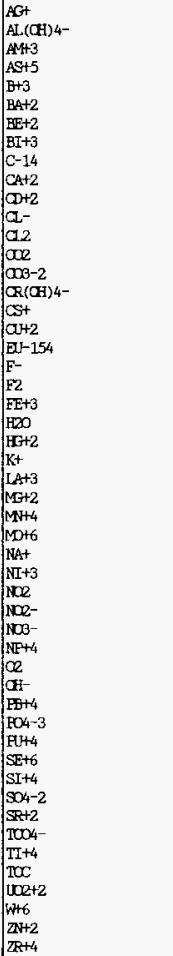 & $\begin{array}{l}1.05 \mathrm{E}-06 \\
5.06 \mathrm{E}+00 \\
1.86 \mathrm{E}-07 \\
4.17 \mathrm{E}-06 \\
9.23 \mathrm{E}-05 \\
1.26 \mathrm{E}-04 \\
1.10 \mathrm{E}-17 \\
7.37 \mathrm{E}-07 \\
1.06 \mathrm{E}-09 \\
4.86 \mathrm{E}-03 \\
8.14 \mathrm{E}-06 \\
2.07 \mathrm{E}-02 \\
\\
4.45 \mathrm{E}+00 \\
3.59 \mathrm{E}-03 \\
4.33 \mathrm{E}-05 \\
1.94 \mathrm{E}-08 \\
6.31 \mathrm{E}-10 \\
2.13 \mathrm{E}-01 \\
2.64 \mathrm{E}-04 \\
3.98 \mathrm{E}+03 \\
1.59 \mathrm{E}-09 \\
1.47 \mathrm{E}-01 \\
1.30 \mathrm{E}-03 \\
3.25 \mathrm{E}-04 \\
6.11 \mathrm{E}-06 \\
1.05 \mathrm{E}-06 \\
2.70 \mathrm{E}+01 \\
1.45 \mathrm{E}-03 \\
\\
8.38 \mathrm{E}+00 \\
2.09 \mathrm{E}+01 \\
6.52 \mathrm{E}-11 \\
1.06 \mathrm{E}+00 \\
2.98 \mathrm{E}-05 \\
5.22 \mathrm{E}-01 \\
3.63 \mathrm{E}-06 \\
6.11 \mathrm{E}-07 \\
6.92 \mathrm{E}-04 \\
9.11 \mathrm{E}-01 \\
9.73 \mathrm{E}-06 \\
6.48 \mathrm{E}-04 \\
1.79 \mathrm{E}-08 \\
3.76 \mathrm{E}+00 \\
1.07 \mathrm{E}-03 \\
5.30 \mathrm{E}-09 \\
4.94 \mathrm{E}-04 \\
1.42 \mathrm{E}-07\end{array}$ & $\begin{array}{l}2.23 \mathrm{E}-02 \\
1.08 \mathrm{E}+05 \\
3.96 \mathrm{E}-03 \\
8.86 \mathrm{E}-02 \\
1.96 \mathrm{E}+00 \\
2.67 \mathrm{E}+00 \\
2.33 \mathrm{E}-13 \\
1.57 \mathrm{E}-02 \\
2.26 \mathrm{E}-05 \\
1.03 \mathrm{E}+02 \\
1.73 \mathrm{E}-01 \\
4.39 \mathrm{E}+02 \\
\\
9.46 \mathrm{E}+04 \\
7.63 \mathrm{E}+01 \\
5.08 \mathrm{E}-02 \\
4.11 \mathrm{E}-04 \\
1.34 \mathrm{E}-05 \\
4.53 \mathrm{E}+03 \\
\\
5.60 \mathrm{E}+00 \\
2.98 \mathrm{E}+06 \\
3.37 \mathrm{E}-05 \\
3.12 \mathrm{E}+03 \\
2.77 \mathrm{E}+01 \\
6.91 \mathrm{E}+00 \\
1.30 \mathrm{E}-01 \\
2.23 \mathrm{E}-02 \\
5.74 \mathrm{E}+05 \\
3.09 \mathrm{E}+01 \\
\\
1.78 \mathrm{E}+05 \\
4.45 \mathrm{E}+05 \\
1.38 \mathrm{E}-06 \\
\\
2.25 \mathrm{E}+04 \\
6.34 \mathrm{E}-01 \\
1.11 \mathrm{E}+04 \\
7.71 \mathrm{E}-02 \\
1.30 \mathrm{E}-02 \\
1.47 \mathrm{E}+01 \\
1.94 \mathrm{E}+04 \\
2.07 \mathrm{E}-01 \\
1.36 \mathrm{E}+01 \\
3.79 \mathrm{E}-04 \\
8.00 \mathrm{E}+04 \\
2.26 \mathrm{E}+01 \\
1.13 \mathrm{E}-04 \\
1.05 \mathrm{E}+01 \\
3.01 \mathrm{E}-03\end{array}$ & $\begin{array}{l}5.76 \mathrm{E}+03 \\
4.27 \mathrm{E}+03\end{array}$ & & $\begin{array}{l}5.76 E+03 \\
4.27 E+03\end{array}$ & $\begin{array}{l}2.23 \mathrm{E}-02 \\
1.08 \mathrm{E}+05 \\
3.96 \mathrm{E}-03 \\
8.86 \mathrm{E}-02 \\
1.96 \mathrm{E}+00 \\
2.67 \mathrm{E}+00 \\
2.33 \mathrm{E}-13 \\
1.57 \mathrm{E}-02 \\
2.26 \mathrm{E}-05 \\
1.03 \mathrm{E}+02 \\
1.73 \mathrm{E}-01 \\
4.39 \mathrm{E}+02 \\
\\
9.46 \mathrm{E}+04 \\
7.63 \mathrm{E}+01 \\
5.08 \mathrm{E}-02 \\
4.11 \mathrm{E}-04 \\
1.34 \mathrm{E}-05 \\
4.53 \mathrm{E}+03 \\
5.60 \mathrm{E}+00 \\
2.98 \mathrm{E}+06 \\
3.37 \mathrm{E}-05 \\
3.12 \mathrm{E}+03 \\
2.7 \mathrm{E}+01 \\
6.91 \mathrm{E}+00 \\
1.30 \mathrm{E}-01 \\
2.23 \mathrm{E}-02 \\
5.74 \mathrm{E}+05 \\
3.09 \mathrm{E}+01 \\
\\
1.78 \mathrm{E}+05 \\
4.45 \mathrm{E}+05 \\
1.38 \mathrm{E}-06 \\
\\
2.25 \mathrm{E}+04 \\
6.34 \mathrm{E}-01 \\
1.11 \mathrm{E}+04 \\
7.71 \mathrm{E}-02 \\
1.30 \mathrm{E}-02 \\
1.47 \mathrm{E}+01 \\
1.94 \mathrm{E}+04 \\
2.07 \mathrm{E}-01 \\
1.36 \mathrm{E}+01 \\
3.79 \mathrm{E}-04 \\
8.00 \mathrm{E}+04 \\
2.26 \mathrm{E}+01 \\
1.13 \mathrm{E}-04 \\
1.05 \mathrm{E}+01 \\
3.01 \mathrm{E}-03\end{array}$ & $\begin{array}{l}\text { 4. 39E+02 } \\
\text { 3. } 62 \mathrm{E}+05 \\
4.53 E+03 \\
3.04 \mathrm{E}+06 \\
5.08 \mathrm{E}+05 \\
\text { 7.52E+05 }\end{array}$ & & $1.00 \mathrm{E}-09$ & $1.00 \mathrm{E}-09$ \\
\hline
\end{tabular}


WHC-SD-WM-TI-774 ReV. 0

TWRS PRIVATIZATION PROCESS TECHNICAL BASELINE

Table B-23 Phase 1 LAW Mass Balance for Batch PC2/23 (6 sheets)

\begin{tabular}{|c|c|c|c|c|c|c|c|c|c|c|}
\hline $\begin{array}{l}\text { SIFEAM NAE } \\
\text { SOLID OOMEONENSS }\end{array}$ & 11 & 12 & 13 & 14 & 15 & 16 & $16 A$ & 17 & 18 & 19 \\
\hline Total Mass Flow (kg) & $4.51 E+02$ & $4.55 E+00$ & & $5.76 \mathrm{E}+03$ & $5.76 E+03$ & $4.552+\infty 0$ & $8.59 E+05$ & & & \\
\hline \multicolumn{11}{|l|}{ RADIONLCIIES (Ci) } \\
\hline $\begin{array}{l}\text { Cesium } \\
\text { Strantium } \\
\text { Tecknetium } \\
\text { TRS }\end{array}$ & $5.77 E+04$ & $5.83 E+02$ & & & & $5.83 E+02$ & $\begin{array}{l}4.40 E+03 \\
2.93 E+04 \\
1.41 E+02 \\
1.91 E+01\end{array}$ & & & \\
\hline \multicolumn{11}{|l|}{ GHEMCALS (kg) } \\
\hline 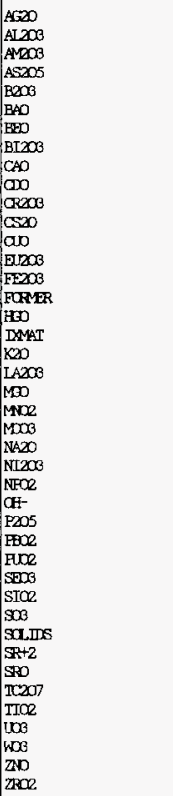 & $\begin{array}{l}1.57 \mathrm{E}-01 \\
\\
4.50 \mathrm{E}+02 \\
4.15 \mathrm{E}-01\end{array}$ & $\begin{array}{l}1.59 \mathrm{E}-03 \\
\\
4.55 \mathrm{E}+00 \\
4.19 \mathrm{E}-03\end{array}$ & & $5.76 \mathrm{E}+03$ & $5.765+03$ & $\begin{array}{l}1.59 E-03 \\
4.55 E+00 \\
4.19 E-03\end{array}$ & $\begin{array}{l}2.39 \mathrm{E}-02 \\
5.7 \mathrm{E}+04 \\
4.35 \mathrm{E}-03 \\
1.36 \mathrm{E}-01 \\
6.31 \mathrm{E}+00 \\
2.99 \mathrm{E}+00 \\
6.4 \mathrm{FE}-13 \\
1.75 \mathrm{E}-02 \\
1.44 \mathrm{E}+02 \\
1.97 \mathrm{E}-01 \\
4.83 \mathrm{E}+01 \\
5.37 \mathrm{E}-02 \\
5.15 \mathrm{E}-04 \\
1.55 \mathrm{E}-05 \\
8.00 \mathrm{E}+00 \\
3.64 \mathrm{E}-05 \\
3.76 \mathrm{E}+03 \\
3.25 \mathrm{E}+01 \\
1.15 \mathrm{E}+01 \\
2.06 \mathrm{E}-01 \\
3.34 \mathrm{E}-02 \\
7.75 \mathrm{E}+05 \\
4.35 \mathrm{E}+01 \\
1.57 \mathrm{E}-06 \\
\\
8.29 \mathrm{E}+03 \\
7.32 \mathrm{E}-01 \\
8.75 \mathrm{E}-02 \\
2.09 \mathrm{E}-02 \\
3.15 \mathrm{E}+01 \\
1.61 \mathrm{E}+04 \\
4.55 \mathrm{E}+00 \\
2.48 \mathrm{E}-01 \\
1.30 \mathrm{E}+01 \\
6.33 \mathrm{E}-04 \\
2.40 \mathrm{E}+01 \\
1.42 \mathrm{E}-04 \\
1.31 \mathrm{E}+01 \\
4.0 \mathrm{E}-03\end{array}$ & & & \\
\hline
\end{tabular}


WHC-SD-WM-TI-774 ReV. 0

TWRS PRIVATIZATION PROCESS TECHNICAL BASELINE

Table B-23 Phase 1. LAW Mass Balance for Batch PC2/23 (6 sheets)

\begin{tabular}{|c|c|c|c|c|c|c|c|c|c|}
\hline $\begin{array}{l}\text { SIREAM IMYE } \\
\text { LIQID COMANBIS }\end{array}$ & 20 & 21 & 22 & 23 & 24 & 25 & 26 & 27 & 28 \\
\hline $\begin{array}{l}\text { Voline }(L) \\
\text { Density }(g / L)\end{array}$ & $\begin{array}{l}\text { 4. 66E+06 } \\
1.00 \mathrm{E}+03\end{array}$ & & & & $\begin{array}{l}\text { 1.63E+06 } \\
1.00 \mathrm{E}+03\end{array}$ & $\begin{array}{l}3.04 E+06 \\
1.00 E+03\end{array}$ & $\begin{array}{l}\text { 3. } 01 \mathrm{E}+03 \\
3.34 \mathrm{E}+03\end{array}$ & $\begin{array}{l}3.00 \mathrm{E}-10 \\
3.34 \mathrm{E}+03\end{array}$ & $\begin{array}{l}\text { 1.00E+06 } \\
1.00 E+03\end{array}$ \\
\hline Total Mass Flaw (kg) & 4.66E+06 & & & & $1.63 E+06$ & $3.04 E+06$ & $1.00 \mathrm{E}+04$ & $1.00 \mathrm{E}-09$ & 1. $.00 E+06$ \\
\hline \multicolumn{10}{|l|}{ RADIOACDDES (Ci) } \\
\hline $\begin{array}{l}\text { Cesium } \\
\text { Struntium } \\
\text { Technetium } \\
\text { TRI }\end{array}$ & & & & & & & & & \\
\hline
\end{tabular}

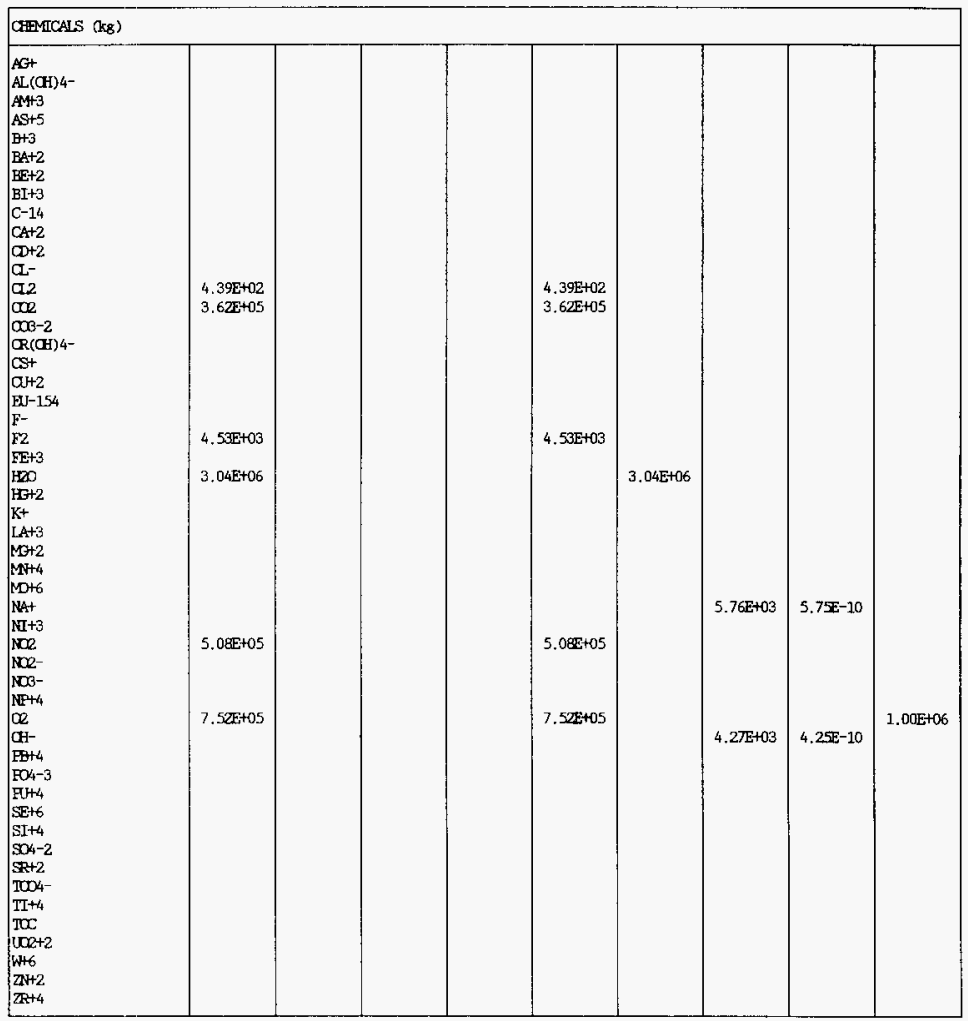


WHC-SD-WM-TI-774 Rev. 0

TWRS PRIVATIZATION PROCESS TECHNICAL BASELINE

Table B-23 Phase 1 LAW Mass Balance for Batch PC2/23 (6 sheets)

\begin{tabular}{|c|c|c|c|c|c|c|c|c|c|}
\hline $\begin{array}{l}\text { SIREAM IAME } \\
\text { SU.ID OOFQNENIS }\end{array}$ & 20 & 21 & 22 & 23 & 24 & 25 & 26 & 27 & 28 \\
\hline Total Mass Flow (kg) & & $8.59 \mathrm{E}+05$ & $3.72 \mathrm{E}+06$ & $4.58 E+06$ & & & & & \\
\hline \multicolumn{10}{|l|}{ RADICNCLIIES (Ci) } \\
\hline $\begin{array}{l}\text { Cesium } \\
\text { Strantium } \\
\text { Technetium } \\
\text { TFI }\end{array}$ & & $\begin{array}{l}4.40 E+03 \\
2.93 E+04 \\
1.41 E+02 \\
1.91 E+01\end{array}$ & & $\begin{array}{l}4.40 \mathrm{E}+03 \\
2.93 \mathrm{E}+04 \\
1.4 \mathrm{E}+02 \\
1.91 \mathrm{E}+01\end{array}$ & & & & & \\
\hline \multicolumn{10}{|l|}{ CHEMICALS（kg) } \\
\hline 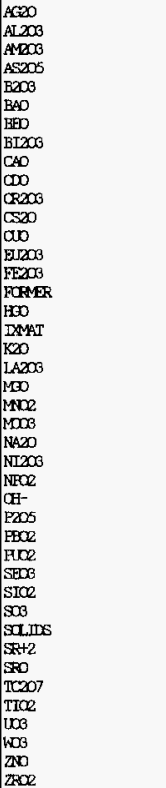 & & $\begin{array}{l}2.39 \mathrm{E}-02 \\
5.7 \mathrm{E}+04 \\
4.35 \mathrm{E}-03 \\
1.36 \mathrm{E}-01 \\
6.31 \mathrm{E}+00 \\
2.99 \mathrm{E}+00 \\
6.4 \pi \mathrm{E}-13 \\
1.7 \mathrm{~F}-02 \\
1.44 \mathrm{E}+02 \\
1.97 \mathrm{E}-01 \\
4.83 \mathrm{E}+01 \\
5.37 \mathrm{E}-02 \\
5.15 \mathrm{E}-04 \\
1.55 \mathrm{E}-05 \\
8.00 \mathrm{E}+00 \\
\\
3.64 \mathrm{E}-05 \\
\\
3.76 \mathrm{E}+03 \\
3.2 \mathrm{E}+01 \\
1.15 \mathrm{E}+01 \\
2.06 \mathrm{E}-01 \\
3.34 \mathrm{E}-02 \\
7.73 \mathrm{E}+05 \\
4.35 \mathrm{~F}+01 \\
1.57 \mathrm{E}-06 \\
\\
8.29 \mathrm{E}+03 \\
7.32 \mathrm{E}-01 \\
8.7 \mathrm{E}-02 \\
2.09 \mathrm{E}-02 \\
3.15 \mathrm{E}+01 \\
1.6 \mathrm{E}+04 \\
4.5 \mathrm{E}+00 \\
\\
2.4 \mathrm{EE}-01 \\
1.30 \mathrm{E}+01 \\
6.33 \mathrm{E}-04 \\
2.40 \mathrm{E}+01 \\
1.4 \mathrm{E}-04 \\
1.3 \mathrm{E}+01 \\
4.0 \mathrm{E}-03\end{array}$ & $3.72 \mathrm{~F}+06$ & $\begin{array}{l}2.39 \mathrm{E}-02 \\
5.77 \mathrm{~F}+04 \\
4.35 \mathrm{E}-03 \\
1.36 \mathrm{E}-01 \\
6.31 \mathrm{E}+00 \\
2.99 \mathrm{E}+00 \\
6.47 \mathrm{E}-13 \\
1.75 \mathrm{E}-02 \\
1.44 \mathrm{E}+02 \\
1.97 \mathrm{E}-01 \\
4.83 \mathrm{E}+01 \\
5.37 \mathrm{E}-02 \\
5.15 \mathrm{E}-04 \\
1.55 \mathrm{E}-05 \\
8.00 \mathrm{E}+00 \\
3.72 \mathrm{E}+06 \\
3.64 \mathrm{E}-05 \\
3.76 \mathrm{E}+03 \\
3.25 \mathrm{E}+01 \\
1.15 \mathrm{E}+01 \\
2.06 \mathrm{E}-01 \\
3.34 \mathrm{E}-02 \\
7.73 \mathrm{E}+05 \\
4.35 \mathrm{E}+01 \\
1.57 \mathrm{E}-06 \\
\\
8.29 \mathrm{E}+03 \\
7.32 \mathrm{E}-01 \\
8.75 \mathrm{E}-02 \\
2.09 \mathrm{E}-02 \\
3.15 \mathrm{E}+01 \\
1.61 \mathrm{E}+04 \\
4.55 \mathrm{E}+00 \\
\\
2.48 \mathrm{E}-01 \\
1.30 \mathrm{E}+01 \\
6.33 \mathrm{E}-04 \\
2.40 \mathrm{E}+01 \\
1.42 \mathrm{E}-04 \\
1.31 \mathrm{E}+01 \\
4.0 \mathrm{E}-03\end{array}$ & & & & & \\
\hline
\end{tabular}


WHC-SD-WM-TI-774 Rev. 0

TWRS PRIVATIZATION PROCESS TECHNICAL BASELINE

Table B-24 Phase 1 LAW Mass Balance for Batch FC2/24 (6 sheets)

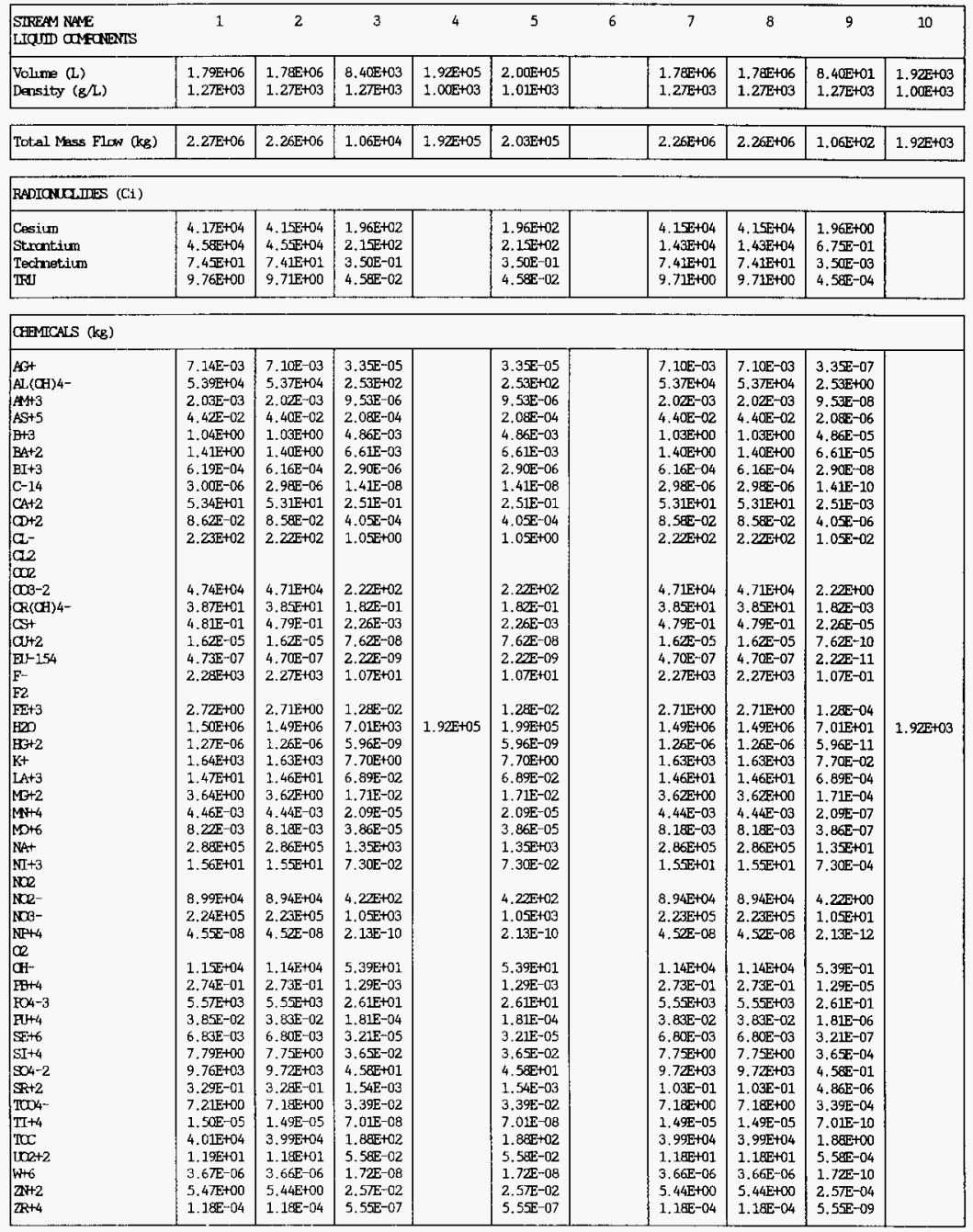


WHC-SD-WM-TI-774 Rev. 0

TWRS PRIVATIZATION PROCESS TECHNICAL BASELINE

Table B-24 Phase 1 LAW Mass Balance for Batch PC2/24 ( 6 sheets)

\begin{tabular}{|c|c|c|c|c|c|c|c|c|c|c|}
\hline $\begin{array}{l}\text { SIREAM RAE } \\
\text { SUW OAFONENTS }\end{array}$ & 1 & 2 & 3 & 4 & 5 & 6 & 7 & 8 & 9 & 10 \\
\hline Total Mass Flas (kg) & $2.2 \pi+04$ & $2.27 \mathrm{E}+02$ & $2.25 \mathrm{E}+04$ & & 2.2. & & 2. $28 \mathrm{EF}+02$ & $2.28 E+00$ & $2.25 \mathrm{E}+02$ & \\
\hline \multicolumn{11}{|l|}{ RADIONUCIIDES (Ci) } \\
\hline $\begin{array}{l}\text { Cesium } \\
\text { Strantiun } \\
\text { Techmetium } \\
\text { TRU }\end{array}$ & & & & & & & $3.12 E+04$ & 3.12 +02 & $3.09 \mathrm{E}+04$ & \\
\hline
\end{tabular}

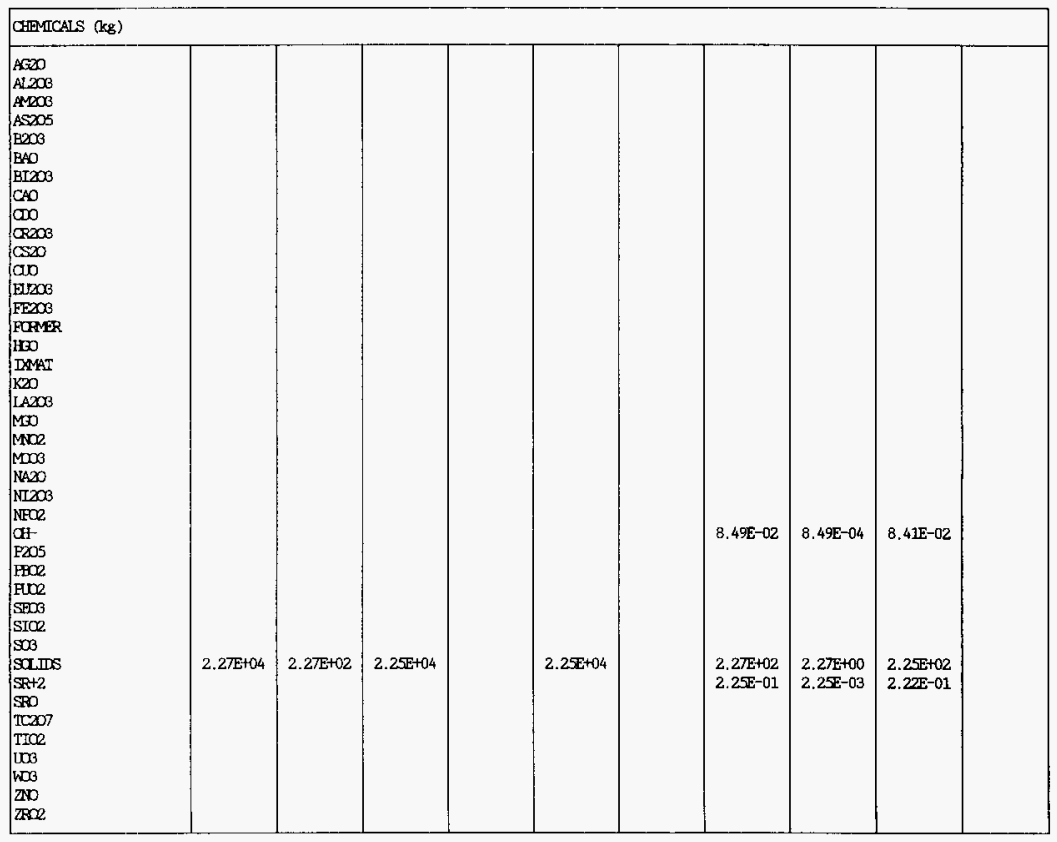


WHC-SD-WM-TI-774 Rev. 0

TWRS PRIVATIZATION PROCESS TECHNICAL BASELINE

Table B-24 Phase 1 LAW Mass Balance for Batch $\mathrm{FC} 2 / 24$ (6 sheets)

\begin{tabular}{|c|c|c|c|c|c|c|c|c|c|c|}
\hline $\begin{array}{l}\text { SIREAM NAME } \\
\text { LIQJI COMONANIS }\end{array}$ & 11 & 12 & 13 & 14 & 15 & 16 & 164 & 17 & 18 & 19 \\
\hline $\begin{array}{l}\text { Volume }(L) \\
\text { Density }(g / L)\end{array}$ & $\begin{array}{l}2.01 \mathrm{E}+03 \\
1.01 \mathrm{E}+03\end{array}$ & $\begin{array}{l}1.78 \mathrm{dE}+06 \\
1.27 \mathrm{E}+03\end{array}$ & $\begin{array}{l}1.50 \mathrm{E}+03 \\
3.34 \mathrm{E}+03\end{array}$ & & $\begin{array}{l}1.50 \mathrm{E}+03 \\
3.34 \mathrm{E}+03\end{array}$ & $\begin{array}{l}1.78 \mathrm{EE}+06 \\
1.27 \mathrm{E}+03\end{array}$ & $\begin{array}{l}2.83 \mathrm{E}+06 \\
1.00 \mathrm{E}+03\end{array}$ & & $\begin{array}{l}1.00 E-09 \\
1.00 E+03\end{array}$ & $\begin{array}{l}\text { 1. } .00 \mathrm{E}-09 \\
1.00 \mathrm{E}+03\end{array}$ \\
\hline Total Mass Flow (kg) & $2.03 E+03$ & $2.26 \mathrm{E}+06$ & $5.015+03$ & & $5.011+03$ & $2.26 \mathrm{E}+06$ & 2. $83 \mathrm{E}+06$ & & 1.00E-09 & $1.00 \mathrm{E}-09$ \\
\hline \multicolumn{11}{|l|}{ RADICNLCIIIES (Ci) } \\
\hline $\begin{array}{l}\text { Cesium } \\
\text { Strontium } \\
\text { Technetium } \\
\text { TRU }\end{array}$ & $\begin{array}{l}1.96 \mathrm{E}+00 \\
6.75 \mathrm{E}-01 \\
3.50 \mathrm{E}-03 \\
4.58 \mathrm{E}-04\end{array}$ & $\begin{array}{l}2.20 \mathrm{E}+03 \\
1.43 \mathrm{E}+04 \\
7.34 \mathrm{E}+01 \\
9.71 \mathrm{E}+00\end{array}$ & $\begin{array}{l}3.93 E+04 \\
7.45 E-01\end{array}$ & & $\begin{array}{l}3.93 \mathrm{E}+04 \\
7.4 \mathrm{E}-01\end{array}$ & $\begin{array}{l}2.20 \mathrm{E}+03 \\
1.43 \mathrm{E}+04 \\
7.34 \mathrm{E}+01 \\
9.71 \mathrm{E}+00\end{array}$ & & & & \\
\hline \multicolumn{11}{|l|}{ CHAMICAIS $(\mathrm{kg})$} \\
\hline 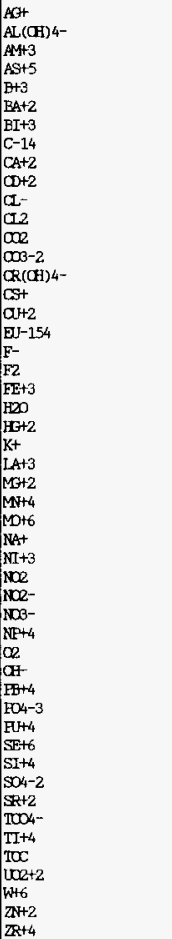 & $\begin{array}{l}3.35 \mathrm{E}-07 \\
2.53 \mathrm{E}+00 \\
9.53 \mathrm{E}-08 \\
2.08 \mathrm{E}-06 \\
4.86 \mathrm{E}-0.5 \\
5.61 \mathrm{E}-05 \\
2.90 \mathrm{E}-08 \\
1.41 \mathrm{E}-10 \\
2.51 \mathrm{E}-03 \\
4.05 \mathrm{E}-06 \\
1.05 \mathrm{E}-02 \\
\\
2.22 \mathrm{E}+00 \\
1.82 \mathrm{E}-03 \\
2.26 \mathrm{E}-05 \\
7.62 \mathrm{E}-10 \\
2.2 \mathrm{E}-11 \\
1.07 \mathrm{E}-01 \\
\\
1.28 \mathrm{E}-04 \\
1.99 \mathrm{E}+03 \\
5.96 \mathrm{E}-11 \\
7.70 \mathrm{E}-02 \\
6.89 \mathrm{E}-04 \\
1.71 \mathrm{E}-04 \\
2.09 \mathrm{E}-07 \\
3.86 \mathrm{E}-07 \\
1.35 \mathrm{E}+01 \\
7.30 \mathrm{E}-04 \\
4.22 \mathrm{E}+00 \\
1.05 \mathrm{E}+01 \\
2.13 \mathrm{E}-12 \\
5.39 \mathrm{E}-01 \\
1.57 \mathrm{E}-04 \\
1.29 \mathrm{E}-05 \\
2.61 \mathrm{E}-01 \\
1.81 \mathrm{E}-06 \\
3.21 \mathrm{E}-07 \\
3.6 \mathrm{E}-04 \\
4.5 \mathrm{E}-01 \\
4.86 \mathrm{E}-06 \\
3.39 \mathrm{E}-04 \\
7.01 \mathrm{E}-10 \\
1.88 \mathrm{E}+00 \\
5.58 \mathrm{E}-04 \\
1.72 \mathrm{E}-10\end{array}$ & $\begin{array}{l}7.10 \mathrm{E}-03 \\
5.3 \mathrm{E}+04 \\
2.02 \mathrm{E}-03 \\
4.40 \mathrm{E}-02 \\
1.03 \mathrm{E}+00 \\
1.40 \mathrm{E}+00 \\
6.16 \mathrm{E}-04 \\
2.9 \mathrm{aE}-06 \\
5.3 \mathrm{EE}+01 \\
8.5 \mathrm{EE}-02 \\
2.22 \mathrm{E}+02 \\
\\
4.71 \mathrm{E}+04 \\
3.85 \mathrm{E}+01 \\
2.53 \mathrm{E}-02 \\
1.62 \mathrm{E}-05 \\
4.70 \mathrm{E}-07 \\
2.2 \mathrm{E}+03 \\
\\
2.71 \mathrm{E}+00 \\
1.49 \mathrm{E}+06 \\
1.26 \mathrm{E}-05 \\
1.63 \mathrm{E}+03 \\
1.46 \mathrm{E}+01 \\
3.62 \mathrm{E}+00 \\
4.44 \mathrm{E}-03 \\
8.28 \mathrm{E}-03 \\
2.86 \mathrm{E}+05 \\
1.5 \mathrm{E}+01 \\
8.94 \mathrm{E}+04 \\
2.23 \mathrm{E}+05 \\
4.52 \mathrm{E}-08 \\
1.14 \mathrm{E}+04 \\
2.73 \mathrm{E}-01 \\
5.5 \mathrm{E}+03 \\
3.83 \mathrm{E}-02 \\
6.80 \mathrm{E}-03 \\
7.75 \mathrm{E}+00 \\
9.72 \mathrm{E}+03 \\
1.03 \mathrm{E}-01 \\
7.11 \mathrm{E}+00 \\
1.49 \mathrm{E}-05 \\
3.99 \mathrm{E}+04 \\
1.18 \mathrm{E}+01 \\
3.66 \mathrm{E}-06 \\
5.44 \mathrm{E}+00 \\
1.1 \mathrm{EE}-04\end{array}$ & $\begin{array}{l}4.54 \mathrm{E}-01 \\
2.88 \mathrm{E}+03 \\
2.13 \mathrm{E}+03\end{array}$ & & $\begin{array}{l}4.54 \mathrm{E}-01 \\
2.8 \mathrm{E}+03 \\
2.13 \mathrm{E}+03\end{array}$ & $\begin{array}{l}7.10 \mathrm{E}-03 \\
5.37 \mathrm{E}+04 \\
2.02 \mathrm{E}-03 \\
4.40 \mathrm{E}-02 \\
1.03 \mathrm{E}+00 \\
1.40 \mathrm{E}+00 \\
6.16 \mathrm{E}-04 \\
2.98 \mathrm{E}-06 \\
5.31 \mathrm{E}+01 \\
8.58 \mathrm{E}-02 \\
2.22 \mathrm{E}+02 \\
\\
4.71 \mathrm{E}+04 \\
3.85 \mathrm{E}+01 \\
2.53 \mathrm{E}-02 \\
1.62 \mathrm{E}-05 \\
4.70 \mathrm{E}-07 \\
2.27 \mathrm{E}+03 \\
\\
2.71 \mathrm{E}+00 \\
1.49 \mathrm{E}+06 \\
1.26 \mathrm{E}-06 \\
1.63 \mathrm{E}+03 \\
1.46 \mathrm{E}+01 \\
3.62 \mathrm{E}+00 \\
4.44 \mathrm{E}-03 \\
8.18 \mathrm{E}-03 \\
2.86 \mathrm{E}+05 \\
1.55 \mathrm{E}+01 \\
8.94 \mathrm{E}+04 \\
2.23 \mathrm{E}+05 \\
4.52 \mathrm{E}-08 \\
1.14 \mathrm{E}+04 \\
2.73 \mathrm{E}-01 \\
5.55 \mathrm{E}+03 \\
3.83 \mathrm{E}-02 \\
6.80 \mathrm{E}-03 \\
7.75 \mathrm{E}+00 \\
9.7 \mathrm{E}+03 \\
1.03 \mathrm{E}-01 \\
7.11 \mathrm{E}+00 \\
1.49 \mathrm{E}-05 \\
3.99 \mathrm{E}+04 \\
1.18 \mathrm{E}+01 \\
5.66 \mathrm{E}-06 \\
1.18 \mathrm{E}-04\end{array}$ & $\begin{array}{l}2.22 \mathrm{E}+02 \\
1.81 \mathrm{E}+05 \\
2.27 \mathrm{E}+03 \\
1.51 \mathrm{E}+06 \\
2.55 \mathrm{E}+05 \\
8.77 \mathrm{E}+05\end{array}$ & & $1.00 \mathrm{E}-09$ & $1,00 \mathrm{E}-09$ \\
\hline
\end{tabular}


WHC-SD-WM-TI-774 Rev. 0

TWRS PRIVATIZATION PROCESS TECHNICAL BASELINE

Table B-24 Phase 1 LAW Mass Balance for Batch PC2/24 (6 sheets)

\begin{tabular}{|c|c|c|c|c|c|c|c|c|c|c|}
\hline $\begin{array}{l}\text { SIREAM NAME } \\
\text { SOWD ONFANDNS }\end{array}$ & 11 & 12 & 13 & 14 & 15 & 16 & $16 \mathrm{~A}$ & 17 & 18 & 19 \\
\hline Total Mass Flaw (kg) & 2. $25 \mathrm{SE}+02$ & $2.28 \mathrm{BF}+00$ & & $2.88 E+03$ & $2.8 \mathrm{EE}+03$ & $2.2 \mathrm{BE}+00$ & $4.29 \mathrm{E}+05$ & & & \\
\hline \multicolumn{11}{|l|}{ RADTONOSTEES (Ci) } \\
\hline $\begin{array}{l}\text { Cesium } \\
\text { Stuntium } \\
\text { Technetium } \\
\text { TRU }\end{array}$ & $3.09 E+04$ & $3.12 \mathrm{E}+02$ & & & & $3.12 \mathrm{E}+02$ & $\begin{array}{l}2.20 \mathrm{E}+03 \\
1.46 \mathrm{E}+04 \\
7.34 \mathrm{E}+01 \\
9.68 \mathrm{E}+00\end{array}$ & & & \\
\hline \multicolumn{11}{|l|}{ CAEMICALS（kg) } \\
\hline 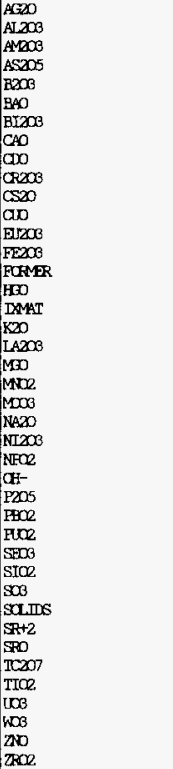 & $\begin{array}{l}8.41 \mathrm{E}-02 \\
\\
2.2 \mathrm{FE}+02 \\
2.2 \mathrm{E}-01\end{array}$ & $\begin{array}{l}8.49 \mathrm{E}-04 \\
2.27 \mathrm{E}+00 \\
2.25 \mathrm{E}-03\end{array}$ & & $2.88 \mathrm{E}+03$ & $2.80 E+03$ & $\begin{array}{l}8.49 \mathrm{E}-04 \\
2.2 \pi+00 \\
2.25 \mathrm{E}-03\end{array}$ & $\begin{array}{l}7.63 \mathrm{E}-03 \\
2.88 \mathrm{E}+04 \\
2.22 \mathrm{E}-03 \\
6.75 \mathrm{E}-02 \\
3.32 \mathrm{E}+00 \\
1.57 \mathrm{E}+00 \\
6.86 \mathrm{E}-04 \\
7.44 \mathrm{E}+01 \\
9.80 \mathrm{E}-02 \\
2.44 \mathrm{E}+01 \\
2.68 \mathrm{E}-02 \\
2.02 \mathrm{E}-05 \\
5.4 \mathrm{EE}-07 \\
3.87 \mathrm{E}+00 \\
1.37 \mathrm{E}-06 \\
1.97 \mathrm{E}+03 \\
1.71 \mathrm{E}+01 \\
6.00 \mathrm{E}+00 \\
7.02 \mathrm{E}-03 \\
1.23 \mathrm{E}-02 \\
3.86 \mathrm{E}+05 \\
2.18 \mathrm{E}+01 \\
5.13 \mathrm{E}-08 \\
\\
4.15 \mathrm{E}+03 \\
3.15 \mathrm{E}-01 \\
4.35 \mathrm{E}-02 \\
1.09 \mathrm{E}-02 \\
1.66 \mathrm{E}+01 \\
8.10 \mathrm{E}+03 \\
2.27 \mathrm{E}+00 \\
1.24 \mathrm{E}-01 \\
6.76 \mathrm{E}+00 \\
2.48 \mathrm{E}-05 \\
1.25 \mathrm{E}+01 \\
4.61 \mathrm{E}-06 \\
6.78 \mathrm{E}+00 \\
1.59 \mathrm{E}-04\end{array}$ & & & \\
\hline
\end{tabular}


WHC-SD-WM-TI-774 Rev. 0

TWRS PRIVATIZATION PROCESS TECHNICAL BASELINE

Table B-24 Phase 1 LAW Mass Balance for Batch PC2/24 (6 sheets)

\begin{tabular}{|c|c|c|c|c|c|c|c|c|c|}
\hline $\begin{array}{l}\text { SIREAM NAM } \\
\text { LIQUID CAMPONENS }\end{array}$ & 20 & 21 & 22 & 23 & 24 & 25 & 26 & 27 & 28 \\
\hline $\begin{array}{l}\text { Volume }(\mathrm{L}) \\
\text { Derisity }(\mathrm{g} / \mathrm{L})\end{array}$ & $\begin{array}{l}2.83 \mathrm{E}+06 \\
1.00 \mathrm{E}+03\end{array}$ & & & & $\begin{array}{l}1.32 \mathrm{EF}+06 \\
1.00 \mathrm{E}+03\end{array}$ & $\begin{array}{l}1.51 \mathrm{E}+06 \\
1.00 \mathrm{E}+03\end{array}$ & $\begin{array}{l}1.50 \mathrm{E}+03 \\
3.34 \mathrm{E}+03\end{array}$ & $\begin{array}{l}3.00 E-10 \\
3.34 E+03\end{array}$ & $\begin{array}{l}1.00 E+06 \\
1.00 E+03\end{array}$ \\
\hline Total Mass Flow ( $\mathrm{cg}$ ) & $2.83 E+06$ & & & & $1.325+06$ & $1.51 E+06$ & $5.01 E+03$ & $1.00 \mathrm{E}-09$ & $1,00 E+06$ \\
\hline \multicolumn{10}{|l|}{ RADIONCDIDES (Ci) } \\
\hline $\begin{array}{l}\text { Cesium } \\
\text { Stuntium } \\
\text { Technotium } \\
\text { TRV }\end{array}$ & & & & & & & & & \\
\hline
\end{tabular}

\begin{tabular}{|c|c|c|c|c|c|c|}
\hline \multicolumn{7}{|c|}{ CAEEICALS (kg) } \\
\hline 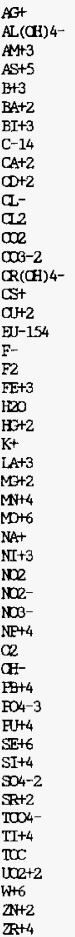 & $\begin{array}{l}2.22 \mathrm{E}+02 \\
1.81 \mathrm{E}+05 \\
\\
2.2 \mathrm{E}+03 \\
1.51 \mathrm{E}+06 \\
2.55 \mathrm{E}+05 \\
8.77 \mathrm{E}+05\end{array}$ & $\begin{array}{l}2.22 \mathrm{E}+02 \\
1.81 \mathrm{E}+05 \\
2.2 \pi+03 \\
2.5 \mathrm{E}+05 \\
8.77 \mathrm{E}+05\end{array}$ & $1.51 E+06$ & $\begin{array}{l}2.88 E+03 \\
\text { 2. } 13 E+03\end{array}$ & $\begin{array}{l}5.75 E-10 \\
4.25 E-10\end{array}$ & $1.00 E+06$ \\
\hline
\end{tabular}


WHC-SD-WM-TI-774 Rev. 0

TWRS PRIVATIZATION PROCESS TECHNICAL BASELINE

Table B-24 Phase 1 LAW Mass Balance for Batch PC2/24 (6 sheets)

\begin{tabular}{|c|c|c|c|c|c|c|c|c|c|}
\hline $\begin{array}{l}\text { SIRFAM NAME } \\
\text { SO.TD COMPUNDNIS }\end{array}$ & 20 & 21 & 22 & 23 & 24 & 25 & 26 & 27 & 28 \\
\hline Total Mass Flow (kg) & & $4.29 \mathrm{E}+0.5$ & $1.86 \mathrm{E}+06$ & $2.29 E+06$ & & & & & \\
\hline \multicolumn{10}{|l|}{ RADTONUCIIJES (Ci) } \\
\hline \begin{tabular}{|l} 
Cesium \\
Strantium \\
Technetium \\
TRU
\end{tabular} & & $\begin{array}{l}2.20 \mathrm{E}+03 \\
1.46 \mathrm{E}+04 \\
7.34 \mathrm{E}+01 \\
9.68 \mathrm{E}+00\end{array}$ & & $\begin{array}{l}2.20 E+03 \\
1.46 E+04 \\
7.34 E+01 \\
9.68 E+00\end{array}$ & & & & & \\
\hline \multicolumn{10}{|l|}{ CHFMICALS (Kg) } \\
\hline 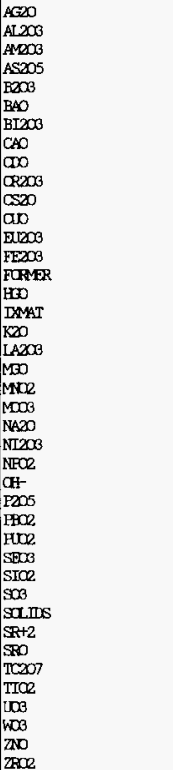 & & $\begin{array}{l}7.63 \mathrm{E}-03 \\
2.88 \mathrm{E}+04 \\
2.22 \mathrm{E}-03 \\
6.7 \mathrm{E}-02 \\
3.32 \mathrm{E}+00 \\
1.57 \mathrm{E}+00 \\
6.86 \mathrm{E}-04 \\
7.44 \mathrm{E}+01 \\
9.80 \mathrm{E}-02 \\
2.44 \mathrm{E}+01 \\
2.68 \mathrm{E}-02 \\
2.02 \mathrm{E}-05 \\
5.45 \mathrm{E}-07 \\
3.87 \mathrm{E}+00 \\
1.37 \mathrm{E}-06 \\
\\
1.97 \mathrm{E}+03 \\
1.71 \mathrm{E}+01 \\
6.00 \mathrm{E}+00 \\
7.02 \mathrm{E}-03 \\
1.23 \mathrm{E}-02 \\
3.86 \mathrm{E}+05 \\
2.18 \mathrm{E}+01 \\
5.13 \mathrm{E}-08 \\
\\
4.15 \mathrm{E}+03 \\
3.15 \mathrm{E}-01 \\
4.35 \mathrm{E}-02 \\
1.09 \mathrm{E}-02 \\
1.66 \mathrm{E}+01 \\
8.10 \mathrm{E}+03 \\
2.27 \mathrm{E}+00 \\
1.24 \mathrm{E}-01 \\
6.76 \mathrm{E}+00 \\
2.48 \mathrm{E}-05 \\
1.25 \mathrm{E}+01 \\
4.61 \mathrm{E}-06 \\
6.78 \mathrm{E}+00 \\
1.59 \mathrm{E}-04\end{array}$ & $1.86 \mathrm{E}+06$ & $\begin{array}{l}7.63 \mathrm{E}-03 \\
2.88 \mathrm{E}+04 \\
2.22 \mathrm{E}-03 \\
6.75 \mathrm{E}-02 \\
3.32 \mathrm{E}+00 \\
1.57 \mathrm{E}+00 \\
6.86 \mathrm{E}-04 \\
7.44 \mathrm{E}+01 \\
9.80 \mathrm{E}-02 \\
2.44 \mathrm{E}+01 \\
2.6 \mathrm{BE}-02 \\
2.02 \mathrm{E}-05 \\
5.4 \mathrm{E}-07 \\
3.87 \mathrm{E}+00 \\
1.86 \mathrm{E}+06 \\
1.37 \mathrm{E}-06 \\
1.97 \mathrm{E}+03 \\
1.7 \mathrm{E}+01 \\
6.00 \mathrm{E}+00 \\
7.02 \mathrm{E}-03 \\
1.23 \mathrm{E}-02 \\
3.86 \mathrm{E}+05 \\
2.18 \mathrm{E}+01 \\
5.13 \mathrm{E}-08 \\
\\
4.15 \mathrm{E}+03 \\
3.15 \mathrm{E}-01 \\
4.35 \mathrm{E}-02 \\
1.09 \mathrm{E}-02 \\
1.66 \mathrm{E}+01 \\
8.10 \mathrm{E}+03 \\
2.27 \mathrm{E}+00 \\
1.24 \mathrm{E}-01 \\
6.76 \mathrm{E}+00 \\
2.48 \mathrm{E}-05 \\
1.25 \mathrm{E}+01 \\
4.61 \mathrm{E}-06 \\
6.78 \mathrm{E}+00 \\
1.59 \mathrm{E}-04\end{array}$ & & & & & \\
\hline
\end{tabular}




\section{APPENDIX C ENVIRONMENTAL SIMULATION PROGRAM}

Shelton (1996) provides the supernate (i.e., soluble) inventories and ionic molarities for Phase 1 feeds. Shelton's inventory is not charge balanced, however. To facilitate rigorous thermodynamic calculations, the Water Analyzer feature of ESP balances ionic charges by adding or subtracting the necessary amount of $\mathrm{OH}^{-}$. The Stream Manager feature of ESP then converts the balanced ionic composition to the "OLI Defined Stream". The "OLI Defined Stream" contains 55.5 mol of water plus several molecular species in amounts that are equivalent to the balanced ionic composition. The "OLI Defined Stream" is compatible with the data entry format required by the ESP calculation engines, which is the input for chemical equilibrium calculations.

Exhibit 1 -- Conversion of Raw Composition Data to ESP Input

Exhibit 2 -- Typical ESP Equilibrium Results 


\section{Exhibit 1 -- Conversion of Raw Composition Data to ESP Input}

\begin{tabular}{|c|c|c|c|c|c|c|c|}
\hline \multirow{3}{*}{$M W$} & \multicolumn{2}{|c|}{ CONCENTRATION ESTIMATES } & & & & \multirow{2}{*}{\multicolumn{2}{|c|}{$\begin{array}{l}\text { ESP } \\
\text { Input }\end{array}$}} \\
\hline & Supernatant & 105AN & & & & & \\
\hline & Chemical & (M) & & $g / L$ & $\mathrm{mg} / \mathrm{L}$ & $\mathrm{mg} / \mathrm{L}$ & Ion \\
\hline $1.08 \mathrm{E}+02$ & $\mathbf{A g +}$ & 0 & & 0 & 0.0 & & \\
\hline $9.50 \mathrm{E}+01$ & AllOH/4: & 1.74 & $\mathrm{Al}+3$ & 46.98 & 46980.0 & 46980.0 & $A \mid+3$ \\
\hline $7.49 \mathrm{E}+01$ & $A s+5$ & 0 & & 0 & 0.0 & & \\
\hline $1.08 E+01$ & $\mathbf{B}+3$ & 0 & & 0 & 0.0 & & \\
\hline $1.37 E+02$ & $B a+2$ & 0 & & 0 & 0.0 & & \\
\hline $9.01 \mathrm{E}+00$ & $\mathrm{Be}+2$ & 0 & & 0 & 0.0 & & \\
\hline $2.09 \mathrm{E}+02$ & $B i+3$ & 0 & & 0 & 0.0 & & \\
\hline $4.01 \mathrm{E}+01$ & $\mathrm{Ca}+2$ & 5.81E-06 & & 0.000233 & 0.2 & 0.2 & $\mathrm{Ca}+2$ \\
\hline $1.12 \mathrm{E}+02$ & $\mathrm{Cd}+2$ & 0 & & 0 & 0.0 & & \\
\hline $1.40 \mathrm{E}+02$ & $\mathrm{Ce}+3$ & 0 & & 0 & 0.0 & & \\
\hline $1.20 \mathrm{E}+02$ & $\mathrm{Cr}(\mathrm{OH}) 4$ & 0.013 & $\mathrm{Cr}+3$ & 0.676 & 676.0 & 676.0 & $\mathrm{Cr}+3$ \\
\hline $6.35 \mathrm{E}+01$ & $\mathrm{Cu}+2$ & 0 & & 0 & 0.0 & & \\
\hline $5.58 \mathrm{E}+01$ & $F_{\mathbf{B}}+3$ & 0.0002 & & 0.011169 & 11.2 & & \\
\hline $2.01 E+02$ & $\mathrm{Hg}+2$ & 0 & & 0 & 0.0 & & \\
\hline $3.91 \mathrm{E}+01$ & $\mathbf{K}+$ & 0.157 & & 6.138433 & 6138.4 & 6138.4 & K+ \\
\hline $1.39 \mathrm{E}+02$ & $\mathrm{La}+3$ & 0 & & 0 & 0.0 & & \\
\hline $6 . \overline{4 E}+00$ & Lit & $\overline{0}$ & & 0 & 0.0 & & \\
\hline $2.43 E+01$ & $\mathrm{Mg}+2$ & 0 & & 0 & 0.0 & & \\
\hline $5.49 \mathrm{E}+01$ & $\mathrm{Mn}+4$ & 0 & & 0 & 0.0 & & \\
\hline $9.69 \mathrm{E}+01$ & $\mathrm{MnO} 2$ & 0 & & 0 & 0.0 & & \\
\hline $9.59 E+01$ & Mo + 6 & 0 & & 0 & 0.0 & & \\
\hline $2.30 \mathrm{E}+01$ & $\mathrm{Na}+$ & 12 & & 276 & 276000.0 & 276000.0 & $\mathrm{Na}+$ \\
\hline $5.87 \mathrm{E}+01$ & $\mathrm{Ni}+3$ & 0 & & 0 & 0.0 & & \\
\hline $2.07 E+02$ & $\mathrm{~Pb}+4$ & 0 & & 0 & 0.0 & & \\
\hline $8.55 \mathrm{E}+01$ & $\mathrm{Rb}+$ & 0 & & 0 & 0.0 & & \\
\hline $1.86 \mathrm{E}+02$ & $R e+7$ & 0 & & 0 & 0.0 & & \\
\hline $1.03 E+02$ & $R h+3$ & 0 & & 0 & 0.0 & & \\
\hline $1.01 \mathrm{E}+02$ & $R u+3$ & 0 & & 0 & 0.0 & & \\
\hline $1.22 \mathrm{E}+02$ & $\mathrm{sb}+5$ & 0 & & 0 & 0.0 & & \\
\hline $7.90 \mathrm{E}+01$ & $\mathrm{Se}+6$ & 0 & & 0 & 0.0 & & \\
\hline $2.81 E+01$ & $\mathrm{Si}+4$ & 0 & & 0 & 0.0 & & \\
\hline $1.19 \mathrm{E}+02$ & $5 n+4$ & 0 & & 0 & 0.0 & & \\
\hline $1.50 \mathrm{E}+02$ & $5 m+3$ & 0 & & 0 & 0.0 & & \\
\hline $1.28 \mathrm{E}+02$ & $\mathrm{Te}+6$ & 0 & & 0 & 0.0 & & \\
\hline $2.32 E+02$ & $T h+4$ & 0 & & 0 & 0.0 & & \\
\hline $4.79 \mathrm{E}+01$ & $T i+4$ & 0 & & 0 & 0.0 & & \\
\hline $2.04 \mathrm{E}+02$ & $\mathrm{TI}+3$ & 0 & & 0 & 0.0 & & \\
\hline $1.00 \mathrm{E}+00$ & $U_{g / l}$ & 0.000233 & $\mathrm{UO} 2+2$ & 0.000264 & 0.3 & 0.3 & $\mathrm{UO} 2+2$ \\
\hline $5.09 E+01$ & $v+5$ & 0 & & 0 & 0.0 & & \\
\hline $1.84 E+02$ & $w+6$ & 0 & & 0 & 0.0 & & \\
\hline $6.54 \mathrm{E}+01$ & $2 n+2$ & 0 & & 0 & 0.0 & & \\
\hline $9.12 \mathrm{E}+01$ & $2 r+4$ & 0 & & 0 & 0.0 & & \\
\hline $6.00 E+01$ & $\cos 3-2$ & 0.363 & & 21.78334 & 21783.3 & 21783.3 & $\mathrm{co3}-2$ \\
\hline $3.55 E+01$ & CL- & 0.24 & & 8.50872 & 8508.7 & 8508.7 & $\mathrm{Cl}$ \\
\hline $1.90 \mathrm{E}+01$ & F- & 0.000123 & & 0.00233 & 2.3 & 2.3 & F- \\
\hline $9.61 \mathrm{E}+01$ & $504-2$ & 0.0682 & & 6.551128 & 6551.1 & 6551.1 & 5042 \\
\hline $6.20 E+01$ & NO3- & 3.12 & & 193.4553 & 193455.3 & 193455.3 & NO3- \\
\hline $4.60 \mathrm{E}+01$ & NO2 & $\overline{2} . \overline{61}$ & & 120.0744 & 120074.4 & 120074.4 & $4 \mathrm{NO}_{2}$ \\
\hline $9.50 \mathrm{E}+01$ & PO4-3 & 0.02 & & 1.899428 & 1899.4 & 1899.4 & $P 04-3$ \\
\hline $1.70 E+01$ & OH- & 3.64 & & 61.90657 & 61906.6 & 61906.6 & $\mathrm{OH}-$ \\
\hline $1.00 \mathrm{E}+00$ & TOC g/l & 388 & EDTA g/L & 9.312 & 9312.0 & 9312.0 & EDTA-4 \\
\hline
\end{tabular}


WHC-SD-WM-TI-774 Rev. 0

TWRS PRIVATIZATION PROCESS TECHNICAL BASELINE

Exhibit 2 -- Typical ESP Equilibrium Results

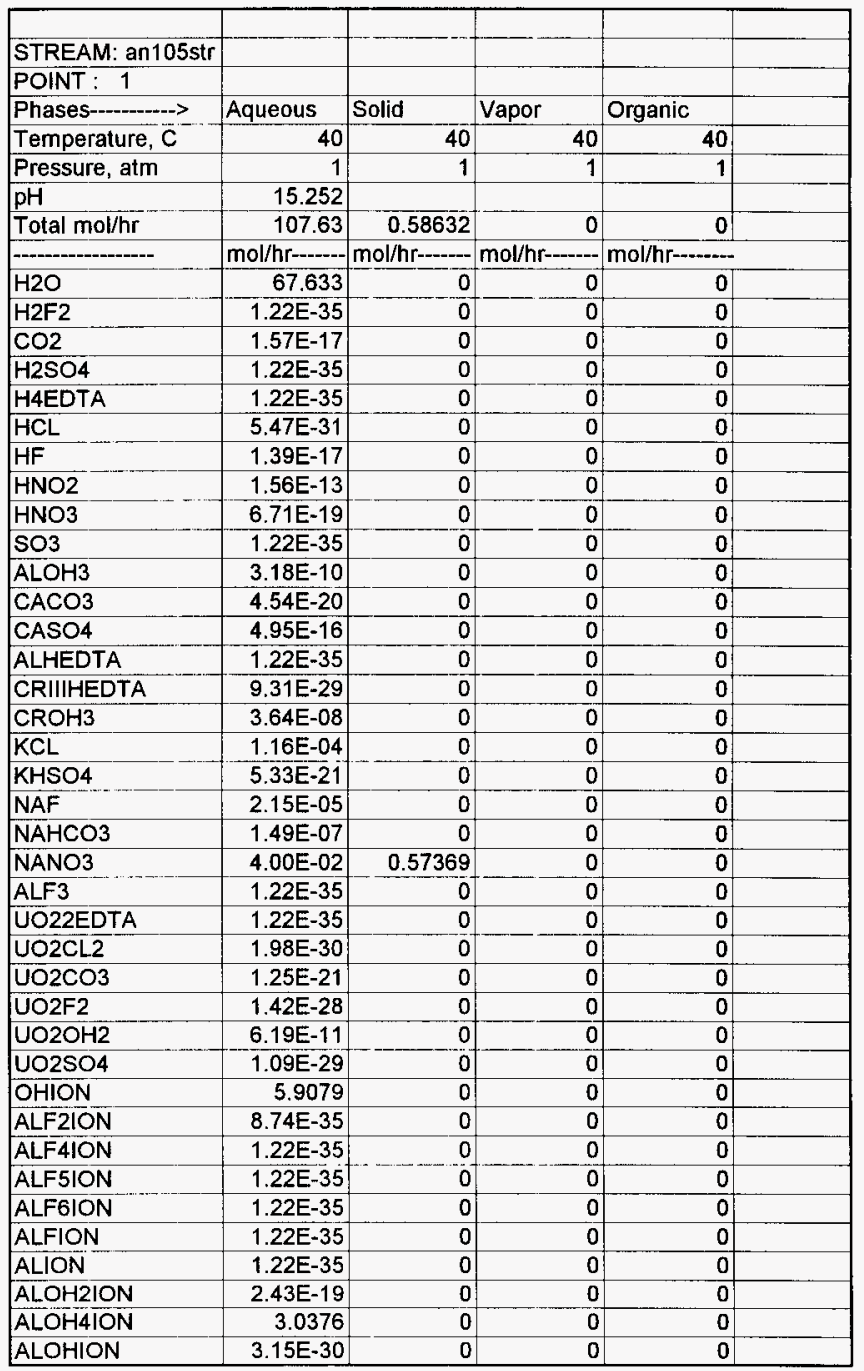




\section{Exhibit 2 -- Typical ESP Equilibrium Results}

\begin{tabular}{|c|c|c|c|c|c|}
\hline \multicolumn{5}{|l|}{\begin{tabular}{|l|} 
STREAM: an105str \\
\end{tabular}} & \\
\hline \multicolumn{6}{|l|}{ POINT : 1} \\
\hline Phases--...-..-->> & Aqueous & Solid & Vapor & Organic & \\
\hline Temperature, C & 40 & 40 & 40 & 40 & \\
\hline Pressure, atm & 1 & 1 & 1 & 1 & \\
\hline $\mathrm{pH}$ & 15.252 & & & & \\
\hline Total $\mathrm{mol} / \mathrm{hr}$ & 107.63 & 0.58632 & 0 & 0 & \\
\hline --.-n- & $\mathrm{mol} / \mathrm{hr}$ & $\mathrm{mol} / \mathrm{hr}$ & mol/hr----- & $\mathrm{mol} / \mathrm{hr}-\mathrm{-a-}$ & \\
\hline CAEDTAION & 8.71E-06 & 0 & 0 & 0 & \\
\hline CAFION & $1.98 \mathrm{E}-16$ & 0 & 0) & 0 & \\
\hline $\mathrm{CAH} 2 \mathrm{PO} 4 \mathrm{ION}$ & $9.28 \mathrm{E}-27$ & 0 & 0 & 0 & \\
\hline CAHCO3ION & $1.47 \mathrm{E}-21$ & 0 & of & 0 & \\
\hline CAHEDTAION & $1.29 \mathrm{E}-18$ & 0 & 0 & 0 & \\
\hline CAION & $2.15 \mathrm{E}-12$ & 0 & 0) & 0 & \\
\hline CAOHION & $6.48 \mathrm{E}-11$ & 0 & 0 & 0 . & \\
\hline CAPO4ION & $2.68 \mathrm{E}-10$ & 0 & 0 & 0 & \\
\hline CLION & 0.4186 & 0 & 0. & 0 & \\
\hline CO3ION & 0.46304 & 0 & 0] & 0 & \\
\hline CRFION & 1.57E-29 & 0 & 0 & 0 & \\
\hline CRIICLION & $2.21 \mathrm{E}-32$ & 0 & 0 & 0 & \\
\hline CRIIICL2ION & $3.01 \mathrm{E}-34$ & 0 & 0 & 0 & \\
\hline CRIIIEDTAION & $3.19 \mathrm{E}-14$ & 0 & 이 & 0. & \\
\hline CRIIIH2PO4ION & 1.22E-35 & 0 & 0 & 0 & \\
\hline CRIIIHPO4ION & $5.24 \mathrm{E}-29$ & 0 & of & 0 & \\
\hline CRIIIION & $2.89 \mathrm{E}-34$ & 0 & 0) & 0 & \\
\hline CRIIINO3ION & 3.05E-32 & 0 & 0 & 0 & \\
\hline $\mathrm{CROH} 2 \mathrm{ION}$ & $1.08 \bar{E}-16$ & 0 & 0 & 0 & \\
\hline CROH4ION & 2.27E-02 & 0 & 0 & 0 & \\
\hline CROHION & $9.79 \mathrm{E}-24$ & 0 & 0 & 0 & \\
\hline EDTAION & $1.24 \mathrm{E}-03$ & 0 & 0 & 0 & \\
\hline FION & $1.62 \mathrm{E}-04$ & 0 & 0 & 0 & \\
\hline H2EDTAION & $1.39 \mathrm{E}-17$ & 0 & 0 & 0 & \\
\hline H2P2O7ION & $5.15 \mathrm{E}-31$ & 0 & 이 & 0 & \\
\hline $\mathrm{H} 2 \mathrm{PO} 4 \mathrm{ION}$ & $5.64 \mathrm{E}-15$ & 0 & 이 & 0 & \\
\hline H3EDTAION & $1.04 \mathrm{E}-31$ & 0 & 0 & 0 & \\
\hline H3P2O7ION & $1.22 \mathrm{E}-35$ & 0 & 0 & 0 & \\
\hline H5EDTAION & $1.22 \mathrm{E}-35$ & 0 & 0 & 0 & \\
\hline H6EDTAION & $1.22 E-35$ & 0 & 0 & 0 & \\
\hline $\mathrm{HCO} 31 \mathrm{ON}$ & $1.46 \mathrm{E}-07$ & 0 & 0 . & 0 & \\
\hline HEDTAION & $2.48 \mathrm{E}-10$ & 0 & 0 & 0 & \\
\hline HF2ION & $2.13 \mathrm{E}-21$ & 0 & 0 & 0 & \\
\hline HION & $2.45 E-16$ & 0 & 0 & 0 & \\
\hline HP2O7ION & $3.04 \mathrm{E}-23$ & 0 & 0 & 0 & \\
\hline HPO4ION & 2.11E-05 & 0 & 0 & 0 & \\
\hline HSO $4 I O N$ & 8.97E-18 & 0 & 0 & 0 & \\
\hline KEDTAION & $2.40 \mathrm{E}-02$ & 0 & 0 & 0 & \\
\hline
\end{tabular}




\section{Exhibit 2 -- Typical ESP Equilibrium Results}

\begin{tabular}{|c|c|c|c|c|c|}
\hline \multirow{2}{*}{\multicolumn{6}{|c|}{ STREAM: an105str }} \\
\hline & & & & & \\
\hline & & & & & \\
\hline Phases---->> & Aqueous & Solid & Vapor & Organic & \\
\hline Temperature, C & 40 & 40 & 40 & 40 & \\
\hline Pressure, atm & 1 & 1 & 1 & 1 & \\
\hline $\mathrm{pH}$ & 15.252 & & & & \\
\hline Total $\mathrm{mol} / \mathrm{hr}$ & 107.63 & 0.58632 & 0 & 0 & \\
\hline 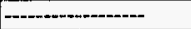 & mol/hr------ & mol/hr------ & mol/hr------ & $\mathrm{mol} / \mathrm{hr}$ & \\
\hline KION & 0.24907 & 0 & 0 & 0 & \\
\hline KSO4ION & $6.92 \mathrm{E}-04$ & 0 & 0 & 0 & \\
\hline NACO3ION & 0.15762 & 0 & 0 & 0 & \\
\hline NAEDTAION & $3.11 E-02$ & 0 & 0 & 0 & \\
\hline NAION & 20.112 & 0 & 0 & 0 & \\
\hline NASO4ION & $5.02 \mathrm{E}-03$ & 0 & 0 & 0 & \\
\hline NO21ON & 4.5534 & 0 & 0 & 0 & \\
\hline NO3ION & 4.8296 & 0 & 0 & 0 & \\
\hline ALEDTAION & $1.19 \mathrm{E}-25$ & 0 & 0 & 0 & \\
\hline P2O7ION & $7.16 \mathrm{E}-15$ & 0 & 0 & 0 & \\
\hline PO4ION & $3.49 \mathrm{E}-02$ & 0 & 0 & 0 & \\
\hline SO4ION & 0.11324 & 0 & 0 & 0 & \\
\hline $\mathrm{UO} 22 \mathrm{OH} 2 \mathrm{ION}$ & $1.31 \mathrm{E}-31$ & 0 & 0 & 0 & \\
\hline UO23OH5ION & $2.03 \mathrm{E}-23$ & 0 & 0 & 0 & \\
\hline UO2CLION & 8.07E-28 & 0 & 0 & 0 & \\
\hline $\mathrm{UO} 2 \mathrm{CO} 32 \mathrm{ION}$ & $1.53 \mathrm{E}-13$ & 0 & 0 & 0 & \\
\hline UO2CO331ON & 1.94E-06 & 0 & 0 & 0 & \\
\hline UO2F3ION & $1.01 \mathrm{E}-28$ & 0 & 0 & 0 & \\
\hline UO2F4ION & $1.24 \mathrm{E}-30$ & 0 & 0 & 0 & \\
\hline UO2FION & $7.43 \mathrm{E}-27$ & 0 & 0 & 0 & \\
\hline UO2HEDTAION & $2.20 \mathrm{E}-29$ & 0 & 0 & 0 & \\
\hline UO2ION & $1.12 \mathrm{E}-28$ & 0 & 0 & 0 & \\
\hline UO2OHION & $4.06 \mathrm{E}-18$ & 0 & 0 & 0 & \\
\hline UO2SO42ION & $1.68 \mathrm{E}-29$ & 0 & 0 & 0 & \\
\hline $\mathrm{KOH}$ & 0 & 0 & 0 & 0 & \\
\hline $\mathrm{NAOH}$ & 0 & 0 & 0 & 0 & \\
\hline NAPHOH & 0 & 0 & 0 & 0 & \\
\hline UCL6 & 0 & 0 & 0 & 0 & \\
\hline AL2SO43 & 0 & 0 & 0 & 0 & \\
\hline ALCL3 & 0 & 0 & 0 & 0 . & \\
\hline ALNO23 & 0 & 0 & 0 & 0 & \\
\hline ALNO33 & 0 & 0 & 0 & 0 & \\
\hline CAH2EDTA & 0 & 0 & 0 & 0 & \\
\hline $\mathrm{CAHCO} 32 \mathrm{CO} 3$ & 0 & 0 & 0 & 0 & \\
\hline $\mathrm{CAHCO} 32$ & 0 & 0 & 0 & 0 & \\
\hline CAHCO32SO4 & 0 & 0 & 0 & 0 & \\
\hline CAHCO3CL & 0 & 0 & 0 & 0 & \\
\hline CAHCO3HCO3 & 0 & 0 & 0 & 0 & \\
\hline
\end{tabular}


WHC-SD-WM-TI-774 ReV. 0

TWRS PRIVATIZATION PROCESS TECHNICAL BASELINE

\section{Exhibit 2 -- Typical ESP Equilibrium Results}

\begin{tabular}{|c|c|c|c|c|c|}
\hline \multicolumn{6}{|l|}{ STREA $\bar{M}$ : an105str } \\
\hline \multicolumn{6}{|l|}{ POINT : 1} \\
\hline Phases--י--->> & Aqueous & Solid & Vapor & Organic & \\
\hline Temperature, $\mathrm{C}$ & 40 & 40 & 40 & 40 & \\
\hline Pressure, atm & 1 & 1 & 1 & 1 & \\
\hline$\overline{\mathrm{pH}}$ & 15.252 & & & & \\
\hline Total $\mathrm{mol} / \mathrm{hr}$ & 107.63 & 0.58632 & 0 & 0 & \\
\hline - & mol/hr------ & mol/hr----- & $\mathrm{mol} / \mathrm{hr}$ & mol/hr------. & \\
\hline $\mathrm{CAHCO} 3 \mathrm{HSO} 4$ & 0 & 0 & 0 & 0 & \\
\hline $\mathrm{CAHCO} 3 \mathrm{OH}$ & 0 & 0 & 0 & 0 & \\
\hline $\mathrm{CAHSO} 42$ & 0 & 0 & 0 & 0 & \\
\hline $\mathrm{CAOHCL}$ & 0 & 0 & 0 & 0 & \\
\hline $\mathrm{CAOH} 2$ & 0 & 0 & 0 & 0 & \\
\hline CRIIINO33 & 0 & 0 & 0 & 0 & \\
\hline $\mathrm{H} 3 \mathrm{PO} 4$ & 0 & 0 & 0 & 0 & \\
\hline $\mathrm{H} 4 \mathrm{P} 2 \mathrm{O} 7$ & 0 & 0 & 0 & 0 & \\
\hline $\mathrm{H} 2 \mathrm{CO} 3$ & 0 & 0 & 0 & 0 & \\
\hline KH3EDTA & 0 & 0 & 0 & 0 & \\
\hline NAH3EDTA & 0 & 0 & 0 & 0 & \\
\hline H6F6 & 0 & 0 & 0 & 0 & \\
\hline ALOOH & 0. & 0 & 0 & 0 & \\
\hline KNO2 & 0 & 0 & 0 & 0 & \\
\hline KNO3 & 0 & 0 & 0 & 0 & \\
\hline $\mathrm{NA2CO} 3$ & 0 & 0 & 0 & 0 & \\
\hline NA2SO4 & 0 & 0 & 0 & 0 & \\
\hline NAALO2 & 0 & 0 & 0 & 0 & \\
\hline NACL & 0 & 0 & 0 & 0 & \\
\hline NANO2 & 0 & 0 & 0 & 0 & \\
\hline $\mathrm{NA} 2 \mathrm{CO} 3.1 \mathrm{H} 2 \mathrm{O}$ & 0 & 1.26E-02 & 0 & 0 & \\
\hline $\mathrm{NA3PO} 4.6 \mathrm{H} 2 \mathrm{O}$ & 0 & 0 & 0 & 0 & \\
\hline $\mathrm{NA3PO} 4.8 \mathrm{H} 2 \mathrm{O}$ & 0 & 0 & 0 & 0 & \\
\hline $\mathrm{NAOH} .1 \mathrm{H} 2 \mathrm{O}$ & 0 & 0 & 0 & 0 & \\
\hline NAPHOH. $12 \mathrm{H} 2 \mathrm{O}$ & 0 & 0 & 0 & 0 & \\
\hline & $========$ & $========$ & $========$ & ========-= & $====$ \\
\hline Total $\mathrm{g} / \mathrm{hr}$ & 2683.2 & 50.327 & 0 & 0 & \\
\hline Volume, $\mathrm{L} / \mathrm{hr}$ & 1.8579 & $2.23 \mathrm{E}-02$ & 0 & 0 & \\
\hline Enthalpy, cal/hr & $-7.71 E+06$ & $-6.82 E+04$ & 0 & 0 & \\
\hline Density, $g / L$ & 1444.2 & 2256.7 & & & \\
\hline Vapor fraction & 0 & 0 & 0 & 0 & \\
\hline Solid fraction & 0 & 1 & 0 & 0 & \\
\hline Organic fraction & 0 & 0 & 0 & 0 & \\
\hline Osmotic Pres, atm & 1100.6 & & & & \\
\hline Ionic Strength & 17.412 & & & & \\
\hline
\end{tabular}


WHC-SD-WM-TI-774 ReV. 0

TWRS PRIVATIZATION PROCESS TECHNICAL BASELINE

APPENDIX D INVENTORY ESTIMATE FOR ENVELOPE D

Source: Phase 1 High-Level Waste Pretreatment and Staging P1an WHC-SD-WM-ES-370 Revision 0 
WHC-SD-WM-TI-774 Rev. 0

TWRS PRIVATIZATION PROCESS TECHNICAL BASELINE

Table D-1 Inventory Assumptions for 241-AZ-101 (4 sheets)

\begin{tabular}{|l|c|c|}
\hline Phase & Soluble & Insoluble \\
\hline $\begin{array}{l}\text { Total Mass Flow } \\
\text { (MT) }\end{array}$ & $4.30 \mathrm{E}+03$ & $1.32 \mathrm{E}+02$ \\
\hline Volume (L) & $3.44 \mathrm{E}+06$ & $8.25 \mathrm{E}+04$ \\
\hline Specific Gravity & 1.25 & 1.60 \\
\hline
\end{tabular}

\begin{tabular}{|l|c|c|}
\hline Radionucl ides (Ci) & Soluble & Insoluble \\
\hline Am-24l & $8.65 \mathrm{E}+02$ & $2.80 \mathrm{E}+04$ \\
\hline $\mathrm{C}-14$ & $1.88 \mathrm{E}+02$ & $1.55 \mathrm{E}+01$ \\
\hline $\mathrm{Cm}-244$ & $1.91 \mathrm{E}+01$ & $7.14 \mathrm{E}+02$ \\
\hline $\mathrm{C} 0-60$ & $0.00 \mathrm{E}+00$ & $0.00 \mathrm{E}+00$ \\
\hline $\mathrm{Cs}-137$ & $6.09 \mathrm{E}+06$ & $2.40 \mathrm{E}+05$ \\
\hline $\mathrm{Ba}-137$ & $5.79 \mathrm{E}+06$ & $2.28 \mathrm{E}+05$ \\
\hline $\mathrm{Eu}-154$ & $0.00 \mathrm{E}+00$ & $0.00 \mathrm{E}+00$ \\
\hline $\mathrm{Np}-237$ & $0.00 \mathrm{E}+00$ & $0.00 \mathrm{E}+00$ \\
\hline $\mathrm{Pu}-239$ & $1.08 \mathrm{E}+00$ & $5.41 \mathrm{E}+02$ \\
\hline $\mathrm{Pu}-240$ & $0.00 \mathrm{E}+00$ & $0.00 \mathrm{E}+00$ \\
\hline $\mathrm{Pu}-241$ & $0.00 \mathrm{E}+00$ & $0.00 \mathrm{E}+00$ \\
\hline Sr-90 & $2.84 \mathrm{E}+05$ & $5.19 \mathrm{E}+06$ \\
\hline Y-90 & $2.84 \mathrm{E}+05$ & $5.19 \mathrm{E}+06$ \\
\hline Tc-99 & $6.74 \mathrm{E}+02$ & $1.47 \mathrm{E}+02$ \\
\hline Total Curies & $1.25 \mathrm{E}+07$ & $1.09 \mathrm{E}+07$ \\
\hline
\end{tabular}


WHC-SD-WM-TI-774 Rev. 0

TWRS PRIVATIZATION PROCESS TECHNICAL BASELINE

Table D-1 Inventory Assumptions for 241-AZ-101 (4 sheets)

\begin{tabular}{|c|c|c|}
\hline Chemicals (MT) & Soluble & Insoluble \\
\hline $\mathrm{Ag}+$ & $0.00 E+00$ & $0.00 \mathrm{E}+00$ \\
\hline$A T+3$ & $0.00 E+00$ & $1.16 \mathrm{E}+01$ \\
\hline $\mathrm{Am}+3$ & $2.52 \mathrm{E}-04$ & $8.15 E-03$ \\
\hline As+5 & $2.65 E-03$ & $1.34 \mathrm{E}-01$ \\
\hline$B+3$ & $8.99 E-04$ & $7.09 \mathrm{E}-02$ \\
\hline$\overline{B a+2}$ & $9.50 \mathrm{E}-05$ & $1.75 \mathrm{E}-01$ \\
\hline $\mathrm{Be}+2$ & $1.08 \mathrm{E}-06$ & $4.21 \mathrm{E}-03$ \\
\hline $\mathrm{Bi}+3$ & $0.00 \mathrm{E}+00$ & $0.00 \mathrm{E}+00$ \\
\hline $\mathrm{Ca}+2$ & $1.60 \mathrm{E}-03$ & $5.85 \mathrm{E}-01$ \\
\hline$C d+2$ & $5.88 \mathrm{E}-05$ & $1.36 \mathrm{E}+00$ \\
\hline $\mathrm{CE}+3$ & $2.42 \mathrm{E}-03$ & $2.91 \mathrm{E}-01$ \\
\hline $\mathrm{Cm}+3$ & $2.36 E-07$ & $8.81 \mathrm{E}-06$ \\
\hline $\mathrm{Co}+3$ & $7.50 \mathrm{E}-07$ & $8.35 \mathrm{E}-07$ \\
\hline $\mathrm{Cr}+3$ & $0.00 \mathrm{E}+00$ & $1.90 \mathrm{E}-01$ \\
\hline Cst & $2.73 \mathrm{E}-01$ & $1.08 \mathrm{E}-02$ \\
\hline $\mathrm{Cu+2}$ & $2.08 \mathrm{E}-04$ & $1.04 \mathrm{E}-01$ \\
\hline$\overline{E u+3}$ & $0.00 \mathrm{E}+00$ & $0.00 \mathrm{E}+00$ \\
\hline $\mathrm{Fe}+2$ & $0.00 \mathrm{E}+00$ & $0.00 \mathrm{E}+00$ \\
\hline $\mathrm{Fe}+3$ & $4.84 \mathrm{E}-04$ & $2.41 \mathrm{E}+01$ \\
\hline $\mathrm{H}+$ & $0.00 \mathrm{E}+00$ & $0.00 \mathrm{E}+00$ \\
\hline $\mathrm{Hg}+2$ & $0.00 \mathrm{E}+00$ & $0.00 \mathrm{E}+00$ \\
\hline $\mathrm{K}+$ & $6.82 E-01$ & $7.38 \mathrm{E}-01$ \\
\hline $\mathrm{La}+3$ & $1.82 \mathrm{E}-04$ & $9.07 \mathrm{E}-01$ \\
\hline $\mathrm{Lit}$ & $4.50 \mathrm{E}-04$ & $1.71 \mathrm{E}-02$ \\
\hline $\mathrm{Mg}+2$ & $8.64 \mathrm{E}-05$ & $1.47 \mathrm{E}-01$ \\
\hline$M n+2$ & $0.00 \mathrm{E}+00$ & $0.00 \mathrm{E}+00$ \\
\hline$M n+4$ & $4.43 E-05$ & $7.28 \mathrm{E}-01$ \\
\hline Mo+6 & $1.37 \mathrm{E}-02$ & $1.31 \mathrm{E}-02$ \\
\hline $\mathrm{Na}+$ & $3.48 \mathrm{E}+02$ & $3.90 \mathrm{E}+00$ \\
\hline $\mathrm{Nb}+5$ & $0.00 E+00$ & $0.00 \mathrm{E}+00$ \\
\hline $\mathrm{Nd}+3$ & $0.00 \mathrm{E}+00$ & $0.00 \mathrm{E}+00$ \\
\hline $\mathrm{Ni+3}$ & $1.27 \mathrm{E}-04$ & $1.07 \mathrm{E}+00$ \\
\hline $\mathrm{Np+4}$ & $0.00 E+00$ & $0.00 \mathrm{E}+00$ \\
\hline$\overline{\mathrm{Pb}+4}$ & $9.59 \mathrm{E}-04$ & $1.27 \mathrm{E}-01$ \\
\hline
\end{tabular}




\section{WHC-SD-WM-TI-774 Rev. 0 \\ TWRS PRIVATIZATION PROCESS TECHNICAL BASELINE}

Table D-1 Inventory Assumptions for 241-AZ-101 (4 sheets)

\begin{tabular}{|l|c|c|}
\hline Chemicals (MT) & Soluble & Insoluble \\
\hline $\mathrm{Pd}+2$ & $0.00 \mathrm{E}+00$ & $0.00 \mathrm{E}+00$ \\
\hline $\mathrm{Pu}+4$ & $1.75 \mathrm{E}-05$ & $8.73 \mathrm{E}-03$ \\
\hline $\mathrm{Rb}+$ & $0.00 \mathrm{E}+00$ & $0.00 \mathrm{E}+00$ \\
\hline $\mathrm{Re}+7$ & $2.25 \mathrm{E}-04$ & $1.36 \mathrm{E}-02$ \\
\hline $\mathrm{Rh}+3$ & $1.61 \mathrm{E}-03$ & $1.04 \mathrm{E}-01$ \\
\hline $\mathrm{Ru}+3$ & $7.68 \mathrm{E}-04$ & $2.13 \mathrm{E}-01$ \\
\hline $\mathrm{Sb}+5$ & $2.08 \mathrm{E}-03$ & $6.54 \mathrm{E}-01$ \\
\hline $\mathrm{Se}+6$ & $3.90 \mathrm{E}-03$ & $4.29 \mathrm{E}-01$ \\
\hline $\mathrm{Si}+4$ & $5.66 \mathrm{E}-02$ & $1.35 \mathrm{E}+00$ \\
\hline $\mathrm{Sm}+3$ & $0.00 \mathrm{E}+00$ & $0.00 \mathrm{E}+00$ \\
\hline $\mathrm{Sn}+4$ & $0.00 \mathrm{E}+00$ & $0.00 \mathrm{E}+00$ \\
\hline $\mathrm{Sr}+2$ & $9.84 \mathrm{E}-03$ & $1.79 \mathrm{E}-01$ \\
\hline $\mathrm{Te}+6$ & $4.17 \mathrm{E}-03$ & $4.61 \mathrm{E}-01$ \\
\hline $\mathrm{Th}+4$ & $3.37 \mathrm{E}-03$ & $2.96 \mathrm{E}-01$ \\
\hline $\mathrm{Ti}+4$ & $1.20 \mathrm{E}-03$ & $1.58 \mathrm{E}-01$ \\
\hline $\mathrm{T}+3$ & $4.17 \mathrm{E}-02$ & $1.58 \mathrm{E}+00$ \\
\hline $\mathrm{U} 02+2$ & $9.24 \mathrm{E}-03$ & $1.49 \mathrm{E}+00$ \\
\hline $\mathrm{V}+5$ & $1.44 \mathrm{E}-04$ & $6.05 \mathrm{E}-03$ \\
\hline $\mathrm{W}+6$ & $0.00 \mathrm{E}+00$ & $0.00 \mathrm{E}+00$ \\
\hline $\mathrm{Zn+2}$ & $2.14 \mathrm{E}-04$ & $9.76 \mathrm{E}-02$ \\
\hline $\mathrm{Zr}+4$ & $0.00 \mathrm{E}+00$ & $0.00 \mathrm{E}+00$ \\
\hline $\mathrm{A} 1(0 \mathrm{H}) 4-$ & $1.21 \mathrm{E}+02$ & $0.00 \mathrm{E}+00$ \\
\hline $\mathrm{B} 02-$ & $0.00 \mathrm{E}+00$ & $0.00 \mathrm{E}+00$ \\
\hline $\mathrm{B} 03-2$ & $0.00 \mathrm{E}+00$ & $0.00 \mathrm{E}+00$ \\
\hline $\mathrm{C} 204-2$ & $0.00 \mathrm{E}+00$ & $0.00 \mathrm{E}+00$ \\
\hline $\mathrm{C} 1-$ & $6.09 \mathrm{E}-01$ & $2.68 \mathrm{E}-02$ \\
\hline $\mathrm{CO} 3-2$ & $1.02 \mathrm{E}+02$ & $3.67 \mathrm{E}+00$ \\
\hline $\mathrm{Cr}(0 \mathrm{H}) 4-$ & $4.80 \mathrm{E}-01$ & $0.00 \mathrm{E}+00$ \\
\hline $\mathrm{F}-$ & $5.93 \mathrm{E}+00$ & $1.48 \mathrm{E}-01$ \\
\hline $\mathrm{FeCN6}-3$ & $0.00 \mathrm{E}+00$ & $0.00 \mathrm{E}+00$ \\
\hline $\mathrm{HCOO}-$ & $0.00 \mathrm{E}+00$ & $0.00 \mathrm{E}+00$ \\
\hline $\mathrm{I}-$ & $3.42 \mathrm{E}-04$ & $2.50 \mathrm{E}-04$ \\
\hline $\mathrm{N} 02-$ & $2.03 \mathrm{E}+02$ & $1.69 \mathrm{E}+00$ \\
\hline $\mathrm{N} 03-$ & $2.36 \mathrm{E}+02$ & $1.38 \mathrm{E}+00$ \\
\hline & & \\
\hline & & \\
\hline
\end{tabular}


WHC-SD-WM-TI-774 Rev. 0

TWRS PRIVATIZATION PROCESS TECHNICAL BASELINE

Table D-1 Inventory Assumptions for 241-AZ-101 (4 sheets)

\begin{tabular}{|l|c|c|}
\hline Chemicals (MT) & Soluble & Insoluble \\
\hline OH- & $3.31 \mathrm{E}+01$ & $5.49 \mathrm{E}+01$ \\
\hline P04-3 & $3.91 \mathrm{E}-02$ & $5.58 \mathrm{E}-02$ \\
\hline PTA-3 & $0.00 \mathrm{E}+00$ & $0.00 \mathrm{E}+00$ \\
\hline S04-2 & $2.20 \mathrm{E}-02$ & $6.18 \mathrm{E}-03$ \\
\hline Tc04- & $6.57 \mathrm{E}-02$ & $1.43 \mathrm{E}-02$ \\
\hline C-14 & $0.00 \mathrm{E}+00$ & $0.00 \mathrm{E}+00$ \\
\hline Cancrinite & $0.00 \mathrm{E}+00$ & $0.00 \mathrm{E}+00$ \\
\hline H20 & $3.25 \mathrm{E}+03$ & $0.00 \mathrm{E}+00$ \\
\hline Mn02 & $0.00 \mathrm{E}+00$ & $0.00 \mathrm{E}+00$ \\
\hline Ni2FeCN6 & $0.00 \mathrm{E}+00$ & $0.00 \mathrm{E}+00$ \\
\hline P205:24W02:44H20 & $0.00 \mathrm{E}+00$ & $0.00 \mathrm{E}+00$ \\
\hline Organic Carbon & $3.60 \mathrm{E}+00$ & $2.02 \mathrm{E}+00$ \\
\hline Zr02:2H20 & $1.29 \mathrm{E}-04$ & $1.48 \mathrm{E}+01$ \\
\hline
\end{tabular}


WHC-SD-WM-TI-774 Rev. 0

TWRS PRIVATIZATION PROCESS TECHNICAL BASELINE

Table D-2 Inventory Assumptions for 241-AZ-102 (4 sheets)

\begin{tabular}{|l|c|c|}
\hline Phase & Soluble & Insoluble \\
\hline $\begin{array}{l}\text { Total Mass Flow } \\
\text { (MT) }\end{array}$ & $4.03 \mathrm{E}+03$ & $1.88 \mathrm{E}+02$ \\
\hline Volume (L) & $3.22 \mathrm{E}+06$ & $1.18 \mathrm{E}+05$ \\
\hline Specific Gravity & 1.25 & 1.60 \\
\hline
\end{tabular}

\begin{tabular}{|l|c|c|}
\hline Radionuc]ides (Ci) & Soluble & Insoluble \\
\hline Am-241 & $1.68 \mathrm{E}+00$ & $1.68 \mathrm{E}+04$ \\
\hline $\mathrm{C}-14$ & $1.34 \mathrm{E}+02$ & $1.24 \mathrm{E}+01$ \\
\hline $\mathrm{Cm}-244$ & $0.00 \mathrm{E}+00$ & $5.41 \mathrm{E}+02$ \\
\hline $\mathrm{C} 0-60$ & $0.00 \mathrm{E}+00$ & $0.00 \mathrm{E}+00$ \\
\hline $\mathrm{C}-137$ & $3.18 \mathrm{E}+06$ & $2.87 \mathrm{E}+05$ \\
\hline $\mathrm{Ba}-137$ & $3.02 \mathrm{E}+06$ & $2.73 \mathrm{E}+05$ \\
\hline $\mathrm{Eu}-154$ & $0.00 \mathrm{E}+00$ & $0.00 \mathrm{E}+00$ \\
\hline $\mathrm{Np}-237$ & $0.00 \mathrm{E}+00$ & $0.00 \mathrm{E}+00$ \\
\hline $\mathrm{Pu}-239$ & $4.02 \mathrm{E}+01$ & $4.82 \mathrm{E}+02$ \\
\hline $\mathrm{Pu}-240$ & $0.00 \mathrm{E}+00$ & $0.00 \mathrm{E}+00$ \\
\hline $\mathrm{Pu}-241$ & $0.00 \mathrm{E}+00$ & $0.00 \mathrm{E}+00$ \\
\hline Sr-90 & $8.94 \mathrm{E}+03$ & $2.97 \mathrm{E}+06$ \\
\hline $\mathrm{Y}-90$ & $8.94 \mathrm{E}+03$ & $2.97 \mathrm{E}+06$ \\
\hline Tc-99 & $3.01 \mathrm{E}+02$ & $1.47 \mathrm{E}+02$ \\
\hline Total Curies & $6.22 \mathrm{E}+06$ & $6.52 \mathrm{E}+06$ \\
\hline
\end{tabular}


WHC-SD-WM-TI-774 Rev. 0

TWRS PRIVATIZATION PROCESS TECHNICAL BASELINE

Table D-2 Inventory Assumptions for 241-AZ-102 (4 sheets)

\begin{tabular}{|l|c|c|}
\hline Chemicals (MT) & Soluble & Insoluble \\
\hline $\mathrm{Ag}+$ & $0.00 \mathrm{E}+00$ & $0.00 \mathrm{E}+00$ \\
\hline $\mathrm{Al}+3$ & $0.00 \mathrm{E}+00$ & $1.54 \mathrm{E}+01$ \\
\hline $\mathrm{Am}+3$ & $4.90 \mathrm{E}-07$ & $4.90 \mathrm{E}-03$ \\
\hline $\mathrm{As}+5$ & $4.15 \mathrm{E}-03$ & $1.66 \mathrm{E}-01$ \\
\hline $\mathrm{B}+3$ & $2.30 \mathrm{E}-03$ & $1.39 \mathrm{E}-01$ \\
\hline $\mathrm{Ba}+2$ & $3.21 \mathrm{E}-04$ & $1.59 \mathrm{E}-01$ \\
\hline $\mathrm{Be}+2$ & $2.12 \mathrm{E}-05$ & $3.84 \mathrm{E}-03$ \\
\hline $\mathrm{Bi}+3$ & $0.00 \mathrm{E}+00$ & $0.00 \mathrm{E}+00$ \\
\hline $\mathrm{Ca}+2$ & $1.12 \mathrm{E}-02$ & $8.11 \mathrm{E}-01$ \\
\hline $\mathrm{Cd}+2$ & $3.61 \mathrm{E}-04$ & $4.32 \mathrm{E}+00$ \\
\hline $\mathrm{CE}+3$ & $4.07 \mathrm{E}-03$ & $2.22 \mathrm{E}-01$ \\
\hline $\mathrm{Cm}+3$ & $0.00 \mathrm{E}+00$ & $6.68 \mathrm{E}-06$ \\
\hline $\mathrm{Co}+3$ & $3.74 \mathrm{E}-08$ & $5.36 \mathrm{E}-08$ \\
\hline $\mathrm{Cr}+3$ & $0.00 \mathrm{E}+00$ & $3.61 \mathrm{E}-01$ \\
\hline $\mathrm{Cs}+$ & $1.43 \mathrm{E}-01$ & $1.29 \mathrm{E}-02$ \\
\hline $\mathrm{Cu}+2$ & $2.94 \mathrm{E}-04$ & $1.00 \mathrm{E}-01$ \\
\hline $\mathrm{Eu}+3$ & $0.00 \mathrm{E}+00$ & $0.00 \mathrm{E}+00$ \\
\hline $\mathrm{Fe}+2$ & $0.00 \mathrm{E}+00$ & $0.00 \mathrm{E}+00$ \\
\hline $\mathrm{Fe}+3$ & $3.05 \mathrm{E}-03$ & $3.77 \mathrm{E}+01$ \\
\hline $\mathrm{H}+$ & $0.00 \mathrm{E}+00$ & $0.00 \mathrm{E}+00$ \\
\hline $\mathrm{Hg}+2$ & $0.00 \mathrm{E}+00$ & $0.00 \mathrm{E}+00$ \\
\hline $\mathrm{K}+$ & $2.61 \mathrm{E}-01$ & $3.37 \mathrm{E}-01$ \\
\hline $\mathrm{La}+3$ & $6.53 \mathrm{E}-04$ & $1.29 \mathrm{E}+00$ \\
\hline $\mathrm{Li}+$ & $2.95 \mathrm{E}-04$ & $8.07 \mathrm{E}-03$ \\
\hline $\mathrm{Mg}+2$ & $3.68 \mathrm{E}-04$ & $2.73 \mathrm{E}-01$ \\
\hline $\mathrm{Mn}+2$ & $0.00 \mathrm{E}+00$ & $0.00 \mathrm{E}+00$ \\
\hline $\mathrm{Mn}+4$ & $2.77 \mathrm{E}-04$ & $8.29 \mathrm{E}-01$ \\
\hline $\mathrm{Mo}+6$ & $6.75 \mathrm{E}-03$ & $6.75 \mathrm{E}-03$ \\
\hline $\mathrm{Na}+$ & $1.84 \mathrm{E}+02$ & $1.19 \mathrm{E}+01$ \\
\hline $\mathrm{Nb}+5$ & $0.00 \mathrm{E}+00$ & $0.00 \mathrm{E}+00$ \\
\hline $\mathrm{Nd}+3$ & $0.00 \mathrm{E}+00$ & $0.00 \mathrm{E}+00$ \\
\hline $\mathrm{Ni}+3$ & $7.02 \mathrm{E}-04$ & $2.55 \mathrm{E}+00$ \\
\hline $\mathrm{Np}+4$ & $0.00 \mathrm{E}+00$ & $0.00 \mathrm{E}+00$ \\
\hline $\mathrm{Pb}+4$ & $1.44 \mathrm{E}-03$ & $3.15 \mathrm{E}-01$ \\
\hline & & \\
\hline & & \\
\hline
\end{tabular}

D-7 
WHC-SD-WM-TI-774 Rev. 0

TWRS PRIVATIZATION PROCESS TECHNICAL BASELINE

Tab7e D-2 Inventory Assumptions for 241-AZ-102 (4 sheets)

\begin{tabular}{|l|c|c|}
\hline Chemicals (MT) & Soluble & Insoluble \\
\hline $\mathrm{Pd}+2$ & $0.00 \mathrm{E}+00$ & $0.00 \mathrm{E}+00$ \\
\hline $\mathrm{Pu}+4$ & $6.49 \mathrm{E}-04$ & $7.77 \mathrm{E}-03$ \\
\hline $\mathrm{Rb}+$ & $0.00 \mathrm{E}+00$ & $0.00 \mathrm{E}+00$ \\
\hline $\mathrm{Re}+7$ & $2.19 \mathrm{E}-04$ & $2.06 \mathrm{E}-02$ \\
\hline $\mathrm{Rh}+3$ & $2.80 \mathrm{E}-03$ & $1.19 \mathrm{E}-01$ \\
\hline $\mathrm{Ru}+3$ & $6.95 \mathrm{E}-04$ & $5.16 \mathrm{E}-02$ \\
\hline $\mathrm{Sb}+5$ & $0.00 \mathrm{E}+00$ & $0.00 \mathrm{E}+00$ \\
\hline $\mathrm{Se}+6$ & $3.41 \mathrm{E}-03$ & $2.93 \mathrm{E}-01$ \\
\hline $\mathrm{Si}+4$ & $1.80 \mathrm{E}+00$ & $1.21 \mathrm{E}+00$ \\
\hline $\mathrm{Sm}+3$ & $0.00 \mathrm{E}+00$ & $0.00 \mathrm{E}+00$ \\
\hline $\mathrm{Sn}+4$ & $0.00 \mathrm{E}+00$ & $0.00 \mathrm{E}+00$ \\
\hline $\mathrm{Sr}+2$ & $9.15 \mathrm{E}-04$ & $1.17 \mathrm{E}-01$ \\
\hline $\mathrm{Te}+6$ & $8.64 \mathrm{E}-04$ & $9.85 \mathrm{E}-02$ \\
\hline $\mathrm{Th}+4$ & $0.00 \mathrm{E}+00$ & $0.00 \mathrm{E}+00$ \\
\hline $\mathrm{Ti}+4$ & $2.45 \mathrm{E}-04$ & $2.21 \mathrm{E}-02$ \\
\hline $\mathrm{Tl}+3$ & $5.98 \mathrm{E}-04$ & $1.59 \mathrm{E}-02$ \\
\hline $\mathrm{NO2}+2$ & $5.77 \mathrm{E}+00$ & $3.94 \mathrm{E}+00$ \\
\hline $\mathrm{V}+5$ & $2.57 \mathrm{E}-04$ & $9.16 \mathrm{E}-03$ \\
\hline $\mathrm{W}+6$ & $0.00 \mathrm{E}+00$ & $0.00 \mathrm{E}+00$ \\
\hline $\mathrm{Zn}+2$ & $1.39 \mathrm{E}-04$ & $4.04 \mathrm{E}-02$ \\
\hline $\mathrm{Zr}+4$ & $0.00 \mathrm{E}+00$ & $0.00 \mathrm{E}+00$ \\
\hline $\mathrm{A} 1(0 \mathrm{H}) 4-$ & $1.78 \mathrm{E}+01$ & $0.00 \mathrm{E}+00$ \\
\hline $\mathrm{B} 02-$ & $0.00 \mathrm{E}+00$ & $0.00 \mathrm{E}+00$ \\
\hline $\mathrm{B} 03-2$ & $0.00 \mathrm{E}+00$ & $0.00 \mathrm{E}+00$ \\
\hline $\mathrm{C} 204-2$ & $0.00 \mathrm{E}+00$ & $0.00 \mathrm{E}+00$ \\
\hline $\mathrm{Cl}-$ & $0.00 \mathrm{E}+00$ & $4.23 \mathrm{E}-02$ \\
\hline $\mathrm{CO}-2$ & $9.42 \mathrm{E}+01$ & $2.24 \mathrm{E}+01$ \\
\hline $\mathrm{Cr}(0 \mathrm{H}) 4-$ & $7.65 \mathrm{E}+00$ & $0.00 \mathrm{E}+00$ \\
\hline $\mathrm{F}-$ & $3.35 \mathrm{E}+00$ & $3.57 \mathrm{E}-02$ \\
\hline $\mathrm{FeCN6}-3$ & $0.00 \mathrm{E}+00$ & $0.00 \mathrm{E}+00$ \\
\hline $\mathrm{HCO0}-$ & $0.00 \mathrm{E}+00$ & $0.00 \mathrm{E}+00$ \\
\hline $\mathrm{I}-$ & $8.56 \mathrm{E}-05$ & $2.39 \mathrm{E}-04$ \\
\hline $\mathrm{N} 02-$ & $9.24 \mathrm{E}+01$ & $1.09 \mathrm{E}+00$ \\
\hline $\mathrm{N} 03-$ & $7.72 \mathrm{E}+01$ & $3.02 \mathrm{E}-01$ \\
\hline & & \\
\hline & & \\
\hline
\end{tabular}

D-8 
WHC-SD-WM-TI-774 Rev. 0

TWRS PRIVATIZATION PROCESS TECHNICAL BASELINE

Tab7e D-2 Inventory Assumptions for 241-AZ-102 (4 sheets)

\begin{tabular}{|l|c|c|}
\hline Chemicals (MT) & Soluble & Insoluble \\
\hline OH- & $5.41 \mathrm{E}+00$ & $7.08 \mathrm{E}+01$ \\
\hline P04-3 & $3.30 \mathrm{E}-02$ & $8.64 \mathrm{E}-02$ \\
\hline PTA-3 & $0.00 \mathrm{E}+00$ & $0.00 \mathrm{E}+00$ \\
\hline S04-2 & $5.59 \mathrm{E}+01$ & $3.94 \mathrm{E}-03$ \\
\hline Tc04- & $2.93 \mathrm{E}-02$ & $1.43 \mathrm{E}-02$ \\
\hline C-14 & $0.00 \mathrm{E}+00$ & $0.00 \mathrm{E}+00$ \\
\hline Cancrinite & $0.00 \mathrm{E}+00$ & $0.00 \mathrm{E}+00$ \\
\hline H20 & $3.48 \mathrm{E}+03$ & $0.00 \mathrm{E}+00$ \\
\hline Mn02 & $0.00 \mathrm{E}+00$ & $0.00 \mathrm{E}+00$ \\
\hline Ni2FeCN6 & $0.00 \mathrm{E}+00$ & $0.00 \mathrm{E}+00$ \\
\hline P205:24W02:44H20 & $0.00 \mathrm{E}+00$ & $0.00 \mathrm{E}+00$ \\
\hline Organic Carbon & $4.97 \mathrm{E}+00$ & $7.91 \mathrm{E}-01$ \\
\hline Zr02:2H20 & $1.18 \mathrm{E}-03$ & $9.16 \mathrm{E}+00$ \\
\hline
\end{tabular}




\section{WHC-SD-WM-TI-774 Rev. 0 \\ TWRS PRIVATIZATION PROCESS TECHNICAL BASELINE}

Table D-3 Inventory Assumptions for 24l-AY-102 (4 sheets)

\begin{tabular}{|l|c|c|}
\hline Phase & Soluble & Insoluble \\
\hline $\begin{array}{l}\text { Total Mass Flow } \\
\text { (MT) }\end{array}$ & $3.18 \mathrm{E}+03$ & $7.55 \mathrm{E}+01$ \\
\hline Volume (L) & $2.54 \mathrm{E}+06$ & $4.72 \mathrm{E}+04$ \\
\hline Specific Gravity & 1.25 & 1.60 \\
\hline
\end{tabular}

\begin{tabular}{|l|c|c|}
\hline Radionuclides (Ci) & Soluble & Insoluble \\
\hline Am-241 & $3.61 \mathrm{E}-01$ & $3.26 \mathrm{E}+03$ \\
\hline $\mathrm{C}-14$ & $0.00 \mathrm{E}+00$ & $1.81 \mathrm{E}-01$ \\
\hline $\mathrm{Cm}-244$ & $1.42 \mathrm{E}-02$ & $0.00 \mathrm{E}+00$ \\
\hline $\mathrm{Co}-60$ & $0.00 \mathrm{E}+00$ & $0.00 \mathrm{E}+00$ \\
\hline $\mathrm{Cs}-137$ & $5.40 \mathrm{E}+03$ & $1.92 \mathrm{E}+04$ \\
\hline Ba-137 & $5.13 \mathrm{E}+03$ & $1.83 \mathrm{E}+04$ \\
\hline $\mathrm{Eu}-154$ & $0.00 \mathrm{E}+00$ & $0.00 \mathrm{E}+00$ \\
\hline $\mathrm{Np}-237$ & $0.00 \mathrm{E}+00$ & $0.00 \mathrm{E}+00$ \\
\hline Pu-239 & $4.61 \mathrm{E}-01$ & $6.59 \mathrm{E}+02$ \\
\hline Pu-240 & $0.00 \mathrm{E}+00$ & $0.00 \mathrm{E}+00$ \\
\hline Pu-241 & $0.00 \mathrm{E}+00$ & $0.00 \mathrm{E}+00$ \\
\hline Sr-90 & $3.69 \mathrm{E}+03$ & $1.97 \mathrm{E}+06$ \\
\hline Y-90 & $3.69 \mathrm{E}+03$ & $1.97 \mathrm{E}+06$ \\
\hline Tc-99 & $2.47 \mathrm{E}+01$ & $0.00 \mathrm{E}+00$ \\
\hline Total Curies & $1.79 \mathrm{E}+04$ & $3.99 \mathrm{E}+06$ \\
\hline
\end{tabular}


WHC-SD-WM-TI-774 Rev. 0

TWRS PRIVATIZATION PROCESS TECHNICAL BASELINE

Table D-3 Inventory Assumptions for 241-AY-102 (4 sheets)

\begin{tabular}{|l|c|c|}
\hline Chemicals (MT) & Soluble & Insoluble \\
\hline $\mathrm{Ag}+$ & $2.82 \mathrm{E}-02$ & $1.04 \mathrm{E}+00$ \\
\hline $\mathrm{Al}+3$ & $0.00 \mathrm{E}+00$ & $5.49 \mathrm{E}+00$ \\
\hline $\mathrm{Am}+3$ & $1.05 \mathrm{E}-07$ & $9.50 \mathrm{E}-04$ \\
\hline $\mathrm{As}+5$ & $0.00 \mathrm{E}+00$ & $0.00 \mathrm{E}+00$ \\
\hline $\mathrm{B}+3$ & $0.00 \mathrm{E}+00$ & $0.00 \mathrm{E}+00$ \\
\hline $\mathrm{Ba}+2$ & $2.06 \mathrm{E}-03$ & $2.89 \mathrm{E}-01$ \\
\hline $\mathrm{Be}+2$ & $0.00 \mathrm{E}+00$ & $0.00 \mathrm{E}+00$ \\
\hline $\mathrm{Bi}+3$ & $0.00 \mathrm{E}+00$ & $0.00 \mathrm{E}+00$ \\
\hline $\mathrm{Ca}+2$ & $1.25 \mathrm{E}-02$ & $2.04 \mathrm{E}+00$ \\
\hline $\mathrm{Cd}+2$ & $3.89 \mathrm{E}-04$ & $6.03 \mathrm{E}-02$ \\
\hline $\mathrm{CE}+3$ & $0.00 \mathrm{E}+00$ & $0.00 \mathrm{E}+00$ \\
\hline $\mathrm{Cm}+3$ & $1.75 \mathrm{E}-10$ & $0.00 \mathrm{E}+00$ \\
\hline $\mathrm{C}+3$ & $0.00 \mathrm{E}+00$ & $0.00 \mathrm{E}+00$ \\
\hline $\mathrm{Cr}+3$ & $0.00 \mathrm{E}+00$ & $4.87 \mathrm{E}-01$ \\
\hline $\mathrm{CS}+$ & $3.35 \mathrm{E}-04$ & $1.20 \mathrm{E}-03$ \\
\hline $\mathrm{Cu}+2$ & $0.00 \mathrm{E}+00$ & $0.00 \mathrm{E}+00$ \\
\hline $\mathrm{Eu}+3$ & $0.00 \mathrm{E}+00$ & $0.00 \mathrm{E}+00$ \\
\hline $\mathrm{Fe}+2$ & $0.00 \mathrm{E}+00$ & $0.00 \mathrm{E}+00$ \\
\hline $\mathrm{Fe}+3$ & $1.22 \mathrm{E}-03$ & $1.22 \mathrm{E}+01$ \\
\hline $\mathrm{H}+$ & $0.00 \mathrm{E}+00$ & $0.00 \mathrm{E}+00$ \\
\hline $\mathrm{Hg}+2$ & $0.00 \mathrm{E}+00$ & $0.00 \mathrm{E}+00$ \\
\hline $\mathrm{K}+$ & $1.81 \mathrm{E}-01$ & $1.47 \mathrm{E}-01$ \\
\hline $\mathrm{La}+3$ & $1.73 \mathrm{E}-04$ & $5.75 \mathrm{E}-01$ \\
\hline $\mathrm{Li}+$ & $0.00 \mathrm{E}+00$ & $0.00 \mathrm{E}+00$ \\
\hline $\mathrm{Mg}+2$ & $0.00 \mathrm{E}+00$ & $0.00 \mathrm{E}+00$ \\
\hline $\mathrm{Mn}+2$ & $0.00 \mathrm{E}+00$ & $0.00 \mathrm{E}+00$ \\
\hline $\mathrm{Mn}+4$ & $0.00 \mathrm{E}+00$ & $1.28 \mathrm{E}+00$ \\
\hline $\mathrm{Mo}+6$ & $0.00 \mathrm{E}+00$ & $0.00 \mathrm{E}+00$ \\
\hline $\mathrm{Na}+$ & $9.50 \mathrm{E}+00$ & $2.79 \mathrm{E}+00$ \\
\hline $\mathrm{Nb}+5$ & $0.00 \mathrm{E}+00$ & $0.00 \mathrm{E}+00$ \\
\hline $\mathrm{Nd}+3$ & $0.00 \mathrm{E}+00$ & $0.00 \mathrm{E}+00$ \\
\hline $\mathrm{Ni}+3$ & $3.96 \mathrm{E}-04$ & $4.39 \mathrm{E}-01$ \\
\hline $\mathrm{Np}+4$ & $0.00 \mathrm{E}+00$ & $0.00 \mathrm{E}+00$ \\
\hline $\mathrm{Pb}+4$ & $0.00 \mathrm{E}+00$ & $0.00 \mathrm{E}+00$ \\
\hline & & \\
\hline & & \\
\hline & & \\
\hline & & \\
\hline
\end{tabular}

D-11 
WHC-SD-WM-TI-774 Rev. 0

TWRS PRIVATIZATION PROCESS TECHNICAL BASELINE sheets)

Table D-3 Inventory Assumptions for 241-AY-102 (4

\begin{tabular}{|c|c|c|}
\hline Chemicals (MT) & Soluble & Insoluble \\
\hline$P d+2$ & $0.00 E+00$ & $0.00 \mathrm{E}+00$ \\
\hline $\mathrm{Pu}+4$ & $7.44 \mathrm{E}-06$ & $1.06 \mathrm{E}-02$ \\
\hline $\mathrm{Rb}+$ & $0.00 \mathrm{E}+00$ & $0.00 \mathrm{E}+00$ \\
\hline $\operatorname{Re}+7$ & $0.00 \mathrm{E}+00$ & $0.00 \mathrm{E}+00$ \\
\hline$R h+3$ & $0.00 \mathrm{E}+00$ & $0.00 E+00$ \\
\hline $\mathrm{Ru}+3$ & $0.00 \mathrm{E}+00$ & $0.00 E+00$ \\
\hline$S b+5$ & $0.00 \mathrm{E}+00$ & $0.00 \mathrm{E}+00$ \\
\hline $\mathrm{Se}+6$ & $0.00 \mathrm{E}+00$ & $0.00 \mathrm{E}+00$ \\
\hline $\mathrm{Si}+4$ & $1.85 \mathrm{E}+00$ & $3.96 \mathrm{E}+00$ \\
\hline $5 m+3$ & $0.00 \mathrm{E}+00$ & $0.00 E+00$ \\
\hline$S n+4$ & $0.00 \mathrm{E}+00$ & $0.00 E+00$ \\
\hline$S r+2$ & $6.12 \mathrm{E}-04$ & $1.20 \mathrm{E}-01$ \\
\hline $\mathrm{Te}+6$ & $0.00 \mathrm{E}+00$ & $0.00 \mathrm{E}+00$ \\
\hline$T h+4$ & $0.00 \mathrm{E}+00$ & $0.00 \mathrm{E}+00$ \\
\hline$T i+4$ & $0.00 \mathrm{E}+00$ & $0.00 \mathrm{E}+00$ \\
\hline$T 1+3$ & $0.00 \mathrm{E}+00$ & $0.00 \mathrm{E}+00$ \\
\hline $402+2$ & $1.81 \mathrm{E}+00$ & $8.90 \mathrm{E}-01$ \\
\hline$\overline{V+5}$ & $0.00 \mathrm{E}+00$ & $0.00 \mathrm{E}+00$ \\
\hline$W+6$ & $0.00 \mathrm{E}+00$ & $0.00 \mathrm{E}+00$ \\
\hline$Z n+2$ & $0.00 \mathrm{E}+00$ & $0.00 \mathrm{E}+00$ \\
\hline $2 r+4$ & $0.00 \mathrm{E}+00$ & $0.00 \mathrm{E}+00$ \\
\hline $\mathrm{Al}(\mathrm{OH}) 4-$ & $2.32 \mathrm{E}-02$ & $0.00 \mathrm{E}+00$ \\
\hline $\mathrm{BO2-}$ & $0.00 \mathrm{E}+00$ & $0.00 E+00$ \\
\hline $\mathrm{BO3-2}$ & $0.00 \mathrm{E}+00$ & $0.00 \mathrm{E}+00$ \\
\hline C204-2 & $0.00 \mathrm{E}+00$ & $0.00 E+00$ \\
\hline $\mathrm{Cl}-$ & $2.75 \mathrm{E}+00$ & $1.56 \mathrm{E}-01$ \\
\hline $\mathrm{CO}-2$ & $0.00 \mathrm{E}+00$ & $0.00 \mathrm{E}+00$ \\
\hline $\mathrm{Cr}(\mathrm{OH}) 4-$ & $1.51 \mathrm{E}-01$ & $0.00 \mathrm{E}+00$ \\
\hline F- & $6.58 \mathrm{E}-01$ & $1.87 \mathrm{E}-01$ \\
\hline FeCN6-3 & $0.00 E+00$ & $0.00 E+00$ \\
\hline HCOO- & $0.00 \mathrm{E}+00$ & $0.00 \mathrm{E}+00$ \\
\hline I- & $0.00 \mathrm{E}+00$ & $0.00 \mathrm{E}+00$ \\
\hline N02- & $3.46 \mathrm{E}+00$ & $3.49 \mathrm{E}-02$ \\
\hline N03- & $7.52 \mathrm{E}-01$ & $2.69 \mathrm{E}-02$ \\
\hline
\end{tabular}




\section{WHC-SD-WM-TI-774 Rev. 0 TWRS PRIVATIZATION PROCESS TECHNICAL BASELINE}

Table D-3 Inventory Assumptions for 241-AY-102 (4 sheets)

\begin{tabular}{|l|c|c|}
\hline Chemicals (MT) & Soluble & Insoluble \\
\hline OH- & $7.48 \mathrm{E}+00$ & $3.77 \mathrm{E}+01$ \\
\hline P04-3 & $3.85 \mathrm{E}-01$ & $3.90 \mathrm{E}-03$ \\
\hline PTA-3 & $0.00 \mathrm{E}+00$ & $0.00 \mathrm{E}+00$ \\
\hline S04-2 & $3.87 \mathrm{E}-01$ & $2.00 \mathrm{E}-02$ \\
\hline Tc04- & $2.40 \mathrm{E}-03$ & $0.00 \mathrm{E}+00$ \\
\hline C-14 & $0.00 \mathrm{E}+00$ & $0.00 \mathrm{E}+00$ \\
\hline Cancrinite & $0.00 \mathrm{E}+00$ & $0.00 \mathrm{E}+00$ \\
\hline H20 & $3.15 \mathrm{E}+03$ & $0.00 \mathrm{E}+00$ \\
\hline Mn02 & $0.00 \mathrm{E}+00$ & $0.00 \mathrm{E}+00$ \\
\hline Ni2FeCN6 & $0.00 \mathrm{E}+00$ & $0.00 \mathrm{E}+00$ \\
\hline P205:24W02:44H20 & $0.00 \mathrm{E}+00$ & $0.00 \mathrm{E}+00$ \\
\hline Organic Carbon & $1.18 \mathrm{E}+00$ & $5.64 \mathrm{E}+00$ \\
\hline Zr02:2H20 & $5.20 \mathrm{E}-04$ & $5.25 \mathrm{E}-06$ \\
\hline
\end{tabular}


WHC-SD-WM-TI-774 Rev. 0

TWRS PRIVATIZATION PROCESS TECHNICAL BASELINE

Table D-4 Inventory Assumptions for 241-C-106 (4 sheets)

\begin{tabular}{|l|c|c|}
\hline Phase & Soluble & Insoluble \\
\hline $\begin{array}{l}\text { Total Mass Flow } \\
\text { (MT) }\end{array}$ & $9.23 \mathrm{E}+02$ & $3.05 \mathrm{E}+02$ \\
\hline Volume (L) & $7.38 \mathrm{E}+05$ & $1.91 \mathrm{E}+05$ \\
\hline Specific Gravity & 1.25 & 1.60 \\
\hline
\end{tabular}

\begin{tabular}{|l|c|c|}
\hline Radionuclides (Ci) & Soluble & Insoluble \\
\hline Am-241 & $1.60 \mathrm{E}+01$ & $1.11 \mathrm{E}+03$ \\
\hline $\mathrm{C}-14$ & $0.00 \mathrm{E}+00$ & $2.94 \mathrm{E}-01$ \\
\hline $\mathrm{Cm}-244$ & $0.00 \mathrm{E}+00$ & $0.00 \mathrm{E}+00$ \\
\hline $\mathrm{Co}-60$ & $4.81 \mathrm{E}+00$ & $1.48 \mathrm{E}+02$ \\
\hline $\mathrm{Cs}-137$ & $6.68 \mathrm{E}+04$ & $2.88 \mathrm{E}+05$ \\
\hline $\mathrm{Ba}-137$ & $6.35 \mathrm{E}+04$ & $2.74 \mathrm{E}+05$ \\
\hline $\mathrm{Eu}-154$ & $0.00 \mathrm{E}+00$ & $0.00 \mathrm{E}+00$ \\
\hline $\mathrm{Np}-237$ & $0.00 \mathrm{E}+00$ & $0.00 \mathrm{E}+00$ \\
\hline $\mathrm{Pu}-239$ & $1.61 \mathrm{E}+02$ & $3.22 \mathrm{E}+03$ \\
\hline $\mathrm{Pu}-240$ & $0.00 \mathrm{E}+00$ & $0.00 \mathrm{E}+00$ \\
\hline $\mathrm{Pu}-241$ & $0.00 \mathrm{E}+00$ & $0.00 \mathrm{E}+00$ \\
\hline Sr-90 & $2.12 \mathrm{E}+02$ & $2.12 \mathrm{E}+06$ \\
\hline $\mathrm{Y}-90$ & $2.12 \mathrm{E}+02$ & $2.12 \mathrm{E}+06$ \\
\hline Tc-99 & $4.01 \mathrm{E}+01$ & $2.09 \mathrm{E}+02$ \\
\hline Total Curies & $1.31 \mathrm{E}+05$ & $4.81 \mathrm{E}+06$ \\
\hline
\end{tabular}


WHC-SD-WM-TI-774 Rev. 0

TWRS PRIVATIZATION PROCESS TECHNICAL BASELINE sheets)

Table D-4 Inventory Assumptions for 241-C-106 (4

\begin{tabular}{|l|c|c|}
\hline $\mathrm{Chemica}$ (s (MT) & & \\
\hline $\mathrm{Ag}+$ & $1.47 \mathrm{E}-03$ & $5.63 \mathrm{E}-01$ \\
\hline $\mathrm{AT}+3$ & $0.00 \mathrm{E}+00$ & $4.36 \mathrm{E}+01$ \\
\hline $\mathrm{Am}+3$ & $4.66 \mathrm{E}-06$ & $3.23 \mathrm{E}-04$ \\
\hline $\mathrm{As}+5$ & $0.00 \mathrm{E}+00$ & $0.00 \mathrm{E}+00$ \\
\hline $\mathrm{B}+3$ & $5.41 \mathrm{E}-03$ & $1.67 \mathrm{E}-02$ \\
\hline $\mathrm{Ba}+2$ & $3.13 \mathrm{E}-03$ & $5.21 \mathrm{E}+00$ \\
\hline $\mathrm{Be}+2$ & $0.00 \mathrm{E}+00$ & $0.00 \mathrm{E}+00$ \\
\hline $\mathrm{Bi}+3$ & $1.64 \mathrm{E}-02$ & $5.32 \mathrm{E}-01$ \\
\hline $\mathrm{Ca}+2$ & $4.83 \mathrm{E}-02$ & $1.27 \mathrm{E}+01$ \\
\hline $\mathrm{Cd}+2$ & $1.29 \mathrm{E}-02$ & $3.85 \mathrm{E}-01$ \\
\hline $\mathrm{CE}+3$ & $0.00 \mathrm{E}+00$ & $0.00 \mathrm{E}+00$ \\
\hline $\mathrm{Cm}+3$ & $0.00 \mathrm{E}+00$ & $0.00 \mathrm{E}+00$ \\
\hline $\mathrm{Co}+3$ & $4.26 \mathrm{E}-09$ & $5.13 \mathrm{E}-03$ \\
\hline $\mathrm{Cr}+3$ & $0.00 \mathrm{E}+00$ & $1.04 \mathrm{E}+00$ \\
\hline $\mathrm{Cs}+$ & $4.06 \mathrm{E}-03$ & $1.75 \mathrm{E}-02$ \\
\hline $\mathrm{Cu}+2$ & $1.63 \mathrm{E}-03$ & $1.36 \mathrm{E}-01$ \\
\hline $\mathrm{Eu}+3$ & $0.00 \mathrm{E}+00$ & $0.00 \mathrm{E}+00$ \\
\hline $\mathrm{Fe}+2$ & $0.00 \mathrm{E}+00$ & $0.00 \mathrm{E}+00$ \\
\hline $\mathrm{Fe}+3$ & $0.00 \mathrm{E}+00$ & $5.56 \mathrm{E}+01$ \\
\hline $\mathrm{H}+$ & $0.00 \mathrm{E}+00$ & $0.00 \mathrm{E}+00$ \\
\hline $\mathrm{Hg}+2$ & $0.00 \mathrm{E}+00$ & $0.00 \mathrm{E}+00$ \\
\hline $\mathrm{K}+$ & $1.72 \mathrm{E}-01$ & $1.46 \mathrm{E}+00$ \\
\hline $\mathrm{La}+3$ & $0.00 \mathrm{E}+00$ & $0.00 \mathrm{E}+00$ \\
\hline $\mathrm{Li}+$ & $0.00 \mathrm{E}+00$ & $0.00 \mathrm{E}+00$ \\
\hline $\mathrm{Mg}+2$ & $1.19 \mathrm{E}-02$ & $6.98 \mathrm{E}+00$ \\
\hline $\mathrm{Mn}+2$ & $0.00 \mathrm{E}+00$ & $0.00 \mathrm{E}+00$ \\
\hline $\mathrm{Mn}+4$ & $5.37 \mathrm{E}-03$ & $1.99 \mathrm{E}+00$ \\
\hline $\mathrm{Mo}+6$ & $0.00 \mathrm{E}+00$ & $0.00 \mathrm{E}+00$ \\
\hline $\mathrm{Na}+$ & $5.34 \mathrm{E}+01$ & $8.41 \mathrm{E}+01$ \\
\hline $\mathrm{Nb}+5$ & $0.00 \mathrm{E}+00$ & $0.00 \mathrm{E}+00$ \\
\hline $\mathrm{Nd}+3$ & $0.00 \mathrm{E}+00$ & $0.00 \mathrm{E}+00$ \\
\hline $\mathrm{Ni}+3$ & $3.47 \mathrm{E}-02$ & $1.01 \mathrm{E}+00$ \\
\hline $\mathrm{Np}+4$ & $0.00 \mathrm{E}+00$ & $0.00 \mathrm{E}+00$ \\
\hline $\mathrm{Pb}+4$ & $4.81 \mathrm{E}-02$ & $2.52 \mathrm{E}+00$ \\
\hline & & \\
\hline & & \\
\hline & & \\
\hline & & \\
\hline
\end{tabular}

D-15 
WHC-SD-WM-TI-774 Rev. 0

TWRS PRIVATIZATION PROCESS TECHNICAL BASELINE

\begin{tabular}{|c|c|c|}
\hline Chemicals (MT) & & \\
\hline $\mathrm{Pd}+2$ & $0.00 \mathrm{E}+00$ & $1.70 \mathrm{E}-01$ \\
\hline $\mathrm{Pu}+4$ & $2.60 \mathrm{E}-03$ & $5.19 \mathrm{E}-02$ \\
\hline $\mathrm{Rb}+$ & $0.00 \mathrm{E}+00$ & $0.00 \mathrm{E}+00$ \\
\hline $\mathrm{Re}+7$ & $0.00 \mathrm{E}+00$ & $0.00 \mathrm{E}+00$ \\
\hline $\mathrm{Rh}+3$ & $0.00 \mathrm{E}+00$ & $0.00 \mathrm{E}+00$ \\
\hline $\mathrm{Ru}+3$ & $0.00 \mathrm{E}+00$ & $0.00 \mathrm{E}+00$ \\
\hline $\mathrm{Sb}+5$ & $0.00 \mathrm{E}+00$ & $0.00 \mathrm{E}+00$ \\
\hline $\mathrm{Se}+6$ & $0.00 \mathrm{E}+00$ & $0.00 \mathrm{E}+00$ \\
\hline $\mathrm{Si}+4$ & $2.27 \mathrm{E}-02$ & $7.57 \mathrm{E}+01$ \\
\hline $\mathrm{Sm}+3$ & $0.00 \mathrm{E}+00$ & $0.00 \mathrm{E}+00$ \\
\hline $\mathrm{Sn}+4$ & $0.00 E+00$ & $0.00 \mathrm{E}+00$ \\
\hline $\mathrm{Sr}+2$ & $1.25 \mathrm{E}-05$ & $1.25 \mathrm{E}-01$ \\
\hline $\mathrm{Te}+6$ & $0.00 \mathrm{E}+00$ & $0.00 \mathrm{E}+00$ \\
\hline $\mathrm{Th}+4$ & $0.00 \mathrm{E}+00$ & $0.00 \mathrm{E}+00$ \\
\hline $\mathrm{Ti}+4$ & $0.00 \mathrm{E}+00$ & $0.00 \mathrm{E}+00$ \\
\hline $\mathrm{T} 1+3$ & $0.00 \mathrm{E}+00$ & $0.00 \mathrm{E}+00$ \\
\hline $\mathrm{U} 02+2$ & $1.43 \mathrm{E}-02$ & $6.25 \mathrm{E}-01$ \\
\hline$V+5$ & $0.00 \mathrm{E}+00$ & $0.00 \mathrm{E}+00$ \\
\hline$W+6$ & $0.00 \mathrm{E}+00$ & $0.00 \mathrm{E}+00$ \\
\hline $\mathrm{Zn}+2$ & $0.00 \mathrm{E}+00$ & $4.93 \mathrm{E}-02$ \\
\hline $\mathrm{Zr}+4$ & $1.23 \mathrm{E}-01$ & $2.23 \mathrm{E}+00$ \\
\hline $\mathrm{Al}(\mathrm{OH}) 4-$ & $7.68 \mathrm{E}-02$ & $0.00 \mathrm{E}+00$ \\
\hline $\mathrm{BO2-}$ & $0.00 \mathrm{E}+00$ & $0.00 \mathrm{E}+00$ \\
\hline $\mathrm{B} 03-2$ & $0.00 \mathrm{E}+00$ & $0.00 \mathrm{E}+00$ \\
\hline C204-2 & $0.00 \mathrm{E}+00$ & $0.00 \mathrm{E}+00$ \\
\hline $\mathrm{Cl}-$ & $0.00 \mathrm{E}+00$ & $0.00 \mathrm{E}+00$ \\
\hline $\mathrm{CO3}-2$ & $0.00 \mathrm{E}+00$ & $0.00 \mathrm{E}+00$ \\
\hline $\mathrm{Cr}(\mathrm{OH}) 4-$ & $3.40 \mathrm{E}-03$ & $0.00 \mathrm{E}+00$ \\
\hline F- & $0.00 \mathrm{E}+00$ & $0.00 \mathrm{E}+00$ \\
\hline FeCN6-3 & $0.00 \mathrm{E}+00$ & $0.00 \mathrm{E}+00$ \\
\hline $\mathrm{HCOO}-$ & $0.00 \mathrm{E}+00$ & $0.00 \mathrm{E}+00$ \\
\hline I- & $0.00 \mathrm{E}+00$ & $0.00 \mathrm{E}+00$ \\
\hline NO2- & $0.00 \mathrm{E}+00$ & $0.00 \mathrm{E}+00$ \\
\hline NO3- & $9.85 \mathrm{E}-01$ & $4.95 \mathrm{E}-04$ \\
\hline
\end{tabular}

Table D-4 Inventory Assumptions for 241-C-106 (4 sheets) 
WHC-SD-WM-TI-774 Rev. 0

TWRS PRIVATIZATION PROCESS TECHNICAL BASELINE

Table D-4 Inventory Assumptions for 241-C-106 (4 sheets)

\begin{tabular}{|l|c|c|}
\hline Chemicals (MT) & & \\
\hline OH- & $0.00 \mathrm{E}+00$ & $0.00 \mathrm{E}+00$ \\
\hline P04-3 & $1.43 \mathrm{E}+00$ & $8.02 \mathrm{E}+00$ \\
\hline PTA-3 & $0.00 \mathrm{E}+00$ & $0.00 \mathrm{E}+00$ \\
\hline S04-2 & $5.91 \mathrm{E}+00$ & $1.21 \mathrm{E}-01$ \\
\hline TC04- & $3.90 \mathrm{E}-03$ & $2.04 \mathrm{E}-02$ \\
\hline $\mathrm{C}-14$ & $0.00 \mathrm{E}+00$ & $0.00 \mathrm{E}+00$ \\
\hline Cancrinite & $0.00 \mathrm{E}+00$ & $0.00 \mathrm{E}+00$ \\
\hline H20 & $8.55 \mathrm{E}+02$ & $0.00 \mathrm{E}+00$ \\
\hline Mn02 & $0.00 \mathrm{E}+00$ & $0.00 \mathrm{E}+00$ \\
\hline Ni2FeCN6 & $0.00 \mathrm{E}+00$ & $0.00 \mathrm{E}+00$ \\
\hline P205:24W02:44H20 & $0.00 \mathrm{E}+00$ & $0.00 \mathrm{E}+00$ \\
\hline Organic Carbon & $5.25 \mathrm{E}+00$ & $5.26 \mathrm{E}-03$ \\
\hline Zr02:2H20 & $0.00 \mathrm{E}+00$ & $0.00 \mathrm{E}+00$ \\
\hline
\end{tabular}


WHC-SD-WM-TI-774 Rev. 0

TWRS PRIVATIZATION PROCESS TECHNICAL BASELINE

Table D-5 Total Phase I HLW Tank Inventory (4 sheets)

\begin{tabular}{|l|c|c|}
\hline Phase & Soluble & Insoluble \\
\hline $\begin{array}{l}\text { Total Mass Flow } \\
\text { (MT) }\end{array}$ & $1.24 \mathrm{E}+04$ & $7.00 \mathrm{E}+02$ \\
\hline Volume (L) & $9.92 \mathrm{E}+06$ & $4.38 \mathrm{E}+05$ \\
\hline Specific Gravity & 1.25 & 1.60 \\
\hline
\end{tabular}

\begin{tabular}{|l|c|c|}
\hline Radionuclides (Ci) & Soluble & Insoluble \\
\hline Am-241 & $8.83 \mathrm{E}+02$ & $4.91 \mathrm{E}+04$ \\
\hline $\mathrm{C}-14$ & $3.22 \mathrm{E}+02$ & $2.84 \mathrm{E}+01$ \\
\hline $\mathrm{Cm}-244$ & $1.91 \mathrm{E}+01$ & $1.26 \mathrm{E}+03$ \\
\hline $\mathrm{C}-60$ & $4.81 \mathrm{E}+00$ & $1.48 \mathrm{E}+02$ \\
\hline $\mathrm{C}-137$ & $9.34 \mathrm{E}+06$ & $8.35 \mathrm{E}+05$ \\
\hline $\mathrm{Ba}-137$ & $8.88 \mathrm{E}+06$ & $7.93 \mathrm{E}+05$ \\
\hline $\mathrm{Eu}-154$ & $0.00 \mathrm{E}+00$ & $0.00 \mathrm{E}+00$ \\
\hline $\mathrm{Np}-237$ & $0.00 \mathrm{E}+00$ & $0.00 \mathrm{E}+00$ \\
\hline $\mathrm{Pu}-239$ & $2.03 \mathrm{E}+02$ & $4.90 \mathrm{E}+03$ \\
\hline $\mathrm{Pu}-240$ & $0.00 \mathrm{E}+00$ & $0.00 \mathrm{E}+00$ \\
\hline $\mathrm{Pu}-241$ & $0.00 \mathrm{E}+00$ & $0.00 \mathrm{E}+00$ \\
\hline Sr-90 & $2.97 \mathrm{E}+05$ & $1.23 \mathrm{E}+07$ \\
\hline $\mathrm{Y}-90$ & $2.97 \mathrm{E}+05$ & $1.23 \mathrm{E}+07$ \\
\hline Tc-99 & $1.04 \mathrm{E}+03$ & $5.04 \mathrm{E}+02$ \\
\hline Total Curies & $1.88 \mathrm{E}+07$ & $2.62 \mathrm{E}+07$ \\
\hline
\end{tabular}


WHC-SD-WM-TI-774 Rev. 0

TWRS PRIVATIZATION PROCESS TECHNICAL BASELINE

Table D-5 Total Phase I HLW Tank Inventory (4 sheets)

\begin{tabular}{|c|c|c|}
\hline Chemicals (MT) & & \\
\hline $\mathrm{Ag}+$ & $2.97 \mathrm{E}-02$ & $1.61 \mathrm{E}+00$ \\
\hline$A T+3$ & $0.00 \mathrm{E}+00$ & $7.61 \mathrm{E}+01$ \\
\hline $\mathrm{Am}+3$ & $2.58 \mathrm{E}-04$ & $1.43 \mathrm{E}-02$ \\
\hline$A s+5$ & $6.80 \mathrm{E}-03$ & $3.00 \mathrm{E}-01$ \\
\hline $\mathrm{B}+3$ & $8.60 \mathrm{E}-03$ & $2.27 \mathrm{E}-01$ \\
\hline $\mathrm{Ba}+2$ & $5.61 \mathrm{E}-03$ & $5.83 \mathrm{E}+00$ \\
\hline $\mathrm{Be}+2$ & $2.23 \mathrm{E}-05$ & $8.04 \mathrm{E}-03$ \\
\hline $\mathrm{Bi}+3$ & $1.64 \mathrm{E}-02$ & $5.32 \mathrm{E}-01$ \\
\hline $\mathrm{Ca}+2$ & $7.37 \mathrm{E}-02$ & $1.61 E+01$ \\
\hline $\mathrm{Cd}+2$ & $1.37 \mathrm{E}-02$ & $6.12 \mathrm{E}+00$ \\
\hline $\mathrm{CE}+3$ & $6.49 \mathrm{E}-03$ & $5.13 \mathrm{E}-01$ \\
\hline $\mathrm{Cm}+3$ & $2.36 \mathrm{E}-07$ & $1.55 \mathrm{E}-05$ \\
\hline $\mathrm{Co+3}$ & $7.92 \mathrm{E}-07$ & $5.13 \mathrm{E}-03$ \\
\hline $\mathrm{Cr}+3$ & $0.00 \mathrm{E}+00$ & $2.08 \mathrm{E}+00$ \\
\hline Cst & $4.21 \mathrm{E}-01$ & $4.24 \mathrm{E}-02$ \\
\hline $\mathrm{Cu}+2$ & $2.13 \mathrm{E}-03$ & $3.40 E-01$ \\
\hline Eu+3 & $0.00 \mathrm{E}+00$ & $0.00 \mathrm{E}+00$ \\
\hline $\mathrm{Fe}+2$ & $0.00 \mathrm{E}+00$ & $0.00 \mathrm{E}+00$ \\
\hline $\mathrm{Fe}+3$ & $4.75 \mathrm{E}-03$ & $1.30 \mathrm{E}+02$ \\
\hline $\mathrm{H}_{+}$ & $0.00 \mathrm{E}+00$ & $0.00 \mathrm{E}+00$ \\
\hline $\mathrm{Hg}+2$ & $0.00 E+00$ & $0.00 E+00$ \\
\hline$K+$ & $1.29 \mathrm{E}+00$ & $2.68 \mathrm{E}+00$ \\
\hline $\mathrm{La}+3$ & $1.01 \mathrm{E}-03$ & $2.77 \mathrm{E}+00$ \\
\hline $\mathrm{Li}+$ & $7.45 \mathrm{E}-04$ & $2.52 \mathrm{E}-02$ \\
\hline $\mathrm{Mg}+2$ & $1.24 \mathrm{E}-02$ & $7.40 \mathrm{E}+00$ \\
\hline$M n+2$ & $0.00 \mathrm{E}+00$ & $0.00 E+00$ \\
\hline$M n+4$ & $5.70 \mathrm{E}-03$ & $4.82 E+00$ \\
\hline Mo+6 & $2.05 \mathrm{E}-02$ & $1.99 \mathrm{E}-02$ \\
\hline $\mathrm{Nat}$ & $5.95 \mathrm{E}+02$ & $1.03 E+02$ \\
\hline $\mathrm{Nb}+5$ & $0.00 \mathrm{E}+00$ & $0.00 \mathrm{E}+00$ \\
\hline $\mathrm{Nd}+3$ & $0.00 \mathrm{E}+00$ & $0.00 \mathrm{E}+00$ \\
\hline $\mathrm{Ni}+3$ & $3.59 \mathrm{E}-02$ & $5.07 \mathrm{E}+00$ \\
\hline $\mathrm{Np}+4$ & $0.00 E+00$ & $0.00 \mathrm{E}+00$ \\
\hline $\mathrm{Pb}+4$ & $5.05 \mathrm{E}-02$ & $2.96 \mathrm{E}+00$ \\
\hline
\end{tabular}

D-19 
WHC-SD-WM-TI-774 Rev. 0

TWRS PRIVATIZATION PROCESS TECHNICAL BASELINE sheets)

Table D-5 Total Phase I HLW Tank Inventory (4

\begin{tabular}{|l|c|c|}
\hline Chemicals (MT) & & \\
\hline $\mathrm{Pd}+2$ & $0.00 \mathrm{E}+00$ & $1.70 \mathrm{E}-01$ \\
\hline $\mathrm{Pu}+4$ & $3.27 \mathrm{E}-03$ & $7.90 \mathrm{E}-02$ \\
\hline $\mathrm{Rb}+$ & $0.00 \mathrm{E}+00$ & $0.00 \mathrm{E}+00$ \\
\hline $\mathrm{Re}+7$ & $4.43 \mathrm{E}-04$ & $3.41 \mathrm{E}-02$ \\
\hline $\mathrm{Rh}+3$ & $4.41 \mathrm{E}-03$ & $2.23 \mathrm{E}-01$ \\
\hline $\mathrm{Ru}+3$ & $1.46 \mathrm{E}-03$ & $2.65 \mathrm{E}-01$ \\
\hline $\mathrm{Sb}+5$ & $2.08 \mathrm{E}-03$ & $6.54 \mathrm{E}-01$ \\
\hline $\mathrm{Se}+6$ & $7.31 \mathrm{E}-03$ & $7.22 \mathrm{E}-01$ \\
\hline $\mathrm{Si}+4$ & $3.72 \mathrm{E}+00$ & $8.22 \mathrm{E}+01$ \\
\hline $\mathrm{Sm}+3$ & $0.00 \mathrm{E}+00$ & $0.00 \mathrm{E}+00$ \\
\hline $\mathrm{Sn}+4$ & $0.00 \mathrm{E}+00$ & $0.00 \mathrm{E}+00$ \\
\hline $\mathrm{Sr}+2$ & $1.14 \mathrm{E}-02$ & $5.41 \mathrm{E}-01$ \\
\hline $\mathrm{Te}+6$ & $5.04 \mathrm{E}-03$ & $5.60 \mathrm{E}-01$ \\
\hline $\mathrm{Th}+4$ & $3.37 \mathrm{E}-03$ & $2.96 \mathrm{E}-01$ \\
\hline $\mathrm{Ti}+4$ & $1.45 \mathrm{E}-03$ & $1.80 \mathrm{E}-01$ \\
\hline $\mathrm{Tl}+3$ & $4.23 \mathrm{E}-02$ & $1.60 \mathrm{E}+00$ \\
\hline $\mathrm{U} 02+2$ & $7.61 \mathrm{E}+00$ & $6.94 \mathrm{E}+00$ \\
\hline $\mathrm{V}+5$ & $4.01 \mathrm{E}-04$ & $1.52 \mathrm{E}-02$ \\
\hline $\mathrm{W}+6$ & $0.00 \mathrm{E}+00$ & $0.00 \mathrm{E}+00$ \\
\hline $\mathrm{Zn}+2$ & $3.53 \mathrm{E}-04$ & $1.87 \mathrm{E}-01$ \\
\hline $\mathrm{Zr}+4$ & $1.23 \mathrm{E}-01$ & $2.23 \mathrm{E}+00$ \\
\hline $\mathrm{Al}(\mathrm{OH}) 4-$ & $1.39 \mathrm{E}+02$ & $0.00 \mathrm{E}+00$ \\
\hline $\mathrm{B} 02-$ & $0.00 \mathrm{E}+00$ & $0.00 \mathrm{E}+00$ \\
\hline $\mathrm{B} 03-2$ & $0.00 \mathrm{E}+00$ & $0.00 \mathrm{E}+00$ \\
\hline $\mathrm{C} 204-2$ & $0.00 \mathrm{E}+00$ & $0.00 \mathrm{E}+00$ \\
\hline $\mathrm{Cl}-$ & $3.36 \mathrm{E}+00$ & $2.26 \mathrm{E}-01$ \\
\hline $\mathrm{CO3}-2$ & $1.96 \mathrm{E}+02$ & $2.60 \mathrm{E}+01$ \\
\hline $\mathrm{Cr}(0 \mathrm{H}) 4-$ & $8.28 \mathrm{E}+00$ & $0.00 \mathrm{E}+00$ \\
\hline $\mathrm{F}-$ & $9.94 \mathrm{E}+00$ & $3.70 \mathrm{E}-01$ \\
\hline $\mathrm{FeCN6}-3$ & $0.00 \mathrm{E}+00$ & $0.00 \mathrm{E}+00$ \\
\hline $\mathrm{HCO0}-$ & $0.00 \mathrm{E}+00$ & $0.00 \mathrm{E}+00$ \\
\hline $\mathrm{I}-$ & $4.28 \mathrm{E}-04$ & $4.89 \mathrm{E}-04$ \\
\hline $\mathrm{NO2}-$ & $2.99 \mathrm{E}+02$ & $2.82 \mathrm{E}+00$ \\
\hline $\mathrm{NO3-}$ & $3.15 \mathrm{E}+02$ & $1.71 \mathrm{E}+00$ \\
\hline & & \\
\hline & $0-20$ & \\
\hline
\end{tabular}

D-20 
WHC-SD-WM-TI-774 Rev. 0

TWRS PRIVATIZATION PROCESS TECHNICAL BASELINE sheets)

Table D-5 Total Phase I HLW Tank Inventory (4

\begin{tabular}{|l|c|c|}
\hline Chemicals (MT) & & \\
\hline OH- & $4.60 \mathrm{E}+01$ & $1.63 \mathrm{E}+02$ \\
\hline P04-3 & $1.88 \mathrm{E}+00$ & $8.16 \mathrm{E}+00$ \\
\hline PTA-3 & $0.00 \mathrm{E}+00$ & $0.00 \mathrm{E}+00$ \\
\hline S04-2 & $6.22 \mathrm{E}+01$ & $1.51 \mathrm{E}-01$ \\
\hline Tc04- & $1.01 \mathrm{E}-01$ & $4.91 \mathrm{E}-02$ \\
\hline C-14 & $0.00 \mathrm{E}+00$ & $0.00 \mathrm{E}+00$ \\
\hline Cancrinite & $0.00 \mathrm{E}+00$ & $0.00 \mathrm{E}+00$ \\
\hline H20 & $1.07 \mathrm{E}+04$ & $0.00 \mathrm{E}+00$ \\
\hline Mn02 & $0.00 \mathrm{E}+00$ & $0.00 \mathrm{E}+00$ \\
\hline Ni2FeCN6 & $0.00 \mathrm{E}+00$ & $0.00 \mathrm{E}+00$ \\
\hline P205:24W02:44H20 & $0.00 \mathrm{E}+00$ & $0.00 \mathrm{E}+00$ \\
\hline Organic Carbon & $1.50 \mathrm{E}+01$ & $8.46 \mathrm{E}+00$ \\
\hline Zr02:2H20 & $1.83 \mathrm{E}-03$ & $2.39 \mathrm{E}+01$ \\
\hline
\end{tabular}


WHC-SD-WM-TI-774 Rev. 0

TWRS PRIVATIZATION PROCESS TECHNICAL BASELINE

APPENDIX E PHASE 2 MASS BALANCE WITH REVISED TWRS INVENTORY 
Table E-1 Comparison of Revised TWRS Inventory and TWRS Inventory

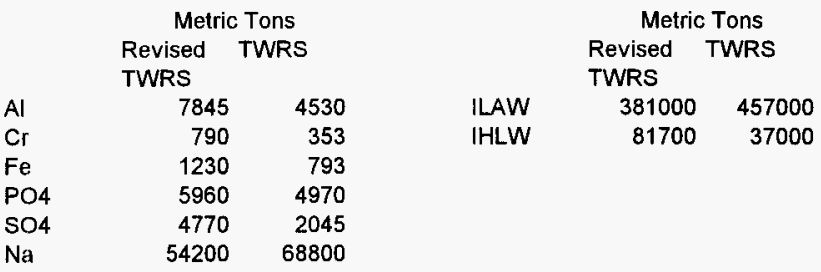

Figure E-1 Major Components of Inventory

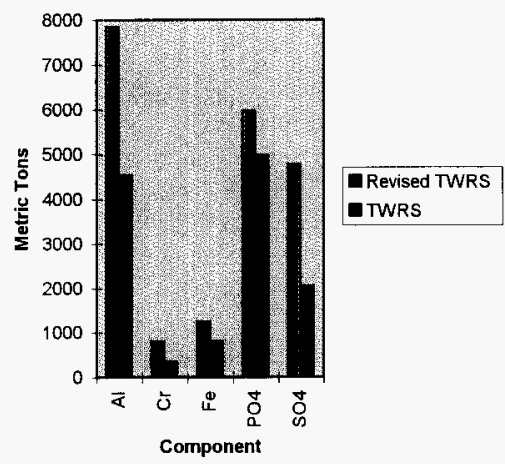

Figure E-2 Comparison of Products

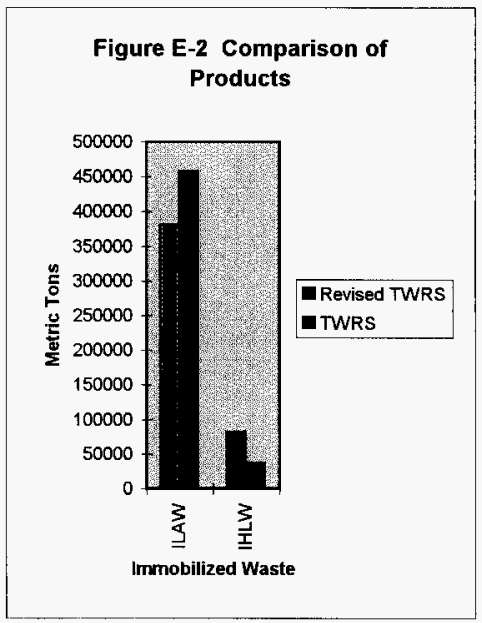

As a special case of Phase 2, several major components of the TWRS Inventory were revised with expected values from the tentative standard inventory. The table and figures above show the TWRS Inventory and the Revised TWRS Inventory total for $\mathrm{Al}, \mathrm{Cr}, \mathrm{Fe}$, phosphate, sulfate and $\mathrm{Na}$. These components were distributed to the liquid and solid phase with the same solubility factors as used in Section 3.0.

The balance of this APPENDIX presents the mass balance resulting from running the Phase 2 process model with this Revised TWRS Inventory.

The results of this APPENDIX should be regarded as an indicator of future trends because finalization of the standard inventory is not expected until late FY-1997. 


\section{Figure E-3 Phase 2 Waste Processing}

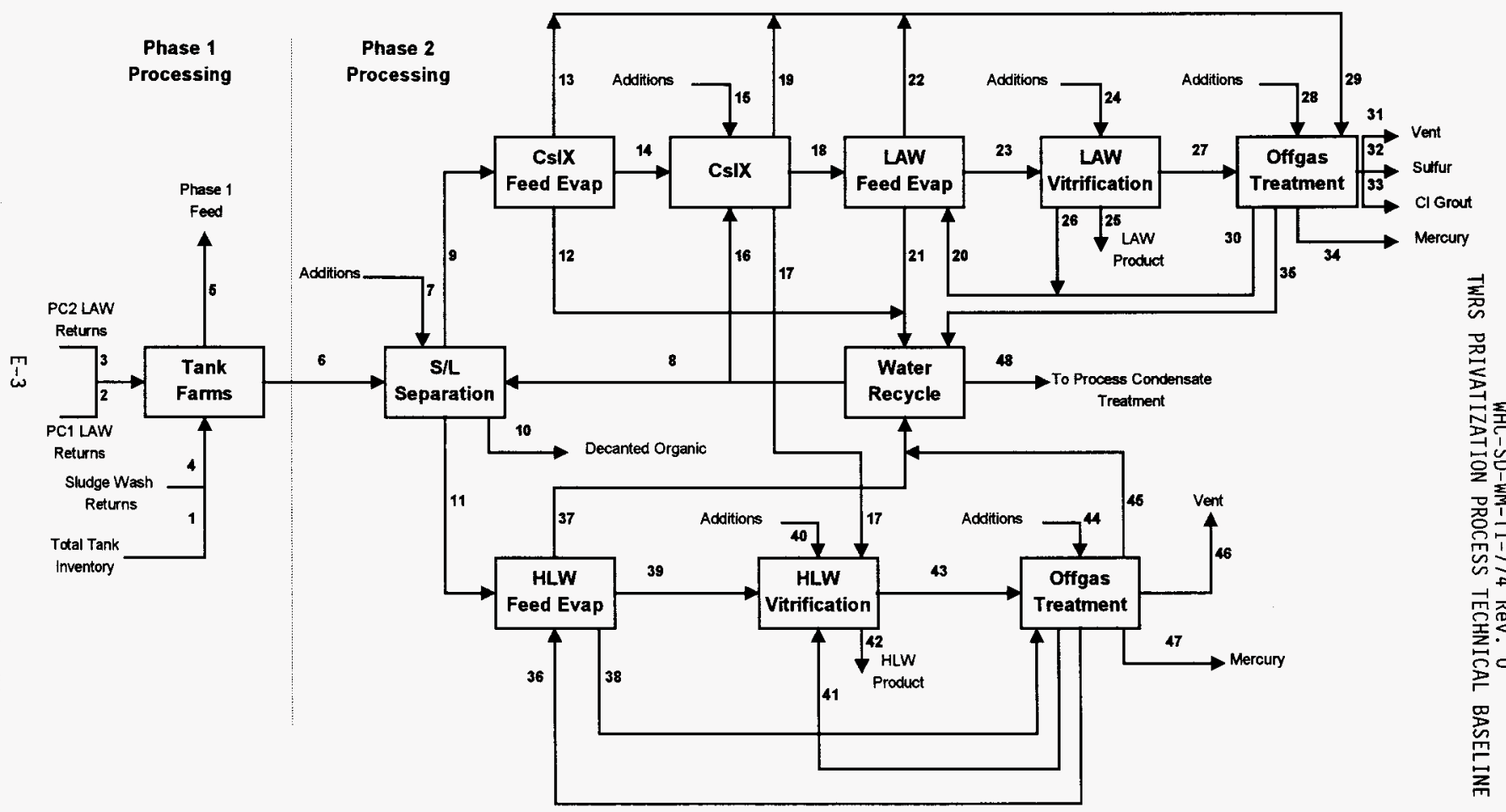




\section{WHC-SD-WM-TI-774 Rev. 0 TWRS PRIVATIZATION PROCESS TECHNICAL BASELINE}

Table E-2 Phase 2 Mass Balance with Revised TWRS Inventory

\begin{tabular}{|c|c|c|c|c|c|c|c|c|c|c|}
\hline STREAM NAME & 1 & 2 & 3 & 4 & 5 & 6 & 7 & 8 & 9 & 10 \\
\hline \multicolumn{11}{|l|}{ ITQUID CAMEANENIS } \\
\hline $\begin{array}{l}\text { Total Mass Flow (MT) } \\
\text { Volume (L) } \\
\text { Specific Gravity }\end{array}$ & $\begin{array}{l}7.13 \mathrm{E}+05 \\
5.77 \mathrm{E}+08 \\
1.24 \mathrm{E}+00\end{array}$ & $\begin{array}{l}3.75 \mathrm{E}+03 \\
3.69 \mathrm{E}+06 \\
1.01 \mathrm{E}+\infty 0\end{array}$ & $\begin{array}{l}3.77 \mathrm{E}+03 \\
3.71 \mathrm{E}+06 \\
1.02 \mathrm{E}+00\end{array}$ & $\begin{array}{l}9.46 \mathrm{E}+03 \\
9.28 \mathrm{EE}+06 \\
1.02 \mathrm{E}+00\end{array}$ & $\begin{array}{l}9.57 \mathrm{E}+04 \\
7.34 \mathrm{E}+07 \\
1.30 \mathrm{E}+100\end{array}$ & $\begin{array}{l}6.34 \mathrm{E}+05 \\
5.20 \mathrm{E}+08 \\
1.22 \mathrm{E}+00\end{array}$ & $\begin{array}{l}4.57 \mathrm{E}+04 \\
3.04 \mathrm{E}+07 \\
1.50 \mathrm{E}+00\end{array}$ & $\begin{array}{l}5.77 \mathrm{E}+0.5 \\
5.77 \mathrm{E}+08 \\
1.00 \mathrm{E}+00\end{array}$ & $\begin{array}{l}1.06 \mathrm{E}+06 \\
9.19 \mathrm{E}+08 \\
1.16 \mathrm{E}+00\end{array}$ & $\begin{array}{l}7.7 \mathrm{EE}+01 \\
7.7 \mathrm{gE}+04 \\
1.00 \mathrm{E}+00\end{array}$ \\
\hline \multicolumn{11}{|l|}{ Radiamolides (Ci) } \\
\hline $\begin{array}{l}\text { Amr-241 } \\
\mathrm{C}-14 \\
\mathrm{Cs}-137 \\
\mathrm{Ba}-137 \\
\mathrm{~Np}-237 \\
\mathrm{Ru}-239 \\
\mathrm{Pu}-240 \\
\mathrm{Pu}-241 \\
\mathrm{Sr}-90 \\
\mathrm{Y}-90 \\
\mathrm{Tc}-99 \\
\text { Total Gries }\end{array}$ & $\begin{array}{l}8.00 E+03 \\
3.22 E+03 \\
3.18 E+07 \\
3.02 E+07 \\
6.94 E+00 \\
1.65 E+03 \\
4.30 E+02 \\
4.76 E+03 \\
1.88 E+06 \\
1.88 E+06 \\
2.27 E+04 \\
6.58 E+07\end{array}$ & $\begin{array}{l}6.11 \mathrm{E}+00 \\
2.09 \mathrm{E}-01 \\
5.96 \mathrm{E}+04 \\
5.67 \mathrm{E}+04 \\
1.60 \mathrm{E}-03 \\
1.16 \mathrm{E}+00 \\
2.90 \mathrm{E}-01 \\
1.81 \mathrm{E}+00 \\
2.02 \mathrm{E}+03 \\
2.02 \mathrm{E}+03 \\
1.75 \mathrm{E}+01 \\
1.20 \mathrm{E}+05\end{array}$ & $\begin{array}{l}5.96 \mathrm{E}+00 \\
1.89 \mathrm{E}-01 \\
3.99 \mathrm{E}+04 \\
3.79 \mathrm{E}+04 \\
7.43 \mathrm{E}-04 \\
1.03 \mathrm{E}+00 \\
2.61 \mathrm{E}-01 \\
1.62 \mathrm{E}+00 \\
2.39 \mathrm{E}+03 \\
2.39 \mathrm{E}+03 \\
5.78 \mathrm{E}+02 \\
8.31 \mathrm{E}+04\end{array}$ & $\begin{array}{l}1.15 \mathrm{E}+02 \\
3.72 \mathrm{E}+01 \\
1.16 \mathrm{E}+06 \\
1.10 \mathrm{E}+06 \\
1.45 \mathrm{E}+02 \\
\\
3.84 \mathrm{E}+04 \\
3.84 \mathrm{E}+04 \\
1.71 \mathrm{E}+02 \\
2.34 \mathrm{E}+06\end{array}$ & $\begin{array}{l}3.35 \mathrm{E}+03 \\
3.78 \mathrm{E}+02 \\
2.70 \mathrm{E}+07 \\
2.57 \mathrm{E}+07 \\
3.84 \mathrm{E}-01 \\
6.321+02 \\
1.10 \mathrm{E}+02 \\
6.90 \mathrm{E}+02 \\
1.21 \mathrm{E}+06 \\
1.21 \mathrm{E}+06 \\
7.04 \mathrm{E}+03 \\
5.51 \mathrm{E}+07\end{array}$ & $\begin{array}{l}4.77 \mathrm{E}+03 \\
2.88 \mathrm{E}+03 \\
6.07 \mathrm{E}+06 \\
5.77 \mathrm{E}+06 \\
6.58 \mathrm{E}+00 \\
1.16 \mathrm{E}+03 \\
3.20 \mathrm{E}+02 \\
4.08 \mathrm{E}+03 \\
7.12 \mathrm{E}+05 \\
7.12 \mathrm{E}+05 \\
1.64 \mathrm{E}+04 \\
1.33 \mathrm{E}+07\end{array}$ & & $\begin{array}{l}5.73 \mathrm{E}-04 \\
3.46 \mathrm{E}-04 \\
6.76 \mathrm{E}-01 \\
6.42 \mathrm{E}-01 \\
2.17 \mathrm{E}-04 \\
1.40 \mathrm{E}-04 \\
3.84 \mathrm{E}-05 \\
4.90 \mathrm{E}-04 \\
8.55 \mathrm{E}-02 \\
8.55 \mathrm{E}-02 \\
4.18 \mathrm{E}-03 \\
1.49 \mathrm{E}+00\end{array}$ & $\begin{array}{l}4.76 \mathrm{E}+03 \\
2.87 \mathrm{E}+03 \\
1.39 \mathrm{E}+07 \\
1.32 \mathrm{E}+07 \\
6.56 \mathrm{E}+00 \\
1.16 \mathrm{E}+03 \\
3.19 \mathrm{E}+02 \\
4.07 \mathrm{E}+03 \\
7.10 \mathrm{E}+05 \\
7.10 \mathrm{E}+05 \\
1.64 \mathrm{E}+04 \\
2.85 \mathrm{E}+07\end{array}$ & \\
\hline
\end{tabular}

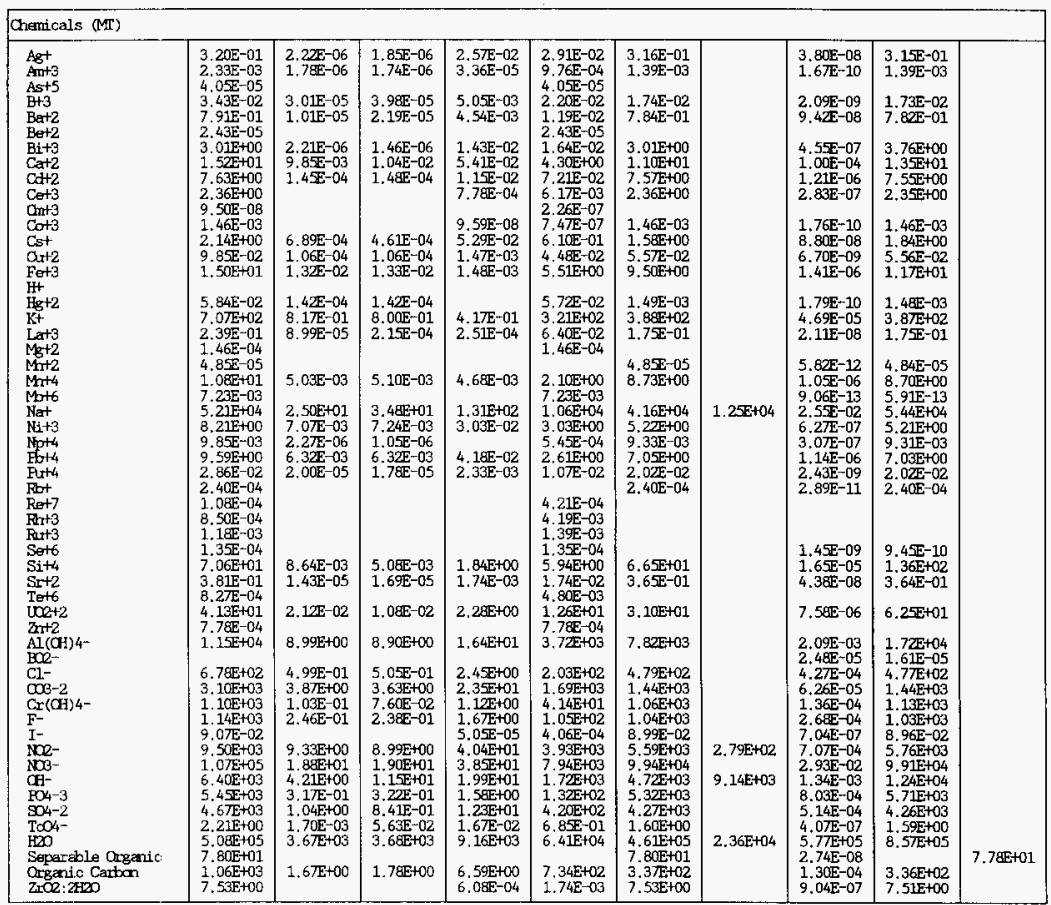


WHC-SD-WM-TI-774 Rev. 0

TWRS PRIVATIZATION PROCESS TECHNICAL BASELINE

Table E-2 Phase 2 Mass Balance with Revised TWRS Inventory

\begin{tabular}{|c|c|c|c|c|c|c|c|c|c|c|}
\hline SIEFAM NAYE & 1 & 2 & 3 & 4 & 5 & 6 & 7 & 8 & 9 & 10 \\
\hline \multicolumn{11}{|l|}{ LIQUID COMPANENS } \\
\hline \multicolumn{11}{|c|}{ Chemicals Contirbued (MT) } \\
\hline 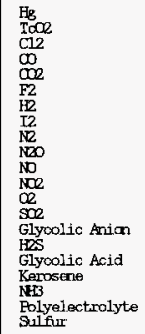 & & & & & & & $1.96 E+02$ & $2.23 \mathrm{E}-07$ & $\begin{array}{l}1.46 \mathrm{E}-07 \\
2.00 \mathrm{E}+01\end{array}$ & \\
\hline
\end{tabular}




\section{WHC-SD-WM-TI-774 Rev. 0 \\ TWRS PRIVATIZATION PROCESS TECHNICAL BASELINE}

Table E-2 Phase 2 Mass Balance with Revised TWRS Inventory

\begin{tabular}{|c|c|c|c|c|c|c|c|c|c|c|}
\hline SIREAM NAME & 1 & 2 & 3 & 4 & 5 & 6 & 7 & 8 & 9 & 10 \\
\hline \multicolumn{11}{|l|}{ Sa.ID COMFOWNIS } \\
\hline Total Mass Flow (MS) & $2.87 \mathrm{E}+04$ & & 4.35E-03 & $5.04 \mathrm{E}+00$ & $5.53 \mathrm{E}+02$ & $2.81 E+04$ & & & $2.385+02$ & \\
\hline \multicolumn{11}{|l|}{ Radicauclides (Ci) } \\
\hline $\begin{array}{l}\mathrm{Amr}-241 \\
\mathrm{C}-14 \\
\mathrm{Cs}-137 \\
\mathrm{Ba}-137 \\
\mathrm{Mp}-237 \\
\mathrm{Pu}-239 \\
\mathrm{Pu}-240 \\
\mathrm{Pu}-241 \\
\mathrm{Sr}-90 \\
\mathrm{Y}-90 \\
\mathrm{Tc}-99 \\
\text { Total Curies }\end{array}$ & $\begin{array}{l}9.7 \mathrm{E}+04 \\
2.12 \mathrm{E}+03 \\
1.39 \mathrm{E}+07 \\
1.32 \mathrm{3}+07 \\
6.27 \mathrm{E}+01 \\
2.53 \mathrm{E}+04 \\
6.26 \mathrm{E}+03 \\
6.95 \mathrm{E}+04 \\
5.1 \mathrm{gE}+07 \\
5.18 \mathrm{E}+07 \\
9.32 \mathrm{E}+03 \\
1.31 \mathrm{E}+08\end{array}$ & & $\begin{array}{l}\text { 3.32E+01 } \\
8.38 \mathrm{E}+00 \\
3.42 \mathrm{E}+05 \\
3.42 \mathrm{E}+05 \\
6.8 \mathrm{E}+05\end{array}$ & $\begin{array}{l}2.88 \mathrm{E}+02 \\
1.64 \mathrm{E}-01 \\
6.01 \mathrm{E}+03 \\
5.71 \mathrm{E}+03 \\
3.99 \mathrm{E}+01 \\
\\
7.72 \mathrm{E}+04 \\
7.7 \mathrm{ZE}+04 \\
3.79 \mathrm{E}+00 \\
1.67 \mathrm{E}+05\end{array}$ & $\begin{array}{l}3.76 \mathrm{E}+04 \\
2.11 \mathrm{E}+01 \\
6.81 \mathrm{E}+05 \\
6.4 \mathrm{E}+05 \\
4.19 \mathrm{E}+03 \\
\\
9.39 \mathrm{E}+06 \\
9.39 \mathrm{E}+06 \\
4.29 \mathrm{E}+02 \\
2.02 \mathrm{E}+07\end{array}$ & $\begin{array}{l}6.11 E+04 \\
2.10 E+03 \\
1.32 E+07 \\
1.26 E+07 \\
6.27 E+01 \\
2.12 E+04 \\
6.28 E+03 \\
6.95 E+04 \\
4.28 E+07 \\
4.28 E+07 \\
8.87 E+03 \\
1.12 E+08\end{array}$ & & & $\begin{array}{l}8.03 E+02 \\
2.75 E+01 \\
7.01 E+04 \\
6.66 E+04 \\
8.25 E-01 \\
2.78 E+02 \\
8.25 E+01 \\
9.14 E+02 \\
5.62 E+05 \\
5.62 E+05 \\
1.17 E+02 \\
1.26 E+06\end{array}$ & \\
\hline
\end{tabular}

\begin{tabular}{|c|c|c|c|c|c|c|}
\hline \multicolumn{7}{|l|}{ Chemicals (MI) } \\
\hline 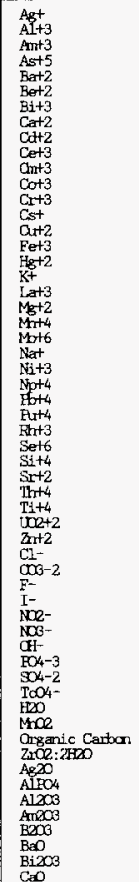 & $\begin{array}{l}1.48 \mathrm{E}+00 \\
4.59 \mathrm{E}+03 \\
2.84 \mathrm{E}-02 \\
2.26 \mathrm{E}-03 \\
3.74 \mathrm{E}+00 \\
3.08 \mathrm{E}-03 \\
2.60 \mathrm{E}+02 \\
1.46 \mathrm{E}+02 \\
6.55 \mathrm{E}+00 \\
2.35 \mathrm{E}+02 \\
1.76 \mathrm{E}-05 \\
1.49 \mathrm{E}-06 \\
3.14 \mathrm{E}+02 \\
4.73 \mathrm{E}-01 \\
1.88 \mathrm{E}-01 \\
1.22 \mathrm{E}+03 \\
8.81 \mathrm{E}-02 \\
2.96 \mathrm{E}+01 \\
2.30 \mathrm{E}+01 \\
8.25 \mathrm{E}+00 \\
1.80 \mathrm{E}+02 \\
3.21 \mathrm{E}-02 \\
2.38 \mathrm{E}+03 \\
2.06 \mathrm{E}+02 \\
8.90 \mathrm{E}-02 \\
2.93 \mathrm{E}+01 \\
4.36 \mathrm{E} \\
1.93 \mathrm{E}-01 \\
3.31 \mathrm{E}+00 \\
6.22 \mathrm{E}+02 \\
3.66 \mathrm{E}+01 \\
2.79 \mathrm{E}+00 \\
1.55 \mathrm{E}-01 \\
1.61 \mathrm{E}+03 \\
5.06 \mathrm{E}-01 \\
8.99 \mathrm{E}+100 \\
1.09 \mathrm{E}+02 \\
6.82 \mathrm{E}+01 \\
1.40 \mathrm{E}-03 \\
6.18 \mathrm{E}+01 \\
9.85 \mathrm{E}+02 \\
1.36 \mathrm{E}+04 \\
5.94 \mathrm{E}+02 \\
1.05 \mathrm{E}+02 \\
9.07 \mathrm{E}-01 \\
\\
8.73 \mathrm{E}+01 \\
1.20 \mathrm{E}+03\end{array}$ & $\begin{array}{l}5.77 \mathrm{E}-04 \\
2.43 \mathrm{E}-03\end{array}$ & $\begin{array}{l}9.25 \mathrm{E}-03 \\
6.07 \mathrm{E}-01 \\
8.3 \mathrm{E}-05 \\
\\
5.20 \mathrm{E}-03 \\
1.40 \mathrm{E}-01 \\
3.76 \mathrm{E}-02 \\
3.04 \mathrm{E}-03 \\
9.16 \mathrm{E}-08 \\
5.02 \mathrm{E}-05 \\
1.52 \mathrm{E}-02 \\
3.16 \mathrm{E}-04 \\
9.50 \mathrm{E}-01 \\
2.11 \mathrm{E}-02 \\
1.51 \mathrm{E}-02 \\
7.07 \mathrm{E}-02 \\
3.32 \mathrm{E}-02 \\
1.18 \mathrm{E}-04 \\
9.2 \mathrm{E}-01 \\
3.28 \mathrm{E}-02 \\
2.73 \mathrm{E}-02 \\
6.43 \mathrm{E}-04 \\
1.32 \mathrm{E}-03 \\
4.27 \mathrm{E}-03 \\
7.68 \mathrm{E}-01 \\
3.40 \mathrm{E}-03 \\
1.7 \mathrm{E}-03 \\
4.15 \mathrm{E}-02 \\
1.30 \mathrm{E}-03 \\
9.6 \mathrm{EE}-04 \\
1.5 \mathrm{E}-01 \\
1.7 \mathrm{E}-03 \\
2.89 \mathrm{E}-06 \\
1.66 \mathrm{E}-02 \\
1.01 \mathrm{E}-02 \\
8.81 \mathrm{E}-01 \\
7.91 \mathrm{E}-02 \\
1.31 \mathrm{E}-03 \\
3.69 \mathrm{E}-04 \\
\\
3.67 \mathrm{E}-02 \\
1.42 \mathrm{E}-01\end{array}$ & 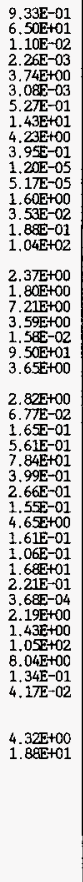 & $\begin{array}{l}5.56 \mathrm{E}-01 \\
4.53 \mathrm{E}+03 \\
1.78 \mathrm{E}-02 \\
\\
2.59 \mathrm{E}+02 \\
1.32 \mathrm{E}+02 \\
2.37 \mathrm{E}+00 \\
2.35 \mathrm{E}+02 \\
5.71 \mathrm{E}-06 \\
3.13 \mathrm{E}+02 \\
4.3 \mathrm{EE}-01 \\
1.12 \mathrm{E}+03 \\
8.81 \mathrm{E}-02 \\
2.72 \mathrm{E}+01 \\
2.13 \mathrm{E}+01 \\
1.12 \mathrm{E}+00 \\
1.76 \mathrm{E}+02 \\
1.63 \mathrm{E}-02 \\
2.29 \mathrm{E}+03 \\
2.02 \mathrm{E}+02 \\
8.90 \mathrm{E}-02 \\
2.6 \mathrm{E}+01 \\
3.70 \mathrm{E}-01 \\
2.96 \mathrm{E}-02 \\
2.76 \mathrm{E}+00 \\
5.44 \mathrm{E}+02 \\
3.62 \mathrm{E}+01 \\
2.52 \mathrm{E}+00 \\
1.61 \mathrm{E}+03 \\
3.47 \mathrm{E}-01 \\
8.90 \mathrm{E}+00 \\
9.25 \mathrm{E}+01 \\
6.80 \mathrm{E}+01 \\
1.04 \mathrm{E}-03 \\
5.96 \mathrm{E}+01 \\
9.85 \mathrm{E}+02 \\
1.34 \mathrm{E}+4 \\
5.86 \mathrm{E}+02 \\
1.05 \mathrm{~F}+02 \\
8.64 \mathrm{E}-01 \\
\\
8.30 \mathrm{E}+01 \\
1.18 \mathrm{E}+03\end{array}$ & $\begin{array}{l}7.31 \mathrm{E}-03 \\
2.40 \mathrm{E}+01 \\
2.34 \mathrm{E}-04 \\
\\
3.40 \mathrm{E}+00 \\
1.70 \mathrm{E}+00 \\
3.11 \mathrm{E}-02 \\
3.09 \mathrm{E}+00 \\
7.51 \mathrm{E}-08 \\
3.70 \mathrm{E}+00 \\
2.32 \mathrm{E}-03 \\
1.46 \mathrm{E}+01 \\
1.16 \mathrm{E}-0.3 \\
3.58 \mathrm{E}-01 \\
2.79 \mathrm{E}-01 \\
1.47 \mathrm{E}-02 \\
2.32 \mathrm{E}+00 \\
2.15 \mathrm{E}-04 \\
1.66 \mathrm{E}+01 \\
2.66 \mathrm{E}+00 \\
1.17 \mathrm{E}-03 \\
3.49 \mathrm{E}-01 \\
4.86 \mathrm{E}-03 \\
3.90 \mathrm{E}-04 \\
3.62 \mathrm{E}-02 \\
6.23 \mathrm{E}+00 \\
4.75 \mathrm{E}-01 \\
3.32 \mathrm{E}-02 \\
2.07 \mathrm{E}+01 \\
4.55 \mathrm{E}-03 \\
1.17 \mathrm{E}-01 \\
1.22 \mathrm{E}+00 \\
8.94 \mathrm{E}-01 \\
1.36 \mathrm{E}-05 \\
7.84 \mathrm{E}-01 \\
1.30 \mathrm{E}+01 \\
9.90 \mathrm{E}+01 \\
2.33 \mathrm{E}+00 \\
1.37 \mathrm{E}+00 \\
1.14 \mathrm{E}-02 \\
\\
1.09 \mathrm{E}+00 \\
1.56 \mathrm{E}+01\end{array}$ \\
\hline
\end{tabular}


WHC-SD-WM-TI-774 Rev. 0

TWRS PRIVATIZATION PROCESS TECHNICAL BASELINE

Table E-2 Phase 2 Mass Balance with Revised TWRS Irventory

\begin{tabular}{|c|c|c|c|c|c|c|c|c|c|c|}
\hline STREAM NAME & 1 & 2 & 3 & 4 & 5 & 6 & 7 & 8 & 9 & 10 \\
\hline \multicolumn{11}{|l|}{ sa.d camakds } \\
\hline \multicolumn{11}{|c|}{ Chenicals Continued $(\mathbb{M})$} \\
\hline 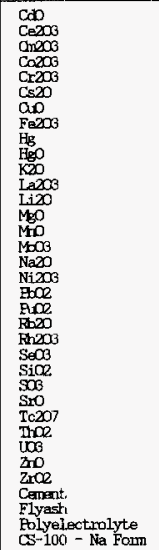 & & & & & & & & & $1.64 E+00$ & \\
\hline
\end{tabular}




\section{WHC-SD-WM-TI-774 Rev. 0 TWRS PRIVATIZATION PROCESS TECHNICAL BASELINE}

Table E-2 Phase 2 Mass Balance with Revised TWRS Inventory

\begin{tabular}{|c|c|c|c|c|c|c|c|c|c|c|}
\hline SIREAM NAME & 11 & 12 & 13 & 14 & 15 & 16 & 17 & 18 & 19 & 20 \\
\hline \multicolumn{11}{|l|}{ LIQUI DOMANEMIS } \\
\hline $\begin{array}{l}\text { Total Mass Flon (MI) } \\
\text { Volime (L) } \\
\text { Specific Gravity }\end{array}$ & $\begin{array}{l}2.05 E+05 \\
2.04 E+08 \\
1.01 E+00\end{array}$ & $\begin{array}{l}5.75 \mathrm{E}+05 \\
5.7 \mathrm{SE}+08 \\
1.00 \mathrm{E}+00\end{array}$ & $\begin{array}{l}6.39 \mathrm{E}+03 \\
6.39 \mathrm{E}+06 \\
1.00 \mathrm{E}+00\end{array}$ & $\begin{array}{l}4,80 \mathrm{E}+05 \\
3,38 \mathrm{gE}+08 \\
1,4 \mathrm{Z}+00\end{array}$ & $\begin{array}{l}7.24 \mathrm{E}+04 \\
7.10 \mathrm{E}+07 \\
1.02 \mathrm{E}+00\end{array}$ & $\begin{array}{l}\text { 1. } 36 \mathrm{E}+04 \\
1.36 \mathrm{E}+07 \\
1.00 \mathrm{E}+00\end{array}$ & $\begin{array}{l}8.84 \mathrm{E}+03 \\
7.94 \mathrm{E}+06 \\
1.11 \mathrm{E}+00\end{array}$ & $\begin{array}{l}5.56 \mathrm{E}+05 \\
4.14 \mathrm{E}+08 \\
1.34 \mathrm{E}+00\end{array}$ & $\begin{array}{l}9.335+02 \\
9.28 E+05 \\
1.01 E+00\end{array}$ & $\begin{array}{l}6.80 \mathrm{E}+05 \\
6.69 \mathrm{E}+08 \\
1.02 \mathrm{E}+00\end{array}$ \\
\hline
\end{tabular}

\begin{tabular}{|c|c|c|c|c|c|c|c|c|c|}
\hline \multicolumn{10}{|c|}{ Radiauclides (Ci) } \\
\hline $\begin{array}{l}\mathrm{Am}-241 \\
\mathrm{C}-14 \\
\mathrm{C}-137 \\
\mathrm{Ba}-137 \\
\mathrm{~Np}-237 \\
\mathrm{Pu}-239 \\
\mathrm{Pu}-240 \\
\mathrm{Pu}-241 \\
\mathrm{Sr}-90 \\
\mathrm{Y}-90 \\
\mathrm{Tc}-99 \\
\text { Total Curies }\end{array}$ & $\begin{array}{l}1.23 \mathrm{E}+01 \\
7.40 \mathrm{E}+00 \\
1.31 \mathrm{E}+05 \\
1.24 \mathrm{E}+05 \\
1.70 \mathrm{E}-02 \\
2.99 \mathrm{E}+00 \\
8.22 \mathrm{E}-01 \\
1.05 \mathrm{E}+01 \\
1.83 \mathrm{E}+03 \\
1.83 \mathrm{E}+03 \\
4.22 \mathrm{E}+01 \\
2.58 \mathrm{E}+05\end{array}$ & $\begin{array}{l}5.76 \mathrm{E}-04 \\
3.47 \mathrm{E}-04 \\
1.68 \mathrm{E}+00 \\
1.59 \mathrm{E}+00 \\
7.94 \mathrm{E}-07 \\
1.40 \mathrm{E}-04 \\
3.86 \mathrm{E}-05 \\
4.92 \mathrm{E}-04 \\
8.59 \mathrm{E}-02 \\
8.59 \mathrm{E}-02 \\
1.98 \mathrm{E}-03 \\
3.45 \mathrm{E}+00\end{array}$ & $\begin{array}{l}5.77 \mathrm{E}-07 \\
3.48 \mathrm{E}-07 \\
1.68 \mathrm{E}-03 \\
1.60 \mathrm{E}-03 \\
7.9 \mathrm{E}-10 \\
1.40 \mathrm{E}-07 \\
3.86 \mathrm{E}-08 \\
4.93 \mathrm{E}-07 \\
8.60 \mathrm{E}-05 \\
8.60 \mathrm{E}-05 \\
1.98 \mathrm{E}-06 \\
3.45 \mathrm{E}-03\end{array}$ & $\begin{array}{l}4.76 \mathrm{E}+03 \\
2.87 \mathrm{E}+03 \\
1.39 \mathrm{E}+07 \\
1.32 \mathrm{E}+07 \\
6.56 \mathrm{E}+00 \\
1.16 \mathrm{E}+03 \\
3.19 \mathrm{E}+02 \\
4.07 \mathrm{E}+03 \\
7.10 \mathrm{E}+05 \\
7.10 \mathrm{E}+05 \\
1.64 \mathrm{E}+04 \\
2.85 \mathrm{E}+07\end{array}$ & $\begin{array}{l}1.36 \mathrm{E}-05 \\
8.18 \mathrm{E}-06 \\
1.60 \mathrm{E}-02 \\
1.52 \mathrm{E}-02 \\
5.12 \mathrm{E}-06 \\
3.30 \mathrm{E}-06 \\
9.09 \mathrm{E}-07 \\
1.16 \mathrm{E}-05 \\
2.02 \mathrm{E}-03 \\
2.02 \mathrm{E}-03 \\
9.89 \mathrm{E}-05 \\
3.54 \mathrm{E}-02\end{array}$ & $\begin{array}{l}\text { 1.34E+07 } \\
1.27 \mathrm{E}+07 \\
2.61 \mathrm{E}+07\end{array}$ & $\begin{array}{l}4.76 \mathrm{E}+03 \\
2.87 \mathrm{E}+03 \\
4.8 \mathrm{EE}+05 \\
4.63 \mathrm{E}+05 \\
6.56 \mathrm{E}+00 \\
1.16 \mathrm{E}+03 \\
3.19 \mathrm{E}+02 \\
4.07 \mathrm{E}+03 \\
7.10 \mathrm{E}+05 \\
7.10 \mathrm{E}+05 \\
1.64 \mathrm{E}+04 \\
2.40 \mathrm{E}+06\end{array}$ & $\begin{array}{l}1.03 \mathrm{E}-02 \\
9.75 \mathrm{E}-03\end{array}$ & $\frac{1.65 g+04}{5.85 g+05}$ \\
\hline
\end{tabular}

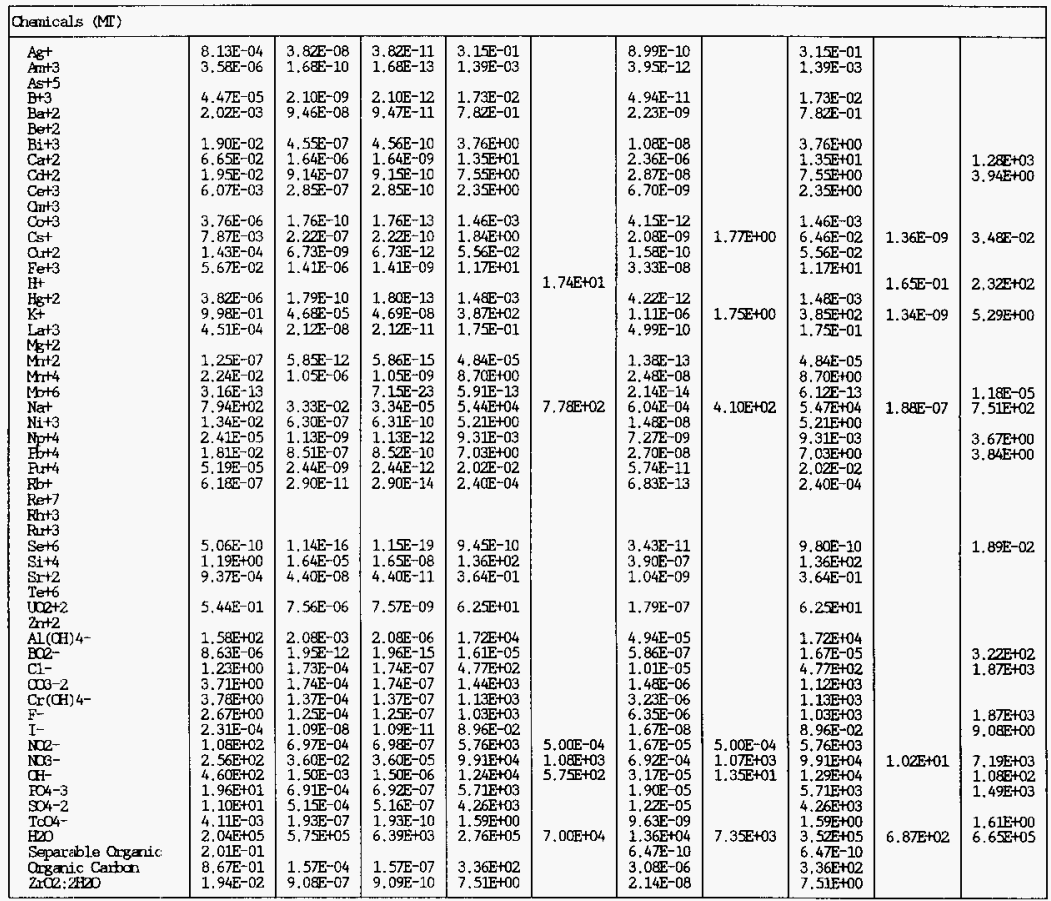




\section{WHC-SD-WM-TI-774 Rev. 0 \\ TWRS PRIVATIZATION PROCESS TECHNICAL BASELINE}

Table E-2 Phase 2 Mass Balance with Revised TWRS Irventory

\begin{tabular}{|c|c|c|c|c|c|c|c|c|c|c|}
\hline SIFFAM NANE & 11 & 12 & 13 & 14 & 15 & 16 & 17 & 18 & 19 & 20 \\
\hline \multicolumn{11}{|l|}{ LTQIII COMENENIS } \\
\hline \multicolumn{11}{|c|}{ Ohmicals Contimed (MT) } \\
\hline 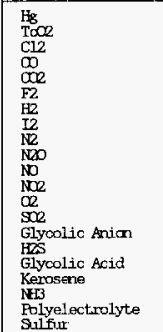 & $\begin{array}{l}7.79 \mathrm{E}-08 \\
2.53 \mathrm{E}+\infty 0\end{array}$ & $\begin{array}{l}1.76 \mathrm{E}-14 \\
2.52 \mathrm{E}-06\end{array}$ & $\begin{array}{l}1.76 \mathrm{E}-17 \\
2.52 \mathrm{E}-09\end{array}$ & $\begin{array}{l}1.46 \mathrm{E}-07 \\
2.08 \mathrm{E}+01\end{array}$ & & $\begin{array}{l}5.29 \mathrm{E}-09 \\
6.73 \mathrm{E}-08\end{array}$ & & $\begin{array}{l}6.94 \mathrm{E}-09 \\
3.3 \mathrm{E}-12 \\
1.51 \mathrm{E}-07 \\
2.08 \mathrm{E}+01\end{array}$ & 2. $36 E+02$ & $\begin{array}{l}2.90 \mathrm{E}-07 \\
6.45 \mathrm{E}-05\end{array}$ \\
\hline
\end{tabular}


WHC-SD-WM-TI-774 Rev, 0

TWRS PRIVATIZATION PROCESS TECHNICAL BASELINE

Table E-2 Phase 2 Mass Balance with Revised TwRS Inventory

\begin{tabular}{|c|c|c|c|c|c|c|c|c|c|c|}
\hline SIREAM NAME & 11 & 12 & 13 & 14 & 15 & 16 & 17 & 18 & 19 & 20 \\
\hline \multicolumn{11}{|l|}{ SOL COMFCNDIS } \\
\hline Total Mass Flow (MT) & $1.79 \mathrm{E}+04$ & & & $2.38 E+02$ & $6.15 E+02$ & & & $8.52 \mathrm{E}+02$ & & $1.60 \mathrm{E}+04$ \\
\hline \multicolumn{11}{|l|}{ Radiaunclides (Ci) } \\
\hline $\begin{array}{l}\mathrm{Am}-241 \\
\mathrm{C}-14 \\
\mathrm{Cs}-137 \\
\mathrm{Ba}-137 \\
\mathrm{Ng}-237 \\
\mathrm{Pu}-230 \\
\mathrm{Pr}-240 \\
\mathrm{Pu}-241 \\
\mathrm{Sr}-90 \\
\mathrm{Y}-90 \\
\mathrm{~T}-99 \\
\text { Total Ouries }\end{array}$ & $\begin{array}{l}6.03 \mathrm{E}+04 \\
2.07 \mathrm{E}+03 \\
5.25 \mathrm{E}+06 \\
4.99 \mathrm{E}+06 \\
6.19 \mathrm{E}+01 \\
2.09 \mathrm{E}+04 \\
6.19 \mathrm{E}+03 \\
6.86 \mathrm{E}+04 \\
4.22 \mathrm{E}+07 \\
4.22 \mathrm{E}+07 \\
8.76 \mathrm{E}+03 \\
9.48 \mathrm{E}+07\end{array}$ & & & $\begin{array}{l}8.03 E+02 \\
2.75 E+01 \\
7.01 E+04 \\
6.66 E+04 \\
8.255-01 \\
2.78 E+02 \\
8.25 E+01 \\
9.14 E+02 \\
5.62 E+05 \\
5.62 E+05 \\
1.17 E+02 \\
1.26 E+06\end{array}$ & & & & $\begin{array}{l}8.03 \mathrm{E}+02 \\
2.75 \mathrm{E}+01 \\
7.01 \mathrm{E}+04 \\
6.66 \mathrm{E}+04 \\
8.25 \mathrm{E}-01 \\
2.78 \mathrm{E}+02 \\
8.25 \mathrm{E}+01 \\
9.14 \mathrm{E}+02 \\
5.62 \mathrm{E}+05 \\
5.62 \mathrm{E}+05 \\
1.17 \mathrm{E}+02 \\
1.26 \mathrm{E}+06\end{array}$ & & $\begin{array}{l}2.35 \mathrm{E}+02 \\
2.35 \mathrm{E}+04 \\
2.23 \mathrm{E}+04 \\
3.48 \mathrm{E}-02 \\
6.06 \mathrm{E}+01 \\
1.69 \mathrm{E}+01 \\
2.10 \mathrm{E}+02 \\
5.36 \mathrm{E}+04 \\
5.36 \mathrm{E}+04 \\
6.95 \mathrm{E}+02 \\
1.54 \mathrm{E}+05\end{array}$ \\
\hline \multicolumn{11}{|l|}{ Chenicals (MI) } \\
\hline 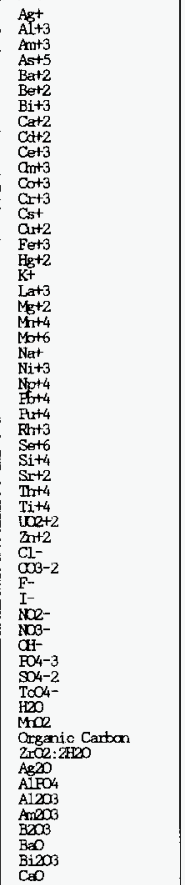 & $\begin{array}{l}5.49 \mathrm{E}-01 \\
1.80 \mathrm{E}+03 \\
1.76 \mathrm{E}-02 \\
\\
2.5 \mathrm{E}+02 \\
1.2 \mathrm{EE}+02 \\
2.34 \mathrm{E}+00 \\
2.32 \mathrm{E}+02 \\
5.64 \mathrm{E}-06 \\
2.78 \mathrm{E}+02 \\
1.74 \mathrm{E}-01 \\
1.10 \mathrm{E}+03 \\
8.70 \mathrm{E}-02 \\
2.69 \mathrm{E}+01 \\
2.10 \mathrm{E}+01 \\
1.10 \mathrm{E}+00 \\
1.74 \mathrm{E}+02 \\
1.61 \mathrm{E}-02 \\
1.25 \mathrm{E}+03 \\
2.00 \mathrm{E}+02 \\
8.78 \mathrm{E}-02 \\
2.62 \mathrm{E}+01 \\
3.65 \mathrm{E}-01 \\
2.93 \mathrm{E}-02 \\
2.72 \mathrm{E}+00 \\
4.68 \mathrm{E}+02 \\
3.5 \mathrm{E}+01 \\
2.49 \mathrm{E}+00 \\
1.55 \mathrm{E}+03 \\
3.42 \mathrm{E}-01 \\
8.78 \mathrm{E}+00 \\
9.12 \mathrm{E}+01 \\
6.71 \mathrm{E}+01 \\
1.02 \mathrm{E}-03 \\
5.88 \mathrm{E}+01 \\
9.722 \mathrm{E}+02 \\
7.42 \mathrm{E}+03 \\
1.75 \mathrm{E}+02 \\
1.03 \mathrm{E}+02 \\
8.53 \mathrm{E}-01 \\
8.19 \mathrm{E}+01 \\
1.17 \mathrm{E}+03\end{array}$ & & & $\begin{array}{l}\text { 7. } 31 \mathrm{E}-03 \\
2.40 \mathrm{E}+01 \\
2.34 \mathrm{E}-04 \\
\\
3.40 \mathrm{E}+00 \\
1.70 \mathrm{E}+00 \\
3.11 \mathrm{E}-02 \\
3.09 \mathrm{E}+00 \\
7.51 \mathrm{E}-08 \\
3.70 \mathrm{E}+00 \\
2.32 \mathrm{E}-03 \\
1.46 \mathrm{E}+01 \\
1.16 \mathrm{E}-03 \\
3.5 \mathrm{E}-01 \\
2.79 \mathrm{E}-01 \\
1.47 \mathrm{E}-02 \\
2.32 \mathrm{E}+00 \\
2.15 \mathrm{E}-04 \\
1.66 \mathrm{E}+01 \\
2.66 \mathrm{E}+00 \\
1.1 \mathrm{E}-03 \\
3.49 \mathrm{E}-01 \\
4.96 \mathrm{E}-03 \\
3.90 \mathrm{E}-04 \\
3.62 \mathrm{E}-02 \\
6.23 \mathrm{E}+00 \\
4.7 \mathrm{E}-01 \\
3.32 \mathrm{E}-02 \\
2.07 \mathrm{E}+01 \\
4.55 \mathrm{E}-03 \\
1.1 \mathrm{E}-01 \\
1.22 \mathrm{E}+00 \\
8.94 \mathrm{E}-01 \\
1.36 \mathrm{E}-05 \\
7.24 \mathrm{E}-01 \\
1.30 \mathrm{E}+01 \\
9.90 \mathrm{E}+01 \\
2.33 \mathrm{E}+00 \\
1.37 \mathrm{E}+00 \\
1.14 \mathrm{E}-02 \\
1.09 \mathrm{E}+00 \\
1.56 \mathrm{E}+01\end{array}$ & 列 & & & $\begin{array}{l}7.31 \mathrm{E}-03 \\
2.40 \mathrm{E}+01 \\
2.34 \mathrm{E}-04 \\
\\
3.40 \mathrm{E}+00 \\
1.70 \mathrm{E}+00 \\
3.11 \mathrm{E}-02 \\
3.09 \mathrm{E}+00 \\
7.51 \mathrm{E}-08 \\
3.70 \mathrm{E}+00 \\
2.32 \mathrm{E}-03 \\
1.46 \mathrm{E}+01 \\
1.16 \mathrm{E}-03 \\
3.58 \mathrm{E}-01 \\
2.79 \mathrm{E}-01 \\
1.47 \mathrm{E}-02 \\
2.32 \mathrm{E}+00 \\
2.15 \mathrm{E}-04 \\
1.66 \mathrm{E}+01 \\
2.66 \mathrm{E}+00 \\
1.17 \mathrm{E}-03 \\
3.49 \mathrm{E}-01 \\
4.86 \mathrm{E}-03 \\
3.90 \mathrm{E}-04 \\
3.62 \mathrm{E}-02 \\
6.23 \mathrm{E}+00 \\
4.7 \mathrm{E}-01 \\
3.32 \mathrm{E}-02 \\
2.07 \mathrm{E}+01 \\
4.5 \mathrm{E}-03 \\
1.17 \mathrm{E}-01 \\
1.22 \mathrm{E}+00 \\
8.94 \mathrm{E}-01 \\
1.36 \mathrm{E}-05 \\
7.84 \mathrm{E}-01 \\
1.30 \mathrm{E}+01 \\
9.90 \mathrm{E}+01 \\
2.33 \mathrm{E}+00 \\
1.37 \mathrm{E}+00 \\
1.14 \mathrm{E}-02 \\
\\
1.09 \mathrm{E}+00 \\
1.56 \mathrm{E}+01 \\
\\
6.43 \mathrm{E}-01 \\
\end{array}$ & & $\begin{array}{l}4.93 \mathrm{E}-05 \\
\\
4.76 \mathrm{E}+00 \\
1.63 \mathrm{E}+02 \\
3.71 \mathrm{E}-03 \\
2.04 \mathrm{E}-14 \\
\\
7.35 \mathrm{E}-01 \\
1.46 \mathrm{E}-02 \\
3.09 \mathrm{E}+02 \\
1.74 \mathrm{E}+03 \\
7.5 \mathrm{Z}-05 \\
7.79 \mathrm{E}+02 \\
3.68 \mathrm{E}-02 \\
3.37 \mathrm{E}-01 \\
6.23 \mathrm{E}+02\end{array}$ \\
\hline
\end{tabular}


WHC-SD-WM-TI-774 Rev. 0

TWRS PRIVATIZATION PROCESS TECHNICAL BASELINE

Table E-2 Phase 2 Mass Balance with Revised TWRS Inventory

\begin{tabular}{|c|c|c|c|c|c|c|c|c|c|c|}
\hline STPEAM NAEE & 11 & 12 & 13 & 14 & 15 & 16 & 17 & 18 & 19 & 20 \\
\hline \multicolumn{11}{|l|}{ SA.ID aMFaENS } \\
\hline \multicolumn{11}{|c|}{ Ohentcals Contimued (M) } \\
\hline 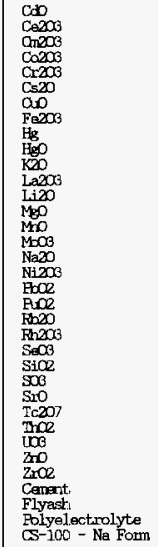 & $1.6 \mathrm{EE}+02$ & & & $1.64 E+00$ & $\begin{array}{l}2.225+00 \\
4.45 E-01 \\
3.11 E+01 \\
5.74 E+02\end{array}$ & & & $\begin{array}{l}2.22 E+00 \\
4.45 E-01 \\
\\
3.11 E+01 \\
1.64 E+00 \\
5.74 E+02\end{array}$ & & 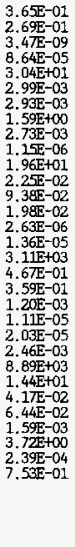 \\
\hline
\end{tabular}

\section{E-11}




\section{WHC-SD-WM-TI-774 Rev. 0 \\ TWRS PRIVATIZATION PROCESS TECHNICAL BASELINE}

Table E-2 Phase 2 Mass Balance with Revised TWRS Inventory

\begin{tabular}{|c|c|c|c|c|c|c|c|c|c|c|}
\hline SIREMM NAME & 21 & 22 & 23 & 24 & 25 & 26 & 27 & 28 & 29 & 30 \\
\hline \multicolumn{11}{|l|}{ LIQUID COMEOENTS } \\
\hline $\begin{array}{l}\text { Total Mass Flow (MT) } \\
\text { Volume (L) } \\
\text { Speciflc Gravity }\end{array}$ & $\begin{array}{l}8.23 E+05 \\
8.23 E+08 \\
1.00 E+00\end{array}$ & $\begin{array}{l}9.96 \mathrm{E}+03 \\
9.96 \mathrm{E}+06 \\
1.00 \mathrm{E}+00\end{array}$ & $\begin{array}{l}4.04 \mathrm{E}+05 \\
2.60 \mathrm{E}+08 \\
1.5 \mathrm{EE}+00\end{array}$ & $\begin{array}{l}3.54 \mathrm{E}+06 \\
3.54 \mathrm{E}+09 \\
1.00 \mathrm{E}+00\end{array}$ & & $\begin{array}{l}\text { 4. } 01 \mathrm{E}+05 \\
\text { 4.01E+08 } \\
1.00 \mathrm{E}+00\end{array}$ & $\begin{array}{l}3.45 \mathrm{E}+06 \\
3.44 \mathrm{E}+09 \\
1.00 \mathrm{E}+00\end{array}$ & $\begin{array}{l}2.56 \mathrm{E}+05 \\
2.52 \mathrm{E}+08 \\
1.02 \mathrm{E}+00\end{array}$ & $\begin{array}{l}1.73 E+04 \\
1.73 E+07 \\
1.00 E+00\end{array}$ & $\begin{array}{l}2.79 \mathrm{E}+05 \\
2.67 \mathrm{E}+08 \\
1.04 \mathrm{E}+00\end{array}$ \\
\hline
\end{tabular}

\begin{tabular}{|c|c|c|c|c|c|c|}
\hline \multicolumn{7}{|c|}{ Radicnuclides (Ci) } \\
\hline $\begin{array}{l}\mathrm{Amr} 241 \\
\mathrm{C}-14 \\
\mathrm{Cs}-137 \\
\mathrm{Ba}-137 \\
\mathrm{Mp}-237 \\
\mathrm{Pu}-239 \\
\mathrm{Pu}-240 \\
\mathrm{Pu}-241 \\
\mathrm{Sr}-90 \\
\mathrm{Y}-90 \\
\mathrm{Tc}-99 \\
\text { Total Curies }\end{array}$ & $\begin{array}{l}1.03 \mathrm{E}-03 \\
6.20 \mathrm{E}-04 \\
1.68 \mathrm{E}-01 \\
1.60 \mathrm{E}-01 \\
5.59 \mathrm{E}-04 \\
2.50 \mathrm{E}-04 \\
6.88 \mathrm{E}-0.05 \\
8.78 \mathrm{E}-04 \\
1.53 \mathrm{E}-01 \\
1.53 \mathrm{E}-01 \\
7.10 \mathrm{E}-03 \\
6.44 \mathrm{E}-01\end{array}$ & $\begin{array}{l}1.03 \mathrm{E}-06 \\
6.20 \mathrm{E}-07 \\
1.68 \mathrm{E}-04 \\
1.60 \mathrm{E}-04 \\
5.60 \mathrm{E}-07 \\
2.51 \mathrm{E}-07 \\
6.89 \mathrm{E}-08 \\
8.79 \mathrm{E}-07 \\
1.53 \mathrm{E}-04 \\
1.53 \mathrm{E}-04 \\
7.10 \mathrm{E}-06 \\
6.4 \mathrm{E}-04\end{array}$ & $\begin{array}{l}4.76 \mathrm{E}+03 \\
2.87 \mathrm{E}+03 \\
7.78 \mathrm{E}+05 \\
7.39 \mathrm{E}+05 \\
2.59 \mathrm{E}+03 \\
1.16 \mathrm{E}+03 \\
3.19 \mathrm{E}+02 \\
4.07 \mathrm{E}+03 \\
7.10 \mathrm{E}+05 \\
7.10 \mathrm{E}+05 \\
3.29 \mathrm{E}+04 \\
2.98 \mathrm{E}+06\end{array}$ & $\begin{array}{l}2.90 \mathrm{E}+03 \\
2.90 \mathrm{E}+05 \\
2.76 \mathrm{E}+05 \\
2.59 \mathrm{E}+03\end{array}$ & $\begin{array}{l}1.61 \mathrm{E}-06 \\
9.68 \mathrm{E}-07 \\
1.21 \mathrm{E}-02 \\
1.15 \mathrm{E}-02 \\
5.61 \mathrm{E}-07 \\
3.91 \mathrm{E}-07 \\
1.08 \mathrm{E}-07 \\
1.37 \mathrm{E}-06 \\
2.39 \mathrm{E}-04 \\
2.39 \mathrm{E}-04 \\
9.09 \mathrm{E}-06 \\
2.41 \mathrm{E}-02\end{array}$ & $\begin{array}{l}2.90 \mathrm{E}+0.5 \\
2.76 \mathrm{E}+05 \\
2.58 \mathrm{E}+03\end{array}$ \\
\hline
\end{tabular}

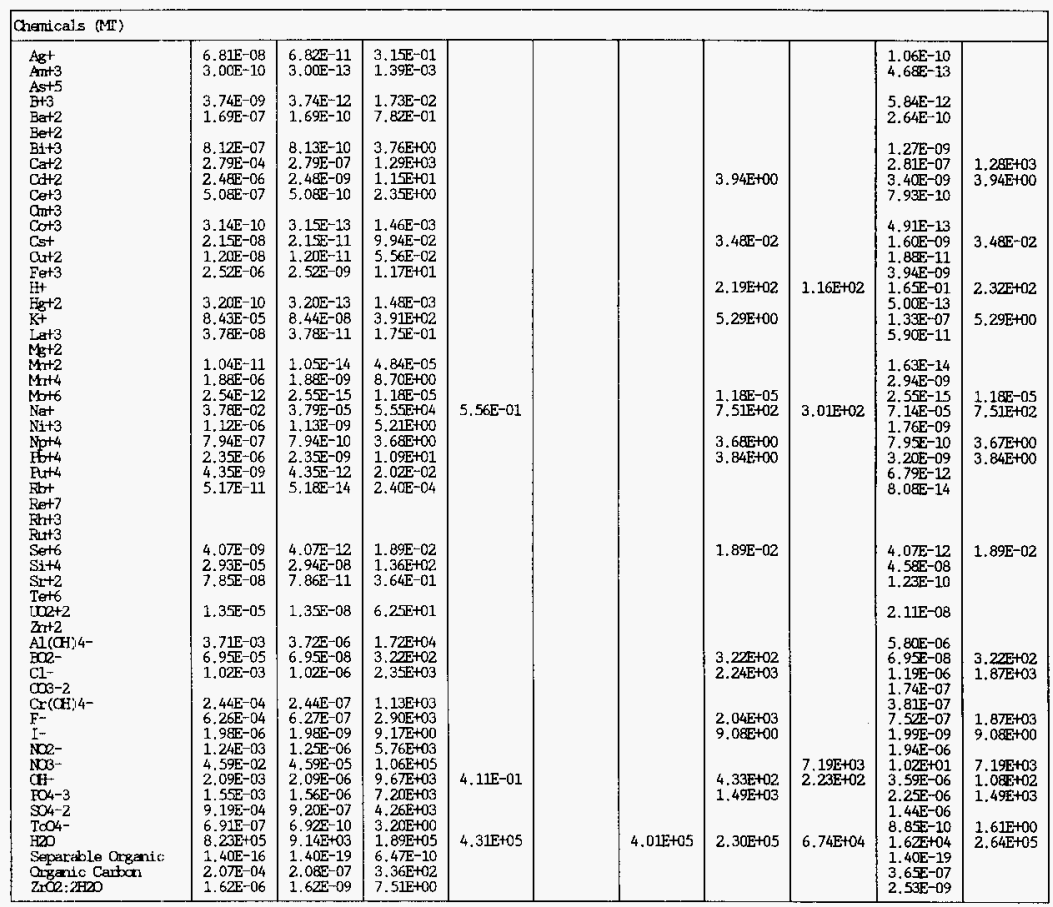


WHC-SD-WM-TI-774 Rev. 0

TWRS PRIVATIZATION PROCESS TECHNICAL BASELINE

Table E-2 Phase 2 Mass Balance with Revised TWRS Irventory

\begin{tabular}{|c|c|c|c|c|c|c|c|c|c|c|}
\hline STREAM NAME & 21 & 22 & 23 & 24 & 25 & 26 & 27 & 28 & 29 & 30 \\
\hline \multicolumn{11}{|l|}{ LIQII CAMRONENIS } \\
\hline \multicolumn{11}{|c|}{ Chendeals Contimied (MT) } \\
\hline 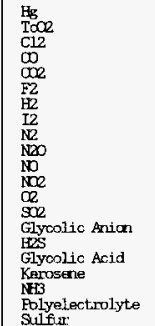 & $\begin{array}{l}3.26 \mathrm{E}-14 \\
4.50 \mathrm{E}-06\end{array}$ & $\begin{array}{l}6.42 \mathrm{E}-17 \\
1.39 \mathrm{E}-14 \\
8.20 \mathrm{E}+02 \\
3.26 \mathrm{E}-17 \\
4.50 \mathrm{E}-09\end{array}$ & $\begin{array}{l}1.51 \mathrm{E}-07 \\
2.08 \mathrm{E}+01\end{array}$ & $\begin{array}{l}2.46 E+06 \\
\text { 6. } 53 \mathrm{E}+05\end{array}$ & & & $\begin{array}{l}2.62 \mathrm{E}-03 \\
1.29 \mathrm{E}+00 \\
2.93 \mathrm{E}+03 \\
\\
2.48 \mathrm{E}+06 \\
1.37 \mathrm{E}+02 \\
8.37 \mathrm{E}+02 \\
7.26 \mathrm{E}+05 \\
2.57 \mathrm{E}+03\end{array}$ & $\begin{array}{l}1.40 \mathrm{E}+05 \\
3.73 \mathrm{E}+04 \\
1.00 \mathrm{E}+01 \\
3.65 \mathrm{E}+03\end{array}$ & $\begin{array}{l}6.50 \mathrm{E}-17 \\
1.39 \mathrm{E}-14 \\
1.06 \mathrm{E}+03 \\
5.02 \mathrm{E}-17 \\
7.03 \mathrm{E}-09\end{array}$ & $\begin{array}{l}2.9005-07 \\
6.452-05\end{array}$ \\
\hline
\end{tabular}


WHC-SD-WM-TI-774 Rev. 0

TWRS PRIVATIZATION PROCESS TECHNICAL BASELINE

Table E-2 Phase 2 Mass Balance with Revised TWRS Inventory

\begin{tabular}{|c|c|c|c|c|c|c|c|c|c|c|}
\hline SIREAM NAME & 21 & 22 & 23 & 24 & 25 & 26 & 27 & 28 & 29 & 30 \\
\hline \multicolumn{11}{|l|}{ 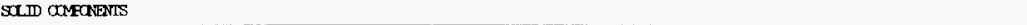 } \\
\hline Total Mass Flon (MI) & & & $1.68 \mathrm{E}+04$ & $2.778+05$ & $3.69 \mathrm{E}+05$ & $7.50 \mathrm{E}+03$ & $8.07 \mathrm{E}+03$ & $5.58 E+03$ & & $8.45 E+03$ \\
\hline \multicolumn{11}{|l|}{ Radicravlides (Ci) } \\
\hline $\begin{array}{l}A m-241 \\
\mathrm{C}-14 \\
\mathrm{Cs}-137 \\
\mathrm{Ba}-137 \\
\mathrm{~N}-237 \\
\mathrm{~F}-239 \\
\mathrm{~F}-240 \\
\mathrm{P}-241 \\
\mathrm{~S}-90 \\
\mathrm{Y}-90 \\
\text { To-99 } \\
\text { Total Curies }\end{array}$ & & & $\begin{array}{l}1.04 \mathrm{E}+03 \\
2.7 \mathrm{E}+01 \\
9.36 \mathrm{E}+04 \\
8.89 \mathrm{E}+04 \\
8.60 \mathrm{E}-01 \\
3.39 \mathrm{E}+02 \\
9.94 \mathrm{E}+01 \\
1.12 \mathrm{E}+03 \\
6.16 \mathrm{E}+05 \\
6.16 \mathrm{E}+05 \\
8.12 \mathrm{E}+02 \\
1.42 \mathrm{E}+06\end{array}$ & & $\begin{array}{l}5.57 \mathrm{E}+03 \\
5.58 \mathrm{E}+05 \\
5.30 \mathrm{E}+05 \\
8.25 \mathrm{E}-01 \\
1.44 \mathrm{E}+03 \\
4.01 \mathrm{E}+02 \\
4.98 \mathrm{E}+03 \\
1.27 \mathrm{E}+06 \\
1.27 \mathrm{E}+06 \\
1.65 \mathrm{E}+04 \\
3.66 \mathrm{E}+06\end{array}$ & $\begin{array}{l}1.13 E+02 \\
1.13 E+04 \\
1.08 E+04 \\
1.68 E-02 \\
2.92 E+01 \\
8.15 E+00 \\
1.01 E+02 \\
2.58 E+04 \\
2.58 E+04 \\
3.35 E+02 \\
7.43 E+04\end{array}$ & $\begin{array}{l}1.22 \mathrm{E}+02 \\
1.22 \mathrm{E}+04 \\
1.16 \mathrm{E}+04 \\
1.80 \mathrm{E}-02 \\
3.14 \mathrm{E}+01 \\
8.77 \mathrm{E}+00 \\
1.09 \mathrm{E}+02 \\
2.7 \mathrm{EE}+04 \\
2.78 \mathrm{E}+04 \\
3.60 \mathrm{E}+02 \\
8.00 \mathrm{E}+04\end{array}$ & & & $\begin{array}{l}1.22 \mathrm{E}+02 \\
1.22 \mathrm{E}+04 \\
1.16 \mathrm{E}+04 \\
1.80 \mathrm{E}-02 \\
3.14 \mathrm{E}+01 \\
8.77 \mathrm{E}+00 \\
1.09 \mathrm{E}+02 \\
2.78 \mathrm{E}+04 \\
2.78 \mathrm{E}+04 \\
3.60 \mathrm{E}+02 \\
8.00 \mathrm{E}+04\end{array}$ \\
\hline \multicolumn{11}{|l|}{ Chenicals (MP) } \\
\hline 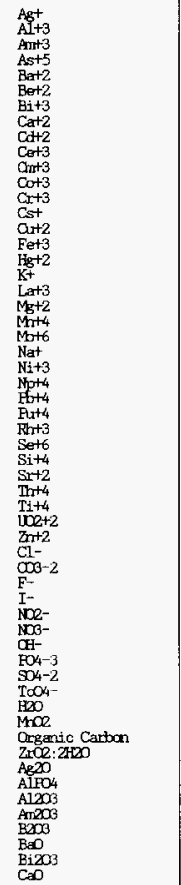 & & & $\begin{array}{l}7.31 \mathrm{E}-03 \\
2.40 \mathrm{E}+01 \\
2.34 \mathrm{E}-04 \\
\\
3.40 \mathrm{E}+00 \\
2.58 \mathrm{E}+02 \\
3.11 \mathrm{E}-02 \\
3.09 \mathrm{E}+00 \\
7.51 \mathrm{E}-08 \\
3.70 \mathrm{E}+00 \\
2.32 \mathrm{E}-03 \\
1.46 \mathrm{E}+01 \\
1.16 \mathrm{E}-03 \\
3.58 \mathrm{E}-01 \\
2.79 \mathrm{E}-01 \\
1.47 \mathrm{E}-02 \\
2.32 \mathrm{E}+00 \\
2.1 \mathrm{E}-04 \\
1.66 \mathrm{E}+01 \\
2.66 \mathrm{E}+00 \\
1.22 \mathrm{E}-03 \\
3.49 \mathrm{E}-01 \\
4.86 \mathrm{E}-03 \\
3.90 \mathrm{E}-04 \\
3.62 \mathrm{E}-02 \\
6.23 \mathrm{E}+00 \\
4.75 \mathrm{E}-01 \\
3.32 \mathrm{E}-02 \\
2.07 \mathrm{E}+01 \\
4.5 \mathrm{E}-03 \\
4.88 \mathrm{E}+00 \\
1.22 \mathrm{E}+00 \\
1.63 \mathrm{E}+02 \\
3.73 \mathrm{E}-03 \\
7.84 \mathrm{E}-01 \\
1.30 \mathrm{E}+01 \\
9.90 \mathrm{E}+01 \\
2.33 \mathrm{E}+00 \\
1.37 \mathrm{E}+00 \\
1.14 \mathrm{E}-02 \\
7.3 \mathrm{E}-01 \\
1.09 \mathrm{E}+00 \\
1.56 \mathrm{E}+01 \\
1.46 \mathrm{E}-02 \\
3.09 \mathrm{E}+02 \\
1.74 \mathrm{E}+03 \\
7.52 \mathrm{E}-05 \\
7.8 \mathrm{E}+02 \\
3.6 \mathrm{EE}-02 \\
3.37 \mathrm{E}-01 \\
6.23 \mathrm{E}+02\end{array}$ & 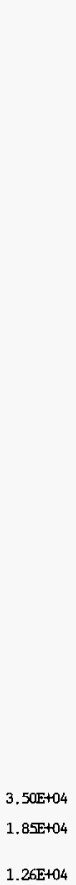 & $\begin{array}{l}1.17 \mathrm{E}-03 \\
\\
\\
1.13 \mathrm{E}+02 \\
9.8 \mathrm{ZE}+02 \\
8.80 \mathrm{E}-02 \\
\\
\\
1.74 \mathrm{E}+01 \\
3.47 \mathrm{E}-01 \\
7.34 \mathrm{E}+03 \\
4.13 \mathrm{E}+04 \\
1.78 \mathrm{E}-09 \\
1.85 \mathrm{E}+04 \\
8.73 \mathrm{E}-01 \\
7.98 \mathrm{E}+00 \\
1.48 \mathrm{E}+04\end{array}$ & $\begin{array}{l}2.38 \mathrm{E}-05 \\
\\
2.30 \mathrm{E}+00 \\
2.00 \mathrm{E}+01 \\
1.79 \mathrm{E}-03 \\
\\
\\
3.54 \mathrm{E}-01 \\
7.04 \mathrm{E}-03 \\
1.49 \mathrm{E}+02 \\
8.38 \mathrm{E}+02 \\
3.6 \mathrm{E}-05 \\
3.75 \mathrm{E}+02 \\
1.77 \mathrm{E}-02 \\
1.52 \mathrm{E}-01 \\
3.00 \mathrm{E}+02\end{array}$ & $\begin{array}{l}2.56 \mathrm{E}-05 \\
\\
\\
2.47 \mathrm{E}+00 \\
2.15 \mathrm{E}+01 \\
1.92 \mathrm{E}-03 \\
\\
\\
3.81 \mathrm{E}-01 \\
7.58 \mathrm{E}-03 \\
1.60 \mathrm{E}+02 \\
9.01 \mathrm{E}+02 \\
3.90 \mathrm{E}-05 \\
4.04 \mathrm{E}+02 \\
1.91 \mathrm{E}-02 \\
1.74 \mathrm{E}-01 \\
3.23 \mathrm{E}+02\end{array}$ & $1.47 \mathrm{E}+03$ & & 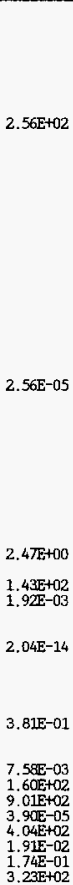 \\
\hline
\end{tabular}




\section{WHC-SD-WM-TI-774 Rev. 0 \\ TWRS PRIVATIZATION PROCESS TECHNICAL BASELINE}

Table E-2 Phase 2 Mass Balance with Revised TWRS Inventory

\begin{tabular}{|c|c|c|c|c|c|c|c|c|c|c|}
\hline SIREAM NAME & 21 & 22. & 23 & 24 & 25 & 26 & 27 & 28 & 29 & 30 \\
\hline \multicolumn{11}{|l|}{ SOLD COMFANENS } \\
\hline \multicolumn{11}{|c|}{ Chenticals Contimued (MT) } \\
\hline 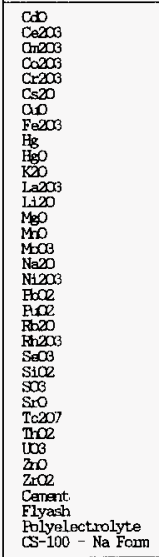 & & & 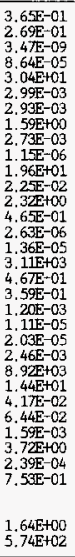 & 2. $10 \mathrm{E}+05$ & 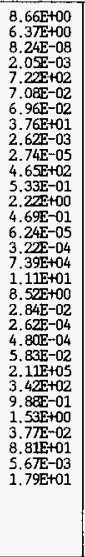 & 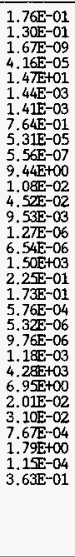 & 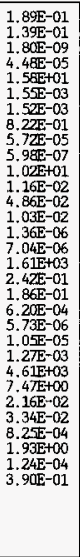 & $\begin{array}{l}1.44 \mathrm{E}+03 \\
1.44 \mathrm{E}+03\end{array}$ & & 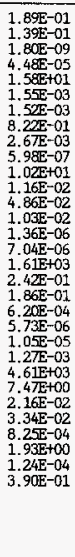 \\
\hline
\end{tabular}




\section{WHC-SD-WM-TI-774 Rev. 0 TWRS PRIVATIZATION PROCESS TECHNICAL BASELINE}

Table E-2 Phase 2 Mass Balance with Revised TWRS Inventory

\begin{tabular}{|c|c|c|c|c|c|c|c|c|c|c|}
\hline SIRFAM NAME & 31 & 32 & 33 & 34 & 35 & 36 & 37 & 38 & 39 & 40 \\
\hline \multicolumn{11}{|l|}{ LTQUIII COMFONENIS } \\
\hline $\begin{array}{l}\text { Total Mass Flow (MT) } \\
\text { Volume (L) } \\
\text { Specific Gravity }\end{array}$ & $\begin{array}{l}3.44 E+06 \\
3.44 E+09 \\
1.00 E+00\end{array}$ & $\begin{array}{l}\text { 1. } 15 E+03 \\
\text { 1.15E+06 } \\
1.00 E+00\end{array}$ & & & $\begin{array}{l}5.86 E+02 \\
5.86 E+05 \\
1.00 E+00\end{array}$ & $\begin{array}{l}2.20 \mathrm{E}+03 \\
2.20 \mathrm{E}+06 \\
1.00 \mathrm{E}+00\end{array}$ & $\begin{array}{l}1.62 E+05 \\
1.62 E+08 \\
1.00 E+00\end{array}$ & $\begin{array}{l}1.79 \mathrm{E}+03 \\
1.79 \mathrm{E}+06 \\
1.00 \mathrm{E}+00\end{array}$ & $\begin{array}{l}4.43 E+04 \\
4.30 \mathrm{E}+07 \\
1.03 \mathrm{E}+00\end{array}$ & $\begin{array}{l}9.7 \mathrm{~J}+03 \\
9.7 \mathrm{~K}+06 \\
1.00 \mathrm{E}+00\end{array}$ \\
\hline \multicolumn{11}{|l|}{ Radianxlides (Ci) } \\
\hline $\begin{array}{l}\mathrm{Am}-241 \\
\mathrm{C}-14 \\
\mathrm{Cs}-13 \mathrm{7} \\
\mathrm{Ba}-137 \\
\mathrm{Nh}-237 \\
\mathrm{Pu}-239 \\
\mathrm{Pu}-240 \\
\mathrm{Au}-241 \\
\mathrm{~S}-90 \\
\mathrm{Y}-90 \\
\text { Tc-99 } \\
\text { Tot-al Orries }\end{array}$ & $\begin{array}{l}1.61 \mathrm{E}-06 \\
2.90 \mathrm{E}+03 \\
1.36 \mathrm{E}-02 \\
1.29 \mathrm{E}-02 \\
1.35 \mathrm{E}-05 \\
3.91 \mathrm{E}-07 \\
1.08 \mathrm{EE}-07 \\
1.37 \mathrm{E}-06 \\
2.39 \mathrm{E}-04 \\
2.39 \mathrm{E}-04 \\
9.15 \mathrm{E}-05 \\
3.48 \mathrm{E}+03\end{array}$ & & & & & $\begin{array}{l}6.07 \mathrm{E}-04 \\
3.66 \mathrm{E}-04 \\
6.69 \mathrm{E}+02 \\
6.35 \mathrm{E}+02 \\
1.63 \mathrm{E}-02 \\
1.48 \mathrm{E}-04 \\
4.07 \mathrm{E}-05 \\
5.19 \mathrm{E}-04 \\
9.06 \mathrm{E}-02 \\
9.06 \mathrm{E}-02 \\
4.37 \mathrm{E}-01 \\
1.30 \mathrm{E}+03\end{array}$ & $\begin{array}{l}4.69 \mathrm{E}-06 \\
2.83 \mathrm{E}-06 \\
5.02 \mathrm{E}-02 \\
4.77 \mathrm{E}-02 \\
1.28 \mathrm{EE}-08 \\
1.14 \mathrm{E}-06 \\
3.1 \mathrm{E}-07 \\
4.01 \mathrm{E}-06 \\
7.00 \mathrm{E}-04 \\
7.00 \mathrm{E}-04 \\
1.63 \mathrm{E}-0 . \\
9.92 \mathrm{E}-02\end{array}$ & $\begin{array}{l}4.70 \mathrm{E}-09 \\
2.83 \mathrm{E}-09 \\
5.02 \mathrm{E}-05 \\
4.77 \mathrm{E}-05 \\
1.28 \mathrm{E}-11 \\
1.15 \mathrm{E}-09 \\
3.15 \mathrm{E}-10 \\
4.01 \mathrm{E}-09 \\
7.01 \mathrm{E}-07 \\
7.01 \mathrm{E}-07 \\
1.63 \mathrm{E}-08 \\
9.93 \mathrm{E}-05\end{array}$ & $\begin{array}{l}1.23 \mathrm{E}+01 \\
7.40 \mathrm{E}+00 \\
1.31 \mathrm{E}+05 \\
1.25 \mathrm{E}+05 \\
3.33 \mathrm{E}-02 \\
2.99 \mathrm{E}+00 \\
8.22 \mathrm{E}-01 \\
1.0 \mathrm{E}+01 \\
1.83 \mathrm{E}+03 \\
1.83 \mathrm{E}+03 \\
4.27 \mathrm{E}+01 \\
2.59 \mathrm{E}+05\end{array}$ & \\
\hline
\end{tabular}

\begin{tabular}{|c|c|c|c|c|c|c|c|}
\hline \multicolumn{8}{|l|}{ Chenicals (MI) } \\
\hline 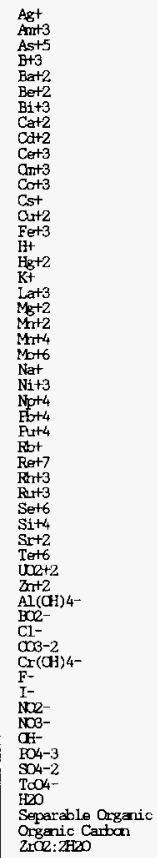 & $\begin{array}{l}1.06 \mathrm{E}-10 \\
4.68 \mathrm{E}-13 \\
5.84 \mathrm{E}-12 \\
2.64 \mathrm{E}-10 \\
1.27 \mathrm{E}-09 \\
2.81 \mathrm{E}-07 \\
2.31 \mathrm{E}-08 \\
7.93 \mathrm{E}-10 \\
4.91 \mathrm{E}-13 \\
1.78 \mathrm{E}-09 \\
1.88 \mathrm{E}-11 \\
3.94 \mathrm{E}-09 \\
1.65 \mathrm{E}-01 \\
5.00 \mathrm{E}-13 \\
1.59 \mathrm{E}-07 \\
5.90 \mathrm{E}-11 \\
1.63 \mathrm{E}-14 \\
2.94 \mathrm{E}-09 \\
6.14 \mathrm{E}-14 \\
7.52 \mathrm{E}-05 \\
1.76 \mathrm{E}-09 \\
1.92 \mathrm{E}-08 \\
2.24 \mathrm{E}-08 \\
6.79 \mathrm{E}-12 \\
8.08 \mathrm{E}-14 \\
\end{array}$ & $\begin{array}{l}\text { 8. } 00 \mathrm{E}-06 \\
1.04 \mathrm{E}-08 \\
1.04 \mathrm{E}-06 \\
5.86 \mathrm{E}+02\end{array}$ & $\begin{array}{l}4.03 \mathrm{E}-08 \\
1.77 \mathrm{E}-10 \\
2.21 \mathrm{E}-09 \\
9.98 \mathrm{E}-08 \\
9.39 \mathrm{E}-07 \\
3.29 \mathrm{E}-06 \\
9.64 \mathrm{E}-07 \\
3.00 \mathrm{E}-07 \\
1.86 \mathrm{E}-10 \\
8.81 \mathrm{E}-05 \\
7.10 \mathrm{E}-09 \\
2.81 \mathrm{E}-06 \\
2.92 \mathrm{E}-05 \\
1.89 \mathrm{E}-10 \\
1.36 \mathrm{E}-04 \\
2.23 \mathrm{E}-08 \\
6.17 \mathrm{E}-12 \\
1.11 \mathrm{E}-06 \\
5.96 \mathrm{E}-02 \\
6.64 \mathrm{E}-07 \\
2.32 \mathrm{E}-05 \\
8.98 \mathrm{E}-07 \\
2.57 \mathrm{E}-09 \\
3.06 \mathrm{E}-11 \\
\end{array}$ & $\begin{array}{l}3.11 \mathrm{E}-10 \\
1.37 \mathrm{E}-12 \\
1.71 \mathrm{E}-11 \\
7.71 \mathrm{E}-10 \\
7.26 \mathrm{E}-09 \\
2.54 \mathrm{E}-08 \\
7.4 \mathrm{EE}-09 \\
2.32 \mathrm{E}-09 \\
1.44 \mathrm{E}-12 \\
3.04 \mathrm{E}-09 \\
5.48 \mathrm{E}-11 \\
2.17 \mathrm{E}-08 \\
1.46 \mathrm{E}-12 \\
3.82 \mathrm{E}-07 \\
1.73 \mathrm{E}-10 \\
4.7 \mathrm{E}-14 \\
8.58 \mathrm{E}-09 \\
4.13 \mathrm{E}-04 \\
5.13 \mathrm{E}-09 \\
1.81 \mathrm{E}-11 \\
6.94 \mathrm{E}-09 \\
1.99 \mathrm{E}-11 \\
2.36 \mathrm{E}-13\end{array}$ & $\begin{array}{l}3.11 \mathrm{E}-13 \\
1.37 \mathrm{E}-15 \\
1.71 \mathrm{E}-14 \\
7.72 \mathrm{E}-13 \\
7.26 \mathrm{E}-12 \\
2.55 \mathrm{E}-11 \\
7.4 \mathrm{E}-12 \\
2.32 \mathrm{E}-12 \\
1.44 \mathrm{E}-15 \\
3.05 \mathrm{E}-12 \\
5.49 \mathrm{E}-14 \\
2.17 \mathrm{E}-11 \\
1.46 \mathrm{E}-15 \\
3.82 \mathrm{E}-10 \\
1.73 \mathrm{E}-13 \\
4.77 \mathrm{E}-17 \\
8.59 \mathrm{E}-12 \\
1.21 \mathrm{E}-22 \\
4.13 \mathrm{E}-07 \\
5.14 \mathrm{E}-12 \\
1.81 \mathrm{E}-14 \\
6.94 \mathrm{E}-12 \\
1.99 \mathrm{E}-14 \\
2.37 \mathrm{E}-16\end{array}$ & $\begin{array}{l}8.13 \mathrm{E}-04 \\
3.58 \mathrm{E}-06 \\
4.47 \mathrm{E}-05 \\
2.02 \mathrm{E}-03 \\
1.90 \mathrm{E}-02 \\
6.6 \mathrm{E}-02 \\
1.95 \mathrm{E}-02 \\
6.07 \mathrm{E}-03 \\
3.76 \mathrm{E}-06 \\
7.96 \mathrm{E}-03 \\
1.43 \mathrm{E}-04 \\
5.67 \mathrm{E}-02 \\
3.82 \mathrm{E}-06 \\
9.9 \mathrm{E}-01 \\
4.51 \mathrm{E}-04 \\
1.2 \mathrm{E}-07 \\
2.24 \mathrm{E}-02 \\
3.16 \mathrm{E}-13 \\
7.94 \mathrm{E}+02 \\
1.34 \mathrm{E}-02 \\
4.73 \mathrm{E}-05 \\
1.81 \mathrm{E}-02 \\
5.20 \mathrm{E}-05 \\
6.18 \mathrm{E}-07 \\
\end{array}$ & 2. $01 E+03$ \\
\hline
\end{tabular}


WHC-SD-WM-TI-774 ReV. 0

\section{TWRS PRIVATIZATION PROCESS TECHNICAL BASELINE}

Table E-2 Thase 2 Mass Balance with Revised TWRS Inventory

\begin{tabular}{|c|c|c|c|c|c|c|c|c|c|c|}
\hline SIREAM NAME & 31 & 32 & 33 & 34 & 35 & 36 & 37 & 38 & 39 & 40 \\
\hline \multicolumn{11}{|l|}{ LIQID COMANENIS } \\
\hline \multicolumn{11}{|c|}{ Chemioals Contiraxed (MI) } \\
\hline 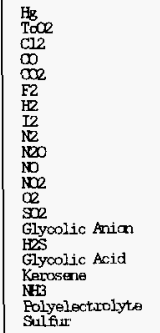 & $\begin{array}{l}1.53 \mathrm{E}-08 \\
6.4 \mathrm{EE}-09 \\
2.04 \mathrm{E}+01 \\
3.9 \mathrm{EE}+03 \\
1.87 \mathrm{E}+02 \\
2.62 \mathrm{E}+06 \\
1.37 \mathrm{E}+00 \\
1.04 \mathrm{E}+01 \\
7.61 \mathrm{E}+05 \\
2.57 \mathrm{E}+02 \\
5.02 \mathrm{E}-17 \\
8.99 \mathrm{E}+00 \\
\\
3.75 \mathrm{E}+01 \\
7.03 \mathrm{E}-09\end{array}$ & 要 & & & & $\begin{array}{l}1.64 E+00 \\
1.25-04\end{array}$ & 9.278-07 & $\begin{array}{l}1.37 \mathrm{E}-18 \\
6.27 \mathrm{E}-10 \\
9.70 \mathrm{E}-10\end{array}$ & $\begin{array}{l}1.64 \mathrm{E}+00 \\
2.53 \mathrm{E}+00\end{array}$ & $\begin{array}{l}2.9 \text { F+103 } \\
4.81 \mathrm{E}+03\end{array}$ \\
\hline
\end{tabular}




\section{WHC-SD-WM-TI-774 Rev. 0 \\ TWRS PRIVATIZATION PROCESS TECHNICAL BASELINE}

Table E-2 Phase 2 Mass Balance with Revised TWRS Inventory

\begin{tabular}{|c|c|c|c|c|c|c|c|c|c|c|}
\hline SIREAM NAME & 31 & 32 & 33 & 34 & 35 & 36 & 37 & 38 & 39 & 40 \\
\hline \multicolumn{11}{|l|}{ \$aL COMAREMS } \\
\hline Total Mass Flow (M) & $1.87 \mathrm{E}-01$ & & $5.74 \mathrm{E}+03$ & & & 4. $222 E+00$ & & & $1.79 \mathrm{E}+04$ & $6.77 E+04$ \\
\hline \multicolumn{11}{|l|}{ Radicauclides (Ci) } \\
\hline $\begin{array}{l}\mathrm{Am}-241 \\
\mathrm{C}-14 \\
\mathrm{Cs}-137 \\
\mathrm{Ba}-137 \\
\mathrm{Mr}-237 \\
\mathrm{RL}-239 \\
\mathrm{Pu}-240 \\
\mathrm{Pu}-241 \\
\mathrm{Sr}-90 \\
\mathrm{Y}-90 \\
\text { Tc-99 } \\
\text { Total Curies }\end{array}$ & $\begin{array}{l}2.81 \mathrm{E}-03 \\
2.82 \mathrm{E}-01 \\
2.68 \mathrm{E}-01 \\
4.17 \mathrm{E}-07 \\
7.27 \mathrm{E}-04 \\
2.03 \mathrm{E}-04 \\
2.52 \mathrm{E}-03 \\
6.43 \mathrm{E}-01 \\
6.43 \mathrm{E}-01 \\
8.34 \mathrm{E}-03 \\
1.85 \mathrm{E}+00\end{array}$ & & & & & $\begin{array}{l}2.99 \mathrm{E}+00 \\
1.02 \mathrm{E}-01 \\
2.62 \mathrm{E}+02 \\
2.49 \mathrm{E}+02 \\
3.07 \mathrm{E}-03 \\
1.04 \mathrm{E}+00 \\
3.07 \mathrm{E}-01 \\
3.40 \mathrm{E}+00 \\
2.09 \mathrm{E}+03 \\
2.09 \mathrm{E}+03 \\
4.67 \mathrm{E}-01 \\
4.71 \mathrm{E}+03\end{array}$ & & & $\begin{array}{l}6.03 E+04 \\
2.07 \mathrm{E}+03 \\
5.2 \mathrm{E}+06 \\
4.99 \mathrm{E}+06 \\
6.19 \mathrm{E}+01 \\
2.09 \mathrm{E}+04 \\
6.19 \mathrm{E}+03 \\
6.86 \mathrm{E}+04 \\
4.22 \mathrm{E}+07 \\
4.22 \mathrm{E}+07 \\
8.76 \mathrm{E}+03 \\
9.4 \mathrm{EE}+07\end{array}$ & \\
\hline
\end{tabular}

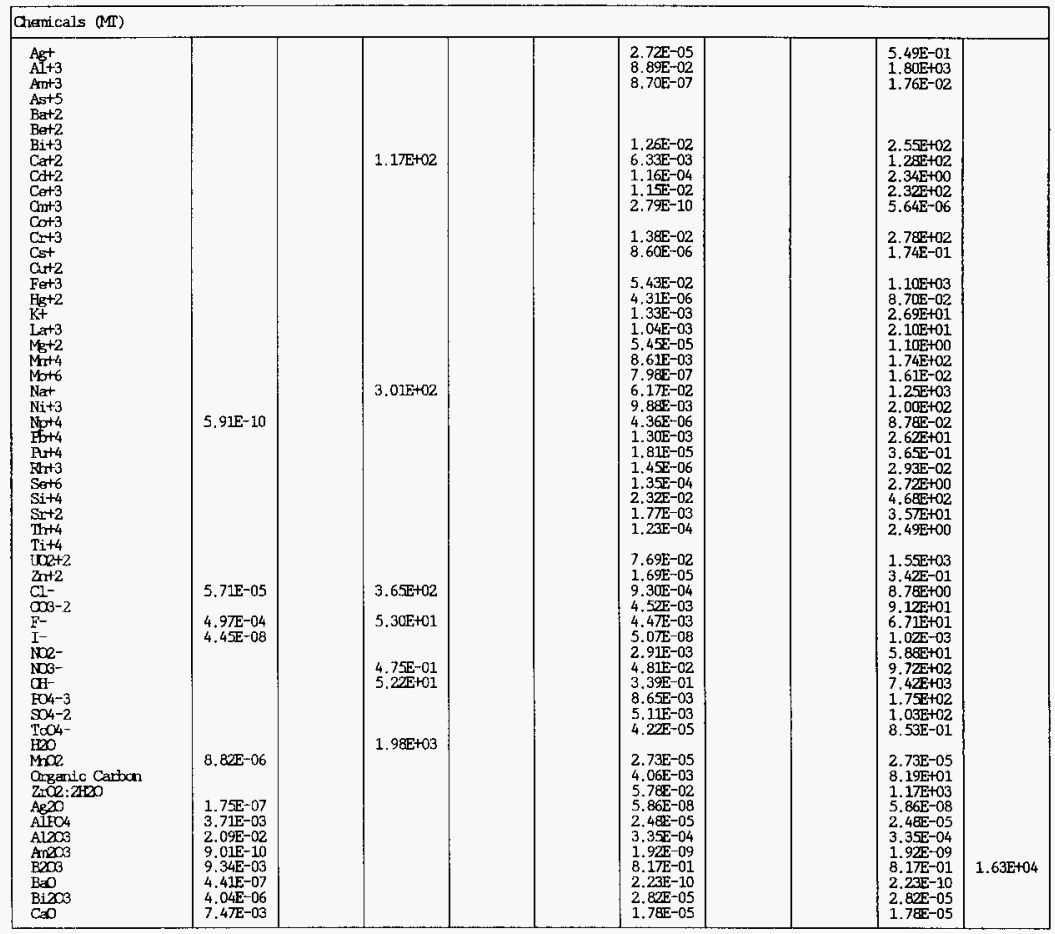




\section{WHC-SD-WM-TI-774 Rev. 0 \\ TWRS PRIVATIZATION PROCESS TECHNICAL BASELINE}

Table E-2 Phase 2 Mass Balance with Revised TWRS Inventory

\begin{tabular}{|c|c|c|c|c|c|c|c|c|c|c|}
\hline STRFAM NANE & 31 & 32 & 33 & 34 & 35 & 36 & 37 & 38 & 39 & 40 \\
\hline \multicolumn{11}{|l|}{ SOCD OMFaveNS } \\
\hline \multicolumn{11}{|c|}{ Chemicals Contirued (MI) } \\
\hline 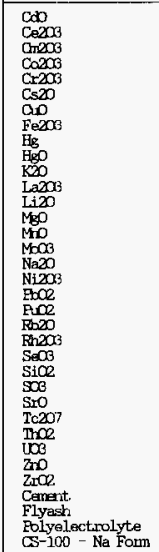 & 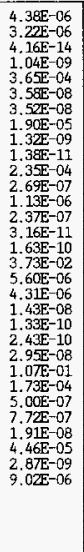 & & $\begin{array}{l}1.44 \bar{E}+03 \\
1.44 \mathrm{E}+03\end{array}$ & & & 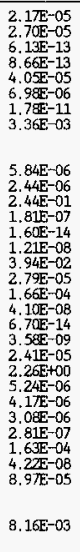 & & & 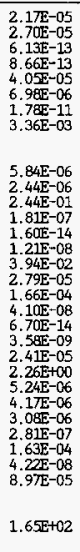 & $\begin{array}{l}6.4 \pi+01 \\
4.92 \mathrm{E}+03 \\
7.83 \mathrm{E}+02\end{array}$ \\
\hline
\end{tabular}




\section{WHC-SD-WM-TI-774 Rev. 0 TWRS PRIVATIZATION PROCESS TECHNICAL BASELINE}

Table E-2 Phase II Mass Balance with Revised TWRS Inventory

\begin{tabular}{|c|c|c|c|c|c|c|c|c|}
\hline SIREAM NAME & 41 & 42 & 43 & 44 & 45 & 46 & 47 & 48 \\
\hline \multicolumn{9}{|l|}{ LTQUD COMOWENIS } \\
\hline $\begin{array}{l}\text { Total Mass Flon (M) } \\
\text { Volime (L) } \\
\text { Specific Gravity }\end{array}$ & $\begin{array}{l}1.9 \mathrm{E}+04 \\
1.96 \mathrm{E}+07 \\
1.00 \mathrm{E}+00\end{array}$ & & $\begin{array}{l}8.64 \mathrm{E}+04 \\
8.64 \mathrm{E}+07 \\
1.00 \mathrm{E}+00\end{array}$ & $\begin{array}{l}2.56 \mathrm{E}+01 \\
2.56 \mathrm{E}+04 \\
1.00 \mathrm{E}+00\end{array}$ & $\begin{array}{l}\text { 5. } 82 E+04 \\
\text { 5. } 82 E+07 \\
1.000+00\end{array}$ & $\begin{array}{l}\text { 8. } 20 \mathrm{E}+03 \\
\text { 8. } 20 \mathrm{E}+06 \\
1.00 \mathrm{E}+00\end{array}$ & $\begin{array}{l}8.22 E-02 \\
8.22 E+01 \\
1.00 E+00\end{array}$ & $\begin{array}{l}\text { 1. } 03 E+06 \\
1.03 E+09 \\
1.00 E+00\end{array}$ \\
\hline
\end{tabular}

\begin{tabular}{|c|c|c|c|c|c|}
\hline \multicolumn{6}{|c|}{ Radianuclides (Ci) } \\
\hline $\begin{array}{l}\mathrm{Am}-241 \\
\mathrm{C}-14 \\
\mathrm{Cs}-137 \\
\mathrm{Ba}-137 \\
\mathrm{~Np}-237 \\
\mathrm{Pu}-239 \\
\mathrm{Pu}-240 \\
\mathrm{Pu}-241 \\
\mathrm{Sr}-90 \\
\mathrm{y}-90 \\
\text { To-99 } \\
\text { Total auries }\end{array}$ & $\begin{array}{l}8.79 E+03 \\
9.12 E+03\end{array}$ & $\begin{array}{l}6.14 \mathrm{E}-04 \\
2.08 \mathrm{E}+03 \\
6.7 \mathrm{E}+02 \\
6.41 \mathrm{E}+02 \\
3.30 \mathrm{E}+02 \\
1.50 \mathrm{E}-04 \\
4.11 \mathrm{E}-05 \\
5.24 \mathrm{E}-04 \\
9.15 \mathrm{E}-02 \\
9.15 \mathrm{E}-02 \\
8.30 \mathrm{E}+03 \\
1.29 \mathrm{E}+04\end{array}$ & $\begin{array}{l}9.89 \mathrm{E}-05 \\
2.64 \mathrm{E}-03 \\
2.73 \mathrm{E}-03\end{array}$ & $\begin{array}{l}6.14 \mathrm{E}-06 \\
2.08 \mathrm{E}+03 \\
6.7 \mathrm{E}+00 \\
6.41 \mathrm{E}+00 \\
2.10 \mathrm{E}-01 \\
1.50 \mathrm{E}-06 \\
4.11 \mathrm{E}-07 \\
5.24 \mathrm{E}-06 \\
9.15 \mathrm{E}-04 \\
9.1 \mathrm{E}-04 \\
5.60 \mathrm{E}+00 \\
2.51 \mathrm{E}+03\end{array}$ & $\begin{array}{l}1.02 \mathrm{E}-03 \\
6.16 \mathrm{E}-04 \\
1.20 \mathrm{E}+00 \\
1.14 \mathrm{E}+00 \\
3.86 \mathrm{E}-04 \\
2.49 \mathrm{E}-04 \\
6.84 \mathrm{E}-05 \\
8.73 \mathrm{E}-04 \\
1.52 \mathrm{E}-01 \\
1.52 \mathrm{E}-01 \\
7.45 \mathrm{E}-03 \\
2.66 \mathrm{E}+00\end{array}$ \\
\hline
\end{tabular}

\begin{tabular}{|c|c|c|c|c|c|c|}
\hline \multicolumn{7}{|l|}{ Chemicals (MIT) } \\
\hline 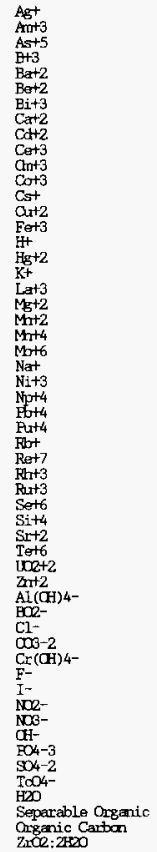 & $\begin{array}{l}1.86 \mathrm{E}+01 \\
1.27 \mathrm{E}+01 \\
8.56 \mathrm{E}-01 \\
1.96 \mathrm{E}+04\end{array}$ & $\begin{array}{l}4.07 \mathrm{E}-08 \\
1.79 \mathrm{E}-10 \\
2.23 \mathrm{E}-09 \\
1.01 \mathrm{E}-07 \\
9.49 \mathrm{E}-07 \\
3.32 \mathrm{E}-06 \\
9.73 \mathrm{E}-07 \\
3.03 \mathrm{E}-07 \\
1.89 \mathrm{E}-10 \\
8.90 \mathrm{E}-05 \\
7.17 \mathrm{E}-09 \\
2.03 \mathrm{E}-06 \\
2.95 \mathrm{E}-05 \\
1.91 \mathrm{E}-10 \\
1.37 \mathrm{E}-04 \\
2.26 \mathrm{E}-08 \\
6.23 \mathrm{E}-12 \\
1.12 \mathrm{E}-06 \\
6.02 \mathrm{E}-02 \\
6.71 \mathrm{E}-07 \\
4.68 \mathrm{E}-01 \\
9.07 \mathrm{E}-07 \\
2.60 \mathrm{E}-09 \\
3.09 \mathrm{E}-11 \\
\\
2.53 \mathrm{E}-14 \\
5.97 \mathrm{E}-05 \\
4.69 \mathrm{E}-08 \\
2.72 \mathrm{E}-05 \\
7.92 \mathrm{E}-03 \\
4.32 \mathrm{E}-10 \\
6.16 \mathrm{E}-05 \\
1.89 \mathrm{E}-04 \\
1.33 \mathrm{E}-04 \\
1.36 \mathrm{E}-08 \\
2.69 \mathrm{E}-03 \\
6.72 \mathrm{E}-02 \\
9.81 \mathrm{E}-04 \\
1.18 \mathrm{E}-03 \\
4.30 \mathrm{E}-05 \\
1.06 \mathrm{E}+04 \\
., 03 \mathrm{E}-05 \\
9.68 \mathrm{E}-07\end{array}$ & $\begin{array}{l}5.61 E-04 \\
2.56 E+01\end{array}$ & $\begin{array}{l}1.11 \mathrm{E}-05 \\
3.20 \mathrm{E}-06 \\
2.57 \mathrm{E}-07 \\
5.82 \mathrm{E}+04\end{array}$ & $\begin{array}{l}4.07 \mathrm{E}-10 \\
1.79 \mathrm{E}-12 \\
2.23 \mathrm{E}-11 \\
1.01 \mathrm{E}-09 \\
9.49 \mathrm{E}-09 \\
3.32 \mathrm{E}-08 \\
9.73 \mathrm{E}-09 \\
3.03 \mathrm{E}-09 \\
1.88 \mathrm{E}-12 \\
8.90 \mathrm{E}-07 \\
7.17 \mathrm{E}-11 \\
2.83 \mathrm{E}-08 \\
3.62 \mathrm{E}-04 \\
1.91 \mathrm{E}-12 \\
1.37 \mathrm{E}-06 \\
2.26 \mathrm{E}-10 \\
6.23 \mathrm{E}-14 \\
1.12 \mathrm{E}-08 \\
6.02 \mathrm{E}-04 \\
6.71 \mathrm{E}-09 \\
2.98 \mathrm{E}-04 \\
9.07 \mathrm{E}-09 \\
2.60 \mathrm{E}-11 \\
3.09 \mathrm{E}-13 \\
\end{array}$ & $\begin{array}{l}6.77 \mathrm{E}-08 \\
2.98 \mathrm{E}-10 \\
3.7 \mathrm{E}-09 \\
1.68 \mathrm{E}-07 \\
8.10 \mathrm{E}-07 \\
1.76 \mathrm{E}-04 \\
2.16 \mathrm{E}-06 \\
5.0 \mathrm{E}-07 \\
3.13 \mathrm{E}-10 \\
1.57 \mathrm{E}-07 \\
1.19 \mathrm{E}-08 \\
2.51 \mathrm{E}-06 \\
3.18 \mathrm{E}-10 \\
8.35 \mathrm{E}-05 \\
3.75 \mathrm{E}-08 \\
1.04 \mathrm{E}-11 \\
1.87 \mathrm{E}-06 \\
1.61 \mathrm{E}-12 \\
4.5 \mathrm{E}-02 \\
1.12 \mathrm{E}-06 \\
5.47 \mathrm{E}-07 \\
2.04 \mathrm{E}-06 \\
4.32 \mathrm{E}-09 \\
5.14 \mathrm{E}-11 \\
\end{array}$ \\
\hline
\end{tabular}


WHC-SD-WM-TI-774 Rev. 0

TWRS PRIVATIZATION PROCESS TECHNICAL BASELINE

Table E-2 Phase II Mass Balance with Revised IWRS Inventory

\begin{tabular}{|c|c|c|c|c|c|c|c|c|}
\hline SIREAM NAME & 41 & 42 & 43 & 44 & 45 & 46 & 47 & 48 \\
\hline \multicolumn{9}{|l|}{ LIQTID COMFONENIS } \\
\hline \multicolumn{9}{|c|}{ Chenicals Cantirued (MT) } \\
\hline 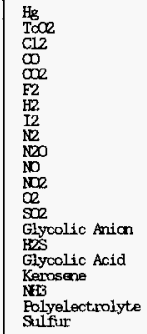 & $9.62 \mathrm{E}-02$ & & $\begin{array}{l}1.83 \mathrm{E}-01 \\
6.88 \mathrm{E}-01 \\
2.00 \mathrm{E}-02 \\
6.41 \mathrm{E}+03 \\
9.30 \mathrm{E}-02 \\
1.26 \mathrm{E}-03 \\
1.35 \mathrm{E}+02 \\
1.72 \mathrm{E}+01 \\
9.12 \mathrm{E}+02 \\
2.68 \mathrm{E}+02 \\
4.23 \mathrm{E}+01 \\
1.66 \mathrm{E}+00 \\
\\
2.71 \mathrm{E}+00 \\
1.27 \mathrm{E}=04\end{array}$ & & $2.88 \mathrm{E}-08$ & $\begin{array}{l}1.25 E-03 \\
4.38 E-04 \\
2.00 E-02 \\
6.41 E+03 \\
9.30 E-02 \\
1.26 E-03 \\
1.35 E+02 \\
1.72 E+01 \\
9.03 E+02 \\
2.59 E+02 \\
3.39 E+01 \\
1.66 E-02 \\
\\
2.71 E+00 \\
1.27 E-06\end{array}$ & $8.22 \mathrm{E}-02$ & $\begin{array}{l}3.98 \mathrm{E}-07 \\
5.0 \mathrm{E}-06\end{array}$ \\
\hline
\end{tabular}




\section{WHC-SD-WM-TI-774 ReV. 0 \\ TWRS PRIVATIZATION PROCESS TECHNICAL BASELINE}

Table E-2 Phase II Mass Balance with Revised IWRS Inventory

\begin{tabular}{|c|c|c|c|c|c|c|c|c|}
\hline SIREAM NAME & 41 & 42 & 43 & 44 & 45 & 46 & 47 & 48 \\
\hline \multicolumn{9}{|l|}{ Sam aMfargms } \\
\hline Total Mass Flon (MI) & $3.39 \mathrm{E}+02$ & $8.17 \mathrm{E}+04$ & $3.43 E+02$ & & & $6.46 \mathrm{E}-08$ & & \\
\hline \multicolumn{9}{|l|}{ Redicauclides (Ct) } \\
\hline $\begin{array}{l}\mathrm{Am}-241 \\
\mathrm{C}-14 \\
\mathrm{Cs}-137 \\
\mathrm{Ba}-137 \\
\mathrm{Mp}-237 \\
\mathrm{Pr}-239 \\
\mathrm{Pu}-240 \\
\mathrm{Pr}-241 \\
\mathrm{Sr}-90 \\
\mathrm{Y}-90 \\
\text { Tc-99 } \\
\text { Total Curles }\end{array}$ & $\begin{array}{l}1.21 \mathrm{E}+02 \\
1.63 \mathrm{E}-03 \\
3.76 \mathrm{E}+04 \\
3.57 \mathrm{E}+04 \\
1.24 \mathrm{E}-01 \\
4.19 \mathrm{E}+01 \\
1.24 \mathrm{E}+01 \\
1.38 \mathrm{E}+02 \\
8.46 \mathrm{E}+04 \\
8.46 \mathrm{E}+04 \\
6.72 \mathrm{E}+02 \\
2.43 \mathrm{E}+05\end{array}$ & $\begin{array}{l}6.03 E+04 \\
1.88 E+07 \\
1.78 E+07 \\
6.19 E+01 \\
2.09 E+04 \\
6.20 E+03 \\
6.86 E+04 \\
4.2 \pi E+07 \\
4.2 \pi E+07 \\
8.80 E+03 \\
1.21 E+08\end{array}$ & $\begin{array}{l}1.24 \mathrm{E}+02 \\
1.03 \mathrm{E}-01 \\
3.79 \mathrm{E}+04 \\
3.60 \mathrm{E}+04 \\
1.27 \mathrm{E}-01 \\
4.29 \mathrm{E}+01 \\
1.27 \mathrm{E}+01 \\
1.41 \mathrm{E}+02 \\
8.67 \mathrm{E}+04 \\
8.67 \mathrm{E}+04 \\
6.73 \mathrm{E}+02 \\
2.48 \mathrm{E}+05\end{array}$ & & & $\begin{array}{l}2.68 \mathrm{E}-08 \\
2.59 \mathrm{E}-10 \\
6.64 \mathrm{E}-06 \\
6.31 \mathrm{E}-06 \\
2.75 \mathrm{E}-11 \\
9.28 \mathrm{E}-09 \\
2.75 \mathrm{E}-09 \\
3.05 \mathrm{E}-08 \\
1.88 \mathrm{E}-05 \\
1.88 \mathrm{E}-05 \\
1.08 \mathrm{E}-07 \\
5.06 \mathrm{E}-05\end{array}$ & & \\
\hline
\end{tabular}

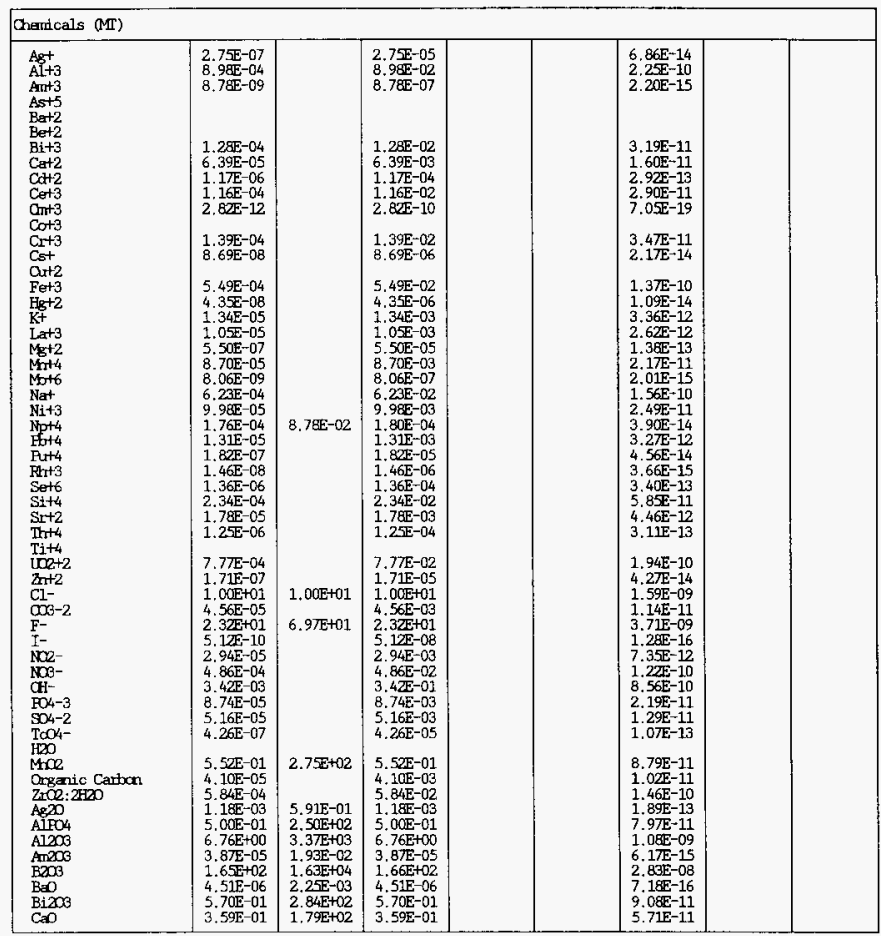


WHC-SD-WM-TI-774 Rev. 0

TWRS PRIVATIZATION PROCESS TECHNICAL BASELINE

Table E-2 Phase II Mass Balance with Revised TWRS Inventory

\begin{tabular}{|c|c|c|c|c|c|c|c|c|}
\hline STREMM NAME & 41 & 42 & 43 & 44 & 45 & 46 & 47 & 48 \\
\hline \multicolumn{9}{|l|}{ SALID COMEAENIS } \\
\hline \multicolumn{9}{|c|}{ Chermicals Contirnied (MT) } \\
\hline 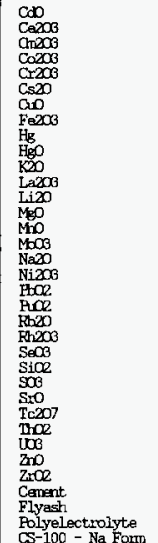 & $\begin{array}{l}4.38 E-01 \\
5.44 E-01 \\
1.24 E-08 \\
1.75 E-08 \\
8.19 E-01 \\
1.41 \mathrm{E}-01 \\
3.60 \mathrm{E}-07 \\
3.28 \mathrm{E}+00 \\
\\
1.18 \mathrm{E}-01 \\
4.93 \mathrm{E}-02 \\
9.86 \mathrm{E}+00 \\
3.66 \mathrm{E}-03 \\
3.23 \mathrm{E}-10 \\
2.44 \mathrm{E}-04 \\
1.35 \mathrm{E}+01 \\
5.63 \mathrm{E}-01 \\
3.36 \mathrm{E}+00 \\
8.29 \mathrm{E}-04 \\
1.3 \mathrm{E}-09 \\
7.23 \mathrm{E}-05 \\
4.86 \mathrm{E}-01 \\
9.34 \mathrm{E}+01 \\
1.06 \mathrm{E}-01 \\
8.42 \mathrm{E}-02 \\
6.22 \mathrm{E}-02 \\
5.68 \mathrm{E}-03 \\
3.30 \mathrm{E}+00 \\
8.5 \mathrm{EE}-04 \\
1.81 \mathrm{E}+00 \\
\\
8.24 \mathrm{E}-0 .\end{array}$ & $\begin{array}{l}2.69 \mathrm{E}+00 \\
2.72+02 \\
6.18 \mathrm{E}-06 \\
5.28 \mathrm{E}-06 \\
4.09 \mathrm{E}+02 \\
2.0 \mathrm{~F}+00 \\
1.79 \mathrm{E}-04 \\
1.63 \mathrm{E}+03 \\
\\
3.57 \mathrm{E}+01 \\
2.46 \mathrm{E}+01 \\
4.92 \mathrm{E}+03 \\
1.82 \mathrm{E}+00 \\
1.61 \mathrm{E}-07 \\
2.4 \mathrm{E}-02 \\
4.09 \mathrm{E}+03 \\
2.81 \mathrm{E}+02 \\
3.0 \mathrm{EF}+01 \\
4.14 \mathrm{E}-01 \\
6.76 \mathrm{E}-07 \\
3.6 \mathrm{E}-02 \\
4.3 \mathrm{E}+00 \\
4.66 \mathrm{E}+04 \\
5.28 \mathrm{E}+01 \\
4.20 \mathrm{E} \\
8.14 \mathrm{E}-01 \\
2.83 \mathrm{E}+00 \\
1.6 \mathrm{FE}+03 \\
4.26 \mathrm{E}-01 \\
9.04 \mathrm{E}+02\end{array}$ & $\begin{array}{l}4.38 \mathrm{E}-01 \\
5.44 \mathrm{E}-01 \\
1.24 \mathrm{E}-08 \\
1.7 \mathrm{E}-08 \\
8.19 \mathrm{E}-01 \\
1.41 \mathrm{E}-01 \\
3.60 \mathrm{E}-07 \\
3.28 \mathrm{E}+00 \\
\\
1.18 \mathrm{E}-01 \\
4.93 \mathrm{E}-02 \\
1.01 \mathrm{E}+01 \\
3.66 \mathrm{E}-03 \\
3.23 \mathrm{E}-10 \\
2.44 \mathrm{E}-04 \\
1.36 \mathrm{E}+01 \\
5.63 \mathrm{E}-01 \\
3.36 \mathrm{E}+00 \\
8.29 \mathrm{E}-04 \\
1.35 \mathrm{E}-09 \\
7.23 \mathrm{E}-05 \\
4.86 \mathrm{E}-01 \\
9.56 \mathrm{E}+01 \\
1.06 \mathrm{E}-01 \\
8.42 \mathrm{E}-02 \\
6.22 \mathrm{E}-02 \\
5.68 \mathrm{E}-03 \\
3.30 \mathrm{E}+00 \\
8.53 \mathrm{E}-04 \\
1.81 \mathrm{E}+00 \\
\\
8.24 \mathrm{E}-03\end{array}$ & & & $\begin{array}{l}6.96 \mathrm{E}-11 \\
8.67 \mathrm{E}-11 \\
1.97 \mathrm{E}-18 \\
2.79 \mathrm{E}-18 \\
1.30 \mathrm{E}-10 \\
2.25 \mathrm{E}-11 \\
5.73 \mathrm{E}-17 \\
5.30 \mathrm{E}-10 \\
\\
1.8 \mathrm{E}-11 \\
7.8 \mathrm{E}-12 \\
2.19 \mathrm{E}-09 \\
5.82 \mathrm{E}-13 \\
5.14 \mathrm{E}-20 \\
3.89 \mathrm{E}-14 \\
2.25 \mathrm{E}-09 \\
8.97 \mathrm{E}-11 \\
5.35 \mathrm{E}-10 \\
1.32 \mathrm{E}-13 \\
2.16 \mathrm{E}-19 \\
1.15 \mathrm{E}-14 \\
7.74 \mathrm{E}-11 \\
2.06 \mathrm{E}-08 \\
1.69 \mathrm{E}-11 \\
1.34 \mathrm{E}-11 \\
9.91 \mathrm{E}-12 \\
9.04 \mathrm{E}-13 \\
5.26 \mathrm{E}-10 \\
1.36 \mathrm{E}-13 \\
2.89 \mathrm{E}-10 \\
2.06 \mathrm{E}-11\end{array}$ & & \\
\hline
\end{tabular}


WHC-SD-WM-TI-774 Rev. 0

TWRS PRIVATIZATION PROCESS TECHNICAL BASELINE

APPENDIX $F$ ASSUMPTIONS AND BASES

F-1 
From: Process Technology

Phone: $\quad 373-2641$ H5-27

Date: $\quad$ May 7,1996

Subject: TWRS PROCESS TECHNICAL BASELINE ASSUMPTIONS AND BASES

To:

J. 0. Honeyman G3-21

$\begin{array}{ll}\text { cC: J. N. Appel } & \text { G3-21 } \\ \text { J. S. Garfield* } & H 5-49 \\ \text { K. A. Gasper* } & \text { G3-21 } \\ \text { M. E. Johnson } & \text { G3-21 } \\ \text { R. A. Kirkbride } & \text { H5-27 RAK } \\ \text { E. J. Kosiancic* } & \text { H5-61 ZJK } \\ \text { R. P. Marsha17* } & \text { H5-61 } \\ \text { G. A. Meyer* } & 52-48 \\ \text { R. J. Murkowski* } & H 5-03 \\ \text { R. M. Orme } & \text { H5-27 fm } \\ \text { R. D. Powell } & \text { G3-21 } \\ \text { 73510 File/LB } & \text { H5-27 } \\ \text { *w/O Attachment } & \end{array}$

This memo transmits the "TWRS Privatization Process Technical Baseline Assumptions and Bases." These Assumptions and Bases are a predecessor to the TWRS Privatization Process Technical Baseline document that will be completed later this year. The Process Technical Baseline, a summary level flowsheet of privatized tank waste processing, will complete High-Level Waste Program milestone T33-96-204 and Low-Level Waste Program milestone T32-96-018. Both are DOE-RL milestones.

A draft of these Assumptions and Bases circulated for comment in January, 1996 (Milestone Control No. T32-96-019). The comments resulted in substantial revisions to the draft. Material from several recently issued studies was also included in these revised and improved assumptions. We are now ready to proceed with preparation of the Process Technical Baseline document.

Further questions or comments on the Attachment should be directed to R. M. Orme $(372-0035)$.

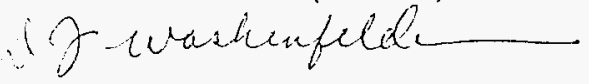

D. J. Washenfelder

Manager

Attachment 


\section{WHC-SD-WM-TI-774 Rev. 0 \\ TWRS PRIVATIZATION PROCESS TECHNICAL BASELINE}

\section{TWRS PRIVATIZATION PROCESS TECHNICAL BASELINE ASSUMPTIONS AND BASES}

\subsection{INTRODUCTION}

In 1995, the United States Department of Energy (USDOE) advised its Hanford contractors to plan for the privatization of certain Tank Waste Remediation System (TWRS) functions (Bader 1995). The privatization strategy is implemented in two phases. Phase I will demonstrate the technical and business viability of using privatized facilities to pretreat and immobilize a limited amount of Hanford tank waste, the treated products returning to USDOE for interim storage and disposal. Phase II shifts more of the TWRS functions (retrieval, in-process storage, sludge pretreatment) into the private sector and builds full-scale treatment facilities to process the balance of the waste.

Responding to the privatization strategy, the Waste Disposal Program identified the need for a TWRS Privatization Process Technical Base 7ine (PTB) (Milestone T32-96-018) to support the Systems Engineering of privatized Hanford waste processing. The intent and scope of the PTB task as defined in the Schedule Activity Planning Form is as follows:

"Revise the TWRS Process Flowsheet" to a summary level technical baseline document. The work will provide the technical bases for privatization to support systems engineering analysis, and will provide an ASPEN model that can be used to support retrieval sequence and blending work. The work will only be performed in sufficient detail to identify $M \& 0$ contractor and private vendor interfaces and support the retrieval sequence work."

The purpose of this letter is to assemble under one cover the Assumptions and Bases for preparation of the PTB.

Our original intention was to produce a TWRS Process Flowsheet-like document. On 1/15/96 we circulated draft Assumptions and Bases (Milestone Control Number T32-96-019) to disposal program managers for discussion and comment. Considering that the TWRS Privatization Request for Proposals (RFP) (DOE 1996) does not obligate private contractors to select previously favored processes, reviewers felt that the Phase I PTB should reflect a level of detail commensurate with the direction found in the RFP.

The RFP, in fact, is silent on separations and immobilization process technology. Even vitrification, the "selected" architecture for high-level waste (HLW) immobilization (DOE 1990), is not fixed because the RFP allows private contractors to propose alternate waste forms. The privatized process envelope is a "black box" producing waste packages that are defined by the RFP in terms of their physical characteristics, minimum waste loading, and maximum

${ }^{1}$ The TWRS Process Flowsheet (Orme 1994, 1995) mentioned above has been the Systems Engineering model for projecting the volume of major products resulting from the processing of tank waste. 
radionuclides. The volume of secondary waste streams is dependent on process selections yet to be made by the private contractors.

Arriving at Assumptions and Bases for Phase I is complicated by the flexibility of the private procurement. There will be two private contractors, each of which can exercise a choice of two options. The lowlevel/high-level option requires private contractors to receive two waste feed streams and return two product streams. The low-level only option requires the receipt of one waste feed stream, and the return of one product stream and three or four intermediate product streams.

Unfortunately, Bader (1995) provides only general guidance for Phase II, and the RFP does not address Phase II at all. We know only the schedule and that Phase II entails low-level and high-level processing of the balance of the waste. Pending further guidance on Phase II, the ASPEN PLUS TWRS Process Flowsheet (Orme 1995a) model, brought up to date with adjusted feed streams and latest process chemistry data, is a reasonable basis for projecting Phase II processing results. There are, incidentally, no plans to issue a second revision of the TWRS Process Flowsheet document. Phase II modeling with the TWRS Process Flowsheet model will be reflected in Rev. 0 of the PIB document,

Phase I Part A is a 20 month period, targeted to end April 30, 1998, for contractors to prepare deliverables, and for USDOE to evaluate and select contractors for Part $B$. The deliverables include a schedule, the equivalent of a conceptual design report, a product qualification plan, a regulatory compliance plan, etc. Phase I Part B allows four years to design and construct, five years for operations, and one year for deactivation. USDOE may exercise options to extend the duration of operations. Some of the key schedule targets (DOE 1996) for Phase I are as follows:

Award none, one, or more Part A design only contracts

September 1, 1996

Complete contractor evaluation and authorize Part B April 30, 1998

Begin proof-of-concept operations

June 1, 2002 follows:

Some of the key scheduie targets (Bader 1995) for Phase II are as

Award contract

Begin LAW operations

Begin HLW operations

Complete processing of LAW

Complete processing of HLW
2005

2011

2013

2021

2028 
As a final note, Systems Engineering is the USDOE-approved approach for selecting and acquiring the waste disposal architecture of TWRS. While Systems Engineering functions and requirements decomposition and supporting documentation for waste processing has progressed to the 4th level (WHC 1996), there are as yet no official decisions (wash sludges vs. dissolve sludges, minimum radionuclide separations vs. extensive radionuclide separations, vitrification vs. some other treatment of LLW) on processing architecture with the exception of HLW vitrification. ${ }^{2}$ It appears that USDOE is using privatization, not only as a contracting strategy, but as a vehicle for expediting architecture decisions under the Systems Engineering umbrella.

${ }^{2}$ As noted above, with the procurement of privatized services, even the vitrification of $\mathrm{HLW}$ is open to alternative architectures. 


\subsection{OBJECTIVES}

We identify under this cover the major flowsheeting Assumptions and Bases that will govern preparation of the TWRS Privatization Process Technical Baseline. The baseline encompasses two flowsheets. The Phase I flowsheet is a high-level flowsheet that projects the volume of major, intermediate and secondary product streams for the RFP-defined scenario without resorting to selection of specific technology. The Phase II flowsheet, which processes all the waste left over from Phase I, is a high-level summary of the TWRS Process Flowsheet .

To date, the customers of the PTB task have expressed a variety of expectations. The process flowsheet format is suitable for meeting some expectations but others are better met by supplemental work such as tank sequence modeling. ${ }^{3}$ The author understands the primary expectations to be:

(1) provide a model for projecting the outcome of privatized TWRS processing,

(2) describe and quantify under one cover the interfaces between the Phase I privatized process envelope and USDOE operations, and

(3) continue support of the M-50-03 annual enhanced sludge washing status report, i.e., project waste volumes to the end of processing using currentiy available information.

We cannot carry the PTB to the same level of detail as our previous flowsheeting efforts because detailed process work is the scope of private contractors; the PTB is not a project definition or process design document. Architecture selections may not be known unti) the private contractors submit their Part A deliverables in December 1997. In the meantime (about one and a half years), we will maintain a PTB at a level of detail that is commensurate with the available procurement guidance. ${ }^{4}$ We expect that the PTB will become more detailed as TWRS Systems Engineering matures in the newTy privatized environment.

${ }^{3}$ For example, our flowsheet format can project total material flow for the two phases of privatization. Minimum processing rates could be inferred from the RFP, but process design (equipment design and equipment sizing) falls within the scope of the private contractor.

${ }^{4}$ Historically, TWRS Process Flowsheet work has proceeded in a somewhat similar environment. We have had to anticipate the results of Systems Engineering studies and decision boards by making tentative architecture selections. 


\subsection{ASSUMPTIONS AND BASES FOR THE PRIVATIZATION PROCESS TECHNICAL BASELINE}

TWRS Technical Integration recently revised the Functions and Requirements (WHC 1996) for the Process Waste function to reflect the new requirements of privatization (Bader 1995). The companion Baseline System Description (Johnson 1996) indicates that the private contractor will evaluate and select suitable architectures for pretreating supernatants and immobilizing LAW, although it should be noted that the January 1996 draft amendment to the Hanford Facility Agreement and Consent Order (Tri-Party Agreement or TPA) still assumes that Hanford will produce a vitrified ILAW.

Key sources either completed or in progress provide DST consolidation recommendations (Powell et a 1.1995$)^{5}$, privatization HLW staging plans (Manuel et al. 1996), privatization LLW staging plans (Certa et al. 1996), and overall tank retrieval sequence recommendations (Penwell et al. 1996). The author of the PTB intends to draw upon these sources when appropriate for establishing the technical baseline feed materials. ${ }^{6}$ The primary vehicle for communicating requirements to private contractors is the TWRS Privatization Request for Proposals (RFP) (DOE 1996). The Assumptions and Bases are derived to a large extent from these sources.

New technical reports addressing important aspects of the process such as settling and thickening of settled sludge are also available. The body of empirical enhanced sludge washing efficiency data grew considerably during 1995, and will continue to expand during 1996. The results of a LLW melter test program are also available. In short, there is a wealth of new information for revising and improving the old technical baseline.

TWRS process knowledge is, to a large extent, empirical. The status of tank waste characterization, the complexity of the chemistry, and the status of commercially available software precludes a rigorous thermodynamic approach to chemical process modeling. The assumptions pertaining to mass balance calculations assembled for this letter are derived from a mixture of laboratory data, engineering approximations, experience, and some intuitive judgement. Improving the flowsheet's calculational methods is a standing objective; readers of this Assumptions and Bases letter and the subsequent PTB are encouraged to challenge assumptions and suggest improvements or alternative methods.

A draft of renegotiated TPA milestones is currently circulating for public comment and should be finalized by April 1996. Major TPA milestones for retrieval (the $M-45-00$ series) remain in effect for privatization, but interim milestones will probably be renegotiated. Sludge immobilization

${ }^{5}$ The current status of the consolidation decision is that DSTs will not be consolidated.

6 Much of the key information in these studies was recently extracted and summarized in the TWRS Disposal Program's periodic submittal of assumptions to the Operational Waste Volume Projection (Honeyman 1996). 
milestones (the M-51-00 series) will be met by privatization plans, assuming that at least one of the private vendors exercises the HLW vitrification option during Phase I. USDOE is still obligated to begin HLW vitrification by December, 2009 if Phase I vendors do not pursue the HLW option. The main effect of renegotiation is the deletion of a number of LLW pretreatment milestones (the $M-50-00$ series), which reappear in the $M-60-00$ series as privatized LAW pretreatment and immobilization milestones. The sludge pretreatment milestones of the M-50-00 series are still in effect.

\subsection{KEY ASSUMPTIONS FOR PHASE I}

The M\&O contractor's role during Phase I is to provide access to process water, potable water and electricity, to prepare and transfer a limited amount of sludges to HLW immobilization, to provide LLW feeds to the private contractors, and to receive back finished products and intermediate products for storage and disposal. The M\&O also receives back secondary wastes that cannot be dispatched through private channels.

Certain private contractor interfaces are excluded from consideration in the PTB because they are either extraneous to the waste disposal process, or because the interface is not with USDOE. Private contractors must, for example, make their own arrangements for non-radioactive/dangerous solid wastes, non-radioactive/non-dangerous solid wastes, and liquid sanitary wastes. Land, deactivated facility and site, roads and rails, and non-routine HLW have no material effect on the process mass balance.

Figures 1 and 2 depict the M\&O/private contractor interfaces for the two contract options: LAW-only processing and LAW/HLW processing. The PTB will track only those interfaces that are pertinent to projecting the volume of products and routine secondary wastes received by the M\&O. Phase I products are defined in general terms because private contractors have yet to select their waste treatment architecture.

\subsubsection{Characterization}

- The Characterization Project's standard inventory task is a work in progress. A best-basis (i.e., standardized tank-by-tank inventory) will not be available to support process baselining.

${ }^{7}$ TPA milestone dates generally are later than those reflected in the official planning documentation. The Washington State Department of Ecology, a cosigner of the Hanford Facility Agreement and Consent Order (Tri-Party Agreement or TPA) fully supports efforts to complete commitments ahead of the TPA schedule. The Assumptions and Bases document is being prepared concurrent with the public comment period for the renegotiated TPA milestones.

Consequently, there may be discrepancies between this Assumptions and Bases document and the final version of TPA. 


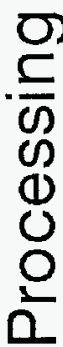

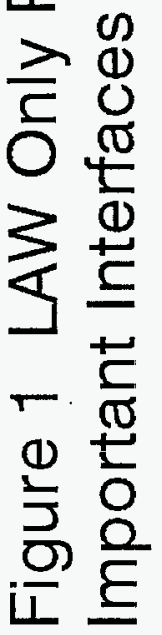

$\sum_{\substack{0 \\ 0}}^{0}$

임

和志

온

ช

ণ̛ ণ

등 늠

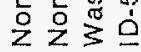

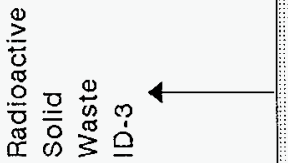

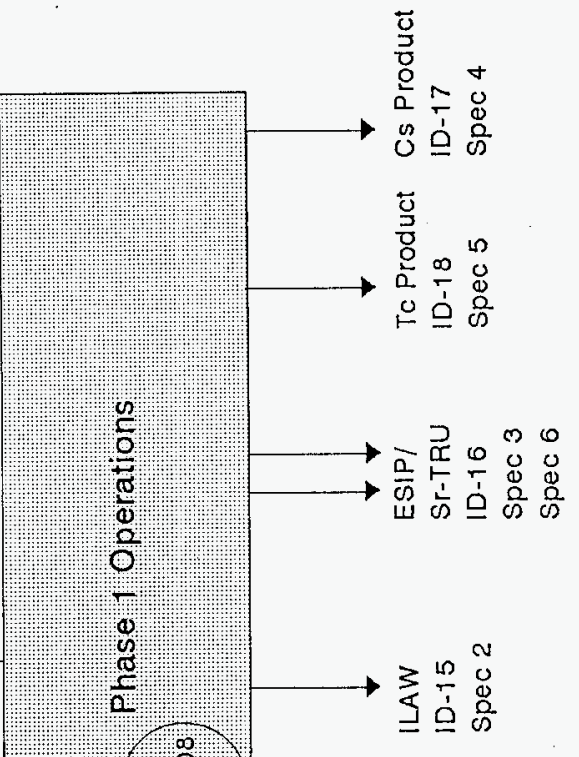




\section{Figure 2 LAW/HLW Processing Important Interfaces}

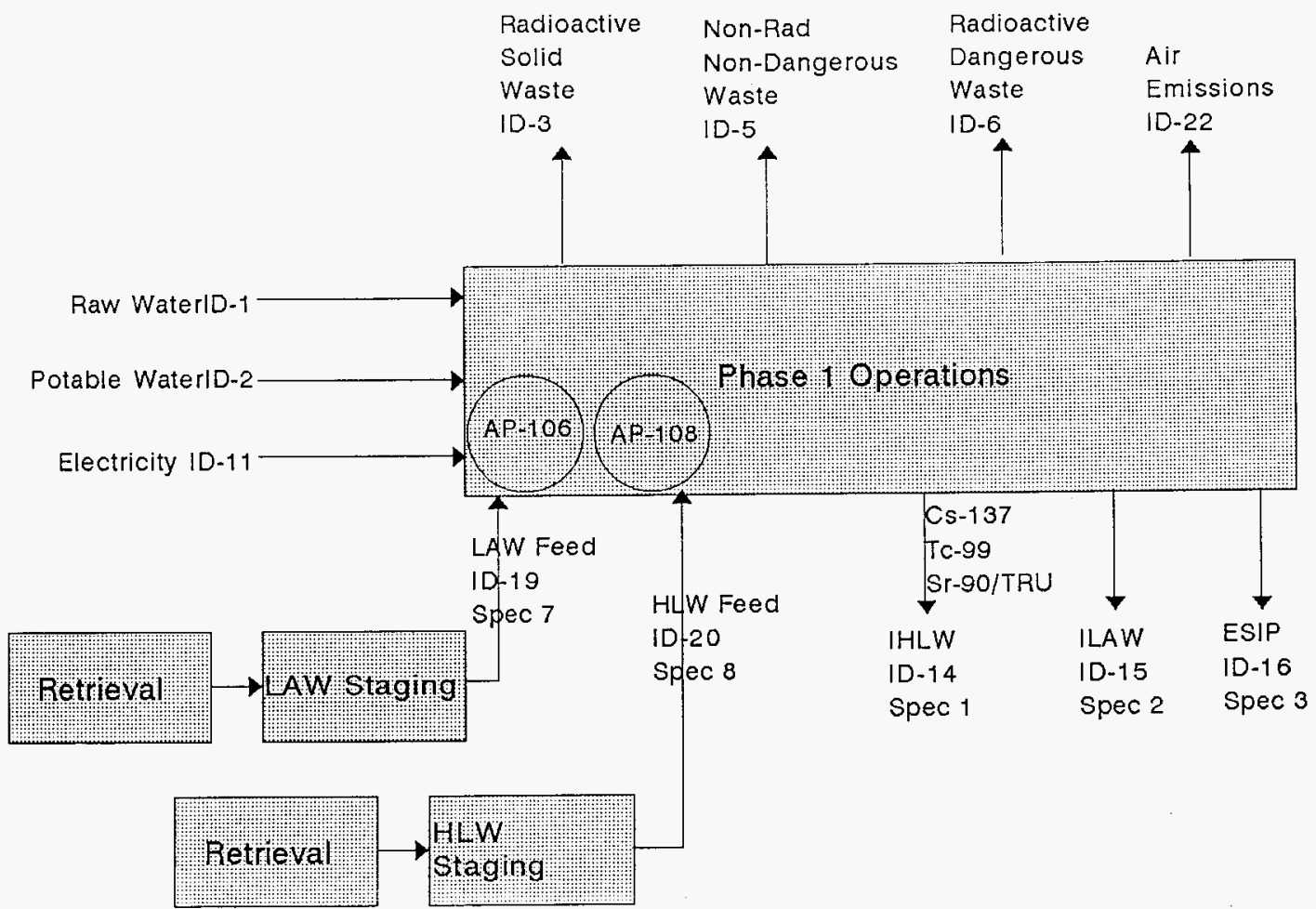




\section{WHC-SD-WM-TI-774 Rev. 0 \\ TWRS PRIVATIZATION PROCESS TECHNICAL BASELINE}

- Phase I feeds are consistent with the feeds as defined in preliminary feed staging plans (Certa et al. 1996 and Manuel et al. 1996). If subsequent revisions of the staging plans become available in time, that information will be included.

- The location of waste is consistent with TWRS Disposal Program's latest waste transfer input to the periodic Operational Waste Volume Projection (Honeyman 1996). Supernate composition and inventory are consistent with Shelton (1996).

- Private contractor intermediate waste returns added to one of three global inventories minus the feed to Phase I constitutes the feed to Phase II. (See Section 3.2.1 for the details pertaining to Phase II feed).

\subsubsection{Retrieve Waste}

- The M\&O contractor will retrieve the full minimum amount of Envelope $A, B$, and $C$ in turn into intermediate feed staging tanks before providing additional orders. The combined amount of Envelope A, B, and C will not exceed 5,100 MT of sodium per contractor, and we assume that each contractor processes the maximum amount of feed. The range of feed from each envelope is as follows:

$$
\begin{array}{lr}
\text { Envelope A } & 2,600-4,900 \text { MT of waste sodium } \\
\text { Envelope B } & 100-1,000 \text { MT of waste sodium } \\
\text { Envelope C } & 100-2,400 \text { MT of waste sodium }
\end{array}
$$

- The amount of envelope D may range from 245-465 MT of waste oxides per contractor excluding sodium and silicon. The flowsheet will process the retrievable amount of DST sludge identified by Manuel et al. 1996, but that may be insufficient to reach the maximum.

- DST liquids and solids for Phase I will be retrieved to the extent shown in the feed staging plans. Solids will be transferred with mixer pump/transfer pump systems.

The total feed to Phase 1 based on the feed staging plans is summarized in Attachment 1 .

\subsubsection{Transfer Waste}

- Waste transfers are within the existing and future underground piping system.

- During retrieval and transfer, highly concentrated liquors are diluted to $1.4 \mathrm{spg}$, the maximum spg allowed without envoking a gas accumulation analysis.

- The PTB will evaluate the potential for solids precipitation during the dilution of concentrated liquors. 


\section{WHC-SD-WM-TI-774 Rev. 0 \\ TWRS PRIVATIZATION PROCESS TECHNICAL BASELINE .}

\subsubsection{Store In-Process Waste}

- AP-102 and AP-104 are set aside for the tank farm operator to prepare and stage retrieved liquids to the private contractors tanks.

- LAW feed is provided to AP-106 and A-108 which have been designated as the Contractor waste feed tanks. The M\&O will transfer no more than 5 vol\% solids to these feeds.

- HLW feed exists in AZ-101 (available in May 1998), AZ-102 (available in May 2001) and AY-102 (combined $A Y-102$ and $C-106$ solids, available in June 2004)) as defined in Honeyman (1996). HLW feed is provided by pipeline to a point of connection in the vicinity of the AP tank farm, but received and stored in Contractor provided facilities.

- A fifth AP tank is set aside for receiving the Entrained Solids intermediate product from the contractors. We assume that the contractors consolidate TRU/Sr intermediate product, if there is one, with Entrained Solids.

- Private contractors are not required to provide evaporator capability for managing waste volume. Therefore, the M\&D contractor will extend operations of 242-A to at least 2011 to manage waste volume and, if necessary, control the concentration of feed to private contractors. (The previous TWRS baseline provided evaporation through the pretreatment facility beginning in 2004).

\subsubsection{Pretreat LAW}

- The transfer schedule for supernatants to the contractor is in Honeyman (1996), unless superseded by the revision of Certa et al. (1996).

- The RFP-defined separations on LAW feeds result in Entrained Solids, Sr-TRU, Tc, and Cs intermediate product streams. It is a contractor responsibility to evaluate and select the separations technology. At this point in time, we can only say that the intermediate product streams are within the specifications defined by the RFP.

Specification 10 limits the impact that intermediate product streams may have on IHLW by placing ceilings on the amount of total oxide equivalents in a11 of the intermediate product streams and the amount of sodium in specific intermediate product streams.

- Per metric ton of $\mathrm{Na}$ in the LAW feed, contractors may add no more than 100 grams in total of the following: fluorine and chlorine, and the oxide equivalent of sulfur, phosphorus and chromium. 


\section{WHC-SD-WM-TI-774 ReV. 0 \\ TWRS PRIVATIZATION PROCESS TECHNICAL BASELINE}

- Given that the total $\mathrm{Na}$ in LAW feed is 10,200 MT, Specification 10 allows private contractors to add/precipitate no more than 102 MT of oxide equivalent (excluding $\mathrm{Si}$ and $\mathrm{Na}$ ) in the four intermediate waste products..

\subsubsection{Entrained Solids Intermediate Product (ESIP)}

The contractors are allowed to return Entrained Solids Intermediate Product, and we assume that they return this stream. Entrained Solids has reference to the carrier liquid and solid particles, i.e., the slurry returned by the Contractor. An LAW-only contractor is allowed to combine Entrained Solids with the Strontium and Transuranics product, and we assume that this is done.

Entrained Solids has the potential to be a large volume stream if the M\&O contractor takes advantage of the 5 vol\% solids allowed in the feed stream. With Entrained Solids required to be $20-30$ vol\% solids, Entrained Solids volume could be as high as $25 \%$ of the LAW feed to the contractor. We expect that the LAW will contain much less than the 5 vol\% solids that is allowed.

- Entrained Solids contain no more than 5\% of the $\mathrm{CS}_{\mathrm{S}} 137$ in the LAW feed (Specification 3 ).

- Entrained Solids contain no more than 5\% of the Tc-99 in the LAW feed (Specification 3).

- Entrained Solids contain no more than 60 grams $\mathrm{Na}$ per $\mathrm{kg}$ of insoluble solids (Specification 10).

\subsubsection{Strontium and Transuranic Intermediate Product (STIP)}

LAW-oniy contractors are allowed to return a strontium and transuranic intermediate product which may be mixed with Entrained Solids. We assume that contractors combine STIP with ESIP and the assumptions are the same as for the Entrained Solids (Specification 6).

\subsubsection{Technetium Intermediate Product (TIP)}

LAW-only contractors are allowed to return a TC intermediate product stream. TIP is returned as a solution or slurry. TIP is not returned to USDOE until the end of Phase I processing.

- TIP contains no more than $0.0015 \mathrm{Ci}$ per liter of gamma emitting radionuclides with energies greater than $0.4 \mathrm{MeV}$ (Specification 5).

${ }^{8}$ In the context of this RFP and this TPB, vol\% is understood to be the settled volume fraction, not the liquid displacement. 
- TIP contains no more than $10 \mathrm{~kg} \mathrm{Na}$ per metric ton of $\mathrm{Na}$ in the LAW feed. Since LAW-only contractors process 10,200 MT of Na, TIP may contain up to $102 \mathrm{MT} \mathrm{Na} \mathrm{(Specification} \mathrm{10).}$

\subsubsection{Cesium Intermediate Product (CIP)}

LAW-only contractors are required to return a Cs intermediate product streanl. Cs intermediate product is a right circular cylinder with external dimensions $33 \mathrm{~cm}$ in diameter and $137 \mathrm{~cm}$ high containing a dry, free flowing material.

- CIP contains no more than $1 \%$ of the TC-99 in the LAW feed (Specification 4).

- The radiolytic heat of any container cannot exceed $1.5 \mathrm{~kW}$ (Specification 4).

- CIP contains no more than $10 \mathrm{~kg} \mathrm{Na}$ per metric ton of $\mathrm{Na}$ in the LAW feed. Since LAW-only contractors process 10,200 MT of Na, CIP may contain up to 102 MT Na (Specification 10).

\subsubsection{Pretreated LAW}

- The amount of Sr-90, Tc-99, and Cs-137 (see Section 3.1.6) allowed in ILAW is assumed to satisfy NRC's requirement to remove key radionuclides to the maximum extent that is technically and economically practical.

- The pretreated waste is capable of being incorporated in a solid physical form at a concentration that does not exceed the applicable concentration limits for Class C LLW as set out in 10 CFR 61 .

\subsubsection{Immobilize LAW}

A Systems Engineering study (Higley 1995) completed during 1995 evaluated the existing data on cement grouts, containerized glass, glass-insulfur, and polyethylene (organic binder) waste forms against systems engineering measures and the U. S. Nuclear Regulatory Commission waste form technical position. Higley's evaluation stopped short of recommending a waste form for ILAW, nor did it de-recommend the glass cullet-in-sulfur waste form that has previously been the TWRS Process Flowsheet baseline.

We will likewise make no assumption about the ILAW form. However, considering the TPA's stated preference for ILAW glass and the time line for Phase I, it's not unreasonable to assume that private contractors will opt for glass in the RFP specified rectangular packages.

- Direction from USDOE (Brown 1996) puts the packaged volume at $182.8 \mathrm{~cm}^{3}$ per gram mole of Envelope $B$ sodium $\left(7.95 \mathrm{~m}^{3}\right.$ per MT of sodium), and $73.1 \mathrm{~cm}^{3}$ per gram mole of Envelope $A / C$ sodium $(3.18$ $\mathrm{m}^{3}$ per MT sodium). The maximum volume of packaged ILAW from Phase 


\section{TWRS PRIVATIZATION PROCESS TECHNICAL BASELINE}

I allowed by the REP is $250 \mathrm{~cm}^{3}$ per gram mole of Envelope $B$ sodium, and $100 \mathrm{~cm}^{3}$ per gram mole of Envelope $A$ or $C$ sodium.

- The package count is flexible because the RFP allows $+/-0.2 \mathrm{~m}$ to the nominal package dimensions of $1.8 \mathrm{~m} \times 1.2 \mathrm{~m} \times 1.2 \mathrm{~m}$ standard package. The minimum size package $1.6 \mathrm{~m} \times 1.0 \mathrm{~m} \times 1.0 \mathrm{~m}$ and the maximum size is $2.0 \mathrm{~m} \times 1.4 \mathrm{~m} \times 1.4 \mathrm{~m}$. The range of package volume is considerable: $1.6 \mathrm{~m}^{3}$ to $3.92 \mathrm{~m}^{3}$. The standard package is 2.59 $\mathrm{m}^{3}$.

- Each package of ILAW shall satisfy the criteria for classification as a Class $C$ waste as defined in 10 CFR 61.55 . (Class $B$ or $A$ is also acceptable). These criteria define suitability for nearsurface disposal. The classification protocol allows the generator to average radionuclide concentration over the volume of the waste. The Branch Technical Position on Concentration Averaging and Encapsulation dated January 1995 clarifjes that classification of solidified liquids is based on the volume or weight of the solidified mass, rather than the volume of the liquid, or the volume of the container.

- The running average concentration in ILAW (total curies divided by total ILAW volume) shall not exceed the following limits for selected radionuclides:

$$
\begin{aligned}
& \mathrm{Sr}-90<20 \mathrm{ci} / \mathrm{m}^{3} \\
& \mathrm{~T} \mathrm{c}-99<0.3 \mathrm{Ci} / \mathrm{m}^{3} \\
& \mathrm{Cs}-137<3 \mathrm{Ci} / \mathrm{m}^{3}
\end{aligned}
$$

- Waste constituents not immobilized in the ILAW form must be accounted for in the intermediate and secondary waste streams. The disposition of water, for example, will depend on the selection of waste form.

- Hot operations begin June, 2002 for Phase I and 2011 for Phase II.

\subsubsection{LLW Disposal}

- To ensure compatibility with transport, interim storage and disposal facilities, ILAW packages shall not exceed $10 \mathrm{MT}$.

- To ensure compatibility, dose rate on the external surface shall not exceed $1 \mathrm{Rem} / \mathrm{hr}$, and surface contamination shall not exceed $367 \mathrm{~Bq} / \mathrm{m}^{2}$ for alpha and $3,670 \mathrm{~Bq} / \mathrm{m}^{2}$ for beta-gamma.

- ILAW packages will be placed in interim storage awaiting placement in a near-surface disposal facility.

- ILAW packages will be placed in an onsite near-surface disposal system that will allow retrieval for up to 50 years from the time of emplacement. 
- Disposal is managed, pursuant to the Atomic Energy Act, so that safety requirements comparable to the performance objectives set out in 10 CFR 61 are satisfied. The performance of ILAW packages is a private contractor responsibility.

\subsubsection{Pretreat HLW}

- As a result of in-tank demonstrations and consolidation actions, ready-to-transfer water-washed solids exist in AZ-101, AZ-102 and $A Y-102$. DOE may elect to do caustic leaching on HLW if it results in a smaller volume of IHLW for the waste form selected by the private contractor. The PTB will describe both the water washed and caustic leached feed to the private contractors. Based on the HLW Staging Plan (Manuel et a1. 1996), caustic leaching does not reduce borosilicate glass production from Phase I because the limiting component in these solids is iron.

\subsubsection{Immobilize High-Level Waste}

- The transfer schedule for washed solids is in Honeyman (1996), unless superseded by a new revision of the HLW staging plan (Manuel et a1. 1996).

- The RFP is not specific about waste form. USDOE will consider alternatives to borosilicate glass, provided the Contractor can provide adequate documentation. Consequently, the PTB is limited to projecting maximum IHLW volume on the basis of equivalent waste oxides in the feed.

- In the IHLW context, waste oxides has reference to the oxide equivalent of the HLW feed excluding sodium and silicon, and also excluding materials originating from LAW processing.

- The Contractor may produce no more than $1.54 \mathrm{~m}^{3}$ of IHLW per metric ton of waste oxides. This limit is equivalent to $25 \mathrm{wt} \%$ waste oxide loading in borosilicate glass.

- During Phase I, the HLW package count may be based on one or more of the following: Defense Waste Processing Facility canister $(0.62$ $\mathrm{m}^{3}$ ), West Valley Demonstration Project canister $\left(0.8 \mathrm{~m}^{3}\right)$, or a contractor proposed canister that requires USDOE approval during Part $A$. The Office of Civilian Radioactive Waste Management recently agreed to the technical acceptability of a $4.5 \mathrm{~m}$ ( $15 \mathrm{ft}$ ) tall canister (1.17 $\mathrm{m}^{3}$ ) (Milner 1996). The parenthetica) volume is the net waste volume in the package.

- Hot operations begin June, 2002 for Phase I and 2013 for Phase II. Phase I satisfies the TPA commitment to begin HLW vitrification by 2009. 


\section{WHC-SD-WM-TI-774 Rev. 0 \\ TWRS PRIVATIZATION PROCESS TECHNICAL BASELINE}

\subsubsection{Store High-Leve1 Waste}

- Interim storage of vitrified HLW canisters uses two vaults in the existing Canister Storage Building (Calmus 1996). Standard canisters are stacked three deep in 220 storage tubes. The CSB can handle up to 1320 standard canisters. Transfer of HLW casks to the geological repository is assumed to begin in 2035 after HLW vitrification is completed.

- Cesium intermediate product cans are likewise stored in the Canister Storage Building if the private contractors do not vitrify HLW.

\subsubsection{Radioactive Solid Wastes}

USDOE will accept an unspecified volume of radioactive solid wastes that comply with Hanford Site Solid Waste Acceptance Criteria (WHC-EP-0063). The volume could differ significantly between contractors depending on their process. For example, vitrification of LAW may generate a secondary waste to contain volatile $\mathrm{Cl}$ an $\mathrm{F}$, where an alternate ILAW form may incorporate those constituents. One contractor may generate spent ion exchange resin, where the other generates no spent resin. It is the contractors' responsibility to estimate the nature and volume of waste that their respective facilities will generate.

\subsubsection{Non-Radioactive, Non-Dangerous Liquid Effluents}

USDOE will accept up to $300,000 \mathrm{~m}^{3} / \mathrm{yr}$ of treated effluents from each contractor for disposal at the Treated Effluent Disposal Facility (TEDF). The effluents must meet the requirements of the TEDF Interface Control Document (WHC-SD-W049H-ICD-001) and the State Waste Discharge Permit. The contractors' treated effluent volume depends entirely on water usage patterns within their respective plants.

\subsubsection{Radioactive, Dangerous Liquids}

The volume and composition of the contractors' untreated effluent depends on the flowsheet within their respective plants. Subject to the conditions outlined below, USDOE will accept up to $100,000 \mathrm{~m}^{3} / \mathrm{yr}$ of radioactive, dangerous 1 iquid effluents from each contractor for treatment through the Liquid Effluent Retention Facility (LERF)/Effluent Treatment Facility (ETF). LERF provides up to $50,000 \mathrm{~m}^{3}(13,000,000 \mathrm{gal})$ of surge capacity between the contractors and ETF. Eștimating that Phase I contractors could generate a total of 10,000 to $20,000 \mathrm{~m}^{3} / \mathrm{yr}$ and assuming that liquids transferred to LERF must be treated at ETF within a year, an annual campaign at ETF appears appropriate for treating Phase I effluents.

Acceptance of waste (McDonald 1994) at ETF is contingent on three mandatory regulatory criteria. Contractors have to characterize their effluents per an approved analysis plan so the waste can be designated. ETF can accept only the waste codes 1 isted in the Delisting Petition and the RCRA Part $B$ Permit. The absorbed radiation dose to a hypothetical individual at 


\section{WHC-SD-WM-TI-774 ReV. 0 \\ TWRS PRIVATIZATION PROCESS TECHNICAL BASELINE}

the site boundary may not exceed the dose permitted by the Radionuclide Air Emission Program (RAEP) permit."

ETF may treat effluents that fall within the known envelope of treatability. ETF personnel can also identify, through the waste acceptance process, facility and/or permit modifications to prepare for accepting other wastes.

In addition to the mandatory criteria, the acceptance process for ETF considers several other factors that could affect the operability of the ETF process such as separable organics, too much dissolved organic, colloidal matter, scale forming compounds, corrosive constituents, UV absorbers, and neutral radionuclides. ETF must also satisfy certain requirements with regard to radioactive inventory in the facility and in the secondary waste product.

\subsubsection{Air Emissions}

For air permitting purposes, privatization contractors are integrated into the Hanford Site Air Operating Permit. To comply with the Hanford Site Air operating Permit ${ }^{10}$, the effective dose equivalent (EDE) from all Hanford facility radionuclide air emissions must not exceed $10 \mathrm{mRem} / \mathrm{yr}$ to any member of the public during any 12-month period. Presumably, a fraction of the allowance will be allocated to the private contractors. In addition, Derived Concentration Guide-public values for individual airborne emissions shall not be exceeded at any ground-level location or occupied area as a result of Hanford operations. Best Available Radionuclide Control Technology (BARCT) and Best Available Control Technology (BACT) for toxics are required.

\subsection{KEY ASSUMPTIONS FOR PHASE II}

\subsubsection{Characterization}

For the purposes of the PTB, the Phase II feed consists of the total inventory plus the intermediate waste products returned from private vendors minus the DST waste transferred to private contractors during Phase I. Phase I feeds, discussed in Section 3.1.1, are based on DST tank-by-tank inventory tables that were projected to the start of Phase I (Shelton 1996 and Manuel 1996).

The total inventory in Hanford tanks is currently in transition as the Standard Inventory project works toward a final recommendation. The Characterization Project's task to develop and maintain a Standard Tank-byTank Inventory for all tanks will not be completed in time, and in fact is not required for the PTB. In the meantime, the PTB will present cases based on all three of the following preliminary total inventories:

${ }^{9}$ Permits can be modified, so being outside of permit conditions does not absolutely preclude acceptance.

${ }^{10}$ Hanford has applied for the Site Air Operating Permit, but approval is not expected until some time in 1997. 


\section{TWRS PRIVATIZATION PROCESS TECHNICAL BASELINE}

The TWRS Process Flowsheet inventory ${ }^{11}$

An adjusted TWRS Process Flowsheet inventory

The LANL Rev. 3 inventory (Agnew et a . 1996)

The Standard Inventory project has arrived at "final" values for certain key waste components: $\mathrm{Al}, \mathrm{Cr}, \mathrm{Fe}, \mathrm{Na}$, and $\mathrm{PO}_{4}$. These account for the "adjustment" to the TWRS Process Flowsheet inventory mentioned above. Reviews of the LANL methodology for estimating tank inventory have identified a number of flaws, and the Standard Inventory project is geared toward fixing those probiems. The Standard Total Inventory and Standard Tank-by-Tank Inventory should be finalized in 1997 .

\subsubsection{Retrieve Waste}

The details of retrieving individual tanks and tank closure is outside the scope of the PTB. Since privatization delays full-scale production from 2004 to 2011 , privatization clearly impacts the first several years of retrieval compared to the previous retrieval baseline (Certa 1995a). The merits of alternate retrieval sequences continues to be studied (Penwell et a1. 1996) in parallel with the preparation of this process flowsheet.

Table 3-1 Primary Retrieval Assumptions

Waste was conditioned at the site of retrieval or in Retrieval Annexes to facilitate long distance transfers. Conditioning may include one or more of the following: further dissolution of salts, dilution, particle size adjustment and blending. Particles should be no larger than $2 \mathrm{~mm}$ to be suspended at normal transport velocity.

The Phase II feed stream to pretreatment is a composite of all tank waste not immobilized during Phase I.

As a simplifying assumption for mass balance purposes, the retrieved composite feed stream shows all water soluble constituents in solution with the volume adjusted to yield a $5 \mathrm{M} \mathrm{Na}$ solution. If the composite slurry is more than $10 \mathrm{wt} \%$ solids, additional retrieval water is added.

No additional DSTs will be provided for receiving SST waste.

- SST wastes will be retrieved starting in December $2003 .^{12}$ The maximum duration of SST retrieval is established in the language

${ }^{17}$ The TWRS Process Flowsheet (Rev. 1) used a revised Hanford Defense Waste Environmental Impact Statement inventory. The revision was an increase in the amount of $\mathrm{Al}$ and $\mathrm{Cr}$.

${ }^{12}$ Retrieval of SST 241-C-106 will be started in October 1996 and completed by September 2003 to demonstrate SST retrieval, and resolve the high heat safety issue. 


\section{WHC-SD-WM-TI-774 Rev, 0 \\ TWRS PRIVATIZATION PROCESS TECHNICAL BASELINE}

of the Tri-Party Agreement. All SST retrieval is completed by September 2018.

- Sluicing will be acceptable as the primary SST retrieval method. other retrieval methods may be required when there is potential for leakage or when residues are resistant to sluicing, but the method does not affect the overall mass balance.

- The process mass balance reflects $100 \%$ SST retrieval. The SST retrieval goal is $99 \%$ waste removal per the TPA so the mass balance is slightly conservative.

- SSTs are retrieved into DSTs and composited with residual DST waste to become the feed for Phase II.

- The allowable content of DSTs at the end of production has not been stipulated, but we assume the DSTs are empty for mass balance purposes.

\subsubsection{Transfer Waste}

The PTB will summarize slurry rheology data to the extent possible. Understanding the rheology of dense salt solutions and small particle (less than 40 microns) slurries is essential for pipeline operations, the assumed method of waste transfer.

Non-settling slurry rheology can be highly dependent on the nature of the particles; for example, boehmite ( $\mathrm{ALOOH}$ ) slurries are considerably more viscous than gibbsite $\left(\mathrm{Al}(\mathrm{OH})_{3}\right)$ at low shear rates. With rheology data in hand, the design of pipeline transfer systems is straightforward. Design methods for non-settling slurry pipelines are readily available (Brown and Heywood 1991).

Transfer systems for settling slurries (containing several percent solids that are greater than 50 microns) must be capable of maintaining the minimum transport velocity. The typical value is $1.8 \mathrm{~m} / \mathrm{sec}$ to preclude solids deposition. Minimum transport velocities are normally correlated using solids concentration, relative densities, particle diameter, and pipe diameter. Design methods for settling slurry pipelines are likewise readily available (Durand 1953, Hughmark 1961, Spells 1955, Brown and Heywood 1991). For sluiced waste, pipeline design should consider up to 10 wt\% slurry at a liquid specific gravity of 1.0 to 1.25 , which corresponds to a carrier liquid ranging from very dilute to $5 \mathrm{M} \mathrm{NaNO}_{3}$ solution.

\subsubsection{Store In-Process Waste}

Waste retrieved in the West Area is accumulated in the SY tank farm and transferred to the A tank farm complex. Waste retrieved in the East Area is accumulated in the A tank farm complex. The A tank farm complex is also the facility for in-tank treatment of sludges. Pretreated solids are stored in the A farm awaiting transfer to the vitrification facility. 


\section{WHC-SD-WM-TI-774 ReV. 0 \\ TWRS PRIVATIZATION PROCESS TECHNICAL BASELINE}

In-process waste storage requirements are driven by a number of factors: successfully matching retrieval rates and pretreatment, facility configuration decisions, and the extent to which the process areas are close coupled (or the desire to decouple process areas from each other). To keep in-process storage requirements for 1 iquids at a minimum requires very reliable and highly coordinated operations. The private contractor may decide to work within the available DST space, or provide contingency space to reduce the risk of unscheduled downtime.

In-process storage requirements for the large volume of retrieved liquids can be minimized if pretreatment processing capacity matches or exceeds the rate of retrieval. In-process storage and in-tank treatment are overlapping functions because to a certain extent they occur at the same time in the same equipment.

\subsubsection{Pretreat Waste}

\subsubsection{In-Tank Enhanced Sludge Washing}

- The sludge washing function architecture is allocated to the DSTS.

- Caustic leaching, sludge washing and incidental blending of Phase II solids will be adequate to achieve an acceptable HLW volume.

- Evaluation of new laboratory results will result in revised insoluble waste estimates and caustic leaching efficiency for Phase II.

Note: the following italicized text will be revised to reflect the additional results of laboratory studies that will be available later in the year.

In-tank enhanced sludge washing includes a retrieval wash (i.e., the solubilization of some components that actually occurs during retrieval and transfer of the slurries), solid/liquid separations by settle/decant, caustic leaching of selected components $\left(\mathrm{Al}, \mathrm{PO}_{4}^{-3}, \mathrm{Cr}\right.$ and $\mathrm{Na}$ are the primary targets of leaching) from the solids, and washing of the leached solids with dilute caustic.

Table 3-2 shows a summary of experimental washing and caustic leaching results that were available as of this writing (Lumetta et. al. 1993, Rapko et. al. 1995, Temer et. al. 1995). The leach efficiencies applied to the inventory of each type of SST waste yields a mass-weighted efficiency for caustic leaching.

The Al leach efficiency deserves additional explanation. During the experimental procedure, S-104 and U-110 samples (high aluminum content sludges) were treated with caustic at $100{ }^{\circ} \mathrm{C}$ and allowed to cool to near ambient temperature before analyzing the A7. Felmy's evaluation (not yet published) of these experiments in Figures 3-3 and 3-4 shows that the experimental Al concentration in room temperature samples of caustic leach solution was at the solubility limit, meaning that revised experimental 
conditions could very likely improve the efficiency of Al leaching. Assuming $62 \%$ for caustic leaching of boiled REDOX wastes in place of the experimental $35 \%$, the overall SST leach efficiency for $A 7$ in this flowsheet is $67 \%$ instead of $55 \%$.

The $\mathrm{Cr}$ and $\mathrm{PO}_{4}$ leach efficiencies are unchanged from the laboratory values. Therefore, ${ }^{4}$ the SST caustic leach efficiency derived from Table 3-4 for $\mathrm{A7}, \mathrm{Cr}$, and $\mathrm{PO}_{\underline{4}}$ is $67 \%, 60 \%$, and $74 \%$, respectively.

Revision 0 of the flowsheet took no credit for Na leaching. The mass weighted average for the $\mathrm{Na}_{2} \mathrm{O}$ content in the leached sludges of 9 recent core samples $(B-111, B 202, B X-105, B X-107, C-103, C-108, S-104, T-107)$ is $11 \%$. To obtain a residual sludge composition of $11 \% \mathrm{Na}_{2} \mathrm{O}$ for the TWRS composite feed, a $25 \%$ caustic leach efficiency is required. Therefore, a $25 \%$ caustic leaching efficiency for $\mathrm{Na}$ is applied to both SSTS and DSTS.

The caustic leach efficiencies for DSTs is assumed to be the same as the previous basis of $85 \%, 75 \%$, and $70 \%$ for $\mathrm{Al}, \mathrm{Cr}$, and $\mathrm{PO}_{4}$, respectively.

Together, the assumptions for SSTs and DSTS discussed above result in overall caustic leach efficiencies of $68 \%, 64 \%, 74 \%$, and $25 \%$ for $\mathrm{Al}, \mathrm{Cr}, \mathrm{PO}_{4}$ and $\mathrm{Na}$, respectively.

The mass balance assumptions pertaining to enhanced sludge washing are summarized in Table 3-3. 
- 7961 •

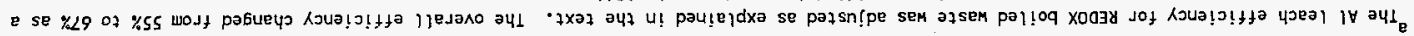

\begin{tabular}{|c|c|c|c|c|c|c|c|c|c|}
\hline$\% \triangleright L$ & $\% 92$ & $\% t 9$ & $\% 09$ & $\% \angle Z$ & $\% 99$ & $\% \angle 9 / \% 9 \subseteq$ & $\% 96$ & $\% \angle I$ & $7 \forall \perp 01$ \\
\hline$\% 0$ & $\% 0$ & $\% 0 L$ & $\% L$ & $\% L$ & $\% t$ & $\% \varepsilon t$ & $\%[2$ & $\%$ IS & $x \exists y \cap$ d \\
\hline$\% 0$ & $\% 0$ & $\% 6$ & $\% \varsigma 6$ & $\% 29$ & $\% s t$ & $\% 29 / \% \subseteq \varepsilon$ & $\% \dagger \varepsilon$ & $\% b$ & $\begin{array}{r}(6 u+!+0 q) \\
\text { ex003y }\end{array}$ \\
\hline$\% 0$ & $\% 0$ & $\% 66$ & $\% 96$ & $\% 6 \mathrm{I}$ & $\% 08$ & $\% \angle L$ & $\% 09$ & $\% 22$ & $x 00 \exists y$ \\
\hline$\% 9 b$ & $\% 9 \varepsilon$ & $\% 22$ & $\% 28$ & $\% I S$ & $\% \angle \varepsilon$ & $\% 18$ & $\% 6 L$ & $\% 2$ & $8 d 1$ \\
\hline$\%+6$ & $\% 92$ & $\% 2 L$ & $\% \angle b$ & $\% 0 b$ & $\% 9 \mathrm{I}$ & $\% 89$ & $\%$ \% & $\% L$ & Tod!8 \\
\hline $\begin{array}{c}\left(\rho_{1 q n j o s u l}\right. \\
\left.0^{2} H \text { to } \%\right) \\
\text { yวe? } 7\end{array}$ & $\begin{array}{l}(10701 \\
j 0 \%) \\
\text { 4007 }\end{array}$ & $\begin{array}{l}(19201 \\
10 \%) \\
45 e 4\end{array}$ & 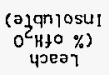 & $\begin{array}{l}(10701 \\
\text { to \%) } \\
\text { 4วea) }\end{array}$ & $\begin{array}{l}(10301 \\
\text { to \% } \\
4 \operatorname{sen}\end{array}$ & 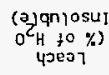 & 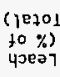 & $\begin{array}{l}(19 z 01 \\
10 \%) \\
4 \mathrm{sen}\end{array}$ & \\
\hline \multicolumn{3}{|c|}{ ә7еudsoud } & \multicolumn{3}{|c|}{ แn เุщохчว } & \multicolumn{3}{|c|}{ unu $\tan \perp \forall$} & \\
\hline
\end{tabular}

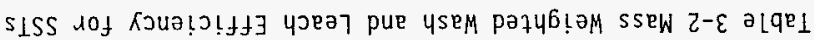




\section{WHC-SD-WM-TI-774 Rev. O \\ TWRS PRIVATIZATION PROCESS TECHNICAL BASELINE}

Table 3-3 Primary Assumptions for Enhanced Sludge Washing

Flocculent Additions: Polyelectrolyte with $4 \mathrm{H}$ to $1 \mathrm{C}$ (this is just a placeholder until the flocculent is actually selected). Flocculent is prepared as a $10 \mathrm{wt} \%$ solution. Flocculent is added to siurries at $0.019 \mathrm{~kg}$ of flocculent per $\mathrm{kg}$ of dry solid. Settled solids tie up $80 \%$ of the flocculent.

1st Stage Settling: Decanted liquids entrain $0.33 \%$ of incoming solids. Settled sludge is $20 \mathrm{wt} \%$ solids. $\mathrm{Al}, \mathrm{Cr}$, phosphate and $\mathrm{Na}$ leach from solids with efficiencies of $68 \%, 64 \%, 74 \%$ and $25 \%$, respectively. Moles of $\mathrm{OH}^{-}$consumed by leaching is $1 \mathrm{~mole} / \mathrm{mole} \mathrm{Al,} 1 \mathrm{~mole} / \mathrm{mole} \mathrm{Cr}, 3 \mathrm{moles} / \mathrm{mole}$ of phosphate. Chemical addition results in an 8 wt\% slurry (Stream 14) with $3 \mathrm{M}$ free $\mathrm{OH}^{-}$and $0.01 \mathrm{M} \mathrm{NO}$ after leaching has gone to completion.

No further solubilization occurs after the caustic leach. Washing of the leached solids is modelled as simple dilution of the interstitial liquor.

First Wash Tank: Decanted 7 iquids entrain $0.33 \%$ of incoming leached solids. Settled sludge is $20 \mathrm{wt} \%$ solids. Chemical addition results in an 8 wt\% slurry (Stream 21) with $0.1 \mathrm{M}$ free $\mathrm{OH}^{-}$and $0.01 \mathrm{M} \mathrm{NO}_{2}$. This addition is the first wash.

Second Wash Tank: Same as First Wash Tank (except Stream 21 is Stream 28). Third Wash Tank: Same as First Wash Tank (except Stream 21 is Stream 51). Fourth Wash Tank: Decanted liquids entrain no solids. Otherwise same as First Wash Tank (except Stream 21 is Stream 58).

2nd Stage Settling: Same as 1st Stage Settling.

Aqueous makeup provides $50 \mathrm{wt} \% \mathrm{NaOH}$ and $50 \mathrm{wt} \% \mathrm{NaNO}_{2}$ for chemical additions. 


\section{WHC-SD-WM-TI-774 ReV. 0 \\ TWRS PRIVATIZATION PROCESS TECHNICAL BASELINE}

The TRU content (both soluble and insoluble) of the combined supernatants (waste liquor, leachates and wash water) resulting from the intank enhanced sludge washing process should average $<100 \mathrm{nCi} / \mathrm{g}$ and $<540 \mathrm{nCi} / \mathrm{g}$ of sodium. This will ensure that the final LLW product is $\angle 100 \mathrm{nCi}$ of soluble $\mathrm{TRU} / \mathrm{g}$ of LLW glass, assuming all TRU in the supernatants goes to LLW glass.

The long range goal in this series of flowsheet revisions is to account for waste solubility and leach efficiency on a tank-by-tank basis using Tank Layer Model distributions, the results of sludge experiments, and the results of chemical modelling. Until the body of laboratory data is complete enough to do true tank-by-tank calculations, mass weighted averaging of the available data supplemented by engineering judgement is the next best alternative.

The Process Technical Baseline will provide for the in-tank treatment of a small volume of TRU/Sr contaminated 1 iquids in the inventory. Adjustment of the hydroxide concentration, chemical displacement with cations (iron, strontium), chemical oxidation and heat treatment are under consideration for this selective treatment. The exact conditions for treatment will be defined at a later date.

\subsubsection{Out-of-Tank Supernate Conditioning}

The process has the capability to condition combined supernates by organic decanting, evaporation, chemical adjustment, and polishing filtration in preparation for ion exchange.

\subsection{Organic Decanting}

Production records indicate 2.6E+6 1iters of non-miscible organic liquids were discharged to the tanks over the years (Bartley et al. 1996). While nowhere near that much remains in the tanks, NPH has been detected in the head space of 38 SSTs suggesting that organic phases may be present in more tanks than just $c-103$. The volume of organic stated below is essentially a quess since there is no basis for estimating the volume of residual organic in the tanks. There is analytical evidence that the TBP content of the organic is $70 \%$ or more, the balance being NPH or TBP degradation products.

Table 3-4 Primary Assumptions for Organic Decanting

The supernates from in-tank processing pass through a continuous gravity decanter prior to evaporation.

The separated organic phase is $75,000 \mathrm{~L}$ of $70 \% \mathrm{TBP} / 30 \% \mathrm{NPH}$.

The decanter removes $100 \%$ of the organic phase.

Separated organic is shipped to off-site incineration.

The potential for adverse impacts on evaporation, filtration and ion exchange is the rationale for organic decanting. 


\subsection{Evaporation}

Conditioning of decanted supernates and washes includes evaporation to a standard concentration. Ion exchange feeds that have been concentrated can be treated more efficientiy than a dilute feed (Kurath et. al. 1994).

Table 3-5 Primary Assumptions for Evaporator and Condenser

Filtrate is evaporated to $7 \mathrm{M} \mathrm{Na}$ for equipment design basis. ${ }^{13}$
Solids formed in the evaporator are removed by downstream polishing filter.
Condenser recovers $99 \%$ of water vapor.
Distribution coefficient (Bottoms/Condensate): $5 \mathrm{E}+6 \mathrm{for} \mathrm{Cl}$ and $\mathrm{NO}_{3}, 3.5 \mathrm{E}+5$
for TOC, and $1 \mathrm{E}+7$ for everything else (Na in condensate is adjusted to
maintain the charge balance).
Bottoms are not returned to DSTs, although a routing is provided.

\subsection{Polishing Filtration}

Evaporator bottoms are filtered through a deep bed frit filter to remove entrained solids, thus preventing blinding in the ion exchange columns. When spent, the filter bed is flushed out and combines with the Cs-depleted ion exchange effluent.

Table 3-6 Polishing Filter Assumptions

Frit composition: $77 \% \mathrm{SiO}_{2}, 15 \% \mathrm{~B}_{2} \mathrm{O}_{3}, 6 \% \mathrm{Li}_{2} \mathrm{O}, 1 \% \mathrm{CaO}, 1 \% \mathrm{MgO}$
Frit replacement: $45 \mathrm{kgs}(100 \mathrm{lbs})$ every $3.785 \mathrm{E}+5 \mathrm{~L}(100,000 \mathrm{gal})$
Filter efficiency: $1 \%$ of solids pass through the filter
Filter flush: $2 \mathrm{wt} \%$ solids in the flush slurry

\subsubsection{Ion Exchange}

Analysis of experimental data and engineering assessments conducted during 1994 have provided an improved technical basis for modelling the ion exchange removal of Cs (Kurath et. a7. 1994; Eager 1994; Johnson 1995). An empirical correlation to predict the cesium distribution (lambda value) of the baseline resin over a range of concentration and temperature is now available. The lambda value and a semi-empirical column breakthrough equation are used for calculating cumulative Cs losses ( $i . e$, bed volumes to breakthrough). on

\footnotetext{
13 Fittrates should be concentrated to the extent permitted by their chemistry. A short evaporation study (Powell 1995) determined that evaporation to $7 \mathrm{M} \mathrm{Na}$ is about the onset of precipitation in a variety of wastes; the chemistry of other waste may limit the extent of evaporation.
} 
the average, 35 bed volumes are treated between elutions, ranging from 8 to 43 bed volumes depending on the type of feed.

$\mathrm{Na}$ and $\mathrm{K}$ are assumed to load on the bed in the same ratio that exists in the feed. Insufficient data is available at this point in time to define the loading behavior of other cations. $\mathrm{Ca}, \mathrm{Sr}, \mathrm{Pu}$ and $\mathrm{Am}$, for example, are expected to load to some extent, but their behavior has not been tracked in column loading studies. This area needs to be addressed in future loading studies.

The column configuration consists of redundant ion exchange lines, each consisting of two columns in series. From a design standpoint, this arrangement substantially reduces pipe and valving complexity.

The parameters selected for modelling ion exchange are as follows:

Table 3-7 Assumptions for. Ion Exchange Modelling

\begin{tabular}{|c|c|}
\hline Parameter & Value \\
\hline Number of Beds in Series & 2 \\
\hline $\begin{array}{l}\text { Volume of Bed } \\
\text { Volume of Series }\end{array}$ & $\begin{array}{l}6500 \mathrm{~L} \\
13000 \mathrm{~L}\end{array}$ \\
\hline Feed Flowrate & $1 \mathrm{BV} / \mathrm{hr}$ \\
\hline Number of BVs Before Regeneration ${ }^{1}$ & $\begin{array}{l}\text { Calculated from correlations } \\
\text { Cum. Cs loss }=1 \mathrm{Ci} / 5000 \text { moles } \mathrm{Na}\end{array}$ \\
\hline $\begin{array}{l}\text { Cesium Elution } \\
\text { Residual Feed Flush } \\
\text { Sodium Scrub } \\
\text { Cesium Elution } \\
\text { Residual Eluent Flush }\end{array}$ & $\begin{array}{l}2 \mathrm{BV} \text { Water at } 2 \mathrm{BV} / \mathrm{hr} \\
6 \mathrm{BV} 0.5 \mathrm{M} \mathrm{HNO} \mathrm{H}_{3} \text { at } 1 \mathrm{BV} / \mathrm{hr} \\
2 \mathrm{BV} \text { Water at } 2 \mathrm{BV} / \mathrm{hr}\end{array}$ \\
\hline Bed Regeneration & $\begin{array}{l}1 \mathrm{BV} 0.5 \mathrm{M} \mathrm{NaOH} \text { at } 2 \mathrm{BV} / \mathrm{hr} \\
1 \mathrm{BV} 2.0 \mathrm{M} \mathrm{NaOH} \text { at } 2 \mathrm{BV} / \mathrm{hr}\end{array}$ \\
\hline
\end{tabular}

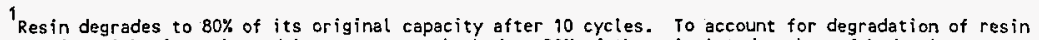
capacity with time, the model regenerates the bed at $90 \%$ of the calculated number of bed volumes.

${ }^{2}$ The sodium elution step (sodium scrub) that preceded cesium elution in Revision 0 has been omitted in Revision 1. The primary benefit of the sodium scrub was to reduce the amount of sodium in the Cs eluate, the down side being inereased cycle time and $C s$ losses to the LLW. In the current flowsheet, the Cs eluate is neutralized and returned to the DSTs prior to vitrification. The value of a sodium scrub has not been determined for these conditions. A sensitivity study may be justified to evaluate the pros and cons of a sodiun scrub.

Cumulative loss of $1 \mathrm{Ci} / \mathrm{m}^{3}$ in $5 \mathrm{M} \mathrm{Na}$ liquid effluent is a technically feasible target, thus satisfying the NRC "incidental waste" requirement (See Section 5.1.3). The total amount of cesium to near surface disposal is considerably less than the amount that has been accepted by the NRC in past negotiations. Cumulative loss is a more meaningful measure of.cesium removal efficiency than percent removal (or DF) since it is consistent with the nonsteady state nature of the ion exchange operation, and also reflects in unambiguous terms the curies of Cs that are permitted to break through to LLW. 


\section{WHC-SD-WM-TI-774 Rev. 0 \\ TWRS PRIVATIZATION PROCESS TECHNICAL BASELINE}

The cesium removal process is based on the cation exchange resin having the properties of CS-100 formerly manufactured by Rohm and Haas. Although it is not the highest capacity resin for Cs, CS-100 has produced the most consistent results under simulated waste processing conditions of the commercially available resins tested. The cesium will be loaded on the resin at high alkaline conditions $(\mathrm{pH} \geq 12)$ from clarified supernatant at about $25{ }^{\circ} \mathrm{C}$.

After 10 cycles (nominally 350 bed volumes) the cesium capacity of the resin has degraded to $80 \%$ of the fresh resin capacity. Spent resin will be flushed into the ion exchange effluent stream and fed to the LLW melter.

\subsubsection{Eluate Treatment}

The eluate stream, which is mostly water and nitric with some sodium nitrate and a little cesium nitrate, is evaporated and neutralized with caustic to a free hydroxide concentration of $0.1 \mathrm{M}$.

Table 3-8 Eluate Treatment Assumptions

Evaporate $90 \%$ of water and $70 \%$ of nitric acid.

Condense $99 \%$ of the vapor and recycle for elution.

Neutralize bottoms $0.1 \mathrm{M} \mathrm{OH}^{-}$.

\subsubsection{Immobilize Low-Level Waste}

\subsubsection{LLW Feed Evaporator}

Table 3-9 Primary Assumptions for Evaporator

Feed is evaporated to $10 \mathrm{M} \mathrm{Na}$ for equipment design basis.

Ignore solids (saits) formed in the evaporator.

Distribution coefficient: same as supernate evaporator.

Bottoms are not returned to DSTs, although routing is provided.

\subsubsection{LLW Glass Formulation}

Low-level glass optimization studies (Feng et a1. 1996) tested sodaalumina-lime-boro-zirconia-iron-silicate systems (and subsets) for processability and durability. The "Phase II" vendor glass study produced six test glasses from a LLW simulant that represents the LLW fraction of SSTs. The glass selected for modeling, LRM-5412, resulted in a homogeneous melt without evidence of phase segregation. LRM-5412 contains no added zirconium or iron. Another glass, LRM-3, has better durability, but the $6 \%$ zirconia content is unattractive from a processability (melting point) and essential material standpoint. LRM-5412 falls within the typical composition ranges for 
soda-lime-boro-alumina-silicate system: 15 to $25 \mathrm{wt} \% \mathrm{Na}_{2} 0,0$ to $12 \mathrm{wt} \% \mathrm{CaO}, 0$ to 12 wt $\% \mathrm{~B}_{2} \mathrm{O}_{3}, 5$ to 12 wt\% $\mathrm{Al}_{2} \mathrm{O}_{3}$, and 40 to $60 \% \mathrm{SiO}_{2}$ (Wilson et. al. 1995).

Chemical additions to the LLW melter feed are made to bring the melt within the formulation constraints stated in Table 3-11. The additives are $\mathrm{Al}_{2} \mathrm{O}_{3}, \mathrm{~B}_{2} \mathrm{O}_{3}, \mathrm{CaO}$, and $\mathrm{SiO}_{2}$.

Table 3-10 LLW Glass Formulation Constraints

\begin{tabular}{||l|l|}
\hline $\mathrm{Al}_{2} \mathrm{O}_{3}$ & $=12 \mathrm{wt} \%$ \\
\hline $\mathrm{B}_{2} \mathrm{O}_{3}$ & $=5 \mathrm{wt} \%$ \\
\hline $\mathrm{CaO}$ & $=4 \mathrm{wt} \%$ \\
\hline $\mathrm{Na}_{2} \mathrm{O}$ & $=20 \mathrm{wt} \%$ \\
\hline $\mathrm{SiO}_{2}$ & $>=50 \mathrm{wt} \%$ \\
\hline
\end{tabular}

Time-phased process modeling (Orme 1995b) shows that occasional slugs of high $\mathrm{Al}$ feed should be adjusted with $\mathrm{Na}$ additions to hold $\mathrm{Al}_{2} \mathrm{O}_{3}: \mathrm{Na}_{2} \mathrm{O}$ at the proper ratio. If the ratio is allowed to float, glass compositions fluctuate widely. This is not an issue with the composite flowsheet because there is more than enough sodium relative to aluminum.

\subsubsection{Meiter Energy}

Energy in the melter is provided by combustion. The minimum energy requirement is based on the vaporization and super heating of water to $1200{ }^{\circ} \mathrm{C}$ and the melting of the major constituent oxides. The model uses $2 \%$ more energy (i.e., kerosene) than the minimum. The heat of melting for the following oxides is considered:

Table 3-11 Heat of Melting

\begin{tabular}{|l|l|}
\hline $\mathrm{Na}_{2} \mathrm{O}$ & $11.4 \mathrm{kcal} / \mathrm{gmole}$ \\
\hline $\mathrm{Al}_{2} \mathrm{O}_{3}$ & 28.0 \\
\hline $\mathrm{CaO}$ & 19.0 \\
\hline $\mathrm{SiO}_{2}$ & 2.3 \\
\hline $\mathrm{B}_{2} \mathrm{O}_{3}$ & 5.8 \\
\hline $\mathrm{Li}_{2} \mathrm{O}$ & 14 \\
\hline $\mathrm{MgO}$ & 18.5 \\
\hline
\end{tabular}

The kerosene assay is $87.3 \% \mathrm{C}, 12.6 \% \mathrm{H}, 0.04 \% \mathrm{O}$, and $0.06 \% \mathrm{~N}$. Kerosene has a heat of combustion of $11,111 \mathrm{kcal} / \mathrm{kg}$. Oxygen for combustion is added in $10 \%$ excess. 


\section{WHC-SD-WM-TI-774 ReV. 0 \\ TWRS PRIVATIZATION PROCESS TECHNICAL BASELINE}

\subsubsection{Volatility From LLW Combustion Melter}

The fractional volatility of the melt is as shown in Table 3-12. In addition to volatility, there is physical entrainment of $2 \%$ of the glass (Boldt 1995). The composition of entrained glass is determined after volatilization.

Table 3-12 LLW Melter Volatility Assumptions

\begin{tabular}{|c|c|c|}
\hline Component & $\%$ Volatile & Comment \\
\hline $\mathrm{B}_{2} \mathrm{O}_{3}$ & 25 & as $\mathrm{NaBO}_{2}$ \\
\hline $\mathrm{CdO}$ & 33 & as $\mathrm{Cd}(\mathrm{OH})_{2}$ \\
\hline CI & 95 & as $\mathrm{HCl}$ \\
\hline $\mathrm{Cs}_{2} \mathrm{O}$ & 33 & as $\mathrm{CsOH}$ \\
\hline $\mathrm{F}$ & 67 & as $\mathrm{HF}$ \\
\hline I & 100 & as $\mathrm{HI}$ \\
\hline $\mathrm{K}_{2} \mathrm{O}$ & $\begin{array}{l}\text { (K/Na ratio same as } \\
\text { feed) }\end{array}$ & as $\mathrm{KOH}$ \\
\hline $\mathrm{MoO}_{3}$ & 5 & as $\mathrm{Mo}(\mathrm{OH})_{6}$ \\
\hline $\mathrm{Na}_{2} \mathrm{O}$ & 1 & as $\mathrm{NaOH}$ \\
\hline $\mathrm{NO}_{\mathrm{x}}$ & $\begin{array}{l}6,000 \mathrm{ppm} \text { noncond } \\
20 \% \mathrm{NO}\end{array}$ & \\
\hline $\mathrm{PbO}_{2}$ & 33 & as $\mathrm{Pb}(\mathrm{OH})_{4}$ \\
\hline $\mathrm{PO}_{4}$ & 20 & as $\mathrm{H}_{3} \mathrm{PO}_{4}$ \\
\hline $\mathrm{Ru}_{2} \mathrm{O}_{3}$ & 33 & as $\mathrm{Ru}(\mathrm{OH})_{3}$ \\
\hline $\mathrm{Se}_{2} \mathrm{O}_{3}$ & 33 & as $\mathrm{Se}(\mathrm{OH})_{6}$ \\
\hline $\mathrm{SO}_{4}$ & $\begin{array}{l}90 \\
10 \\
\end{array}$ & $\begin{array}{l}\text { as } \mathrm{SO}_{2} \\
\text { as } \mathrm{SO}_{3}\end{array}$ \\
\hline $\mathrm{TC}_{2} \mathrm{O}_{7}$ & $50 \%$ & as $\mathrm{TCO}_{2}$ \\
\hline $\mathrm{TeO}_{3}$ & 33 & as $\mathrm{Te}(\mathrm{OH})_{6}$ \\
\hline
\end{tabular}




\subsubsection{ILAW Packages}

Note: The following is a major change from the TWRS Process Flowsheet Rev. 1. The entire $L L W$ cullet handling operation is replaced by casting glass monoliths in the RFP specified container (Brown 1996).

Table 3-13 ILAW Package Assumptions

Each gram-mole of waste sodium generates $73.1 \mathrm{~cm}^{3}$ of ILAW package.

The standard package is $1.2 \mathrm{~m} \times 1.2 \mathrm{~m} \times 1.8 \mathrm{~m}\left(2.59 \mathrm{~m}^{3}\right)$.

\subsubsection{LLW Melter Offgas Treatment}

Note: Modifications to these assumptions are currently under consideration. It is likely that they will change.

LLW melter offgas treatment consists of a quench tower, venturj scrubber, demister, HEPA filtration, $\mathrm{SO}_{2}$ absorption, and catalytic reduction of $\mathrm{NO}_{\mathrm{x}}$. Quenching is rapid cooling and condensing of a gas/vapor stream with a liquid spray. A venturi scrubber completes the particulate removal. Clean air requirements are assumed to drive $\mathrm{SO}_{\mathrm{x}}$ and $\mathrm{NO}_{\mathrm{x}}$ removal.

\section{Table 3-14 LLW Melter Offgas Treatment Assumptions}

Quench Tower: The quench liquid is $1.5 \mathrm{M}$ nitric acid. Quench flow rate is 26.54 times the water in melter offgas plus 2 times the gases in melter offgas. The gas effluent from the quench tower is saturated with quench liquid vapor at $75{ }^{\circ} \mathrm{C}(0.40$ lbs vapor per $1 \mathrm{~b}$ of gases) and entrains $7.6 \mathrm{~L}$ (2 gal) of quench 1 iquid per $1530 \mathrm{scfm}$ of gas. Removes $100 \%$ of $\mathrm{TcO}_{2}, 95 \%$ of $\mathrm{Hg}, \mathrm{Cl}$ and other solids.

Venturi/Separator: The scrub 7 iquid is $1.5 \mathrm{M}$ nitric acid. Liquid flow to venturi is 1 volume per 1000 volumes of gas. The gas effluent from the venturi/separator is saturated with quench 1 iquid vapor at $75^{\circ} \mathrm{C}(0.4$ ibs vapor per $1 \mathrm{~b}$ of gas) and entrains $7.6 \mathrm{~L}$ (2 gal) of quench liquid per 1530 scfm of gas. Removes $95 \%$ of $\mathrm{Hg}, \mathrm{Cl}$ and other solids.

Demister: Removes $95 \%$ of $\mathrm{Hg}$, $98 \%$ of solids. The gas effluent is saturated at $30{ }^{\circ} \mathrm{C}(0.0265$ lbs vapor per $1 \mathrm{~b}$ of gas), with no entrainment of liquid. Demister wash is set to zero.

Scrub Solution Tank: Maintain at 1.5M nitric acid. $\mathrm{TcO}_{2}$ converts to $\mathrm{TcO}_{4}{ }^{-}$.

CuO Bed: Removes $90 \%$ of $\mathrm{SO}_{2}$. Maintain $10 \%$ excess $\mathrm{O}_{2}$ in reactor feed.

Reactor chemistry is $\mathrm{SO}_{2}+\mathrm{O}_{2}+\mathrm{CuO} \Rightarrow \mathrm{CuSO}_{4}$. Cu/S mole ratio is 2.0 at full loading.

$\mathrm{NO}_{x}$ Reactor: Reduces $-99 \%$ of $\mathrm{NO}_{x}$. Maintain $10 \%$ excess $\mathrm{NH}_{3}$ in reactor feed.

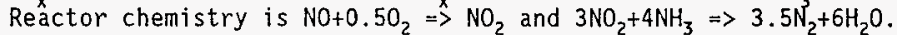




\section{WHC-SD-WM-TI-774 Rev. 0 \\ TWRS PRIVATIZATION PROCESS TECHNICAL BASELINE}

Quench tower flow rate are based on ASPEN simulations. Entrainment assumptions are based on New Waste Calcining Facility design criteria (INEL). Venturi scrubber flow rate based on Perry's Handbook.

\subsubsection{Sulfur Recovery}

Sulfur recovery is completed by regenerating the Cu0 beds to release $\mathrm{H}_{2} \mathrm{~S}$, partial burning of the $\mathrm{H}_{2} \mathrm{~S}$ to $\mathrm{SO}_{2}$, and reduction to elemental sulfur in Claus Reactors.

Table 3-15 Sulfur Reduction Assumptions

$\mathrm{CuSO}_{4}$ Bed: Removes $100 \%$ of sulfur. Feed $10 \%$ excess $\mathrm{H}_{2}$ to $\mathrm{CuSO}_{4}$ bed. Reaction chemistry is $\mathrm{CuSO}_{4}+5 \mathrm{H}_{2} \Rightarrow \mathrm{H}_{2} \mathrm{~S}+4 \mathrm{H}_{2} \mathrm{O}+\mathrm{Cu}$. Regenerate CuO bed with air purge.

Combustion Chamber: Add enough fuel to initiate the reaction (1 MT). Onethird of $\mathrm{H}_{2} \mathrm{~S}$ is converted to $\mathrm{SO}_{2}$. Reaction chemistry is $\mathrm{H}_{2} \mathrm{~S}+1.5 \mathrm{O}_{2} \Rightarrow$ $\mathrm{SO}_{2}+\mathrm{H}_{2} \mathrm{O}$.

Claus Reactors: Convert $90 \%$ in first reactor. Convert $90 \%$ in second reactor. Reactor chemistry is $2 \mathrm{H}_{2} \mathrm{~S}+\mathrm{SO}_{2} \Rightarrow 3 \mathrm{~S}+2 \mathrm{H}_{2} \mathrm{O}$. Gas effluent is recycled to feed $\mathrm{SO}_{2}$ absorbers.

\subsubsection{Sulfur Secondary Waste}

Sulfur recovered from the melter offgas creates a radioactive solid waste that must be returned to DOE. The molten sulfur is poured into 55 gallon drums, allowed to cool before transfer to DOE. 


\section{WHC-SD-WM-TI-774 Rev. 0 \\ TWRS PRIVATIZATION PROCESS TECHNICAL BASELINE}

\subsubsection{Chloride Removal From Scrub Solution}

Note: Modifications to these assumptions are currently under consideration. It is likely that they will change.

\section{Table 3-16 Chloride Removal Assumptions}

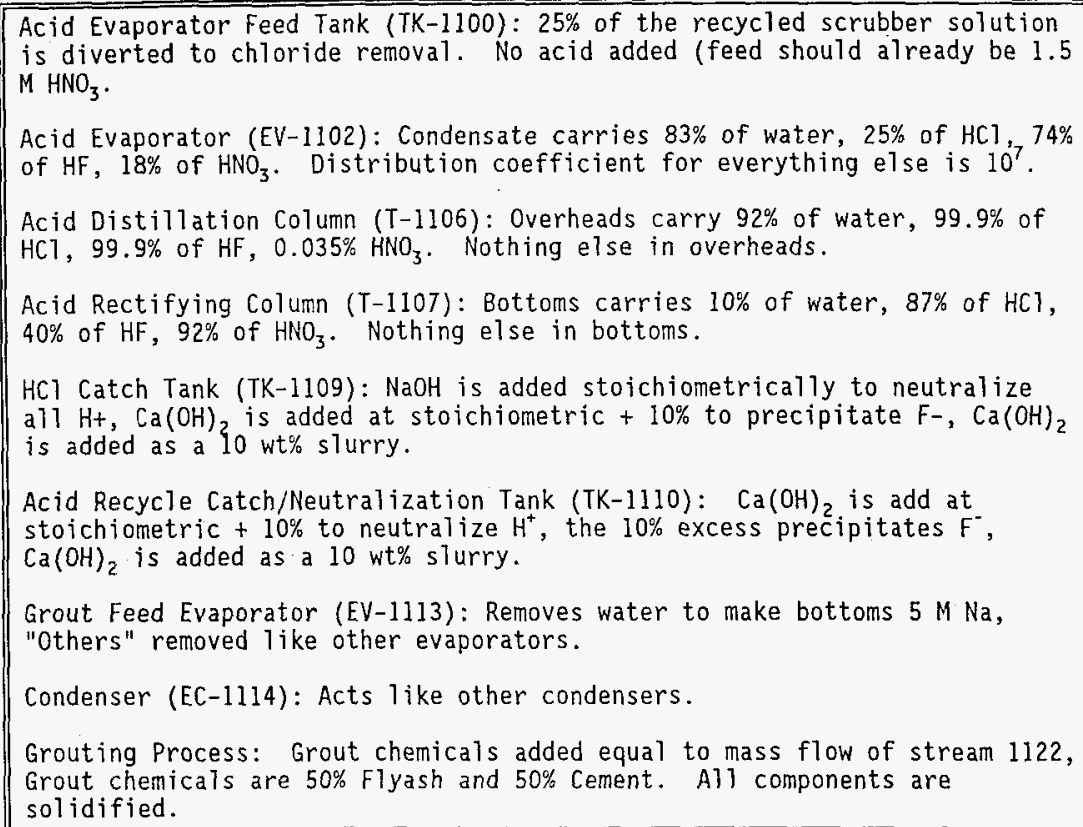




\subsubsection{Immobilize High-Level Waste}

- The feed to the TWRS Process Flowsheet for Phase II will be the global best-basis tank estimate minus the materials processed during Phase I.

- During Phase II, the basis for the IHLW volume projection will be the TWRS Process Flowsheet, adjusted by the blending factor and/or loading factors that are considered appropriate at that time.

- Before 2013 , a 15 foot tall HLW canister is approved for geologic disposal (Milner 1996). It is the sole HLW package during Phase II, having a net glass volume of $1.17 \mathrm{~m}^{3}$.

\subsubsection{HLW Meiter Feed Preparation}

Note: Assumptions around the centrate evaporator are being reconsidered. Assumptions around the feed adjustment reactor are being reconsidered for consistency with latest feed preparation technology. They are likely to change.

Table 3-17 HLW Melter Feed Preparation Assumptions

Centrifuge: Centrate is 0.1 wt\% solids. Liquid carryover in solids is 0.12 times the centrifuged solids.

Centrate Evaporator and Centrate Evaporator Condenser: Evaporate centrate to the extent that Stream 311 is a $20 \mathrm{wt} \%$ slurry. Distribution coefficient (Bottoms/Condensate) $5 \mathrm{E}+6$ for $\mathrm{Cl}$ and $\mathrm{NO}_{3}, 3.5 \mathrm{E}+5$ for $\mathrm{TOC}$, and $\mathrm{IE}+7$ for everything else ( $\mathrm{Na}$ in condensate is adjusted to maintain the charge balance)

Feed Adjustment Reactor (FAR): 0xides with lower limits in glass are added to meet the glass composition envelope in Table 3-22, while minimizing the amount of HLW glass produced. Glycolic acid $(70.6 \mathrm{wt} \%)$ solution added in amount equal to 0.486 of the waste oxides is in excess of the requirement. FAR evaporates water so melter feed contains at least $0.376 \mathrm{~kg}$ of oxide equivalent per $\mathrm{kg}$.

FAR Reactions: Carbonate converts to $\mathrm{CO}_{2}, 50 \%$ of nitrite converts to NO, $\mathrm{N}_{2} \mathrm{O}, \mathrm{CO}_{2}$, and water, $90 \%$ of $\mathrm{Hg}^{++}$reduced to $\mathrm{Hg}$ by glycolic acid.

FAR Offgas: Contains all gases. Contains $90 \%$ of all types of mercury, $98.6 \%$ of $\mathrm{NH}_{3}$, and $0.03 \%$ of carbonate, nitrite, nitrate, sulfate, TOC and glycolic acid plus $0.005 \%$ of a 11 other components.

FAR Condenser: The FAR offgas passes through the condenser as follows: $100 \%$ of all gases, $50 \%$ of mercury, and $10 \%$ of everything else. 


\subsubsection{HLW Glass Formulation}

HLW glass formulation for the purposes of the PTB follows a simple set of rules that is applied to the composite feed. This approach is not optimized. It may be possible to develop formulation rules for subsets of the composite feed that achieve higher waste loadings. Until those rules are developed, what we have available is a property/composition study that examines a composition region of single component constraints (lower and upper bounds for each of 10 components) and multiple component constraints that is assumed to produce reasonable giass quality (Hrma et al. 1994). Hrma cautions that solubility 1 imits for $\mathrm{Cr}_{2} \mathrm{O}_{3}, \mathrm{~F}, \mathrm{P}_{2} \mathrm{O}_{5}$, noble metals and $\mathrm{SO}_{3}$ previousiy determined for specific glasses may not be applicable across the tested composition region because solubility limits are composition dependent. For example, glasses that are relatively low in $\mathrm{Ca}$ and relatively high in $\mathrm{Al}$ can solubilize more phosphorus.

Table 3-18 shows the single component ranges and solubility limits used for formulating the HLW glass in the computer model. The multiple component ranges are ignored. The ranges are based on Hrma 1994.

Table 3-18 HLW Glass Formulation Ranges (CVSO1150 ${ }^{\circ} \mathrm{C}$ )

\begin{tabular}{|c|c|c|}
\hline \multirow[t]{2}{*}{ Component } & \multicolumn{2}{|c|}{ Glass } \\
\hline & Lower & Upper \\
\hline \multicolumn{3}{|c|}{ Single-Component Ranges ${ }^{a}$} \\
\hline $\mathrm{Al}_{2} \mathrm{O}_{3}$ & $0.0 \%$ & $15.0 \%$ \\
\hline $\mathrm{B}_{2} \mathrm{O}_{3}$ & $5.0 \%$ & $20.0 \%$ \\
\hline $\mathrm{CaO}$ & $0.0 \%$ & $10.0 \%$ \\
\hline $\mathrm{Fe}_{2} \mathrm{O}_{3}$ & $2.0 \%$ & $15.0 \%$ \\
\hline $\mathrm{Li}, \mathrm{O}$ & $1.0 \%$ & $7.0 \%$ \\
\hline Mgo & $0.0 \%$ & $8.0 \%$ \\
\hline $\mathrm{Na}_{2} \mathrm{O}^{\mathrm{B}}$ & $5.0 \%$ & $20.0 \%$ \\
\hline $\mathrm{SiO}_{2}$ & $42.0 \%$ & $57.0 \%$ \\
\hline $\mathrm{ZrO}_{2}$ & $0.0 \%$ & $13.0 \%$ \\
\hline \multicolumn{3}{|c|}{ Multi-Component Ranges ${ }^{c}$} \\
\hline $\mathrm{Al}_{2} \mathrm{O}_{3}+\mathrm{ZrO}_{2}$ & \multicolumn{2}{|c|}{$<=16.0 \%$} \\
\hline $\mathrm{Al}_{2} \mathrm{O}_{3}+\mathrm{ZrO}_{2}+\mathrm{Fe}_{2} \mathrm{O}_{3}$ & \multicolumn{2}{|c|}{$<=21.0 \%$} \\
\hline $\mathrm{MgO}+\mathrm{CaO}$ & \multicolumn{2}{|c|}{$<=24.0 \%$} \\
\hline \multicolumn{3}{|c|}{ Solubility Limits } \\
\hline $\mathrm{Cr}_{2} \mathrm{O}_{3}$ & \multicolumn{2}{|c|}{$<=0.5 \%$} \\
\hline $\mathbf{F}$ & \multicolumn{2}{|c|}{$<=1.7 \%$} \\
\hline $\mathrm{P}_{2} \mathrm{O}_{5}{ }^{\mathrm{d}}$ & \multicolumn{2}{|c|}{$<=3.0 \%$} \\
\hline $\mathrm{Rh}_{2} \mathrm{O}_{3}+\mathrm{Ru}_{2} \mathrm{O}_{3}+\mathrm{Ru}_{2} \mathrm{O}_{3}$ & \multicolumn{2}{|c|}{$<=0.25 \%$} \\
\hline $\mathrm{SO}_{3}$ & \multicolumn{2}{|c|}{$<=0.5 \%$} \\
\hline
\end{tabular}

a the sum of al! components not listed may range from $1 \%$ to $10 \%$.

Includes $\mathrm{K}_{2} \mathrm{O}$.

Attempts to eliminate formulations with poor processability by the application of multiple component constraints have been "only partially successful" per Hrma 1994. Multi-component gonstraints are ignored in the model.

This limit differs from the $1 \%$ ceiling used for HWNP formulations as shoun in Hrma 1994. It is an engineering judgment that TWRS composite glass can solubilize up to $3 \% \mathrm{P}_{2} \mathrm{O}_{5}$. 
Use of the above formulation rules generally produces less glass than the previously used HWVP formulation rules (0rme 1995a). A preliminary study of Phase I feeds comparing CVS rules and HWVP rules shows that the waste loading is still reasonable even though the glass volume is smaller (Manuel et a1. 1996).

\subsubsection{Volatility From HLW Melter}

Physical conditions and chemistry in the HLW melter are quite different from the LLW melter. Volatilization occurs in the cold cap, but the cold cap also functions as a barrier to physical entrainment. All components except Al and $\mathrm{PO}_{4}$ and those noted in Table 3-19 are completely oxidized and remain in the glass. Some gases volatilized from $\mathrm{NO}_{\mathrm{x}(\mathrm{aq})}$ undergo further gas phase reactions.

Table 3-19 High Level Melter Volatility Assumptions

\begin{tabular}{|c|c|c|}
\hline Component & $\%$ Volatile & Comment \\
\hline $\mathrm{B}_{2} \mathrm{O}_{3}$ & $1.0 \%$ & \\
\hline Cdo & $14 \%$ & \\
\hline $\mathrm{CO}_{2} \mathrm{O}_{3}$ & $0.33 \%$ & \\
\hline $\mathrm{Cl}$ & $\begin{array}{l}0.1 \% \\
50 \% \text { of } \\
\text { balance }\end{array}$ & $\begin{array}{l}\text { as } \mathrm{Cl}_{2} \\
\text { as solid } \mathrm{Cl}\end{array}$ \\
\hline $\mathrm{Cs}_{2} \mathrm{O}$ & $7.1 \%$ & \\
\hline $\bar{F}$ & $\begin{array}{l}0.1 \% \\
25 \% \text { of } \\
\text { balance }\end{array}$ & $\begin{array}{l}\text { as } F_{2} \\
\text { as solid } F\end{array}$ \\
\hline $\mathrm{k}_{2} \mathrm{O}$ & $0.33 \%$ & \\
\hline $\mathrm{MoO}_{3}$ & $1.0 \%$ & \\
\hline $\mathrm{Na}_{2} \mathrm{O}$ & $0.33 \%$ & \\
\hline $\mathrm{NO}_{\mathrm{x}}$ & $100 \%$ & $\begin{array}{l}75 \% \text { as } \mathrm{NO} \text { and } \mathrm{O}_{2} \\
92 \% \text { of remainder as } \mathrm{N}_{2} \text { and } \mathrm{O}_{2} \\
100 \% \text { of remainder as } \mathrm{NH}_{3} \text { and } \mathrm{O}_{2}\end{array}$ \\
\hline $\mathrm{PbO}_{2}$ & $10 \%$ & \\
\hline $\mathrm{Ru}_{2} \mathrm{O}_{3}$ & $2.5 \%$ & \\
\hline $\mathrm{SeO}_{3}$ & $10 \%$ & \\
\hline $\mathrm{TCO}_{4}$ & $\begin{array}{l}50 \% \\
7.1 \% \\
\end{array}$ & $\begin{array}{l}\text { as } \mathrm{TCO}_{2} \\
\text { as } \mathrm{Tc}_{2} \mathrm{O}_{7}\end{array}$ \\
\hline $\mathrm{TeO}_{3}$ & $10 \%$ & \\
\hline
\end{tabular}




\subsubsection{HLW Melter Offgas Treatment}

Note: Assumptions around the scrubbing section are being reconsidered and are likely to change. Assumptions around mercury removal and ammonia destruction are being reconsidered and are likely to change.

Table 3-20 HLW Melter. offgas Treatment Assumptions

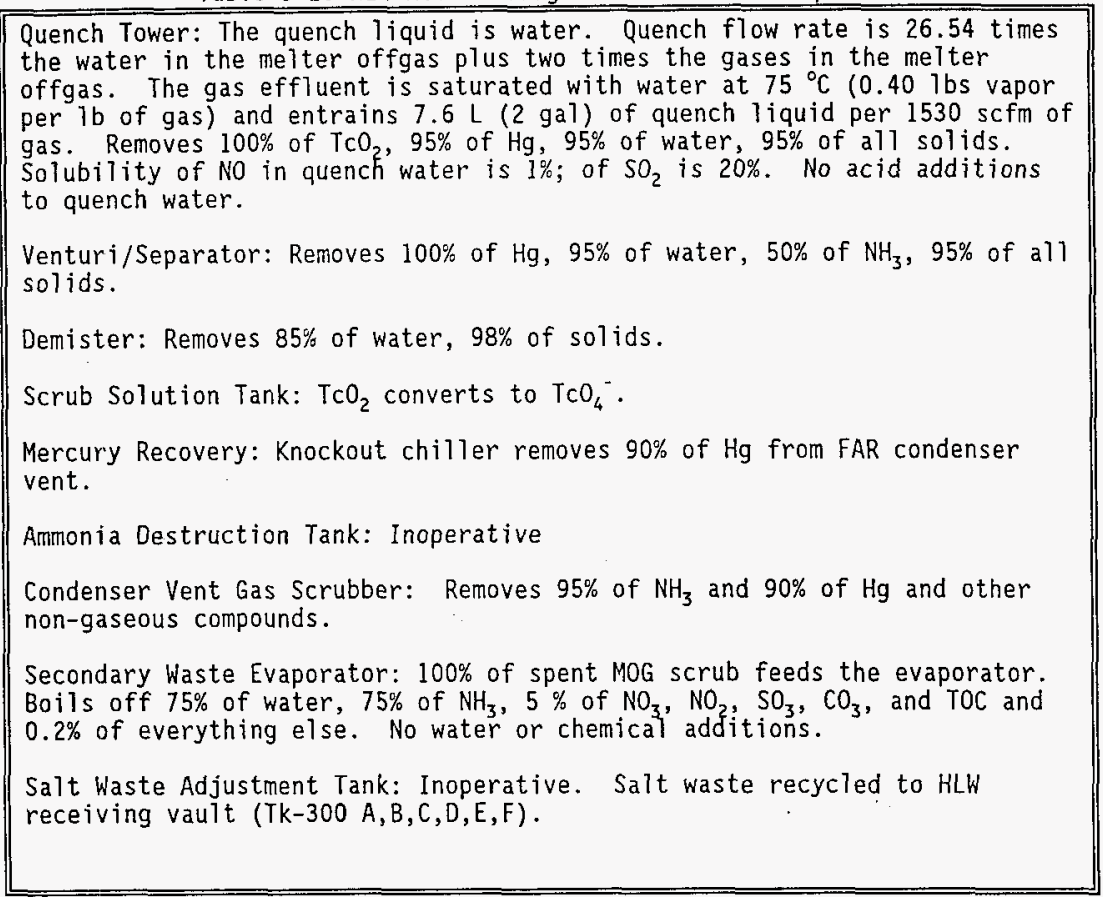

\subsubsection{HLW Package}

Tentative acceptance of a $15 \mathrm{ft}$ canister was obtained from RW (Milner 1996). The net glass volume of $1.17 \mathrm{~m}^{\frac{3}{3}}$ is assumed. The mechanical operations of canister closure, decontamination, smear testing, etc. are not depicted in this flowsheet. 


\section{References}

Agnew 1994a, Estimating Chemical Inventories for Hanford Tank Wastes, LA-UR94-273, Los Alamos National Laboratory, Los Alamos, New Mexico.

Agnew 1994b, Hanford Defined Wastes: Chemical and Radionuclide Compositions, LA-UR-94-2657, August 1994 .

Agnew et. al. 1995, Tank Layer Model (TLM) for Northwest, Southwest, and Northeast Quadrants, LA-UR-94-4269.

Agnew et al. 1996, Hanford Tank Chemical and Radionuclide Inventories:HDW Model Rev. 0, draft, March 1996.

Alumkal 1994a, Internal Memo, Tank Waste Remediation Technical Strategy, March $18,1994$.

Alumkal 1994b, Alumkal to Sheridan (Letter 9454691), Configuration Selection for the Tank Waste Remediation System, July 18, 1994.

Bader 1995, Tank Waste Remediation System (TWRS) Guidance for Update of the Multi-Year Program Plan (MYPP) -- Supplemental Guidance for the Disposal Strategy, (95-PRI-073), July 1995.

Bartley et al. 1996, Tank 241-C-103 Systems Engineering Study:Separable Phase Skiming, Storage, Treatment and Disposal Options, WHC-SD-WM-ES-384, May 1996.

Beard et. a1. 1964, Waste. Management Program Chemical Processing Department, HW-81481, 1964.

Boldt, A. L., K. D. Boomer and E. J. Slaathaug 1995, Determination of LowActivity Waste Fraction From Hanford Site Tanks, WHC-SD-WM-TI-699 Draft Rev. A, November 1995.

Boldt 1995, Personal Communication, 1/31/95.

Boomer et. al. 1993, Tank Waste Technical Options Report, WHC-EP-0616, March 1993.

Boomer et. al. 1994, Tank Waste Remediation System Facility Configuration Study, WHC-SD-WM-ES-295, Rev.0.

Brevik 1995a, Historical Tank Content Estimate for the Southwest Quadrant of the Hanford 200 West Area, WHC-SD-WM-ER-352, March 1995.

Brevik et al 1995, Historical Tank Content Estimate for the Northwest Quadrant of the Hanford 200 West Area, WHC-SD-WM-ER-351, March 1995.

Brevik 1995b, Historical Tank Content Estimate for the Northeast Quadrant of the Hanford 200 East Area, WHC-SD-ER-349, March 1995. 
Brown 1996, LLW Product Loading Assumptions for the TWRS Flowsheet, DSI from N. R. Brown to R. M. Orme, April 23, 1996.

Brown and Heywood 199l, Slurry Handling Design of Solid-Liquid Systems, Elsevier Applied Science, 1991.

Calmus 1996, Solidified High-Level Waste Interim Storage Alternative Analysis amd Path Forward Recommendation, WHC-SD-WM-SP-011 Rev. 0, May 1996.

Certa 1995a, Select Retrieval Sequence and Blending Strategy Decision Analysis Frame, WHC-SD-WM-RPT-107, March 1995.

Certa 1995b, Preliminary Retrieval Sequence and Blending Strategy, WHC-SD-WMRPT-167 Rev. 0, August 1995.

Certa et al. 1996, Preliminary Low-Level Waste Feed Staging Plan, WHC-SD-WMRPT-210, February 1996.

Colton et. a). 1995, Pretreatment Chemistry Evaluation: A Status Report, TWRSPP-95-024, June 30, 1995.

Colton 1995, Sludge Pretreatment Chemistry Evaluation: Enhanced Sludge Washing Separation Factors, PNL-10512, March 1995.

Croft 1980a, ORIGEN2 - A Revised and Updated Version of the Oak Ridge Isotope Generation and Depletion Code, ORNL-5621.

Croft 1980b, A User's Manual for the ORIGEN2 Computer Code, ORNL/TM7175.

DOE 1987, Final Environmental Impact Statement, Disposal of Hanford High-Leve] Waste, Transuranic and Tank Waste, DOE/EIS-0113.

DOE 1990, Evaluation and Selection of Borosilicate Glass as the Waste Form for Hanford High-Level Radioactive Waste, DOE/RL-90-27 Rev. 1, September 1990.

DOE 1991, Integrated Data Base for 1991: U. S. Spent Fuel and Radioactive Waste Inventories, Projections, and Characterization, DOE/RQ-0006, Rev. 7.

DOE 1996, TWRS Privatization Request for Proposals, DE-RP06-96RL13308, United States Department of Energy, Richland, Washington.

DOE-OCRWM 1993, Waste Acceptance System Requirements Document, Rev. 0, DOE/RW0351P, Office of Civilian Radioactive Waste Management.

DOE-WIPP 1991, Waste Acceptance Criteria for the Waste Isolation Pilot Plant, WIPP/DOE-069, Rev. 4, 1991.

Durand 1953, Proceedings of the Minnesota International Hydraulics Convention, September, 1953, Part I, pg. 89-103. 
Eager 1994, Preliminary Flowsheet: Ion Exchange Process for the Separation of Cesium From Hanford Tank Waste Using Duolite CS-100 Resin, WHC-SD-WM-TI-667, Rev. O, December 1994.

Ecology et. a1. 1994, Hanford Facility Agreement and Consent Order, Fourth Amendment, January 1994.

Felmy et. al. 1994, The Solubility of $\mathrm{Cr}(\mathrm{OH})_{3(a m)}$ in Concentrated $\mathrm{NaOH}$ and $\mathrm{NaOH}-\mathrm{NaNO}_{3}$ Solutions, PNL-SA-24027, August 1994 .

Feng et a1. 1996, Glass Optimization for Vitrification of Hanford Site LowLeve? Tank Waste, PNNL-10918, March 1996.

Gumprecht 1968, Mathematical Basis for Computer Code, DUN-4136, June 1968.

Hanion 1993, Tank Farm Surveillance and Waste Status Sumary Report for October 1993, WHC-EP-0182-67.

Higley 1995, Evaluation of Low-Level Waste Forms for Immobilization of Hanford Site Tank Wastes, WHC-SD-WM-ES-319, Rev. 0, June 1995.

Hill et. al. 1995, The Sort on Radioactive Waste Type Model: A Method to Sort Single-Shell Tanks into Characteristic Groups, PNL-9814 Rev. 2, March 1995.

Honeyman 1996, Submittal of the TWRS Disposal Program Assumptions for the Operational Waste Volume Projection, DP0-96-14, March 1, 1996.

Hrma et a1. 1994, Property/Composition Relationships for Hanford High-Level Waste Glasses Melting at $1150^{\circ} \mathrm{C}$, PNL-10359, December 1994.

Gasper 1995, Gasper to Sanders, Letter 9501609B R1, PROJECT W-236B TANK WASTE REMEDIATION SYSTEM (TWRS) WASTE PRETREATMENT FACILITY PRELIMINARY DESIGN REQUIREMENTS DOCUMENT, May 15, 1995.

Hughmark 1961, Aqueous Transport of Settling Slurries, Industrial and Engineering Chemistry, Vol. 53, May 1961.

INEL, Final Design Criteria for the New Waste Calcining Facility (NWCF), Allied Chemical Corporation, Idaho Falls, Idaho.

Johnson 1995, Recommended Cesium Ion Exchange Process Modelling Parameters for Inclusion in the Revised TWRS Process Flowsheet, Internal Memo, M. E. Johnson to D. J. Washenfelder, March 14, 1995.

Johnson 1996, Tank Waste Remediation System Baseline System Description, WHCEP-0856 Rev. 1, March 1996.

Jungfleisch 1984, TRAC: A Preliminary Estimation of the Waste Inventories in Hanford Tanks through 1980, WHC-SD-WM-TI-057, Rockwell Hanford Operations, Richland, Washington. 
Kupfer et. a1. 1994, WHC-SD-WM-TA-154, Strategy for Sampling Hanford Site Tank Wastes for Development of Disposal Technology, November 1994.

Kurath et. al. 1994, Experimental Data and Analysis to Support the Design of an Ion-Exchanger Process for the Treatment of Hanford Tank Waste Supernatant Liquids, PNL-10187, December 1994.

Lumetta et. a1. 1993, Sludge Treatment and Extraction Technology Development: Results of FY 1993 Studies, TWRSPP-93-071, September 1993.

Manue 1 et a1. 1996, Phase I High-Level Waste Pretreatment and Feed Staging Plan, WHC-SD-WM-ES-370 Rev. 0, February 1996.

McDonald 1994, Acceptance of Feed Streams for Treatment at the LERF/ETF Complex, WHC-SD-ETF-WAC-001 Rev. 0, November 18, 1994.

Milner 1996, Evaluation of Hanford Longer High-Level Waste Product Canister Option for Acceptance by the Civilian Radioactive Waste Management System, memorandum to Jackson Kinzer, April 5, 1996.

Mitche11 1995, Immobilized Low Level Waste Disposal Options Configuration Study, WHC-SD-WM-TI-686 Rev. O, February 1995.

Orme 1995a, TWRS Process Flowsheet, WHC-SD-WM-TI-613 Rev. 1, August 1995.

Orme 1995b, Preliminary Time-Phased TWRS Process Model Results, WHC-SD-WM-TI693 Rev. O, March 1995.

Penwell et al. 1996, Initial Retrieval Sequence, WHC-SD-WM-RPT-229 Rev. 0, September 1996.

Perry 1973, Chemical Engineers Handbook, Fifth Edition, 1973.

Powell 1995, Internal Memo 71210-95-005, Concentration of Low-Level Waste (LLW) Feed Using the PREDICT Model, March 23, 1995.

Powell et al. 1996, Neutralized Current Acid Waste Consolidation Management Plan, WHC-SD-WM-ER-532 Rev. 0, January 1996.

RHO 1980, Hanford High-Level Defense Waste Characterization - A Status Report, RHO-CD-1019.

RHO 1985, Hanford Defense Waste Disposal Alternatives: Engineering Support Data for the HDW-EIS, RHO-RE-ST-3OP.

Rapko et. al. 1995, Washing and Caustic Leaching of Hanford Tank Sludges: Resuits of FY 1995 Studies, TWRSPP-95-021, June 1995.

Schulz et. al. 1995, In-Tank Processes for Destruction of Organic Complexants and Removal of Selected Radionuclides, WHC-SD-WM-ES-321, April 1995. 
Shelton 1994a, Shelton to Garfield, Revised Inventory Estimates of Chemical and Radionuclides in Single- and Double-Shell Tanks, Internal Memo 7132094.016 , December 8, 1994.

Shelton 1994b, Shelton to Higley, Estimated Chloride Inventory of Hanford Tank Waste, August 30, 1994.

Shelton 1995a, Shelton to Kupfer, Double Shell Tank Inventories, Internal Memo 71320-95-003, February 24, 1995.

Shelton 1995b, Shelton to Cooney, Radionuclide Inventory for Single- and Double-Shel1 Tanks, Internal Memo 71320-95-002, February 14, 1995.

Shelton 1996, Projected Double-Shell Tank Supernate Composition and Inventory for Phase I Privatization, SD-WM-TI-751 Rev. 0, May 1996.

Slaathaug, E. J., W. A. Peiffer, and K. D. Boomer 1995, Determine Waste Separations Process Trade Study, WHC-SD-WM-ES-356 Rev. 0, August 1995.

Spells 1995, Transactions of the Institute of Chemical Engineers, 33, 79-84, 1955.

Temer et. a1. 1995, Sludge Washing and Alkaline Leaching Tests on Actual

Hanford Tank Sludge: A Status Report, LAUR-95-2070, June 1995.

Varma et. a). 1988, Identification of Glass Compositions Suitable for Disposal of Waste Reactive Metal, ANL-88-39, DOE/HWP-70, Argonne National Lab.

WHC 1996, Tank Waste Remediation System Functions and Requirements Document, WHC-SD-WM-FRD-020, Rev. 0, March 1996.

Witson et. a1. 1995, Melter Technology Evaluation for Vitrification of Hanford Site Low-Level Wastes, WHC-SA-2857-FP, April 1995. 
WHC-SD-WM-TI-774 Rev. 0

TWRS PRIVATIZATION PROCESS TECHNICAL BASELINE

Attachment 1

Note: the following table will be filled in with current numbers when they are available from Certa and Manuel.

Table 3-1a Phase 1 Chemical Feed

\begin{tabular}{|c|c|c|c|c|c|c|}
\hline \multirow{2}{*}{ Component } & \multicolumn{3}{|c|}{ LAW } & \multicolumn{3}{|c|}{$\mathrm{HLW}$} \\
\hline & $\begin{array}{l}\text { Soluble } \\
(\mathrm{kg})\end{array}$ & $\begin{array}{c}\text { Insoluble } \\
(\mathrm{kg})\end{array}$ & $\begin{array}{c}\text { Total } \\
(\mathrm{kg})\end{array}$ & $\begin{array}{c}\text { Soluble } \\
(\mathrm{kg})\end{array}$ & $\begin{array}{c}\text { Insoluble } \\
(\mathrm{kg})\end{array}$ & $\begin{array}{c}\text { Total } \\
(\mathrm{kg})\end{array}$ \\
\hline \multicolumn{7}{|l|}{$\begin{array}{c}\text { Total Mass } \\
\text { Flow }\end{array}$} \\
\hline \multicolumn{7}{|l|}{ Al $(\mathrm{OH}) 4-$} \\
\hline \multicolumn{7}{|l|}{$\mathrm{AT}+3$} \\
\hline \multicolumn{7}{|l|}{$\mathrm{Bi}+3$} \\
\hline \multicolumn{7}{|l|}{$\mathrm{Ca}+2$} \\
\hline \multicolumn{7}{|l|}{ Cancrinite } \\
\hline \multicolumn{7}{|l|}{$\mathrm{Ce}+3$} \\
\hline \multicolumn{7}{|l|}{$\mathrm{C} 1-$} \\
\hline \multicolumn{7}{|l|}{$\mathrm{CO}-2$} \\
\hline \multicolumn{7}{|l|}{$\mathrm{Cr}(\mathrm{OH}) 4-$} \\
\hline \multicolumn{7}{|l|}{$\mathrm{Cr}+3$} \\
\hline \multicolumn{7}{|l|}{$\mathrm{Cs}+$} \\
\hline \multicolumn{7}{|l|}{$F-$} \\
\hline $\mathrm{Fe}+3$ & & & & & & . \\
\hline \multicolumn{7}{|l|}{$\mathrm{H} 20$} \\
\hline \multicolumn{7}{|l|}{$\mathrm{La}+3$} \\
\hline \multicolumn{7}{|l|}{$M n+4$} \\
\hline \multicolumn{7}{|l|}{$\mathrm{Na}+$} \\
\hline $\mathrm{Ni}+3$ & & & & & & \\
\hline
\end{tabular}




\begin{tabular}{||l|l|l|l||l|l|l||}
\hline NO2- & & & & & & \\
\hline NO3- & & & & & & \\
\hline OH- & & & & & & \\
\hline$P 04-3$ & & & & & & \\
\hline$S i+4$ & & & & & & \\
\hline$S 04-2$ & & & & & & \\
\hline$S r+2$ & & & & & & \\
\hline$T C 04-$ & & & & & & \\
\hline$T O C$ & & & & & & \\
\hline$U 02+2$ & & & & & & \\
\hline$Z$ ZrO2:2H2O & & & & & & \\
\hline
\end{tabular}

Table 3-1b Phase 1 Radionuclide Feed ${ }^{1,2,3}$

\begin{tabular}{|c|c|c|c|c|c|c|}
\hline \multirow{2}{*}{ Radionucl ides } & \multicolumn{3}{|c|}{ LAH } & \multicolumn{3}{|c|}{ HLW } \\
\hline & $\begin{array}{c}\text { Soluble } \\
\text { (ci) }\end{array}$ & $\begin{array}{c}\text { Insoluble } \\
\text { (Ci) }\end{array}$ & $\begin{array}{l}\text { Total } \\
\text { (Ci) }\end{array}$ & $\begin{array}{c}\text { Sotuble } \\
\text { (ci) }\end{array}$ & $\begin{array}{c}\text { Insoluble } \\
\text { (ci) }\end{array}$ & $\begin{array}{l}\text { rotal } \\
\text { (Ci) }\end{array}$ \\
\hline Total Activity & & & & & & \\
\hline$A m-241$ & & & & & & \\
\hline$c-14$ & & & & & & \\
\hline Cs-137 & & & & & & \\
\hline Ba-137 & & & & & & \\
\hline $\mathrm{cm}-244$ & & & & & & \\
\hline Np-237 & & & & & & \\
\hline $\mathrm{Pu}-238$ & & & & & & \\
\hline Pu-239 & & & & & & \\
\hline$P u-240$ & & & & & & \\
\hline Pu-241 & & & & & & \\
\hline$s r-90$ & & & & & & \\
\hline$y-90$ & & & & & & \\
\hline Te- 99 & & & & & & \\
\hline
\end{tabular}

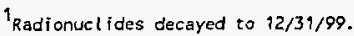

2 Amounts are consistent with the 1995 Integrated Database.

${ }^{3}$ SST is from IRAC; DST is from tank analysis. 


\section{DISTRIBUTION SHEET}

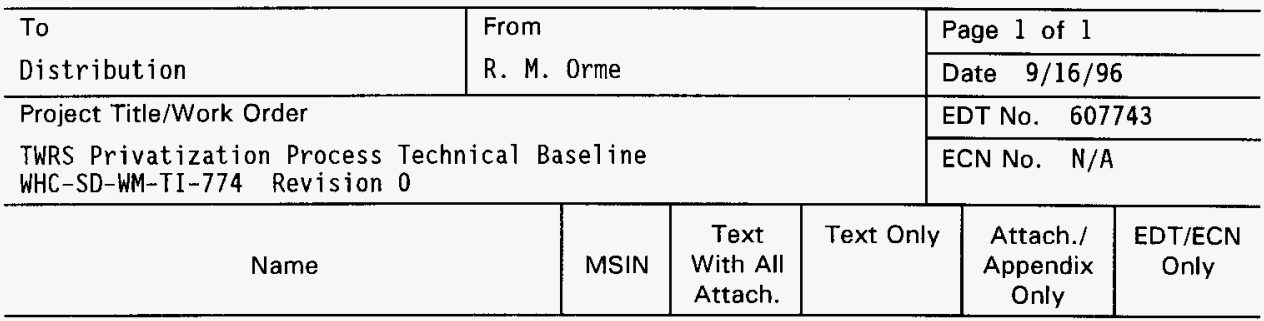

Central Files

J. N. Appel

A. L. Boldt

P. J. Certa

J. S. Garfield

K. A. Gasper

J. 0. Honeyman

R. A. Kirkbride

E. J. Kosiancic

A. F. Manuel

G. A. Meyer

R. J. Murkowski

R. M. Orme (25) **RETURN ORIGINAL **

C. A. Petersen

R. W. Powell

D. L. Penwell

E. J. Slaathaug

J. P. Sloughter

D. J. Washenfelder

L. K. Holton (5)

\section{$\underline{\text { PNL }}$}

A3-88

G3-21

H5-49

H5-61

H5-49

G3-21

G3-21

H5-27

H5-61

H5-49

S2-48

H5-03

H5-27

H5-27

G3-21

H5-27

H5- 49

R2-54

H5-27

\section{$X$}

$X$

$\mathrm{X}$

$X$

$x$

$X$

$x$

$X$

$x$

$x$

$X$

$\mathrm{X}$

$\mathrm{X}$

$x$

$x$

$x$

$x$

$X$
$X$

$\mathrm{kg}-73$

$X$ 